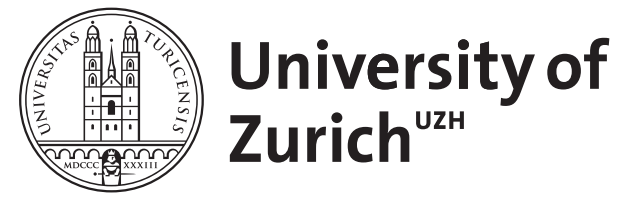

\title{
Urnamma of Ur in Sumerian Literary Tradition
}

\author{
Flückiger-Hawker, Esther
}

\begin{abstract}
This book presents new standard editions of all the hitherto known hymns of Urnamma, the founder of the Third Dynasty of Ur (fl. 2100 B.C.), and adds new perspectives to the compositions and development of the genre of Sumerian royal hymns in general. The first chapter (I) is introductory in nature (historical background, the reading of the name Urnamma, Sumerian royal hymns). The second chapter (II) presents a general survey of Urnamma's hymnic corpus, including arguments for a broader definition of Sumerian royal hymns and an attempt at classifying the non-standard orthography found in Urnamma's hymns. The third chapter (III) deals with correlations of Urnamma's hymns with other textual sources pertaining to him. A fourth chapter (IV) is devoted to aspects of continuity and change in royal hymnography by analyzing the Urnamma hymns in relation to other royal hymns and related genres. A discussion of topoi of legitimation and kingship and narrative materials in different text types during different periods of time and other findings concerning statues, stelas and royal hymns add new perspectives to the ongoing discussion of the original setting of royal hymns. Also, reasons are given why a version of the Sumerian King List may well be dated to Urnamma and the thesis advanced that Išmēdagan of Isin was not only an imitator of Šulgi but also of Urnamma. The final of the chapter IV shows that Urnamma A, also known as Urnamma's Death, uses the language of lamentation literature and Curse of Agade which describe the destruction of cities, and applies it to the death of a king. The last chapter (V) presents critical editions of Urnamma hymns A-H.
\end{abstract}

Posted at the Zurich Open Repository and Archive, University of Zurich

ZORA URL: https://doi.org/10.5167/uzh-152507

Monograph

Published Version

Originally published at:

Flückiger-Hawker, Esther (1999). Urnamma of Ur in Sumerian Literary Tradition. Fribourg, Switzerland / Göttingen, Germany: University Press / Vandenhoeck Ruprecht. 
Esther Flückiger-Hawker Urnamma of Ur in Sumerian Literary Tradition 


\section{ORBIS BIBLICUS ET ORIENTALIS}

Published by Othmar Keel and Christoph Uehlinger on behalf of the Biblical Institute of the University of Fribourg Switzerland, the Egyptological Seminar of the University of Basel, the Institute for Ancient Near Eastern Archaeology and Languages ot the University of Berne, and the Swiss Society for Ancient Near Eastern Studies

The author

Esther Flückiger-Hawker (1964) studied ancient Near Eastern cultures and languages at the University of Berne, Johns Hopkins University, Baltimore (M.A. 1989), and as participant of the Erasmus programme in Paris. From 1993-1999 she held a lectureship in Ugaritic and Akkadian at the University of Berne. 


\section{Orbis Biblicus et Orientalis $\quad 166$}

Esther Flückiger-Hawker

\section{Urnamma of Ur \\ in Sumerian Literary Tradition}

University Fribourg Switzerland Vandenhoeck \& Ruprecht Göttingen 


\section{Die Deutsche Bibliothek - CIP-Einheitsaufnahme}

\section{Flückiger-Hawker, Esther:}

Urnamma of Ur in Sumerian Literary Tradition/Esther Flückiger-Hawker.

Fribourg, Switzerland: Univ.-Press; Göttingen: Vandenhoeck und Ruprecht 1999.

(Orbis biblicus et orientalis; 166 )

Zugl.: Bern, Univ., Diss., 1996

ISBN 3-7278-1229-X (Univ.-Verl.)

ISBN 3-525-53342-X (Vandenhoeck \& Ruprecht)

Publication subsidized by the "Fonds für Alterstumswissenschaft"

of the Classics Departement, University of Zurich

Camera-ready text

submitted by the autor

(C) 1999 by University Press Fribourg Switzerland/Universitätsverlag Freiburg Schweiz Vandenhoeck \& Ruprecht Göttingen

Paulusdruckerei Freiburg Schweiz

ISBN 3-7278-1229-X (University Press)

ISBN 3-525-53342-X (Vandenhoeck \& Ruprecht)

Digitalisat erstellt durch Florina Tischhauser,

Religionswissenschaftliches Seminar, Universität Zürich 
TO MY PARENTS 



\section{TABLE OF CONTENTS}

\section{PREFACE}

1. Bibliographic Abbreviations

2. Other Abbreviations

3. Symbols

1. Historical Background

2. The Reading of the Name (d) ur-dnamma

3. Sumerian Royal Hymns 9

Chapter II: A GENERAL SURVEY OF THE URNAMMA HYMNS

1. Typology 12

2. Catalogue 17

3. Orthography 22

3.1 Archaic Orthography 22

3.2 Non-standard Orthography 23

4. Glosses

Chapter III: ON THE HISTORICAL CORRELATIONS OF THE URNAMMA HYMNS

1. Urnamma and His Deeds in the Hymns and Other Sources

2. Is Urnamma C a Chronological Summary of His Reign?

Chapter IV: CONTINUITY AND CHANGE IN ROYAL HYMNOGRAPHY

1. Legitimacy and Kingship 41

1.1 Urnamma and the Sumerian King List 41

1.2 Topoi of Legitimation and Kingship 42

1.3 Royal Titles and Epithets $\quad 58$

1.4 Enlil and Urnamma's Kingship 63

2. Urnamma and Išmedagān 
3. The Urnamma Hymns and Related Genres

3.1 The Urnamma Hymns and other Royal and

Divine Hymns

3.2 Statues, Stelas and Self-laudatory Hymns 78

3.3 Urnamma A and Lamentation Literature 85

Chapter V: EDITIONS OF URNAMMA A-H

0. Introductory Remarks

1. Urnamma A = Urnamma's Death 93

1.1 Introduction $\quad 93$

1.2 Transliteration and Translation 101

1.3 The Susa Version of Urnamma A 143

2. Urnamma $B$

1.4 Philological Commentary 164

2.1 Introduction

2.2 Transliteration and Translation

2.3 Philological Commentary

3. Urnamma $C$

3.1 Introduction 204

3.2 Transliteration and Translation $\quad 208$

3.3 Philological Commentary 220

4. Urnamma D

4.1 Introduction 228

4.2 Transliteration and Translation of the Nippur 234

Recension (source A only)

4.3 Transliteration and Translation of the Ur Recension 238

4.4 A Synopsis of Urnamma D: Nippur and Ur 244

Recensions

4.5 Collective Philological Commentary 254

5. Urnamma $E F$

5.1 Introduction

5.2 Transliteration and Translation of Urnamma E 266 (source A)

5.3 Transliteration and Translation of Urnamma F 270 (source B)

5.4 A Synopsis of Urnamma EF: Recensions E and F 276

6. Urnamma $G$

5.5 Collective Philological Commentary 286

6.1 Introduction $\quad 290$

6.2 Transliteration and Translation 292

6.3 Philological Commentary 296 
A LEXICAL INDEX OF URNAMMA COMPOSITIONS INDEX OF PROPER NAMES

INDEX OF TEXTS QUOTED 



\section{P R E F A C E}

This book is the published form of my dissertation which was submitted to and accepted by the Arts Faculty of the University of Berne in June 1996. Official readers were Profs. P. Attinger and M. Wäfler. The topic of the dissertation was first suggested to me some years ago by Prof. J.S. Cooper who felt that there was a need for new editions of all hitherto known hymns pertaining to Urnamma, the founder of the Third Dynasty of Ur, whose hymns are among the earliest examples of Sumerian royal hymns and are therefore crucial to the study of the genre of royal hymns in general. Whereas the studies in Sumerian hymnography have concentrated on the hymns of Urnamma's son and successor Sulgi and on the literary dependence of the Isin and Larsa rulers on his hymns, Urnamma's hymns have never been treated as a corpus and compared to both earlier and later writings. The purpose of this dissertation is to meet this need.

I express my gratitude to all my teachers at the University of Berne and Johns Hopkins University who guided my studies and stimulated my interest in ancient Near Eastern texts. Special thanks go to Profs. P. Attinger and J.S. Cooper who kindly served as advisors for this dissertation and without whose help and patience this thesis would not have been possible. I am also particularly grateful to Prof. M. Wäfler who has always shown keen interest in and support of my academic endeavours, has furthermore enabled me to gain teaching experience over the years, and kindly served also as official reader.

Through the generosity of a number of scholars and institutions I have been given access to materials from their collections and permission to incorporate them in the various editions. I am particularly indebted to Prof. $\AA$. W. Sjöberg of the University Museum, Dr. B. André-Salvini of the Musée du Louvre, and Prof. J.A. Brinkman of the Oriental Institute in Chicago, for allowing me to study published and unpublished materials, and to Prof. C.B.F. Walker for providing excellent photos which are published by permission of the Trustees of the British Museum.

I am grateful to Prof. P. Attinger for enabling me to use his extensive Sumerian files, to Dr. H. Behrens for generously enabling access to PSD manuscripts, to Prof. M. Civil for his list of sources in Index For a Corpus of Sumerian Literature, for a transliteration of Urnamma $G$ and his permission to include it, together with the unpublished Susa version of Urnamma A, in this study, to Prof. J.-M. Durand for collations of Urnamma C and Dr. Ph. Jones and Prof. S. Tinney for collations of Urnamma H, to Prof. S. Tinney for his unpublished University Museum manuscripts of Urnamma A and D prepared for the Sumerian Dictionary Project, and to Prof. C. Wilcke for his unpublished Habilitationsschrift Urnammus Tod, Tod und Bestattung eines Königs in neusumerischer Zeit. Thanks are due to Prof. Å. W. Sjöberg and his University Museum team, to Dr. B. André-Salvini, 
and Prof. J.A. Brinkman for their hospitality and help during my stays in Philadelphia, Paris, and Chicago. I was able to benefit from discussions with Dr. A. Zgoll, Prof. S. Tinney, and G. Rubio for which I thank them.

Two institutions have supplied travel funds for collation of tablets, the University of Berne (Prof. J.M. López) and the Erasmus Programme (Prof. D. Willers). I am indebted to both. I also thank Johns Hopkins University and its Department of Near Eastern Studies for generous financial help during my years of graduate study.

Appreciated is the help I had from Dr. T. Nelson who patiently corrected my English. My husband helped me prepare and typeset the manuscript for publication. Finally I am indebted to Prof. O. Keel and PD Dr. Chr. Uehlinger in enabling me to publish this work in their series Orbis Biblicus et Orientalis and to the 'Fonds Altertumswissenschaft' of the Classics Department of the University of Zürich which generously helped to finance this publication.

Engelberg, January 1999

Esther Flückiger-Hawker 


\section{A B B R E V I A T I O N S}

\section{Bibliographic Abbreviations}

All abbreviations used are basically those of the Assyrian Dictionary of the Oriental Institute of the University of Chicago (Chicago-Glückstadt 1956-), for Sumerian compositions those of the Sumerian Dictionary of the University of Pennsylvania (Philadelphia 1984-). Exceptions and additions follow below:

AUWE

Codex Urnamma

Correlations

CRRAI

Death of Gilgameš A, B

Dialogue 3

Dialogue 4

Eléments

Emesal-Studien

ENEWO
Ausgrabungen in Uruk-Warka Endberichte.

= Laws of Urnamma: edition in M.T. Roth, Law Collections from Mesopotamia and Asia Minor, SBL (Writings from the Ancient World Series) 6 (1995) 1522; line numbering of the prologue according to D.R. Frayne, Royal Inscriptions of Mesopotamia, Early Periods (= RIME), vol. 3/2: Ur III Period (2112-2004 B.C.), Toronto-Buffalo-London (1997) 46-49.

D.R. Frayne, The Historical Correlations of the Sumerian Royal Hymns (2400-1900 B.C.), Ph.D. Thesis Yale University (1981).

Compte rendu, Rencontre Assyriologique Internationale.

Cf. S.N. Kramer, "The Death of Gilgameš", BASOR 94 (1944) 2-12 and A. Cavigneaux, F. Al-Rawi, "New Sumerian Literary Texts from Tell Haddad (Ancient Meturan): A First Survey", Iraq 55 (1993) 93.

= Enkimansum and Giriniisag: edition in W.H.Ph. Römer, UF 20 (1988) 233-45.

= Supervisor and Scribe (= Eduba C): unpub. ms. UM.

$\mathrm{P}$. Attinger, Eléments de linguistique sumérienne, la construction de du 11 le/di "dire", ОВO Sonderband, Fribourg-Göttingen (1993).

M. Schretter, Emesal-Studien, Innsbrucker Beiträge zur Kulturwissenschaft, Sonderheft 69, Innsbruck (1990).

C.A. Benito, 'Enki and Ninmah' and 'Enki and the World Order', Ph.D. Thesis University of Pennsylvania (1969); line numbering of Enki and the World Order according to unpub. ms. UM. 
Enl.sudr.

Figurative Language

Gungunum A

Ibbīsu'en A

Ibbīsu'en D

Ibbīsu'en E

Iddindagān A

Iddindagān B

Iddindagān D

Inanna

Isin $* 30$

Išbi’erra B

Išbi’erra D
= Enlil in the Ekur: edition in D. Reisman, TNSRH (1969) 41-102.

M. Mindlin, M.J. Geller, J.E. Wansbrough, Figurative Language in the Ancient Near East, School of Oriental and African Studies, London (1987).

Cf. D.R. Frayne, Correlations (1981) 369 and 375, fn. 12; edition in Å.W. Sjöberg, "Miscellaneous Sumerian Hymns", ZA 63 (1973) 24-31 (no. 4).

Cf. D.R. Frayne, Correlations (1981) 291; edition in A.W. Sjöberg, "Hymns to Meslamtaea, Lugalgirra and Nanna-Suen in Honour of King Ibbīsuen (Ibbīsîn) of Ur", OrSuec 19-20 (1970-71) 144f. (no. 2), 161-63 (commentary).

Cf. D.R. Frayne, Correlations (1981) 291; edition in Å.W. Sjöberg, "Hymns to Meslamtaea, Lugalgirra and Nanna-Suen in Honour of King Ibbīsuen (Ibbīsîn) of Ur", OrSuec 19-20 (1970-71) 145-47 (no. 3), 163-66 (commentary).

Cf. D.R. Frayne, Correlations (1981) 291; edition in Å.W. Sjöberg, "Hymns to Meslamtaea, Lugalgirra and Nanna-Suen in Honour of King Ibbīsuen (Ibbīsîn) of Ur", OrSuec 19-20 (1970-71) 149 (no. 5), $170 f$. (commentary).

= Inana and Iddin-Dagān (= Isin *6): edition in D. Reisman, TNSRH (1969) 147-211; idem, "IddinDagan's Sacred Marriage Hymn", JCS 25 (1973) 185202.

= Isin *7: edition in W.H.Ph. Römer, SKIZ (1965) 209-35.

Cf. D.R. Frayne, Correlations (1981) 381; edition in O.R. Gurney, S.N. Kramer, Sumerian Literary Texts in the Ashmolean Museum, OECT 5 (1976) 20-26.

F. Bruschweiler, Inanna, La déesse triomphante et vaincue dans la cosmologie sumérienne, Les Cahiers du CEPOA 4, Louvain (1987).

$=\mathrm{a} \mathrm{da} \mathrm{b}$ of Inana mentioning Urninurta: edition in $\mathrm{A}$. Falkenstein, "Sumerische religiöse Texte", ZA 52 (1957) 58-75.

= Išbierra and Kindattu: edition in J.J.A. v. Dijk, "Išbi'erra, Kindattu, l'homme d'Elam, et la chute de la ville d'Ur", JCS 30 (1978) 189-208.

$=$ Isin *1: edition in W.H.Ph. Römer, SKIZ (1965) 77 82. 
Išmedagān A

Išmedagān B

Išmedagān E

Išmedagān $\mathrm{K}$

Išmedagān $Q$

Lugalbanda I

Lugalbanda II

MHEO

Ninegala

Nippur Lament

Nungal

"Politik und Literatur"

Recueil de Travaux
$=$ Isin $* 12+* 19+* 20=$ Enlildiriše: unpub. ms. UM; cf. M.-C. Ludwig, Išme-Dagan (1990) 2-4 and S. Tinney, OLZ 90 (1995) 20f.; partial edition in W.H.Ph. Römer, SKIZ (1965) 39-55.

= Isin *9; cf. M.-C. Ludwig, Išme-Dagan (1990) 4f. and S. Tinney, OLZ 90 (1995) 22; edition in W.H.Ph. Römer, SKIZ (1965) 236-65.

$=$ Isin *21; cf. M.-C. Ludwig, Išme-Dagan (1990) 7.

$=$ Isin *15; cf. M.-C. Ludwig, Išme-Dagan (1990) 12 and S. Tinney, OLZ 90 (1995) 22; edition in W.H.Ph. Römer, BiOr. 45 (1988) 24-35; 35-54 (commentary).

Cf. M.-C. Ludwig, Išme-Dagan (1990) 16; edition in Å.W. Sjöberg, "Miscellaneous Sumerian Hymns", ZA 63 (1973) 16ff. (no. 3).

= Lugalbanda Epic I: unpub. ms. UM; cf. C. Wilcke, RlA 7 (1987-90) 121f. s.v. "Lugalbanda".

= Lugalbanda Epic II: cf. C. Wilcke, Lugalbandaepos, Wiesbaden (1969).

Mesopotamian History and Environment, Occasional Publications.

= Ninegalla Hymn (SEM 87 // SEM 89 // CBS 14187 // 3N-T 339 // BE 3112 // UM 29-25-557 // Ni. 9721): unpub. ms. UM.

S. Tinney, The Nippur Lament, Royal Rhetoric and Divine Legitimation in the Reign of Išme-Dagan of Isin (1953-1935 B.C.), Occasional Publications of the Samuel Noah Kramer Fund 16, Philadelphia (1996).

= Nungal Hymn; cf. P. Attinger, Eléments (1993) 51, s.v. "Nungal"; edition in Å.W. Sjöberg, "Nungal in the Ekur", AfO 24 (1973) 19-46; cf. also, Civil, Studies Hallo (1993) 72-74.

"Paradigm and Propaganda" = J.S. Cooper, "Paradigm and Propaganda, The Dynasty of Akkade in the 21st Century", in M. Liverani (ed.), Akkad, the First World Empire: Structure, Ideology, Tradition, History of the Ancient Near East 5, Padua (1993) 11-23.

= C. Wilcke, "Politik im Spiegel der Literatur, Literatur als Mittel der Politik im älteren Babylonien", in K. Raaflaub (ed.), Anfänge politischen Denkens in der Antike, die nahöstlichen Kulturen und die Griechen, Schriften des Historischen Kollegs, Kolloquien 24, München (1993) 29-75.

Recueil de Travaux et Communications de l'Association des Etudes du Proche-Orient Ancien. 
"Sacred Marriage and Popular Cult"

SGL 1

SGL 2

Sîniddinam A

StPohl (SM)

Sumer and Ur Lament

"Sumerische Königsliste"

Šūilišu A

Šūsu'en D

ThŠH

TMH NF

TNSRH

TSO

Ur III Catalogue

UT
J.S. Cooper, "Sacred Marriage and Popular Cult in Early Mesopotamia", in E. Matsushima (ed.), Official Cult and Popular Religion in the Ancient Near East, Heidelberg (1993) 81-96.

A. Falkenstein, Sumerische Götterlieder, 1. Teil, AHAW Phil.-hist. Klasse 1959/1, Heidelberg (1959).

J.J.A. van Dijk, Sumerische Götterlieder, 2. Teil, AHAW Phil.-hist. Klasse 1960/1, Heidelberg (1960).

Cf. D.R. Frayne, Correlations (1981) 371 and 376, fn. 18; edition in J.J.A. v. Dijk, JCS 19 (1965) 21f.

Studia Pohl (Series Maior), Dissertationes Scientificae de Rebus Orientis Antiqui (Rome).

= Lamentation over Sumer and Ur; cf. P. Michalowski, Lamentation (1989).

C. Wilcke, "Die Sumerische Königsliste und erzählte Vergangenheit", in J. v. Ungern-Sternberg, H. Reinau (eds.), Vergangenheit in mündlicher Überlieferung, Colloquium Rauricum 1, Stuttgart (1988) 113-40.

= Isin *4: cf. D.R. Frayne, Correlations (1981) 366; editions in W.H.Ph. Römer, SKIZ (1965) 91-127; Å.W. Sjöberg, "Miscellaneous Sumerian Hymns", ZA 63 (1973) 2-13 (no. 1), and S.N. Kramer, "BM 100042: A Hymn to Šu-Sin and an Adab of Nergal", Studies Sjöberg (1989) 303-16; line numbering according to Sjöberg, ZA 63 (1973) 2-5.

Cf. D.R. Frayne, Correlatons (1981) 266; edition in Å.W. Sjöberg, "Hymns to Ninurta with Prayers for Šūsîn of Ur and Būrsîn of Isin", AOAT 25 (1976) 41215, 421-24.

J. Klein, Three Šulgi Hymns, Sumerian Royal Hymns Glorifying King Šulgi of Ur, Bar-Ilan Studies in Near Eastern Languages and Cultures, Ramat Gan (1981).

Texte und Materialien der Frau Professor Hilprecht Sammlung, Friedrich Schiller-Universität Jena, Neue Folge.

D. Reisman, Two Neo-Sumerian Royal Hymns, Ph.D. University of Pennsylvania (1969).

Texte und Studien zur Orientalistik.

M. Sigrist, T. Gomi, The Comprehensive Catalogue of Published Ur III Tablets, Bethesda (1991).

C. Wilcke, Urnammus Tod, Tod und Bestattung eines Königs in neusumerischer Zeit, unpub. Habilitationsschrift (1972). 


\section{Other Abbreviations}

Cf. further the abbreviations given in the Lexical Index of Urnamma Compositions, p. 301.

\begin{tabular}{|c|c|c|c|}
\hline Akk. & Akkadian & $\begin{array}{l}\text { OB } \\
\text { obv. }\end{array}$ & $\begin{array}{l}\text { Old Babylonian } \\
\text { obverse }\end{array}$ \\
\hline $\mathrm{C}$ & consonant & om. & omisit \\
\hline coll. & collation, collated & $\mathrm{p}$ & page \\
\hline $\mathrm{DN}$ & Divine Name & pp. & pages \\
\hline $\mathrm{ed}(\mathrm{s})$ & editor(s) & $\mathrm{pl}(\mathrm{s})$ & plate(s) \\
\hline ED & Early Dynastic & rev. & reverse \\
\hline$f(f)$ & and following & sect. & section \\
\hline $\mathrm{fn}(\mathrm{s})$ & footnote(s) & suppl. & supplement \\
\hline $\begin{array}{l}\text { frgm. } \\
\text { gen. ind. }\end{array}$ & $\begin{array}{l}\text { fragment } \\
\text { general index }\end{array}$ & UM & $\begin{array}{l}\text { University Museum, } \\
\text { Philadelphia }\end{array}$ \\
\hline lex. (sect.) & lexical (section) & unpub. & unpublished \\
\hline MA & Middle Assyrian & $\mathrm{V}$ & Vowel \\
\hline $\mathrm{MB}$ & Middle Babylonian & $\operatorname{var}(\mathrm{s})$. & variant(s) \\
\hline $\mathrm{ms}$. & manuscript & vs & versus \\
\hline
\end{tabular}

\section{Symbols}

\begin{tabular}{|c|c|}
\hline 11 & allomorphe \\
\hline\{\} & morpheme \\
\hline$/ /$ & duplicate source(s) \\
\hline । & new line \\
\hline$\|$ & $\begin{array}{l}\text { 1. parallel line(s), } \\
\text { 2. parallel Sumerian term(s) }\end{array}$ \\
\hline l & $\begin{array}{l}\text { 1. indented line on cuneiform tablet } \\
\text { 2. alternation }\end{array}$ \\
\hline$\approx$ & approximately \\
\hline$\cdots$ & untranslatable word(s) \\
\hline$[\ldots]$ & break in the text \\
\hline cursive script & tentative translation \\
\hline $\mathrm{H}$ & $\begin{array}{l}\text { indicates no contraction between a final vowel of a lexeme and a } \\
\text { subsequent /e/ }\end{array}$ \\
\hline
\end{tabular}




\title{
CHAPTER I
}

\author{
I N T R O D U C T I O N
}

\section{Historical Background}

We know little about the complex events that followed the collapse of the Akkade dynasty (ca. 2300-2200 B.C.), founded by Sargon, which reached its zenith under Narāmsu'en, Sargon's grandson, and saw its final moments under Šarkališarrī, Narāmsu'en's son. In the aftermath of its fall, parts of lower Mesopotamia, known as Sumer, with parochial states such as Uruk, Ur, Lagaš, Umma and Šuruppak, seem to have come under temporary domination of the Guti, whom Utuhegal of Uruk (ca. 2100 B.C.), sole member of the fifth dynasty of Uruk, claimed to have expelled. Urnamma, š a g i n a "military governor" of Ur under Utuheĝal and very possibly a member of the royal family at Uruk, ${ }^{1}$ asserted the independence of Ur from Uruk and was able to found a new dynasty which is commonly known as the Third Dynasty of Ur, or Ur III (ca. $2100-2000$ B.C.). ${ }^{2}$ Urnamma reigned eighteen years (2111-2094 B.C.) and was succeeded by his son Sulgi (2093-2046 B.C.), under whose reign the house of Ur rose to become the first large territorial state after the Akkade empire, matching "its scope and power, through the unification of Babylonia and control of the periphery, its elaboration of an imperial bureaucracy, and its new conception of royalty that included, among other things, the deification of the king". ${ }^{3}$ The Ur III state, however, was not to last long. As sudden and swift as its rise was its decline under Sulgi's son Amarsu'en (2045-2037 B.C.) and his successor Šūsu'en (2036-2028 B.C.), ending in complete destruction under its last king Ibbīsu'en (2027-2003 B.C.).

New texts and interpretations of previously available data have enabled scholars to make progress in establishing the relative chronology of the Ur III state and

\footnotetext{
1 Wilcke, CRRAI 19 (1974) 180; 192f., fn. 67; idem, "Sumerische Königsliste" 119; idem, Studies Sjöberg (1989) 566; idem, "Politik und Literatur" 32. Cf. also Cooper, "Paradigm and Propaganda" 20, and fn. 43 for his reservations that Unamma was Utuh egal's brother. Urnamma's unnamed "father" (a b - b a) is mentioned in the Ur III administrative document I 870 (= Neumann, Hruška, ArOr. 62 [1994] 241) 8 which also lists another family member (?) by the name of Damiqtum, possibly his mother (Boese, Sallaberger, AoF 23 [1996] 29).

2 For proposals for the complex chronological and political situation between the fall of the Akkade empire and the beginnings of the Third Dynasty of Ur, cf, e.g. Carroué, ASJ 7 (1985) 89-96 (especially the chart on p. 96); Monaco, ASJ 12 (1990) 101 (chart); Glassner, N.A.B.U. 1994/9 with previous literature; most recently Carroué, ASJ 17 (1995) 69ff.

3 Cooper, "Paradigm and Propaganda" 12.
} 
other dynasties, although substantial problems regarding these states' internal chronologies and interrelationships still await solutions. It is posssible to establish contemporaneity, though not absolute synchronisms, between Urnamma and representatives of some of these successor dynasties to the Akkad empire, namely, besides the aforementioned fifth dynasty of Uruk under Utuhegal, Awan, Mari, Gutium and Lagaš II:

In Isin an Old Babylonian tablet (IB 1537) $)^{4}$ was discovered which contains copies of earlier inscriptions, of which one can probably be attributed to Urnamma. ${ }^{5}$ It mentions a military conflict in the north-east, involving Puzur/Kutik-Inšušinak of Awan ${ }^{6}$ whose reign has traditionally been dated ca. fifty years earlier, following that of Šarkališarrī, the last ruler of Akkade. As a result of this new text the interval between the end of the Akkade empire and the beginning of the Third Dynasty of Ur under Urnamma has been recently estimated by J.-J. Glassner to have been no more than thirty years. ${ }^{7}$

An Old Babylonian collection of abbreviated (probably mostly Sulgi) inscriptions from Nippur $(\mathrm{N} 2230+\mathrm{N} 4006)^{8}$ establishes the synchronism between Urnamma and Apilkīn, the šakkanakku at Mari. ${ }^{9}$ The inscription MŠ C 1 (= Gelb, Kienast, FAOS 7 [1990] 366) vii 5'-12' mentions Apilkīn's daughter Tarāmur(i)am as the $\mathrm{e}_{2}-\mathrm{g} \mathrm{e}_{4}-$ a, i.e. probably the "daughter-in-law" of Urnamma. ${ }^{10}$

Contemporaneity between Urnamma and a Gutian named Gutarla can be established on the basis of an inscription on a cylinder fragment from Nippur (6N-T 908 a $(+)),{ }^{11}$ if it can indeed be attributed to Urnamma. Gutarla might have unsuccessfully aspired to the throne ${ }^{12}$ by joining forces with Elam, Babylonia's enemy to the east.

The earlier prevailing opinion that the Lagaš II dynasty ended with the defeat of its last $\mathrm{e} \mathrm{ns} \mathrm{i}_{2}$ Namhani by Urnamma, ${ }^{13}$ at the very beginning of the latter's reign and that therefore the dynasty's greatest ruler, Gudea, and some of his

\footnotetext{
4 Published by Wilcke in Hrouda (ed.), Isin-Išān Baḥrīyāt III, Die Ergebnisse der Ausgrabungen 1983-84, ABAW NF 94 (1987) 108-111. [cf. now also Frayne, RIME 3/2 (1997) 65f. as RIME 3/2.1.1.29].

5 Also Michalowski, Lamentation 2; Glassner, OLZ 88 (1993) 382 and idem, N.A.B.U. 1994/9. With reservation W.G. Lambert, CRRAI 36 (1991) 54, fn. 8.

6 According to Vallat in N.A.B.U. 1997/37 the final subduer of Puzur/Kutik-Inš ušinak was Gudea of Lagaš in the course of his conquest of Anš an (refuted by Quintana, N.A.B.U. 1997/71).

7 Glassner, N.A.B.U. 1994/9.

8 Published and discussed by Civil, RA 56 (1962) 213 and idem, Or. 54 (1985) 37-45. [cf. now also Frayne, RIME 3/2 (1997) 86 as RIME 3/2.1.1.52].

9 For the synchronism Apilkīn 35 = Urnamma 1, cf. Durand, M.A.R.I. 4 (1985) 153ff.; Wilcke, Studies Sjöberg (1989) 560, fn. 20 with literature on Mari in Ur III times. For Apilkin and his relations with the Ur III kings, cf. most recently Boese, Sallaberger, AoF 23 (1996) 24-39.

10 For Tarāmur(i)am as Sulgi's wife and probably the mother of Amarsu'en, cf. Boese, Sallaberger, ibid. $34 f$. Frayne, RIME 2 (1993) 219 cites an inscribed seal from Ur bearing her name. [ now as seal inscription RIME 3/2.1.1.53].

11 Edited by Civil, Or. 54 (1985) 27-32. [cf. now also Frayne, RIME 3/2 (1997) 66-68 as RIME 3/2.1.1.30].

12 Civil, ibid. 31 ad 4'-6'.

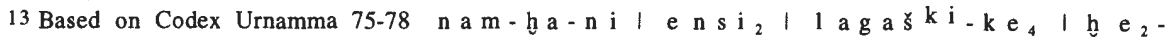
$\mathrm{m}[\mathrm{i}]-\ulcorner\mathrm{x}\urcorner$. The final sign is surely not $\mathrm{ug}_{5}$ implying Urnamma's defeat of the Lagas ruler, but apparently $\mathrm{i}_{2}$ "to install, promote", cf. Roth, Law Collections from Mesopotamia and Asia Minor, SBL (Writings from the Ancient World Series) 6 (1995) 15. [cf. now also Frayne, RIME 3/2 (1997) 46 (coll. Donbaz)].
} 
successors must have reigned prior to Urnamma, has recently been challenged by $P$. Steinkeller. ${ }^{14} \mathrm{He}$ was able to show that the same officials were engaged in the distribution of garments in documents dated from the reign of Gudea up to year 11 of Urnamma's son and successor Sulgi (2093-2046 B.C.). This finding seems to considerably substantiate the possibility of an overlap of Gudea's reign with that of Urnamma and Sulgi, since an administrative career rarely lasted more than twenty years. ${ }^{15}$ However, F. Carroue has recently put forth arguments for dating the end of Gudea's reign again prior to Urnamma's. ${ }^{16}$ Also, if we maintain an overlap of Gudea's reign with Urnamma's and even Sulgi's, as P. Steinkeller suggests, it does indeed become difficult to accommodate Gudea's successors within the reigns of Urnamma and Sulgi, or else they must have each reigned very short periods of time. ${ }^{17}$ Unfortunately, however, the chronology of the Lagaš II dynasty remains an enigma in the reconstruction of Mesopotamian history despite all the efforts of recent years. ${ }^{18}$ Problems yet to be solved include the number and order of the rulers, the length of their reigns and the relative chronology between these rulers and those of the Uruk IV-V, Ur III, Umma and Gutium dynasties. E. Sollberger's and A. Falkenstein's chronological charts of the Lagaš II dynasty ${ }^{19}$ have been recently challenged by T. Maeda and S.F. Monaco. On the basis of two economic texts, T. Maeda has suggested two different rulers by the name of Urningirsu, namely Urningirsu I, the father of Pirigme, and Urningirsu II, Gudea's son. ${ }^{20}$ The ruler Nammahni, son-in law of Urba'u, ${ }^{21}$ Gudea's predecessor, is generally viewed as being identical with Namhani, the ruler who is mentioned in Codex Urnamma and is therefore Urnamma's contemporary. ${ }^{22}$ S.F. Monaco, however, has argued for a distinction between them and furthermore equated the e n s $\mathrm{i}_{2} \quad \mathrm{Nammahni}$ of Lagaš with the e $\mathrm{si}_{2}$ of Umma by the same name. ${ }^{23}$ The differences in the

\footnotetext{
14 Steinkeller, JCS 40 (1988) 47-53.

15 A possible overlap of Gudea's dynasty with that of Urnamma and his successor Sulgi was voiced by several scholars prior to Steinkeller's finding (cf. Frayne, Correlations 96 and 130, fn. 45 with previous literature, and Steible, FAOS 9/1 [1991] 7 with previous literature). Most recent proponents of a contemporaneity between Gudea and Urnamma include Vallat, N.A.B.U. 1997/37 and Quintana, N.A.B.U. 1997/71.

16 Carroué, ASJ 16 (1994) 72f. Cf. also Fischer, BaM 27 (1996) 215, and fn. 1 with reference to Renner, Zur Chronologie der Gudeazeit (in preparation).

17 If e.g. Uraba was e $\mathrm{s} \mathrm{i}_{2}$ of Lagaš under Urnamma, as outlined immediately below, then Gudea's reign can hardly have overlapped Sulgi's.

18 Cf. Maeda, ASJ 10 (1988) 19-35; idem, ASJ 15 (1993) 294-97; Monaco, ASJ 12 (1990) 89-105, and most recently Carroué, ASJ 16 (1994) 47-75.

19 Sollberger, AfO 17 (1954-56) 45; Falkenstein, AnOr. 30 (1966) 6.

20 Maeda, ASJ 10 (1988) 19-35; idem, ASJ 15 (1993) 294-97.

21 Nammahni 7 (= Steible, FAOS 9/1 [1991] 380) 9-13. The numbering of inscriptions of the Lagaš II rulers follows Steible, FAOS 9/1 (1991) 123-430. The latest edition of Lagaš II inscriptions by Edzard, Royal Inscriptions of Mesopotamia, Early Periods (= RIME), vol. 3/1: Gudea and His Dynasty, Toronto-BuffaloLondon (1997) appeared too late to be used systematically.

22 Maeda, ibid. Note that both Nammahni and Nambani seem to be associated with a female person by the name of Ningula (Maeda, ASJ 1019 rev. 2-3 and Perlov, CRRAI 2678 rev. 25-26), which argues for an identity of the two persons.

23 Monaco, ASJ 12 (1990) 89-105; also Grégoire, Lagaš 40. Positively inclined towards an identification of Nammahni of Lagaš with Nammahni of Umma is Sallaberger, "Urkunden aus der Zeit der Dritten Dynastie von Ur, eine Einführung" in Attinger, Wäfler (eds.), Mesopotamien, Akkade-Zeit und Ur III-Zeit, Annäherungen 3, OBO $\mathrm{XXX}$ (in preparation).
} 
sequence of these rulers proposed are readily apparent in B. Lafont's convenient chart in BiOr. 50 (1993) 677f.: the father-son succession Urningirsu - Pirigme appears in T. Maeda's proposal before Urba'u and Gudea, whereas E. Sollberger had previously dated these two rulers after Gudea. In the sequence Urgar - Uraba Urmama - $\mathrm{Na}(\mathrm{ma}) \mathrm{h}(\mathrm{a}) \mathrm{ni}$, established by T. Maeda, S.F. Monaco inserts Nammahni, whom he considers distinct from Namhani, between Urgarar and Uraba. In view of these uncertainties it is not yet possible to establish the exact synchronism between the Lagaš II rulers and the first pair of kings of the Third Dynasty of Ur.

There is also no general agreement as to the precise nature of relations between Lagaš and Ur before Urnamma takes control of the former. B. Lafont and others are inclined to see no hostility between these two cities, whereas F. Carroué recently argued for a rivalry between them. ${ }^{24}$ It is quite possible that Lagaš controlled $\mathrm{Ur}$ sometime after the downfall of Akkade..$^{25}$ Gudea's predecessor Urba'u is known to have installed his daughter under the name Enanepada as e n- priestess of Nanna in Ur and may therefore have dominated that city at that time. ${ }^{26} \mathrm{~A}$ rivalry between these two cities must have existed during the time of Utuhegal, under whom Urnamma served as "military governor" in Ur before usurping power: three of Utuhegal's inscriptions ${ }^{27}$ tell us that he settled a boundary dispute between Ur and Lagaš in Lagaš's favour, which may indicate that Uruk had control over both cities during this time. ${ }^{28}$

The texts available do not permit us to grasp the circumstances of Urnamma's rise in Ur and his subsequent claim on hegemony over all Babylonia by assuming the title "king of Sumer and Akkad" (l u g a 1 k i - e n - g i k i - u r i (-k )). ${ }^{29}$ It might be that the fragmentary prologue of the Codex Urnamma ${ }^{30}$ tells us how Urnamma came to be king of Ur. ${ }^{31}$ Urnamma may have taken over power from the

\footnotetext{
24 Lafont, BiOr. 50 (1993) 678 and 681 (with previous literature) draws attention especially to the persistence of local elites and traditions at Lagaš in the Ur III period; Carroué, ASJ 16 (1994) 75 is in favour of a rivalry in view of both these cities' claim upon the religious and cultural heritage of Uruk. This view is also shared by Wilcke, "Politik und Literatur" 60.

25 Wilcke, ibid. 44.

26 Urba'u 11 and 12 (= Steible, FAOS 9/1 [1992] 150-52). Cf. also Carroué, ASJ 16 (1994) 64. Urnamma 35 (= Steible, ibid. 142) tells us that subsequently a daughter of Unnamma was e n-priestess of Nanna in Ur under the name of Ennirg alana.

27 RIME 2.13.6.1-3.

28 Carroué, ASJ 16 (1994) 47-75 and idem, ASJ 17 (1995) 70ff. argues for a dominance of Uruk over Lagaš during the time of Gudea and his son Urning irsu.

29 Steinkeller, SAOC 46 (1987) 15; Wilcke, "Politik und Literatur" 32, fn. 15 with previous literature.

30 For the latest edition of Codex Urnamma known from later manuscripts found at Nippur, Ur and Sippar, cf. now Roth, Law Collections from Mesopotamia and Asia Minor, SBL (Writings from the Ancient World Series) 6 (1995) 15-22 and 249. [ now also Frayne, RIME 3/2 (1997) 43-49 as RIME 3/2.1.1.20, without the edition of the actual laws]. For a translation, cf. also Saporetti, Le leggi della Mesopotamia, Tradotte dai testo originali, Studi e Manuali di Archeologia 2 (1984) 21-25. For the attribution of this law code to Urnamma, cf. the recent persuasive arguments in Michalowski, Walker, Studies Sjöberg (1989) 384-86; Sauren, OLP 20 (1989) 5-21; Geller, ZA 81 (1991) 145f.; Wilcke, "Politik und Literatur" 37, fn. 45. Arguments in favour of a Sulgi authorship have been voiced by Steinkeller, SAOC 46 (1987) 15f., fn. 1 and 17, fn. 10 with previous literature; Neumann, AoF 19 (1992) 37f.; Gomi, ZA 83 (1993) 31, fn. 1.
} 31 Cooper, "Paradigm and Propaganda" 20, fn. 42. 
legitimate heir as a supposed member of the royal family following Utuhegal's death and then decided to move the capital to Ur because he was already in residence there and because Ur, as Sumer's most important seaport, offered the best conditions for sea trade with the Gulf region of Magan. Urnamma $28^{32}$ reports the excavation of the $\mathrm{d}_{\mathrm{n}}$ a $\mathrm{n} \mathrm{n}$ a- $\mathrm{g} \mathrm{u}_{2}-\mathrm{g}$ a l-canal ${ }^{33}$ at a time when Urnamma had already assumed the titulary "king of Sumer and Akkad" and had conducted reconstruction work on Enlil's Ekur in Nippur. The canal is called on Urnamma's stela the "boundary canal of Ningirsu" 34 and must have therefore demarcated the territory of Ur under Urnamma and that of the city-state of Lagaš under an unnamed e $\mathrm{n} \mathrm{s} \mathrm{i}_{2}$. According to Urnamma 28, 1:14 its "outlet" $\left(\mathrm{k} \mathrm{u}_{\mathrm{x}}\right)^{35}$ was made to reach the sea waters $(a-a b-b a(-k)),{ }^{36}$ thus opening the way to Gulf trade for products from Magan. According to inscriptions 26, 47, and Codex Urnamma 7984, Urnamma, as "king of Sumer and Akkad", was able to take control of the Gulf trade when Namhani was e $n \mathrm{~s}_{2}$ of Lagaš (Codex Urnamma 75-78). At that time Urnamma must have already been in control of Lagaš for some time, at least as early as the e $\mathrm{s} \mathrm{i}_{2}$-ship of Uraba, who, according to T. Madea's and S.F.

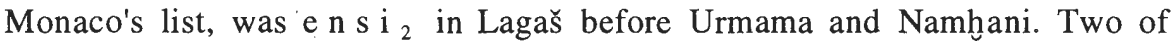
Urnamma's year names, ${ }^{37}$ " 4 " and " 8 ", possibly a third, namely "6", appear on tablets from Girsu together with the statement that Uraba was e $\mathrm{n} \mathrm{s} \mathrm{i}_{2}$ ( $R T C$ $261 / / 263 ; 264 ; 265)$. Nevertheless, the fact that the local Lagaš calendar was used in Ur until Sulgi's regnal year $30,{ }^{38}$ shows that the cultural effect of an earlier domination of Lagaš over Ur persisted into the Ur III period.

There is evidence for Gutian settlements around Ur III times in the south ${ }^{39}$ and some references to the conflict with the Guti in the texts pertaining to Urnamma ${ }^{40}$ and his successors. ${ }^{41}$ Urnamma might have been involved in military action while governor of Ur under his lord Utuhegal who claimed to have expelled the Guti under Tirigan in the vicinity of Umma and returned kingship to the control of Sumer. ${ }^{42}$ Urnamma credits himself alone with the Guti's complete defeat, perhaps to further

\footnotetext{
32 Urnamma 28, 1 (= Steible, FAOS 9/2 131) 10-13. The numbering of inscriptions of the Ur III kings follows Steible, FAOS 9/2 (1991) 93-317. The latest edition of Ur III inscriptions by Frayne, Royal Inscriptions of Mesopotamia, Early Periods (= RIME), vol. 3/2: Ur III Period (2II2-2004 B.C.), Toronto-Buffalo-London (1997) appeared too late to be used systematically.

33 For collected references for this canal dating from Ur III times and onward, cf. Sauren, ASJ 2 (1980) 147f., and fns. $57-60$.

34 Urnamma 29, b 1 (= Steible, FAOS 9/2 136) 10"-11". Note the recent reconstruction of Urnamma's stela by Canby, Expedition 29/1 (1987) 54-64.

35 Literally "tail", $\mathrm{k}$ u $\hat{\mathrm{g}}_{\mathrm{x}}$ zibbatu (in opposition to $\mathrm{k} \mathrm{a} . \mathrm{k}$ ) designates "the point where a river or canal joined another body of water - either the sea, a storage basin or another canal" (Frayne, AOS 74 [1992] 34).

36 Edzard, G. Farber, Rép. géogr. 2 (1974) 251 s.v., differentiate between a sea west and one east of Lagaš .

37 Due to the lack of a date list, the sequence of Urnamma's year names is still not definitively fixed (cf. Renner, BiOr. 44 [1987] 468 and recently Waetzoldt, N.A.B.U. 1990/6). In view of this, year numbers follow those in Sigrist, Gomi, Ur III Catalogue 319f. in quotation marks.

38 Sallaberger, Kalender 7 and Wilcke, "Politik und Literatur" 44; similarly already Sauren, ZDMG Suppl. I/1 (1969) 127f., fn. 41 .

39 Civil, Or. 54 (1985) 30, and fn. 5 with previous literature.

40 Civil, ibid. 27-32; Unamma C 90f., perhaps 57f. (the storm as a metaphor for the Guti?); Ni. 4375 iv $4^{\prime}-6^{*}$ :

41 Cf. Sjöberg, Studies Hallo (1993) 212 for references to the Guti in literary texts.

42 RIME 2.13.6.4.
} 
legitimise his new independence at Ur, or he might actually have had to face persistant attempts of Gutian intrusion throughout his rule which may have continued into his successor Sulgi's reign.

Much of the extent of the Ur III state at its height during the second part of Sulgi's reign ${ }^{43}$ had already been reached by Urnamma, for Urnamma had assumed the role played by Gudea (Stat. B 6:64-69) and earlier rulers of combating Babylonia's enemies to the north-east, Anšan and Awan/Elam, ${ }^{44}$ thereby laying the ground for fixing the empire's north-eastern boundary. Several documents bear on Urnamma's activities in the north-east: the so-called Cadaster text of Urnamma, in the form of two Old Babylonian copies from Nippur, copied from an original stela, ${ }^{45}$ delineates the four neighbouring districts of Kiritab, ${ }^{46}$ Apiak, [Uru]m ${ }^{47}$ and Marada ${ }^{48}$ which may be correlated to the area, mentioned in Codex Urnamma 12534 , in which the cities of Akšak, ${ }^{49}$ Marada, ĜIRkal, ${ }^{50}$ Kazallu and Ușarum lay, whose freedom from Anšan's control Urnamma establishes. Control over cities on the Kazallu canal downward was of strategic importance as they gave access to the water route to Ur in the south..$^{51}$ The status of the cities and territories mentioned in connection with a military conflict against Puzur/Kutik-Inšušinak of $\mathrm{Awan}^{52}$ is uncertain. They are Awal, Kismar and Maškanšarrum, and the $\mathrm{ma-da}$ "territories" Ešnuna, Tutub, Zimudar, Agade [...] (IB 1537 rev. 16'-23'). The first three cities are located in the Diyāla and Ǧebel Hamrīn basin and may have been first occupied by Puzur/Kutik-Inšušinak's troops ${ }^{53}$ before coming under control of the Ur III state. This area controlled the main access to Elam and thus the main Transtigridian trade routes ${ }^{54}$ and was in time fully incorporated into the Ur III state, for the military personnel of these cities are known to have paid tax, the so-called

\footnotetext{
43 Cf. Steinkeller, SAOC 46 (1987) 15-33 (especially p. 31); Maeda, ASJ 14 (1992) 135-72.

44 For Gudea's military conflict with the Elamites, cf. Vallat, N.A.B.U. 1997/37.

45 Edited by Kraus, ZA 51 (1955) 45-75; cf. also Steinkeller, JCS 32 (1980) 23-33; Edzard, RlA 6 (1980-83) 62 ad $\S 3.7$, s.v. "Königsinschriften, A. Sumerisch"; Frayne, BiOr. 48 (1991) 388 passim; idem, AOS 74 (1992) 22ff. [cf. now Frayne, RIME 3/2 (1997) 50-56 as RIME 3/2.1.1.21, including several stone fragments (PBS 15 28-30, 32, 33-39) which might come from the original stela].

46 For Kiritab, cf. the references in Römer, UF 21 (1989) 325 ad 1.

47 For the restoration, cf. Kraus, ZA 51 (1955) 62f. and especially Steinkeller, JCS 32 (1980) 25, and figure 1, p. 33 (a hypothetical reconstruction of the district of Urum).

48 For a reconstruction of the Ur III district of Marada, cf. Frayne, AOS 74 (1992) 51, map 5.

49 The reading Ak $̌$ ak instead of Umma (for Umma as a reading, cf. Yildiz, Or. 50 [1981] 87, and fn. 1, followed by e.g. Römer, TUAT I/1 [1982] 18, Frayne, AOS 74 [1992] 27, idem, RIME 3/2 [1997] 48:126, and Sallaberger in Attinger, Wäfler [eds.], Mesopotamien, Akkade-Zeit und Ur III-Zeit, Annäherungen 3, OBO XXX [in preparation]) was first proposed by Kramer, Or. 50 (1981) 455f., fn. 15, followed by Michalowski in Weiss (ed.), The Origins of Cities in Dry-Farming Syria and Mesopotamia (1986) 141, fn. 22, Steinkeller, SAOC 46 (1987) 15, fn. 1, and Wilcke in Hrouda (ed.), Isin-IŠān Baḥrīyāt III..., ABAW NF 94 (1987) 111. For the uncertain location of Akšak, cf. Frayne, AOS 74 (1992) 43 (map 4), 47f., and fn. 380 with previous literature.

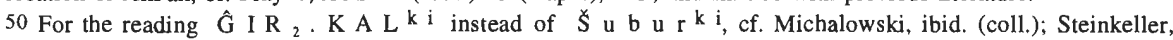
ibid., with reference to Michalowski; Wilcke, ibid.

51 Frayne, AOS 74 (1992) 26.

52 Cf. above, p. 2.

53 Glassner, OLZ 88 (1993) 382.

54 Steinkeller in Gibson (ed.), Uch Tepe 1: Tell Razuk, Tell Ahmed al-Mughir, Tell Ajamat, Kopenhagen (1981) 163-68; idem, JNES 41 (1982) 289 for the location of Maš kanšarrum.
} 
$\mathrm{g} \mathrm{u} \mathrm{n}_{2} \mathrm{~m} \mathrm{a-da}$ (attested from Sulgi's year 43 on). ${ }^{55}$ The region marked out by the above mentioned texts remained the main northern and north-eastern line of defences throughout the Ur III period. ${ }^{56}$

The territorial expansion climaxing under Urnamma's son Sulgi during the second part of his reign had thus already been set in motion by the father. We may also surmise that it was Urnamma who had laid the basis for economic, administrative and political reforms that were carried out under Sulgi and which led to a centralized ${ }^{57}$ bureaucratic state. Urnamma is known to have imposed the standardization of weights and measures within the borders of his state, initiated a "scribal reform",58 and, by excavation of numerous canals, Urnamma laid the foundation for a well functioning irrigation system and infrastructure. Unfortunately however, only a small amount of administrative tablets that date to his reign are available ${ }^{59}$ and as a result the beginnings of Ur III institutions which comprised the bureaucratic state under his successor Sulgi ${ }^{60}$ are still poorly understood. Hopefully future excavations may produce a significant batch of Urnamma texts that could add to our knowledge of his year names and reign.

Urnamma A, a literary composition of epic length and unique content, ${ }^{61}$ tells us of an evil that has come upon Ur and of Urnamma's premature death, the causes of which are kept in the dark. It may be that Urnamma actually faced military defeat, ${ }^{62}$ though at whose hands we do not know, ${ }^{63}$ or he may have died from an illness. He is simply returned to his capital where he dies and vanishes to the realm of the dead. After Urnamma's death, his son Sulgi succeeded him on the throne of Ur as legitimate heir.

\footnotetext{
55 Steinkeller, SAOC 46 (1987) $25 \mathrm{ff}$.

56 Cf. Maeda, ASJ 14 (1992) 135-72, especially 153-56; 161-63.

57 Opposed by Waetzoldt, JAOS 111 (1991) 638f. ad no. 10.

58 Waetzoldt, ibid. 638 ad nos 6-8.

59 Sigrist, Gomi, Ur III Catalogue 99.

$60 \mathrm{Cf}$. Steinkeller, SAOC 46 (1987) $16 \mathrm{ff}$.

61 Cf. below, II 1., p. $16 f$, and V 1.1, pp. $93 \mathrm{ff}$.

62 Apart from the very broken line 32 there is no mention of military action in Urnamma A. In line 58 k i $1 \mathrm{u} 1-1 \mathrm{a}$ is generally viewed as meaning "the place of treachery, slaughter" and thus taken as evidence that Urnamma died on the battlefield, but the philological commentary ad 58 in V 1.4, p. 169 argues that $\mathrm{k} \mathrm{i} \mathrm{-}$ l u 1 - 1 a may instead be the dwelling place of a "spirit (of a dead person)" ( $\mathrm{g} \mathrm{e} \mathrm{d} \mathrm{i} \mathrm{m}$ ) whose case has not yet been decided by Utu. Cf. also the commentary ad 168 for $\mathrm{n} \mathrm{i}_{2}-\mathrm{b}$ a in ibid., p. 177. The only passage that may mention an unnamed enemy demolishing Urnamma's palace is found in lines $47 \mathrm{f}$.

63 For Wilcke's surmise that it may have been the Guti, cf. the commentary ad 6-7 (with references) in V 1.4, p. 164.
} 


\section{The Reading of the Name (d) ur-dnamma}

Both elements of the name ( $\mathrm{d}$ ) $\mathrm{u} \mathrm{r}-\mathrm{d} \mathrm{n}$ a $\mathrm{m} \mathrm{m}$ a have been the subject of controversy regarding their correct reading. ${ }^{64}$ The reading of the first element U R as $\mathrm{u} r$, against $\mathrm{E}$. Sollberger's proposed reading $\mathrm{s} \mathrm{u} \mathrm{r}_{\mathrm{x}},{ }^{65}$ is very probable but not certain: the non-standard writing ${ }^{66} \mathrm{~s} \mathrm{i}-\mathrm{p}$ a $\mathrm{u} \mathrm{r}-\mathrm{d} \mathrm{n} \mathrm{a}-\mathrm{n} \mathrm{a}-\mathrm{m}$ a-k e (Urnamma B $53 ; 56 ; 60 ; 64 ; 68$, source B), instead of $\mathrm{s} \mathrm{i}-\mathrm{p}$ a $\mathrm{s} \mathrm{u}-\mathrm{u} \mathrm{r}-\mathrm{d} \mathrm{n}$ a $-\mathrm{n} \mathrm{a}-\mathrm{m} \mathrm{a}-$ $\mathrm{k}$ e, and the non-standard writing $\Gamma_{1} 1^{767}$ in the inscription Ur C $1=$ Sulgi 544 (= Gelb, Kienast, FAOS 7 [1990] 344) ${ }^{68}$ argue for / u r/. The reading of the second element $\mathrm{L}$ A G A B $\times$ H A L (E N G UR) is complex because attested spellings in both lexical texts and texts in non-standard orthography contradict each other. The conventional reading is $\mathrm{n} \mathrm{a} \mathrm{m} \mathrm{m} \mathrm{u}$, but more recently $\mathrm{M}$. Civil has argued for a reading $\mathrm{n} \mathrm{a} \mathrm{m} \mathrm{m} \mathrm{a.}{ }^{69}$ The following discussion presents the evidence which makes a reading $n$ a $m$ a in the name $U R$. d N A M M U preferable, and argues that $\mathrm{L} \mathrm{A} \mathrm{G} \mathrm{A} \mathrm{B} \times$ H A L (ENG UR) might originally be both a single and a reduplicated lexeme.

For L A G A B $\times$ H A L (E N G U R) the Old Babylonian lexical list ProtoEa 53 (=MSL 1433 ) gives the readings $\mathrm{n}$ a $-\mathrm{a} \mathrm{m}-\mathrm{m}$ a $(1 \times)$, $\mathrm{n}$ a $-\mathrm{m}$ a $(1 \times)$, and five manuscripts have - $\mathrm{m} u$ as final sign. The lexical list Ea 171 (=MSL 14 180) has $\mathrm{n} \mathrm{a}-\mathrm{a} \mathrm{m}-\mathrm{m} \mathrm{a}(1 \times)$ and $\mathrm{n}$ a $\mathrm{m}-\mathrm{m}$ u (2x) (cf. also Aa I/2 235, $\mathrm{n}$ a m $\mathrm{mu}$ ). Thus, the lexical evidence makes it difficult to decide if $\mathrm{n} \mathrm{am} \mathrm{m} \mathrm{u}$ or $\mathrm{n} \mathrm{a} \mathrm{m} \mathrm{m} \mathrm{a}$ is the original reading. In view of the non-standard writing $\mathrm{u} \mathrm{r}-\mathrm{d} \mathrm{n} \mathrm{a}-$

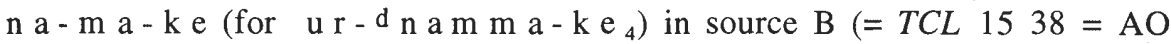
6316) of Urnamma B 53;56;60;64; 68 and the Akkadian ur-na-am-ma in the bilingual Ur C $1=$ Sulgi 546 the reading $/ \mathrm{n} \mathrm{am} \mathrm{ma/} \mathrm{in} \mathrm{the} \mathrm{name}$ $\mathrm{UR}$. d N A M M U is preferred here over / $\mathrm{n} \mathrm{a} \mathrm{m} \mathrm{m} \mathrm{u/.}$

Besides the non-standard writing of the name in source B of Urnamma B u r $\mathrm{d} \mathrm{n} \mathrm{a}-\mathrm{n} \mathrm{a}-\mathrm{m} \mathrm{a}-\mathrm{k}$ e, there is another non-standard writing in the bilingual Ur C 1 = Sulgi $544\ulcorner\mathrm{i} 1\urcorner-\mathrm{n}$ a $-\mathrm{a} \mathrm{m}-\mathrm{n}$ a $-\mathrm{a} \mathrm{m}-\mathrm{m}$ i, the Sumerian version's equivalent of the Akkadian version's ur-na-am-ma, mentioned above, $\mathrm{n} a-\mathrm{n}$ a-m a can be explained as $<\mathrm{na}(\mathrm{m})-\mathrm{nama}$ and $\mathrm{na}-\mathrm{am}-\mathrm{na}-\mathrm{am}-\mathrm{mi}$ as

\footnotetext{
64 For the first element u r, cf. Sjöberg, OrSuec 10 (1961) 7; Sollberger, RA 61 (1967) 69; W.G. Lambert, RA 75 (1981) 61f. and $R A 76$ (1982) 93f. (response to Steinkeller, $R A 74$ [1980] 178f.); Sollberger, $R A 79$ (1985) 87f. For the second element n a m m a, cf. Falkenstein, $S G L 1$ (1959) 89, fn. 5; Sjöberg, OrSuec 10 (1961) 7; Wilcke, CRRAI 19 (1974) 211 ad D.2. and fn. 28; Civil, Or. 54 (1985) 27, fn. 1; Jacobsen, Harps 155, fn. 5; Römer, BiOr. 49 (1992) 678 ad 198.

65 Sollberger, RA 61 (1967) 69.

66 For non-standard orthography in general, cf. II 3.2, pp. $23 \mathrm{ff}$.

67 Reading according to Conti, EVO 16 (1993) 87:4; 89, against ${ }^{\prime} \mathrm{u} \mathrm{r}_{2} \sqcap$ (also Sollberger, RA 79 [ 1985] 87f. maintains that the sign is not $\mathrm{u} \mathrm{r}_{2}$ ), with $\mathrm{i} / \mathrm{u}-$ and $1 / \mathrm{r}$ - alternation. Compare also v. Dijk, ActOr. 28 (1964) 9, fn. 13 who reads the sign in question as [ a ] 1 .

68 For this unusual inscription, cf., besides the standard editions in Kärki, StOr. 58 (1986) 59ff. and Gelb, Kienast, FAOS 7 (1990) 344ff., also Wilcke, CRRAI 19 (1974) 211, fn. 28, Steible, FAOS 9/2 (1991) 201 ad Sulgi 54 (bibliography), and most recently Conti, EVO 16 (1993) 87-96.

69 Civil, Or. 54 (1985) 27, fn. 1.
} 
$<\mathrm{nam}-\mathrm{n}$ am (i). This looks like $\{\mathrm{namma}+\mathrm{namma}\}$, an original reduplicated lexeme $* / \mathrm{n}$ am m a $\mathrm{m}$ m a/ which developed into > $* / \mathrm{n}$ a $\mathrm{m} \mathrm{amma} /$ and finally $>/ \mathrm{n}$ a $\mathrm{n}$ a a $/ 70$ according to the pattern / barbar/ > / babbar/. In the last stage, the $\mathrm{m}$ either assimilated to the following $\mathrm{n}$ or dropped out. ${ }^{71}$ A similar instance of a noun that is a reduplicated lexeme may be $\mathrm{K} \mathrm{A}_{2}$ "gate", for the non-standard writing $\mathrm{ka}$ - a $\hat{\mathrm{g}}_{2}-\mathrm{k} \mathrm{a}$ (a n ) in Manchester Tammuz 19 and 21 (// Dumuzi-Inana H rev. 4' and 6' which has $\mathrm{K} \mathrm{A}_{2}$ ) and the evidence from the lexical lists Proto-Ea 238 and Kagal I i 26 argue for a reading / $\mathrm{kank}$ an/ which reflects $\left\{\mathrm{ka} \mathrm{a}_{2}+\mathrm{k} \mathrm{a}_{2}\right\}$, next to / ( a ) k a n /. ${ }^{72}$ The reading / k a n k a n / for $\mathrm{K} \mathrm{A}_{2}$ is also attested for $\mathrm{g} \mathrm{e} \mathrm{s}$ $\mathrm{KA}_{2}-\mathrm{n} \mathrm{a}(-\mathrm{k})$ giškanakku "door-frame" for which compare the non-standard

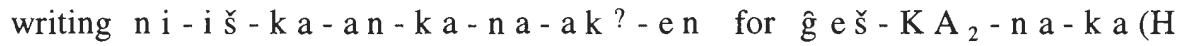
103 iv 15) in A. Cavigneaux, F. Al-Rawi, Iraq 55 (1993) 94.

This shows that we may have to postulate for the sign $\mathrm{L} \mathrm{A} \mathrm{G} \mathrm{A} \mathrm{B} \times \mathrm{HAL}$ ( $E N G U R$ ) both a single and a reduplicated lexeme. In summary, the reading of the name UR.d NAM M U cannot be established with certainty, but the comments made above argue for / u r $\mathrm{n}$ a $\mathrm{n}$ a m a / or / u r n a m m a / rather than / u r nam m $/$ or / $\mathrm{surnam} \mathrm{mu/.} \mathrm{The} \mathrm{reading} \mathrm{/} \mathrm{nam} \mathrm{ma/,} \mathrm{instead}$ of / $\mathrm{n}$ a $\mathrm{n} \mathrm{a} \mathrm{m} \mathrm{a/,} \mathrm{is} \mathrm{maintained} \mathrm{in} \mathrm{this} \mathrm{study} \mathrm{because} \mathrm{it} \mathrm{is} \mathrm{a} \mathrm{conventional} \mathrm{reading.}$

\section{Sumerian Royal Hymns}

Sumerian royal hymns, which have come down to us almost exclusively in copies of the Old Babylonian scribal schools, go back at least to Gudea of Lagaš (ca. 2100 B.C.) and span a time period of something like four hundred years (ca. 2100-1700 B.C.), from the Ur III period to the first dynasty of Babylon, that is the Old Babylonian period. The finest examples of royal hymns come from the Ur III (2100-2000 B.C.) and the succeeding Isin-Larsa periods (2000-1750 B.C.). ${ }^{73}$ Aside from the hymn Gudea A, which makes reference to Gudea of Lagaš, the hymns pertaining to Urnamma present the earliest stream of royal hymnic tradition culminating in the hymns of his son and successor Sulgi (2093-2046 B.C.) whose literary themes are still apparent in the hymns of the Isin-Larsa kings. It is to the Sulgi hymns and the hymns of the Isin kings that scholars have paid most attention in their studies of Sumerian hymnography. These hymns have been the subject of many articles and monographs. W.H.Ph. Römer, whose monumental work Sumerische 'Königshymnen' der Isin-Zeit (1965) gave a comprehensive overview of the Isin hymns, presented a classification based on A. Falkenstein's earlier attempts and edited a representative selection of them. A recent study,

\footnotetext{
70 Cavigneaux and Al-Rawi in ZA 83 (1993) 174, fn. 7 apparently reach the same conclusions regarding the reading of $\mathrm{ENGUR}$ as / $\mathrm{n}$ a $\mathrm{n}$ a $\mathrm{m}$ a /, without supplying any arguments.

71 For a very different interpretation, cf. Jacobsen, Harps 155, fn. 5; Compare also W.G. Lambert, Studies Birot (1986) 186.

72 Cf. Attinger, $Z A 85$ (1995) 135, fn. 33.

73 For an extensive bibliography of Ur III, Isin and OB royal hymns, cf. Klein, ThŠH 226-34.
} 
focusing on the Isin ruler Išmedagān, was undertaken by M.-C. Ludwig in Untersuchungen zu den Hymnen des Išme-Dagan von Isin (1990). But it is undoubtedly J. Klein who should be most credited for the progress in Sumerian hymnography. Many monographs and articles bear witness to his laborious task of studying and comparing royal hymns with each other to elucidate their literary dependence, their stylistic features, and their orthographical and grammatical peculiarities. These studies have been done mainly within the framework of his project of editing the numerous hymns of Sulgi and which in some cases served as literary models on which the Isin kings, especially Išmedagān, composed their hymns. ${ }^{74}$

With the exception of Urnamma G, all Urnamma hymns have been previously treated by others. Standard editions include those of J. Klein for Urnamma B ${ }^{75}$ and of M. E. Cohen for Urnamma EF. ${ }^{76}$ The edition of Urnamma C by G. Castellino has become outdated. ${ }^{77}$ Most recently S.N. Kramer presented a composite text of Urnamma A without, however, including a score of individual text sources and without the composition's version from Susa. ${ }^{78}$ W.W. Hallo's edition of Urnamma $\mathrm{D}$ lacks a philological commentary and a detailed comparison of the two recensions from Nippur and Ur. ${ }^{79}$ This study therefore presents in Chapter V new editions of the Urnamma hymns, incorporating previously known and new duplicates. It endeavours to follow the same direction taken by J. Klein, and to some degree also by W.H.Ph. Römer and M.-C. Ludwig, in their various editions of royal hymns. Chapter II offers a general survey of the hymns including a typology, which recapitulates the attempts in that area made first by A. Falkenstein and followed by W.H.Ph. Römer, J. Klein and M.-C. Ludwig, and argues for a broader definition of the royal hymns (1.), a catalogue of the hymns (2.), a discussion of the orthography, including an attempt at classifying the non-standard orthography (3.) and glosses (4.), as J. Klein has done for the Sulgi hymns. Chapter III evaluates and expands on the findings which D.R. Frayne presented in The Historical Correlations of the Sumerian Royal Hymns (2400-1900 B.C.), Ph.D. dissertation, Yale University (1981) with regard to Urnamma and thus presents an overview of Urnamma's endeavours during his reign based on his royal inscriptions, year names, the Cadaster text, the prologue of his law code, and his hymns. A first section (1.) shows that the picture of Urnamma and his deeds in the hymns correlates well with what is reported in the other textual sources pertaining to him, thus corroborating W.W. Hallo and D.R. Frayne's theory that events narrated in literary compositions may be correlated with events known from sources such as year names and royal inscriptions. A following section (2.), however, illustrates that contrary to D.R. Frayne's theory, self-laudatory hymns such as Urnamma $C$ do not have a chronological order which follows the sequence of year names. Chapter IV is

\footnotetext{
74 For comparative studies in particular, cf. e.g. Klein, ASJ 11 (1989) 27-62; idem, Studies Artzi (1990) 65-136; in general, idem, Studies Sjöberg (1989) 289-301.

75 Klein, ASJ 11 (1989) 44-56; 61f. (footnotes).

76 Cohen, JAOS 95 (1975) 596-600.

77 Castellino, ZA 53 (1959) 118-31.

78 Kramer, Studies Mikasa (1991) 193-214.

79 Hallo, JCS 20 (1966) 133-41.
} 
devoted to aspects of continuity and change in royal hymnography by analysing the Urnamma hymns in relation to other royal hymns and related genres. A first section (1.) concentrates on aspects of legitimacy and kingship. It gives reasons why the Sumerian King List may well have been first compiled in Urnamma's reign (1.1), and discusses topoi of legitimation and kingship (1.2), Urnamma's royal titles and epithets (1.3), and Enlil's outstanding role in Urnamma's kingship (1.4). It can also be shown (2.) that Išmedagān's self-laudatory hymn A contains passages directly borrowed from Urnamma C, indicating that Išmedagān was not only an imitator of Sulgi but also of Urnamma. The discussion of topoi of legitimation and kingship, and narrative material describing royal achievements (1.2 and 3.1), show much continuity from Pre-Sargonic to Isin-Larsa times, but appear in different text types in different periods. The fact that during the Lagaš II, Ur III and Isin-Larsa periods they are attested in royal hymns as well as in statue and stela inscriptions, shows a close affinity between the two text types. In addition to other findings concerning statues, stelas, and royal hymns presented in another section (3.2), this bolsters in general W.W. Hallo's thesis that royal hymns were originally inscribed on stelas and statues. On the other hand section (3.2) also restricts W.W. Hallo's thesis insofar as it argues for the possibility that during the transmission of royal hymns on monuments to copies thereof, the Old Babylonian scribes in fact adapted the texts in many instances, rather than copying the texts on stelas and statues verbatim. In the Larsa period, royal inscriptions which encompass statue and stela inscriptions and inscriptions inscribed on smaller artefacts, such as cones, bricks, etc. are given such a strong literary flavour that they are often congruent with hymns of the same period. A study of Urnamma D illustrates that hymns praising a deity may have been adapted to royal hymns in which the praise is centered on the king instead (3.1). The final section (3.3) presents a comparison between Urnamma A, which describes the king's death and its consequences, and lamentation literature, which includes laments over the distant god or person, and city laments. It shows how Urnamma A uses the language of lamentation literature and the Curse of Agade which describe the destruction of cities, by applying them to the death of a king.

This study and the text editions that form its core show that the use of royal hymns, first evident in Lagaš II, was reinforced under Urnamma both formally and functionally in the same manner that would continue throughout the Third Dynasty of Ur and in the centuries following. 


\section{CHAPTER II}

\section{A General SURVEY OF THE URNAMMA H Y M N S}

\section{Typology}

The basis for the study of Sumerian hymnography was laid in the first postwar decades by A. Falkenstein in articles and monographs in which he presented editions of hymns and an attempt at their classification. Subsequent years have seen considerable progress in this field with the appearance of many more editions of Sumerian hymns. Hymns are "songs" of praise, and depending on what the object of praise is, we generally speak of divine hymns praising a deity, royal hymns praising a king, temple (and city) hymns praising a temple and/or a city (e.g. Išmedagān $\mathrm{W}_{\mathrm{A}}$ ), and hymns praising objects like a hoe (Creation of the Hoe), a chariot (Išmedagān I), or a boat (Sulgi R). ${ }^{1}$ The inadequacy of this simple categorization ${ }^{2}$ is readily apparent: all these categories or types of hymns do not exclude each other, for temple hymns naturally encompass the praise of the deity to whom the temple is dedicated, and divine hymns very often praise an anonymous or named king. Also, many hymns of the Ur III and Old Babylonian periods praise the king as a deity, a custom connected with the practice of deifying kings at that time. ${ }^{3}$ The so-called Dumuzi texts, for example, portray the king as Inana's divine lover. It is evident that these hymns are really royal and divine at the same time and a division is therefore often made more on practical than formal grounds. ${ }^{4} \mathrm{~A}$ case in point is source A of Išmedagān J. In one line it substitutes Dumuzi's name with that of the king. ${ }^{5}$ The last decades have seen much work on the royal hymns in particular, with the publication of W.H.Ph. Römer's Sumerische 'Königshymnen' der Isin-Zeit (1965), J. Klein's Three Šulgi Hymns (1981), his monograph on the royal hymns of Sulgi ${ }^{6}$ as well as many other articles, and most recently M.-C. Ludwig's Untersuchungen zu den Hymnen des Išme-Dagan von Isin (1990).

\footnotetext{
1 Edzard, $O B O 131$ (1994) 21f.; Klein, $T h S_{H} H$ 21f., and fns. 3ff., divides Sumerian hymns into the three categories of divine, royal and temple hymns.

$2 \mathrm{Cf}$. also Tinney, OLZ 90 (1995) 6.

3 Klein, $T h \grave{S H}$ 29-36.

4 Cf. Edzard, $O B O 131$ (1994) 21.

5 Cf. Römer, $S K I Z$ 22:24 and Hallo, BiOr. 23 (1966) 244, fn. 51, and 245:34.

6 Klein, TAPS 71/7 (1981) 1-48.
} 
W.H.Ph. Römer refined A. Falkenstein's classification of the royal hymns, and he was followed by J. Klein and M.-C. Ludwig in their above mentioned studies. W.H.Ph. Römer classified hymns that are addressed to a deity but contain a petition and blessing for a king as royal hymns type $\mathrm{A}$, in contrast to the royal hymns proper (type B) in which the praise is centered on the king himself, either in 2nd and 3rd person (type B. I), or in 1st person (type B. II). ${ }^{7}$ The earliest known type A hymn that fits this definition is Gudea $\mathrm{A}$, a $\mathrm{t} \mathrm{i} \mathrm{g}$ i of Ba'u mentioning Gudea of Lagaš (STVC 36). ${ }^{8}$ It is usually maintained that type A hymns contain rubrics marking subdivisions within the composition, and end with a subscript, either

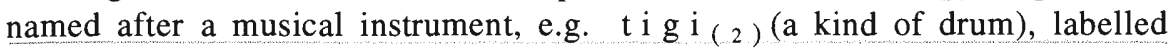

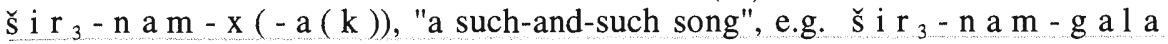
("g a 1 a-ship song"), or designated b a 1 - b a 1 - e, a term whose meaning is still obscure. ${ }^{9}$ Type $\mathrm{B}$ hymns often end with a $\mathrm{z} \mathrm{a}_{3}-\mathrm{m} \mathrm{i}_{2}$ doxology ${ }^{10}$ which is mistakenly considered by W.W. Hallo (and others) as having almost "generic force". ${ }^{11}$ In fact a formal division into hymns with either rubrics and subscripts (type A), or $\mathrm{z} \mathrm{a}_{3}-\mathrm{m} \mathrm{i}_{2}$ doxologies (type B) is often not possible, ${ }^{12}$ as some contain both. ${ }^{13}$ Also, the hymns Išmedagān $\mathrm{K}, \mathrm{T},\left(\mathrm{W}_{\mathrm{A}}+\right) \mathrm{W}_{\mathrm{B}}+\mathrm{W}_{\mathrm{C}},{ }^{14}$ and $\mathrm{AC}^{15}$ all sharing the concluding "punchline" $d i \check{s}-m e-d a-g a n-\mathrm{m} \mathrm{e}-\mathrm{e} \mathrm{n} \quad \mathrm{du}-\mathrm{r} \mathrm{i}_{2}-\check{\mathrm{s}}_{3} \quad \mathrm{k} \mathrm{a}-$ $\mathrm{k} \mathrm{a} \mathrm{m} \mathrm{u}-\mathrm{n} \mathrm{i}-\mathrm{g}$ a r, focus exclusively on the praise of a deity and should therefore be categorized as type A hymns but have no rubrics at all. Finally, some hymns with rubrics which should consequently belong to type A really belong to type $\mathrm{B}$ because they almost exclusively praise the king and his deeds, and not a deity. ${ }^{16}$

The Urnamma hymns which, aside from the just mentioned Gudea hymn, represent the earliest stream of royal hymnic tradition, illustrate this point: together with some of Sulgi's hymns ${ }^{17}$ they do not fit the traditional classification of royal hymns of type A and B thereby showing that these standard definitions, almost exclusively based on the Isin(-Larsa) material that A. Falkenstein and especially W.H.Ph. Römer have worked on, are inadequate for the classification of the entire

\footnotetext{
7 Römer, SKIZ 5f.

8 Cf. Falkenstein's translation of the text in $S A H G$ 85-87 (no. 16).

9 Ludwig, Išme-Dagan 29, and fn. 18 with previous literature; also Sefati, Studies Artzi (1990) 50.

10 Edzard, $O B O 131$ (1994) 20f. with previous literature.

11 Hallo, BiOr. 23 (1966) 240, and 241 ad 5.

12 Cf, e.g. Reisman, AOAT 25 (1976) 357.

13 Cf. Cooper, AnOr. 52 (1978) 4, fn. 8; Ludwig, Išme-Dagan 34, and fn. 41. Also Ninĝeš zida A rev. 4'-5' [ e ] n d n in-ge $[\check{s}-z] \mathrm{i}-\mathrm{da}\left[\mathrm{za}_{3}-\mathrm{mi}_{2}\right]-\mathrm{zu}_{\mathrm{a}} \mathrm{du}_{10}-\left[\mathrm{ga}\left(-\mathrm{a}_{3}\right)\right] \quad$ b a $1-$ b a $1-\mathrm{e}[\mathrm{d} \mathrm{n}$ i n-g e š $-\mathrm{zi}-\mathrm{d}] \mathrm{a}-\mathrm{k}$ a; CBS 10220+// (= Sjöberg, JCS 34 68) iv 12-13 (partially broken). UET 6101 (= Steible, Haja 5-16) adds to the $\mathrm{z} \mathrm{a}_{3}-\mathrm{m} \mathrm{i}_{2}$ doxology the $\mathrm{g}$ e š g e $\mathrm{g}$ a 1 and / u r u / - b i sections (for the / u r u / - b i section, cf. in general, Ludwig, Išme-Dagan 32, and fn. 32). Note in addition that Iš medagān $\mathrm{AB}$ contains rubrics and ends with a $\mathrm{z} \mathrm{a}_{3}-\mathrm{m} \mathrm{i}{ }_{2}$ doxology; also Iddindagān $\mathrm{A}$ (= Inana and Iddindagān) has rubrics and $\mathrm{a}_{\mathrm{z}} \mathrm{a}_{3}-\mathrm{m} \mathrm{i}_{2}$ doxology near the end (line 220).

14 For the problematical reconstruction of Išmedagăn W, cf. Ludwig, Išme-Dagan 93-95 and now Tinney, OLZ 90 (1995) 14-17.

15 Cf. Tinney, ibid. $15 ; 18-20$.

$16 \mathrm{Cf}$. below, p. 14f. for examples.

17 Cf. below, p. 14.
} 
corpus of Sumerian royal hymns. ${ }^{18}$ The Isin(-Larsa) hymnic corpus contains a very high proportion of $\mathrm{a} \mathrm{d} a \mathrm{~b}$ compositions forming the core of hymns that belong to type $\mathrm{A}$ and whose content consequently gave rise to its narrow definition. ${ }^{19}$ These $\mathrm{a} \mathrm{d}$ a b compositions, to which we can add Ur III hymns like Sulgi U and Ibbīsu'en $C,{ }^{20}$ usually follow a well-formed structure praising a deity, but contain a petition and blessing for the king which always appear in the $\mathrm{g}$ e š g e $\mathrm{g}$ a $l$ and / u r u / - b i sections. ${ }^{21}$ However, such a narrow definition hardly applies to every $\mathrm{ad} \mathrm{a} \mathrm{b}$ composition or to hymns with other subscripts, and this is especially true of the Urnamma and some Sulgi hymns: Sulgi G is an a d a b hymn which is not primarily concerned with Enlil in whose praise the hymn is sung, but really with king Sulgi's birth and his subsequent investiture. Likewise, URNAMMA B, a $\mathrm{t}$ i g i of Enlil, which according to its subscript should be considered a type A hymn, is really a type B. I hymn and has hardly any praise of Enlil. Instead it narrates Urnamma's divine selection and his building of the Ekur in the first section ( $\mathrm{s} \mathrm{a} \mathrm{i} \mathrm{da}$ ), and continues by praising him in 3rd person in the following $\mathrm{s}$ a g a r a section. ${ }^{22}$ Similarly, Sulgi $\mathrm{R}$, a t i g i or a dab of Ninlil, ${ }^{23}$ and Išmedagān I, a t i g i of Enlil,,$^{24}$ addressed to the boat and chariot respectively, whose construction and dedication the hymns narrate, end with a petition for the king who commissioned their construction. In content Urnamma B, Sulgi R, and Išmedagān I in fact resemble the building reports of Gudea found on his cylinders and on some statues which the scribes put into a hymnic form for liturgical use. URNAMMA EF, a š i r $\mathrm{n}$ a m š u b of Nanna, is unique among š i r n a m š u b compositions because the king is named and figures prominently in it. This is not the case in other š i r n a m š u b compositions, which focus more on the deity and his or her deeds. Urnamma EF praises Urnamma, not Nanna, in the 2nd and 3rd person and therefore fits the definition of a type B. I hymn. Thus compositions with a "liturgical" subscript do not always address a deity and primarily praise his or her deeds, but were also composed to praise a king's deeds.

Just as the accepted distinction between types A and B can no longer be upheld for the whole Sumerian royal hymnic corpus, so too must previous characterization of the type $\mathrm{B}$ hymns be modified. URNAMMA $\mathrm{D}$ ends with a $\mathrm{z} \mathrm{a}_{3}-\mathrm{m} \mathrm{i}_{2}$ doxology in the 2nd person and would therefore be a type B. I hymn, but the main and longest section of the composition (Nippur lines 7-36 || Ur lines 10'-37') is in

\footnotetext{
18 Wilcke, however, assumes that the early stream of royal hymnic tradition represented by Urnamma's and Sulgi's corpus had not yet developed a well-formed formal and contextual structure apparent in the hymns of their Ur III and Isin-Larsa successors (Kindlers Literatur Lexikon im dtv, Band 10 [1986] 9099, s.v. "Sumerische Königshymnen").

19 Cf. Hallo's listing in BiOr. 23 (1966) 240, and 241, fn. 16, Wilcke's in AS 20 (1975) 266-73, and Klein's in ThŠH 227-33.

20 Edition in Sjöberg, OrSuec 19-20 (1970-71) 147-49 (no. 4), 166-70 (commentary).

21 Cf. Falkenstein, ZA 49 (1950) 87ff.; especially 97ff. for the ĝ e š g e g a 1 and / u r u / - b i sections.

22 For these rubrics, cf. Ludwig, ISme-Dagan 30; with Wilcke, AS 20 (1975) 259f., possibly musical terms or annotations; also Kilmer, CRRAI 35 (1992) 104ff., Černy, ArOr. 62 (1994) 25, and most recently Kilmer, RlA 8 (1995) 471 ad $\$ 4.2$., s.v. "Musik A. I.".

23 Cf. Klein, Studies Artzi (1990) 80.

24 For a possible literary dependence of Iš medagān I on Sulgi R, cf. Klein, Studies Artzi (1990) 68ff.
} 
direct speech (i.e. type B. II) letting the king describe his election and praise his irrigation projects for his city Ur. The hymn further displays a symmetrical structure of repetitious parallelisms lacking in both B. I and II type hymns ${ }^{25}$ but which are common in b al b a le compositions, ${ }^{26}$ a type of hymn which normally has no rubrics, ${ }^{27}$ just as B. I and II type hymns. In fact, the Nippur version of Urnamma D shares lines 25-30 with a b a l b a l e of Nanna ${ }^{28}$ so that Urnamma $D$ might be an adaption of $\mathrm{a}$ b a $1 \mathrm{~b}$ a $1 \mathrm{e}$ composition, generally considered as a type A hymn. ${ }^{29}$ URNAMMA C seems to be the earliest example hitherto known for a type B. II hymn which we find more fully developed under Urnamma's successor Sulgi ${ }^{30}$ and the Isin kings Išmedagān and Lipiteštar. ${ }^{31}$ Such hymns contain a king's self-praise including mention of his divine genealogy, special endowments by the gods, and his achievements and deeds for the gods. Urnamma $\mathrm{C}$ shows a very similar structure to Nungal, ${ }^{32}$ a divine hymn, with which it shares a $\mathrm{z} \mathrm{a}_{3}-\mathrm{m} \mathrm{i}_{2}$ doxology. ${ }^{33}$ So in fact many Urnamma hymns resemble hymns of the same types to deities. This finding, and the occasional archaic spellings in the Urnamma hymns which substantiate the assumption that they originated in Urnamma's times, ${ }^{34}$ support the notion that many of the divine hymns we know from Old Babylonian manuscripts are modernized versions of genuine Ur III originals.

The findings outlined above show then that the classification of the royal hymns, first attempted by A. Falkenstein and followed by W.H.Ph. Römer, J. Klein, and M.-C. Ludwig, cannot be fully applied to the Urnamma hymns and only to a lesser degree to Sulgi's. It also shows how difficult it is to find appropriate criteria which enable a categorization. Attempts on neither formal nor contextual grounds are wholly satisfactory: rubrics, subscripts (type $A$ ) and $\mathrm{z} \mathrm{a}_{3}-\mathrm{m} \mathrm{i}_{2}$ doxologies (type B) do not exclude each other, nor do we yet fully understand the

25 Pace Hallo, BiOr. 23 (1966) 241 ad 5.

26 E.g. URNAMMA G. Other examples of $\mathrm{b}$ a $1 \mathrm{~b}$ a $1 \mathrm{e}$ compositions with a symmetrical structure of repetitious parallelisms are "love song" b a 1 b a 1 e s of Inana in dialogue form, and Ning ešzida A. Note that Urnamma G is so far the sole example of $\mathrm{a}$ b a $1 \mathrm{~b}$ a 1 e to Enlil, with $\mathrm{b}$ a $1 \mathrm{~b}$ a 1 e $\mathrm{s}$ to Inana, almost exclusively in "sacred marriage" context, overwhelmingly first in number and Nanna a distant second (cf. Wilcke, AS 20 [1975] 274-77).

27 Cf. Wilcke, AS 20 (1975) 274-80. Three certain exceptions so far are Išmedagān E (= Sjöberg, OrSuec 23-24 [1974-75] 166f.) and TMH NF 47 iii 107- iv 168 (= J. Westenholz, Studies Sjöberg [1989] 552-55), which have a $\hat{\mathrm{g}}$ e $\mathrm{s} \mathrm{g}$ e $\hat{\mathrm{g}}$ a 1 section before the subscript, and Dumuzi-Inana C (= Alster, $R A 79$ [ 1985] 146-52), which has a $\hat{\mathrm{g}}$ e $\breve{\mathrm{g}} \mathrm{g}$ e $\hat{\mathrm{g}}$ a 1 section after the subscript.

28 TMH NF 47 iv 190-95 // (cf. Hall, Moon-God 779f.).

$29 \mathrm{Cf}$. in detail IV 3.1 , p. $74 \mathrm{ff}$.

30 Sulgi B, C (doxology missing), E, probably Y (doxology missing), and a self-laudatory Sulgi hymn fragment (N $3130+3131$ ) published by Klein, Studies Hallo (1993) 124-31. Sulgi A may also have to be considered a type B. II hymn, rather than a hymnic epic (cf. below) because it is entirely written in 1st person with the exception of the "doxology" at the end (lines 95-102), cf. also Wilcke, RlA 4 (1972-75) 540 ad $\& 3.5$., s.v. "Hymne, A. Nach sumerischen Quellen".

31 Išmedagān A (doxology missing), Lipiteštar A.

32 Cf. Attinger, Eléments 51 s.v. "Nungal" for references to the edition and subsequent additions. An additional partial translation and commentary is now at hand in Civil, Studies Hallo (1993) 72-78.

$33 \mathrm{Cf}$. in detail IV 3.1, p. 73.

34 Cf. below, 3.1 , p. $22 f$. 
meaning of and exact reason for setting rubrics, so these formal criteria cannot be used in a satisfactory manner to construct a system of categorization. Likewise, a classification on the basis of context is difficult because it is often not evident why the ancient scribes should have assigned certain compositions with such diverse content to the same "genre". ${ }^{35}$ Especially type A needs a broader definition to include hymns with an initial address to a deity or an object ${ }^{36}$ followed by the praise of the king as its core.

URNAMMA A, also known as "Urnamma's Death", is unique within the corpus of literary Sumerian compositions, insofar as it honours a king posthumously and tells of his actual death. The core of the composition is made up of laments, some in direct speech, as those of Urnamma himself and Inana, Urnamma's divine lover. ${ }^{37}$ The overall lamenting tenor of this composition is reflected in the two last lines

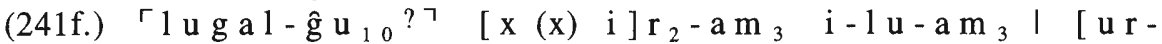

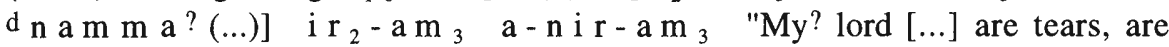
wails! [Urnamma? (..)] are tears, are laments!". ${ }^{38}$ The composition's proximity to lamentation literature can be demonstrated by comparing Urnamma A with lamentation literature in general..$^{39}$ It shows that the author of Urnamma A utilized the same language as lamentation literature and the Curse of Agade. However, Urnamma A lacks the $\mathrm{k}$ i r u g u sections known in all the major lamentations, which indicate their liturgical use. The only other compositions that can be compared as a whole with Urnamma $\mathrm{A}^{40}$ are the Two Elegies which are made up, following an introductory narrative section, of dirges by Ludigira over his father $\mathrm{d}_{\mathrm{n}} \mathrm{a} \mathrm{n} \mathrm{n}$ - a and his wife Nawirtum. The second dirge ends in $\mathrm{i}-1 \mathrm{u}-\mathrm{z} \mathrm{u}$ [ $\mathrm{g} \mathrm{i}] \mathrm{g}-\mathrm{g} \mathrm{a}-\mathrm{a} \mathrm{m}_{3}$ "your dirge is bitter!" which is comparable to the ending of Urnamma A. ${ }^{41}$ Some passages of Urnamma A are reminiscent in content and form of the Death of Gilgameš, another composition which deals with the death of a king, ${ }^{42}$ despite major differences. ${ }^{43}$ On the other hand, Urnamma A undeniably shows traits that characterize the so-called "hymnic epics", a term coined by J. Klein to translate C. Wilcke's "Königsepen". ${ }^{44}$ These compositions consist of a narrative or narrative sections with epic traits centring around the king and including passages in direct speech. Examples of hymnic epics are Sulgi D, whose

\footnotetext{
35 Cf. Michalowski, JCS 39 (1987) 40f.

$36 \mathrm{Cf}$. Iš medagān I; Sulgi R, mentioned above, and hymns with an introductory address to a city or temple

37 Cf. also V 1.1, p. 93

$38 \mathrm{Cf}$. also ibid., p. $93 \mathrm{f}$.

39 Cf. IV 3.3 , pp. $85 \mathrm{ff}$.

40 Cf. Wilcke, UT 48-50.

41 A b a 1 b a 1 e of Nanna, TMH NF 47 ii 67- iii 106 (= J. Westenholz, Studies Sjöberg [1989] 550-52, and fn. 52 with previous literature), whose last line before the subscript has a parallel structure (line 105 ${ }^{\mathrm{d}} \mathrm{n}$ a n n a $\left.-\hat{\mathrm{g}}\left[\mathrm{u}_{10}{ }^{\text {? }} \mathrm{i}-\mathrm{lu}\right]-\mathrm{zu} \quad \mathrm{ze}_{2}-\mathrm{b} \mathrm{a}-\mathrm{a} \mathrm{m}_{3} \mathrm{i}-1 \mathrm{u} \quad \mathrm{s}_{3}-\mathrm{a} \mathrm{b}-[\mathrm{ma}-\mathrm{k} \mathrm{a} \mathrm{m}]\right)$ shows that these kind of endings cannot be considered as a generic designation.

42 For a nearly complete non-Nippur version from Meturan/Tell Haddād of the composition, cf. in general Cavigneaux, Al-Rawi, Iraq 55 (1993) 93.

43 Wilcke, UT 27f. with previous literature.

$44 \mathrm{Cf}$. the bibliography in Ludwig, Išme-Dagan 33, fns. $37 \mathrm{f}$.
} 
conclusion is thought to be Sulgi $\mathrm{X}$, Sulgi F, and Sulgi P. ${ }^{45}$ Sulgi D $+\mathrm{X}$ and F share with Urnamma $\mathrm{A}$ the same $\mathrm{z} \mathrm{a}_{3}-\mathrm{m} \mathrm{i}_{2}$ doxology, preceded by a hymnic epilogue.

\section{Catalogue}

There are at least eight separate literary compositions which can be assigned to Urnamma. With the exception of hymns $\mathrm{E}, \mathrm{G}$ and $\mathrm{H}$, whose beginning and/or end are broken off, every hymn is more or less preserved in its entirety. They have come down to us in Old Babylonian copies (ca. 1800 B.C.) but are, like the hymns of Urnamma's son and successor Sulgi, almost certainly genuine Ur III (ca. 2100 B.C.) compositions. ${ }^{46}$ The assumption that the Urnamma hymns are genuine documents of that king's time is based on the occasional archaic spellings that some of his hymns preserve and on the correlations between the hymns and events of Urnamma's reign, as proposed by D.R. Frayne in his dissertation The Historical Correlations of the Sumerian Royal Hymns (1981). Corroboration also comes from one fragmentary manuscript (source D) of Urnamma B which very likely dates to Ur III. ${ }^{47}$ In any case, it is unlikely that Urnamma's hymns would have been composed after Ur III, with the one possible exception of Urnamma A, which was composed just after his death, in all likelihood by the same scribes that composed his hymns when he was alive. The manuscripts of the Urnamma hymns are mostly from Nippur, but there are also tablets from Ur (Urnamma D), Babylon (Urnamma B), Lagaš (Urnamma E), possibly Sippar (Urnamma F) and Susa (Urnamma A). Both Urnamma D and EF appear in catalogues from Nippur; Urnamma D was also known in Uruk. ${ }^{48}$

An additional fragmentary piece, ISET 1 (1969/71) p. 177 (no. 119), Ni. $4375,{ }^{49}$ case-ruled, in short-line format ${ }^{50}$ and therefore originally probably inscribed on a stela, could be part of a self-laudatory hymn of Urnamma, as S.N. Kramer and

\footnotetext{
45 For Sulgi A, a borderline case between a hymnic epic and a self-laudatory hymn (type B. II hymn), cf. above, p. 15 , fn. 30 .

46 Indeed, most Sumerian compositions are only known from Old Babylonian copies. For the very few known original Ur III literary texts, cf. Sallaberger, "Urkunden aus der Zeit der Dritten Dynastie von Ur, eine Einführung", in Attinger, Wäfler (eds.), Mesopotamien, Akkade-Zeit und Ur III-Zeit, Annäherungen 3, OBO XXX (in preparation).

${ }^{47}$ Cf. now also the Ur III text mentioning Urnamma published by Civil, AulOr. 14 (1996) 163-67. The article appeared too late to be fully incorporated into this study.

48 Catalogues CBS 8086 (an inventory of tablets) in Michalowski, OA 19 (1980) 265-68, and STVC 41 rev.? in Hallo, StOr. $46=$ Studies A. Salonen (1975) 77-80. The "Yale Catalogue" YBC 3654 published by Hallo, JAOS 83 (1963) 167-76, which most probably registers the opening line of the second $\mathrm{k} \mathrm{i} \mathrm{rug} \mathrm{u}$ section of Urnamma EF, is of unknown provenance. The fragment published by Cavigneaux in AUWE 23 (1996) 45 as no. 83, containing the Urnamma D incipit, may be a letter partly in Akkadian containing ritual instructions. What is left of the reverse may be an enumeration of Sumerian incipits (cf. Cavigneaux, ibid. 45).

49 For a transliteration of the major parts of Ni. 4375, cf. Frayne, Correlations $82 \mathrm{ff}$. (subsequently in BiOr. 42 [1985] 16-17). [Cf. now the edition in Frayne, RIME 3/2 (1997) 20f. as RIME 3/2.1.1.1].

50 For a classification of this type of line format into groups, cf. now Tinney, OLZ 90 (1995) $9 \mathrm{ff}$.
} 
J. Klein surmise,$^{51}$ rather than a copy of a royal inscription of a narrative nature which might, according to M. Civil,,$^{52}$ be part of another copy of a royal inscription on the cylinder fragment $6 \mathrm{~N}-\mathrm{T} 908 \mathrm{a}(+),{ }^{53}$ because Ur III and early Isin royal inscriptions are generally composed in the 3 rd and not in the 1 st person. ${ }^{54}$

The sigla for the individual hymns follow those of $\mathrm{M}$. Civil in his unpublished Index For a Corpus of Sumerian Literature (ICSL, sometimes referred to as $H K L$ 4). M. Civil kindly made available to me sections $2.411-2.418$ (pp. 28-30) of his index with a list of all textual sources for the hymns, as well as his transliteration of Urnamma G. Hymns $\mathrm{E}$ and $\mathrm{F}$ are probably two non-Nippur recensions of an original Urnamma hymn, so they are listed here together as Urnamma EF and the separate recensions are distinguished as $\mathrm{E}$ and $\mathrm{F}$ respectively. $\mathrm{C}$. Wilcke kindly provided me with his unpublished manuscript of Urnammus Tod, Tod und Bestattung eines Königs in neusumerischer Zeit, and S. Tinney generously gave me access to his unpublished University Museum manuscripts of Urnamma A and D prepared for the Sumerian Dictionary Project.

The following catalogue of the Urnamma hymns includes for each individual hymn a list of the manuscript sources (and their provenance), ${ }^{55}$ the incipit, subscript, or the last line of the composition, and where available, rubrics and ancient catalogue entries, followed by a bibliography ${ }^{56}$ and short summary of content. ${ }^{57}$

\section{URNAMMA A = URNAMMA'S DEATH}

\section{Sources:}

N i p p u r: $\mathbf{A}=P B S 10 / 26$ (CBS 4560) + C. Wilcke, CRRAI 17 (1970) 83 and 85 (pls. 2 and 4; photo pls. 1 and $3=$ C. Wilcke, Kollationen 66-67) + N 7095. $\mathbf{B}=$ ISET 1 p. 76-77 (Ni. 4487). - C = N 3135. - D = 3 N-T $523=$ IM 58534. - E = C. Wilcke, CRRAI 17 (1970) 90 (pl. 5 = C. Wilcke, Kollationen 68f.). $\mathbf{F}=I S E T 1$ p. $186(\mathrm{Ni} .9918) .-\mathbf{G}=\mathrm{N} 2355$.

S u s a: $\mathbf{S b}_{\mathbf{1}}=$ Sb 12363. $-\mathbf{S b}_{\mathbf{2}}=$ Sb $14083+$ Sb 14137. $-\mathbf{S b}_{\mathbf{3}}=$ Sb $12358+$ Sb 12362. For details, cf. V 1.1, pp. $98 \mathrm{ff}$.

Incipit: [...]-ta kalam te $\check{2}_{2}$-a mi-ni- $\left.\mathrm{ib}-\mathrm{x}\right\urcorner$

Last lines of composition: 'lugal-g $\mathrm{u}_{10} ?[\mathrm{x}(\mathrm{x}) \mathrm{i}] \mathrm{r}_{2}-\mathrm{am}_{3}$ i-lu-am $\mathrm{am}_{3} \mid\left[\mathrm{ur}-\mathrm{d}_{\text {namma? }}\right.$ (...)] $\mathrm{ir}_{2}-\mathrm{am}_{3}$ a-nir-am 3

Bibliography: S. Langdon, PBS 10/2 (1917) 127-36 (edition of parts of CBS 4560); G. Castellino, ZA 52 (1957) 1-57 (edition of CBS 4560); idem, ZA 53 (1959) 131f. (Appendix); S.N. Kramer, JCS 21 (1967) 104-22 (edition of sources

\footnotetext{
51 Kramer, ISET 1 p. 46 and Klein, Th $\breve{H} H 226$.

52 Civil, Or. 41 (1972) 84 and idem, Or. 54 (1985) 29.

53 Published by Civil in Or. 54 (1985) 27-32.

54 Cf. IV 3.2 , p. 84 f.

55 To avoid confusion the sigla for the individual sources generally follow those used by the authors of previous editions.

56 Listed in chronological order.

57 For details, cf. ad "Introduction" of the individual editions in Chapter V.
} 
A and B); C. Wilcke, CRRAI 17 (1970) 81-92 (Jena joins to source A, and E); idem, Urnammus Tod, Tod und Bestattung eines Königs in neusumerischer Zeit, unpub. Habilitationsschrift (1972) (edition of all sources except Susa); idem, Kollationen 66-69; S.N. Kramer, Studies Mikasa (1991) 193-214 (latest edition). ${ }^{58}$

The composition tells of the events that lead to Urnamma's untimely death, describes the king's journey to the netherworld, his offerings to the deities there and his installation as judge. It continues with Urnamma's lament concerning himself and Inana's futile attempt to bring back her royal lover, and ends with a blessing for the king, extolling his posthumous fame instead.

\section{URNAMMA B}

\section{Sources:}

N i p p u r: $\mathbf{A}=S R T 11$ (Ni. 2430). $-\mathbf{C}=\left(\mathrm{C}_{1}\right)$ CBS 15168 (copy in J. Klein,

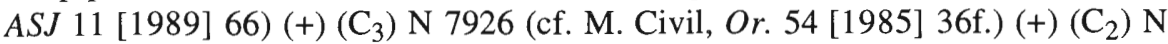
6876 (copy in J. Klein, ASJ 11 [1989] 66). - D = 6 N-T $288=$ IM 61500 (copy in M. Civil, Or. 54 [1985] 34).

B a b y 1 o $\mathrm{n}: \mathbf{E}=V S 2442$ (VAT 17417).

Un kn ow n: $\mathbf{B}=T C L 1538($ AO 6316) $=($ copy in A. Cavigneaux, ASJ 9 [1987] 60). For details, cf. V 2.1, p. 187.

Incipit: den-lil ${ }_{2}$ mah $[\ldots] / \mathrm{UB}$ ? [...]

Subscript: tigi ${ }_{2} \mathrm{den}_{\mathrm{en}}\left[\mathrm{lil}_{2}-\mathrm{la}_{2}\right.$-kam]

Rubrics: sa-gid ${ }_{2}$-da-am 3 , [sa]-gar-ra-am 3

Bibliography: A. Falkenstein, SAHG (1953) 87-90, no. 17 (translation and short summary of source A); S.N. Kramer, BiOr. 11 (1954) 173f., fn. 27 (review of A. Falkenstein); idem, ZA 52 (1957) 81f. (collations of source A); idem, ANET 3 583f. (translation of source A); G. Castellino, ZA 53 (1959) 106-18 (edition of source A); A.W. Sjöberg, OrSuec 10 (1961) 3-12 (edition of source B); M. Civil, Or. 54 (1985) 33-37 (copy of source D, transliteration of source C); A. Cavigneaux, ASJ 9 (1987) 49-51 ad 6. (comments on source B) and 60 (copy of source B); J. Klein, ASJ 11 (1989) 44-56 and fns. pp. 61f. (latest edition). ${ }^{59}$

The composition tells of Urnamma's restoration and inauguration of the Ekur. For this Urnamma is both praised and rewarded with fame, and kingship is established in Ur.

\section{URNAMMA C}

\section{Source:}

$\mathrm{N}$ i p p u r: TCL 1512 (AO 5378). For details, cf. V 3.1, p. 206.

Incipit: iri me $\mathrm{du}_{10}-\mathrm{du}_{10}$-ga para ${ }_{10}$ mah nam-lugal-la

Last line of composition: [sip]a ur-dnamma-me-en $\mathrm{za}_{3}-\mathrm{mi}_{2}-\mathrm{gu}_{10} \mathrm{du}_{10}-\mathrm{ga}^{-\mathrm{am}_{3}}$ 
Bibliography: M. Lambert, Sumer 6 (1950) 162f. (edition of lines 1-12); G. Castellino, ZA 53 (1959) 118-31 (edition); Å.W. Sjöberg, Mondgott 119-22 (edition of lines 1-16); D.R. Frayne, Correlations 84ff. (discussion of selected lines); idem, BiOr. 42 (1985) 15-17 (discussion of selected lines). ${ }^{60}$

The hymn opens with praise of the temple Ekišnugal and goes on to introduce Urnamma. Then follow Urnamma's self-praise, which relates divine approval and designation of his kingship, various activities of the king, and a description of the well-being of Ur, and Sumer and Akkad as a whole.

\section{URNAMMA D (NIPPUR AND UR RECENSIONS)}

\section{Sources:}

N i p p u r: $\mathbf{A}^{61}=$ YBC 4617 (cf. W.W. Hallo, JCS 20 [1966] 139f.). $-\mathbf{D}=$ CBS $8037+\mathrm{N} 1703$ iii 25'- iv 6' (unpub.). - E = UM 29-16-93 (unpub.).

$\mathrm{U}$ r: B = UET 676 (U 16895) + UET $6 * 147$ (unpub.). - C = UET 677 (U 16860). For details, cf. V 4.1, p. 232.

Incipit: (Nippur) [a-ba-a mu-un-b]a-al-e a-ba-a mu'-[un-ba-al-e / $\mathrm{i}_{7}$ ] a-ba-a mu$\mathrm{u}[\mathrm{n}$-ba-al-e]

Last line of composition: (Nippur) dur-dnamma lugal uri ${ }_{2} \mathrm{ki}_{-} \mathrm{ma} \quad \mathrm{za}_{3}-\mathrm{mi}_{2}-\mathrm{Zu} \mathrm{du}_{10^{-}}$ ga-am ${ }_{3}$; (Ur) ur-dnamma lugal mu da-a-ri $\mathrm{Za}_{3}-\mathrm{mi}_{2}-\mathrm{zu} \mathrm{du} \mathrm{du}_{10}$-ga

Catalogues:

a. Nippur Catalogue STVC 41 rev.? i' 3: a-ba-a mu-un-ba-a[1-e] (cf. W.W. Hallo, StOr. 46 = Studies A. Salonen [1975] 79).

b. Uruk: A. Cavigneaux, AUWE 23 (1996) 45, no. 83 rev. 4': [...-b]a-al-e a-ba-a mu-un-ba-al!-e.

Bibliography: W.W. Hallo, JCS 20 (1966) 133-41 (edition of sources A, B, and C); D.R. Frayne, Correlations 104ff.; 116ff. (discussion of selected lines, incorporating unpub. sources D and E); M.G. Hall, Moon-God 407-09; 786 ad 190195 (commentary to lines 25-30). ${ }^{62}$

The prologue in which Urnamma is introduced as constructing canal(s) for Ur is followed by Urnamma's self-praise, describing his selection and election to kingship by Enlil and praising his canal(s) which bring(s) abundance to Ur. The closing section praises Urnamma as the king of the four corners and the provider for Sumer and Akkad (Nippur and Ur).

\section{URNAMMA EF}

\section{Sources:}

L a g a š: A = ISET 1 pp. 224f. (L 1499) = recension E.

$\mathrm{S}$ i p p a r ?: B = CT $4416(\mathrm{BM} 78183)=$ recension F. For details, cf. V 5.1, p. $265 f$.

60 Cf. also V 3.1, p. 204.

61 Unknown provenance but Nippur orthography.

62 Cf. also V 4.1 , p. 228. 
Incipit: (recension F) $\left[\mathrm{uru}_{2}\right.$ ? $\left.(\mathrm{x})\right] \mathrm{bad}_{3}$ ? $\mathrm{ku}_{3}$-ga-ta hi-li $\operatorname{guru}_{3} \mathrm{ru}$

Rubric: instead of the $\mathrm{k} \mathrm{i}-\mathrm{r} \mathrm{u}-\mathrm{g} \mathrm{u}_{2}$ rubric, a ruled line alone divides the text into two sections.

first line in second $\mathrm{k} \mathrm{i}-\mathrm{r} \mathrm{u}-\mathrm{g} \mathrm{u}_{2}$ : lugal hi-li guru $_{3}$ ru me- $\lim _{\mathrm{x}}$ kalam-ma dul-la; entered in two catalogues (see below).

Subscript: (recension F) šir ${ }_{3}$-nam-šub-dnanna-kam! (/ 51? mu-bi)

Catalogues:

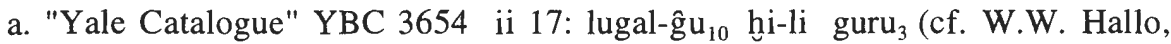
JAOS 83 [1963] 171).

b. "Nippur Catalogue" CBS 8086 12: lugal hi-li guru ${ }_{3}^{\text {ru }}$ (cf. P. Michalowski, OA 19 [1980] 266).

Bibliography: S. Langdon, PSBA 40 (1918) 45-50 (edition of recension F); M.E. Cohen, JAOS 95 (1975) 596-600 (latest edition). ${ }^{63}$

The first $\mathrm{k}$ i r u g u section praises the Ekišnugal and introduces Urnamma. The second section tells how Urnamma is chosen by Su'en in order to enforce law and order and ends with the king's blessing.

\section{URNAMMA G}

Source: unnumbered text of unknown provenance, columns ii 1'-17'- iii 1'-2'. For details, cf. V 6.1, p. 291.

Incipit: not preserved

Subscript: 'bal'-bal-e den-lil-[la $\left.\mathrm{l}_{2}-\mathrm{kam}\right]$ (/ 27 [mu?-bi?])

Bibliography: none

The composition tells how Enlil has given Urnamma agricultural prosperity, then praises Urnamma as the faithful farmer who tends Enlil's field.

\section{URNAMMA H}

\section{Sources:}

Ni p p u r: $\mathbf{A}=$ PBS 540 (CBS 15046). - B = N 1511 (unpub.). The two sources might belong to different compositions. For details, cf. V 7.1, p. 297.

Incipit: ur-d namma lugal [kalam-ma (...)] I sud-ra ${ }_{2}$ bad-DU $\left.{ }^{\mathrm{X}}\right\urcorner[\ldots]$

Subscript/Last line of composition: not preserved

Bibliography: W.W Hallo, HUCA 33 (1962) 28, no. 37 (edition of source A); I. Kärki, StOr. 58 (1986) 24, no. 37 (edition of source A); H. Steible, FAOS 9/2 (1991) 143 , no. 37 (description). ${ }^{64}$

Too fragmentary for a summary. 


\section{Orthography}

\subsection{Archaic Orthography}

In his various editions of Sulgi hymns, J. Klein was able to show that those hymns whose sources all stem from the Old Babylonian period sometimes preserve orthography found in Gudea and Ur III texts dating centuries earlier. Such orthographical peculiarities can be considered as genuine survivals from the Ur III period and substantiate the assumption that these hymns originated in Sulgi's own time. In the course of their transmission, some hymns were thoroughly "modernized" to conform to Old Babylonian orthographical and grammatical practices, whereas other hymns retained some of the archaic spellings. ${ }^{65}$

Only a few archaic spellings can be found in the Urnamma hymns. They support the assumption, set forth above, that these hymns, too, are genuine Ur III compositions. On the whole though, the hymns exhibit orthography and grammar of the Old Babylonian period and so underwent "modernization" in the course of their transmission. The relative paucity of archaic spellings, however, poses a problem: we expect more because Urnamma's hymns, unlike those of Sulgi, seem to have been neither part of the basic scribal curriculum, nor part of the everyday subject-matter the scribal students were taught, found in catalogues such as UM 2915-155 $5^{66}$ and TCL $1528,{ }^{67}$ and which thus underwent thorough modernization. If Urnamma's hymns had been widely used in the scribal schools we would expect a greater number of duplicates, such as in those compositions listed at the beginning of the above mentioned catalogues (Sulgi A, Lipiteštar A, Hymn to the Hoe, Ninmešara, Enlil in the Ekur, Keši Hymn etc.). Why this is so remains unclear.

The following archaic spellings are attested in Urnamma hymns:

The etymologically obscure $\mathrm{a}-\mathrm{n}$ e for e $-\mathrm{n} \mathrm{e}^{68}$ : Urnamma A 19 (source B) $\mathrm{ki}$ a-n e-di [ $\mathrm{g} \mathrm{a}] 1_{2}-1$ a "where merriment had reigned"; Urnamma C $81 \mathrm{a}-\mathrm{n} \mathrm{e} \mathrm{hu} \mathrm{l}_{2}-\mathrm{la} \mathrm{m} \mathrm{u}-\mathrm{e}$ "they joyfully follow".

\footnotetext{
65 Klein's orthographical and grammatical observations of his hitherto published Sulgi hymns are in Klein, $T h \breve{S} H$ 64ff. (for Sulgi D), $131 \mathrm{ff}$. (for Sulgi X); idem, TAPS $71 / 7$ (1981) 27ff. (for Sulgi P); idem, Beer-Sheva 2 (1985) 14*ff. (for Sulgi V); idem, Studies Artzi (1990) 96ff. (for Sulgi R); idem, Studies Tadmor (1991) 299ff. (for Sulgi G). Klein has announced a "study of the orthography and grammar of the Neo-Sumerian royal hymns" in Studies Sjöberg (1989) 291, fn. 16.

66 Edited by Kramer in BASOR 88 (1942) 10-16, collations in Bernhardt, Kramer, WZJ 6 (1956/57) 393, fn. 2. 67 Cf. Kramer, ibid. 17-19, collations in Bernhardt, Kramer, ibid. 393, fn. 3 and Flückiger-Hawker, N.A.B.U. $1996 / 119$.

68 Klein, Beer-Sheva 2 (1985) 15*f., and fn. 42 with bibliography for Ur III a - $\mathrm{n}$ e for the 3rd person sg. independent pronoun $\mathrm{e}-\mathrm{n}$ e; for archaic $\mathrm{a}-\mathrm{n} \mathrm{e}$ in $\mathrm{a} / \mathrm{e}-\mathrm{n} \mathrm{e}\left(\mathrm{h} \mathrm{u}_{2} \mathrm{l}_{2} \mathrm{~d} \mathrm{u}_{1 / \mathrm{l}} / \mathrm{e} / \mathrm{d} \mathrm{i}\right.$, cf. Attinger, Eléments 472, § 351 .
} 
The 1st person sg. independent pronoun written $\hat{g}_{2}$ without following - e / - a in Urnamma B 40 || 46 (source A) $\mathrm{g} \mathrm{a}_{2}$ - $\mathrm{m}$ e - e n "I am"; perhaps also Urnamma D 32' (Ur, source B) ' $\left.\mathrm{g} \mathrm{a}_{2}\right\urcorner$ "(due to) me".

"Plene" writings ${ }^{69}$ :

1. - N I ( $\left.\mathrm{i}_{3}\right)$ - in Unnamma B 35 (source A) a $\mathrm{m}_{3}-\mathrm{m} \mathrm{i}-\mathrm{N} \mathrm{I}\left(\mathrm{i}_{3}\right)-\mathrm{du}_{10}$ "he had tastily prepared (i.e. huge quantities of food)"; Urnamma B 61 (source A) a $\mathrm{m}_{3}-\mathrm{m} \mathrm{i}-\mathrm{N} \mathrm{I}\left(\mathrm{i}_{3}\right)-\mathrm{i} \mathrm{n}-\mathrm{s} \mathrm{u}-\mathrm{u}$ b "he (i.e. Urnamma) made sweep away (i.e. the great oppression)".

2. Perhaps - a - in Urnamma A 17 (source A) [ $\mathrm{n} \mathrm{a} \mathrm{m} \mathrm{]} \mathrm{(...)} \mathrm{m} \mathrm{u} \mathrm{-} \mathrm{u} \mathrm{n} \mathrm{-}$ $\mathrm{t}$ a r $-\mathrm{r} \mathrm{a}-\ulcorner\mathrm{a}\urcorner-\check{s}_{3} \mathrm{e}_{3}$ "because of the fate that was allotted"; perhaps in Urnamma C 111 d n a n n a - a - m e - e n "of Nanna I am (i.e. the creature)".

The spelling $-\mathrm{ib}_{2}$ - of which there are several occurences in the Urnamma hymns is the standard Ur III writing of the pronominal infix $\{b\}$ (3rd person inanimate ergative/absolutive) after / $\mathrm{i} / \mathrm{but}$ is not considered here as an actual archaism against Old Babylonian standard spelling - i b - . ${ }^{70}$

Other archaic spellings established by J. Klein, as e.g. the assimilation of the locative-terminative/ergative postposition - e to the preceding vowel, ${ }^{71}$ or the writing $-\mathrm{m} \mathrm{e}-\mathrm{e} \mathrm{n}_{3}$ for standard Old Babylonian $-\mathrm{m}$ e $-\mathrm{e}^{72}$ are wholly absent in the Urnamma hymns.

\subsection{Non-standard Orthography}

"Non-standard" is used here as a generic term for all orthography which diverges from so-called "standard" spelling for whatever reasons (e.g. intentionally, or as a dictation error). Non-standard orthography includes simple non-standard spellings which are not primarily and deliberately phonetic (e.g. Urnamma A, source G and the Susa version), spellings which can be termed phonetic (e.g. Urnamma D, Ur sources B and C, and Urnamma E) and whole texts or compositions in so-called "unorthographic" or "syllabic" (phonetic) writing as e.g. Urnamma B (source B). Deliberate rendering of the phonetic value of a word unit or syllabification of word units (resulting often in Sandhi-writings) in order to render the phonetic value of these units (as e.g. in exercise texts such as source B of Urnamma B), and simple auditory errors, result in non-standard spellings which can be considered phonetic writings, such as $\mathrm{i}-\mathrm{t} \mathrm{i}$ for $\mathrm{i} \mathrm{t}_{6}$ "moonlight" in Urnamma C 57, $\mathrm{m}$ a š $\mathrm{g} \mathrm{i} \mathrm{-} \mathrm{i}$ for $\mathrm{m}$ a š k i m "enforcer" in Urnamma $\mathrm{E} \mathrm{30} /|| 32^{\prime}$, or $\mathrm{g} \mathrm{u}_{4}-\mathrm{u} \mathrm{l}$ -

\footnotetext{
69 Cf. Klein, Th $\breve{S H}$ 64-67; 131f.; idem, TAPS 71/7 (1981) 28; idem, Beer-Sheva 2 (1985) 16*; idem, Studies Artzi (1990) 96f; idem, Studies Tadmor (1991) 299.

70 Pace Klein, Studies Tadmor (1991) 300, and fn. 45 with previous literature. Cf. e.g. the occurences of - $\mathrm{i} \mathrm{b}_{2}$ - in other OB literary texts in Heimpel, The Structure of the Sumerian Prefix Chain (unpub.) (1974) $135 \mathrm{ff}$.

71 Klein, Beer-Sheva 2 (1985) 16*, and fn. 44 with previous literature; idem, Studies Artzi (1990) $96 \mathrm{f}$.

72 Klein, Studies Artzi (1990) 97, and fn. 188 with previous literature.
} 
$\mathrm{g} \mathrm{u}_{4}-\mathrm{u} 1$ for $\mathrm{g} \mathrm{u} 1-\mathrm{g} \mathrm{u} \mathrm{l}$ "to destroy" in source B of Urnamma B 58 obv. 7' II 60 obv. 8'. These phonetic non-standard writings include mono- and polysyllabic nouns, verbs and postpositions, such as $1 \mathrm{u}$ for $1 \mathrm{u}_{2}$ "person" in source B of Urnamma B 63 obv. 10' || 65 obv. 12', [ p ] a - r a n a- l u-g a- 1 a (-k) for

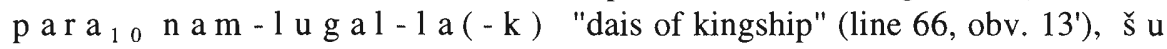

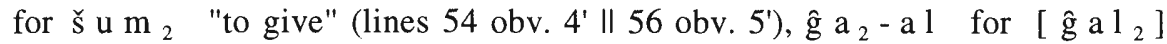
"to exist, to cause to be" (line 70, rev. 2), - $\mathrm{ke}$ for $-\mathrm{ke}_{4} \quad\{\mathrm{a} \mathrm{k}+\mathrm{e}$ (ergative/locative-terminative) $\}$ in $\mathrm{d} \mathrm{u} \mathrm{r}-\mathrm{d} \mathrm{n}$ a $\mathrm{m} \mathrm{m} \mathrm{a-k} \mathrm{e} \mathrm{(lines} 53$ obv. 2', 56 obv. 5', 60 obv. 8', 64 obv. 11', 68 obv. 14'), and - e (-) e d-, with Sandhiwriting, for - e š in $\mathrm{s} a-\mathrm{h} \mathrm{a}-\mathrm{ar}-\mathrm{e}(-) \mathrm{ed}-\mathrm{bu}=\mathrm{s}$ a h $\mathrm{ar}-\mathrm{re}-\mathrm{e} \check{\mathrm{s}}$ $\mathrm{d} u \mathrm{~b}-\mathrm{b} \mathrm{u}$ "which piles up (i.e. heads) as sand dunes" (line 53, obv. 3'). Besides purely phonetic non-standard spellings, semantically conditioned non-standard spellings and reinterpretations based on phonetic affinity can be found in the Urnamma hymns. Phonetic non-standard spellings which are semantically nonconditioned and non-standard spellings which are semantically conditioned include homophonic replacements as well as forms with vowel and consonant interchange.

I. Phonetic non-standard spellings which are semantically non-conditioned involve

a.) homophonic replacements:

\section{Urnamma A Susa:}

$\mathrm{a}_{2}{ }^{73}=\mathrm{a}$ "o, $\operatorname{alas"}(16), \mathrm{s} \mathrm{a}_{2} \mathrm{du}=\mathrm{s} \mathrm{a}_{2} \mathrm{du}_{11} \cdot \mathrm{g}$ "to reach" (51), $\mathrm{du}$ $=\mathrm{du}_{7} \quad$ "perfect" $(87,129), \mathrm{g} \mathrm{u}_{2}=\mathrm{gu}_{3}$ "voice" (116), perhaps $\mathrm{ra}=$ $\mathrm{A} \mathrm{K}=\mathrm{ra}_{6}$ in $\breve{\mathrm{s}} \mathrm{u} \quad \mathrm{dul}_{3} \quad \mathrm{ra}$ "to put a protecting hand over something" (150), b a-ra.g = b a r a ${ }_{3} \cdot \mathrm{g}$ "to spread" (159), $\mathrm{ge}=\mathrm{ge}_{4}$ in $\mathrm{k} \mathrm{i} \hat{\mathrm{g}}_{2}-\mathrm{g} \mathrm{e}_{4}-\mathrm{a} \quad \mathrm{g} \mathrm{e}_{4}$ "to send a message" (197), $\mathrm{du}=\mathrm{du}_{8}$ in $\mathrm{ig} \mathrm{i}$ $\mathrm{d} \mathrm{u}_{8}{ }^{74}$ "to see" (202).

Urnamma A (source G):

$-1 \mathrm{a}_{2}-=-1 \mathrm{a}-$ in $\mathrm{b} \mathrm{a}-\mathrm{a} 1-1 \mathrm{a}-\mathrm{zu}$ "which you have dug" (225).

Urnamma $C$ :

$\mathrm{i}-\mathrm{t} \mathrm{i}^{75}=\mathrm{i} \mathrm{t} \mathrm{i}_{6} \quad$ "moonlight" (57).

Urnamma D Ur:

[k] $\mathrm{u}_{3}-\mathrm{si}_{2}(\mathrm{ZI}) \cdot \mathrm{g}=\mathrm{k} \mathrm{u}_{3}-\mathrm{si} \mathrm{g}{ }_{17}$ "gold" (29', source B), m u - š e $=\mathrm{mu}(-) \check{\mathrm{s}} \mathrm{e}_{21}$ "to name", less likely $=\mathrm{m} \mathrm{u} \mathrm{š} \mathrm{e} \mathrm{n}$ "bird"76 (30', sources B and $\mathrm{C}), \mathrm{da}-\mathrm{ri}^{77}=\mathrm{da}-\mathrm{ri}_{2}$ "lasting" (31', sources B and C), $\mathrm{d} \mathrm{u}=\mathrm{d} \mathrm{u}_{7}$ in $\mathrm{k} \mathrm{a}-\mathrm{g} \mathrm{e} \mathrm{du}_{7}$ "(to be made) worthy to be praised" (31', sources B and C), $\mathrm{mu}-\breve{\mathrm{s}} \mathrm{e}-\mathrm{n} \mathrm{a}=\mathrm{m}$ u š e $\mathrm{n}-\mathrm{a} \mathrm{m}_{3}$ "there are fish" (32'-34', source B), $1 \mathrm{u}_{2}$ $=1 \mathrm{u}$ in $1 \mathrm{u}-\mathrm{a}$ "where it (= the liquorice) is plentiful" (36', sources B and $\mathrm{C}), \mathrm{s} \mathrm{u}-\mathrm{s} \mathrm{u}=\mathrm{s} \mathrm{u}_{3}-\mathrm{s} \mathrm{u}_{3} \cdot \mathrm{d}$ "to grow tall" (37', sources B and C).

\footnotetext{
73 A semantically conditioned spelling (cf. ad II., p. 25), i.e. $a_{2}=$ "force", cannot be excluded (cf. Attinger, Eléments 416, fn. 1112).

$74 \mathrm{~d} \mathrm{u}_{8}$ in source $\mathrm{A}$ is restored.

75 Cf. $\mathrm{i}_{3}$ - $\mathrm{t}$ i, presumedly archaic. References in Klein, Studies Artzi (1990) 116 ad 23-24.

$76 \mathrm{Cf}$. the commentary ad Urnamma D 4, p. 254 and 22-23, p. 256 (sound play with $\mathrm{m}$ u š e n).

$77 \mathrm{Cf}$. the spelling $\mathrm{d}$ a $-\mathrm{a}-\mathrm{r} \mathrm{i}$ in Urnamma D $41^{\prime}$ (Ur, source C).
} 
Urnamma F:

$\mathrm{g} \mathrm{e}=\mathrm{ge}_{4}$ in a d $\mathrm{g} \mathrm{e}_{4}-\mathrm{g} \mathrm{e}_{4}$ "to confer" (17).

b.) vowel and consonant interchange:

Urnamma A Susa:

$\breve{\mathrm{s}} \mathrm{i}-\breve{\mathrm{s}} \mathrm{i}=\breve{\mathrm{s}} \mathrm{e}_{8}-\breve{s}_{\mathrm{e}} \mathrm{e}_{8}$ in $\mathrm{i} \mathrm{r}_{2} \check{\mathrm{s}}_{\mathrm{e}}{ }_{8}-\mathrm{š}_{8}$ "to weep tears" (19), d u - d i $\mathrm{d} a=\mathrm{t} u-\mathrm{di}-\mathrm{da}, \mathrm{t} \mathrm{u}-\mathrm{di}-\mathrm{tu} \mathrm{m}$ "toggle pin" (121), i n - n a = e n $\mathrm{n}$ a "so far as" (139-40), $\mathrm{z} \mathrm{a}_{3}-\mathrm{z} \mathrm{a}_{3}-\mathrm{m} \mathrm{i}_{2}{ }^{78}=\mathrm{z} \mathrm{a}-\mathrm{a} \mathrm{m}-\mathrm{za}-\mathrm{a} \mathrm{m}-\mathrm{g} \mathrm{u} 10$ "my z a m z a m-instruments"79 (187).

Urnamma D Ur:

$\mathrm{me}=\mathrm{g} \mathrm{e}_{26}-\mathrm{e}$ "me" (12', source B), $\mathrm{ka}-\mathrm{ke}=\mathrm{ka}-\mathrm{ge}$ in $\mathrm{ka}-\mathrm{ge}$ $\mathrm{d} \mathrm{u}_{7}$ "(to be made) worthy to be praised" (31', sources $\mathrm{B}$ and $\left.\mathrm{C}\right), \mathrm{t} \mathrm{e}-1 \mathrm{i}=$ $\mathrm{diri}$ in $\mathrm{diri-bi}$ "what it makes glide" (32'-34', sources B and C), $\mathrm{mu}-\check{\mathrm{s}} \mathrm{i}-\mathrm{x}=\mathrm{muš}$ e $n-\mathrm{a} \mathrm{m}_{3}$ "there are fish" (33'-34', source C), $\mathrm{m} \mathrm{u}$ $\mathrm{s} \mathrm{u}-\mathrm{ur}=\mathrm{u}_{2} \mathrm{~m}$ u n ze r ! (U D. d N A N N A) "liquorice" (36', source C).

Urnamma E:

$\mathrm{ki} \quad \mathrm{u} \mathrm{t}-\mathrm{t} \mathrm{i}=$ ? $\mathrm{ki} \quad \mathrm{u}_{4} \quad \mathrm{e}_{3}(-\mathrm{a})$ "place where daylight breaks" (4'), a $\mathrm{ra}_{2} !-\mathrm{ab}=\mathrm{rab}$ "shackle" (7'), g i - š $\mathrm{a}_{3}=$ ? k i s s a "platform" $\left(11^{\prime}\right), \mathrm{m}$ a $\breve{s}-\mathrm{g} \mathrm{i}-\mathrm{i} \mathrm{d} \mathrm{u}_{11} \cdot \mathrm{g}=\mathrm{m}$ a $\breve{k} \mathrm{i} \mathrm{m} \mathrm{du}_{11} \cdot \mathrm{g}$ "to be in charge" (30' II 32').

Urnamma F:

$\mathrm{gi}$ ? $-\mathrm{s} \mathrm{a}_{2}=$ ? $\mathrm{k}$ i s s a "platform" (16).

II. Semantically conditioned non-standard spellings also include

a.) homophonic replacements:

Urnamma A Susa:

$\mathrm{de}_{6}=\mathrm{de}_{2}$ "to pour into" (22).

Urnamma D Nippur, source E:

$\mathrm{du}_{10}=\mathrm{DU}$ in a DU (- a ) - b i "what water it (i.e. the canal) carries" (25).

b.) vowel and consonant interchange:

Urnamma A Susa:

$\mathrm{s} \mathrm{a} \mathrm{g}(-) \mathrm{g} \mathrm{u}_{2}(-) \mathrm{g} \mathrm{a} \mathrm{l}_{2}=\mathrm{s} \mathrm{a} \mathrm{g}(-) \mathrm{k} \mathrm{u}_{3}(-) \hat{\mathrm{g} \mathrm{a} \mathrm{l}_{2}}$ "proud one" (42), $\mathrm{a}\left(=\mathrm{e}_{4}\right)-\mathrm{ma}-\mathrm{ru}=\mathrm{e}_{2}-\mathrm{mar}-\mathrm{uru}_{5}$ "quiver"80 $(88)$.

Urnamma D Ur:

$\mathrm{ku}_{6}-\mathrm{ab}=\mathrm{ku}_{6}-\mathrm{am}_{3}$ plus the association with $\mathrm{ab}$ "body of water, sea" (32'-34', sources B and C).

III. Reinterpretations based on phonetic affinity are:

\footnotetext{
78 Possibly with Sandhi-writing.

79 A semantically conditioned spelling with a pun on $\mathrm{z} \mathrm{a}_{3}-\mathrm{mi}_{2}$ "praise", cannot be excluded.

$80 \mathrm{This}$ is not a certain semantically conditioned spelling, as a $\left(=\mathrm{e}_{4}\right)-\mathrm{ma}-\mathrm{r} \mathrm{u}$ in the sense of "quiver" is sporadically attested (Eichler, Studies Hallo [1993] 92f., and fn. 53).
} 
Urnamma A Susa:

perhaps $1 \mathrm{i} \mathrm{b}$ "illusion, dreams" = $1 \mathrm{i}-\mathrm{b} \mathrm{i} \mathrm{i} \mathrm{b}_{2}$ - "their bliss(fulness)" (20), e ri / e "cities" = e re n 2 "troops" (43), ${ }^{81}$ a l a n "healthy appearance" $=\mathrm{a}-1 \mathrm{a}$ "vitality" in $\mathrm{a}-1 \mathrm{a}-\mathrm{n}$ a $\mathrm{b}$ a- $\mathrm{ra}-\mathrm{e}_{3}$ "he has lost his vitality" (51), i m - š e $\hat{g}_{3}-\hat{g}_{2} e_{26}$ "it precipitates" = i m - š i - g e n "it went there" (59), ${ }^{82}$ perhaps $\hat{\mathrm{g}}$ e š - $\mathrm{n} \mathrm{u}_{1} 1$ "light" = $\mathrm{g} \mathrm{i} \mathrm{d} \mathrm{r} \mathrm{i} / \mathrm{u}$ "sceptre" (103), $\mathrm{s} \mathrm{a}_{7}-\mathrm{g}$ a "beautiful" $=\mathrm{s} \mathrm{i}_{3}$ ? / $\mathrm{s} \mathrm{i} \mathrm{g?} \mathrm{-} \mathrm{g} \mathrm{a} \mathrm{"formed} \mathrm{as"} \mathrm{(106),} \mathrm{g} \mathrm{u}_{2}$ $\mathrm{nun}$ ? $\mathrm{du}_{11}-\mathrm{du}_{11}$ "to bray? loudly" = ? ( $\left.\mathrm{u} \mathrm{r}_{2}\right) \mathrm{gu} \mathrm{nu}_{3}-\mathrm{gunu} \mathrm{u}_{3}$ "dappled (thighs)" (116), ĝ e š $\mathrm{g} \mathrm{u}-\mathrm{z}$ a $\mathrm{z} \mathrm{a}-\mathrm{g} \mathrm{i} \mathrm{n}_{3}$ "lapis lazuli throne(s)" = $\hat{\mathrm{g}} \mathrm{e} \breve{s}-\mathrm{n} \mathrm{u}_{2} \quad \mathrm{u}_{2} \quad \mathrm{z}$ a $-\mathrm{g} \mathrm{i} \mathrm{n}_{3}$ "beds with fresh herbs"(159). ${ }^{83}$

Urnamma D Ur:

$\mathrm{d}_{\mathrm{s} \text { u } 1-\mathrm{gi} \text {.r }}$ "Sulgi" = s u 1 zi.d "faithful youth" (8', source B), $\mathrm{na}(-) \mathrm{ri}-\mathrm{MU}(-) \mathrm{u}_{4} \quad \mathrm{~h} \mathrm{e}_{2}-\mathrm{g} \mathrm{al}_{2}-1 \mathrm{a} "$ ". . days of abundance" = ?

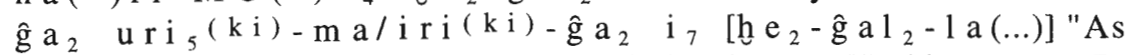
for me, at Ur/in my city, (...) a canal [of abundance ...]" (30', sources B, partially broken, and C).

IV. Source B which preserves lines 52-71 of Urnamma B is an example for a whole text or version written exclusively in "syllabic" or "unorthographic" writing. ${ }^{84}$ As with all "syllabic" texts, CV- and VC- sequences are predominant and several Sandhi-writings can be observed, as e.g. - ̌̌ u ( - ) n u - n a - a m - n i - r a for $-\mathrm{s}_{\mathrm{u} \mathrm{m}}$ e n d n u-n a m-n i r-re (lines 54 obv. 4' || 56 obv. 5'), the interesting $\mathrm{b} \mathrm{i}-\mathrm{ni}(-) \mathrm{l}_{2}$ ? $-\mathrm{g}$ a l $\urcorner$ (line 68 obv. 14'f.) and $\mathrm{la}-1 \mathrm{a}-\mathrm{m} \mathrm{i}-$ $\mathrm{du}=/ \mathrm{lalami} / \mathrm{idu}(\mathrm{b}) /<1 \mathrm{il}_{2} \quad \mathrm{am}_{3}-\mathrm{mi}\left(-\mathrm{i}_{3}\right)-\mathrm{in}-\mathrm{su}-\mathrm{ub}$ (Sandhi plus assimilation, lines 59 obv. 7' || 61 obv. 9').

Note that standard orthography generally can appear in "syllabic" texts, as e.g. k u r "foreign land" (lines 52 obv. 1' || 53 obv. 2', 55 obv. 4' || 57 obv. 5'), s a g "head" (line 68 obv. 14'). Also, a specific non-standard spelling does not have to be compulsory for the whole text: we encounter e.g. s a $\hat{g}$ "head" in the same text in different renderings, i.e. as $\mathrm{s}$ i - i m (lines 52 obv. 1' || 53 obv. 3') with common a/i- alternation, as s a-g (line $69 \mathrm{rev} .1$ ), and as $\mathrm{s}$ a $\hat{\mathrm{g}}$ (line $68 \mathrm{obv}$. 14'); e $\mathrm{rim} \mathrm{m}_{2}-\mathrm{gal}_{2}$ "enemy" as $\mathrm{r}^{\mathrm{i}-\mathrm{ri}}$ - $\mathrm{i} \mathrm{m}-\mathrm{m}[\mathrm{a}(-\mathrm{g} \mathrm{a}-\mathrm{la})]$ (lines 52 obv. $1^{\prime} \| 53$ obv. 2') and as i - r i - g a - a 1 (lines 63 obv. 10' || 65 obv. 12'); 1 u g a 1 "king, lord" as $1 \mathrm{u}-\mathrm{g}$ a -1 (line 66 obv. 13' in n a m-1 u g a 1 "kingship"), as $\left\ulcorner\mathrm{lu} \mathrm{u}_{2} ?-\mathrm{gal}\right\urcorner$ (line $68 \mathrm{obv} .1^{\prime}$ ) and perhaps as $\left[1 \mathrm{u}\left({ }_{2}\right)-\mathrm{g} \mathrm{a}-\mathrm{a}\right] \mathrm{l}$ (line 52 obv. 1').

For the spellings and their correspondences in standard orthography in general I refer to the discussion in $\AA$.W. Sjöberg, OrSuec 10 (1961) 3-12, A. Cavigneaux,

81 This could also be a semantically conditioned non-standard spelling.

$82 \mathrm{Cf}$. the preceding footnote.

83 Cf. also V 1.3 ad II f., p. 152.

84 For a bibliography of studies on "unorthographic" writings, cf. the lists in Thomsen, Mesopotamia 10 (1984) 283f., and in Römer, AOAT 238 (1994) 145. Add Cavigneaux's and Al-Rawi's studies on Tell Haddād texts in ZA 83 (1993) 170-205, iidem, ZA 85 (1995) $19-46$ and 169-220, and iidem, Iraq 55 (1993) 91-105; Cavigneaux, ASJ 17 (1995) 75-99. Also, Alster's edition of Manchester Tammuz in ASJ 14 (1992) 1-46. 
ASJ 9 (1987) 49-51 ad 6. and to my own few additions in the commentary to the corresponding lines of Urnamma B. Note also that they are listed in the Lexical Index, pp. $301 \mathrm{ff}$.

\section{Glosses}

Urnamma A, B and especially C exhibit glosses in smaller script which remain for the most part obscure. They can be divided into:

I. Akkadian glosses: Urnamma B 34, source E (Babylon) obv. 7': zi-kir šu-mi glossing $\mathrm{m} \mathrm{u} \mathrm{pa}_{3}-\mathrm{da}$ "mentioned by name"; Urnamma C 33 (paleographically uncertain) $i$-na $m u-x-x$-ri-ia(-)AŠ which looks like the Akkadian translation of the whole line or at least the verbal form $\mathrm{ni}_{2} \mathrm{su}-\mathrm{e} \quad \mathrm{bi}_{2}-\mathrm{u} \mathrm{s}_{2}-\mathrm{s} \mathrm{a}-\mathrm{g} \mathrm{u}_{10} \Gamma_{\mathrm{x}}$ $x\urcorner$ - a "Thanks to the fear I have inspired ...".

II. Possible Sumerian (verbal) variants: Urnamma C $57\ulcorner x \quad x\urcorner-a-b a$ ?

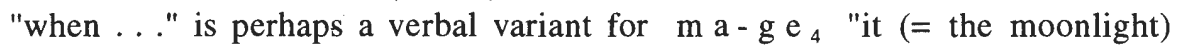
returned to/for me" (note that $\mathrm{a}-\mathrm{m} \mathrm{a}-\mathrm{r} \mathrm{u} \quad \mathrm{g} \mathrm{e}_{4}-a-\mathrm{b}$ a is expected for the first part of the line); Unamma C $78 \times \mathrm{x} \mathrm{m} \mathrm{u}$ ? $-\mathrm{n} \mathrm{i}-\check{s}_{\mathrm{a}}{ }_{2}$ ? "I have multiplied ...", is perhaps a variant for $\left(\mathrm{s} \mathrm{u} \mathrm{b} \mathrm{a}_{2}\right) \quad \mathrm{m} \mathrm{a}-\mathrm{s}_{\mathrm{a}} \mathrm{r}_{2}$ "(. . .) were multiplied for me".

III. Illegible glosses are Urnamma A 150 (source A), 160 (source A), Urnamma C 44, and possibly 92 . 


\section{CHAPTER III}

\section{ON THE HISTORICAL CORRELATIONS OF THE URNAMMA HYMNS}

\section{Urnamma and His Deeds in the Hymns and Other Sources}

In reconstructing the political, cultural, and religious history of the ancient Near East, scholars must decide what degree of scepticism should form the conclusions they draw from the limited textual evidence at their disposal. Some take a minimalist view and insist that textual representations of events and views are limited to the literary universe and do not necessarily reflect reality, and are therefore inadequate for the reconstruction of ancient Near Eastern history in all its facets. ${ }^{1}$ Others treat the cuneiform record, despite its epistemological limits, as a valid resource in historical reconstruction. ${ }^{2}$ With regard to Sumerian royal hymns, W.W. Hallo and D.R. Frayne, among others, maintain that it is legitimate to address the question, with due caution, of the historical setting of these hymns. Caution is certainly justified in the utilization of solely literary sources, in our case the royal hymns, for these hymns, unlike inscriptions, tend to reduce royal accomplishments to patterns and topoi, and are therefore often unsuitable for the reconstruction of historical events. ${ }^{3}$ However, W.W. Hallo noted decades ago that events narrated in year names could be correlated with inscriptions of the same king, and that correlations existed between year names and royal hymns, although he went too far in suggesting an annual or biennial ceremony in which each year name was introduced together with the promulgation of a new royal hymn. ${ }^{4}$ Most type A royal hymns have few if any references to possible historical events, ${ }^{5}$ and type B. I and II hymns usually display a variety of royal accomplishments. W.W.

\footnotetext{
1 E.g. Civil in Barrelet (ed.), L'archéologie de l'Iraq: Perspectives et limites de l'interprétation anthropologique des documents, Paris (1980) 225-32 (Colloques internationaux du C.N.R.S., no. 580).

2 Cf. Hallo's weighing of these alternatives in JAOS 110 (1990) 187-99.

3 Cf. aiso IV 1.2, p. 43.

4 Cf. Hallo, CRRAI 17 (1970) $118 \mathrm{f}$. On the problems of involvement of hymnic material in royal ritual activity in general, cf. Tinney, Nippur Lament $82 \mathrm{f}$. Two probable correlations between a year name and a royal hymn are Sulgi's year name 8 (= Sigrist, Gomi, Ur III Catalogue 320:8) and Sulgi R which commemorate the construction of Ninlil's boat, and year name 7 and Sulgi A and V (really an inscription, cf. IV 3.2, p. 83) which commemorate the return trip between Ur and Nippur. With year name 6 compare perhaps also Sulgi A, both referring to the maintenance of overland routes (to Nippur).

5 Examples to the contrary noted above, II 1., p. 14, namely Urnamma B, Sulgi G and R, and Iš medagān I.
} 
Hallo is correct however, when he insists that when combined with evidence provided by contemporary monuments and archives, the suitability of the literary tradition is enhanced for the reconstruction of historical events. ${ }^{6}$ D.R. Frayne in his Yale dissertation The Historical Correlations of the Sumerian Royal Hymns (24001900 B.C.), substantiated and supplemented W.W. Hallo's findings by correlating year names with royal inscriptions from the Pre-Sargonic period onward, and year names, royal inscriptions and hymns from the Third Dynasty of Ur to Lipiteštar of Isin. The intention of this section is to evaluate and expand on D.R. Frayne's results with regard to the reign of $\mathrm{Urnamma}^{7}$ and to show that the picture of Urnamma and his deeds in the hymns correlates well with what is reported in his inscriptions, year names, the Cadaster text, ${ }^{8}$ and the prologue of his law $\operatorname{code}^{9}$ as demonstrated in the following list:

I. The care of the gods ${ }^{10}$ involves a.) the provision of a home ${ }^{11}$ and b.) of food supplies.

a.) temples and their (re)construction:

1. general: A 157-159.

2. specific:

\begin{tabular}{|c|c|c|c|c|}
\hline & Temple (Name) & $\operatorname{Verb}^{12}$ & Attestations $^{13}$ & Provenance \\
\hline \multirow[t]{3}{*}{ Enlil } & $e_{2}$ & $\mathrm{a}$ & $23: 7-8$ & $\begin{array}{l}\text { Diqdiqqah, Uruk, } \\
\text { Eridu (?) }\end{array}$ \\
\hline & $e_{2} d_{e n-l i l}-1 a_{2}$ & $\mathrm{a}$ & $\begin{array}{l}3: 4-5, \text { C } 103 \\
28,1: 8-9\end{array}$ & $\begin{array}{l}\text { Nippur } \\
\text { Ur }\end{array}$ \\
\hline & $\begin{array}{l}e_{2} \text {-kur } \\
+ \text { its different parts }\end{array}$ & $\mathrm{a}$ & $\begin{array}{l}16: 8-10 \\
\text { B passim }\end{array}$ & $\begin{array}{l}\text { Nippur, SE of the } \\
\text { ziggurat }\end{array}$ \\
\hline \multirow[t]{2}{*}{ Ninlil } & $\mathrm{e}_{2}$-šu-tum & $\mathrm{a}$ & $21: 7-8$ & Nippur \\
\hline & $\hat{\mathrm{ga}} \mathrm{a}_{2}-\hat{\mathrm{ges}}-\breve{s ̆}_{2}-\mathrm{a}$ & & B 31f. & \\
\hline \multirow[t]{2}{*}{ Nanna } & $e_{2}$ & a & $9,2: 1-2$ & Ur \\
\hline & $e_{2} d_{\text {nanna }}$ & $\begin{array}{l}\mathrm{a} \\
\mathrm{a} \\
\mathrm{a}\end{array}$ & $\begin{array}{l}1: 3-4 \\
26,1: 9-10 \\
40: 8-9 \\
47,1: 12-13\end{array}$ & $\begin{array}{l}\text { Ur } \\
\text { Ur, Diqdiqqah } \\
\text { Ur, mausoleums of } \\
\text { Sulgi and } \\
\text { Amarsu'en } \\
?\end{array}$ \\
\hline
\end{tabular}

\footnotetext{
6 Hallo, JCS 20 (1966) 139.

7 Frayne, Correlations 72-138.

8 Cf. I 1., p. 6.

9 Cf. I 1., p. 4 , fn. 30.

$10 \mathrm{Cf}$. also below, IV 1.2 , p. $57 \mathrm{f}$.

11 Sumerian $\mathrm{e}_{2}$ and Akkadian bitu are both used in the sense of "house(hold), home, temple, estate".

$12 \mathrm{a}=\mathrm{d} \mathrm{u}_{3}$ "to construct" and $\mathrm{b}=\mathrm{k} \mathrm{i}-\mathrm{b}$ i $\mathrm{g} \mathrm{e}_{4}$ "to restore".

13 The numbering of inscriptions follows Steible, FAOS 9/2 (1991) 93-152, of year names, Sigrist, Gomi, Ur III Catalogue $319 \mathrm{f}$.
} 


\begin{tabular}{|c|c|c|c|c|}
\hline \multirow[t]{2}{*}{ Nanna } & $\mathrm{e}_{2}$-kiš-nu-ĝal ${ }_{2}$ & $\mathrm{a}$ & $\begin{array}{l}\text { C } 108-110, \\
\text { EF passim }\end{array}$ & \\
\hline & $\mathrm{e}_{2}$-temen-ni ${ }_{2}$-guru ${ }_{3}$ & $\begin{array}{l}a, b \\
a\end{array}$ & $\begin{array}{l}10: 10-13 \\
25: 9-10 \\
\text { E } 18^{\prime}\end{array}$ & $\begin{array}{l}\text { Ur, in the walls of } \\
\text { the ziggurat } \\
\text { Ur, Eridu (?) }\end{array}$ \\
\hline Ningal & $\hat{\mathrm{gi}} \mathrm{i}_{6}-\mathrm{par}_{3}-\mathrm{ku}_{3} \cdot \mathrm{g}$ & $\mathrm{a}$ & $19: 7-8$ & Ur, Ĝiparku \\
\hline Ningublaga & $\mathrm{e}_{2}$ & \begin{tabular}{ll|} 
u š & ki \\
gar &
\end{tabular} & year name $" 17 "$ & \\
\hline \multirow[t]{2}{*}{ Enki } & $\mathrm{e}_{2}$ & $\begin{array}{l}\mathrm{a} \\
\mathrm{a} \\
\end{array}$ & $\begin{array}{l}12: 7-8 \\
46: 7-8 \\
\end{array}$ & $\begin{array}{l}\text { Eridu } \\
? \\
\end{array}$ \\
\hline & $\mathrm{e}_{2} \mathrm{den}_{\mathrm{e}} \mathrm{ki}$ eriduki-ga & a & $4: 3-6$ & Eridu \\
\hline Ninhursaĝ & {$\left[\mathrm{e}_{2}(?)-\mathrm{k}\right] \mathrm{es}(\mathrm{i})_{3} \mathrm{ki}$} & a & 14 obv. 7-rev. 1 & $\begin{array}{l}\text { Northern Babylo- } \\
\text { nia, perhaps Keš }\end{array}$ \\
\hline \multirow[t]{2}{*}{ Ninsumun } & $\begin{array}{l}\mathrm{e}_{2} \mathrm{~d}_{\text {nin-sumun }} \\
\mathrm{e}_{2} \mathrm{~d}_{\text {nin-sumun }} \\
\mathrm{uri}_{2} \mathrm{ki}_{\text {-ma }}\end{array}$ & $\mathrm{a}$ & $\begin{array}{l}2: 3-4 \\
\text { year name "6" }\end{array}$ & $\begin{array}{l}\text { Radhibah, in the } \\
\text { vicinity of } U r\end{array}$ \\
\hline & $\mathrm{e}_{2}-\mathrm{mah}$ & a & 15 obv. 7 -rev. 2 & palace of Ur \\
\hline \multirow[t]{3}{*}{ Inana } & $e_{2}$ & $\begin{array}{l}\mathrm{a} \\
\mathrm{a} \\
\end{array}$ & $\begin{array}{l}6: 6-7 \\
8: 6-7 \\
\end{array}$ & $\begin{array}{l}\text { Ur } \\
\text { Enunmah in Ur }\end{array}$ \\
\hline & $e_{2}$ & $\begin{array}{l}a \\
a, b\end{array}$ & $\begin{array}{l}7,2: 3-4 \\
13 \text { rev. } 1-3\end{array}$ & $\begin{array}{l}\text { Eana in Uruk } \\
\text { Eana ziggurat in } \\
\text { Uruk }\end{array}$ \\
\hline & ešs ${ }_{3}$-bur & $\mathrm{a}$ & $17: 8-10$ & Ur, Ĝiparku \\
\hline Ninegal & $e_{2}$ & a & $18: 7-8$ & Ur, Ĝiparku \\
\hline Ninšagepada & $e_{2}$ & a & $38: 5-6$ & $\begin{array}{l}\text { Ur, mausoleums of } \\
\text { Sulgi and } \\
\text { Amarsu'en }\end{array}$ \\
\hline Utu & $\mathrm{e}_{2}$ & $\mathrm{a}$ & $11: 7-8$ & Larsa \\
\hline
\end{tabular}

b.) offerings ( $\mathrm{n} \mathrm{d} b \mathrm{~b}$ ):

1. general: A 163; A 85-133 (offerings for/of the netherworld); B 35 (for Enlil and Ninlil); C 42 (for Nanna); 93 (obscure, perhaps for Enlil); C 103-106 (possibly the innovation of the first-fruit offerings for Enlil in Nippur); D (Ni) 33 ॥ 34 and D (Ur) 35' (birds and fish for Nanna); EF 20 (offerings of Ekišnugal's g i $\mathrm{g} \mathrm{u} \mathrm{n}_{4}-\mathrm{n}$ a); Codex Urnamma 25-30 (regular offerings).

2. canals for (= to transport) offerings ( $\left.i_{7} \mathrm{n} \mathrm{i} \mathrm{d} \mathrm{b} \mathrm{a} \mathrm{(}-\mathrm{k}\right)$ ): 
$\alpha$ ) the $\mathrm{i}_{7}-\mathrm{uri}{ }_{5} \mathrm{ki}-\mathrm{ma}$ : Urnamma 22:8-9; $\beta$ ) the $\mathrm{i}_{7}$ EN.ERE $N_{2}$. NUN (var. $i_{7}-E N . N U N$ ): Urnamma 23:9-10, both for Enlil. ${ }^{14}$

3. libations: C 106 (for Enlil in Nippur).

4. royal epithets: D (Ni) 38 "provider $\left(\mathrm{u}_{2}-\mathrm{a}\right)$ for Nippur", "supporter (s a $\hat{g}$ - $\mathrm{u} \mathrm{s}_{2}$ ) of Ur"; D (Ur) 39' "provider ( $\left.\mathrm{u}_{2}-\mathrm{a}\right)$ for Sumer and Akkad".

II. Maintenance of a.) overland and b.) maritime routes ${ }^{15}$ :

a.) overland routes ( $\mathrm{g}$ i $\mathrm{ri}_{3}$ s i $\mathrm{s} \mathrm{a}_{2}$ ): $\mathrm{C} \mathrm{19;54;} \mathrm{year} \mathrm{name} \mathrm{"4";} \mathrm{Codex}$ Urnamma 155-157 (broken, very uncertain).

b.) maritime routes (n a m - g a - e š 8 s i 1 i m): Urnamma 26, 2:2-3; Codex Urnamma 150-154 (broken, very uncertain).

III. Territorial (military) operations:

a.) general military: A 32; 35 (as military leader); C 41 (broken context); C 72 (vigorous troops for the security of the land); C 85-89 (broken passage in which Ur's control over a territory is established after the repulsion of enemy troops [?]); B 52-65; F 30-35 (enemy lands).

b.) specific military ${ }^{16}$ :

1. The Guti: C 90; Ni. 4375 iv 4'.

2. Anšan (indirect): establishment of freedom from the slavery of Anšan for Akšak, Marada, ĜIRkal, Kazallu and its settlements, Ușarum: Codex Urnamma 125-134.

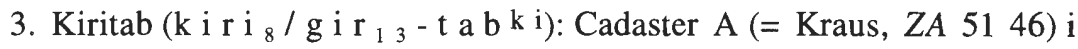
13.

4. Apiak (a - $\mathrm{p} \mathrm{i}_{5}-\mathrm{a} \mathrm{k} \mathrm{k} \mathrm{i)}$ ): Cadaster A (= Kraus, ibid.) ii 20-21

5. Most probably Urum ([ u r u ] $\mathrm{m}_{2} \mathrm{k} \mathrm{i}^{17}{ }^{17}$ : Cadaster A (= Kraus, ibid. 47) iv $20-21$.

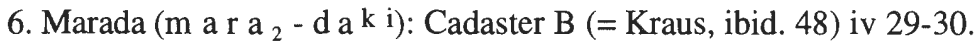

7. Urnamma mentioned with Puzur/Kutik-Inšušinak of Awan: Wilcke in Hrouda (ed.), Isin-Išān Baḥrīyāt III..., ABAW NF 94 (1987) 109 (= IB 1537) v' $15^{\prime}$ and pl. 44.

\footnotetext{
14 Cf. Carroué, ASJ 15 (1993) $11 \mathrm{ff}$. With Carroué, ibid. 11 and $18 \mathrm{ff}$. read for E N. E R E N ${ }_{2}$. N U N perhaps u r u ${ }_{16} / \mathrm{u} \mathbf{r} \mathrm{n} \mathrm{ur} \mathrm{u}_{3}-\mathrm{g}$ a $\mathrm{l}$.

$15 \mathrm{Cf}$. also above, I 1., p. 5 and below, IV 1.2, p. 56.

$16 \mathrm{Cf}$, also above, I 1., pp. $5 \mathrm{ff}$.

17 Cf. Steinkeller, JCS 32 (1980) 25.
} 
c.) maintenance of boundaries ${ }^{18}$ :

\begin{tabular}{|c|c|c|}
\hline Term & Object & Attestations \\
\hline $\begin{array}{l}\mathrm{b} \text { a } \mathrm{r} \mathrm{t} \text { a } \mathrm{m} \text { "to clear up } \\
\text { the matter" }\end{array}$ & $\begin{array}{l}\text { demarcation canal } \\
\mathrm{N} \text { a n n a g u a l }\end{array}$ & $28,1: 17$ \\
\hline $\mathrm{g} \mathrm{e}_{4}$ "to return" & the Magan-boats & Codex Urnamma 79-84 \\
\hline $\begin{array}{l}\mathrm{KA} \mathrm{g} \mathrm{e} / \mathrm{i} \cdot \mathrm{n} " t o \\
\text { confirm" }\end{array}$ & $\begin{array}{l}\text { demarcation canal } \\
\mathrm{N} \text { a n n a } \mathrm{g} \mathrm{u} \mathrm{g} \text { a } 1 \\
\text { (demarcated) Magan } \\
\text { maritime territory } \\
\text { border territory of Sumer } \\
\text { field of Numuš da of } \\
\text { Kiritab } \\
\text { the (demarcated) territory } \\
\text { of Meslamtaea of Apiak } \\
\text { the (demarcated) territory } \\
\text { of Su'en of [Uru]m } \\
\text { the (demarcated) territory } \\
\text { of Lugalmarada of Marada }\end{array}$ & $\begin{array}{l}28,1: 18 \\
47,2: 3 \\
\text { Ni. } 4375 \text { v } 13^{\prime} \\
\text { Cadaster A (= Kraus, ZA } \\
5146 \text { ) i } 15 \\
\text { Cadaster A (= Kraus, ibid. } \\
46 \text { ) ii } 22 \\
\text { Cadaster A (= Kraus, ibid. } \\
\text { 47) iv } 22 \\
\text { Cadaster B (= Kraus, ibid. } \\
48 \text { ) iv } 31\end{array}$ \\
\hline $\begin{array}{l}\mathrm{k} \mathrm{i} \quad \mathrm{s} \text { u r - r a "demar- } \\
\text { cated territories" }\end{array}$ & $\begin{array}{l}\text { of Sumer } \\
\text { Magan maritime territory } \\
\text { demarcation canal } \\
\text { N a n n a g u g a l } \\
\text { of Meslamtaea of Apiak } \\
\text { of Su'en of [Uru]m } \\
\text { of Kiš and Kazallu } \\
\text { of Lugalmarada of Marada }\end{array}$ & $\begin{array}{l}\text { C } 82 \\
47,1: 3-4 \\
28,1: 12 \\
29, \text { b } 1: 10^{\prime \prime}-11 " \\
\text { Cadaster A (= Kraus, ZA } \\
5146 \text { ) i } 30 \text {; ii } 1 \\
\text { Cadaster A (= Kraus, ibid. } \\
\text { 46) ii } 20 \\
\text { Cadaster A (= Kraus, ibid. } \\
\text { 47) iv } 20 \\
\text { Cadaster B (= Kraus, ibid. } \\
\text { 47f.) i } 1 \text {; iv } 25 \\
\text { Cadaster B (= Kraus, ibid. } \\
\text { 48) iv } 29\end{array}$ \\
\hline $\begin{array}{l}\mathrm{s} \text { i } \mathrm{s} \mathrm{a}_{2} \text { "to bring in } \\
\text { order" }\end{array}$ & $\begin{array}{l}\text { hostile and rebellious } \\
\text { lands }\end{array}$ & B 14 \\
\hline $\begin{array}{l}\text { š } \mathrm{u}-\mathrm{a} \mathrm{g} \mathrm{e}_{4} \text { "to return } \\
\text { to somebody/DN/some- } \\
\text { thing('s control), to keep } \\
\text { secure" }\end{array}$ & $\begin{array}{l}\text { the land } \\
\text { (demarcated) Magan } \\
\text { maritime territory } \\
\text { the Magan-boats } \\
\text { broken context }\end{array}$ & $\begin{array}{l}\text { C } 72 \\
47,2: 4 \\
26,2: 4 \\
\text { C } 86\end{array}$ \\
\hline
\end{tabular}

18 Cf. also above, I 1., p. 6 f. 
IV. Juridical activities: A 139-144 (as judge); C 32-39/40; E 27'-32'; F 30-33; Codex Urnamma 41-42 (broken); 104-113; 177-181 (establishing justice in the land); C 56 (exemptions from obligation a $\mathrm{m} \mathrm{a} \mathrm{-} \mathrm{a} \mathrm{r} \mathrm{g} \mathrm{e}_{4}$ ); Codex Urnamma 125134 (release a m a-ar $\mathrm{g} \mathrm{e}_{4} \quad \mathrm{~g}$ ar from slavery $\mathrm{n}$ a m-u rdu); Codex Urnamma 162-165 (care of widows and orphans).

V. Construction $\left(\mathrm{d} \mathrm{u}_{3}\right)$ of walls ${ }^{19}$ :

a.) $\mathrm{b} \mathrm{ad}_{3}$ ( $\mathrm{u} \mathrm{ri}_{2 / 5} \mathrm{k} \mathrm{i}-\mathrm{m} \mathrm{a}$ ): A 148 (not finished); C 92; Ni. 4375 iv 14'; Urnamma 9, 2:3-4; year name "11".

b.) b a d 3 n i b r u k i : Urnamma 45:8-9.

VI. Building of fortified villages ( $\mathrm{a}-\mathrm{z} \mathrm{a}-\mathrm{g} \mathrm{a} \mathrm{r}_{3}$ ) and settlements $\left(\mathrm{a}_{2}-\mathrm{d} \mathrm{a} \mathrm{m}\right.$ ): A 229.

VII. Irrigation and cultivation descriptions are abundant in the hymns. The inscriptions concern mainly canal construction, the draining of swamps and the layout of gardens, two regnal years are named after the digging of a canal.

a.) digging of canals ( $i_{7} \quad$ b a - a l):

1. general: A 225.

2. specific:

\begin{tabular}{|c|c|c|}
\hline $\begin{array}{l}\text { Canal name (in alphabetical order) and type } \\
\text { of canal }\end{array}$ & Attestations & Provenance \\
\hline$i_{7}-a-d n i n-t u \cdot r$ & year name " 15 " & \\
\hline 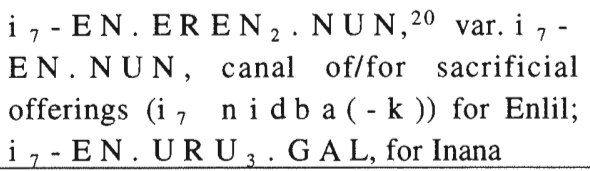 & $\begin{array}{l}23: 9-11 ; \text { Al-Rawi, Sumer } \\
46(1989-90) 84: 8-10\end{array}$ & $\begin{array}{l}\text { Ur, } \\
\text { Diqdiqqah, } \\
\text { Eridu, Uruk }\end{array}$ \\
\hline $\begin{array}{l}\mathrm{i}_{7}-\mathrm{gu}_{2}-\mathrm{b} \mathrm{i} \text { e } \mathrm{riduki}-\mathrm{ga}(\| \text { ?) } \\
\mathrm{i}_{7}-\mathrm{gu}_{2}-[\mathrm{x}]-\mathrm{ur}_{2} ?(-) \mathrm{d}_{\mathrm{n}} \mathrm{in}- \\
\mathrm{g} \mathrm{ir}_{2}-\mathrm{su}\end{array}$ & 29, b $1: 13^{\prime \prime}-16^{\prime \prime}$ & Ur \\
\hline$i_{2}-\hat{g}$ e $\check{s}-\check{s} u b-b a$ & year name "16" & \\
\hline $\begin{array}{l}\mathrm{i}_{7}(-) \hat{\mathrm{G}} \mathrm{E} \check{S} . \mathrm{B} \mathrm{I} . \hat{\mathrm{G}} \mathrm{E} \check{S}(-) \text { a }(-) \\
\hat{\mathrm{g}} \text { a } \mathrm{r}-\mathrm{r} \text { a }(?)\end{array}$ & $\mathrm{D}(\mathrm{Ur}) 4^{21}$ & \\
\hline $\mathrm{i}_{7}-\mathrm{KES}_{2}-\mathrm{k} \mathrm{u}{ }_{3} \cdot \mathrm{g}$ & $\begin{array}{l}\text { D (Ni) } 2 \text { (broken); } 22 \| \\
23 ; \mathrm{D} \text { (Ur) } 30^{\prime} ; 33^{\prime}\end{array}$ & \\
\hline
\end{tabular}

19 Cf. also below, p. 36.

20 For a possible reading u $\mathrm{r} \mathrm{u}_{16} / \mathrm{u} \mathrm{r} \mathrm{u} \mathrm{n}_{\mathrm{r}} \mathrm{u}_{3}-\mathrm{g}$ a $\mathrm{l}$, cf. above, fn. 14 .

21 Cf. the commentary ad $4 \mathrm{a}$ in V 4.5 , p. 254. 


\begin{tabular}{|c|c|c|}
\hline 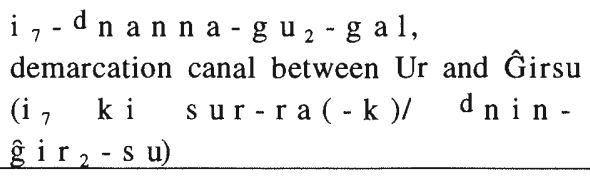 & $\begin{array}{l}29, \text { b } 1: 9^{\prime \prime}-12^{\prime \prime}=28 \\
1: 12\end{array}$ & Ur \\
\hline $\mathrm{i}_{7}-\mathrm{n}$ u $\mathrm{n}$, main irrigation canal & $24: 7-9$ & $\begin{array}{l}\text { Ur, } \\
\text { Diqdiqgah }\end{array}$ \\
\hline $\mathrm{i}_{7}(-) \mathrm{p} \mathrm{a}_{4 / 5}-\mathrm{b} \mathrm{i}(-) 1 \mathrm{u} \mathrm{h}$ & $\begin{array}{l}\text { D (Ur) 2' (broken); 31'; } \\
34^{\prime 22}\end{array}$ & \\
\hline $\begin{array}{l}\mathrm{i}_{7}-\mathrm{u} \mathrm{r} \mathrm{i}_{5} \mathrm{ki}-\mathrm{ma} \text {, canal of/for sacri- } \\
\text { ficial offerings }\left(\mathrm{i}_{7} \mathrm{nidb} \mathrm{a}(-\mathrm{k})\right) \text { for } \\
\text { Enlil }\end{array}$ & $22: 6-10$ & $\begin{array}{l}\text { Ur, } \\
\text { Diqdiqqah, } \\
\text { Uruk }\end{array}$ \\
\hline $\begin{array}{l}a-b\left[a-d n \text { a } n \text { a }-g \text { i } n_{7}\right] \\
\text { embankment for drainage in Ur, for Nanna }\end{array}$ & $27,2: 3-8$ & $\mathrm{Ur}$ \\
\hline broken and therefore unidentifiable canals & $\begin{array}{l}29, \text { b } 1: 2^{\prime \prime}-4 " ; \text { b } 1: 5^{\prime \prime}-8 " ; \\
29 \text {, b } 1: 6^{\prime \prime}-8^{\prime \prime}\end{array}$ & \\
\hline
\end{tabular}

b.) drainage (a-t a e $\left.\mathrm{e}_{3} / \mathrm{e}_{11} / \mathrm{D} \mathrm{U}\right)$ : A 227 ( $\mathrm{g}$ e $\breve{s}-\mathrm{g} \mathrm{i}$ "canebrakes"); Urnamma 27, 1:11-2:2 (broken) (a - š a ${ }_{3} \cdot g$ "field").

c.) embankments and ditches (e $\mathrm{g}_{2}$ and $\left.\mathrm{p} \mathrm{a}_{5} . \mathrm{r}\right)$ : A 25; G 19 \|ा 20; 21; Urnamma 27, 2:3-4 (broken).

d.) irrigation/floods: A 22; C $23 \| \mathrm{G} 8$; C 83.

e.) lay-out of gardens ( $\mathrm{k}$ i $\mathrm{r} \mathrm{i}_{6}$ D U): Urnamma 5:5-6 (for An); Codex Urnamma 158-160 (broken); 161 (employment of gardeners).

f.) field work:

1. ploughing and furrowing: $\mathrm{G} 10-18$.

g.) husbandry:

1. cattle (pens) and sheep(-folds): A $29 ; 30 ; 87$; C 26; 76; 77; D (Ni) 29-30; G $13 ; 15$.

2. fish and birds: D (Ni) $25-28 ; 31 ; 33-34 ; \mathrm{D}$ (Ur) $32^{\prime}-35^{\prime}$.

h.) agriculture:

1. fields and crops: A 23; 24; 228; C 23 ॥ G 8; C 53; 55;80;88; D (Ur) 37'; G 10-15; 19 ॥| 20.

2. river bank plants and thickets: C 83; G 11 (g e š "wood"); D (Ni) 27-28; D (Ur) 36' (u ${ }_{2}-1$ a $l_{3}$ "honey-plants"); D (Ni) 29-30 (g i - z i "reed fodder");

22 Perhaps an epithet of the $\mathrm{i}_{7}-\mathrm{KE} \mathrm{S}_{2}-\mathrm{k} \mathrm{u}{ }_{3} \cdot \mathrm{g}$ in the Nippur recension, cf. the commentary ad 4 in $\mathrm{V}$ 4.5 , p. 254. 
D (Ur) 36' (" z u n z e r "liquorice"); perhaps H 3 (̂ e še s i "ebony").

3. pastures and watering places: $\mathrm{C} 78$.

4. food $\left(\mathrm{u}_{2}\right)$ : A 27; C 75 .

5. Perhaps G A N A $2(-)$ de $\mathrm{n}-1 \mathrm{il}_{2}-1 \mathrm{a}_{2}$ in $\mathrm{G} 16 \| 17$ is a field name.

The last narrative section of Urnamma A tells of the decreeing of fate for the dead king Urnamma (lines 217-233). In a fragmentary passage the king is assured of posthumous fame, or perhaps more specifically, of continuous funerary offerings, ${ }^{23}$ and it is stated that this derives from his economic achievements that brought prosperity to the land (lines 225-229). There is indeed ample reference in other Urnamma texts of his reclamation of land, and his irrigation and cultivation projects, all of which support this very general claim. The focal point of canal construction seems to have been the state's capital at Ur and its vicinity because most of Urnamma's inscriptions that centre on irrigation projects have been found at Ur and also his hymn D is exclusively devoted to canal digging at Ur. None of his Ur III successors mention canal construction in their inscriptions and year names, so the canals documented in the Urnamma texts may have fulfilled the needs of irrigation in that area for that stretch of time, a finding further supported by the fact that administrative texts from Umma and Ĝirsu mention no major irrigation works during the six decades following Urnamma's reign. ${ }^{24}$

Urnamma's royal inscriptions refer extensively to building and work on temples for all the major gods. His early building projects as "king of Ur" (l u g a l $\mathrm{u} \mathrm{r} \mathrm{i}_{5} \mathrm{ki}-\mathrm{m}$ a) involved the capital Ur and its vicinity and were mainly intended for the city-god Nanna and for originally Urukian deities that were important for the royal family cult, Ninsumun, the newly founded dynasty's divine mother, ${ }^{25}$ and Inana, the king's divine wife. ${ }^{26}$ In Ur construction took place of Nanna's temple ( $e_{2} \mathrm{~d} n$ a n n a, Urnamma 1), the Ekišnugal, and its ziggurat with the temple terrace, the Etemenniguru (Urnamma 25). Further attested for this early phase are building inscriptions for Inana-Ninkununa's temple (Urnamma 6 and as Ninana perhaps Urnamma $8^{27}$ ) and for Ninšagepada's (Urnamma 38). In the vicinity of Ur, in modern Radhibah, Unnamma constructed Ninsumun's temple $\left(e_{2} d \mathrm{n}\right.$ i $\mathrm{n}$ s u m u $\mathrm{n}_{2}$, Urnamma 2), in Eridu Enki's ( $e_{2}$ de $\mathrm{n}-\mathrm{ki}$ e ri duki-g a, Urnamma 4). Construction of the Ekišnugaal (Urnamma 40, also 26 and 47) with the Etemenniguru (Urnamma 10), as well as that of Enki's temple in Eridu (Urnamma 12,46), was continued in a later phase when the king used the titulary "king of Sumer and Akkad" (l u g a l k i - e n-g i k i-u r i (-k)). The other

\footnotetext{
$23 \mathrm{Cf}$. the commentary ad 222 in V 1.4, p. 181.

24 Cf. Civil, Farmer's Instructions 135.

25 Cf. V 3.3 , p. 86.

26 Cf. ibid.

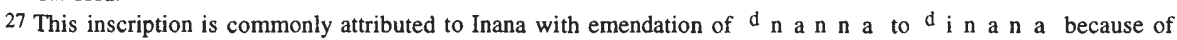
the following epithet $\mathrm{n}$ i $\mathrm{n}$ a $\mathrm{n}$ - $\mathrm{n}$ a (cf. Steible, FAOS 9/2 [1991] 102 ad 1)).
} 
temple projects attested for this period in his reign are in Ur Ningal's Giparku, part of the Ekišnuĝal complex (Urnamma 19), Ninegal's temple in the Ĝiparku (Urnamma 18), Inana-Ninkununa's sanctuary e š ${ }_{3}-\mathrm{b} \mathrm{u} \mathrm{r}{ }^{28}$ (Urnamma 17), and Ninsumun's temple $\mathrm{e}_{2}-\mathrm{m} \mathrm{ah}^{29}$ in the palace complex (Urnamma 15). Work on temples in other places under the king's dominion include Enlil's main temple $\left(\mathrm{e}_{2}\right.$ de n - 1 i $1_{2}-1 \mathrm{a}_{2}$ ) Ekur (Urnamma 3 and 16) and Ninlil's "storeroom" (?) $\left(\mathrm{e}_{2}-\right.$ š u - t u m, Urnamma 21) in Nippur, Inana's temple Eana and its ziggurat in Uruk (Urnamma 7 and 13), Ninhursaĝ's temple, perhaps in Keš, (Urnamma 14), and Utu's in Larsa (Urnamma 11).

Urnamma's year names, in contrast to those of his successors, only refer to temple construction marginally: year "6" and "17" are named after temple constructions for Ninsumun and Ningublaga respectively.

The hymns are in general not explicit on temple construction. Only two major building projects, one for Nanna-Su'en, the city-god of the capital Ur, and the other for Enlil, the national god, deserved special mention: hymn B commemorates the building of the Ekur and also mentions Ninlil's Ĝaĝeššua in the Ekur complex. Hymn C was probably composed to mark the reconstruction of Nanna/Su'en's temple Ekišnuĝal and the subsequent inauguration of the first-fruit offerings for Nippur; the Ekišnugal also features prominently in hymn EF.

Wall constructions are mentioned in all major data, i.e. inscriptions, year names and literary compositions. ${ }^{30}$ They took place in Ur in Urnamma's early reign as "king of Ur" (Urnamma 9) and later in Nippur as "king of Sumer and Akkad" (Urnamma 45). It is uncertain if the walls refer to city-walls or rather walls surrounding the cities' temple precincts, for which there is ample written evidence. ${ }^{31}$ The wall mentioned in Urnamma C 92 (perhaps also referred to in Ni. 4375 iv 14') whose construction Urnamma undertook after the expulsion of the Guti (lines 9091, perhaps already 85ff.) could also possibly refer to the temple precinct wall of $\mathrm{Ur}$, as $\mathrm{e} \mathrm{š}_{3} \mathrm{ur} \mathrm{i}_{5} \mathrm{ki}$ is mentioned in the same line 92. According to W. Sallaberger the wall construction recorded in Urnamma 9 may likewise refer to the wall surrounding the temenos of the Ekišnugal. ${ }^{32}$ At least it is apparent that Urnamma 9, in which Urnamma is called "king of Ur", combines the construction of the wall with that of Nanna's temple, just as Urnamma C mentions the construction of Nanna's temple Ekišnugal after the restoration of the wall.

Urnamma's juridical activities or references to them are found mainly in hymns $\mathrm{C}$ and $\mathrm{EF}$, and one can of course add to this material the promulgation of his law code. That his reign saw military operations and border disputes can be deduced mainly from references in royal inscriptions, from the prologue of the law code and

\footnotetext{
28 According to George, House Most High 165 ad 1328 perhaps identical with Inana's temple at $\mathrm{URU} \times \mathrm{KAR}_{2}{ }^{\mathrm{ki}}$, built by Urba'u, but all sources for Urnamma 17 come from Ur.

29 Cf. George, House Most High 119 ad 717 (no. 5).

$30 \mathrm{Cf}$. above, V a.)-b.), p. 33.

31 Cf. e.g. Gudea, Cyl. B 12:20; Gudea 4 rev. 4-5 I| 5:9-10; Gudea 31:14-15, of the $\mathrm{e}_{2}$ - s i r a r a; Sulgi 11 rev, 3-4, of Inana's Eana.

32 Sallaberger, "Urkunden aus der Zeit der Dritten Dynastie von Ur, eine Einführung", in Attinger, Wäfler (eds.), Mesopotamien, Akkade-Zeit und Ur III-Zeit, Annäherungen 3, OBO XXX (in preparation).
} 
from the Cadaster text. Only hymn $\mathrm{C}$ makes mention of a specific military conflict, this being with the Guti, a fact also mentioned in the fragment Ni. 4375. A passage in hymn B describes in rigid poetic structure Urnamma's combat against enemy lands.

Urnamma $\mathrm{C}$ is the only hymn in which all deeds mentioned are supported by the other sources. However, the deeds described remain general, except for the specific mention of the Ekišnugal, the journey to Nippur, and the military encounter with the Guti. Several passages in Urnamma $\mathrm{C}$ describe general territorial operations, ${ }^{33}$ whereas the other sources refer to adversaries by name. Border territories in connection with the maintenance of boundaries ${ }^{34}$ are simply called "land" (k a l a m), ${ }^{35}$ or "the region of Sumer" ( $\mathrm{k}$ i s u r - r a k i - e n - g i - r a), ${ }^{36}$ while on the other hand non-hymnic sources refer to a specific object (e.g. canal, field, such-and-such territory). Other hymns do not encompass so broad a range of royal deeds, but focus rather on one aspect of Urnamma's reign: Urnamma $G$ concentrates solely on agriculture, Urnamma D on the digging of canals, Urnamma $\mathrm{B}$ and EF on the temples Ekur and Ekišnugal and Urnamma's relationship with the gods Enlil and Nanna.

One topic, though, is suspiciously and consistently absent in the Urnamma hymns, namely the praise of scribal art, patronage of the scribal schools, and the kings' literary achievements. This absence is puzzling, as Urnamma's successors Sulgi, Išmedagān and Lipiteštar refer to the composition of their hymns and/or their scribal schools in their hymns, as does even Urnamma's predecessor Gudea in his Statue B, which presupposes in turn a more or less well-established literary topos that had already existed in Lagaš in Gudea's time.

\section{Is Urnamma C a Chronological Summary of His Reign?}

D.R. Frayne put forward in some detail possible correlations of the hymn Urnamma $\mathrm{C}$ with year names and information in royal inscriptions and other material. ${ }^{37}$ He maintained that the order of events in Urnamma $\mathrm{C}$ is chronological and follows the order of events cited in the year names, rather than being ordered thematically, as in other self-laudatory hymns. ${ }^{38} \mathrm{He}$ thought his hypothesis confirmed by evidence found in Ni. $4375 .{ }^{39}$ The fragment lists, according to D.R. Frayne, some events in exactly the same order as does Urnamma C. However, there are some difficulties with this assumption, as with his hypothesis in general that

\footnotetext{
33 Cf. above, III a.), p. 31.

34 Cf. above, III c.), p. 32.

35 Unamma C 72.

36 Urnamma C 82.

37 Frayne, Correlations 79-121; idem, BiOr. 42 (1985) 15-17.

$38 \mathrm{Cf}$. Frayne, BiOr. 42 (1985) 15, and fn. 53, for another example of an alleged chronicle hymn.

39 For this fragmentary piece, cf. II 2,, p. $17 \mathrm{f}$.
} 
the chronological order of Urnamma $C$ follows that of his year names. To be sure, the hymn does contain biographical features, as do other Urnamma hymns and selflaudatory hymns of Urnamma's successors. It is difficult, however, to correlate the biographical information contained in hymn $\mathrm{C}$ with the sequence of Urnamma's year names, which are so far only partially known. The only royal titles used in the hymn are "king of Ur" $1 \mathrm{u} \mathrm{gal}$ u r i ${ }_{5} \mathrm{ki}-\mathrm{m}$ a (lines 19 and 31) and "king of the land" $1 \mathrm{ug}$ a l k a l a m-m a (line 25). ${ }^{40} \mathrm{He}$ is $\mathrm{d} 1 \mathrm{am} \mathrm{m}$ a "guardianspirit" of Ur (line 31) and later on of the Land Sumer and Akkad (line 50), but it is not possible to divide the hymn into events that happened early in his reign, as king of Ur, and later, as "king of Sumer and Akkad" (l u gal k i - e n - g i k i - u ri ( - k )).

It is unlikely that the very fragmentary piece Ni. 4375 lists all events in the same order as Urnamma $C$. There is no way in which to determine the approximate length of the gaps, nor is it sure if the fragment has to be read from left to right. ${ }^{41}$ Also, D.R. Frayne based his correlation suggestions on the edition of Urnamma C by G. Castellino, some of whose readings and restorations are shown to be incorrect in this study. Note, in detail, the following:

Lines 73-75 of Urnamma $C$ describe Urnamma's cultic function as e $n$-priest. D.R. Frayne wants to correlate this section with Ni. 4375 v 1'-5' in which full implementation of e $\mathrm{n}$-ship and fate decreed in the Ekišnugal is mentioned. ${ }^{42} \mathrm{He}$ rightly states that in Urnamma C 73-75 the king is involved in a "sacred marriage" type of ritual, and as this seems to take place in the Ekišnugal complex, he may have been involved in designating the e $\mathrm{n}$-priestess of Nanna. But we know that Urnamma was e $\mathrm{n}$-priest of Uruk, that is of Inana, so $\mathrm{g}$ i $\mathrm{p}$ a $\mathrm{r}$ in line 73 must refer to the one of Eana in Uruk, ${ }^{43}$ where the "sacred marriage" rite possibly took place and not, as D.R. Frayne subsequently surmises, ${ }^{44}$ to the $\mathrm{g}$ i p a r of the Ekišnugal. There is no reason to assume that these lines and the following lines that describe the resulting abundance (Urnamma C 76-80) are specifically linked to $\mathrm{Ur}$, and that therefore the $\hat{\mathrm{g}}$ i $\mathrm{p}$ a $\mathrm{r}$ mentioned is part of the Ekišnugal complex. On the contrary, lines 50-84 seem to describe Sumer (and Akkad)'s well-being. Only lines 85 and following focus again on Ur. The Ekišnugal was reserved for the e n -priestess of Nanna, and we know that a daughter of Urnamma bore that title. So the ritual sexual union between the king and the e $n$ of Nanna for which D.R. Frayne argues, would imply, in our case at least, ritual incest. ${ }^{45}$ It is therefore easier to see in the Urnamma $\mathrm{C}$ passage nothing else than a description of Urnamma as e $\mathrm{n}$-priest of Inana involved in the "sacred marriage" rite of which descriptions repeatedly mention the flowered/-ing ( $g$ e $r$ i $n$ ) bed. Seen in that way, however, there remains no basis for D.R. Frayne's above mentioned correlation

\footnotetext{
40 For details, cf. below, IV 1.3, p. $61 \mathrm{f}$.

41 Pace Frayne, BiOr. 42 (1985) 16, fn. 62.

$42 \mathrm{Cf}$. the Appendix, Ni. 4375 v 1'-5'.

43 Cf. Urnamma A 202 and 212-213.

44 Frayne, BiOr. 42 (1985) 16-17.

$45 \mathrm{Cf}$. in more detail Cooper, Sacred Marriage and Popular Cult 88.
} 
with $\mathrm{Ni} .4375$, nor is there any need to assume a hypothetical year name based on this correlation.

The "putting in order" of routes, and thus the promotion of overland trade $\left(\begin{array}{llll}\mathrm{g}^{-} & \mathrm{r} \mathrm{i}_{3} & \mathrm{~s} \mathrm{i} & \mathrm{S} \mathrm{a}_{2}\end{array}\right)$, is an event that happened most probably early in Urnamma's reign ${ }^{46}$ and in fact might be alluded to in Urnamma C $19,{ }^{47}$ but note that line 54 uses the same expression too.

The establishment of justice and the following setting in order of the roads are difficult to correlate with the mention of the promulgation of the law code after the reestablishment of the Magan trade ${ }^{48}$ in the prologue of Codex Urnamma, ${ }^{49}$ for there Urnamma uses the title "king of Sumer and Akkad", whereas in the Urnamma C passage he is simply "king of Ur" (lines 19 and 31), assuming that he adopted the latter title earlier in his reign.

In summary, Urnamma $\mathrm{C}$ undoubtedly has biographical features that are in part substantiated by non-literary data. It is difficult, however, to claim that these features are in chronological order in Urnamma C. The hymn seems to stress one important event, that being the erection of Nanna's temple in Ur. ${ }^{50}$ The prologue (lines 1-12) gives a hymnic description of the Ekišnugal and the king who commissioned its construction (lines 13-19). Urnamma's maintaining of law and order in all lands and territories under his rule (lines 32-41) guarantee an incessant flow of offerings for Nanna (line 42). A more general description of prosperity under Urnamma's reign finally culminates in the climactic final section in which the journey to Nippur is described and in which Urnamma summarises the main topic, namely that he has built the Ekišnugal for Nanna. We have no year name that fixes this event chronologically, but the royal inscriptions refer to the construction of "Nanna's temple" ( $\mathrm{e}_{2} \mathrm{~d} n \mathrm{n} n \mathrm{n}$ a) in two phases, early in Urnamma's reign as "king of Ur" and later on as "king of Sumer and Akkad". ${ }^{51}$ It is likely that Urnamma's first cultic act subsequent to his gaining control over Ur was to rebuild the Ekišnugal complex and innovate the yearly ceremony of first-fruit offerings for Enlil in Nippur, ${ }^{52}$ a ceremony that was repeated by his successor Sulgi. ${ }^{53}$ A slightly different interpretation was put forward by D.R. Frayne where he argued that Urnamma's trip to Nippur, in order to get recognition by the Nippur authorities of his hegemony over Sumer and Akkad, was the sole act which served as an impetus for the creation of Urnamma C. ${ }^{54}$

The marking of the first cultic act subsequent to (re)gaining or securing control over a city can be seen as a pattern in successive kings: one of the first events commemorated in year names by kings Sulgi (year 2) and Amarsu'en (year 3) is the

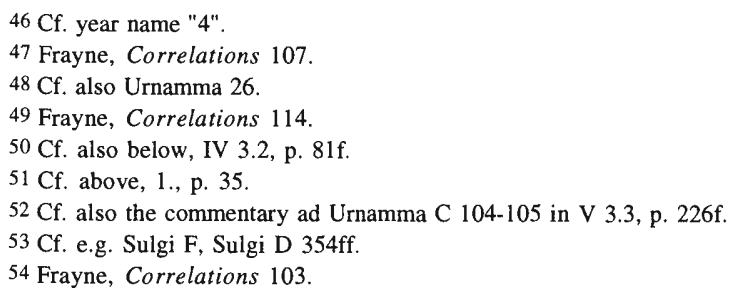


introduction of a throne for Enlil in Nippur..$^{55}$ Išbi'erra introduces Nanna's and Ningal's thrones (year 29) after gaining control over Ur (year 26). His son Šüilišu

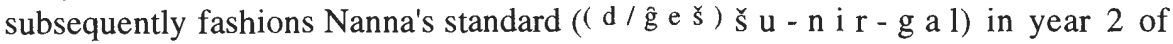
his reign, ${ }^{56}$ as does Gungunum after his conquest of Ur. ${ }^{57}$ The introduction of the standard to Nanna's temple is coupled with the bringing of first-fruit offerings to Enlil, and was an event which also seems to have been commemorated in a hymn, Gungunum A. ${ }^{58}$ Furthermore, Išmedagān installs thrones for Enlil and Ninlil in Nippur (year 6) after gaining control over that city, an event that is most probably also described in his self-laudatory hymn A, lines $285 \mathrm{ff}$. which mention different statues as well. ${ }^{59}$ In RIME 4.1.4.5 Išmedagān fashions a number of cult objects for Enlil and Ninlil, and the š i t a-weapon, the mace of fifty heads for Ninurta. Finally, Sîniqišam's year 4 and his royal inscription RIME 4.2.11.1 commemorate the introduction of a large number of statues to Nippur once that city is under his control. 


\section{CHAPTER IV}

\section{CONTINUITY AND CHANGE IN ROYAL H Y M N O G R A P H}

\section{Legitimacy and Kingship}

\subsection{Urnamma and the Sumerian King List}

Scholars generally agree at present that the so-called Sumerian King List ${ }^{1}$ was composed as a charter to legitimise the claim of a dynasty as rightful successor of a previous one. All copies of the list end with the names of the rulers of Isin who used the list to present their dynasty as legitimite successor of the Ur III state. ${ }^{2}$ No general consensus exists, however, as to the date of its earliest version. Th. Jacobsen, followed more recently by J.-J. Glassner ${ }^{3}$ and C.-A. Vincente, ${ }^{4}$ maintained that the list might have originated under Utuhegal of Uruk. But C. Wilcke, and most recently J.S. Cooper, have convincingly argued that the list was first compiled under the Third Dynasty of Ur to provide legitimation for the dynasty's hegemony over northern and southern Babylonia. C. Wilcke specifically preferred a Sulgi date, on the basis of the geographical horizon presented in the list and a literary allusion in Sulgi O 56-60. ${ }^{5}$ But two passages in Urnamma C show that a version could well be dated to Urnamma.

The passages Urnamma C 57-58 $r_{a}$ ? ? $-\mathrm{ma}-\mathrm{ru} \quad[\mathrm{g}] \mathrm{e}_{4}$ ? - $\mathrm{b}$ a $\mathrm{i}-\mathrm{t} \mathrm{i}$

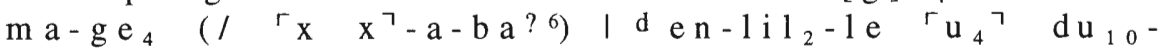
$\left.\mathrm{du}_{10}-\mathrm{ga}-\mathrm{na} \mathrm{mašs}-\mathrm{e} r \mathrm{bi} \mathrm{i}_{2}-\mathrm{in}\right\urcorner-\mathrm{pa}_{3}-\mathrm{de}_{3}-\mathrm{en}$ "When the storm had receded?, the moonlight returned to/for me (when ... ), Enlil designated me on his very auspicious day through extispicy", and Urnamma C 114 [a n-t] a

\footnotetext{
1 Edition by Jacobsen, AS 11 (1939). For a bibliography, cf. Wilcke, "Sumerische Königsliste" 114, fn. 7; Add now also Steiner, CRRAI 35 (1992) 261-79 with previous literature; Geller, Eblaitica 1 (1987) 141-45; Vincente, N.A.B.U. 1990/11; Glassner, Chroniques mésopotamiennes, Paris (1993) 137-42; Cooper, "Paradigm and Propaganda" 19-23; Vincente, ZA 85 (1995) 234-70.

2 Wilcke, "Sumerische Königsliste" 116; idem, Studies Sjöberg (1989) 558; Cooper, "Paradigm and Propaganda" $22 \mathrm{f}$.

3 Glassner, Chroniques mésopotamiennes, Paris (1993) $113 \mathrm{ff}$.

4 Vincente, ZA 85 (1995) 267.

5 Wilcke, "Sumerische Königsliste" 117; idem, Studies Sjöberg (1989) 560ff,; idem, "Politik und Literatur" 36, and fn. 39.

6 Possible verbal variant; cf. also II 4., p. 27.
} 
n a m-l ugal m a-ra- $\mathrm{e}_{11}$ ! ( S I. D U) "Fro[m heaven] kingship has come down to me", ${ }^{7}$ are two direct allusions to the ideology of the Sumerian King List. The vocabulary of these two passages are combined in Sumerian King List $i$ 40-41 e gir a-m a-ru ba-ur ${ }_{3}-\mathrm{ra}-\mathrm{ta} \quad \mathrm{nam}-1 \mathrm{ugal} \quad \mathrm{an}-\mathrm{ta}$ $\mathrm{e}_{11}-\mathrm{de}_{3}-\mathrm{a}-\mathrm{b}$ a "After the flood had swept over it (= the land), when kingship had come down from heaven", and show that the ideology of a single legitimate kingship, and the topoi of the deluge and divine origin of kingship found in the Sumerian King List, were used by Urnamma in his self-laudatory hymn. Thus the Sumerian King List may well have been first compiled in Urnamma's reign. Also, Urnamma, rather than Sulgi, whose succession to his father's throne seems not to have been in doubt, had every reason to find means to present his newly founded dynasty as the legitimate successor of the kingship of Uruk under Utuhegal. The list reflects, in fact, the pattern of the kingship of Ur always following the one of Uruk and moving from north to south, ${ }^{8}$ a pattern which fit Urnamma's circumstances precisely.

An Urnamma date might also explain the absence of the Lagaš rulers in the Sumerian King List. There is a possibility of an overlap of independent Lagaš rulers with the reign of Urnamma at Ur, ${ }^{9}$ and we know that a rivalry between Lagaš and Ur existed at the time of Utuhegal of Uruk who settled a boundary dispute in Lagaš's favour. ${ }^{10}$ That the boundary of Lagaš with Ur remained under dispute, is evident from Urnamma 28, which reports the digging of the $\mathrm{d} n \mathrm{n} n \mathrm{na}-\mathrm{g} \mathrm{u}_{2}$ g a l-canal, ${ }^{11}$ the "boundary canal of Ningirsu" (i,$\quad \mathrm{k}$ i - s u r - r a d $\mathrm{n}$ i $\mathrm{n}$ $\mathrm{g}$ i $\left.\mathrm{r}_{2}-\mathrm{s} \mathrm{u}\right),{ }^{12}$ demarcating the territory of Ur and that of Lagaš.

\subsection{Topoi of Legitimation and Kingship}

With reference to biblical studies on the history of genre, ${ }^{13} \mathrm{~S}$. Franke devoted one section of her dissertation to the question of the development and practice of the ancient Near Eastern literary tradition as a whole. ${ }^{14}$ In creating literary compositions, the ancient author was bound to certain traditional rules of composition, structure, and a repertoire of formal and stylistic features and vocabulary, but could also vary them according to his or her intention. Analysis of different stylistic and formal components allows us to draw conclusions as to the

\footnotetext{
7 With Steiner, CRRAI 35 (1992) 270, and fn. 74; cf. also the commentary ad 114 in V 3.3, p. 227.

8 Wilcke, Studies Sjöberg (1989) 559

9 Cf. I 1., p. 3.

10 Cf. ibid., p. 4.

11 Urnamma 28, 1:10-13.

12 Urnamma 29, b 1:10"-11". Cf. I 1., p. 5.

13 Also known as "Formgeschichte".

14 Franke, Königsinschriften und Königsideologie, Die Könige von Akkade zwischen Tradition und Neuerung, Altorientalistik 1, Hamburg (1995) 7-20.
} 
underlying tradition ${ }^{15}$ and its course of transmission. Different terms are in use for naming these components, and S. Franke presents a survey and attempts a definition of the most common terms, i.e. formula, motif, and topos, found in the secondary literature. From S. Franke's discussion it appears that these definitions do not exclude each other, and it is in fact often difficult to distinguish between them. The term formula is used on the formal level to mean the smallest stylistic and literary unit which can consist of a single expression or a complete sentence and appears in different types of texts. Some components of the expression can, however, change in the course of transmission. An example is $m u \mathrm{pa}_{3}-\mathrm{da}$ D N ( - k ) "called by name by DN" which appears in this form, or as a sentence with a verbal chain, but with different divine names. ${ }^{16}$ On the level of content, the formula as a text unit gives way to the term motif with which we stress content rather than form. It likewise consists of a recurrent image or pattern and is independent of context. The term topos can also encompass both formula and motif. Topoi are literary clichés or patterns in the form of fixed (mental) images, i.e. formulae or motifs, which belong to a specific tradition. They are used by the author to convey a specific message. Unlike so-called royal inscriptions, which often make specific reference to royal accomplishments, it is often unclear whether an event mentioned in a hymn occurred as described, or if the description just uses topoi or literary patterns ${ }^{17}$ in order to fill out the text. What seems to occur, especially in type B royal hymns without epic features, is often a deliberate avoidance of narrative by reducing the events of a ruler's reign to stock topoi. ${ }^{18}$ For example, the self-laudatory (type B. II) hymn Lipiteštar $\mathrm{A}^{19}$ lists the king's special endowments and accomplishments in form of thematically arranged motifs and displays rigid poetic parallelisms ending in - ( C ) a - m e - e n "am I". Recurrent topoi in hymnic literature are the maintenance of overland (and maritime) routes, the irrigation and cultivation of fields, juridical activities involving the elimination of social disorder, and the care and upkeep of the gods' dwellings and the king's incessant rendering of service. Naturally these topoi share the same kind of phraseology, and occasionally they become stock formulae, consisting of one sentence, as in the topos of taking care of widows and orphans discussed below.

Just as a predilection for certain stylistic features exists within one composition, so a certain preference can sometimes be observed in the hymns commissioned by different kings. A classic example is Išmedagān, who can be rightfully considered a fervent admirer and imitator of literary achievements of his predecessor Sulgi, as J. Klein has shown in some detail in various studies. This preference shows itself not only with regard to topoi, motifs or formulae, but also on a wider thematic and structural level. ${ }^{20} \mathrm{~J}$. Klein has also recently drawn attention

\footnotetext{
15 For a definition of tradition, cf. Franke, ibid. 7-9.

$16 \mathrm{Cf}$. also below for examples with different divine names, p. 50.

17 For this term, cf. Ludwig, Išme-Dagan $59 \mathrm{f}$. with previous literature.

18 Cf. also III 1., p. 28.

19 Cf. Römer, SKIZ 29-38.

$20 \mathrm{Cf}$. for example the double trips made by Sulgi and Iš medagän, or Gudea, Stat. B and Sulgi E which share the same purpose and function according to Klein, Studies Sjöberg (1989) $294 \mathrm{ff}$.
} 
to a possible dependence of the Sulgi hymns on the literary tradition of Lagaš known from the compositions of Gudea of Lagaš. ${ }^{21}$ The influence of the literary tradition of Lagaš on the hymns of Sulgi, and indeed on the whole Ur III literary corpus, is apparent on the levels of orthography, ${ }^{22}$ grammar, vocabulary, and the repertoire of topoi, motifs and formulae. Ur III dependence on the Lagaš II literary tradition would fit well with the proposal that Gudea's reign might have overlapped with that of Urnamma. ${ }^{23}$ Furthermore, an analysis of the archaeological, i.e. especially the glyptic material we have for the time of Gudea, shows that this material may have to be considered as a local development at Lagaš in Late Akkadian or Sargonic times which formed the basis for the Ur III and Isin style of art, ${ }^{24}$ just as Lagaš II literary material is the foundation for the Ur III and Isin literary style.

Moreover, it can be shown that many topoi in form of motifs and formulae in the Ur III and Isin-Larsa hymns have predecessors even as far back as Pre-Sargonic Lagaš and Uruk under Lugalzagesi (24th. century B.C.). It was A. Falkenstein who noted that royal inscriptions of these earlier periods contain some of the formulae and topoi found in the hymns of the Ur III and Isin-Larsa periods, and royal inscriptions contemporary with the hymns also share formulae and topoi with them. ${ }^{25}$ This is particularly the case with regard to topoi, motifs and formulae of legitimation and kingship. The aim of the following discussion is to carry A. Falkenstein's finding one step further by dividing the available texts, i.e. basically royal inscriptions and hymns, into certain text types, in order to investigate for each text type if and in what time periods these topoi appear to have been used. The division into text types is the following: a.) royal inscriptions, encompassing all types of inscriptions, i.e. the types b.) and c.), b.) monumental, i.e. statue and stela inscriptions, c.) artefact inscriptions, which are royal inscriptions without statues and stela inscriptions, and d.) royal hymns, which also include the cylinders A and B of Gudea of Lagaš. "Royal" inscriptions ${ }^{26}$ are inscriptions commissioned by kings or by a person in honour of the king or his family which display the royal commissioner's achievements (e.g. construction work on temples and canals, military victories, social reforms) and titles, sometimes also containing a dedication. They are attested from the Pre-Sargonic period on (after 2500 B.C.), and are inscribed on all kinds of objects, e.g. bricks, door sockets, cones, clay nails, beads, ceremonial maceheads, vessels, statue(tte)s, slabs, various stone tablets, stelas and cylinders. ${ }^{27}$ "Artefact" inscriptions are defined here as royal inscriptions

\footnotetext{
21 Klein, ibid. 290 , fn. 9.

22 Cf. above, II 3.1 , p. $22 f$., for the Umamma hymns.

23 Cf. I 1., p. 3.

24 Dittmann, BaM 25 (1994) 101. Sceptical towards this finding is Fischer in BaM 27 (1996) 220. According to Dittmann, Sargonic (= Akkad) seals continued to be produced in Ur III times and seals of the Lagaš II rulers Urning irsu and Pirigme are Sargonic in appearance.

25 Falkenstein, AnOr. 30 (1951) 175.

26 For the confusing terminology and difficult classification of these inscriptions, cf. Edzard, RlA 6 (1980-83) 5965 , s.v. "Königsinschriften A. Sumerisch", especially p. 59f. ad § 2.; also Steible, Behrens, FAOS 5 (1982) 2 with literature on problems of terminology.

27 Cf. Cooper, Presarg. Inscr. 4-7 for a description of inscribed artefacts of the Pre-Sargonic period.
} 
inscribed on artefacts or objects mentioned above but excluding statues and stelas. Statue and stela inscriptions of the Sargonic, Ur III and Isin-Larsa periods are predominantly Old Babylonian copies of the original monuments, because these larger pieces of Sargonic, Ur III and Isin-Larsa monumental art were susceptible to pillage or reuse. ${ }^{28}$ The earliest examples of royal hymns date from the Lagaš II and Ur III periods, that is, about four centuries after the appearance of royal inscriptions. ${ }^{29}$ Literary expression of the notion of one legitimate, predestined ruler, selected and elected by divine will, existed as early as Early Dynastic times. Kings made use of similar stock expressions or topoi throughout the following periods to describe certain events in the process of their selection and investiture. These topoi show much continuity from the Early Dynastic and Sargonic periods through the Isin-Larsa periods, but appear in different text types in different periods: topoi of legitimation and kingship appear in artefact inscriptions of Pre-Sargonic Lagaš and Uruk, and only again show up in artefact inscriptions of the Isin-Larsa period. The artefact inscriptions of the Sargonic through Ur III periods are in general devoid of topoi of legitimation and kingship. They appear instead in statue and stela inscriptions of those periods, as well as in the royal hymns of the Lagaš II (including Gudea's cylinders), Ur III and Isin-Larsa periods. The fact that during the Lagaš II, Ur III and Isin-Larsa periods the same topoi are attested in royal hymns, as well as in statue and stela inscriptions, shows a close affinity between the two text types and hardens the thesis, first put forward by W.W. Hallo, ${ }^{30}$ that royal hymns were originally inscribed on monumental objects, i.e. stelas and statues. ${ }^{31}$ Some compositions of the Ur III and Isin-Larsa periods which are commonly known as royal "hymns" and have come down to us in the form of Old Babylonian copies, may indeed have been inscribed originally on statues (e.g. Sulgi V and Išmedagān S), and we now know for sure that at least some self-laudatory hymns were written on stelas, ${ }^{32}$ which explains the occasional difficulties in differentiating royal hymns of the Ur III, Isin-Larsa, and Babylon dynasties from royal inscriptions of the same time periods. ${ }^{33}$

The distribution of topoi outlined above will be illustrated by a chart following this section in which the topoi of legitimation and kingship are introduced and listed thematically. Special attention is drawn to attestations of topoi in the Urnamma hymns to show how their language relates to both earlier and later writings. The topoi are discussed under the following headings: A) divine parentage and type scenes of birth and divine nurture; B) predestination; C) designation and divine election from the multitudes and endowment with divine favours (wisdom, strength, etc.); D) investiture with symbols of kingship.

\footnotetext{
28 Cooper, ibid. 6 and Winter, Journal of Ritual Studies 6 (1992) 25, and fn. 17.

29 Gudea A is the earliest example of the type A hymn, Urnamma C the earliest example of a type B. II hymn (cf. II $1 .$, pp. 13 and 15$)$.

30 Hallo, CRRAI 17 (1970) 121; idem, AS 20 (1975) 195.

$31 \mathrm{Cf}$. also below, 3.2 , pp. $78 \mathrm{ff}$.

$32 \mathrm{Cf}$. below, 3.2, p. 80 .

33 Cf. Tinney, OLZ 90 (1995) $7 f$.
} 
A) Divine predestination to rule can be expressed through the claim to divine parentage. This tradition is old and goes back to Eanatum of Lagaš, followed by Šarkališarrī of Akkade, and the rulers of Gudea's dynasty. ${ }^{34}$ Divine parentage does not guarantee that the ruler himself is divine. Many kings regarded themselves as $\mathrm{du} \mathrm{m} \mathrm{u} \mathrm{du}_{2}-\mathrm{da}$ DN "natural son" of a deity, ${ }^{35}$ often of their local citygoddess, without laying claim on being divine or supressing the mention of their human fathers. But the king is "functionally" god in the sense that he is the earthly representative of the deity. This is, according to $\mathrm{G}$. Selz, ${ }^{36}$ apparent in epithets like the above mentioned $\mathrm{dum} \mathrm{u} \mathrm{du}_{2}-\mathrm{da} D N, \mathrm{~d} \mathrm{u} u$ "Sun", d $1 \mathrm{am} \mathrm{m}$ a "guardian-spirit", ${ }^{37}$ and probably also d i g i r k a l a m - m a "god of the land". The tradition of claiming divinity in one's own lifetime is first attested in inscriptions of Narāmsu'en and Šarkališarrī of Akkade and is only again revived by Urnamma's son Sulgi and his successors. ${ }^{38}$ Urnamma was venerated as god only posthumously ${ }^{39}$ but his hymns exhibit a series of "functional" epithets, as e.g. in

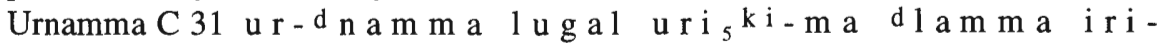
$\mathrm{g} \mathrm{a}_{2}-\mathrm{m}$ e - e n "I am Urnamma, king of Ur, the guardian-spirit of my city"; Urnamma C 50 ur-d n a m m a-m e-e n m a-da ki-e n-gi ki$\ulcorner\mathrm{uri}\urcorner / \mathrm{d}$ lam m a m u- un - da-an-tuk u "In me!, Urnamma, the Land Sumer and Akkad has got a guardian-spirit"; ${ }^{40}$ Urnamma C $75 \mathrm{u} \mathrm{g}_{3}-\mathrm{e} \quad \mathrm{u}_{2}$

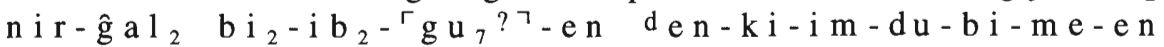
"I let people eat tasty food, I am their Enkimdu"; Urnamma C $70 \mathrm{u} \mathrm{r}$ d n a m m a di g i r $-\breve{S} E_{3} \quad \mathrm{du}_{2}-\left\ulcorner\mathrm{da}^{\urcorner} \mathrm{k} \mathrm{u}_{3}-\mathrm{ge}-\mathrm{e} \check{\mathrm{s}}\ulcorner\mathrm{x}\urcorner \quad[\ldots]\right.$ "[I?] Urnamma, born to be a god, in pure fashion [...]"; perhaps Urnamma A 238 (source A) (...) $\left.\mathrm{p}_{\mathrm{p}} \mathrm{i} \mathrm{ri} \mathrm{g}\right\urcorner \mathrm{di} \mathrm{g} \mathrm{i} \mathrm{r}-\mathrm{S}_{\mathrm{S}} \mathrm{E}_{3} \mathrm{du}_{2}-\mathrm{d}$ a "(..) a lion born to be a god".

Topoi of divine or divinely assisted conception and birth are attested as early as Pre-Sargonic times and are subsequently used, in more elaborate form, in royal Ur III and Isin-Larsa hymns. ${ }^{41}$ Attestations in Urnamma hymns are: Urnamma C 43 $\mathrm{a} !-\mathrm{g} \mathrm{u}_{10} \quad \mathrm{~s}^{\mathrm{a}} \mathrm{a}_{3} \mathrm{k} \mathrm{u}_{3}-\mathrm{g} \mathrm{e} \quad \mathrm{b}$ a $-\mathrm{r} \mathrm{i}-\mathrm{a}-\mathrm{t}$ a "When my semen was ejaculated into the pure womb ${ }^{42 "}$. Nintur, the birth-goddess herself forms him and stands by at his birth: Urnamma C $24\ulcorner\mathrm{~d} n \mathrm{in}\urcorner-\mathrm{tu}-\mathrm{re} \hat{g ~ e}_{26}-\mathrm{e} \mathrm{mu}-\mathrm{un}-\mathrm{di} \mathrm{m}_{2}-$ $\mathrm{di} \mathrm{m}_{2}$ - e n $\mathrm{g} \mathrm{a}-\mathrm{ri}-\mathrm{g} \mathrm{u}_{10} \mathrm{n} \mathrm{u}-\mathrm{t} \mathrm{u} \mathrm{k} \mathrm{u} \mathrm{"Nintur} \mathrm{has} \mathrm{formed} \mathrm{me} \mathrm{meticulously,}$ (so that) I have no equal", and Urnamma C $47 \mathrm{~d} n \mathrm{i} \mathrm{n} !\left(\mathrm{N} \mathrm{I} \mathrm{N}_{9}\right)-\mathrm{tu} \mathrm{du}_{2}$ $\left\ulcorner\mathrm{du}_{2}\right\urcorner-\mathrm{a}-\mathrm{g} \mathrm{u}_{10}<\mathrm{m} \mathrm{u}>-\mathrm{u} \mathrm{n}-\mathrm{gu} \mathrm{b}-\mathrm{bu}$ ! "Nintur stood by in the process

\footnotetext{
34 A general discussion is offered in Sjöberg, OrSuec 21 (1972) 87-112.

35 For Pre-Sargonic references, cf. Behrens, Steible, FAOS 6 (1983) 90 s.v. dumu tu-da (4.).

36 Selz, ASJ 14 (1992) 258, fn. 5.

37 Cf. also Sallaberger, Kalender 86.

$38 \mathrm{Cf}$. in general Wilcke, CRRAI 19 (1974) 179f.; also Klein, ThŠH $29 \mathrm{ff}$.

39 For posthumous worship of kings, cf. below, 3.2, p. $79 \mathrm{f}$.

$40 \mathrm{~d} \mathbf{l} \mathrm{a} \mathrm{m} \mathrm{m} \mathrm{a} \mathrm{is,} \mathrm{e.g.,} \mathrm{similarly} \mathrm{used} \mathrm{in} \mathrm{Sulgi:} \mathrm{Sulgi} \mathrm{26,} \mathrm{4:25} \mathrm{and} \mathrm{Sulgi} \mathrm{G} \mathrm{23;} \mathrm{the} \mathrm{king} \mathrm{is}{ }_{\mathrm{i}}^{\mathrm{i}} \mathrm{s} \mathrm{t}$ a $\mathrm{r}$ a $\mathrm{n}$ in Sulgi C 102; Sulgi F 25; Sulgi X 142. Similarly in Gudea, Cyl. A 10:26 (but there d i š t a r a n - g i n ${ }_{7}$ ). 41 For a selection of references in general, cf. PSD A/1 22-24 s.v. a A 9. "semen, (...) offspring", 9.2 in a ri/ru/ra, and 9.3 in a š $\mathrm{a}_{3}$-ga ri/ru and a ša $\mathrm{a}_{3}$-ga šu du $\mathrm{du}_{11}$.

42 i.e. the womb of Ninsumun (cf. Urnamma C 48).
} 
of my birth". ${ }^{43}$ The rearing of kings (and gods) on divine knees is already attested in the Pre-Sargonic inscription Eanatum 1, 4:24-26. Compare perhaps Urnamma C 25

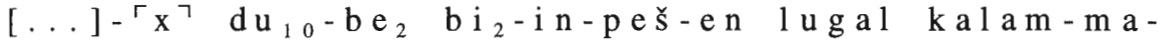
$\mathrm{m}$ e - e $\mathrm{n}$ "[...] has raised me on the knees, I am the king of the land". The topos is subsequently taken up by other Ur III and Isin-Larsa kings, ${ }^{44}$ and is also used of gods, e.g. in Nanna A (= Sjöberg, Mondgott 14) 28, said of Nanna and Ninlil, and in Išbi'erra D 7, said of Ninisina and An.

B) Predestination of a king takes part in the heart of a god $\left(\check{s} \mathrm{a}_{3}\left(\mathrm{k} \mathrm{u}_{3}\right)\right.$ $\left.\mathrm{g} \mathrm{a} /-\mathrm{g} \mathrm{e} \mathrm{pa}_{3} . \mathrm{d}\right)$. It is often but not necessarily the local city-god or patron deity which predestines the king: in Pre-Sargonic times for Eanatum, Enmetena, Enanatum II, and IriKAgina, ${ }^{45}$ as well as in Lagaš II, for Piriĝme (1:10-11) and Urba'u $(1,1: 9)$ it is Nanše. Gudea is chosen in the heart of Ningirsu (Stat. B 2:8-9 II D 1:11-12) and Ba'u (Stat. E 1:18-20; Gudea A rev. 14' || 17'), Utuhegal of Uruk in Inana's (Utuhegal Inscr. = RIME 2.13.6.4:48), Urnamma in Nanna-Su'en's in Urnamma E 26' < d > u r - d n a m m a A Š - i m 2 $_{2}$ - b a b bar-re š a $\mathrm{ku}_{3}-\mathrm{g} \mathrm{e}\left[\ldots-\mathrm{pa}_{3}\right.$ ?] "Urnamma, AŠimbabbar [has chosen?] in (his) precious heart!" II Urnamma F 29 d u r - d n a m m a d A S - i m ${ }_{2}-$ b a b b a r š $\mathrm{a}_{3}-\mathrm{g} \mathrm{e}$ b a-n i-i n- $\mathrm{a}_{3}$ "Urnamma, AŠimbabbar has chosen in (his)

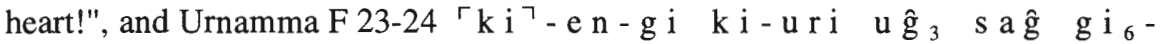
ga I dur-dnamma ds u'en š a ${ }_{3}-g$ e ba-ni-i n-p a ${ }_{3}$ "For Sumer and Akkad, for/among the black-headed people, Su'en has chosen Urnamma in (his) heart". For Urnamma's successor Sulgi, different gods are mentioned, e.g. An, Nanna-Su'en and Enlil, ${ }^{46}$ and for the Isin-Larsa kings An and other gods. ${ }^{47}$ The formula also appears in nominalised form in the inscriptions of the Isin-Larsa kings: e.g. RIME 4.1.10.1:12-13 (Enlilbāni) d a m š $\mathrm{a}_{3}-\mathrm{g}$ e $\mathrm{p} \mathrm{a}_{3}-\mathrm{da}$ । $\mathrm{d}$ i n a n a "spouse chosen in Inana's heart"; RIME 4.2.8.1:7-10 (Nūradad) s u 1 d u t u | ša $\mathrm{s}_{3} \mathrm{ku}_{3}-\mathrm{ga}-\mathrm{n} \mathrm{i}-\mathrm{ra}^{\mathrm{a}}\left|\mathrm{z} \mathrm{i}-\mathrm{de} \mathrm{e}_{3}-[\mathrm{e} \check{\mathrm{s}}]\right| \mathrm{b} \mathrm{i}_{2}-\mathrm{i} \mathrm{n}-\mathrm{p}\left[\mathrm{a}_{3}-\mathrm{da}\right]$ "(...) whom youthful Utu has truly ch[osen] in his precious heart"; similarly RIME 4.2.8.7 i 18-21 (Nūradad); RIME 4.2.13.15 frgm. 3:4'-5' (Waradsîn); RIME 4.2.14.14 i 6' (Rīmsîn); RIME 4.2.14.27:22 (Rīmsîn). Šūsu'en who is chosen in Enlil's heart, is the only one of the Ur III kings to use this titulary in his artefact inscriptions, i.e. royal inscriptions inscribed on artefacts excluding statues and

$43 \mathrm{Cf}$. for Isin-Larsa references, e.g. RIME 4.1.5.8:3-4 d $\mathrm{i} \mathrm{n}$ a n a $\mathrm{s}$ a $\hat{\mathrm{g}} \mathrm{d} \mathrm{u}-\hat{\mathrm{g}}$ a $\mathrm{a}_{2}$ । a m a $\mathrm{t} \mathrm{u}_{2}$ $\hat{\mathrm{g}} \mathrm{u}, \mathrm{o}-\mathrm{r}$ a "(For Ninlil ...), the goddess who created me (= Lipites tar), the mother who gave birth to me"; similarly $R I M E$ 4.2.14.5:21-22; RIME 4.2.14.9 || 10:31-32 || 30 "(..) Nergal, the god who created him/me $(=$ Rìmsîn)".

44 References in Sjöberg, Mondgott 25 ad 32. The formula $\mathrm{g} \mathrm{a} \mathrm{z} \mathrm{i} \mathrm{g} \mathrm{u},-\mathrm{a}$ d $\mathrm{n} \mathrm{i} \mathrm{n}-\mathrm{h} \mathrm{u} \mathrm{r}-\mathrm{s}$ a $\hat{\mathrm{g}}$ $\mathrm{k} \mathrm{a}(-\mathrm{k})$ "fed with the true milk of Ninh ursag" turns up in Pre-Sargonic inscriptions (cf. Behrens, Steible, FAOS 6 [1983] 202 s.v. $\mathrm{ku}_{2}$ 1. b) and is only continued by Puzurmama of Lagaš, RIME 2.12.5.1 ii 7'-8' (cf, also Hallo, Royal Titles 136f.), probably a contemporary of Sarkališ arrī of Akkade (cf. Frayne, RIME 2 [1993] 186 and 271 with previous literature). Isin-Larsa kings were also nurtured by divine milk, cf. e.g. Lipiteš tar D 6.

45 References in Behrens, Steible, FAOS 6 (1983) 272 s.v. $\breve{s}_{3}-(-) \mathrm{pa}_{3}$ 1. b). The formula $\varsigma_{3} \mathrm{a}_{3} \quad \mathrm{z} \mathrm{i} \quad \mathrm{p} \mathrm{a}_{3}-\mathrm{d} \mathrm{a}$ $\mathrm{D} \mathrm{N}(-\mathrm{k})$ is also attested in a Sargonic fragmentary votive inscription for the life of Rīmuš in $R I M E$ 2.1.2.2001:2'-3'.

46 Sulgi A 8; Sulgi F 85; 92-93; Sulgi G 24; 68.

47 Lipiteš tar C i 33. 
stelas, ${ }^{48}$ which might suggest a problematical succession to the throne ${ }^{49}$ The same goes for the formula $\mathrm{m} \mathrm{u} \mathrm{p} \mathrm{a}_{3}-\mathrm{d}$ a DN (-k) "called by name by $\mathrm{DN}^{50}$ which is attested in Amarsu'en's artefact inscriptions (Amarsu'en 2:3-4 ॥ 3, 1:3-4 et passim, called by Enlil) and in Šüsu'en 12:2-3 (called by An). These are the only two instances where formulae of kingship occur in Ur III artefact inscriptions and not exclusively in statue and stela inscriptions and royal hymns of that period.

Thus, the choosing god for Gudea, Utuhegal and Urnamma is the city-god, whereas for Sulgi and his successors no pattern is apparent, and different gods may function as divine choosers.

C) Actual selection and designation need not to have been carried out by the god who has chosen the ruler in his heart. Utuhegal, and after him Urnamma and Sulgi, are designated by Enlil, but only from Sulgi onward could Enlil figure as the god who also predestines the ruler. The designation and confirmation of a king's sovereignty by Enlil, chief of the Sumerian pantheon, was politically, of course, of utmost importance, especially in the case of usurpers. ${ }^{51}$ Divine selection is described as a process in which the god "looks at something or somebody" in order to find a suitable person ( $\mathrm{ig} \mathrm{i} \quad \mathrm{i}_{2}$ )..$^{52}$ Thus Enlil looks at the people and picks Urnamma from their midst: Urnamma B 4-5 u $\hat{\mathrm{g}}_{3}-\mathrm{g} \mathrm{a}_{2}$ i g i $\mathrm{m} \mathrm{i}-\mathrm{n} \mathrm{i}-\mathrm{i} \mathrm{n}-$ $\mathrm{i}_{1}{ }_{2}$ sipa zi ur-dn[amma] I kur-gal den-li $1_{2}-1$ e ug $\hat{g}_{3}$ $\breve{s} a r_{2}-r a-n i-a ~ i m-m a-n i-i n-r p a_{3}$ ? 7 "He (= Nunamnir) looked at the people, Great Mountain Enlil chose? the faithful shepherd Urnamma from among his innumerable people". RIME 4.1.6.2 ii 18'-21' (Urninurta) de n- 1 i $_{2}$ lugal kur-kur-[ra-ke $\left.{ }_{4}\right] \mid u \hat{g}_{3}$ dagal šar $\left.-r a-r d a\right\urcorner । i g i$ $\mathrm{mi}-\mathrm{ni}-\mathrm{in}-\mathrm{i}\left[1_{2}\right] \mathrm{Izi}-\mathrm{de}_{3}-\left\ulcorner\mathrm{es} \mathrm{bi}_{2}{ }^{7}-\left[\mathrm{i} \mathrm{n}-\mathrm{p} \mathrm{a}_{3}\right]\right.$ "Enlil, lord of all the foreign lands, looked among the innumerable people and truly [chose] him (= Urninurta)" ${ }^{53}$ Ningirsu looks at his city favourably and appoints Gudea as faithful shepherd for the land (Gudea, Stat. B 3:6-9). The exclusiveness of the designated person is stressed by the fact that selection takes place from a multitude of people, ${ }^{54}$ a topos that goes back to Pre-Sargonic times and can be traced throughout successive periods. Enmetena (Ent. 32, 1:2"-3") is taken by the hand by Enlil "from innumerable multitudes" ( $\breve{\mathrm{s}} \mathrm{a}_{3} \quad 1 \mathrm{u}_{2} \quad 36000-\mathrm{ta} \breve{\mathrm{s} u} \quad \mathrm{~d} \mathrm{a} \mathrm{b}_{5}$ ), as are IriKAgina (Ukg. 4, 8:5-6 \| 5, 7:18-19) and Gudea (Gudea, Stat. B 3:6-11) by Ningiirsu. Urnamma is explicitly chosen by Enlil in Sumer and Akkad: Urnamma D (Ni) 9-11 lu gal ša ${ }_{3}$ zi-ta nam tar-ra nam-nir-ra sag i $1_{2} \mid$ dur-dnamma sul igi i $1_{2}-1$ a kur-[gal] den-1i $1_{2}$ le ld nu-nam-nir-re ki-en-gi rki-uri-a ${ }^{7} \mathrm{ge}_{26}-\mathrm{e} \mathrm{mu}-$ $\mathrm{u} \mathrm{n}-\mathrm{s} \mathrm{u} \mathrm{h-e} \mathrm{n} \mathrm{"It} \mathrm{is} \mathrm{me,} \mathrm{the} \mathrm{king,} \mathrm{destined} \mathrm{from} \mathrm{the} \mathrm{true} \mathrm{womb} \mathrm{on,} \mathrm{lifting} \mathrm{the}$ head confidently, me, Urnamma, the selected youth, [Great] Mountain Enlil,

\footnotetext{
48 Šū su'en 3:3-5 || 4 obv. 3'-5' et passim.

49 Cf. Wilcke, CRRAI 19 (1974) 180 ad 5.

$50 \mathrm{Cf}$. also ad C) below, p. 49 f.

$51 \mathrm{Cf}$. below, 1.4 , p. $63 \mathrm{f}$.

$52 \mathrm{Cf}$. also V 2.3 ad 4 with previous literature, p. 200.

53 Similarly also RIME 4.2.9.15:51-53 (Sîniddinam).

54 Cf. e.g. Urnamma B 5 above; Šù iliš̌u A 57.
} 
Nunamnir has chosen in Sumer and Akkad" (cf. also (Ur) 10'-12'), ${ }^{55}$ as are other kings (e.g. Išmedagān A 55, from among the people). In Urnamma C 58, the king is specifically chosen by Enlil through extispicy ( $\mathrm{m}$ a $\check{\mathrm{s}}_{2}-\mathrm{e} \quad \mathrm{p} \mathrm{a} \mathrm{a}_{3} . \mathrm{d}$ ). The process of selection also involves the divine glance: the predestined person is "looked at approvingly" (i g i $\mathrm{z}$ i $\quad$ b a r), ${ }^{56}$ or "smiled radiantly upon" (s a g - $\mathrm{k}$ i $\mathrm{z}$ a 1 a g-g a b a r), ${ }^{57}$ e.g. Urnamma D (Ni) 13 s a g - k i z a l a g-g a - n i

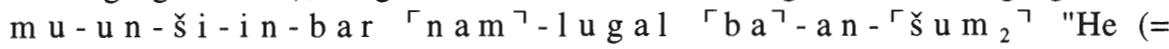
Nunamnir) smiled radiantly upon me and gave me! kingship", and Urnamma B 36 i g i zi m u-un-ši-i n-bar-re-eř si pa d u r-d n a m m a-ra "They (= Enlil and Ninlil) looked at shepherd Urnamma approvingly" (in connection with the restoration work of the Ekur). ${ }^{58}$ Urdukuga is "spouse, looked at approvingly by Inana" ( $\mathrm{d}$ a $\mathrm{m}$ i g i $\mathrm{z} \mathrm{i} \mathrm{b} \mathrm{a} \mathrm{r} \mathrm{-} \mathrm{r}$ a I d i $\mathrm{n} \mathrm{a} \mathrm{n} \mathrm{a} \mathrm{(-} \mathrm{k}$ )) in RIME 4.1.13.1:19-20. ${ }^{59}$ Once found and selected, the king is explicitly "called by name" $\left(\mathrm{m} \mathrm{u} \quad \mathrm{p} \mathrm{a}_{3} . \mathrm{d}\right){ }^{60}$ "given a good name" (m u d u $\left.{ }_{10} / \mathrm{s} \mathrm{a}{ }_{6}(-\mathrm{ga}) \mathrm{s}_{\mathrm{e}}{ }_{21}\right)$, or is "truly called out" $\left(\mathrm{g} \mathrm{u}_{3} \mathrm{zi}\left(-\mathrm{de}_{3}-\mathrm{e} \breve{s}\right) \mathrm{d} \mathrm{e}_{2}\right),{ }^{61}$ very common formulae found in inscriptions throughout the course of Mesopotamian history. It is always Enlil who calls Urnamma by name or gives him a good name: Urnamma B 34 (...) s u 1 $\mathrm{zi} \mathrm{m} \mathrm{u} \mathrm{pa}_{3}-\mathrm{da} \mathrm{d} \mathrm{n}-\mathrm{n}$ am - n i r - ra-k a "(..) the faithful young man, mentioned by name by Nunamnir", and Urnamma C $46 \mathrm{den}-1 \mathrm{i} 1_{2}-1 \mathrm{e}$ $\mathrm{dutu}-\mathrm{gin}, \mathrm{kalam}-\mathrm{ma}_{7} \mathrm{e}_{3}-\mathrm{de}_{3} / \mathrm{mu} \quad \mathrm{du}_{10} \mathrm{mu}-\mathrm{un}-$ $\left\ulcorner\breve{s} e_{21}\right\urcorner$ "Enlil who rises like the sun over the land, gave me a good name". Ningirsu calls out, i.e. approves, of Gudea among the people ( $\mathrm{u} \hat{g}_{3}-\mathrm{g} \mathrm{a}_{2} \quad \mathrm{~g} \mathrm{u}_{3}$ $\mathrm{de}_{2}$ in Stat. B 8:16, in the final curse passage, with a pun on Gudea's name) at Ningirsu's main festival, the highlight of the year $\left(\mathrm{z} \mathrm{a}_{3}-\mathrm{m} \mathrm{u}\right) .{ }^{62}$ Accordingly, Enlil looks at Iddindagān and speaks to him approvingly in Iddindagān B 5-6.

A consequence of (divine) election (i $\mathrm{g} \mathrm{i} \mathrm{il}_{2}$ ) or approval is expressed by $\mathrm{s}$ a $\mathrm{g}\left(\mathrm{a} \mathrm{n}-\mathrm{s} \mathrm{e}_{3}\right) \mathrm{i}_{2}$, and its synonym $\mathrm{g} \mathrm{u}_{2}\left(\mathrm{a} \mathrm{n}-\mathrm{s} \mathrm{e}_{3}\right) \mathrm{z} \mathrm{i} \cdot \mathrm{g}$ "to lift the head (heavenward)". It describes the proud and privileged position or posture of the

\footnotetext{
55 Sînmāgir is "chosen" ( $s$ u h - a) in his city so that he exercise kingship, cf. RIME 4.1.14.1:11-12.

56 Pre-Sargonic references in Behrens, Steible, FAOS 6 (1983) 168f. s.v. igi bar.

57 Literally "to turn a shining forehead towards somebody". References in PSD B 111 s.v. bar E 4.2. The expression could be the opposite of $\mathrm{s} \mathrm{a} \mathrm{g}-\mathrm{k} \mathrm{i} \mathrm{g} \mathrm{i} \mathrm{d}_{2}$ "to frown". Cf. also Sulgi X 80 (with var. $z$ i $-z$ i).

58 The expression is often used in context of a blessing, e.g. Iddindagān A 119.

59 Cf. also RIME 4.2.9.6:13-14 (Sîniddinam); RIME 4.2.13.12:25 (Waradsîn); RIME 4.2.13.16:28-29; RIME 4.2.14.5:23 (Rīmsîn); RIME 4.2.14.15:1-2; RIME 4.2.14.20:15-16; Ǐ̌medagān A 104 and Gudea, Stat. C 2:1213 have the formula i g i $\mathrm{n} \mathrm{a} \mathrm{m-t} \mathrm{i}{ }_{3}(-1 \mathrm{a})(-\mathrm{k}) \mathrm{b}$ a r "to look at somebody exuberantly" (literally "with an eye of life").

60 For Pre-Sargonic references, cf. Behrens, Steible, FAOS 6 (1983) 272f. s.v. mu-(-)pa a a) and b). Note also

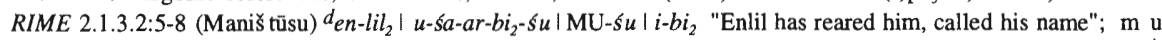
$\mathrm{p} \mathrm{a}_{3}-\mathrm{d}$ a D N ( - $\mathrm{k}$ ) in RIME 2.1.2.2001:4'-5' (votive inscription for the life of Rīmuš). For attestations in the artefact inscriptions of Amarsu'en and Sū su'en, cf. already ad B) above, p. 48.

61 For Pre-Sargonic references, cf. Behrens, Steible, FAOS 6 (1983) 151f. s.v. gu de $_{2}$. Attestations in Larsa inscriptions are e.g. RIME 4.2.13.15 frgm. 14:14'-15' (Waradsîn); RIME 4.2.13.17 i 14'; RIME 4.2.14.15:18 (Rīmsîn); RIME 4.2.14.17:36; RIME 4.2.14.23:18-19.

62 For $2 . \mathrm{a}_{3}-\mathrm{m}$ u, cf. Sallaberger, Kalender 142f., and fn. 669.
} 
elected object and can also be said of animals, ${ }^{63}$ and of inanimate objects, such as temples, ${ }^{64}$ walls, ${ }^{65}$ cities, ${ }^{66}$ bricks,,${ }^{67}$ boats, ${ }^{68}$ and daises. ${ }^{69}$

The topos of divine favour benefiting the designated king is very common. The king is usually favoured by a group of gods and endowed with special gifts that characterize each particular deity. This enumeration of divine favours already exists in rudimentary form, as epithets in the form of formulae with nominalisation in Pre-Sargonic inscriptions from Lagaš, ${ }^{70}$ in inscriptions of Lugalzagesi of Uruk, ${ }^{71}$ continues in Lagaš II texts, ${ }^{72}$ and in the Isin-Larsa inscriptions: compare e.g. RIME 4.1.3.2:14 (Iddindagān) ĝ e š t $\mathrm{u}_{2}$ š u $\mathrm{m}_{2}-\mathrm{m} \mathrm{a} \quad \mathrm{d}$ e $\mathrm{n}-\mathrm{k} \mathrm{i}-\mathrm{k}$ a "given wisdom by Enki" and RIME 4.2.13.27:27-29 (Waradsîn) ĝ e š t u ${ }_{2} \quad \mathrm{~d}$ a g a 1 ।

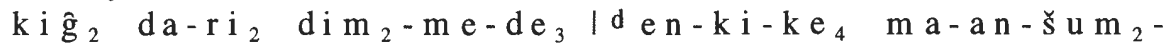
$\mathrm{m} \mathrm{a}$ "(Me) to whom Enki gave broad wisdom in order to create lasting works". The topos finds its climax in more elaborate and poetic sentences in the royal Ur III and Isin-Larsa hymns. ${ }^{73}$ The kings receive a name, strength in combat, wisdom, the capacity to judge, and are specifically chosen or approved. Within the Lagaš tradition, for example, the sequence can show some variability with regard to the formulae, the sequence of divine names, and their length. Certain formulae are restricted to certain rulers (e.g. the formulae $\mathrm{g} \mathrm{a} \mathrm{z} \mathrm{i} \mathrm{g} \mathrm{u}_{7}-\mathrm{a} \mathrm{d} \mathrm{n} \mathrm{i} \mathrm{n-h} \mathrm{u} \mathrm{r-}$

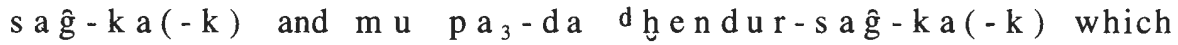
are exclusively assumed by Eanatum, Enanatum and Puzurmama), and different deities can be associated with the same endowment in different texts. The formula $\mathrm{mu} \quad \mathrm{p} \mathrm{a}_{3}-\mathrm{da}$ D N ( - k ) "called by name by DN", e.g., applies to different deities, to Ningirsu in inscriptions of Eanatum, Enmetena, and Pirigme, ${ }^{74}$ to Inana in inscriptions of Enanatum I and Enmetena, ${ }^{75}$ to Utu in Luzag. 1, 1:19-20, and to Hendursaga in En. I 29, 2:5-6. The formula $\hat{\mathrm{g}} \mathrm{e} \breve{\mathrm{s}} \mathrm{t} \mathrm{u}_{2} \quad \breve{\mathrm{s}} \mathrm{u} \mathrm{m} \mathrm{m}_{2}-\mathrm{m}$ a $\mathrm{D} \mathrm{N}$ ( $\mathrm{k}$ ) "given intelligence by $\mathrm{DN}$ " is, however, restricted to one god, namely Enki, e.g. Ean. 1 rev. 5:51-52 || En. I 33, 2:2-3 || Ent. 28 || 29, 5:14-15 || Luzag. 1, 1:1718 II Puzurmama $1,2^{\prime}: 4^{\prime}-5^{\prime} \cdot{ }^{76}$

\footnotetext{
63 E.g. Iddindagān A 138.

64 E.g. Urnamma B 10 11 said of Ekur and then of Urnamma in the following line; RIME 4.2.14.2:18 (Rimsîn).

65 E.g. RIME 4.2.13.21:86 (Waradsîn).

66 E.g. Luzag. 1, 2:30-32 and 1, 2:46-3:2, with $\mathrm{g} \mathrm{u}_{2}$ a $\mathrm{n}-\mathrm{s}_{3} \mathrm{e}_{3} \mathrm{zi} . \mathrm{g}$.

67 Gudea, Cyl. A 1:15; Cyl. A 19:17.

68 E.g. Sulgi R 60, partially broken.

69 E.g. Ibbīsu'en E obv. 9'; Sîniddinam A (=v. Dijk, JCS 19 22) 27.

70 E.g. Ean. 1 rev. 5:45-6:9, Ean. 2, 1:5-2:13 || Ean. 3-4, 1:10-2:14 || et passim; similarly Ent. 28, 5:22-27 || 29 , 6:3-8.

7I Luzag. 1, 1:12-13; 17-20; 28-29.

72 E.g. Piriĝme 1:10-13, Urba'u 1, 1:9-12; Gudea, Stat. B 2:8-17; cf. also Puzurmama who uses e.g. the same gods with epithets as in Eanatum: Puzurmama 1, 2':1'-9'.

73 E.g. Urnamma C 20-30 and 43-47; Sulgi A 7-15; Iddindagān B 1ff.; Iš medagān A 65ff.; Lipiteštar A 23ff.; Lipiteš tar B $43 \mathrm{ff}$.

74 E.g. Ean. 1, 6:2-3 || Ent. 28 || 29, 5:4-5; Piriĝ me 1:12-13.

75 E.g. En. I 10, 1:4-5 II Ent. 74, 3:4-4:1.

76 This is also the case in later texts, cf. the references above; also RIME 4.2.6.1 ii 1'-3' (Abīsarẽ); RIME 4.2.9.11:24 (Sîniddinam); RIME 4.2.9.15:41-42; RIME 4.2.14.10:29 (Rïmsîn).
} 
D) Similar investiture phraseology can be found in all periods. Common formulae are $\mathrm{n} \mathrm{a} \mathrm{m-1} \mathrm{u} \mathrm{g} \mathrm{a} 1 \mathrm{~s}_{\mathrm{u} \mathrm{m}} \mathrm{m}_{2}$ "to give kingship" and $\mathrm{g}$ i dri $\check{\mathrm{s} u ~ \mathrm{~m}_{2}}$ "to give the sceptre", which have their origin in Pre-Sargonic times, ${ }^{77}$ appear in Sargonic royal inscriptions, ${ }^{78}$ and are also attested for the Gutian king Erridupizir in RIME 2.2.1.2 vii 1'-8', for Gudea in e.g. Stat. B 2:18-19 || Stat. D 1:19-2:1 et passim and also Cyl. B 6:16, for the Ur III period (e.g. Sulgi B 25), and in the IsinLarsa royal hymns (e.g. Lipiteštar A 26) and royal inscriptions. ${ }^{79}$ Some topoi seem

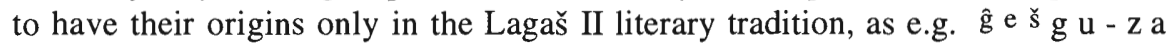
$\mathrm{s} \mathrm{u} \mathrm{h} \mathrm{u} \mathrm{s} \mathrm{-} \mathrm{b} \mathrm{i} \mathrm{g} \mathrm{e} \mathrm{-} \mathrm{e} \mathrm{n} \mathrm{"to} \mathrm{make} \mathrm{the} \mathrm{foundations} \mathrm{of} \mathrm{the} \mathrm{throne} \mathrm{firm",}{ }^{80}$ a topos that might have been inspired by a Sargonic predecessor of Narämsu'en, ${ }^{81}$ and which continues to be used in Ur III and Isin royal hymns ${ }^{82}$ and the Isin-Larsa royal inscriptions. ${ }^{83}$ Urnamma D (Ni) 15-17 and (Ur) 15'-18' contains a sequence of standard regalia, but the most complete list of insignia comes from Sulgi X 56$67,{ }^{84}$ other passages being Sulgi A 87-89, Sulgi D 387-92, Sulgi G 25-27, Sulgi R 85-87, Sulgi B 335-36, Sulgi P b 37-42. Standard regalia also appear in Ur III inscriptions, copied from statues and stelas, ${ }^{85}$ in the Isin-Larsa royal hymns, ${ }^{86}$ and in the Isin-Larsa royal inscriptions. ${ }^{87}$ Enlil alone is responsible for Urnamma's investiture, whereas with successive kings, beginning with Sulgi, it is usually different gods getting credit for the distribution of regalia. ${ }^{88}$ Also, Urnamma's selfpraise hymn $\mathrm{C}$, in contrast to those of successive kings, is devoid of any formulae of investiture. Instead we hear of the journey to Nippur (perhaps inaugurating the annually conducted first-fruit offerings) and the fact that kingship came down from heaven, an allusion to the tradition of the Sumerian King List.

From the references given above under different thematic headings, it becomes apparent that formulae, topoi and motifs of legitimation and kingship show much continuity from the Pre-Sargonic to the Isin-Larsa periods. The following chart illustrates this finding, and in addition lists the topoi for different periods and textual contexts to show the change in use for the different text types listed above. ${ }^{89}$ The chart distinguishes between statue and stela inscriptions (originals and Old Babylonian copies thereof) and artefact inscriptions, in order to show the change in

\footnotetext{
77 Cf. Behrens, Steible, FAOS 6 (1983) 249 s.v. nam-lugal and Behrens, Steible, ibid. 142 s.v. gidri.

78 Cf. Kienast, Sommerfeld, FAOS 8 (1994) 293f. s.v. š arrütum (śarrūtum) and 208 s.v. ḩ aț̣um (GIŠ.GIDRI).

79 E.g. RIME 4.1.6.2 ii 5' (Urninurta); RIME 4.2.13.13:40-46 (Waradsîn); RIME 4.2.13.21:46.

80 E.g. Gudea, Cyl. B 6:16, Stat. E 8:1-3 and Stat. C 4:13-15, as curse.

81 RIME 2.1.4.3 rev. iii 1-3 mu-ki $i_{2}$-in । SUHUŠ.SUHUS । $a-g a-d e_{3}{ }^{k i}$ "Who made the foundations of Agade firm".

82 E.g. Unamma D 15; Sulgi A 89; Sulgi R 87; similarly Sulgi P b 61 ĝ e $ّ$ g u - z a b a 1 a g e n a (...); Ibbīsu'en D obv. 23; Iddindagān B 71-72, source A (cf. Römer, SKIZ 212 ad 72 a-a); Lipiteštar B 54

83 E.g. RIME 4.1.2.2 iii 2'-3' ('̌u ilišu); RIME 4.2.8.1:14-16 (Nū radad); RIME 4.2.8.7 i 3-4; RIME 4.2.9.13:18-19 (Sîniddinam); RIME 4.2.13.10:45 et passim (Waradsîn); RIME 4.2.14.15:57 (Rīmsîn).

84 Cf. Klein, $T h S S H$ 127, fn. 207 with literature. Regalia mentioned in Sargonic texts are the sceptre and the "leadrope of the people" in RIME 2.1.4.3 rev. v l-4 (Narămsu'en) șe $e_{2}-r a-a t\left|\mathrm{NI}_{.} \mathrm{SI}_{11}\right| q a_{2}-t i-i s_{2}-s u \mid i-d i_{3}-n u$ "(When Enlil) entrusted the lead-rope of the people into his hands".

85 E.g. Šu su'en Hist. Inscr. A i 20-24.

86 E.g. Iక̌ medagän A 73-78.

87 E.g. RIME 4.1.6.2 ii 5' (Urninurta); RIME 4.2.8.3:18-19 (Nū radad); RIME 4.2.11.1 v 1-4 (Sîniqī̌sam).

88 Cf. below, 1.4 , p. 63 .

89 Cf. p. 44 f.
} 
use of the topoi for these two text types, and the close affinity between statue and stela inscriptions and royal hymns of the same periods. Note the following abbreviations: $\mathrm{A}=$ topos of divine parentage, birth and nurture, $\mathrm{B}=$ predestination, $\mathrm{C}=$ selection and designation, and the topos of divine favours, and $\mathrm{D}=$ investiture phraseology; $\varnothing=$ little or no attestation of topoi. If a certain text type is not represented by any texts, then this is marked by "no attestations".

\begin{tabular}{|c|c|c|c|}
\hline & $\begin{array}{l}\text { Artefact } \\
\text { Inscriptions }\end{array}$ & $\begin{array}{l}\text { Statue and Stela } \\
\text { Inscriptions (and } \\
\text { copies thereof) }\end{array}$ & $\begin{array}{l}\text { Royal Hymns } \\
\text { (including cylinders } \\
\text { of Gudea) }\end{array}$ \\
\hline $\begin{array}{l}\text { Pre-Sargonic } \\
\text { Lagaš and Uruk }\end{array}$ & $\begin{array}{l}1 \\
\mathrm{ABCD}\end{array}$ & $\begin{array}{l}2 \\
\mathrm{ABCD}\end{array}$ & no attestations \\
\hline Sargonic & $\varnothing^{90}$ & $\begin{array}{l}3 \\
\mathrm{ACD}\end{array}$ & no attestations \\
\hline Uruk V (Utuheĝal) & $\varnothing$ & $\begin{array}{l}4 \\
\mathrm{BC} \\
\end{array}$ & no attestations \\
\hline Lagaš II & $\varnothing^{91}$ & $\begin{array}{l}5 \\
\mathrm{ABCD}\end{array}$ & $\begin{array}{l}6 \\
\mathrm{ABCD}\end{array}$ \\
\hline Ur III & $\varnothing^{92}$ & $\begin{array}{l}7 \\
\mathrm{ABCD}\end{array}$ & $\begin{array}{l}8 \\
\mathrm{ABCD}\end{array}$ \\
\hline Isin-Larsa & $\begin{array}{l}9 \\
\mathrm{ABCD}\end{array}$ & $\begin{array}{l}10 \\
\mathrm{ABCD}\end{array}$ & $\begin{array}{l}11 \\
\mathrm{ABCD}\end{array}$ \\
\hline
\end{tabular}

\section{References:}

1. $\mathrm{A}=$ Ean. 2, 2:2-3; Ean. 3:5-6 et passim; En. I 9:8-9; En. I 28, 1:6-7 et passim; Ent. 32, 1:7'-8' et passim; Lug. 15, 1':6'-7'; Luzag. 1, 1:26-29; Luzag. 3, 1':4'-5'.

B = Ean. 2, 1:9-2:1; Ean. 3, 2:3-4 et passim; En. I 2, 1:7-2:1; En. I 9, 1:4-5; En. I 28, 1:4-5 et passim; Ent. 25:5-6; Ent. 26:6-7; Ent. 27:6-7 et passim; En. II 1:6-7; Lug. 15, 1':2'-3'.

$\mathrm{C}=$ Ean. 2, 1:4-8; 2:4-7; 4:28-5:1; 7:8-9; Ean. 3, 1:10-2:2; 7-10 et passim; En. I 10, 1:4-5; En. I 29, 1:6-7; 2:3-6; Ent. 26:17-18; Ent. 32, 1:2"-3" et passim; Ukg. 4, 8:5-6; Lukin. 2:4-5; Lukin 4:15-17; Lukin. 7, 3:2'; Luzag. 1, 1:13-14; 17-20; Luzag. 2:15; Luzag. 3, 2':3'-4'.

$\mathrm{D}=$ Ean. 2, 5:26-6:5; Ean. 69, 3:7-8; En. I 9, 2:8-3:1; En. I 33, 2:13-3:4; Ent. 26:13-16; Ent. 32, 1:4"-8"; Lug. 15, 1':4'-5'; Ukg. 4, 7:29-8:4; Lukin. 2:9-14 || 4:10-14; Luzag. 1, 1:36-41.

2. $\mathrm{A}=$ Ean. $1,4: 9-12 ; 24-29 ; 5: 1-3 ; 18: 8-9$; rev. 5:47-48; En. I 26, 1:14-15.

90 An exception is RIME 2.1.5.2:1-2 ( Sarkališ arrī) (topos A).

91 Exceptions are an inscription of Pirig me and some of Urba'u: Piriĝme 1:14-15 (topos A); Piriĝ me 1:10-11 (topos B); Piriĝ me 1:12-13 (topos C); Urba'u 3:7-8 ॥ 4:6-7 et passim (topos A).

92 Exceptions are Amarsu'en 2:3-4 et passim (topos C) and Šũ su'en 3:3-5 et passim (topos B); Šũsu'en 12:2-3 (topos C). Cf. also above, p. $47 \mathrm{f}$. 
$\mathrm{B}=$ Ean. 1, rev. 5:53-54; En. I 26, 1:10-11; Ent. 1, 1:6-7.

$\mathrm{C}=$ Ean. 1, 4:20-23; 5:24-25; 6:2-3; rev. 5:45-46; 49-52; rev. 6:4-5; En. I 25, $2: 2^{\prime}-4^{\prime}$.

$\mathrm{D}=$ Ean. 1, 5:13-17.

3. mainly copies of statue and stela inscriptions. ${ }^{93}$

$\mathrm{A}=R I M E \quad 2.1 \cdot 3.2: 5-6 \quad$ (Maništūsu); $R I M E$ 2.1.5.6 i 4-5; i 2'-ii 1 (Šarkališarrī).

$\mathrm{C}=R I M E$ 2.1.1.15:18-19 (Sargon); RIME 2.1.3.2:7-8 (Maništūsu).

$\mathrm{D}=R I M E$ 2.1.1.15:14-17 (Sargon); RIME 2.1.2.4:4-7 (Rīmuš); RIME

2.1.2.6:71-73; RIME 2.1.3.2:9-12 (Maništūsu); RIME 2.1.4.3 v 1-4 (Narāmsu'en); ${ }^{94}$ RIME 2.1.4.5 iii' 9-13.

4. $\mathrm{B}=$ Utuhegal Inscr. $=$ RIME 2.13.6.4:48.

$\mathrm{C}=$ Utuheĝal Inscr. $=$ RIME 2.13.6.4:46-47; 111 .

5. $A=$ Urba'u 1, 1:7-8; Gudea, Stat. B 2:16-17; Gudea, Stat. D 1:17-18; Gudea, Stat. F 1:12-2:1.

B = Urba'u 1, 1:9; Gudea, Stat. B 2:8-9; Gudea, Stat. D 1:11-12; Gudea, Stat. E 1:18-20.

C = Urba'u 1, 1:10-12; Gudea, Stat. B 2:10-13; 3:6-11; Gudea, Stat. C 2:1113.

D = Gudea, Stat. B 2:18-19; Gudea, Stat. D 1:19-2:1; 4:5-6; Gudea, Stat. E 8:4-8.

6. $\quad A=$ Gudea, Cyl. A 1:29; 3:8; 17:13-14; Gudea, Cyl. B 23:19-21; 24:7.

$\mathrm{B}=$ Gudea, Cyl. A 17:11; 23:22-23 (as name of a $\mathrm{n}$ a "stone"); Gudea A (= Klein, TAPS 71/7 39) rev. 14' II 17'.

$\mathrm{C}=$ Gudea, Cyl. A 3:5; 17:10; 23:16-17 (as name of a n a "stone"); Gudea, Cyl. B 2:3; Gudea A obv. 17; rev. 13' || 16'.

$\mathrm{D}=$ Gudea, Cyl. B 6:15-16.

7. mainly copies of statue and stela inscriptions. ${ }^{95}$

A = Codex Urnamma 37-38; Sulgi Cc (STVC 59) 18; Sulgi O 29.

$\mathrm{B}=$ Šūsu'en Hist. Inscr. A (= Kutscher, Brockmon 74) i 9-11; (p.75) ii 12;

Šūsu'en Hist. Inscr. B (= Civil, JCS 2133 ) x 9-10; Šūsu'en Hist. Inscr. C (= Sjöberg, JCS 24 71) ii 23'-24'; Šūsu'en 9:12-15.

C = Sulgi 26, 2:2-3 (as name of a statue); Sulgi E 64; Sulgi V 16; Šūsu'en Hist. Inscr. A (= Kutscher, Brockmon 74) i 5-6; (p. 79) v 22-23.

$\mathrm{D}=$ Codex Urnamma 31-35; Sulgi C 7; Klein, Studies Hallo 125 i 5'-7';96 Sulgi E 8; 11; 63; Šūsu'en Hist. Inscr. C (= Sjöberg, JCS 24 70) i 13'-16'.

8. $\mathrm{A}=$ Urnamma C 24; 43; 47; 113; E 6' II F 12; Sulgi B 7; 112-113; D 40-43; F (= Wilcke, CRRAI 19 201, fn. 131) 4-5 et passim; P b 22-24; X 47; Kramer, Studies Sjöberg 304 i 4; (p. 305) ii 31 (Šūsu'en hymn).

93 Cf. Edzard, Studies Tadmor (1991) 258, and fn. 1 with previous literature

$94 \mathrm{Cf}$. Foster, ARRIM 8 (1990) 39 for the possibility that the inscription might have been originally inscribed on a monument, i.e. a stela inscription.

95 For Sulgi C, E and O as compositions inscribed on stelas, cf. below, 3.2, p. 80.

96 Cf. Klein, Studies Hallo (1993) 124f. as possible part of Sulgi C, and Tinney, OLZ 90 (1995) 13, fn. 31. 
B = Urnamma E 26' II F 29; F 23-24; Sulgi F (= Klein, TAPS 71/7 12) 81; G 24; 68; Kramer, Studies Sjöberg 304 i 6 (Šūsu'en hymn); Ibbīsu'en D (= Sjöberg OrSuec 19/20 146) obv. 10-11.

$\mathrm{C}=$ Urnamma B 4-5; 36; D (Ni) 9-11; 13; Sulgi D 11-13; 44; G 41; P a 1314; 39, Šūsu'en D (= Sjöberg, AOAT 25 414) 34 et passim; Kramer, Studies Sjöberg 304 i 3; 8 (Šūsu'en hymn); Ibbīsu'en D (= Sjöberg OrSuec 19/20 146) obv. 28.

$\mathrm{D}=$ Urnamma D (Ni) 15-17; Sulgi B 25; D 8-10; G 14; 20;25-26; 49; P b 37; 41; 54-55; Kramer, Studies Sjöberg 305 ii 31 (Šūsu'en hymn); Ibbīsu'en A (= Sjöberg OrSuec 19/20 145) obv. 10-11; Ibbīsu'en D (= Sjöberg OrSuec 19/20 146) obv. 22-24.

9. $\mathrm{A}=R I M E$ 4.1.5.3:28 (Lipiteštar); RIME 4.1.5.8:3-4; RIME 4.2.14.5:21-22 (Rīmsîn); RIME 4.2.14.9 \| 10:31-32 || 30.

$\mathrm{B}=$ RIME 4.1.10.1 || 2:12-13 || 7-8 (Enlilbāni); RIME 4.2.8.1 || 3:7-10 || 1517 et passim (Nūradad); RIME 4.2.8.7 i 18-21; RIME 4.2.14.14:6' (Rīmsîn); RIME 4.2.14.17:22; RIME 4.2.14.20:3.

$\mathrm{C}=$ RIME 4.1.3.2:14 (Iddindagān); RIME 4.1.6.1:12-13 (Urninurta); RIME 4.1.11.1:12-13 (Zambīya); RIME 4.1.13.1:19-20 (Urdukuga); RIME 4.1.14.1:9; 11-12 (Sînmāgir); RIME 4.2.8.1:12-13 (Nūradad); $R I M E$ 4.2.9.6:13-14 (Sîniddinam); RIME 4.2.13.12:25 (Waradsîn); RIME 4.2.13.16:28-29; RIME 4.2.13.27:27-29; RIME 4.2.14.5:21-23 et passim (Rīmsîn).

$\mathrm{D}=$ RIME 4.2.8.3:18-19 (Nüradad); RIME 4.2.9.6:15-16 (Sîniddinam); RIME 4.2.13.21:45-46 (Waradsîn); RIME 4.2.13.27:49-50.

10. mainly copies of statue and stela inscriptions.

A = Išmedagān A 42; 62; Išmedagān S 20; 23;97 RIME 4.2.9.1 (= Kärki, StOr. 49 69) 27 (Sîniddinam).

B = Išmedagān A 239; RIME 4.2.13.15 frgm. 3:4'-5' (Waradsîn) (either a fragment of a stela or a stone tablet, i.e. artefact inscription).

C = Išmedagān A 44; 60; 104; Išmedagān S 4; 27-28; Codex Lipiteštar (= Szlechter, Les lois sumériennes 58) i 23-24; RIME 4.1.6.2 ii 18'-21' (Urninurta); RIME 4.2.6.1 ii 1'-3' (Abīsarē); Kärki, StOr. 49 70:101-105 (Sîniddinam); RIME 4.2.13.15 frgm. 14:13'-15' (Waradsîn) (either a fragment of a stela or a stone tablet, i.e. artefact inscription); RIME 4.2.13.17 i 15'.

$\mathrm{D}=$ Išmedagān A 61; 69-70; 77-78; RIME 4.1.6.2 ii 4'-5' (Urninurta) (perhaps not related to king); Kärki, StOr. 49 70:106-109; 71:185-90 (Sîniddinam); RIME 4.2.11.1 (p. 192) v 1-4 (Sîniqī̌am).

11. A = Išbi'erra A (= Sjöberg, Studies Hallo 213) i 3'; Šūilišu A (= Kramer, Studies Sjöberg 307) 106; Išmedagān D (= Sjöberg, JCS 29 31) rev. 1; Iddindagān B (= Römer, SKIZ 210) 18; Lipiteštar A 1-2; 25; 108; Lipiteštar B 10 et passim; Lipiteštar D 6; Isin *32 (= Kapp, ZA 51 78) i 18 (Enlilbāni hymn); Sjöberg, Mondgott 25 ad 32 with references. 
B = Išbi'erra A (= Sjöberg, Studies Hallo 214) source D 7'; Iddindagān B 12; Lipiteštar A 33; Lipiteštar B 43; Gungunum A (= Sjöberg, ZA 63 25) rev. 13; UET 6101 (=Steible, Haja 8) 50; UET 6102 (= Charpin, Clergé 275) 11.

C = Išbi' erra A (= Sjöberg, Studies Hallo 214) iv 9; 18; Šũilišu A (= Kramer, Studies Sjöberg 307) 105; Iddindagān B 5-6; Išmedagān B 41; Lipiteštar A 31 32; Lipiteštar B 17; 46-46a; Urninurta A (= Sjöberg, Finkelstein Memorial Vol. 191) 81; Isin *28 (= Falkenstein, ZA 49 116) 12 (Urninurta hymn); Isin *31c (= Sjöberg, AOAT 25 420) 162 (Būrsîn hymn); Isin *32 (= Kapp, ZA 51 78) i 12; (p. 79) iv 120-21 (Enlilbāni hymn); Sîniddinam A (= v. Dijk, JCS 19 21) 18 || 19; UET 6102 (= Charpin, Clergé 275) 1-2; 6; UET 6103 (Charpin, Clergé 282) 6; UET 6104 (= Steible, FAOS 1 33) 3; (p. 34) 58; UET 6106 (= Charpin, Clergé 295) 11 (Rīmsîn hymns).

D = Iddindagān B 2-3; Išmedagān B 43-44; Lipiteštar A 24; 26; 36; Lipiteštar B 7-9; Urninurta A (= Sjöberg, Finkelstein Memorial Vol. 190) 20; 38-39; Isin *32 (= Kapp, ZA 51 78) i 14; (p. 80) v 163-67 (Enlilbāni hymn); UET 6 102 (= Charpin, Clergé 275) 18-22; UET 6104 (= Steible, FAOS 1 33) 4-6; (p. 34) 60-62; (p. 35) 74; UET 6106 (= Charpin, Clergé 296) 22 (Rìmsîn hymns).

The chart shows that topoi of legitimation and kingship appear in artefact inscriptions of Pre-Sargonic Lagaš and Uruk, inscribed on bricks, door sockets, cones, and votive objects, and only again in artefact inscriptions of the Isin-Larsa period. From the Sargonic through Ur III period, topoi of legitimation and kingship are in general absent from these inscriptions. These topoi then appear only in statue and stela inscriptions, predominantly known from Old Babylonian copies, in the Lagaš II statues and cylinders, and in the hymns of the Lagaš II (= Gudea A) and Ur III periods. The only exceptions are the Lagaš rulers Piriĝme and Urba'u, two of Gudea's predecessors, and the Ur III kings Šūsu'en and Amarsu'en, whose artefact inscriptions can sometimes contain particular formulae of divine birth and selection, reflecting perhaps a problematical succession of these rulers. This shift is similar to what happens to narrative material describing royal achievements first found in Pre-Sargonic artefact inscriptions. Absent from most inscribed objects, these narratives appear only in the Lagaš statues, Gudea's cylinders, and in the Old Babylonian copies of statue and stela inscriptions of the Ur III and Isin periods, and in a more literary and less explicit form in the royal hymns. In the Larsa period this changes, and narratives can be found again in both hymns and artefact inscriptions. ${ }^{98}$ The comparison of topoi found in Old Babylonian copies of statue and stelas inscriptions with those in hymns shows the close affinity between the two text types and bolsters the thesis of W.W. Hallo that royal hymns were originally inscribed on stelas and statues.

One can also observe a common pool of topoi which are used once the king is invested with insignia and assumes his role as monarch. These topoi or motifs are

$98 \mathrm{Cf}$. immediately below on topoi of royal achievements and also 3.1 , pp. $69 \mathrm{ff}$. and 3.2, p. 84 . 
centered on the king's deeds on behalf of his people and the gods. The earliest examples go back to the Pre-Sargonic royal inscriptions of Lugalzagesi and IriKAgina, occur in Gudea's statues and cylinders, and find their way into the Ur III and Isin-Larsa royal hymns.

One topos, the care of widows and orphans, is expressed as a stock formula of one sentence. The attestations in Gudea and Urnamma show slighty varied prefix chains: Codex Urnamma 162-165 $\mathrm{nu}-\mathrm{siki} \quad \mathrm{lu}_{2} \quad \mathrm{ni} \hat{g}_{2} \quad \mathrm{tuku}-\mathrm{ra}$ । $\mathrm{b} a-\mathrm{ra}(-[\mathrm{n}] \mathrm{a})-\mathrm{a} n-\hat{\mathrm{g}} \mathrm{ar} \mid \mathrm{nu}-\mathrm{mu}(-\mathrm{un})-\mathrm{KUS} \mathrm{L}_{2} \mathrm{u}_{2} \mathrm{tuku}-$ $\mathrm{r} a \mid \mathrm{b} a-\mathrm{r} a-\mathrm{n}$ a- $\mathrm{a} n-\mathrm{g}$ a $r$ "The orphan was not delivered to the wealthy, the widow was not delivered to the mighty", and Gudea, Stat. B 7:42-43 (I Cyl. B 18:6-7) nu-siki l u ${ }_{2}$ ni g $\hat{g}_{2}$ tuku nu-mu-na-gar I n a/nu$\mathrm{ma}-\mathrm{KUS} \mathrm{S}_{2} \quad \mathrm{u}_{2} \quad \mathrm{tuku} \mathrm{nu}-\mathrm{n} \mathrm{a}-\mathrm{g}$ a r "The orphan was not delivered to the wealthy, the widow was not delivered to the mighty".99 These in turn are modelled on similar phraseology appearing 150 years earlier in Ukg. 4, 12:23-25 ॥ $5,11: 30-31,{ }^{100}$ and the same formula appears later in the Old Babylonian period in Codex Hammurapi xl 61. ${ }^{101}$

The securing of routes for maintenance of infra-structure finds literary expres-

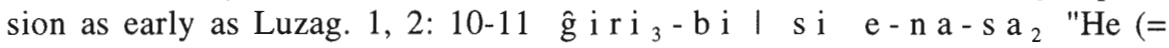
Enlil) has put for him (= Lugalzagesi) their (= the lands') roads in order", with which compare Urnamma C 19 [ u ] r $-r^{d} \mathrm{na} \mathrm{m} \mathrm{ma}{ }^{\urcorner} 1 \mathrm{ugal}$ u ri ${ }_{5} \mathrm{ki}-\mathrm{ma}$ $\mathrm{nam} \quad \mathrm{du}_{10}$ tar-ra-ba $/$ giri ${ }_{3}$ si mu-un-da-ab-sa "Urnamma, the king of Ur: after an auspicious fate was determined, the roads were put in order due to him", and line 54 re di m ${ }_{x}^{\urcorner}$(EDIN)-m a e ze m -

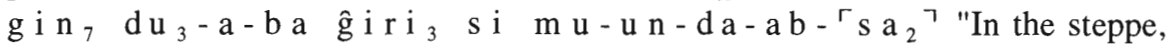
after being prepared as for a festival, the roads were put in order due to me!". ${ }^{102}$ Besides the royal hymns of Urnamma and Sulgi, the topos is only rarely attested in other literary compositions. ${ }^{103}$

The description of abundance under royal rule: compare e.g. Gudea, Cyl. A

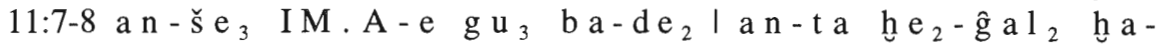
$\mathrm{m} \mathrm{u}-\mathrm{r} \mathrm{a}-\mathrm{t}$ a - D U "'I (= Ningirsu) will call towards heaven for (a) rain(storm). From heaven abundance will verily come forth for you (= Gudea)'", with Urnamma C 20-21 a n-e ka $\left\ulcorner\mathrm{ku}_{3}\right\urcorner-\mathrm{ga}-\mathrm{ni}$ mu-un-ba IM. A ma-u ${ }_{3}-$ $\mathrm{du}_{2} \mid \mathrm{ki}-\check{s}_{3} \mathrm{ša}_{3}-\mathrm{ga} \mathrm{si} \mathrm{ba}-\mathrm{an}-\mathrm{sa} \mathrm{a}_{2} \mathrm{~h}_{2}-\mathrm{g} \mathrm{al}_{2} \mathrm{ma}-\mathrm{ra}-\mathrm{DU}$ "An opened his pure mouth and rain(storms) was produced for me. He made it fall right into the deep earth, and abundance came forth to/for me". The same motif can be found in Luzag. 1, 3:27-31 u bu r - a n- $\mathrm{na}^{-\mathrm{ke}_{4}}$ । $\mathrm{s} \mathrm{i}$ h a - m u-dab ${ }_{6}$ -

99 Cf. also Steible, FAOS 9/2 (1991) 31 ad 92.

$100 \mathrm{Cf}$. also Szlechter, Les lois sumériennes (1983) 25 ad IV.

$101 \mathrm{Cf} . C A D \mathrm{~A} / 1363$ s.v. almattu c) and CAD E 72f. s.v. ekütu for other Akkadian references, Nanše Hymn $20 \mathrm{ff}$. is a literary elaboration of the same topos.

102 The expression $\mathrm{g}^{\mathrm{r} \mathrm{i}_{3}} \mathrm{~s} \mathrm{i}_{\mathrm{s} \mathrm{a}_{2}}$ is attested in Unamma's year name "4" and in Sulgi's year name "6". For the concern for roads in the ancient Near East in general, cf. Frayne, JAOS 103 (1983) $740 \mathrm{ff}$.

103 Cf. e.g. Hoe and Plow (= Vanstiphout, ASJ 14 [1992] 362, fn. 53) 153 (..) ĝ i r i ${ }_{3}$ s i u m - m i $\mathrm{s} \mathrm{a}_{2}$ "(...) after $\mathrm{I}(=$ the hoe) made (instead) a straight path". In a less literal sense in Nanše Hymn 113 , Utudug to Ilakniid 6, and Ininš agura 118 . 
$\mathrm{s} \mathrm{a}_{2}\left|\mathrm{ug}_{3}-\mathrm{e}\right| \mathrm{ki} \mathrm{s} \mathrm{a}_{6}-\mathrm{ga} \mid \mathrm{ig} \mathrm{i} \mathrm{ha}-\mathrm{mu}-\mathrm{da}-\mathrm{du}_{8}$ "May the teats of heaven flow straight (down) under my (= Lugalzagesi's) reign. May the people witness fertile ground under my reign". This may be compared to UET 6102 (cf. Charpin, Clergé $275=$ Steible, FAOS 1 [1975] 604) 23-24 u bu r a n s u d$\mathrm{agg}_{2} \mathrm{~g} \mathrm{al}_{2} \mathrm{hu}-\mathrm{mu}-\mathrm{ra}-\mathrm{ab}-\mathrm{taka}_{4} \mathrm{IM}$. A a n-n a hu u-m u-ra-

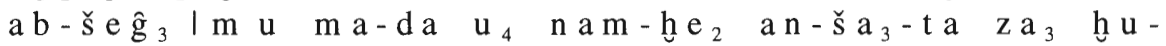
$\mathrm{m} \mathrm{u}-\mathrm{r} \mathrm{a}-\mathrm{a} \mathrm{b}-\mathrm{k}$ e š e 2 "May the teats of the sparkling heavens be opened for you (= Rìmsîn), may it rain for you from heaven. May you be provided with years of wealth ${ }^{105}$ and days of abundance from within the midst of heaven". ${ }^{106}$

The king as incessant provider of the gods is a recurrent topos throughout royal hymns, as e.g. in Sulgi B 244-245 d i g i r-r e-e-n e g u b-b u i n - g a a n-zu I d a-nun-na-k e ${ }_{4}-\mathrm{ne} \quad \check{\mathrm{s}} \mathrm{a}_{3} \quad \check{s ̌ ~}_{17}-\mathrm{de}_{3} \quad \mathrm{mu}-\mathrm{zu} \quad$ "I (= Sulgi) also know how to serve the gods. I know how to cool the heart for the Anuna". ${ }^{107}$ Urnamma A 157-159 has di g i r-re-e-n e-e r m u - n e $\mathrm{gub}-\mathrm{bu}-\mathrm{nam} / \mathrm{ki}-\mathrm{ur}_{3} \mathrm{mu}-\mathrm{ne}-\mathrm{g} a 1_{2} \mid \mathrm{d} \mathrm{a}-\mathrm{nu} \mathrm{n}-\mathrm{na}-\mathrm{ke}_{4}-$ ne $\quad \mathrm{he}_{2}-\mathrm{gal}_{2}-1 \mathrm{a} \quad \mathrm{pa} \quad \mathrm{mu}-\mathrm{ne}-\mathrm{e}_{3}-\mathrm{a} \mid \mathrm{g}$ e $\check{\mathrm{s}}-[\mathrm{n}] \mathrm{u}_{2} \quad \mathrm{u}_{2} \quad \mathrm{za}-$ $\mathrm{gin}_{3} \mathrm{bara}_{3}-\mathrm{ga}-\mathrm{ba} \mathrm{gi}_{16}-\mathrm{sa} \mathrm{mu}-\mathrm{ne}-\mathrm{g} \mathrm{ar}-\mathrm{rra}^{-\mathrm{g} \mathrm{u}_{10}}{ }$ (...) "I indeed served the gods and have provided them with homes. Although, having revealed abundance to the Anuna, I have placed for them treasures on their beds spread with fresh herbs (...)". Urnamma is the "provider for Nippur" $\left(\mathrm{u}_{2}-\mathrm{a}\right.$ n i b r u k i), the "supporter of Ur" (s a g - u s ${ }_{2} \quad \mathrm{u} \mathrm{r} \mathrm{i}_{2} \mathrm{k} \mathrm{i}-\mathrm{m} \mathrm{a}$ ) and the "provider for Sumer and Akkad" ( $\mathrm{u}_{2}-\mathrm{a}$ k i - e n-g i k i - u r i) in Urnamma D (Ni) 38 and (Ur) 39'. Rìmsîn is "the one who took in hand the renovation of the gods'

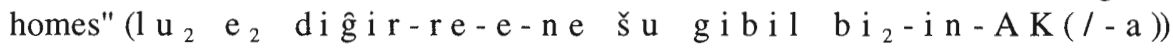
in RIME 4.2.14.8 || 11:16 || 20-21. ${ }^{108}$

The motif of "sleeplessness as a sign of industriousness"109 appears in several passages in context of carrying out a divine command, e.g. Gudea, Cyl. A 6:11, 17:8, 19:23 and Stat. F 2:2-5 (to build a temple), and Sulgi R 6 (to build a boat), ${ }^{110}$ or in generally caring for somebody or something, e.g. Urnamma A 163 (care for the gods) [ $\mathrm{g}] \mathrm{i}_{6}-\mathrm{da} \quad \mathrm{gub} \quad \mathrm{u}_{3} \quad \mathrm{n} \mathrm{u}-\mathrm{ku}-\mathrm{g} \mathrm{a}_{2}-\mathrm{a} \quad \mathrm{u}_{4} \quad \mathrm{i} \mathrm{m}-$ $\mathrm{m} \mathrm{a}-\mathrm{n}$ i - t i 1 "I have (even) spent the time sleeplessly serving (the gods) by

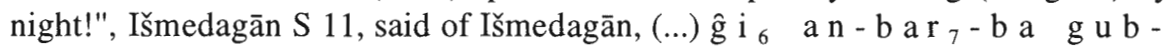
$\mathrm{b} \mathrm{u} \quad \mathrm{m} \mathrm{u} \mathrm{š}_{3} \mathrm{nu}-\mathrm{t} \mathrm{u} \mathrm{m}{ }_{2}-\mathrm{m} \mathrm{u}$ "to serve incessantly night and midday", Curse of Agade 24, said of Inana for her city, TMH NF 47 iii 153-55, a b a 1 b a 1 e of Nanna, said of some functionaries of the temple Ekišnugal, among them a

104 Cf. also Steible's commentary, ibid. 21f. ad 23.

$105 \mathrm{~m} \mathrm{a}-\mathrm{d}$ a is taken here (with Charpin, Clergé 276) as a variant for $\mathrm{m} \mathrm{a}-\mathrm{d}$ a $\mathrm{m}$ h hiṣbu "abundance, produce, wealth"; compare Sjöberg, Studies Widengren $64: 29^{\prime} \mathrm{u}_{4} \mathrm{ma}-\mathrm{d} \mathrm{a} \mathrm{m} \mathrm{m} \mathrm{u}$ h $\mathrm{e}_{2}-\hat{\mathrm{g}}$ a $1_{2}-1$ a $t$ i $1_{3}[\ldots]$.

106 In general, cf. also the commentary ad Urnamma C 20-23 in V 3.3, p. 222.

107 The verb $\mathrm{g} \mathrm{u} \mathrm{b}$ and other terms that are used to characterize unending (royal) service to the gods have been listed and supplied with references by Ludwig, Išme-Dagan 67, and fn. 167;201, and fn. 476 .

108 All artefact inscriptions.

109 Cooper, Curse of Agade 238 ad 24.

110 Similarly Išmedagān I 6 (in context of building a chariot) with the expression $\hat{\mathrm{g}} \mathrm{a}_{2}-1 \mathrm{a} \quad \mathrm{n} \mathrm{u}-\mathrm{d}$ a g "to be unceasing". 
miller, ${ }^{111}$ performing incessant work for Nanna, and RIME 4.2.13.17 i 14', said of Waradsîn, for the "land" ( $\mathrm{k} \mathrm{a} 1 \mathrm{a}$ m). Unrelated to this topos is sleeplessness caused by calamity in Urnamma A $20 \mathrm{nam}-1 \mathrm{u}_{2}-\mathrm{u}_{1} \mathrm{u}_{3} 1 \mathrm{i}-\mathrm{b}$ i i b $-\mathrm{til}-\mathrm{la}-$ $\mathrm{a} \mathrm{m}_{3} \quad \mathrm{u}_{3} \quad \mathrm{du}_{10} \quad \mathrm{nu}-\mathrm{mu}-\mathrm{u} \mathrm{n}-\mathrm{ku}-\mathrm{ku}$ "With their bliss(fulness) having come to an end, the people do not sleep soundly".

Submission to divine will and knowing how to carry out divine commands is found in texts involving construction projects, describing preparations and then the actual work that follows, as in Gudea, Cyl. B 13:11-13 (bestowing gifts on the Eninnu); Gudea, Stat. C 2:14ff. (building the Eana in Ĝirsu for Inana); similarly Gudea, Stat. F 2:6ff. (building the temple of Gatumdug), Sulgi R 5ff. (construction of Ninlil's boat), Išmedagān I 3ff.(construction of Enlil's chariot); RIME 4.2.14.15:19-24 ${ }^{112}$ (Rīmsîn) (digging canals for irrigation projects). Išmedagān is called s i p a g a l-z u "the wise shepherd" in Išmedagān I 3. Urnamma is "the one who knows judgment, the lord of [broad und]erstanding" $\mathrm{d} i \quad \mathrm{z} \mathrm{u}$ e $\mathrm{n}$ g e š $\left[\mathrm{t} \mathrm{u}_{2} \mathrm{da} \mathrm{g}\right.$ a l ] - l a - k a m in hymn B 13 (after Enlil has commissioned Urnamma to rebuild the Ekur), Rimsîn is one who "has intelligence, is equipped

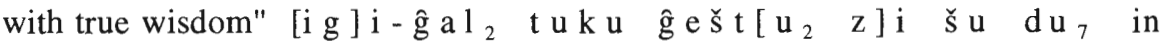
RIME 4.2.14.15:27 (cf. also lines 28-31; after being commissioned by Enlil). Preparations involve the making of plans and the ritual moulding of bricks in the case of temple constructions (cf. Gudea and Urnamma), the supply of raw-materials in the case of the construction of Ninlil's boat (Sulgi R 8), and the making of plans and assembling of people to help work on the canals in RIME 4.2.14.15 (Rīmsîn). ${ }^{113}$

It is evident that these topoi of royal achievements show much continuity from the Pre-Sargonic to the Larsa period. As the previously discussed topoi of legitimation, they appear in the artefact inscriptions of the Pre-Sargonic and the Larsa period, in the statues and cylinders of Gudea, and in the Ur III and Isin-Larsa hymns and literary compositions. They do not appear in Lagaš II or Ur III artefact inscriptions.

\subsection{Royal Titles and Epithets}

Royal titles and epithets ${ }^{114}$ are selected according to individual circumstances and show greater selectivity than topoi of royal achievements. They get dropped in certain periods and reappear in others. Attested titles and epithets Urnamma uses in Codex Urnamma, his royal inscriptions, and hymns are:

\footnotetext{
111 According to J. Westenholz, Studies Sjöberg (1989) 547 in the person of Enh eduana.

112 A tablet copy, probably of an original foundation tablet (cf. line 59).

$113 \mathrm{Cf}$. also below, 3.1 , pp. $69 \mathrm{ff}$.

114 For problems in distinguishing titles from epithets, cf. Hallo, Royal Titles $129 \mathrm{ff}$.
} 


\begin{tabular}{|c|c|c|}
\hline Title / Epithet & & Attestations $^{115}$ \\
\hline$a_{2}$ nun $g e_{4}-a$ & "of indomitable strength" & C 14 \\
\hline $\begin{array}{l}\text { dumu } d_{\text {nin- }} \operatorname{sumun}_{2}(-\mathrm{ka}) \\
\text { dumu } \mathrm{du}_{2} \text {-da } \mathrm{d}_{\text {nin-sumun }} \text { - } \\
\mathrm{ka}^{116}\end{array}$ & $\begin{array}{l}\text { "son of Ninsumun"; } \\
\text { "natural son of Ninsumun" }\end{array}$ & $\begin{array}{l}\text { A } 63 ; \text { E } 6 \text { II F 12; F 40; } \\
\text { C } 113, \text { CU 37-38 }\end{array}$ \\
\hline en & "e n-priest, lord" & $\begin{array}{l}\text { C } 69 ; \text { E }^{\prime} \| \text { F } 11 ; \text { Ni. } 4375 \\
\text { iv } 7\end{array}$ \\
\hline en geštu ${ }_{2}$ daĝal-la & $\begin{array}{l}\text { "lord of broad under- } \\
\text { standing" }\end{array}$ & B 13 (broken) \\
\hline en $s a_{7} \cdot g$ & "comely lord" & E $5^{\prime} \|$ F $11 ;$ E $20^{\prime}$ \\
\hline en sukud & "eminent lord" & F $6^{*}$ \\
\hline en unuki-ga ${ }^{117}$ & "e n of Uruk" & $10: 7 ; 34: 5$ \\
\hline en $\mathrm{uru}_{16} \cdot \mathrm{n}$ & "unswerving lord" & B $44 * \| 50$ \\
\hline engar zi.d & "faithful farmer" & $\mathrm{G} 19 * \| 20$ \\
\hline igi(-)ĝal ${ }_{2}$ kur-kur-ra & $\begin{array}{l}\text { "overseer of all (the } \\
\text { foreign) lands" }\end{array}$ & A 44 \\
\hline ka mud-gal ${ }_{2}$ ki-en-gi-ra & "advocate of Sumer" & A $33 \| 34 *$ (broken) \\
\hline 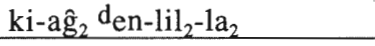 & "beloved of Enlil" & $\mathrm{D}(\mathrm{Ur}) 39^{\prime}$ \\
\hline [ki-en-g]i-ra uz z $_{3}$-saĝ-bi & ". . of [Sum]er" & C $62^{*}$ \\
\hline $\begin{array}{l}\text { KI.LUGAL.GUB-la he } \mathrm{h}_{2}-\mathrm{du}_{7^{-}} \\
\text {bi }\end{array}$ & "adornment of . . ." & C $13 *$ \\
\hline $\mathrm{ku}_{3}$ tuku & "wealthy one" & $\mathrm{D}(\mathrm{Ni}) 5^{*} \|(\mathrm{Ur}) 6^{\prime}$ \\
\hline $\begin{array}{l}\text { dlamma } \\
\text { dlamma iri-g } a_{2}\end{array}$ & $\begin{array}{l}\text { "guardian-spirit" } \\
\text { "guardian-spirit of my } \\
\text { city" }\end{array}$ & $\begin{array}{l}\text { C } 50 \\
\text { C } 31\end{array}$ \\
\hline $\begin{array}{l}\text { lugal an }\left(/-\mathrm{ne}_{2}\right) \text { ub-da } \\
\operatorname{limmu}_{2}-\mathrm{ba}(/ \mathrm{bi})\end{array}$ & "king of the four corners" & $\mathrm{D}(\mathrm{Ni}) 37 \|(\mathrm{Ur}) 38^{\prime}$ \\
\hline lugal kalam-ma(-k) & "king of the land" & $\begin{array}{l}\text { A } 40 ; \text { B } 68 ; \text { C } 25 ; \mathrm{H} 1 \\
\text { (broken) ॥ } 10\end{array}$ \\
\hline
\end{tabular}

115 An asterisk * after a line number indicates that the title/epithet is discussed in the philological commentary to that line. For a discussion of the titles, cf. below.

$116 \mathrm{Cf}$. also below, 3.3, p. 86, and fn. 277.

$117 \mathrm{Cf}$. also above, III 2., p. 38 , and below, 2., p. $65 \mathrm{f}$. 


\begin{tabular}{|c|c|c|}
\hline lugal ki-en-gi ki-uri(-k) & $\begin{array}{l}\text { "king of Sumer and } \\
\text { Akkad" }\end{array}$ & $\begin{array}{l}\text { CU } 13 ; 107 \text { (broken); } 3: 3 \\
7,2: 2 ; 10: 9 ; 11: 6 ; 12: 6 ; \\
13 \text { obv. } 7 ; 14 \text { obv. 6; } 15 \\
\text { obv. } 6 ; 16: 7 ; 17: 7 ; 18: 6 ; \\
19: 6 ; 21: 6 ; 22: 7 ; 23: 6 ; \\
24: 6 ; 26,1: 8 ; 27,1: 8 ; 28, \\
1: 7 ; 31: 6 ; 32: 6 ; 33: 6 ; \\
34: 7 ; 35: 7 ; 40: 7 ; 45: 7 \\
46: 6 ; 47,1: 11 ; \text { Al-Rawi, } \\
\text { Sumer 46 (1989-90) 84:7; } \\
\text { IB } 1537 \text { rev. v' 4' }\end{array}$ \\
\hline lugal mu da-a-ri & $\begin{array}{l}\text { "king with a lasting } \\
\text { name" }\end{array}$ & $\mathrm{D}(\mathrm{Ur}) 41^{\prime}$ \\
\hline lugal uri $2 / 5$ ki-ma & "king of Ur" & 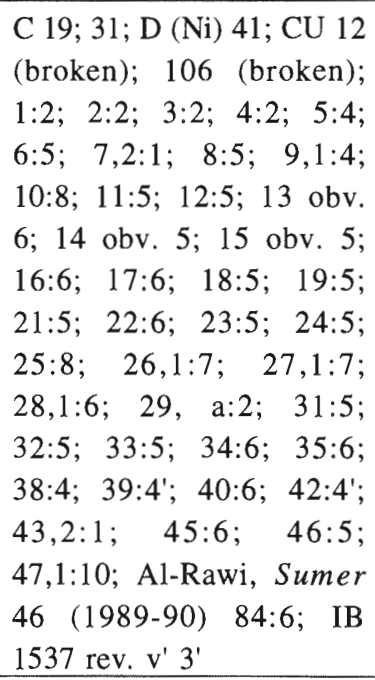 \\
\hline mas-su ki-en-gi-ra & "leader of Sumer" & A 35 \\
\hline maškim (maš-gi-i) & "enforcer" & E $30^{\prime} \| 32^{\prime}$ || F 35 \\
\hline $\begin{array}{l}\text { me-te } \\
\text { me-te kur-kur-ra } \\
\text { me-te? unken-na }\end{array}$ & $\begin{array}{l}\text { "adornment" } \\
\text { "adornment of all (the } \\
\text { foreign) lands" } \\
\text { "adornment of the } \\
\text { assembly" }\end{array}$ & $\begin{array}{l}\text { E } 6 \text { ' | F } 12 \\
\text { A } 33 \text { (broken) \| } 34^{*}\end{array}$ \\
\hline mu pa ${ }_{3}$-da DN(-k) & "called by name by DN" & B $34 ;$ E 5 ' $\mid$ F $11 ; 14$ \\
\hline nig $\hat{g}_{2}$ tuku & "rich one, wealthy" & $\mathrm{D}(\mathrm{Ni}) 6^{*} \| \mathrm{D}(\mathrm{Ur}) 8^{\prime}$ \\
\hline saĝ-us ${ }_{2}$ urì $_{2} \mathrm{ki}_{\text {-ma }}$ & "supporter of Ur" & $\mathrm{D}(\mathrm{Ni}) 38$ \\
\hline ses $\mathrm{d}_{\mathrm{bil}}{ }_{3}$-ga-mes gu-la & $\begin{array}{l}\text { "eldest of the brothers of } \\
\text { Gilgameš" }\end{array}$ & C 112 \\
\hline
\end{tabular}




\begin{tabular}{|c|c|c|}
\hline $\begin{array}{l}\text { sipa.d } \\
\text { sipa } \mathrm{ku}_{3}-\mathrm{zu} \\
\text { sipa (d)ur-dnamma(-k) }\end{array}$ & $\begin{array}{l}\text { "faithful shepherd" } \\
\text { "faithful shepherd } \\
\text { Urnamma" }\end{array}$ & 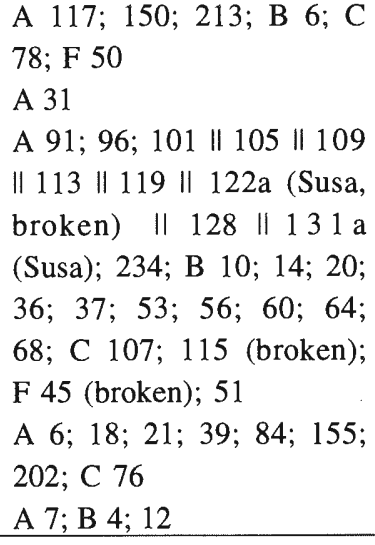 \\
\hline $\mathrm{su}_{6} \mathrm{za}-\mathrm{gin}_{3} \mathrm{su}_{3 / 13}-\mathrm{su}_{3 / 13}$ & $\begin{array}{l}\text { "wearing a long lapis } \\
\text { lazuli beard" }\end{array}$ & E $24 ;$ F $5 ; 45$ \\
\hline $\begin{array}{l}\text { sul } \\
\qquad \text { sul igi il }{ }_{2} \text {-la } \\
\text { sul zi.d }\end{array}$ & $\begin{array}{l}\text { "youth" } \\
\text { "selected youth" } \\
\text { "faithful young man, } \\
\text { faithful youth" }\end{array}$ & $\begin{array}{l}\mathrm{D}(\mathrm{Ni}) 10 \|(\mathrm{Ur}) 11^{\prime} \\
\text { B } 34 ; 43 \| 49 ; \mathrm{D}(\mathrm{Ni}) 6\end{array}$ \\
\hline še-ga den-lil ${ }_{2}-\mathrm{la}_{2}$ & "favourite of Enlil" & $\mathrm{D}(\mathrm{Ur}) 38^{\prime}$ \\
\hline šu-du ${ }_{11}-g a-e d_{\text {nanna-a }}$ & "creature of Nanna" & C 111 \\
\hline tešs kalam-ma & "the land's vigour" & A $45^{*}$ \\
\hline $\begin{array}{l}\mathrm{u}_{2}-\mathrm{a} \\
\mathrm{u}_{2} \text {-a ki-en-gi ki-uri } \\
\mathrm{u}_{2} \text {-a nibruki118 }\end{array}$ & $\begin{array}{l}\text { "provider" } \\
\text { "provider for Sumer and } \\
\text { Akkad" } \\
\text { "provider for Nippur" }\end{array}$ & $\begin{array}{l}\mathrm{D}(\mathrm{Ur}) 39^{\prime} \\
\mathrm{D}(\mathrm{Ni}) 38\end{array}$ \\
\hline $\mathrm{UL}_{4}$-gal ki-en-gi-ra & $" \ldots$ of Sumer" & A $39^{*}$ \\
\hline ur-saĝ & "warrior, hero" & A 169 \\
\hline
\end{tabular}

The title lugal an u b-da li m m ${ }_{2}$ - b a / LUGAL kibrātim arba'im "king of the four corners" is attested in Urnamma's hymn D (Ni) $37 \|$ (Ur) 38 ' but not in his royal inscriptions, in contrast to his successors, the Ur III kings from Sulgi through the Isin and Old Babylonian kings. ${ }^{119}$ The title was first assumed by Narāmsu'en of Akkade and subsequently by the Gutian king Erridupizir ${ }^{120}$ and by Utuhegal, ${ }^{121}$ Urnamma's former overlord in Uruk. Perhaps Urnamma was not able to claim this title from Utuhegal legitimately to make it part of his titulary in his royal inscriptions. Urnamma uses the title $1 \mathrm{u} \mathrm{g}$ a $1 \mathrm{k} \mathrm{a} 1 \mathrm{a} \mathrm{m}$ -

118 Cf. also V 4.1 , p. 231

119 E.g. Sulgi 1 b:4 et passim; Amarsu'en 3:9 et passim; Šū su'en 1-2:6-7 et passim; Ibbīsu'en 1-2, 1:5 et passim; also in Sulgi A 4. Some references to the Isin kings are: RIME 4.1.1.2006:3 (Ǐ bi'erra); RIME 4.1.4.5:4 (Iśmedagān). Cf. also Hallo, Royal Titles 152 ad (5). For this royal title in general, cf. Wilcke, CRRAI 19 (1974) 178.

120 RIME 2.2.1.1 i 3'-7' LUGAL | gu-ti-im $\left|u_{3}\right|$ ki-ib-ra-tim $\mid$ ar-ba-im "king of Gutium and the four corners".

I21 RIME 2.13.6.1:5 et passim; Utuh eĝal Inscr. (= RIME 2.13.6.4) 20. 
$\mathrm{m}$ a "king of the land"122 exclusively in his hymns (Urnamma A 40, B 68, C 25 , and H $1 \| 10$ ) as do some of his successors (e.g. Sulgi E 201, Lipiteštar B 53, said of Išmedagān, and Lipiteštar A 17). ${ }^{123}$ Other kings of the Ur III and Isin dynasties may use it to avoid the more prosaic titulary $1 \mathrm{u} \mathrm{g} \mathrm{a} 1 \mathrm{u} \mathrm{ri}_{2 / 5} \mathrm{k} \mathrm{i}-\mathrm{m}$ a "king of Ur", ${ }^{124}$ but Urnamma uses both these titles in Urnamma C. The title $1 \mathrm{u} g$ a 1 $\mathrm{k}$ a 1 a $\mathrm{m}-\mathrm{m}$ a is first used by Enšakušana of Uruk, who reigned shortly before Sargon, ${ }^{125}$ in inscriptions from Nippur and Uruk (1:5 and 5:4), next to the more specific and probably politically relevant ${ }^{126}$ title e $\mathrm{n} \mathrm{ki}-\mathrm{e} \mathrm{n}-\mathrm{g} \mathrm{i}$ "e $\mathrm{n}$ of Sumer" (1:4 and 5:3). The titulary was used again by Lugalzagesi $(1,1: 5 \| 1,3: 3)$ and Sargon. ${ }^{127}$ By assuming this title, these rulers expressed the rule over all of Sumer, and therefore legitimised themselves foremost through Enlil who gave them kingship over the land Sumer, ${ }^{128}$ and not through the god of their city. By combining e n-ship of Uruk (Urnamma 10:7; 34:5) with kingship of Ur, Urnamma followed a strategy that is attested in Pre-Sargonic times by Lugalkighenedudu of Uruk, a contemporary of Enmetena of Lagaš. Two of his inscriptions tell us that he exercised e n-ship of Uruk and kingship of Ur simultaneously. ${ }^{129}$ The only title first attested under Urnamma is $1 \mathrm{u} g$ a $1 \mathrm{k} \mathrm{i}$ - e n g i k i - u r i "king of Sumer and Akkad", by which Urnamma claimed hegemony over the whole of Babylonia. ${ }^{130}$ The title is exclusively used in his inscriptions and was subsequently born by his successor Sulgi. ${ }^{131}$ After that it is attested for Šūilišu of Isin and his successors. ${ }^{132}$ According to D.R. Frayne the area to the north, around Urum, encountered as one of the territories mentioned in the Cadaster text of Urnamma, is what is meant by $\mathrm{k} \mathrm{i}-\mathrm{u} \mathrm{ri} .{ }^{133}$ But the area called $\mathrm{k} \mathrm{i}-\mathrm{u} \mathrm{r} \mathrm{i} \mathrm{must}$ have encompassed Transtigridian areas as far as the districts in the (upper) Diyāla region, as well as the area around the Ğebel Hamrīn, mentioned in IB 1537, an Old Babylonian tablet from Isin, ${ }^{134}$ and in the prologue of Urnamma's law code.

\footnotetext{
122 For this title, cf. also Steiner, CRRAI 35 (=OPBF 14) (1992) 268f., and fns. 58 and 60; Franke, Königsinschriften und Königsideologie, Die Könige von Akkade zwischen Tradition und Neuerung, Altorientalistik 1, Hamburg (1995) 71f; 78, and fn. 192.

123 Note that the same title occurs in Lugale (lines 144 and 361) for the anonymous king who scholars think must be Gudea (cf. Wilcke, "Politik und Literatur" 60, fn. 137 with previous literature). Did the Nippurian scribes add additional weight to Gudea's legitimation by calling him "king of the land", a title otherwise unknown from texts pertaining to him?

124 Cf. Hallo, Royal Titles 19.

125 Cf. Cooper, Presarg. Inscr. 4, and fn. 9.

126 Wilcke, CRRAI 19 (1974) 227.

127 References in Kienast, Sommerfeld, FAOS 8 (1994) 146f. s.v. lugal kalam-ma.

128 E.g. Luzag. 1, 1:36-41; RIME 2.1.1.1:68-73 = 73-78 et passim (Sargon). For the significance of Enlil and Nippur in general for Pre-Sargonic and Sargonic rulers, cf. now Tinney, Nippur Lament 55-58.

129 LuKin 2:4-14 and LuKin 4:5-14.

130 Cf. also I l., p. 4, and fn. 29.

$131 \mathrm{Cf}$. the references in Wilcke, CRRAI 19 (1974) 186, fn. 3 ,

132 E.g. RIME 4.1.2.3:3 (Šù ilišu); RIME 4.1.3.1:6 (Iddindagān); RIME 4.1.4.1:9 (Iš medagān); RIME 4.1.5.1:11 (Lipiteš tar); RIME 4,1,6.1:11 et passim (Urninurta).

133 Frayne, BiOr. 48 (1991) 398.

134 Cf. I 1., p. 6.
} 


\subsection{Enlil and Urnamma's Kingship}

As noted above in the discussion of investiture phraseology, ${ }^{135} \mathrm{Ur}$ III and Isin-Larsa kings generally receive kingship and its accoutrements from a variety of gods, although Enlil is the source of sovereignty for all kings of the land. ${ }^{136}$ Sulgi, for instance, receives them from An (Sulgi A 87, B 23-25, P b 37), Enlil (Sulgi B 2325, G 24-27, R 86), Enki (Sulgi R 87), Lugalbanda (Sulgi P b 38-42) and the Anuna gods (Sulgi P b 61-64), Ibbīsu'en from Nanna (Ibbīsu'en A obv. 10-11), and Lipiteštar from An (Lipiteštar A 24), Enlil (Lipiteštar A 25-26), and Enki (Lipiteštar A 35-36, B 48). Urnamma, however, couples sovereignty exclusively with Enlil, chief of the Sumerian pantheon (cf. Urnamma D (Ni) 9-17; D (Ur) 10'$18^{\prime}$ ), and receives royal insignia only from Enlil. ${ }^{137}$ As noted above, the kings of the Akkade dynasty also claimed to have been given kingship by Enlil, without including other gods, and this is also true of Utuhegal of Uruk. Many references in the hymns show Urnamma's close relationship with Enlil: Enlil approves of Urnamma (Urnamma C 22), he calls him by name or gives him a good name (Urnamma B 34; C 46), designates him through extispicy (C 57-59), and gives him troops to keep the land secure (C 72). Urnamma is Enlil's "perfect workman" (C 93), he is Enlil's "beloved" (Urnamma D (Ur) 39'), and his "favourite" (D (Ur) 38'). Even Urnamma B, which centres exclusively on the building and dedication of the Ekur in Nippur, ends with the erection of a dais of kingship in Ur, and the text states that this was done in the presence of Enlil, his lord, and that it was given to Urnamma as a present (line 69), thereby underlining Urnamma's legitimation. Hymn $\mathrm{G}$ goes so far as to arrogate to Enlil certain functions that Urnamma $\mathrm{C}$ properly attributes to other deities. Thus, in Urnamma C 23, it is naturally Enki who gives the carp-flood, with which he is commonly associated, and barley, but Urnamma G 8 has Enlil as subject instead of Enki. Also, Urnamma G 18 recalls Urnamma C 20-21 where it is An who is, as expected, responsible for the rain, and not, as in hymn G, Enlil.

This constant reference to Enlil as the source of a king's vocation and his charisma is a form of ideological legitimization utilized especially by founders of a new dynasty. Linking kingship to Enlil expresses the claim of sovereignty over Nippur, the religious capital of Babylonia, which was naturally of paramount importance for establishing the right to rule. Thus also Išbi'erra, founder of the Isin dynasty, particularly stresses his relationship with Enlil and claims sovereignty over Nippur in his hymns $\mathrm{A}^{138}$ and $\mathrm{B}$, and other literary sources seem to contain

\footnotetext{
1351.2 , ad D), p. 51 .

136 For the significance of Enlil and Nippur in general for Ur III and Isin rulers, cf. now Tinney, Nippur Lament 58-62.

$137 \mathrm{Cf}$, fn. 135.

138 Cf. Sjöberg, Studies Hallo (1993) 211f. with previous literature.
} 
references to Nippur's change in allegiance from Ur to Isin. ${ }^{139}$ Išbi'erra is Enlil's s u 1 z i . d "faithful young man", as is Urnamma (Urnamma B 34; 43 || 49; D (Ni) 6). Išbi'erra calls himself "Enlil's son", ${ }^{140}$ whereas Urnamma seems to avoid any genealogical claim of his own, reserving it for the chief god of Ur, NannaSu'en, who is called $\mathrm{dumu}$ s a $\hat{\mathrm{g}} \mathrm{d}$ e $\mathrm{n}-1 \mathrm{il}_{2}-1 \mathrm{a}_{2}$ "first born (child) of Enlil". ${ }^{141}$ Both Urnamma and Išbi'erra particularly stress the fact that their actions are determined by Enlil's word which was very likely conveyed in form of an oracle. ${ }^{142}$ A favourable Enlil oracle was most probably obtained in the case of Išbi'erra's usurpation, ${ }^{143}$ once he controlled Nippur, and this change was even acknowledged by the last king of Ur, Ibbīsu'en himself. ${ }^{144}$

A passage in Urnamma's self-laudatory hymn $\mathrm{C}$ indicates that a similar procedure took place when Urnamma "arranged" a positive omen to validate his coming to power, a theme picked up by Išmedagān and used in his self-laudatory hymn A. ${ }^{145}$ Urnamma states that he was chosen by Enlil through extispicy $\left(\mathrm{m} \mathrm{a} \breve{s}_{2}-\mathrm{e} \mathrm{p} \mathrm{a}_{3}\right.$. d) immediately after the flood had receded. ${ }^{146}$ Urnamma C 57-58 $\ulcorner\mathrm{a} ?\urcorner-\mathrm{ma}-\mathrm{ru}[\mathrm{g}] \mathrm{e}_{4}$ ? - b a i - t i ma-ge $\mathrm{e}_{4}(/\ulcorner\mathrm{x} \quad \mathrm{x}\urcorner-\mathrm{a}-\mathrm{b} a$ ? $)$ ।

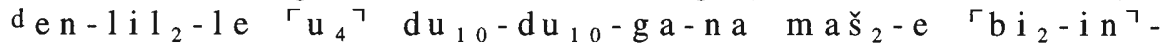
$\mathrm{p} \mathrm{a}_{3}-\mathrm{de}_{3}$ - e n "When the storm had receded?, the moonlight returned to/for me (when ... .), Enlil designated me on his very auspicious day through extispicy". The term $\mathrm{m} \mathrm{a} \mathrm{s}_{2}-\mathrm{e} \mathrm{pa}_{3} . \mathrm{d}$ is attested in Pre-Sargonic Lagaš (Urn. 24 3:3-6), in a royal inscription from the Second Dynasty of Lagaš (Urninĝirsu I.? $62^{\prime}: 8^{\prime}-9^{\prime}$ ), and abundantly in Ur III and Isin-Larsa year names and literary texts in connection with the selection of a cultic official. Undoubtedly one of the more important tasks of new rulers or usurpers was to control Nippur and take custody of the cult of Enlil, and it is likely that both Urnamma's inauguration of first-fruit offerings for Enlil described at the end of Urnamma $\mathrm{C}$ as well as the introduction of a throne or other objects for Enlil (and Ninlil) in Nippur, attested in many early year names of Ur III and Isin kings, occured for that reason.

\footnotetext{
139 Frayne, Correlations 309ff. Note especially the letter of Puzursulgi (= Puzurnumuš da?) to Ibbīsu'en (= Michalowski, Correspondence 254ff.; cf. also Wilcke, ZA 60 [1970] 57-59). In it he relates to his king a letter of Išbi'erra in which the latter challenges Ibbīsu'en, by order of Enlil, to hand over Kazallu.

140 Sjöberg, Studies Hallo (1993) 211f. with references.

141 Urnamma $10: 2-3 ; 25: 3-4 ; 26,1: 2-3 ; 27,1: 2-3 ; 28,1: 2$.

142 Wilcke, CRRAI 19 (1974) 229, fn. 53; idem, "Politik und Literatur" 64.

143 Wilcke, ZA 60 (1970) 59f.; v. Dijk, JCS 30 (1978) 192 ad 4'-9'.

144 Wilcke, ibid. 60.

$145 \mathrm{Cf}$. below, 2., p. $66 f$.

$146 \mathrm{Cf}$. also above, 1.1, p. 41.
} 


\section{Urnamma and Išmedagān}

It is difficult to give a detailed outline of Išmedagann's reign with the available textual data, ${ }^{147}$ but there are indications that aspects of Išmedagān's political biography and his use of specific titulary seem to resemble some of Urnamma's aspects of reign, in so far as they can be reconstructed, and use of titulary. This seems to corroborate the observation that the literary portrayals of Išmedagān and his reign in his hymns were not only styled on those that were partly used by the Old Babylonian scribes to present Sulgi, as noticed and discussed especially by J. Klein, ${ }^{148}$ but perhaps also Urnamma. The following discussion centres therefore first on possible similarities between the political biographies of the two kings and then attempts to present textual evidence from Išmedagān's self-laudatory hymn A that may show literary dependence on Urnamma's self-laudatory hymn C.

The beginnings of Išmedagān's political career can be viewed as similar to Urnamma's: he was šakkanakku "military governor" for his father in Dēr before becoming king, just as Urnamma in Ur for Utuhegal of Uruk, a possible relative of his. ${ }^{149}$ On becoming king, Išmedagān, too, encountered problems with tribes in the north. The Nippur and the Uruk laments which can be dated to Išmedagān, as his name is mentioned explicitly in both compositions, describe widespread destruction of these two cities and their temples, attributed to divine disfavour, at the hand of foreign tribes. ${ }^{150}$ Išmedagān A 277-80 tells of the time when Sumer and Akkad were turned upside down and no king was able to introduce statues into the Ekur complex in Nippur. Other texts show that Isin was probably not in control of Nippur early in Išmedagān's reign. ${ }^{151}$ Thus, although not the first ruler of a new dynasty, Išmedagān faced problems of reconstruction and assertion of hegemony similar to those encountered by Urnamma. The Nippur Lament depicts not only the pitiful state of the stricken Ekur but also its succeeding restoration, commissioned by Enlil, at the hands of devout Išmedagān. Other data attest to this ruler's extensive attention to religious matters, ${ }^{152}$ as in the case of Urnamma. ${ }^{153}$ Išmedagān was the first ruler after Urnamma to use e $\mathrm{n} u \mathrm{n} \mathrm{uk} \mathrm{i}-\mathrm{g}$ a "e $\mathrm{n}$ of Uruk" as a

147 Cf. Edzard, ZZB 21f.; 76-90, and idem, RlA 5 (1976-80) 194f. s.v. "Iš medagān"; also Tinney, Nippur Lament 4 ff.

148 Cf. above, 1.2, p. 43 f. Cf. also Tinney, $O L Z 90$ (1995) 8, and fn. 8 with bibliography.

149 Cf. I 1., p. 1, fn. 1.

$150 \mathrm{Cf}$. however the reservations of Tinney, Nippur Lament $6 \mathrm{ff}$. in using the Nippur Lament for historical reconstruction.

151 Cf. Frayne, Correlations $407 \mathrm{ff}$.

152 Cf. Ǐs medagān's year names in Sigrist, Isin Year Names 26f., and his inscriptions in RIME 4.

153 Note also both ruler's special relationship with Inana and her intercessory role for them (cf. below, 3.3, p. 91), as well as Enlil's centrality in ideological matters of both kings (for Unnamma, cf. above, 1.4, p. 63f., for Išmedagān, cf. Tinney, Nippur Lament 63ff.). 
titulary in his inscriptions, ${ }^{154}$ next to the more explicit "spouse of Inana". Subsequent Isin rulers used these two titles. As noted above, ${ }^{155}$ Urnamma exercised e n-ship of Uruk and kingship of Ur simultaneously, in imitation of Lugalkigenedudu of Uruk approximately 300 years earlier. Išmedagān expresses the same idea in his self-laudatory hymn A $108 \mathrm{n}$ a m-e n n a m 1 u g a l-d a $\mathrm{t} a \mathrm{~b}-\mathrm{e}-\mathrm{g} \mathrm{a}_{2}$ "That I combine e n-ship with kingship". The epithets $\mathrm{u}_{2}-\mathrm{a}$ $\mathrm{n} \mathrm{ibruki} \mathrm{s}_{\mathrm{ag}}-\mathrm{u} \mathrm{s}_{2} \quad \mathrm{u} \mathrm{ri}_{5} \mathrm{ki}-\mathrm{m}$ a "provider for Nippur, supporter of Ur" are also part of his standard titulary, ${ }^{156}$ whereas Urnamma uses it in one of his hymns. ${ }^{157}$ This is good evidence for a conscious dependence on the part of Išmedagān, because whereas Urnamma had had a reason to insist he was e $n$ of Uruk as well as king of Ur, since he was replacing his former sovereign, Utuhegal, king of Uruk, Išmedagān did not, but rather did it in deliberate reference to Unnamma.

The ideology of kingship, expressed through the formulae, topoi or motifs discussed above, and literary portraits of imperial and royal (proto)types, ${ }^{158}$ were fostered in the Old Babylonian schools of Nippur, Ur and other sites. The language utilized in the hymns of the Third Dynasty of Ur was used by the scribal scholars composing the hymns of the kings of Isin, the successor state to Ur. The earlier material could be modified, rearranged, or so closely imitated that we may assume wholesale literary borrowing. Thus, marked similarities between the hymns of Sulgi of Ur and Išmedagān of Isin on formal, thematic, and structural levels have been pointed out, especially by J. Klein, as noted above. They reflect a possible literary dependence of Išmedagān on Sulgi, although distinctive and subtle differences in the portrayal of these two kings are also apparent. ${ }^{159}$ The following citations may indicate that literary portrayals of Išmedagān and his reign also borrowed from Urnamma's hymns. On the formal level, a few passages in Išmedagān's self-laudatory hymn A (= Isin $* 12+* 19+* 20$ ) testify to a possible direct borrowing on part of Išmedagān of "Urnamma" phraseology contained in the latter's self-praise hymn C. There is, however, always the possibility that an earlier unattested source served as a model for both Urnamma and Išmedagān, or that more attestations will turn up to make these phrases no more than a common topos, based on a general literary tradition. The lines ${ }^{160}$ in question are:

Išmedagān A 118-123 (TCL 159 obv. iii 25'-30' // PBS 10/2 9 rev. i 20-25+

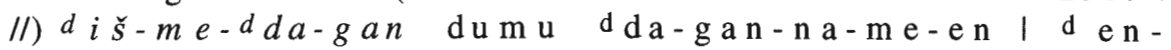
$\mathrm{lil}_{2} \mathrm{lugal} \mathrm{kur}-\mathrm{kur}-\mathrm{ra}-\mathrm{ke}_{4}$ leg i r a-ma-ru ur $\mathrm{r}_{3}-\mathrm{ra}-\mathrm{ta}$ ।

\footnotetext{
154 RIME 4.1.4.1 || 2:7 et passim.

1551.3 , p. 62 .

156 RIME 4.1.4.1 || 2:2-4 et passim.

157 Urnamma D (Ni) 38.

158 Cf. Cooper, "Paradigm and Propaganda" 22f., and fn. 51; Tinney, OLZ 90 (1995) 8, and fn. 7.

$159 \mathrm{Cf}$. Tinney, ibid. 8f.; idem, Nippur Lament $76 \mathrm{ff}$.

160 The line counting is according to the unpub. University Museum manuscript (B. Eichler). For a list of sources, cf. Ludwig, Ǐ̌me-Dagan 2-4. A partial edition is in Römer, SKIZ 39-55. Many passages are cited by Tinney in Nippur Lament (cf. p. 272f. ad Išme-Dagan A). Tinney has announced a forthcoming edition in $O L Z$ 90 (1995) 9, fn. 9 and Nippur Lament 37.
} 


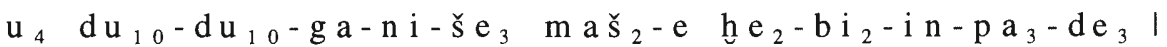

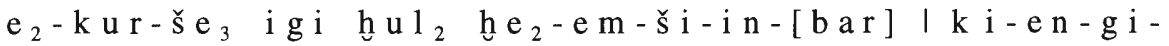
re $\mathrm{g} \mathrm{u}_{3} \mathrm{zi}-\mathrm{de}_{3}-\mathrm{e} \check{\mathrm{s}}\ulcorner\mathrm{h} \mathrm{u}\urcorner-\left[\mathrm{m} \mathrm{u}-\mathrm{un}-\mathrm{de}_{2}\right]^{161}$ "It is me, Išmedagān, son of Dagan, that Enlil, the lord of all the foreign lands, after the flood had swept over, has designated through extispicy for his very favourable day. He has lo[oked] at the Ekur happily indeed, sp[oken] approvingly of Sumer." Compare Urnamma C 57-59 $\ulcorner\mathrm{a} ?\urcorner-\mathrm{ma}-\mathrm{ru} \quad[\mathrm{g}] \mathrm{e}_{4}$ ? - b a $\mathrm{i}-\mathrm{t} \mathrm{i} \quad \mathrm{ma}^{-g} \mathrm{e}_{4}(/\ulcorner\mathrm{x} \quad \mathrm{x}\urcorner-\mathrm{a}-$ ba?) I d en-1il -1 e $\left\ulcorner_{u_{4}}\right\urcorner \quad \mathrm{du}_{10}-\mathrm{du} \mathrm{u}_{10}-\mathrm{ga}-\mathrm{na} \quad \mathrm{mas} \check{\mathrm{s}}_{2}-\mathrm{e}$ $\left\ulcorner\mathrm{bi}_{2}-\mathrm{in}\right\urcorner-\mathrm{pa}_{3}-\mathrm{de} \mathrm{e}_{3}-\mathrm{en} \mid \mathrm{ki}-\mathrm{en}-\mathrm{gi}-\mathrm{r}[\mathrm{a}] \mathrm{gu}_{3} \mathrm{zi} \mathrm{mu}-\mathrm{un}-$ $\mathrm{de}_{2} \quad \mathrm{~g} \mathrm{a}_{2}-\mathrm{a}$ i n - da-a n-zi - $\ulcorner\mathrm{g} \mathrm{e}-\mathrm{e} \mathrm{n}\urcorner$ "When the storm had receded?, the moonlight returned to/for me (when ...), Enlil designated me on his very auspicious day through extispicy. He spoke authoritatively to Sumer, through him I rise over/in front of it (= Sumer)".

Išmedagān A 224-225 (TCL 159 rev. ii 32-33 // SEM 112 obv. i 1'-2' +) a š $\mathrm{a}_{3}-\mathrm{g}$ a $\mathrm{nir}-\mathrm{g} \mathrm{a}\left[\mathrm{l}_{2}-\mathrm{b}\right] \mathrm{i} \quad \mathrm{u}_{2}$ hu $\mathrm{u}-\mathrm{m} \mathrm{u}-\mathrm{un}-\mathrm{DU}$ । e din-na $\mathrm{b} \mathrm{ar}-\mathrm{ku}_{3}{ }^{162}[(\mathrm{x}(-) \mathrm{x})] \quad \mathrm{h} \mathrm{e}_{2}-\mathrm{n} \mathrm{i}-\mathrm{i} \mathrm{n}-\mathrm{g}$ a r $-\mathrm{g}$ a r "Men indeed stood confidently in the fields, in the steppe they set indeed [...] the bark u s." Compare Urnamma C $55 \quad \mathrm{lu}_{2} \quad \mathrm{a}-\breve{s}_{\mathrm{a}_{3}}-\mathrm{g}$ a $\mathrm{n} \mathrm{i} \mathrm{r-g} \mathrm{a} \mathrm{l}_{2}-\mathrm{b}$ i $\mathrm{m} \mathrm{u}-\mathrm{u} \mathrm{n}-$ $\mathrm{DU} / \mathrm{gab} \mathrm{a}-\mathrm{n} \mathrm{a} \mathrm{i}_{2}-\mathrm{t} \mathrm{a}-\mathrm{a} \mathrm{n}-\mathrm{z} \mathrm{i}$ "Men stood confidently in the fields, up to their chests it (= the produce of the fields) rose".

Another passage in Urnamma $\mathrm{C}$ which involves Urnamma's divine predestination and designation may have served as a model for portraying Išmedagān's divine predestination and designation at the hands of Enlil. Compare Išmedagān A 43-45 (in S. Tinney's reconstruction of the lines in Nippur Lament 37) [ i ] r i $\mathrm{ku}_{3}-\mathrm{ga} \mathrm{nam} \mathrm{du}_{10}$ h $\mathrm{a}-\mathrm{ma}-\mathrm{ni}-\mathrm{in}-\mathrm{t}$ ar $\mid\ulcorner\mathrm{a}\urcorner \mathrm{ša}_{3}-\mathrm{ga}$ r u - a g a $a_{2} \mathrm{mu} \quad \mathrm{du}_{10} \mathrm{ha}-\mathrm{ma}-\mathrm{ni}-\mathrm{in}-\check{s}_{2} \mathrm{e}_{2} \mid[\mathrm{d}] \mathrm{nin}-\mathrm{tu} \quad \mathrm{du}_{2}-\mathrm{du}_{2}-\mathrm{a}$ $\mathrm{h} \mathrm{a}-\mathrm{m}$ a - n i - i n - g u b "In the splendid city he (= Enlil) verily determined for me an auspicious fate, when I was conceived in the womb he verily gave me a good name, Nintur verily stood by for me in the process of the birth", with Urnamma C 46-49 d en-1i $1_{2}-1$ e d utu-gin $\mathrm{kalam}_{7} \mathrm{ma} \mathrm{e}_{3}-\mathrm{de}_{3} / \mathrm{mu}$

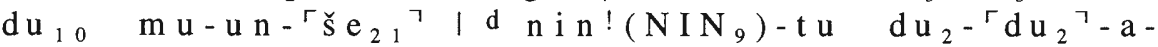
$\mathrm{g} \mathrm{u}_{10}<\mathrm{mu}>-\mathrm{un}-\mathrm{gub}-\mathrm{bu} ! \quad \mid \check{s}_{3} \quad \mathrm{ama}-\hat{\mathrm{g} u} \mathrm{a}_{10} \quad \mathrm{~d} \mathrm{nin}-$ $\mathrm{sum} \mathrm{un} \mathrm{n}_{2}-\mathrm{ka}-\mathrm{ta} \mathrm{In}$ a m $\mathrm{t}$ ar $-\mathrm{ra} \quad \mathrm{s} \mathrm{a}_{6}-\mathrm{g}$ a $\mathrm{ma}-\mathrm{ta}-\mathrm{e}_{3}$ "Enlil who rises like the sun over the land, gave me a good name, Nintur stood by in the process of my birth, from the womb of my mother Ninsumun a propitious fate has emerged for me". Note subtle differences, such as line order and addition of epithets, and especially the use of a different ideology by having Urnamma mention his divine mother Ninsumun, whereas Išmedagān naturally does not.

A less likely but possible literary allusion may be found in Išmedagān A 91-92 $\left(P B S\right.$ 10/2 9 obv. ii 21-22+) d u t u ni g ${ }_{2}-\mathrm{si}-\mathrm{s}_{2}$ e $\mathrm{n}$ i m g e - n a

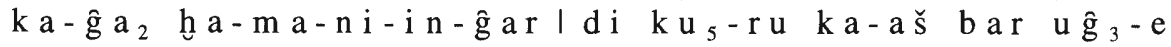

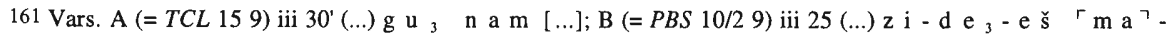
[...].

$162 \mathrm{~A}(=T C L 159)$ rev. ii has B A R. U D.
} 
$\mathrm{s} \mathrm{i}-\mathrm{s} \mathrm{a}_{2}$-e "Utu has indeed put justice, firm orders into my mouth. To pronounce judgments, to decide verdicts!, to lead the people". This passage might be modelled on Urnamma C 27-28 d u t u k a - $\mathrm{g} \mathrm{a}_{2}$ e n i m b a-n i - i n $\mathrm{gal}_{2} \quad \mathrm{~d} \mathrm{~d} \mathrm{i} \mathrm{ku}_{5}-\mathrm{ru}-\mathrm{gu}_{10} \mathrm{ki}-\mathrm{en}-\mathrm{gi} \quad \mathrm{ki}-\mathrm{uri} \quad \mathrm{gu}_{3} \quad \mathrm{te} \check{\mathrm{s}}_{2}-\mathrm{a}$ $\mathrm{b}_{2}-\mathrm{in}_{2}-\mathrm{s}_{3}$ "Utu has put orders in my mouth. Through my capacity to pronounce judgments he has permitted me to make Sumer and Akkad obedient." It shows the same sequence, but thematically this is a common topos describing the sungod as giver of justice. Finally, there is a slight chance that a curse formula found in Išmedagān $S$ and $Z$, and also in Lipiteštar's law code, matches the one preserved on fragments possibly constituting the end of Urnamma's law code. ${ }^{163}$ But it is likewise possible that these fragments are part of a new code written in the name of Išmedagān.

These examples may show that Išmedagān's literary portrait was not solely modelled on Sulgi but also on Urnamma.

\section{The Urnamma Hymns and Related Genres}

Sumerian royal and divine hymns from the Ur III and Isin-Larsa periods, like other literary compositions, are known almost exclusively from later copies made at the Old Babylonian schools in Nippur, Ur and other sites. Despite the relative paucity of archaic orthography apparent in some Sulgi hymns and, as shown in this study, the Urnamma hymns, there can be little doubt that the hymns of the kings of Ur are in fact modernized versions of Ur III originals, and that also the hymns mentioning Isin-Larsa rulers are datable to these kings themselves. Since hymns known from Old Babylonian manuscripts addressed to deities with no reference to a king resemble royal hymns of the same types, ${ }^{164}$ many of these divine hymns, too, are probably modernized versions of Ur III or Isin-Larsa originals. The hymn Urnamma D might even indicate that scribes adapted divine hymns praising deities to royal hymns in which the praise was centered on the king instead. ${ }^{165}$ Similarly, Urnamma EF, known from two non-Nippur recensions, centres on the praise of the king, rather than on the deity, as is usual with hymns that have the subscript š i r $\mathrm{n} \mathrm{a} \mathrm{m} \mathrm{š} \mathrm{u} \mathrm{b.}{ }^{166}$ Although the bulk of royal hymns is from the Ur III and the Isin-Larsa period, we know that the genre had at least already been in existence in Lagaš under Gudea. Gudea A (STVC 36) is the earliest example of a divine hymn mentioning a royal figure ${ }^{167}$ and can therefore be considered a kind of "precursor" of type A hymns, known especially from Sulgi and the Isin-Larsa hymns which are addressed to a deity and briefly mention the king. The discussion of topoi of

163 Cf. Michalowski, Walker, Studies Sjoberg (1989) 391; 395.

164 Cf. below, p. $73 f$.

$165 \mathrm{Cf}$. below, pp. $74 \mathrm{ff}$.

$166 \mathrm{Cf}$. below, p. 77.

167 Cf. also II l., p. 13. 
legitimation and kingship above shows that Gudea's statues and cylinders express the ideology of kingship in ways similar to Ur III royal hymns and Isin-Larsa hymns and royal inscriptions. Gudea's statues and cylinders also contain narrative passages with content and structure similar to these royal hymns and the Larsa royal inscriptions. Thus Urnamma B, Sulgi $R$, and Išmedagān I resemble the building reports of Gudea found on his cylinders and statues, and two Larsa royal inscriptions of Sîniddinam (RIME 4.2.9.2) and Rīmsîn (RIME 4.2.14.15), commemorating the digging of canals, contain language and have a structure which is also similar to Urnamma B, Sulgi R, and Išmedagān I. It is well known that royal inscriptions of the Larsa period in particular have a strong literary flavour and could in many cases be classified as royal hymns with a lengthy address to a deity. Some Ur III and Isin compositions on tablets copied from statues or other artefacts have, in fact, been classified either as hymns or as royal inscriptions. ${ }^{168}$ All this raises questions pertaining to the composition and development of the royal hymns as a genre. The following sections will investigate the relationship between the Urnamma hymns, which represent the early stream of the royal hymnic tradition, and other related genres, thus adding new perspectives to the ongoing discussion. The sections include a discussion of the relationship between the Urnamma hymns and other royal and divine hymns (3.1), between stelas and self-laudatory hymns in particular, and royal inscriptions and royal hymns in general (3.2), and Urnamma A and lamentation literature (3.3).

\subsection{The Urnamma Hymns and other Royal and Divine Hymns}

J. Klein has shown that so-called building and dedication hymns in general share a common sequence of events. ${ }^{169}$ Similar elements are used to articulate the building or manufacturing narrative, since the progress from intention to the finished object is fixed by the nature of the enterprise. His study incorporated a thematic comparison of Gudea's temple-building cylinders with the $\mathrm{t} i \mathrm{~g}$ i compositions Urnamma B, also a building hymn, Sulgi $\mathrm{R},{ }^{170}$ which commemorates the construction and dedication of Ninlil's ceremonial boat, and Išmedagān I, a $\mathrm{t}$ i g i of Enlil composed in commemoration of the completion of Enlil's chariot. After the introduction of the object (element 1), sometimes preceded by the divine selection of the ruler, as in Urnamma B 1-6, divine instruction (element 2) follows. The wise ruler knows how to act (element 3 ) and subsequently prepares and realizes the building project (element 4). The subsequent preparation and realization of building events described in Urnamma B are listed in the same sequence, but not with the same poetic structure as in Sulgi R and Išmedagān I. The descriptive praise

$168 \mathrm{Cf}$. Tinney, OLZ 90 (1995) 7, and below, 3.2, pp. 83ff.

169 Klein, ASJ 11 (1989) 27-62 and idem, Studies Artzi (1990) 65-136.

170 The subscript is missing, but very likely a $t$ i g i composition, cf. Klein, Studies Artzi (1990) 80. 
of the object (element 5) in Sulgi R and Išmedagān I, for example, is a direct address, whereas the description of the Ekur in Urnamma B is in the 3rd person. Then follow the dedication (element 6) and finally divine blessings and reward, often a firm reign and a long life-span (element 7). Similarities in some of the narrative features in the famous reform texts of IriKAgina (Ukg. 4-5) suggest that the pattern goes back to Early Dynastic times. Although the inscriptions' purpose is to commemorate the excavation of a canal, most of the texts are taken up by a long narrative of the abuses of former times and the succeeding reforms undertaken by IriKAgina. The narrative sequence which tells of these reforms is introduced by an initial element of divine selection and election of the ruler (Ukg 4, 7:29-8:6 || 5, 7:12-19). Then the "object" is introduced, namely the correction of former abuses (Ukg. 4, 8:7-9 || 5, 7:20-22), followed by divine instruction which IriKAgina heeds (Ukg. 4, 8:10-13 || 5, 7:23-26). Then he realizes his reforms (Ukg. 4, 8:14ff. II 5, 7:27ff.). An Early Dynastic building narrative containing the elements in rudimentary form might be Enmetena's inscription 35: Enmetena is favoured by the gods, realizes the building of a dam for Ningirsu among other construction work (elements 1 and 4), and also lists exemptions from obligations. Finally Ningirsu rewards him (element 7).

Artefact inscriptions of the Larsa kings commemorating the dedication of a structure or object by the ruler to a god are very similar to building and dedication hymns, as mentioned above. An example: RIME 4.2.14.15 (Rìmsîn) commemorates the excavation of canal(s). The text is very literary in style, and contains, unlike Lagaš II and Ur III artefact inscriptions, narrative sections which are congruent with those of hymns. The sequence of elements follows that of Urnamma B and Sulgi R fairly closely:

1. Introduction of (building) object: Urnamma $\mathrm{B} 7-9 \approx$ Sulgi $\mathrm{R} 1-2 \approx R I M E$ 4.2.14.15:8-15

2. Divine instruction $\left(\mathrm{a}_{2} \quad \mathrm{a}_{2}\right)$ : Urnamma $\mathrm{B} 10 \approx$ Sulgi $\mathrm{R} 3-4 \approx R I M E$ 4.2.14.15:19-24

3. The wise ruler knows what to do ( $\mathrm{g}$ e š t $\mathrm{u}_{2}$ da $\mathrm{g}$ a $\mathrm{l}-1 \mathrm{a}-\mathrm{k}$ a m): Urnamma B $12-13 \approx$ Sulgi $\mathrm{R} 5-7 \approx R I M E$ 4.2.14.15:25-31

4. Preparations and realization: Unnamma B $13-19 \approx$ Sulgi $\mathrm{R} 8-9 \approx R I M E$ 4.2.14.15:32-40 171

5. Detailed description: Urnamma B $22-32 \approx$ Sulgi $\mathrm{R} 10-39 \approx R I M E 4.2 \cdot 14.15: 41$ 47

6. Dedication including food offerings: Urnamma B 33-35 $\approx$ Sulgi $\mathrm{R}$ 40-81 (including a journey) $\approx R I M E 4 \cdot 2 \cdot 14.15: 48-54$ (produce for the people)

7. Blessings and reward: Urnamma $\mathrm{B} 36-38 ; 40-71 \approx$ Sulgi $\mathrm{R} 82-90 \approx R I M E$ 4.2.14.15:55-60

171 The finished work is displayed for admiration ( $\mathrm{u}_{6}(\mathrm{~d} \mathrm{i})+($ loc.-)term. $\mathrm{g} \mathrm{u}$ b) in Urnamma B 21 and Sulgi R 9. 
In fact RIME 4.2.14.15:1-7 and 16-18 also share with Urnamma B 1-6 the topos of divine selection, the initial element of narrative, preceding the introduction of the object. In both compositions the preparations and realization (element 4) include performances of certain rites (cf. RIME 4.2.14.15:36) and people from foreign lands to help work on the temple (RIME 4.2.14.15:37-38). Two artefact inscriptions of Sîniddinam, RIME 4.2.9.2, commemorating construction work on the Tigris, and RIME 4.2.9.6, commemorating construction work on the $\mathrm{e}_{2}$ $\mathrm{b}$ a b b a r temple at Larsa, have a less literary flavour than the Rìmsîn text, but they, too, display the same elements, albeit in a slightly different sequence. These two texts follow more strictly the formal structure of building and dedication inscriptions. ${ }^{172}$ Element 3 (the wise ruler) in $R I M E$ 4.2.9.2:14-16 precedes the introduction of the object (element 1 ) in lines 17-18, as the inscription begins with the name of the king, followed by epithets in form of adjectives and subordinate clauses (lines 1-9). Then follow the divine instruction (element 2) in line 32 ( $\mathrm{a}_{2}$ a $\hat{g}_{2}$ ), the realization and description of details, including the wages of the workers (lines 39-62), and finally the setting up of the king's inscription as a reward (lines 65-70). RIME 4.2.9.6 introduces the object first (element 1) in lines 1-7, then the king and his divine selection are mentioned (lines 8-16), followed by the pacification of foreign lands (lines 17-20), as in Urnamma B 14, and the divine instruction ( $\left.\mathrm{a}_{2} \quad \mathrm{a} \mathrm{g}_{2}\right)$ to enlarge the temple in lines 21-24 (element 2). As in RIME 4.2.9.2, the realization and description of details (elements 4 and 5) include a list of wages of the workers (lines 49-57) and current market values of commodities (lines 58-69). Furthermore, similar to RIME 4.2.14.15:54 (Rimsîn), the text states in lines 76-78 (element 6) that the finished construction work has made the gods happy ( $\check{\mathrm{s}}_{3} \mathrm{du}_{10} \cdot \mathrm{g}$ ), but unlike the Rīmsin inscription and the other compositions mentioned above, blessings and reward (element 7) are absent from the inscription.

The description of food offerings at dedication ceremonies as an act to please the gods and elicit from them a favourable blessing, elements 6-7 above, is a common topos in other hymns. For example, an episode in Sulgi G (lines 41-53), an $\mathrm{adab}$ of Enlil with $\mathrm{s}$ a $\mathrm{i} \mathrm{da}$ and $\mathrm{s}$ a $\mathrm{g}$ a $\mathrm{r}$ a sections as in $\mathrm{t} \mathrm{i} g \mathrm{i}$ compositions, is comparable with the $\mathrm{t}$ i $\mathrm{g}$ i Urnamma B 34-38: in Sulgi G 41 Sulgi is "called by name by Ninlil" (m u * p $\left[\mathrm{a}_{3}\right]-\mathrm{da} \mathrm{d} \mathrm{n} \mathrm{n}-1 \mathrm{i} 1_{2}-1 \mathrm{a}_{2}$ ), in line 47 "the very large food offerings" ([ $\mathrm{n}$ i ] d b a g a l - g a l) "make the Ekur joyful" $\left(\mathrm{e}_{2}-\mathrm{k} \mathrm{u} \mathrm{r} \mathrm{hu} 1_{2}\right.$ ), and for the evening meals (?) "in the dining halls of the Ekur" (line 52: $\mathrm{u} \mathrm{n} \mathrm{u}_{2} \quad \mathrm{e}_{2}-[\mathrm{k} \mathrm{u}] \mathrm{r}-\mathrm{ra}-\mathrm{k}$ a (...)) Enlil "decrees a profound fate" for Sulgi (line 53: $\mathrm{n}$ a $\mathrm{m} \quad \mathrm{n} \mathrm{u} \mathrm{n}-\mathrm{n}$ a $\mathrm{t}$ a $\mathrm{r}$ ?). ${ }^{173}$

Furthermore, the beginning of Sulgi G contains a literary allusion to the rebuilding of the Ekur, described in Urnamma B, by Urnamma, called the $1 \mathrm{u}_{2}$ z i . d "faithful man" in Sulgi G. The similar structure and language at the beginning of the two hymns is noteworthy: as in Urnamma B, Sulgi G begins 
with a hymnic praise of Enlil (lines 1-7). The sequence $d e n-1 i l_{2}-d n u-$ $\mathrm{n}$ a m-n i $\mathrm{r}$ - e $\mathrm{n} n$ a m-n u n corresponds in Urnamma B 1-3 to d e $\mathrm{n}$ $\mathrm{l} \mathrm{i} \mathrm{l}_{2}$ - e n n m-n un-d n u - n a m-n i r. Enlil thinks up an important matter and makes a decision ${ }^{174}$ concerning the $\mathrm{m} e$ of the Ekur ${ }^{175}$ : the building of the Ekur under the "faithful man", and the maintenance thereof by his successor Sulgi.

The texts discussed above all contain the same message in the form of a building report which uses similar elements to articulate the building or manufacturing narrative. The pattern of building narratives might go back to Early Dynastic times, as the reform texts of IriKAgina and perhaps Enmetena 35 suggest, followed by Gudea's cylinders and statues, and the Ur III hymns. In the subsequent Larsa period such building narratives also appear in artefact inscriptions. ${ }^{176}$ However, the use of these texts is different. Gudea's statues were consecrated and placed in the temples in order to act and speak on Gudea's behalf. ${ }^{177}$ The artefacts inscribed with the Larsa artefact inscriptions were ceremonially buried in foundations. The $\mathrm{t}$ i g i compositions Unnamma B, Sulgi R, and Išmedagān I were probably used for recitation in the cult, as indicated by the rubrics which probably referred to musical performance, and Gudea's cylinders, as building reports, might also have served a cultic function.

Despite the absence of the rubrics which usually mark literary units in royal hymns, URNAMMA C, a self-laudatory hymn, can be divided into two parts: a hymnic prologue in praise of Ur and its main shrine, the Ekišnugal, and a main section consisting of Urnamma's self-praise. Sulgi $O$, whose end portion and subscript are unfortunately missing, is another example of a hymnic prologue followed by praise, this time though not in the form of self-praise, but rather in the form of a dialogue in which Sulgi and his brother Gilgameš praise each other mutually (in the 2 nd person): as in Urnamma $\mathrm{C}$, the prologue begins with praise of the city, followed by the temple Ekišnugal and its parts, e.g. the Abzu and the $\mathrm{g}$ i $\mathrm{p}$ a $\mathrm{r}$ (lines 1-15). Then, unlike Urnamma $\mathrm{C}$, it goes on to praise Ur's $\mathrm{i}_{7}$ $\mathrm{n}$ u n-canal, its wall, people, settlements and foreign lands (lines 16-24). In the following lines (25-30) Sulgi is introduced.

Išmedagān's self-laudatory hymn Išmedagān $\mathrm{A}$, which shares a number of literary parallels with Urnamma C, ${ }^{178}$ has, to be sure, a more complicated sequence of sections, but the basic formal structure is the same: a prologue, partially broken off and marked by common grammatical forms, contains a laud of Enlil and introduces other gods (lines 1-41). The main section comprises the king's selfpraise, expressing divine approval and listing of endowments by various gods to which the king's respective achievements are added. The statement, for example,

\footnotetext{
174 Cf. š a , D U in Sulgi G 9 and Urnamma B 9.

175 Compare Sulgi G 11-12 mentioning the $\mathrm{me} \mathrm{e}_{2}-\mathrm{k} \mathrm{u} \mathrm{r}-\mathrm{r}$ a "the $\mathrm{me}$ of the Ekur" and the $\mathrm{s}^{\mathrm{e}} \mathrm{g}, 12$

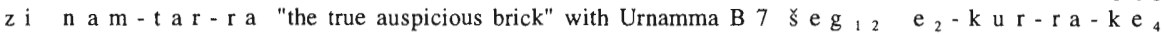
$\mathrm{me} \mathrm{a} \mathrm{m}_{3}$ - h u $\mathrm{r}$ "The $\mathrm{m}$ e are traced out for Ekur's brickwork".

$176 \mathrm{Cf}$. also above, 1.2 , p. 55 and below, 3.2 , p. 84 .

177 Cf. in more detail, below, 3.2, p. $79 f$.

$178 \mathrm{Cf}$. above, 2., pp. $66 \mathrm{ff}$.
} 
that it is Utu himself who endows the king with justice is followed by a series of statements regarding the king's juridical activities (lines 91-100). Inana is connected with Išmedagān's role as her husband in the "sacred marriage" ceremony in the $\mathrm{g}$ i p a r of Eana and his function as its provider (lines 101-112). Some achievements undoubtedly have autobiographical traits, as e.g. the relief of debts for the citizens of Nippur, in lines $185-98,{ }^{179}$ just as a number of passages in Urnamma C have historical allusions. The last sections of Išmedagān A tell us, in narrative form, of cultic acts, namely the erection of statues and other votive objects for Enlil and Ninlil in the Ekur and the commissioning of hymns to be sung there, just as the last section in Urnamma $\mathrm{C}$ narrates the building of the Ekišnugal for Nanna in Ur.

The Nungal hymn, ${ }^{180}$ which like Urnamma $\mathrm{C}$ also concludes with a $\mathrm{z} \mathrm{a}_{3}$ $\mathrm{m} \mathrm{i}_{2}$ doxology, is an example of a divine hymn which shows basically the same formal structure as Urnamma $C^{181}$ : it begins with a hymnic description of the $\mathrm{e}_{2}$ $\mathrm{k} \mathrm{u} \mathrm{r} \mathrm{"prison"} \mathrm{and} \mathrm{its} \mathrm{different} \mathrm{parts,} \mathrm{followed} \mathrm{by} \mathrm{an} \mathrm{introduction} \mathrm{of} \mathrm{Nungal} \mathrm{that}$ leads to her self-praise. ${ }^{182}$ The corresponding sections of Urnamma $\mathrm{C}$ and the Nungal hymn can be outlined as follows:

I. Hymnic prologue: Urnamma C $1-19 \approx$ Nungal $1-62$ in the 3 rd person

1. Ur with the Ekišnugal and its different parts $\approx$ The Ekur and its different parts (Urnamma C 1-12 $\approx$ Nungal 1-26)

2. Introduction of Urnamma $\approx$ Introduction of Nungal/Ninegala with a description of transport and gaoling of the accused

(Urnamma C 13-19 $\approx$ Nungal 27-61)

II. Self-Praise: Urnamma C $20-114 \approx$ Nungal $64-116$ in the 1 st person

1. Introduction to the self-praise (Urnamma C $18-19 \approx$ Nungal 62-63)

2. Divine approval and endowments (Urnamma C $20-30 \approx$ Nungal 64approx. 74)

3. Description of functions/achievements (Urnamma C $31-114 \approx$ Nungal 75-116)

III. Doxology: Urnamma C $115\left(\mathrm{z} \mathrm{a}_{3}-\mathrm{m} \mathrm{i}_{2}-\mathrm{g} \mathrm{u}_{10}\right) \approx$ Nungal 117-121

$\left(\mathrm{d}_{\mathrm{n} \mathrm{u} \mathrm{n}}-\mathrm{g} \mathrm{a} 1(/-1 \mathrm{a}) \mathrm{z} \mathrm{a}_{3}-\mathrm{mi}_{2}\right)$

Nungal's self-praise shows similar traits to that of Urnamma, and both tend to use similar, traditional introductory formulae. Nungal also mentions her divine lineage as well as her functions, with which she is endowed by other gods. Another such self-praise is that of Enki in Enki and the World Order 62-80 and 88-125(?). Urnamma C is so far the earliest known type B. II (self-praise) hymn, and therefore

$179 \mathrm{Cf}$. in detail Frayne, Correlations $411 \mathrm{ff}$.

180 For references to this hymn, cf. already II $1 .$, p. 15 , fn. 32 .

181 Already Wilcke, RlA 4 (1972-75) 542 ad $\S 6$, s.v. "Hymne, A. Nach sumerischen Quellen".

182 For Komoróczy, Acta Antiqua Academiae Scientarum Hungaricae 23 (1975) 164f., the first part of the

Nungal hymn belongs to the temple hymn genre, the second part to the self-laudatory hymns group. 
self-laudatory hymns might indeed have originated with Urnamma. We might also imagine that divine self-praise derived from this royal self-praise.

Praise of a deity in the 2 nd or 3 rd person can also resemble royal praise. Topoi of legitimation and kingship, as well as other formulae, are applied to gods as well as kings. In Nisaba and Enki 3, Nisaba is "fed with true milk" ( $\begin{aligned} & \text { g a } \\ & \mathrm{z} \mathrm{i}\end{aligned} \mathrm{g} \mathrm{u}_{7}-\mathrm{a}$ ), as are kings, and Nanna and Ninurta are reared on the knees and breasts of their divine mothers Ninlil and Nintur. ${ }^{183}$ Ninurta, like a king, ${ }^{184}$ is "given strength" $\left(a_{2}\right.$ š u $\mathrm{m}_{2}-\mathrm{m}$ a) by Enlil, ${ }^{185}$ and Enlil looks at him happily and determines his fate. ${ }^{186}$ Lipiteštar as well as the god Nuska are $1 \mathrm{u}_{2} \quad \check{\mathrm{s}} \mathrm{a}_{3}-\mathrm{g}$ a $-\mathrm{n}$ a literally "the one of his (i.e. the god's) heart". ${ }^{187}$ Nanna is given a good name by Enlil (Nanna A 50), and $\mathrm{n}$ a $\mathrm{m}$ - $\mathrm{s}$ i p a $\mathrm{k}$ a l a $\mathrm{m}$ - $\mathrm{m}$ a "shepherdship over/of the land" by An (Nanna A 49), as are e.g. Šūsu'en, ${ }^{188}$ Išbi' erra, ${ }^{189}$ Sîniddinam, ${ }^{190}$ Sîniqī̌sam, ${ }^{191}$ and Waradsîn. ${ }^{192}$ Enlil gives Nuska the sceptre to exercise his s u k k a $1 \mathrm{~m}$ a h -ship in Išmedagān $Q_{A}$ (= Sjöberg, ZA 63 17) 4'-5', and Inana receives a number of royal insignia from An in FLP 2627 (= Sjöberg, JCS 40 167) i 6-9. Thus in structure and the use of topoi and formulae divine hymns are very similar to royal hymns of type $\mathrm{B}$.

URNAMMA D might indicate that divine hymns were actually adapted to royal hymns in which praise was centered on the king instead of the deity. There are several indications that corroborate the hypothesis that Urnamma D might be an adapted $\mathrm{b}$ a l b a $1 \mathrm{e}$ rather than an original type $\mathrm{B}$. I royal hymn addressed to the king. Urnamma $\mathrm{D}$ formally ends with the $\mathrm{z} \mathrm{a}_{3}-\mathrm{m} \mathrm{i}_{2}-\mathrm{zu} \quad \mathrm{du} \mathrm{u}_{10}-\mathrm{g} \mathrm{a}(/-$ $\mathrm{a} \mathrm{m}_{3}$ ) ("your praise is sweet") doxology, although the main part of the hymn (lines 7-36) consists of the king's self-praise for which we would expect the $\mathrm{z} \mathrm{a}_{3}$ $\mathrm{mi}_{2}-\mathrm{g} \mathrm{u}_{10} \mathrm{du}_{10}-\mathrm{g} \mathrm{a}\left(/-\mathrm{a} \mathrm{m}_{3}\right)$ ("my praise is sweet") doxology. Unlike royal hymns praising the king in either the 2 nd or the 3 rd person (type B. I), or in the 1st person (type B. II), Urnamma D displays a rigorous poetic structure consisting of line pairs linked by repetitive parallelism, which is a common device in type $\mathrm{A} \mathrm{b}$ a 1 b a 1 e compositions (cf. e.g. Urnamma G, Išmedagān J). This is especially apparent in lines 1-6 and in lines 22-36, whereas the description of divine selection and election to kingship (lines 9-21) consists of a narrative sequence reminiscent of self-laudatory hymns (cf. Urnamma C). Also, the unpublished source D of the Nippur version is part of a "Sammeltafel", a four-column tablet which contains, besides Urnamma D, a b a 1 b a 1 e of Inana, ${ }^{193}$ Dumuzi-Inana C,

\footnotetext{
183 Nanna A (= Sjöberg, Mondgott 16) 28; Lipiteš tar D 6.

184 For some references, cf. Hallo, Royal Titles 136 s.v. a 2 sum-ma DN.

185 Sjöberg, AOAT 25 (1976) 416:72-74.

186 Lipiteštar D 13.

187 Lipiteštar A 33; Sjöberg, JCS 29 (1977) 27 = v. Dijk, SGL 2144 obv. 8-9. Other references in Sjöberg, ibid. 15 ad obv. 1

188 Šũ su'en 12:5-8.

189 Ibbīsu'en to Puzurnumuš da 15-17.

190 RIME 4.2.9.1 (= no. 13 in Kärki, StOr. 49 71) 189-90.

191 RIME 4.2.11.1 2-4.

192 RIME 4.2.13.29:45.

193 Cf. Alster, RA 79 (1985) 146, no. 5 ad source B.
} 
and Dumuzi-Inana N (courtesy of S. Tinney). Finally, the Nippur version of Urnamma D shares lines 25-30/31? with a b a $1 \mathrm{~b}$ a 1 e of Nanna, ${ }^{194}$ the fourth and last b a l b a le of Nanna written on the "Sammeltafel" TMH NF 47 iv "169-99" (HS 1513) // ISET 1 p. 62 (Ni. 9788). ${ }^{195}$ It is possible that Urnamma D was indeed partially modelled on or reinterpreted from this $\mathrm{b}$ a $1 \mathrm{~b}$ a $1 \mathrm{e}$. The Nippur recension of Urnamma D shares more lines with the $\mathrm{b} a \mathrm{l}$ b a l e than the Ur recension, ${ }^{196}$ which only shares lines $32^{\prime}-34^{\prime}$ with the $\mathrm{b}$ a $1 \mathrm{~b}$ a $1 \mathrm{e}$, perhaps because Nanna features more prominently in the Nippur recension than in the Ur recension. The $\mathrm{b}$ a l b a l e shares with Urnamma $\mathrm{D}$ the poetic device of line pairs linked by repetitive parallelism, as noted above, and it has, like Urnamma D, no rubrics. ${ }^{197}$ The beginning lines (TMH NF 47 iv 169-86//) describe Nanna's presence in the cattle pens resulting in productivity, plenty of cow herds, Nanna's sacred attributes, and dairy products, a theme which the $\mathrm{b} \mathrm{al} \mathrm{b} \mathrm{ale} \mathrm{shares} \mathrm{with} \mathrm{the} \mathrm{beginning} \mathrm{of}$ Nanna A, the first b a l b a le on the above mentioned "Sammeltafel" (cf. also below). ${ }^{198}$ Line $187 / /$ introduces a praise ${ }^{199}$ in the 1 st person. The beginning of the line is broken, so it is not clear who speaks the praise, but it is very likely Nanna himself, ${ }^{200}$ rather than the king of Ur, as C. Wilcke assumes, ${ }^{201}$ for there is neither an indication in the preceding nor in the succeeding lines of a necessary shift from god to a(n unnamed) king, and the song is wholly occupied with Nanna and his function. ${ }^{202}$ The praise in the 1st person starts in line 188 and probably continues to the end. ${ }^{203}$ Lines 188-89 share two lines of the unpublished Nippur sources D and $E$ of Urnamma D (courtesy of S. Tinney), and the following lines 190195(/96?) match the published Nippur recension (= source A), lines 25-30(/31? $)^{204}$ :

iv 190

[(...) iri-ĝa ${ }_{2}$ a DU-a-b]i ${ }^{205} \mathrm{ku}_{6}-\mathrm{am}_{3}{ }^{\urcorner}$diri-bi mušen-am 3

$25 \mathrm{ge}_{26}$-e iri-ĝa $a_{2}$ a DU-a-bi $\mathrm{ku}_{6}-\mathrm{am}_{3}$ diri-bi mušen-am ${ }_{3}$

"(Due to) me, what water it ${ }^{206}$ carries in my city are fish, what it makes glide are birds."

\footnotetext{
194 Edited by Hall, Moon-God 776-87 and discussed by him on pp. 404ff.

195 References to all four songs are given in J.G. Westenholz, Studies Sjöberg (1989) 550, fn. 52. b a 1 b a 1 e nos 2 and 3 which mention Enh eduana (in these compositions perhaps as personification of Ningal) have been subsequently treated by Westenholz, ibid. 539-56 (editions on pp. 550-56).

196 For a general comparison between the Nippur und Ur recensions of Urnamma D, cf. V 4.1, pp. $228 \mathrm{ff}$.

197 Cf. II 1., p. 15.

$198 \mathrm{Cf}$. also Sumer and Ur Lament 329-37, and Michalowski, Lamentation 97 ad 331. The Nanna hymn UET 6 $68+$ referred to by Michalowski, ibid., is now also edited by Hall, JCS 38 (1986) 152-66.

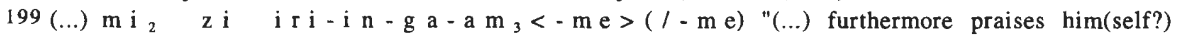
deservingly".

200 Bernhardt, Kramer, TMH NF 4 (1967) 13.

201 Wilcke, Kollationen 48 ad line 187 who restores $[\ldots 1 \mathrm{u}] \mathrm{g} \mathrm{a}{ }^{?} \mathrm{u}\left[\mathrm{r} \mathrm{i}_{2}{ }^{\mathrm{k}}\right.$ ] $-\mathrm{m}$ a, and thinks it might possibly be Urnamma (cf. idem, AS 20 [1975] 280 ad u).

202 The preceding line $186 / /$ states that "Nanna is lord" ( $\mathrm{d}$ n a n n a $1 \mathrm{ug}$ a $1-1 \mathrm{a}-\mathrm{a} \mathrm{m}_{3}$ ).

203 Cf. Ni. 9788 rev. 6' ... g e ${ }_{26}$ - e [ ... " ... I/me [ ...]".

204 For philological matters, cf. the commentary ad $25 \mathrm{ff}$. in V 4.5 , pp. $256 \mathrm{ff}$.

205 Restore perhaps in this and the next line, instead of a D U - a - b i, a d u $10-\mathrm{g}$ a, as in the unpub source $\mathrm{E}$.
}

206 i.e. the canal. 
iv 191 [uri ${ }_{2} /{ }_{5} \mathrm{ki}-\mathrm{ma}$ a DU-a-b]i $\mathrm{ku}_{6}-\mathrm{Cam}_{3}{ }^{\urcorner}$diri-bi mušen-am 26 uri $_{2} \mathrm{ki}_{-}$ma a DU-a-bi $\mathrm{ku}_{6^{-}} \mathrm{am}_{3}$ diri-bi mušen-am "What water it carries in Ur are fish, what it makes glide are birds,"

iv $192\left[(\ldots) \mathrm{i}_{7}-\mathrm{gaa}_{2} \mathrm{u}_{2}-\mathrm{lal}_{3}\right.$-e m]u-un-du suhurku $_{6}-\mathrm{e} \Gamma_{\mathrm{a}}$ ? $-\mathrm{ab}-\mathrm{si} / \mathrm{NIĜ} \mathrm{IN}_{2}$

$27 \quad \mathrm{ge}_{26}-\mathrm{e} \mathrm{i}_{7}-\mathrm{ga}_{2} \mathrm{u}_{2}-\mathrm{lal}_{3}$-e mu- un-du $\mathrm{u}_{3}$ suhurku $\mathrm{u}_{6}-\mathrm{e} \quad \mathrm{am}_{3}$-si-e (gloss) [l]i-și-i-ma [li]-ir-te-e "(Due to) me, honey-plants were planted at my canal, the s u h u rfish fill up on them,"

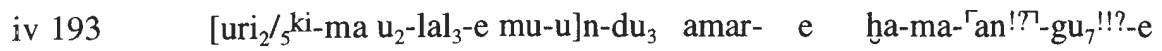
28 uri $_{2} \quad \mathrm{ki}_{-} \mathrm{ma} \mathrm{u}_{2}-\mathrm{lal}_{3}$-e mu- un- $\mathrm{du}_{3}$ suhurku $\mathrm{s}_{6}-\mathrm{e} \quad\left[\mathrm{am}_{3}\right]$-si-e "In Ur honey-plants were planted, the su hu $\mathrm{r}$-fish fill up on them." 207

iv $194 \quad$ [(...) iri-ĝa $a_{2}$ gi-zi-bi m]u- ${ }^{\ulcorner}{ }^{\top}-\mathrm{du}_{3} \quad \mathrm{ab}_{2}$-e ha-ma- ${ }^{\ulcorner} \mathrm{gu}_{7}$ ? ${ }^{\Upsilon}-\mathrm{e}$ $\mathrm{ge}_{26}$-e iri-gat $\mathrm{ga}_{2}$ gi-zi-bi $\operatorname{lal}_{3}-\mathrm{am}_{3}[?] / \mathrm{ab}_{2}-\mathrm{e}$ ha-ma- $\mathrm{gu}_{7^{-}} \mathrm{e}$ "(Due to) me, in my city its reed fodder is (honey-)sweet, may the cows eat it for me." 208

The theme of abundant fish and birds (Urnamma D (Ni) 25-26) is also found in the Ur version which lacks on the other hand the description of the cows eating reed fodder, and the $\mathrm{s}$ u h u r-fish honey-plants. ${ }^{210}$

The first b a $1 \mathrm{~b}$ a $1 \mathrm{e}$ on the Sammeltafel TMH NF 4 7, Nanna A (according to Civil's sigla), ${ }^{211}$ describes in the first few lines the same theme of abundance and prosperity in the cattle pen as the fourth $\mathrm{b}$ a $1 \mathrm{~b}$ a $1 \mathrm{e}$ which shares lines with the

207 TMH NF 47 iv 193: "[ In Ur honey-plants were] planted, may the calves eat? it for me".

208 TMH NF 47 iv 194: "[ (...) in my city its reed fodder was] planted, may the cows eat? it for me".

209 Or perhaps read $[\ldots$...h]u-.

$210 \mathrm{Cf}$. in more detail, V 4.1, p. 231.

211 Nanna A is edited by Sjöberg, Mondgott 13-34 (// N 3667, cf. Sjöberg, JCS 40 [1988] 173, fn. 6) and supplemented by Wilcke, Kollationen 45f. Another duplicate of Nanna A is written on the unpub. Chicago "Sammeltafel", A w/n (cf. V 6.1, p. 290; also Klein, Th $\breve{S} H 43$, fn. 84), together with two other b a 1 b a 1 e compositions, namely a duplicate of Sulgi Z, but replacing Sulgi's name with that of Šu su'en, and Urnamma G. Note that both Nanna A and "Sulgi Z" are mentioned in the literary catalogue TMH NF 354 (= HS 1504) lines 2 and 4 (cf. Wilcke, ibid. 41 ad 2 and 4). 
Nippur recension of Urnamma D. But Nanna A is chiefly concerned with Nanna's lineage as first-born son of Ninlil and Enlil, with his function as provider of the Ekur, and with his investiture by An. An grants him shepherdship over/of the land (line 49) and kingship (line 52), and he enthrones him in Ur and brings abundance to its canal $\mathrm{i}_{7}-\mathrm{n}$ u $\mathrm{n}$. At the end (line 60) an anonymous king is mentioned. The phraseology and content are thus reminiscent of Ur III royal hymns, ${ }^{212}$ and the themes similar to those in Urnamma $D$ : the mention of the $i_{7}-n$ u n-canal ${ }^{213}$ is noteworthy for it was dug by Urnamma specifically for Nanna. ${ }^{214}$ The bringing of fish and birds in line $54^{215}$ recalls Urnamma D (Ni) 31, and especially 33-34, and (Ur) 35'. Just as Urnamma D deals with the kingship of Urnamma and the resulting prosperity for his city Ur, so too is Nanna A concerned with that of Nanna and with prosperity for Nippur.

Urnamma $\mathrm{D}$ then, is closely connected with $\mathrm{b}$ a $1 \mathrm{~b}$ a 1 e compositions on the basis of thematic similarities, and poetic structure. Furthermore, the fact that a section of Urnamma $D$ turns up in a b a l b a l e of Nanna shows that it is possible that Urnamma $\mathrm{D}$ might be an adaption of $\mathrm{a} b \mathrm{~b} / \mathrm{b}$ a $1 \mathrm{e}$ composition of Nanna, whereby the divine self-praise is centered on the king instead. ${ }^{216}$

URNAMMA EF, a š i $\mathrm{r} \mathrm{n}$ a $\mathrm{m}$ š u b composition, ${ }^{217}$ is witnessed by two nonNippur recensions, referred to as $E$ and $F$, of an original Urnamma hymn. It occupies a special position within the $\breve{s}$ i $\mathrm{r} n$ a $\mathrm{m}$ š u b compositions of which we have twelve examples so far, for it centres on the praise of the king, rather than on the deity. ${ }^{218}$ It is, in fact, the only hymn of that type explicitly mentioning a king. This leads to the possibility that a hymn to a god was modified and altered to compose Urnamma EF. ${ }^{219}$ This type of hymn is susceptible to a composition technique using so-called "stock phrases" ("Versatzstücke") inserted into different contexts. ك̌ i r n a m š u b compositions share these "stock phrases" of variable length with $\mathrm{b}$ a l a g songs whose proximity to the $\check{\mathrm{s}} \mathrm{r} \mathrm{n}$ a m $\breve{\mathrm{sub}}$ compositions is also evident on formal grounds. It is possible that the $\check{\mathrm{s}} \mathrm{ir} \mathrm{n} \mathrm{a} \mathrm{m} \mathrm{š} \mathrm{u} \mathrm{b}$ compositions, like the $\mathrm{b}$ a $\mathrm{l}$ a $\mathrm{g}$ songs, were part of the $\mathrm{g}$ a 1 a-singer's repertoire and therefore would have been sung in the temple cult. Urnamma EF may have been composed for ceremonies in the Ekišnugal involving the king.

\footnotetext{
212 Already Wilcke, Kollationen 47.

213 Cf. in detail, Carroué, ASJ 15 (1993) 52-61.

214 Urnamma 24:7-9. Cf. also III 1., p. 34.

215 Cf. Wilcke, Kollationen 46; 54.

216 It is possible, but unlikely, that the $\mathrm{b}$ a 1 b a 1 e composition was modelled on Urnamma $D$, an original royal hymn with rigid poetic structure (to my knowledge the only example so far), and that therefore the boundaries between type A and B hymns had not yet been so sharply drawn for the early stream of royal hymnic tradition.

217 For details on this type of hymn, cf. V 5.1, pp. 260ff.

218 Cf. V ibid., p. 262.

219 Or, again, that the lines between type A and B hymns had not yet been so sharply drawn for the Urnamma hymns.
} 


\subsection{Statues, Stelas and Self-laudatory Hymns}

The discussion of topoi of legitimation and kingship and narrative material describing royal achievements in sections 1.2 and 3.1 of this chapter illustrates that during the Lagaš II, Ur III and Isin-Larsa periods such material can be found both in statue and stela inscriptions and/or Old Babylonian copies thereof, and in a more literary form in the royal hymns of those periods. This finding shows the close relationship between these two text types and raises in particular the question of the original setting of royal hymns that have come down to us almost exclusively in Old Babylonian scribal copies. Already decades ago W.W. Hallo surmised that royal, divine and temple hymns were originally composed as monumental inscriptions. ${ }^{220}$ More recently M.-C. Ludwig has suggested that especially selflaudatory hymns were written on stelas and exhibited, for they contain ample "autobiographical" narrative. And, like the Old Akkadian Sargonic stela inscriptions, ${ }^{221}$ the content of some of the hymns is asserted to be "true" in the hymns themselves. 222 The following section reiterates previously known observations which indicate that royal hymns were originally written on monuments and presents additional ones contributing to the ongoing discussion of the original setting of royal hymns.

Archaeological evidence for self-laudatory hymns, i.e. B. II type hymns inscribed on stelas, comes so far only from Old Babylonian fragments of stelas with hymnic contents from Ur and Kiš. They contain self-praise of Hammurapi. ${ }^{223}$ RIME 4.2.1.3.15 (Waradsîn) is a fragmentary text containing a self-praise of Enanedu, e n-priestess of Nanna, and could represent part of a stela, although according to D.R. Frayne a stone tablet is more likely than a stela. ${ }^{224} \mathrm{Un}$ fortunately, most statues and stelas of the Sargonic, Ur III, and Isin-Larsa periods were either pillaged or reused, ${ }^{225}$ and when we do have fragments of original pieces of those periods, such as e.g. Urnamma's stela (Urnamma 29), too little of the text is usually preserved to make any comments about its contents or its style. An indication that hymns could be written on stelas are Old Babylonian tablet copies written in the so-called short-line format and case-ruled and thus probably made from the original monuments themselves by imitating the layout of their inscriptions in cases. ${ }^{226}$ Further, the curses at the end of Sulgi E and Išmedagān A

220 Hallo, CRRAI 17 (1970) 121; idem, AS 20 (1975) 195.

221 E.g. RIME 2.1.2.4 || 6:73-78 || 78-83 et passim (Rīmuš); RIME 2.1.3.1:47-52 (Maništū su); RIME 2.1.4.2 vii 28-viii 1 (Narāmsu'en).

222 Ludwig, Ǐ̌me-Dagan 62f.; 67.

223 Cf. Frayne, RIME 4357 (no. 20) with references.

224 Frayne, ibid. 224.

225 Cf. above, 1.2 , p. 45 , fn. 28.

226 For examples, including tablets containing Sulgi and Iš medagān hymns, cf. Tinney's short-line groups $\mathrm{S}_{3}-\mathrm{S}_{5}$ discussed in $O L Z 90$ (1995) 11-14. 
$\left(+\mathrm{V}_{\mathrm{A}}+\mathrm{Z}^{227}\right)$, both type $\mathrm{B}$. II hymns, are reminiscent of those that were used to end texts on statues and stelas and therefore bolster the assumption that type B. II hymns were inscribed on stelas or statues. The stela on which Išmedagān's selflaudatory hymn A was inscribed ${ }^{228}$ may actually be mentioned in the hymn itself, for $Z_{A}$ 5-10 states that Išmedagān has constructed a magnificent copper stela inscribed with "hymns" (e $\mathrm{n}_{3}-\mathrm{du}$ ) and "songs" ( $\check{\mathrm{s}}$ i $\mathrm{r}_{3}$ ) and has brought it (into the Ekur?) to Enlil. ${ }^{229}$ Besides cultic provisions for the Ekur and the stela, the hymn also mentions the erection of statues and votive objects which the king gives to Enlil and Ninlil in the Ekur. This is similar to inscriptions on statues which mention the statue itself and the occasion which prompted its fashioning, consecration, and installation in the temple. Gudea's statues, for example, are mentioned in their respective inscriptions which centre on a cultic deed, most often the (re)construction of a temple, and like Išmedagān $\mathrm{A}$, some inscriptions end in curse formulae.

In addition to the findings just mentioned it can be shown that both royal hymns and statues and stelas serve a common function and also share common themes, again indicating the close affinity of these two text types. Both the hymns and the inscriptions on statues and stelas functioned as messages to the gods, rendering account of royal deeds: the former were recited in sanctuaries, ${ }^{230}$ the latter were erected in courtyards ${ }^{231}$ and sanctuaries of temples. ${ }^{232}$ Such accounts go back to Pre-Sargonic times (cf. e.g. Eanatum's Stele of the Vultures [= Ean. 1] and Ent. 1). Far from being mute reminders of royal achievements alone, statues or sculptural images of rulers, identified by likeness as the ruler himself, ${ }^{233}$ were empowered to speak on the ruler's behalf, through a set of rituals of consecration, installation and maintenance, ${ }^{234}$ and represent him in the funerary sanctuary after his death at the

\footnotetext{
227 For Išmedagān $\mathrm{V}_{\mathrm{A}}$ and $\mathrm{Z}$ as part of Iš medagān $\mathrm{A}$, cf. Ludwig, Išme-Dagan $4 ; 23 ; 165$. For reservations that Iśmedagān $\mathrm{Z}$ is part of $\mathrm{A}$, cf. however Tinney, ibid. 20f. ad IšD A.

228 Cf. immediately below, p. 80.

229 Cf. Ludwig, Išme-Dagan $62 \mathrm{f}$.

$230 \mathrm{Cf}$. Ludwig, ibid. 44ff. with references to Sulgi E 57ff.; $252 \mathrm{ff}$., Iš medagān $\mathrm{V}_{\mathrm{A}}$ 44-50. Another reference is possibly $\mathrm{e}_{3} \breve{\mathrm{g}}_{3}$ a r - r a - b i in Gudea, Stat. B 8:24-25, for which see Klein, Studies Sjöberg (1989) 297, and fn. 51 and Steible, FAOS 9/2 (1991) 34 ad 104. A translation of "sanctuary" for e $\check{s}_{3}$, at which hymns should not be neglected, rather than "festivals", as an abbreviated form of $\mathrm{e} \breve{s}_{3}$ - e $\breve{s}_{3}$ (Klein, ibid.) in the Gudea passage is supported by two other passages: Ibbisu'en A 9-10:67-70 (the object is a vessel) $d u_{8} \quad m a h$

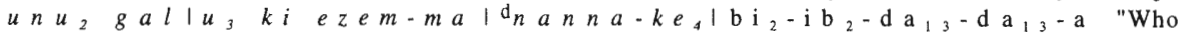
neglects them ( $=$ the vessels) at the ..., the large dining hall, and the place of Nanna's festival", which Steible

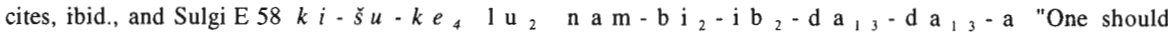
not neglect them (= the songs) at the cult-places" (cf. Ludwig, Išme-Dagan 44 and Klein, ibid. 297 with vars.) both refer to locations. It remains uncertain what a $\mathrm{d} \mathrm{u}_{8} \quad \mathrm{~m} \mathrm{a} \mathrm{h}$ is (for suggestions and previous literature, cf. Frayne, BiOr. 45 [1988] 354) but it always appears in connection with eating facilities or kitchens, cf. perhaps also RIME 4.1.4.15:2'-6' (Iš medagān).

231 Cf. e.g. Gudea, Stat. B 6:9-12; RIME 4.1.6.2 vi 10'-12' (Urninurta); RIME 4.1.10.11:18-19 (Enlilbāni). For Sargonic statues and stelas in the courtyard of Enlil's temple Ekur in Nippur and other cities of the Sargonic kings' realm, cf. Frayne, BiOr. 48 (1991) 394, and fn. 79; 384 with previous literature.

232 Cf, e.g. Gelb, Kienast, FAOS 7 (1990) $219 ; 349$ (the $\mathrm{e}_{2}-\mathrm{g} \mathrm{u}-1$ a of Ninlil as the site of a Š su'en stela). 233 Cf. e.g. RIME 2.1.4.23:15-16; 26 iii 32-34; 50 iii 1-2 (Narām-Su'en); RIME 4.1.6.2 vi 6'-12' (Urninurta); RIME 4.2.9.1:28-33 (Sîniddinam).

234 In detail Winter, Journal of Ritual Studies 6 (1992) $21 \mathrm{ff}$. It must be noted that the only evidence so far for the so-called mouth-opening ritual, as part of the consecration ritual of a statue of a ruler, is for the statue of the
} 
$\mathrm{k} \mathrm{i}-\mathrm{a}-\mathrm{n}$ a $\mathrm{g}$, the place where the statues received libations and food rations (n i $\hat{g}_{2}-\mathrm{b}$ a), thereby guaranteeing the king's continuous existence after death. ${ }^{235}$ Urnamma received daily offerings at his $\mathrm{k} i$ - a - $\mathrm{n}$ a $\hat{\mathrm{g}}$, probably located at Ur, and also at his "throne" ( $\hat{\mathrm{g}} \mathrm{e} \breve{\mathrm{s}} \mathrm{g} \mathrm{u}-\mathrm{z}$ a), as late as the reign of the last Ur III ruler, Ibbīsu'en. ${ }^{236}$

Just as the statues' presence in the temple would have kept their creator visibly alive and memorialized his achievements, so also do hymns memorialize royal achievements by continued recitation. This function of hymns is clearly stated in the curse section at the end of Gudea's statue B and is also expressed by Sulgi in his self-laudatory hymn E. ${ }^{237}$ A collation of the Old Babylonian Louvre Catalogue of Sumerian compositions, TCL $1528,{ }^{238}$ now provides evidence for and thus supports M.-C. Ludwig's assumption that at least self-laudatory hymns were actually inscribed on stelas, erected in temple courtyards, and that they, too, like statues, would therefore have perpetuated the ruler and his deeds more concretely. The collation indicates that the fourteen last incipit (iv 54-67) are indeed of compositions written on stelas (iv 68: $* 14 \mathrm{n} \mathrm{a}-\mathrm{r} \mathrm{u}_{2}-\mathrm{a}$ ). Only four incipit can be identified so far: Išmedagān A (iv 58), Sulgi E (iv 61), Sulgi C (iv 63), which are self-laudatory hymns, and Sulgi O (iv 62), broken off at the end and therefore uncertain as to which type the hymn belongs.

Besides the functional proximity of hymns, statues, and stelas, common themes in similar sequence are also evident in these two text types. ${ }^{239}$ Gudea, for example, entrusts his statue B, being empowered to speak on the ruler's behalf, with a message for his lord Ningirsu, to specifically remind him that his temple's construction took place together with social reforms ${ }^{240}$ (Gudea, Stat. B 7:26-46) thus showing that Gudea had attended to the justice demanded by Nanše and Ningirsu. The same thematic sequence leading to and reporting the accomplishment of these reforms is found in the Gudea building hymn Cylinder B: after a description of the construction work and the completed temple (Stat. B 2:1-6:76 Cyl. B -17:11) a summary statement follows: the temple is built (Stat. B 6:77-7:4 $\mathrm{e}_{2} \mathrm{ur}_{5}-\mathrm{gin}_{7} \mathrm{dim} \mathrm{m}_{2}-\mathrm{ma}(\ldots) \mid \mathrm{n} \mathrm{a}-\mathrm{m} \mathrm{u}-\mathrm{du}_{3} \approx \mathrm{Cyl}$. B 17:13 $\mathrm{g} \mathrm{u}_{3}-$ $\mathrm{de}_{2}-\mathrm{a} \quad \mathrm{e}_{2}-\mathrm{nin} \mathrm{n} \quad \mathrm{mu}-\mathrm{du}_{3}$ ), whereby the vital regulations are made to function (Stat. B 7:6 $\mathrm{n} \mathrm{i} \hat{g}_{2}-\mathrm{du}_{7} \mathrm{pa} \mathrm{b} \mathrm{i}_{2}-\mathrm{e}_{3} \approx \mathrm{Cyl}$. B 17:12 $\mathrm{n} \mathrm{i} \hat{\mathrm{g}}_{2}-$ $\mathrm{du}_{7}$ i ri $-\mathrm{na}^{-\mathrm{ke}_{4}} \mathrm{pa} \mathrm{bi}_{2}-\mathrm{e}_{3}$ ) and the $\mathrm{me}$ put in full force (Cyl. B 17:14 $\mathrm{m} \mathrm{e}-\mathrm{b}$ i $\breve{\mathrm{s}} \mathrm{u} \quad \mathrm{b} \mathrm{i}_{2}-\mathrm{du}_{7}$ ). Agricultural produce enters the temple (Cyl. B

\footnotetext{
deceased ruler Gudea of Lagaš in Ur III times. Given the documentation for Nippur from Drēhim, one would expect to hear about mouth-openings for royal statues of living rulers in the Ekur.

235 This is nicely expressed in Lugale 475-79; cf. perhaps also RIME 4.2.13.27:18-20 (Waradsîn) where $\mathrm{m} \mathrm{u}$ $\mathrm{p}_{3}$. d could be understood in context of the funerary cult (cf. V 1.4 ad 222, p. 181); in general, cf. Klein, Studies Sjöberg (1989) 296, and fn. 45; Winter, ibid. $26 \mathrm{ff}$.

236 Additional offerings were handed out at the beginning and the middle of the month. Cf. Sallaberger, Kalender 63ff.; 105; 147 (in Nippur).

237 Cf. Klein, Studies Sjöberg (1989) 296ff

238 Cf. Flückiger-Hawker, N.A.B.U. 1996/119 with reference to the edition and previous collations.

$239 \mathrm{Cf}$. also above, 3.1 , pp. $70 \mathrm{ff}$. (similar sequence in hymns and especially artefact inscriptions).

$240 \mathrm{Cf}$. also Averbeck's general remarks on the social function of the temple in A Preliminary Study of Ritual and Structure in the Cylinders of Gudea, Ph.D. Dissertation, The Dropsie College (1987) $168 \mathrm{ff}$.
} 
17:15-16) and reforms are accomplished. In the text of statue B the statue enters the temple (Stat. B 7:19-20) and then tells of the accomplished reforms (Stat. B 7:26$46 \approx \mathrm{Cyl} . \mathrm{B} 17: 17-18: 11$ ). Thus, at the same point in the sequence, the singer of the hymn and the statue would be reporting the same royal reform acts to Ningirsu, and both statue and cylinder would have memorialized the same royal achievements by regular performance of the former and continuous recitation of the latter.

As a reward for the construction of Ningirsu's temple, Gudea shall get life as a gift. The name of statue $\mathrm{B}(7: 14-17)$ reflects this message: $1 \mathrm{u} \mathrm{g} \mathrm{a} \mathrm{l}-\hat{\mathrm{g} \mathrm{u}} \mathrm{u}_{0}$ । $\mathrm{e}_{2}-\mathrm{a}-\mathrm{ni}\left|\mathrm{mu}-\mathrm{na}-\mathrm{du}_{3}\right| \mathrm{n} \mathrm{am}-\mathrm{til} \mathrm{l}_{3} \mathrm{ni} \mathrm{g}_{2}-\mathrm{b} \mathrm{a}-\mathrm{g} \mathrm{u}_{10}$ "For my lord I have built his temple, (may) life (be) my gift!", and similarly also Gudea,

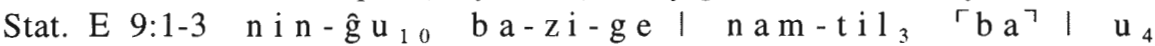
$\mathrm{du}_{\mathrm{N}_{1}} !$ ( $\left.\mathrm{S} \mathrm{A} \hat{\mathrm{G}}\right)-\mathrm{g} \mathrm{a}-\mathrm{b} \mathrm{a} \mathrm{i}_{3}-\mathrm{du}_{3}$ "My mistress, you have made me rise, ${ }^{241}$ allot life! (For) at its (= the temple's) appointed time I have built it!". In fact, many names of the Gudea statues ask a deity in whose honour a temple has been built to bestow long life on Gudea, ${ }^{242}$ sometimes mentioning explicitly that life is being granted for his construction work. Blessings for a happy reign and long life at the end of statue and other royal inscriptions are already in evidence for Early Dynastic $^{243}$ and in later Isin-Larsa times. ${ }^{244}$ They recall passages in royal hymns containing a prayer or blessing for the long life of the mentioned king. In Urnamma C 107-108, Urnamma asks for life (from Enlil?) for the construction of Nanna's temple: (...) $\mathrm{til}_{3} \quad \mathrm{ni} \hat{\mathrm{g}}_{2}-\mathrm{ba}-\hat{\mathrm{g}} \mathrm{u}_{10} \quad \mathrm{~h}_{\mathrm{e}_{2}}-\mathrm{a}$ I d $\mathrm{n}$ an n a $1 \mathrm{ug} \mathrm{a} \mathrm{l}-\mathrm{g} \mathrm{u}_{10} \quad \mathrm{e}_{2}-\mathrm{gal}-1 \mathrm{a}-\mathrm{n}$ a $\mathrm{mu}-\mathrm{n} \mathrm{a}-\mathrm{du}_{3} \quad$ "(..) let life be my gift! For Nanna, my lord, I have built his palace".

The occasion which prompted the realization of Urnamma's self-laudatory hymn $\mathrm{C}$ was probably the (re)construction of the Ekišnugal, the temple complex of the city-god Nanna in Ur, and the inauguration of the yearly ceremony of first-fruit offerings for Enlil in Nippur, ${ }^{245}$ just as the construction of the Eninnu, Ningirsu's temple in Girsu, prompted the realization of Gudea' statue B. Both Urnamma C and Gudea's statue B share common themes. Statue B, however, sticks more closely to the subject at hand, whereas Urnamma $C$ is more literary and uses poetic devices such as parallel sequences of matching or similarly constructed sequences. Both texts describe their focal point, the construction of the city-god's temple, at some length. Urnamma $C$ does this in form of hymnic praise of the Ekišnugal, listing its parts at the beginning. Statue B elaborates on the actual construction of certain parts of the Eninnu. Preparations include the reform and purification of society (Stat. B 3:12-5:11) as well as the opening of routes (Stat. B 5:24-27) ${ }^{246}$ for the supply of raw materials from foreign lands (Stat. B 5:28-6:63). Similarly, in

\footnotetext{
$241 \mathrm{Cf}$. also the name of the š i t a-weapon in Nammahni 4:12-13 l u g a l- ĝ u ${ }_{10}\left(=\mathrm{d}_{\mathrm{k}} \mathrm{k} \mathrm{n} \mathrm{d} \mathrm{a} \mathrm{a}_{2}-\mathrm{z}_{\mathrm{i}}\right.$ ) $\mathrm{b}$ a $-\mathrm{z} \mathrm{i}-\mathrm{g}$ e I h $\mathrm{e}_{2}-\mathrm{ma}-\mathrm{d}$ a $-\mathrm{zi}-\mathrm{z}$ i (and similarly Nammahni 16:4').

242 Exceptions are Stat. D 5:2-8, Stat. M 3:2-3, Stat. O 3:2-4, and Stat. Q 2:4-5.

243 E.g. Luzag. 1, 3:19-21.

244 E.g. RIME 4.1.10.11:20-22 (Enlilbāni); RIME 4.2.8.3:53-56 (Nū radad); RIME 4.2.9.4:22-25 (Sîniddinam); $R I M E$ 4.2.13.2:22-26 et passim (Waradsîn).

245 Cf. above, III 2., p. 39.

246 The technical term is ${\mathrm{g} \mathrm{i} \mathrm{ri}_{3}}_{\mathrm{g} \mathrm{a} l_{2}} \quad \mathrm{t} \mathrm{a} \mathrm{k} \mathrm{a}_{4}$ (line 27).
} 
Urnamma C, Urnamma's securing of routes (Urnamma C 19 and 54) (47 $^{24}$ and his enforcement of law and order bring social stability, a prerequisite for work on the temple, and this ensures that regular offerings for the Ekišnuĝal can be made (Urnamma C 32-42). Both Gudea and Urnamma are endowed with attributes from different gods to show their unique qualification for the job (Urnamma C 20-30; 43 49 and Gudea, Stat. B 2:5-3:5). At the end of statue B's inscription, as well as Urnamma $\mathrm{C}$ is the request for life in perpetuity as recompense for the construction of the city-god's temple.

In summary, both the collation of the Louvre Catalogue TCL 1528 , listing fourteen compositions inscribed on stelas of which those identifiable are selflaudatory, together with the fact that statues and self-laudatory hymns share common themes and the purpose to keep their creator visibly alive and memorialize his achievements through the ages, indicate that self-laudatory hymns (type B. II), like Urnamma $C$, were originally inscribed on stelas erected in the temple ${ }^{248}$ and copied on tablets by the scribes of the Old Babylonian schools. On the other hand comparison with e.g. the texts of Gudea's cylinders, a type B I. hymn, and Gudea's statue B show the use of the same materials and suggests that royal type B I. hymns may also have been originally inscribed on stelas. In fact, examples given by. S. Tinney of short-line formatted and case-ruled fragments of type A hymns containing rubrics ${ }^{249}$ may raise the possibility of an original monumental setting of all types of royal hymns, as W.W. Hallo suggested. Still, the following observations should caution us to take the view that Old Babylonian copies of all types of royal hymns are exclusively verbatim texts of statue and stela inscriptions: a common but not exclusive ${ }^{250}$ feature of texts inscribed on statues and stelas is the ending curse formulae which we would therefore also expect royal hymns to have, but unlike many statue and stela inscriptions, only two examples of hymns discovered to date have curses at the end, Sulgi $E$ and Išmedagān $A\left(+V_{A}+Z\right)$, both type B. II hymns, reminiscent of those that were used to end texts on statues and stelas. ${ }^{251}$ This could indicate that during the transmission of royal hymns from monument to copy, the Old Babylonian scribes in fact adapted the texts in many instances, rather than copying verbatim the texts found on stelas and statues, among other things by leaving out the curses at the end. Adaption of many royal hymns may find additional support in the fact that the quality of the narrative in the hymns seems so different from royal inscriptions.

\footnotetext{
247 The technical term is $\mathrm{g} \mathrm{i}_{3} \mathrm{~s}_{3} \mathrm{~S} \mathrm{a}_{2}$.

248 Already suggested for Urnamma C by Falkenstein, Iraq 22 (1960) 147 and followed by Hallo, JCS 17 (1963) 117 , fn. 93.

249 Išmedagān D, source A (= CBS 2343), a fragmentary piece of a z a m z a m of Enlil (= N 1045), cf. Tinney, OLZ 90 (1995) 12, and an unidentifiable Iš medagän hymnic fragment (= N 3326), cf. Tinney, ibid. 23. Note also source N $5873+$ N 6989 of Išmedagān K (Tinney, ibid. 13, and fn. 32), a hymn that focuses entirely on the praise of Inana and mentions Iš medagān as Inana's spouse at the end. It contains no rubrics but has a concluding punchline which it shares with other Iš medagān hymns (cf. above, II I., p. 13).

250 E.g. some of Gudea's statues.

251 Cf. already above, p. $78 f$.
} 
Basic components of royal inscriptions such as the deity for whom the structure or object is built or fashioned and/or dedicated to (element 1), the royal benefactor (element 2), and the act of building and/or dedication, may be expanded to sections which elaborate more fully on the components and incorporate additional information in temporal clauses. The "when-then" $\left(\mathrm{u}_{4} \ldots-\mathrm{a}-\mathrm{u}_{4}-\mathrm{b}\right.$ a / $-\mathrm{b}$ i - a) schema (elements 3 and 4) is typical of royal inscriptions. It is a way to introduce "historical" and other information and is already found in Pre-Sargonic inscriptions $^{252}$ and continues to be used in Sargonic through Larsa royal inscriptions. By introducing a temporal clause with "at that time" (vars. "in this same year", 253 "on the first, second etc. day"254), an important event can be singled out of a series of events or narratives and the purpose added to it in subordinate $\{\mathrm{ed}+\mathrm{e}\}$ clauses. Often this event prompted the fashioning of the object on which the inscription was written and with which the event was commemorated. A dedicatory clause (element 5) stating on whose behalf ("for his life, for the life of so-and-so") the dedication is made may be added together with concluding curses and/or blessings for the benefactor at the end of the inscription (element 6). ${ }^{255}$ The "when-then" schema is also apparent in prologues to law codes which have come down to us in copies of original stela inscriptions (e.g. Codex Urnamma 31; 36; [104]; 125; Codex Lipiteštar [1]; 20;38). The statue inscriptions Sulgi V and Išmedagān S, 256 although commonly classified as royal hymns, show this same formal structure:

1. Dedication to deity (DN + epithets): Sulgi V $1-2 \approx$ Išmedagān S 1-2

2. Royal subject (RN + epithets): Sulgi V 3-21 $\approx$ Išmedagān S 3-8

3. $\mathrm{u}_{4} \ldots$ clause: Sulgi V 22-25

4. $\mathrm{u}_{4}$ - b a clauses: Sulgi V 26-29; 30-33(/35) $\approx$ Išmedagān S 9-22; 23-25

(fashioning of royal sculptural image)

5. "Dedicatory clause" (placing of image in front of deity): Sulgi V $34-35 \approx$ Išmedagān S 26-28 (in form of a blessing)

6. Concluding curses: Išmedagān S 29-34

Royal hymns, too, may contain the components listed in the formal structure of royal inscriptions. Urnamma $B$, for example, introduces Enlil, to whom the reconstructed Ekur is dedicated, first (element 1). Then follows the introduction of the royal subject, Urnamma (element 2), followed by the building account (element 4). The successful completion of the work prompts the setting up of a dais of kingship at Ur (element 4) in the presence of Enlil (cf. element 1) who bestows a

252 Cooper, Presarg. Inscr. 9.

253 E.g. Ukg. 4, 12:29 || 5, 12:5. Cf. also e.g. Gudea, Stat. E 8:16 \| G 2:17 (̌ a $3-\mathrm{m} \mathrm{u}-\mathrm{b}$ a - k a), Gudea, Stat. R 2:9 (m u - b i - a).

254 E.g. Utuheghal Inscr. = RIME 2.13.6.4:73; 75; 84. Cf. also e.g. RIME 2.1.2.6:68f. (in śanutim saliśtim "in the third year").

255 Cf. e.g. Frayne, BiOr. 48 (1991) 405 for the Šū su'en Inscription Collection A.

256 For discussions and editions, cf. Ludwig, Išme-Dagan 75-91; for Sulgi V also Klein, Beer-Sheva 2 (1985) 7*-38* [ cf. now also Frayne, RIME 3/2 (1997) 156f., as RIME 3/2.1.2.54], and for Iš medagān S Frayne, RIME 4 36ff. (= RIME 4.1.4.8). 
blessing upon Urnamma (element 5). ${ }^{257}$ But the difference is that in this case the "when-then" schema seems to be replaced by poetic structure. This is true of royal hymns in general: they adhere less to chronological order, as e.g. the discussion of Urnamma $C$ in the previous chapter shows, ${ }^{258}$ and by dropping the "when-then" schema may reduce events to literary patterns or topoi. Many have an intrinsic poetic structure as their rubrics demonstrate.

As to the development of narrative materials of the formal structure with its expanded sections discussed above, one can say that for the Ur III and Isin periods such materials appear mainly in inscriptions on statues and stelas, known from Old Babylonian copies, a pattern first noted for the Sargonic and Lagaš II periods of shifting narrative materials out of artefact inscriptions into statue and stela inscriptions, and in a more literary vein, into hymns. For the Larsa dynasty, beginning with Nüradad (1865-1850 B.C.), and under the last kings of Larsa who were his successors, Sîniddinam, Waradsîn, Rīmsîn, and the Babylonian kings Hammurapi and Samsu'iluna, however, artefact inscriptions inscribed on cone shafts, foundation tablets etc., also include narrative materials and make use of the same structure. Here again an important event prompts the fashioning of an object, but the inscription is this time not only written on the object itself, but on some other artefact. The "when-then" schema may remain, ${ }^{259}$ but each section is given such a strong literary flavour that it often cannot be differentiated from hymnic passages. ${ }^{260}$ This literary development has already been noticed in a similar manner for topoi of legitimation and kingship in section $1.2 .{ }^{261}$

Another difference between the narrative of royal inscriptions and hymns can be observed at the beginning of these texts: royal inscriptions usually begin with the divine name, followed by epithets, whereas many hymns begin with epithets of the god, followed by the divine name a few lines later. ${ }^{262}$ Thus, adaption of statue and stela inscriptions to hymns may also have taken place at the beginning of a text.

Also, the use of persons is handled differently: hymns use the 1st and 3rd persons, sometimes including addresses in the 2 nd person. Royal inscriptions through Ur III times use predominantly the 3rd person. ${ }^{263}$ From the Isin period onward the 1st person starts to get used, i.e. in the artefact inscriptions of Lipiteštar ${ }^{264}$ and in Old Babylonian copies of texts inscribed most likely on stelas

257 Cf. already above, 3.1, pp. 69ff. For a detailed structural analysis of Urnamma B, cf. V 2.1, pp. $183 \mathrm{ff}$.

258 III 2., pp. $37 \mathrm{ff}$.

259 E.g. RIME 4.2.8.3 || 7:26; 37 \| 64 (Nū radad); RIME 4.2.9.2:10; 33; 51 (Sîniddinam); RIME 4.2.13.3:20 (Waradsîn).

260 Edzard, ZZB 148; Michalowski, Sachs Memorial Vol. (1988) 267.

$261 \mathrm{Cf}$. pp. 55ff. Also above, 3.1, pp. $69 \mathrm{ff}$

262 Of course there are well-known exceptions, e.g. Enl.sudr. (= Enlil in the Ekur); note that Sulgi E and Iśmedagān A, two compositions on stelas, also begin with the divine name.

263 An exception is the statue inscription of Urba'u (no. 1 = Steible, FAOS 9/1 134-40) which uses the 1st person throughout (pace Steible). Note also that some statue and stela inscriptions in the 3rd person may have passages that contain a direct address: e.g. RIME 2.1.2.4:73-78 (Narāmsu'en); Gudea, Stat. B 7:24ff.; Utuḩ egal Inscr. (= RIME 2.13.6.4) 27-32 et passim; RIME 4.1.6.2 vi l'ff. (Urninurta); Kärki, StOr. 49 (1980) 69:46ff. (Sîniddinam).

264 RIME 4.1.5.2ff. 
of Išmedagān ${ }^{265}$ and Enlilbāni. ${ }^{266}$ In the Larsa period, from Nūradad onward, the 1st person is widely used both in artefact and statue and stela inscriptions, a finding which coincides with the comments on the development of narrative materials made above.

In short, the fact that hymns generally have no curses at the end, omit the "when-then" schema in favour of a more poetic structure which adheres less to chronological order, most often begin with epithets of the god invoked, rather than with the divine name itself, and do not restrict the use of persons, as in the case of royal inscriptions, all argue against viewing Old Babylonian copies of all types of royal hymns as exclusive verbatim texts of statue and stela inscriptions, but rather corroborate the assumption that in many instances the scribes may in the process of copying statue and stela texts actually have adapted parts thereof.

\subsection{Urnamma $A$ and Lamentation Literature}

C. Wilcke, in a series of published articles and in his unpublished, comprehensive study of Urnamma A, studied the relationship of this composition with other Sumerian literary texts and has drawn attention to numerous parallels to the Gilgameš epics, ${ }^{267}$ the lamentations over Ur (and Sumer), ${ }^{268}$ laments concerning distant gods, i.e. Dumuzi, Damu and Ningešzida, ${ }^{269}$ and in Two Elegies. ${ }^{270}$ Job-like themes in Urnamma's lament over himself have prompted scholars to see thematic parallels with so-called wisdom literature, like Man and his God. ${ }^{271}$

Urnamma A describes the king's death and its consequences, and so naturally contains allusions to myths which centre around the laments of divine mother and sister, and of the widowed goddess over the disappearance of their loved one. ${ }^{272}$ Main representatives of this type of myth are the cult song e de n-n a $u_{2}$ $\mathrm{s}$ a $\mathrm{g}-\mathrm{g} \mathrm{a}_{2},{ }^{273}$ the cult song of Damu $\mathrm{u}_{3}-\mathrm{m} \mathrm{u}-\mathrm{un}-\mathrm{e} \quad \mathrm{du} \mathrm{m} \mathrm{u} \mathrm{nun} \quad \mathrm{g}$ a 1 $\mathrm{a} \mathrm{n}-\mathrm{k} \mathrm{i}-\check{s}_{3} \mathrm{e}_{3} \mathrm{~m} \mathrm{a} \mathrm{h}-\mathrm{a} \mathrm{m}_{3}(=T C L 158 / /),{ }^{274}$ and also the composition known

265 RIME 4.1.4.6 vi l'ff. (Iš medagān); classified by Edzard, ZZB 81f. as a royal hymn, by Frayne, RIME 433 as an inscription.

266 RIME 4.1.10.1001 (Enlilbāni); classified by Edzard, ZZB 83 and Römer, SKIZ 3 and 38 as a royal hymn, by Kraus, Verfügungen 28, fn. 60, and Frayne, RIME 487 as an inscription. Cf. also Tinney, OLZ 90 (1995) 14. 267 Wilcke, CRRAI 17 (1970) 82; 84; 91f.; idem, UT 27-29.

268 Wilcke, UT $30 \mathrm{f}$.

269 Wilcke, CRRAI 17 (1970) 86-91; idem, RlA 5 (1976-80) 84 s.v. "Inanna/Išstar"; idem, Studies Vajda (1988) 246-50; idem, UT 32-47; idem, "Politik und Literatur" 35f. and 52f.

270 Wilcke, UT 48-52. For an edition of Two Elegies, cf. Kramer, Two Elegies on a Pushkin Museum Tablet: A New Sumerian Literary Genre, Moscow (1960) with additions by Sjöberg, JAOS 103 (1983) 315-20.

271 Kramer, JCS 21 (1967) 104; with reservation Wilcke, CRRAI 17 (1970) 86. For an edition of Man and his God, cf. Kramer, VTSuppl. 3 (1955) 170-82; supplemented with a new translation by Römer, TUAT III/1 (1990) 102-09.

272 Wilcke, UT 32-42; idem, Studies Vajda (1988) 246-49.

$273 \mathrm{Cf}$. Wilcke, Studies Vajda (1988) 248, and fn. 21 for references.

274 For an edition, cf. Römer, BiOr. 49 (1992) 636-80. 
as "Ninĝešzida and Ninazimua" (= TMH NF $44 / /){ }^{275}$ There is evidence from Ur III administrative documents from Ur and Umma for actual rituals in the first month of the year (around April), at the beginning of harvest time, in the $\mathrm{u}_{2} \quad \mathrm{~s}$ a $\hat{\mathrm{g}}$ "high? grass", all involving lamenting goddesses, and which were coupled, in the case of Ur, with the cult of the dead Ur III kings. ${ }^{276}$ Urnamma and his son and successor Sulgi claim Ninsumun and Gilgameš as their divine mother and brother. ${ }^{277}$ In addition, Sulgi explicitly mentions in his hymns Lugalbanda and Ĝeštinana his divine father and sister, ${ }^{278}$ and the Susa version of Urnamma A (line 126) testifies to the tradition that the goddess Geštinana/Ninazimua was regarded as Urnamma's divine sister. P. Steinkeller has demonstrated that Sulgi most probably venerated his mother S I. A - $t u m^{279}$ after her death (and perhaps already during her lifetime) as one of the personifications of Ĝeštinana, naming her d $\hat{g}$ e š $\mathrm{t}$ i $\mathrm{n}$ - a n $\mathrm{n}$ a - S I . A - $t u m$. $^{280}$ The association of Ġeštinana with Urnamma's wife probably has to do with Urnamma being the god Dumuzi, since, as e n-priest of Uruk, ${ }^{281}$ he identifies himself with Dumuzi, husband of the goddess Inana, the chief deity of Uruk. ${ }^{282}$ Although we do not have any explicit reference that Urnamma and Inana are husband and wife, as we do for two late Early Dynastic kings (ca. 2400 B.C.), Mesanepada of Ur and Eanatum of Lagaš, and later rulers, ${ }^{283}$ such an intimate relationship is certainly referred to in Inana's lament over the dead Urnamma, condemned to a life in the netherworld. ${ }^{284}$ In addition to his divine wife, Urnamma can also be mourned by his real wife S I. A - $t u m$ in the guise of a divine sister, which shows how in this case divine and genetic genealogies are being juggled. Two laments, known under the titles of $\mathrm{e}-\mathrm{n} \mathrm{e}-\mathrm{e} \hat{\mathrm{g}}_{3}-\hat{\mathrm{g}}_{2}-\mathrm{n} \mathrm{i} \mathrm{i}-\mathrm{lu} \mathrm{i}-\mathrm{lu}$, and $\mathrm{u}_{3}-\mathrm{u}_{8} \mathrm{ga}-\mathrm{am} \mathrm{m}_{3}-\mathrm{du}_{11}$, the former a $\mathrm{b}$ al a $\mathrm{g}$ song of Dumuzi, the latter an e r š e m a song of Inana, ${ }^{285}$ centre on the myth of Inana's attempted rescue of Dumuzi from the netherworld in which she humbly asks for an audience with Enlil and pleads with him for Dumuzi's release. ${ }^{286}$ Urnamma A 195 and following seem to allude to this myth: Inana is not present when An and Enlil's decision is changed (lines 8-9). But when she hears of the loss of her lover, she

\footnotetext{
275 Cf. Wilcke, Studies Vajda (1988) 248, and fn. 20 for references.

276 Sallaberger, Kalender 183 , and fn. 865; 233f. (for the Umma ritual).

277 Urnamma A 16; 63; C 48; 113; EF 12; F 40 and 49 (broken); e.g. Sulgi A 7; B 7; 184; D 41; 43; F 4-5 et passim (cf. Wilcke, CRRAI 19 [1974] 201, fn. 131); O 29; X 47, for Ninsumun as divine mother. Urnamma $A$ 143; C 112; e.g. Sulgi D 292; O 50 || 86 || 139, for Gilgameš as divine brother.

278 E.g. Sulgi D 42; P b 23; 38, for Lugalbanda as divine father; e.g. Sulgi E 21 (cf. Ludwig, Išme-Dagan 206); $\mathrm{P}$ b 43 , for Ĝeš tinana as divine sister.

279 For the suggested readings of S I. A $-t u m$ as Watartum and Zibnatum, cf. the summary in Steible, FAOS 9/2 (1991) 195f. with reference to Michalowksi, ASJ 4 (1982) 130ff. for the reading Zibnatum, but for ziib-na-tum, cf. now Cavigneaux, ASJ 18 (1996) 38, fn. 19 ("a ceremony").

280 Steinkeller, ASJ 3 (1981) $77 \mathrm{f}$.

281 Urnamma 10:7 and 34:5. Note also Urnamma C 73-75 which refers to Urnamma as e n-priest of Inana involved in the "sacred marriage" rite (cf. also above, 1II 2, p. 38).

282 Cf. Cooper, Sacred Marriage and Popular Cult 91.

283 Cooper, ibid. $83 \mathrm{ff}$.

284 Wilcke, CRRAI 17 (1970) 89; idem, Studies Vajda (1988) 246.

285 Cf. Wilcke, Studies Vajda (1988) 247, fns. 15f. for references.

286 Wilcke, CRRAI 17 (1970) 86-89; idem, UT 42-46; idem, RlA 5 (1976-80) 84 s.v. "Inanna/Ǐ̌ tar"; idem, Studies Vajda (1988) 246; idem, "Politik und Literatur" 35f. and $52 \mathrm{f}$.
} 
humbly appears before Enlil (a topos) only to hear that Urnamma will never appear again. She directs an angry speech at An and reproaches him for the fact that Urnamma's fate has been changed, against the established decrees of the land (lines 208-210). The expression in lines 208-209 "who has changed that word?", implying the sarcastic answer that only An and Enlil themselves could have done so, is the same used to describe the futile attempt at altering a divine decision once taken. Aware of this, Inana sets up a wail over the fact that she indeed cannot bring back her lover Urnamma. ${ }^{287}$

Just as the representation of Inana's husband Dumuzi by a king in the "sacred marriage" ceremony seems to have become common practice from Ur III times onward, ${ }^{288}$ it is likely that the presentation of Urnamma's death was mediated by the Dumuzi-Inana myths, rather than Urnamma's premature death and its consequences giving rise to the myths mentioned above. The cult song of Damu (=TCL $158 / /$ ) ends with a list of Ur III and Isin kings headed by Urnamma and shows that these rulers were considered as representatives of Damu/Dumuzi.

Urnamma A can also be compared with the city laments. Due to its theme of calamity that has befallen Ur and its inhabitants at the loss of their king, Urnamma A shows the same "generic set of symbols" employed by the creators of the city laments to describe the devastating consequences that can befall a city from military attack and destruction. Urnamma A thus shares similar themes in similar language, if not always similar form, with the city laments and to some degree also with the $\mathrm{b}$ a $\mathrm{l}$ a g / e r š e m a genre, which in turn is similar in content to the city laments. ${ }^{289}$ The city laments are the most explicit geographically and historically, and name the enemy at whose attack the city collapses, ${ }^{290}$ whereas in the b a $\mathrm{l}$ a $\mathrm{g} /$ e r š e m a songs it is most frequently just "the enemy", or Enlil's storm, and in turn his pronouncement (e $\mathrm{n} \mathrm{i} \mathrm{m}$ ) which is the destructive force. In Urnamma A the enemy's name is not mentioned and appears as the evil (h $\mathrm{u} 1-\mathrm{g}$ a $1_{2}$ ) that overcomes Ur, its king, and inhabitants; less likely, the enemy may have been named in the broken section at the very beginning of the composition. ${ }^{291}$

Common themes apparent in the laments and in Urnamma A include the initial description of devastation (lines 1-7) and the finality of the gods' decision (lines 8 9, 52-55, and lines 208-209), as well as various descriptions that centre around destruction, that is Urnamma's premature death in the case of Urnamma A, and the cities' destruction with regard to the city laments, and its consequences: disruption of husbandry and agriculture, cessation of urban happiness, wrecking, etc. Other themes are the laments over their own fates by deities in the city laments, and in the $\mathrm{b}$ a $1 \mathrm{a} \mathrm{g} / \mathrm{e} \mathrm{r}$ š e $\mathrm{m}$ a songs over their destroyed homes, ${ }^{292}$ and by Urnamma in Urnamma A over his condition and that of his family. These laments can be seen as

\footnotetext{
287 In summary Wilcke, "Politik und Literatur" $35 f$.

288 Cf. Cooper, Sacred Marriage and Popular Cult 84ff.; 91.

289 Black, Studies Civil (1991) 30f., and fn. 60; Tinney, Nippur Lament $47 \mathrm{ff}$.

290 Black, ibid. 30 , fn. 59.

291 Cf. also I 1., p. 7, and fn. 63, and the commentary ad 6-7 in V 1.4, p. 164.

292 E.g. Inana in M. Cohen, Eršemma 66ff. (no. 32), 70f. (no. 106), Ningal in the Ur Lament, Nanna-Su'en in the Lament over Sumer and Ur.
} 
an attempt at intervention and entreaty, sometimes on behalf of somebody else, before Enlil and An to stop the calamity. In the city laments they lead to the restoration of the city and the decreeing of a good fate for it or its king. In Urnamma A this theme is coupled with the above mentioned mythological narrative of Inana's attempted rescue of her lover in the netherworld. Here the lament results in Urnamma's posthumuous fame.

The imagery that is used in the city laments to describe the destruction of a specific city and the resulting consequences for its people and their land is used in Urnamma A to describe the "destruction" of Urnamma, i.e. his premature death, and the fate of his widow. Actions and reactions of all the participants and victims are described in similar language and metaphors: the gods' retreat in the face of calamity, Urnamma's futile attempt at pleasing the gods with lavish sacrifices trying to change An and Enlil's pronouncement echoing both that of Narämsu'en in Curse of Agade, and Ningal's attempt in the Ur Lament to change the gods' minds. Animal imagery is used in the description of the destroyed cities ${ }^{293}$ and for Urnamma in lines 170-173, the description of his widow at the absence of her dead husband (lines 183-185), and perhaps in reference to Ningal in Ur Lament 320. The following twelve paragraphs list these various themes in more detail to show the close relationship in tone, and sometimes also form, between Unnamma A and the city laments. They are additions to the themes conveniently listed by J.S. Cooper in Curse of Agade 20ff.:

I. The initial portrait of destruction (lines 1-9) includes Urnamma's departure in lines 6-7: $\left\ulcorner\mathrm{uri}{ }_{5} \mathrm{ki}\right\urcorner-\mathrm{m}$ a $\mathrm{hu} \mathrm{l}-\mathrm{g}$ a $1_{2}$ i m-š $-\mathrm{DU} \quad \mathrm{si} \mathrm{pa} \quad \mathrm{zi} \quad \mathrm{b}$ a $\mathrm{ra}-\mathrm{ab}-\mathrm{e}_{3} \quad \mathrm{I}[\mathrm{si}] \mathrm{pa} \quad \mathrm{zi}^{\urcorner} \quad \mathrm{ur}-\mathrm{d}^{\Gamma} \mathrm{namma} \quad \mathrm{ba} \mathrm{a}^{\urcorner}-\mathrm{ra}-\mathrm{ab}-\mathrm{e}_{3}$ $\mathrm{sipa} \mathrm{zi} \quad \mathrm{ba}-\mathrm{ra}-\mathrm{ab}-\mathrm{e}_{3}$ "Evil came upon Ur and made the faithful shepherd leave it! It made the faithful shepherd Urnamma leave it, it made the faithful [shep]herd leave it!" (similarly line 18). Compare e.g. Nippur Lament 77 $\mathrm{me}$ g a 1 š $\mathrm{a}_{3}-\mathrm{bi} \quad \mathrm{b} a-\mathrm{ra}-\mathrm{an}-\mathrm{e}_{3}-\mathrm{a}-\mathrm{a} \breve{\mathrm{s}}(\ldots)$ "Because he (= its lord) made the great $\mathrm{me}$ depart from its (= the Ekur's) midst (...)"; $111 \mathrm{u}_{3}-\mathrm{m} \mathrm{u}$ u n-bi me-bi ba-ra-an-e ${ }_{3}$ - a "Its lord who made its me depart"; 114 me gal-gal-1a-ni a-gin 7 ba-ra-an-e ${ }_{3}-\mathrm{a}$ "He who made his great $\mathrm{m}$ e depart thus!", ${ }^{294}$ and the abandonment of the city-gods in the city laments. ${ }^{295}$ Urnamma's departure is final, the king cannot return back to his city (lines 164-165). The same case applies to Ibbīsu'en in Sumer and Ur Lament 37.

II. Other deities withdraw their support: in Urnamma A the gods retreat in sorrow (lines 10-16).

Themes of destruction and calamity appear in Urnamma A in three blocks: a.) following Urnamma's departure from Ur and the retreat of the gods (lines 19-30), b.) describing Urnamma's dying and eventual death (lines 31-61), and c.)

293 Cf. Cooper, Curse of Agade 23

294 Var. $\mathrm{N}_{4}:$ b a - $\mathrm{r}$ a - a n - d a 1 "he made fly off". Cf. also the commentary ad Urnamma A 6-7 in V 1.4, p. 164.

295 E.g. Curse of Agade 60ff. and Sumer and Ur Lament 373-376. 
Urnamma's lament over his and his family's pitiable condition (lines 155-196, possibly 215). They include the following topoi:

III. The topos of sleeplessness in the face of calamity: Urnamma A $20 \mathrm{n} \mathrm{a} \mathrm{m} \mathrm{-}$ $1 \mathrm{u}_{2}-\mathrm{u} 1 \mathrm{u}_{3} \quad \mathrm{li}-\mathrm{bi} \quad \mathrm{ib}_{2}-\mathrm{ti}-\mathrm{la}-\mathrm{a}_{3} \mathrm{u}_{3} \quad \mathrm{du}_{10} \quad \mathrm{nu}-\mathrm{mu}-\mathrm{u} n-$ $\mathrm{k} \mathrm{u}-\mathrm{k} \mathrm{u}$ "With their bliss(fulness) having come to an end, the people do not sleep soundly" recalls Uruk Lament 3. 23-24 $\mathrm{a}_{2}-\mathrm{g}_{\mathrm{i}_{6}}-\mathrm{b}$ a $\quad \mathrm{n} \mathrm{i}_{2} \quad \mathrm{i}_{2} \mathrm{~m} \mathrm{u}$ -

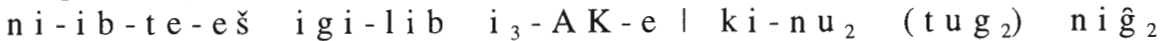
$\mathrm{b}$ a r a $\mathrm{a}_{3}-\mathrm{bi} \quad \mathrm{u}_{3} \quad \mathrm{du}_{10} \quad \mathrm{li}-\mathrm{bi}\left({ }_{2}\right)(-\mathrm{i} \mathrm{n})-\mathrm{k} \mathrm{u}-\mathrm{k} \mathrm{u}-\mathrm{n}$ e "In the middle of the night they become terrified and tearful, and suffer insomnia, in? their resting places strewn with bedding they cannot sleep soundly".

IV. Disruption of agriculture and husbandry ${ }^{296}$ is described in Urnamma A 22 30: lack of control over the spring floods (lines 22-23) results in crop failure (line 24), the removal of embankments and ditches (lines 25-26?) results in flooding (line 27), and

V. The alteration of landscape:297 Urnamma A 28 e di n-e di n - e $u_{2}$ $\mathrm{s}\left[\mathrm{a}_{6}\right.$ ? - g a $] \mathrm{nu}-\mathrm{mu}-\mathrm{u}[\mathrm{n}-\mathrm{m}] \mathrm{u}_{2} \mathrm{u}_{2} \quad \mathrm{a}-\mathrm{n} \mathrm{ir} \quad \mathrm{b} \mathrm{a}-\mathrm{a} \mathrm{n}-\mathrm{m} \mathrm{u}_{2}$ "On the steppes no f[ine? grass] grew any more, mourning grass grew there" recalls Curse

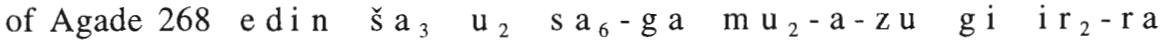
$\mathrm{h}_{2}-\mathrm{em}-\mathrm{mu}_{2}$ "On your interior steppes, where fine grass grew may lamentation reeds grow!" (similarly Sumer and Ur Lament 11). The verb $\mathrm{u}_{2}-\mathrm{g} \mathrm{u}$ $\mathrm{de}_{2}$ "to disappear", attested in Urnamma A 27, presupposes in general the removal or abandonment of preceding or succeeding objects, ${ }^{298}$ as in Ur Lament 231ff. and Curse of Agade 144-148. Compare Urnamma A 27 u m u š [ ( . . ) ] $\left.\mathrm{k} \mathrm{al} \mathrm{a} \mathrm{m-m} \mathrm{a}\left\ulcorner\mathrm{u}_{2}\right\urcorner-[\mathrm{g}] \mathrm{u} \quad \mathrm{im}-\mathrm{ma}-\mathrm{an}-{ }^{-} \mathrm{de}_{2} ?\right\urcorner \quad \mathrm{u}_{2} \quad \mathrm{nir}-\mathrm{g}$ al $l_{2}$ $\mathrm{b}$ a - s u d "The senses [(and...)] of the land disappeared, splendid food has been withdrawn"299 with Ur Lament $231 \mathrm{di} \mathrm{m}{ }_{2}-\mathrm{m}$ a $\mathrm{kalam}-\mathrm{m}$ a $\mathrm{u}_{2}-\mathrm{g} \mathrm{u}$ $\mathrm{i} \mathrm{m}-\mathrm{m} \mathrm{a}-\mathrm{an}-\mathrm{de}_{2} \quad \mathrm{u} \mathrm{g}_{3}-\mathrm{e} \quad \check{\mathrm{s}} \mathrm{e} \quad \mathrm{am}_{3}-\check{\mathrm{s}}_{\mathrm{a}_{4}}$ "The good sense of the land disappeared, the people moan".

VI. The state of the dying Urnamma is described in language reminiscent of the wrecking, profanation and pillaging of the city and its temples in the city laments. ${ }^{300}$ Indeed, Urnamma's "destruction" stands for the ruining of the land: line

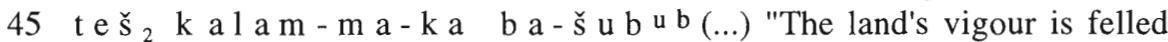
(...)", line 46 (Susa) (..) a - $\mathrm{ra}_{2}\ulcorner\mathrm{ka} \mathrm{la} \mathrm{m-ma}\urcorner$ b a-e - s u h ${ }_{3}$ "(..) the state of the land is confused", 46a (Susa) (...) a $-\left\ulcorner\mathrm{ra}_{2} \quad \mathrm{k} \mathrm{a} 1 \mathrm{a} \mathrm{m}\right\urcorner-\mathrm{m} \mathrm{a} \quad \mathrm{b}$ a $\mathrm{e}-\mathrm{k} \mathrm{u} \mathrm{r}_{2}$ "(...) the state of the land is altered". Just as the temples are laid open by the removal of the gates and their appearance alters ${ }^{301}$ so Urnamma's appearance changes when he is felled like a tree (Urnamma A 45-46a). In line $45 \mathrm{t}$ e š 2 $\mathrm{k}$ a $1 \mathrm{a} \mathrm{m}-\mathrm{m}$ a "the land's vigour" is a well known Ur III royal epithet. The

296 Cf. Cooper, Curse of Agade 24f.

297 Cf. also Sulgi D 222-227.

298 Cf. Urnamma A 25 k a r "to take away", and perhaps line 26 k i t a g "to put on the ground".

299 For the reading s u d and translation "has been withdrawn", cf. the commentary ad 27 in V 1.4, p. 165.

300 Cf. Cooper, Curse of Agade 23f.

301 Curse of Agade 122; Eridu Lament 2. 17-18. 
distortion ( $\mathrm{k} \mathrm{u} \mathrm{r}_{2}, \check{\mathrm{s}} \mathrm{u}$ b a l a $\mathrm{A} \mathrm{K}, \mathrm{s} \mathrm{u} \mathrm{h}_{3}$ ) of a peoples', a city's or territory's ( $\mathrm{m} \mathrm{a}-\mathrm{d}$ a) healthy status quo, i.e. the people's good sense, their (intellectual) ability in conducting successful affairs ( $\mathrm{d}$ i m $\mathrm{m}_{2}-\mathrm{m} \mathrm{a}, \mathrm{u} \mathrm{m} \mathrm{u} \mathrm{š),} \mathrm{is} \mathrm{a} \mathrm{common}$ literary topos. ${ }^{302}$ We find it also in the royal correspondence of Ur III kings. ${ }^{303}$

It is the people who are distorted in Urnamma A 55-57 ( $\mathrm{k} \mathrm{u} \mathrm{r}_{2}$ and b a 1 a) after Urnamma's futile attempt at changing his fortune. His fate, however, is already decided: Urnamma's sacrifices to the gods are rejected, An and Enlil's word stands (lines 54-55). This might be an allusion to the passage in Curse of Agade where Narāmsu'en performs extispicy and looks for a favourable sign. The same tradition is preserved in two fragmentary texts about Amarsu'en (Amarsu'en A and B) ${ }^{304}$ But Enlil's words cannot be altered (Curse of Agade 94-101), and just as it is futile to attempt this by oracle, so too it is in Urnamma A by lavish offerings for the gods. The topos of trying to change the pronouncements of An and Enlil can also be found in Ur Lament 145ff. where Ningal twice asks An and Enlil to change their minds and not destroy Ur.

The third distortion takes place, now of the land, in line 72 where Urnamma crosses over the ... of the land and starts his journey to the netherworld.

VII. The passage in Urnamma A 49-50 is partially broken and rather obscure, but perhaps the underlying image of a sand storm that covers everything may be compared with the storm that envelops the land like a (linen) garment and linen in Ur Lament 203-204 and Eridu Lament 1. 5-6 and "the storm" in b a l a g songs.

VIII. Urnamma's abandonment and final death is described in the common image of people likened to broken pots. ${ }^{305}$

IX. Images of mourning: musical entertainment ceases, ${ }^{306}$ wails are intoned instead: Urnamma $\mathrm{A}_{187} \mathrm{t} \mathrm{i} \mathrm{g} \mathrm{i}_{2} \quad \mathrm{a}-{ }^{-\mathrm{da}\urcorner-\mathrm{ab}} \quad \mathrm{gi}-\mathrm{S} \mathrm{U}_{3} \quad \mathrm{za}-\mathrm{a} \mathrm{m}-\mathrm{za}-$ $\mathrm{am}-\hat{g ~ u}_{10} / \mathrm{rir}_{2}{ }^{\urcorner}-\mathrm{ra} \mathrm{mu}-\mathrm{da}-\mathrm{an}-\mathrm{ku}_{4}$ "My $\mathrm{tigi-}$ and $\mathrm{adab}-$ instruments, my ... flutes and my $\mathrm{z}$ a $\mathrm{m} \mathrm{z}$ a m-instruments were turned into tears because of me" recalls Ur Lament 359-360 e $\mathrm{n}_{3}-\mathrm{du}-\mathrm{z} u$ i $\mathrm{r}_{2}-\mathrm{r}$ a (/ r e)

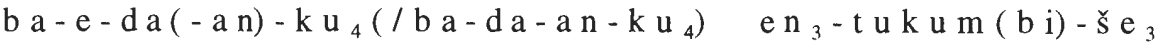
$\mathrm{SAR}(/-\mathrm{e}) / \mathrm{t}$ i g i $\mathrm{i}_{2}-\mathrm{z} \mathrm{u}$ a - n i r - r a b a - e - da $(-\mathrm{a} n)-\mathrm{ku}{ }_{4}(/ \mathrm{ba}-\mathrm{da}-$ $\mathrm{a} \mathrm{n}-\mathrm{ku}_{4}$ ) e $\mathrm{n}_{3}-\mathrm{tukum}(\mathrm{bi})-\mathrm{s}^{\mathrm{e}} \mathrm{H}_{3} \mathrm{~S} \mathrm{AR}(/$ - e) "Your songs are turned into wails, how long ... ? Your $\mathrm{t}$ i g $\mathrm{i}$-instruments are turned into lamentations, how long . . .?".

X. Unnamma A 189-190 ĝ e šg u-za hy i-li-b i n u-m u-ti $1-$

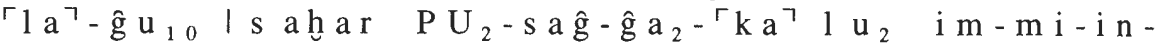
$\mathrm{t}$ u š ? - $\left[\mathrm{u}_{3}\right.$ ?] $-\left\ulcorner_{\mathrm{x}}\right\urcorner$ "That (/ because), instead of my throne, whose luxuriance I had not exhausted, they make me squat in the dust of a pit!"307 is comparable to Sumer and Ur Lament 410 g e š g u - z a - b i i g i - b i - t a b a ( - e ) - š u 2

\footnotetext{
302 E.g. also Nippur Lament 47-48; 103-104; Uruk Lament 1. 22; Curse of Agade 147-148.

303 Šarrumbāni to Šũ su'en 23 and 26. Cf. Michalowski, Correspondence 233 ad 23 with previous literature. 304 Cooper, Curse of Agade $27 \mathrm{f}$.

305 Cf. Michalowski, Lamentation 100f. ad 406.

306 Urnamma A 187-188; Ur Lament 356; Nippur Lament 83; cf. also Enki and the World Order 447-448.

307 Similarly Gudea, Stat. B 9:10-11 in the curse passage, cf. the commentary ad 189-190 in V 1.4, p. 179.
} 
$\mathrm{s}$ a h $\mathrm{ar}-\mathrm{ra}(/-\mathrm{t} a) \quad \mathrm{b} a(-\mathrm{e})-\mathrm{da}-(\mathrm{a} n)-\mathrm{t} u \breve{s}$ "In their (= the enemy's) presence its (= Ekišnugal's) throne is/was covered, she (= Niniagara) squatted (instead) in the dust". ${ }^{308}$ Urnamma in the netherworld obviously shares a fate similar to that of a deity whose city is doomed to destruction. In city laments the deities (have to) leave their temple and city and retreat to the steppe. We find the same theme in some mythological narratives of various b a l a $\mathrm{g}$ hymns. An e r š e m a song, ${ }^{309}$ for example, tells of Ninisina's sojourn in Arali (the netherworld). This can be compared with Urnamma leaving his city and setting up his dwelling in Arali. ${ }^{310}$

XI. The city laments exhibit a positive turn at the end: after destruction follows restoration and the return of the gods. Some city laments elaborate on royal accomplishments in the city's reconstruction. A possible allusion to this may be found at the end of Urnamma A where the king's memorable accomplishments are described. Whereas the kings in the city laments will be known for their rebuilding the city and its holy precinct in order to regain and maintain divine favour, Urnamma will be always known by his legacy.

XII. In the closing section of the Uruk Lament, Inana takes an intercessory role before the gods for Išmedagān and Uruk, to persuade them to decree a good fate for him and his city. ${ }^{311}$ In Urnamma A Inana is aware that An and Enlil's decision cannot be altered. But it is her lament over her dead lover that perhaps prompts Ningešzida - if the reconstruction in line 217 is correct, and he is still the subject of line 221 - to proclaim Urnamma's posthumous fame.

Urnamma A, Curse of Agade, and the city laments all draw on a common stock of topoi and motifs. The earliest of the compositions are Urnamma A and Curse of Agade, dating to Ur III, ${ }^{312}$ but they can hardly have originated this repertoire of topoi and motifs, which seems at home in a context of ritual lament. Although none of the liturgical laments, such as the $\mathrm{b}$ a $1 \mathrm{a} \hat{\mathrm{g}}$ and e $\mathrm{r} \breve{\mathrm{s}}$ e $\mathrm{m}$ a songs, is attested earlier than the Old Babylonian period, the Ur III composition Curse of Agade 196-208 and Ur III administrative texts refer to ceremonies using ritual laments, ${ }^{313}$ and professional lamentation performers are known as early as the Early Dynastic period. ${ }^{314}$ Thus, the presence of a stock of lamentation topoi and motifs in Urnamma $\mathrm{A}$ is a strong if indirect argument for the existence of ritual laments in the Ur III and earlier periods.

$308 \mathrm{Cf}$. Michalowski, Lamentation 101 ad 410 who interprets $\mathrm{s}$ a h a $\mathrm{r}-\mathrm{r}$ a $(/ \mathrm{t}$ a) $\mathrm{t} \mathrm{u} \preccurlyeq$ (with ablative infix) as a "willful act of despair", similarly Green, JAOS 104 (1984) 278 ad 1. 21 (some references collected by Attinger, ZA 74 [1984] 44 ad 220). The references mentioned above seem to contrast sitting in the dust rather than on a throne.

309 M. Cohen, Eršmma 96-103 (no. 171).

$310 \mathrm{Cf}$. also the commentary ad Urnamma A 6-7 in V 1.4, p. 164.

311 For the relationship between Iš medagān and Inana manifested in the Uruk Lament and Išmedagān's hymns, cf. Tinney, Nippur Lament 68-70.

312 For Ur III manuscripts of Curse of Agade, cf. Cooper, Curse of Agade 41ff., and Alster, ASJ 15 (1993) 1-3.

313 Cooper, "Genre, Gender and Lamentation" (unpub. paper held at the Third Mesopotamian Literature Group Meeting, Groningen, 1995).

314 PSD B 79, s.v. balaĝ -di B; Attinger, Eléments 451-53. 


\title{
CHAPTER V
}

\author{
EDITIONS OF URNAMMA A-H
}

\section{Introductory Remarks}

The layout of each edited hymn is basically the same, i.e. an introduction, transliteration and translation, followed by a philological commentary. The transliteration and translation of the two recensions of both Urnamma D and EF are followed by synoptic transliterations and translations, and a collective philological commentary to facilitate comparison. In the introduction a short summary of the history of the text publication, where appropriate, is given, followed by an outline of the structure of the composition which is also intended as a guide to the translation. ${ }^{1}$ At the end a short description and list of the sources is presented.

Although methodologically problematical, I have created a composite text for Urnamma A and B for which more than one text source exists for a given line. Because the text sources are so small in number, each eclectic line is immediately followed by a score of individual text sources for that line, rather than listing each line more conventionally in a separate score at the end of the edition. Sign index numbers follow F. Ellermeier, Sumerisches Glossar. The translation is given on facing pages, for Urnamma A and B in blocks of ca. five to seven lines below the transliteration on the same page.

The commentary is kept as brief as possible and concentrates more on philological than interpretative matters. These are mainly discussed within the framework of the other chapters. Material presented in the commentaries of previous editions is in general not repeated.

Note that $[\ldots]$ signifies a break in the text, . . indicates that the word(s) is/are untranslatable, or the corresponding signs unreadable. Words in brackets [ ] are restored with a high degree of certainty, unless they are followed by a question mark. A translation which is only very tentative appears in cursive script. 


\section{URNAMMA A $=U$ R NAMA'S DEATH}

\subsection{Introduction}

\section{Previous studies $^{2}$}

S. Langdon published a first edition of the composition based on a part of source A (CBS 4560) in PBS 10/2 (1917) 127-36. A subsequent edition using photos and collations by S.N. Kramer of CBS 4560 was attempted by G. Castellino in ZA 52 (1957) 1-57 with an appendix in ZA 53 (1959) 131f. In JCS 21 (1967) 104-22 S.N. Kramer presented a new edition incorporating newly identified fragments from Jena of source A and the Istanbul source B. C.Wilcke published his joins of the Jena fragments to source $\mathrm{A}$ and source $\mathrm{E}$ with photos and new copies in CRRAI 17 (1970) 81-92. In his unpublished Habilitationsschrift Urnammus Tod, Tod und Bestattung eines Königs in neusumerischer Zeit (1972) he was able to use new photos of source A, unpublished collations by D.O. Edzard of sources B and F, and unpublished transliterations by $\mathrm{M}$. Civil of sources $\mathrm{C}$ and $\mathrm{D}$. The copies of the Jena fragments of sources A and $\mathrm{E}$ were subsequently published in Kollationen (1976) 66-69. The latest revised edition to date is by S.N. Kramer in Studies Mikasa (1991) 193-214. He consulted M. Civil's unpublished manuscript which includes the unpublished small Nippur fragments and the Susa duplicates.

\section{Structural Analysis}

The composition ${ }^{3}$ begins with a long narrative section (lines 1-155) describing the evil that befalls the city of Ur and its inhabitants and the events that lead to Urnamma's death, his death and the journey to the Netherworld, and Urnamma's installation there. Then follow passages in direct speech in response to the events of lines 1-155: Urnamma speaks in lines 156-196 (possibly 156-215), Enlil in 201-203, Inana in 2074-215 and Ningešzida (?) in 222-233. At the end the composition has a doxology (lines 234-240) with the usual $\mathrm{z} \mathrm{a}_{3}-\mathrm{m} \mathrm{i}_{2}$ ending. The two last lines presumably sum up the overall lamenting tenor of the composition

2 Cf. also II 2 , p. $18 \mathrm{f}$.

3 For a general assessment of Urnamma A within the corpus of Sumerian literary compositions, cf. II 1., p. 16f.

4 Or 204, cf. below, 1.2 , p. 137 , fn. 145 . 
which includes the long wails of Urnamma, his wife, and also of Inana as Urnamma's divine lover. ${ }^{5}$

The last section (3.3) of the preceding chapter IV discusses the relationship of Urnamma A with lamentation literature and shows that this composition uses both the form and the language of laments and the Curse of Agade which describe the destruction of cities, and applies them to the death of a monarch. Some of these passages are unusually rich in similes that mostly occur in groups of four lines $(45-48 ; 170-173 ; 182-185 ; 214-215)$. They use animal imagery for the description of Urnamma's state (170-173) and that of his lamenting widow (183-185). The dying Urnamma is likened to a mountain (mine) that is cut away and to different kinds of trees that are felled (45-48). His widow is a boat that gusty winds have torn from the mooring pole and set adrift (182). In Inana's lament over her dead lover, Urnamma is likened to herbs in the steppe and to a river boat holding firm in its calm harbour (214-215).

The passage describing the sacrificial offerings to the netherworld deities follows a rigorous, repetitious pattern: object - receiver $(\mathrm{DN}+$ epithet $)-\mathrm{s}$ i p a $\mathrm{u} \mathrm{r}-$

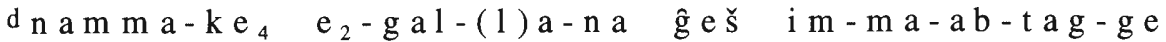
"Shepherd Urnamma offers as a sacrifice in her/his palace". In Urnamma A cases of absence of postpositions, a well known phenomenon in Old Babylonian Sumerian literary texts, are probably due to rhythmical reasons. Note especially the pattern $\mathrm{lug}$ a $\mathrm{l}+$ postposition $\mathrm{II} \mathrm{u} \mathrm{r-d} \mathrm{namm}$ a in lines 70-71 (broken), 74-75 (broken) 81-82, 85-86, 132-133 (broken), and 146-147. One way of indicating a strophic arrangement of lines is by abbreviating repeated lines with ornamental repetition. ${ }^{6}$ Such examples are Urnamma A 70-71, of which line 71 writes only the

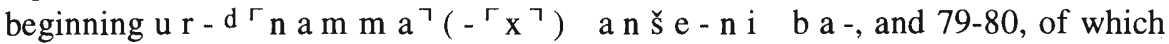
line 80 likewise writes only the beginning ur-d namma ge $n-n a-n i$. Earliest hymnic example of this technique is Gudea A (STVC 36).

Urnamma A starts off with a description of evil that has come upon Ur and from which Urnamma cannot escape (1-9). In the face of such calamity the gods are helpless, the inhabitants of Ur mourn, and successful husbandry comes to an end. (10-30). The dying king is returned to the capital and vanishes to the realm of the dead (31-63). He is buried, journeys to Arali, the abode of the dead, arrives at the gates of the netherworld, and gets a tumultuous welcome which is followed by a banquet (64-83). He presents customary animal sacrifices to the gods of the netherworld and presents gifts to each one of them (84-131). The gods set up a dwelling place for Urnamma and make him a judge (132-144). But Urnamma starts craving for past activities he enjoyed and intones a lament (145-154). He utters a bitter invective against the gods and shows his sorrow over the lamentable state of his widow and his own pitiable situation (155-196). Inana is absent at Urnamma's judgment and is ordered before Enlil in Ekur only to be informed that Urnamma has left her temple Eana for good. Inana is angry and mourns Urnamma (197-216). The

\footnotetext{
5 For similar endings, cf. TMH NF 47 (= J. Westenholz, Studies Sjöberg 552) iii 105 (before the subscript b a 1 b a 1 e); Two Elegies 178 .

6 Cf. Wilcke, AS 20 (1975) 233.
} 
end of the composition is marked by a peripety in which Ningešzida (?) decrees Urnamma's fate (217-233) and a doxology in which Ninĝešzida is praised (234240).

In summary the composition can be divided into the following sequences:

I. The setting (1-30)

1. Initial portrait of destruction: evil comes upon Ur, Urnamma's fate changed deceitfully (1-9)

2. Impact on the gods, the people and the land (10-30)

a. Passive retreat of the gods Ninmah, Enki-Nudimmud, Nanna, Utu and

Ninsumun, Urnamma's divine mother (10-16)

b. The people mourn in the streets and cannot sleep well (17-21)

c. Devastating impact on agriculture (crops and animals) (22-30)

II. Urnamma's return to Ur, his untimely death, its impact and his vanishing to the realm of the dead (31-63)

1. The dying Urnamma returns to his palace in $\mathrm{Ur}(31-42)$

2. Urnamma lies dying, the state of the land is altered (tree similes) (43-48)

3. Urnamma's death $(49-51)^{7}$

4. Its impact: the gods turn away, the people become irrational (52-57)

5. Urnamma vanishes to the realm of the dead $(58-63)^{8}$

III. The burial scene (64-71)

1. Urnamma is likened to a boat in a storm (64-69)

2. The burial scene (70-71)

IV. Urnamma's journey to Arali and his arrival (72-83)

1. The hazardous journey on a chariot (72-75)

2. Arrival at the gates of the netherworld, tumultuous welcome with following banquet (76-83)

$\mathrm{V}$. The offerings to the gods in the netherworld (84-131)

1. Animal sacrifices to the gods (84-87) (cf. below V. 3)

2. Individual offerings associated with that particular deity (88-128)
a. Nergal (88-91)
b. Gilgameš (92-96)
c. Ereškigal (97-101)
d. Dumuzi (102-105)
e. Namtar (106-109)
f. Hušbisag (110-113)

\footnotetext{
7 Wilcke, UT 54 assumes direct speech of Urnamma's wife in lines 51-69.

8 Lines 60-61 seem to be spoken by Urnamma's wife.

$9 \mathrm{Cf}$. the commentary ad $64-75$, p. 170 . That this passage describes Urnamma's hazardous journey by boat cannot be excluded.
} 
g. Ningešzida (114-119)

h. Dimpi(me)kug (120-122) ${ }^{10}$

i. Ninazimua (123-128)

3. Summary of sacrifices to the above mentioned gods (?) (129-131) (cf. above V. 1)

VI. Establishment of a dwelling place and induction as a judge (132-144)

1. Enthronement on the dais of the netherworld (132-137)

2. Induction as a judge (138-144)

VII. Urnamma's craving for past activities that leads to his lament (145-154)

1. Sumer's mourning makes Urnamma think of past, unfinished activities (145147)

a. Public activities (148-149)

b. Family activities (150-153)

2. Summary line of the preceding description leading to his lament (154)

VIII. Urnamma's lament concerning himself $(155-196 \text {, possibly }-215)^{11}$

1. Invective against the gods (156-163)

2. No return (164-165)

3. The sorrow and lamentable state of his widow (166-194)

a. Sorrow over Urnamma's failing strength and resulting death (?) (animal similes) (166-175)

b. His widow's abandonment by her protective spirits and gods (176-181)

c. Her resulting defencelessness (boat and animal similes) (182-186)

4. Laments over Urnamma's pitiable state in front of his family (187-194)

a. Instead of merry music making, chanting of laments (187-188)

b. Instead of royal comfort, miserable existence in the netherworld (189192)

c. Summary lines: Urnamma's lament (156-192) is chanted by people in front of his family (193-194)

5. Transition lines to the next narrative sequence: Inana's absence at Urnamma's judgment (195-196)

IX. Inana's reaction to the fate of Urnamma (197-216) ${ }^{12}$

1. By order of Enlil Inana appears before Enlil in the Ekur (197-200)

2. Enlil tells Inana that Urnamma has left her temple Eana for good (201-203)

3. Inana becomes angry (204-206)

4. Inana's invective and lament over her lover Urnamma (207-215)

a. The divine pronouncements have been changed, the rules of the land not maintained (207-212)

\footnotetext{
10 In source D Dimpi(me)kug is inserted between Dumuzi and Namtar, cf. also the commentary ad 122, p. 175.

$11 \mathrm{Cf}$. also the commentary ad 155 , p. 176.

12 Lines 197-215 possibly narrated by Urnamma himself.
} 
b. Lament over her lover Urnamma (similes) (213-216)

X. The Peripety: Ningešzida's (?) decreeing of Urnamma's fate (217-233)

1. Introductory lines (217-221)

2. Ninĝešzida (?) ${ }^{13}$ decrees Urnamma's fate (222-233)

a. His name and royal function acclaimed (222-224) ${ }^{14}$

b. His agricultural achievements acclaimed (225-230)

c. Summary lines: his name invoked, the evil u d u g-spirit driven away (231-333)

XI. Doxology: praise of Ninĝešzida (234-240)

XII. Ending lines: laments over Urnamma (241-242)

\section{Manuscripts}

1. "Single-tablet edition" ('Gesamttafeln') ${ }^{15}$ :

Source A: $\quad$ six-column tablet.

Source C: $\quad$ fragment of lower left edge of tablet, originally containing possibly six columns, as well.

2. "Tablets from multi-tablet editions" ('Teiltafeln'):

Source B: $\quad$ one-column tablet with the first 52 lines of the composition.

Source E: one-column tablet with probably a little missing at the beginning of the obverse and the end of the reverse.

Source D: $\quad$ fragment of probably one-column tablet (source E?).

Source F: $\quad$ small fragment of a tablet (one-column or multi-column).

Source G: $\quad$ lower left edge of tablet containing end of the composition.

Sources $\mathrm{Sb}_{1}-\mathrm{Sb}_{3}$ : three one-column tablets containing presumably the whole composition. ${ }^{16}$

Sources D (especially lines 106ff. and 120-122), C and F (especially lines 212-213) show partially divergent variants and we have therefore at least two Nippur recensions of the composition, one represented by source A, the other by sources C?, D and $\mathrm{F}$. A third, different, and strikingly shorter version is represented by the Susa tablets. ${ }^{17}$

\footnotetext{
$13 \mathrm{Cf}$. the commentary ad 221 , p. 181.

$14 \mathrm{Cf}$. also the commentary ad 222, p. 181.

15 Cf. Edzard, ZA 80 (1991) 168, and fn. 11a. for the terms 'Gesamttafeln' and 'Teiltafeln'.

$16 \mathrm{Cf}$. also 1.3 , p. $143 \mathrm{f}$.

$17 \mathrm{Cf}$. in more detail, ibid., pp. 143ff. (especially pp. 143, 150 and 152f.).
} 
The following transliteration is based on personal collations of sources A (CBS $4560+N$ 7095) C, D and G conducted at the University Museum with kind permission of A.W. Sjöberg. M. Civil, who has the publication rights to the Susa tablets, kindly agreed to let me incorporate them in this edition. The Susa tablets $\mathrm{Sb}_{1}-\mathrm{Sb}_{3}$ have been personally collated at the Louvre with the kind permission of $\mathrm{B}$. André-Salvini. The transliteration of each Susa line appears below the score of individual text sources from Nippur although the Susa line sequence sometimes considerably differs from the Nippur line sequence. Therefore a separate transliteration and translation of the Susa version is added after the Urnamma A text and before the collective philological commentary. C. Wilcke generously made his unpublished Habilitationsschrift available to me, as did S. Tinney his unpublished University Museum manuscript with contributions by C. Wilcke, M. Civil and A. Cavigneaux.

\section{Sources}

See in general C. Wilcke, Kollationen 65 . The sigla are those used in S. Tinney's unpub. University Museum manuscript (3/15/92).

Nippur:

A CBS $4560+$ HS $1428+$ HS $1560+$ HS $1450+$ HS $1549+$ HS $1570+$ HS $1581+$ HS $1528+$ HS $1548+$ N 7095

$$
\begin{aligned}
& \text { i } 1-40=\mathbf{1 - 4 0} \\
& \text { ii } 1-44=\mathbf{4 1 - 8 4} \\
& \text { iii } 1-43=\mathbf{8 5 - 1 2 7} \\
& \text { iv } 1-40=\mathbf{1 2 8 - 1 6 7} \\
& \text { v } 1-36=\mathbf{1 6 8 - 2 0 3} \\
& \text { vi } 1-39=\mathbf{2 0 4 - 2 4 2}
\end{aligned}
$$

copy of CBS 4560: S. Langdon, PBS 10/2 (1917) 6.

copies of HS 1428 +: C. Wilcke, CRRAI 17 (1970) 83 and 85 (pls. 2 and 4) and idem, Kollationen 66f.; copies of the individual fragments in I. Bernhardt, S.N. Kramer, TMH NF 4 (1967) 28; 30; 32-35 = 82; 65; all HS fragments, except HS 1528 and HS 1548, also in S.N. Kramer, JCS 21 (1967) 107-09.

copy (1:1) of N 7095: E. Flückiger-Hawker, cf. pl. 1.

photo of CBS 4560: G. Castellino, ZA 52 (1957) after p. 16; obv. and rev. mistakenly exchanged.

photos of HS $1428+$ : C. Wilcke, CRRAI 17 (1970) pls. 1 and 3.

collation of CBS 4560: E. Chiera, AJSL 36 (1919/20) 233 and 236-38; S.N. Kramer apud G. Castellino, ZA 52 (1957) 15-17; E. FlückigerHawker.

collation of N 7095: E. Flückiger-Hawker. 
B Ni. 4487

obv. $1-24=\mathbf{1 - 2 4}$

rev. $1-28=25-52$

copy: M. Çiğ, H. Kizilyay, ISET 1 (1969/71) pp. 76f. and in S.N. Kramer, JCS 21 (1967) 105f.

unpub. collation: D.O. Edzard; marked by preceding *.

C N 3135

obv, $1^{\prime}-7^{\prime}=\mathbf{3 1 - 3 7}$

rev. $1^{\prime}-7^{\prime}=\mathbf{2 1 2 - 2 1 9}$ ?

copy (1:1): E. Flückiger-Hawker, cf. pl. 1.

transliteration: M. Civil in letter (11-20-69) to C. Wilcke, cf. C. Wilcke, UT Appendix.

collation: E. Flückiger-Hawker.

D $\quad 3$ N-T $523=$ IM 58534

obv. $1^{\prime}-13^{\prime}=\mathbf{1 0 2 - 1 1 1}$

obv. $5^{\prime}-7^{\prime}=120-122$

rev. $1^{\prime}-14^{\prime}=146-159$

transliteration: M. Civil in letter (11-20-69) to C. Wilcke, cf. C. Wilcke, UT Appendix.

collation: E. Flückiger-Hawker.

E HS $1440+$ HS 1529

obv. $1^{\prime}-29^{\prime}=164-192$

rev. $1-29=193-221$

copies: C. Wilcke, CRRAI 17 (1970) 90 (pl. 5) and idem, Kollationen 68f.; copies of the individual fragments in I. Bernhardt, S.N. Kramer, TMH NF 4 (1967) 29; 31; also in S.N. Kramer, JCS 21 (1967) 110.

F Ni. 9918

obv. $1^{\prime}-9^{\prime}=\mathbf{2 1 0 - 2 2 0}$

copy: S.N. Kramer, ISET 1 (1969/71) p. 186.

unpub. collation: D.O. Edzard; marked by preceding *.

G $\quad$ N 2355

obv. $1^{\prime}-8^{\prime}=222-231$

rev. $1^{\prime}-7^{\prime}=\mathbf{2 3 5 - 2 4 1}$

copy (1:1): E. Flückiger-Hawker, cf. pl. 1.

collation: E. Flückiger-Hawker. 
Susa:

$\mathrm{Sb}_{1} \quad \mathrm{Sb} 12363$

obv. $1^{\prime}-19^{\prime}=1^{\prime}-19^{\prime}=\mathbf{1 2 - 2 9}{ }^{18}$

rev. $1^{\prime}-22^{\prime}=\mathbf{2 0}-\mathbf{- 4} 1^{\prime}=\mathbf{3 5 - 6 1}$

photos made available by B. André-Salvini, cf. pls. 2-4.

collation: E. Flückiger-Hawker.

measurements: $9,3 \times 6,7 \times 3,0 \mathrm{~cm}$.

one-column tablet; upper half broken with about 9 to 10 lines missing; on lower edge perhaps one to two lines missing; probably the same format as $\mathrm{Sb}_{2}$ and $\mathrm{Sb}_{3}$ (about 30 lines on each side).

$\mathrm{Sb}_{2} \quad \mathrm{Sb} 14137+\mathrm{Sb} 14083$

obv. $1-31 / 14^{\prime}=\mathbf{4 2}^{\prime}-\mathbf{7 1 ^ { \prime }}=\mathbf{6 3}$ ?-99

rev. $1-31 / 16^{\prime}=\mathbf{7 2}^{\prime}-102^{\prime}=\mathbf{1 0 0}-\mathbf{1 2 8} \mathbf{a}$

join: A. Cavigneaux.

photos made available by B. André-Salvini, cf. pls. 5-10.

collations: E. Flückiger-Hawker.

measurements: $14,5 \times 6,5 \times 3,0 \mathrm{~cm}$.

one-column tablet with 30 lines on each side; lower and upper edge preserved; the same ductus as $\mathrm{Sb}_{1}$.

$\mathrm{Sb}_{3} \quad \mathrm{Sb} 12358+\mathrm{Sb} 12362$

obv. $1-28=103^{\prime}-130^{\prime}=129-162$

rev, $1^{\prime}-21^{\prime}=131^{\prime}-151^{\prime}=183 ?-213$

colophon rev. 22': ${ }^{\top} \mathrm{im}^{\top} \mathrm{gid}_{2}$-da pir-hu-um ${ }^{\mathrm{u}} \mathrm{u}_{4}$ ? $\mathrm{x} \times \mathrm{x} \times \mathrm{x} \mathrm{x}^{\urcorner}$

join: M. Civil.

photos made available by B. André-Salvini, cf. pls. 11-13.

collations: E. Flückiger-Hawker.

measurements: $11,0 \times 6,7 \times 3,0 \mathrm{~cm}$.

one column tablet with 28 lines; upper edge preserved; on lower edge (obv.), upper edge of rev. about two to three lines missing; the same ductus as $\mathrm{Sb}_{2} \cdot{ }^{19}$ 


\subsection{Transliteration and Translation ${ }^{20}$}

$1 \quad[\ldots]$-ta kalam tešs ${ }_{2}-\mathrm{a}$ mi-ni- $\mathrm{Tib}-\mathrm{x}^{\top}$

A i obv. 1 [...]-ta kalam te $\check{s}_{2}-\mathbf{a}$ mi-ni- ${ }^{\top} \mathbf{i b}-\mathbf{x}^{\urcorner}$

B obv. $1 \quad[\ldots] \quad$ kalam' te $\check{s}_{2}-\mathrm{a}$ i-[... ]

$2 \quad[\ldots]-\mathrm{i}_{3} ?-\mathrm{sag}_{3} \mathrm{e}_{2}$-gal im-si $\mathrm{in}_{3}-\mathrm{si}_{3}$

A i obv. $2 \quad[\ldots]-\mathrm{ri}_{3}{ }^{n 21}-\mathrm{sag}_{3} \mathrm{e}_{2}-$ gal $\mathrm{im}-\mathrm{si}_{3}-\mathrm{si}_{3}$ B obv. $2 \quad[\ldots]^{r} \mathrm{x}^{\urcorner} \quad\left\ulcorner\mathrm{e}_{2}^{\urcorner}\right.$-gal $*$ in- $[\ldots]$

$3 \quad[\ldots s] a \hat{a} ! ?$ gi $i_{6}$ tuš-a-ba $\mathrm{ni}_{2} \quad \mathrm{ul}_{4}-\mathrm{la}^{\mathrm{bi}} \mathrm{bi}_{2}-\mathrm{ib}_{2}$-te

A i obv. 3 [.. $\quad]-[x\urcorner n_{2} \quad u_{4}-$ la ba-an- te

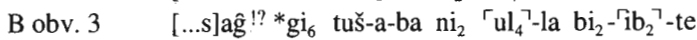

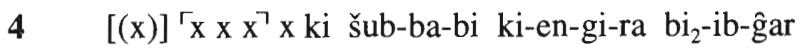

A i obv. 4 [... ]-bi ki-en-gi-ra bi ${ }_{2}$ - ib-ĝar

B obv. $4 \quad[(\mathrm{x})]^{\ulcorner} \times \mathrm{xx}^{\urcorner} \times \mathrm{ki}$ šub-ba-bi ki-en-gi-ra bi ${ }_{2}-\Gamma_{\mathrm{ib}-\hat{\mathrm{g} a r}}{ }^{?\urcorner}$

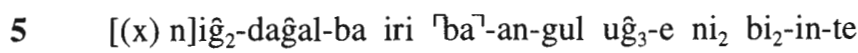

A i obv. $5 \quad[\ldots \quad-g u] l \hat{g}_{3}-\mathrm{e} \quad \mathrm{ni}_{2} \quad \mathrm{bi}_{2}$-in-te

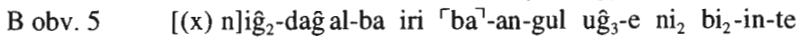

$6 \mathrm{Curi}_{5} \mathrm{k}^{\mathrm{T}}$-ma hul-ĝal ${ }_{2}$ im-ši-DU sipa zi ba-ra-ab-e $\mathrm{e}_{3}$

A i obv. 6 [... ]- $\left.{ }_{\mathrm{s}} \mathrm{i}-\mathrm{DU}\right\urcorner$ sipa(PA.UDU!?) zi ba- ra-ab-e

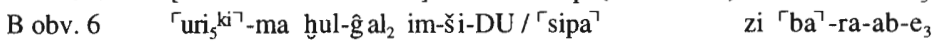

1 From the $[\ldots$, the ...] was [...] evenly in/on the land.

2 [The ...] struck, the palace(s) collapsed.

3 [The ...] spread panic rapidly among its Black-Headed who dwelt there.

$4 \quad[$ The ...] established its abandoned places in Sumer.

5 In its vast [...] cities are destroyed, the people are seized with panic.

6 Evil came upon Ur and made the faithful shepherd leave it!

20 Variants between the Nippur versions, as well as variants of the Susa version, are noted in footnotes.

21 A reading i] n- sag $_{3}$ is epigraphically also possible. 
7 [si]pa $\left\ulcorner_{\mathrm{zi}}\right\urcorner$ ur-d ${ }^{\top}{ }_{\text {namma }}$ ba $\urcorner-$ ra-ab-e ${ }_{3}$ sipa zi ba-ra-ab-e ${ }_{3}$

A i obv. $7 \quad[\ldots \quad$ sip $] a$ zi ba-ra-ab-e

B obv. $7 \quad\left[\right.$ si]pa $\left\ulcorner\right.$ zi ${ }^{\top}$ ur- $d\left\ulcorner\right.$ namma ba ${ }^{\top}-$ ra-ab-e $e_{3} /$ sipa zi ba-ra-ab-e $e_{3}$

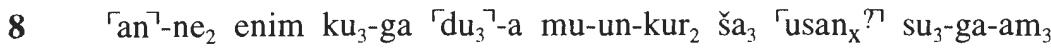

A i obv. 8 [.. $\quad]$ AN. 'USAN?? $\left(\operatorname{usan}_{\mathrm{x}}\right) \mathrm{su}_{3}$-ga- $\mathrm{am}_{3}$

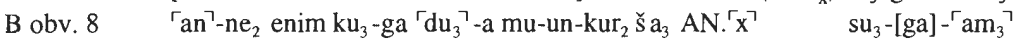

$9 \quad\left\ulcorner_{\mathrm{den}}\right\urcorner-\mathrm{lil}_{2}-\mathrm{le} \operatorname{nam}(-){ }^{\ulcorner} \operatorname{tar}^{\urcorner}-\mathrm{ra} \mathrm{du}_{3}-\mathrm{a}\left\ulcorner_{\mathrm{Su}}\right\urcorner$ lul [mi]-ni-ib-bala

A i obv. 9 [... ]-ni- ib-bala

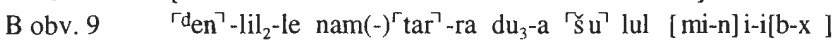

$10 \mathrm{~d}\left\ulcorner\right.$ nin-mahn $-\mathrm{e}\ulcorner\mathrm{x}\urcorner[\mathrm{x}]\ulcorner\mathrm{x}\urcorner \cdot \mathrm{A}_{2} \cdot A \cdot B A-n a$ a-nir mu-un-ga $a_{2}-\hat{g} a_{2}$

\begin{tabular}{|c|}
\hline $\mathrm{A}$ i obv. 10 \\
\hline
\end{tabular}

11 den-k[i-k]e $e_{4}$ geš [i]g gal eriduki-ga gu $_{2}$-bi ba-an-ge ${ }_{4}$

A i obv. 11 [.. i]g gal eriduki-ga gu ${ }_{2}$-bi ba-an-ge ${ }_{4}$

B obv. $11{ }^{\mathrm{d} e n-k[1-k] e_{4}}$ ges $[\mathrm{ig}]{ }^{\ulcorner} \mathrm{gal}$ eridu ${ }^{\mathrm{ki}}{ }_{\text {-ga }} \mathrm{g}\left[\mathrm{u}_{2}-\ldots\right]$

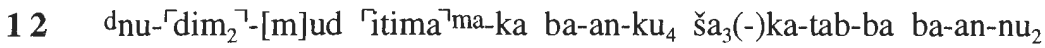

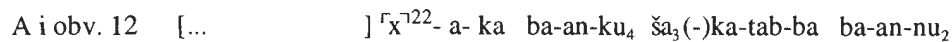

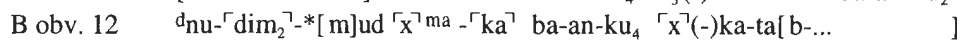

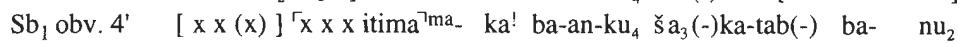

7 It made the faithful shepherd Urnamma leave it, it made the faithful [shep]herd leave it!

8 An changed the precious pronouncement which he had fixed, ${ }^{23}$ it is an empty midst of the evening. ${ }^{24}$

9 The decreed fate that Enlil had fixed ${ }^{25}$ was altered deceitfully.

10 Ninmah sets up laments in/over her [...].

11 Enki hermetically closed the great door of Eridu.

12 Nudimmud entered the bedchamber and lay down listlessly.

22 Traces are compatible with itim] a? as well as $-\mathrm{m}^{\mathrm{a}} \mathrm{a}^{\mathrm{?}}$.

23 Literally: "What An had invested in the precious pronouncement, he changed".

24 Or: "the heart . . . is empty".

25 Literally: "What Enlil had invested in the decreed fate". 
13 enim $\mathrm{Kku}_{3}$ ? ${ }^{26}$ an-na- ${ }^{\top} \mathrm{ka} ?{ }^{?}$ dnanna si-un ${ }_{3}$-na saĝ-ki ba-da-ni-in-gid ${ }_{2}$

A i obv. 13 en[im ... dnan] na si-un ${ }_{3}$-na sag -ki ba-da-ni-in- gid $_{2}$

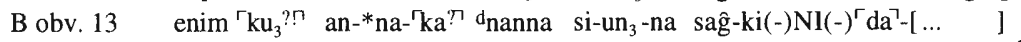

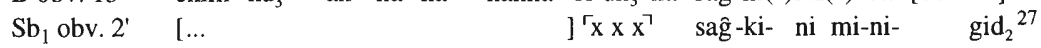

14 dutu(-) $\left.\Gamma^{a n}\right\urcorner^{\urcorner}-n\left[a^{?}\right]$ nu-um-e $e_{3}-e u_{4}$ - de $e_{3}$ i-si-iš im-la

A i obv. 14 d $[$ utu(-)... $] \mathrm{u}_{4}{ }^{\urcorner}-\mathrm{de}_{3}$ i- si- iš im-la

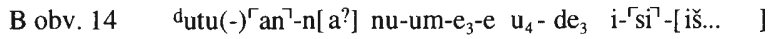

$\mathrm{Sb}_{1}$ obv. $3^{\prime} \quad[\ldots \quad] \mathrm{u}_{4}-\mathrm{de}_{3}$ i- si- iš im-la

15 ama dumu-ni-šs $e_{3}$ hulu til ${ }_{3}-\mathrm{la}-\mathrm{e}$
A i obv. $15 \quad[\ldots$
h]julu til ${ }_{3}$ - la- e
B obv. 15 ama dumu-ni-š $e_{3}$ h hulu til $\left.{ }_{3}{ }^{\ulcorner}{ }^{-} l a\right\urcorner-e$

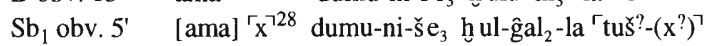

16 ama lugal-la $\mathrm{ku}_{3}$ dnin-sumun ${ }_{2}$-na a $\check{s ̆}_{3}$ - $\mathrm{gu}_{10}$ im-me

A i obv. $16 \quad[\ldots \quad \quad]^{\Gamma d}$ nin-sumun 2 -na $a^{\urcorner}\left[\mathrm{ša}_{3}\right]-\mathrm{gu}_{10}$ im- me

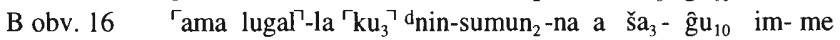

$\mathrm{Sb}_{1}$ obv. 6' ama lugal- la $\mathrm{ku}_{3}{ }^{\mathrm{d}}$ nin-sumun 2 -ka $\left.\mathrm{a}_{2} \mathrm{ša}_{3}-\mathrm{gu}_{10}{ }^{\prime} \mathrm{im}\right\urcorner-\mathrm{me}$

17 nam ur-dnamma mu-un-tar-ra-šs

A i obv. $17 \quad\left[\ldots \quad\right.$ ur- d $_{\text {nam }}$ ma mu- un-tar-ra- $-\mathrm{ra}^{\urcorner}-\mathrm{s}_{3}$

B obv. 17 'nam? ur-d namma' mu- un-tar-ra- $\mathrm{še}_{3}$

$\mathrm{Sb}_{1}$ obv. 7' nam ur-dnamma ${ }^{\prime} \mathrm{mu}^{\top}$-un-bala-e-eš- $\mathrm{am}_{3}$

13 Nanna at the zenith frowned at/because of An's precious? pronouncement.

14 Utu does not rise in the sky, ${ }^{29}$ the days are full of sorrow.

15 The mother who is miserable because of her son, ${ }^{30}$

16 The mother of the king, dazzling Ninsumun, says: "O my heart!"

17 Because of the fate that was allotted to Urnamma, ${ }^{31}$

$26 \mathrm{Ku}_{3}{ }^{7}$ on copy of source B possible; according to Edzard's collations very unlikely.

27 At the beginning of $\mathrm{Sb}_{1}$ obv. approximately 9-10 lines are missing. Line $1^{+}$reads [...] ${ }^{\ulcorner} \times x^{\urcorner}[(x \times)]$.

28 Or simply a scratch.

29 Or: "Utu-of-Heaven does not rise".

30 Susa: "[ The mother] who sits? in a wretched state because of her son".

31 Susa: "They (= the gods?) have overturned Urnamma('s) destiny". 
18 mu sipa zi ba-ra-ab- $e_{3}-a-s ̌ e_{3}$
A i obv. $18 \quad[\ldots$
] ba-ra- ${ }^{r} a b-e_{3}^{\urcorner}-a-s ̌ e_{3}$
B obv. 18
'mu' sipa zi ba- ra- ab- $e_{3}-a-s ̌ e_{3}$
$\mathrm{Sb}_{1}$ obv. $8^{\prime} \quad$ mu sipa zi ba- ${ }^{\top} \mathrm{ra}-\mathrm{ab}{ }^{\urcorner}-\mathrm{e}_{3}-\mathrm{a}-\mathrm{ta}$

19 sila daĝal ki a-ne-di gal ${ }_{2}$-la-ba $\mathrm{ir}_{2}$ gig $\mathrm{i}_{3}-\breve{s ̌}_{8}-\breve{s ̌ e}_{8}$
A i obv. $19 \quad[\ldots$
] $\mathrm{r}_{\mathrm{x}} \mathrm{gal}_{2} ?-\mathrm{la}^{?} \mathrm{P}-[\ldots$
]$_{1_{3}} ?_{-}-\mathrm{du}_{11}-\mathrm{du}_{11}$

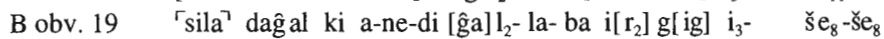

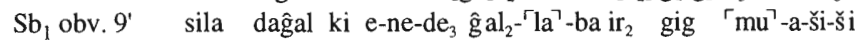

20 nam- $\mathrm{lu}_{2}-\mathrm{ulu}_{3}$ li-bi ib $\mathrm{ib}_{2}-\mathrm{til}-\mathrm{la}_{-} \mathrm{am}_{3} \quad \mathrm{u}_{3} \quad \mathrm{du}_{10}$ nu-mu-un-ku-ku
A i obv. 20
B obv. 20
$[\ldots$
] $\mathbf{u}_{3} \quad \mathrm{du} \mathrm{u}_{10} \quad$ nu-mu-un-ku-ku
A
$\mathrm{Sb}_{1}$ obv. 11' nam-lu $\mathrm{u}_{2}-\mathrm{ulu}_{3} \quad$ lib ib $\mathrm{b}_{2}$-til-la- $\mathrm{am}_{3} \mathrm{u}_{3} \mathrm{~d}\left[\mathrm{u}_{10} \mathrm{x}(\mathrm{x})\right]^{\ulcorner} \mathrm{x}(-\mathrm{x})^{\top}[\mathrm{x}]-\mathrm{ku}$

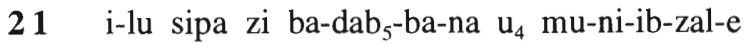
A i obv. $21 \quad[\ldots \quad$ si $] p a{ }^{2} \mathrm{zi} \mathrm{ba}^{\top}-\mathrm{dab}_{5}$-ba-
$\mathrm{u}_{4}$ mu-ni- ib- zal- e
B obv. 21 i- $\ulcorner * l u\urcorner$ si[pa] zi ba- dab ${ }_{5}$-ba- na $[\ldots \quad$-i]b- zal- e
$\mathrm{Sb}_{1}$ obv. $10^{\prime}$ i- lu sipa zi ba-an-dab $b_{5}-$ be $_{2}-\mathrm{NE}-\mathrm{eš}-\mathrm{a}{ }^{\ulcorner} \mathrm{u}_{4}{ }^{\top} \mathrm{mi}-\mathrm{n}[\mathrm{i}$ ? $-\mathrm{i}] \mathrm{b}_{2}$-zal-zal-e

22 a-eštub $i_{7}$-da de $_{2}$-a-bi ku$_{3}$-gal ${ }_{2}$-bi ba-si

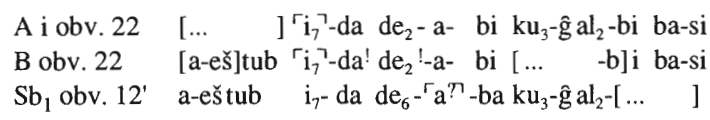

18 Because $i^{32}$ made the faithful shepherd leave,

19 They ${ }^{33}$ weep bitter tears in their broad squares where merriment had reigned.

20 With their bliss(fulness) having come to an end, the people do not sleep soundly.

21 They spend (their) days in lamenting the faithful shepherd who has been snatched away. ${ }^{34}$

22 When the early flood had poured into the canals, their (canal-)inspector became/was weary, ${ }^{35}$

\footnotetext{
32 i.e. the evil (cf. lines 6-7).

33 i.e. the people.

34 Literally i-lu (...)-na means "in the lamentations over him" (-ani in an objective, rather than subjective sense). Susa: "(As) they (= the gods?) have snatched him away (...)".

35 If $\mathrm{ku}_{3}-\mathrm{g} \mathrm{al}_{2}$ represents Urnamma, then translate perhaps "(...) was/became silent (or: weak)".
} 
23 še gu-nu a-gar ${ }_{3}$-re $\mathrm{mu}_{2}$-a- $\left.-\mathrm{bi}\right\urcorner$ zi kalam-ma ba-su

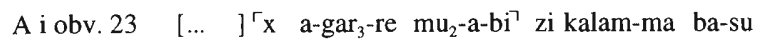

B obv. 23 [še gu]-nu a-gar ${ }_{3}-\mathrm{re} \mathrm{mu}_{2}-\mathrm{a}-\mathrm{b}\left[\mathrm{i} \ldots \quad\right.$-m] a ba-su $\mathrm{su}_{13}$

$\mathrm{Sb}_{1}$ obv. 13' še gu-nu a-gar ${ }_{3}-\mathrm{re}{ }^{\top} \mathrm{x}^{\urcorner}-\mathrm{e}_{3}-\mathrm{a} \quad \mathrm{z}[\mathrm{i} \ldots$ ]

24 engar $\mathrm{GANA}_{2}$ zi-de ${ }_{3}$ gub $\Gamma_{\mathrm{x}(-) n i}{ }^{\top}$ mu-na-ab-tur-re
A i obv. $24 \quad[\ldots]\ulcorner\times\urcorner[\ldots$
] mu-na-ab- ${ }^{r}$ tur-re?

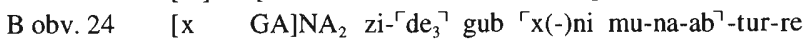
$\mathrm{Sb}_{1}$ obv. 14' engar GANA $\mathrm{Gi}_{2}$ zi- de ${ }_{3} \mathrm{Cgub}^{\top}-\mathrm{bu}\ulcorner\mathrm{x}\urcorner{ }^{\top}[\ldots]$

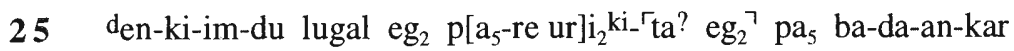
A i obv. $25 \quad[\ldots]$

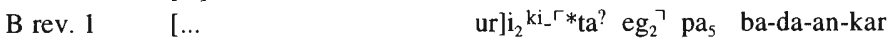
$\mathrm{Sb}_{1}$ obv. $15^{\prime} \quad$ den-ki-im-du lugal eg $\mathrm{p}_{2}\left[\mathrm{a}_{5}-\ldots\right.$

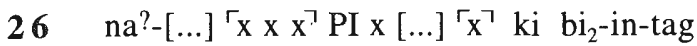
A i obv. 26 na? $-[\ldots$
] ${ }^{\ulcorner} \mathrm{x} \times \mathbf{k i ~ b i}_{2}$-in-tag
B rev. $2 \quad[\ldots]^{\ulcorner} \times x^{\top} x^{*}$ PI $x[\ldots,] \mathrm{ki} \mathrm{bi}_{2}$-in-tag
$\mathrm{Sb}_{1}$ obv. 16' $\mathrm{XX} \mathrm{AB}^{n}{ }^{n}$ ug $\hat{g}_{3}$ daĝal-bi $\left.{ }^{\ulcorner} \mathrm{ba}\right\urcorner-[\ldots]$

27 umuš $[(\ldots)]$ kalam-ma $\left.{ }^{\prime} u_{2}\right\urcorner-[g] u$ im-ma-an- ${ }^{2} \mathrm{de}_{2} ? \mathrm{u}_{2}$ nir-gal ${ }_{2}$ ba-sud
A i obv. 27 umuš [(..) kalam-ma...
] $\mathrm{u}_{2}$ nir-ĝal ${ }_{2}$ ba-sud
B rev. 3 [... $\quad \mathrm{u}_{2}$-g] u im-ma-an- $\mathrm{Cde}_{2}{ }^{n} \mathrm{u}_{2}$ nir-gal ${ }_{2}$ ba-sud ${ }_{4}$
$\mathrm{Sb}_{1}$ obv. $17^{\prime} \quad\ulcorner(\mathrm{x}) \mathrm{x}\urcorner^{\urcorner}$BU kalam-ma-kam! $\left\ulcorner\mathrm{u}_{2}^{\urcorner}-[\ldots\right.$

23 (So that) when the mottled barley had been growing in the arable tracts, ${ }^{36}$ 'the life of the land' became inundated.

24 For the farmer, who stood on the cultivated field, his ... diminishes it for him.

25 Enkimdu, the lord of embankments and di[tches], took away embankments and ditches from? [U]r.

$26[\ldots]$ he? has put on the ground. ${ }^{37}$

27 The senses [(and...)] of the land disappeared, splendid food has been withdrawn. 
28 edin-edin-e $u_{2} s\left[a_{6}{ }^{?}\right.$-ga $]$ nu-mu-u[n-m] $u_{2} u_{2}$ a-nir ba-an-mu
A i obv. 28 edin-e[ din-e $u_{2} s a_{6}$-ga...
$\mathrm{u}_{2}$ a]-nir ba- $\mathrm{mu}_{2}$
B rev. $4 \quad\ulcorner\mathrm{x}\urcorner[\ldots$
$u_{2}$ aj-nir ba- $\mathrm{mu}_{2}$
$\mathrm{Sb}_{1}$ obv. $18^{\prime} \quad$ [ed]in-edin-e $\mathrm{u}_{2} s\left[\mathrm{a}_{6}{ }^{?}{ }^{\prime} \ldots\right.$

$29 \mathrm{ab}_{2}-\ulcorner\mathrm{e} ? \mathrm{x}\urcorner[\ldots]$ mu-un- $\ulcorner\mathrm{x}\urcorner \operatorname{tur}_{3}\ulcorner\mathrm{x}\urcorner$-bi ba-gul
A i obv. $29 \quad a b_{2}-{ }^{\top} e^{?} \times(-)^{\top}\left[\ldots \quad\right.$ ] ${ }^{\ulcorner} x^{\top}-b i$ ba- gul
B rev. $5 \quad\left\ulcorner a b_{2}{ }^{?}\left[\ldots \quad\right.\right.$ ] mu-un $-{ }^{\ulcorner} * x^{\top}$ tur $_{3}{ }^{\ulcorner} \mathrm{x}-\mathrm{bi} b \mathrm{ba}^{\urcorner}$-gul
$\mathrm{Sb}_{1}$ obv. 19' $\left.[(\mathrm{x}) \mathrm{x}]^{\ulcorner} \mathrm{x}\right\urcorner \mathrm{ab}_{2}$ dugud-d[ $\left.\mathrm{a}^{?} \ldots\right]$

30 amar $a_{2}\ulcorner x\urcorner[\ldots]\ulcorner x\urcorner-b i$ im-DU

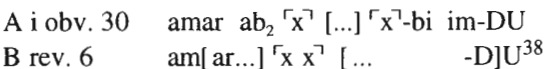

31 sipa $\mathrm{ku}_{3}-\mathrm{zu}[\ldots] \times \mathrm{A}[\ldots] \times \mathrm{a}_{2}$ ? $\mathrm{n}[\mathrm{u} ?-\mathrm{mu}]-\mathrm{da}-\mathrm{an}-\mathrm{ag} \hat{g}_{2}-\mathrm{e}$
A i obv. 31 sipa $\mathrm{ku}_{3}-\mathrm{zu}[\ldots$
B rev. 7
sipa $\mathrm{ku}_{3}-* \mathrm{zu}[\ldots](-) * \mathrm{x}(-) * \mathrm{~A}(-)[\ldots]^{*} \mathrm{x} * \mathrm{a}_{2}{ } * \mathrm{n}\left[\mathrm{u}^{?}{ }^{?}\right.$.
]-da-an-ag $\hat{g}_{2}-\mathrm{e}$
C obv. 1
$[\ldots]^{\ulcorner} x^{\urcorner}[\ldots]$

$32 \mathrm{me}_{3}$ š[en-šen-na?...] A SI.`A ba'-da-「ab-TAB?-e?
A i obv. $32 \mathrm{me}_{3}$ šsen-...
B rev. $8 \quad{ }^{*} \mathrm{me}_{3}$ š[ en-...
C obv. 2' ${ }^{\prime} \quad \mathrm{x} \mathrm{x} \mathrm{x}^{\urcorner}[\ldots$
]- ${ }^{r} \mathrm{x}-\mathrm{ab}-\mathrm{TAB} ?-\mathrm{e}^{\mathrm{n}}$

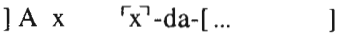
]/SI.'A ba? $-\mathrm{d}[\mathrm{a}-\ldots$

33 lugal $\mathrm{ka}$ mud-gal ${ }_{2} \mathrm{ki}^{\top}$-[e]n-gi-r[a me-te? unken-na]

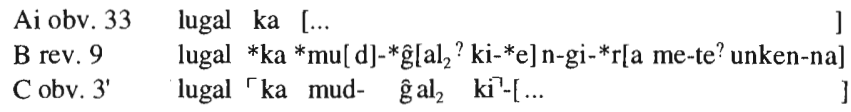

28 On the steppes no f[ine?] grass grew any more, mourning grass grew there.

29 Cows [...], their [...] cattle pens are destroyed.

30 Calves $[\ldots]$ cows $[\ldots]$.

31 The wise shepherd [..., cea]ses to give instructions.

32 [In?] battle and com[bat...] ...

33 The king, the advocate of Sumer, [the adornment? of the assembly],

38 Restore and read possibly with Wilcke, UT 63 amar ab ${ }_{2}$-š i[lam-ta ku ku $_{5}$ da] $\left\ulcorner * u_{5}{ }^{\urcorner}\right.$g[ig-g] a-bi im-ša $a_{4}$ "Calves [ that had been cut off from their mother] cows mooed bitterly." 
34 ur-dnamma ka ${ }^{\top}$ mud-ĝal ${ }_{2}{ }^{\top}$ ki-en-[gi-ra me-t]e? unken-na
A i obv. 34 ur-dnamma [...
me-t]e? unken-na
B rev. 10
ur- ${ }^{\mathrm{d}}$ namma ka $\mathrm{m}\left[\mathrm{ud}-\mathrm{gal}_{2}\right]$ ki-en-[ gi-ra..
Cobv. $4^{\prime}$ ur-- ${ }^{\mathrm{d}}$ namma ka ${ }^{\ulcorner}$mud-gal $_{2}{ }^{\urcorner}\left(\left\ulcorner\mathrm{x}^{\urcorner}\right)[\ldots\right.$

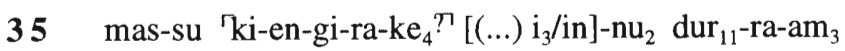
A i obv. 35 mas-su $x\left[(\ldots) \mathrm{i}_{3} / \mathrm{in}^{-}-\mathrm{nu}_{2}\right.$ dur 11 -ra-am ${ }_{3}$
B rev. 11
C obv. $5^{\prime}$
mas-su $\times$ x $[$...
mas-' su ki-en-gi-ra-ke ${ }_{4}^{\text {? }}[\ldots$
$\mathrm{Sb}_{1}$ rev. 1' [ur]- ${ }^{\ulcorner\mathrm{d}}$ namma ${ }^{\top} \mathrm{ki}-[\ldots$

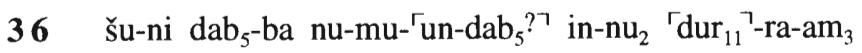
A i obv. 36 šu!-ni [
B rev. 12 ร̌u $[\mathrm{x}(\mathrm{x})] \mathrm{x} \mathrm{x}^{\urcorner}[\ldots$
]- $\left\ulcorner\mathrm{x}-\mathrm{dab}_{5}{ }^{?\urcorner}\right.$ in- $\mathrm{nu}_{2}\left\ulcorner\mathrm{dur}_{11}{ }^{\urcorner}-\mathrm{ra}^{-a m_{3}}\right.$

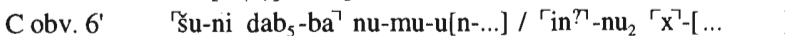
$\mathrm{Sb}_{1}$ rev. $2^{\prime} \quad[\mathrm{x}]-\mathrm{ni} \mathrm{dab}_{5}$-ba $\mathrm{n}[\mathrm{u}-\ldots] \mathrm{r}^{\mathrm{x}} \mathrm{x}^{\mathrm{C}}[\ldots$

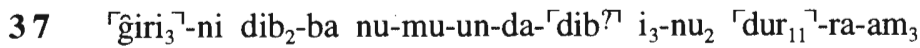
A i obv. $37 \quad[\ldots$
]- $\left\ulcorner\mathrm{mu}^{\top}-\mathrm{un}-\mathrm{da}-\left\ulcorner\mathrm{dib}{ }^{?} \mathrm{i}_{3}-\mathrm{nu}_{2}\left\ulcorner\mathrm{dur}_{11}\right\urcorner-\mathrm{ra}^{-\mathrm{am}_{3}}\right.\right.$

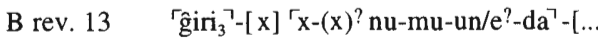

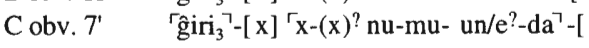
$\mathrm{Sb}_{1}$ rev. 3' [ĝi $] \mathrm{ri}_{3}-$ ni dib 2 -ba [ x x x (x)]-ĝ $\mathrm{a}_{2}-\mathrm{g} \mathrm{a}_{2}[\ldots$

$3^{39}[\ldots]\ulcorner\mathrm{x} x\urcorner \mathrm{IM}\ulcorner\mathrm{x}\urcorner[\ldots \mathrm{SA}] \hat{\mathrm{G}} ? \mathrm{ME}$ ba-BU
A i obv. 38 [...] $\left.]^{\ulcorner} \mathrm{x}^{\urcorner} \mathrm{IM} \mathrm{M}^{\ulcorner} \mathrm{x}\right\urcorner[\ldots \mathrm{SA}] \hat{G}^{? 40}$.ME ba-BU
B rev. $14 \quad[\ldots]$
$\mathrm{Sb}_{1}$ rev. 4' za-pa-a $\hat{\mathrm{g}}_{2}\left\ulcorner\mathrm{~A} \mathrm{x}^{\urcorner}\left[\mathrm{x} \mathrm{x}\right.\right.$ x (x)-b] a GAM-e $\mathrm{US}_{2}[\ldots]$

34 Urnamma, the advocate of Sum[er, the adornm]ent? of the assembly,

35 The leader of Sumer [(...)] lies suffering.

36 With his hands which had seized, he was not able to seize? any more. He lies suffering.

37 With his feet which had tread, he was not able to tread? any more. He lies suffering.

$38 \quad[\ldots] \ldots$... was torn. ${ }^{41}$

\footnotetext{
39 Source A.

40 The sign could also be KA.

41 Susa: "Tumult $[\ldots]$. . . .".
} 
39 sipa zi lug[al] $\mathrm{UL}_{4}$-gal ki-en-gi-ra-ke ${ }_{4}$

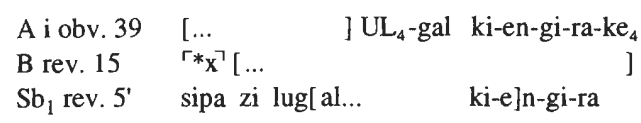

40 ur-dnamma lugal kalam-ma-ke ${ }_{4} \mathrm{e}_{2}$-sumur-ra ba-an-te

\begin{tabular}{|c|c|c|}
\hline A i obv. 40 & ] lugal kalam-ma-ke ${ }_{4}$ & $e_{2}$-sumur-ra ba-an-te \\
\hline B rev. 16 & $\ulcorner * x\urcorner[\ldots$ & \\
\hline $\mathrm{Sb}_{1}$ rev. $5^{\prime}$ & ur-dnamma $[\ldots$ & \\
\hline
\end{tabular}

41 uri ${ }_{2}$ ki-ma im-te ur-dnamma $e_{2}-\mathrm{zu}_{2}-\mathrm{ra}-\mathrm{ah}-\mathrm{ra}_{\mathrm{x}} \mathrm{x}^{\mathrm{k}}-\mathrm{ku}_{4}$

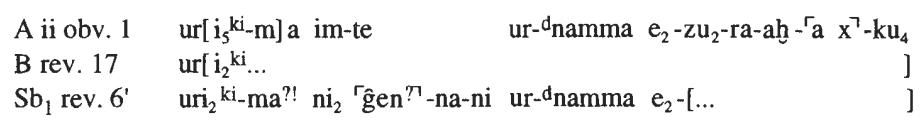

42 saĝ(-)ku $3(-)$ gal $_{2} e_{2}$-gal-a-na $i_{3}-n u_{2}$

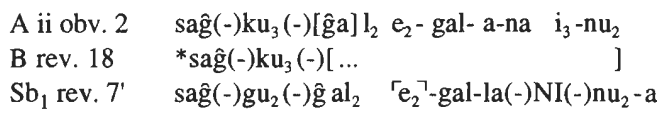

43 ur-dnamma $\operatorname{lu}_{2}$ eren ${ }_{2}$-e ki-ag $\hat{g}_{2}-\mathrm{ga}_{2} \mathrm{gu}_{2}$ nu-mu-un-da-zi-ge

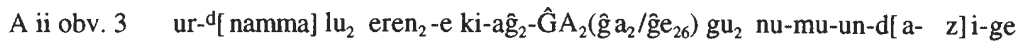
B rev. $19 \quad[\ldots]$

$\mathrm{Sb}_{1}$ rev. 7'-8' ur-dnamma $\mathrm{lu}_{2}$ eri/e(-)[... ] $/ \mathrm{ur}_{5}$ nu- un-da-an-zi

39 The faithful shepherd, the king, the ... of Sumer,

40 Urnamma, the king of the land, let himself be brought to the Furious House.

41 Urnamma approached Ur and entered the ... House. ${ }^{42}$

42 The proud one lies in his palace.

43 Urnamma, the beloved of troops, is not able to lift (his) head ${ }^{43}$ any more.

\footnotetext{
42 A literal translation of $\mathrm{e}_{2}-\mathrm{zu}_{2}-\mathrm{ra}-\mathrm{ah}$ (so far as the reading of $\mathrm{KA}$ as $\mathrm{zu}_{2}$ is correct) "Tooth-Gnashing House" is not assured. Susa: "When Urnamma himself had arrived? at Ur (...)".

43 Literally "neck". Susa: "Urnamma whom the cities [...], was not able to raise himself any more".
} 
44 igi(-)gal ${ }_{2}$ kur-kur-ra $i_{3}-$ nu $_{2}$ geš-la ${ }_{2}$-bi im-DU

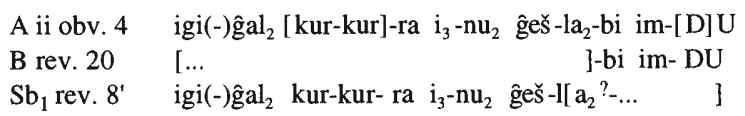

45 teš $\check{2}_{2}$ kalam-ma-ka ba-šubub hur-saĝ-gin ${ }_{7}$ ba-gul

\begin{tabular}{|c|c|c|}
\hline & $\begin{array}{l}\text { tešs }[\text { kalam-m] a-ka ba- } \\
\text { tešs } \check{S}_{2}[\ldots\end{array}$ & 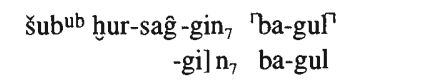 \\
\hline & teš & hur-sa $\hat{g}-\operatorname{gin}_{7}$ ba-g[ul? $\left(\begin{array}{lll}x & x & x\end{array}\right)^{?}$ \\
\hline
\end{tabular}

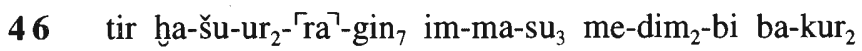

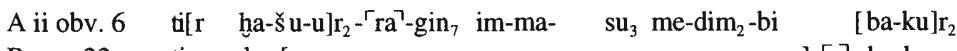 B rev. 22 tir ha- $\left[\ldots\right.$ ] ${ }^{\prime} \mathrm{x}$ ' ba-kur ${ }_{2}$

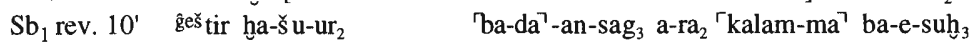

46a $\mathrm{Sb}_{1}$ rev. 11' geš eren? ${ }^{44}$ kalam-ma- $\left.{ }^{\top} \mathrm{ke}_{4}\right\urcorner$ ba-da-bala a- ${ }^{\ulcorner} \mathrm{ra}_{2}$ kalam?-ma ba-e-kur ${ }_{2}$

47 geš taškarin-gin 7 ki-tuš gir $_{17}$-zal- $\left.7 a\right\urcorner-n a \mathrm{GIN}_{2}$ mu-ni-in-gar-re-eš
A ii obv. 7 geš [
]$(-)^{\ulcorner} \mathrm{x}$-la ${ }^{\top}-$ na GIN ${ }_{2}$ !mu- ni-in- $[.$.
$-\mathrm{e}] \mathrm{s}^{\mathrm{s}}$
B rev. 23
geses taškarin!? $\left.{ }^{\mathrm{S}} \mathrm{SE}_{3}\right)$-gin 7 ki[-tuš
] ${ }^{*} \mathrm{GIN}_{2}$ mu- ni-in?- gar-re-eš

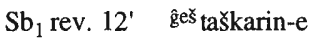
ki-tuš gir $_{17}$-zal-a-ni AGA ${ }^{r}$ mu'-un-na-an-gar-re-eš

44 The one who oversees all (the foreign) lands is lying, deathly silence settles in.

45 The land's vigour is felled, like a mountain (mine) it is cut away.

46 Like a grove of h a š u r-trees it is clear cut, its appearance is altered. ${ }^{45}$

46a $\mathrm{He}^{46}$ passed the cedar trees? of the land, the state of the land is altered.

47 Like to a boxwood tree they ${ }^{47}$ set axes against his delightful dwelling place.

\footnotetext{
44 The sign does not look like a classic EREN but rather a simplified form of $K W U 896$ (cf. $L A K 668$ ) = also (?) EREN/ $/ \mathrm{SES}_{4}$ (cf. Ferwerda, $T L B / S L B$ V, p. 6).

45 Susa: "A grove of h $h$ a $s$ u r-trees was felled, the state of the land is confused".

46 i.e. Urnamma.

47 i.e. the enemy? Cf, also I 1., p. 7, fn. 62
} 


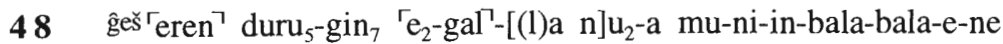

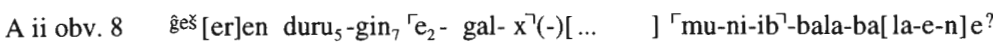

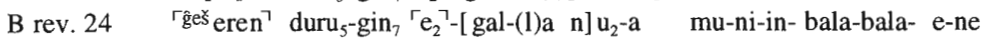
$\mathrm{Sb}_{1}$ om.

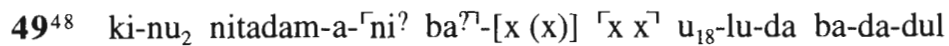
A ii obv. 9

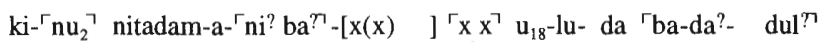
B rev. 25
$\mathrm{Sb}_{1}$

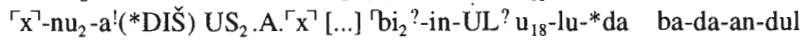 om.

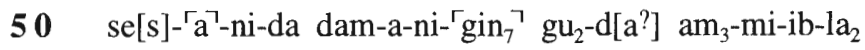
A ii obv. 10 se[s]- $\left\ulcorner\right.$ a - -ni-da dam-a-ni- $-\operatorname{gin}_{7} x^{\urcorner} \quad[\ldots \quad$-m]i-ib-la
B rev. $26 \quad[\ldots$
$\mathrm{Sb}_{1} \quad$ om.

$51 \quad u_{4}{ }^{2} d_{11} u^{-}$ga-ni sa $a_{2}$ mu-ni- ${ }^{2}{ }^{?} ?-d^{-} u_{11}$ a-la-na ba-ra-e ${ }_{3}$
A ii obv. $11 \quad \mathrm{u}_{4} \quad\left\ulcorner\mathrm{du}_{11}{ }^{749}\right.$-ga-ni $\quad \mathrm{sa}_{2} \quad$ mu-ni- $\mathrm{Cib}^{?}$-du $\mathrm{du}_{11}$ a- la- na ba-[x-x ]
B rev. $27 \quad[\ldots] \quad]-d u_{11} a^{-*}{ }^{*} l a-* x \quad b a-r a-{ }^{\ulcorner *} e_{3}^{\urcorner}$
$\mathrm{Sb}_{1}$ rev. 13' $\left.\mathrm{u}_{4}{ }^{\top} \mathrm{sa}_{2}\right\urcorner \mathrm{du}_{11}-\mathrm{Cga}^{\top}-\mathrm{ni}-\mathrm{a} \mathrm{sa}_{2}$ mi-ri- ib $\mathrm{b}_{2}-\mathrm{du}$ alan-a-ni ba-ra- $\mathrm{e}_{3}$

$52\left\ulcorner_{\text {sizkur }_{2}}^{\urcorner}\right.$niğ $_{2}$ du ${ }_{10}$-ga la-ba-an-tag-ge šu gig ba- ${ }^{-n i-x}{ }^{\urcorner}-$gid $_{2}$
A ii obv. $12\left\ulcorner^{\prime}\right.$ sizkur $_{2}^{\urcorner}$niğ $_{2} \quad$ du $_{10}$-ga la-ba-an-tag-ge šu gig ba- ${ }^{\ulcorner}$ni-x ${ }^{\urcorner}-[\ldots]$
B rev. $28 \quad[\ldots]]^{\ulcorner *} \mathrm{x} \mathrm{x}^{\urcorner}[\ldots$

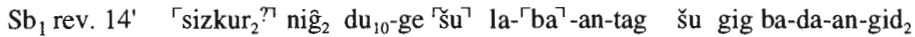

48 Like a sappy cedar tree they uproot him [in?] the palace [where he is] lying.

49 His wife ... (his) resting place [...], it is covered with a storm (from the South).

$50 \quad \mathrm{It}^{50}$ embraced $\mathrm{it}^{51}$ as a spouse her sweetheart.

51 His appointed time has reached him, he has lost his vitality. ${ }^{52}$

52 Pleasing sacrifices are no longer seized, (because) afflicted hands have been stretched out towards them.

\footnotetext{
48 Source A.

49 Possibly $s\left[a_{2} d\right] u_{11}$-ga-ni but hardly any space.

50 Referring to the storm of the previous line.

51 Referring to the resting place of the previous line.

52 i.e. "he has lost his hold on life". Susa: ". . ., he has lost his healthy appearance".
} 
53 kadra ${ }_{2}{ }^{a}$ ni ${ }^{d a}$-nun-na-ke $e_{4}$-ne $\mathrm{KA}(\mathrm{enim})$ im-ma-an- ${ }^{\ulcorner} \mathrm{ge}_{4}{ }_{4}$ - $[\mathrm{x}]$

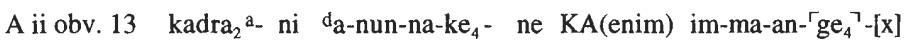

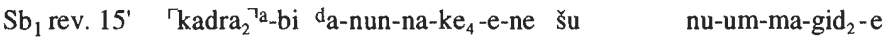

54 an $\left\ulcorner^{r} \check{s}_{3}\right.$ ? $\urcorner-a_{3}{ }^{r} x$ ? la-ba-e-gub $\urcorner u_{4}$-bi la-ba-ni-ib-si

A ii obv. 14 an $m u\left[\check{s}_{3}{ }^{?}\right]-{ }^{\ulcorner} \mathrm{am}_{3} x^{?}$ la-ba-e- gub $\mathrm{u}_{4}$-bi la-ba-ni-ib-si

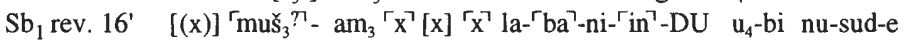

55 enim de[n]-lil $1_{2}-\mathrm{la}_{2}$ du $_{11}$-ga-še ${ }_{3}$ ur $_{5}$ zi-zi la-ba-gagl ${ }_{2}$

A ii obv. 15 enim de[n]-lil ${ }_{2}-\mathrm{la}_{2} \quad \mathrm{du}_{11}-\mathrm{ga}-\check{s ̌}_{3} \quad \mathrm{ur}_{5} \mathrm{r}_{\mathrm{zi}} \mathrm{zi}{ }^{\top}$ la-ba-ĝal ${ }_{2}$

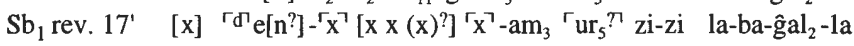

$56 \Gamma_{x}(-x)-$ ulu $_{3}$ ? -ni ki ba-ag $\hat{g}_{2}-\mathrm{ga}_{2}$-bi igi-ĝal ${ }_{2}-$ bi ba-kur ${ }_{2}$

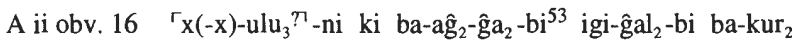
$\mathrm{Sb}_{1} \quad$ om.

$57 \quad \Gamma^{\urcorner}[(x)]-l a \quad l_{2}$ nu-zu- $u_{3}$-ne i-im-bala-bala-e-ne

A ii obv. $17 \Gamma^{\prime} x^{\urcorner}[(x)]-l a l_{2}$ nu-zu-u $u_{3}$-ne i-im- bala-bala-e-ne

$\mathrm{Sb}_{1}$ rev. $19^{\prime} \quad[\ldots \quad-n]$ mu-ni-bala-bala-e

58 a-g[in ${ }_{7}$ k]i- $l u \Gamma-$-la ur-dnamma dug gaz-gin ${ }_{7}$ a-ba-ni-in-taka ${ }_{4}$-aš

A ii obv. 18 a-g[in ${ }_{7}$ k] i- ${ }^{-} l u \Gamma-l a$ ur- ${ }^{d}$ namma dug gaz-gin ${ }_{7}$ a-ba-ni-in-taka ${ }_{4}$-as

$\mathrm{Sb}_{1}$ rev. $18^{\prime} \quad[\mathrm{x} \mathrm{x}(\mathrm{x})]^{\Gamma} \mathrm{x}(\mathrm{x})^{\top}[(\mathrm{x} \mathrm{x})$ ur $]{ }^{\top \mathrm{d}}$ namma dug $[\mathrm{g}] \mathrm{az}$ im-mi-ni- taka ${ }_{4}$-e

53 (Therefore) the Anuna reject his gifts. ${ }^{54}$

54 An did not stand by (his) ahulap ..., the days for that were not (yet) accomplished..$^{55}$

55 Because of Enlil's command, there was no getting up.

56 His people, the ones he had loved, their insight is altered.

57 [...] strangers turn over.

58 After they had thus abandoned Urnamma in the Place of Treachery as if he were a broken jar, 
$59 r_{x}[(x)]-a-n i \quad$ IM.UD $\operatorname{sir}_{2}$-da-gin 7 gal-bi im-ši-ĝen

A ii obv. $19\left\ulcorner_{X}\right\urcorner[(x)]-a-n i$ IM.UD $\operatorname{sir}_{2}$-da-gin ${ }_{7}$ gal-bi im-š-ĝen

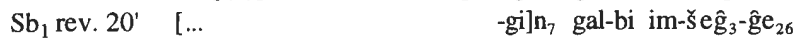

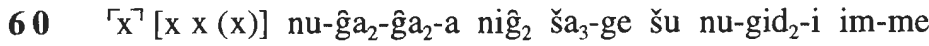

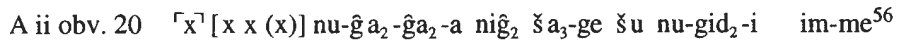

$\mathrm{Sb}_{1}$ rev. 21' [... ] su nu-dab ${ }_{5}$-be $\mathrm{be}_{2}$ im-me

$61 \Gamma_{x} \times x$ x ur?-dnamma me-li-e-a nam-ĝ $u_{10}$

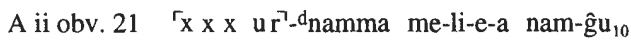

$\mathrm{Sb}_{1}$ rev. $22^{\prime} \quad[\ldots \quad$ na $] \mathrm{m}-\hat{\mathrm{gu}}_{10}$

62 a-ra-li ki(-)saĝ-ki kalam-ma-še ${ }_{3}$

A ii obv. 22 a-ra-li ki(-)saĝ-ki kalam-ma- $\mathrm{se}_{3}$

63 ur-dnamma dumu $\mathrm{rd}_{\text {nin-sumun }}$-ka hi-li-na ba-da-DU

A ii obv. 23 ur-dnamma dumu ${ }^{r d n}$ nin-sumun ${ }_{2}$-ka hi-li-na ba-da-DU

$\mathrm{Sb}_{2}$ obv. $1 \quad[\ldots]-\mathrm{x}-\mathrm{bi}$ im- $-\mathrm{x}^{\top}-[\ldots]^{57}$

64 eren 2 lugal-da $\left.\Gamma_{1_{3}}\right\urcorner-$ re $_{7}$-eš-a ir $_{2}$ mu-da-ab-us ${ }_{2}$-e

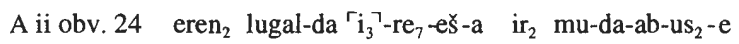

$\mathrm{Sb}_{2}$ obv. $2 \quad[\ldots \quad]-{ }^{-} \mathrm{x}-\mathrm{a}^{?} ? \mathrm{ir}_{2}{ }^{\mathrm{C}} \mathrm{im}-\mathrm{x}^{\top}-[\ldots]$

59 His [...] went there in grandiose fashion like cumulated clouds. ${ }^{58}$

60 "[...] that he does not set, he does not reach out any more for desirable things!" she? says.

61 ". . Urnamma, alas, what is it to me?"

62 To Arali, the ...-place of the land,

63 Urnamma, the son of Ninsumun, was brought in his physical prime.

64 The soldiers who had gone with (their) lord, shed tears because of him. 
65 dilmunki-gin ${ }_{7}$ kur $^{\urcorner}$ki nu-zu-na geš ma $a_{2}$-bi ba-da-ab-su

A ii obv. 25 dilmun ${ }^{k i}$-gin ${ }_{7}{ }^{\prime} \mathrm{kur}^{\top} \mathrm{ki}$ nu-zu-na $\mathrm{ges}^{\mathrm{k}} \mathrm{ma}_{2}$-bi ba-da-ab-su

$\mathrm{Sb}_{2}$ om.

$66[\check{S}] U /[\check{S}] E_{3} \quad M_{I N} D_{3}$ E E $\check{S}_{3}$ ba-da-ab-kud
A ii obv. 26
$\mathrm{Sb}_{2}$

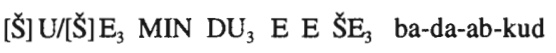 om.

67 geš gisal geš gi-muš gešzi-gan gala ${ }_{2}$-la-bi gu $_{2}$-guru ga-ab-du $_{11}$

A ii obv. 27 ĝes ĝisal ĝes gi-muš ĝex zi-gan gaal ${ }_{2}-\mathrm{la}-\mathrm{bi} \quad \mathrm{gu}_{2}-\mathrm{guru}_{5}$ ba-ab-du

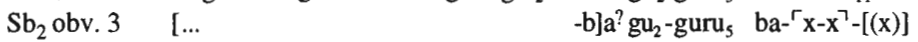

68 geš \ulcorner\urcorner$\urcorner[x(x)]-n a$ KIŠIB ba-da-tab gešsaĝ-kul-bi ba-kud

A ii obv. 28 ĝeš $\left\ulcorner x^{\urcorner}[x(x)]\right.$-na KIŠIB ba-da-tab gês sâg-kul-bi ba-kud

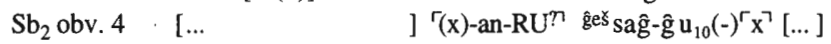

69 gิeร̌ $\ulcorner\mathrm{x}\urcorner[\mathrm{x}(\mathrm{x})]\ulcorner\mathrm{A}\urcorner$ IGI.MIN/A? SU ba-da-gar sahar ses-a ba-DU

A ii obv. 29 gešr ${ }^{\top} x^{\urcorner}[x(x)]{ }^{r} A^{\urcorner}$IGI.MIN/A? SU ba-da-gar sah ar ses-a ba- $\quad$ DU

$\mathrm{Sb}_{2}$ obv. 5 [... $]$ - $\mathrm{Cda}^{\top}$-TAR sahar ses ba-da-an-'TUŠ-x ${ }^{759}$

70 lugal- \ulcorner\urcorner$\urcorner$ [anše]-ni ba-da-dur ${ }_{2}$-ru anše ki mu-un-di-ni-ib-tum ${ }_{2}$

A ii obv. 30 lugal- $r x^{7}[a n s ̌ e]^{60}$-ni ba-da-dur $r_{2}-r u$ anše ki mu-un-di-ni-ib-tum ${ }_{2}$

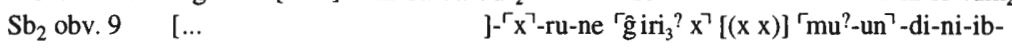
$\mathrm{us}_{2}$

65 Their ship, as if from/in Dilmun, was sunk in the (foreign) land, a place unknown to him. ${ }^{61}$

66 ... was cut.

67 It was stripped of its existing oars, punting poles and rudder.

$68[\ldots]$... . was devastated, its bolt was/is broken.

$69[\ldots]$... . was put aside, it stood in bitter dust.

70 With the king his [donkeys] were to be found, the donkeys were buried with him. ${ }^{62}$ 
71 ur-d ${ }^{\ulcorner}$namma ${ }^{\top}\left(-{ }^{\top} \mathrm{x}^{\top}\right)$ anše-ni ba(-da-dur ${ }_{2}$-ru anše ki mu-un-di-ni-ib-tum $\left.{ }_{2}\right)$

A ii obv. $31^{63}$ ur-d ${ }^{\mathrm{C}}{ }^{\mathrm{n}}$ namma $\left(-{ }^{\ulcorner} \mathrm{x}^{\urcorner}\right)^{64}$ anš e-ni ba(-da-dur ${ }_{2}$-ru anše ki mu-un-di-ni-ib-tum $\left.{ }_{2}\right)$

$\mathrm{Sb}_{2}$ obv. $10 \quad[\ldots]$ kaskal kur-ra-ke ${ }_{4}[\ldots$-u $]$ n-di-ni-ib-us ${ }_{2}$

72 'ĝeš?-x` kalam-ma-ke ${ }_{4}$ ba-da-bala teš ${ }_{2}$ kalam-ma ba-kur ${ }_{2}$

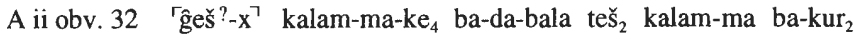

$\mathrm{Sb}_{2}$ om.

73 Kaska $\Gamma$ [kur]-ra in- $\mathrm{di}_{3} \quad \mathrm{su}_{3}-\mathrm{ga}-\mathrm{am}_{3}$
A ii obv. 33 'kaskal' [kur]-ra in-di ${ }_{3} \quad \mathrm{su}_{3}-\mathrm{ga}^{-\mathrm{am}_{3}}$
$\mathrm{Sb}_{2}$ obv. $\left.8 \quad[\ldots] \quad\right] \mathrm{ki}$-in- $\left.{ }^{\mathrm{d} d u}\right\urcorner \mathrm{su}_{3}$-ud-da

74 'luga $\Gamma$-[da?] ĝeš gigir ba-da-šu ${ }_{2}$ har-ra-an im-ma-da-suḩ ${ }_{3}$ šu nu-um-ma$\mathrm{ni}_{10}-\mathrm{ni}_{10}$

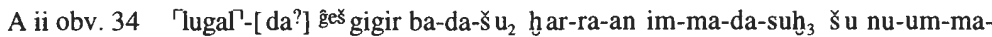
$\mathrm{ni}_{10}-\mathrm{ni}_{10}$

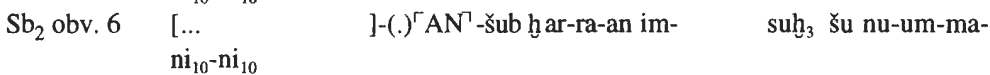

75 [ur-dnamma(-da?)] ĝeš gigir ba-da-šu ${ }_{2}$ har-ra-an im-ma-da-suh 33 šu nu-umma-ni $10-\mathrm{ni}_{10}$

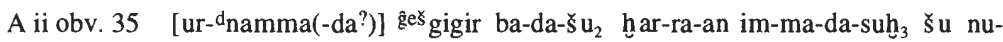
um- ${ }^{*}$ ma-ni $i_{10}-$ ni $_{10}$

$\begin{array}{ll}\mathrm{Sb}_{2} \text { obv. } 7 & {[\ldots} \\ & \text { um-ma-ni } \\ & \end{array}$ ]$^{\ulcorner} x^{765}-() A N-.s ̌ u b \quad$ har-ra-an im- $\quad \operatorname{suh}_{3}$ šu nu-

71 With Urnamma his donkeys (were to be found, the donkeys were buried with him). ${ }^{66}$

72 He crossed over the ... of the land, the land's vigour was altered.

73 The journey to the [netherworld] is a desolate ${ }^{67}$ stretch of road,

74 To the king's [disadvantage?] the chariot was covered, the roads became twisted and one could not hurry along on them (any more).

75 [To Urnamma's disadvantage?] the chariot was covered, the roads became twisted and one could not hurry along on them (any more).

\footnotetext{
63 Interlinear.

64 The first visible sign on the CBS tablet could either be -namma or another sign; - $\mathrm{ke}_{4}$ is very unlikely.

$65{ }^{\ulcorner} \mathrm{x}$ ' could be $\left.{ }^{\ulcorner} \mathrm{A}\right\urcorner$; in that case read perhaps $\Gamma^{\top} \mathrm{am}_{3}{ }^{\urcorner}-\mathrm{s}$ ub.

66 Susa: "[ ...] they undertook with him the journey to the netherworld".

67 Susa:"long".
} 
$76 \quad \Gamma_{i_{3}}-$ du $\left._{8}\right\urcorner$ g[al] kur $^{\urcorner}$-ra imin-bi nig ${ }_{2}$-ba ba-ab-šum ${ }_{2}-\mathrm{mu}$

A ii obv. $36 \quad \Gamma_{i_{3}}-\mathrm{du}_{8}{ }^{\top} \mathrm{g}[\mathrm{al}] \mathrm{kur}{ }^{\top}-\mathrm{ra}$ imin-bi nig ${ }_{2}$-ba ba-ab-šum ${ }_{2}-\mathrm{mu}$

$\mathrm{Sb}_{2}$ obv. $\left.11 \quad[\ldots] \quad\right] \mathrm{x}^{\urcorner}-\mathrm{bi}$ nig $\mathrm{g}_{2}(-) \mathrm{ba}(-)^{\ulcorner} \mathrm{ab}^{?}{ }^{?}-[\ldots-\mathrm{m}] \mathbf{u}^{?}$ ?

76a $\mathrm{Sb}_{2}$ obv. $12[\ldots] \mathrm{i}_{3}-\mathrm{du}_{8}$ gal mu-ši- ${ }^{\mathrm{X}} \mathrm{X}^{\urcorner}-[\ldots] \mathrm{X}^{\urcorner}$

77 lugal mu tuku ba-ug ${ }_{5}$-ge-eš-a

A ii obv. 37 lugal mu tuku ba-ug ${ }_{5}$-ge-eš-a

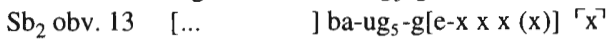

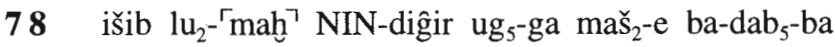

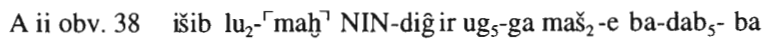

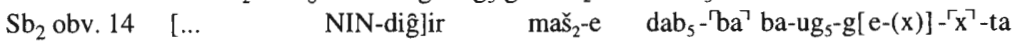

$78 \mathbf{a} \mathrm{Sb}_{2}$ obv. $15[\ldots] \Gamma_{\mathrm{XX}} \mathrm{X}-\mathrm{AG}_{2}^{\top}$

79 lugal ĝen-na-ni uĝ $\hat{g}_{3}$ mu-un-zu-uš kur-ra za-pa-ağ $\hat{g}_{2}$ mu-un-gar

A ii obv. 39 lugal gen-na-ni ug $\hat{g}_{3}$ mu-un-zu-uš kur-ra za-pa-aĝ $\hat{g}_{2}$ mu-un-ĝar

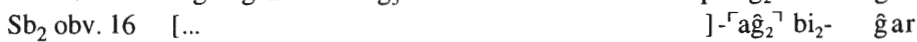

80 ur-dnamma ĝen-na-ni (ug $\hat{g}_{3}$ mu-un-zu-uš kur-ra za-pa-a $\hat{g}_{2}$ mu-un-ĝar)

A ii obv. $40^{68}$ ur- ${ }^{d}$ namma gen-na-ni (uĝ $\hat{g}_{3}$ mu-un-zu-uš kur-ra za-pa-a $\hat{g}_{2}$ mu-un-ĝar)

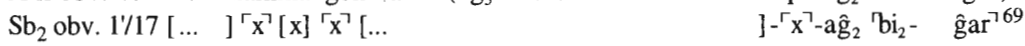

76 He gives presents to the seven chief porters of the netherworld.

76a $[\ldots]$ the chief porter(s) [...].

77 The famous kings who had died,

78 The dead i š i b- and $\mathrm{l} u \mathrm{~m}$ a h-priests and the $\mathrm{N} \mathrm{IN} \mathrm{di} \mathrm{g} \mathrm{i} \mathrm{r-priestesses}$ who had been chosen by extispicy

78a $[\ldots] \ldots$

79 Let the people know when the king had arrived, they ${ }^{70}$ became tumultuous in the netherworld.

80 (Let the people know) when Urnamma had arrived, (they became tumultuous in the netherworld).

68 Interlinear.

69 It is uncertain if $\mathrm{Sb} 14083$ 1' is to be equated with $\mathrm{Sb} 1413717$; the only visible sign on the last line of Sb 14137 (= line 18) could be part of the $\left.-r_{\mathrm{zu}}\right\urcorner$ of $\mathrm{Sb} 140832$ '

70 i.e. the people. 
81 lugal-e gud im-ma-ab-gaz-e udu im-ma-ab-šar ${ }_{2}-$ re

A ii obv. 41 lugal-e gud im-ma-ab-gaz-e udu im-ma-ab-šar ${ }_{2}$-re $\mathrm{Sb}_{2} \quad$ om.

82 ur-dnamma gìšbun gal-gal-la ba-ši-in-dur ${ }_{2}$-ru-ne-eš

A ii obv. 42 ur- ${ }^{d}$ namma gîs bun gal-gal-la ba-ši-in-dur ${ }_{2}$-ru-ne-eš

$\mathrm{Sb}_{2} \quad$ om.

$83 \mathrm{u}_{2}$ kur-ra ses-am 3 a kur-ra mun $_{4}$-na-am 3
A ii obv. 43
$\mathrm{Sb}_{2}$
$\mathrm{u}_{2}$ kur-ra ses-am ${ }_{3}$ a kur-ra mun 4 -na-am 3 om.

84 sipa zi garza kur-ra-ke ${ }_{4} / \check{s ̆ a}_{3}$-ga-ni mu-un-zu

A ii obv. 44 sipa zi garza kur-ra-ke ${ }_{4} / \varsigma_{3} a_{3}$-ga-ni mu-un-zu

$\mathrm{Sb}_{2}$ obv. 2' lu[gal gar]za kur-ra-ke ${ }_{4} \quad \mathrm{sa}_{3}$-ga-ni $\mathrm{r}_{3}-\mathrm{zu}^{\top}$

$84 a S_{2}$ obv. $3^{\prime}$ ur-dnamma garza kur-ra- ${ }^{\top} \mathrm{ke}_{4}{ }^{\urcorner} \mathrm{ša}_{3}$-ga-ni $\mathrm{i}_{3}$-zu

85 lugal-e nidba kur-ra-ke ${ }_{4}$ geš im-ma-ab- ${ }^{\ulcorner}$tag-ge ${ }^{\urcorner}$

A iii obv. 1 lugal-e nidba kur-ra-ke ${ }_{4}$ ge eš im-ma-ab- ${ }^{\top}$ tag-ge ${ }^{\top}$

$\mathrm{Sb}_{2} \quad$ om.

86 ur-dnamma nidba kur-ra-ke ${ }_{4}$ geš im-ma-ab-tag-ge

A iii obv. 2 ur-dnamma nidba kur-ra-ke ${ }_{4}$ geš im-ma-ab-tag-ge

$\mathrm{Sb}_{2} \quad$ om.

81 The king slaughters numerous bulls and sheep.

82 Urnamma seated them ${ }^{71}$ at huge banquet-tables.

83 (For) the food of the netherworld is bitter and the drink of the netherworld is salty.

84 The faithful shepherd - his heart knew of the cultic norms of the netherworld ${ }^{72}$ :

84a Urnamma - his heart knew of the cultic norms of the netherworld:

85 The king offers sacrifices for/of the netherworld,

86 Urnamma offers sacrifices for/of the netherworld,

72 Or: "(...) he knew in his heart the cultic norms of the netherworld" (although one expects $\mathrm{s}_{3}$-ga-na). 
87 gud $\mathrm{du}_{7} \operatorname{maš}_{2} \mathrm{du}_{7}$ udu niga en-na ab-lah ${ }_{5}-\mathrm{a}$

A iii obv. 3 gud du $\operatorname{mašs}_{2}$ du $_{7}$ udu niga en-na $a$-lahs ${ }_{5}$-a

$\mathrm{Sb}_{2}$ obv. 4' gud $\mathrm{sa}_{7}$ mašs $_{2}$ du-du' 'udu' niga im-ma-ab-lah ${ }_{4}-\mathrm{e}$

88 geš middu $_{2}$ gešpana gal $e_{2}$-mar-uru ${ }_{5}$ geš gag-pana giri ${ }_{2}-\mathrm{zu}_{2}$ galam

A iii obv. 4 ĝes middu $_{2}$ gè pana gal $e_{2}$-mar-uru ${ }_{5}$ geł gag-pana giri ${ }_{2}-z_{2}$ galam

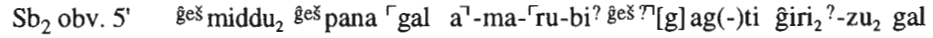

89 kušlu-ub gunu $_{3}-\mathrm{a} \mathrm{ib}_{2}$-ba gal $\mathrm{gal}_{2}$-la-ba

A iii obv. 5 kušlu-ub $b_{2} \quad$ gunu $_{3}$-a ib $b_{2}$-ba gal gal $_{2}-\mathrm{a}$-ba

$\mathrm{Sb}_{2}$ obv. $6^{+} \quad \mathrm{kus}^{\mathrm{S}} \mathrm{lu}-\mathrm{ub}_{2}$ gunu $_{3}$-a [x]-ba gal $\mathrm{g}_{2}-\mathrm{la}-\mathrm{ni}$ !(IR)

$90 \mathrm{~d}_{\mathrm{ne}_{3}}$-eri ${ }_{11}$-gal den-lil 2 kur-ra-ra

A iii obv. $6 \quad \mathrm{~d}_{\mathrm{ne}_{3}}$-eri ${ }_{11}$-gal den- $\mathrm{lil}_{2}$ kur-ra-ra

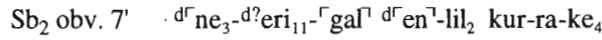

91 sipa ur-dnamma-ke ${ }_{4} e_{2}$-gal-a-na geř im-ma-ab-tag-ge

A iii obv. 7 sipa ur-d namma-ke ${ }_{4} e_{2}$-gal- a-na ĝ ě̌ im-ma-ab-tag-ge

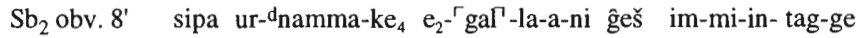

92 geš gid ${ }_{2}$-da kušlu-ub ${ }_{2}$ dag-si AK-a i-mi-tum pirig an-na

A iii obv. 8 ĝes gid $_{2}$-da kuš lu-ub ${ }_{2}$ dag-si AK-a i-mi-tum piriĝ an-na

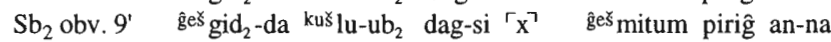

93 kuš E.IB ${ }_{2} \cdot \mathrm{UR}_{3}$ ki us $\mathrm{us}_{2}$-sa $\mathrm{a}_{2}$ nam-ur-saĝ-ĝa

A iii obv. 9 kuš E.IB IB $_{2} \cdot \mathrm{UR}_{3}$ ki us $\mathrm{s}_{2}-\mathrm{sa} \mathrm{a}_{2}$ nam-ur-saĝ-ĝa

$\mathrm{Sb}_{2}$ obv. $10^{\prime} \quad{ }^{\text {kus E.IB }} \mathrm{IB}_{2} \quad \mathrm{ki}^{\mathrm{Cus}} \mathrm{s}_{2}-\mathrm{sa} \mathrm{x}^{\mathrm{T}}$

87 As many perfect bulls, ${ }^{73}$ perfect bucks and fattened sheep as could be brought.

88 A mace, a large bow with quiver and arrows, an artfully fashioned ... dagger, ${ }^{74}$

89 And a multicoloured leather-bag which is worn at the hip

90 To Nergal, the Enlil of the netherworld,

91 Shepherd Urnamma offers as a sacrifice in his palace.

92 A spear, a leather-bag made for the saddle(-hook), an i $\mathrm{m}$ i t u m-weapon (with) a celestial lion,

93 A shield which is (firmly) pressed to the ground, the valorous arm,

73 Susa: "magnificent bulls".

74 Susa: "A mace, a large bow with its? quiver and arrows, a large . . . dagger". 
94 [z]a-ḩa-da ni $\hat{g}_{2}$ ki-aĝ $\hat{g}_{2}$ dereš-ki-gal-la

A iii obv. 10 [z]a-ḩa-da niğ ki-aĝ $_{2}$ dereš-ki-gal-la

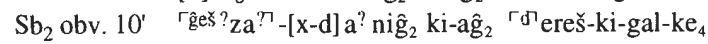

$95 \mathrm{dbil}_{4}$-ga-mes lugal kur-ra-ke 4

A iii obv. $11 \Gamma_{\mathrm{d}} \mathrm{bil}_{4}$-ga-mes lugal kur-ra-ke ${ }_{4}$

$\mathrm{Sb}_{2}$ obv. $11^{\prime} \mathrm{d}^{\circ} \mathrm{bil}_{3}{ }^{7}$-ga-mes lugal kur-ra-ke ${ }_{4}$

96 [s]ipa ur-dnamma-ke ${ }_{4} \mathrm{e}_{2}$-gal-la-na geš im-ma-ab-tag-ge

A iii obv. 12 [si]pa ur-dnamma-ke ${ }_{4} e_{2}$ - gal- la-na geř im-ma-ab-tag-ge

$\mathrm{Sb}_{2}$ obv. 12' [s]ipa ur-dnamma-ke ${ }_{4} \mathrm{e}_{2}-{ }^{-}-\mathrm{gal}{ }^{\prime}-\mathrm{a}-\mathrm{ni}$ geš im-mi-in-tag-ge

97 'ĝeš-keš $\breve{2}_{2}$-da $i_{3}$ ba-ni-in-de ${ }_{2}$-a bur-šagan šu du $u_{7}$-a

A iii obv. $\left.13 r_{x}\right\urcorner(-) k e \breve{s}_{2}$-da $\quad i_{3}$ ba-ni-in-de ${ }_{2}-a$ bur- šagan šu du du $_{7}-\mathbf{a}$

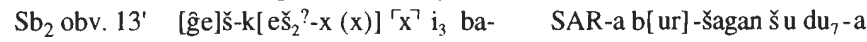

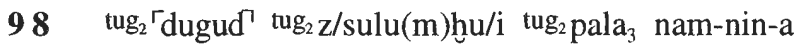

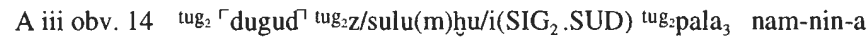
$\mathrm{Sb}_{2} \quad$ om.

$\left.99 \Gamma_{\mathrm{x}} \mathrm{x}(\mathrm{x}) \times \mathrm{x}\right\urcorner \mathrm{SAR}$ dalla me kur-ra

A iii obv. $\left.15 \quad \Gamma_{x} x(x) \times x\right\urcorner$ SAR dalla me ${ }^{\ulcorner}$kur-ra ${ }^{\urcorner}$

$\mathrm{Sb}_{2}$ obv. 14' [...](-)lugal-la sig NIG $\hat{G}_{2} . \breve{S}^{\prime} \mathrm{U}() P$.$I me kur-ra$

100 dereš-ki-gal ama ${ }^{\mathrm{d}} \mathrm{n} n[\mathrm{in}]-r_{\mathrm{a}} \mathrm{\top}$-zu-ra

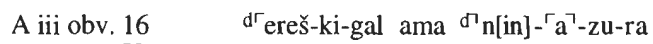

$\mathrm{Sb}_{2}$ rev. $1^{75}[(\mathrm{x})]^{\ulcorner} \mathrm{x}^{\urcorner}$ereš-ki-gal ama $\left[\begin{array}{ll}\mathrm{x} & \mathrm{x}\end{array}\right]-\left\ulcorner^{\top} \mathrm{a}^{\urcorner}-\mathrm{zu}-[\ldots]\right.$

94 And a battle-axe, Ereškigal's favourite,

95 To Gilgameš, king of the netherworld,

96 Shepherd Urnamma offers as a sacrifice in his palace.

97 A container in which oil has been poured, a š a g a n-bowl of perfect make,

98 A heavy garment, a long-fleeced garment, a $\mathrm{p}$ a 1 a-robe fit for a queen,

99 A . . resplendent..., the $m$ e of the netherworld

100 To Ereškigal, the mother of Ninazu, 
101 sipa ur-dnamma(-ke $\left.{ }_{4}\right) e_{2}$-gal-(l)a-na 'ĝeš' im-[ma-ab-tag-ge]

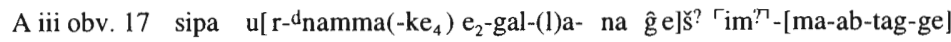

$\mathrm{Sb}_{2}$ rev. 2 [s]ipa ur- ${ }^{-}$namma-ke ${ }_{4} \quad \mathrm{e}_{2}$-gal- la- ${ }^{\circ}$ a-ni geš $\mathrm{im-}$ mi-i[n-tag-ge ]

102 udu A.LUM udu z/sulu(m)hu/i $\mathrm{i}_{\mathrm{x}}$ maš $\check{2}_{2}$ gal kur-ra- $\mathrm{ke}_{4}{ }^{\urcorner}$

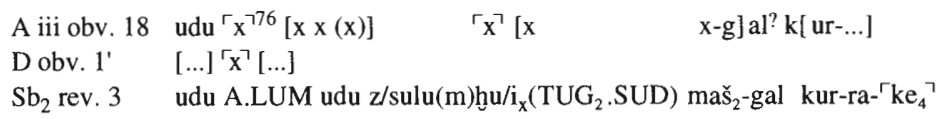

103 gidri $\left.\mathrm{ku}_{3}-{ }^{-} \operatorname{sig}_{17}\right\urcorner$ nam-en-na šu za-gin $\left.{ }_{3}-{ }^{\top} \mathrm{Se}_{3} \times(-) \mathrm{x}\right\urcorner$

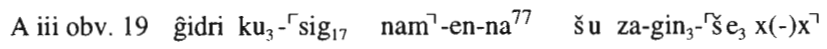
D obv. 2' [... n] am-en-na šu [...
$\mathrm{Sb}_{2}$ rev. 4 geš-nu ${ }_{11}$ geš ma-nu nam- en-na-kam šu za-gin ${ }_{3}$-na tum $_{2}-\mathrm{m}[\mathrm{a}]$

$103 a \mathrm{Sb}_{2}$ rev. 5 šibir $\left(E N \times G A N A_{2}\right.$-t. $)$ ešgiri(U.EN $\times G A N A_{2}$-t. $)$ geš ma-nu nam-sipada nam-en-na tum tha $^{-m a}$

104 ddumu-zi dam ki-ag $\hat{g}_{2}$ dinana-ra

\begin{tabular}{|c|c|}
\hline A iii obv. 20 & ${ }^{d}$ dumu-zi $\left\ulcorner\right.$ dam ${ }^{78}$ ki-ag $\hat{g}_{2}$ dinana-ra \\
\hline ob & {$[\ldots]$ ]-zi nitadam $\mathrm{k}[\mathrm{i}-\ldots$} \\
\hline$b_{2}$ rev. 6 & ddumu-zi \\
\hline
\end{tabular}

105 sipa ur-dnamma(-ke $\left.{ }_{4}\right) e_{2}$-gal-a-na geš im-ma-ab-tag-ge

A iii obv. 21 sipa ur- ${ }^{d} n a m m a \quad e_{2}$-gal-a-na ges im-ma-ab-tag-ge

D obv. 4' [sipa u]r-d namma-ke ${ }_{4} \mathrm{e}_{2}$-gal-la-na $\mathrm{g}[\mathrm{es} \ldots]^{79}$

$\mathrm{Sb}_{2}$ rev. 7 sipa ur-dnamma- $\mathrm{ke}_{4} \mathrm{e}_{2}$-gal-a-ni geš im-mi-in-tag-ge

101 Shepherd Urnamma of [fers] as a sacrifice in her palace.

102 A L U M-sheep, long-fleeced sheep, and mountain he-goats,

103 A golden sceptre of e $n$-ship, ... of a shining hand, ${ }^{80}$

103a Staff and nose-leash, (a staff) made of $m$ a $n$ u-wood of shepherdship, worthy of e n-ship,

104 To Dumuzi, Inana's beloved husband,

105 Shepherd Urnamma offers as a sacrifice in his palace.

\footnotetext{
$76\ulcorner\mathbf{x}\urcorner$ could be \ulcorner\urcorner$\urcorner-[\operatorname{lum}]$ (but this writing is only attested in a bilingual text, cf. PSD A/1 108 s.v. a-lum A 5.), or $\operatorname{si}\left[\mathrm{la}_{4}\right]$.

77 After -na and before šu possible traces of erasure.

78 Over erasure; 'nitadam? cannot be entirely excluded.

79 After 105 source D inserts three lines which correspond to lines 121,120 , and 122. They read:

obv. 5' [tu-di-t]um $\mathrm{ku}_{3}$-sig ${ }_{17} \mathrm{ku}_{3}$-babbar [...]

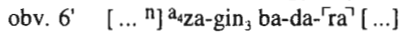

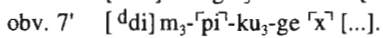

80 Susa: "A . . made of $\mathrm{m}$ a $\mathrm{n}$ u-wood of e $\mathrm{n}$-ship, worthy of a shining hand". 
$106 \mathrm{gi}_{16}$-sa šu $\mathrm{du}_{7}-\mathrm{a}$ har $\mathrm{ku}_{3}-\mathrm{sig}_{17} \mathrm{ma}_{2}-\operatorname{gur}_{8}(-) \mathrm{BI}(. /+)$ x $\mathrm{si}_{3}$ ?/sig?-ga

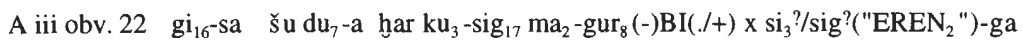

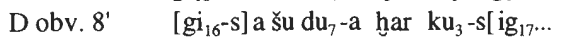

$\mathrm{Sb}_{2}$ rev. $8 \quad \mathrm{gi}_{16}-\mathrm{sa} \quad \check{\mathrm{su} \mathrm{du}} \mathrm{u}_{7}$-a ḩar $\mathrm{ku}_{3}-\mathrm{sig}_{17} \mathrm{ma}_{2}-\mathrm{gur}_{8}(-) \mathrm{BI}(. /+) \mathrm{x} \mathrm{sa}_{7}-$

$107 \mathrm{na}_{4}$ gug $\mathrm{ku}_{3}$ ? $\left.\Gamma_{\text {nig }}\right\urcorner$ gaba diĝir-re-e-ne
A iii obv. $23 \mathrm{na}_{4} \mathrm{gug} \mathrm{ku}_{3}$ ? $\mathrm{nnig}_{2}{ }^{\urcorner}$gaba dig ir- re-e-ne

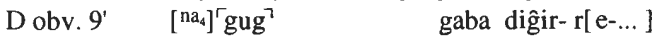
$\mathrm{Sb}_{2}$ rev. $9 \quad \mathrm{na}_{4} g u g\left\ulcorner\mathrm{su} / \mathrm{zu} / \mathrm{ku}_{3} ! ? \mathrm{x}^{\urcorner}[(\mathrm{x})]^{\ulcorner} \mathrm{x}\right.$ digigi ${ }^{\urcorner}$-re-e-ne-ke ${ }_{4}$

$108 \mathrm{~d}_{\text {nam-tar }} \mathrm{lu}_{2}$ nam tar-tar-ra-ra

A iii obv. $24 d{ }^{d}{ }^{n}$ nam? ${ }^{7}$-tar $l u_{2}$ nam tar-tar-ra-ra

D obv. $10^{\prime} \quad$ [dnam]-tar $1 \mathrm{u}_{2} \mathrm{na}$ (m-... ]

$\mathrm{Sb}_{2}$ rev. $10 \quad \mathrm{~d}_{\text {nam-tar }} \mathrm{lu}_{2}$ nam $\mathrm{t}\left[\mathrm{ar}^{?}-\ldots\right]-\mathrm{ke}_{4}$

109 sipa ur-dnamma(-ke $\left.{ }_{4}\right) e_{2}$-gal-a-na geš im-ma-ab-tag-ge

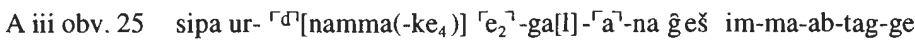
D obv. 11' [sipa ur]- ${ }^{-d_{n a m m a}-\mathrm{ke}_{4}} \quad \mathrm{e}_{2}-$ gal $-1[\mathrm{a}-\ldots$
$\mathrm{Sb}_{2}$ rev. 11 sipa ur- ${ }^{d}$ namma-ke $_{4}$ e e $_{2}$-gal- a- ni ĝer im-mi- tag-ge

110 DUB šu za-gin ${ }_{3}(-[x])$ niĝ $_{2}$-nam irigal-a-ke 4

A iii obv. 26 DUB šu [za] $-\left\ulcorner\operatorname{gin}_{3}\right\urcorner(-[\mathrm{x}])\left\ulcorner\right.$ nig $_{2}-$ nam irigal- $\quad$ a-ke

D obv. 12' [... $\quad]{ }^{\top} \mathrm{x}^{\top} \quad$ nig. $_{2}$-nam [...

$\mathrm{Sb}_{2}$ rev. 12 dub-šen šu za- gin $_{3}$ niğ $\hat{g}_{2}$-nam irigal ${ }_{2}$ gal-la

111 geškirid $\left.\mathrm{Ku}_{3} \quad \mathrm{na}_{4}\right\urcorner$ za-gin ${ }_{3}$ šu tag-ga geš ga-rig nam-munus-a

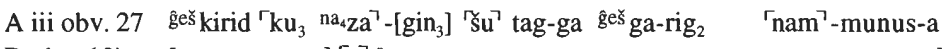 D obv. 13' [ [ ] ] ${ }^{\top} \mathrm{x}^{\top}[\ldots$
$\mathrm{Sb}_{2}$ rev. 13 ĝ $\mathrm{es}$ kirid za- gin $_{3}$ šu tag-ga ĝes ga-rig $_{2}$ imin? nam-munus-a

106 Perfectly wrought jewellery, a golden ring, formed as a . . cargo boat, ${ }^{81}$

107 And a pure? carnelian-stone which is for the chest of gods

108 To Namtar who holds all the decreed fates ${ }^{82}$

109 Shepherd Urnamma offers as a sacrifice in his palace.

110 A (treasure) chest with a lapis lazuli handle, (with) everything (concerning) the underworld,

111 A silver hair clasp decorated with lapis lazuli ${ }^{83}$, and a comb of womenly fashion $^{84}$ 
112 dhuš-bi-sa dam dnam-tar-ra- $\left.{ }^{\prime} \mathrm{ra}\right\urcorner$

A iii obv. 28 dhuš-bi-sa $a_{6}$ dam ${ }^{d}$ nam-tar- ${ }^{-}$ra-ra?

$\mathrm{Sb}_{2}$ rev. 14 dhuš-bi-sa ${ }_{6}{ }^{\circ}$ dam? nam-tar- ra-ke ${ }_{4}$

113 sipa ur-dnamma-ke ${ }_{4}\left\ulcorner e_{2}^{\urcorner}\right.$-gal-a-na geš im-ma-ab-tag-ge

A iii obv. 29 sipa ur-dnamma- $\mathrm{ke}_{4}{ }^{\mathrm{d}} \mathrm{e}_{2}{ }^{\urcorner}$-gal- a-na geš im-ma-ab-tag-ge

$\mathrm{Sb}_{2}$ rev. 15 sipa ur-dnamma- ${ }^{-\mathrm{ke}_{4}} \mathrm{e}_{2}$ - gal'-[(la-)a-ni geš im-m] i-in-tag-ge

114 gešnig $\hat{g}_{2}$-šu umbin(-) $\left.\Gamma^{\mathrm{x}}\right\urcorner-[\mathrm{b}] \mathrm{i} \mathrm{ku}_{3}-\mathrm{sig}_{17}$-ta $\mathrm{gunu}_{3}$-a

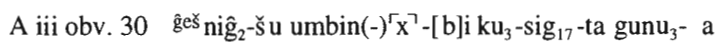

$\mathrm{Sb}_{2}$ rev. $1^{185} \quad[\ldots \quad] \mathrm{x}^{\mathrm{r}} \mathrm{gunu}_{3}$ ? $\mathrm{a}$-a

115 ANŠE.KI anš enisku(m)(PIRIĜ) $\left\ulcorner_{\mathrm{X}}\right\urcorner[\ldots]\left\ulcorner_{\mathrm{x}} \mathrm{x} \times \mathrm{x}\right.$ x

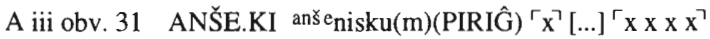

$\mathrm{Sb}_{2} \quad$ om.

$116^{86}$ anše ur $_{2}$ gunu $_{3}-$ gunu $\left._{3}[\ldots]{ }^{\top}\right\urcorner$

A iii obv. 32 anše $\mathrm{ur}_{2}$ gunu $_{3}-\mathrm{gunu}_{3}[\ldots] \mathrm{x}$ ?

$\mathrm{Sb}_{2}$ rev. 2' [...AN]S̆E.NITA? gu $\mathrm{gun}_{2}$ ' $\mathrm{du}_{11}-\mathrm{du}_{11}$

117 sipa PA.USAN A [...]- $-\mathrm{x}\urcorner-\mathrm{ab}^{-}-\mathrm{us}_{2}-\mathrm{e}$

A iii obv. 33 sipa PA.USAN A [ ...]- $\left.{ }^{\ulcorner} \mathrm{x}-\mathrm{ab}\right\urcorner-\mathrm{us}_{2}-\mathrm{e}$

$\mathrm{Sb}_{2}$ rev. $3^{\prime} \quad[\ldots]$ ]-da-ab- $\mathrm{us}_{2}$-sa

112 To Hušbisag, Namtar's wife,

113 Shepherd Urnamma offers as a sacrifice in her palace.

114 A chariot with . . . wheels painted with gold,

115 ... donkeys, thoroughbred donkeys [...] . ..,

116 Donkeys with dappled thighs [...],, 87

117 A shepherd and a herdsman followed by [...],

84 Susa: "A hair clasp decorated with lapis lazuli, and seven? combs of womenly fashion".

85 Sb 14137 rev. 1' = most likely Sb 14083 rev. 16.

86 Source A.

87 Susa: "[... as] ses that bray loudly?". 
118 sul ur-saĝ ${ }^{\mathrm{d}}$ nnin-ĝeš-zi-da-ra

A iii obv. 34 sul ur-sag ${ }^{\Gamma d}$ nin $\urcorner$-ĝeš-zi-da-ra

$\mathrm{Sb}_{2}$ rev. $4^{\prime} \quad\left[\ldots \quad\right.$ d] ${ }^{\prime}$ nin- geš-zi-da-ra

119 sipa ur-dnamma- $\mathrm{ke}_{4}{ }^{\top} \mathrm{e}_{2}$-gal-a-na geš im-ma-ab-tag-ge

A iii obv. 35 sipa ur- ${ }^{d}$ namma- $-\mathrm{ke}_{4}{ }^{\lambda} \mathrm{e}_{2}-$ gal-a-na $\mathrm{geš}$ im-ma-ab-tag-ge

$\mathrm{Sb}_{2}$ rev. 5' [sipa ur- ${ }^{-}$namma-ke ${ }_{4}{ }^{\prime}{ }^{\top} \mathrm{e}_{2}^{\urcorner}$-gal-a-ni ĝes im-mi-in-tag-ge

120 na $_{4}$ kišib za-gin ${ }_{3}$ ba-da-ra $i_{3}-l_{2}-a$
A iii obv. 36 na $a_{4}$ iš ib za-gin ${ }_{3}$ ba-da-ra $i_{3}-l_{2}-a$

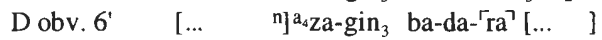

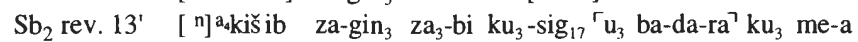

121 tu-di-da $\mathrm{ku}_{3}$-sig ${ }_{17} \mathrm{ku}_{3}$-babbar sag-bi alim-ma
A iii obv. 37 tu-di-da $\mathrm{k}\left[\mathrm{u}_{3}\right]$-sig $\mathrm{s}_{17} \mathrm{ku}_{3}$-babbar saĝ-bi alim-ma
D obv. 5' [tu-di-t]um $\mathrm{ku}_{3}$ - sig $_{17} \quad \mathrm{ku}_{3}$-babbar [ ...
$\mathrm{Sb}_{2}$ rev. $12^{\prime}$ du-di-da $\mathrm{ku}_{3}-\mathrm{sig}_{17} \quad \mathrm{ku}_{3}$-babbar 'saĝ'-bi alim-ma

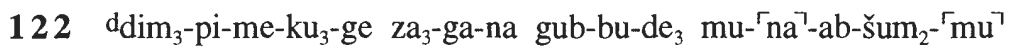

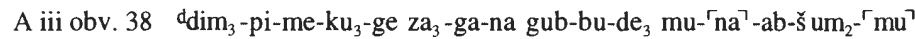

D obv. $7^{\top} \quad$ [di] $\mathrm{m}_{3}-{ }^{\top} \mathrm{pi}^{\top}-\mathrm{ku}_{3}-\mathrm{ge}\left\ulcorner\mathrm{x}^{\urcorner}[\ldots]\right.$

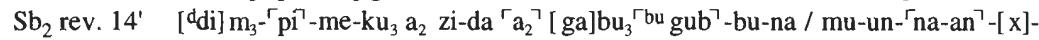
$r x(x)^{\urcorner}$

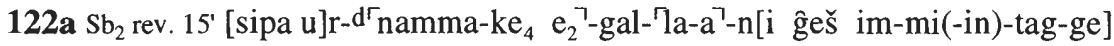

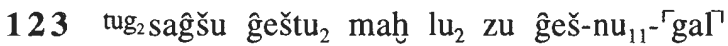

A iii obv. 39 tug saĝšu ĝ eštu $_{2}$ mah lu $l_{2}$ zu g geš-nu ${ }_{11}-{ }^{-g a l}$

$\mathrm{Sb}_{2} \quad$ om.

118 To the youthful hero Ninĝešzida

119 Shepherd Urnamma offers as a sacrifice in his palace.

120 A lapis lazuli seal which is hanging from a pin, ${ }^{88}$

121 And a toggle pin made of gold and silver whose head (is) that of a bison

122 He gives to Dimpi(me)kug for her to stand at his side. ${ }^{89}$

123 A head-dress with great ears of a sage, made of alabaster,

88 Susa: "A lapis lazuli seal, its edge made of gold and the pin of pure silver".

89 Susa: "He . . to Dimpimekug who stands at the right and left side". 122a: [Shepherd Ur]namma [offers (this) as a sacrifice] in/for her palace". 
124 gi dub-ba za $_{3}(-)$ bar-ra niğ $\hat{2}_{2}(-)$ nam(-)dub-sar- $\ulcorner$ ra $\urcorner-\mathrm{ke}_{4}$

A iii obv. 40 gi dub-ba $z_{3}(-)$ bar-ra ni $\hat{g}_{2}(-)$ nam(-)dub-sar- ${ }^{\top} \mathrm{ra}^{\top}-\mathrm{ke}_{4}$

$\mathrm{Sb}_{2}$ rev. $6^{\prime} \quad[\ldots \quad-\mathrm{r}] \mathrm{a}$ niğ ${ }_{2}(-)$ nam(-)dub!-sar- $\quad$ kam

125 eš $_{2}-$ gana $_{2}$ [z]a-gin 3 gi(-)DIŠ-nindan $\left.\Gamma_{x}(-) x\right\urcorner$

A iii obv. 41 ešs -gana $_{2}$ [z]a-gin ${ }_{3}$ gi(-)DIŠs- ${ }^{-}$nindan $x(-) x^{\urcorner}$

$\mathrm{Sb}_{2}$ rev. $7^{\prime} \quad[\ldots]^{\text {gees }}$ gag gi- nindan $\mathrm{KAD}^{\text {?-na }}$

126 nit[adam]-a-ni $\left.\Gamma_{\text {nin }}(-){ }^{d} a-z i-m u_{2}\right\urcorner-a$

A iii obv. 42 nit[adam]-a-ni $\left.{ }^{\ulcorner} \operatorname{nin}(-)^{d a} a-z i\right\urcorner-m\left[u_{2}-a\right]$

$\mathrm{Sb}_{2}$ rev. $\left.8^{\prime} \quad[\ldots] \quad\right]-{ }^{\circ}-\mathrm{mu}_{2}{ }^{\mathrm{n}}-\mathrm{a} \operatorname{~nin}_{9}$ lugal-la-ra

127 dub-[sar mah] 'dumu? a-ra-li-[ra]

A iii obv. 43 dub-[ sar mah dumu? a-ra]-li-[ra ${ }^{90}$

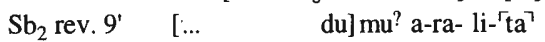

127 a $\mathrm{Sb}_{2}$ rev. $10^{\prime}$ [dge] $\mathrm{g}$ štin-an-na nin 9 lugal-la-'ra?

128 [s]ipa ur-dnamma(-ke $\left.{ }_{4}\right) e_{2}$-gal-(l)a-na geš im-ma-ab-tag-ge

A iv rev. 1 [sipa ur-dnamma(-ke $\left.{ }_{4}\right) e_{2}$-gal-(l)a- na ĝeš im-ma-ab-tag-ge]

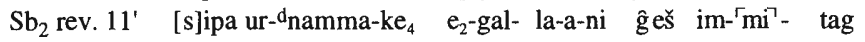

128a $\mathrm{Sb}_{2}$ rev. 16' [gud $\mathrm{sa}_{7} \mathrm{ma} \mathrm{s}_{2} \mathrm{~d}[\mathrm{u}-\mathrm{du}]$ udu niga i[m-ma-ab-lah- $\left.{ }_{4}{ }^{?}-\mathrm{a}\right]^{91}$

124 A stylus ... (with) everything (concerning) the scribe, ${ }^{92}$

125 A surveying tape made of lapis lazuli and a measuring rod of one $n$ i $n \mathrm{~d}$ a $n$ . . $9^{93}$

126 To his $^{94}$ sp[ouse] Ninazimua ${ }^{95}$

127 The [chief] scribe, denizen? of Arali,

127 a [Ĝe]štinana, the king's sister,

128 Shepherd Urnamma offers as a sacrifice in her palace.

128a [The magnificent bulls], the per[fect bu]cks and the fattened sheep [which have been brought?],

\footnotetext{
90 Read according to photo; Langdon's copy shows -ra-li; neither sign exists on the tablet any more.

91 After this line only a line after a break is visible, so maybe one line is not preserved. If this is not so and line $128 \mathrm{a}$ is the last line on tablet $\mathrm{Sb}_{2}$, then line 129 could be the catchline to $\mathrm{Sb}_{3}$ and line 128a must be restored accordingly i[m-ma-ab-tuku-a]. For this phenomenon, cf. Heimpel, JCS 33 (1981) 71 ad (4) and Cooper, Curse of Agade 45.

92 Or: "(...) which belongs to the scribal art".

93 Susa: "[...] a peg, a (n i n d a n) measuring rod ... .".

94 i.e. Ninĝ ešzida's.

95 Susa adds "(...) the king's sister".
} 
129 [gud $\mathrm{sa}_{7}$ ] $\operatorname{mašs}_{2}$ du-du udu niga im-ma-ab-tuku-a

A iv rev. $2 \quad[\ldots]\left\ulcorner\mathrm{x} \mathrm{x}^{\urcorner}[\ldots]\right.$

$\mathrm{Sb}_{3}$ obv. $1^{96}$ [gud sa $\mathrm{sa}_{7}$ mašs $\check{s}_{2}$ du-du udu niga im-ma-ab-tuku-a

$130[\ldots]\left\ulcorner_{x}\right\urcorner-a-b i\left[\left(\begin{array}{lll}x & x\end{array}\right)\right]\left\ulcorner_{x}\right.$ ?

$\begin{array}{ll}\mathrm{A} \text { iv rev. } 3 & {[\ldots]\ulcorner\mathrm{x}\urcorner \text {-a-bi }[(\mathrm{x} x \mathrm{x})]\ulcorner\mathrm{x} ?} \\ \mathrm{Sb}_{3} & \text { om.? }\end{array}$

131 [d?a?-nun?-n]a ensi ${ }_{2}$ gal kur-ra-ke ${ }_{4}$ mu-na-da-ab-š[um $\left.{ }_{2} ?-\mathrm{m}\right] \mathrm{u}$

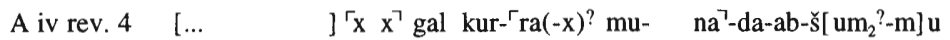

$\mathrm{Sb}_{3}$ obv. 2 [d? $\mathrm{a}$ ?-nun?-n] a ensi ${ }_{2}$ gal kur- ra-ke ${ }_{4}$ mu-un-na- da-ab-ku ${ }_{4}$

131a $\mathrm{Sb}_{3}$ obv. 3 [sipa u]r-d namma-ke $_{4} \mathrm{e}_{2}$-gal-a-ni!(IN) geš im-mi-in-tag-ge

132 [lugal-e] $\ulcorner\mathrm{x}\urcorner$ kur-ra-ke ${ }_{4}$ si bi ${ }_{2}$-in-sa ${ }_{2}$-a-ta

A iv rev. 5 [lugal-e] ${ }^{\ulcorner} \mathrm{x}^{797}$ kur-ra-ke ${ }_{4}$ si bi ${ }_{2}$-in-sa - -a-ta

$\mathrm{Sb}_{3}$ om.

133 [ur-d namma(-ke $\left.\left.\left.{ }_{4}\right)\right]{ }^{\prime}\right\urcorner$ kur-ra-ke ${ }_{4}$ si bi ${ }_{2}$-in-sa $a_{2}$-a-ta

A iv rev. 6 [ur- ${ }^{\mathrm{d}}$ namma(-ke $\left.\left.\left.{ }_{4}\right)\right]^{\ulcorner} \mathrm{x}\right\urcorner \mathrm{kur}-\mathrm{ra}-\mathrm{ke}_{4}$ si bi $\mathrm{bi}_{2}$-in- $\mathrm{sa}_{2}$-a-ta

$\mathrm{Sb}_{3}$ om.

$134\left[\right.$ ensi $_{2}$ ?] gal irigal-la-ke ${ }_{4}$-ne

A iv rev. 7 [.. ] ] irigal- la- $\mathrm{ke}_{4}-\mathrm{ne}$

$\mathrm{Sb}_{3}$ obv. 4 [ensi $\left.{ }_{2}^{?}\right]$ gal irigal ${ }_{2}-\mathrm{Ca}^{?}-\mathrm{ke}_{4}-\mathrm{e}-\mathrm{ne}$

129 [The magnificent bulls], the perfect bucks and the fattened sheep which have been obtained?,

$130[\ldots] \ldots$

131 He [giv]es? to the [Anun] a?, the great e $\mathrm{n} \mathrm{s}_{2}$ of the netherworld. ${ }^{98}$

131a [Shepherd U]rnamma offers as a sacrifice in/for their/his palace.

132 After [the king] had provided ${ }^{99}$ for the . . . of the netherworld,

133 After [Urnamma] had provided ${ }^{100}$ for the . . . of the netherworld,

134 The great [e $\mathrm{n} \mathrm{S}_{2}$ ?] of the underworld,

$96=$ Sb 12358 obv. 1.

97 Wilcke, $U T 116$ ad $132-33$ reads [ ...KUR ${ }_{6}$. ${ }^{I N A}$ ]NA in lines $132 \mathrm{f}$. and refers to lines $85 \mathrm{f}$.

98 Susa: "Were ushered with him (= Urnamma) into the presence of the [Anun]a? , the great $e \mathrm{n} \mathrm{s} \mathrm{i}_{2}$ of the netherworld".

99 Or: "properly performed".

100 Cf. preceding footnote. 
$\left.\left.135\ulcorner\mathrm{x}\urcorner[\ldots] \Gamma_{\mathrm{X}}\right\urcorner-\mathrm{su}_{2}-\mathrm{ke}_{4}\right\urcorner-\mathrm{ne}$

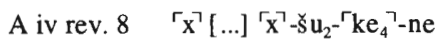

$\mathrm{Sb}_{3}$ obv. 5 [da]-nun- ${ }^{-n a}{ }^{\top} \mathrm{NI}_{3}\left(\right.$ inda $_{3} /$ nig $_{2}$ ) šu tag-ga-ba

136 ur-dnamma para ${ }_{10}$ gal kur-ra-ke ${ }_{4}$ mu-ni-ib-tuš- $\mathrm{u}_{3}-\mathrm{ne}$

A iv rev. 9 ur- ${ }^{\Gamma d]}\left[\right.$ namma para ${ }_{10}$ gal kur-r]a-ke ${ }_{4}$ mu-ni-ib-tuš- $\mathrm{u}_{3}$-ne

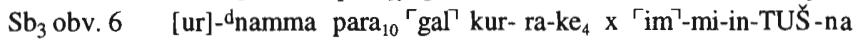

137 kur-ra ki-t[uš (...)] mu-na-ĝa $a_{2}-\mathrm{gaa}_{2}$-ne

A iv rev. 10 kur-ra ki-t $\left[\right.$ uš (...)] mu- na-ĝa $a_{2}-\mathrm{ga}_{2}-n e$

$\mathrm{Sb}_{3}$ obv. $7 \quad[\mathrm{x}-\mathrm{r}] \mathrm{a} \cdot \mathrm{ki}$-tus $\quad$ mu-un-na-ga $\mathrm{g}_{2}-\mathrm{ga}_{2}$

138 enim du $\mathrm{du}_{11}$-ga ([...]) 「dereš-ki-gal-la-ka-ta

A iv rev. 11 enim du du $_{11}$-ga $([\ldots])^{\Gamma \mathrm{d}\urcorner}$ ereš-ki-gal-la-ka-ta

$\mathrm{Sb}_{3}$ obv. 8 「enim? du $\mathrm{u}_{11}$-ga dereš-ki-gal-la-ke

139 eren $_{2}$ geštukul(-) $\Gamma^{\top} \mathrm{X}^{\urcorner}([\ldots])$ en-na ba-ug ${ }_{5}$-ga

A iv rev. 12 eren 2 ĝeš tukul(-) $\ulcorner x\urcorner([\ldots])$ en-na ba-ug ${ }_{5}-$ ga

$\mathrm{Sb}_{3}$ obv. 9 lu ĝestukul-la in-na ba- $\mathrm{rub}_{2}{ }^{\urcorner}-\mathrm{e}$

$140 \mathrm{lu}_{2}$ nam-da - ga en-na ba- $\left.{ }^{\ulcorner} \mathrm{zu} \cdot-\mathrm{x}\right\urcorner-\mathrm{a}$

A iv rev. $13 \quad \mathrm{lu}_{2}$ nam-da $-\ulcorner$ ga $\urcorner$ en-na ba- $\left.{ }^{\ulcorner} \mathrm{zu} ?-\mathrm{x}\right\urcorner-\mathrm{a}$

$\mathrm{Sb}_{3}$ obv. $\left.10 \Gamma \mathrm{lu}_{2}\right\urcorner$ nam-da - ga in-na ba-mud-e

135 The $[\ldots]$ of the $[\ldots]^{101}$

136 Seat Urnamma on the great dais of the netherworld, ${ }^{102}$

137 Set up a dwelling place for him in the netherworld.

138 At the command of Ereškigal

139 Soldiers, so far as they have died in action ${ }^{103}$

140 And sinners, so far as they have been recognized? ${ }^{104}$

101 Susa: "The [A]nuna, after having seized the offerings".

102 Susa: "And having . . . seated Unnamma on the great dais of the netherworld".

103 Susa: "Men of arms, so far as they have fallen".

104 Susa: "And sinners, so far as they have been produced". 
141 lugal-la šu-ni-še $\left.{ }_{3} \Gamma_{i m}\right\urcorner$-ma-ab-šum ${ }_{2}$-mu-ne

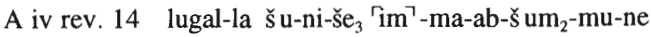 $\mathrm{Sb}_{3}$ om.

142 ur-dnamma ki-bi-še ${ }_{3}\ulcorner x\urcorner[x(x)]\ulcorner x\urcorner-e s ̌ ~ i[m]-\left\ulcorner x\right.$ x x ${ }^{\prime}([\ldots])$

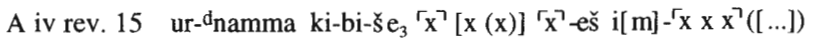

$\mathrm{Sb}_{3} \quad$ om.

143 ses ki-ag $\hat{g}_{2}-\mathrm{ga}_{2}$-ni d bil $_{4}$-ga-mes-ra

A iv rev. 16 ses ki-ag $\hat{g}_{2}-\mathrm{g} \mathrm{a}_{2}-\mathrm{ni}{ }^{\mathrm{d}} \mathrm{bil}_{4}-\mathrm{g}[\mathrm{a}-\mathrm{m}] \mathrm{es}-[\mathrm{ra} / \mathrm{da}]$

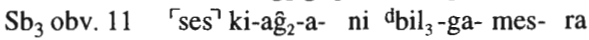

144 e-ne di kur-ra $i_{3}-k_{5}$-de $e_{3}$ ka-aš kur-ra $i_{3}$-bar?-re

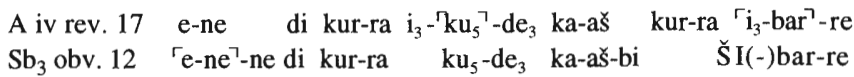

$145 \mathrm{u}_{4} \quad \operatorname{imin}_{4} \quad \mathrm{u}_{4}$ u-am ${ }_{3}$ ba-zal-la-ba
A iv rev. 18
$u_{4}$ imin
$u_{4} \quad u-a m_{3} \quad$ ba-zal-la-ba
$\mathrm{Sb}_{3}$ obv. 13

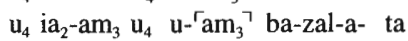

146 lugal-ĝu $u_{10}$ i-si-iš ki-en-gi-ra-ke ${ }_{4} / \mathrm{sa}_{2}$ nam-ga-mu-ni-ib-du ${ }_{11}$
A iv rev. 19 lugal-ĝu ${ }_{10}$ i-si-iš ki- en-gi-ra-ke ${ }_{4} / \mathrm{sa}_{2}$ nam-ga- ${ }^{-} \mathrm{mu}^{\urcorner}$-ni-ib-du ${ }_{11}$ D rev. $1^{\prime} \quad[\ldots]^{\top} \mathrm{x}^{\top}[\ldots]$
$\mathrm{Sb}_{3}$ obv. 14 lugal-e i-si-iš k[i]-en-gi-ra si(-) $\mathrm{gu}_{7}$-mu-un-na- ${ }^{\ulcorner} \mathrm{du}_{11}{ }^{7}$

141 They give into the king's hands.

142 They ... [...] Urnamma there [...].

143 For ${ }^{105}$ his beloved brother Gilgameš

144 He passes the judgment of the netherworld and renders the decisions of the netherworld. 106

145 After seven ${ }^{107}$ days, ten days had passed,

146 The wails of Sumer reached also my lord, 108

\footnotetext{
105 Or: "With".

106 Susa: "They pass the judgment of the netherworld and render its decisions". However, cf. also the commentary ad 144, p. 176.

107 Susa: "After five days (...)".

108 Susa: "(..) the king".
} 
147 ur-dnamma i-si-iš ki-en-gi-ra-ke ${ }_{4} / \mathrm{sa}_{2}$ nam-ga-mu-ni-ib-du ${ }_{11}$

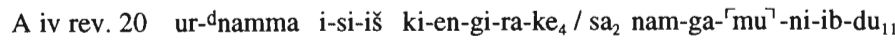
D rev. $2^{\prime} \quad[\ldots \quad]$ ki-en- ${ }^{-}$gi $-[\ldots$
$\mathrm{Sb}_{3}$ obv. $15 \quad{ }^{\prime} \mathrm{ur}^{\top}-\mathrm{d}_{\text {namma i-si-iš }}$ ki-en-gi-ra $\quad$ si(-) $\quad \mathrm{gu}_{7}-\mathrm{mu}-\mathrm{un}-{ }^{\ulcorner} \mathrm{na}^{\urcorner}-[\mathrm{d}] \mathrm{u}_{11}$

$148 \operatorname{bad}_{3}$ uri $_{2}{ }^{k i}$-ma nu-mu-un-til-la-ni
A iv rev. 21 bad $_{3}$ uri $_{2}{ }^{\mathrm{ki}}-\mathrm{ma} \Gamma^{\top} \mathrm{nu}{ }^{\top}-$ mu-un-til-la-ni
D rev. 3' [... $\quad]^{\text {nki? }}$-ma nu- mu-[... ]
$\mathrm{Sb}_{3}$ obv. 16 [ba]d $\mathrm{d}_{3}$ uri $_{2} \mathrm{ki}_{-}$ma nu-mu-un-til-li-na

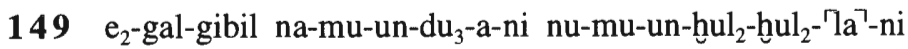
A iv rev. 22 e $e_{2}$ gal-gibil na-mu-un- ${ }^{\top} u_{3}-a^{\urcorner}-n i$ nu-mu-un-hul $2-$ hul $_{2}-\left\ulcorner\mathrm{la}^{\urcorner}-\right.$ni
D rev. 4' [... ]-mu-un- du $_{3}-a-n a$
$\mathrm{Sb}_{3}$ obv. $\left.17 \quad \mathrm{e}_{2}\right\urcorner$-gal- $\left\ulcorner\right.$ gibil na-mu-un- $\mathrm{du}_{3}-\mathrm{a} \quad \breve{s} \mathrm{a}_{3}$-bi nu- nu-mu- $[\ldots]$ $\mathrm{hul}_{2}-\quad \mathrm{l}[\mathrm{a} \cdot-\mathrm{x}(\mathrm{x})]$

150 sipa-de e $_{2}$-a-ni sag li-bi $i_{2}$-in-AK-ni
A iv rev. 23 sipa- de e $_{2}$-a-ni ${ }^{109} \Gamma_{\text {sag }} \quad$ li $^{\top}-$-bi $_{2}-$-in-AK-ni
D rev. $5^{\prime} \quad[\ldots \quad] \quad{ }^{\top} \mathrm{e}_{2}{ }^{\top}$-a-ni sag $\quad l i-b_{2}-i n-{ }^{\ulcorner}{ }^{\top 110}-[x]$
$\mathrm{Sb}_{3}$ obv. 18 [si]pa-[d]e ${ }_{3}$ ? $\mathrm{e}_{2}-\mathrm{a}-{ }^{r} \mathrm{ni}{ }^{\circ}$ šu dul ${ }_{3}$ li- bi-ra-a(-)[(xx)]

151 dam-a-ni ur $_{2}$-ra-na a-la nu-mu-un-ge ${ }_{4}$-a-ni

A iv rev. 24 dam-a-ni $u_{2}$ - ra-na $\left.\Gamma^{\top}\right\urcorner-[1] a$ nu-mu-un-ge 4 -a-ni

D rev. $6^{\prime} \quad\left[\ldots \quad\right.$ u $r_{2}-$ ra-na a- la nu-mu- $g\left[e_{4}-\mathrm{x}-\mathrm{x}\right]$

$\mathrm{Sb}_{3}$ obv. 19 [d]am ${ }^{r} \mathrm{ur}_{2}{ }^{?}{ }^{\top}$-ra-ni la-la-bi ${ }^{\mathrm{r}} \mathrm{nu}-\mathrm{ge}{ }_{4}{ }^{\mathrm{a}}-\mathrm{a}(-)[(\mathrm{xx})]$

152 dumu-ni du ${ }_{10}$-ba-na li-bi ${ }_{2}$-in-peš-a-ni
A iv rev. 25 dumu-ni du ${ }_{10}$-ba-na ${ }^{\top} l i{ }^{\top}-[b] i_{2}$-in-peš-
a- ni
D rev. 7' [... d]u $\mathrm{u}_{10}$-ba li- bi $\mathrm{i}_{2}$ - in-peš-
a- ${ }^{r}$ nî
$\mathrm{Sb}_{3}$ obv. 20 dumu-ni du $u_{10}$-ba-na li- bi- in-Š $\mathrm{A}_{3}\left(\right.$ peš $_{\mathrm{x}}$ ?). $\check{\mathrm{S}}_{3}-\ulcorner\mathrm{na}$

147 The wails of Sumer reached also Urnamma.

148 Over the fact that he had not completed the (city-)wall of Ur,

149. That he indeed had built the New-Palace but did not enjoy it (long enough), ${ }^{111}$

150 That the shepherd ${ }^{112}$ no longer fully satisfied his house(hold), ${ }^{113}$

151 That he no longer brought pleasure to his wife on his lap,

152 That he no longer raised his children on his knees,

\footnotetext{
109 Under -a-ni of $\mathrm{e}_{2}$-a-ni two gloss-signs are visible: AN and possibly MU? $\mathrm{MU}^{\text {? }}$. Wilcke, UT 42 reads $\mathrm{e}_{2^{-}} \mathrm{a}^{\text {an }}$-ni. 110 Beginning of AK possible.

111 Susa: "That the New Palace's interior, which he indeed had built, had not delighted him".

112 i.e. Urnamma.

113 Susa: "(..) put a protecting hand over his house(hold)".
} 
$153 \operatorname{nin}_{9} \mathrm{di}_{4}-\mathrm{di}_{4}$ im-bulug $\hat{g}_{3}$-bulug $\hat{g}_{3}-\mathrm{e}-\mathrm{NE}(\mathrm{ne})$ hi-li nu-mu-un-til-la-ni
A iv rev. $26 \quad \operatorname{nin}_{9} \mathrm{di}_{4}{ }^{\top}-\mathrm{di}_{4} \quad$ in $-\left\ulcorner\mathrm{x}^{\top}-[\ldots\right.$
] 'hुi-li nu-mu-un-til-la-ni?

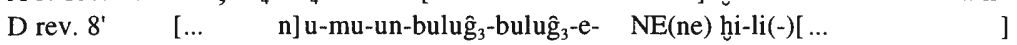

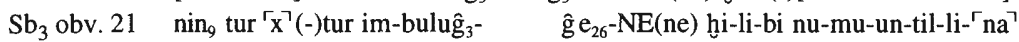

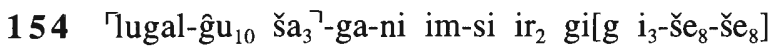

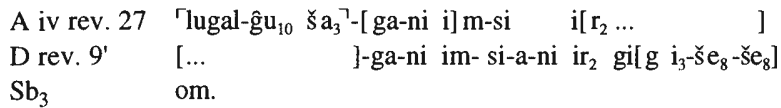

155 sipa zi i-lu niĝ $\hat{g}_{2}(-)$ me-gar ni ${ }_{2}$-te-na mi-ni-ib-be ${ }_{2}$

A iv rev. 28 sipa $z i \mathrm{i}-\left\ulcorner\mathrm{lu}^{\urcorner}[\right.$ni $] \hat{\mathrm{g}}_{2}(-)$ me-gar ni $_{2}$-te- na mi- $-\mathrm{x}^{\urcorner}(-\mathrm{x})-[\ldots]$

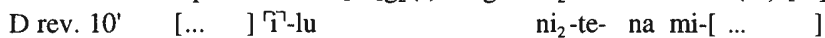

$\mathrm{Sb}_{3}$ obv. 22 sipa $\left\ulcorner\right.$ zi ${ }^{\mathrm{i}} \mathrm{i}-\mathrm{lu}$ nig. $\hat{\mathrm{g}}_{2}(-)$ me-gar $\mathrm{ni}_{2}$-ta-a- ni mi-ni-ib-be

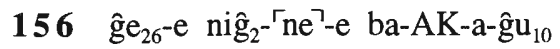

A iv rev. $29 \quad \mathrm{ge}_{26}-\mathrm{e} \mathrm{ni \hat {g } _ { 2 } -}-\mathrm{ne}^{\urcorner}-\mathrm{e}$ ba-AK-a-g $\mathrm{u}_{10}$

D rev. 11' [... m]a?-zu-a NE i[m-... ]

$\mathrm{Sb}_{3}$ obv. $23 \Gamma^{\mathrm{ge}} \mathrm{e}_{26} \mathrm{e}^{? ?}$ im-ma- zu-a ni ${ }_{2}$ im-ma-an-zu-a

157 digirir-re-e-ne-er mu-ne-gub-bu-nam / ki-ur ${ }_{3}$ mu-ne-ĝal ${ }_{2}$

A iv rev. 30 digirir- re-e-n[e]-er mu-ne-gub-bu-nam / ' $\mathrm{ki}^{\top}-\mathrm{ur}_{3}$ mu-ne-gal ${ }_{2}$

D rev. 12' [... ] nu-mu-ne-gub-b[u... ]

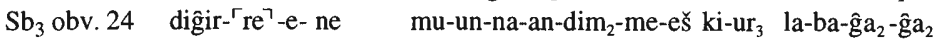

158 da-nun-na-ke $e_{4}$-ne he $e_{2}-$ gal $_{2}-1 \mathrm{la}$ pa mu-ne- $\mathrm{e}_{3}$-a
$A$ iv rev. 31 da-[nun-n]a-ke $e_{4}-$ ne he $e_{2}-g a_{2}-l a ~ p a ~ m u-n e-e_{3}-a$
D rev. 13' [... ] he $\mathrm{e}_{2}-\mathrm{g} \mathrm{al}_{2}-1[\mathrm{a} \ldots$
$\mathrm{Sb}_{3}$ obv. 25 da-nun-na- $\mathrm{ke}_{4}-\mathrm{ne} \mathrm{hu}_{2}-\mathrm{gal}_{2}$ pa
]
$\mathrm{e}_{3}$ AK-NE

153 That he no longer brought the attractiveness of the young, growing up sisters to maturity, ${ }^{114}$

154 My lord - his heart is choked up - [weeps bit]ter tears on account of that.

155 The faithful shepherd utters a silence-imposing lament concerning himself ${ }^{115}$ :

156 "Although it was me who has done all this ${ }^{116}$ :

157 I indeed served the gods and have provided them with homes. ${ }^{117}$

158 Although, having revealed abundance to the Anuna,

114 Source D: "(...) who had not yet grown up (...)".

115 Source D omits "silence-imposing".

116 Susa and perhaps source D: "(For) me who has experienced, who has experienced fear".

117 Source D: "That I have not served [ the gods, ...]". Susa may have a corrupt text. 
159 geš- $[\mathrm{n}] \mathrm{u}_{2} \quad \mathrm{u}_{2}$ za-gin ${ }_{3}$ bara ${ }_{3}$-ga-ba gi $_{16}$-sa mu-ne-gar- ${ }^{-}{ }^{r a}$-ĝu $\left.\mathrm{u}_{10}\right\urcorner$

A iv rev. 32 geš- $[n] u_{2} u_{2}$ za-gin ${ }_{3} \quad$ bara $_{3}$-ga-ba gi $1_{16}$-sa mu-ne-ĝ ar- ${ }^{\ulcorner}$ra-ĝ $u_{10}{ }^{\urcorner}$

D rev. 14' [... $]{ }^{\top} \mathrm{xxx}^{\top} \mathrm{x}^{\top}[\ldots]$

$\mathrm{Sb}_{3}$ obv. 26 ĝě̌ gu-za za-gin ${ }_{3}$ niĝ $_{2}$ ba-ra-ga-aš gi ${ }_{16}$-sa ${ }^{\prime} \mathrm{mu}^{?}$ '(-x)-ni-ib ${ }_{2}^{\top}$-ge-na

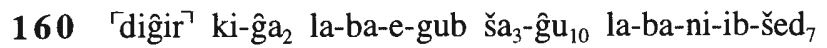

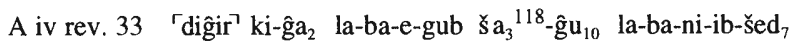

$\mathrm{Sb}_{3}$ om.

$161\ulcorner x\urcorner$-me-en niĝ $\hat{g}_{2}$ giškim $\mathrm{sa}_{6}-\mathrm{ga}-\mathrm{gu}_{10}$ an-gin ${ }_{7}$ mu-de ${ }_{3}-\mathrm{su}_{3}-\mathrm{ud}$

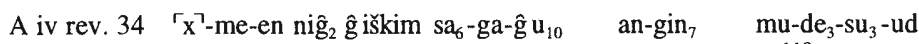
$\mathrm{Sb}_{3}$ obv. $27 \quad\ulcorner\mathrm{x}\urcorner[\mathrm{x}-\mathrm{e}] \mathrm{n} \quad \hat{\mathrm{g}}$ iškim $\mathrm{sa}_{6}$-ga-ĝ $\mathrm{u}_{10}$ kur an- ${ }^{\ulcorner} \operatorname{gin}_{7}{ }^{?} / \mathrm{ba} \mathrm{x}{ }^{1119}-\mathrm{DU}$

$\left.162[(x)] ?{ }^{r} u_{4}\right\urcorner$-da gub-ba $s a_{2}-a-g a_{2}$ a-na šu ba-ni-ti

A iv rev. $35 \quad[(x)]^{?}{ }^{r} u_{4}{ }^{\top}$-da gub-ba sa $a_{2}-a-g a_{2}$ a-na šu ba-ni-ti

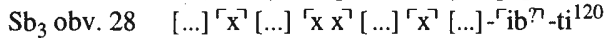

$163[\hat{g}] \mathrm{i}_{6}-\mathrm{da}$ gub $\mathrm{u}_{3}$ nu-ku-ga $\mathrm{a}_{2}-\mathrm{a} \quad \mathrm{u}_{4}$ im-ma-ni-til

A iv rev. $36[\hat{g}] \mathrm{i}_{6}$-da gub $\mathrm{u}_{3} \quad$ nu-ku-ĝ $a_{2}-\mathbf{a} \quad u_{4}$ im-ma-ni-til

$164\left[\mathrm{i}_{3} / \mathrm{i} / \mathrm{e}\right]-\mathrm{ne}-\mathrm{es}_{2}$ im an-ta $\check{\mathrm{s}}^{\mathrm{g}} \mathrm{g}_{3}-\mathrm{ga}_{2}-\mathrm{gin}_{7}$

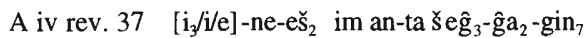

E obv. 1' $[\ldots] \quad]^{\top} x^{\top}[\ldots$

159 I have placed for them treasures on their beds spread with fresh herbs, ${ }^{121}$

160 No god whatsoever assisted me, nor was my heart relieved!

161 I am ...., anything that could have been a portent favourable to me was as far from me as heaven. ${ }^{122}$

162 What have I obtained by being so zealous serving (the gods) by day?

163 I have (even) spent the time sleeplessly serving (the gods) by night!

164 But now, like rain that has fallen from the skies,

118 Underneath the $\mathrm{SA}_{3}$-sign there is a gloss GES.

$119\ulcorner\mathrm{X}\urcorner \neq \mathrm{su}_{3}$; perhaps read $[\mathrm{m}] \mathrm{u}$ ?-DU.

120 Space of about two to three lines at the end of the obv. and at the beginning of the rev.

121 Susa does not make any sense and might be due to a dictation error.

122 Susa: "(..) as? the netherworld and heaven". 
165 [me]--li?-e-a šeg ${ }_{12}$ uri ${ }_{2}{ }^{k i}-m a-s ̌ e_{3}$ šu nu-um-ma-ni $i_{10}-n i_{10}$

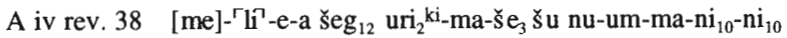

E obv. 2' [.. $\quad]]^{\ulcorner} \mathrm{Seg}_{12}{ }^{\prime} \mathrm{u}\left[\mathrm{ri}_{2 / 5}{ }^{\mathrm{ki}}-\mathrm{ma} \ldots\right.$

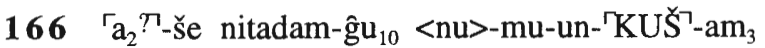

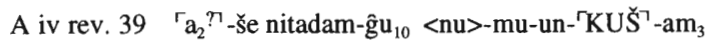

E obv. $3^{\prime} \quad[\ldots \quad$ ni] $\operatorname{ta}[$ dam-...

167 [i-1]u a-nir nigh ${ }_{2}$ gig-ga-a $u_{4}$ mi-ni- ${ }^{i b\urcorner}$-zal-zal-e

A iv rev. 40 [i-1]u a-nir nig $\hat{g}_{2}$ gig-ga-a $\mathrm{u}_{4}$ mi-ni- ${ }^{\mathrm{ib}} \mathrm{C}^{-}$-zal-zal-e

E obv. 4' [... a-ni]r nig $\hat{g}_{2}$ g[ig-ga-a...

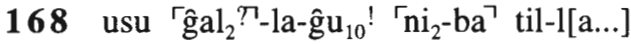

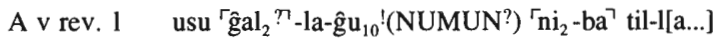

$\left.\begin{array}{llll}\text { E obv. } 5^{\prime} \quad[\ldots & -\hat{\mathrm{g}}] \mathrm{u}_{10} & \mathrm{n}\left[\mathrm{i}_{2}-\ldots\right. & \end{array}\right]$

169 ur-saĝ-me-`en šu nam? tar?-ra x-a? gi[g...]

A v rev. 2 ur-saĝ-me-`en š u nam? tar?-ra x-a` gi[g...]

E obv. $\left.6^{\prime} \quad[\ldots] \quad\right] \mathrm{x}^{\urcorner}[\ldots]$

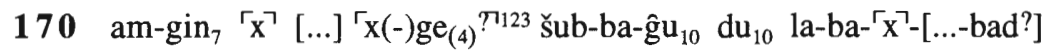

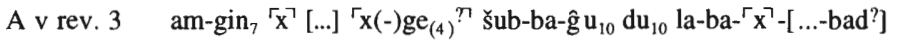

E obv. 7 [...]

171 gud mah-gin m $_{7}[\ldots]\ulcorner\urcorner$ SES-ga $a_{2}$ ba-[...]

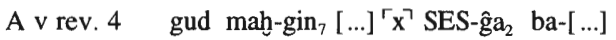

E obv. $8^{\prime} \quad[\ldots \quad]{ }^{\top} x^{\top}[\ldots$

165 Alas, I cannot return quickly back to the brickwork of Ur!

166 Is not my wife now a widow?

167 She spends (her) days in bitter wailing and lamentation!

168 My strength, which I once had?, but has spontaneously come to an end [...],

169 I, the hero: the hand of fate? [...] bitter[ly...].

170 Because I fell [...] . . . like a wild bull ${ }^{124}$ I was not [able to go] swiftly? any more.

171 Like a mighty bull $[\ldots] \ldots[\ldots]$.

123 The traces after $-\operatorname{gin}_{7}$ do not seem to support Wilcke's reading ${ }^{\mathrm{saman}_{\mathrm{x}}}{ }^{7}$ in $U T 68$, despite the well attested topos am/gud...-gin $\operatorname{gaman}_{(\mathrm{x})}$ šub "to throw over a tether as over a bull/ox".

124 Depending on $\left.{ }^{\prime} \times(-) g_{(4)}\right\urcorner$, alternatively perhaps: "Because $[\ldots] \ldots$ had fallen on me as on a wild bull". 


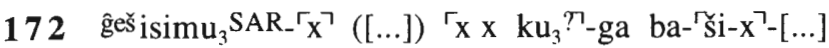

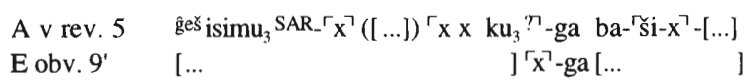

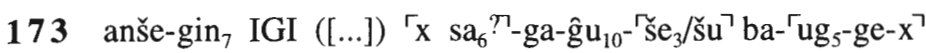

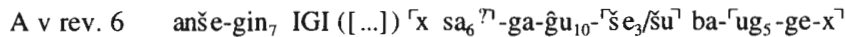

E obv. $10^{\prime} \quad[\ldots \quad]{ }^{\ulcorner} x^{\top}$-ga $[\ldots$

174 nitadam $\left\ulcorner x(x)^{\urcorner}\right.$-ĝu $u_{10}$ ma-ab?-hulu ši-in-TU-ra- ${ }^{\top} x^{\urcorner}$

A v rev. 7 nitadam $\left\ulcorner x(x)^{\urcorner}-g \hat{~} u_{10}\right.$ ma-ab?-hulu $s$ i-in-TU-ra- $\left\ulcorner x^{\urcorner 125}\right.$

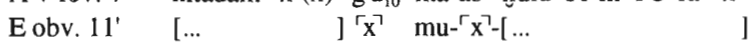

175 i-lu a- ${ }^{\prime}$ nir $\urcorner$ nig $\hat{g}_{2}$ gig-ga-a $\mathrm{u}_{4}$ mi-ni-ib-zal-zal-e

A v rev. 8 i-lu a- $\ulcorner$ nir $\urcorner$ nig $\hat{g}_{2}$ gig-ga-a $u_{4}$ mi-ni-ib-zal-zal-e

E obv. $12^{\prime} \quad[\ldots \quad$ gi] $]$ g-ga-a $[\ldots$

176 d ${ }^{\top}$ udug-sa ${ }^{\urcorner}$-ga-ni bar-ta ba-da-gub

A v rev. 9 drudug-sa ${ }_{6}^{\urcorner}$-ga-ni bar-ta ba-da-gub

E obv. 13' [... ]-ni b[ar-.. ]

177 d[lamma s]a $a_{6}$-ga-ni saĝ-ĝa $a_{2}-{ }^{\ulcorner} n a^{\urcorner}$li-bi $i_{2}$-in-haa-za

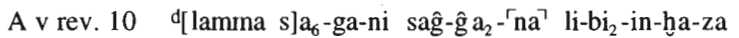

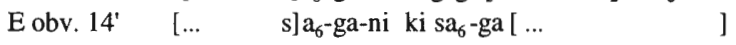

$178 \mathrm{~d} n[\mathrm{i}] \mathrm{n}$-sumun ${ }_{2}$-na-ke ${ }_{4} \mathrm{a}_{2}$ mah̆-a-ni saĝ-ĝa ${ }_{2}$-na li-bi ${ }_{2}$-in-ge-en

A v rev. $11 \quad d_{n}$ [in-sumu] $n_{2}$-na-ke ${ }_{4} \quad a_{2}$ mah-a-ni saĝ-g $a_{2}$-na li-bi $i_{2}$-in-ge-en

E obv. 15' [dni] n-sumun ${ }_{2}$-na-ke ${ }_{4}$ a $_{2}$ mah-a- $[\ldots$

172 [Like?] a shoot [...], the precious [...].

173 Like a donkey [...] my fine [...], I have died.

174 One has destroyed for me my ... wife, and now she has fallen ill?

175 She spends (her) days in bitter wailing and lamentation!

176 Her benevolent $\mathrm{u}$ d u g-spirit stood aside (from her),

177 Her benevolent [guardian]-spirit did not take care of her. ${ }^{126}$

178 Ninsumun did not firmly rest her mighty arm on her head. 
179 dnanna en dAŠ-im ${ }_{2}$-babbar šu-ta nu-un-ri

A v rev. 12 dnan[n]a en ${ }^{d} A \breve{S}$-im ${ }_{2}$-babbar šu-ta nu-un-ri

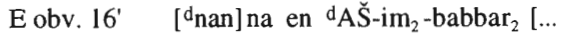

180 den-ki lugal eriduki-ga-ke ${ }_{4}{ }^{2} \mathrm{~T}$-ra ba-ra-ta-an- $\mathrm{e}_{3}$

A v rev. 13 den-ki $\left\ulcorner\right.$ luga $\left\ulcorner\right.$ eriduki-ga-ke ${ }_{4}{ }^{\ulcorner}{ }^{\top}{ }^{127}$-ra ba-ra-ta-an-e ${ }_{3}$

E obv. 17' [d]en-ki lugal eriduki-ga-k[ $e_{4} \ldots$

181 PEŠ.PEŠ-a-ni im-ma-ni-in-si-ig enim šu nu-mu-un-di-ni-ib-ge ${ }_{4}$

A v rev. 14 PEŠ.PEŠ-a-ni im-ma-ni-in-si-ig enim šu nu-mu-un-di-ni-ib-ge ${ }_{4}$

E obv. 18' [P]EŠ- a-ni ba- ni-in- ${ }^{\ulcorner}$si-ig ${ }^{\prime}[\ldots$

182 geš $\mathrm{ma}_{2}-$ gin $_{7}$ tumu sumur ${ }_{\mathrm{x}}$-ra ba-ra-ab-diri geš dimgul nu-mu-na-kalag

A v rev. 15 ĝeš $\left\ulcorner\operatorname{ma}_{2}\right.$-gin 7 tumu sumur ${ }_{x}$ (SAĜ)-ra ba-ra-ab-diri $\hat{g} e s ̌$ dimgul nu-mu-na-kalag

E obv. 19' $\operatorname{ma}_{2}$-gin 7 tumu sumur-ra $[\ldots$

183 anše edin-na-gin ${ }_{7} \mathrm{PU}_{2}$ hulu ba-an-tum ${ }_{2}$-mu-da? šu dugud $\operatorname{lu}_{2}$ mu-un-ĝar

A v rev. $16 \quad[\ldots \quad-n] a-g i n_{7} \mathrm{PU}_{2}$ hulu ba-an-tum ${ }_{2}$-mu-da ${ }^{?}{ }^{128}$ su dugud $\mathrm{lu}_{2}$ mu-un-g ar E obv. $20^{\prime} \quad$ anše edin-na-gin ${ }_{7} P\left[\mathrm{U}_{2} \ldots\right.$

$\mathrm{Sb}_{3}$ rev. $1^{129}$ traces

$184 \Gamma_{\text {piriộ }}-$ gin $_{7}$ a-RU-ub-ba ba-šub-ba en-nu $l_{2}$ mu-un-du

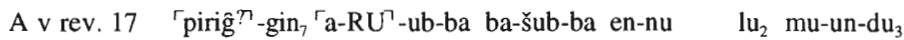

E obv. 21' ${ }^{\prime}$ piri ${ }^{\urcorner}-\operatorname{gin}_{7}$ a-RU- ba ba-[... ]

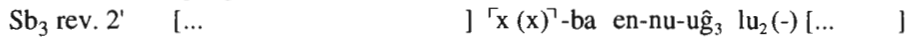

179 Nanna, lord AŠimbabbar, was/did not ....

180 Enki, the lord of Eridu, brought her out of . ...

181 He tore out her ...., to her disadvantage there was no answer to that.

182 Like a boat in gusty winds one set her adrift, the mooring pole was not strong enough for her.

183 As on a wild ass for which one lays out a perilous pit, they laid a heavy hand (on her).

184 As for a lion which has fallen into a pitfall, they set up a guard. 
185 ur-gin ĝešaz-la $_{2}$-e mu-un-dab ${ }_{5}$ me-a lu $\mathrm{lu}_{2}$ mu-un-gar

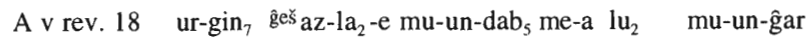
E obv. $22^{\prime} \quad$ [ur $]-\mathrm{gin}_{7} \quad \mathrm{az}^{-} \mathrm{la}_{2}-[\ldots$
$\mathrm{Sb}_{3}$ rev. $\left.3^{\prime} \quad[\ldots] \quad\right]$ mu-un-DI me-a lu $\mathrm{u}_{2}-$ bi nu- $\left.{ }^{-} \mathrm{x}(-\mathrm{x})\right)^{-}-[\ldots]$

186 dutu DI $\left.r_{x(-)}\right\urcorner^{\urcorner}$geš nu-um-mi-in-la $/$a $\urcorner u_{2}^{\urcorner} /\left[\right.$lu]gal-ĝu $u_{10}$ mu-un-si
A v rev. 19 dutu DI $\ulcorner x(-) x\urcorner$ g eš nu-um-mi-in- $\left.\left.l a_{2} / a^{\top}\right\urcorner u_{2}\right\urcorner /[l u]$ gal- $\hat{g} u_{10}$ mu-un-si
E obv. $23^{\prime} \quad[\ldots]^{\top} \mathrm{DI}^{?} \mathrm{x}^{\urcorner}[\ldots$
$\mathrm{Sb}_{3} \quad$ om.

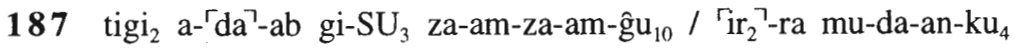

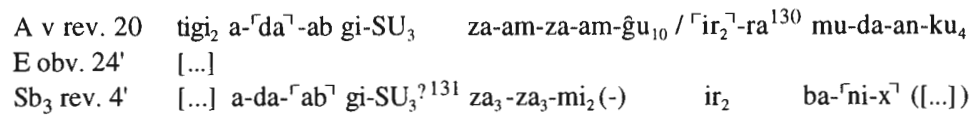

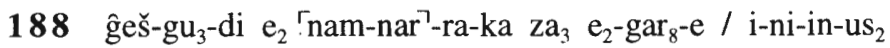

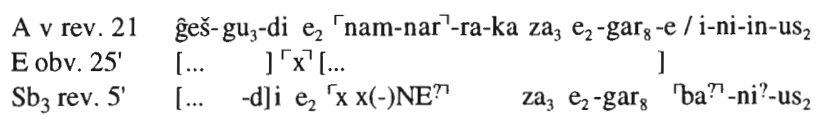

189 geš gu-za hi-li-bi nu-mu-til- -la?-ĝ $\mathrm{gu}_{10}$

\begin{tabular}{|c|c|}
\hline & 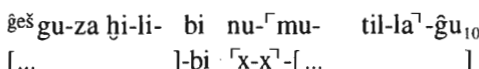 \\
\hline $\mathrm{b}_{3} \mathrm{re}$ & {$[\ldots] \Gamma^{\ulcorner} x^{\top}[\ldots-1] i^{?}-\left\ulcorner b^{\urcorner}\right.$nu- mu-un-tij-li-na } \\
\hline
\end{tabular}

185 Like a dog she was snatched for the cage, they (thus) silenced her. ${ }^{132}$

186 Utu . . did not pay heed, the "O my man/lord!" filled her.

187 My t i g i- and a d a b-instruments, my ... flutes and my $\mathrm{z} \mathrm{a} \mathrm{m} \mathrm{z} \mathrm{a} \mathrm{m-}$ instruments were turned into tears because of me.

188 Someone propped the musical instruments against the wall in the conservatory of music.

189 That (/because), instead of my throne, whose luxuriance I had not exhausted,

\footnotetext{
130 A reading a-[ ni $] \mathrm{r}-\mathrm{ra}$ instead of $\mathrm{Tir}_{2}{ }^{-}$-ra cannot be ruled out.

131 Read perhaps -BU.

132 Or: "Like for a dog someone took hold of a cage". For the second half of this line a less likely translation is: "where (me-a) did they place her?".
} 
190 sahar $\mathrm{PU}_{2}$-saĝ-ĝga $\mathrm{a}_{2}-\mathrm{ka}^{\urcorner} \mathrm{lu}_{2}$ im-mi-in-tuš?-[ $\left[\mathrm{u}_{3} ?\right]-\ulcorner\mathrm{X}\urcorner$

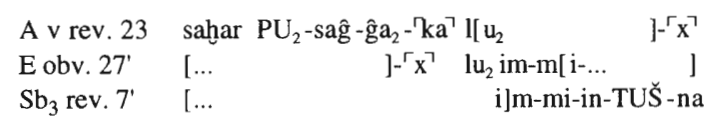

191 「geš-nu ki-nu $_{2}$ TUR-bi nu-mu-til-la?-ĝu $\mathrm{g}_{10}$

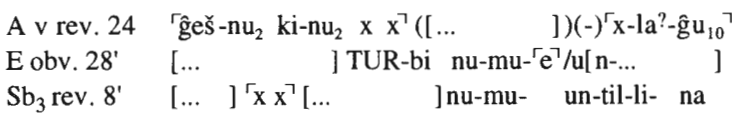

192 edin bar $s_{3}-g a-k a ~ l u_{2}$ im-mi-in- $n u_{2}-u_{3}-d a$

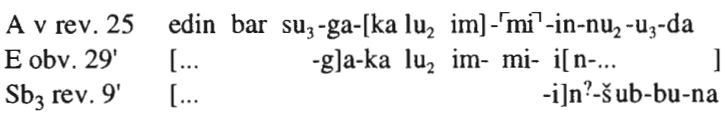

193 me-li-e-a dam-ĝu $\mathrm{gr}_{10} \quad \mathrm{ir}_{2}$-ra dumu-ĝu $\mathrm{u}_{10}$ a-nir-ra

A v rev. 26 me-li-e-a dam- $\left.{ }^{-} \hat{g} u_{10} i_{2}-r a\right\urcorner$ dumu-ĝu $u_{10}$ a-nir-ra

E rev. $1 \quad[\ldots \quad]$ dam- $\mathrm{gu}_{10} \quad \mathrm{ir}_{2}-\mathrm{am}_{3}$ dumu-g $\mathrm{u}_{10}$ a-ni $\left[\mathrm{r}-\mathrm{am}_{3}\right]$

$\mathrm{Sb}_{3}$ rev. $10^{\prime} \quad[\ldots]$ traces $[\ldots]^{\mathrm{X}} \mathrm{X}-\mathrm{KU} \mathrm{T}^{\text {? } 133}$

$194 \operatorname{lu}_{2}$ nig $\hat{g}_{2} \quad$ du $_{11}$-ga-ĝa $a_{2}$ i-lu balaĝ-di-gin ḩe $_{2}$-na-du ${ }_{12}$-uš

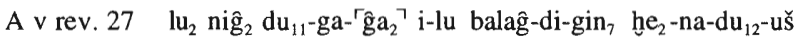
E rev. $2 \quad\left[\ldots \quad\right.$ d] $u_{11}$-ga- ga $_{2}$ i-lu balag - di-gin ${ }_{7}$ he $\left.e_{2}-[\ldots]\right]$
$\mathrm{Sb}_{3} \quad$ om.

$195 \mathrm{u}_{4} \quad \mathrm{ur}_{5}-\mathrm{gin}_{7}$ im-ma-ab-AK-a-ĝ $\mathrm{u}_{10}$
A v rev. $28 \quad \mathrm{u}_{4} \quad \mathrm{ur}_{5}-\mathrm{gin}_{7}$ im-ma- ab-AK-a-ĝ $\mathrm{u}_{10}$
E rev. 3
$\mathrm{Sb}_{3}$
$\left[\ldots \mathrm{ur}_{5}-\mathrm{gi}\right] \mathrm{n}_{7}$ im-ma!?-ab-[ ...
om.

190 They make me squat? in the dust of a pit!

191 That (/because), instead of my bed, the sleeping place whose ... I had not exhausted,

192 They make me lie down (way out) in the open, desolate steppe ${ }^{134}$ :

193 Alas, in front of my tearful wife, in front of my wailing children, ${ }^{135}$

194 They chanted like lamentation and dirge singers what I had uttered. ${ }^{136}$

195 When I was thus treated

\footnotetext{
$133 \mathrm{It}$ is not clear to which lines (if any) $\mathrm{Sb}_{3}$ rev. 9'-10' correspond.

134 Literally: "(..) in the steppe of the desolate exterior".

135 Literally: "(...) my wife, (all) tears, my children (all) wails".

136 Or: "They chanted as a lamentation like dirge singers what I had uttered".
} 
196 saĝ-kal dinana nin $\mathrm{me}_{3}$-a di-ga $\mathrm{a}_{2}$ nu-mu-un-til ${ }_{3}$

A v rev. 29 sâg-kal dinana nin $\mathrm{me}_{3}$-a di- $\mathrm{ga}_{2}$ nu-mu-un-til ${ }_{3}$

E rev. 4 [saĝ-ka]l ${ }^{d}$ inana nin $\mathrm{me}_{3}$-a di- $\mathrm{ga} \mathrm{a}_{2}$ nu-[... ]

$\mathrm{Sb}_{3}$ rev. 11' ${ }^{\prime} \mathrm{ki}^{\top}-$-sikil dinana nin ${ }^{\ulcorner} \mathrm{me}_{3}-\mathrm{a} \quad \mathrm{x}^{\urcorner}[\mathrm{x}]-\mathrm{a}^{\top}{ }^{\urcorner}$-ba si mu-da- $\left.{ }^{\ulcorner} \mathrm{ab}\right\urcorner-[\ldots]$

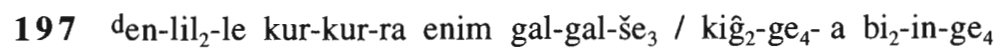

A v rev. 30 den-lil ${ }_{2}$-e kur-kur-ra enim gal-gal-še ${ }_{3} / \mathrm{kig}_{2}{ }^{1}$ ?-ge $\mathrm{ge}_{4}$-a bi $_{2}{ }^{7}$-in-ge

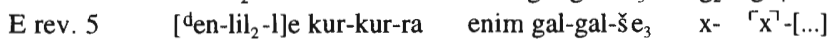

$\mathrm{Sb}_{3}$ rev. 12' den-lil $2_{2}$-le hur-saĝ gal-gal $\mathrm{kig}_{2^{-}} \mathrm{ge}_{4}-{ }^{-} \mathrm{a}^{?} \mathrm{bi}_{2^{-}} \mathrm{g}[\mathrm{e}]$

198 ki-bi-ta igi-ni gar-ra-ni

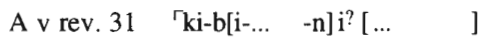

E rev. 6 'ki-bi-ta' igi-ni ĝar-r[a-n]i

$\mathrm{Sb}_{3}$ rev. 13' ki-bi-ta igi-ni g ar-ra- ni $[(\ldots)]^{137}$

199 dinana $e_{2}$-kur-za-gin ${ }_{3}-\check{s ̌}_{3}$ sun $_{5}$-na-bi mu-un-[...]

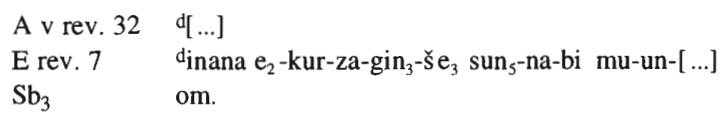

200 saĝ-ki huš den-lil $l_{2}-l_{2}-k a$ igi dub $_{2}-$ dub $_{2}-b u-\ulcorner x-[(x)]$
A v rev. 33
E rev. 8
saĝ-[ de] n-lil - -la - -ka
igi $\mathrm{dub}_{2}{ }^{?}-\mathrm{dub}_{2}{ }^{?}-\mathrm{x}^{\top}[\ldots \quad]$
saĝ-ki ḩuš den-lil $\mathrm{l}_{2}-\mathrm{la}_{2}-\mathrm{ka}$
igi dub $_{2}-$ dub $_{2}-$ bu- $-{ }^{\top} x^{\urcorner}-[(x)]^{138}$
$\mathrm{Sb}_{3}$ rev. 15
saĝ-ki ḩuš den- ${ }^{\top} \operatorname{lil}_{2}^{\urcorner}$
$\mathrm{ni}_{2}$ igi $\mathrm{dub}_{2}-\mathrm{dub}_{2}-\mathrm{be}_{2}$

196 The foremost, ${ }^{139}$ Inana, the lady (who was) in battle, was not present at my judgment."

197 Enlil sent a message to all (the foreign) lands ${ }^{140}$ concerning (this) very important matter.

198 Having set her gaze from there, ${ }^{141}$

199 Inana humbly [entered] Shining Ekur.

200 When she ... at Enlil's fierce forehead (he said):

\footnotetext{
137 After -ni the tablet surface is broken off but probably no more signs follow.

138 The traces in sources $\mathrm{A}$ and $\mathrm{E}$ after $\mathrm{dub}_{2}$ - $\mathrm{dub}_{2}$-bu- seem to exclude -d[a!-ni] (Wilcke's reading in UT 69 and 125).

139 Susa: "The young woman (...)".

140 Susa: "(...) all the big mountain ranges (...)".

141 "There" refers to the (foreign) lands (in line 197) where Inana received the news.
} 
201 nin gal $e_{2}$-an-na ${ }^{\top} \mathrm{GAM}^{\top}$-ma-ni nam-ma-da-ra- ${ }^{\top} \mathrm{ta}^{\top}-\left[\mathrm{e}_{3} / \mathrm{e}_{11}\right]$
A v rev. 34 nin gal $e_{2}-[\ldots \quad]{ }^{\ulcorner} G A M{ }^{\top}-m a-$ ni nam-ma-da-ra- $\left.{ }^{\top}{ }^{\top}\right\urcorner-\left[e_{3} / e_{11}\right]$
E rev. 9 nin gal $e_{2}$-an-na ${ }^{\top}$ GAM-ma!? -ni nam-ma- ${ }^{-}{ }^{-}{ }^{\top} x-(x)^{\urcorner}-[(x)]$
$\mathrm{Sb}_{3} \quad$ om.

202 sipa zi $e_{2}$-an-na-[k]a? mu-un-e $e_{3}$ igi nu-mu-ni-i[n-du $\left.u_{8}\right]$

A v rev. 35 sipa zi $e_{2}-[a n-n a-k]$ a? mu-un- $e_{3}$ igi nu-mu-ni-i[n-du $]$

E rev. 10 sipa zi $e_{2}$-an-na- $\left.{ }^{\top} \mathrm{ta}\right\urcorner$ mu-un- $e_{3}[\ldots]$

$\mathrm{Sb}_{3}$ rev. $14^{\prime}$ sipa zi $\mathrm{e}_{2}$-an-na mi-ni-ib $\mathrm{b}_{2}-\mathrm{e}_{3}$ igi nu-mu-ni- $\mathrm{d}[\mathrm{u}(-\mathrm{x})]$

$\mathbf{2 0 3}^{142}$ nin- $\mathrm{gu}_{10}\ulcorner\mathrm{~A}\urcorner[\mathrm{x}]\ulcorner\mathrm{x}\urcorner-\mathrm{a}-\mathrm{ba} \quad \mathrm{ug}_{3}-\mathrm{g} \mathrm{ga}_{2} \quad \mathrm{mu}-\mathrm{u}[\mathrm{n}-\ldots]$

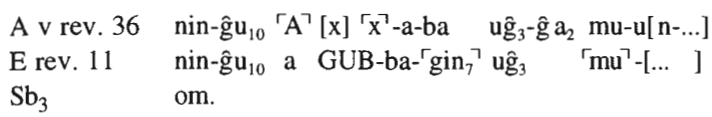

204 dinana $\mathrm{u}_{4}$ hुuš dumu gal dsu'en-na $\mathrm{A}\left\ulcorner\mathrm{x}\right.$ x x (x) ${ }^{\urcorner}$-ga

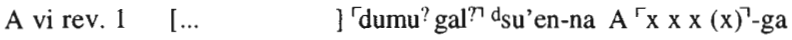

E rev. 12 dinana $u_{4}$ huš dumu gal dsu'en-na $\ulcorner A$ ? $[\ldots]$

$\mathrm{Sb}_{3} \quad$ om.

205 an $\mathrm{i}_{3}$ - dub $_{2}$-be ${ }_{2} \mathrm{Kki}^{\mathrm{r}} \mathrm{i}_{3}-\mathrm{sag}_{3}$-ge
A vi rev. $2 \quad[\ldots] \quad]-\mathrm{x}^{\urcorner}-\mathrm{be}_{2} \quad\left\ulcorner\mathrm{ki} \mathrm{i}^{\top}{ }^{\urcorner}-\mathrm{sag}_{3}-\mathrm{ge}\right.$
E rev. 13 an $\mathrm{i}_{3}-\mathrm{dub}_{2}-\mathrm{be}_{2}{ }^{143} \mathrm{k}[\mathrm{i} \ldots$ ]
$\mathrm{Sb}_{3}$
om.

206 dinana-ke tur $_{3}$ im-gul-e amaš im-tab-e
A vi rev. $3 \quad\left[\ldots \quad\right.$ t] $_{3}$ im-gul-e amaš im-tab-e
E rev. 14 dinana-ke tur $_{3}$ im-gul-e amaš [... ]
$\mathrm{Sb}_{3} \quad$ om.

201 "Great lady of the Eana, because he is bent down, he will not [come back] from there,

202 The faithful shepherd has left the Eana, one has not se[en] him (since). ${ }^{144}$

203 My lady, ... among the people [...]."

204 Inana, the fierce storm, eldest child of Su'en who....,

205 Makes heaven tremble, earth shake,

206 Inana destroys the cattle pen, devastates the sheepfold (saying):

\footnotetext{
142 Source A.

143 Erasure.

144 Susa: "One made the faithful shepherd leave the Eana, I? have not seen him (since)".
} 
207 an lugal diĝir-re-e-ne-ke ${ }_{4}$ in-ŠE $E_{3}$ ga-mu-un- $\left\ulcorner\mathrm{dub}_{2}\right\urcorner$

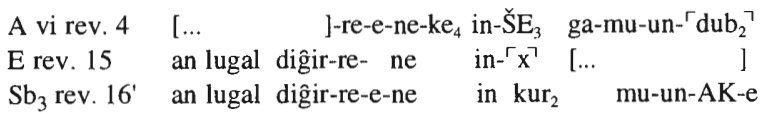

208 den-lil $1_{2}$-le sag mu-da-an-zi- ${ }^{\mathrm{ga}}{ }$ ? ${ }^{\circ}$ enim-bi a-ba mu-un-kur ${ }_{2}$

A vi rev. 5 [den-lil $\left.{ }_{2}-1\right]$ e saĝ mu-da-an-zi- $\left\ulcorner\mathrm{ga}^{?}{ }^{\text {? }}\right.$ enim-bi a-ba mu-un-kur ${ }_{2}$

E rev. 16 den-lil $l_{2}$-le saĝ mu-da-an-zi-g[ e? $\ldots$

$\mathrm{Sb}_{3} \quad$ om.

209 an lugal enim mah $d_{11}$ ga-ni enim-b[i] $r^{\top}$-ba mu-un-kur ${ }_{2}$

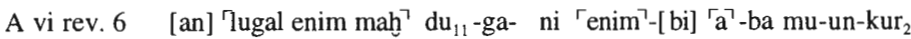

E rev. 17 an lugal enim mah $\mathrm{du}_{11}-\mathrm{gaa}^{\top}-\mathrm{ni}$ enim-b[i ]

$\mathrm{Sb}_{3}$ rev. 17 an lugal $\mathrm{du}_{11}$-ga-a-ni $\mathrm{du}_{11}-\mathrm{ga}-\mathrm{a}-\mathrm{ni}$ nu- $\mathrm{kur}_{2}-\mathrm{x}^{\urcorner}$

210 geš-hur kalam-ma hye ${ }_{2}$-me-a-gub-ba sag ba- ${ }^{\top}$ ra-ba-an?-us ${ }_{2}$-sa

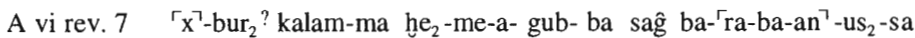

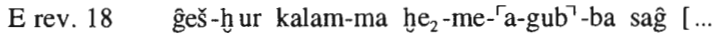

Fobv. $1^{\prime} \quad[\ldots \quad-b] a$ sag b[a?

$\mathrm{Sb}_{3}$ rev. 18' ur-dnamma DA?-mu-de ${ }_{3} \mathrm{ib}_{2}-\mathrm{la}_{2}{ }^{\circ} \mathrm{u}_{4}^{\urcorner}[\ldots]$

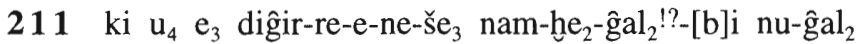

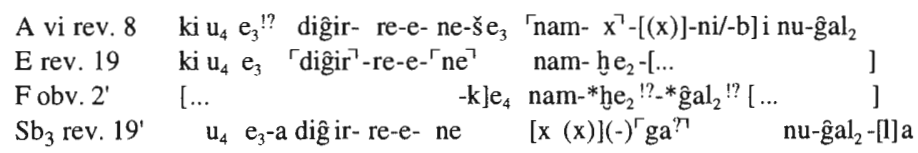

207 "I want to hurl the following as an insult at An, the lord of the gods ${ }^{145}$ :

208 That Enlil has raised the head with/in front of me - who has changed that word?

209 The sublime word that king An has uttered - who has changed that word? ${ }^{146}$

210 Rules in the land may have been established for us, but they have not been observed. ${ }^{147}$

211 For the place of the gods where daylight breaks, its abundance does not exist (any more).

145 Susa: "She (= Inana) gravely insulted An, the lord of the gods". If lines 204-206 are the content of the insult (cf. the commentary ad 204-206, p. 180), translate lines 204-207: "'Inana (...) devastates the sheepfold'. This is what I want to hurl as an insult at An (...)".

146 Susa: "What king An has uttered, what he has uttered, should" not be changed".

147 Susa differs totally from the Nippur version. 


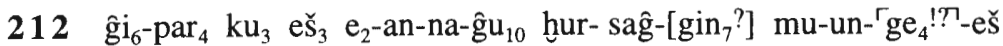

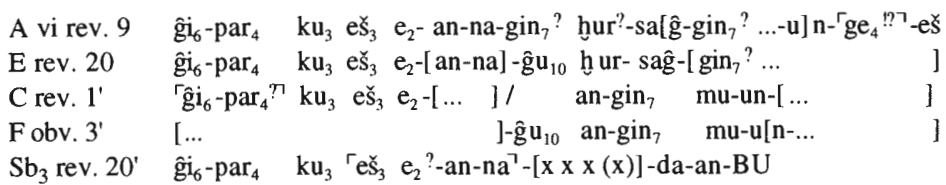

213 sipa-ĝu ${ }_{10}$ hुi-li-a-ni nu-uš-ma-an- ${ }^{\top} \mathrm{ku}_{4}{ }^{\top}-\mathrm{ku}_{4} / \mathrm{ge}_{26}$-e ba-ra-ku${ }_{4}-\mathrm{ku}_{4}-\mathrm{de}_{3}-\mathrm{en}$

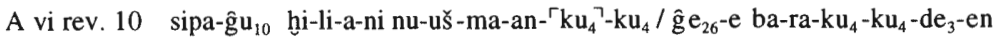

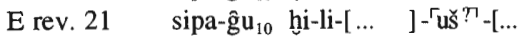

C rev. 2' sipa 'hi-li- na' nu-uš-m[a? $\left.\mathrm{a}^{?}-\ldots \quad\right] / \mathrm{ge}_{26}$-e a-na-aš ${ }^{\prime} \mathrm{x}^{\top}(-)[\ldots]$

F obv. 4' $\quad\left[\ldots \quad\right.$ n] u-uš ${ }^{\prime}-\mathrm{ma} !(* \mathrm{BA})-\mathrm{da}-\mathrm{an}-\mathrm{k}\left[\mathrm{u}_{4}-\mathrm{ku}_{4}\right] /[\ldots \quad$ a-n $] \mathrm{a}-\mathrm{aš} \mathrm{mu}-\mathrm{ku}_{4}-\mathrm{k}\left[\mathrm{u}_{4}{ }^{?}\right]$

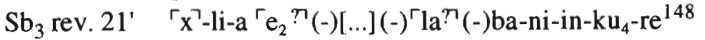

214 kala-ga-ĝu $u_{10} \quad \mathrm{u}_{2}$-šem-gin 7 edin-na nu-uš-ma-da-mu ${ }_{2}-\mathrm{am}_{3}$

A vi rev. 11 kala-ga-ĝgu $\mathrm{u}_{10} \quad \mathrm{u}_{2}$ - šem-gin $_{7} \quad$ edin- ${ }^{\ulcorner} \mathrm{na}{ }^{\top} \quad$ nu-uš-ma-da- $\mathrm{mu}_{2}-\mathrm{am}_{3}$

E rev. 22 kala-ga-g $u_{10} \quad u_{2}-\varsigma[e m]-g i n_{7}$ e[ din-na...

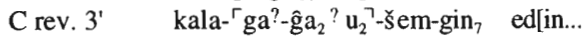

F obv. $5^{\prime} \quad[\ldots \quad-$ gi $] n_{7}$ ! edin-na nu-uš-ma-d[a- $\left.\mathrm{x} \mathrm{x}\right]$

215 ĝeš $\mathrm{ma}_{2} i_{7}$-da-gin 7 kar si-ga-ba nu-uš-ma-da-ge-na

\begin{tabular}{|c|c|c|}
\hline A vi rev. 12 & $\mathrm{i}_{7}$-da-gin ${ }_{7} \mathrm{kar}$ & si-ga- ${ }^{-} \mathrm{ba}^{n}$ nu-uš-ma- \\
\hline E rev. 23 & $\mathrm{ma}_{2} \quad \mathrm{i}_{7}-\mathrm{x}^{\urcorner}-[\ldots]$ & si-ga-na $[\ldots$ \\
\hline C rev. 4' & ges $\mathrm{ma}_{2} \mathrm{i}_{7}$-da- gin $\mathrm{k}[\mathrm{ar}$. & ]/nu-uš -ma- \\
\hline
\end{tabular}

212 My precious ĝ i p a r, my sanctuary Eana, they have ... [like?] a mountain! ${ }^{149}$

213 If only my shepherd would bring in to me his sexual charm (again); (otherwise) I will not enter there! ${ }^{150}$

214 If only my strong one would grow for me like herbs in the steppe!

215 If only like a river boat in its calm harbour he would hold firm for me!"151

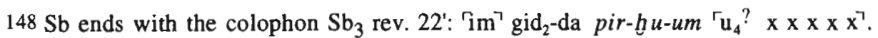

149 Sources C and F: "[...] like the heavens". Susa: "(...) [...] has been uprooted".

150 Sources $C$ and F: "If only the shepherd would enter to me (again) in/with his sexual charm. Why should I

(otherwise) enter there?".

151 Source $\mathrm{E}:$ " $(\ldots)$ in his calm harbour $(\ldots)$ ".
} 
216 dinana-ke ${ }_{4}$ i'-lu-ni he $e_{2}-k u r-k u-k u$ !

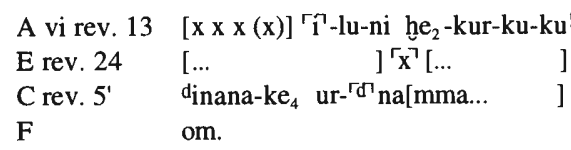

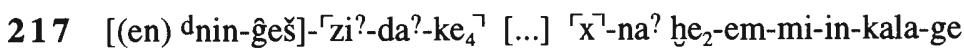

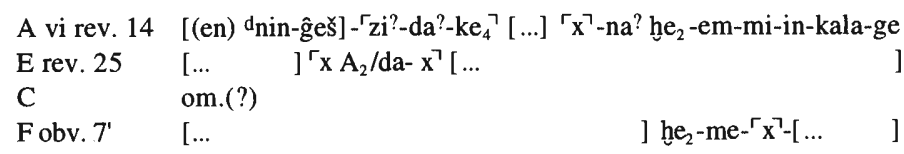

218 ur-dnamma(-)x (x-)[...] ba-ug ${ }_{5}$-ga-ĝ $\mathrm{gu}_{10}$

\begin{tabular}{|c|c|c|}
\hline A vi rev. 15 & ]$\left\ulcorner x^{\urcorner}[\ldots\right.$ & ] ${ }^{\ulcorner} \mathrm{ba}^{\top}-\mathrm{ug}_{5}-\mathrm{ga}-\hat{g u}_{10}$ \\
\hline E rev. 26 & ]$\left\ulcorner x^{\urcorner}[\ldots\right.$ & ] \\
\hline Crev. $6^{\prime}$ & ur- ${ }^{-d}$ namma(-)x $(x-)[$ & ]$/ \mathrm{mu}-[\ldots \quad]^{152}$ \\
\hline Fobv. $8^{\prime}$ & {$[\ldots$} & ]$(-)^{\top} x^{\urcorner}$ba- $u_{5}-[\ldots \quad]$ \\
\hline
\end{tabular}

$219[\ldots]\left\ulcorner x \quad x \quad b a ?-a n-l a_{2}\right\urcorner$
A vi rev. $16 \quad[\ldots$
E rev. 27
$[\ldots$
C rev. 7'
$[\ldots]\left[\mathrm{x}(\mathrm{x})^{\urcorner}[\ldots\right.$
F obv. 8'
$[\ldots$
] ${ }^{\ulcorner} \times$x ba?-an- $\left.-1 a_{2}\right\urcorner$ ]$^{\ulcorner} \mathrm{x} \mathrm{a}^{\urcorner}-\mathrm{na}[\ldots$
] a-na $M[U / A[N . .]$.

220 [ir ${ }_{2}$ DIŠ] $\left.-r^{\top}\right\urcorner$ a-nir DIŠ-e
A vi rev. $17 \quad\left[i_{2}\right.$ DIŠ $]-\mathrm{r}^{? ?}$ a-nir DIŠ-e
E rev. $28 \quad[\ldots]-\ldots,\left\ulcorner e \quad a^{\urcorner}-[\ldots, \quad]\right.$

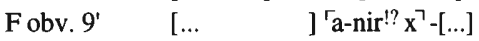

221 [...ur-dnamma]- ${ }^{r a}{ }^{?}$ nam mu-ni-ib-tar-re
A vi rev. $18 \quad[\ldots$
] $\mathrm{x}^{\top}$ nam mu-ni-ib-tar-re
E rev. 29
[...ur-dnamma] - 'ra? nam? m[u?-..

216 (Thus) did Inana indeed observe attentively a lament over him. ${ }^{153}$

217 [(Lord) Ningeš] zida? verily strengthens him with his? .. . [...].

218 My Urnamma . . . [...] who has died,

$219[\ldots] \ldots$

220 Amidst [tears on the one hand], amidst laments on the other hand,

221 [...] decrees the fate for [Urnamma ...]:

152 This line could, however, belong to line 217. Read x (x-) perhaps as $\hat{\mathrm{g} e \zeta ̌} \mathrm{UL}_{4}-[\mathrm{gal} \ldots]$ and cf. line 39. 153 Or "her lament". Source C: "(...) over Umamma (...)". 
$222\left[(\mathrm{x})\right.$ ur] $\left.{ }^{-\mathrm{d}_{\text {namma }}} \mathrm{x}\right\urcorner[\ldots-\mathrm{g}] \mathrm{e}$ ?-en mu mah-zu he $\mathrm{h}_{2}-\mathrm{pa}_{3}$

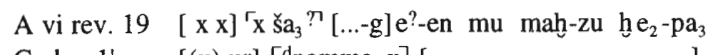
G obv. $1^{\prime} \quad[(\mathrm{x}) \text { ur }]^{\ulcorner\mathrm{d}}$ namma $\mathrm{x}^{\urcorner}[\ldots$

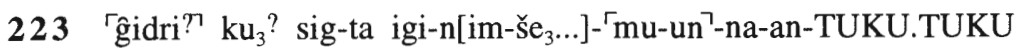

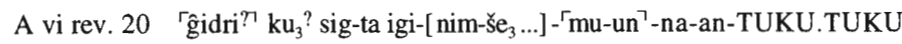

G obv. 2' [... ] ${ }^{\prime} x^{\top}$ sig-ta igi-n[im-š $e_{3} \ldots$

$224 e_{2}$-gal-zu-še $e_{3}$ ki-en-gi [(ki-uri)? ...]- $\mathrm{pa}_{3}-\mathrm{de}_{3}$-eš

A vi rev. $21 \quad e_{2}$-gal- zu- še ${ }_{3}$ ki-en-gi [(ki-uri) $\left.{ }^{?} \ldots\right]-\mathrm{pa}_{3}-\mathrm{de}_{3}$-eš

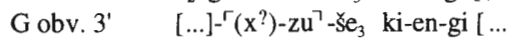

225 i $_{7}$ ba-al-la-zu [...]- $\ulcorner$ x $-z u$

A vi rev. $22 \quad i_{7} \quad$ ba- al-la- zu [...]- $\left.-{ }^{\ulcorner}\right\urcorner-z u$

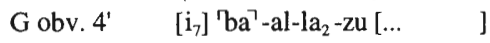

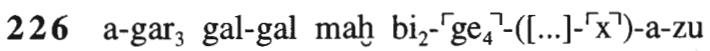

A vi rev. 23 a-gar 3 gal- gal [... $]-\mathrm{r}^{\top}-\mathrm{a}-\mathrm{zu}$

Gobv. ${ }^{\prime} \quad\left[\ldots \quad\right.$ ga]l? $-\mathrm{gal}^{\circ}$ mah $\mathrm{bi}_{2}-\mathrm{ge}_{4}{ }^{\top}-[\ldots]$

227 geš-gi a-ta i[m-...]- $\left\ulcorner\mathrm{e}_{3} / \mathrm{e}_{11}\right\urcorner-\mathrm{a}-\mathrm{zu}$

A vi rev. 24 ĝeš-gi a-ta i[m-... $]-\mathrm{e}_{3} / \mathrm{e}_{11}{ }^{\urcorner}-\mathrm{a}-\mathrm{zu}$

228 še daĝal še daĝal-e [...]- ${ }^{\ulcorner} !-z u !$

A vi rev. 25 še daĝal še daĝal-e $[\ldots]-{ }^{\ulcorner} \mathrm{a} !-z u ?$

G om.

222 "[Ur]namma ... ., you [...], may your sublime name be called!

223 [...] make him possess the dazzling? sceptre? from below [to ab]ove!

224 To your palace [...] Sumer [and Akkad?] were called!

225 The canals which you have dug, the [...] which you have....,

226 All the large and grand arable tracts which? you (thereby) created ${ }^{154}$ (and [...]),

227 The canebrakes which you have drained,

228 The vast barley (fields) which you have [...] to vast barley (fields), ${ }^{155}$ 
229 an-za-gar ${ }_{3} a_{2}-[$ dam ...]-a-zu

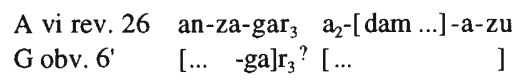

230 nam- $-u_{2}-u l u_{3}\left\ulcorner\bar{u}_{6}^{\urcorner}[\ldots]-\ulcorner x-e-e \breve{s}\urcorner\right.$

A vi rev. 27 nam-lu $u_{2}-u_{l} u_{3}\left\ulcorner u_{6}\right\urcorner[\ldots]-\left\ulcorner x-e-e s^{-}\right.$

G obv. $7^{\prime} \quad[\ldots]-u_{3}\left(r^{r}{ }^{?}\right)[\ldots]$

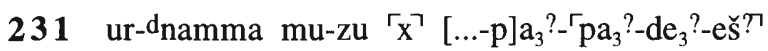

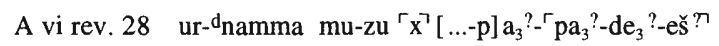

Gobv. $8^{\prime} \quad[\ldots,]^{\top}$ mu-zu' $[\ldots$

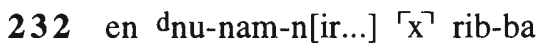

A vi rev. 29 en ${ }^{d}$ nu-nam-n[ir... $\left.]^{\ulcorner} x\right\urcorner$ rib-ba

233 dudug hulu $\left\ulcorner_{x}\right\urcorner \cdot[\ldots(-) b] i_{2}$-in-sar-re

A vi rev. 30 dudug hulu $\left\ulcorner x^{\urcorner}[\ldots(-) b] i_{2}\right.$-in-sar-re

234 sipa dur-namma $\left.\Gamma_{x}\right\urcorner[\ldots b] a ?-s ̌ i-i n-U-a-t a$

A vi rev. 31 sipa dur-namma $\Gamma^{\top}{ }^{\urcorner}[\ldots b] a^{?}-$-si-in-U-a-ta

235 dnanna $\left.\Gamma_{e n}\right\urcorner\left[{ }^{d} A \breve{S}-i m_{2}\right.$-babbar šu-ta] $\left.\Gamma_{X}\right\urcorner-r i-a-b i$

A vi rev. 32 dnanna ${ }^{\ulcorner} e^{\urcorner}{ }^{d}\left[{ }^{d} A S_{\text {S }}-i_{2}\right.$-babbar š u-ta] $\left.{ }^{\ulcorner} \mathrm{x}\right\urcorner$-ri-a-bi

G rev. $1^{\prime} \quad[\ldots]^{\ulcorner} \mathrm{x} x(\mathrm{x})^{\urcorner}[\ldots]$

229 Fortified villages and settl[ements] which you have [...],

$230[\ldots]$ the people [looked at] in admiration!

231 Urnamma, your name they [...] called?!

232 The lord Nunamnir mighty [...],

233 Will drive away [...] the evil u du g-spirit!"

234 After shepherd Urnamma [...] had been ....,

235 (And) that Nanna, lord [AŠimbabbar, was/did (not)] . . , 
236 [d] $]^{\Gamma} e^{\urcorner}$-ki lugal eriduki-ga-[ke $\left.{ }_{4} \ldots\right]$-ta-an- $e_{11}$-da

A vi rev. 33 [den-k]i lugal eridu[ki-ga-ke $\left.{ }_{4} \ldots\right]-$ ta-an- $e_{11}-$ da

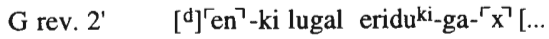

237 G rev. 3' saĝ-kal a-ma-ru mar-r $\left[\mathrm{u}_{10} \ldots\right]$

A vi rev. $\left.34[\mathrm{x} \mathrm{x}(\mathrm{x})]^{{ }^{\mathrm{d}} \mathrm{x}}\right\urcorner[\ldots-1] \mathrm{a}$ ? amaš tab-tab-ba

238 G rev. 4' gi GAM-ma KAL $\hat{G A L}_{2}$ ba-n[i-...].

A vi rev. $35[\ldots] \quad \mathrm{ku}_{3}$ ? DU piriĝ̣ diğir- $\mathrm{SE}_{3} \quad \mathrm{du}_{2}$-da

239 uru-zu-ta $\mathrm{mi}_{2} \mathrm{z}[\mathrm{i}] \mathrm{du}_{11}$-ga di si- $\mathrm{sa}_{2} \mathrm{ku}_{5}-\mathrm{ku}_{5}$

A vi rev. $36[\ldots \quad] u_{11}$-ga di si-sa $k_{5}-k_{5}$

G rev. $5^{\prime} \quad$ uru-zu-ta $\mathrm{mi}_{2} \mathrm{z}[\mathrm{i} \ldots$

240 dumu HII-re $\ulcorner x\urcorner([\ldots]\ulcorner\urcorner\urcorner)$ en dnin-ĝeš-zi-da $z_{3}-m_{2}$

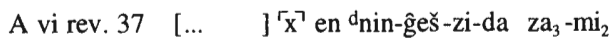

G rev. $6^{\prime}$ dumu HII-re ${ }^{r} x^{\urcorner}[\ldots$

241 'lugal-ĝu $\mathrm{u}_{10}$ ? [x (x) i] $\mathbf{r}_{2}-\mathrm{am}_{3}$ i-lu-am 3

A vi rev. 38 [lugal-ĝu $u_{10}$ ? $x(x)$ i] $\mathrm{r}_{2}-\mathrm{am}_{3}$ i-lu-am

G rev. $7^{\prime} \quad \Gamma^{\prime}$ lugal-g $\mathrm{gu}_{10}{ }^{?}[\ldots$

242 [ur-dnamma? (...)] $\mathrm{ir}_{2}$-am 3 a-nir-am 3

A vi rev. 39 [ur-dnamma? (...)] $\mathrm{ir}_{2}-\mathrm{am}_{3}$ a-nir-am 3

236 That Enki, the lord of Eridu, brought him? out of [...],

237 That the foremost, flood (and) tempest [...], ${ }^{156}$

238 That the reed which is bent down .. . [...], ${ }^{157}$

239 That the one who duly looked after your city, renders just judgments,

240 That the child/denizen . . ., lord Ningešzida be praise!

241 My? lord [...] are tears, are wails!

242 [Urnamma? (...)] are tears, are laments! 


\subsection{The Susa Version of Urnamma A}

\section{Introduction}

Besides the versions from Nippur the composition "Urnamma's Death" is also known in form of a multi-tablet edition from Susa. The three one-column i m $\mathrm{g} \mathrm{i} \mathrm{d}_{2}$ - $\mathrm{d}$ a-tablets numbered $\mathrm{Sb}_{1}-\mathrm{Sb}_{3}{ }^{158}$ were probably written by the same scribe in Old Babylonian ductus using occasionally more archaic signs. ${ }^{159}$ All tablets are heavily scored with a stylus and for each tablet the individual lines are precisely 0.4 $\mathrm{cm}$ apart. Originally each tablet must have contained approximately 30 to 32 lines on one side, a standard count for this type of exercise tablet used by pupils to write perhaps daily exercises of approximately that amount. ${ }^{160} \mathrm{Sb}_{2}$ and $\mathrm{Sb}_{3}$ show each a ten-mark for lines $81^{\prime}$ and $112^{\prime}$ respectively. There is a possibility that the last preserved line of $\mathrm{Sb}_{2}$ is the catchline to $\mathrm{Sb}_{3}{ }^{161}$ The column of the reverse of $\mathrm{Sb}_{3}$ is not fully inscribed and the last line ends with double ruling followed by a blank and then a colophon with most of it illegible. ${ }^{162}$ This is probably the end of the composition with no other tablets following, as one would have expected the scribe to fill in the whole reverse of tablet $\mathrm{Sb}_{3}$, thus making this version of the composition much shorter than the ones from Nippur.

\section{Paleography}

The most striking paleographical feature of the three tablets is the occasional use of more archaic signs than the normal Old Babylonian ductus. They resemble Old Babylonian signs found on monumental inscriptions. Giving the line number in brackets, the signs in question are: - $\mathrm{u} \mathrm{n}-\left(7^{\prime}\right)$, perhaps $\mathrm{g} \mathrm{a} 1_{2}-\left(9^{\prime}\right), \mathrm{n}$ a m (11'), perhaps - ešt u b, $\mathrm{ku}_{3}-\left(12^{\prime}\right)$; perhaps g u - (13'), u $\hat{g}_{3}$ (16'), $\mathrm{k}$ a l a m - (17'), - edin- (18'), perhaps - ma (25'), u $\mathrm{r}_{5}$, - u n - (27'), k a l a m - (28'), k a l a m - (29'), e r e n ?, k a l a m- (30'), A G A , - u n -

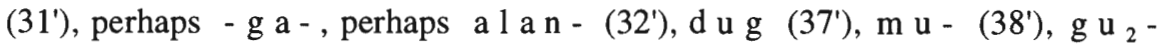
$\left(44^{\prime}\right)$, perhaps s a g - $\left(45^{\prime}\right)$, perhaps - i n - $\left(49^{\prime}\right)$, - g a - $\left(59^{\prime}\right),-\mathrm{g}$ a - $\left(60^{\prime}\right)$,

\footnotetext{
$158 \mathrm{Cf}$. also above, 1.1, p. $100 . \mathrm{Sb}_{2}$ and $\mathrm{Sb}_{3}$ are joins by $\mathrm{A}$. Cavigneaux and $\mathrm{M}$. Civil respectively. The reconstruction of the $\mathrm{Sb}_{2}$ join is not entirely clear, cf. below, p. 158 , fn. 198 .

$159 \mathrm{Cf}$. immediately below, p. $143 \mathrm{f}$.

160 Michalowski, Lamentation 18 and Civil, Farmer's Instructions 12.

161 Cf. below, p. 160 , fn. 204.

162 It presumedly contained the name of the scribe (Pirhum) and a date.
} 


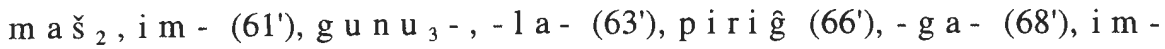
$\left(69^{\prime}\right)$, - š a g a n (70'), - g u $\mathrm{r}_{8}(-)\left(79^{\prime}\right), \mathrm{g} \mathrm{u}_{2}\left(88^{\prime}\right)$, a $\mathrm{l} \mathrm{i} \mathrm{m}-\left(98^{\prime}\right)$, perhaps

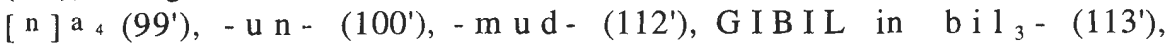

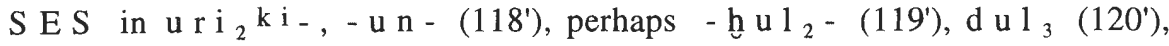
- bu l u g ${ }_{3}-\left(123^{\prime}\right), \mathrm{h}_{2} \mathrm{e}_{2}-\left(127^{\prime}\right)$, g i š k i m, s a $6^{-}\left(129^{\prime}\right)$, - u g ${ }_{3}$ (132'), - u n - (133'), - u n - (136'), - g a - , - g a - (147').

\section{Variations}

The following list gives all the variations between the main Nippur version (source A) ${ }^{163}$ and the texts from Susa:

\begin{tabular}{|c|c|c|}
\hline line & $\operatorname{Nippur}(A)$ & $\operatorname{Susa}\left(S b_{I}-S b_{3}\right)$ \\
\hline$(12)^{164}$ & $-n-$ & $-\varnothing$ \\
\hline (13) & $-\varnothing ;-n-$ & - ni; - $\varnothing-$ \\
\hline$(15)$ & hulu til ${ }_{3-}^{-}$ & hul-ĝal ${ }_{2}$-la tuš? $(-)$ \\
\hline$(16)$ & $-\mathrm{Ca} ; \mathrm{a}$ & $-\mathrm{ka} ; \mathrm{a}_{2}$ \\
\hline (17) & nam -tar-; -še $e_{3}$ & -bala-; -eš-am 3 \\
\hline$(18)$ & $-\mathrm{še}_{3}$ & $-\mathrm{ta}$ \\
\hline$(19)$ & B: ki a-ne-di; $-d u_{11}-d u_{11}$, B: $-\breve{s}_{8}-\breve{s e}_{8}$ & ki e-ne-de $;$; -ši-ši \\
\hline$(20)$ & B: li-bi & lib \\
\hline$(21)$ & $-\varnothing-;-$ na; -zal- & -n-; -e-NE-eš-a; -zal-zal- \\
\hline$(22)$ & $\mathrm{de}_{2}-;-\mathrm{bi}$ & $\mathrm{de}_{6^{-}} ;-\mathrm{ba}$ \\
\hline (23) & $\mathrm{mu}_{2-;} ;-\mathrm{bi}$ & $-e_{3} ;-a$ \\
\hline$(26)$ & & different line variation? \\
\hline (35) & mas-su & [ur]-dnamma \\
\hline$(37)$ & $-\mathrm{dib} ?$ & $-\hat{g} a_{2}-\hat{g} a_{2}$ \\
\hline$(38)$ & & different line variation? \\
\hline (39) & $-\mathrm{ke}_{4}$ & $-\varnothing$ \\
\hline$(41)$ & $\varnothing ;-\varnothing$ & $\mathrm{ni}_{2} ;-\mathrm{ni}$ \\
\hline$(42)$ & $\operatorname{sag}(-)-\mathrm{ku}_{3}(-)[\mathrm{ga}] \mathrm{l}_{2} ;-\mathrm{na} ;-\varnothing$ & $\operatorname{sag}(-) \mathrm{gu}_{2}(-) \mathrm{gal}_{2} ;-\mathrm{ni} /-\varnothing ;-\mathrm{a}$ \\
\hline (43) & $\mathrm{eren}_{2}-; \mathrm{gu}_{2} ;-\varnothing-;-\mathrm{e}$ & eri/e $(-) ; u_{5} ;-n-;-\varnothing$ \\
\hline (45) & $-\mathrm{ka} ;-\varnothing-$ & $-\varnothing ;-n-$ \\
\hline (46) & $\begin{array}{l}\text { tir; }-\operatorname{gin}_{7} ;-\varnothing-;-\mathrm{su}_{3} ; \text { me-dim } \\
\text { kur }\end{array}$ & $\begin{array}{l}\text { geštir; }-\varnothing ;-n-;- \text { sag }_{3} ; \text { a-ra }{ }_{2} \text { kalam- } \\
\text { ma } \operatorname{suh}_{3}\end{array}$ \\
\hline (46a) & & line addition ${ }^{165}$ \\
\hline
\end{tabular}

163 Other Nippur sources are noted if they differ from source A, or if source A is not present. 164 Nippur line numbering.

$165 \mathrm{Cf}$. the commentary ad $46 \mathrm{a}$, p. 167. 


\begin{tabular}{|c|c|c|}
\hline$(47)$ & B: - $\operatorname{gin}_{7} ;-\mathrm{na} ; \mathrm{GIN}_{2}$ & -e; -ni; AGA \\
\hline$(48-50)$ & & line omission \\
\hline$(51)$ & $\mathrm{du}_{11}-;-\varnothing ; \mathrm{sa}_{2}-\mathrm{du}_{1} ; \mathrm{a}-\mathrm{la} ;-$ na & 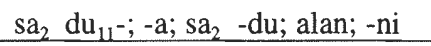 \\
\hline$(52)$ & -a; -tag; -e & $-\mathrm{e} ; \check{\mathrm{s}} \mathrm{u} \quad-\operatorname{tag} ;-\varnothing$ \\
\hline$(53)$ & $-\mathrm{ni} ; \mathrm{im}-;-\mathrm{n}-; \mathrm{KA}-\mathrm{ge}_{4}$ & -bi; nu-; $-\varnothing-;$ šu nu - gid $_{2}$ \\
\hline (54) & $-\emptyset-;$-gub; la-; -b-; -si; - $\varnothing$ & -n-; -DU; nu-; - $\varnothing$-; -sud-; -e \\
\hline$(55)$ & $-\varnothing$ & $-\mathrm{a}$ \\
\hline$(56)$ & & line omission \\
\hline$(57)$ & -e-ne & $-\mathrm{e}$ \\
\hline$(58)$ & $-\operatorname{gin}_{7} ; a-b a-;-n-;-a s ̌$ & $-\varnothing ;$ im-mi-; $-\varnothing-;-\mathrm{e}$ \\
\hline (59) & -ši-ĝen & $-{ }^{-s ̌ e} \hat{g}_{3}-\hat{g e}_{26}$ \\
\hline$(60)$ & šu $\operatorname{gid}_{2}$ & šu dab ${ }_{5}$ \\
\hline$(63)$ & & different line variation? \\
\hline$(65-6)$ & & line omission \\
\hline$(67)$ & $-\mathrm{bi}$ & -b]a? \\
\hline$(68)$ & $-\varnothing-;-$ tab; gešsậ-kul & -n-; -RU?; geš saĝ-ĝu ${ }_{10}$ \\
\hline (69) & -gar; -a; - Ø-; -DU & -TAR; - $\varnothing ;-n-;-$ TUŠ \\
\hline$(70)$ & $-\varnothing$; anše; ki tum 2 & -e; $\varnothing ;$ giri $_{3} ?\left[\mathrm{ki}^{?}\right] \mathrm{us}_{2}$ \\
\hline$(71)$ & $\varnothing$; anše; ki tum 2 & kaskal kur-ra-ke $_{4} ;[\ldots] ;[\ldots]$ us $_{2}$ \\
\hline$(72)$ & & line omission \\
\hline$(73)$ & in-di ${ }_{3} ; \mathrm{su}_{3} \cdot \mathrm{g} ;-\mathrm{am}_{3}$ & ki-in-du; sud.r; -a \\
\hline$(74 \| 75)$ & $(-\varnothing-) ;-\check{s}_{2}$ & $(-n-) ;-$ šub \\
\hline$(76 a)$ & & line addition \\
\hline$(78)$ & $\mathrm{ug}_{5}-\mathrm{ga}$ & ba- $\operatorname{ug}_{5}-g[e(x)]-x^{\urcorner}-t a$ \\
\hline$(78 \mathrm{a})$ & & line addition \\
\hline$(79 \| 80)$ & $-n-$ & $-\varnothing-$ \\
\hline$(81-3)$ & & line omission \\
\hline$(84)$ & sipa zi; -n- & lu[gal]; $-\varnothing-$ \\
\hline$(84 a)$ & & line addition \\
\hline$(85-6)$ & & line omission \\
\hline (87) & $\mathrm{du}_{7} ; \mathrm{du}_{7} ;$ en-na; -lah $; 5 ;-\mathrm{a}$ & $\mathrm{sa}_{7} ; \mathrm{du}-\mathrm{du} ; \mathrm{im}-\mathrm{ma}-;-\mathrm{lah}_{4} ;-\mathrm{e}$ \\
\hline$(88)$ & $\mathrm{e}_{2}$-mar-uru $;$; geš gag-pana; galam & a-ma-ru-bi?; ĝeš ?[ga]g(-)ti; gal \\
\hline$(89)$ & -ba & $-\mathrm{ni}$ \\
\hline (90) & -ra & $-\mathrm{ke}_{4}$ \\
\hline (91) & $-n a ;-b-$ & $-\mathrm{ni} ;-\mathrm{n}-$ \\
\hline (92) & i-mi-tum & gešmitum \\
\hline (93) & kušE.IB ${ }_{2} \cdot U_{3} ; a_{2}$ nam-ur-saĝ-ĝa $a_{2}$ & kuš $\underline{E} . \mathrm{IB}_{2} ; \varnothing(?)$ \\
\hline (94) & [z]a-ha-da; $-\varnothing$ & rgeš? za? - $[\mathrm{x}-\mathrm{d}] \mathrm{a} ? ;-\mathrm{ke}_{4}$ \\
\hline (95) & $\mathrm{bil}_{4}^{-}$ & $\mathrm{bil}_{3}-$ \\
\hline (96) & -na; -b- & $-n i ;-n-$ \\
\hline (97) & $-n-;-d e_{2}$ & $-\varnothing-;-S A R$ \\
\hline
\end{tabular}




\begin{tabular}{|c|c|c|}
\hline$(98)$ & & line omission \\
\hline$(101)$ & {$[-n a] ;[-b-]$} & $-n i ;-n-$ \\
\hline$(103)$ & gidri $\mathrm{ku}_{3}-\mathrm{sig}_{17} ;-\varnothing ;-\mathrm{se}_{3}$ & geš-nu ${ }_{11}$ geš ma-nu; -kam; -a \\
\hline$(103 a)$ & & line addition \\
\hline$(105)$ & $-\varnothing, \mathrm{D}:-\mathrm{ke}_{4} ;-\mathrm{na} ;-\mathrm{b}-$ & $-\mathrm{ke}_{4} ;-\mathrm{ni} ;-\mathrm{n}-$ \\
\hline (106) & $\mathrm{si}_{3} ? / \mathrm{sig}^{2}$ & $\mathrm{sa}_{7}-$ \\
\hline$(107)$ & $-\varnothing$ & $-\mathrm{ke}_{4}$ \\
\hline$(108)$ & -ra & $-\mathrm{ke}_{4}$ \\
\hline (109) & $-n a ;-b-$ & $-\mathrm{ni} ;-\varnothing-166$ \\
\hline$(110)$ & DUB; $-\mathrm{ke}_{4}$ & dub-šen; - $\varnothing$ \\
\hline (111) & $\mathrm{ku}_{3} ; \mathrm{na}_{4} \mathrm{za}-\operatorname{gin}_{3} ; \varnothing$ & $\varnothing ;$ za-gin $;$ imin? \\
\hline (112) & -ra & $-\mathrm{ke}_{4}$ \\
\hline (113) & -na; -b- & $-n i ;-n-$ \\
\hline$(115)$ & & line omission \\
\hline (116) & $\left(\mathrm{ur}_{2}\right)$ gunu $_{3}-$ gunu $_{3}$ & $\mathrm{gu}_{2}$ nun? \\
\hline$(117)$ & $-\mathrm{e}$ & $-\mathrm{a}$ \\
\hline$(119)$ & -na; -b- & $-n i ;-n-$ \\
\hline$(120)$ & & different line variation \\
\hline$(121)$ & tu-di-da; D: [tu-di-t]um & du-di-da \\
\hline$(122)$ & -e; za - -ga-na; -de $;$; -b- & $-\varnothing ; a_{2}$ zi-da $a_{2}$ [ga]bu ${ }_{3}$ bu; -na; -n- \\
\hline (122a) & & line addition \\
\hline$(123)$ & & line omission \\
\hline$(124)$ & $-\mathrm{ke}_{4}$ & -kam \\
\hline$(125)$ & $\begin{array}{l}\mathrm{es}_{2} \text {-gana } \\
\text { nindan }\end{array}$ & {$[\ldots]$ ĝeš gag; gi-nindan } \\
\hline$(126)$ & $\varnothing$ & nin $_{9}$ lugal-la-ra \\
\hline (127a) & & line addition \\
\hline$(128)$ & -na; -b- & $-n i ;-\varnothing-167$ \\
\hline$(128 a)$ & & line addition \\
\hline$(130)$ & & line omission? \\
\hline$(131)$ & $-s ̌\left[\mathrm{um}_{2} ?-\mathrm{m}\right] \mathrm{u}$ & $-\mathrm{ku}_{4} \cdot \mathrm{r}$ \\
\hline (131a) & & line addition \\
\hline$(132-3)$ & & line omission \\
\hline$(134)$ & irigal- & irigal $_{2}-$ \\
\hline$(135)$ & & different line variation \\
\hline$(136)$ & -b-; -tuš-u $u_{3}-n e$ & -n-; -TUŠ-na \\
\hline (137) & -ne & $-\varnothing$ \\
\hline$(138)$ & $-\mathrm{ka}-\mathrm{ta}$ & $-\mathrm{ke}_{4}$ \\
\hline
\end{tabular}




\begin{tabular}{|c|c|c|}
\hline (139) & eren $_{2} ;$ en-na; -ug $5_{5} ;-$ a & $\mathrm{lu}_{2} ;$ in-na; -šub-; -e \\
\hline$(140)$ & en-na; -zu?-; -a & in-na; -mud-; -e \\
\hline$(141-2)$ & & line omission \\
\hline$(143)$ & $\mathrm{bil}_{4^{-}}$ & $\mathrm{bil}_{3}-$ \\
\hline$(144)$ & e-ne; - $\varnothing ;$ kur-ra & e-ne-ne ${ }^{168} ;-$ bi; $\varnothing$ \\
\hline$(145)$ & imin; - $\varnothing ;-$ ba & $\mathrm{ia}_{2}-;-\mathrm{am}_{3} ;-\mathrm{ta}$ \\
\hline$(14611147)$ & $-\mathrm{gu}_{10} ;-\mathrm{ke}_{4} ;-\mathrm{b}-; \mathrm{sa}_{2} \mathrm{du}_{1 \mathrm{u}}$ & $-\mathrm{e} ;-\varnothing ;-\varnothing-; \mathrm{si}(-) \mathrm{du}_{\mu}$ \\
\hline$(148)$ & $-\mathrm{ni}$ & -na \\
\hline$(149)$ & -ni, D: -na; $\varnothing ;-$-n-; -hul ${ }_{2}-$ hul $_{2}$ - & $-\varnothing ; \check{s ̆ a}_{3}-\mathrm{bi} ;-\varnothing-;-$ hul $_{2-}$ \\
\hline$(150)$ & $-n-;$ sag AK & $-\emptyset-;$ šu dul 3 ra \\
\hline$(151)$ & -na; a-la; -n-, D: -Ø- & - ni; la-la-bi; $-\varnothing-$ \\
\hline$(152)$ & -na, D: - Ø; -peš-; -ni & 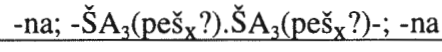 \\
\hline$(153)$ & $\begin{array}{l}\mathrm{di}_{4}-\mathrm{di}_{4} ; \text { in-, D: n]u-mu-; D: -bulug } \hat{3}_{3}- \\
\text { bulug }{ }_{3^{-}} ;-\emptyset ;- \text { ni }\end{array}$ & tur x(-)tur; im-; -bulug $\hat{3}_{3}-;$-bi; -na \\
\hline$(154)$ & & line omission \\
\hline$(155)$ & 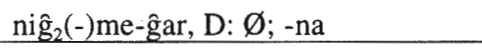 & nig $\hat{g}_{2}(-) m e-g a r ;-n i$ \\
\hline$(156)$ & $\mathrm{D}: \mathrm{NE}$ & $\mathrm{ni}_{2}{ }^{169}$ \\
\hline$(157)$ & & corrupt text? \\
\hline$(158)$ & $-\mathrm{a} ;$ pa $_{3} ;-\mathrm{a}$ & $-\varnothing ; \mathrm{pa}_{3} \mathrm{AK} ;-\mathrm{NE}$ \\
\hline$(159)$ & & corrupt text? \\
\hline$(160)$ & & line omission \\
\hline$(161)$ & nig $_{2} ; \varnothing ;$-sud.r & $\emptyset ;$ kur; -DU \\
\hline$(162)$ & $-\varnothing-$ & $-b ?$ \\
\hline (184) & en-nu & en-nu-ug $\hat{g}_{3}$ \\
\hline$(185)$ & $-\mathrm{dab}_{5} ;-\varnothing ; \mathrm{mu}-$ & -DI; -bi; nu- \\
\hline$(186)$ & & line omission \\
\hline (187) & za-am-za-am-ĝu $u_{10} ;-a$ & $\mathrm{za}_{3}-\mathrm{za}_{3}-\mathrm{mi}_{2}(-) ;-\varnothing$ \\
\hline (188) & $-e:-n-$ & $-\varnothing ;-\varnothing-$ \\
\hline$(189)$ & $-\emptyset-;-g u_{10}$ & -n-; -na \\
\hline (191) & $-\hat{g} \mathbf{u}_{10}$ & -na \\
\hline (192) & $-\mathrm{nu}_{2}-;-\mathrm{da}$ & $\begin{array}{l}\text {-šub-; -na or different line vari- } \\
\text { ation? }\end{array}$ \\
\hline$(193)$ & & different line variation? \\
\hline$(194-5)$ & & line omission \\
\hline$(196)$ & saĝ-kal; -ĝa $a_{2} ;$ nu-; -n-; -til 3 & ki-sikil; -ba; mu-; -b-; si [...] \\
\hline$(197)$ & kur-kur-ra; enim gal-gal-š ${ }_{3} ;$-n- & hur-sâे gal-gal; $\varnothing ;-\varnothing-$ \\
\hline (199) & & line omission \\
\hline$(200)$ & $-\mathrm{ka} ; \varnothing$ & $-\varnothing ; \mathrm{ni}_{2}$ \\
\hline
\end{tabular}




\begin{tabular}{|c|c|c|}
\hline$(201)$ & & line omission \\
\hline (202) & $-\mathrm{k}] \mathrm{a}, \mathrm{E}:-\mathrm{ta} ;-\mathrm{n}-;-\mathrm{n}-;-\left[\mathrm{du}_{8}\right]$ & $-\varnothing ;-\mathrm{b}-;-\varnothing-;-\mathrm{d}[\mathrm{u}]$ \\
\hline$(203-6)$ & & line omission \\
\hline$(207)$ & $-\mathrm{ke}_{4}, \mathrm{E}:-\varnothing ;$ in- $\breve{\mathrm{S}} \mathrm{E}_{3} ;$ ga- $;-\mathrm{dub}_{2} ;-\varnothing$ & $-\varnothing$; in $\mathrm{kur}_{2} ; \mathrm{mu}-;-\mathrm{AK}-;-\mathrm{e}$ \\
\hline$(208)$ & & line omission \\
\hline$(209)$ & enim mah; enim-bi; a-ba; mu-; -n- & $\varnothing ;$ du $_{11}$-ga-a-ni; $\varnothing ;$ nu-; - $\varnothing$ - \\
\hline$(210)$ & & different line variation \\
\hline$(211)$ & $\left.\mathrm{ki} ;-\varnothing ;-\check{\mathrm{se}}_{3}, \mathrm{E}:-\varnothing, \mathrm{F}:-\mathrm{k}\right] \mathrm{e}_{4} ;-\varnothing$ & $\varnothing ;-\mathrm{a} ;-\varnothing ;-\mathrm{a}$ \\
\hline$(212)$ & $-\mathrm{ge}_{4} ? !-;-\mathrm{es}$ & $-\mathrm{BU} ;-\varnothing$ \\
\hline (213) & $\begin{array}{l}-n i, C:-n a ; b a-r a-, F: m u-;-k u_{4}- \\
k u_{4} \text { d; -en }\end{array}$ & $-\mathrm{a} ; \mathrm{la} ?(-) \mathrm{ba}-;-\mathrm{ku}_{4}, \mathrm{r} ;-\mathrm{e}$ \\
\hline
\end{tabular}

The variations which the Susa texts display in comparison with the main Nippur version of the composition can be grouped into (I) variations on graphic-grammatical level encompassing a.) non-standard orthography, b.) interchange of postpositions, c.) omission or alteration of unstable elements, usually in final position, d.) preradical interchange of - $n-$ and $-\varnothing-,-b-$ and $-\varnothing-,-n-$ and - b - , and (II) variations on text level, which include a.) omission of one to two lines within the narrative sequence, b.) omission of more than two lines, c.) line addition, d.) use of variant lines, e.) variation in narrative sequence or order of lines, and f.) use of synonymous or different words or phrases.

(I) a.) The version from Susa contains a relatively large amount of non-standard orthography, including phonetic non-standard spellings which are semantically non-. conditioned as well as semantically conditioned spellings, and reinterpretations based on phonetic affinity. For a list of these spellings with references the reader is referred to II 3.2, pp. $24 \mathrm{ff}$.

b.) A noticeably consistent pattern can be observed for locative - locativeterminative interchange. Where Nippur has the locative postposition, Susa uses the locative-terminative postposition: $47,{ }^{170} 51,89,91$ || 96 || 101 || 105 || 109 || 113 || $119 \| 128,151,155$. In the three instances where Nippur uses the personal dative postposition - $\mathrm{r}$ a, Susa has $-\mathrm{k} \mathrm{e}_{4}: 90,108,112$.

c.) Omission of unstable elements, mainly dropping of final - n , - ̌s , and - m can be detected in quite a number of lines: perhaps 21,53 , perhaps $55,57-58,73$, 137, 144, perhaps 211, and 213. It is much less often the case in the Nippur version of source A: examples are 45, $70 \| 71$.

d.) For preradical interchange of verbal prefixes - $n$ - and $-\varnothing-,-b-$ and $-\varnothing-$, - $\mathrm{n}$ - and - b - , before the stem no consistency for either the Nippur or the Susa texts can be observed, as expected, ${ }^{171}$ though the infix - b - is used more by the 
Nippur text (- b - vs - $\varnothing$ - in lines 54, $146 \| 147$; for lines 109 and 128, cf. immediately below; perhaps - b - in the Susa text for line 162).

Some of these graphic variants result in different grammatical variants: difference in person may occur in line 202 and certainly in 189ff. and 207. Marû vs hamtu verbal forms can be found for lines 37, 43, 52, 54 and 57. The Nippur version tends to use subordinate conjugations more often than Susa: 17, 21, 23, $87,139-140,158$ vs $41-42$. Lines 117 and 136 may or may not be examples of - a $=-\mathrm{a} \mathrm{m}_{3}$ (likewise 55 and 211 under c.) above). Note also that Susa has $-\mathrm{n}$ a vs Nippur - $\mathrm{g} \mathrm{u}_{10}(189,191$ with change of person), - $\mathrm{n}$ a vs - $\mathrm{n} \mathrm{i}$ (148[ff.], 152153), - b a vs - b i $(22,67$ ? ). Pronominal - b i is much more often used in the Susa than the Nippur texts: note - b i vs - $\varnothing$ in $88,144,151,153,185$.

Dropping of postpositions occurs in lines 39, $146 \| 147$ (omission of ergative), 188 (omission of locative-terminative), 69, 197 (omission of locative), 200 (omission of locative(-terminative)), 202 (omission of ablative/locative). Completely different verbal prefix chains can be found in $58,87,153$ (source D), 207 , and 209. In view of occasional shortage of space where the corresponding line of the opposite column is written well over the edge, some verbal forms appear in shortened versions. The forms in question are $\mathrm{g}$ e š i $\mathrm{m}-\mathrm{m} \mathrm{i}-\mathrm{t}$ a $\mathrm{g}-\mathrm{g}$ e of line 82' (Nippur line 109) and ĝ e š i $\mathrm{m}-\ulcorner\mathrm{m} \mathrm{i}\urcorner-\mathrm{t}$ a g of line 97' (Nippur line 128) for $\hat{\mathrm{g}} \mathrm{e} \check{\mathrm{s}} \mathrm{i} \mathrm{m}-\mathrm{m}$ i - i n - t a g-g e.

Idiosyncratic scribal errors to be especially noted are a hybrid form b a - a n $\mathrm{d} \mathrm{a} \mathrm{b}_{5}-\mathrm{be}_{2}-\mathrm{N} \mathrm{E}-\mathrm{e} \check{\mathrm{s}}$ - a (line 21). ${ }^{172}$ Also, the Susa variant s $\mathrm{a}_{2} \mathrm{~m} \mathrm{i}-\mathrm{r} \mathrm{i}$ $\mathrm{i} \mathrm{b}_{2}-\mathrm{du}$ "it has reached you" in line 51 makes no sense in context. ${ }^{173}$ In fact some auditory errors of the scribe have resulted in whole lines that are unintelligble, i.e. that have been corrupted during the process of transmission: lines 157 and 159 .

(II) A comparison with the main Nippur version of the composition on text level shows:

a.) Omission of one to two lines within the narrative sequence: 56, 65-66, $72,{ }^{174} 85-86,98,115,123,130$ ? $132-133,141-142,154,160,186,194-195,199$, 201,208 . Omission of most of these lines can be said to have no fundamental alteration of the sense of the narrative sequence. With the omission of line 56 the contrast between loved acquaintances and strangers is lost. Omission of lines 65-66 results in a shortened boat episode. In lines 85-86 and 132-133 the somewhat superfluous summary statements that Urnamma offers sacrifices at the beginning and end of the list of offerings, is dropped. Lines 98, 115, and 123 omit items in the list of presents for the netherworld deities. Awkward, however, is the omission of lines 141,160 , and perhaps $194^{175}$ because their preceding lines appear to have

\footnotetext{
$172 \mathrm{Cf}$. the commentary ad 21 , p. 165.

$173 \mathrm{Cf}$. the commentary ad 51, p. 168.

$174 \mathrm{Cf}$. the commentary ad $46 \mathrm{a}$, p. 167.

175 Unless line 193 with its unintelligible traces is the main clause on which the preceding lines in -na are dependent.
} 
no logical, and syntactical conclusion. It also remains unclear how the narrative sequence in the passage in lines 199-202 is to be understood: one expects line 202, which may be Enlil's speech to Inana, after line 200 (Inana's gesture towards Enlil), which is the opposite case in Susa, and it is not readily apparent that Inana actually visits Enlil's Ekur - line 199 omitted in the Susa text - to hear the news about Urnamma's death.

b.) Omission of more than two lines: 48-50, 81-83, 203-206. Omission of lines 48-50 results in a shortened description of the dying Urnamma lying in his palace. The Susa version omits the banquet scene (lines 81-83) upon Urnamma's tumultuous welcome in the netherworld. Lines 204-206 either omit the content of Inana's insult against An, or a real destruction scene on part of Inana. ${ }^{176}$ Between lines 162 and 184 an unknown number of lines is omitted, due to a break in the tablet. But from the approximately six missing lines at the end, it is clear that a relatively large part of Urnamma's lament concerning himself and the pitiable state of his wife has been left out in the Susa version.

c.) Line addition: Nippur lines 46a, ${ }^{177} 76 \mathrm{a}, 78 \mathrm{a}, 103 \mathrm{a}, 122 \mathrm{a}, 127 \mathrm{a}, 128 \mathrm{a}, 131 \mathrm{a}$. None of these added lines alter the sense of the narrative fundamentally. They can either be considered as poetic parallelisms of one of the previous or succeeding lines as probably 78a, with minor substitutions $103 \mathrm{a}$ ( $\breve{s}$ i b i r e šg i r i for $\hat{\mathrm{g}}$ e š $\mathrm{nu}_{11}, \mathrm{nam}-\mathrm{sipa}-\mathrm{da}$ for $\mathrm{nam}-\mathrm{en}-\mathrm{na}-\mathrm{kam}$ ), 127a (parallel with 126), and 128a, or are the refrain line ( $\mathrm{sipa} \mathrm{ur}-\mathrm{dn}$ am m a-k $\mathrm{e}_{4} \quad \mathrm{e}_{2}$ g a $1-1 \mathrm{a}-\mathrm{a}-\mathrm{n}$ i $\mathrm{g}$ e $\breve{~ i ~ m-m i ~-~ i ~ n-t ~ a ~ g-g ~ e) ~ o m i t t e d ~ b y ~ t h e ~ N i p p u r ~ v e r-~}$ sion of the line in question, as 122a and 131a. Line 76a is very broken but could be an expansion of the previous line 76 .

The following variations under d.) and e.) can be said to involve a real change of the sense of the line in question or the narrative passage as a whole:

d.) Use of variant lines: 26?, 38?, 63?, 120, ${ }^{178} 135,156,192-193$ ?, 210. The broken state of some of these lines makes it impossible to determine for sure if they actually should be compared with the Nippur line in question (lines 26 ? 38 ?, 63 ?, 192-93?). Lines 135,156 , and 210 can be regarded as actual line variations and may thus follow a version of the composition other than the one represented by source A. They involve a real alteration of the sense of the line in question. Line 156 matches that of Nippur source D, and as the Susa text also displays the same line order as source D for lines 120-122, i.e. 121-120-122, as noted above, this could indicate that Susa may follow the Nippur version represented by sources D, $\mathrm{C}^{\text {? }}$, and F more closely than that of source A.

e.) Variation in narrative sequence or order of lines: $12-14,20-21,57-58,70-$ $71,73-75,116-117,120-122 a, 200-202$. Lines 12-14 and 120-122 involve changes in the order of enumeration of deities: the passive retreat of the gods [Ninmah'] Nanna, Utu, Enki-Nudimmud and Ninsumun, rather than Ninmah, EnkiNudimmud, Nanna, Utu and Ninsumun (12-14), and in the list of offerings to the

176 Cf. the commentary ad 204-206, p. 180.

177 Perhaps a variant line, cf. the commentary ad $46 \mathrm{a}$, p. 167.

178 Cf. below ad f.), p. 152. 
gods of the netherworld, Dimpimekug is mentioned after, rather than before, Ĝeštinana/Ninazimua (120-122a). Source D has Dimpimekug inserted between Dumuzi and Namtar. A major change is involved in lines 70-75: the burial scene with the donkeys - if this interpretation is indeed correct - is omitted in Susa. The boat scene (simile or actual boat trip to the netherworld?) is immediately followed by the troublesome journey on the road to the netherworld. Lines 120-121 change the order of objects presented to Dimpimekug; thus the toggle pin is listed before the lapis lazuli seal, as in Nippur source D. Inana's gesture towards Enlil in line 200 appears in Susa after and not, as in the Nippur texts, before her hearing of Urnamma having left her Eana (200-202). In lines 20-21, 57-58, and 116-117 no noticeable change of the sense of the narrative is involved.

f.) Use of lexical variants resulting in (partially) synonymous or different words or phrases ${ }^{179}: 15,17,19,20,23,35,37,41,43,46-47,51-54,59-60,68-71,73-$ $75,84,87-88,97,103,106,110,122,125,131,139-140,145-147,150,153$, $157-159,161,185,192$ ?, 196-197, 207, 212. The tables below present (partially) synonymous verbs, adjectives, nouns, and one phrase:

verbs:

\begin{tabular}{|c|c|c|}
\hline line & $\operatorname{Nippur}(A)$ & Susa $\left(S b_{1}-S b_{3}\right)$ \\
\hline (15) & hulu $\mathrm{til}_{3}$ & hul-gal ${ }_{2}$-la tuš \\
\hline (23) & $\mathrm{mu}_{2}$ & $e_{3}$ \\
\hline (37) & dib? & $\hat{\mathrm{ga}} \mathrm{a}_{2}-\mathrm{ga}_{2}$ \\
\hline (41) & te & gen \\
\hline$(46)$ & $\mathrm{su}_{3} \cdot \mathrm{g}$ & $\mathrm{sag}_{3}$ \\
\hline$(52)$ & $\operatorname{tag}$ & šu tag \\
\hline (53) & $\mathrm{KA} \mathrm{ge}_{4}$ & šu nu $\quad-\operatorname{gid}_{2}$ \\
\hline (54) & $\mathrm{si}$ & sud.r \\
\hline (59) & -ši-ĝen & $\mathrm{seg}_{3}-\mathrm{ge}_{26}$ \\
\hline$(60)$ & šu $\mathrm{gid}_{2}$ & šu dab $b_{5}$ \\
\hline (139) & $u_{5}$ & šub \\
\hline (207) & $\mathrm{dub}_{2}$ & $\mathrm{AK}$ \\
\hline
\end{tabular}

Where nu - or $1 \mathrm{a}-\mathrm{b}$ a - instead of $\mathrm{m} \mathrm{u}$ - is involved, as in line 53, a different verb altogether must be assumed: $\mathrm{n} \mathrm{u} \mathrm{-} \mathrm{[ \ldots ]} \mathrm{for} \mathrm{g}$ a $\mathrm{r}(185), \mathrm{s} \mathrm{i}[\ldots]$ for $\mathrm{n} \mathrm{u}$ -

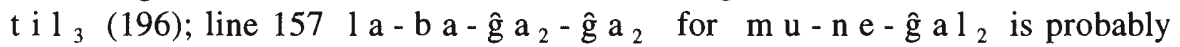
corrupt.

adjectives:

\begin{tabular}{|l|l|l|}
\hline$(87)$ & $\mathrm{du}_{7}$ & $\mathrm{sa}_{7}$ \\
\hline$(88)$ & galam & gal \\
\hline
\end{tabular}


nouns:

\begin{tabular}{|l|l|l|}
\hline$(73)$ & in-di $_{3}$ & ki-in-du \\
\hline$(88)$ & geš gag-pana & geš $[\mathrm{g}] \mathrm{ag}(-) \mathrm{ti}$ \\
\hline$(122)$ & $\mathrm{za}_{3} \cdot \mathrm{g}$ & $\mathrm{a}_{2}$ \\
\hline$(139)$ & eren $_{2}$ & $\mathrm{lu}_{2}$ \\
\hline$(197)$ & kur-kur & hur-sag gal-gal \\
\hline
\end{tabular}

phrase:

\begin{tabular}{|l|l|l|}
\hline (46) & me-dim & -bi kur \\
\hline
\end{tabular}

Some lexical variants are less apparent, such as $\mathrm{n}$ a m b a l a for $\mathrm{n} \mathrm{a} \mathrm{m}$

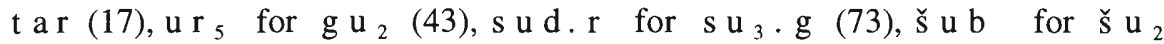
(74 || 75), $\mathrm{s} \mathrm{a}_{7} \cdot \mathrm{g}$ for $\mathrm{s}_{3} \cdot \mathrm{g}$ ? / $\mathrm{s} \mathrm{ig}$ ? (106), $\mathrm{k} \mathrm{u}_{4}$ for $\check{s}\left[\mathrm{u} \mathrm{m}_{2}\right.$ ?] (131), and naturally in the cases where the exact meaning of one of the terms is not clear, as RU? for $\mathrm{tab}(68), \mathrm{TAR}$ for $\mathrm{g}$ a r (69), $\mathrm{SAR}$ for $\mathrm{de}_{2}$ (97), $\mathrm{m} \mathrm{u} \mathrm{d}$ for $\mathrm{zu}$ ? (140), š u du $1_{3} \quad \mathrm{r}$ a for $\mathrm{s} \mathrm{a} \mathrm{g} \mathrm{AK} \mathrm{(150),} \mathrm{D} \mathrm{U} \mathrm{for} \mathrm{sud}$. $\mathrm{r}$ (161), D I for $\mathrm{dab}_{5}$ (185), B U for $\mathrm{g} \mathrm{e}_{4}$ ?! (212). The lexical variants in

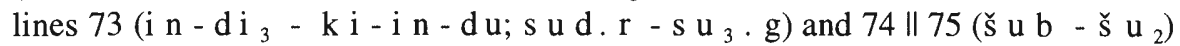
may be due to phonetic affinity. Other lexical variants that can be explained as auditory errors resulting in semantically conditioned non-standard writings are eri/e for eren $n_{2}$ (43), a lan for a-1 a (51), etc. ${ }^{180}$ Some epithets are replaced by different ones, as $1 \mathrm{u}[\mathrm{gal}]$ for $\mathrm{si} \mathrm{pa} \mathrm{zi} . \mathrm{d}$ (84) and $\mathrm{k} \mathrm{i}$ $\mathrm{sikil}$ for $\mathrm{sag}-\mathrm{kal}$ (196), and in one instance by the PN [ u r ]d n a m m a for mas - s u (35).

Some lines add words or terms that expand the sense, or are explanatory in nature: $\mathrm{z} \mathrm{a}_{3}-\mathrm{bi} \mathrm{k} \mathrm{u}_{3}-\mathrm{s}$ i g ${ }_{1}$ "its (= the lapis lazuli seal) edge made of gold" (120), $\mathrm{a}_{2} \mathrm{zi}-\mathrm{da} \mathrm{a}_{2} \quad[\mathrm{~g} \mathrm{a}] \mathrm{b} \mathrm{u} \mathrm{u}_{3} \mathrm{~b}$ u "the right and left side", for simple $\mathrm{z} \mathrm{a}_{3} \cdot \mathrm{g}$ (122), $\mathrm{g}$ e š g a g "peg", along with "surveying tape" and "measuring rod" (125), n i n 9 l u g a l-1 a "the king's sister" as an additional epithet of Geštinana/Ninazimua (126), and the obscure $\mathrm{n}_{2}$ in the hapax $\mathrm{ig} \mathrm{i} \mathrm{du} \mathrm{b}_{2}$ $\mathrm{du} \mathrm{b}_{2}$ (200).

In summary, the Susa texts can thus be characterized as the work of a less competent scribe than the one(s) responsible for the Nippur versions of the composition. One gets this impression from the many auditory errors resulting in non-standard orthography, the syntactically unexplainable omissions of lines, and the grammatically erroneous deviations. Also, the Susa texts seem to present a much shorter version of the composition, completely omitting both the peripety, in which Ningešzida (?) decrees Urnamma's fate, and the praise of Ningešzida in the doxology. The few very different line variations, the variation in narrative sequence 
or order of lines, and the omission of scenes like the one of the burial (?) and the banquet in the netherworld, add to the assumption that different versions of "Urnamma's Death" were current. The Susa texts may present a separate version altogether, or, more likely, follow a Nippur version other than that represented by source A. 


\section{Transliteration and Translation}

\section{[9-10 lines not preserved]}

$\begin{array}{ll}\text { 1' }^{\prime} & \\ \mathbf{2}^{\prime} & 13^{18 \prime} \\ 3^{\prime} & 14 \\ \mathbf{4}^{\prime} & 12 \\ \mathbf{5}^{\prime} & 15 \\ \mathbf{6}^{\prime} & 16 \\ \mathbf{7}^{\prime} & 17 \\ \mathbf{8}^{\prime} & 18 \\ \mathbf{9}^{\prime} & 19 \\ \mathbf{1 0}^{\prime} & 21\end{array}$

11' 20

12' 22

13' 23

14' 24

15' 25

16 ' 26?

17' 27

18' 28

19' 29

20' 35

21' 36

22' 37

23' 38 ?

24' $39-40$

25' 41

26' $42-43$

$27^{\prime} \quad 43-44$

[...] $\left\ulcorner\mathrm{x} x \mathrm{x}^{\urcorner}[(\mathrm{x} x)]\right.$

[...] $\left.{ }^{\mathrm{x}} \mathrm{x} \times \mathrm{x}\right\urcorner$ saĝ-ki-ni mi-ni-gid ${ }_{2}$

[...] $\mathrm{u}_{4}-\mathrm{de}_{3}$ i-si-iš im- $\mathrm{la}_{2}$

[x x (x)] $\Gamma^{x}$ x x itima ${ }^{\top m a-k a ! ~ b a-a n-k u_{4}} \breve{s ̆ a}_{3}(-) k a-t a b(-) b a-n u_{2}$

[ama] ${ }^{\top} x^{\urcorner 182}$ dumu-ni-še ${ }_{3}$ hul-ĝal ${ }_{2}-l a{ }^{\top}$ tuš?-(x? ${ }^{\urcorner}$

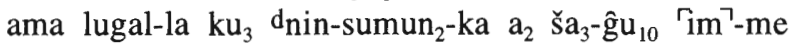

nam ur-dnamma ' $\mathrm{mu}^{\top}$-un-bala-e-eš-am ${ }_{3}$

mu sipa zi ba- ${ }^{\top} \mathrm{ra}-\mathrm{ab}^{\top}-\mathrm{e}_{3}-\mathrm{a}-\mathrm{ta}$

sila daĝal ki e-ne-de ${ }_{3}$ gal $_{2}-{ }^{\top} \mathrm{la}^{\top}-\mathrm{ba} \mathrm{ir}_{2}$ gig ${ }^{\top} \mathrm{mu}^{\top}$-a-šsi-ši

i-lu sipa zi ba-an-dab ${ }_{5}$-be ${ }_{2}$-NE-eš-a ${ }^{\top} \mathrm{u}_{4}{ }^{\urcorner}$mi-n[i?-i] $\mathrm{b}_{2}$-zal-zal-e

nam- $-\mathrm{lu}_{2}-\mathrm{ulu}_{3} \quad$ lib ib $\mathrm{ib}_{2}$-til-la- $\mathrm{am}_{3} \quad \mathrm{u}_{3} \mathrm{~d}\left[\mathrm{u}_{10} \mathrm{x}(\mathrm{x})\right]{ }^{\mathrm{x}} \mathrm{x}(-\mathrm{x})^{\urcorner}[\mathrm{x}]-\mathrm{ku}$

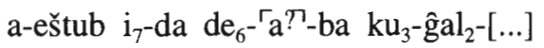

še gu-nu a-gar ${ }_{3}-r e{ }^{r} x^{\urcorner}-e_{3}-a \quad z[i \ldots]$

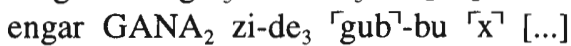

den-ki-im-du lugal eg $_{2} \quad \mathrm{p}\left[\mathrm{a}_{5}-\ldots\right]$

$\left\ulcorner\times \mathrm{AB}^{\text {? }}\right.$ ug $_{3}$ daĝal-bi 'ba ${ }^{7}-[\ldots]$

$\ulcorner(\mathrm{x}) \mathrm{x}\urcorner \mathrm{BU}$ kalam-ma-kam! ${ }^{\top} \mathrm{u}_{2}{ }^{\urcorner}-[\ldots]$

[ed]in-edin-e $u_{2} s\left[a_{6} ?-\ldots\right]$

[(x) $\mathrm{x}]\ulcorner\mathrm{x}\urcorner \mathrm{ab}_{2}$ dugud-d[a? ...]

[Approximately 2-4 lines not preserved, one to two lines each at the end of the obv. and the beginning of the rev.]

[ur] $\left[{ }^{\top}\right.$ namma $\urcorner \mathrm{ki}-[\ldots]$

[x]-ni dab $\mathrm{dab}_{5}$-ba $\left.\left.\mathrm{u}-\ldots\right] \Gamma_{\mathrm{x}}\right\urcorner[\ldots]$

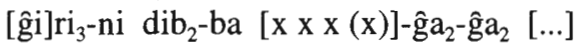

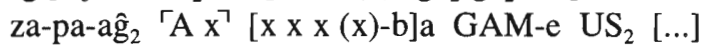

sipa zi lug[al...ki-e]n-gi-ra ur-dnamma [...]

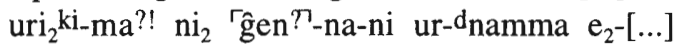

saĝ(-)gu ${ }_{2}(-) \mathrm{gal}_{2}{ }^{\top} \mathrm{e}_{2}{ }^{\top}$-gal-la(-)NI(-)nu ${ }_{2}$-a ur-d ${ }^{-}$namma $l_{2}$ eri/e(-)[...]

$\mathrm{ur}_{5}$ nu-un-da-an-zi igi(-)ğal ${ }_{2}$ kur-kur-ra $\mathrm{i}_{3}-\mathrm{nu}_{2}$ geš- $1\left[\mathrm{a}_{2} ?-\ldots\right]$

181 This and the following numbers refer to the Nippur main text numbering. Question marks after these numbers indicate that Susa may have a different version to the corresponding Nippur line. Cf. also the list above ad "Variations" and II d.), p. 150.

182 Or simply a scratch. 


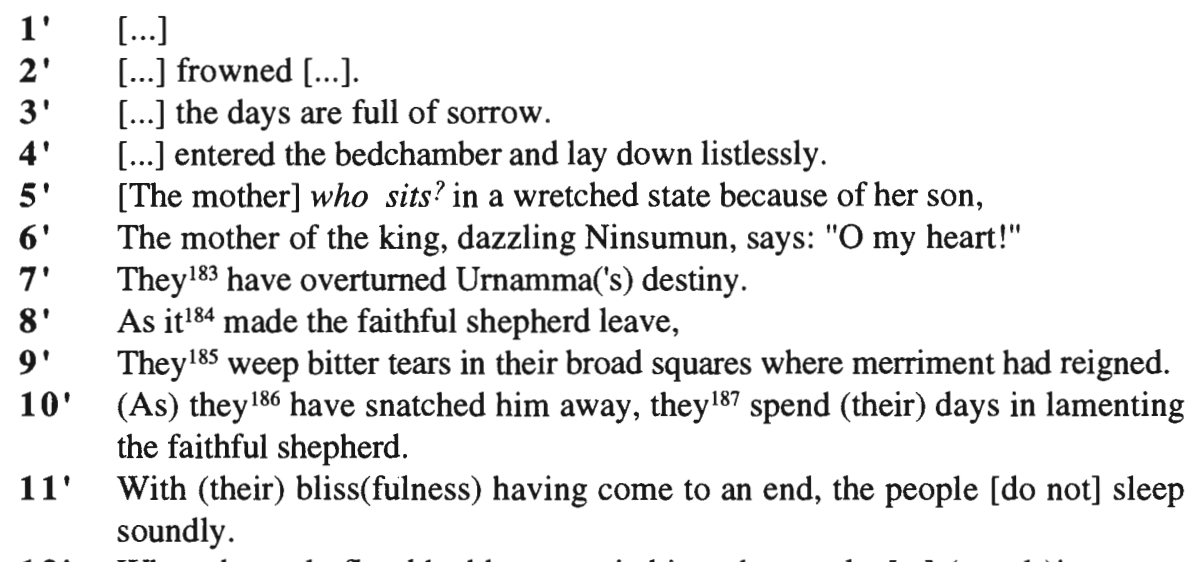

12' When the early flood had been carried into the canals, [...] (canal-)inspector [...].

13' Mottled barley sprouted in the arable tracts, 'the lif[e' ...].

14' For the farmer standing on the cultivated field ... [...].

15' Enkimdu, the lord of embankments and di[tches ...].

16' ... its numerous people [...].

17 , . . of the land dis[appeared?...].

18' On the steppes f[ine?] grass [...].

$19^{\prime}[\ldots] \ldots$ heavy cows ... [...].

[Approximately 2-4 lines not preserved]

20' [Ur]namma ... [...].

21' [...] his [...] which had seized, [...] not [...].

22' His [fe]et which had tread, [...] set [...].

23' Tumult [...] ....

24 The faithful shepherd, the ki[ng ...] of [Su]mer, Urnamma [...].

25. When Urnamma himself had arrived? at Ur and [...] House,

26. The proud one who lies in the palace, Urnamma whom the cities [...],

27. Was not able to raise himself any more. The one who oversees all (the foreign) lands is lying, deathly sile[nce ...].

\footnotetext{
183 i.e. the gods?

184 i.e. the evil (cf. lines 6-7 of the Nippur version).

185 i.e. the people.

186 i.e. the gods?

187 i.e. the people.
} 
28. 45 teš 2 kalam-ma ba-da-an-šub hur-saĝ-gin ${ }_{7}$ ba-g[ul? $\left(\begin{array}{lll}x & x & \text { x }\end{array}\right.$ ?] $^{\text {? }}$

$\mathbf{2 9}^{\prime} \quad 46$

30' $46 a^{188}$ gešeren? ${ }^{189}$ kalam-ma- ${ }^{\top} \mathrm{ke}_{4}{ }^{\top}$ ba-da-bala a- ${ }^{\top} \mathrm{ra}_{2}$ kalam ${ }^{\urcorner}$-ma ba-ekur $_{2}$

31' 47 geštaškarin-e ki-tuš gir ${ }_{17}$-zal-a-ni AGA ${ }^{\prime} \mathrm{mu}$ '-un-na-an-ĝar-re-eš

32' $51 \quad \mathrm{u}_{4}{ }^{\top} \mathrm{sa}_{2}{ }^{\top} \mathrm{du}_{11^{-}}{ }^{\top} \mathrm{ga}^{\top}{ }^{\top}$-ni-a $\mathrm{sa}_{2}$ mi-ri-ib ${ }_{2}$-du alan-a-ni ba-ra-e ${ }_{3}$

33' $52 \quad{ }^{\prime}$ sizkur $_{2}$ ? ${ }^{?}$ niğ $_{2} \mathrm{du}_{10}$ ge 'šu' la-'ba'-an-tag šu gig ba-da-an-gid ${ }_{2}$

34' $53 \quad$ Kadra $_{2}{ }^{\urcorner a-b i} d_{a-n u n-n a-k e}$-e-ne šu nu-um-ma-gid ${ }_{2}$-e

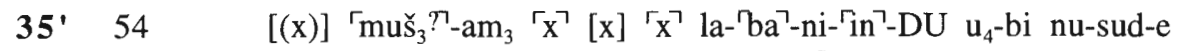

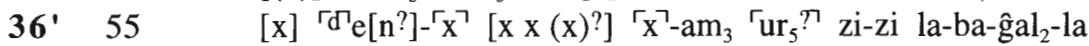

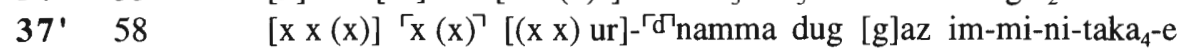

$38^{\prime} \quad 57 \quad$ [...-n]e mu-ni-bala-bala-e

$39^{\prime} \quad 59$

[...-gi] $\mathrm{n}_{7}$ gal-bi im-še $\hat{\mathrm{g}}_{3}-\mathrm{ge}_{26}$

$40^{\prime} 60$

[...] šu nu-dab ${ }_{5}-$ be $_{2}$ im-me

41' 61

[...na $] \mathrm{m}-\mathrm{g} \mathrm{u}_{10}$

[Approximately 5 lines not preserved]

42' 63? [...]- ${ }^{\circ} \mathrm{x}-\mathrm{bi}$ im- $\mathrm{x}^{\urcorner}-[\ldots]$

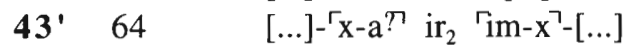

$44^{\prime} 67$

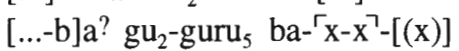

$4^{\prime} \quad 68$

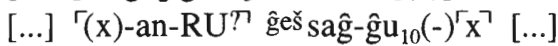

$\mathbf{4 6}^{\prime} \quad 69$

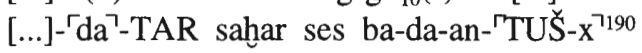

$47^{\prime} \quad 74$

[...]-(.) ${ }^{\Upsilon} \mathrm{AN}^{\top}$-šub har-ra-an im-suh ${ }_{3}$ šu nu-um-ma-ni ${ }_{10}-\mathrm{ni}_{10}$

48' $75 \quad[\ldots] \mathrm{x}^{7191}-(.) \mathrm{AN}$-šub har-ra-an $\mathrm{im}^{\prime} \mathrm{suh}_{3}$ šu nu-um-ma-ni ${ }_{10}-\mathrm{ni}_{10}$

49' $73 \quad[\ldots]$ ki-in- ${ }^{\ulcorner} d{ }^{\prime} \mathrm{su}_{3}$-ud-da

50' 70

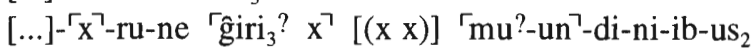

51' $71^{\text {? }}$

[...] kaskal kur-ra-ke ${ }_{4}\left[\ldots\right.$-u]n-di-ni-ib-us ${ }_{2}$

52' 76

[...] $\mathrm{x}^{\top}$-bi nig $\hat{\mathrm{g}}_{2}(-) \mathrm{ba}(-) \mathrm{ab}^{?}$ ? $-[\ldots-\mathrm{m}] \mathrm{u}$ ?

53' $76 a^{192}$

[...] $\mathrm{i}_{3}-\mathrm{du}_{8}$ gal mu-ši- $\left.\left.\ulcorner\mathrm{x}\urcorner-[\ldots]\right]^{\ulcorner} \mathrm{x}\right\urcorner$

54' 77

[...] ba-ug ${ }^{-}$g[e-x x x (x)] $\left.{ }^{r} \mathrm{x}\right\urcorner$

55' 78

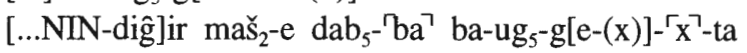

56' $\left.78 \mathrm{a}^{193} \quad[\ldots] \mathrm{r}^{\mathrm{x}} \mathrm{x}-\mathrm{AG}_{2}\right\urcorner$

57. $\left.79 \quad[\ldots]-\mathrm{ag}_{2}\right\urcorner \mathrm{bi}_{2}$-gar

$188=$ line 72 ; cf. the commentary ad 46 a, p. 167.

189 The sign does not look like a classic ERIN but rather a simplified form of $K W U 896$ (cf. $L A K 668$ ) = also (?) ERIN/SES $_{4}$ (cf. Ferwerda, TLB/SLB V, p. 6).

$190-\ulcorner\mathrm{X}\urcorner$ belongs perhaps to the line on the rev.

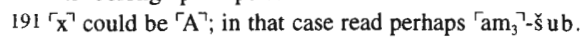

192 Om. in Nippur.

193 Cf. the preceding footnote. 
28' The land's vigour is felled, like a mountain (mine) it is c[ut away?(...)].

29. A grove of h a š u r-trees was felled, the state of the land is confused.

30 $\mathrm{He}^{194}$ passed the cedar trees? of the land, the state of the land is altered.

31 (As) to a boxwood tree they set axes? against his delightful dwelling place.

32' ..., he has lost his healthy appearance.

33. Pleasing sacrifices were no longer seized, (because) afflicted hands have been stretched out towards them.

34' (Therefore) the Anuna no longer stretched out (their) hands towards these gifts.

35' [...] did not ... (his) ahulap, he ${ }^{195}$ does not remove that day.

36 ' $[. .$.$] ..., there was no getting up.$

37 [...] they had abandoned [Ur]namma (as) a broken jar.

38' [...] turned over.

$39^{\prime}[\ldots]$ precipitates in vast quantity like [...].

40 ' "[...] he does not grab any more [...]!" she? says.

41' "[... wh] is it to me?"

[Approximately 5 lines not preserved]

$42, \quad[\ldots] \ldots[\ldots]$

43, $[\ldots]$ who $[\ldots]$ tears $[\ldots]$.

44' [...] strip[ped of ...].

$45^{\prime}[\ldots]$... bolt? [...].

46' $[\ldots] \ldots$ was found bitter dust.

47' [...] fell, the roads became twisted and one could not hurry along on them (any more).

48' [...] fell, the roads became twisted and one could not hurry along on them (any more).

49' [...] is a long stretch of road.

$50^{\prime} \quad[\ldots] \ldots$ they ${ }^{196}$ made (their) way with him.

51' [...] they undertook with him the journey to the netherworld.

52' He [...] presents [...].

$53^{\prime}[\ldots]$ the chief porter(s) [...].

54' [...] died,

55' When [... N I N d i g ] i r-priestesses who had been chosen by extispicy had died,

$56^{\prime}[\ldots] \ldots$

57' $[\ldots]$, he $^{197}$ raised a [tumu]lt?

\footnotetext{
194 i.e. Urnamma.

195 i.e. An?

196 i.e. donkeys, Urnamma's entourage?

197 i.e. Urnamma.
} 


\begin{tabular}{|c|c|c|}
\hline $5^{\prime}$ & 80 & $\left.[\ldots]\ulcorner\mathrm{x}\urcorner[\mathrm{x}]\ulcorner\mathrm{x}\urcorner[\ldots]-{ }^{2}\right\urcorner-\mathrm{ag}_{2} \mathrm{bi}_{2}-\mathrm{gar}^{\urcorner 198}$ \\
\hline $59^{\prime}$ & 84 & lu[gal gar]za kur-ra-ke ${ }_{4}$ ša $_{3}$-ga-ni ${ }_{\mathrm{i}_{3}}-\mathrm{zu}{ }^{\urcorner}$ \\
\hline $60^{\prime}$ & $84 a^{199}$ & ur-dnamma garza kur-ra- $\mathrm{ke}_{4}^{\urcorner} \mathrm{ša}_{3}$-ga-ni $\mathrm{i}_{3}-\mathrm{zu}$ \\
\hline $61^{\prime}$ & 87 & gud $\mathrm{sa}_{7}$ maš $_{2}$ du-du $\left\ulcorner^{\mathrm{udu}}\right\urcorner$ niga im-ma-ab-lah- ${ }_{4}-\mathrm{e}$ \\
\hline $62^{\prime}$ & 88 & $\begin{array}{l}\text { gešmiddu }{ }_{2} \text { gešpana }\left\ulcorner\text { gal a }{ }^{\urcorner}-\text {ma- }{ }^{\top} \text { ru-bi? geš? }\left[\text { g]ag(-)ti giri, }{ }_{2} ?-\mathrm{zu}_{2}\right.\right. \\
\text { gal }\end{array}$ \\
\hline $6^{\prime}$ & 89 & kušlu-ub gunu $_{3}-\mathrm{a}[\mathrm{x}]-\mathrm{ba}$ gal $_{2}$-la-ni!(IR) \\
\hline $64^{\prime}$ & 90 & 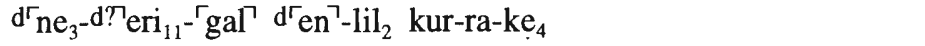 \\
\hline $65^{\prime}$ & 91 & sipa ur-dnamma-ke ${ }_{4} \mathrm{e}_{2}-{ }^{-}$gal -la-a-ni geš im-mi-in-tag-ge \\
\hline $6^{\circ}$ & 92 & geš gid ${ }_{2}$-da kušlu-ub $b_{2}$ dag-si $\left.\Gamma_{x}\right\urcorner$ gešmitum pirig an-na \\
\hline $67^{\prime}$ & 93f. & 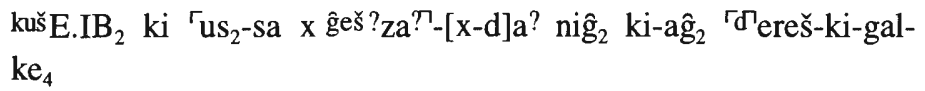 \\
\hline $6^{\prime}$ & 95 & $\left.\mathrm{~d}^{\top} \mathrm{bil}_{3}\right\urcorner$-ga-mes lugal kur-ra-ke 4 \\
\hline $69^{\prime}$ & 96 & [s]ipa ur-dnamma-ke ${ }_{4} \mathrm{e}_{2}-{ }^{\mathrm{g}} \mathrm{ga} \Gamma-\mathrm{a}-\mathrm{ni}$ geš im-mi-in-tag-ge \\
\hline $70^{\prime}$ & 97 & [ge]š-k[ešs? $\left.{ }_{2}^{?}-x(x)\right]\ulcorner x\urcorner i_{3}$ ba-SAR-a b[ur]-šagan šu $d_{7}-a$ \\
\hline $71^{\prime}$ & 99 & {$[\ldots](-)$ lugal-la sig $\mathrm{NIG}_{2} . \hat{S}^{\mathrm{S} U}(.) \mathrm{PI}$ me kur-ra } \\
\hline $72^{\prime}$ & 100 & $\left.[(\mathrm{x})]{ }^{\ulcorner} \mathrm{x}\right\urcorner$ ereš-ki-gal ama $[\mathrm{x}$ x] $]-\ulcorner\mathrm{a}-\mathrm{zu}-[\ldots]$ \\
\hline $73^{\prime}$ & 101 & [s]ipa ur-dnamma-ke ${ }_{4} \mathrm{e}_{2}$-gal-la- ${ }^{-\mathrm{a}}$-ni geš im-mi-i[n-tag-ge] \\
\hline $74^{\prime}$ & 102 & $\begin{array}{l}\text { udu A.LUM udu z/sulu(m)hu/i } \mathbf{x}_{\mathbf{x}}\left(\mathrm{TUG}_{2} . \mathrm{SUD}\right) \mathrm{maš}_{2} \text {-gal kur-ra- } \\
\left.\mathrm{Ke}_{4}\right\urcorner\end{array}$ \\
\hline $75^{\prime}$ & 103 & geš-nu ${ }_{11}$ gešma-nu nam-en-na-kam šu za-gin ${ }_{3}$-na tum tum[a] $_{2}$ \\
\hline $\mathbf{7 6}^{\prime}$ & $103 \mathrm{a}^{200}$ & $\begin{array}{l}\text { šibir }\left(E N \times G A N A_{2} \text {-t. }\right) \text { ešgiri(U.EN } \times G_{A N A} \text {-t.) gešma-nu nam- } \\
\text { sipa-da nam-en-na tum }{ }_{2} \text {-ma }\end{array}$ \\
\hline $77^{\prime}$ & 104 & ddumu-zi dam ki-ag $_{2}$ dinana-ra \\
\hline $7^{\prime}$ & 105 & sipa ur-dnamma-ke ${ }_{4} e_{2}$-gal-a-ni geš im-mi-in-tag-ge \\
\hline $79^{\prime}$ & 106 & $\mathrm{gi}_{16}$-sa šu $\mathrm{du}_{7}-\mathrm{a}$ har $\mathrm{ku}_{3}-\operatorname{sig}_{17} \mathrm{ma}_{2}-\operatorname{gur}_{8}(-) \mathrm{BI}(. /+) \times \mathrm{sa}_{7}-\mathrm{ga}$ \\
\hline $80^{\prime}$ & 107 & 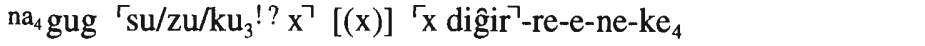 \\
\hline $81^{\prime}$ & 108 & $\mathrm{~d}_{\text {nam-tar }} \mathrm{lu}_{2}$ nam $\mathrm{t}[\mathrm{ar} ?-\ldots]-\mathrm{ke}_{4}$ \\
\hline $8^{\prime}$ & 109 & sipa ur-dnamma-ke ${ }_{4} e_{2}$-gal-a-ni geš im-mi-tag-ge \\
\hline $\mathbf{8 3}^{\prime}$ & 110 & dub-šen šu za-gin ${ }_{3}$ nig $_{2}$-nam irigal ${ }_{2}$ gal-la \\
\hline
\end{tabular}

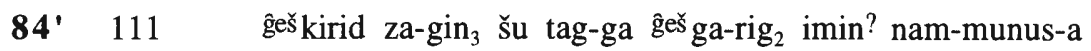

\begin{tabular}{|c|c|c|}
\hline $8^{\prime}$ & 112 & dhuš-bi-sa ${ }_{6}\ulcorner$ dam $\urcorner$ nam-tar-ra-ke ${ }_{4}$ \\
\hline $\mathbf{8 6}^{\prime}$ & 113 & sipa ur-dnamma- $\mathrm{ke}_{4} \mathrm{e}_{2}-\mathrm{gal}-[(\mathrm{la}-) \mathrm{a}-\mathrm{ni}$ geš im-m]i-in-tag-ge \\
\hline $87^{\prime}$ & 114 & {$[\ldots] \times \mathrm{gunu}_{3} ?-\mathrm{a}$} \\
\hline $\mathbf{8 8}^{\prime}$ & 116 & [...AN]ŠE.NITA? $\mathrm{gu}_{2}$ nun? $\mathrm{du}_{11}-\mathrm{du}_{11}$ \\
\hline
\end{tabular}

\footnotetext{
198 It is uncertain if Sb $140831^{\prime}$ is to be equated with Sb 1413717 ; the only visible sign on the last line of Sb 14137 (= line 18) could be part of the - ${ }^{2} \mathrm{zu}^{\top}$ of $\mathrm{Sb} 140832^{\prime}$.

199 Om. in Nippur.

$200 \mathrm{Cf}$. the preceding footnote.
} 
58, $[. .$.$] , he raised a [tumu]lt?.$

59' The ki[ng] - his heart knew of the [cultic n]orms of the netherworld:

60' Urnamma - his heart knew of the cultic norms of the netherworld:

61' He brings magnificent bulls, perfect bucks and fattened sheep.

62' A mace, a large bow with its? quiver and arrows, a large . . . dagger,

63 And his multicoloured leather-bag which he wears at [...]

64. To Nergal, the Enlil of the netherworld,

65. Shepherd Urnamma offers as a sacrifice in/for his palace.

66' A spear, a leather-bag ... saddle(-hook), a m i t u m-weapon (with) a celestial lion,

67' A shield which is (firmly) pressed to the ground, ...., and a ba[ttle-a]xe?, Ereškigal's favourite,

68. To Gilgameš, king of the netherworld,

69. Shepherd Urnamma offers as a sacrifice in/for his palace.

70' A [con]ta[iner] in which oil has been poured, a š a g a n-bowl of perfect make,

$71^{\prime}$ [...] royal ..., the $\mathrm{m} \mathrm{e}$ of the netherworld

72' To Ereškigal, the mother of [Nin]azu,

73' Shepherd Urnamma of[fers] as a sacrifice in/for her palace.

74' A L U M-sheep, long-fleeced sheep, and mountain he-goats,

75 A . . made of $m$ a $n$ u-wood of e $n$-ship, worthy of a shining hand,

76. Staff and nose-leash, (a staff) made of $m$ a $n$ u-wood of shepherdship, worthy of e n-ship,

77. To Dumuzi, Inana's beloved husband,

78. Shepherd Urnamma offers as a sacrifice in/for his palace.

79' Perfectly wrought jewellery, a golden ring, a beautiful . . . cargo boat,

$\mathbf{8 0}^{\prime}$ And a ... carnelian-stone $[\ldots]$... . of gods

81' To Namtar who [...] the decreed fates

82' Shepherd Urnamma offers as a sacrifice in/for his palace.

83. A (treasure) chest with a lapis lazuli handle, (with) everything (concerning) the underworld,

84' A hair clasp decorated with lapis lazuli, and seven? combs of womenly fashion

85 $^{\circ}$ To Hušbisag, Namtar's wife,

86 $^{\circ}$ Shepherd Urnamma offers as a sacrifice in/for her palace.

87' [...] painted? with [...],

$\mathbf{8 8}^{\prime} \quad[\ldots$ as $]$ ses that bray loudly?, 


$\begin{array}{ll}\mathbf{8 9}^{\prime} & 117 \\ \mathbf{9 0}^{\prime} & 118 \\ \mathbf{9 1}^{\prime} & 119 \\ \mathbf{9 2}^{\prime} & 124 \\ \mathbf{9 3}^{\prime} & 125 \\ \mathbf{9 4}^{\prime} & 126 \\ \mathbf{9 5}^{\prime} & 127 \\ \mathbf{9 6}^{\prime} & 127 \mathrm{a}^{201} \\ \mathbf{9 7}^{\prime} & 128 \\ \mathbf{9 8}^{\prime} & 121 \\ \mathbf{9 9}^{\prime} & 120 \\ \mathbf{1 0 0}^{\prime} & 122\end{array}$

$101^{\prime} 122 \mathrm{a}^{202}$

$102^{\prime} 128 \mathrm{a}^{203}$

103' 129

104' 131

105' $131 \mathrm{a}^{205}$

106' 134

107' 135

108' 136

109' 137

110' 138

111' 139

112' 140

$113^{\prime} 143$

114' 144

115' 145

$116^{\prime} 146$

117' 147

118' $148^{\prime}$

119' 149 [...]-da-ab-us ${ }_{2}$-sa

[...d]nin-ĝeš-zi-da-ra

[sipa ur-dnamma-ke $\left.{ }_{4}{ }^{\top} \mathrm{e}_{2}\right\urcorner$-gal-a-ni geš im-mi-in-tag-ge

[...-r]a nig ${ }_{2}(-)$ nam(-)dub!-sar-kam

[...] geš gag gi-nindan $\mathrm{KAD}^{\text {?-na }}$

[...]- $\left\ulcorner\mathrm{x}-\mathrm{mu}_{2}\right.$ ? $-\mathrm{a} \operatorname{nin}_{9}$ lugal-la-ra

[...du]mu? a-ra-li- ${ }^{\top} \mathrm{ta}$ ?

[dge]štin-an-na nin ${ }_{9}$ lugal-la- ${ }^{\text {ra?? }}$

[s]ipa ur-dnamma-ke ${ }_{4} e_{2}$-gal-la-a-ni geš im- ${ }^{-m i}{ }^{\top}$-tag

du-di-da $\mathrm{ku}_{3}-\mathrm{sig}_{17} \mathrm{ku}_{3}$-babbar 'saĝ'-bi alim-ma

[n] $\mathrm{a}_{4}$ kišib za-gin ${ }_{3} \mathrm{za}_{3}$-bi $\mathrm{ku}_{3}$ - sig $_{17} \mathrm{ru}_{3}$ ba-da-ra $\mathrm{ku}_{3}$ me-a

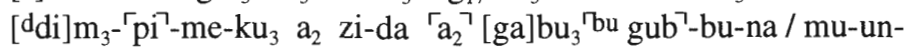
$\Gamma_{\text {na-an }}{ }^{-}-[\mathrm{x}]-\Gamma_{\mathrm{x}}(\mathrm{x}) \mathrm{T}$

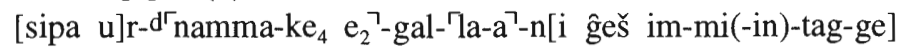

[gud $\left.\mathrm{sa}_{7} \mathrm{ma}\right] \mathrm{s}_{2} \mathrm{~d}[\mathrm{u}-\mathrm{du}]$ udu niga $\mathrm{i}\left[\mathrm{m}-\mathrm{ma}-\mathrm{ab}-\mathrm{lah}_{4} \text { ?-a }\right]^{204}$

[gud $\mathrm{sa}_{7}$ ] maš $\check{\mathrm{S}}_{2}$ du-du udu niga im-ma-ab-tuku-a

[d?a?-nun?-n]a ensi $i_{2}$ gal kur-ra-ke ${ }_{4}$ mu-un-na-da-ab-ku ${ }_{4}$

[sipa u]r-dnamma-ke ${ }_{4} e_{2}$-gal-a-ni!(IN) geš im-mi-in-tag-ge

[ensi ${ }_{2}$ ?] gal irigal ${ }_{2}-\mathrm{la}^{\text {? }}-\mathrm{ke}_{4}$-e-ne

[da]-nun- ${ }^{\mathrm{d}} \mathrm{C}^{\top} \mathrm{NI}_{3}\left(\mathrm{inda}_{3} /\right.$ niğ $\left._{2}\right)$ šu tag-ga-ba

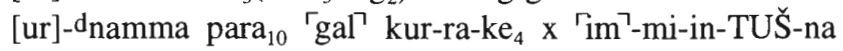

[x-r]a? ki-tuš mu-un-na-ĝa $\mathrm{a}_{2}-\mathrm{ga}_{2}$

$\ulcorner$ enim $\urcorner d_{11}$ ga dereš-ki-gal-la-ke ${ }_{4}$

$\mathrm{lu}_{2}$ geštukul-la in-na ba- $\widetilde{s ̌ u b}^{\mathrm{s}} \mathrm{-e}$

$\mathrm{lu}_{2}$ nam-da ${ }_{6}$-ga in-na ba-mud-e

$\Gamma_{\text {ses }}$ ki-ag $\hat{2}_{2}$-a-ni dbil ${ }_{3}$-ga-mes-ra

$\ulcorner$ e-ne $\urcorner$-ne di kur-ra $k_{5}$-de 3 ka-aš-bi ŠI(-)bar-re

$\mathrm{u}_{4} \quad \mathrm{ia}_{2}-\mathrm{am}_{3} \quad \mathrm{u}_{4} \quad \mathrm{u}-\mathrm{ram}_{3} \mathrm{ar}^{\urcorner}$ba-zal-a-ta

lugal-e i-si-iš $\mathrm{k}[\mathrm{i}]$-en-gi-ra si(-)gu $\mathrm{u}_{7}$-mu-un-na- $\left\ulcorner\mathrm{du}_{11}\right\urcorner$

'ur'-dnamma i-si-iš ki-en-gi-ra si(-)gu $u_{7}$-mu-un- $\left.{ }^{\top} n a\right\urcorner-[d] u_{11}$

[ba]d uri $_{2}$ ki-ma nu-mu-un-til-li-na

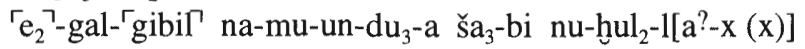

120' 150 [si]pa-[d] $\mathrm{e}_{3} ? \mathrm{e}_{2}$-a- ${ }^{\mathrm{ni}} \mathrm{n}$ šu dul $_{3}$ li-bi-ra-a(-)[(x x)]

\footnotetext{
201 Om. in Nippur.

$202 \mathrm{Om}$. in Nippur.

$203 \mathrm{Cf}$. the preceding footnote.

204 After this line only a line after a break is visible, so maybe one line is not preserved. If this is not so and line $102^{\prime}$ is the last line on tablet $\mathrm{Sb}_{2}$, then line $103^{\prime}$ could be the catchline to $\mathrm{Sb}_{3}$ and line $102^{\prime}$ must be restored accordingly i[ m-ma-ab-tuku-a]. For the catchline phenomenon, cf. Heimpel, JCS 33 (1981) 71 ad (4) and Cooper, Curse of Agade 45.

$205 \mathrm{Om}$. in Nippur.
} 
$\mathbf{8 9}^{\prime}[\ldots]$ followed by $[\ldots]$,

90' To [...] Ningešzida

91' [Shepherd Urnamma] offers as a sacrifice in/for his palace.

92' [...] (with) everything (concerning) the scribe, ${ }^{206}$

93. [...] a peg, a ( $\mathrm{n}$ i $\mathrm{n} \mathrm{d} \mathrm{a} \mathrm{n}$ ) measuring rod...

94. To [...(Nin)azi]mua, the king's sister,

95' [... den]izen? from/in Arali,

96' [Ĝe]štinana, the king's sister,

97. Shepherd Urnamma offers as a sacrifice in/for her palace.

98 A toggle pin made of gold and silver whose head (is) that of a bison,

99' A lapis lazuli seal, its edge made of gold and the pin of pure silver

$100^{\prime} \mathrm{He}$. . . to Dimpimekug who stands at the right and left side.

101' [Shepherd Ur]namma [offers (this) as a sacrifice] in/for her palace.

102' [The magnificent bulls], the per[fect bu]cks and the fattened sheep [which have been brought?],

103' [The magnificent bulls], the perfect bucks and the fattened sheep which have been obtained?

$104^{\prime}$ Were ushered with him ${ }^{207}$ into the presence of the [Anun]a? , the great e $\mathrm{n} \mathrm{i}_{2}$ of the netherworld.

105' [Shepherd U]rnamma offers as a sacrifice in/for their palace.

106' The great [e $\mathrm{n} \mathrm{s}_{2}$ ? ] of the underworld,

107' The [A]nuna, after having seized the offerings

108 And having ... seated Urnamma on the great dais of the netherworld,

$109^{\prime}$ Set up a dwelling place for him in the [...].

$110^{\prime}$ At the command of Ereškigal

111' Men of arms, so far as they have fallen,

112' And sinners, so far as they have been produced,

113' 'With? his beloved brother Gilgameš

114' They pass the judgment of the netherworld and render its decisions. ${ }^{208}$

115' After five days, ten days had passed,

116 The wails of Sumer reached also the king,

117' The wails of Sumer reached also Urnamma.

118' Over the fact that he had not completed the ([ci]ty-)wall of Ur,

$19^{\prime}$ That the New Palace's interior, which he indeed had built, had not delighted him,

$120^{\prime}$ That the shepherd ${ }^{209}$ no longer put a protecting hand over his house(hold),

206 Or: "(...) which belongs to the scribal art".

207 i.e. Urnamma.

208 But cf. also the commentary ad 144, p. 176.

209 i.e. Umamma. 


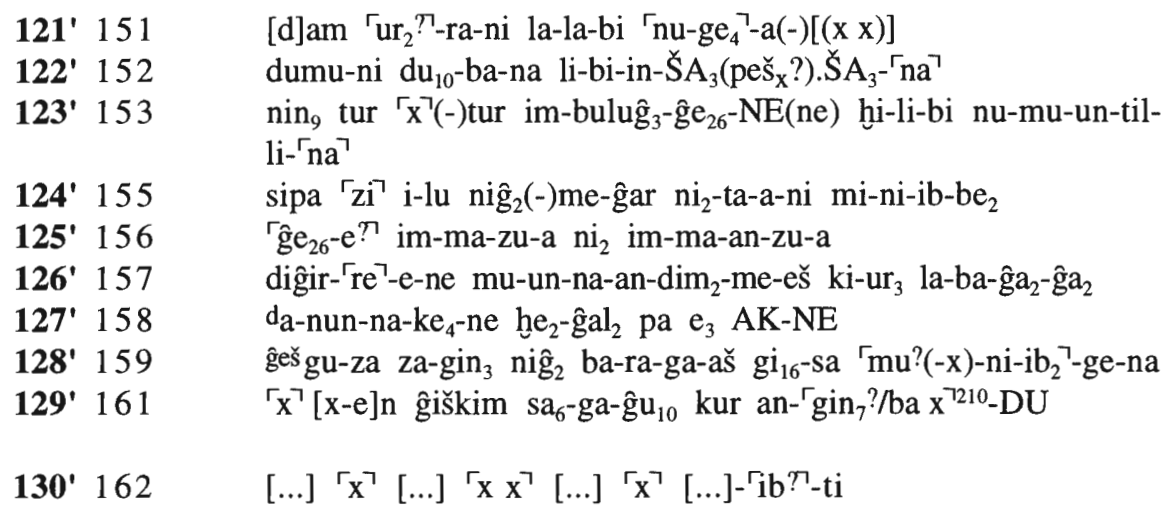

[Approximately 4-6 lines not preserved, two to three lines each at the end of the obv. and the beginning of the rev.]

131' 183 ? Traces

132' 184

[...] $\left\ulcorner_{x}(x)\right\urcorner$-ba en-nu-ug $\hat{g}_{3} \operatorname{lu}_{2}(-)[\ldots]$

133' 185

[...] mu-un-DI me-a $1 u_{2}$-bi nu- $\ulcorner x(-x)\urcorner-[\ldots]$

134' 187

[...] a-da- ${ }^{\ulcorner} \mathrm{ab}^{\urcorner}$gi-SU ${ }^{?{ }^{211}} \mathrm{za}_{3}-\mathrm{za}_{3}-\mathrm{mi}_{2}(-) \mathrm{ir}_{2}$ ba- ${ }^{\mathrm{ni}-\mathrm{x}\urcorner}([\ldots])$

135' 188

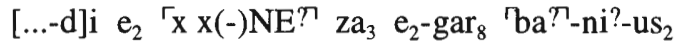

136' 189

[...] $\ulcorner\mathrm{X}\urcorner[\ldots-1] \mathrm{i}$ ?- $\mathrm{bi}\urcorner$ nu-mu-un-til-li-na

137' 190

[...i]m-mi-in-TUŠ-na

138' 191

[...] $\left.{ }^{x} x^{\top}\right\urcorner[. .$.$] nu-mu-un-til-li-na$

139' 192 ?

[... -i] $]$ ? -šub-bu-na

140 ' 193 ?

[...] traces [...] ${ }^{\mathrm{X}} \mathrm{X}-\mathrm{KU}$ ?

141' 196

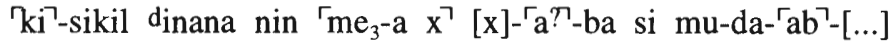

142' 197

den-lil ${ }_{2}$-le hur-sag gal-gal kig $\hat{2}_{2}-\mathrm{ge}_{4}-\mathrm{a}^{\text {? }} \mathrm{bi}_{2}-\mathrm{g}[\mathrm{e}]$

143' 198

ki-bi-ta igi-ni gar-ra-ni $[(\ldots)]^{212}$

144' 202

sipa zi $e_{2}$-an-na mi-ni-ib ${ }_{2}-e_{3}$ igi nu-mu-ni-d[u(-x)]

$145^{\prime} 200$

146' 207

saĝ-ki huš den- $\left.\mathrm{Clil}_{2}\right\urcorner \mathrm{ni}_{2}$ igi dub $\mathrm{dub}_{2}-\mathrm{de}_{2}$

147' 209

an lugal digir-re-e-ne in $\mathrm{kur}_{2}$ mu-un-AK-e

148' 210

an lugal $\mathrm{du}_{11}$-ga-a-ni du $\mathrm{d}_{11}$-ga-a-ni nu- $\left.\mathrm{kur}_{2}-\mathrm{x}\right\urcorner$

149' 211

ur-dnamma DA?-mu-de $\left.\mathrm{ib}_{2}-\mathrm{la}_{2} \mathrm{Cu}_{4}\right\urcorner[\ldots]$

150' 212

$\mathrm{u}_{4} \mathrm{e}_{3}$-a digir-re-e-ne $\left.[\mathrm{x}(\mathrm{x})](-)\right)^{\circ} \mathrm{ga}^{\Upsilon}$ nu-gal ${ }_{2}-[1] \mathrm{a}$

151' 213

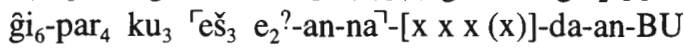

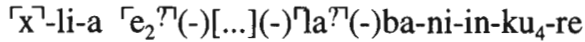

$\left.\Gamma^{\mathrm{im}}\right\urcorner \mathrm{gid}_{2}$-da pir-hu-um $\mathrm{u}_{4}$ ? $\mathrm{x} \times \mathrm{x} \times \mathrm{x}^{\urcorner 213}$

\footnotetext{
$210\ulcorner\mathrm{X}\urcorner \neq \mathrm{su}_{3}$; perhaps read $[\mathrm{m}] \mathbf{u}^{?}-\mathrm{DU}$.

211 Read perhaps -BU.

212 After -ni the tablet surface is broken off but probably no more signs follow.

213 Followed by single ruling above and below the line
} 
121' That he no longer brought pleasure to (his) wife on/with his lap,

122' That he no longer raised? his children on his knees,

123' That he no longer brought the attractiveness of the young, growing up sisters to maturity,

124' The faithful shepherd utters a silence-imposing lament concerning himself:

125' "(For) me who has experienced, who has experienced fear,

$126^{\prime} \ldots .^{214}$

127' Reveal . . . abundance to the Anuna,

$128^{\prime} \ldots{ }^{215}$

129' I $[\mathrm{am}]$... ., anything that could have been a portent favourable to me was ... as? the netherworld and heaven.

130 ' [...] obt [ained ...] ?/!

[Approximately 6 lines not preserved]

$131^{\prime}[\ldots]$

$132^{\prime}[\ldots] \ldots$ they/[these $]$ people $[\ldots]$ a guard.

133 ' $[. .$.$] . . these people were not [$ able? to $]$ sile $[$ nce? ...].

$134^{\prime}[\ldots]$ and a d a b-instruments, $m y$... flutes and $\mathrm{z} \mathrm{a} \mathrm{m} \mathrm{z} \mathrm{a} \mathrm{m-instruments}$ were $[\ldots]$ tears.

$135^{\prime}$ The $[. .$.$] were propped against? the wall ... [...].$

136' Over the fact that [...] whose ... he had not exhausted,

137' That one made him squat [...].

138' That $[. .$.$] he had not exhausted,$

139' That $[\ldots]$ he had fallen,

$140,[\ldots] \ldots$

141' The young woman, Inana, the lady (who was) in battle, ... . [...

142' Enlil sent a message to? all the big mountain ranges.

143' Having set her ${ }^{216}$ gaze from there, ${ }^{217}$

$144^{\prime}$ (")One made the faithful shepherd leave the Eana, I? have not seen him (since)("). ${ }^{218}$

$145^{\prime}$ She ... at? Enlil's fierce forehead.

146' She gravely insulted An, the lord of the gods:

147" "What king An has uttered, what he has uttered, should? not be changed!

148' Urnamma .... [...]

$149^{\prime}$ Where daylight breaks for the gods its [...] does not exist (any more).

150' The precious g i p a r, the sanctuary Eana [...] has been uprooted.

$151^{\prime}$... he did not let me enter."

\footnotetext{
214 Corrupt text?

215 Corrupt text?

216 i.e. Inana.

217 "There" refers to all the big mountain ranges (in line 142') where Inana received the news.

218 Maybe direct speech of Enlil, or the content of his sent message.
} 


\subsection{Philological Commentary}

1 Compare the same imagery in Curse of Agade 149 and Attinger's commentary on k a la m te š ${ }_{2}$ - a $\hat{\mathrm{g}}$ a r "to place evenly on the land" in $R A 78$ (1984) 115 ad 149. Instead of $\mathrm{g} \mathrm{a} \mathrm{r}$, restore perhaps $\mathrm{r} \mathrm{i}$ (/r a) and compare Ur Lament $388 \mathrm{E}(/ \mathrm{x}) \quad \mathrm{u}_{4}-\mathrm{NE} \quad \mathrm{u}_{4}-\mathrm{de}_{3} \quad \mathrm{kalam} \quad \mathrm{te} \mathrm{s}_{2}-\mathrm{a} \quad \mathrm{mi}(/ \mathrm{i})-$ $\mathrm{ni}-\mathrm{i} \mathrm{b}_{(2)} \mathrm{ri}(/ \mathrm{r}$ a) ". . the storm raged over the whole land" (also Lugale 490). Perhaps the agent(s) of lines $1 \mathrm{ff}$. is the storm (cf. Sumer and Ur Lament 2), or the evil in lines $6 \mathrm{f}$. (cf. also the commentary ad 6-7 below).

5 Restore at the beginning perhaps [ $\mathrm{ki}$ ] or [ e d i n ]. According to Wilcke, UT 85 there is not enough space for a restoration [ $\mathrm{k} \mathrm{a}$ l a m ] (cf. Sulgi Pa 12). For $\mathrm{n} \mathrm{i} \hat{\mathrm{g}}_{2}-\mathrm{d}$ a g a $\mathrm{l}-\mathrm{b}$ a denoting geographical and cosmological terms, cf. Klein, TAPS 71/7 (1981) 38 ad 12.

For the reading i r i / e r i / e r e "city" for U R U, cf. Edzard, Studies Civil = AulOr. 9 (1991) 77ff., with reservation W.G. Lambert, AulOr. 10 (1992) 257 (also / u ru /), and Sassmannshausen, BaM 26 (1995) 97, fn. 84 (/i ri / not assured). Compare also the commentary to Susa's e ri / e in line 43 as reinterpretation of e r e $\mathrm{n}_{2}$ "troops" in source A.

6-7 The translation "it made the faithful shepherd (Urnamma) leave it" is preferred over "it did not let the faithful shepherd (Urnamma) escape" in view of Nippur Lament 77, 111, and 114 (cited in IV 3.3, p. 88) and the general theme in lamentation literature of the gods abandoning their cities and retreating to the steppe (cf. also ibid., p. 91), with which Urnamma leaving his city and setting up his dwelling in Arali can be compared.

There is no substantial evidence that h $\mathrm{u} 1-\mathrm{g} \mathrm{a}_{2}$ "evil" in line 6 is a metaphor for the Guti and that Urnamma was killed in military action against them, as Wilcke surmises in UT 85 and CRRAI 19 (1970) 84 (cf. also I 1., p. 7 and IV 3.3, p. 87).

8-9 e $\mathrm{n} \mathrm{i} \mathrm{m} \mathrm{k} \mathrm{u}_{3}(-\mathrm{g} \mathrm{a})$ "precious pronouncement" and $\mathrm{n} \mathrm{a} \mathrm{m} \mathrm{(-)} \mathrm{t} \mathrm{a} \mathrm{r} \mathrm{(-}$ $\mathrm{r}$ a) "decreed fate" allude to Urnamma's destiny.

For $\breve{\mathrm{s}_{3}}$ u s a $\mathrm{n}_{\mathrm{x}}$ (A N. U S A N) "evening midst", i.e. "midst of the evening" (if the reading is correct!), cf. Nungal 3, Temple Hymns 93, and Iddindagān D 35 (= Gurney, Kramer, OECT 5 [1976] 20, no. 8). But what exactly the expression means here, is unclear.

10-16 These lines describe the gods' reaction to the change of An and Enlil's decision. Whereas in the city laments the gods actively withdraw their divine support from a city following An and Enlil's decision and the abandonment by its city-god (references in Cooper, Curse of Agade 21f.; add perhaps Sulgi D 243-249), the gods in this passage passively retreat or moan in the face of calamity.

12 Cf. Cooper, Curse of Agade 253 ad 209 for other references of this topos. 
13 The reading of the first half of the line as e $\mathrm{n} \mathrm{i} \mathrm{m}\left\ulcorner\mathrm{k} \mathrm{u}_{3}\right.$ ? ! $\urcorner$ a $\mathrm{n}-\mathbf{n ~ a -}$ $\ulcorner\mathrm{k} \mathrm{a}$ ? $\urcorner$ "An's precious pronouncement" (referring to line 8 ) is very uncertain.

$14-\mathrm{e}_{3}-\mathrm{e}$ may stand here for $\left\{\mathrm{E}_{3}+\mathrm{ed}\right\}$.

16 The absence of the ergative might be due to the preservation of rhythm (a m a dumuni š hul (u) tila'e (9) l a ma lug (a) la ku n i n s u m ( u ) n a). Other instances are lines 70-71 (broken), 74-75 (broken) 81$82,85-86,132-133$ (broken), and 146-147 (cf. also the remarks in V 1.1, p. 94).

For the reading and etymology of the DN ${ }^{d} \mathrm{n} \mathrm{i} \mathrm{n}-\mathrm{s} \mathrm{u} \mathrm{m} \mathrm{u} \mathrm{n}_{2}(-\mathrm{n} \mathrm{a}-\mathrm{k})$, cf. Cavigneaux, RA 87 (1993) 109f., and fns. 17f.; idem, Al-Rawi, Iraq 55 (1993) 93.

17 Despite the absence of the dative (or genitive) postposition after $\mathrm{u} \mathrm{r}$ $\mathrm{d} \mathrm{n} \mathrm{a} \mathrm{m} \mathrm{m} \mathrm{a,} \mathrm{and} \mathrm{mu} \ldots-\mathrm{a}-\mathrm{s̆}_{3}$ "because" in line 18 (instead of simply - $a-\breve{s} e_{3}$ as in this line), n a m probably means here "fate", and connotatively "essence", i.e. Urnamma's essence or being that has been "cut off" (in the Susa version "overturned").

20 For 1 i . b hadî, râšu "to be happy" and rīšātu, hidiātu "happiness", cf. Krecher, Kultlyrik 96 ad I 20-21, S. Cohen, ELA 285 ad 478, Klein, Studies Artzi (1990) 128 ad 76, and Wu Yuhong, N.A.B.U. 1990/107. In view of the missing - $b$ after $1 \mathrm{i} \mathrm{b}$ in the Susa version, the writing $1 \mathrm{i} \mathrm{b}$ is probably due to a reinterpretation under dictation of $1 \mathrm{i}-\mathrm{b} \mathrm{i} \quad \mathrm{i} \mathrm{b}_{2}$ - and due to the context $\mathrm{u}_{3} \mathrm{k} \mathrm{u}$ $\mathrm{k} \mathrm{u}$. The exact meaning of $1 \mathrm{i}$ b (cf. Ludwig, Išme-Dagan 56, fn. 140 and 58f., fn. 149 "Traumbild, Illusion, Benommenheit, Phantasie o.ä", with literature) is not clear, but it might carry both a positive (especially Ur Lament 100) as well as a negative connotation (cf. perhaps i g i 1 i b diliptu "sleeplessness").

$21 \mathrm{~b} a-\mathrm{an}-\mathrm{dab} \mathrm{b}_{5}-\mathrm{b} \mathrm{e}_{2}-\mathrm{NE}-\mathrm{e} \breve{\mathrm{s}}-\mathrm{a}$ in the Susa version seems to be a hybrid form, 3rd person plural h. $(-\mathrm{n}-\ldots-\mathrm{e} \check{\mathrm{s}})+m$. $(-\mathrm{n}$ e).

22-23 In Babylonia the spring floods come too late in the growing season and have to be controlled, lest the crops be ruined.

$24 \mathrm{~g} \mathrm{u} \mathrm{b}$ must be parallel to the Susa version's $\mathrm{g} \mathrm{u} \mathrm{b}-\mathrm{b} u$, as *g u b $\mathrm{b}$ a ( ? ) - $\mathrm{n}$ i does not seem to exist. The exact sense of $\mathrm{t} u \mathrm{r}$ depends naturally on the broken $r_{\mathrm{x}}(-) \mathrm{ni}$ ?.

27 The reading $\mathrm{sud}$ (in source $\mathrm{B} \mathrm{s} \mathrm{u} \mathrm{d}_{4}$ ) and the translation "splendid food has been withdrawn" is preferable over a non-standard reading $s u_{3}$ (source $B$ $\mathrm{S} \mathrm{u}_{1_{3}}$ ) and the translation "splendid grass has been submerged", as in line 23 source A has s u "to be inundated" and in this line S UD is written. The author plays here with different expressions, as $\mathrm{u}_{2} \quad \mathrm{n}$ i $\mathrm{r}-\mathrm{g}$ a $l_{2}$ rhymes with $\mathrm{u}_{2} \quad \mathrm{a}-\mathrm{n}$ i $\mathrm{r}$ "mourning grass" of the following line.

28 For the restoration $\mathrm{u}_{2} \mathrm{~s}\left[\mathrm{a}_{6}\right.$ ? - $\mathrm{g}$ a $]$ "f[ine? ] grass", cf. the Susa version and especially Curse of Agade 268 (II 277).

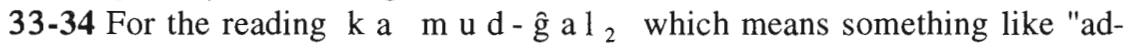
vocate" (especially Sulgi X 51 in connection with the u n k e n "assembly"), cf. Michalowski, Sachs Memorial Vol. (1988) 272 ad 3.

The epithet me-te unken-n a "the adornment of the assembly" (if correctly restored) appears e.g. in Two Elegies 7 (said of I d n a n n a - a ) and in 
Iddindagān A (= Inana and Iddindagān) 218 with the variant $\mathrm{m}$ e - t e e d i n - n a "the adornment of the steppe" (said of Inana).

For this line as an indication of the political structure of the Ur III state under Urnamma and his successors, in which the king takes actively part in the u n k e n "assembly", cf. Wilcke, CRRAI 19 (1974) $182 \mathrm{f}$.

35 The structure of this and the following lines with initial epithets followed by repetitive $\mathrm{in}-\mathrm{nu}_{2} \quad \mathrm{du} \mathrm{r}_{11}-\mathrm{ra}-\mathrm{am}_{3}$ "he lies suffering" recalls Two Elegies 3-9 where the same device is employed with repetitive $\mathrm{du}_{1} \mathrm{r}_{1}-\mathrm{r}$ a g a b a ba (- a n ) - ri "he faced illness".

37 For $\mathrm{g} \mathrm{i} \mathrm{r} \mathrm{i}_{3} \mathrm{di} \mathrm{b}_{2}$ which could mean "to tread with the feet, to pass", compare $\mathrm{g} \mathrm{i} \mathrm{r} \mathrm{i}_{3} \mathrm{di} \mathrm{b}$ which has been analysed by v. Dijk, JCS 19 (1965) 24 ad 225 .

39 Wilcke, $U T 64$ reads d i m g a 1 "great mast", but references in Ludwig, Išme-Dagan 120-22 ("(Halte)pflock"), Römer, AOAT 232 (1993) 390 and George, OLA 40 (1992) 244f. ("pole by which it [i.e. the boat] is moored") and $266 f$. ("bond"), are mostly to temples and cities. Read therefore perhaps $U L_{4}-g$ a 1 , lexically equated with šarhu, šitrāhu "proud, magnificent" in CAD Š/2 61 s.v. šarhu and $A H w 1252$ s.v. šitrăhu. The term appears in personal names of the type d D N - / a m a - / a - / l u ga l - , etc. - U L ${ }_{4} / \hat{G} \mathrm{IR}_{2}-\mathrm{g}$ a 1 from ED times onwards, cf. Biggs, OIP 99 (1974) 69f. ad 8, Di Vito, StPohl SM 16 (1993) 23, $25,29,33,41,63,302$, and fn. 10, and Selz, FAOS 15/2 (1993) 290. It is probably to be connected with $\mathrm{g}$ e $\breve{\mathrm{U}} \mathrm{L}_{4}-\mathrm{g}$ a 1 , a type of tree, cf. Klein, Studies Sjöberg (1989) 292, fn. 23 (also in line 218? Cf. p. 139, fn. 152).

39-40 A causative, reflexive translation is given here in view of the difficult ergative (despite the absence of e.g. $n \mathrm{i}_{2}-\mathrm{t} \mathrm{e}-\mathrm{a}-\mathrm{n} \mathrm{i}$ ).

$\mathrm{e}_{2}-\mathrm{s} \mathrm{u} \mathrm{m} \mathrm{u} \mathrm{r}-\mathrm{r}$ a and $\mathrm{e}_{2}-\mathrm{zu}_{2}-\mathrm{r} \mathrm{a}-\mathrm{a} \mathrm{h}$ (note the assonance) may be rooms in the palace complex (line 42) where the residents were brought to die or to be laid out (in state). In connection with the latter name note perhaps also $\hat{\mathrm{g}}$ e $\mathrm{s}_{\mathrm{Z} \mathrm{u}} \mathrm{u}_{2}$ -

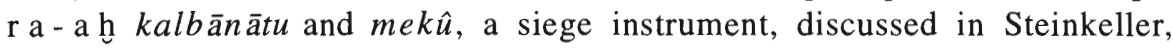
N.A.B.U. $1987 / 27$.

42-43 s a ĝ (-) $\mathrm{k} \mathrm{u}_{3}$ (-) $\mathrm{g}$ a $1_{2}$ šarhu "proud, noble", normally a divine epithet, is discussed in Wiggermann, ZA 78 (1988) 226, and fn. 3. The epithet occurs perhaps also in Uruk Lament 2.13', said of the city, and perhaps as a non-standard spelling in Luzag. 1, 3:35-36 $\mathrm{s}$ i pa $\mathrm{s} \mathrm{ag}(-) \mathrm{g} \mathrm{u}_{4}(-) \mathrm{g} \mathrm{al} \mathrm{l}_{2} \mathrm{I} \mathrm{d} \mathrm{a}-\mathrm{ri}_{2}$ $\mathrm{h} \mathrm{e}_{2}-\mathrm{m}$ e "May I (= Lugalzagesi) always be a noble shepherd!". s a g ( - ) $\mathrm{g} \mathrm{u}_{2}(-) \mathrm{g} \mathrm{a} \mathrm{l}_{2}$ in the Susa version is either another writing of $\mathrm{s}$ a $\mathrm{g}(-) \mathrm{k} \mathrm{u}_{3}$ $(-) \hat{\mathrm{g} \mathrm{a}} \mathrm{l}_{2}$, or a synonym of $\mathrm{s}$ a $\mathrm{g}(-) \mathrm{g} \mathrm{u}_{2}(-) \mathrm{t} \mathrm{u} \mathrm{k} \mathrm{u}$, also lexically equated with šarhu "proud" (cf. CAD Š/2 61 s.v. šarḩu and $A H w 1186$ s.v. šarhuu).

Compare the two lines with the refrain in Death of Gilgameš A 62ff. (partially restored) (...) b a- $\mathrm{nu}_{2} \quad \mathrm{ur}_{5} \mathrm{nu}-\mathrm{m} \mathrm{u}-\mathrm{e}-\mathrm{d} \mathrm{a}-\mathrm{a} \mathrm{n}-\mathrm{zi}-\mathrm{zi} \quad$ "(..) lay down, was not able to raise himself any more", the incipit of the Meturan version of the

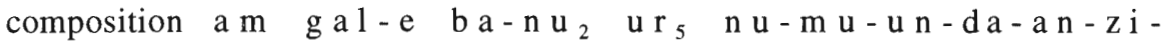
$\mathrm{zi}$ "The great bull lay down, was not able to raise itself any more" (cf. Cavigneaux, Al-Rawi, Iraq 55 [1993] 93), and M. Cohen, Eršemma no. 60, p. 
91:16 II 17 a m-e a - $\mathrm{g}$ i $\mathrm{n}_{7} \mathrm{n} \mathrm{u}_{2}-\mathrm{de}_{3}-\mathrm{e} \mathrm{n}$ "How you, the bull, lie down", referring to Dumuzi. A reading $\mathrm{g} \mathrm{u}_{2} \mathrm{nu}-\mathrm{m} \mathrm{u}-\mathrm{u} \mathrm{n}-\mathrm{d} \mathrm{a}-\mathrm{z} \mathrm{i}-\mathrm{z} \mathrm{i}$ ! instead of - $\mathrm{z} \mathrm{i}$ - $\mathrm{g}$ e in line 43, source A, is excluded after collation.

An alternative reading and translation of $l_{\mathrm{u}_{2}}$ e r e $\mathrm{n}_{2}-\mathrm{e} \quad \mathrm{k} \mathrm{i}-\mathrm{a} \hat{\mathrm{g}}_{2}-\hat{\mathrm{g}} \mathrm{a}_{2}$ "the beloved of troops" is $1 \mathrm{u}_{2}$ e r e $\mathrm{n}_{2}-\mathrm{e} \mathrm{k} \mathrm{i}-\mathrm{a} \hat{\mathrm{g}}_{2}-\hat{\mathrm{g}} \mathrm{e}_{26}$ "who loves the troops". Susa's e r i / e "cities" is a reinterpretation under dictation of e $\mathrm{r}$ e $\mathrm{n}_{2}$ "troops" (cf. also II 3.2, p. 26) and bolsters the reading e r i / i r i for U R U (cf. the commentary ad 5).

$44 \hat{\mathrm{g}}$ e $\breve{\mathrm{s}}-\mathrm{l} \mathrm{a}_{2}$ - b i D U "to settle in (said of) deathly silence" has been studied by Heimpel in JCS 33 (1981) 117 ad 176; - b i belongs to the expression and might be in all cases a possessive pronoun 3rd person impersonal in an objective sense, referring in general to the situation or matter. Besides $\hat{g}$ e $\breve{s}-1 a_{2}$ qultu "silence" (so in Enl.sudr. 64, Ur Lament 102 and Nanše Hymn 176) there are references of $\mathrm{g}$ e š $-1 \mathrm{a}_{2}$ in a military connection (cf. Römer, BiOr. 45 [1988] 38f.).

$45-\mathrm{C}$ a $=\mathrm{C}$ a $\mathrm{m}$ (also in lines 210 and 215 ).

For t e $\check{\mathrm{s}}_{2} \mathrm{k} \mathrm{a} \mathrm{l} \mathrm{a} \mathrm{m} \mathrm{-} \mathrm{m} \mathrm{a} \mathrm{"the} \mathrm{land's} \mathrm{vigour"} \mathrm{as} \mathrm{a} \mathrm{royal} \mathrm{epithet,} \mathrm{cf.} \mathrm{Loding,}$ AOAT 203 (1979) 36. For the image underlining g u 1 "to cut away" here, cf. Curse of Agade 109-110 where mountains are said to be either mined (b a - a l) or cut up ( $\mathrm{k}$ u d).

46 For $\mathrm{s} \mathrm{u}_{3} \cdot \mathrm{g}$ urrû "to cut clear, to strip" in tree imagery, cf. Wilcke, Lugalbandaepos $168 \mathrm{ff}$. ad 124. The "grove of h a š u r-trees" could be an allusion to the h a š u r-Mountain (with a possible pun on s u d "to withdraw, to absent oneself") where access to the netherworld was thought to be. This is where Utu, the sun-god and great judge, rises, cf. Enki and the World Order 374 (Benito, ENEWO 107, line 373) (said of Utu) u r - s a g g u d h a - š u- u r $\mathrm{r}_{2}-\mathrm{ta} \mathrm{e}_{3}-\mathrm{a} \quad \mathrm{g} \mathrm{u}_{3}$ h $\mathrm{u} \check{\mathrm{s}} \mathrm{de}_{2}-\mathrm{de}_{2}(-\mathrm{a})$ "Warrior, bull who appears from the h a š u r-trees, who roars frightfully". Compare also the commentary ad 58 and 211 for the $\mathrm{k}$ $\mathrm{d} u \mathrm{t} \mathrm{u} / \mathrm{u}_{4} \mathrm{e}_{3}(-\mathrm{a})$.

With the Susa variants, compare Curse of Agade 122 g e š - K A $2-n$ a - b i $\mathrm{b}$ a - r a - a n - s i - i g t e š ${ }_{2} \mathrm{k}$ a l a m-m a b a - k u r ${ }_{2}$ "He (= Narāmsu'en) tore out its (= the Ekur's) door frames, the land's vigour was altered" (cf. also IV 3.3 , p. 89 f.).

46a This Susa line seems to correspond roughly to line 72 of source A (omitted in the Susa version of that line). As the end of the second sign in source A of line 72 does not fit e $\mathrm{r}$ e $\mathrm{n}$ and the narrative sequence in the Susa version would be strange, line 46 a may be only contaminated by line 72 , and rather a variant of line 48 (cf. ĝ e š e re $n$ and b a 1 a), omitted in the Susa version. Perhaps the line involves an allusion to the crossing through of the cedar forest in Gilgameš and Huwawa.

47 The felling of a building like a tree is nicely illustrated in Curse of Agade 112-117.

The alternation $\mathrm{G} \mathrm{N}_{2} / \mathrm{A} \mathrm{GA}$ (Susa) argues for a reading / a g a /, not / g i g / (for $\mathrm{G} \mathrm{I} \mathrm{N}_{2}=\mathrm{g} \mathrm{i}_{4}$ "axe", cf. Krecher, Studies Matouš II 38). But 
/ a g a / does not normally denominate an "axe" (cf. also Waetzoldt, OA 29 [1990] 24f. and Attinger, Eléments 518, § 440).

Note the hamtu - marû sequence in lines 47-48. Subject is probably the enemy (cf. also I 1., p. 7, fn. 62f.).

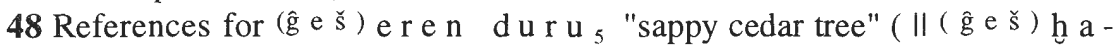
š u $-\mathrm{u} \mathrm{r}_{2}$ ) are Gudea, Cyl. A 22:3; Sulgi P a 5; Sulgi D 35; cult song of Damu TCL 158 // (= Römer, BiOr. 49 [1992] 647f.) B 29 (II C 10'), A 140; Incantation to Utu 18-19, and similarly in NBC 7915 (= Kutscher, AOAT 25 [1976] 307) obv. 10 .

The restoration in source B is my guess (cf. line 42), but is probably more likely than Kramer's: "(..) $\mathrm{e}_{2}-\mathrm{g}$ a $\mathrm{l}-[\mathrm{a}-\mathrm{n}$ a $\mathrm{k} \mathrm{i}]-\mathrm{n} \mathrm{u}_{2}-\mathrm{a}(\ldots)$ " in Studies Mikasa 200:48, in view of the space.

- b - in source A, instead of - $\mathrm{n}$ - in source B, referring to Urnamma, is a result of contamination by the syntagm in $-\mathrm{g}^{\mathrm{i}} \mathrm{n}_{7}$.

$50 \mathrm{~s}$ e s "brother" is used here perhaps for "sweetheart, darling", as it can be in love poetry, cf. Alster, ASJ 14 (1992) 29 ad 133, and idem, Studies Hallo (1993) 17 , and fns. $16 \mathrm{ff}$.

51 The content is comparable with Sumer and Ur Lament 173-174 in which the "day" $\mathrm{u}_{4}$ (i.e. of her death) has "reached" ( $\left.\mathrm{s}_{2} \mathrm{~d} \mathrm{u}_{1}{ }_{1} \cdot \mathrm{g}\right)$ the goddess Ba'u, and with Death of Gilgameš A 40 in which the "dark day" ( $\left.\mathrm{u}_{4} \quad \mathrm{k} \mathrm{u} \mathrm{k} \mathrm{k} \mathrm{u}{ }_{2} \cdot \mathrm{g}\right)$ has "reached" (s a d u $_{11}$. g) Gilgameš (cf. Klein, ASJ 12 [1990] 64, fn. 15).

Susa's $\mathrm{s} \mathrm{a}_{2} \mathrm{~m} \mathrm{i}-\mathrm{ri}-\mathrm{i} \mathrm{b}_{2}-\mathrm{du}$ "it has reached you" may be contaminated by Death of Gilgameš A 40 ( $\mathrm{s} \mathrm{a}_{2} \mathrm{~m} \mathrm{i}-\mathrm{r} \mathrm{i}-\mathrm{i}$ b- $\left.\mathrm{du}_{1}{ }_{1}\right)$. The locative $\left(\mathrm{u}_{4} \ldots-\mathrm{a}\right)$ seems to be an inexplicable reinterpretation.

a 1 a n lānu "figure, appearance" in the Susa version is a semantically conditioned non-standard spelling based on phonetic affinity with $\mathrm{a}-1 \mathrm{a}-\mathrm{n}$ a in sources A and B (cf. also II 3.2, p. 26).

52-53 Sacrifices and gifts are not acceptable to the gods because the divination ( $\breve{\mathrm{u}} \mathrm{g} \mathrm{i} \mathrm{d}_{2}$ ) is tainted (cf. $\mathrm{g} \mathrm{i} \mathrm{g}$ ) and Urnamma's fatal fate has already been decided. For a possible allusion to Narāmsu'en's futile attempt to change Enlil's words by extispicy in Curse of Agade 94-101, cf. IV 3.3, p. 90.

For $\mathrm{K} \mathrm{A}(\mathrm{e} \mathrm{n} \mathrm{i} \mathrm{m}) \mathrm{g} \mathrm{e}_{4}$ "to reject" which normally takes the locative postposition, cf. e.g. Behrens, Steible, FAOS 6 (1983) 176 with previous literature, Farber, Babybeschwörungen 99f., and Steible, FAOS 9/2 (1991) 6, 7 and 8.

In the verbal chain of the Susa version in line 53 - e equals - e š, or is a collective construction whereby an animate noun in the plural is taken up by a plural affix in the verbal chain (cf. Attinger, Eléments 161ff., $\S 102 \mathrm{ff}$., no. 7). Other examples of final consonant dropping in the Susa version are lines 57-58 (cf. also V 1.3 ad I c.), p. 148).

54 The first part of the sentence might be an allusion to $\mathrm{m} \mathrm{u} \breve{s}_{2} /{ }_{3}-\mathrm{a} \mathrm{m}_{3}$ $\mathrm{du}_{1} 1 . \mathrm{g}$ "to utter ahulap", associated with An in Ur Lament 381 and Inninšagura 258.

55 Compare $\mathrm{u} \mathrm{r}_{5} \mathrm{zi}-\mathrm{zi}$. g "to raise oneself" perhaps with the lines in Death of Gilgameš given in the commentary above, ad 42-43. 
57 The opposite term $1 \mathrm{u}_{2} \quad \mathrm{zu} \quad\left(-\mathrm{u}_{3}\right)-\mathrm{n}$ e "acquaintances" is found in Nungal 54, Curse of Agade 215, and Lugalbanda I 33-34 l $\mathrm{lu}_{2}(-) \mathrm{ul} \mathrm{u}_{3}$ $\ulcorner\mathrm{zu}\urcorner-\mathrm{ne} \mathrm{na}-\mathrm{an}-\mathrm{ni}-\mathrm{pa}_{3}-\mathrm{de}_{3}$ Ises DIŠ ses-a-ne ĝ iškim $\mathrm{n} \mathrm{a}-\mathrm{a}[\mathrm{n}]-\hat{\mathrm{g} \mathrm{a}}{ }_{2}-\mathrm{g} \mathrm{a}_{2}$ (cf. Attinger, Eléments 549, § 493) "The acquaintances cannot find themselves at all there, a brother cannot recognize his brother!".

58 a - g i n $_{7}$ is translated here "thus" to avoid the syntactical problem of having otherwise two similes in the same line in source A, namely a - $\mathrm{g}$ i $\mathrm{n}_{7}$ "like water" and $\mathrm{d} \mathrm{ug} \mathrm{g} \mathrm{a} \mathrm{z-g} \mathrm{i}{ }_{7}$ "like a broken jar". But a-g i ${ }_{7}$ here is certainly also a play on the common topos a $-\mathrm{g}$ i $\mathrm{n}_{7} \mathrm{k} \mathrm{i-l} \mathrm{u} \mathrm{l-l} \mathrm{a} \mathrm{(references} \mathrm{in}$ $P S D \mathrm{~A} / 12$ s.v. a A 1.2).

Incantation to Utu 117-119 seems to suggest that $\mathrm{k} \mathrm{i-l} \mathrm{u} \mathrm{l-1} \mathrm{a} \mathrm{"Place} \mathrm{of}$ Treachery" could be the dwelling place of a g e d i m "spirit" (of a dead person) associated with evil (also Incantation to Utu 161) and whose case has not yet been decided by Utu, for which see also Sinšamuh to Enki (= Hallo, JAOS 88 [1968] 85) iii 11-15. No food and water libations and no name invocation (Incantation to Utu passim) takes place. Instead there is "muddy water" a $1 \mathrm{u}_{3}$ - a (Gilgameš and the Netherworld, Ur version, rev. 11) to drink and "bitter dust" s a h a r s e s to eat (Nanše Hymn 221 || Lugalbanda I 165 [cf. Wilcke, Lugalbandaepos 79:162]; cf. also line 69 of our composition). Ninurta and the Turtle 37-38 (cf. Alster, JCS 24 [1972] 120-25; Kramer, AulOr. 2 [1984] 231-37) associate the k i - 1 u l - I a near the "Abzu Gate" where Enki punishes Ninurta. Temple entryways were known to be places where fates were determined ( $\mathrm{k}$ i $\mathrm{n}$ a $\mathrm{m}$ t a r - r a (/ - r e), cf. Urnamma EF 21-22 (said of the $\mathrm{du} \mathrm{b}-1 \mathrm{a}_{2}-\mathrm{m}$ a h of the Ekišnugal complex from which one had access to the ziggurat), and also Green, JCS 30 (1978) 148 ad 2.16 with other references. Such a place was also the k i d u t u/ u ${ }_{4} e_{3}$ (- a ) "place where the sun rises/the daylight breaks", at the entry to the netherworld, for which see the commentary below ad 211 and Urnamma EF 10. Once judged the g e d i m is received by the door-keeper of the netherworld (Incantation to Utu 237-241).

59 I M . UD s i $r_{2}-\mathrm{da}$ "cumulated clouds" is also attested in Curse of Agade 175 and might be a variant for $\mathrm{d} \mathrm{u} \mathrm{n} \mathrm{g} \mathrm{u} \quad \mathrm{s}_{\text {i }} \mathrm{r}_{2}-\mathrm{d}$ a/ $\mathrm{r}$ a "heavy/cumulated cloud(s)".

$\mathrm{i} \mathrm{m}-\breve{\mathrm{s}}$ e $\hat{\mathrm{g}}_{3}-\hat{\mathrm{g} \mathrm{e}}_{26}$ "it precipitates" in the Susa version is a reinterpretation based on phonetic affinity with i m-š i - g e n "it went there" of source A, or a semantically conditioned non-standard spelling, probably attracted by I M . U D $\mathrm{s} \mathrm{i}_{2}-\mathrm{d}$ a (cf. also II 3.2, p. 26).

60 Wilcke's interpretation of the signs - a $\mathrm{n} \mathrm{i} \hat{g}_{2} \check{s} \mathrm{a}_{3}-\mathrm{g}$ e as a $\mathrm{n}$ i n da? $\check{\mathrm{s}}_{3}-\mathrm{ge}$ "water and bread for the heart/inside" is also possible, for š u $\mathrm{g} \mathrm{i} \mathrm{d}_{2}$ "to reach out" in association with food is not rare (e.g. Enki and Ninmah 97); š a ${ }_{3}-\mathrm{g}$ e, however, is difficult.

62 In Izi C iii 10-15 (MSL 13 [1971] 177f.:10-15) k i (-) s a g - $\mathrm{k}$ i and its synonymes (?) k i - g u l-1 a and k i - s a g - $\mathrm{g} \mathrm{a} l_{2}-1$ a (cf. Ur Lament 236 and Nippur Lament 209) are associated with tears (Izi C iii 14) and trouble (?) (Izi C iii 13: samû, differently Tinney, Nippur Lament 165 ad 209), but also with rites (Izi C iii 12: $s a k k \hat{u})$. In view of the equation $\mathrm{s}$ a $\hat{\mathrm{g}}-\mathrm{k} \mathrm{i}=\operatorname{sakk\hat {u}}$, the syntagm $\mathrm{k} \mathrm{i}(-)$ 
$\mathrm{s}$ a $\mathrm{g}-\mathrm{k} \mathrm{i}$ is probably $\mathrm{k} \mathrm{i}+\mathrm{s}$ a $\mathrm{g}-\mathrm{k} \mathrm{i}$ ("forehead"?). Maybe k i ( - ) s a $\mathrm{g}-\mathrm{k} \mathrm{i}$ which is also attested in Lugalbanda I 153 (cf. Wilcke, Lugalbandaepos 79:150 with a corrected reading $\mathrm{k} \mathrm{i} \mathrm{()} \mathrm{-} \mathrm{s} \mathrm{a} \mathrm{g}-\mathrm{k} \mathrm{i} \mathrm{-} \mathrm{k}$ a in UT 110) and possibly in Incantation to Utu 241 (?) is the place where the $\mathrm{g}$ e $\mathrm{di} \mathrm{m}$ are gathered after entering the netherworld (cf. PSD A/1 138 s.v. a-ra-li 7. "gathering place", perhaps with the lexical text Sag B [MSL SS 129$] 38 \mathrm{~s}$ a $\mathrm{g}-\mathrm{k} \mathrm{i}=p u-u h_{2}-r u m$ in mind).

64-75 The exact sense of this passage is elusive. According to Kramer, Studies Mikasa 195, this passage describes how Urnamma (as a g e d i m ?) embarks on a hazardous boat journey to the netherworld followed by his journey on a chariot in lines 70-75 until he reaches the gates through which he is admitted into Arali, the abode of the dead. But we only have texts describing boat trips to the netherworld by gods (cf. Kuwabara, The Netherworld in Sumero-Akkadian Literature, Ph.D. Thesis Univ. of California, Berkeley [1991] 116f.; for the netherworld journeys in general, cf. now Selz, AOF 22 [1995] 205ff. with previous literature). Another difficulty with this interpretation is the notion that Urnamma's ship should sink on its trip to Arali. But on the other hand waters that lead to the netherworld are known to be both torrential and destructive (e.g. Cohen, Eršemma no. 97, p. $80: 114$ || 115). Still, it is more likely that lines 65-69 are a retrospective of Urnamma and his destiny which is perhaps put in the mouth of the soldiers. Understood in this way, Urnamma is thus metaphorically likened to a boat in a storm (cf. lines 182 and 215, Lugalnisag to a King 1 [= Ali, Letters 86, no. 7] 11, Kramer, Studies Kraus [1982] 139:25, and K. 890 in Strong, BA 2 [1894] 634 [= Wilcke, UT 51f.]), with the subsequent burial scene in lines 70-71 (also Civil, AulOr. 1 [1983] 51f.). The burial scene can be compared with Death of Gilgameš B 1-7 where Gilgameš' family and retinue lie with him in the tomb (?) (cf. also Cavigneaux, Al-Rawi, Iraq 55 [1993] 93). Also, we have textual and archaeological evidence of ED burials from several sites in which equids or bovids and remains of chariots were discovered (cf. McGinnis, SAA I/I [1987] 10, and fns. 41-44 with literature). Another, but less likely possibility, is to read with Wilcke, UT 65 in lines

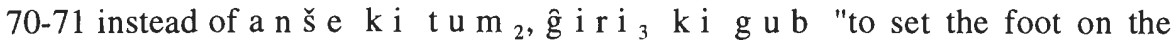
ground", thus marking the point of departure to the netherworld. The corresponding line from Susa (with the final verbal root $\mathrm{u} \mathrm{s}_{2}$ ) which could in fact substantiate this interpretation of the signs is too damaged for comparison. As to exactly where the kings of Ur III were buried, Moorey in Iraq 46 (1984) 1-18 argued that they must have been buried in their palace (cf. also Sallaberger, Kalender vol. I 63, fn. 273, and 147, fn. 698), as is known for later times (cf. also McGinnis, SAA I/I [1987] 8 , and fns. 8-14 with literature).

64-65 $\mathrm{i} \mathrm{r}_{2} \quad \mathrm{u} \mathrm{s}_{2}$ is a hapax with a literal meaning "to let tears draw near, to let tears touch something", i.e. "to shed tears (?)", cf. perhaps $A H w 967$ s.v. redî $\breve{S}$ 4. said of liquids, and D 8. said of tears.

The sinking of a ship from Dilmun (in the reed marshes) might have in later texts proverbial character, cf. Krecher, Kultlyrik 217 ad VIII 48*-49*. A reference to Dilmun (Bahrein) as a possible burial place is unlikely, cf. Michalowski's justified 
caution for interpreting Dilmun as a burial place, in Weiss (ed.), The Origins of Cities in Dry-Farming Syria and Mesopotamia (1986) $133 \mathrm{f}$.

For k u r k i n u-z u "(foreign) land, an unknown place", cf. also Sulgi E 214 in which Sulgi's troops "like a single person (?) in a (foreign) land unknown to him/them, [...]". Instead of $\mathrm{k} \mathrm{u} \mathrm{r,} \mathrm{the} \mathrm{e} \mathrm{di} \mathrm{n} \mathrm{"steppe"} \mathrm{is} \mathrm{k} \mathrm{i} \mathrm{n} \mathrm{u}-\mathrm{zu}$ "an un-

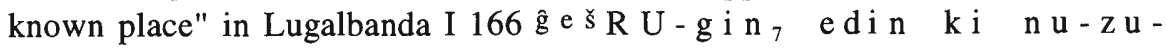
$\mathrm{g} \mathrm{a}_{2} \mathrm{n} \mathrm{a} \mathrm{m-b} \mathrm{a-e}\left(-\mathrm{de}_{3}\right)-\breve{\mathrm{s}} \mathrm{b}-\mathrm{b} \mathrm{u}-\mathrm{de}_{3}$ (- e n) (cf. Wilcke, Lugalbandaepos 79:163) "I do not want to be thrown (away) like a stick in the steppe unknown to me"; Ur Lament $285 \mathrm{sul-g} \mathrm{u}_{10}$ e di n k i $\mathrm{nu}-\mathrm{zu}-\mathrm{n}$ a tug $\mathrm{g}_{2} \mathrm{mu}$ ($\mathrm{u}$ ) - s i $\mathrm{r}_{2}$ h $\mathrm{a}-\mathrm{b}$ a - a n - A K / D U "My young man has verily donned mourning garb in the steppe unknown to him"; Sumer and Ur Lament $332 \mathrm{ab}_{2}$ $u_{2}$ munzer-e edin ki nu-zu-bi giri ${ }_{3}$ kur ${ }_{2}$ ba-ra-an$\mathrm{d}_{\mathrm{a}} \mathrm{b}_{5}-\mathrm{be}_{2}-\mathrm{e} \breve{s}$ "The liquorice-fed cows took an unfamiliar trail, in a steppe unknown to them". $\mathrm{k} \mathrm{u} \mathrm{r}$ in our line may allude to the netherworld.

66-69 References to boat accessories are found in Römer, AOAT 232 (1993) $390 \mathrm{ff}$.

68 Susa's $\hat{\mathrm{g}}$ e $\mathrm{s}_{\mathrm{s}}$ a $\hat{\mathrm{g}}-\hat{\mathrm{g}} \mathrm{u}_{10}$ may be a phonetic non-standard spelling of ĝ e š s a g - k u 1 "bolt".

70-71 In view of the ending $-\mathrm{ru}-\mathrm{n}$ e in Susa, $\mathrm{du} \mathrm{r}_{2}-\mathrm{ru}$ represents /d u r u ( $\mathrm{n}$ )/ with dropping of final / $\mathrm{n} /$ (e.g. Ur Lament 362).

72 Compare line 46a (Susa) and also IV 3.3, p. 89f.

74-75 The restoration at the beginning is uncertain. Wilcke, UT 65 restores $\mathrm{l} \mathrm{u} \mathrm{g} \mathrm{a} 1-[\mathrm{e}]$, thus having the king covering the chariot but $\mathrm{g}$ e š g i g i r - r a (-

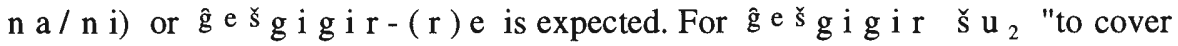
the chariot" and its implications (i.e. unfit for service), cf. Cooper, Curse of Agade

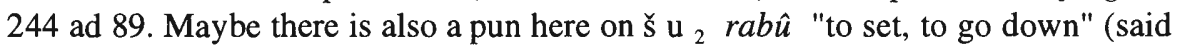
of the sun/day; cf. also d u t u - š $\mathrm{u}_{2}-\mathrm{a}$ as a possible entrance to the netherworld).

76 According to Inana's Descent 78 (et passim) and Incantation to Utu 239f. $\mathrm{d} \mathrm{b} \mathrm{i}_{2}-\mathrm{t} \mathrm{i}$ is "the chief porter of the netherworld" $\left(\mathrm{i}_{3}-\mathrm{du}_{8} \quad \mathrm{gal} \quad \mathrm{kur}-\mathrm{ra}\right.$ ) who is in charge of the "seven gates of the netherworld" (a b u 11 a k u r-ra i n i m - b i) (Inana's Descent 119 et passim). This line seems to be a contamination of that version, or another tradition.

77-78 Farber-Flügge, StPohl 10 (1973) 104 gives references for similar enumerations of priests who are generally chosen by exta for different functions (add also Puzursulgi to Ibbīsu'en [cf. Wilcke, $Z A 60$ 59, and fn. 16] 21-22). Note especially the more elaborate list of dead priests and priestesses in Death of Gilgameš B 23-25, preceded by that of the deities that receive offerings from Gilgameš. The e n-priest is missing in our text (maybe because Urnamma himself was next to being $1 \mathrm{u} g$ a 1 "king" also an e n-priest).

For the possibility that $\mathrm{NIN}$ is to be read /eri š/ in NIN-dig i r "N I N d i g i r/entu-priestess", cf. Fleming, HSS 42 (1992) 80f. with previous literature, and Sjöberg, ZA 83 (1993) 16.

References for $\mathrm{m} \mathrm{a} \mathrm{s}_{2}-\mathrm{a} / \mathrm{e} \mathrm{da} \mathrm{b}_{5}$ "to choose by extispicy" (instead of the more common $\mathrm{m}$ a š ${ }_{2}-\mathrm{e} \mathrm{p} \mathrm{a}_{3}$. d) are Hendursaga Hymn 75, Incantation to Utu 
46, and an anonymous year name formula (D-60) in Gelb, Kienast, FAOS 7 (1990) 60 .

81-82 The absence of a postposition after a PN as here in $1 \mathrm{u} \mathrm{g}$ a $1-\mathrm{x} \| \mathrm{u} \mathrm{r}$ $\mathrm{d} \mathrm{n} \mathrm{a} \mathrm{m} \mathrm{m}$ a and elsewhere is frequent in this composition for reasons of rhythm, cf. the commentary above ad 16.

84 This line probably introduces the following lines: Urnamma knows what sacrifices to perform (summarised in lines 132-133) and what presents to hand out to the netherworld deities. It is less likely that the line goes with the preceding line, suggesting that Urnamma knew how disgusting the food was in the netherworld and therefore offered a banquet.

85-86 After the presentation of food offerings and animal sacrifices to the gods of the netherworld in general (lines 85-87, probably summarised again in lines 128a-131a), Urnamma hands out to each one of the gods presents specifically associated with that particular deity (88-128). The list has been compared by Wilcke in CRRAI 17 (1970) 82f. fn. 5 with the similar enumeration of gods which receive offerings from Gilgameš in Death of Gilgameš B 9-22. Note also that some items Urnamma presents to the particular deities match those worn by Inana in Inana's Descent 17-25 and passim, and which are subsequently removed by her before entering the netherworld (also Katz, ZA 85 [1995] 223). Other allusions to Inana's Descent are found in lines 97 and 151-152 (cf. also the commentary to these lines), which make it likely that the author of Urnamma A knew of the composition Inana's Descent.

87 For e n-n a "as many as ", cf. Attinger, Eléments 305, § 199 b).

88 Waetzoldt, OA 29 (1990) 13 gives a translation "Messer oder Dolchmesser" for $\mathrm{g}$ i ri $\mathrm{i}_{2}-\mathrm{zu}_{2}$.

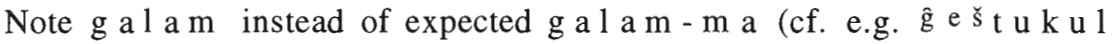
$\mathrm{g} \mathrm{a} \mathrm{l} \mathrm{a} \mathrm{m-m} \mathrm{a} \mathrm{in} \mathrm{Angim} 150$ and $\mathrm{t} \mathrm{i} \mathrm{g} \mathrm{al} \mathrm{a} \mathrm{m-m} \mathrm{a} \mathrm{in} \mathrm{Sulgi} \mathrm{B} \mathrm{82).}$

$\mathrm{a}\left(=\mathrm{e}_{4}\right)-\mathrm{m} \mathrm{a}-\mathrm{r} \mathrm{u}$ may be a semantically conditioned non-standard spelling for $\mathrm{e}_{2}-\mathrm{m}$ a r $-\mathrm{u} \mathrm{r} \mathrm{u}{ }_{5}$ "quiver", but cf. II 3.2, p. 25, fn. 80 for the possibility that the term may itself mean "quiver".

89 In view of an absolutive construction with $\mathrm{g}$ e š $\mathrm{t} \mathrm{a} \mathrm{g} \mathrm{"to} \mathrm{sacrifice,} \mathrm{to}$ offer as a sacrifice" in this and subsequent passages (except lines 110 and 124), - $b$ a should perhaps literally be understood as "of those that are worn on the hip" (vs $\mathrm{k} \mathrm{u} \check{\mathrm{s}} 1 \mathrm{u}-\mathrm{u} \mathrm{b}_{2} \mathrm{dag}-\mathrm{s}$ i A K - a in line 92).

For $\mathrm{k} \mathrm{u} \mathrm{s}_{1} \mathrm{u}-\mathrm{u} \mathrm{b}_{2}$ luppu "leather-bag" as container of basic provisions and as standard equipment of soldiers (also in line 92), cf. Civil, AOAT 25 (1976) 91 and fn. 32 .

$90 \mathrm{~d} \mathrm{ne}_{3}-\mathrm{eri}_{11}-\mathrm{gal}$ is a conventional reading. For the problems involved, cf. W.G. Lambert, ZA 80 (1990) 40-52, Steinkeller, ZA 77 (1987) 161-68 and ZA 80 (1990) 53-59, and Conti M.A.R.I. 7 (1993) 346f.

92 The meaning "spear" for $\mathrm{g}$ e š g i $\mathrm{d}_{2}-\mathrm{da}$ (with Bauer in AfO 36/37 [1989/90] 90 vs ĝ e š - $\mathrm{g} \mathrm{i} \mathrm{d}_{2}-\mathrm{d}$ a; cf. u r u d a $\mathrm{g} \mathrm{i} \mathrm{d}_{2}-\mathrm{d}_{\text {a }}$ in Foster, Umma 38 ad 4.) is disputed. Civil in $R A 81$ (1987) 187f. gives the meaning "lance" (equated 
with Akk. maraddu). For a most recent discussion without definite conclusions, cf. Römer, AfO 40/41 (1993/94) 24-28.

For d a g - s i dakšiu "saddle(-hook)" as part of a donkey's harness for transportation of leather-bags, cf. Civil, Studies Reiner (1987) 47.

With $\mathrm{i}-\mathrm{m} \mathrm{i}-\mathrm{t}$ u m (CAD I/J 126 s.v. imittu $\mathrm{E}$; a weapon that might have been hung from the shoulder) compare perhaps the entry ${ }^{2}{ }^{7}$-mi-it-tum in the section concerned with lances, from a lexical list found at Emar (cf. Arnaud, Emar 6/2 540 and Emar 6/2 730) mentioned by Civil in RA 81 (1987) $187 \mathrm{ff}$.

$\mathrm{p}$ i r i $\mathrm{g}$ a $\mathrm{n}-\mathrm{n}$ a "celestial lion" is either part of the i $\mathrm{m}$ i t u m-weapon (e.g. Gudea, Cyl. B 13:23 mi-t u m tukul Z A. N IM sa g pi ri g where a weapon has a lion-headed . . .) or perhaps an epithet. It is also an epithet of Iškur (Sjöberg, Mondgott 42, fn. 5) and Inana (Isin *30 3, Ninegala 2, cf. Bruschweiler, Inanna 106). For a $\mathrm{n}-\mathrm{n}$ a "celestial", cf. also Angim 131 and 140.

93 For a discussion of $\mathrm{k}$ u š E . I B ${ }_{2}$. U R 3 "shield", cf. Eichler, JAOS 103 (1983) 99 and 100, fn. 36 who argues for a translation "siege-shield". Civil in

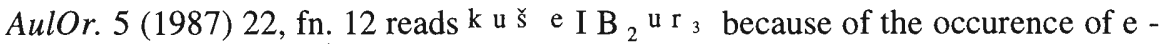
u r $_{3}$ (cf. also Selz, FAOS 15/1 [1989] 508 ad 1:2 and Bauer, AfO 36/37 [1989/90] 90 "eine alte, defektive syllabische Schreibung, die später durch das Silbenzeichen $\mathrm{i} \mathrm{b}_{2}$ verdeutlicht wurde"). For references, cf. also Römer, AfO 40/41 (1993/94) 3335 and 37 , fn. 130.

For $\mathrm{a}_{2} \mathrm{n}$ a m - u r- $\mathrm{s}$ a $\hat{\mathrm{g}}-\mathrm{g} \mathrm{a}_{2}$ "valorous arm" (references in PSD A/2 8789 s.v. $a_{2}$ nam-ur-saĝ-ĝa $a_{2}$ ), cf. Cooper's commentary in AnOr 52 (1978) 116f. ad $90 \mathrm{f}$.

$97 \mathrm{~g}$ e š - $\mathrm{k}$ e š ${ }_{2}-\mathrm{d}$ a is otherwise known as "dam" (Bauer, WO 7 [1973-74] 9 "Staubecken") and appears exclusively in context with canals. One expects some kind of jar, or it may determine the š a g a n-bowl. b u r-š a g a n "š a g a nbowl" is probably an allusion to the well known topos in Inana's Descent 230-233 |l (note also Ereškigal's title "mother of Ninazu" a m a d $\mathrm{n}$ i $\mathrm{n}-\mathrm{a}-\mathrm{zu}$ in line 100 below). The oil is used for anointing the body after a cleaning ritual and before putting on the garment mentioned in the following line.

Susa's b a - S A R - a may represent $b$ a - $n$ is s a - a which may have resulted from hearing ba-ni-in-de $e_{2}-a$ of source $A$ as $/ b$ anida('a)/ (spirantisation of the / $\mathrm{d} /$ between two vowels).

98 For the reading / $/ \mathrm{s} \mathrm{ulu}(\mathrm{m}) \mathrm{hu} / \mathrm{i} /$ for $\mathrm{SIG}_{2}$. S UD (/ B U) "long-fleeced", cf. CAD S 371 s.v. sulumh $\hat{u}$, lex. sect. and $C A D$ I/J 299 s.v. itqu, lex. sect. (also Steinkeller, BSA 8 [1995] 52/66, fns. 55 and 58 reads s u 1 u h u). This type of garment is part of the regalia of kings, e.g. Sulgi X 60 .

The objects that Ereškigal receives are items that occur in parallel texts to customary ablutions and toilet, for which see Gurney and Kramer, OECT 5 (1976) 42f. Add to these references Uruamairabi 19:64-72, said of Inana before going to Dumuzi, and cult song of Damu TCL 158 // (= Römer, BiOr. 49 [1992] 645) A 88-91. These texts involve people a.) descending to the netherworld, b.) wandering into the e di n "steppe" and c.) getting ready to receive their lover as in DumuziInana C 3-7, Dumuzi-Inana $C_{1}$ obv. ii 13-19, Iddindagān A 180-184, and Dumuzi- 
Inana P obv. i 27-30. Freshly washed and robed people descending to the netherworld are thus visibly contrasted to the dead spirits.

99 Susa's NI $\hat{G}_{2}$. Š U (. ) P I is obscure. P I may be $t a l_{2}$ "broad", conditioned by $\mathrm{d} \mathrm{a} 11 \mathrm{a}$ of source $\mathrm{A}$, or, less likely, a phonetic writing of $\mathrm{d}$ a $11 \mathrm{a}$ ( $\mathrm{t} \mathrm{a} \mathrm{l}_{2}-1 \mathrm{a}$ expected). Another reading is $\mathrm{g}$ e $\breve{\mathrm{t}} \mathrm{u} \mathrm{g}$, referring to a piece of jewellery ("earring"). N I $\hat{\mathrm{G}}_{2} . \breve{S} \mathrm{U}$ is difficult. Neither $\mathrm{n} \mathrm{i} \hat{g}_{2}-\check{s}^{\mathrm{u}}$ "goods", nor $\mathrm{n} \mathrm{i} \hat{\mathrm{g}}_{2}-\breve{s} \mathrm{u} . \mathrm{k}$ "chariot" are satisfactory meanings in this context.

102 For the u d u A. L U M (a s $1 \mathrm{u} \mathrm{m}_{\mathrm{x}}$ ), a. "long-fleeced sheep" (u d u z/ s u l u ( m ) h u / i $_{\text {x }}$ ) breed, cf. Steinkeller, BSA 8 (1995) 52.

$103 \mathrm{~g}$ e $\breve{s}-\mathrm{n} \mathrm{u}_{11}$ "light" (?) in the Susa version may be a reinterpretation based on phonetic affinity with $\mathrm{g}$ i d r i / u "sceptre" (cf. also II 3.2, p. 26).

110 In view of the Susa variant $d u b-s ̌$ e $n$ "treasure chest" (cf. Michalowski, Lamentation 103 ad 442 with references), D U B must be a similar object which was fitted with a handle. Compare perhaps Steinkeller's comment on $\mathrm{d} u \mathrm{~b}$ in $O A 23$ (1984) 41 "d u b could conceivably mean box or cabinet. This hypothetical sense of $\mathrm{d} \mathrm{u} \mathrm{b}$ is possibly preserved in the $\log$ ogram $\mathrm{D} \mathrm{U} \mathrm{B} \mathrm{.} \mathrm{N} \mathrm{A} \mathrm{G} \mathrm{A} \mathrm{R} \mathrm{,}$ standing for $\mathrm{t}$ i b i $\mathrm{r}$ a, a craftsman working in metal and wood (thus "cabinetmaker"?)". A reading k i š i b "seal" (cf. Kramer, Studies Mikasa [1991] 204) for $\mathrm{D} U \mathrm{~B}$ is unlikely in view of the following $\breve{\mathrm{u}} \mathrm{za}-\mathrm{g} \mathrm{i} \mathrm{n_{3 }}$ and of $n a_{4} \mathrm{k} \mathrm{i} \mathrm{š} \mathrm{i} \mathrm{b}$ $\mathrm{z}$ a $-\mathrm{g} \mathrm{i}_{3}$ in line 120 . The easy solution of simply reading $\mathrm{dub}<-$ s e $\mathrm{n}>$ in source A cannot be entirely excluded.

An alternative reading $\mathrm{n}$ a $\mathrm{m}$ - i r i g a $\mathbf{l}$ cannot be dismissed but the meaning "function/state of the tomb" does not seem to make sense here. Compare also the structurally identical line 124: both take the locative-terminative postposition with g e š $\mathrm{t}$ a $\mathrm{g}$ "to sacrifice, to offer as a sacrifice" that is otherwise constructed with the absolutive postposition in the preceding and following lines. For $\mathrm{n}$ i $\mathrm{g}_{2}-\mathrm{n}$ a $\mathrm{m}$ = mimma šumšu in this context, cf. McGinnis, SAA I/I (1987) 2 (= K. $7856+\mathrm{K}$. $6323)$ i 13 'f. $u_{2}$-nu-ut $\mathrm{KU}_{3} \cdot \mathrm{SIG}_{17} \mathrm{KU}_{3} \cdot \mathrm{BABBAR}$ I mim-ma tar-si-it KI.MAH "utensils of gold and silver, all furnishings for the tomb".

111 For $\hat{\mathrm{g}}$ e š k i r i d "hair clasp", cf. Michalowski, Correspondence 166 ad 4 and W. Farber, Studies Reiner (1987) 96-99 (kirissu "Gewandnadel" [?]).

115 The compound ANŠE.PIRIG is probably to be read a n š e n i s k u ( $\mathrm{m}$ ) and translated as "a choice quality (= thoroughbred) donkey" (cf. CAD N/2 272 s.v. nisqu, lex. sect.). It turns up as a variant in Sulgi B 22 and Curse of Agade 247 for syllabic a n š e $\mathrm{n}$ i - i s - k u ( $\mathrm{m}$ ). For a general discussion of the nisku-ass, cf. Cooper's commentary in Curse of Agade 255 ad 247.

116 Susa's $\mathrm{g} \mathrm{u}_{2} \quad \mathrm{n} \mathrm{u} \mathrm{n}$ (with $\mathrm{g} \mathrm{u}_{2}$ as non-standard spelling for $\mathrm{g} \mathrm{u}_{3}$ ) seems to be a reinterpretation of $\left(\mathrm{u}_{2}\right) \mathrm{g} \mathrm{un} \mathrm{u}_{3}-\mathrm{gun \textrm {u } _ { 3 }}$ of source A (cf. also II 3.2, p. 26).

117 The reading of $\mathrm{m} \mathrm{u}_{6}-\mathrm{su} \mathrm{b}_{3}$ for $\mathrm{PA}$. U S A N "herdsman" is uncertain, cf. Bauer, AfO 36/37 (1989/90) 84 ad 53 v 2 and Gelb, Steinkeller, Whiting, OIP 104 (1991) 99 ad i 4, iii 1, v 11, and rev. ii 8.

For Ning ǧžida's connection with shepherding, cf. W.G. Lambert, Studies Moran (1990) 296ff., especially 300. 
120 The exact sense of patarru / b a - d a - r a is still in dispute, cf. Hallo, JCS 37 (1985) 124, Steinkeller, JNES 46 (1987) 58 and most recently Sjöberg, ZA 86 (1996) 225, and fn. 4. It is often preceded by $\mathrm{g}$ i $\mathrm{r} \mathrm{i}_{2}$ and the lexical equations quppû and șibārum (in $A H w$ translated as "spitzer Stift") make it likely that we are dealing with some sort of stiletto. Here it seems to denote a pin (a synonym to b u $1 \mathrm{u}$ g ?) by which the cylinder seal as part of a necklace or a bracelet was hung from. Hallo in JCS 37 (1985) 124 thinks that this passage may be "an instance of wearing one's seal suspended from one's dagger".

In the Susa version the reading $\mathrm{m} \mathrm{e}$ in $\mathrm{k} \mathrm{u}_{3} \mathrm{~m} \mathrm{e}-\mathrm{a}$ "pure silver" is assured by source $\mathrm{H}$ of Creation of the Hoe $13\left(=V S 10207\right.$ i 11') [ . . ]-n i $\mathrm{k} \mathrm{u}_{3} \quad \mathrm{~m} \mathrm{a}$ $\mathrm{KU}_{3}$. S I G $17-\mathrm{g}$ a.

$121 \mathrm{t} \mathrm{u}-\mathrm{di}-\mathrm{t}$ u m (vars. $\mathrm{t} / \mathrm{du}-\mathrm{di}-\mathrm{da}$ ) "toggle pin", used to secure garments, has been extensively discussed by H. Klein, ZA 73 (1983) 255-84, cf. also most recently Sjöberg, ZA 86 (1996) 224 f.

122 Another possibility with Wilcke, UT 116 is to have Dimpimekug in the agentive and the dative infix in $\mathrm{m} u-\mathrm{n}$ a - referring to Ninĝešzida: "He gives to him so that Dimpimekug lets him stand at his (= Ninĝešzida's) side". The Nippur versions (in contrast to Susa in line 122a) lack the repetitive syntagm "shepherd Urnamma offers as a sacrifice in her palace". In view of the g e š $t$ a $g$ in line 122a, a restoration [ $\left[\mathrm{s} \mathrm{u} \mathrm{m}_{2}\right.$ ] "to give" for Susa line 122 remains uncertain (compare lines 131-131a).

In source $\left.\mathrm{D} \mathrm{d} \mathrm{d} \mathrm{i} \mathrm{m}_{3}-\mathrm{p} \mathrm{i} \mathrm{(} \mathrm{-} \mathrm{me}\right)-\mathrm{k} \mathrm{u}_{3} \cdot \mathrm{g}$ (for this deity, cf. also H. Klein, ZA 73 [1983] 274, fn. 110 and Katz, ZA 85 [1995] 223, fn. 10 ["still enigmatic"]) is mentioned after Dumuzi and before Namtar and in Death of Gilgameš B 10-11 immediately after Namtar, and succeeded by $\mathrm{d}_{\mathrm{b}} \mathrm{i}_{2}-\mathrm{t} \mathrm{i}$ and Ninĝešzida. Perhaps one may connect her name therefore with $\mathrm{d}_{\mathrm{G} \mathrm{AN}}-\mathrm{di} \mathrm{m} \mathrm{m}_{3}(-\mathrm{m} \mathrm{e})-\mathrm{k} \mathrm{u}_{3} \cdot \mathrm{g}$, a daughter of Namtar for which see Litke, An-Anum v 221 and also W.G. Lambert, RlA 4 (1972-75) 244 s.v. Hedimmeku. The Susa version places her after Geštinana/Ninazimua, Ninĝešzida's wife.

$124 \mathrm{z} \mathrm{a}_{3}(-) \mathrm{bar}-\mathrm{r}$ a remains obscure. A connection with $\mathrm{z} \mathrm{a}_{3}-\mathrm{b}$ ar "cuttings, chippings" (cf. Durand, M.A.R.I. 7 [1993] 378f. concerning qirrêtum) seems unlikely. Kramer takes $\mathrm{z} \mathrm{a}_{3}-\mathrm{b}$ a $\mathrm{r}-\mathrm{r}$ a as a syllabic writing for $\mathrm{z} \mathrm{ab}$ a r "bronze".

For the alternative reading $\mathrm{n} \mathrm{i} \hat{\mathrm{g}}_{2} \mathrm{n}$ a m- $\mathrm{dub}-\mathrm{s}$ a r- $\mathrm{ra}-\mathrm{ke}_{4}$ and translation "which belongs to the scribal art", cf. the commentary ad 110 .

$125 \mathrm{e} \mathrm{š}_{2}-\mathrm{gan} \mathrm{a}_{2}$ and $\mathrm{gi}(-) \mathrm{DI} \breve{S}-\mathrm{n}$ indan are the classical instruments for field surveying, e.g. Dialogue 3 (= Römer, UF 20 [1988] 237) obv. ii 22

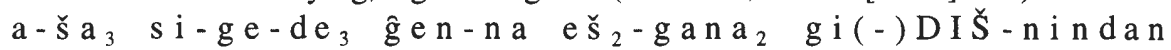
$\mathrm{n} \mathrm{u}-\mathrm{mu}-\mathrm{da}-\mathrm{h} \mathrm{a}-\mathrm{z}$ a "Having gone to peg out the field, you will not be able to hold the surveying tape and measuring rod of one $\mathrm{n}$ i $\mathrm{n} \mathrm{d} \mathrm{a} \mathrm{n".} \mathrm{In} \mathrm{Inana's} \mathrm{Descent}$ 25 they are attributed to Inana, in Lipiteštar B 23 and Enki and the World Order 413-414 (Benito, ENEWO 110, lines 412-413) to Nisaba.

126-127a According to Steible, FAOS 9/2 (1991) 73ff. the identification of Geštinana with (Nin)azimua, which the Susa version makes, goes back to Gudea of 
Lagaš. In the local pantheon of Lagaš of that time Geštinana appears as the wife of Ninĝě̌zida (cf. Gudea 16:1-2; Stat. M 1:1-4 = N 1:1-4 = O 1: 1-4; Urba'u 1 6:5-6). W.G. Lambert, Studies Moran (1990) 298 speaks of Azimua as second name of Ningešzida's wife Ĝeštinana. For Ĝeštinana's title "(chief) scribe (of Arali)" d u b $\mathrm{s}$ a r (m a h ( a - r a - 1 i )), cf. the references given by Alster, Dumuzi's Dream 89 (add Cohen, Studies Sjöberg [1989] 80:9-10) and PSD A/1 137f. s.v. a-ra-li 5., and for the title "sister of the king" $\mathrm{n}^{\mathrm{i}} \mathrm{n}_{9} \quad \mathrm{l}$ u g a $\mathrm{l}-\mathrm{l}$ a (in the Susa version), cf. IV 3.3, p. 86.

136 Note that Urnamma is treated here as inanimate or impersonal $(\mathrm{m} \mathrm{u}-\mathrm{n} \mathrm{i}$ $i b-\mathrm{t} \mathrm{u} \breve{\mathrm{s}}-\mathrm{u}_{3}-\mathrm{n} \mathrm{e}$ ) because he is dead. For the few other instances in which a dead person is treated as being inanimate or impersonal, cf. Attinger, Eléments 561, ex. 295, and Death of Gilgameš B 9ff.

139-140 For i $\mathrm{n}-\mathrm{n}$ a with a non-nominalised verbal form, cf. Attinger, Eléments 304, and fn. 906.

144 For Susa's Š I (-) bar-re read either š i-bar-re or ig i bar re.

Also possible is that $\mathrm{e}-\mathrm{n} \mathrm{e}-\mathrm{n}$ e is an error for $\mathrm{e}-\mathrm{n} \mathrm{e}<<\mathrm{NE} \gg$, in which case the same translation as for the Nippur version applies.

146-147 Susa's $\mathrm{si}(-) \mathrm{g} \mathrm{u}_{7}-\mathrm{m} \mathrm{u}$ - stands for $\mathrm{s}$ i (non-standard spelling of $\mathrm{s} \mathrm{a}_{2}$ ) i $\mathrm{n}-\mathrm{g} \mathrm{a}-\mathrm{mu}-=/ \mathrm{ing} \mathrm{u} \mathrm{mu/}$, with Sandhi-writing /s i ( $\left.\mathrm{n}\right) \mathrm{gu} \mathrm{mu}$ /. Compare i $\mathrm{n}-\mathrm{g} \mathrm{u}_{2}-\mathrm{m} u-\breve{\mathrm{s}} \mathrm{u} \mathrm{m}_{2}-\mathrm{m}[\mathrm{u}-\ldots]$ in Sulgi $\mathrm{O} 83$.

148 The "(city-)wall of Ur" is mentioned in Urnamma's year name "11" and Urnamma 9, 2:3-4, and Urnamma C 92 may possibly refer to the same wall that fell into ruin (cf. also III 1., p. 36).

$149 \mathrm{e}_{2}-\mathrm{g}$ a l - g i b i 1 is the name of Urnamma's palace (cf. Michalowski, Lamentation 81 ad 106).

150 The meaning of s a $\hat{g}$ A K is obscure, cf. Attinger, Eléments 179, $\S$ $116 \mathrm{a}$ and $654, \S 722$, "parachever (?)".

$\mathrm{r}$ a in Susa's š u $\mathrm{dul}_{3} \mathrm{ra}$ "to put a protecting hand over somebody/something" is presumably a non-standard spelling for $\mathrm{A} \mathrm{K}\left(=\mathrm{r} \mathrm{a}_{6}\right)$.

151/3 For a-la (-bi) ge ${ }_{4}$ II h i-li (-b i ) t i l, cf. especially Ninmešara 88 (said of a temple).

A variation of the topos of having intercourse with one's spouse (line 151) and raising children on one's knees (line 152) can be found in Inana's Descent 303-304 ( II 364-366).

153 The variant $\mathrm{n} \mathrm{u}$ - in source $\mathrm{D}$ may be contaminated by the verbal forms in $\mathrm{n} \mathrm{u}-\ldots$-verb- $\mathrm{a}-\mathrm{n} \mathrm{i}$ of this and the previous lines.

154 Here again the verbal form in source D i m-s $i-a-n i$ is probably contaminated by the forms in $-\mathrm{a}-\mathrm{n} \mathrm{i}$ of the preceding lines.

$155 \mathrm{n} \mathrm{i} \hat{\mathrm{g}}_{2}(-) \mathrm{m} \mathrm{e}-\hat{\mathrm{g}}$ a $\mathrm{r}$ is used attributively in this line.

Here begins the long lament of Urnamma in the netherworld ending probably in line 196 where he states that Inana did not realise what had happened to him and was not present at his judgment. Yet another possibility is that his lament only ends in 215 and the poet has Urnamma narrate Inana's direct speech. A similar 
introduction to a lament is Ur Lament $87 \mathrm{i}-1 \mathrm{u} \quad \mathrm{e}_{2} \quad \mathrm{~s} \mathrm{i}-\mathrm{ga} \quad \mathrm{di}_{4}-\mathrm{di}_{4}-\mathrm{b}$ i $\mathrm{n} \mathrm{i}_{2}-\mathrm{t} \mathrm{e}-\mathrm{n} \mathrm{a} \mathrm{mi}-\mathrm{ni}-\mathrm{ib}-\mathrm{be}_{2}$ "She (= Ningal) utters in a very low voice for herself a lament over the silenced house".

156 This line is a summary statement of the following lines. Although Urnamma has served the gods well (lines 157-159; 162-163), they have abandoned him (lines 160-161) to a life in the netherworld (lines 164-165).

156-160 The syntax of this passage is complex: verb-a- $\hat{g} u_{10} \mid \operatorname{verb}(-$ a ) - $\mathrm{a}_{3}$ verb / verb- $\mathrm{a} \mid$ verb- $\mathrm{a}-\hat{\mathrm{g}} \mathrm{u}_{10} \mid$ main clause with $\mathrm{ki}-\hat{\mathrm{g}} \mathrm{a}_{2}$ referring semantically to the two $-\mathrm{g} \mathrm{u}_{10}$ which frame the subordinate clauses.

159 The precise meaning of $\mathrm{u}_{2} \mathrm{za}-\mathrm{g} \mathrm{i} \mathrm{n}_{3}$ has not been established, but $\mathrm{z} \mathrm{a}-\mathrm{g}$ i $\mathrm{n}_{3}$ probably denotes the colour (green) and therefore the freshness of the "herbs", hence the translation "fresh herbs" (cf. $\mathrm{u}_{2} \quad \mathrm{za}-\mathrm{g} \mathrm{i} \mathrm{n}_{3} \quad \mathrm{du} \mathrm{r} \mathrm{u}_{5} \mathrm{ru}$ in Dumuzi-Inana T 40-41).

162-163 $\mathrm{u}_{4} / \mathrm{d}$ u t u - da g u b (- - b a ) and $\mathrm{g} \mathrm{i}_{6}-\mathrm{da} \mathrm{gub}$ belong semantically together (cf. Sumer and Ur Lament 237-238), with a literal translation "present/occupied with the day II night", "assigned to (work during) the day II night" (cf. a - d a g u b-b a "occupied with water" in PSD A/1 10 s.v. a A 2.3.10). The alternation $\mathrm{gub}-\mathrm{b}$ a $/ \mathrm{g} \mathrm{u}$, however, is difficult. Maybe $\left\ulcorner\mathrm{u}_{4}\right\urcorner-\mathrm{d} \mathrm{a}$ $\mathrm{g} \mathrm{u} \mathrm{b}-\mathrm{b}$ a in line 162 is a locative dependent on $\mathrm{s} \mathrm{a}_{2}$ "to be zealous", literally "by my zealousness concerning service by day (...)" and "by my service by night and my sleeplessness (...)".

164 Compare Ur Lament $409 \mathrm{u}_{4}$ - b i i m a n-t a š e $\hat{g}_{3}-\hat{g}_{a_{2}}-\mathrm{g}$ i n 7 $\mathrm{k} \mathrm{i}-\mathrm{t} \mathrm{u} \breve{s}-\mathrm{b} \mathrm{i} \mathrm{n}$ a m-b a-g u r - r u where the comparison is more explicit. Just as rain has fallen on the ground (and cannot return to heaven) so Urnamma has "fallen" and cannot return to Ur. Wilcke, UT 38f. suggests that in this line Urnamma is likened to the vegetation that sprouts from the earth when rain has fallen (cf. also the commentary below ad 213-215, especially 214).

For the reading i m "rain" (instead of š e $\hat{g}_{7}$ ), cf. Cavigneaux, ZA 85 (1995) 188ff., fn. 11.

167 The translation "bitter wailing and lamentation" is conventional.

168 Compare perhaps Sumer and Ur Lament 295 u s u - b i n i i $_{2}$ - b i - a $\mathrm{nu}-\mathrm{gal}_{2} \quad \mathrm{ne}_{3}-\mathrm{bi} \quad \mathrm{ba}-\mathrm{ra}-\mathrm{an}-\mathrm{T}[\mathrm{UR}$ ?] (var. (...) [ ...] (-) a n B A) "Their (= the inhabitants of Ur's) strength spontaneously dissolved, their vigour dim[inished?]". $\mathrm{n}_{\mathrm{i}_{2}}$ - b a "spontaneously" in this line could argue for a non-violent death of Urnamma, unless the whole line refers to his pitiable state in the netherworld (as do the following lines), rather than on earth.

170-173 The animal similes in these lines (except for line 172) are similar to those said of his wife in lines 183-185 and similarly appear in the curse passage of Gudea, Stat. B 9:6-9, to describe a cursed person.

176-177 References to the guardian spirits $\mathrm{d} u \mathrm{dug}$ and $\mathrm{d} \mathrm{l} \mathrm{a} \mathrm{m} \mathrm{m} \mathrm{a} \mathrm{fol-}$ lowing a person on either side are e.g. Gudea, Cyl. A 3:20-21; B 2:9-10; Sulgi D 221 || 337 (negative); Lugalbanda II 330-331 (negative), CT 16 4:153 u d u g $\mathrm{sig}_{5}-\mathrm{ga} \mathrm{d} \mathrm{lamma} \mathrm{sig}_{5}-\mathrm{ga} \mathrm{da}-\mathrm{g} \mathrm{u}_{10} \mathrm{~h}_{\mathrm{e}_{2}}-\mathrm{gub}$ and Geller, UHF 22:46-47. 
For a discussion of $\mathrm{s}$ a $\mathrm{g}\left(-\hat{\mathrm{g}} \mathrm{a}_{2}\right) \quad \mathrm{h} \mathrm{a}-\mathrm{z}$ a "to take care of somebody, to be at the disposal of", cf. Wilcke, Figurative Language (1987) 83 and Jagersma, N.A.B.U. 1990/105.

179 For the possibility that the reading of $\mathrm{A} \breve{S}$ in $\mathrm{A} \mathrm{S}-\mathrm{i} \mathrm{m} \mathrm{m}_{2 / 4}-\mathrm{b}$ a b b a r is / di $1 \mathrm{i} /$, cf. Cavigneaux, Al-Rawi, MHEO 2 (1994) 76 ad 8 with previous literature.

In view of the absence of the ergative here (and in line 235 below), $\mathrm{n} \mathrm{u} \mathrm{-} \mathrm{u} \mathrm{n}$ $\mathrm{r} \mathrm{i}$ is probably intransitive. Wilcke, $U T$ 121, following Falkenstein, apud Castellino, ZA 52 (1957) 55 interprets $\mathrm{s} \mathrm{u}-\mathrm{t}$ a $\mathrm{r}$ i transitively as "to lead by the hand". S. Cohen's translation in ELA 242 ad 290 "to cast from the hand" does not apply here.

$181 \mathrm{P} \mathrm{E} \check{\mathrm{S}}$. P E $\check{S}$ is obscure as is the sense of the line in general (cf. also Römer, BiOr. 49 [1992] 324 and fn. 46 with a translation "Dreimal (?) schwieg sie (?) ...").

182 For a person metaphorically likened to a boat in a storm, cf. the references in the commentary above ad 64-75, especially Lugalnisag to a King 1 (= Ali, Letters 86, no. 7) 11. Compare line 215 below where on the contrary Urnamma is likened to a river-boat holding firmly in the calm harbour (probably with sexual connotation).

183 If the imagery follows that of line $184 \mathrm{P} \mathrm{U}_{2}$ is the "pit" in which the wild ass falls. References are Sulgi D 169 and Sulgi B 91, and those cited by Sjöberg, ZA 65 (1975) 215-16 ad 26. The translation "waterhole" cannot be ruled

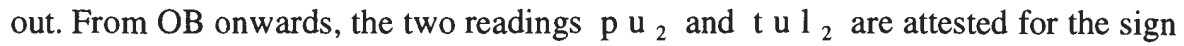
L A G A B $\times$ U.

184 e $\mathrm{n}-\mathrm{n} \mathrm{u}\left(-\mathrm{u} \hat{\mathrm{g}}_{3}\right) \quad \mathrm{d} \mathrm{u}_{3}$ "to set up a guard" is rare (Gudea, Cyl. B 12:20 and Curse of Agade 166). More common is e $\mathrm{n}-\mathrm{n} \mathrm{u}\left(-\mathbf{u} \mathrm{g}_{3}\right)$ A K.

186 Possible restorations at the beginning are $\mathrm{d} u \mathrm{t} \mathrm{u} \quad \mathrm{di} \quad \mathrm{k}\left[\mathrm{u}_{5}-\mathrm{r}\right] \mathrm{u}$ or perhaps d u t u di k [ $\mathrm{u}_{5}-\mathrm{D}$ ] U "Utu who renders verdicts".

$\mathrm{g}$ e s $1 \mathrm{a}_{2}$ could be understood in the sense of "to pay heed, to pay attention", derived from "to become silent" (cf. the bilingual texts in the lex. sect. of CAD $\mathrm{Q}$ 72 s.v. qâlu). This sense fits also passages like Enki and the World Order 100 or Dialogue 4 31-32 (SEM 59:2-3 //; cf. Heimpel, Tierbilder 157f.) and 68 (cf. Gragg, AOATS 5 [1973] 77 ad D4. 68 "to listen").

187-188 For the same imagery in Ur Lament 359-360, cf. IV 3.3, p. 90. Note that $\mathrm{k} \mathrm{u}_{4}$ in line 187 and in the Ur Lament passage is intransitive (- a $\mathrm{n} \mathrm{-}$ $\mathrm{k} \mathrm{u}_{4}=\left\{\mathrm{n} \mathrm{i}\right.$ (loc.) $\left.\left.+\mathrm{K} \mathrm{U}_{4}\right\}\right)$. For the instruments listed, cf. Krispijn, Akkadica 70 (1990) passim and for secondary literature, Attinger, Eléments 416, $\$ 225$ (a - d a a b), 516, § 436 ( $\mathrm{g} \mathrm{i}-\mathrm{S} \mathrm{U}_{3} / \mathrm{S} \mathrm{U}_{13}$ ), 730, § 877 (t i g i ${ }_{2}$ ), 753, §927 (z a $\mathrm{a} \mathrm{m}-\mathrm{z} \mathrm{a}-\mathrm{a} \mathrm{m})$ and 531, and fn. $1470\left(\hat{\mathrm{g}} \mathrm{e} \check{\mathrm{s}}-\mathrm{g} \mathrm{u}_{3}-\mathrm{di} / \mathrm{g}\right.$ e ̌s g u $\left.\mathrm{u}_{3}-\mathrm{di}\right)$. After a preceding description of her destructive force, Inana is responsible for setting up wails instead of musical entertainment in Enki and the World Order 447-448 (Benito, ENEWO 113, lines 442-443) š e $\mathrm{m}_{3}$ a - n i r - r a - d a $\mathrm{t} \mathrm{u} \mathrm{g}_{2} \mathrm{~h} \mathrm{~h}_{2}$ e m-mi-si-ig (/ h $\left.\mathrm{e}_{2}-\mathrm{em}-\mathrm{de}_{3}-\mathrm{si}\right) / \mathrm{ki}-\mathrm{sikil} \mathrm{d}_{\mathrm{inana}} \mathrm{tigi}$ $\mathrm{a}-\mathrm{d} \mathrm{a}-\mathrm{ab} \quad \mathrm{e}_{2}-\mathrm{b}$ a $\mathrm{h}_{\mathrm{e}} \mathrm{e}_{2}-\mathrm{e} \mathrm{m}-\mathrm{m} \mathrm{i}-\mathrm{g} \mathrm{e}_{4}$ "You have indeed removed the cloth 
from the lamentation drum, young woman Inana, you have indeed returned $\mathrm{t}$ i $\mathrm{g}$ iand a $\mathrm{d}$ a b-instruments to their (storage) rooms".

$\mathrm{za}_{3} \mathrm{e}-\mathrm{g} \mathrm{a} \mathrm{r}_{8}-\mathrm{e} \mathrm{u} \mathrm{s}_{2}$ "to prop against the wall", is according to Edzard apud Alster, Mesopotamia 3 (1975) 142 ad 161 a sign of inactivity (accepted by Wilcke, ZA 68 [1978] 222).

189-192 The syntagma in - $\mathrm{g} \mathrm{u}_{10}$ are considered here as pendens with an ablative meaning "far from", i.e. "instead of", but locative-terminative is also possible, i.e. "(over the fact) that they make me squat in the dust of a pit on my throne, whose luxuriance I had not exhausted, (...)". / n / before the verbal roots in lines 190 and 192 probably stands for the 1st person absolutive suffix $(\{e n\})$ in a marû transitive form, or for the 3rd person animate, referring to Urnamma's wife (cf. Wilcke, UT 51).

Note that Susa has verbal forms ending in - $\mathrm{n}$ a, apparently replacing - $\mathrm{d}$ a (line 192) and - $\mathrm{g} \mathrm{u}_{10}$ (lines 189 and 191) of the Nippur version represented by source A, cf. also V 1.3 (I), p. 149.

189-190 Compare these lines thematically with Gudea, Stat. B 9:10-11

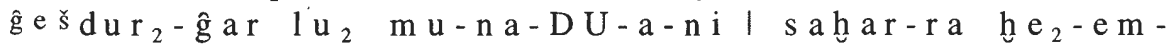
$\mathrm{t} \mathrm{a}-\mathrm{t} \mathrm{u} \check{\mathrm{s}}$ and Steible's commentary to these lines in FAOS 9/2 (1991) 36 ad 113 in which he favours an ablative meaning, i.e. "from his seat (...)". Note that Steible restores Urnamma 47, 4:5-6 accordingly. For other thematic parallels, cf. also IV 3.3 , p. $90 \mathrm{f}$.

For $\mathrm{P} \mathrm{U}_{2}$ - s a ĝ šatpu "pit, water hole", cf. Selz, FAOS 15/2 (1993) $175 \mathrm{f}$. and Michalowski, Lamentation 98 ad 351.

$194-\mathrm{g} \mathrm{a}_{2}$ in $\mathrm{n} \mathrm{i} \hat{\mathrm{g}}_{2} \mathrm{du}_{11}-\mathrm{g} \mathrm{a}-\mathrm{g} \mathrm{a}_{2}$ is understood as a genitive, rather than locative, - $\mathrm{n}$ a - in the verbal chain in a distributive sense ("before each one of them").

196 This line introduces the shift from Urnamma's terrestrial wife who is powerless, to his heavenly wife Inana who is not mentioned in lines 8-16 because she is absent in other lands when Urnamma's fate is changed. Urnamma hopes that Inana will use her right of veto and intercede for him in front of Enlil. Wilcke in Studies L. Vajda = Münchner Beiträge zur Völkerkunde 1 (1988) 247, fn. 9 thinks this is a case of mute consent of a person present at a judicial ruling.

$\mathrm{n}$ i $\mathrm{n} \mathrm{m} \mathrm{e}_{3}-\mathrm{a}$ "the lady (who was) in battle" may be a playful reference to Inana's well known epithet $\mathrm{n}$ i $\mathrm{n} \mathrm{m} \mathrm{e}_{3}(-\mathrm{k})$ "lady of battle".

199 Possible restorations are $\mathrm{mu}-\mathrm{u} n-\left[\breve{\mathrm{s}} \mathrm{i}-\mathrm{k} \mathrm{u}{ }_{4}\right]$ or $\mathrm{mu}-\mathrm{u} \mathbf{n}-$ [ $\mathrm{g} \mathrm{u} \mathrm{r} / \mathrm{D}$ U ]. Cf. IV 3.3, p. 86f., for cult songs that centre on Inana's attempted rescue of Dumuzi from the netherworld including the motif of her humble appearance before Enlil.

200 i g i $\mathrm{dub}_{2}-\mathrm{dub}_{2}$ is a hapax (Wilcke, UT 81 translates "mit den Augen rollen?", Kramer, Studies Mikasa 209 "to cast a shattering look"). It may be a gesture of despair and sadness, or of anger, as this line appears in the Susa version after the statement that Urnamma has left Eana (line 202) and before Inana insults Enlil (line 207). 
204-206 These lines could allude to a real destruction or they might simply be the content of the insult itself in the following line (because of $-\breve{S} E_{3}$ in $i \mathrm{n}$ $\breve{S} \mathrm{E}_{3}$, cf. Attinger, Eléments 566f., § 548, and fn. 1579).

204 For $\mathrm{u}_{4}$ h u š "fierce storm" as epithet of gods, temples and kings, cf. Sjöberg, TCS 3 (1969) 99f.

205 a $\mathrm{m}$ a s $\mathrm{t}$ a b "to devastate the sheepfold" has been treated by Michalowski, Lamentation 71 ad 6. For t a b sapānu, cf. also Civil, N.A.B.U. $1987 / 49$.

208 The implications of this line are not clear. Has Enlil raised his head before Inana as a gesture of promise, or has he raised Urnamma's head ( $\mathrm{s}$ a $\mathrm{g}\left(-\mathrm{g} \mathrm{a}_{2}\right)-\mathrm{n} \mathrm{i}$ expected), i.e. elevated Urnamma to kingship and thus to be Inana's spouse?

210 I have assumed two independent syntagma with $-\mathrm{C} a=-\mathrm{C}$ a $\mathrm{m}$ (cf. also line 215).

$\mathrm{s}$ a $\hat{\mathrm{g}} \mathrm{u} \mathrm{S}_{2}$ "to support, to supply", i.e. "to observe" is translated by Alster, JCS 24 (1972) 123 with "to be persistent". Charpin, CRRAI 35 (1992) 17 ad 9' notes that this verb is "... possibly an artificial copy of the Akk. qaqqadam ummudum". It can be connected with $\mathrm{s}$ a $\hat{\mathrm{g}} \mathrm{u} \mathrm{s}_{2} \mathrm{gub}$ "to stand by constantly".

$211 \mathrm{k} \mathrm{i}(/ \mathrm{k} \mathrm{u} \mathrm{r}) \mathrm{u}_{4}(/ \mathrm{d} \mathrm{u} \mathrm{t} \mathrm{u}) \mathrm{e}_{3}(-\mathrm{a})$ "place (/mountain) where daylight breaks/the sun rises" is connected with the entrance to the netherworld and determining of the fates (for the dead?). For a general discussion, cf. Bruschweiler, Inanna 45-47 and also Selz, AOF 22 (1995) 206, fn. 44 with previous literature. Note the diffcult text in Zimmern, Sumerische Kultlieder no. 44 rev. 2-7 (quoted by Kramer, PAPS 124 [1980] 311f.) where abundance (food, water, house(hold), sheepfold) at "the place where the sun rises" has come to an end because of the death of Inana's husband.

212-213 Sources $A$ and $E$ diverge from $C$ and $F$ in lines 212-213. The - $\mathrm{g} \mathrm{i}_{7}$ in line 212, source $\mathrm{A} \mathrm{e}_{2}-\mathrm{a} \mathrm{n}-\mathrm{n}$ a $-\mathrm{g} \mathrm{in}_{7}$ ? appears to be misplaced.

213 The line probably refers to rituals with Urnamma as e n-priest, and Inana. Compare Urnamma C 73-75 where Urnamma, clad in a linen garment in the g i p a r (in Uruk), lies on the flowered bed, and is able to feed the people with good food. For the connection of entering the $\mathrm{g}$ i $\mathrm{p}$ a $\mathrm{r}$ with sexual intention, $\mathrm{cf}$. also Išmedagān AB (= Volk, FAOS 1849 , fn. 19) 56 a m a-n a m-d a 6 k i sikil $\mathrm{g} \mathrm{i}_{6}-\mathrm{par}_{3}-\mathrm{zu}$ h i - li mu-e-š i - i n-ti-a "Amanamda, the young woman who brought (her) sexual charm near/to your g i p a r", and Dumuzi-Inana T 29-30.

213-215 These lines were compared by Wilcke (bibliographical references in IV 3.3, p. 85f.) with texts belonging to the Dumuzi/Damu/Ningešzida-circle which mention a person (mother, sister or wife) lamenting the absence of a partner (son, brother or husband). Although no direct influence can be found it is quite certain that the composer of Urnamma A knew of such compositions having the distant god or king as theme, cf. also the list of Ur III and Isin kings, headed by Urnamma, that represent the god Damu in cult song of Damu TCL $158 / /$ (= Römer, BiOr. 49 [1992] 652) A 198ff. 
214 Inana expresses the desire that like vegetation shooting forth each year, Urnamma may appear annually. Herbs in the steppe are a sign of abundance (cf. Sulgi F 53; Sulgi P b 10; Enki and the World Order 361) and may be associated with Dumuzi the shepherd as producer of abundance and fertility. This line may therefore have a secondary sexual connotation. In Dumuzi-Inana $\mathrm{H}$ rev. 19' $\| 2^{\prime}$

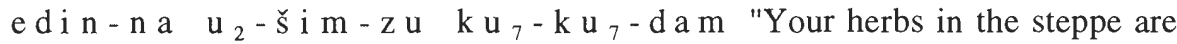
very sweet", Dumuzi is praised by Inana for his abundance (lines 18' || 20') in form of herbs in the steppe (cf. also Enki and the World Order 358-367).

215 The harbour and boat may sexually refer to Inana and Urnamma.

216 The exact meaning of $\mathrm{ku} \mathrm{r}-\mathrm{ku}(-\mathrm{k} \mathrm{u})$ is difficult to ascertain. In

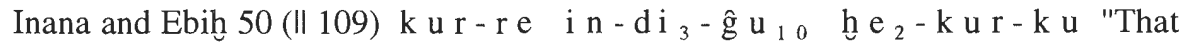
the mountain may ... my conduct" it appears in context of praise (line 51) but in view of Lugale 571 (also with i n - $\mathrm{d} \mathrm{i}_{3}$ "way, conduct" as direct object) which is followed by a malediction, it may mean something like "to observe attentively, to characterize", rather than "to praise (oneself)" (cf. Sjöberg, AS 16 [1965] 69 ad 2 f., with addendum).

221 About six signs are damaged at the beginning. In UT 70 Wilcke's re-

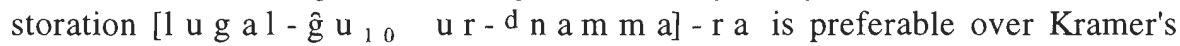
[d $\mathrm{i}$ n a n a - $\mathrm{k} \mathrm{e}_{4}$ ? u r-d $\mathrm{n}$ a m m a] - $\mathrm{r}$ a in Studies Mikasa 210. With Wilcke, UT 129 it is most probably Ningešzida who decrees the fate of Urnamma, not Inana, because the doxology is in praise of Ningešzida (line 240; cf. also line 217 where the reading is, however, not certain).

222 The following lines are a reflection on Urnamma's posthumous fame, cf. Wilcke, CRRAI 17 (1970) 91f. and in general in "Zum Geschichtsbewusstsein im alten Mesopotamien", Archäologie und Geschichtsbewusstsein, Kolloquien zur allgemeinen und vergleichenden Archäologie 3 (1982) $43 \mathrm{ff}$.

The formula $\mathrm{m} \mathrm{u} \mathrm{p} \mathrm{a}_{3}$. d "to call the name, to invoke the name" here could be connected specifically with Urnamma's funerary cult (cf. Steible, FAOS 9/2 [1991] 64 ad 15 for Gudea's funerary cult). In context of the funerary cult the expression is found in Incantation to Utu 133 et passim; SP Coll. 1.38 (cf. PSD A/1 14 s.v. a A 3.3.2); YBC 5641:6-7 $\mathrm{u}_{2}$ h $\mathrm{h}_{2}-\mathrm{t} \mathrm{u} \mathrm{k} \mathrm{u} \mathrm{m} \mathrm{u}-\mathrm{zu} \quad \mathrm{b} \mathrm{a}-\mathrm{e}-$ $\mathrm{n} \mathrm{i}-\mathrm{pa}_{3} \quad \mathrm{a} \mathrm{h} \mathrm{e}_{2}-\mathrm{t} \mathrm{u} \mathrm{k} \mathrm{u} \mathrm{mu}-\mathrm{zu}$ b a - e - n i - $\mathrm{p} \mathrm{a}_{3}$ "May you have food, your name is invoked there, may you have drink, your name is invoked there" (cf. $P S D$ A/1 18 s.v. a A 8.1.1), and Geller, UHF 141 (= Ni. 630) 61'-63'.

223 Does - $\mathrm{n}$ a - in the verbal chain refer to Urnamma's successor Sulgi taking over kingship from his father?

227 Note the drainage of a swamp in Urnamma 27, 1:9-2:2.

235-236 Compare lines 179-180, referring to Urnamma's wife. Lines $235 \mathrm{f}$. presumably refer to Urnamma. One expects, however, a positive sense.

237-238 It is unclear if sources $A$ and $G$ represent the same version in lines 237-238. Therefore no attempt at reconstructing an eclectic text has been made.

238ff. I take the epithets in lines 238-240 to refer to Urnamma.

For $\mathrm{d}$ i g i r $-\breve{S} \mathrm{E}_{3} \mathrm{du}_{2}-\mathrm{d}$ a "born to be a god" in line 238, cf. Urnamma C

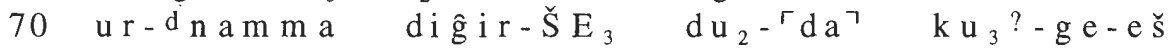


$\ulcorner\mathrm{x}\urcorner[\ldots]$, Išmedagān A 239 (TCL 159 rev. ii 47) $d i \check{s}-m e-d$ dagan

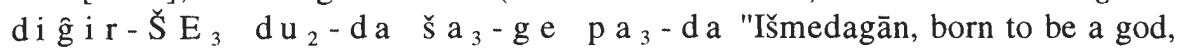
chosen in the heart", and Kramer, Studies Sjöberg (1989) 305 (= BM 100042) obv. ii $41\left\ulcorner u r^{\urcorner}-[\mathrm{sag}] \mathrm{nam}-\mathrm{dig} \mathrm{ir}-\mathrm{SE}_{3}\left\ulcorner\mathrm{du}_{2}{ }^{\urcorner}-\mathrm{da}\right.\right.$ me-te $\mathrm{nam}$ $1 \mathrm{u} \mathrm{g}$ a $\mathrm{l}-1 \mathrm{a}$ "Warrior, born to be a god, adornment of kingship" (a Šūsu'enHymn).

241-242 For the two last lines, cf. above ad 1.1, p. 93f. 


\section{U R N A M M A B}

\subsection{Introduction}

\section{Previous studies ${ }^{l}$}

Urnamma B, a t i g i of Enlil, ${ }^{2}$ has been discussed by several scholars since A. Falkenstein presented a translation and a short summary of it in SAHG (1953) 8790 (no. 17), subsequently reviewed by S.N. Kramer in BiOr. 11 (1954) 173f., fn. 27. The text has come down to us in a generally well preserved state, and for the last third of the composition we have an interesting duplicate with non-standard orthography, source B, first identified, edited, and discussed by $\AA$.W. Sjöberg, OrSuec 10 (1961) 3-12, followed by M. Civil's few comments on some lines in Or. 54 (1985) 35f. (lines 52-53 and 66-68) together with a copy of source D (p. 34) and a transliteration of source $C$ (pp. 36f.). More recently A. Cavigneaux published his own copy of source B and made some valuable suggestions for a few readings in ASJ 9 (1987) $49-51$ ad no. $6 .^{3}$

In $1959 \mathrm{G}$. Castellino edited Urnamma B on the basis of source A, SRT 11, in ZA 53 (1959) 106-18, using S.N. Kramer's collations published in ZA 52 (1957) 81f. In the same year in which G. Castellino presented his edition Kramer's translation and short comments appeared in $A N E T^{3}$ 583f. The most recent and comprehensive treatment was presented by J. Klein in ASJ 11 (1989) 44-56 and 61f. (footnotes) as part of his comparative study on building and dedication hymns in Sumerian literature. ${ }^{4}$ In his revised edition he used all hitherto identified duplicates (including source $E$ ) and offered copies on p. 66 of sources $C_{1}$ and $C_{2}$.

\section{Structural Analysis ${ }^{5}$}

Urnamma $\mathrm{B}$ falls into a $\mathrm{s}$ agi $\mathrm{da}$ and $\mathrm{sa}$ gara section as do all $\mathrm{t} \mathrm{igi}$ compositions. The opening $\mathrm{s}$ a $\mathrm{g}$ id a section of $\mathrm{ti} \mathrm{g}$ i hymns usually extols the deity in whose honour the hymn is composed, and the short, concluding

\footnotetext{
1 Cf. also II 2., p. 19.

2 Cf. also II 1., p. 14.

3 For a discussion of non-standard orthography in the Urnamma hymns, cf. II 3.2 , pp. $23 \mathrm{ff}$.

$4 \mathrm{Cf}$. also IV 3.1 , pp. $69 \mathrm{ff}$.

$5 \mathrm{Cf}$. also IV ibid.
} 
$\mathrm{s}$ a $\mathrm{g}$ a r a section is usually in praise of the king. ${ }^{6}$ Whereas the first part of the compositon (I 1-38), the s a $\mathrm{g}$ i d a section, has a thematic structure consisting of several narrative elements (1-5), ${ }^{7}$ the $\mathrm{s}$ a $\mathrm{g}$ a $\mathrm{r}$ a section can be divided into three parts (II-IV), of which the first two parts (II 40-51, and III 52-65) clearly exhibit strict formal and at the same time thematic patterns. Lines 40-43 || 46-49 (II 1) are somewhat summary lines that link the second part thematically to the first one (I) and lines 44-45 || 50-51 (II 2) introduce a theme (Urnamma's reward and fame) which is expounded in detail in the following part (III). The hymn concludes with a fourth part (IV 66-71) which has, like the first part (I), a thematic structure devoid of any formal patterns. Parts two and three (II-III) which show patterns of repetition are thus framed by a beginning and ending part (I and IV) of a narrative nature. This can be diagrammed as follows:

I. Narrative

II. Hymnic

III. Hymnic

IV. Narrative

The opening s a g i d a section (I) begins with Enlil's introduction and relates his selection of Urnamma from among his innumerable people (1-6), a topos that can be traced back to Pre-Sargonic Lagaš and to Gudea. ${ }^{8}$ For Enlil has Ekur's restoration in mind and thus commissions Urnamma to give Ekur and its $m e$ their former beauty back (7-10). Urnamma knows how to act and accordingly starts preparations by preparing the brickmould (11-13), while Enlil ensures the necessary infra-structure by putting the rebellious lands in order (for the supply of raw material) and thus making Sumer sufficiently prosperous to start building (14-16). The next lines recount the actual restoration work (17-19), followed by a detailed architectural description of the temple complex Ekur (20-32). The building work results in admiration for Ekur's regained beauty (20-21): the gates are lavishly decorated, the ziggurat and its $\mathrm{g}$ i $\mathrm{g} \mathrm{u} \mathrm{n}$ a rise from its midst and Enlil and Ninlil are happily installed in the Ĝageššua (22-32). A big feast marks Ekur's inauguration (33-35) and is followed by divine approval and a blessing: Enlil grants Urnamma enormous power (36-38). The thematic sequence of divine preference (34 "mentioned by name"), meal supplies (34-35), and the resulting happiness for the temple and its inhabitants (35-36) prompting the gods to decree a positive fate (3738 ) is common and apparent in other literary texts. ${ }^{9}$

Part two (II) introduces the $\mathrm{s}$ a $\mathrm{g}$ a $\mathrm{r}$ a section of the hymn and is transitional in nature, linking part one (I) with part three (III). Because Urnamma has restored Ekur so beautifully (40-43 || 46-49) his fame will be far reaching (44-45 || 50-51). This section exhibits strict formal units of parallelism. Lines 40-45 || 46-51 cor-

6 Cf. Hallo, BiOr. 23 (1966) 242.

7 Cf. also IV 3.1, pp. 69ff., for a comparison with other compositions which contain elements that articulate the building or creative narrative.

8 Cf. IV 1.2, p. $48 f$.

9 Cf. IV 3.1, p. 71. 
respond to C. Wilcke's R-3 type of parallelism ${ }^{10}$ in which a sequence of lines is repeated, but a term in the first line is substituted by another one, often a synonymous name. Thus "Nunamnir" in line 40 is substituted with "Great Mountain, father Enlil" in line 46.

Part three (III) elucidates in hymnic detail Urnamma's reward: with Enlil's help Urnamma achieves military successes (52-57), he destroys evil, sweeps away the great oppression (58-61), and his storm delivers the evil person (62-65), themes that are recurrent in other hymns such as Urnamma $\mathrm{C}$ and EF. Again, this section is characterized by a balanced poetic structure of parellelisms: lines $52-65$ can be termed as a $a^{\prime} b b^{\prime} c d$ e d' e $f f^{\prime} g$. The general term of lines a (52), $b$ (54), d (58), and f (62), i.e. "my lord", "him", "he", and "his", is substituted with "shepherd Urnamma" in lines a' (53), b' (56), d' (60) and f' (64).

The last part (IV) has no distinctive strophic structure and concludes the hymn with a narrative sequence that tells of the erection of Urnamma's dais in Ur, presented to him in front of and by Enlil, thus symbolizing Urnamma's establishment of kingship in Ur through Enlil (66-69) which results in prosperity for Ur (70-71).

In summary, Urnamma B is made up of the following sequences:

\section{Ekur's restoration (1-38)}

1. Divine selection of Urnamma and commission to restore Ekur (1-10)

a. Enlil selects Urnamma as shepherd (1-6)

b. He commissions him to restore Ekur and its $\mathrm{m}$ e to former beauty (710)

2. Preparations for and realization of Ekur's restoration (11-19)

a. Urnamma understands and acts accordingly by preparing the brickmould (11-13)

b. Enlil puts the rebellious lands in order for him, whereby Sumer experiences sufficient prosperity and happiness (14-16)

c. The actual restoration work (17-19)

3. Detailed description of Ekur's parts (20-32)

a. The Ekur as object of admiration (20-21)

b. Description of Ekur's various parts (22-32): gates (22-26), the ziggurat and its $\mathrm{g}$ i g u $\mathrm{n}$ a (29-30), the Ĝageššua (31-32)

4. The dedication (33-35)

5. Urnamma's reward: divine approval and blessing (36-38)

II. Praise for Urnamma (40-51)

1. Reason for praise: Urnamma has restored Ekur to its former beauty (40-43 II 46-49)

2. Urnamma's reward: fame (44-45 || 50-51) 
III. Urnamma's reward and fame (52-65)

1. Military fame with the help of Enlil (52-57)

2. Urnamma destroys evil and sweeps away oppression (58-61)

3. His fame is frightful and his storm delivers the evil person to him (62-65)

IV. Conclusion: the establishment of kingship in Ur (66-71)

1. Erection of Urnamma's dais of kingship in Ur, presented to him by Enlil (6669)

2. By decision of Enlil it brings delight and abundance to Ur (70-71)

\section{Manuscripts}

The whole composition of Urnamma B is preserved on source A, an Old Babylonian one-column tablet from Nippur, of which only the beginning lines are partially broken. All other duplicates are in a fragmentary condition, but some exhibit interesting features. Sources $\mathrm{C}$ and $\mathrm{E}$ are both Old Babylonian one-column fragments from Nippur and Babylon respectively, whereas source B is late Old Babylonian and of unknown provenance. It adds to the version in standard orthography (lines 52 to the end of the composition) the parallel version written exclusively in non-standard or "syllabic" writing. ${ }^{11}$ The tablet is pillow- or lensshaped. This wide i $\mathrm{m} \quad \mathrm{g} \mathrm{i} \mathrm{d}_{2}-\mathrm{d} \mathrm{a}^{12}$ type is used at Nippur and Ur only beginning with the Kassite period, for, according to P. Michalowski, most Old Babylonian i $\mathrm{m} \mathrm{g} \mathrm{i} \mathrm{d} \mathrm{a} \mathrm{type} \mathrm{tablets} \mathrm{from} \mathrm{Nippur} \mathrm{and} \mathrm{Ur} \mathrm{are} \mathrm{vertical.} .^{13}$ Old Babylonian pillowshaped tablets are known from Uruk.

The most significant features of source D are its possible Ur III date ${ }^{14}$ and its short-line format, very likely reflecting its nature as a scribal exercise. Judging from its carelessly written and omitted signs, it probably presents an early attempt at copying in the course of scribal training. It is also line-ruled, very likely for the purpose of guiding the script. ${ }^{15}$ The short-line format of source D uses e.g. three lines for one line in source A (line 53), written in normal-line format, whereas the scribe of source B in long-line format has written two lines of A on one line. ${ }^{16}$ The first preserved line of the obverse of source D does not match any of the lines of our hymn which might either indicate that the scribe of source D based his copy on a slightly different (Ur III?) version of the hymn, or that the tablet contained two excerpts of different compositions. ${ }^{17}$

\footnotetext{
11 Cf. II 3.2, p. 26 f.

12 The native Sumerian terminology given to the one-column exercise tablets.

13 Michalowski, Annali di Napoli 41 (1981) 386.

14 Civil, Or. 54 (1985) 33f.

15 Cf. Tinney, OLZ 90 (1995) 11.

16 The terms "Normalzeile", "Langzeile" and "Kurzzeile" were coined by Wilcke, AS 20 (1975) 221ff.

17 Civil, Or. 54 (1985) 34
} 


\section{Sources}

Nippur:

A

Ni. 2430

$$
\text { obv. } 1-33=\mathbf{1 - 3 3}
$$

rev. $1-39=\mathbf{3 4 - 7 2}$

copy: E. Chiera, SRT 11.

collations: S.N. Kramer, ZA 52 (1957) 81f. J. Klein's readings from a photo in $A S J 11$ (1989) 45-50 are marked with * in the transliteration.

$\mathrm{C}\left(\mathrm{C}_{1}(+) \mathrm{C}_{3}(+) \mathrm{C}_{2}\right) \quad$ CBS $15168(+) \mathrm{N} 7926(+) \mathrm{N} 6876$

$\mathrm{C}_{1}$ obv. $1^{\prime}-10^{\prime}=\mathbf{3 - 1 2}$

$\mathrm{C}_{2}$ obv. $0^{\prime}-8^{\prime}=13 ?-21$

$\mathrm{C}_{3}$ obv. $1^{\prime}-6^{\prime}=\mathbf{2 1 - 2 6}$

copies of $\mathrm{C}_{1}$ and $\mathrm{C}_{2}$ : J. Klein, ASJ 11 (1989) 66. $\mathrm{C}_{3}$ could not be located according to J. Klein, ibid. 61, fn. 59. transliteration of C: M. Civil, Or. 54 (1985) 36f. Reconstruction of lines $20 \mathrm{ff}$. is problematical.

D

$6 \mathrm{~N}-\mathrm{T} 288(=\mathrm{IM} 61500)$ obv. 2'-6' $=\mathbf{5 2 - 5 3}$

copy: M. Civil, Or. 54 (1985) 34.

date: Ur III?

Babylon:

$\mathrm{E}$

VAT 17417

obv. 1'- edge $12^{\prime}=\mathbf{2 8 - 3 8}$

rev. $1-5=39-43$

copy: J.J.A. van Dijk, VS 2442.

measurements: $3 \times 4,5 \times 2,5 \mathrm{~cm}$.

Unknown:

B

AO 6316

obv. $1^{\prime}-14^{\prime}=\mathbf{5 2 - 6 8}$

rev. $1-3=69-71$

copies: H. de Genouillac, TCL 15 38; A. Cavigneaux, ASJ 9 (1987) 60, cf. ibid. 49-51.

photos made available by B. André-Salvini, cf. pls. 14-15.

collation: E. Flückiger-Hawker.

measurements: $123 \times 97 \times 24,5 \mathrm{~cm}$. 


\subsection{Transliteration and Translation}

1 den-lil $l_{2}$ mah $[\ldots] /$ UB? [...]

A obv. 1 den-lil ${ }_{2}$ mah $[\ldots] / \mathrm{UB}^{?}[\ldots]$

2 en nam-nun $\left\ulcorner_{\mathrm{ga}} \Gamma^{\top} \mathrm{x} \times[\mathrm{x}]\left\ulcorner\mathrm{x} x \mathrm{x}^{\urcorner}\left[\begin{array}{lll}\mathrm{x} & \mathrm{x} & \mathrm{x}\end{array}\right]\right.\right.$

A obv. 2 en nam-nun ${ }^{\ulcorner} \mathrm{ga} \Gamma{ }^{*} \mathrm{x} * \mathrm{x}[\mathrm{x}]^{\ulcorner *} \mathrm{x} * \mathrm{x}{ }^{\urcorner}[\mathrm{x} x \mathrm{x}]$

3 dnu-nam-nir an-ki lugal [...]

A obv. 3 dnu-nam-nir an-ki lugal $[\ldots]$

$\mathrm{C}_{1}$ obv. $1^{\prime} \quad[\ldots \quad]^{\mathrm{r}} \mathrm{x}$ lugal $\mathrm{x}^{7}[\ldots]$

4 ug $_{3}-\mathrm{gaa}_{2}$ igi mi-ni-in-il ${ }_{2}$ sipa zi ur-dn[amma]

A obv. $4 \quad u \hat{g}_{3}-\hat{g}_{a_{2}}$ igi mi-ni-in-il ${ }_{2}$ sipa $* z[\mathrm{i} \ldots]$

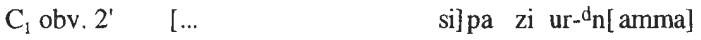

5 kur-gal den-lil $1_{2}$-le ug $\hat{g}_{3}$ šar ${ }_{2}$-ra-ni-a im-ma-ni-in- ${ }^{\Gamma} \mathrm{pa}_{3}$ ?

A obv. 5 kur-gal den-lil ${ }_{2}-l e{ }^{*} \mathrm{ug}_{3} \mathrm{sar}_{2}$-ra-ni-a im-ma-ni-[... ]

$\mathrm{C}_{1}$ obv. $3^{\prime} \quad[\ldots \quad]-\mathrm{a}^{7}$ im-ma-ni-in- ${ }^{-} \mathrm{pa}_{3}{ }^{\text {? }}$

6 sipa ḩe $e_{2}$-a dnu-nam-nir-ra-ka ni ${ }_{2}$ hušs mu-un-da-ri

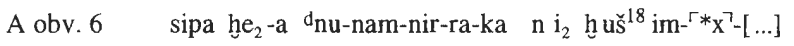

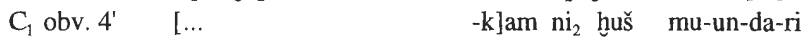

1 Enlil, the magnificent $[\ldots] \ldots[\ldots]$,

2 Lord, [...] great nobility [...],

3 Nunamnir, lord of heaven and earth [...],

$4 \quad$ Looked at the people, the faithful shepherd Urnamma

5 Great Mountain Enlil chose? from among his innumerable people:

6 "Let him ${ }^{19}$ be(come) a shepherd - that of Nunamnir - (for) he is laden with a terrible splendour!" 
$7 \quad$ šeg $_{12} \mathrm{e}_{2}$-kur-ra-ke ${ }_{4}$ me am $_{3}$-hur

A obv. $7 \quad * \mathrm{~S} e g_{12} * e_{2}-$ kur-ra-ke ${ }_{4}$ me am am $_{3}-\ulcorner *$ hur

$\mathrm{C}_{1}$ obv. $5^{\prime} \quad[\ldots \quad \mathrm{m}] \mathrm{e} \mathrm{am}_{3}$ - hur

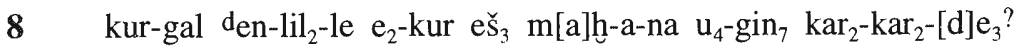

A obv. 8 kur-gal den-lil ${ }_{2}-\mathrm{le} \mathrm{e}_{2}$-kur eš $\check{\mathrm{s}}_{3} \mathrm{~m}$ [a]h-a-na $\mathrm{u}_{4}-\mathrm{gin}_{7}\left\ulcorner * \mathrm{kar}_{2}-{ }^{*} \mathrm{kar}_{2}{ }^{\urcorner}-{ }^{*}[\mathrm{~d}] \mathrm{e}_{3}\right.$ ?

$\mathrm{C}_{1}$ obv. 6 [... ma $]$ - $-\mathrm{Ca}^{\urcorner}-\mathrm{na} \mathrm{u}_{4}-\mathrm{gin}_{7} \mathrm{kar}_{2}-\mathrm{kar}_{2}-$ da

$9 \quad \mathrm{sa}_{3} \mathrm{KA}(\mathrm{enim}) \mathrm{gal}_{2} \mathrm{ku}_{3}$ zi-de ${ }_{3}$ si-a-ni nam-DU
A obv. 9
$\mathrm{ša}_{3} \mathrm{KA}(\mathrm{enim}) \hat{\mathrm{g} a l}{ }_{2} \mathrm{ku}_{3} * \mathrm{zi}-\mathrm{de}_{3} *$ si- a-ni nam-DU!
$\mathrm{C}_{1}$ obv. $7 \quad[\ldots$

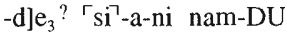

10 sipa dur-dnamma- ${ }^{-d a} e_{2}^{\urcorner}$-kur-ra sag an-še $e_{3} \quad i_{2}$-i-da $a_{2}$-bi mu- $\left.{ }^{\ulcorner} u_{8}\right\urcorner$-da-ag $\hat{g}_{2}$

A obv. 10 sipa dur-dnamma- $\left\ulcorner *\right.$ da $* e_{2}^{\urcorner}$-kur-ra sag an- š $_{3} \mathrm{il}_{2}$-i-da $\mathrm{a}_{2}$-bi mu- $\left\ulcorner * \mathrm{u}_{8}\right\urcorner$-da-ag $\hat{g}_{2}$

$\mathrm{C}_{1}$ obv. $8^{\prime} \quad\left[\ldots \quad \mathrm{e}_{2}-\mathrm{k}\right]$ ur-ra sag an-š $\left.\mathrm{e}_{3} \mathrm{il}_{2}-\mathrm{i}-\mathrm{de}_{3} \mathrm{a}_{2}-\mathrm{bi}{ }^{\mathrm{m}} \mathrm{mu}-\mathrm{da}-\mathrm{ag} \hat{g}_{2}\right\urcorner$

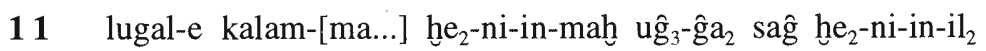

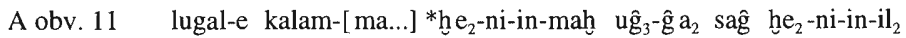

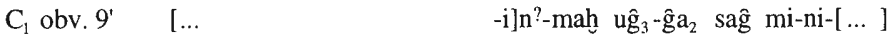

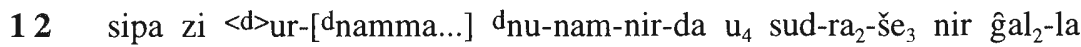

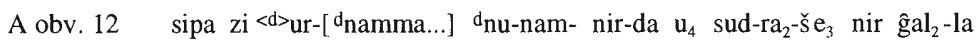

$\mathrm{C}_{1}$ obv. $10^{\prime} \quad[\ldots \quad$ dnu-nam $]-\left\ulcorner\right.$ nir-da $\mathrm{u}_{4}{ }^{\urcorner} \mathrm{s}[\mathrm{ud}-\ldots$

7 The $\mathrm{m}$ e are traced out for Ekur's brickwork.

8 To make them shine forth like daylight for Ekur, his magnificent shrine, Great Mountain Enlil -

9 His heart, filled with splendid and proper notions was moved to (do so) -

10 Commissioned shepherd Urnamma to make Ekur lift its head heavenward.

11 The king indeed made eminent [... in] the land, raised his ${ }^{20}$ head among the people.

12 Faithful shepherd Ur[namma ...] who has put (his) trust in Nunamnir for all time, 
13 di zu en geš[tu ${ }_{2}$ daĝal]-la-kam geš $\mathrm{u}_{3}$-šub-ba si $\mathrm{am}_{3}-\mathrm{mi}-\mathrm{in}-\mathrm{sa}_{2}$
A obv. 13

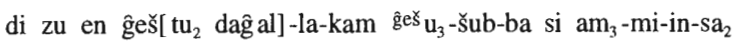
$\mathrm{C}_{2}$ obv. $0^{\prime}$ $[\ldots]^{21}$

14 den-lil ${ }_{2}$-le $\Gamma_{\text {sipa }}$ dur $^{\urcorner}-d_{\text {namma-ra ki-bala NE.RU-gal }}$-la-ni si mu-na-an$\mathrm{sa}_{2}$

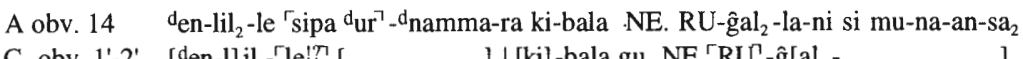

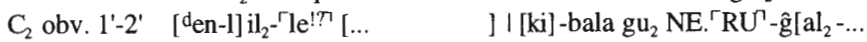

15 ki-en-gi-re $u_{4}$ nam-ḩe ${ }_{2}$-a $A K$
A obv. 15
ki- en-*gi-re $u_{4}$ nam-hye ${ }_{2}-\mathrm{a} \quad \mathrm{AK}$
$\mathrm{C}_{2}$ obv. $3^{\prime}$
[k]i-en- gi-ra $u_{4}$ nam-hye ${ }_{2}-a[\ldots]$

16 asila $_{3} \mathrm{gu}_{2}$ mu-un-di-ni-ib-mar-re

A obv. 16 asila gu $_{2}$ mu-un-di-ni-ib-mar-re ${ }^{22}$

17 uš $\check{L}_{8}$ mu-un-dug ${ }_{3}$-eš temen $\mathrm{ku}_{3}$ mi-ni-in-sig ${ }_{9}$-eš

A obv. 17 uš $\check{s}_{8}$ mu-un-dug ${ }_{3}$-eš temen $\mathrm{ku}_{3}$ mi-ni-in-sigg -eš

$\mathrm{C}_{2}$ obv. 4' [u]š mu-un- dug $_{3}$-eš $[\ldots$

18 enkum ninkum-e me-teš $\check{a m}_{3}-\mathrm{i}-\mathrm{i}-\mathrm{ne}$

A obv. 18 enkum ninkum-e me-teš $\mathrm{am}_{3}$-i-i-ne

$\mathrm{C}_{2}$ obv. 5 , enkum $\mathrm{n}[$ inkum...

13 The one who knows judgment, the lord of [broad und]erstanding, prepared (there) the brickmold.

14 Enlil put for shepherd Urnamma his hostile and rebellious land(s) in order.

15 He made Sumer thrive? in prosperous times and

16 in joy with/because of him.

17 They made the foundations well and drove in the sparkling foundation pegs.

18 The e $\mathrm{n} \mathrm{k} \mathrm{u} \mathrm{m}$ and $\mathrm{n}$ i $\mathrm{n} \mathrm{k} \mathrm{u} \mathrm{m} \mathrm{duly} \mathrm{praise} \mathrm{(it).}$

\footnotetext{
21 The reconstruction of $\mathrm{C}_{2}$ is very doubtful and therefore only provisional. For the beginning of line 14 there does not seem to be enough space at the end of line 1 ' nor at the beginning of line 2 '.

$22 \mathrm{C}_{2}$ either omits this line (cf. Civil, Or. 54 [1985] 36) or it is part of the preceding line $3^{\prime}$ (cf. Klein, ASJ 11 [1989] 54 ad 15-16) for which there is, however, hardly any space.
} 
19 nam-ĝeš-šub galam-ma-na den-ki-ke e $_{2}$-e ul ba-ni-in-sa - ga

A obv. 19 nam-ĝeš-šub galam-ma-na d en-ki-ke ${ }_{2} * e_{2}$-e ul ba-ni-in-sa

$\mathrm{C}_{2}$ obv. 6' nam- šub galam-ma-na ${ }^{\Gamma \mathrm{d}} \mathrm{e}$ [n-ki-...

20 sipa dur-dnamma-ke ${ }_{4} e_{2}$-kur mah dur-an-ki-a-ka an-še ${ }_{3}$ mi-ni-in-mu $\mathrm{m}_{2}$

A obv. 20 sipa dur- ${ }^{d}$ namma-ke ${ }_{4} e_{2}$-kur mah *dur-an-ki-a-ka an-še ${ }_{3}$ mi-ni-in-mu

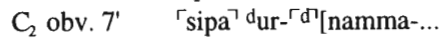

$21 u_{6}$ di-bi-še $u_{3} \quad g_{3} \check{s ̌ a r}_{2}$-šar ${ }_{2}$-ra-ba ši-im-ma-gub

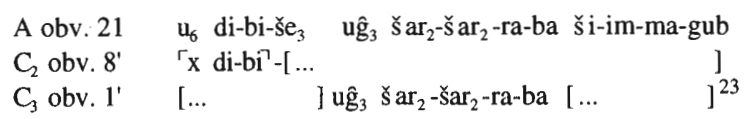

$22 \mathrm{KA}_{2}$-mah $\mathrm{KA}_{2}(.) \mathrm{GAL} \mathrm{KA}_{2}$-silim-ma hur-saĝ-galam-ma $\mathrm{KA}_{2}(-)$ še-nu-ku $5^{-}$ da
A obv. 22
$\mathrm{KA}_{2}$-mah $\mathrm{KA}_{2}(.) \mathrm{GAL} \mathrm{KA_{2 }}$-silim-ma ḩur-saĝ-galam-ma $\mathrm{KA}_{2}(-)$ še-nu-ku ${ }_{5}^{-}$
$\mathrm{C}_{3}$ obv. $2^{\prime}$ da $[\ldots$
] $\mathrm{KA}_{2}$-silim-ma hur-sậ $-[\ldots$

23 sud-ra ${ }_{2}-\mathrm{ag}_{2} \quad \mathrm{ku}_{3}$ me-a ugur ${ }_{2}$-igi-ba še-er-ka-an mu-ni-in-du ${ }_{11}$

A obv. 23 sud-ra ${ }_{2}-\mathrm{ag}_{2} \quad \mathrm{ku}_{3}$ me-a ugur $_{2}$-igi-ba še-er-ka-an mu-ni-in-du ${ }_{11}$

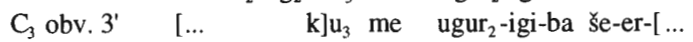

24 anzumušen-de du $_{10} \quad \mathrm{am}_{3}$-ma-ni-in-bad

$\left.\begin{array}{llrl}\text { A obv. } 24 & \text { anzu }^{\text {muš }_{-}-\mathrm{de}_{3}} & * \mathrm{du}_{10} & \mathrm{am}_{3} \text {-ma-ni-in-bad } \\ \mathrm{C}_{3} \text { obv. } 4 & {[\ldots} & {\left[-\mathrm{de}_{3}\right.} & \mathrm{am}_{3}-\mathrm{m}[\mathrm{a}-\ldots \quad\end{array}\right]$

19 Enki having made the temple(-building) flourish with his cunning spell,

20 Shepherd Urnamma made magnificent Ekur grow heavenward in Duranki.

21 He placed it among that endless multitude of people ${ }^{24}$ so that they might admire it.

22 The lintels of the August Gate, the Great Gate, ${ }^{25}$ the Gate of Salvation, ${ }^{26}$ the one (leading to) the Hursaĝgalama, the Gate That Does Not Hold Off Grain,

$23 \mathrm{He}^{27}$ decorated with electrum and pure silver.

24 The Anzû-bird has spread its talons there,

23 The transliteration of $\mathrm{C}_{3}$ follows Civil, Or. 54 (1985) 36f. who counts line $\mathrm{C}_{3}$ obv. $\mathrm{I}^{\prime}$ as line 22, whereas Klein, ASJ 11 (1989) 48 has it as indented line, counting it as line 21.

24 Or: "its (= Duranki's) endless multitude of people".

25 Or possibly read abulla "the (city-)gate", cf. also the commentary ad 22, p. 201.

26 Or: "the Gate of 'Salvation!"'.

27 i.e. Urnamma. 
25 hu-ri-in-ba $l_{2}$ NE.RU AŠ mu-un-dab ${ }_{5}$

A obv. 25 hुu-ri-in-ba lu $u_{2}$ NE.RU AS̆ mu-un-dab

$\mathrm{C}_{3}$ obv. $5^{\prime} \quad[\ldots] \mathrm{lu}_{2}$ NE.RU AŠ $[\ldots]$

26 gešig-bi mah- $\mathrm{am}_{3}$ ul-la mi-ni-in-sig 9

A obv. 26 ĝeš ig-bi mah-am ul-la mi-ni-in-sig $_{9}$

$\mathrm{C}_{3}$ obv. $\left.6 \quad[\ldots] \quad\right]-\mathrm{am}_{3}$ ul- $[\ldots$

$27 \mathrm{e}_{2} \quad$ mah-am $_{3}$ su-zi am ${ }_{3}$-da-gal ${ }_{2}$

A obv. 27 e mah-am su- $_{2}^{*}$ zi am $_{3}-$ da-ĝal

28 dagal am ${ }_{3}$-tag ni $_{2}$-bi gal ši-ri

A obv. 28 dagal $a m_{3}$-tag $n_{2}$-bi gal ši-ri

E obv. 1' [...]

29 hur-saĝ-galam-ma gi-gun ${ }_{4}$-na ki-tuš $\mathrm{ku}_{3}$ kur-gal-la-ra

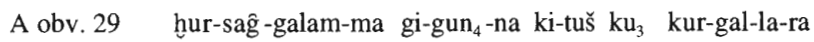

E obv. 2' $\quad\left[\ldots \quad\right.$ g]i-gun ${ }_{4}$-na ki-tuš $\mathrm{ku}_{3}$ kur-ga[1-... $]$

$30 \mathrm{u}_{18}$-ru mah-gin mă $_{7}\left[\mathrm{a}_{3}\right.$-bi-a ki am ${ }_{3}$-ma-ni-in-us ${ }_{2}$

A obv. $30 \quad \mathrm{u}_{18}$-ru mah̆-gin m $_{7}[*$ š $] \mathrm{a}_{3}$-bi-a ki am ama-ni-in-us $_{2}$

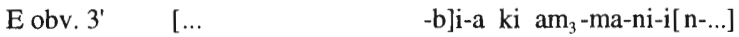

25 In their ${ }^{28}$ (capacity) as eagles they have caught the malefactor alone.

26 Their ${ }^{29}$ doors are magnificent, he ${ }^{30}$ inlayed them with blossoms.

27 The temple is magnificent, it is imbued with dread.

28 It stretches out wide, it grandly inspires its awe.

29 The Hursaggalama and the $\mathrm{g}$ i g u $\mathrm{n}$ a, the precious dwelling of Great Mountain,

$30 \mathrm{He}^{31}$ made touch the ground in its ${ }^{32}$ midst like a huge tornado.

\footnotetext{
28 i.e. the gates.

29 i.e. the gates.

30 i.e. Urnamma.

31 i.e. Urnamma.

32 i.e. the temple Ekur.
} 
31 ga $a_{2}-$ geš-šu $\mathrm{u}_{2}-\mathrm{a}\left\ulcorner\mathrm{e}_{2}\right\urcorner$-gal mah di gal $\mathrm{ku}_{5}-\mathrm{ru}-\mathrm{da}-\mathrm{ni}$

A obv. $31 \quad \mathrm{ga}_{2}-\mathrm{g}$ eš-š $\mathrm{u}_{2}-\mathrm{a} \Gamma * \mathrm{e}_{2}{ }^{\urcorner}$-gal mah di gal $k u_{5}-r u-d a-n i$

E obv. 4' [... m]ah di gal $\mathrm{ku}_{5}-\mathrm{ru}-[\ldots]$

32 [am]a gal dnin-lil ${ }_{2}$-ra ul mu-ni-in-DU

A obv. 32 [am]a gal ${ }^{d}$ nin-lil ${ }_{2}$-ra ul mu- ni-in-DU

E obv. $5^{\prime} \quad[\ldots \quad]$ ul mu-na-ni-i[ $[\mathbf{n}-\ldots]$

33 den-lil ${ }_{2} d_{\text {nin-lil }}$-bi du du $_{10}$ mi-ni-in-gal ${ }_{2}$-le-eš

A obv. 33 den-lil ${ }_{2}{ }^{d_{n i n}-\mathrm{lil}_{2}}$-bi du $\mathrm{du}_{10}$ mi-ni-in-ĝal ${ }_{2}$-le-eš

E obv. $6^{\prime} \quad\left[\ldots{ }^{\prime}\right.$ nin-li $] l_{2}$-bi du $\mathrm{du}_{10}$ mi-ni-i[n-... ]

34 unu $_{2}$ gal-ba sul zi mu pa -da $^{d_{n u-n a m-n i r-r a-k a}}$

A rev. 1 unu $u_{2}$ gal-ba sul zi mu pa -da $^{\mathrm{d}}$ nu-nam-nir-ra-ka

E obv. $7 \cdot \quad[\ldots \quad$ su $]$ zi mu pa pa $^{\mathrm{d}}$ (nu-[nam-nir-... ]

zi-kir šu-mi

$35 \mathrm{NI}_{3}\left(\right.$ ninda/nig $\left.\hat{g}_{2}\right)$ mah $\mathrm{am}_{3}-\mathrm{mi}-\mathrm{NI}\left(\mathrm{i}_{3}\right)-\mathrm{du}_{10} \mathrm{e}_{2}-\mathrm{kur}_{\mathrm{hul}}$-la-am

A rev. $2 \quad \mathrm{NI}_{3}$ (ninda/nig $\hat{g}_{2}$ ) mah $\mathrm{am}_{3}-\mathrm{mi}-\mathrm{NI}\left(\mathrm{i}_{3}\right)-\mathrm{du}_{10}{ }^{33} \mathrm{e}_{2}-\mathrm{kur}$ hul $-1 \mathrm{la}-\mathrm{am}_{3}$

$\left.\begin{array}{llll}\text { E obv. } 8^{\prime} \quad[\ldots & -n] \text { i-in-du } & \mathrm{e}_{2}-\text { kur }^{\text {h }} \mathrm{ul}_{2}-[\ldots\end{array}\right]$

36 igi zi mu-un-ši-in-bar-re-eš sipa dur-dnamma-ra

A rev. 3 igi zi mu-un-ši-in-bar-re-eš sipa dur- ${ }^{d}$ namma-ra

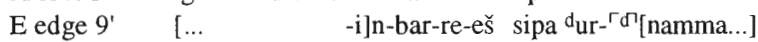

31 The Ĝâ̌eššua, the magnificent palace where she renders important verdicts,

32 He decorated for great [moth]er Ninlil.

33 Enlil and Ninlil relaxed therein.

34 In its ${ }^{34}$ large dining hall the faithful young man, mentioned by name by $\mathrm{Nu}$ namnir,

35 Had huge quantities of food tastily prepared, the Ekur was joyful.

36 They ${ }^{35}$ looked at shepherd Urnamma approvingly.

33 Or read $\mathrm{NI}_{3}$ mah-am $-\mathrm{am}_{3}$ mi-ni-du . $_{10}$

34 i.e. the Ekur.

35 i.e. Enlil and Ninlil. 
37 kur-gal-e sipa dur-dnamma-ra nam gal $\mathrm{u}_{4}$ sud-ra ${ }_{2}-\mathrm{še}_{3}$ mu-ni-in-tar

A rev. 4 kur-gal-e sipa ${ }^{d}$ ur-dnamma-ra nam gal $\mathrm{u}_{4}$ sud-ra $_{2}$-še ${ }_{3}$ mu-ni-in-tar

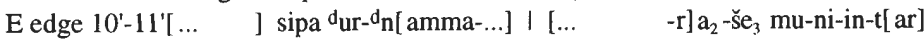

38 saĝ gi $i_{6}$-ga-na $a_{2}$ mi-ni-in-maḩ

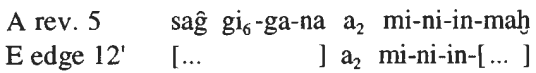

39 sa-gid 2 -da-am 3

A rev. 6 sa-gid 2 -da-am 3

E rev. $1 \quad$ sa-gid 2 -da- $\left\ulcorner\mathrm{am}_{3}\right\urcorner$

40 dnu-nam-nir du d1 $_{1}$-ga eš-bar zi niğ $\hat{2}_{2}$ nu-kur ${ }_{2}$-ru ga $\mathrm{g}_{2}$-me-en

A rev. 7 dnu-nam-nir du du $_{11}$-ga eš-bar zi niĝ $\hat{g}_{2}$ nu-kur ${ }_{2}$-ru ga $a_{2}$-me-en

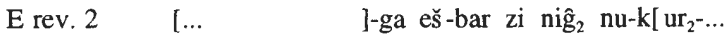

$41 \mathrm{e}_{2}$-kur mah-g $\mathrm{u}_{10}$ dalla mu-e-a-e

A rev. $8 \quad \mathrm{e}_{2}$-kur mah-g $\mathrm{u}_{10}$ dalla mu-e-a-e

E rev. $3 \quad[\ldots \quad]$ dalla $\Gamma^{\mathrm{mu}}{ }^{?-\mathrm{x}^{\urcorner}-[\ldots]}$

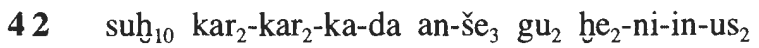

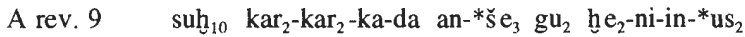

E rev. $4 \quad[\ldots \quad]$ an $-\widetilde{s}_{3} e_{3}{ }^{7}[\ldots$

43 sul zi kalam-ma dalla hu-mu-ni-in- $e_{3}$

A rev. 10 sul zi kalam-ma dalla hu-mu-ni-in-e ${ }_{3}$

E rev. $5 \quad[\ldots \quad]$ dal[ la...

37 Great Mountain decreed a great fate for shepherd Urnamma for all time,

38 Granted him enormous power over his Black-Headed.

39 (It is the $\mathrm{s}$ a g i d a)

40 "I am Nunamnir whose proper utterance and decision are immutable:

41 My magnificent Ekur is resplendent!"

42 (In $=$ ) With a radiant crown $\mathrm{he}^{36}$ has raised its neck heavenward.

43 The faithful young man has made it resplendent in the land. ${ }^{37}$

36 i.e. Umamma.

37 Or translate lines 42-43: "(..) it (= Ekur) has lifted its neck heavenward and made the faithful young man become famous in the land". 
44 dur-dnamma en uru $_{16}$ nam-lugal-la gu ${ }_{2}$ an-ta-bi he $\mathrm{f}_{2}-\mathrm{em}$

A rev. 11 dur-dnamma en uru $_{16}$ nam-lugal-la $g_{2}$ an-ta-bi he ${ }_{2}{ }^{*}$ em

45 mu-zu an-za 3 -še ${ }_{3}$ kur-ur ${ }_{2}-\check{s ̌}_{3}$ he $_{2}-$ gal $_{2}$

A rev. 12 mu-zu an-za 3 -še ${\text { kur- } u r_{2}-\mathrm{se}_{3}}_{3}$ he $_{2}-\mathrm{g} \mathrm{al}_{2}$

46 kur-gal a-a den-lil ${ }_{2}$ du $_{11}$-ga eš-bar zi niĝ $\hat{g}_{2}$ nu-kur ${ }_{2}$-ru gaa $a_{2}$-me-en

A rev. 13 kur-gal a-a den-lil ${ }_{2}$ du $_{11}$-ga eš-bar zi niĝ $\hat{g}_{2}$ nu-kur 2 -ru ga $a_{2}$-me-en

47 e $\mathrm{e}_{2}$-kur mah-ğ $\mathrm{u}_{10}$ dalla mu-e-a-e $\mathrm{e}_{3}$

A rev. $14 \quad \mathrm{e}_{2}$-kur mah-g $\mathrm{g} \mathrm{u}_{10}$ dalla mu-e-a-e

$48 \operatorname{suh}_{10} \mathrm{kar}_{2}-\mathrm{kar}_{2}-\mathrm{ka}$-da an-še $\mathrm{e}_{3} \mathrm{gu}_{2}$ he $_{2}$-ni-in-us 2

A rev. $15 \operatorname{suh}_{10} \quad \mathrm{kar}_{2}-\mathrm{kar}_{2}-\mathrm{ka}$-da an-š $\mathrm{e}_{3} \quad \mathrm{gu}_{2} \quad \mathrm{hg}_{2}$-ni-in-us ${ }_{2}$

49 sul zi kalam-ma dalla hu-mu-ni-in- $e_{3}$

A rev. 16 sul zi kalam-ma dalla ḩu-mu-ni-in- $\mathrm{e}_{3}$

50 dur-dnamma en uru ${ }_{16}$ nam-lugal-la $\mathrm{gu}_{2}$ an-ta-bi he $\mathrm{f}_{2}$-em

A rev. $17{ }^{d}{ }^{-d}{ }^{-}{ }^{n a m m a}$ en uru $_{16}$ nam-lugal-la $g_{2}$ an-ta-bi he $e_{2}$-em

51 mu-zu an-za 3 -še $e_{3}$ kur-ur 2 -še ${ }_{3}$ he $_{2}-$ gal $_{2}$

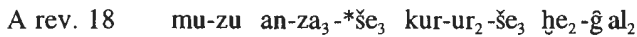

44 May Urnamma, the unswerving lord, be the . . of kingship!

45 May your name reach (as far as) the horizon and the foot of the mountains!

46 "I am Great Mountain, father Enlil, whose proper utterance and decision are immutable:

47 My magnificent Ekur is resplendent!"

48 With a radiant crown he has raised its neck heavenward.

49 The faithful young man has made it resplendent in the land.

50 May Urnamma, the unswerving lord, be the . . of kingship!

51 May your name reach (as far as) the horizon and the foot of the mountains! 


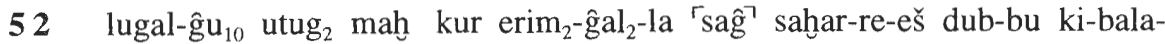
a AK-AK

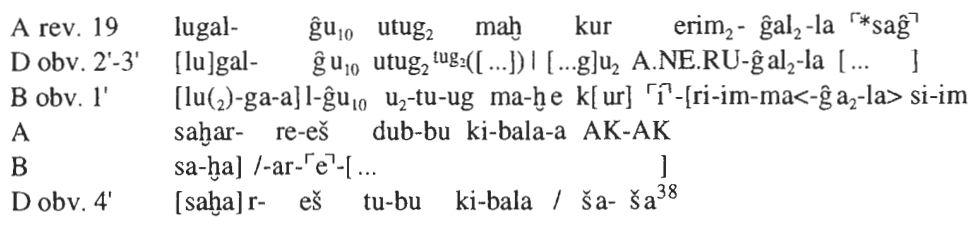

53 sipa dur-dnamma-ke ${ }_{4}$ utug $_{2}$ mah kur erim ${ }_{2}$-gal ${ }_{2}$-la saĝ sa[h]ar-re-[eš] dub-bu ki-bala-a AK-AK
A rev. 20
sipa ${ }^{d}{ }_{u r-}{ }^{d}$ namma- $\mathrm{ke}_{4}$ utug $_{2}$
mah kur erime- $\mathrm{g}_{\mathrm{al}}-\mathrm{la}$
D obv. $5^{\prime}$ $1\left\ulcorner\left(x^{?}-\right) x^{\urcorner}\right.$utug ${ }_{2}^{\text {tug }}{ }_{2}\ulcorner$ mah $\urcorner g u_{2}[\ldots$
na-na-ma-ke $\mathrm{u}_{2}$-tu-ug ma-he kur
B obv. 2' $[$...
A

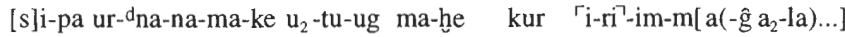
D obv. 6 *saĝ sa[h]ar-*re-[eš] dub-bu ki-bala-a AK-AK
B obv. 3 '

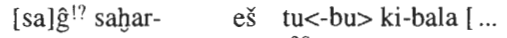

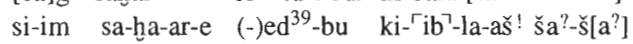

54 e-ne-er mu-na-an-šum ${ }_{2}$ en $d_{\text {nu-nam-nir-re }}$

A rev. 21 e-ne-er mu-na-an-šsum ${ }_{2}$ en ${ }^{d}$ nu-nam-nir-re

B obv. 4' i-ni-ir mu-na-an-šu(-) nu-na-am-ni-ra

55 kur $\mathrm{am}_{3}-\mathrm{tu}_{11}-\mathrm{be}_{2}$ girii ${ }_{3}-\mathrm{Saga}_{11} \mathrm{am}_{3}-\mathrm{me}$
A rev. 22 kur $a m_{3}-$ tu $_{11}-\mathrm{be}_{2}$ giri $_{3}$ saga $_{11} \quad \mathrm{am}_{3}-\mathrm{me}$ B

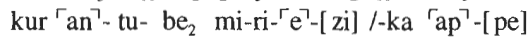

56 sipa dur-d namma-ke ${ }_{4}$ mu-na-an-šum ${ }_{2}$ en dnu-nam-nir-re

A rev. 23 sipa ${ }^{d} u r-{ }^{d}$ namma- ke $_{4}$ mu-na-an-šum ${ }_{2}$ en ${ }^{d}$ nu-nam-nir-re

B obv. $5^{\prime}$ si-pa ur- ${ }^{\mathrm{d} n a-n a-m a-k e}$ mu-na-an-šu(-) nu-na-am-ni-ra

52 To my lord - the huge u t u g-weapon which piles up heads as sand dunes in enemy lands and which rages in the rebellious lands -,

53 To shepherd Urnamma - the huge u t u g-weapon which piles up heads as sand dunes in enemy lands and which rages in the rebellious lands -,

54 To him lord Nunamnir gave it.

55 (And so) he heaps up the foreign land, tramples on it.

56 To shepherd Urnamma lord Nunamnir gave it.

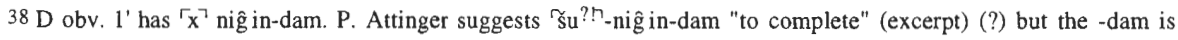
awkward.

39 A reading da- cannot be ruled out (cf. also Cavigneaux, ASJ 9 [ 1987] 49). 
57 kur am $_{3}-\mathrm{tu}_{11}-\mathrm{be}_{2}$ giri $\mathrm{giga}_{3}-\mathrm{sam}_{3}-\mathrm{me}$

A rev. 24 kur $\mathrm{am}_{3}-\mathrm{tu}_{11}$-be $\mathrm{b}_{2}$ giri $_{3}-\mathrm{saga}_{11} \mathrm{am}_{3}-\mathrm{me}$

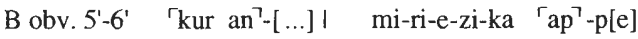

58 hul-ĝal ${ }_{2}$-la uru $_{2} \mathrm{am}_{3}$-mi-in-gul-gul

A rev. 25 hul- ga $\mathrm{gl}_{2}-\mathrm{la} \quad \mathrm{uru}_{2} \mathrm{am}_{3}$-mi-in-gul- gul

B obv. $7^{\prime} \quad$ [h] u-ur- $\mathrm{ga}_{2}-\mathrm{la} \mathrm{u}_{2}-\mathrm{ru}$ am-mi- $\mathrm{gu}_{4}-\mathrm{ul}^{-\mathrm{gu}_{4}-\mathrm{ul}}$

59 nam-gu mah- $_{2} \mathrm{~m}_{3} \quad \mathrm{lil}_{2} \quad \mathrm{am}_{3}$-mi-in-su-ub

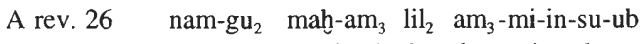

B na- $\mathrm{gu}_{4}-\mathrm{u}_{8}$ ma-hुa/ la- la- mi- du

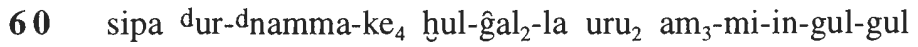

A rev. 27 sipa dur-dnamma- $\mathrm{ke}_{4}$ hul- gal $_{2}-\mathrm{la}$ uru $_{2} \mathrm{am}_{3}$-mi-in-gul- gul

B obv. 8' ' [si]-pa ur- ${ }^{\mathrm{d}}$ na-na-ma-ke hu-ur--g $\mathrm{a}_{2}-\mathrm{la}_{2} \mathrm{u}_{2}-\mathrm{ru}$ am-mi- $\mathrm{gu}_{4}-\mathrm{ul}^{-} \mathrm{gu}_{4}-\mathrm{u}[\mathrm{l}]$

61 nam-gu mah- $_{2} \mathrm{am}_{3} \quad \operatorname{lil}_{2} \quad \mathrm{am}_{3}-\mathrm{mi}-\mathrm{NI}\left(\mathrm{i}_{3}\right)$-in-su-ub

A rev. 28 nam-gu ${ }_{2} \quad$ mah- $\mathrm{am}_{3} \quad \mathrm{lil}_{2} \mathrm{am}_{3}-\mathrm{mi}-\mathrm{NI}\left(\mathrm{i}_{3}\right)$-in-su-ub

B obv. $9^{\prime} \quad\left[\mathrm{na}^{40}-\mathrm{gu}_{4}-\mathrm{u}_{8}\right.$ ma-h a la- la- mi- du

$62 \quad a_{2}$-a-ni hušs-am $e_{2}$ ki-bala

A rev. $29 \quad a_{2}$-a-ni huš-am $e_{3} \quad$ ki-bala

B obv. 10' ' ${ }^{\top}{ }^{\top}-$-ri-ni 'hu-ša' e ki-ib-la

$63 \mathrm{u}_{18}-\mathrm{lu}-\mathrm{ne}_{2} \quad \mathrm{lu}_{2} \quad$ erim $_{2}-\mathrm{gal}_{2}$ mu-ni-ib $\mathrm{b}_{2}-\mathrm{DU}$

A rev. $30 \quad \mathrm{u}_{18}$-lu-ne ${ }_{2} \quad \mathrm{lu}_{2} \quad$ erim $_{2}$ - $\mathrm{g} \mathrm{al}_{2} \quad$ mu- ni- $\quad \mathrm{ib}_{2}$-DU

B $\quad \mathrm{u}_{2}-\mathrm{ru}-\mathrm{ne}_{2}$ lu i-ri- $\mathrm{g} \mathrm{a}_{2}-\mathrm{al} \mathrm{mu}-[\mathrm{ni}] /$-ib-ša-a[š $]^{41}$

57 (And so) he heaps up the foreign land, tramples on it.

58 He made the storm completely destroy evil.

59 He made the wind sweep away the great oppression.

60 Shepherd Urnamma made the storm completely destroy evil.

61 He made the wind sweep away the great oppression.

62 His fame is frightful, dynasties of rebellious lands!

63 His storm has delivered the evil person to him. ${ }^{42}$

40 Genouillac's copy shows na-.

41 Genouillac's copy shows mu-ni/nib-š a-ă̌s.

42 Or translate lines 62-63: "His frightful fame has delivered to him dynasties of rebellious lands and his storm the evil person". 
64 sipa dur-dnamma-ke ${ }_{4} \quad \operatorname{ar}_{2}$-a-ni huš-am ${ }_{3} \quad e_{2}$ ki-bala

A rev. 31 sipa dur- ${ }^{d}$ namma- $\mathrm{ke}_{4} \mathrm{ar}_{2}$-a-ni hušs-am $\mathrm{e}_{2}$ ki-bala

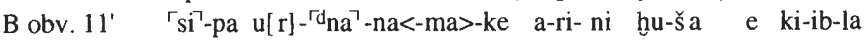

$65 \mathrm{u}_{18}$-lu-ne $\mathrm{lu}_{2}$ erim -gal $_{2}$ mu-ni-ib $-\mathrm{DU}$

A rev. $32 \quad \mathrm{u}_{18}$-lu-ne $\mathrm{ll}_{2} \quad \mathrm{lu}_{2} \quad$ erim $_{2}-\mathrm{g} \mathrm{al}_{2} \quad$ mu-ni-ib ${ }_{2}$-DU

B obv. 11'-12' $\mathrm{u}_{2}$-ru-ne ${ }_{2}$ [ [1]u i-ri- ' $\mathrm{gga}_{2}{ }^{\top}$-al mu-ni-ib- ša-aš

66 para $_{10}$ nam-lugal-la-ke ${ }_{4}$ ki-a mu-ni-in-us ${ }_{2}$

A rev. 33 para ${ }_{10}$ nam-lugal- la-ke ${ }_{4}$ ki-a mu-ni-in-us

B obv. 13' [p]a-ra na- lu-ga- ${ }^{\ulcorner}$la-ka ${ }^{\top}$ ki (-)am-mu- us ${ }_{2}$

D rev. 1' $\quad[\ldots \quad-u] s_{2}$

67 uri ${ }_{2}{ }^{k i-m a ~ p a ~} e_{3}$ mu-ni-ib-AK
A rev. $34 \quad$ uri $_{2}{ }^{k i}$-ma $\left[{ }^{*}\right.$ p $] \mathrm{a} e_{3} \quad$ mu-ni-ib-AK

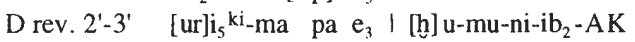

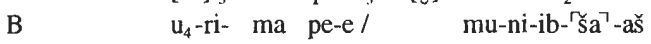

68 sipa dur-d namma-ke ${ }_{4} \mathrm{ni}_{2}$ bi $_{2}$-in-guru ${ }_{3}{ }^{\mathrm{ru}} / \mathrm{sag}$ he $_{2}$-ni-in-il ${ }_{2}$ lugal kalam$\mathrm{ma}-\left[\mathrm{kam} / \mathrm{ke}_{4}\right]$
A rev. 35 sipa dur- ${ }^{d}$ namma- $\mathrm{ke}_{4} \mathrm{ni}_{2} \quad \mathrm{bi}_{2}$-in-guru ${ }_{3}{ }^{\text {ru }} / \mathrm{sag}$ h he $\mathrm{e}_{2}$-ni-in-il ${ }_{2}$
D rev. 4' [si]pa ur-dnamma- $\mathrm{ke}_{4}$
B obv. 14' 'si'-pa ur-dna-na-ma-ke ni(-)ip-pi-ig-ru saĝ bi-ni(-)
A lugal kalam- ma- $\left[\mathrm{kam} / \mathrm{ke}_{4}\right]$

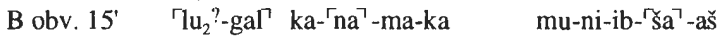

69 ki lugal-a-ni den-lil ${ }_{2}-\mathrm{la}_{2}$-ka saĝ-e-eš ḩe $\mathrm{e}_{2}-[\ldots]$
A rev. 36 ki lugal-a-ni den-lil ${ }_{2}-\mathrm{la}_{2}-$ ka sậ -e-eš hye $\mathrm{e}_{2}-[\ldots \quad]$
B rev. $1 \quad[\ldots]^{\ulcorner} x^{\urcorner}[\ldots]$ den-lil ${ }_{2}$-a-ak-ka sa-gi- - is $\quad$ mu-ni $-[\ldots]$

64 Shepherd Urnamma - his fame is frightful, dynasties of rebellious lands!

65 His storm has delivered the evil person to him.

66 He firmly founded the dais of kingship.

67 It shone forth in Ur. ${ }^{43}$

68 Shepherd Urnamma imbued it ${ }^{44}$ with awe, indeed he raised it high ${ }^{45}$ - he who is king of the land. ${ }^{46}$

69 In the presence of his lord Enlil it was [presented] to him.

\footnotetext{
43 Source D: "In Ur it verily shone".

44 i.e. either the dais of kingship or Ur.

45 Or: "indeed he raised his head".

46 Source B: "He indeed raised his head towards it (= the dais), it was brought to the king of the land".
} 
70 nam am ${ }_{3}$-tar-re šu zi a[m ${ }_{3}$-mi(-in)-gal $\left.{ }_{2}\right]$
A rev. 37
B rev. 2
nam
nam
$\mathrm{a}\left[\mathrm{m}_{3}-\mathrm{mi}(-\mathrm{in})-\mathrm{g}_{\mathrm{al}} \mathrm{l}_{2}\right]$
]$^{r} \times \times \times-a^{\top}-\hat{g} a_{2}-a l$

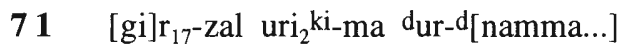

A rev. 38 [gi] $\mathrm{r}_{17}$-zal uri $_{2}{ }^{\mathrm{ki}}$-ma ${ }^{\mathrm{d}} \mathrm{dr}-\mathrm{d}[$ namma...]

B rev. 2-3 gi-ir- za-[...]। $\quad[\ldots](-)$ ur nam-hi $\mathrm{i}-\mathrm{i}-\mathrm{a}(-)[\ldots]^{47}$

72 [sa]-gar-ra-am tigi $_{2}$ den-[lil $\left.{ }_{2}-\mathrm{la}_{2}-\mathrm{kam}\right]$

A rev. 39 [sa]-ĝar-ra- $\mathrm{am}_{3} \quad$ tigi $_{2}$ den-[ lil $\left._{2}-\mathrm{la}_{2}-\mathrm{kam}\right]$

$70 \mathrm{He}^{48}$ decrees the fate, be[stowed] it upon him:

71 Delight in/of Ur [...] Ur[namma ...] in/of abundance [...].

72 (It is the $\mathrm{s}$ a $\mathrm{g}$ a r a, a $\mathrm{ti} \mathrm{g} \mathrm{i}$ of En[lil]) 


\subsection{Philological Commentary}

4 i g i i $1_{2}$ means here "to look at somebody/something (with intent, desire)" in order to find and select somebody. References are found in Klein, TAPS 71/7 (1981) 38f. ad 12-14. Add RIME 4.1.6.2 ii 18'-20' (with incorrect u $\hat{g}_{3} \mathrm{~d}$ a $\mathrm{g}$ a $\mathrm{l}$ $\left.\check{\mathrm{s}} \mathrm{ar}_{2}-\mathrm{ra}-{ }^{-} \mathrm{da}\right\urcorner$ ). For this topos of selection and designation, cf. IV 1.2, pp. $48 \mathrm{ff}$.

6 The possibility that $\mathrm{h}_{\mathrm{e}} \mathrm{e}_{2}-\mathrm{a}$ here is a variant of the frozen form $\mathrm{h}_{2}-\mathrm{a}_{3}$ (cf. Michalowski, Sachs Memorial Vol. [1988] 273 ad 36 "let it be" in the meaning of "favorable verdict"), and therefore to be translated "the shepherd, (the 'let it be' of Nunamnir $\approx$ ) the chosen one of Nunamnir, is laden with a terrible splendour!", cannot be dismissed despite the lack of other references in which $\mathrm{h}_{2}-\mathrm{a}$ is used attributively and the fact that the text predominantly writes - a $\mathrm{m}_{3}$.

$7 \mathrm{~m}$ e hu $\mathrm{r}$ "to trace the $\mathrm{m}$ " recalls the more common and semantically similar ĝ e š - h u r h u r (- h u r), cf. Farber-Flügge, StPohl 10 (1973) 187 and Sumerian Poem 4 (=Alster, OLP 21 [1990] 15) 1.

8-10 k u r-gal d e n-1 i $1_{2}-1$ e is agent of line 10. Line 9 seems to be made up of two idioms, namely the obscure $\breve{s} \mathrm{a}_{3} \quad \mathrm{~K} \mathrm{~A}\left(\mathrm{e} \mathrm{n} \mathrm{i} \mathrm{m} \mathrm{?)} \mathrm{g} \mathrm{a} \mathrm{l}_{2}\right.$ and $\mathrm{s}_{\mathrm{a}_{3}}(-\mathrm{g} \mathrm{e} / \mathrm{g} \mathrm{a}) \mathrm{DU}$, and expanded by $\mathrm{s} \mathrm{i}$ "to fill" in the sense of "to be occupied with".

14-16 Line 14 probably refers to the pacification of foreign lands that will supply raw materials (cf. Gudea, Cyl. A 15:6ff.; perhaps RIME 4.2.9.6:17-20 [Sîniddinam]) and labourers to work on the temple (cf. Gudea, Cyl. A 18:27f.; RIME 4.2.9.6:29-34; RIME 4.2.14.15:37-39 [Rimsîn], work on the canal), whereby Sumer rejoices (cf. Gudea, Cyl. A 19:1f.).

$\mathrm{u}_{4} \mathrm{AK}$ (respectively $\mathrm{n}$ a $\mathrm{m}-\mathrm{h} \mathrm{e}_{2}-\mathrm{a} \mathrm{A} \mathrm{K}$ ) in line 15 is a hapax (Steible, FAOS 1 [1975] 23 translates "to experience days of abundance"), perhaps literally "days which bring? prosperity", i.e. "prosperous times". The syntax is difficult, too, but maybe it goes with the locative? in the next line (a s i l a $\mathrm{a}_{3}$ ) although a s i $1 \mathrm{a}_{3}-\mathrm{a}$ is expected (cf. next paragraph ad Urnamma G $9 \mathrm{n}$ a $\mathrm{m}-\mathrm{h}_{\mathrm{e}}-\mathrm{a}$ ).

For the elusive $\mathrm{g} \mathrm{u}_{2} \mathrm{~m} \mathrm{ar}(-\mathrm{m} \mathrm{a} \mathrm{r})$ in line 16, cf. Klein's discussion in Studies Artzi (1990) 124 ad 60. The verb probably expresses a confident, happy, and thriving attitude, said of people: Urnamma G 9, Isin *30 (= Falkenstein, ZA 52 59) obv. 19 ĝ e š- $\mathrm{nu}_{2} \quad \mathrm{~g} \mathrm{e}_{4}-\mathrm{rin} \quad \mathrm{h} \mathrm{i}-1 \mathrm{i} \quad \mathrm{si}-\mathrm{a}-\mathrm{za} \quad \mathrm{gu}_{2}$ h $\mathrm{h}-\mathrm{mu}$ $\mathrm{u} \mathrm{n}-\mathrm{di}-\ulcorner\mathrm{m}$ a r $\urcorner-\mathrm{r}$ e "On your flowered bed, filled with luxuriance, may you (= Inana) thrive? with him (= king Urninurta)!", and possibly Kramer, Studies Birot (1986) 126 (= BM 86535) rev. iv 251 and 266; said of animals: Sulgi D 3; of boats: Sulgi R 60, Enki and the World Order 110, and Lugale 676 (in all three passages in context with $\mathrm{a}_{2} \mathrm{~s}$ u d "to sail swiftly"). It may thus be formally and semantically related to $\mathrm{s}$ a $\hat{\mathrm{g}} \mathrm{i}_{\mathrm{l}_{2}}$ which also appears in contexts of abundance and happiness. Note that our line 16 has a nearly identical parallel in Urnamma G 9 


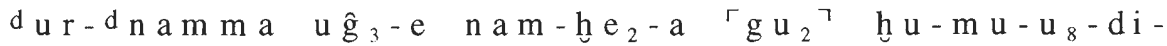
n i - i b-m a r-re "Urnamma, may he (= Enlil) make the people thrive? in abundance with you!".

$19 \mathrm{n}$ a m- g e š - š u b alternates with $\mathrm{n}$ a m - š u b also in Enki's Journey to Nippur 125 (cf. Attinger, Eléments 625, § 673 "scribal error or pun" on g e š š u b ( - b a ) "fate, allotment").

$\mathrm{ul}$ in u $\mathrm{l} \mathrm{s} \mathrm{a}_{7} . \mathrm{g}$ probably has the original meaning "bud, blossom", associated with pa-pa-al and gurun in gurun i $1_{2} \| \mathrm{ul} \quad \mathrm{guru}_{3}(\mathrm{ru})$ (cf. Falkenstein, ZA 56 [1964] 122 and Alster, Dumuzi's Dream 87f. ad 15-16 with comments by M. Cohen, Eršemma 155f. ad no. 79 [1]). u l s a $7 . \mathrm{g}$ might therefore take a literal meaning "to be sap-green", in the causative "to make flourish, to burgeon, to make mature, to ripen" and would fit well with $\mathrm{m} \mathrm{u}_{2}$ "to grow" of the following line 20. See further the commentary ad 26 and 32.

22 The non-standard writing $\mathrm{k} \mathrm{a}-\mathrm{a} \hat{\mathrm{g}}_{2}-\mathrm{ka}(-\mathrm{an})$ in Manchester Tammuz 19 and 21 (// Dumuzi-Inana $\mathrm{H}$ rev. 4' and 6') for $\mathrm{K} \mathrm{A}_{2}$ "gate" may show an original reduplicated form $\left\{\mathrm{k} \mathrm{a}_{2}+\mathrm{k} \mathrm{a}_{2}\right\}$ and make a reading $\mathrm{k} \mathrm{a}_{2}$ uncertain (cf. Attinger, ZA 85 [1995] 135, fn. 33, and the discussion in I 2., p. 8f., with regard to $\{\mathrm{n}$ a $m \mathrm{ma}+\mathrm{n}$ a m $\mathrm{ma}\}$ ).

The gates mentioned in line 22 appear in roughly the same topographical sequence in Hymn to the Ekur obv. 6ff. (and in M. Cohen, Lamentations 1 97:22ff. II 349:19ff.), cf. also Jacobsen, EI 20 (1989) 82*f. = OIP 98 (1991) 64-66, and EI 21 (1990) $40^{*}-46 * . \mathrm{K} \mathrm{A}_{2}$. G A L could be either the $\mathrm{K} \mathrm{A}_{2}-\mathrm{g}$ a l - $\mathrm{di} / \mathrm{k} \mathrm{i}$ ? - $\mathrm{k} \mathrm{u}_{3}$ of Hymn to the Ekur obv. 10, or with a reading a b u 11 a (cf. Kutscher, YNER 6 [1975] 110f.), refer to the $\mathrm{K} \mathrm{A}_{2}-\mathrm{m}$ a h which presumably led from the city into the Ekur compound. The $\mathrm{K} \mathrm{A}_{2}-\mathrm{s}$ i 1 i m - $\mathrm{m}$ a is the gate leading through Enlil's courtyard (Hymn to the Ekur obv. 8) to the ziggurat Hursaĝgalama.

25 For the difficult - b a in h u-ri-i n-b a, I follow Jacobsen's interpretation (locative) in Studies Hallo (1993) 121 ad 4, "in its (capacity) of eagle (...)". - b i, however, refers to the gates.

26 u $1-1$ a $\mathrm{s}$ i g g means "to inlay with blossoms, to decorate with blossoms" and may refer to rosette decorations on doors. This fits well with the silver and gold u 1 on temple doors in CBS 342 obv. 6, an unpublished piece of the pseudoepigraphic Lugalanemundu inscription (courtesy of J.S. Cooper), and the silver u 1 for the doors of Ningirsu's Eninnu in Gudea, Stat. B 5:48 (cf. Steible, FAOS 9/2 [1991] 20 ad 51). Likewise, chariots were decorated with ornamental buds, cf. e.g. Gudea, Cyl. B 16:15 and Sallaberger, Kalender 242 ad g., as were boats, e.g. Sallaberger, ibid. 242 ad k., and shoes, cf. Wilcke, CRRAI 35 (1988) 317 ff. (buds [Wilcke, ibid. 318 leaf?] of less than $1 / 4$ gr. gold).

29-30-ra in k u r-gal-1 a-r a is perhaps with Wilcke, Lugalbandaepos 142 , fn. 390 , an "isolating postposition". Or it might have been intended as a dative postposition (cf. line 32 "for Ninlil") which got syntactically jumbled because of the genitive.

$\mathrm{u}_{18}-\mathrm{r} \mathrm{u}$, for which a translation "giant" and perhaps "tornado" is conceivable, has been discussed most recently by Ludwig, Išme-Dagan 107-13. For $\mathrm{u}_{18}-\mathrm{r} \mathrm{u}-$ 
$\mathrm{g} \mathrm{i} \mathrm{n}_{7} \mathrm{ki} \mathrm{u} \mathrm{s}_{2}$ "to touch the ground like a tornado", cf. now also the Sulgi hymn fragment N $3130+$ N 3131 (= Klein, Studies Hallo [1993] 125) i 2' and Klein's commentary on p. 126 ad 2'.

32 u 1 D U (cf. the commentary ad 19 and 26) could perhaps mean "to bring to maturity, to blossom, i. e. to decorate". Compare Enki's Journey to Nippur 6-10 $\mathrm{e}_{2}-\mathrm{a}-\mathrm{ni} \quad \mathrm{ku}_{3} \quad \mathrm{na}_{4} \mathrm{Za}-\mathrm{g} \mathrm{in}_{3}-\mathrm{na} \quad \mathrm{tes}_{2}-\mathrm{bi} \quad \mathrm{ba}-\mathrm{ni}-\mathrm{in}-\mathrm{du}_{3}$ । $\mathrm{ku}_{3} \quad \mathrm{na}_{4} \mathrm{Za}-\mathrm{gin} \mathrm{i}_{3}-\mathrm{bi} \mathrm{u}_{4} \mathrm{kar}_{2}-\mathrm{kar}_{2}(-\mathrm{a})-\mathrm{ka} \mathrm{l}$ e $\check{\mathrm{s}}_{3}-\mathrm{e} \quad \mathrm{abzu}-$

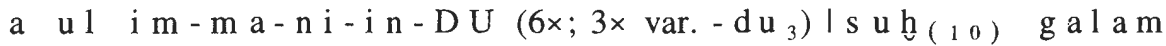

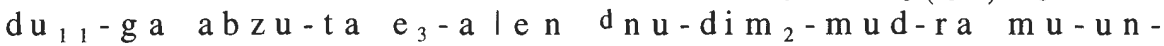
$\mathrm{n} \mathrm{a}-\mathrm{s} \mathrm{u}_{8}-\mathrm{s} \mathrm{u}_{8}-\mathrm{g}$ e $-\mathrm{e} \check{\mathrm{s}}$ "He (= Enki) built his house all with silver and lapis lazuli - with silver and lapis lazuli, a shining light. He decorated the shrine Abzu with a crown artfully decorated, coming out from the Abzu. They (= the gods) stood before lord Nudimmud." (conjectural translation).

33 The usual translation of "to go swiftly, to hurry up" for $\mathrm{d} \mathrm{u}_{10} \cdot \mathrm{b} \quad \mathrm{g} \mathrm{a} \mathrm{l}{ }_{2}$ (cf. Wilcke, Lugalbandaepos 36, and fn. 67, Heimpel, Tierbilder 80 and 109) certainly does not suggest itself here. Here $\mathrm{d} \mathrm{u}_{1_{0}}: \mathrm{b}$ (= birku, not $\left.\mathrm{d} \mathrm{u}_{10} \cdot \mathrm{g}\right)$ $\mathrm{g} \mathrm{a} \mathrm{l}_{2}+$ locative(-terminative) means "to relax" and is used to describe the relaxed intimacy of gods as in RIME 4.2.13.16:20-21 and maybe in a sexual sense in v. Dijk apud Owen, $Z A 71$ (1981) 42 (=VS 17 12) 2. For $\mathrm{d} \mathrm{u}_{10} \cdot \mathrm{b}$ $\mathrm{g} \mathrm{a} \mathrm{r} \mathrm{/} \mathrm{g} \mathrm{a}_{2} / \mathrm{g} \mathrm{a}_{2}$ in the sense "to relax" (especially said of animals), cf. Civil, Le débat sumérien entre la houe et l'araire (unpub.), Paris (1965) 134 (with references).

41 For the verbal chain $\mathrm{b}$ a/ $\mathrm{m} \mathrm{u}-\mathrm{e}-\mathrm{a}$ - before roots beginning with $\mathrm{a}$ vowel, cf. Attinger, Eléments 218, fn. 496 (- a - has no morphological function).

42 The form $\mathrm{k} \mathrm{a} \mathrm{r}_{2}-\mathrm{kar}_{2}-\mathrm{ka}-\mathrm{da}$ can hardly stand for $\mathrm{k} \mathrm{a}_{2}-\mathrm{k} \mathrm{a} \mathrm{r}_{2}$ $\mathrm{k} \mathrm{a} \mathrm{r}_{2}$ - d a (Klein, ASJ 11 [1989] 55 ad 42 and v. Dijk, HSAO 1 [1967] 257) because of the variant $\mathrm{k} \mathrm{a}_{2}-\mathrm{k} \mathrm{a}_{2}-\mathrm{a}-\mathrm{k}$ a (e.g. Enki's Journey to Nippur 7). More likely - k a is for A K (cf. v. Dijk, SGL 211 , fn. 2 and S. Cohen, ELA 277f. ad 442) and we therefore perhaps have to analyse $\left\{\mathrm{k} \mathrm{a} \mathrm{r}{ }_{2}\right.$ $\mathrm{kar}{ }_{2}+\mathrm{AK}+\mathrm{ed}+\mathrm{a}$ (locative) $\}$ with / e da/ > / a da/ assimilation, for a comitative in this context is very unlikely (cf. Sulgi D $388 \mathrm{n} \mathrm{i}_{2} \quad \mathrm{~m} \mathrm{e}_{-1} \mathrm{i} \mathrm{m}_{\mathrm{x}}$ $\left.m a \mathrm{~g} \mathrm{u}_{2} \mathrm{hu}-\mathrm{m} \mathrm{u}-n i-\mathrm{u} \mathrm{s}_{2}\right)$. For $\left(\mathrm{k} \mathrm{a} \mathrm{r}_{2}-\right) \mathrm{k} \mathrm{a} \mathrm{r}_{2}-\mathrm{k} \mathrm{a}$, cf. now also Krecher, Studies $v$. Soden $=$ AOAT 240 (1995) 158-60 who claims this is a maru form. This analysis of ( $\left.\mathrm{k} \mathrm{a} \mathrm{r}_{2}-\right) \mathrm{k} \mathrm{a} \mathrm{r}_{2}-\mathrm{k}$ a applies well to conjugated forms (cf. Enmerkar and the Lord of Aratta 442) but does not explain forms like the above mentioned $\mathrm{kar}_{2}-\mathrm{kar}_{2}-a-\mathrm{ka}$ nor $\mathrm{kar}_{2}-\mathrm{kar}_{2}-\mathrm{re}-\mathrm{de}_{3}$ in Kramer, JANES 5 (1973) 245:5.

44 For a recent discussion of $\mathrm{u} \mathrm{ru}_{16} \cdot \mathrm{n} / \mathrm{u} \mathrm{r} \mathrm{u} \mathrm{n/,} \mathrm{which} \mathrm{originally} \mathrm{might}$ mean "massive, unshakeable", cf. Civil, Studies Sjöberg (1989) 55 ad 2.

$\mathrm{h}_{\mathrm{e}}-\mathrm{e} \mathrm{m}$ is $\left\{\mathrm{h} \mathrm{e}+\mathrm{a} \mathrm{m}_{3}\right\}$, cf. also Yoshikawa, ASJ 11 (1989) 294. Compare Išmedagān $\mathrm{F}_{\mathrm{B}}$ (= Isin *13b) (= TCL 1518 obv. ii 11'-12') 9-10 $d i \check{s}-m e-d d a-$ gan dum u den-li $1_{2}-1 \mathrm{a}_{2} \mathrm{ub}-\mathrm{da} \quad \mathrm{immu} \mathrm{m}_{2}-\mathrm{ba}$ ! ul- $1 \mathrm{i}_{2}$ $\mathrm{s}_{3} \quad \mathrm{kalam}-\mathrm{ma} \quad \mathrm{gu}_{2} \quad \mathrm{he}_{2}-\mathrm{ni}-\mathrm{in}-\mathrm{zi} \quad \mathrm{e}-\mathrm{ne} \quad\ulcorner\mathrm{dig} \mathrm{ir}-\mathrm{bi}\urcorner$ 
h $\mathrm{e}_{2}-\mathrm{e} \mathrm{m}$ "Išmedagān, the son of Enlil, he of the four corners, may he raise his neck forever in the land, may he be its god!".

52 The writing $\mathrm{gu}_{2} \mathrm{~A} . \mathrm{NE} . \mathrm{RU}-\mathrm{g} \mathrm{al}_{2}-1 \mathrm{a}$ in source $\mathrm{D}$ is discussed by Attinger, Eléments 630, fn. 1813.

54/56 Note the virtual disappearance of e $n$ "lord" in source B because of Sandhi-writing before $\mathrm{n} \mathrm{u}-\mathrm{n}$ a- a m-n i - r a.

58 In view of the syntactical parallelism in line 59, $\mathrm{u} \mathrm{r} \mathrm{u}_{2}$ could be $\mathrm{u}_{18}$ $\mathrm{r} \mathrm{u} a b \bar{u} b u$, with possibly a pun on the common ES u r u ${ }_{2} \mathrm{gul}-\mathrm{gu} 1$ "to destroy cities". For u r u ${ }_{2}=\mathrm{u}_{18}-\mathrm{r}$ u, cf. e.g. Al-Fouadi, Enki's Journey to Nippur 129 ad 56, Alster, Vanstiphout, ASJ 9 (1987) 37 ad 134 and 137, and Išmedagān $V_{B}$ 7. Problematical is h $\mathrm{u} 1-\hat{\mathrm{g}}$ a $\mathrm{l}_{2}-1$ a for h $\mathrm{h} \mathrm{u} 1-\hat{\mathrm{g}}$ a $\mathrm{l}_{2}-\mathrm{a} \mathrm{m}_{3}$, succeeded by $\mathrm{n} \mathrm{am}-\mathrm{gu}_{2} \mathrm{mah}-a m_{3}$ in line 59 . However, the $-\mathrm{a} /-\mathrm{a} \mathrm{m}_{3}$ alternation is not uncommon.

66 The verbal form in source B might be a reinterpretation of original k i $\mathrm{a} \mathrm{m}_{3} \mathrm{mi}-\mathrm{ni}-\mathrm{in}-\mathrm{u} \mathrm{s}_{2}$.

68 The verbal form in source B b i - $\mathrm{ni} / \mathrm{b}$ i n i (1)/ is Sandhi-writing before $1 \mathrm{u}_{2}-\mathrm{g}$ a 1 .

$70 \breve{\mathrm{s} ~ \mathrm{z}} \mathrm{zi} \mathrm{g} \mathrm{al}_{2}$ is presumably a synonym of $\check{\mathrm{s}} \mathrm{u} \mathrm{zi}$ g a r šutlumu "to bestow", cf. Tinney, Nippur Lament 172 ad 238 and Michalowski, Correspondence 181f. ad 4. 


\section{U R N A M M A C}

\subsection{Introduction}

Previous studies ${ }^{l}$

G. Castellino published the first complete edition of this self-laudatory hymn with a transliteration, translation, and a philological commentary in ZA 53 (1959) 11831. Previously M. Lambert had transliterated and translated the hymnal prologue concerning Ur and the Ekišnugal (lines 1-12) in Sumer 6 (1950) 162f. In 1960 a treatment of lines 1-16 appeared in $\AA$.W. Sjöberg's dissertation (Mondgott 119-22). Within the framework of his dissertation in 1981 on historical correlations of the Sumerian royal hymns D.R. Frayne, on the basis of G. Castellino's text edition, translated and discussed many lines and attempted to correlate events narrated in them with those found in other records of Urnamma's reign.

\section{Structural Analysis}

Urnamma $\mathrm{C}$ is divided into two main sections (I-II) ending in a $\mathrm{z} \mathrm{a}_{3}-\mathrm{m} \mathrm{i}_{2}$ doxology. The first part (I) of the composition consists of a hymnic prologue in praise of the Ekišnugal (1-12) and introduces Urnamma in the 3rd person (13-19). The second part (II) is marked by a shift of person and contains Urnamma's selfpraise $(20-114)^{3}$. As in e.g. Sulgi O, the hymnic praise at the beginning includes the city as a whole (1-5), its main shrine, the Ekišnugal, and describes the shrine's various parts before it introduces the king (13-19). This second section (II) contains features which can be termed autobiographical, but do not necessarily follow a chronological order as D.R. Frayne assumed. ${ }^{4}$ It focuses to a large extent on royal legitimation: Urnamma's divine predestination, his designation and his achievements as king of Ur, and of Sumer and Akkad. Urnamma is specially favoured and endowed by the gods (20-30). Given judicial authority by Utu and strength by Ningublaga (27-30), Urnamma is well equipped to enforce law and order in Sumer and Akkad (31-40). This pleases Nanna-Su'en who has favoured Urnamma even be-

\footnotetext{
1 Cf. also II 2., p. 20.

2 Cf. also IV 3.1, p. 73.

3 Note that lines 103-106 seem to be in the 3rd person.

4 Frayne, Correlations $79 \mathrm{ff}$., cf. in more detail, III 2., pp. $37 \mathrm{ff}$.
} 
fore birth (43-45). The text continues with Urnamma's divine predestination and lineage (46-49). The following lines describe Urnamma's propitious fate: as leader of Sumer he is the source of happiness, political stability, and prosperity (50-84), and has established and consolidated Ur's control by expulsion of the Guti and restoration of the wall (85?-92). After a short description of the journey to Enlil in Nippur with offerings ${ }^{5}$ (103-106) the section ends with a final self-acknowledgment and legitimation (107-114).

It is difficult to see any formal structure in this hymn except that it is made up of descriptive passages that focus on individual features or situations, some doubtless with historical allusions (cf. the Guti). Furthermore, the beginning and end concentrate both on Urnamma's cultic relationship with Ur, i.e. the Ekišnugal which he extensively rebuilt, and on his relationship with Nanna, Ur's main god, whereas the middle section contains legitimation phraseology and a description of his individual achievements.

In summary, the composition is made up of the following sequences:

I. Prologue (1-19) 3rd person

1. Sanctuary Ur, the Ekišnugal (1-12)

2. Urnamma (13-19)

II. Self-praise (20-114) 1st person

1. Divine approval and endowments (20-30) from:
a. An $(20-21)$
b. Enlil (22)
c. Enki (23)
d. Nintur $(24-25 / 6)$
e. Utu (27-28)
f. Ningublaga (29-30)

2. Description of judicial activities as king and guardian-spirit of Ur (31-39/40)

3. Transition: Nanna receiving offerings in the Ekišnugal (41-42)

4. Divine predestination and designation (43-49)

a. favoured by Nanna-Su'en before birth (43-45)

b. favoured by Enlil (46)

c. favoured by Nintur (47)

d. divine parentage (48-49)

5. Description of Sumer and Akkad's well-being thanks to Urnamma, their guardian-spirit (50-56)

6. Designation as leader of Sumer by Enlil (57-61)

7. Self-description (62-69, partially broken)

8. Political stability (70-72)

9. Cultic function as e n-priest (in the $\mathrm{g}$ i p a r of Uruk) (73-75)

10. Resulting agricultural abundance (76-80) 
11. Well-being of Sumer (81-84)

12. Establishing and consolidating Ur's control with expulsion of the Guti and restoration of the wall (85?-92)

13. Abundance for Ur (?) (mostly broken) (93-102)

14. Urnamma's (?) journey to Nippur with (first-fruit) offerings for Enlil (103106) 3rd person ${ }^{6}$

15. Final self-acknowledgment and legitimation: Nanna's creature, part of the divine Uruk family, kingship passed on (107-114)

III. $\mathrm{z} \mathrm{a}_{3}-\mathrm{m} \mathrm{i}_{2}-\hat{\mathrm{g}} \mathrm{u}_{10}$ doxology (115)

Source

Nippur:

AO 5378

i $1-26=1-26$

ii $1-25=\mathbf{2 7 - 5 1}$

iii $1-33=\mathbf{5 2 - 8 4}$

iv $1-31=85-115$

copy: H. de Genouillac, TCL 1512.

photo of obv.: B. André-Leicknam, C. Ziegler, alii (eds.),

Naissance de l'écriture [...], Paris (1982) 221; photos of obv. and rev. made available by B. André-Salvini, cf. pls. 16-20.

collations: J.-M. Durand (unpub.); E. Flückiger-Hawker.

measurements: $130 \times 104 \times 36 \mathrm{~cm}$. 



\subsection{Transliteration and Translation}

1 i 1 iri me $\mathrm{du}_{10}$ - $^{-\mathrm{du}_{10}}$-ga para $\mathrm{a}_{10}$ mah nam-lugal-la

2 i 2 eš $\check{\text { uri }}_{5} \mathrm{ki}^{\mathrm{gu}} \mathrm{gu}_{2}$-gal 'ki'-en-gi-ra $\mathrm{ki} \mathrm{ku}_{3}$-ga du $\mathrm{du}_{3}$-a

3 i 3 iri bad 3 gal ki gar-ra-ba abzu-ta $m_{2}-\mathrm{a}$

4 i 4 iri an-gin ${ }_{7} \mathrm{sa}_{7}$-ga hi-li guru ${ }_{3}^{\text {ru }}$ ki-gal-la gunu $_{3}$-gunu

5 i 5 ešs uri $_{5}$ ki gi $_{6}-$ par $_{4}$ ki gar-ra ki-tuš an den-lil $2-1 a_{2}$

6 i $6 \quad e_{2}$-gal mah-ba $e_{2}$-kiš-nu-gala ${ }_{2} \check{s ̌ a}_{3}$-bi nam tar-ra

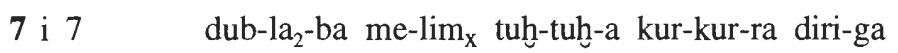

8 i 8 gi-gun - -na-bi dungu babbar-gin ${ }_{7}$ an-ša $a_{3}$-ga $u_{6}$-di

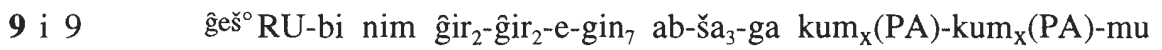

10 i 10 DIŠ! gud ĝeššdul ${ }_{4}^{-a-g_{n}}$ ur $_{2}$ gur-ra $\times$ ku$_{3}$ DA.RA-ga

11 i 11 gešbansur 'rikil-la’ ki-aĝ $\hat{g}_{2}$ su'en-na

12 i $12 e_{2}$-kiš-nu-ğal ${ }_{2}$ gešs bansur 'sikil`-la ki-ag $\hat{g}_{2}$ dsu'en-na

13 i 13 lugal KI.LUGAL.GUB-la he ${ }_{2}$-du $\mathrm{du}_{7}$-bi 'kisaГ(-)mah-e si-a

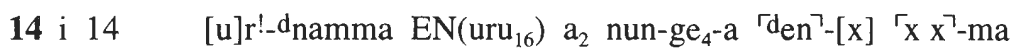

15 i $15 \quad[(\mathrm{x})$ ur $] \mathrm{i}_{5}^{\mathrm{ki}} \Gamma_{\text {iri? }}$ dagal $(-) \mathrm{b}\left[\mathrm{a} / \mathrm{z}\left[\mathrm{u}^{\circ}\right] \operatorname{SSAR}^{?} \mathrm{x}^{\urcorner}[(\mathrm{x}) \mathrm{x} \mathrm{x}]\right.$

16 i 16 [...] nam ${ }^{x}$ x-ga pa? ba-e-ni-a-e ${ }_{3}$

17 i $17 \quad[\ldots]\ulcorner x(-x)\urcorner[(x) x]-\ulcorner x\urcorner$ nir-ga $a_{2}-\mathrm{e}$

18 i 18 [ni 2 -te(-a)-n]i mi $_{2}$ zi i-ri-in-ga-am ${ }_{3}$-me 
1 City of all good $\mathrm{m} \mathrm{e}$, highest dais of kingship,

2 Sanctuary Ur, foremost in Sumer, built on splendid ground,

3 City, great wall, when (firmly) founded, has grown from the Abzu, ${ }^{7}$

4 City, azure like the heavens, full of luxuriance, iridescent upon the (building) platform,

5 Sanctuary Ur, (with a) firmly founded $\mathrm{g}$ i $\mathrm{p}$ a r, dwelling place of An and Enlil,

6 Of its greatest palace - the Ekišnugal: its centre where fate is determined,

7 Its! $\mathrm{d} \mathrm{u} \mathrm{b} 1 \mathrm{a}$, laden with radiance, exceeding all (the foreign) lands,

8 Its g i g u n a, spectacular as white clouds in the midst of the sky,

9 Its . . sparkling in the depths of the sea like flashing lightening,

10 Like a single bull under a yoke, with stumpy legs, ....

11 Pure (offering) table, beloved of Su'en,

12 Ekišnugal, pure table, beloved of Su'en,

13 The king, the adornment of ... who occupies the main courtyard,

14 Urnamma, the valiant, of indomitable strength, ....

$15[\ldots \mathrm{U}] \mathrm{r},[\ldots]$ broad city? . . [ [...],

$16[\ldots]$... made appear.

$17[\ldots] \ldots$ the noble,

18 Furthermore praises [himse]lf deservingly,

7 Or: "City, which owing to its great wall (firmly) founded, has grown from the Abzu". 
19 i $\left.19 \quad[u] r-{ }^{-} d_{\text {namma }}\right\urcorner$ lugal uri ${ }_{5} \mathrm{ki}_{-m a}$ nam $\mathrm{du}_{10}$ tar-ra-ba / giri ${ }_{3}$ si muun-da-ab-sa

20 i 20 an-e $\mathrm{ka} \mathrm{ku}_{3}{ }^{\urcorner}$-ga-ni mu-un-ba IM.A ma- $\mathrm{u}_{3}-\mathrm{du}_{2}$

21 i 21 ki-še $\check{s ̌ a}_{3}$-ga si ba-an-sa ḩe $_{2}-\mathrm{gal}_{2}$ ma-ra-DU

22 i 22 den-lil 2 -le mi $_{2}$ zi mu-un-du ${ }_{11}$ UN mu-ši-in- $x^{8}$

23 i $23 \quad d\ulcorner$ en $\urcorner-k i-k e_{4} m i_{2}$ zi mu-un-du ${ }_{11}$ a-eštub dezina ${ }_{2} /$ še gu-nu saĝ-eeš mu-un-rigg

24 i $24 \quad \Gamma_{n i n}$-tu-re ge $_{26}$-e mu-un-dim ${ }_{2}$-dim ${ }_{2}$-en ga-ri-ĝu $u_{10}$ nu-tuku

25 i $25 \quad[\ldots]-x^{\urcorner} \mathrm{du}_{10}$-be ${ }_{2}$ bi $_{2}$-in-peš-en lugal kalam-ma-me-en

26 i $26 \quad$ [...ga $]_{2}$ zi-da-me-en $\operatorname{tur}_{3}$ amaš mu-da- ${ }^{\text {daghal }}$

27 ii 1 dutu ka-ĝa $a_{2}$ enim ba-ni-in-gal

28 ii 2. di $k_{5}$-ru-ĝ $u_{10}$ ki-en-gi ki-uri gu $_{3}$ teš $\check{2}_{2}$-a bi bin-si $_{3}$

29 ii 3 dnin-gublaga-ke $\mathrm{a}_{4}$ ma-an-šum ${ }_{2}$

30 ii $4 \quad \mathrm{me}_{3}-\hat{g u}_{10}$ an-ki $\check{s}_{2}$-a-bi $l_{2}$ la-ba-ra-e $\mathrm{e}_{3}$

31 ii 5 ur-dnamma lugal uri ${ }_{5} \mathrm{ki}_{-}$ma dlamma iri-ga $\mathrm{a}_{2}$-me-en

32 ii $6 \quad$ šer $_{7}$-da mu-dub ${ }_{2}$ su mu-un- $\operatorname{sag}_{3}-\mathrm{sag}_{3}$

33 ii $7 \quad$ ni $_{2}$ su-e bi $_{2}-\mathrm{us}_{2}-\mathrm{sa}-\hat{g u}_{10}\left\ulcorner\mathrm{x} \times \mathrm{x}^{\urcorner}-\mathrm{a}\right.$ i-na mu-x $x$-ri-ia(-)A $\check{S}^{9}$

34 ii 8 di $\mathrm{ku}_{5}$-ru-ĝgu $\mathrm{g}_{10}$ ki-en-gi ki- $\mathrm{uri}^{\urcorner} \mathrm{us}_{2}$ AŠ-a mi-ni-ib-dab

35 ii $9 \quad$ ni $_{2}$-zuh lu $_{2}$ i-dutu-ka gu $_{2}$-ba giri ${ }_{3}$ bi $_{2}$-gub

36 ii $10 \quad$ NE.RU-du muš-gin ${ }_{7}$ šu gid $_{2}-$ gid $_{2}$-da šu im-da-an-šu ${ }_{2}-\breve{s ̆ u}_{2}$

37 ii $11 \quad$ lu $_{2}$ kar-da gur $_{5}$-ru-uš im-da-ab-be ${ }_{2}$ ša $_{3}$-bi si bi $i_{2}-$ ib-sa $_{2}$ 
19 Urnamma, the king of Ur: after an auspicious fate had been determined, the roads were put in order due to him:

20 "An opened his pure mouth and rain(storms) was produced for me,

21 He made it fall right into the deep earth, and abundance came forth to/for me,

22 Enlil approved of me, has ... the land/people to me,

23 Enki approved of me, has presented me with the early flood, wheat and mottled barley,

24 Nintur has formed me meticulously, (so that) I have no equal.

$25[\ldots]$ has raised me on the knees, I am the king of the land.

26 I am the [...] of the just [...], cattle pen and sheepfold were expanded under my reign.

27 Utu has put orders in my mouth,

28 Through my capacity to pronounce judgments he has permitted me to make Sumer and Akkad obedient.

29 Ningublaga has given me strength,

30 When my battle covers heaven and earth, nobody escapes.

31 I am Urnamma, king of Ur, the guardian-spirit of my city:

32 I caused offense to tremble, bodies shook there.

33 Thanks to the fear I have inspired ...,

34 The judgments I pronounce made Sumer and Akkad hew to the one and same path.

35 I put my foot on the neck of thieves and oppressors.

36 Reaching out for malefactors as for a snake, I clasped them.

37 Against the fugitives I rushed forth, their hearts were set aright, 
38 ii 12 nig $g_{2}-\mathrm{si}_{-} \mathrm{sa}_{2}$-e pa $\mathrm{e}_{3} \quad \mathrm{bi}_{2}-\mathrm{AK}$ nig $\hat{g}_{2}-\mathrm{NE}$.RU $\mathrm{sa}_{2} \quad \mathrm{bi}_{2}-\mathrm{du}_{11}$

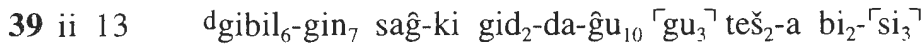

40 ii $14 \quad \mathrm{KA}-\mathrm{gu}_{10} \mathrm{ME}(.) \mathrm{ME}(.) \mathrm{DU}_{8}$ ba-gub-be $\left.\mathrm{UN}_{2} \times \mathrm{A}^{\urcorner}[\ldots]{ }^{\ulcorner} \mathrm{x}(-\mathrm{x})-\mathrm{e}\right\urcorner$

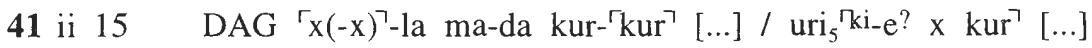

42 ii 16 nidba-bi $e_{2}$-kiš-nu- ${ }^{-}$gal $_{2}$-la-na $\urcorner / d_{\text {nanna-ar mi-ni-in-hul }}$-le

43 ii $17 \quad$ a!-g $\mathrm{gu}_{10} \quad \mathrm{ša}_{3} \mathrm{ku}_{3}$-ge ba-ri-a-ta

44 ii 18 dsu'en-e $u_{6}$-e ki-ag $\hat{g}_{2}$-ni

$$
r_{x} x^{\urcorner 10}
$$

45 ii 19 dnanna-ar hi-li-na ba-ni-in-ku -re $_{4}$

46 ii 20 den-lil 2 -le dutu-gin 7 kalam-ma $e_{3}-\mathrm{de}_{3} / \mathrm{mu} \mathrm{du} \mathrm{du}_{10}$ mu-un- $\left.\breve{\mathrm{se}}_{21}\right\urcorner$

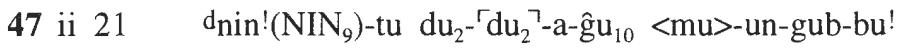

48 ii $22 \quad \mathrm{s̆a}_{3}$ ama-ĝ $\mathrm{u}_{10}$ dnin-sumun $\mathrm{d}_{2}$-ka-ta

49 ii 23 nam tar-ra $\mathrm{sa}_{6}$-ga ma-ta-e ${ }_{3}$

50 ii 24 ur-dnamma-me-en ma-da ki-en-gi ki- $\ulcorner u r i\urcorner /$ dlamma mu-un-da-antuku

51 ii 25 kalam-ma ki ur sa $_{6}$-ge-bi ge $_{26}$-e-me-en $z i-\hat{g} u_{10} \quad$ he $_{2}-\mathrm{u}_{3}-\mathrm{du}_{2}$

52 iii 1 piriĝ ušumgal? x A(.)KA IGI(.x).LA $A_{2}$ a-ša mu-da-dadag

53 iii 2 [GA]NA $A_{2}$ gi hulu $\mathrm{mu}_{2}-\mathrm{a}$ suba ${ }_{2}$ nu-mu- $\mathrm{u}_{8}$-da-lu

54 iii $3 \quad \operatorname{edim}_{\mathbf{x}}^{\urcorner}(\mathrm{EDIN})$-ma ezem-gin ${ }_{7}$ du $_{3}$-a-ba ĝiri ${ }_{3}$ si mu-un-da-ab- ${ }^{\mathrm{sa}_{2}}{ }^{\urcorner}$

55 iii $4 \quad \mathrm{lu}_{2}$ a-ša $a_{3}$-ga nir-ğal ${ }_{2}$-bi mu-un-DU / gaba-na ib-ta-an-zi

56 iii 5 dumu-uku $u_{2}-\mathrm{ra} \mathrm{u}_{2} \mathrm{il}_{2}$-i-de 3 gen-na ama-ni-ir mu-un-ge - $_{4} \mathrm{ge}_{4}$ 
38 I made justice appear, subdued evil,

39 Like Gibil, my frown made them obedient. ${ }^{11}$

40 My mouth/command puts ... [... ...

$41 \ldots$, the territories and all (the foreign) lands $[\ldots] \mathrm{Ur}[\ldots]$,

42 Their sacrifices make me rejoice before Nanna in his Ekišnuĝal.

43 When my semen was ejaculated into the pure womb,

44 Su'en who loves marvellous things

45 Made me turn (be)for(e) Nanna into his darling.

46 Enlil who rises like the sun over the land, gave me a good name,

47 Nintur stood by in the process of my birth,

48 From the womb of my mother Ninsumun

49 A propitious fate has emerged for me.

50 In me!, Urnamma, the Land Sumer and Akkad has got a guardian-spirit.

51 I am the source of the land's happiness, my life is a creative force.

52 Lion(s) and dragon(s)? ..., the fields were bright under my reign.

53 (On) the [gro]und? on which bad reeds grew, did not . . multiply under my reign?

54 In the steppe, after being prepared as for a festival, the roads were put in order due to me!.

55 Men stood confidently in the fields, up to their chests it ${ }^{12}$ rose.

56 The poor who went to gather fuel, were exempted from their obligations.

11 Literally: "(...), I made my frown make them obedient", for otherwise $\mathrm{bi}_{2}-\mathrm{ib}_{(2)}-\mathrm{si}_{3}$ is expected.

12 i.e. the produce of the fields. 
57 iii $6 \quad \Gamma_{\mathrm{a}}$ ??-ma-ru [g]e ${ }_{4}$ ?-ba i-ti ma-ge ${ }_{4}$

$$
{ }_{\mathrm{x}} \mathrm{x}^{\urcorner}-\mathrm{a}-\mathrm{ba}^{?+13}
$$

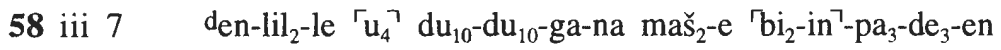

59 iii 8 ki-en-gi-[r]a $\mathrm{gu}_{3}$ zi mu-un-de ${ }_{2} \mathrm{ga}_{2}-\mathrm{a}$ in-da-an-zi- ${ }_{\text {ge-en }} ?$

60 iii 9 ' geštu $_{2}$ daĝal igi-ĝal ${ }_{2}$ tuku-ĝu $u_{10}-\check{s ̌}_{3}$

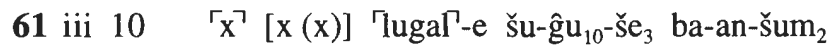

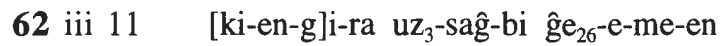

63 iii $12[\ldots]\ulcorner x\urcorner[(x)]\left\ulcorner x x^{\urcorner}\right.$sa - ga-me-en

64 iii $13 \quad[\ldots]-\left\ulcorner^{?} ?-m e-e n\right.$

65 iii $14 \quad[\ldots]\ulcorner x\urcorner[\ldots]\ulcorner x\urcorner$ kalam-ma-me-en

66 iii $15 \quad[\ldots]-\left\ulcorner\mathrm{x}-\right.$ tum $_{2}-\mathrm{mu}$

67 iii $16 \quad\left\ulcorner\times x \times x^{\urcorner}[\ldots]\right.$

68 iii $17 \quad{ }^{x}$ H HI? $x^{\urcorner}[\ldots]$

69 iii 18 en-me-`en $z i ? \times x^{\urcorner}[\ldots]\left\ulcorner x x^{\urcorner}[\ldots]\right.$

70 iii 19 ur-dnamma diĝir- $\breve{S E}_{3} \quad \mathrm{du}_{2}-\ulcorner\mathrm{da}\urcorner \mathrm{ku}_{3}$-ge-eš $\ulcorner\mathrm{x}\urcorner \quad[\ldots]$

71 iii 20 'unken? igi-ĝ $u_{10}-\mathrm{š}_{3}$ si im- $\left\ulcorner\mathrm{sa}_{2}\right\urcorner$

72 iii 21 eren 2 silim-ma kalam šu-a ge $_{4}-\mathrm{ge}_{4}$ den-lil $_{2}$-le ma-ra-an-šum 2

73 iii $22 \quad$ gi $i_{6}-$ par $_{4}$-ra gada nam-mi-la 2

74 iii 23 geš-nu $u_{2}$ ge-rin-na ki-nu du $_{10}$-ba mu- $\left.\mathrm{nu}_{2}\right\urcorner$

75 iii $24 \quad$ ug $_{3}$-e $u_{2}$ nir-gal ${ }_{2} \quad$ bi $_{2}-\mathrm{ib}_{2}-\mathrm{gu}_{7}$ ? -en den-ki-im-du-bi-me-en

76 iii 25 sipa zi udu?-ni diri gal ${ }_{2}$-la-me-en

13 Possible verbal variant: "(...) when ... .", cf. also II 4., p. 27. 
57 When the storm had receded? ${ }^{14}$ the moonlight returned to/for me,

58 Enlil designated me on his very auspicious day through extispicy.

59 He spoke authoritatively to Sumer, through him I rise over/in front of it. ${ }^{15}$

60 Because I possess broad wisdom and intelligence,

$61[\ldots]$, the lord, put $\mathrm{it}^{16}$ in my control.

62 I am the ... of [Sum]er.

$63[\ldots]$ the beneficial ... am I.

$64[\ldots]$ am I,

$65[\ldots]$ the $[\ldots]$ of the land am I.

$66[\ldots]$ who carries $[\ldots]$.

$67 \quad \ldots[\ldots]$

$68 \quad \ldots[\ldots]$

69 I am the e n-priest ${ }^{17} \ldots[\ldots]$.

70 [I?] Urnamma, born to be a god, in pure fashion [...].

71 The assembly? is properly arranged before me,

72 Enlil has given me vigorous troops who keep the land secure.

73 In the $\mathrm{g}$ i $\mathrm{p}$ a $\mathrm{r}$ I put on a linen garment,

74 I lay down on the flowered bed, its sweet resting place,

75 I let people eat? tasty food, I am their Enkimdu,

76 I am the faithful shepherd who has increased his flock?,

\footnotetext{
14 Expected is [ $\mathrm{g}] \mathrm{e}_{4}{ }^{?}$-a-ba.

15 i.e. Sumer. Less likely: "(..) and elevated me with it", with in-da- < im-da- (assimilation)

16 i.e. perhaps Sumer.

17 In view of lines 73-74, rather than "lord".
} 
77 iii $26 \operatorname{tur}_{3}$ amaš daĝal $\mathrm{KA} \times \mathrm{MAS}$-bi gal $_{2}$ bi $_{2}$-taka ${ }_{4}$ gaba-ri-ĝ, $\mathrm{u}_{10}$ nu-tuku

78 iii 27 sipa $u_{2}$ naĝ-ĝa $a_{2}$-bi suba ma-šar $_{2}$

$$
\text { x x mu?-ni-šar } 2 \text { ?18 }
$$

79 iii 28 nam-EN-na-bi $\mathrm{u}_{3}$-me-ni-tag

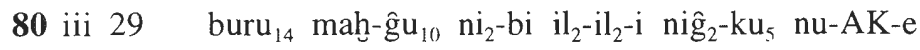

81 iii $30 \quad a_{2}-\hat{g}_{2}-\hat{g a}_{2}-\hat{g u}_{10}$ bad $_{3}$ gal kur-ra-ka a-ne hul ${ }_{2}$-la mu-e

82 iii 31 iri-ga $a_{2}$ ki sur-ra ki-en-gi-ra gir $_{17}$-zal-bi ma-du ${ }_{10}$

83 iii 32 ki-en-gi $i_{7}$-ba a šu bi ${ }_{2}$-ba ĝeš $g_{2}$-ba mu-zi

84 iii 33 saĝ-ur-saĝ-bi ĝeššudul ${ }_{4}$-bi mu-zi

85 iv 1 [...k]ur-ra-ka $\mathrm{ZA}_{3} \cdot \mathrm{LA}_{2}-{ }^{-} \mathrm{bi}{ }^{\text {? }} \mathrm{m}[\mathrm{u}]-{ }^{\ulcorner}$tuh? $?$

86 iv 2 [..u]ri $\mathrm{ki}_{5}\left\ulcorner_{\mathrm{S} u}\right\urcorner-$ ba im-mi- $\left.{ }^{-} \mathrm{ge}_{4}\right\urcorner$

87 iv $3 \cdot\left\ulcorner_{x}\right.$-ba ITIMA-šeššig-gin 7 kur- $\left.{ }^{r a}\right\urcorner-n a b_{2}-g_{4}$

88 iv 4 še-bi $\mathrm{ma}_{2}-$ gur $_{8}-\mathrm{ra}^{-k_{4}} \mathrm{bi}_{2}-\mathrm{la}_{2} \quad \mathrm{~g} \mathrm{a}_{2}$-nun-bi ${ }^{\ulcorner} \mathrm{bi}_{2}{ }^{\urcorner}-\mathrm{ge}_{4}$

89 iv 5 dumu $\left\ulcorner\mathrm{KIG}_{2}{ }^{\text {? }}{ }^{19}\right.$-bi e $\mathrm{e}_{2}$-a-ni!(IR) im-mi-ge dubsig $_{\mathrm{x}}$-bi mu-ge ${ }_{4}$

90 iv 6 gu-ti-umki $\mathrm{LU}_{2} \cdot \breve{S}_{3} \times \mathrm{TAR}$ ?A-ke ${ }_{4}$ Šu urin-na mu-du

91 iv 7 i-dutu ka-ba um-mi-ge ${ }_{4}$

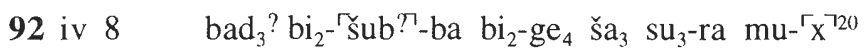
iri? DU mu-gul? eš uri $\check{s}_{5} \mathrm{k}[\mathrm{i} \ldots]^{21}$

93 iv 9 guruš? gu ${ }_{2}\left\ulcorner_{\text {tuku }}\right\urcorner$ den-lil $_{2}-l_{2}$-me-en nidba $\left\ulcorner_{\mathrm{x}}-(\mathrm{x}-) \mathrm{x}\right\urcorner-\mathrm{me}-\left\ulcorner_{\mathrm{en}}\right\urcorner$

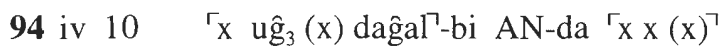

95 iv $11 \quad[\ldots]-{ }^{-} \mathrm{x}$-bi $\left.\mathrm{AN}\right\urcorner$-da $\ulcorner\mathrm{NI} ? \mathrm{x}(-\mathrm{x})\urcorner$

\footnotetext{
18 Possible variant, cf. also II 4., p. 27.

19 A reading $-\mathrm{gi}_{7}$ is excluded.

20 Or $[\mathrm{x}]$ instead of $\mathrm{x}$ ' , as the broken sign could also belong to the squeezed signs below.

21 Possibly an additional line (or a variant?) squeezed between lines 92 and 93 .
} 
77 I opened the ... of the wide cattle pens and sheepfolds, I have nobody equal to me.

$78 \ldots$ were multiplied for me in? the shepherd's pastures and watering places, ${ }^{22}$

79 After having...,

80 No one taxes my enormous harvest which raises itself high,

81 In the big fortress of the $\mathrm{k} \mathrm{u} \mathrm{r}$, they joyfully follow my instructions, ${ }^{23}$

82 The delight of my city (and) the region of Sumer, pleases me,

83 I released water into Sumer's canals, trees grew tall on their banks,

$84 \mathrm{Its}^{24}$ s a $\hat{g}$ u r s a $\hat{g}$ lifted their yoke,

85 The ... of the $[\ldots]$ of the foreign land I released?,

$86[\ldots]$ I returned to $[\mathrm{U}] \mathrm{r}$ 's control.

87 I made. . return like a ... to his land,

88 I loaded its ${ }^{25}$ grain on cargo boats, restocked its granaries with it.

89 I let its working? citizens return home, they returned to their (work) basket.

90 The captive Guti I put in bloody fetters.

91 And when I had diverted the cry of the oppressed into their ${ }^{26}$ mouths,

92 I restored the wall? that had been torn down?, and . . impenetrable hearts/ inside, I . . . the sanctuary Ur [...].

93 I am the perfect workman? of Enlil, I am the one who ... sacrifices.

94 ... its numerous people....

$95[\ldots]$ its ....

\footnotetext{
22 Variant: "I have multiplied? ...".

23 Or: "My instructions, the big fortress of the $\mathrm{k} \mathrm{u} \mathrm{r}$, they joyfully follow", i.e. Urnamma's instructions are likened to a fortress. Cf. perhaps Iš medagān A 241 (TCL 159 rev. ii 49) where Išmedagăn calls himself "the tallest fortress" (b a d ${ }_{3} r \mathrm{~m} \mathrm{a} \mathrm{b}$ ?).

24 i.e. Sumer.

25 i.e. Sumer or Ur.

26 i.e. the Guti.
} 
96 iv $12[\ldots]\left\ulcorner\mathrm{x}^{\urcorner}[(\mathrm{x})]\left\ulcorner\mathrm{x} \mathrm{x}^{\urcorner}[\ldots]-\left\ulcorner\mathrm{du}_{10} ?\right.\right.\right.$

97 iv $13 \quad[\ldots]\ulcorner\mathrm{x}\urcorner[\ldots]\ulcorner\mathrm{x}\urcorner$

98 iv $14 \quad[\ldots]$

99 iv $\left.15 \quad[\ldots] \Gamma^{\top}\right\urcorner[\ldots]^{27}$

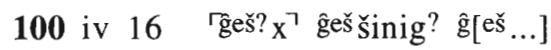

101 iv 17 iri-a ğišbun-e mu- ${ }^{\ulcorner} a^{\top}-a[n-\ldots]$

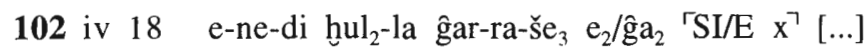

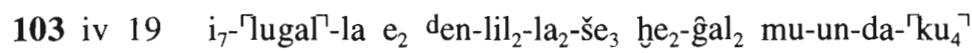

104 iv 20 kar-ĝeštin-na den-lil ${ }_{2}-\mathrm{la}_{2}$ - $\mathrm{se}_{3} \quad \mathrm{ma}_{2}$ na-an-ga-mu-ni- ${ }^{-i n ?-r i}$

105 iv 21 kar-za-gin ${ }_{3}$-na(-)dnanna-ka $\mathrm{ma}_{2}$ na-an-ga-mu-ni-in-ri

106 iv 22 den-lil 2 -ra gurun lal $_{3}$ ba-an-na-de 2

107 iv 23 sipa ur-dnamma-me-en til ${ }_{3}$ nig $\hat{g}_{2}$-ba-g $\mathrm{gu}_{10}$ he $\mathrm{e}_{2}$-a

108 iv 24 dnanna lugal-g $\mathrm{gu}_{10} \mathrm{e}_{2}$-gal-la-na mu-na-du

109 iv $25 \mathrm{e}_{2}$-kiš-nu-ĝal ${ }_{2}$ hurur-sag sa $_{7}$-ga-gin 7 ki-gal-la bi ${ }_{2}$-gub

110 iv 26 gi-gun ${ }_{4}$-na-bi $\mathrm{ku}_{3}$ - $\operatorname{sig}_{17} \mathrm{na}_{4} \mathrm{Za}$ gin $_{3}$-na dub-ba-an ba-la

111 iv 27 šu-du ${ }_{11}$-ga-e dnanna-a-me-en

112 iv 28 ses dbil $_{3}$-ga-mes gu-la-me-en

113 iv 29 [dumu-d] $\mathrm{u}_{2}$-da ${ }^{\mathrm{d} n i n-\mathrm{sumun}_{2}}$-ka-me-en numun nam-en-na-me-en

114 iv 30 [an-t]a nam-lugal ma-ra- $\mathrm{e}_{11}$ ! (SI

$$
\text { DU })^{28}
$$

115 iv 31 [sip]a ur-dnamma-me-en $\mathrm{za}_{3}-\mathrm{mi}_{2}-\mathrm{guu}_{10} \mathrm{du}_{10}$-ga-am 
96f. $[\ldots] \ldots$

$98[\ldots]$

$99[\ldots] \ldots[\ldots]$

$100 \ldots$., tamarisks, $[\ldots]$.

101 In the city he? [sat down?] with me? to a banquet.

102 To organized merry playing ... [ [...]".

103 Thanks to him abundance entered the Royal Canal and the temple of Enlil.

104 To the Wine Quay of Enlil did he navigate (his) ship,

105 (Departing) from the Shining Quay of Nanna did he navigate (his) ship.

106 He libated for Enlil liquors and syrup:

107 "I am shepherd Urnamma, let life be my gift!

108 For Nanna, my lord, I have built his palace,

109 I have erected the Ekišnugal, like a verdant mountain, on a foundation platform,

110 For its $\mathrm{g} \mathrm{i} \mathrm{g} \mathrm{u} \mathrm{n}$ a a fence was/is bound together with gold and lapis lazuli.

111 I am the creature of Nanna!

112 I am the eldest of the brothers of Gilgameš!

113 I am the na[tural son] of Ninsumun, the seed of e n-ship!

114 Fro[m heaven ] kingship has come down to me!

115 I am [sheph]erd Urnamma, my praise is sweet!" 


\subsection{Philological Commentary}

2 For the significance of the right quality of the foundation soil, cf. Jacobsen, EI 20 (1989) 88*, fn. 35 = OIP 98 (1991) 66f., fn. 74, and Ludwig, Išme-Dagan $115 \mathrm{ff}$.

4 For $\mathrm{s} \mathrm{a}_{7} \cdot \mathrm{g}$, said of heaven, cf. Sjöberg, Mondgott 120f. The translation "azure", i.e."brilliant, crispy blue" - and not just "beautiful" - is based on $\mathrm{gunu}{ }_{3}-\mathrm{gunu}_{3}$ which follows. On the sequence $\mathrm{sa}_{7} \cdot \mathrm{g}-\mathrm{gunu}{ }_{3}$, cf. Waetzoldt, Textilindustrie 52. In more general terms $\mathrm{s} \mathrm{a}_{7} \cdot \mathrm{g}$ describes an object or being in its prime, (sexually) attractive or fecund, growing state (cf. also the commentary ad Urnamma B 19).

A translation "great place" i.e. "netherworld" in opposition to $\mathrm{ab} \mathrm{zu}$ and a n is also possible for $\mathrm{k} \mathrm{i-g} \mathrm{a} \mathrm{l} \mathrm{which} \mathrm{normally} \mathrm{means} \mathrm{"postament,} \mathrm{building} \mathrm{plat-}$ form, foundation platform" (kigallu).

5 The $\mathrm{g}$ i p a r was the residential quarters of the e n-priest(ess) (e.g. Ur Lament 349; 353-354; Sulgi B 134; Sumer and Ur Lament 184 || 192 || 250) and of her/his personnel (Enmerkar and Ensuhkešdana 118). The two $\hat{g}$ i p a r south of the Ekišnuĝal in OB Ur are discussed in Charpin, Clergé 192ff.

$\mathrm{ki}-\mathrm{t} \mathrm{u} \breve{\mathrm{s}}$ a n d e n-1 i $1_{2}-1 \mathrm{a}_{2}$ "dwelling place of An and Enlil" is in apposition to e $\check{s}_{3}$ u r $i_{5}$ k i "sanctuary Ur".

6 i.e. Ur's greatest palace is the Ekišnugal (topicalised and focalised).

$7 \mathrm{~d} \mathrm{u} \mathrm{b}-1 \mathrm{a}_{2}-b i$ (as in line 8) is expected. The form might be contaminated by line $6 \mathrm{e}_{2}-\mathrm{gal}-\mathrm{m} \mathrm{a} \mathrm{h}-b a$. For a discussion of $\mathrm{dub}-1 \mathrm{a}_{2}$, cf. Cooper, Curse of Agade 248 ad 131 ("gateway"); Lambert, Or. 54 (1985) 193-96 ("stone block in which the door-pole turned at its base"); Steinkeller, ZA 75 (1985) 39, fn.1 ("platform or terrace"); Jacobsen, EI 20 (1989) 82*, 85*, and fn. $49=$ OIP 98 (1991) 64; 72, and fn. 89 ("upper platform"); George, Iraq 57 (1995) 174, and fn. 14, 180f., 183ff., esp. 185f. ("pilaster").

$9 \hat{\mathrm{g}}$ e š $\mathrm{R} \mathrm{U}$ is epigraphically uncertain (erasure [?] between $\hat{\mathrm{G}} \mathrm{E} \breve{\mathrm{S}}$ and $\mathrm{R} U$ ) and the meaning elusive. Suggestions have been made by Groneberg, $R A$ 81 (1987) 115ff. ("Bogen", in mythological texts "magischer Stab") and RA 82 (1988) 71-73 ("numinöser Zauber-Gegenstand"), Wilcke, N.A.B.U. 1991/17 ("Reflexbögen"), Alster, RA 85 (1991) 6-8 ("boomerang" [?]), and most recently Römer, AfO 40/41 (1993/94) 32-38 (perhaps "Wurfspeer"). The connection with a part of a temple, however, remains unclear and therefore the term is not translated here.

In view of line $8\left(\mathrm{a} n-\breve{s} \mathrm{a}_{3}-\mathrm{g}\right.$ a) a reading $\mathrm{a} b-\check{s} \mathrm{a}_{3}-\mathrm{g}$ a is preferable to e š ${ }_{3}-\check{s}_{a}{ }_{3}-g$ a (Castellino and Sjöberg). Here a b "sea" is maybe used as a designation of the a b z u (cf. Charpin, Clergé 371 ad 1.).

For k u m $\mathrm{x}_{\mathrm{x}}$ (P A ) - k u m ${ }_{\mathrm{x}}$ ( P A ) compare perhaps $\mathrm{k} \mathrm{u} \mathrm{n}_{2}$ nabātu, namāru ( / k u n / already in Proto-Ea 492a). 
10 The curious D I Š ! appears in Roth, Mesop. Law 43/359 v 45 (= Law Collections 51) D I $\check{S} \mathrm{~g} \mathrm{u} \mathrm{d} \mathrm{a}_{2}-\mathrm{u} \mathrm{r}_{3}-\mathrm{r}$ [ a ] (commentary p. 80). Cf. perhaps also Cavigneaux, Al-Rawi, ZA 85 (1995) 169:1 and 170:20 (commentary p. 173).

Compare $\mathrm{u} \mathrm{r}_{2}$ g u r-ra with $\mathrm{a}_{2} \mathrm{~g} \mathrm{u} \mathrm{r}-\mathrm{r}$ a "stumpy/stocky 'arms'/horns" (already v. Dijk, SGL 267 , fn. 21). The expression u ${ }_{2}$ g u r appears, however, exclusively in context of tree imagery, cf. Lullaby 4 , Sulgi P a 17, and Išmedagān A 242 (= TCL 159 rev. ii 50). The image is possibly of a single bull straining because bulls are usually yoked in pairs. The second part of the line is totally unclear.

$13 \mathrm{~K} \mathrm{I}$. L U G A L. G UB is probably the place where royal sacrificial offerings and libations are made to the gods (most recently discussed by Tinney, Nippur Lament 135 ad 24, with reference to Michalowski, Lamentation 102f. ad 435; add Šūsu'en D [= Sjöberg, AOAT 25 412] 9-10, and Uruk Lament 12.10-15). For a possible archaeological identification, cf. Jacobsen, EI 20 (1989) 84* and fn. $47=\operatorname{OIP} 98$ (1991) 70f. and fn. 87. It is undoubtedly distinct from u r u da ( / u ruda) KI. L U G L. GUB ( . B A ), a royal pedestal from where the offerings were conducted (cf. Ludwig, Išme-Dagan 201 and fn. 477 with references) or possibly a votive vessel or basin (cf. Frayne, Correlations $437 \mathrm{ff}$. and BiOr. 45 [1988] 351 who proposes a reading š it e $\mathrm{n}_{\mathrm{x}}$ as "variant" of š i t a /e š ${ }_{2}$ - d a; a proposal apparently abandoned in JAOS 112 [1992] 623).

We probably have to look for two distinctive terms with related meaning (?) behind K I. L U G A L. G U B:

1. / a 1 a $1 /$ or the like (cf. OB Diri Nippur sect. 2:11 in PSD A/1 105 s.v. a$\mathrm{lal}_{3} \mathrm{~A}$ and our line), perhaps connected with $\mathrm{a} / \mathrm{e}_{4}-1 \mathrm{a} \mathrm{l}_{3}$, a yet unidentifiable room (of a temple?) in which prayers and blessings take place, cf. PSD A/1 ibid. s.v. a-lal ${ }_{3}$ A 1. citing Gudea, Cyl. A 27:14-16, Sulgi A 77b (source H), and N $1363+$ UM 29-16-785:26 (unpub.). It may be significant that $\mathrm{KI}$. L U G A L. G U B is not attested in Gudea, so a -1 a $l_{3}$ could be a substitute for it.

2. $\mathrm{k} \mathrm{i}-1 \mathrm{u} \mathrm{g} \mathrm{a} \mathrm{l}-\mathrm{g} \mathrm{u} \mathrm{b}$ or the like (cf. Uruk Lament 12.14 which has locative - $\mathrm{g} \mathrm{u} \mathrm{b}-\mathrm{b}$ a and Sumer and Ur Lament 435 which has -g u b - b u - n a / b a).

For k i s a l ( - ) $\mathrm{m}$ a h as part of the Ekišnugal, cf. Steible, FAOS 1 (1975) 104 (probably with Frayne, BiOr. 45 [1988] 353 the courtyard of Nanna; pace Charpin, Clergé 333 [the ziggurat terrace in Ur]). Courtyards of temples were used for sacrificial offerings (Jacobsen, EI 20 [1989] 90*, fn. 47; add to his references e.g. our passage, Sulgi F 17, UET 6106 17-18, Enki and the World Order 33), athletic events (Jacobsen, ibid., $90 *$ f., fn. 48 for references) and display of royal statues and other objects (e.g. Lugale 495; Gudea, Cyl. A 23:8; Gudea, Stat. E 4:12-15; Sulgi Y 22-23; v. Dijk, JCS 19 [1965] 6:36ff.; RIME 4.1.10.11:15-19).

$14 \mathrm{E} \mathrm{N}$ here could also have a reading e $\mathrm{n}$ "e n-priest", instead of $\mathrm{u} \mathrm{r} \mathrm{u}_{16} \cdot \mathrm{n}$ "valiant" (cf. the commentary ad Urnamma B 44).

16 For the verbal form, cf. the commentary ad Urnamma B 41.

18 For the elusive prefix $\{$ i $\mathrm{r}$ i $\}$ which is regularly preceded by $\mathrm{m} \mathrm{i}_{2}$ ( $\mathrm{zi}$ ( $\left.\mathrm{de}_{3}-\mathrm{e} \check{s}_{2}\right)$ ), cf. Attinger, Eléments 296f., § 194. 
19 In view of lines $20 \mathrm{ff}$. the $3 \mathrm{rd}$ person is very strange here. One expects Urnamma's self-praise to begin after line 18. Line 19 could have been misplaced.

20-23 For these lines, cf. S. Cohen, ELA 150f. ad 9-10. I M. A in line 20 may have to be read with Cavigneaux, Al-Rawi, ZA 85 (1995) 190f., and fn. 12 i $\mathrm{m}$ - a (type a $\mathrm{n}$ - $\mathrm{k}$ i), perhaps in the meaning of "rain(storm)", in view of the next line where the imagery may be that of rain drenching the earth. Lines 20-21 find a literary analogy in Gudea, Cyl. A 11:7-8 in which the calling for rain makes abundance come forth from heaven (cf. also IV 1.2, p. 56f.). Urnamma G 8 is a parallel to the second part of line 23, though in Urnamma G Enlil is the subject.

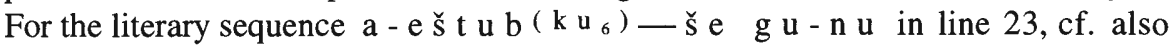
Ferrara, StPohl SM 2 (1973) 150ff. and the references in PSD A/1 66f. s.v. aeštub.

24 Note how the object is emphasized by the personal pronoun 1st person absolutive and the reduplication of the verbal basis (Edzard, ZA 61 [1971] $231 \mathrm{~d}$ ).

$\mathrm{g} \mathrm{a} \mathrm{r} \mathrm{i}$ instead of $\mathrm{g} \mathrm{a} \mathrm{b} \mathrm{a} \mathrm{ri}$ is probably due to a hearing mistake: $\mathrm{g} \mathrm{a} \mathrm{b} \mathrm{a} \mathrm{-}$ r i $(=/ \mathrm{g}$ á b r i /!) > / gá r i /. The correct form g a b a r i appears in line 77 .

25 In view of $\mathrm{du}_{10}-\mathrm{b} \mathrm{a}-\mathrm{n}$ a $\mathrm{p}$ e $\breve{s}$ in Urnamma A 152, $\mathrm{d} \mathrm{u}_{10}-\mathrm{b}$ i "tenderly" is less likely.

Perhaps [ $\mathrm{d} \mathrm{n}$ i $\mathrm{n}-\mathrm{s} \mathrm{u} \mathrm{m} \mathrm{u} \mathrm{n}_{2}-\mathrm{k}$ ] $\mathrm{e}_{4}$ ? can be restored at the beginning, cf. Sulgi P b 24 where Sulgi is raised on Ninsumun's pure lap.

27 For this topos, cf. Römer, SKIZ 218f. ad 26.

28 Compare line 34 for its near parallel in content and the verbal form $\mathrm{m} \mathrm{i}$ $\mathrm{n} \mathrm{i}-i b-\mathrm{da} \mathrm{b}_{5}$. In line $28 \mathrm{Utu}$ is therefore probably subject ( $\mathrm{b}_{2}-i n-\mathrm{s}_{3}$ ); literally: "he has made the judgments which I pronounce make Sumer and Akkad of one mind = obey".

32 The line is difficult. One expects the personal "offender" rather than the abstract "offense". For the reading š e $\mathrm{r}_{7}$ - d a šêrtu "offense", cf. Steinkeller apud Gelb in Studies Kraus (1982) 74 and Alster, ASJ 13 (1991) 87 ad 147. Civil, Studies Hallo (1993) 75-78 reads N I R - d a and translates "capital offense". Add to his references (courtesy of P. Attinger) Sulgi to Aradmu 2 (=OECT 5 [1976] 13) 5 and 8 [no. 26]); SP Coll. 3.93; BE 31 28:4 // FAOS 2180 ii 16 // ISET 222 , Ni. 4509:8' (= Two Women B = Dialogue 5). The PN š e $\mathrm{r}_{7}-\mathrm{da}-\mathrm{d} b \mathrm{a}-\mathrm{u}_{2}-$ $\mathrm{i} \mathrm{b}_{2}-\mathrm{g} \mathrm{u}\left(M V N 6320\right.$ i 10 , preceded by $\left.\mathrm{n} \mathrm{am}-\mathrm{da}_{6}-\mathrm{du}_{8}\right)$ makes Civil's explanation (p. 76 ad 2.9.) unlikely.

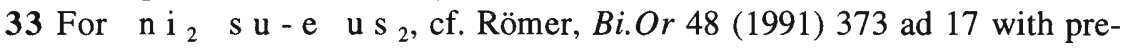
vious literature. The Akkadian gloss is unclear.

35ff. Compare Codex Urnamma 177-181 with similar vocabulary: $\mathrm{n}$ i $\hat{\mathrm{g}}_{2}$ NE.RU In i g ${ }_{2}-a_{2}-z i\left|i-d u t u \quad u g-g u \quad h e_{2}-n i-d e_{2}\right| n i \hat{g}_{2}-$ $\mathrm{si}-\mathrm{s} \mathrm{a}_{2}$ । $\mathrm{kal}$ a m-m a $\mathrm{h} u-\mathrm{m} \mathrm{u}-\mathrm{n} \mathrm{i}-\mathrm{g}$ a r "Evil, violence, and the cry of the oppressed I verily made disappear, (instead) I established justice in the land".

$36 \breve{s} \mathrm{u} ~ \breve{s} \mathrm{u}_{2}-\breve{s} \mathrm{u}_{2}$ literally "to cover with the hands", i.e. "to clasp, to clamp down, to get hold of somebody" is more likely than Heimpel's "to fling, to hurl (out of the hands)" in Tierbilder 469. 
37 For the problematical $\mathrm{g} \mathrm{u} \mathrm{r}_{5}-\mathrm{ru}-\mathrm{u} \check{\mathrm{s}} \mathrm{e}$ and possible translations, cf. Attinger, Eléments 522, fn. 1449. The construction with the comitative postposition is exceptional!

$42 \mathrm{~m} \mathrm{i}-\mathrm{n} \mathrm{i}-\mathrm{i} \mathrm{n}$ - in the prefix chain (instead of e.g. $\mathrm{m} \mathrm{u}-\mathrm{n} \mathrm{a}-\mathrm{n} \mathrm{i}-\mathrm{i} \mathrm{n}-$ ) is difficult.

44-45 These lines are problematical. An - $r$ Auslaut on $d n$ a $n$ n a seems a too early attestation and line 111 writes d $\mathrm{n}$ a $\mathrm{n} \mathrm{n} \mathrm{a}-a-\mathrm{m}$ e-e $\mathrm{n}$. Compare, however, Nanna's Journey to Nippur 349-352 where in line 350 one text source, namely $\mathrm{C}$ (and perhaps also V), writes $\mathrm{d}_{\mathrm{n}}$ a $\mathrm{n} \mathrm{n}$ a - a $\mathrm{r} \mathrm{d}_{\mathrm{s} \mathrm{u}}$ ' e $\mathrm{n}$ - e! The gloss (?) is unclear. For the curious separation of Nanna and Su'en, cf. also Cavigneaux, Al-Rawi, MHEO 2 (1994) 76 ad 8.

47 For the reduplicated form $\mathrm{d} \mathrm{u}_{2}-\mathrm{du}_{2}$, compare Gragg, TCS 3 (1969) 184 ad 78, and for $\left(\mathrm{u}_{3}-\right) \mathrm{du}_{2}$ vs $\left(\mathrm{u}_{3}-\right) \mathrm{du}_{2} . \mathrm{d}$ in general, cf. Edzard, Or. 43 (1974) 109.

A literary parallel for this line can be found in Išmedagān A 45 (read according to Tinney, Nippur Lament 37) [ $\mathrm{d}$ ] $\mathrm{n} \mathrm{i} \mathrm{n}-\mathrm{t} \mathrm{u} \quad \mathrm{du}_{2}-\mathrm{du}_{2}-\mathrm{a} \quad \mathrm{h} \mathrm{a}-\mathrm{m}$ a - n i i $\mathrm{n}$ - $\mathrm{g} \mathrm{u} \mathrm{b}$ "Nintur verily stood by for me in the process of the birth" (cf. in detail IV 2., p. 67).

50-51 Sumer and Kiengi are probably personified (- $a n-\mathrm{t} \mathrm{u} \mathrm{k} \mathrm{u}$ ) here. Difficult is - $u n-\mathrm{d}$ a - for the 1 st person dative infix (cf. also the commentary ad 54, below).

For $\mathrm{z} \mathrm{i} \mathrm{u}_{3}-\mathrm{du}_{2}$. d "to engender life", cf. Sjöberg, JCS 26 (1974) 171 and Attinger, Eléments 729, $\$ 876$.

52 The first part of the line may have to be compared with Urnamma $\mathrm{H} 9$, which, however, is paleographically very uncertain.

53 The exact meaning of the noun $\mathrm{s} \mathrm{uba/i_{2 }}$, used here with $1 \mathrm{u}$ "to be numerous, to multiply" and in line 78 with $\breve{\mathrm{s}}$ a $\mathrm{r}_{2}$ "to multiply", is not clear (the context argues for something that flourishes). Perhaps there is a connection with the $\mathrm{n} \mathrm{a}_{4} \breve{\mathrm{s}} \mathrm{u} \mathrm{b}$ a $\breve{s} u b \hat{u}$ stones which might be representations of this unknown object $\mathrm{s} \mathrm{ub}$ a / $\mathrm{i}_{2}$. $\breve{S} u b \hat{u}$ stones are symbols of sexuality and fertility and associated with u r u 4 "to plough" in Sumerian love songs (cf. e.g. Alster, Studies Hallo [1993] 18f., and fn. 36). For the adjective s u b a/ i ( 2/3) "bright" in connection with $\mathrm{k} \mathrm{u} \mathrm{r}$ "mountain" and $\mathrm{du}_{6}$ "mound", cf. Sjöberg, JCS 40 (1988) 172f., fn. 6 (compare also a - š $a_{3}$ s u b a / i in Shepherd and Farmer 7879).

54-55 These lines find a literary parallel in Išmedagān A 224-225 (cf. in detail IV 2., p. 67).

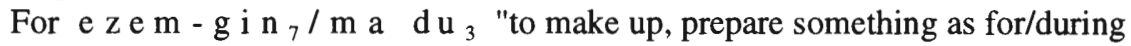
a festival", cf. Römer, Or. 62 (1993) 96 with previous literature. It is said of roads and streets: e.g. Ninurta's Journey to Eridu ii 7 (also in context of e d i n "steppe"), Ur Lament 214 and perhaps Iddindagān A 102 (k i - a - n e - d i), and of buildings, especially the Ekur: e.g. Nungal 58, Išmedagān $Q_{B}$ (= Sjöberg, ZA 63 [1973] 18) 9' \|l 13' and Išmedagān A (= TCL 159 rev. i 25 // PBS 10/2 9 rev. ii 21) 166 (cf. 
Sjöberg, Or. 35 [1966] 297 and idem, AfO 24 [1973] 42 for the reading e z e m $\mathrm{g}$ i ${ }_{7}$ ).

If the reading is correct, then e di $\mathrm{n}$ has also final - $\mathrm{m}$ (cf. e.g. e ze m but e z e $\mathrm{n}$ in pause position) although $\mathrm{OB}$ literary texts show predominantly - $\mathrm{n}$ Auslaut. Note the writing E D I N in an Ur III source of Curse of Agade 128 for $\mathrm{g}$ i ( 2 ) - $\mathrm{di} \mathrm{m}$ "spade" (Cooper, Curse of Agade 246 ad 115). Compare perhaps also the cult song of Damu (= TCL $158 / /$ ) in Römer, BiOr. 49 (1992) 649 A 142 which shows a writing i di m for B 45 \| C 24' e di n , and Römer's commentary p. 676 ad A 142. Finally, e di n - n a in Išmedagān A 225 (cf. IV 2., p. 67) supports a reading e d i $\mathrm{m}_{\mathrm{x}}$ (E D I N) "steppe" in line 54.

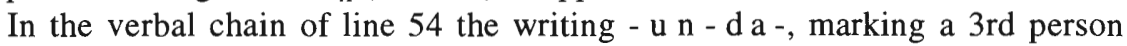
animate, is perhaps due to the identical verbal form in line 19 .

56-57 Note the pun and the play on sound in these two lines: a $\mathrm{m} \mathrm{a-n} \mathrm{i-i} \mathrm{r}$ $\mathrm{mu}-\mathrm{u} \mathrm{n}-\mathrm{ge}_{4}-\mathrm{ge}_{4}$ and $\ulcorner\mathrm{a}$ ? $\urcorner-\mathrm{ma}-\mathrm{ru}[\mathrm{g}] \mathrm{e}_{4}$ ? - b a.

57-59 These lines find a literary parallel in Išmedagān A 118-123 (cf. IV 2., p. 66f.). Furthermore, line 57 is an allusion to the ideology of the Sumerian King List (cf. IV 1.1, p. 41f.). The "storm" may refer to the Guti whom Urnamma claims to have expelled (Ni. 4375 iv 2'-6'; Urnamma C 90-91, perhaps already $85 \mathrm{ff}$. .).

62 For the elusive $\mathrm{u} \mathrm{z}_{3}$ - $\mathrm{s}$ a $\mathrm{g}$, cf. Ludwig's discussion in Išme-Dagan $117 \mathrm{ff}$. and George, OLA 40 (1992) 261f. J.S. Cooper prefers in this context the late Akkadian equation ašarē du "foremost, "outstanding".

72 For š u - a $\mathrm{g} \mathrm{e}_{4}$ (+ absolutive), literally "to give over", cf. most recently Römer, BiOr. 49 (1992) 317ff.; $\mathrm{UN}$ is tentatively read $\mathrm{k} \mathrm{a} \mathrm{la} \mathrm{m} \mathrm{in} \mathrm{view} \mathrm{of}$

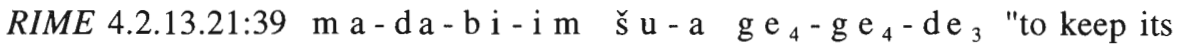
(=Ur's) territories secure". The ablative infix $-\mathrm{ra}-$ in $\mathrm{ma}-\mathrm{ra}-\mathrm{an}-\check{\mathrm{s}} \mathrm{u} \mathrm{m}{ }_{2}$ is difficult to explain. Is this a case of "Ferndeixis"?

73-75 These lines describe Urnamma's cultic function as e n-priest in the g i p a r of the Eana temple in Uruk (cf. also III 2., p. 38f.).

77 In view of the striking parallel in Curse of Agade 43-44 a b u 11 a a $\mathrm{ba}(/ \mathrm{bi})(\ldots) \mid \mathrm{ku}_{3}$ dinana-ke $\mathrm{e}_{4} \mathrm{ka}-\mathrm{bi} \quad \mathrm{ga} l_{2} \quad \mathrm{bi}_{2}-\mathrm{in}-\mathrm{taka}{ }_{4}$ "Dazzling Inana opened the passage through (= of) its (= Agade's) city-gates (...)", $\mathrm{K} A \times \mathrm{M}$ A $\check{S}$ probably denotes some sort of "opening". J.S. Cooper tentatively suggests a connection with $\mathrm{k} \mathrm{a}-\mathrm{b}$ a $\mathrm{r}$ "herdsman".

78 For $\mathrm{s} \mathrm{u} \mathrm{b} \mathrm{a} \mathrm{/} \mathrm{i}_{2}$ in this context, cf. the commentary above, ad 53.

$\mathrm{u}_{2} \quad \mathrm{n} \mathrm{a} \mathrm{g}-\mathrm{g} \mathrm{a}_{2}$ is obscure. The translation follows the late (!) Akkadian equation ri'ìtu u mašqītu in Thureau-Dangin, RAcc. 109:15f. (as object of $\breve{s}$ a $\mathrm{r}_{2}=$ dešu $\mathrm{D}$ ), which on the other hand is equated e.g. in RIME 4.3.9.2:23' with $\mathrm{u}_{2}$ $\mathrm{g} \mathrm{u}_{7} \quad \mathrm{u}_{3}$ a $\mathrm{n}$ a $\hat{\mathrm{g}}$.

$\mathrm{mu}-\mathrm{n} \mathrm{i}-\breve{\mathrm{s}}$ a $\mathrm{r}_{2}$ looks like a variant of $\mathrm{m} \mathrm{a}-\breve{s}_{\mathrm{ar}} \mathrm{r}_{2}$.

$79 \mathrm{u}_{3}-\mathrm{me}-\mathrm{ni}-\mathrm{tag}$ is semantically and grammatically difficult. For the sequence - m e - n i -, cf. Attinger, Eléments 219f. R.2.

$\mathrm{n}$ a $\mathrm{m}-\mathrm{E} \mathrm{N}-\mathrm{n}$ a which is lexically equated with bitrû "outstanding, superb" (cf. $C A D$ B 279 s.v. bitrû adj.) and šapṣu "strong, resistant" (cf. CAD ک̌/1 $481 f$. 
s.v. šapșu), qualifying domestic animals, fields and products thereof (cf. Nisaba and Enki 15), has been discussed by Civil, Studies Sjöberg (1989) 55, Alster, Dumuzi's Dream 103f. ad 97 ॥ 109, Waetzoldt, Textilindustrie 31f., and most recently by van de Mieroop, BSA 7 (1993) 168 (n a m - E N - n a-herd vs a r u - a-herd) and Stol, RlA 8 (1994) 192 (in opposition to $\mathrm{g} \mathrm{a}-\mathrm{z}$ a - P I? Compare the chart of Heimpel, $B S A 7$ [1993] 152). E N is perhaps to be read $\mathrm{u} \mathrm{r} \mathrm{u}_{16} . \mathrm{n} / \mathrm{u} \mathrm{r} \mathrm{u} \mathrm{n/}$ and the term might therefore denote an object that is rugged, resistant, and therefore of quality.

$80 \mathrm{n} \mathrm{i} \hat{\mathrm{g}}_{2}-\mathrm{k} \mathrm{u}_{5}$ A K "to make a profit, to tax" (compare CAD M/1 127 s.v. makāsu) is also attested in Gudea, Cyl. B 12:14-15 and Hendursaĝa Hymn (line references in Edzard, Wilcke, AOAT 25 [1976] 170 s.v.).

$81 \mathrm{~b} \mathrm{ad}_{3} \mathrm{~g} \mathrm{al} \mathrm{k} \mathrm{u} \mathrm{r}-\mathrm{ra}$ "big fortress of the $\mathrm{k} \mathrm{u} \mathrm{r}$ " is so far only attested in this line and Angim 33. What $\mathrm{k} \mathrm{u} \mathrm{r}$ refers to is not clear. A meaning "big fortress against the (foreign) land" does not apply to Angim 33.

The usage of $\mathrm{a}-\mathrm{ne} \quad \mathrm{hu}_{2}-1 \mathrm{a} \quad \mathrm{du}_{11} \cdot \mathrm{g}, \mathrm{e}, \mathrm{di}$ "to relax, to amuse oneself" with $\mathrm{a}_{2}-\mathrm{a} \hat{\mathrm{g}}_{2}-\mathrm{g} \mathrm{a}_{2}$ "instruction" in this line is strange. The term is normally associated with activites such as playing music, dancing, singing, swimming and sexual foreplay (cf. Attinger, Eléments 471, § 350).

82 Similarly Angim $173 \mathrm{k}$ i - $\mathrm{s}$ u r-ra i ri-g a $\mathrm{P}_{2} \mathrm{PU}_{2}$ a $\mathrm{du}_{10}-\mathrm{ga}$ $\mathrm{ki}-\mathrm{e} \mathrm{n}-\mathrm{g} \mathrm{i}-\mathrm{ra} \mathrm{h} \mathrm{e}_{2}-\mathrm{a}$ "Let the region of my city be the sweet water well of Sumer" (MB Version).

84 In light of line 89 the given translation is better than "I lifted the yoke of(f) its $\mathrm{s}$ a $\mathrm{g}-\mathrm{u} \mathrm{r}-\mathrm{s}$ a $\hat{\mathrm{g}}^{\prime \prime} . \mathrm{m} \mathrm{u}-\mathrm{zi}=/ \mathrm{m} \mathrm{u} \mathrm{n} \mathrm{z} \mathrm{i} \mathrm{/} \mathrm{(singular} \mathrm{with} \mathrm{collective} \mathrm{meaning).}$

In this line and in Gudea, Stat. B 4:6 the $\mathrm{s}$ a $\hat{\mathrm{g}}-\mathrm{u} \mathrm{r}-\mathrm{s}$ a $\mathrm{g}$ (usually as cult personnel of Inana, cf. in general Sjöberg, JCS 40 [1988] 177f. and Steible, FAOS $9 / 2$ [1991] 13) are portrayed as some sort of workers. In the Gudea passage they take over temple-building work from impure women, perhaps implying some play on the femininity of the $\mathrm{s}$ a $\hat{g}-\mathrm{ur}-\mathrm{s}$ a $\hat{\mathrm{g}}$, or the opposite. In Sulgi A 77 (there mentioned in connection with the e $\breve{s}_{3}$-e šs ${ }_{3}$-festival) and in Ewe and Grain 74 (with a play on their strength?) they are connected with the royal palace. In Šusu'en Hist. Inscr. A iii 12-13 they seem to be mentioned in a fighting context (for the hapax $\mathrm{g} \mathrm{u}_{2}(-) \check{\mathrm{S}} \mathrm{E} . \mathrm{UR}_{4} \mathrm{du}_{11}$. $\mathrm{g}$ in line 13, cf. Attinger, Eléments 526, § 454).

87 This line probably refers to the repulsion of enemy (troops; perhaps the Guti?). Compare Ean. 2, 6:8 e l a m k u r - r a - n a b i - g e ${ }_{4}$ "He (= Eanatum) has made the Elamites return to their country", and Šūsu'en 9:24-26 $\mathrm{u}_{3} \quad \mathrm{n} \mathrm{e}_{3}$ g a r ${ }_{7}-\mathrm{du}_{2}\left|\mathrm{ma}-\mathrm{da}-\mathrm{ne}_{2}-\mathrm{e}\right| \mathrm{b} \mathrm{i}_{2}-\mathrm{in}-\mathrm{g} \mathrm{e}_{4}-\mathrm{a}$ "And when he (= Šūsu'en, after building the Mardu-wall) made the military force of the Mardu return to their land" (with Steible, FAOS 9/2 [1991] 261). Perhaps Ni. 4375 iv 6' can be restored accordingly: $\mathrm{k} \mathrm{u} \mathrm{r}-\left\ulcorner\mathrm{ba}\right.$ ? $>$ i $\mathrm{m}-\mathrm{m}\left[\mathrm{i}-\mathrm{g} \mathrm{e}_{4}\right]$ "I made them (= the evil Guti) [return] to their? country".

I T I M A - ̌̌ $e \check{s} \check{s} i g$ is unknown to me.

89 Were d u m u "citizens" + $\mathrm{KI}_{\mathrm{G}_{2}}\left(\mathrm{ki} \hat{\mathrm{g}}_{2}\right.$ ?) workers liable for corvée work and in times of trouble for conscription? Another reading of $\mathrm{K} \mathrm{I} \hat{\mathrm{G}}_{2}$ could be s a g a $a_{11}$. 
For the reading $\mathrm{d} \mathrm{u}$ b s i g $\mathrm{x}$ "(work) basket", compare W.G. Lambert, CRRAI 38 (1992) 133.

$90 \mathrm{~L} \mathrm{U}_{2}$. $\breve{S} \mathrm{~A}_{3} \times \mathrm{T} \mathrm{AR}$ ?. A ( - k ) "captive" (?) is probably connected with $\mathrm{L} \mathrm{U}_{2} \cdot / \times \mathrm{GA} \mathrm{N} \mathrm{A}_{2}-\mathrm{t}$. and variants, cf. most recently Tinney, Nippur Lament 180f. ad 288 with previous literature.

For the reading $\mathrm{SES}=\mathrm{uru} / \mathrm{i}_{3}$. n or urin / u ri n / "blood(y)", cf. Cooper, Curse of Agade 251 ad 192. For "bloody hands", compare perhaps Alster, Šuruppak 85f. ad 45. I tentatively interpret $\check{s}^{\mathrm{u}} \quad \mathrm{du}_{8}$ here as non-standard writing for $\breve{~ u ~} \mathrm{~d} \mathrm{u}_{3}$ "to bind", as in Cavigneaux, Al-Rawi, ZA 85 (1995) 21:5 (compare the frequent $\breve{s} \mathrm{u}-\mathrm{d} \mathrm{u}_{3}-\mathrm{a}$ for $\breve{\mathrm{s}} \mathrm{u}-\mathrm{d} \mathrm{u}_{8}-\mathrm{a}$ "pledge"). This avoids a translation "I gripped with a bloody hand", referring to Urnamma's grip rather than that of the Guti, although such an interpretation cannot be ruled out.

92 The wall of Ur is mentioned in Urnamma 9, in Urnamma year name "11", in the fragment Ni. 4375 (ISET 1 p. 177) iv 14', and in Urnamma A 148, which, however, mentions the wall in an unfinished state. It is either the city-wall or possibly the wall surrounding the Ekišnugal temple precinct (cf. III 1., p. 36).

The second half of the line which is squeezed between 92 and 93 is paleographically and thematically difficult.

93 Read possibly $n$ i d b a $\left\ulcorner_{x}-(x-) d i b\right\urcorner-m e-\ulcorner e n\urcorner$ "I am the one who brings him (= Enlil) ... offerings" and compare Sulgi R 67 s u l-g i sipa nidba gal-gal-la-ni mu-ne-ši-ib ${ }_{2}-d i b-d i b-b e_{2}$ "Sulgi, the shepherd, brings them (= the gods) his huge meal offerings".

101-102 For $\mathrm{g}$ i š b u n "banquet" in connection with merry entertainment, cf. the references in Ludwig, Išme-Dagan $205 \mathrm{f}$.

103 Note the 3 rd person in line $103 \mathrm{ff}$. From the preceding broken passage the subject is not clear; possibly Nanna is meant, more likely though it is Urnamma himself with a request to Enlil for long life in line 107.

$\mathrm{i}_{7}-1 \mathrm{u} \mathrm{gal}(-1 \mathrm{a}(-\mathrm{k}))$ "Royal Canal" is attested as a canal name in Sollberger, TCS 1 (1966) 89, no. 365:4-6 and in Ur III administrative documents (cf. e.g. Sigrist, Syracuse 15:1f., 28:4, etc.), together with the a-š a ${ }_{3} \mathrm{i}_{7}-$ 1 u g a 1 (cf. Sigrist, ibid. 24:5, 366:2, Edzard, Farber, Rép. géogr. 2 275, and Maekawa, BSA 5 [1990] 139f.). The documents come from Umma and date from Sulgi's late to Amarsu'en's early years.

104-105 The locative in line 105 is understood in the sense of ablative "at" $\approx$ "(departing) from".

Note the repetitive usage of the conjunctions $\{(\mathrm{i}) \mathrm{n} \mathbf{g}$ a $\} \ldots\{(\mathrm{i}) \mathrm{n} \mathbf{g}$ a $\}$, with $\mathrm{m} \mathrm{a}_{2} \mathrm{u} \mathrm{s}_{2}$ "to navigate" in Sulgi X 4 (cf. also Klein's commentary, Th ̌̆H 146 ad 1-4) and 92, and in Nanna's Journey to Nippur 255 and 257. For k a r g e š t i n - n a "Wine Quay" as part of the temple complex in Nippur, cf. Behrens, StPohl SM 8 (1978) 65f. ad 5, and Klein, Th $\breve{H} H 25$ ad 375-377. For the $\mathrm{k}$ a r $\mathrm{za}-\mathrm{g} \mathrm{i} \mathrm{n}_{3}-\mathrm{na}(-) \mathrm{d} \mathrm{n}$ a n $\mathrm{a}(-\mathrm{k})$ "Shining Quay of Nanna", cf. Michalowski, Lamentation 96 ad 318. Possibly the first-fruit offerings (n e s a $\mathrm{g}$ ) were brought to this quay in $\mathrm{Ur}$ in a yearly ceremony to be shipped to Enlil's temple in Nippur. References to this ceremony are in Michalowski, Lamentation 97 ad 325 - 
326; add Gungunum A (= Sjöberg, ZA 63 [1973] 25, source A) rev. 9; Sîniddinam A (= v. Dijk, JCS 19 [1965] 21) 12ff. and Rīmsîn year name 23. Nanna's Journey to Nippur might be a literary reflexion of that same ceremony and journey, as well as our lines 103-106 (cf. Frayne, Correlations 103f. for similarities to Nanna's Journey to Nippur and Urnamma D). It is possible that the ceremony was constituted under Urnamma and then conducted on a yearly basis (cf. also III 2., p. 39f.).

106 For alcoholic beverages (often wine but also beer) and (date-)syrups as main componants of libations, cf. Heimpel, RlA 7 (1987) 1 ff. For g u r u n 6 $1 \mathrm{a} \mathrm{l}_{3}$, cf. Römer, BiOr. 45 (1988) 53 ad 39.

107 Compare thematically Nanna's Journey to Nippur 350 || 352 and Urnamma D 18-19.

108 (- ( C ) - a ) - $\mathrm{n}$ a in $\mathrm{e}_{2}-\mathrm{g}$ a $\mathrm{l}-\mathrm{a}-\mathrm{n}$ a very rarely stands for $-\mathrm{a}-\mathrm{n} \mathrm{i}$, but as absolutive is not attested before OB, cf. Attinger, Eléments 172f., § 108 a), R.

Lines 107-108 recall thematically the name of the statue Gudea fashioned for his lord, Ningirsu, in Gudea, Stat. B 7:14-17 l u g a l-g u ${ }_{10}\left|\mathrm{e}_{2}-\mathrm{a}-\mathrm{n} \mathrm{i}\right| \mathrm{m} \mathrm{u}$ $\mathrm{na}-\mathrm{du}_{3} \mid \mathrm{nam}-\mathrm{til}_{3} \mathrm{n} \mathrm{i} \hat{\mathrm{g}}_{2}-\mathrm{b} \mathrm{a}-\mathrm{g} \mathrm{u}_{10}$ "For my lord $\mathrm{I}$ have built his temple, (may) life (be) my gift!" (similarly, Gudea, Stat. E 9:1-3). Cf. also IV 3.2, p. 81.

110 For ( $\mathrm{g} \mathrm{i}$ - ) d u b - b a - a n, a type of (reed) fence, cf. the discussion in Michalowski, Lamentation 97 ad 329; add Sladek, Inanna's Descent 216f. ad 293294, Alster, ASJ 15 (1993) 6, fn. 13, and Civil, Farmer's Instructions = AulOr. Suppl. 5 (1994) 103, fn. 62. In the term $\mathrm{g} i$ is treated as a determinative (e.g. Enki's Journey to Nippur 41) and a lexeme (e.g. Inana's Descent 294). Here and in Enki's Journey to Nippur $41 \mathrm{~d} u$ b - b a - a n seems to be some kind of barrier or surrounding wall (also Charpin, Clergé 291 ad 14).

111 For forms in - (C ) a - e, cf. Attinger, Eléments 144f., $\$ 862^{\circ}$.

$\mathrm{d} \mathrm{n}$ a $\mathrm{n} \mathrm{a}-a$ argues for / $\mathrm{n}$ a $\mathrm{n} \mathrm{a} \mathrm{H} /$ (cf. the commentary ad 44-45!).

114 In context of line 57 this is a very likely allusion to the Sumerian King List (contra Wilcke, Studies Sjöberg [1989] 566, fn. 41), cf. also IV 1.1, p. 41 f. 


\section{U R N A M M A}

\subsection{Introduction}

\section{Previous study}

W.W. Hallo presented a first edition of Urnamma D, a hymn addressed to the king with a $\mathrm{z} \mathrm{a}_{3}-\mathrm{m} \mathrm{i}_{2}$ doxology, in JCS 20 (1966) 133-41, utilising sources A (Nippur recension), and $\mathrm{B}$ and $\mathrm{C}$ (Ur recension), sources diverging from each other considerably, but also showing striking similarities. The purpose of his study was to show in general that "the fixation of many Neo-Sumerian texts was a continuous process" and that literary texts can contain historical material which can be correlated with other text material such as year names and inscriptions. This has been done in more detail by D.R. Frayne in his dissertation The Historical Correlations of the Sumerian Royal Hymns, which incorporates the unpublished sources $\mathrm{D}$ and $\mathrm{E}$ in the discussion. ${ }^{2} \mathrm{~S}$. Tinney is planning a complete edition of all the hitherto known text duplicates in the near future and therefore this presentation on the basis of sources A, B, and C is incomplete and kept as brief as possible.

\section{Structural Analysis}

Several indications, expounded in the previous chapter, ${ }^{3}$ strengthen the hypothesis that both the Nippur and Ur recensions of Urnamma D might be adapted type A $\mathrm{b}$ a $1 \mathrm{~b}$ a $1 \mathrm{e}$ compositions rather than original type B. I royal hymns addressed to the king. ${ }^{4}$ One indication is that both recensions show a rigorous poetic structure consisting of line pairs linked by repetitive parallelism, common in b a l b a le compositions.

\section{The Nippur Recension (source A)}

Source A begins with a repetitive sequence of a question ("Who will dig (the canal/ k e š k u g-canal/canal + epithet) there?") which finds its answer in the introduction

1 Cf. also II 2., p. 20.

2 Frayne, Correlations 116-21. Cf. also III 1., pp. $28 \mathrm{ff}$.

3 IV 3.1 , pp. $74 \mathrm{ff}$.

4 For the typology, cf. II 1., pp. $13 \mathrm{ff}$. 
of Urnamma in lines 5-6. This "prologue" is followed by a self-laudatory passage (7-36) in which Urnamma describes his selection by Enlil and election to kingship at Nippur and Ur (7-17). He is favoured by Nanna, Enlil, and Enki who presents him with broad wisdom (18-21). Then follows a relatively well structured passage which takes up again the theme of the $\mathrm{k}$ e š $\mathrm{k} \mathrm{u}$ g-canal dug at Ur: it produces an abundance of fish, birds and reed fodder for cows (22-36). The end of the composition (37-41) is marked by a shift of person, mentioning Urnamma again and closing with the $\mathrm{z} \mathrm{a}_{3}-\mathrm{m} \mathrm{i}_{2}$ doxology "Urnamma, king of Ur, your praise is sweet!". Note in summary the following sequences:

I. Introduction (1-6) 3rd person

1. Theme of canal construction (1-4)

2. Introduction of Urnamma (5-6)

II. Main section (7-36) 1st person

1. Kingship (7-21)

a. Lord AŠimbabbar's throne (7-8)

b. Divine selection and election to kingship in Nippur and Ur (9-17)

c. Divine favours (18-21)

2. Canal construction at Ur results in abundance (22-36)

a. The $\mathrm{k}$ e š k u g-canal (22-24)

b. It produces fish and birds (25-26), s u h u r-fish which feed on honeyplants (27-28), reed fodder for cows (29-30), and special types of fish (?) (3134 ), it is filled with Enki, the lord of Eridu's joyful cries (35-36)

III. Closing section (37-40) 2nd person

1. Urnamma, king of the four corners, and Enlil (37)

2. Urnamma, provider for Nippur and Ur (38-40)

IV. $\mathrm{z} \mathrm{a}_{3}-\mathrm{m} \mathrm{i}_{2}$ doxology (41)

\section{The Ur Recension (sources B and C)}

The general outline given above for the Nippur recension (source A) is valid for this version as well. Note in summary the following sequences and their divergence in relationship to source $\mathrm{A}$ :

I. Introduction $\left(1^{\prime}-9^{\prime}\right) \quad 3 r d$ person

1. Theme of canal construction $\left(1^{\prime}-5^{\prime}\right)$

2. Introduction of Urnamma (6') and his son and successor Sulgi (7'-8') 
II. Main section (10'-37') 1st person

1. Kingship (10'-29'?)

a. Divine selection and election to kingship in Nippur and Ur $\left(10^{1}-\text { ? }\right)^{5}$

2. Canal construction results in abundance $\left(30^{\prime}-37^{\prime}\right)$

a. The k e š k u g-and p a b i l u h-canals (30'-31')

b. They produce fish and birds (32'-35') for the Ekišnugal, liquorice and honey-plants on their banks (36'), and mottled barley on their arable tracts (37')

III. Closing section (38'-40') 2nd (/3rd?) person

1. Urnamma, king of the four corners, and Enlil (38')

2. Urnamma, provider for Sumer and Akkad (39'-40')

IV. $\mathrm{za}_{3}-\mathrm{m} \mathrm{i}_{2}$ doxology (41')

\section{Manuscripts}

Source A, an unpublished Yale piece (YBC 4617) of unknown provenance, but "strictly Nippurian orthography"6 is presented only in transliteration in W.W. Hallo's study. A copy of the tablet has been promised to be included in a projected volume of Sumerian royal hymns from the Yale Collection. ${ }^{7}$ Sources D and E are unpublished fragmentary pieces from Nippur which contain lines similar to those of source $A$ and which will be discussed in detail by S. Tinney in his forthcoming edition. Source D (= CBS $8037+$ N 1703 iii 25'-iv 6') is a four-column tablet which contains besides Urnamma D love songs that centre on Dumuzi and Inana. ${ }^{8}$

Sources B and C, of which photos were kindly made available by C.B.F. Walker, represent the Ur recension of our composition. The upper part of the obverse of source B is missing and the last couple of lines are unfortunately erased. The obverse of source $\mathrm{C}$, with both ends broken off, has such a badly scratched surface that the few odd preserved signs could not be read from the photo. Source C looks like a mere duplicate of B, whereas both sources' relationship to the Nippur source A is more complex. The first ten lines or so of the Nippur recension (i.e. the digging of the $\mathrm{k} \mathrm{e} \mathrm{š} \mathrm{k} \mathrm{u} \mathrm{g-canal} \mathrm{and} \mathrm{the} \mathrm{selection} \mathrm{to} \mathrm{kingship} \mathrm{by} \mathrm{Enlil)} \mathrm{seem} \mathrm{to}$ have counterparts in the Ur sources, as does the topos of abundant fish and birds of Ur's $\mathrm{k}$ e š k u g-canal, as well as the final lines (Ni 37-41= Ur 38'-41'). But other lines are omitted, e.g. Nippur recension 7-8 with reference to Nanna/AŠimbabbar, and 35-36 with reference to Enki and Eridu. ${ }^{9}$

\footnotetext{
5 This passage is too fragmentary for interpretation.

6 Hallo, JCS 20 (1966) 133, fn. 3.

7 Hallo, ibid.

8 Cf. IV 3.1, p. $74 \mathrm{f}$.

$9 \mathrm{Cf}$. also the divergent sequences in "Structural Analysis", above, p. 229f., and below, 4.4, pp. $244 \mathrm{ff}$.
} 
The recension from Nippur seems to stress Urnamma's legitimation and function especially as king of Ur (line $38 \mathrm{~d} u \mathrm{r}-\mathrm{d} \mathrm{n}$ a m m a $\mathrm{u}_{2}-\mathrm{a} \quad \mathrm{n} \mathrm{i} \mathrm{b} \mathrm{r} \mathrm{uk} \mathrm{i}$ $\mathrm{s} \mathrm{a} \mathrm{g} \mathrm{-} \mathrm{u} \mathrm{S}_{2} \quad \mathrm{u} \mathrm{r} \mathrm{i}_{2} \mathrm{k} \mathrm{i}-\mathrm{m} \mathrm{a}$ "Urnamma, the provider for Nippur, the supporter of Ur", and line $41 \mathrm{dur}-\mathrm{d} \mathrm{n}$ a $\mathrm{m} \mathrm{m}$ a $1 \mathrm{ugal}$ ur i ${ }_{2} \mathrm{ki}-\mathrm{m}$ a $\mathrm{za}_{3}-\mathrm{m} \mathrm{i}_{2}-\mathrm{zu}$ $\mathrm{d} \mathrm{u}_{10}-\mathrm{g} \mathrm{a}-\mathrm{a} \mathrm{m}_{3}$ "Urnamma, king of Ur, your praise is sweet"). In contrast, the recension from Ur lacks the titulary "king of Ur" and does not connect Urnamma's kingship in any way with Nanna. Only the Nippur recension mentions Nanna/AŠimbabbar, the god of Ur, whom we would expect being named in the Ur recension.

A passage in the Nippur recension which the Ur recension lacks, is found more or less verbatim in a composition specifically concerned with Nanna and Ur, namely the elliptical (?) phrase connecting Su'en and Enlil in lines 7-8 which is modeled on Nanna's Journey to Nippur 349-352. ${ }^{10}$ Also, not all lines in a section of the Nippur recension (25-30) describing Ur's fertility, which matches a passage in a b a 1 b a 1 e of Nanna in M.G. Hall, Moon-God (= TMH NF 47 iv 190-195 /1) 779f., ${ }^{11}$ are found in the Ur recension. The theme of cows in lines 29-30 of the Nippur recension, which the Ur recension lacks, is a citation of the lines in the above mentioned $\mathrm{b}$ a $1 \mathrm{~b}$ a $l \mathrm{e}$ of Nanna. Their mention is due to the fact that the beginning of that $\mathrm{b}$ a $1 \mathrm{~b}$ a l e focuses exclusively on the cattle pen and its productivity. This is not the case with the Ur recension which wholly concentrates on the produce of the canals and their surroundings, i.e. fish and birds, honey-plants and liquorice growing on their river banks, and barley on the arable tracks situated beyond the river banks.

It is unclear which of the recensions is the "original". The Nippur source A deifies Urnamma and might suggest a later manuscript tradition, or else deification of the royal name in this and the other Urnamma hymns ${ }^{12}$ could simply be a matter of scribal preference. Source B from Ur in a reinterpretation of the Nippur version adds the deified Sulgi next to Urnamma digging the canal. W.W. Hallo's dating of the Ur recension - on the comparative basis of the different titles worn by Urnamma in the two recensions - something like a century later than the one from Nippur, has been rightly questioned by $\mathrm{C}$. Wilcke. ${ }^{13}$

The many non-standard writings of the Ur sources are noteworthy. These nonstandard writings include those which are semantically conditioned and those which are reinterpretations based on phonetic similarity. The texts also exhibit many Sandhi-writings and spellings which can be explained as dictation errors. ${ }^{14}$

Note finally that the incipit is mentioned in the Nippur Catalogue STVC 41 rev.? i' 3: a-b a-a m u-u n-b a-a [1-e] (cf. W.W. Hallo, StOr. $46=$ Studies A. Salonen [1975] 79) and in a text from Uruk, published by A.

\footnotetext{
10 For a discussion of these lines, cf. the commentary ad 7.8 with previous literature, p. $254 \mathrm{f}$.

11 For more details, cf. IV 3.1 , p. $75 f$.

12 Cf. the Lexical Index, s.v. ur- ${ }^{-}$namma and ${ }^{d}{ }_{u r-}{ }^{d}$ namma, p. $358 f$.

13 Wilcke, CRRAI 19 (1974) 187, fn. 12.

14 For details, cf. II 3.2 , pp. 24ff. For philological matters, cf. below, 4.5, pp. $254 \mathrm{ff}$.
} 
Cavigneaux, AUWE 23 (1996) 45, no. 83 rev. 4': [ . - - b] a - a l - e a - b a - a $\mathrm{mu}-\mathrm{u} \mathrm{n}-\mathrm{b}$ a - a 1 ! - e.

\section{Sources}

Nippur:

$\mathrm{A}^{15} \quad \mathrm{YBC} 4617$

1-41

transliteration: W.W. Hallo, JCS 20 (1966) 139f.; transliteration below is W.W. Hallo's.

D CBS $8037+$ N 1703 iii 25'-iv 6' (unpub.)

This Sammeltafel also contains Dumuzi-Inana $C$, a b a l b a le of Inana (cf. B. Alster, RA 79 [1985] 146, no. 5.), and Dumuzi-Inana N (courtesy of S. Tinney).

[for a photo of this Sammeltafel, cf. now Y. Sefati, Love Songs in Sumerian Literature, Critical Edition of the Dumuzi-Inanna Songs, Ramat Gan (1998) pls. XVIII-XIX]

E UM 29-16-93 (unpub.)

Publication of D and E by S. Tinney in a forthcoming edition of the hymn.

Ur:

B U $16895+$ UET $6 * 147$ (unpub.)

obv. $1^{\prime}-24^{\prime}=\mathbf{1}^{\prime}-\mathbf{2 4} 4^{\prime}=\mathbf{3}-\mathbf{2 1 b ^ { 1 6 }}$

rev. $1-17=25^{\prime}-41^{\prime}=21 \mathrm{c}-41$

copy of U 16895: C.J. Gadd, UET 676.

photos made available by C.B.F. Walker, cf. pls. 21-22; read from photos.

C U 16860

$$
\text { rev. } 1^{\prime}-13^{\prime}=\mathbf{2 9}-\mathbf{4 1} 1^{\prime}=\mathbf{2 1 g}-\mathbf{4 1}
$$

copy: C.J. Gadd, UET 677 ; rev. only.

photos of obv. and rev. made available by C.B.F. Walker, cf. pls. 23-24; rev. read from photo. 



\subsection{Transliteration and Translation of the Nippur Recension (source A only)}

The corresponding lines of the Ur recension are given in parenthesis. To facilitate comparison of the two versions a synopsis is given below, 4.4. "A Synopsis of Urnamma D: Nippur and Ur Recensions".

1 [a-ba-a mu-un-b]a-al-e a- ${ }^{\top}$ ba-a mu'-[un-ba-al-e / $\left.i_{7}\right]$ a-ba-a mu-u[n-ba-al-e]

$2 \quad\left[i_{7}-\mathrm{KES}_{2}-\mathrm{ku} \mathrm{u}_{3}\right]$ a-ba-a mu-un-ba-[al-e]

$\left.3 \quad / \Gamma_{7}\right\urcorner$ a-ba-a mu-un-ba-al-e (Ur 1')

$4 \quad\left[\mathrm{i}_{7} \mathrm{pa}_{5}\right.$-bi] luh a-ba-a mu-un-ba-al-e $/ \mathrm{i}_{7}{ }^{\top}$ a-ba-a mu-un-ba-al-e (Ur 2'-3')

5 dur-dnamma $\mathrm{ku}_{3}$ tuku mu-un-ba-al-e (Ur 6')

6 sul zi ${ }^{\ulcorner}$nig $\hat{g}_{2}$ tuku' mu-un-ba-al- ${ }^{\top} \mathrm{e}^{\top}$ (Ur 8')

7 lugal-ĝu $\mathrm{u}_{10}$ para ${ }_{10}$-za den-lil $\mathrm{I}_{2}-\mathrm{le}$ en dA $\mathrm{S}_{\text {- }} \mathrm{im}_{2}$-babbar

8 sul dsu'en para ${ }_{10}$-za den-lil 2 -le en dAŠ-im 2 -babbar

9 lugal ša $\mathrm{s}_{3}$ zi-ta nam tar-ra nam-nir-ra saĝ $\mathrm{il}_{2}$ (Ur 10')

10 dur-dnamma sul igi $\mathrm{il}_{2}$-la kur-[gal] den-lil ${ }_{2}$-le (Ur 11')

11 dnu-nam-nir-re ki-en-gi 'ki-uri-a' $\mathrm{ge}_{26}$-e mu-un-suh-en (Ur 12')

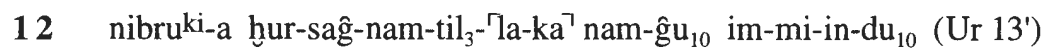

13 saĝ-ki zalag-ga-ni mu-un-ši-in-bar ${ }^{\ulcorner}$nam? ${ }^{\urcorner}$-lugal ${ }^{~} \mathrm{ba}^{\urcorner 17}$-an- ${ }^{\ulcorner} \mathrm{sum}_{2}{ }^{\urcorner}$

14 uri ${ }^{\text {ki-ma }} \mathrm{e}_{2}$-mud-kur-ra-ka (Ur 14')

15 ĝe[šgu-z]a-ĝa $a_{2}$ suhuš-[bi im-mi-in-g]e-en (Ur 15') 
1 [Who will] dig there, ${ }^{18}$ who will [dig there], who will [dig the canal there]?

2 Who will dig [the k e š k u g-canal] there?

3 Who will dig the canal there?

4 Who will dig [the canal] there [whose ditches] are clean? Who will dig the canal there?

5 Urnamma, the wealthy one, will dig it there!

6 The faithful youth, the rich one, will dig it there!

7 "My lord, for your throne, Enlil's, o lord AŠimbabbar,

8 Youthful Su'en, for your throne, Enlil's, o lord AŠimbabbar,

9 It is me, the king, destined from the true womb on, lifting the head confidently,

$10 \mathrm{Me}$, Urnamma, the selected youth, [Great] Mountain Enlil,

11 Nunamnir has chosen in Sumer and Akkad.

12 For Nippur, in the Hursagnnamtila, he has made my destiny pleasing,

13. Smiled radiantly upon $\mathrm{me}^{19}$ and gave me! kingship.

14 For Ur, in the Emudkura,

15 He has made the foundation of my [thro]ne firm. 
16 gidri $\mathrm{ku}_{3} \quad$ ug $\hat{g}_{3} \mathrm{~s} a\left[\mathrm{r}_{2} \ldots\right] \quad\left(\mathrm{Ur} 17^{\prime}\right)$

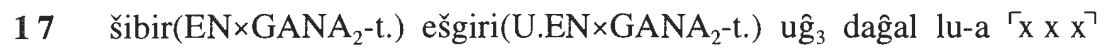
$\mathrm{h}\left[\mathrm{e}_{2}-\ldots\right]\left(\mathrm{Ur} 18^{\prime}\right)$

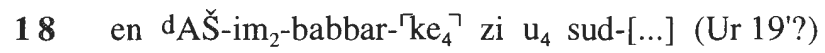

19 den-lil ${ }_{2}$-le BI DA I ba- ${ }^{\mathrm{e}}$ ? ("T[E]")-[x] ${ }^{20}$ (Ur 20'?)

20 mu da-ri $i_{2}$ mu ka-ge $d\left[u_{7} \ldots\right]$

21 den-ki- $\left.\mathrm{ke}_{4}\right\urcorner$ geštu ${ }_{2}$ daĝ[al...s]aĝ-e-eš m[u-rig $\left.{ }_{7}\right]$

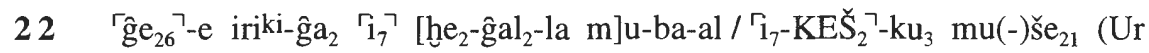
$\left.30^{\prime}\right)$

23 [ur] $\left.\mathrm{i}_{2} \mathrm{ki}-\mathrm{ma} \quad \Gamma_{1_{7}} \mathrm{hge}_{2}-\mathrm{gal}_{2}\right\urcorner$-la mu-ba-al $\left./ \Gamma_{\mathrm{i}_{7}}-\mathrm{KESS}_{2}\right\urcorner-\mathrm{ku}_{3} \operatorname{mu}(-) \mathrm{še}_{21}$

24 mu da-ri ${ }_{2}$ ka-ge ba-ab-du $-\mathrm{am}_{3} \mathrm{i}_{7} \mathrm{pa}_{5}$-bi luh muše ${ }^{21}$ (Ur 31')

25 ge $_{26}$-e iri-gaa a DU-a-bi ku kum $_{6}$ diri-bi mušen-am ${ }_{3}$ (Ur 32')

26 uri ${ }_{2}$ ki-ma a DU-a-bi ku $_{6}$-am am $_{3}$ diri-bi mušen-am ${ }_{3}$ (Ur 33'-34')

$27 \quad \mathrm{ge}_{26}-\mathrm{e} \quad \mathrm{i}_{7}-\mathrm{ga}_{2} \quad \mathrm{u}_{2}-\mathrm{lal}_{3}$-e mu-un-du suhurku$_{6}-\mathrm{e} \quad \mathrm{am}_{3}$-si-e

28 uri ${ }_{2}{ }^{k i}-m a \quad u_{2}-l a l_{3}$-e mu-un-du suhurku $_{6}-\mathrm{e}\left[\mathrm{am}_{3}\right]$-si-e (Ur 36'?)

$29 \mathrm{ge}_{26}$-e iri-ga $a_{2}$ gi-zi-bi $\operatorname{lal}_{3}-\mathrm{am}_{3}[?] / \mathrm{ab}_{2}-\mathrm{e}$ ha-ma-gu $\mathrm{u}_{7}$-e

30 uri ${ }_{2} \mathrm{ki}_{-}$ma gi-zi-bi $\mathrm{lal}_{3}-\mathrm{a}\left[\mathrm{m}_{3}\right.$ ?] / $\mathrm{ab}_{2}$-e ha-ma-gu $\mathrm{u}_{7}$-e

$31 \mathrm{ge}_{26}-\mathrm{e}[\ldots] \mathrm{xku}_{6} / \mathrm{ku}_{6}$ hu-[...]

$32 \operatorname{uri}_{2} \mathrm{k}\left[\mathrm{i}_{-}-\mathrm{ma} . ..\right]$

$33 \mathrm{ge}_{26}-\mathrm{e} \mathrm{i}_{7}-\mathrm{ga}_{2}$ a [DU-a-bi hu-mu]-un-[tum $\left.{ }_{3}\right] /$ ĝeš dubsig $_{\mathrm{x}}-\mathrm{e}$ hu-mu-un-na-la ${ }_{2}$-e 
16 [Made me take possession of (?)] the dazzling sceptre [for guiding (?)] the innumerable people,

17 The staff and nose-leash for [...] the many widespread people [...].

18 Lord AŠimbabbar [gave me (?)] life [for] all time.

19 Enlil ... [...],

20 A lasting name, a name worthy to be prais[ed ...].

21 Enki presen[ted] me with [bro]ad wisdom [...].

22 As for me, in my city, I have dug a canal [of abundance], naming it the $\mathrm{k}$ e š k u g-canal,

23 At U[r] I have dug a canal of abundance, naming it the $\mathrm{k}$ e š k u g-canal,

24 The lasting name is made worthy to be praised, the canal whose ditches are clean has birds.

25 (Due to) me, what water it $^{22}$ carries in my city are fish, what it makes glide are birds.

26 What water it carries in Ur are fish, what it makes glide are birds,

27 (Due to) me, honey-plants were planted at my canal, the s u h u r-fish fill up on them,

28 In Ur honey-plants were planted, the s u h $\mathrm{u}$ r-fish fill up on them.

29 (Due to) me, in my city its reed fodder is (honey-)sweet, may the cows eat it for $\mathrm{me}^{23}$

30 In Ur its reed fodder is (honey-)sweet, may the cows eat it for me.

31 (Due to) me, [in my ...] may the fish [...],

32 [In] Ur [...].

33 (Due to) me, [may] the water [carried] by my canal [bring them ${ }^{24}$, may baskets place them at his ${ }^{25}$ disposal, ${ }^{26}$

22 i.e. the canal.

23 Or in this and the succeeding line: "(..) the cows indeed eat it for me".

24 i.e. fish.

25 i.e. Nanna.

26 Or in this and the succeeding line: "(..) the water [carried] by my canal indeed [brings] them, baskets place them indeed at his disposal". 
34 uri ${ }_{2}$ ki-ma $\mathrm{i}_{7}-\mathrm{ga}_{2}$ a DU-a<-bi> hu-mu-un-tum ${ }_{3} /$ geš $_{\text {dubsig }}$-e hu-mu-un-na$1 a_{2}-\mathrm{e}$

35 lugal-bi lugal eriduki-ga PA-a-zu $\mathrm{SU}_{3}-\mathrm{am}_{3}$

36 dnu-dim-mud lugal eriduki-ga PA-a-zu $\mathrm{SU}_{3}-\mathrm{am}_{3}$

37 lugal an ub-da limmu -ba ša $_{3}$ den- lil $_{2}-\mathrm{la}_{2} \mathrm{du}_{10^{-}}$-ge-en (Ur 38')

38 dur-dnamma u $u_{2}$-a nibruki saĝ-us ${ }_{2}$ uri ${ }_{2}^{k i-m a ~(U r ~ 39 ') ~}$

39 iti $_{6}-\mathrm{SLE}_{3} \quad \mathrm{ug}_{3} \quad \mathrm{uri}_{2} \mathrm{ki}_{-\mathrm{ma}} \breve{\mathrm{Se}}_{3}\left(\mathrm{Ur} 40^{\prime}\right)$

40 sila ${ }_{x}\left(\right.$ UBARA)-a $u_{4}$ mi-ni-ib-zal-zal-le-de ${ }_{3}$ (Ur 40')

41 dur-dnamma lugal uri ${ }_{2} \mathbf{k i}_{-}$ma $\mathrm{za}_{3}-\mathrm{mi}_{2}-\mathrm{zu} \mathrm{du}_{10}$-ga-am ${ }_{3}\left(\mathrm{Ur} 41^{\prime}\right)$

\subsection{Transliteration and Translation of the Ur Recension ${ }^{27}$}

[Two or four lines missing]

1' B obv. 1' $\left[\mathrm{i}_{7}\right.$ a-ba] mu-un-ba-[al-e]

2' B obv. 2' [i 7 -pa $a_{4}$-bi]-luh-ha(-)a-ba $\left.{ }^{\prime} \mathrm{mu}\right\urcorner-u[n-b a-a l-e]$

3' B obv. 3' $\left[i_{7}\right.$ a-b]a mu-un-ba-al- $\mathrm{Ce}^{\urcorner}$

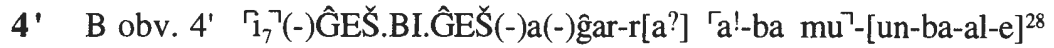

$5^{\prime} \quad$ B obv. $5^{\prime}$ i

6' B obv. 6' ur-dnamma $\mathrm{ku}_{3}$ tuku mu-un-ba'-[al-e] (Ni 5)

7' $\quad$ B obv. 7' $\mathbf{i}_{7}$ a-ba mu-un-ba-a[1-e]

8' B obv. 8' dsul-gi nig $\hat{g}_{2}$ tuku mu-un-ba-al- $\mathrm{C}^{\mathrm{\urcorner}}$ (Ni 6)

9' B obv. 9' i $_{7}$ a-ba mu-un-ba-al-e

\footnotetext{
27 The semantically conditioned non-standard writings and reinterpretations based on phonetic affinity are translated literally, even though they change the intended sense of the composition.

28 Hardly space available for such a restoration which is, however, expected.
} 
34 In Ur, may the water carried by my canal bring them, may baskets place them at his disposal.

$35 \mathrm{O}$ its ${ }^{29}$ lord, lord of Eridu, it is full of your PA-a-cry!

36 O Nudimmud, lord of Eridu, it is full of your PA-a-cry!"

37 King of the four corners, you make Enlil happy,

38 Urnamma, the provider for Nippur, the supporter of Ur,

39f. As the moonlight, for the people of Ur, you make them pass the time in joy.

41 Urnamma, king of Ur, your praise is sweet!

1' [Who] will dig [the canal] there?

2. Who will [dig] the [ $\mathrm{p}$ a b i $] 1 \mathrm{u}$ h-canal there?

3. Who will dig [the canal] there?

4' Who will [dig] the canal which has irrigated . . . there?

5. Who will dig the canal there?

6' Urnamma, the wealthy one, will dig it there!

7. Who will dig the canal there?

8. Sulgi, the rich one, will dig it there!

9' Who will dig the canal there?

29 i.e. the canal. 
10' B obv. 10' lugal ša ${ }_{3}$ zi-da nam tar-ra nam-nir-ra sag $\mathrm{il}_{2}$ (Ni 9)

11' $\mathrm{B}$ obv. 11' ur-dnamma sul igi $\mathrm{il}_{2}$-la kur-gal UD den-lil $1_{2}-\mathrm{la}_{2}-\mathrm{ke}_{4}(\mathrm{Ni} 10)$

12' B obv. 12' dnu-nam-nir ki-en-gi uri-e me-am ${ }_{3}(-)$ mu-un-suh ${ }_{10}$-e (Ni 11)

13' B obv. 13' nibruki-e hur-saĝ-nam-til ${ }_{3}$-la-ka nam-mi(-)im-MI (Ni 12)

14' B obv. 14' urikiki-e $e_{2}$-mud-kur-ra-kam (Ni 14)

15' B obv. 15' ĝě̌ gu-za-a-ni suhuš-bi im-mi-in-ge (Ni 15)

16. B obv. 16' aga me-lim ${ }_{x}$ me-teš ${ }_{2}$ nam-lugal-la saĝ-ĝa $a_{2}$ im-mi-gall

17' B obv. 17' geš ĝidri ku $_{3}$ ug $\hat{\mathrm{g}}_{3}$ šar $_{2}$ si si-e-DI šu-ĝa ${ }_{2}$ im-mi-in-sa ${ }_{2}$ (Ni 16)

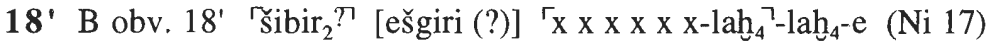

1.9' B obv. 19' $[\ldots]$

$20^{\prime}$ B obv. 20' [...]-NE

21' B obv. 21' $[\ldots]$

22' B obv. 22' $[\ldots]$

23' B obv. 23' [...]

24' B obv. 24' [...]

25' B rev. 1 [x x (x)] ' $\mathrm{x}^{\urcorner}-\mathrm{gal}_{2}$ sag GI gal $_{2}{ }^{-} \mathrm{r}^{\urcorner 30}$

26' B rev. 2 [x x x g] $]^{\prime}{ }^{\prime}{ }^{\text {ru }}$ ki-tuš ša $_{3}$ hull $_{2}{ }^{-} 7 a^{731}$

27' B rev. 3 [x x x (x)] ${ }^{\prime}{ }^{\urcorner}-$da ur $_{2}$-bi im-mi-in-ge

28' B rev. 4 [x x x (x-)n]a-kam ${ }^{32}$ gu $_{2}$-da(-)am bi-šsu

29' B rev. 5 [x x x (x) k]u ${ }_{3}-\mathrm{si}_{2}(\mathrm{ZI}) \mathrm{ku}_{3}$-babbar-ra gub-ba-am ${ }_{3} /$ im-mi-ir-mi-re C rev. 1' [...] $\left.{ }^{\prime} \mathrm{x}\right\urcorner \quad[\ldots]$

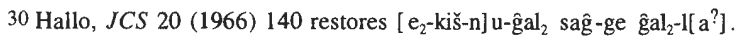

31 Hallo, ibid. restores [ $\mathrm{e}_{2}$-temen- $\mathrm{ni}_{2}$-g] $\mathrm{gru}_{3}{ }^{\mathrm{ru}}$.

32 A reading [ ...] $\mathrm{x}^{\mathrm{T}} \mathrm{-}-\mathrm{ki}-\mathrm{kam}$ cannot be excluded. 
10' "It is me, the king, destined from the true womb on, lifting the head confidently,

11 Me, Urnamma, the selected youth, shining Great Mountain Enlil,

12' Nunamnir has chosen for Sumer and Akkad.

13' For Nippur, in the Hursagnamtila, he has made my destiny pleasing,

14. For Ur, in the Emudkura,

15' He has made the foundation of! his ${ }^{33}$ throne firm.

16 He has placed the radiant crown, the adornment of kingship, on my head.

17 Made me take possession of the dazzling sceptre for guiding the innumerable people,

18 The staff? [and nose-leash (?)] for leading ....

19'-24' [six lines not preserved]

25' $[\ldots] \ldots$ the head ....

26 $[\ldots] \ldots$ the dwelling of the joyful heart.

27 $[\ldots]$ makes the foundation of $[. .$.$] firm.$

$\mathbf{2 8}^{\prime} \ldots$ of the $[\ldots]$.

$2^{\prime}[\ldots] \ldots$ which stands in gold and silver. 
30' B rev. 6 [x x x (x)] $\mathrm{u}_{4}$ he $_{2}$-gala ${ }_{2}$-la bala ub-ba /(?) $\mathrm{i}_{7}-\mathrm{KES}_{2}-\mathrm{ku}_{3} \mathrm{mu}(-)$ še

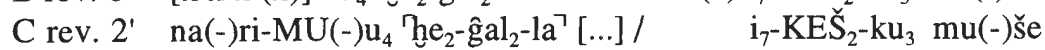
$[(\mathrm{x})](\mathrm{Ni} 22)$

31' B rev. 7 [mu d]a-ri ka-ke du-a-ba $\mathrm{i}_{7^{-}} \mathrm{pa}_{4^{-}}$bi-luh / mu(-)še (Ni 24) C rev. 3' ${ }^{\prime} \mathrm{mu}^{\prime}$ da-ri ka-ke du-a-ba $\mathrm{i}_{7}-\mathrm{pa}_{4} / \mathrm{p}\left[\mathrm{a}_{5}\right.$-bi-luh... ]

32' B rev. 8 ' ĝa $\left._{2}\right\urcorner$ iriki-ĝa ${ }_{2}$ a DU-bi ku ku $_{6}$-ab / te-li-bi mu-še-na (Ni 25)

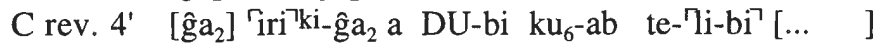

33' B rev. 9 i ${ }_{7}-\mathrm{KES}_{2}-\mathrm{ku}_{3}$ iriki-bi $\mathrm{ku}_{6}$-ab / te-li-bi mu-še-na

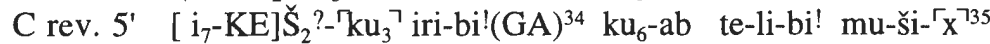

34' B rev. 10 i $\mathrm{i}_{7}-\mathrm{pa}_{4}$-bi-luh a DU-bi $\mathrm{ku}_{6}$-ab/ te-li-bi mu-še-na

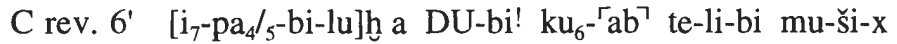

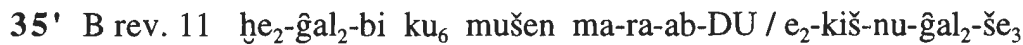
$\mathrm{C}$ rev. $7 \quad\left[\ldots \quad \mathrm{k}^{\prime} \mathrm{u}_{6}\right.$ mušen ma-ra-ab-DU $\mathrm{e}_{2}$-kiš-nu-gal ${ }_{2}$-šse

36' B rev. $12 \mathrm{gu}_{2}-\mathrm{gu}_{2}$-bi $\quad \mathrm{u}_{2}$ munzer!(UD.dNANNA) $\mathrm{lu}_{2}$-a $\mathrm{u}_{2}-\mathrm{lal}_{3}-\mathrm{e}(-) / \mathrm{gu}_{7}-\mathrm{e}$

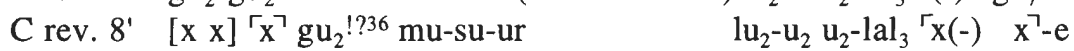

37' B rev. 13 a-gar ${ }_{3}$ gal-bi še gu-nu $\mathrm{mu}_{2}-\mathrm{mu}_{2}$ 'geštir-gin ${ }^{\prime}$ ? / 「su-su? [x (x)]

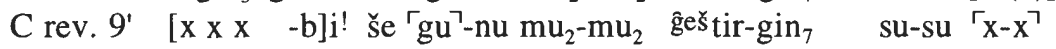

38' B rev. 14 lugal an-n[e $e_{2}$ ub-da $\operatorname{limmu}_{2}$-b]i še-ga de[n-lil $\left.1_{2}-\mathrm{la}_{2}\right]$ (Ni 37) $\mathrm{C}$ rev. 10' lugal an-ne ${ }_{2}$ u]b-da limmu ${ }_{2}$-bi! še-ga den-lil ${ }_{2}-\mathrm{la}_{2}$

39' B rev. 15 'ur-d'[namma... k]i-'`en'-gi u[ri-e x x x] (Ni 38) C rev. 11' [ur] ${ }^{\Gamma \mathrm{d} !}$ namma! $\mathrm{u}_{2}$-a ki- en-gi ki-uri-e ki-a $\hat{g}_{2}$ den-lil ${ }_{2}-\mathrm{la}_{2}$

40' C rev. 12' [it] $\mathrm{i}_{6}{ }^{137}$ ĜAR uri ${ }_{5}{ }^{\mathrm{ki}-m a(-) x(-)}$ sila-am ${ }_{3} \mathrm{u}_{4}$ mi-ni-in- ${ }^{\circ} \mathrm{x}$ ? / za-e ${ }^{! 38}$-enza-e-le za-e-me-en (Ni 39-40)

B rev. 16 [...] $\left\ulcorner^{x}\right\urcorner[\ldots]$

41' C rev. 13' ur-dnamma lugal mu da-a-ri $\mathrm{za}_{3}-\mathrm{mi}_{2}-\mathrm{zu} \mathrm{du}_{10}-\mathrm{ga}^{39}$ (Ni 41) B rev. 17 [...]

\footnotetext{
$34 \mathrm{C}$ does not distinguish $\mathrm{BI}$ from GA in this and subsequent lines.

35 The last sign in rev. 6 is UD on the copy.

36 The copied sign $\mathrm{gu}_{2}$ is not clear on the photo (-bi! expected!).

37 The restoration [UD.SE]S!(GA?).KI!(NA) at the beginning of the line is very uncertain.

38 Attached to the vertical of -e is a horizontal, perhaps mistakenly written in view of za-e-me-en at the end of the same line.

39 Followed by double ruling
} 
30' ... days of abundance..., naming it the $\mathrm{k}$ e š k u g-canal.

31' After the lasting name has been made worthy to be praised, naming it the p a b i l u h-canal,

32. (Due to) me, what water $\mathrm{it}^{40}$ carries in my city are fish, what it makes glide are birds.

33' The k e š k u g-canal: its city has fish, what it makes glide are birds,

34' The p a b i 1 u h-canal: what water it carries are fish, what it makes glide are birds.

35. Their ${ }^{41}$ abundance has brought fish and birds for me to the Ekišnugal.

36' On their banks where liquorice is plentiful, they ${ }^{42}$ eat of honey-plants.

37' On their large arable tract(s) mottled barley that sprouts grows tall like riverine thickets."

38' King of the four corners, the favourite of Enlil,

39. Urnamma, the provider for Sumer and Akkad, the beloved of Enlil,

$4^{\prime}$ [... the moon]light $!, \ldots$ of Ur, you make them pass the time in joy, you are the one!

41' Urnamma, king with a lasting name, your praise is sweet!

\footnotetext{
40 i.e. the canal.

41 i.e. the $k$ e š k u g-and the p a b i $1 \mathrm{u}$ h-canal.

42 i.e. the fish.
} 


\subsection{A Synopsis of Urnamma D: Nippur and Ur Recensions}

The line numbering follows the Nippur recension (source A only). The lines in the Ur recension that are lacking in the Nippur recension are given lower case letters (a, $b$, etc.). Note that they have been fitted in with the Nippur recension line sequence arbitrarily (cf. especially lines $18 \mathrm{ff}$. and $28 \mathrm{ff}$.).

[a-ba-a mu-un-b]a-al-e a-'ba-a mu'-[un-ba-al-e / $\mathrm{i}_{7}$ ] a-ba-a muu[n-ba-al-e]

2

$\left[\mathrm{i}_{7}-\mathrm{KES}_{2}-\mathrm{Ku}_{3}\right]$ a-ba-a mu-un-ba-[al-e]

3

$\left./ \mathrm{r}_{7}\right\urcorner$ a-ba-a mu-un-ba-al-e

B obv. 1' $\left[\mathrm{i}_{7}\right.$ a-ba] mu-un-ba-[al-e]

4

$\left[i_{7} \mathrm{pa}_{5}\right.$-bi] luh a-ba-a mu-un-ba-al-e

$$
/\left\ulcorner_{i_{7}}\right\urcorner \text { a-ba-a mu-un-ba-al-e }
$$

B obv. 2' [i ${ }_{1}-$ pa $_{4}$-bi]-luh-ha(-) a-ba $\quad \mathrm{mu}^{\top}-\mathrm{u}[\mathrm{n}$-ba-al-e]

B obv. 3' [i ${ }_{7}$ a-b]a mu-un-ba-al- $\mathrm{r}^{\top}$

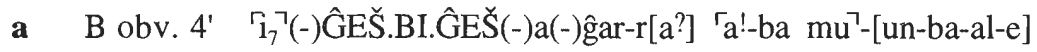

b B obv. 5' i $_{7}$ a-ba mu- ${ }^{\ulcorner} u n-b a^{\urcorner}-a[1-e]$

5 dur-dnamma $\mathrm{ku}_{3}$ tuku mu-un-ba-al-e

B obv. 6' ur-dnamma ku $\mathrm{ku}_{3}$ tuku mu-un-'ba'-[al-e]

a $\quad$ B obv. 7 $\quad \mathbf{i}_{7}$ a-ba mu-un-ba-a[l-e]

6 sul zi $\left\ulcorner^{\prime} \hat{g}_{2}\right.$ tuku ${ }^{\urcorner}$mu-un-ba-al- $-\Gamma^{\urcorner}$

B obv. 8' dsul-gi niğ tuku mu-un-ba-al- $\mathrm{e}^{\mathrm{e}}$

a B obv. 9' $\mathrm{i}_{7}$ a-ba mu-un-ba-al-e

7 lugal-ĝu $\mathrm{u}_{10}$ para ${ }_{10}$-za den-lil $1_{2}$-le en dAŠ-im ${ }_{2}$-babbar sul dsu'en para ${ }_{10}$-za den-lil ${ }_{2}$-le en ${ }^{\mathrm{d}} \mathrm{AS}$ - -im $_{2}$-babbar 
1 [Who will] dig there, ${ }^{43}$ who will [dig there], who will [dig the canal there]?

2 Who will dig [the k e š k u g-canal] there?

3 Who will dig the canal there?

[Who] will dig [the canal] there?

4 Who will dig [the canal] there [whose ditches] are clean? Who will dig the canal there?

Who will [dig] the [ $\mathrm{pab}$ i $] \mathrm{l}$ u h-canal there? Who will dig [the canal] there?

a Who will [dig] the canal which has irrigated . . there?

b Who will dig the canal there?

5 Urnamma, the wealthy one, will dig it there!

Urnamma, the wealthy one, will dig it there!

a Who will dig the canal there?

6 The faithful youth, the rich one, will dig it there!

Sulgi, the rich one, will dig it there!

a Who will dig the canal there?

7 "My lord, for your throne, Enlil's, o lord AŠimbabbar,

8 Youthful Su'en, for your throne, Enlil's, o lord AŠimbabbar, 
B obv. 10' lugal ša $\mathrm{s}_{3}$ zi-da nam tar-ra nam-nir-ra sag $\mathrm{il}_{2}$

10 dur-dnamma sul igi il $1_{2}$-la kur-[gal] den-lil $1_{2}-l e$

B obv. 11' ur-dnamma sul igi $\mathrm{il}_{2}$-la kur-gal UD den-lil $\mathrm{l}_{2}-\mathrm{la}_{2}-\mathrm{ke}_{4}$

11 dnu-nam-nir-re ki-en-gi ' $\mathrm{ki-uri-a} \mathrm{ge}_{26}$-e mu-un-suh-en

B obv. 12' dnu-nam-nir ki-en-gi uri-e me-am ${ }_{3}(-)$ mu-un-suh ${ }_{10}$-e

12 nibruki-a hur-saĝ-nam-til $\left.{ }_{3}-{ }^{\top} l a-k a\right\urcorner$ nam- $\mathrm{gu}_{10}$ im-mi-in-du ${ }_{10}$ B obv. 13' nibruki-e hur-saĝ-nam-til ${ }_{3}$ - la-ka nam-mi(-) im- MI

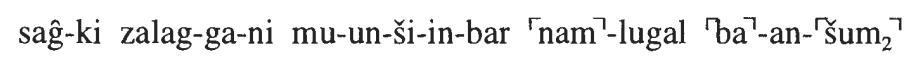

14 uri $_{2}$ ki-ma $_{2}$-mud-kur-ra-ka

B obv. 14' uri ${ }_{5}$ ki-e $^{2} \quad e_{2}$-mud-kur-ra-kam

15 ge [šgu-z]a-ĝa ${ }_{2}$ suhuš-[bi im-mi-in-g]e-en B obv. 15' geš gu-za-a-ni suhušs-bi im-mi-in-ge

a B obv. 16' aga me-lim $x_{x}$ me-teš $\check{2}_{2}$ nam-lugal-la saĝ-ĝa ${ }_{2}$ im-mi-galal ${ }_{2}$

16 gidri $\quad \mathrm{ku}_{3} \quad u \hat{g}_{3} \quad \check{\mathrm{sa}}\left[\mathrm{r}_{2} \ldots\right.$

B obv. 17' geš ğidri ku $\mathrm{ku}_{3}$ ug $\hat{g}_{3}$ šar $_{2}$ si si-e-DI šu-ğa $\mathrm{g}_{2}$ im-mi-in-sa

17 šibir $\left(E N \times G A N A_{2}-\right.$ t. $)$ ešgiri(U.EN $\times G A N A_{2}-t$. $)$ ug $\hat{g}_{3}$ daĝal lu-a $\Gamma_{x}$ $\mathrm{x} \mathrm{x}^{\urcorner} \mathrm{h}\left[\mathrm{e}_{2}-\ldots\right]$

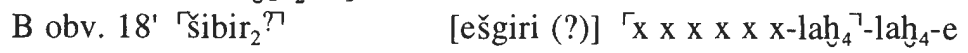

18 en dAŠ-im ${ }_{2}$-babbar- ${ }^{-} \mathrm{ke}_{4}{ }^{\urcorner}$zi $\mathrm{u}_{4}$ sud-[...]

B obv. 19' [...]

19 den-lil ${ }_{2}$-le BI DA I ba-'e?'("T[E]")-[x]

B obv. 20' [...]-NE

20 B obv. 21' [...] mu da-ri ${ }_{2}$ mu ka-ge $d\left[u_{7} \ldots\right]$

21 den-ki--ke ${ }_{4}^{\urcorner}$geštu ${ }_{2}$ daĝ[al...s]aĝ-e-eš m[u-rig $]$

B obv. 22' [...] 
9 It is me, the king, destined from the true womb on, lifting the head confidently, "It is me, the king, destined from the true womb on, lifting the head confidently,

10 Me, Urnamma, the selected youth, [Great] Mountain Enlil,

Me, Urnamma, the selected youth, shining Great Mountain Enlil,

11 Nunamnir has chosen in Sumer and Akkad.

Nunamnir has chosen for Sumer and Akkad.

12 For Nippur, in the Hursagnamtila, he has made my destiny pleasing, For Nippur, in the Hursagnnamtila, he has made my destiny pleasing,

13 Smiled radiantly upon me and gave me! kingship.

14 For Ur, in the Emudkura, For Ur, in the Emudkura,

15 He has made the foundation of my [thro]ne firm.

He has made the foundation of! his ${ }^{44}$ throne firm.

a He has placed the radiant crown, the adornment of kingship, on my head.

16 [Made me take possession of (?)] the dazzling sceptre [for guiding (?)] the innumerable people,

Made me take possession of the dazzling sceptre for guiding the innumerable people,

17 The staff and nose-leash for [...] the many widespread people [...].

The staff? [and nose-leash (?)] for leading ....

18 Lord AŠimbabbar [gave me(?)] life [for] all time.

19 Enlil ... . [...],

20 A lasting name, a name worthy to be prais[ed ...].

21 Enki presen[ted] me with [bro]ad wisdom [...].

44 Probably error for "the foundation of my throne" (cf. Nippur). 
$\begin{array}{lll}\text { a } & \text { B obv. } 23^{\prime} & {[\ldots]} \\ \text { b } & \text { B obv. } 24^{\prime}[\ldots]\end{array}$

c B rev. $1 \quad[\mathrm{x} x(\mathrm{x})][\mathrm{x}\urcorner-\mathrm{gal}_{2}$ sag GI gall $\left.{ }_{2}-\mathrm{r}^{\mathrm{x}}\right\urcorner$

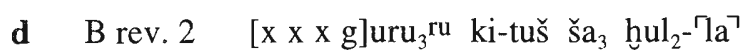

e B rev. 3 [x x x (x)] ${ }^{\ulcorner} \mathrm{x}^{\urcorner}$-da $\mathrm{ur}_{2}$-bi im-mi-in-ge

f $\quad \mathrm{B}$ rev. $4 \quad[\mathrm{x} \times \mathrm{x}(\mathrm{x}-) \mathrm{n}] \mathrm{a}-\mathrm{kam}^{45} \mathrm{gu}_{2}$-da(-)am bi-šu

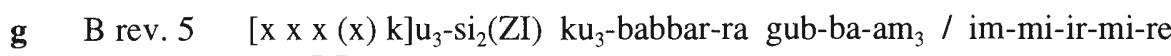
C rev. 1' $\left.[\ldots]{ }^{\prime} \mathrm{x}\right\urcorner[\ldots]$

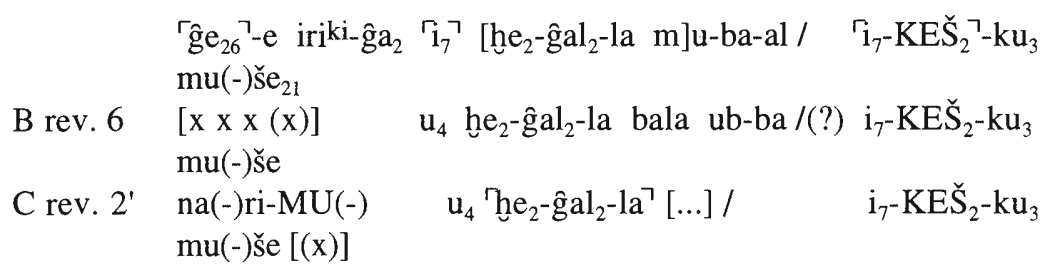

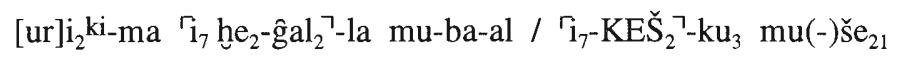

24

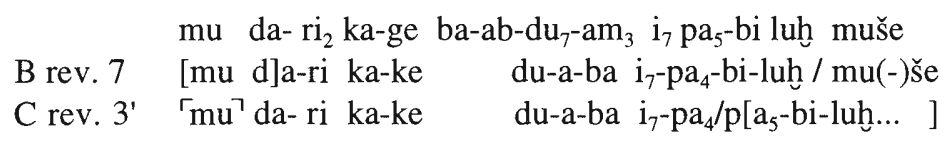
$\mathrm{ge}_{26}$-e iri- $\mathrm{ga}_{2}$ a DU-a-bi ku $\mathrm{k}_{6}-\mathrm{am}_{3}$ diri-bi mušen-am

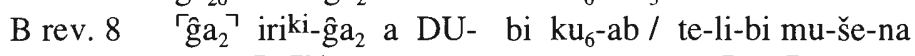

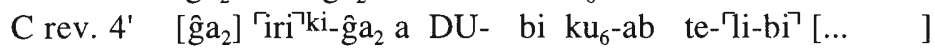

26

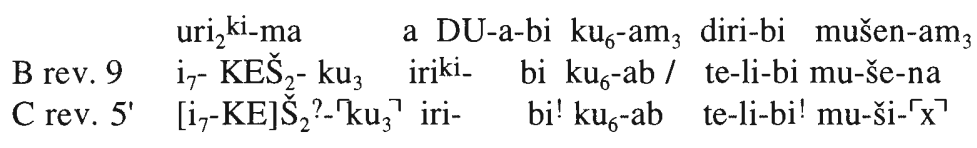

a B rev. $10 \quad \mathrm{i}_{7}-\mathrm{pa}_{4}$-bi-luh a DU-bi ku $\mathrm{ku}_{6}$-ab / te-li-bi mu-še-na C rev. 6' $\left[\mathrm{i}_{7}-\mathrm{pa}_{4} /{ }^{-}\right.$-bi-lu] h a DU-bi! $\mathrm{ku}_{6}-{ }^{\top} \mathrm{ab} \mathrm{b}^{\urcorner}$te-li-bi mu-ši-x

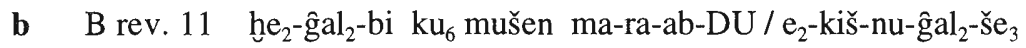
$\mathrm{C}$ rev. $7^{\prime} \quad[\ldots \quad \mathrm{k}] \mathrm{u}_{6}$ mušen ma-ra-ab-DU $\mathrm{e}_{2}$-kiš-nu-gal ${ }_{2}-\mathrm{še}_{3}$ 
a-b [not preserved]

c $\quad[\ldots] \ldots$ the head ...

d $[\ldots]$ the dwelling of the joyful heart.

e $\quad[\ldots]$ makes the foundation of $[. .$.$] firm.$

f $\ldots$ of the $[\ldots]$.

g $\quad[\ldots] \ldots$ which stands in gold and silver.

22 As for me, in my city, I have dug a canal [of abundance], naming it the $\mathrm{k}$ e š k u g-canal,

... days of abundance..., naming it the $\mathrm{k}$ e $\breve{\mathrm{k}} \mathrm{u}$ g-canal.

23 At U[r] I have dug a canal of abundance, naming it the $\mathrm{k}$ e š k u g-canal,

24 The lasting name is made worthy to be praised, the canal whose ditches are clean has birds.

After the lasting name has been made worthy to be praised, naming it the p a b i 1 u h-canal,

25 (Due to) me, what water $\mathrm{it}^{46}$ carries in my city are fish, what it makes glide are birds.

(Due to) me, what water it carries in my city are fish, what it makes glide are birds.

26 What water it carries in Ur are fish, what it makes glide are birds,

The $\mathrm{k}$ e š k u g-canal: its city has fish, what it makes glide are birds,

a The p a b i $1 \mathrm{u}$ h-canal: what water it carries are fish, what it makes glide are birds.

b Their ${ }^{47}$ abundance has brought fish and birds for me to the Ekišnugal. 
27

28

a B rev. $12 \quad \mathrm{gu}_{2}-\mathrm{gu}_{2}$-bi $\mathrm{u}_{2}$ munzer!(UD.dNANNA) $\mathrm{lu}_{2}-\mathrm{a}_{2} \mathrm{u}_{2}-\mathrm{lal}_{3}-\mathrm{e}(-) / \mathrm{gu}_{7}-\mathrm{e}$

$\mathrm{C}$ rev. 8' $\left.^{\prime} \quad[\mathrm{x} \mathrm{x}]{ }^{\ulcorner} \mathrm{X}\right\urcorner \mathrm{gu}_{2}$ !? mu-su-ur

29

30

31

32

33

34

$\mathrm{ge}_{26}$-e $\mathrm{i}_{7}-\mathrm{ga}_{2} \mathrm{u}_{2}-\mathrm{lal}_{3}$-e mu-un-du suhurku $_{6}$-e $\mathrm{am}_{3}$-si-e uri $_{2} \mathbf{k i}_{-}-\mathrm{ma} \mathrm{u}_{2}$-lal ${ }_{3}$-e mu-un-du suhurku $_{6}$-e $\left[\mathrm{am}_{3}\right]$-si-e

$\mathrm{ge}_{26}$-e iri-ĝa $a_{2}$ gi-zi-bi $\operatorname{lal}_{3}-\mathrm{am}_{3}[?] / \mathrm{ab}_{2}$-e ha-ma-gu $-\mathrm{e}$

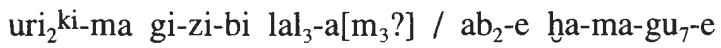

$\mathrm{ge}_{26}-\mathrm{e}[\ldots] \mathrm{xku}_{6} / \mathrm{ku}_{6}$ h hu-[..]

$\operatorname{uri}_{2} \mathrm{k}[\mathrm{i}$-ma...] mu-un-na-la $\mathrm{a}_{2}$-e

uri ${ }_{2}$ ki-ma $i_{7}-$ ga $_{2}$ a DU-a<-bi> hu-mu-un-tum ${ }_{3} /$ geš dubsig $_{x}-\mathrm{e}$ $\mathrm{ge}_{26}-\mathrm{e} \mathrm{i}_{7}-\mathrm{ga}_{2}$ a [DU-a-bi hu-mu]-un-[tum $\left.{ }_{3}\right] /$ gheš dubsig $_{\mathrm{x}}-\mathrm{e}$ huhu-mu-un-na-la $\mathrm{a}_{2}$-e

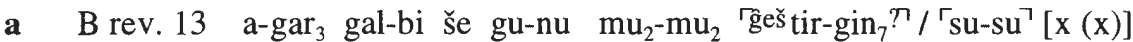

C rev. 9' $\left[\begin{array}{llll}\mathrm{x} & \mathrm{x} & \mathrm{x} & -\mathrm{b}\end{array}\right] \mathrm{i} ! \mathrm{še}^{\ulcorner} \mathrm{gu}^{\mathrm{g}}-\mathrm{nu} \mathrm{mu}_{2}-\mathrm{mu}_{2}$ ĝeštir- gin ${ }_{7} \quad$ su-su $\left.{ }^{\circ} \mathrm{x}-\mathrm{x}\right\urcorner$

35 lugal-bi lugal eriduki-ga PA-a-zu $\mathrm{SU}_{3}-\mathrm{am}_{3}$

36

dnu-dim-mud lugal eriduki-ga PA-a-zu $\mathrm{SU}_{3}-\mathrm{am}_{3}$

37 lugal an ub-da limmu $u_{2}$-ba ša $\mathrm{s}_{3} \quad \mathrm{den}_{\mathrm{e}}-\mathrm{lil}_{2}-\mathrm{la}_{2} \quad \mathrm{du}_{10}$-ge-en

B rev. 14 lugal an-n[e $e_{2}$ ub-da $\operatorname{limmu}_{2}$-b]i še-ga de[n-lil $\left.{ }_{2}-l_{2}\right]$

C rev. 10' [lugal an-ne ${ }_{2}$ u]b-da limmu ${ }_{2}$-bi! še-ga den-lil ${ }_{2}-\mathrm{la}_{2}$

38 dur-dnamma $\mathrm{u}_{2}$-a nibruki saĝ-us ${ }_{2} \quad$ uri $_{2} \mathrm{ki}_{-\mathrm{ma}}$

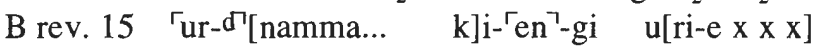

C rev. 11' [ur] $]^{\ulcorner d ! n a m m a ! ~} \mathrm{u}_{2}$-a ki- en-gi ki-uri-e ki-ag $\hat{2}_{2}$ den-lil ${ }_{2}-\mathrm{la}_{2}$ 
27 (Due to) me, honey-plants were planted at my canal, the s u h u r-fish fill up on them,

28 In Ur honey-plants were planted, the s u h u r-fish fill up on them.

a On their banks where liquorice is plentiful, they ${ }^{48}$ eat of honey-plants.

29 (Due to) me, in my city its reed fodder is (honey-)sweet, may the cows eat it for $\mathrm{me},{ }^{49}$

30 In Ur its reed fodder is (honey-)sweet, may the cows eat it for me.

31 (Due to) me, [in my ...] may the fish [...],

32 [In] Ur [...].

33 (Due to) me, [may] the water [carried] by my canal [bring them ${ }^{50}$ ], may baskets place them at his ${ }^{51}$ disposal, ${ }^{52}$

34 In Ur, may the water carried by my canal bring them, may baskets place them at his disposal.

a On their large arable tract(s) mottled barley that sprouts grows tall like riverine thickets."

$35 \mathrm{O}$ its ${ }^{53}$ lord, lord of Eridu, it is full of your PA-a-cry!

36 O Nudimmud, lord of Eridu, it is full of your PA-a-cry!"

37 King of the four corners, you make Enlil happy, King of the four corners, the favourite of Enlil,

38 Urnamma, the provider for Nippur, the supporter of Ur,

Urnamma, the provider for Sumer and Akkad, the beloved of Enlil,

\footnotetext{
48 i.e. the fish.

49 Or in this and the succeeding line: "(...) the cows indeed eat it for me".

50 i.e. the fish.

51 i.e. Nanna.

52 Or in this and the succeeding line: "(..) the water carried by my canal indeed [brings] them, baskets place them indeed at his disposal".

53 i.e. the canal.
} 
39
$\mathrm{iti}_{6}-\breve{S}_{3} \mathrm{ug}_{3} \quad \mathrm{uri}_{2} \mathrm{ki}_{-}-\mathrm{ma}-\check{\mathrm{S}}_{3}$
C rev. 12' [it] $\mathrm{i}_{6} ! \quad$ GAR uri ${ }_{5}^{\mathrm{ki}-\mathrm{ma}(-) \mathrm{x}(-)}$
B rev. $16 \quad[\ldots]{ }^{\top}{ }^{\top}[\ldots]$

40

$$
\text { sila }_{\mathrm{x}}\left(\text { UBARA)-a } \quad \mathrm{u}_{4} \text { mi-ni-ib- zal-zal-le-de }{ }_{3}\right.
$$

C rev. 12' sila-

$\mathrm{am}_{3} \quad \mathrm{u}_{4}$ mi-ni-in- $\ulcorner$ ? $/ \mathrm{za}$-e!-en-za-e-le za-e-me-en

41 dur-dnamma lugal uri $\mathrm{ki}_{-}$ma $\mathrm{za}_{3}-\mathrm{mi}_{2}-\mathrm{zu} \mathrm{du}_{10}-\mathrm{ga}-\mathrm{am}_{3}$

C rev. 13' ur-dnamma lugal mu da-a-ri $\mathrm{za}_{3}-\mathrm{mi}_{2}-\mathrm{zu} \mathrm{du}_{10}-\mathrm{ga}^{54}$ $\mathrm{B}$ rev. $17 \quad[\ldots]$ 
39 As the moonlight, for the people of Ur, [... the moon]light $!, \ldots$ of Ur,

40 You make them pass the time in joy.

You make them pass the time in joy, you are the one!

41 Urnamma, king of Ur, your praise is sweet!

Urnamma, king with a lasting name, your praise is sweet! 


\subsection{Collective Philological Commentary}

As in the Synopsis (4.4), line numbers refer to the Nippur recension, lower case letters to the Ur recension.

2 The $\mathrm{i}_{7}-\mathrm{KE} \mathrm{S}_{2}-\mathrm{k} \mathrm{u}_{3}$. g-canal is to my knowledge only attested in this hymn. Perhaps there is a connection with $\mathrm{g}$ e $\breve{s}-\mathrm{k}$ e š ${ }_{2}-\mathrm{da}$ "dam".

$4 \mathrm{i}_{7} \mathrm{p} \mathrm{a}_{5}-\mathrm{b} \mathrm{i} 1 \mathrm{u} \mathrm{h}$ "canal whose ditches are clean" is taken as an epithet of the $\mathrm{i}_{7}-\mathrm{KES} \check{S}_{2}-\mathrm{ku}_{3} \cdot \mathrm{g}$ because, contrary to the $\mathrm{i}_{7}-\mathrm{KE} \check{S}_{2}-\mathrm{k} \mathrm{u}{ }_{3} \cdot \mathrm{g}$ (line 23), it is not "named" $\mathrm{mu} \check{\mathrm{s}}_{\mathrm{e}} \mathrm{i}_{1}$ in line 24 (cf. also Civil, Farmer's Instructions 179). In Ur recension 2', however, it seems to be treated as a canal name, as the $\mathrm{mu}(-)$ š e of line 31' (= Ni 24) is more likely a non-standard writing of $\mathrm{m} \mathrm{u} \breve{s} \mathrm{e}_{21}$ "to name" rather than $\mathrm{m} \mathrm{u}$ š e n "bird" without the copula. The only other attestation of $\mathrm{i}_{7}(-) \mathrm{p} \mathrm{a}_{4} /{ }_{5}-\mathrm{b} \mathrm{i}-1 \mathrm{u} \mathrm{h}$ is Sjöberg, Mondgott 46:6'. Compare perhaps also $\mathrm{p} \mathrm{a}_{5}-\mathrm{a}(/ \mathrm{N} \mathrm{I})(-) 1 \mathrm{u} \mathrm{h}-\mathrm{h}$ a in Urenlila to Ensi and Sanga (= Ali, Letters 105) 3. For $1 \mathrm{u} \mathrm{h}$, cf. $M S L 1127$ sect. 4 A ii 7 (/3')ff. ( $\mathrm{i}_{7}-\mathrm{p} \mathrm{a}_{5}-1 \mathrm{u} \mathrm{h}-\mathrm{h} \mathrm{a}$ in sect. $7 \mathrm{~A}$ iii 16$)$. The writing $-1 \mathrm{u} \mathrm{h}-\mathrm{h}$ a in Ur recension $2^{\prime}$ is most probably Sandhi-writing (compare source B line 31' [ $=\mathrm{Ni} 24$ ] $\left.\mathrm{i}_{7}-\mathrm{p} \mathrm{a}_{4}-\mathrm{b} \mathrm{i}-1 \mathrm{u} \mathrm{h}\right)$.

a In Ur recension $4^{\prime} i_{7} \hat{G}$ E Š . B I. Ĝ E Š a g a r-r a "canal which has irrigated . . .", not mentioned in the Nippur recension, could in turn be an epithet of the $\mathrm{i}_{7}-\mathrm{KE} \mathrm{S}_{2}-\mathrm{k} \mathrm{u}_{3} \cdot \mathrm{g}$, which is only mentioned later on in line $\mathbf{3 0}$, or else it is an otherwise unattested canal name.

5-6 = Ur recension 6' and 8'. The two terms $\mathrm{k} \mathrm{u}_{3} \mathrm{t} \mathrm{u} \mathrm{k} \mathrm{u} \mathrm{"wealthy"} \mathrm{and}$ $\mathrm{n} \mathrm{i} \hat{\mathrm{g}}_{2} \mathrm{t} \mathrm{u} \mathrm{k} \mathrm{u}$ "rich" in the following line appear in context also in Dumuzi-Inana O 27ff. and in Enlil and Namzitara 19ff. (cf. also Arnaud, Emar 6/4 [1987] 368:12'ff., no. 771) where they are part of a topos-like sequence which includes $\mathrm{ku}_{3} \quad \mathrm{tuku} \quad \mathrm{za} \quad \mathrm{tuku} \quad \mathrm{gud} \quad \mathrm{tuku} \quad \mathrm{udu} \quad \mathrm{tuku}$ and $\mathrm{s} \mathrm{e} \quad \mathrm{tuku}$ (cf. also in Ewe and Grain 189-190). Being rich and exercising kingship are coupled in Nisaba Hymn (= Reisman, AOAT 25 360) $431 \mathrm{u}_{2} \quad \mathrm{ni} \hat{g}_{2} \quad \mathrm{t} \mathrm{u} \mathrm{k} \mathrm{u} \quad \mathrm{n} \mathrm{a} \mathrm{m} \mathrm{-}$

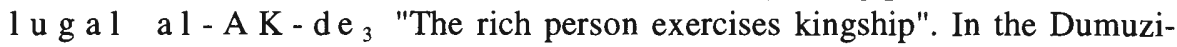
Inana $\mathrm{O}$ and Ewe and Grain passages the two terms are also preceded by $1 \mathrm{u}_{2}$.

In $\mathrm{Ur}$ recension $\mathbf{8}^{\prime}, \mathrm{d} \mathrm{s}$ u $\mathrm{l}-\mathrm{g} \mathrm{i} . \mathrm{r}$ is a reinterpretation based on phonetic affinity with s u $1 \mathrm{z} \mathrm{i}$. d "faithful youth" in Nippur recension 6 (cf. also II 3.2, p. 26). Note that whereas Urnamma does not get deified in this recension, Sulgi does.

7-8 These lines are a shortened citation of the concluding lines in Nanna's Journey to Nippur 349-352, observed by Ferrara, StPohl SM 2 (1973) 155ff., and fn. 28, also commented on by Edzard, ZA 63 (1973) 298-300, and Wilcke in CRRAI 19 (1974) 187, fn. 12 (with vars. for Nanna's Journey to Nippur), idem, $A S 20$ (1975) 245, fn. 65, and most recently in "Politik und Literatur" 38f., and 
fns. 48-51. The syntax is in both cases difficult. In view of the fact that the unpub. source E omits lines $8 \mathrm{ff}$. completely, and that lines $7-8$ are not extant in the Ur recension, it is probably an elliptical phrase without any syntactical reference to the following line (pace Edzard and Wilcke, "Politik und Literatur" 39). But admittedly d e $n-1 \mathrm{i} 1_{2}-1$ e (II - $\mathrm{a}_{2}$ in the two duplicates of Nanna's Journey to Nippur which preserve the end of the line) remains difficult. For genitives in - e, cf. Attinger, Eléments 259, $\$ 1683^{\circ}$.

10-11 U D after ku r-gal "Great Mountain" in Ur recension 11' is unusual, perhaps read as $\mathrm{z}$ a $1 \mathrm{ag}$ or $\mathrm{b}$ a b b a $\mathrm{r}$ "bright, shining", but it is said mostly of the day (and Inana who brightens the day). d e n - $1 \mathrm{il}_{2}-1 \mathrm{a}_{2}-\mathrm{ke}_{4}$ could be a "genitive ending in $-\mathrm{K} \mathrm{e}_{4}$ " with a reinterpretation of the Nippur recension 10 which has $\mathrm{d}$ e $\mathrm{n}-1 \mathrm{i} 1_{2}-1$ e, or we have to translate "Great Mountain, the ... of Enlil", parallel to Nunamnir in line 11.

Note the Sandhi-writing $\mathrm{m} \mathrm{e}-\mathrm{a} \mathrm{m}_{3}(-)$ in Ur recension 12', for the Nippur recension's $\mathrm{g} \mathrm{e}_{26}-\mathrm{e}$ in line 11 .

12-14 In view of the locative-terminative - e in Ur recension 13'-14' and the verbal chain i $\mathrm{m}-\mathrm{m} \mathrm{i}-(=\{\mathrm{i}+\mathrm{m}+\mathrm{b}+\mathrm{i}\})$, which reflects a locative-terminative, rather than a peripheric complement in the locative (cf. Attinger, Eléments 286, $\S$ 185), the following locatives $\mathrm{n} \mathrm{i} \mathrm{b} \mathrm{u} \mathrm{k} \mathrm{i}-\mathrm{a}$ and $\mathrm{u} \mathrm{ri}{ }_{2} \mathrm{k} \mathrm{i}-\mathrm{m}$ a in lines 12 and 14 of the Nippur recension are translated "for Nippur/Ur" rather than "in Nippur/Ur".

If the $\mathrm{e}_{2}-\mathrm{m} \mathrm{u} \mathrm{d}-\mathrm{k} \mathrm{u} \mathrm{r}-\mathrm{r}$ a is a cella in the Ekišnughal at Ur (cf. George, House Most High 128 ad no. 816; add Frayne, AOS 74 [1992] 33 and 119, fn. 246), perhaps the $\mathrm{h} u \mathrm{r}-\mathrm{s}$ a $\hat{\mathrm{g}}-\mathrm{nam}-\mathrm{til} \mathrm{n}_{3}-1 \mathrm{a}$ "Mountain of Life" is the $\left(\mathrm{e}_{2}-\right)$ h u r $-\mathrm{s}$ a $\mathrm{g}-\mathrm{g}$ a $\mathrm{l}$ a $\mathrm{m}-\mathrm{m}$ a or a part thereof, i.e. Enlil's cella on the ziggurat at Nippur (cf. the commentary ad Urnamma B 22-23).

$\mathrm{n}$ a $\mathrm{m}-\mathrm{m} \mathrm{i} \mathrm{(-)} \mathrm{i} \mathrm{m-M} \mathrm{I} \mathrm{in} \mathrm{Ur} \mathrm{recension} \mathrm{13'} \mathrm{is} \mathrm{Sandhi-writing} \mathrm{for} \mathrm{na} \mathrm{m}$ $\hat{\mathrm{g}} \mathrm{u}_{1}$ a $\mathrm{i} \mathrm{m}-\mathrm{M}$ I. The verbal base $\mathrm{M} \mathrm{I}$ should perhaps be read $\mathrm{k} \mathrm{u} \mathrm{k} \mathrm{k} \mathrm{u}{ }_{2}$ (or $\left.\mathrm{k} \mathrm{u}_{10}\right)$, and that in turn could be a variant for $\mathrm{k} \mathrm{u}_{7}\left(-\mathrm{k} \mathrm{u}_{7} . \mathrm{d}\right)$ țābu "sweet", as the Nippur recension in line 12 has $\mathrm{d} \mathrm{u}_{10} . \mathrm{g}$ "to be sweet". But maybe it is simpler to assume that the scribe has forgotten to write the verbal base, i.e. $\mathrm{n} \mathrm{a} \mathrm{m}-\mathrm{m} \mathrm{i} \mathrm{(=}$ - $\hat{g} \mathrm{u}_{10}$ with assimilation and vowel harmony) $\mathrm{i} \mathrm{m}-\mathrm{m} \mathrm{i}\left\langle(-\mathrm{i} \mathrm{n})-\mathrm{d} \mathrm{u}_{1_{0}}\right\rangle$.

15a In Ur recension 16' I understand a $\mathrm{g}$ a $\mathrm{m} \mathrm{e}-1 \mathrm{i} \mathrm{m}_{\mathrm{x}}$ "crown and radiance" as "radiant crown".

I interpret $\mathrm{me}-\mathrm{t}$ e $\check{s}_{2}$ as an error for $\mathrm{m} \mathrm{e}-\mathrm{t} \mathrm{e}$ "adornment", rather than $\mathrm{m} \mathrm{e}$ $\mathrm{t}$ e $\breve{s}_{2}$ "appeal and vigour" (cf. Ininšagura 125 where the two nouns are equated with Akk. dütu "appeal" and baštu "vigour, essence").

16 Read in Ur recension 17' $\mathrm{s}$ i $\mathrm{si}-\mathrm{e}-\mathrm{D}$ I as $\mathrm{si} \mathrm{si}-\mathrm{e}-\mathrm{s} \mathrm{a}_{2}$ (with difficult-e-), or perhaps $\mathrm{si} \mathrm{s} \mathrm{i}-\mathrm{e}-\mathrm{de}$ for $\mathrm{si} \mathrm{s} \mathrm{a}_{2}-\mathrm{e}-\mathrm{de}_{3}$.

18-19 The structure and grammar of these lines are obscure. - $\mathrm{ke}_{4}$ for - e / $\mathrm{re}$ in line 18 is dubious and needs collation. Hallo reads in line $19 \mathrm{~d}$ e $\mathrm{n}-1 \mathrm{il} \mathrm{l}_{2}$ $1 \mathrm{e}-\mathrm{b} \mathrm{i}-\mathrm{da} \mathrm{i}-\mathrm{b} \mathrm{a}-\ulcorner\mathrm{e}\urcorner$ ! - [ n e ] "Together with Enlil - they bestow". But for $\mathrm{z} \mathrm{i} \mathrm{b}$ a "to bestow life" there is only one (more) reference, Abaindasa to Sulgi (= Ali, Letters 54) 24. Furthermore, i - before the verbal base is very rare. One 
expects de n-1 i $1_{2}-1$ e to be parallel with e $n$ dA S S - i m $m_{2}-b$ ab bar $-\ulcorner$ re $\urcorner$ (!) of line 18 , and B I D A I, with different readings, is perhaps some nominal syntagm.

20 This line probably relates to the preceding line 19, as Enlil gives Urnamma a good name in Urnamma C 46, and Enki is usually associated with giving wisdom (line 21), cf. also IV 1.2, p. 50.

For $\mathrm{k} \mathrm{a}-\mathrm{ge} \mathrm{du}_{7}$ "worthy to be praised" (Ur recension 31' has the nonstandard writing k a-k e du), cf. Attinger, Eléments $371, \S 2133^{\circ}$ s.v. "du ${ }_{11^{-}}$ ge", with previous literature.

21c In Ur recension $25^{\prime} \mathrm{s}$ a $\hat{g}$ G I could be $\mathrm{s}$ a $\hat{g}-\mathrm{g}$ e for $\mathrm{s}$ a $\hat{\mathrm{g}}-\mathrm{e} / \hat{\mathrm{g}} \mathrm{e}_{26}$ "for the head", or perhaps read the second part of the line as s a $\hat{g}-\mathrm{g} i$ ( - ) I G $\ulcorner\mathrm{x}\urcorner$ for $\mathrm{s}$ a $\mathrm{g} \mathrm{g} \mathrm{i}_{6} \cdot \mathrm{g}$ "Black-Headed".

f In Ur recension $28^{\prime} \mathrm{g} \mathrm{u}_{2}-\mathrm{da}(-)$ a $\mathrm{m} \quad \mathrm{b} \mathrm{i}-\check{s}_{\mathrm{u}} \mathrm{u}_{2}$ might stand for $\mathrm{gu}_{2}-$ $\mathrm{da}-\mathrm{a} \mathrm{m} \mathrm{m}_{3} \mathrm{~b} \mathrm{i}-\check{s ̆}_{2}$. The sense, however, eludes me.

$\mathrm{g}$ In Ur recension line 29' the $\mathrm{k} \mathrm{u}_{3}-$ in [ . . k ] u ${ }_{3}-\mathrm{si}_{2}(\mathrm{Z} \mathrm{I}) . \mathrm{g}$ "gold", a non-standard writing of $\mathrm{k} \mathrm{u}_{3}-\mathrm{s} \mathrm{i}{ }_{17}$, is read from context. For / $\left.\mathrm{k} \mathrm{u} \mathrm{s} \mathrm{i} \mathrm{(} \mathrm{g}\right) /$, cf. Sjöberg, JCS 40 (1988) 174 ad 4 with previous literature.

I tentatively connect $\mathrm{m} \mathrm{i-i} \mathrm{r-m} \mathrm{i} \mathrm{r} \mathrm{with} \mathrm{b} \mathrm{i-b} \mathrm{i} \mathrm{r} \| \mathrm{b}$ a-ba. $r$ in Enki's Journey to Nippur 113 || Römer, BiOr. 48 [1991] 366 A 2 [= Gudam] t i $1 \mathrm{i} \mathrm{m-da} \mathrm{ma}_{2}-\mathrm{gur}_{8} \quad \mathrm{ku}_{3} \quad \mathrm{i} \mathrm{m}-\mathrm{ba}(/ \mathrm{bi})-\mathrm{ba}(/ \mathrm{bi})-\mathrm{re}(-\mathrm{e}-\mathrm{ne})$ "They (= the gods)/he (= Gudam) . . . the $\mathrm{t}$ i $1 \mathrm{i} \mathrm{m} \mathrm{da-vessel} \mathrm{and} \mathrm{the} \mathrm{splendid} \mathrm{cargo}$ boat" (source B of Enki's Journey to Nippur has the variant [ i m ] - m i r - $\mathrm{m}$ i r $\mathrm{e}-\mathrm{n}$ e, sources EE, $\mathrm{M}$ and $\mathrm{W}$ have $\mathrm{i} \mathrm{m}-\mathrm{k} \mathrm{ar}_{2}-\mathrm{kar}_{2}-\mathrm{re}-\mathrm{n}$ e "they [= the gods] make shine forth"). It is very unlikely that b i - b i . r II is a non-standard writing of $\mathrm{b} a \mathrm{~b} \mathrm{~b}$ a r "to be white, to shine" (PSD B 30 s.v. babbar C), despite the variant $\mathrm{kar}_{2}-\mathrm{kar}_{2}$, because $\mathrm{babbar}$ is not attested in any of the variants in this topos.

22-23 $\mathrm{m} \mathrm{u}(-) \check{s} \mathrm{e}_{21}$ (the Ur recension has $\mathrm{mu}(-) \check{s}$ e) is very difficult. One expects $\mathrm{mu}\left(-\breve{\mathrm{S}} \mathrm{E}_{3}\right) \mathrm{b}$ a $/ \mathrm{b} \mathrm{i}_{2}-\breve{s}_{2} \mathrm{e}_{2}$ "I have named it". š $\mathrm{e}_{21}$ alone can mean "to lie" (Wilcke, Lugalbandaepos 145 with literature), but that does not make any sense here. There is probably a sound play with $\mathrm{m} u$ š e $\mathrm{n}$ in lines 24-26.

In source $\mathrm{C}$ of Ur recension 30', $\mathrm{n}$ a ( - ) r i - M U ( - ) $\mathrm{u}_{4}$ with Sandhi-writing probably reflects original $\mathrm{g} \mathrm{a}_{2} \mathrm{uri} \mathrm{i}_{5}(\mathrm{ki})-\mathrm{ma} / \mathrm{iri}(\mathrm{ki})-\hat{\mathrm{g}} \mathrm{a}_{2} \mathrm{i}_{7}$ with reinterpretation. $\mathrm{u}_{4}$ for $\mathrm{i}_{7}$ in the Nippur version is due to attraction of - $\mathrm{M} \mathrm{U}$ $(-)$. $u b-b$ a could be reinterpreted from $(\mathrm{m}) \mathrm{u}-\mathrm{b} \mathrm{a}(-\mathrm{al})$ but the sense of $\mathrm{b}$ a $1 \mathrm{a}$ u b-b a eludes me.

25-30 These lines roughly correspond to lines $190-195$ of a b a l b a le of Nanna (= TMH NF 47 iv 190-195 // ISET 162 [Ni. 9788]), discussed by Hall, Moon-God 776-87 with previous literature (cf. in detail the discussion in IV 3.1, p. 75f.).

25-26 In view of $-\mathrm{a}$ - before - $\mathrm{b} i$ in the Nippur recension, $\mathrm{a}\left(=\mathrm{e}_{4}\right)$ $\mathrm{D} U(-\mathrm{a})-\mathrm{b} \mathrm{i}$ is a pronominal conjugation which excludes the noun $\mathrm{a}-\mathrm{r} \mathrm{a}_{2}$ but in the meaning of "way, course" with reference to water (cf. PSD A/1 149f. s.v. a$\mathrm{ra}_{2}$ B 5.; note also that $\mathrm{a}-\mathrm{ra}{ }_{2}$ with water is used for negative descriptions). 
Because of the Ur variant i ri (ki) ( = / e ri /, / i ri /) in line 33', which only can be explained if the scribe heard / e r a /, a D U might still have to be read a $\mathrm{r} \mathrm{a}_{2}$ "to carry water" or the like (instead of a $\mathrm{de}_{6} / \mathrm{t} \mathrm{u} \mathrm{m}{ }_{2}$ ), for which compare perhaps $\check{\mathrm{s}} \mathrm{u} \mathrm{d}_{3} \mathrm{DU}\left(\mathrm{r}_{2}\right)$ "to address a prayer". Note that the form i $\mathrm{r} \mathrm{i}(\mathrm{k} \mathrm{i})-\mathrm{b} i$ in Ur recension 33' appears in both duplicates and the correct form a D U - b i is used in lines $32^{\prime}$ and $34^{\prime}$. On the other hand the unpub. source $E$ of the Nippur recension has a $\mathrm{du}_{10} 0^{-} \mathrm{g}$ a "sweet water" (Tinney's reading, vs Hall, Moon-God 786 who reads - b i instead of - $\mathrm{g}$ a) for a D U ( - a ) - b i in parallel with line 26 of source $A$, and $a d_{1_{10}}$ in parallel with lines 33-34. This looks like a reinterpretation based on phonetic affinity and argues for a reading a $\mathrm{du}($ - a ) - b i "its coming water", "when the water is coming" for a D U ( a )- b i. If $a d u(-a)-b i$ instead of $a \mathrm{ra}_{2}(-\mathrm{a})-\mathrm{b} i$ turns out to be the correct reading in the Nippur version in view of source $E$, then the Ur sources in line 33' (= Ni 26) must represent a different version altogether (note also in the same line $\mathrm{i}_{7}-\mathrm{KE} \check{\mathrm{S}}_{2}-\mathrm{k} \mathrm{u}_{3} \cdot \mathrm{g}$ instead of $\mathrm{u} \mathrm{r}_{2} \mathrm{ki}-\mathrm{m} \mathrm{a}$ ).

$\mathrm{ku}_{6}-\mathrm{ab}$ in Ur recension 32 'ff. is a semantically conditioned non-standard writing: < $\mathrm{ku}_{6}-\mathrm{am}_{3}$ plus the association with $\mathrm{ab}$ "body of water, sea" (cf. also II 3.2 , p. 25).

In view of the variant $\mathrm{d}$ a 1 "to fly" (courtesy of S. Tinney) in the unpub. source E, d i r i means here most probably "to glide" (said of birds which roam along the riverine thickets and marshes of the canals preying on fish), rather than di ri.g "surplus" (Hallo), or "upper areas" (Hall), which however, cannot be entirely dismissed. $\mathrm{d}$ i $\mathrm{r}$ i underlines here movement as in a $\mathrm{DU}\left(\mathrm{ra}_{2}\right)$ "to carry water".

For abundance of fish and birds as literary topos, cf. Ferrara, StPohl SM 2 (1973) $139 f$.

26b In Ur recension 35' a reading $\mathrm{k} \mathrm{u}_{6} \mathrm{mu}$ š e $\mathrm{n}$ m a- $\mathrm{ra}-\mathrm{a}-\mathrm{b}-\mathrm{D} U$ is preferred over $\mathrm{k} \mathrm{u}_{6} \mathrm{~h} \mathrm{u}-\mathrm{m} \mathrm{a}-\mathrm{r} \mathrm{a}-\mathrm{a} \mathrm{b}-\mathrm{D} \mathrm{U}$. But $\mathrm{h} \mathrm{u}-\mathrm{m} \mathrm{a}-$ cannot be excluded because the text otherwise does not write $\mathrm{m} \mathrm{u}$ š e $\mathrm{n}$ and $\mathrm{h} \mathrm{u}$ - instead of $\mathrm{h} \mathrm{a}$ could possibly be explained as influenced by the preceding $\mathrm{k} u_{6}$.

27-28 The parallel line of line 27 in the b a 1 b a le TMH NF 47 iv 192 has $\mathrm{s} \mathrm{uhurku}{ }_{6}-\mathrm{e}\left\ulcorner\mathrm{a}\right.$ ? ᄀ - a b-s i / N I G I N ${ }_{2}$ and the obscure Akk. gloss [li]-ir-te-e, cf. Hall, Moon-God 786. The b a 1 b a 1 e 's parallel line (iv 193) of line 28 has calves eating honey-plants (cf. also IV 3.1, p. 76).

For the association of the $\mathrm{s} u \mathrm{~h} u \mathrm{r}$-fish with the $\mathrm{u}_{2}-1$ a $1_{3}$ "honey-plant", cf. Civil, Iraq 23 (1961) 170 and the schematic outline of references in Gragg, AfO 24 (1973) 69. The "honey-plant" grows on canal banks (cf. Lugalbanda I 391-392 and Ur recension $36^{\prime}$ ), but apparently also further out in the steppe region (e.g. Nisaba Hymn 80 e din-edin-e $u_{2}-1 a_{3} \quad b_{i_{2}}-m_{u_{2}}-m_{u_{2}}$ "The steppes let honey-plants grow").

28a Ur recension 36' is influenced by lines 27-28 of the Nippur recension.

For $\mathrm{u}_{2} \mathrm{~m}$ u n zer (usually written $\mathrm{u}_{2} \mathrm{~K} \mathrm{I}$. d N A N N A) "liquorice" or the like, cf. Civil, JCS 20 (1966) 122f. and Studies Reiner (1987) 45f. The occurrence of this plant in this line might be due to the mentioning of cows eating $\mathrm{g} \mathrm{i}-\mathrm{z} \mathrm{i}$ 
"reed fodder" in lines 29-30 of the Nippur recension (cf. below), for the liquorice ( $\mathrm{m}$ u $\mathrm{n} \mathrm{z}$ e r)-fed cows are a literary topos. Note that the plant was used as a sweetener (e.g. SP Coll. $3.131=$ Falkowitz, Sumerian Rhetoric Collections 223; compare also Dumuzi-Inana W 23) and was therefore connected with the honeyplant.

For $1 \mathrm{u}_{2}$ as a non-standard writing for $1 \mathrm{u}$ "to be numerous, to be plentiful", cf. Steinkeller, SEL 1 (1984) 15, fn. 21 and Michalowski, JCS 40 (1988) 161. It is normally said of animals and people, but $\mathrm{u}_{2} \quad \mathrm{u}$ is sporadically attested, cf. Heimpel, Tierbilder 219 ad n, and also Inana and Ebih 125 a m - b i $u_{2} \quad 1$ u - a $\mathrm{m} \mathrm{u}-\mathrm{u} \mathrm{n}-\mathrm{D} \mathrm{U}$ "Wild bulls roam about there (i.e. Ebih) in plentiful grass". This interpretation is preferred over $1 \mathrm{u}_{2}$ "person" and a translation "(even) people eat of honey-plants". Humans are not usually associated with eating the honey-plant (examples to the contrary are v. Dijk, Or. 44 [1975] 53 [= UM 29-15-367//] obv. 5 II, said of a woman who wants to become pregnant, and perhaps Instructions of Šuruppak 110), and in Ewe and Grain 24 and Nippur Lament 35, where people are said to eat plants like sheep, the imagery is negative, whereas in our line it should be positive.

$1 \mathrm{u}_{2}-\mathrm{u}_{2}$ in source $\mathrm{C}$ instead of $1 \mathrm{u}_{2}-\mathrm{a}$ is phonetically influenced $\left(1 u_{2}-\mathrm{u}_{2}\right.$ $\left.u_{2}-\right) . \mathrm{u}_{2}-1 \mathrm{al}_{3}-\mathrm{e}(-) \mathrm{gu} \mathrm{u}_{7}-\mathrm{e}$ reflects $\mathrm{u}_{2}-1 \mathrm{al}_{3}-\mathrm{e}\left(\mathrm{i}_{3}-\right) \mathrm{gu} 7-\mathrm{e}$ ("to eat of" + locative-terminative).

29 For a more recent discussion of $\mathrm{g} \mathrm{i}-\mathrm{z}$ i, cf. Klein, Studies Artzi (1990) 117f. ad 28-31 and Waetzoldt, BSA 6 (1992) 129f.; cf. also Englund, ASJ 14 (1992) 90. These young, edible reeds grow along river banks and, when cut, become excellent reed fodder for cattle and animals of the steppe, cf. e.g. Tree and Reed 189 (in Civil, Studies Reiner [1987] 45), and Heron and Turtle 8-9 || 46-47 || 87-88). They are also associated with (marsh-)carps ( $\mathrm{g} \mathrm{u} \mathrm{d}$, vars. $\mathrm{g} \mathrm{u} \mathrm{d}-\mathrm{du}$ and $\mathrm{g} \mathrm{u}_{4}$ $\mathrm{u}$ d) as in Home of the Fish 73-76, Enki's Journey to Nippur 79 ॥ Enki and the World Order 98, and Heron and Turtle $28 \| 75$.

33-34 For $1 \mathrm{a}_{2}$ with dative, cf. Civil, JAOS 103 (1983) 62 ad 41.

34a In Ur recension 37' $\mathrm{s} \mathrm{u}-\mathrm{s}$ u could be a non-standard writing for $\mathrm{s} \mathrm{u}_{3}$ $\mathrm{s} \mathrm{u}_{3} . \mathrm{d}$ "to become long, to become tall". Compare thematically Isin *28 (=

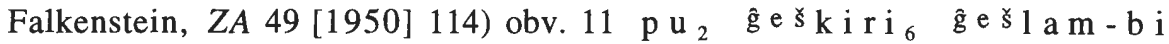
$\mathrm{k} \mathrm{i} \mathrm{tag}-\mathrm{gat} \mathrm{ir}-\mathrm{gin} \mathrm{s} \mathrm{u}_{3}-\mathrm{s} \mathrm{u}_{3}-\mathrm{e}\left(/-\left\ulcorner\mathrm{de}_{3}\right\urcorner\right)$ "to let the planted nut (bearing) trees of the orchards grow tall like riverine thickets".

35-36 P A - a is usually connected with $\mathrm{u}_{2}$ - a (cf. Sjöberg, AOAT 25 [1976] 423 ad 22 and idem, JCS 29 [1977] 29 ad 12' with previous literature), but the meaning "provider" does not seem to fit our line. The translation given here "it (= the canal) is full of your P A - a-cry" is only a guess. P A - a, which might have a reading p a-a (cf. Alster, ASJ 14 [1992] 25 ad 8 and 49), is usually mentioned next to a $-1 \mathrm{a}-1 \mathrm{a}$ as some sort of an exclamation, perhaps of joy, and/or a working song refrain (cf. PSD A/1 100 s.v. a-la-la A).

The translation "full of" for $\mathrm{S} \mathrm{U}_{3}-\mathrm{a}$, normally reflecting $\mathrm{s} u \mathrm{~d}-\mathrm{a}$ "made long", is based on the unpub. sources $D$ and $E$ which have $s u_{3}-g a-a m_{3}$ 
(courtesy of S. Tinney). However, a semantic variation "your PA-a-cry resounds far (?)" cannot be ruled out.

37 In Ur recension $38^{\prime}$ 's e - $g$ a "favourite" is possibly influenced by $\breve{s} \mathrm{a}_{3}(. \mathrm{g})$ of the Nippur recension.

39-40 Ur recension $40^{\prime}$ is syntactically and epigraphically difficult. $\mathrm{z}$ a - e $\mathrm{e} \mathrm{n}-\mathrm{z}$ a-e - 1 e probably stands for $\mathrm{z}$ a $1-\mathrm{za} 1-1 \mathrm{e}$, rhyming with succeeding $\mathrm{z}$ a - e, but $\mathrm{z}$ a-e - $\mathrm{me}-\mathrm{e} \mathrm{n}$ does not seem to fit with the verbal chain $\mathrm{m} \mathrm{i}$ $\mathrm{n} \mathrm{i}-\mathrm{i} \mathrm{n}-\Gamma_{\mathrm{X}}$ ? $\urcorner$ which looks like 3rd person hamtu sg. animate. Maybe the line has been reinterpreted with $\mathrm{d} u \mathrm{t} u$ as subject. Read then (...) s i $1 \mathrm{a}-\mathrm{a} \quad \mathrm{d} u \mathrm{t} u$ $\mathrm{m}$ i - $\mathrm{n} \mathrm{i}-\mathrm{i} \mathrm{n}-{ }^{-} \mathrm{x}$ ? ᄀ "(..) in joy, Utu has ...". 


\title{
5. UR N A M A EF
}

\subsection{Introduction}

\section{Previous studies $^{l}$}

\begin{abstract}
A first transliteration with translation and a copy (pl. 2) of source B (= Urnamma F) of Urnamma EF was given by S. Langdon in PSBA 40 (1918) 45-50. M. Cohen presented an edition of Urnamma F, together with Urnamma E (= source A), in JAOS 95 (1975) 596-600 as part of his treatment of the so-called š i r $\mathrm{n}$ a $\mathrm{m} \breve{s}$ u b compositions to which Urnamma EF belongs. ${ }^{2}$
\end{abstract}

\section{Urnamma EF: a širnamšub composition}

M. Civil listed Urnamma EF separately under Urnamma $E$ and $F$ in his unpublished Index for a Corpus of Sumerian Literature ${ }^{3}$ and noted that Urnamma F was very similar to Urnamma E. The line sequence and content of both Urnamma E and $\mathrm{F}$, despite some line additions and omissions, are indeed so strikingly similar ${ }^{4}$ that Urnamma $\mathrm{E}$ and $\mathrm{F}$ probably present two non-Nippur ${ }^{5}$ recensions $^{6}$ of an original Urnamma hymn which served as a common model. In this study they are therefore treated as the same composition (Urnamma EF) in two different recensions (Urnamma $\mathrm{E}$ and $\mathrm{F}$ ).

Urnamma EF ends with the subscript "š i $\mathrm{r} n$ a m š u b of Nanna" and thus belongs to the small and heterogeneous group of Old Babylonian ${ }^{7}$ š i r n a m š u b compositions coveniently listed by C. Wilcke in $A S 20$ (1975) $288^{8}$ and M. Cohen in JAOS 95 (1975) 593. Four more can now be added:

\footnotetext{
1 Cf. also II 2., p. $20 \mathrm{f}$.

2 Cf. also Schretter's short description of this group of hymns in Emesal-Studien (1990) 90f., and Black, Studies Civil (1991) 24.

3 p. 29 ad 2.415. and 2.416 .

4 Cf. below, "Structural Analysis", p. 263f. and 5.4, pp. $276 \mathrm{ff}$.

5 The provenance of Urnamma $E$ is Lagaš, of Urnamma F probably Sippar.

6 Cf. also Cohen, JAOS 95 (1975) 594 and fn. 8 ("redactions"); Black, Studies Civil (1991) 24, fn. 14 ("versions"); Schretter, Emesal-Studien (1990) 90, fn. 38.

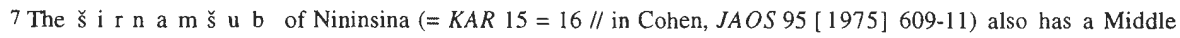
Assyrian bilingual version.

$8 \mathrm{Cf}$. also the previous list and discussion in Krecher, Kultlyrik $31 \mathrm{f}$., and fn. $68 \mathrm{ff}$.
} 
Dumuzi-Inana M, an unpublished Nippur text (UM 29-15-242), has been transliterated and commented on by Y. Sefati in Love Songs $232 \mathrm{f} .{ }^{9}$ It skips the divine name in the subscript ( $\check{\mathrm{s}} \mathrm{i} \mathrm{r}_{3}-\mathrm{n}$ a m-š u b-b a $-\ulcorner\mathrm{k} \mathrm{a} \mathrm{m}\urcorner$ ). ${ }^{10}$ We have another š i r $\mathrm{n}$ a m š u b of Inana published by S.N. Kramer in Recueil de Travaux 2 (1984) 5-9,11 and two of Utu inscribed together on a four-column tablet (two columns on either side) in the British Museum (BM 23631) and published by S.N. Kramer in Or. 54 (1985) 117-32. ${ }^{12}$ This raises the number to 12 in all so far. ${ }^{13}$ The Jena Catalogue (TMH NF $353+453)$ which lists š i r n a m š u b compositions in column one shows that quite a few more are extant.

The precise meaning of the subscript $\breve{\mathrm{s}} \mathrm{i}_{3}-\mathrm{n}$ a m - $\breve{\mathrm{s}} \mathrm{u} \mathrm{b}(-\mathrm{b}$ a ), lexically attested in the Old Babylonian lexical list Proto-Lu (MSL 12 54) 592, ${ }^{14}$ as well as the nature and function of the genre as a whole remain elusive. The term $\mathrm{n}$ a $\mathrm{m}$ $\check{\mathrm{s}} \mathrm{u} \mathrm{b}$ is equated in the post-Old Babylonian period with Akkadian šiptu "incantation, spell", but there might be an original association with g e $\check{s}-\breve{s} \mathrm{u} b(-\mathrm{b}$ a $)=$ isqu "lot, share, destiny", and thus "casting a spell" with "casting lots". ${ }^{15}$ The $\mathrm{n}$ a $\mathrm{m}-\check{\mathrm{s}} \mathrm{u} \mathrm{b}$ could be recited in form of a hymn and involve the act of cleansing.

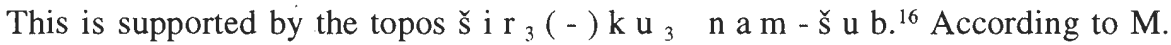
Cohen the genre $\check{s} \mathrm{i}_{3}-\mathrm{n}$ a m-š u b ( - b a ) and the š i $\mathrm{r}_{3}(-) \mathrm{k} \mathrm{u}_{3} \mathrm{n}$ a m š u b are synonymous, ${ }^{17}$ but note that $\check{\mathrm{s}} \mathrm{i}_{3}(-) \mathrm{k} \mathrm{u}_{3}$ seems to be a technical term $^{18}$ and intoned on different types of musical instruments, e.g. the $\mathrm{t} \mathrm{i} \mathrm{g} \mathrm{i-,}$ s e $\mathrm{m} / \mathrm{u}$ b-, and a $\mathrm{l}$ a-instruments, ${ }^{19}$ and on the b a $1 \mathrm{a}$ g-instrument. ${ }^{20}$ It is associ-

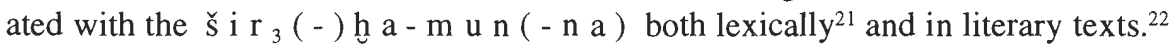
The š i r n a m š u b genre may have been part of the g a 1 a-singer's ${ }^{23}$ repertoire

9 [Cf. now the published form as Sefati, Love Songs in Sumerian Literature, Critical Edition of the DumuziInanna Songs, Ramat Gan (1998) 208f.].

10 This practice is also attested for the e $\mathrm{r} \breve{s}$ e m a cult songs (cf. Krecher, Kultlyrik 29, and fn. 55).

11 A copy of source BM 88318 is now CT 5813 , pl. 14.

12 The second $\breve{s}$ i r n a $\mathrm{m} \breve{s} \mathrm{u}$ b composition on the tablet has been subsequently treated by Jacobsen, JANES 22 (1993) 63-68.

13 Note that UM 29-15-570 in Sjöberg, JCS 29 (1977) 8-13 (with additions by Krecher apud Klein, TAPS 71/7 [1981] 42) is very likely another member of the š i r n a m š u b genre: it has stock phrases which appear in another š i r n a m š u b hymn (Cohen, JAOS 95 605f:38-41 \| 51-53= Sjöberg, JCS 299 rev. 7'-10') and in RA 15 (1918) 128:18-21 (according to Black, BiOr. 44 [1987] 76 not yet assigned to a known b a 1 a $\hat{g}$ cult song), it uses dividing lines, exhibits Eme-sal and main dialect passages, and refers to a king (for these characteristics of the $\breve{s}$ i r n a m š u b genre, cf. in more detail below, p. 262).

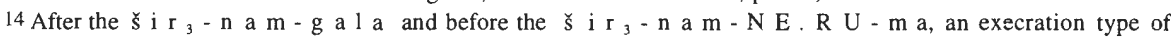
hymn.

15 Cf. Hallo, JCS 19 (1965) 57 ad no. 16 "fate-fixing song. . .". Attinger apud Uehlinger, OBO 101 (1990) 411 , fn. 18, and idem, Eléments 625, § 673, and fn. 1790 .

16 Cohen, JAOS 95 (1975) 595; add to the references Geller, UHF 22:48 (š i r ${ }_{3}$ ( - ) k u ${ }_{3}$ n a m - š u b $\left.\mathrm{k} \mathrm{u}_{3}(-\mathrm{g} \mathrm{a})\right)$.

17 Cohen, ibid. 595; also Uehlinger, OBO 101 (1990) 411, fn. 18.

18 Klein, ThS̆H 216 ad 93; cf. also idem, Studies Artzi (1990) 120 ad 4l-42.

19 Enki's Journey to Nippur 125; Sumer and Ur Lament 436-437; Eridu Lament 3.10-11; KAR $15=16 / /$ (= Cohen, JAOS 95 610) 15'.

20 Nanš e Hymn 41-42; KAR $15=16 / /$ (= Cohen, ibid. 610) $15^{\prime}$.

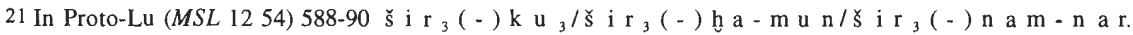

22 Temple Hymns 298; Nanše Hymn 42; Eridu Lament 3.10. Gudea, Cyl. A 2712 has n a m-š u b šir ${ }_{3}(-)$ h a $-\mathrm{mu} \mathrm{n}$.

23 For the g a $1 \mathrm{a}=$ kalû, cf. e.g. Black, Studies Civil (1991) $26 \mathrm{ff}$. 
and thus sung in the temple cult because some hymns are exclusively written in Eme-sal. ${ }^{24}$ Others, however, show a mixing of Eme-sal forms with the main dialect, ${ }^{25}$ or are wholly written in the main dialect. ${ }^{26}$

The š i r n a m š u b compositions share some formal characteristics with two other types of cultic songs, namely the š i r $\mathrm{n}$ a m g a l $\mathrm{a}^{27}$ and the $\mathrm{b}$ a $\mathrm{l} \mathrm{a} \mathrm{g}$ songs belonging to the province of the $\mathrm{g}$ a l a- singers. The $\check{\mathrm{s}}$ i $\mathrm{r} \mathrm{n}$ a $\mathrm{m} \breve{s} \mathrm{u} \mathrm{b}$ and $\breve{\mathrm{s}}$ i $\mathrm{r}$ $\mathrm{n}$ a $\mathrm{m} \mathrm{g}$ a $\mathrm{l}$ a compositions use similar rubrics, refer to (anonymous) kings, and both exhibit a slight mixing of Eme-sal forms with the main dialect. The $\check{s}$ i $\mathrm{r}$ $\mathrm{n}$ a $\mathrm{m} \check{\mathrm{s}} \mathrm{u} \mathrm{b}$ compositions are listed together with $\mathrm{b}$ a $\mathrm{l}$ a $\mathrm{g}$ and e $\mathrm{r} \check{\mathrm{s}} \mathrm{e} \mathrm{m}$ a songs in the Old Babylonian catalogue VS 10216 , both types of songs use the same repertoire of rubrics ${ }^{28}$ and the device of dividing lines which are very likely substi-

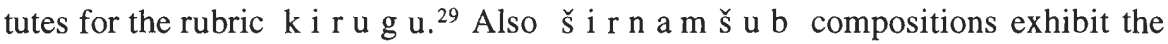
so-called "stock phrases" ("Versatzstücke") found in b a l a g and e r š e m a songs. ${ }^{30}$ Major differences between the š i $\mathrm{r} \mathrm{n}$ a m š u b and b a la g songs, however, are also apparent: the b a 1 a $\mathrm{g}$ songs are in Eme-sal entirely and represent a huge group of hymns which were popular over a very long period of time,

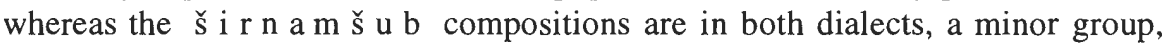
and apparently did not survive into the later tradition. Also, the main themes of the b a $1 \mathrm{a} g$ songs, such as images of the storm, the enemy, destruction and abandonment of temples, humiliation and the disappearance of deities, are never broached in the $\check{\mathrm{s}}$ i $\mathrm{r} \mathrm{n} \mathrm{a} \mathrm{m} \breve{\mathrm{u}} \mathrm{b}$ compositions. Unlike the $\mathrm{b}$ a l a $\hat{\mathrm{g}}$ songs, the $\check{\mathrm{s}}$ i $\mathrm{r} \mathrm{n}$ a m s u b compositions make reference to kings who, however, remain anonymous, with the sole exception of Urnamma EF which explicitly names the king. Urnamma EF shows another feature which is unique to, or at least anomalous for, š i r n a m š u b compositions: instead of an introductory hymn of praise to a deity, here Nanna-Su'en, in whose honour the hymn was composed, as is usual

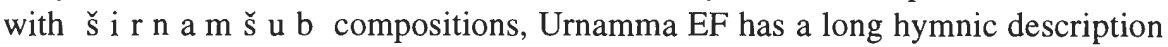
of the temple Ekišnugal at Ur and its lord, Urnamma, elected by Nanna to kingship and recipient of blessings. Perhaps then an original hymn to a god was modified and altered to compose Urnamma EF. ${ }^{31}$ If the $\check{\text { s }} \mathrm{r} \mathrm{n}$ a $\mathrm{m} \breve{\mathrm{s}} \mathrm{u} \mathrm{b}$ compositions were

24 E.g. CT 4213 (= Kramer, PAPS 107 [1963] 503f.) and CT 4222 (= Cohen, JAOS 95 605-09), Dumuzi-Inana $\mathrm{M}$ (= Sefati, Love Songs 232f.).

25 E.g. Urnamma F (cf. below); VS 268 (= Sjöberg, Mondgott 80-88).

26 E.g. KAR $15=16 / /$ (= Cohen, JAOS 95 609-11); SLTNi 61 (= Cohen, WO 8 [1975-76] 22-36).

27 Listed by Wilcke, $A S 20$ (1975) 288; add the š i r n a m g a 1 a of Su'en, mentioning Šũ su'en, in Kramer, Studies Sjöberg (1989) 303-05 (= BM 100042 i obv. 1-48). Its incipit appears in the Jena Catalogue (TMH NF $353 / /: 35)$ and in the "Nippur Catalogue" in Michalowski, OA 19 (1980) 266:4.

28 The $\mathrm{b}$ a $1 \mathrm{a} \hat{\mathrm{g}}$ songs have in addition the $\breve{s ̆}_{\mathrm{u} \mathrm{d}} \mathrm{d}_{3}$ and $\mathrm{s}_{\mathrm{a}} \mathrm{a}_{3}-\mathrm{b} \mathrm{a}-\mathrm{a}-\mathrm{T} U \mathrm{KU}$ rubrics.

$29 \mathrm{On} \mathrm{k} \mathrm{i} \mathrm{-} \mathrm{r} \mathrm{u}-\mathrm{g} \mathrm{u}_{2}$ and its possible meaning, cf. Ludwig, Išme-Dagan 30ff. with previous literature; also Vanstiphout, JEOL 31 (1989/90) 54f. and 57ff.; Č erny, ArOr. 62 (1994) 25f.; Tinney, Nippur Lament 21, fn.

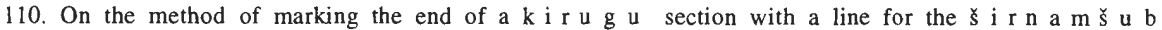
compositions, cf. Wilcke, AS 20 (1975) 288 ad (a); also Kramer, Recueil de Travaux 2 (1984) 8, fn. 3; for the b a 1 a $\mathrm{g}$ songs, cf. Wilcke, ibid. 258 ad (c) and 286, and ad (a) - (c); Kramer, PAPS 124 (1980) 296, fn. 8; Römer, BiOr. 37 (1980) 190; Kramer, ASJ 3 (1981) 8, fn. 8.

$30 \mathrm{Cf}$. Black, Studies Civil (1991) 24, and fn. 13.

31 Cf. also IV 3.1, p. 77 , and the discussion of Umamma D, ibid., pp. $74 \mathrm{ff}$. 
indeed part of the g a l a-singer's repertoire, Urnamma EF may have been composed for temple ceremonies in which the king participated.

\section{Structural Analysis}

Urnamma $\mathrm{E}$ and Urnamma $\mathrm{F}$ fall into two major sections, an introductory hymn and the main, second $\mathrm{k} \mathrm{i} \mathrm{r} \mathrm{u} \mathrm{g} \mathrm{u} \mathrm{section.} \mathrm{The} \mathrm{prologue,} \mathrm{or} \mathrm{introductory} \mathrm{hymn} \mathrm{(I),}$ begins with a general description of Ur and introduces Urnamma (1.). ${ }^{32}$ Then it focuses on Ur's main shrine, the Ekišnugal, and enumerates and describes in varying detail the various parts of the temple, leading us through the gate into its inner sanctum (2.) and mentioning Urnamma again at the end (3.). In the first part of the main section (II) Urnamma is chosen by Su'en (1.) in order to enforce law and order (2.). It ends with Urnamma's blessing in form of a decreeing of fate (3./4.).

\section{Urnamma E (source A)}

I. Introductory hymn to [Ur], the Ekišnugal and Urnamma (1'-24') 2nd person

1. [...], the (city-)gate (1')

2. The [Eki]š[nugal] and its lord Urnamma (2'-8'), its gate (9'), its platform? $\left(10^{\prime}-12^{\prime}\right)$, its interior $\left(13^{\prime}-14^{\prime}\right)$, its g i g u n a $\left(15^{\prime}\right)$, its d u b l a m a h $\left(16^{\prime}-\right.$ $\left.17^{\prime}\right)$, the Etemenniguru (18'), its lord Urnamma (19'-20'), [...], the Esaga (22')

3. Urnamma (23'-24')

II. Main section (25'-40') 3rd person

1. Urnamma's divine election (25'-26')

2. Urnamma enforces justice (27'-32')

3. Urnamma and the Ekišnuĝal (33'-34')

4. Decreeing of fate for Urnamma (35'-40')

\section{Urnamma F (source B)}

I. Introductory hymn to Ur, the Ekišnugal and Urnamma (1-24) 2nd person

1. Ur's foundations (2), its lord Urnamma (3-5), the assembly (6), the (city-)gate (7)

2. The Ekišnugal and its lord Urnamma (8-13), its gate (14), its platform? (1517), its interior (?), its $\mathrm{g}$ i g u n a (20), its $\mathrm{d} \mathrm{u} \mathrm{b} 1$ a m a h (21-22)

3. Urnamma's divine election (23-24) 
II. Main section (25-51) 3rd person

1. Urnamma's divine election (25-29)

2. Urnamma submits rebellious lands to his law and order (30-35)

3. Decreeing of fate for Urnamma (36-51)

\section{Manuscripts}

As noted above, Urnamma $\mathrm{E}$ (source $\mathrm{A}$ ) and $\mathrm{F}$ (source $\mathrm{B}$ ) probably present two nonNippur recensions of an original Urnamma hymn serving as a common model. Urnamma E (source A), L 1499, published in copy in ISET 1 (1969/71) pp. 224f. (nos 166-67), comes from Lagaš, exhibits quite a few non-standard writings and, judging from what is preserved of the text, may have been written entirely in the main dialect. ${ }^{33}$ The number of lines missing at the beginning and end of the composition cannot be determined with any certainty. Urnamma F, containing 51 lines, is of no help as the divergence from Urnamma $\mathrm{E}$ in line addition and, furthermore, omission is too considerable. In the first $\mathrm{k} \mathrm{i} \mathrm{r} \mathrm{u} \mathrm{g} \mathrm{u}$ section 24 lines are preserved, the second $\mathrm{k} \mathrm{i} \mathrm{r} \mathrm{u} \mathrm{g} \mathrm{u}$ section consists of 16 preserved lines with the end and subscript missing.

Urnamma F (source B) is BM 78183 (= CT 44 16), a well preserved onecolumn tablet with inscribed edges, containing the whole composition consisting of two k i r u g u sections divided by a line. This source probably comes from Sippar and uses twice the Eme-sal form $\mathrm{u}_{3}-\mathrm{mu}-\mathrm{u} \mathrm{n}$ "lord" (next to the more often recurring main dialect form e $n$ ) and once $\mathrm{ur} \mathrm{u}_{2}$ "city" in an otherwise wholly main dialect text. ${ }^{34}$ The following transliteration of Urnamma $E$ is based on the copy in ISET; Urnamma F was read from a photo kindly made available by C.B.F. Walker.

The two manuscripts show some divergence, as do the Nippur and Ur recensions of Urnamma D. Urnamma $\mathrm{E}$ and $\mathrm{F}$ follow the same sequence of lines, i.e. narrative, but diverge from each other through additions (whole lines or only parts of lines), omissions, and line division, so the two manuscripts cannot be considered just basic scribal variants. There are additions in both versions that repeat lines of similar content. Urnamma EF $19 \mathrm{a}^{35}$ (= Urnamma E 14') is an addition which is influenced by the preceding line 19 ( $\breve{\mathrm{s}_{3}}$ and $\mathrm{h} \mathrm{u} 1-\mathrm{g} \mathrm{a} l_{2}$ are taken up again) and somewhat echoes Urnamma EF 9 (= Urnamma E 3'). Urnamma E inserts additions (Urnamma EF 34a-c; 36a) by using ornamental repetition of line pairs in the passage Urnamma EF 34-36. Urnamma $F 17$ is a thematic expansion of the preceding line 16. Urnamma F 24 is paralleled in line 29 , substituting Su'en with

\footnotetext{
33 Line 3, where Urnamma $\mathrm{F}$ has the Eme-sal forms u $\mathrm{r} \mathrm{u}_{2}$ "city" and $\mathrm{u}_{3}-\mathrm{m} \mathrm{u}-\mathrm{u} \mathrm{n}$ "lord", is not preserved in $\mathrm{E} ; \mathrm{u}_{3}-\mathrm{mu}-\mathrm{u} \mathrm{n}$ in Urnamma F 26 is not extant in Urnamma $\mathrm{E}$.

$34 \mathrm{Cf}$. the preceding footnote.

35 Line numbering of the Synopsis (5.4).
} 
AŠimbabbar. Another addition is the continuous description of the Ekišnugal in Urnamma E 18'-24' (= Urnamma EF 24a-g), thus making the first $\mathrm{k}$ i r u g u section a couple of lines longer than the one of Urnamma F. Unmatched in Urnamma $\mathrm{F}$ is also the "refrain" t e $\check{s}_{2} \mathrm{mu}-\mathrm{zu} \quad \mathrm{h} \mathrm{e}_{2}-\mathrm{i}-\mathrm{i}$ "he reveals? your vigour and name indeed" which recurs four times in Urnamma E 8' || 12' || 19' || 23'. The theme of repression and wickedness in general, and the evil lands in particular $(\mathrm{k} \mathrm{i} \mathrm{-}$ $\mathrm{b}$ a $\mathrm{l}$ a "rebellious land" in lines 20 and $35, \mathrm{k} \mathrm{u} \mathrm{r} \mathrm{-} \mathrm{k}$ u r "all (the foreign) lands" in line 30 and $\mathrm{k} \mathrm{u} \mathrm{r} \mathrm{NE.R} \mathrm{U-m} \mathrm{a} \mathrm{"the} \mathrm{enemy} \mathrm{land"} \mathrm{in} \mathrm{line} \mathrm{34),} \mathrm{is} \mathrm{more} \mathrm{fully}$ elaborated in Urnamma $\mathrm{F}$, whereas Urnamma $\mathrm{E}$ lacks any mention of lands at all.

The fact that the two recensions handle line divisions differently (in Urnamma $F$ $13,16,21 \mathrm{f} ., 32 \mathrm{f}$. , and 37 the end of the line falls together with the end of the sentence, whereas in the parallel lines of Urnamma $\mathrm{E}$ this is not the case) might stem from a different interpretation of a common model, perhaps written in short-line format. Urnamma $\mathrm{E}$ might even have been compiled from two different models as the king's name is deified in the second $\mathrm{k} \mathrm{i} \mathrm{r} \mathrm{u} \mathrm{g} \mathrm{u}$ section but not in the first. ${ }^{36}$

Both recensions are beset with syntactical and grammatical traits unknown in texts of Gudea and the hymns of Sulgi which have not been modernised. One of the more often recurring phenomenon in both Urnamma $\mathrm{E}$, and even more so in Urnamma $F$, is the replacement of the dative postposition by the locativeterminative postposition. This case is so far only well attested in Ur III juridical and administrative documents. Other syntactical and grammatical difficulties encountered in Urnamma EF are mentioned in the collective philological commentary below.

The first part of the opening line of the second $\mathrm{k}$ i $\mathrm{r} \mathrm{u} \mathrm{g} \mathrm{u} \mathrm{section,} \mathrm{marked} \mathrm{in}$ both Urnamma $\mathrm{E}$ and $\mathrm{F}$ by a dividing line, ${ }^{37}$ is listed in two catalogues, namely in the "Yale Catalogue" YBC 3654 ii 17 (cf. W.W. Hallo, JAOS 83 [1963] 171; $\mathrm{l} \mathrm{u} \mathrm{g} \mathrm{a} \mathrm{l}-\mathrm{g} \mathrm{u}_{10}$ instead of $1 \mathrm{u} \mathrm{g}$ a 1 , though) and in the "Nippur Catalogue" CBS 8086 12, published by P. Michalowski, OA 19 (1980) 266f., among other opening lines of $\mathrm{k}$ i r u g u sections.

\section{Sources}

Lagaš:

$\mathrm{A}=$ Recension $\mathrm{E} \quad \mathrm{L} 1499$

$$
\begin{aligned}
& \text { obv. } 1^{\prime}-22^{\prime}=\mathbf{1}^{\prime}-\mathbf{2 2} \mathbf{2}^{\prime}=\mathbf{7 - 2 4 \mathbf { e } ^ { 3 8 }} \\
& \text { rev. } 1-18=\mathbf{2 3} \mathbf{- 4 0}^{\prime}=\mathbf{2 4 f - 4 5} \\
& \text { copy: M. Çiğ, H. Kizilyay, ISET } 1(1969 / 71) \text { pp. } 224 \mathrm{f} .
\end{aligned}
$$

\footnotetext{
$36 \mathrm{Cf}$. the commentary ad 29.

37 For this method of substituting the rubric for a line which can also be observed for b a 1 a $\mathrm{g}$ songs, cf. above, p. 262, and fn. 29 .

38 Line counting of the Synopsis of Urnamma EF.
} 
Sippar(?):

$\mathrm{B}=$ Recension $\mathrm{F} \quad$ BM 78183

$$
\begin{aligned}
& \text { obv. } 1-20=\mathbf{1 - 2 0}=\mathbf{1 - 2 0} \\
& \text { rev. } 1-31=\mathbf{2 1 - 5 1}=\mathbf{2 1 - 5 1}
\end{aligned}
$$

copy: Th.G. Pinches, CT 4416.

photos made available by C.B.F. Walker, cf. pls. 23-24; read from photos.

\subsection{Transliteration and Translation of Urnamma $E$ (source A) ${ }^{39}$}

The corresponding lines of Urnamma F (source B) are given in parenthesis. To facilitate comparison of the two recensions a synopsis is given below, 5.4 "A Synopsis of Urnamma EF: Recensions E and F".

1' obv. 1' [abul]la-zu ' $\left.{ }^{\prime}\right\urcorner$ ' [...] (F 7)

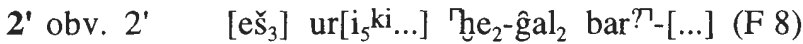

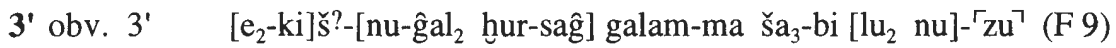

4' obv. 4' ki ut-ti-z[u? kur? šem?] ĝeš eren-na mu-zu-še ${ }_{3}$ UN $\left.{ }^{r} \mathrm{x}(\mathrm{x})\right)^{\urcorner}$(F 10)

5' obv. 5' en-zu en sa $5^{\prime}$-ga mu $\mathrm{pa}_{3}$-da (F 11)

6' obv. 6' dumu ${ }^{1}$ nin- ${ }^{\top}$ sumun $_{2}{ }^{7}$-ka me-te kur-kur-ra (F 12)

7' obv. 7' uri ${ }_{5}^{k i}$ me gal-zu a-ra ${ }_{2}$-ab diĝir-re-ne (F 13)

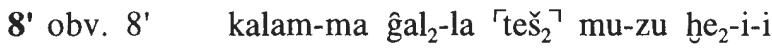

9' obv. 9' $\mathrm{KA}_{2}$-zu an $\mathrm{sa}_{7}$-ga su-zi $\mathrm{guru}_{3}{ }^{\Gamma \mathrm{ru}\urcorner}$ (F 14)

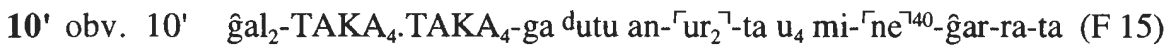

11' obv. 11' gi-ša ${ }_{3}$-zu-ta ki nam tar-re diĝir-re-ne (F 16)

12' obv. 12' di si-sa $\mathrm{ku}_{5}^{\prime}$-me-en teš mu-zu hुe $\mathrm{s}_{2}-\mathrm{i}-\mathrm{i}$

39 The translation of Urnamma $\mathrm{E}$ and $\mathrm{F}$ is a line-by-line translation of both sources which sometimes do not make sense because of the confusion of their model.

40 For - ni-?! 
$1^{\prime} \quad[\ldots]$ your $[($ city-)ga]te $[\ldots]$.

$2^{\prime} \quad[$ Sanctuary $]$ Ur, $[\ldots]$ abundance, $[\ldots]$ façade? $[\ldots]$,

3' [Eki]š[nugal], skilfully built [mountain (range)] whose interior [nobody] fathoms,

4' Your? place where daylight breaks, (is) a [mountain? of fragrant?] cedar, at your name, the people/land....

5. Your lord, the comely lord, who is called by name,

6' (Is) the son of Ninsumun, the adornment of all (the foreign) lands.

7. Ur, your great $\mathrm{m} e$, the shackles of the gods,

8. Are positioned over the land. He ${ }^{41}$ reveals? your vigour and name indeed!

9' Your gate (is) the azure heaven, full of awe.

10. After Utu has set light from the horizon in the openings,

11' At your platform? , the place where fate is determined by the gods,

12' You render just judgments. He reveals? your vigour and name indeed! 
13' obv. 13' ša ${ }_{3}$-ga-ta geš-hur zi-da hul-gala ${ }_{2}$ nu-[dib?-b]e ${ }_{2}$ (F 19)

14' obv. 14' $\mathrm{e}_{2}$-kiš-nu-ğal ${ }_{2}$ ša $_{3}$-zu ušumgal hul-ĝal ${ }_{2}$ nu-[u]n-zu

15' obv. 15' e $_{2}$ gi-gun ${ }_{4}$-na-zu nidba-zu LIL $_{2}$. DIM/GIR ${ }_{2}$ ? den-[li]l $2_{2}$ ? sud $_{4}$-ru (F 20)

16' obv. 16' dub-la ${ }^{\prime}$-mah ki nam tar-re-za digìir gal-gal-e-ne (F 21)

17' obv. 17' nam mi-ni-ib-tar-re-ne (F 22)

18' obv. $18^{\prime} \quad \mathrm{e}_{2}$-temen-ni ${ }_{2}-{ }^{\prime}$ guru $_{3}{ }^{\text {ru }}{ }^{\prime}$ tum $_{2} !-$ ma

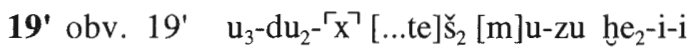

20' obv. 20' en $\mathrm{sa}_{7}-[\mathrm{ga} \ldots ..]{ }^{\prime} \mathrm{x}^{\urcorner}$zi ur- ${ }^{\ulcorner} \mathrm{d}_{\text {namma }}{ }^{\prime}$

21' obv. $21^{\prime} \quad u r\left[i_{5} \mathrm{ki}^{\ldots} ..\right]$

22' obv. 22' $\mathrm{e}_{2}-\mathrm{sag}_{3}-$ ga $^{\top}{ }^{\top} \mathrm{dutu}-\mathrm{gin}_{7} \mathrm{x}^{\urcorner} \quad[\ldots]$

23' rev. 1 teš $\check{S}_{2}$ mu-zu he $e_{2}-\mathrm{i}-\mathrm{i}$ ur-dnamma! $\ulcorner\mathrm{x}\urcorner[\ldots]$

24' rev. $2 \quad \mathrm{su}_{6} \quad \mathrm{za}^{\prime} \mathrm{gin}_{3} \quad \mathrm{su}_{3}-\mathrm{su}_{3}\left\ulcorner^{\mathrm{x}} \mathrm{x}^{\urcorner}[\ldots]^{42}\right.$

25' rev. 3 lugal hi-li guru ${ }_{3}^{\text {ru }}$ me-lim $x_{x}$ k[alam-ma dul-la] (F 25)

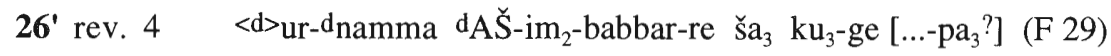

27' rev. 5 niğ $\hat{g}_{2}$-NE.RU igi-ni-šse ${ }_{3}$ nu-dib-ba ni $\hat{g}_{2}-\mathrm{s}\left[\mathrm{i}-\mathrm{sa}_{2}\right]$ (F 32)

28' rev. 6 dur-dnamma-ke ${ }_{4}$ nig $_{2}-$ gur $_{11} \mathrm{sa}_{2} \quad$ bi $_{2}-\mathrm{in}^{\mathrm{n}} \mathrm{du}_{11}$ (F 33)

29' rev. 7 'lugal-e` pa mul pa mul- ${ }^{\ulcorner} \mathrm{zu}^{\top}$

30' rev. 8 dur-dnamma-ke ${ }_{4}$ maš-gi-i(-)i- $\left.{ }^{\top} \mathrm{im}\right\urcorner-m e$

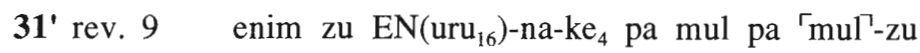

32' rev. 10 dur-dnamma-ke ${ }_{4}$ maš-gi-i(-) $)^{\Gamma}$-im-me (F 35)

33' rev. 11 lugal-e $\left.{ }^{\ulcorner} e_{2}\right\urcorner d^{\top}{ }^{2}$ su'en-na'-ke $e_{4}$ (F 36) 
13 On! the inside, the evil-doer does not [have access?] to the righteous plans. ${ }^{43}$

14' Ekišnugal, your interior (is) a dragon, the evil-doer cannot fathom it.

15' House, your g i g u n a ... your offerings ... lengthens,

16 At your d u b l a m a h, the place where fate is determined, all the great gods

17' Determine the fate.

18' The one worthy of the Etemenniguru,

19' Born [...]. He reveals? your [vigo]ur and [na]me indeed!

20' The comely lord [...], the faithful ..., Urnamma,

21' Ur [...].

22' The Esaga, like Utu ... [...].

23' He reveals? your vigour and name indeed! Urnamma . . . [...],

24' Wearing a long lapis lazuli beard ... . [...].

25' The king, full of charms, who has [covered the la]nd with radiance,

26' Urnamma, AŠimbabbar [has chosen?] in (his) precious heart!

27' Evil does not pass before him.

28 (Rather) Urnamma has imposed jus[tice] on property (matters).

29' The king - under your ${ }^{44}$ ramifying branches -

30' Urnamma is in charge,

31' The eloquent facing the obstinate - under your ramifying branches -

32' Urnamma is in charge.

33' May the king, at Su'en's temple,

43 Or, with a restoration - dab $_{s}$ ? (and omission of the ergative): "On! the inside, the evil-doer cannot [ seize?] the righteous plans".

44 i.e. the Ekiš nuĝal. 
34' rev. 12 dur-dnamma-- ${ }^{\top} \mathrm{ke}_{4} \mathrm{ni}_{2} \mathrm{he}_{2}{ }^{\top}$-eb-ši-ib ${ }_{2}$-te-en-te

35' rev. 13 lugal-e $i_{7}$ idigna $i_{7}$ buran[u]n-ke ${ }_{4}$ (F 37)

36' rev. 14 dur-dnamma-ke ${ }_{4}$ nam mu- ${ }^{r}{ }^{\top}{ }^{\top}-\mathrm{ib}$ !?(ZU)-ta[r-r]e

37' rev. 15 nin-bi nin nig $\hat{g}_{2}-$ gur $_{11}-$ ra-ke $_{4}$ nin $\mathrm{e}_{2}(-)[\ldots]$ (F 41)

38' rev. 16 dur-dnamma-ke ${ }_{4}$ nam mu-ni-'ib-tar?-[re] (F 42)

39' rev. 17 munus a ${ }^{\Gamma}$ nun-na'- $-\mathrm{ke}_{4} \mathrm{mi}_{2}$ zi-de $_{3}{ }^{\ulcorner} \mathrm{Cs}^{\top}[\ldots]$ (F 44)

40' rev. 18 d[ur-dnamma-k] ${ }_{4} \hat{G A}_{2} \cdot$ NE.N[A...] $(\mathrm{F} 45)$

[the end of the composition is not preserved]

\subsection{Transliteration and Translation of Urnamma $F$ (source B)}

1 obv. $1 \quad\left[\mathrm{uru}_{2} ?(\mathrm{x})\right] \mathrm{bad}_{3} ? \mathrm{ku}_{3}$-ga-ta hi-li guru ${ }_{3}^{\mathrm{ru}}$

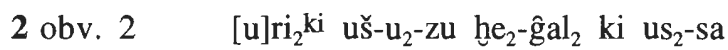

3 obv. 3 asil 3 -la $a_{2}$-a ${ }^{\top}$ uru $_{2}{ }^{\urcorner} u_{3}$-mu-un-zu he ${ }_{2}-a_{-}-u_{5} !(H U . R U)$

4 obv. $4 \quad$ dur-d ${ }^{\top}{ }^{n a m m a}{ }^{\top}$ he $_{2}-\mathrm{a}-\mathrm{u}_{5}$ ! (HU.RU)

5 obv. $5 \quad \mathrm{su}_{6}$ za-gin ${ }_{3} \mathrm{su}_{13}-\mathrm{su}_{13} \mathrm{he}_{2}-\mathrm{a}-\mathrm{u}_{5} !(\mathrm{HU} \cdot \mathrm{RU})$

6 obv. 6 gu ${ }_{2}$-en- ${ }^{\top}$ ta en ${ }^{\top}$ sukud-da $e_{3}$-de ${ }_{3}$-bi-ta nir gal ${ }_{2}$

7 obv. 7 abulla-zu e e mah gaba-šu-ĝar nu-tuku (E 1')

8 obv. 8 eš uri $_{2}$ ki $^{2} \check{s ̌ a}_{3}$-zu kur he he $_{2}$-gal ${ }_{2}$ bar-zu x x (x) (E 2')

9 obv. $9 \mathrm{e}_{2}$-kiš-nu-ĝal ${ }_{2}$ hur-saĝ galam-ma ša $\mathrm{s}_{3}$-bi $\mathrm{lu}_{2}$ nu-zu (E 3')

10 obv. $10 \quad e_{2}-z u !(S U)$ kur ge-rin-na mu-zu ša ${ }_{3}$ gur-ra (E 4'?)

11 obv. 11 en-zu en sa sa $^{-g a} \mathrm{pa}_{3}$-da (E 5') 
34 May Urnamma refresh himself!

35. For the king, the Tigris and the Euphrates, ${ }^{45}$

36 For Urnamma she determines the fate.

37. That lady, the lady of treasures, the lady of . . . [...],

38' Determines? the fate for Urnamma!

39' The woman of noble stock appropriately [...],

40' (For/) [Urnamma $\ldots . . . .]$.

1 [City?], at/from the splendid wall?, full of charms,

2 Ur, your foundations (are) abundance, firmly secured.

3 In jubilation, o city, your lord is indeed riding high!

4 Urnamma is indeed riding high!

5 The one wearing a long lapis lazuli beard is indeed riding high!

6 Placing confidence in the assembly and the eminent lord coming forth there of.

7 Whatever leaves your (city-)gate (is) a flood which has no counterpart.

8 Sanctuary Ur, your interior (is) a mountain (of) abundance, your façade is a

9 Ekišnugal, skilfully built mountain (range) whose interior nobody fathoms,

10 Your house is a blossoming mountain, your name is merciful.

11 Your lord, the comely lord, who is called by name,

45 Faulty $i_{7 i d i g n a} i_{3}$ buranun-ke ${ }_{4}$ is perhaps contaminated by the following ${ }^{d}{ }_{u r}-{ }{ }_{n a m m a-k e}$. Alternatively: "For the king, for the one of the Tigris and Euphrates". 
12 obv. 12 dumu dnin-sumun ${ }_{2}$ me-te kur-kur-ra (E 6')

13 obv. $13 \mathrm{e}_{2}$ me gal-zu rab digirir-re-e-ne kalam-ma $\operatorname{la}_{2}-\mathrm{am}_{3}$ (E 7'-8')

14 obv. $14 \quad \mathrm{KA}_{2}$-zu an-zu an $\mathrm{sa}_{7}$-ga mu pa ${ }_{3}$-da (E $\left.9^{\prime}\right)$

15 obv. 15 gal ${ }_{2}-\mathrm{TAKA}_{4} \cdot \mathrm{TAKA}_{4}$-ga dutu an-ur ${ }_{2}$-ta $\mathrm{u}_{4}$ mi-ni-in-gar-ra (E 10')

16 obv. $16 \quad \mathrm{gi}^{2}$ ?-sa ${ }_{2}{ }^{\top}$-zu ki nam tar-ra diĝir-re-e-ne di! $\mathrm{si}^{-\mathrm{sa}_{2}}$ kud-ru-de ${ }_{3}(\mathrm{E}$ $\left.11^{\prime}-12^{\prime}\right)$

17 obv. 17 [da-nu]n-na diĝir an-ki-ka ad mi-ni-in-ge-ge-'ne

18 obv. 18 [...](-) $)^{\ulcorner} \mathrm{x}^{\urcorner}$-zu-ta munus zi gir ${ }_{17}$-zal-a-a gu $_{2}$ peš-a

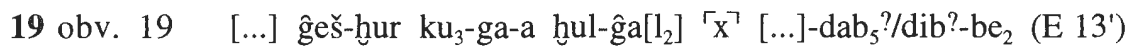

20 obv. $20 \quad$ [...gi-gu] $n_{4}$-na inda $a_{3}$-ba!-bi ki-bala IŠ $\left\ulcorner^{\top}\right][\ldots]$ (E 15')

21 rev. 1 [dub-la ${ }_{2}$-m]ah ki nam tar-re-za (E 16')

22 rev. 2 [digirir ga]l-gal-e-ne nam mi-ni-tar-re-ne (E 16'-17')

23 rev. $3 \quad \mathrm{ki}^{\urcorner}$-en-gi ki-uri ug $\hat{g}_{3}$ sag $\mathrm{gi}_{6}$-ga

24 rev. 4 dur-dnamma dsu'en ša ${ }_{3}$-ge ba-ni-in- pa $_{3}{ }^{46}$

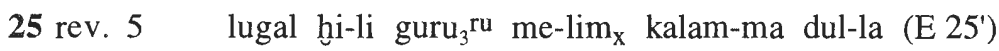

26 rev. 6 me-e(-)EN u u $_{3}$-mu-un-ra mi $_{2}$ zi-de ${ }_{3}$-eš

27 rev. 7 dur-dnamma ga-an-i-i-de 3

28 rev. 8 dur-dnamma hi-li guru ${ }_{3}^{\text {ru }}$ me-lim x $_{x}$ kalam-ma dul-la

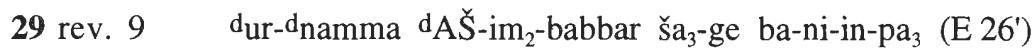

30 rev. 10 gešrab-ba kur-kur-ra im-mi-in-ĝar 
12 (Is) the son of Ninsumun, the adornment of all (the foreign) lands.

13 House, your great $\mathrm{m} \mathrm{e}$, the shackles of the gods, are suspended over the land.

14 Your gate (is) your heaven, an azure heaven which is called by name.

15 When Utu has set light from the horizon in the openings,

16 At your platform?, the place of fate determined by the gods, you render just judgments.

17 [The Anu]na, the gods of heaven and earth, confer with each other there.

18 At your [...] the good and proud woman has stiffened (her) neck,

19 [On the inside], the evil-doer does [not] have access? to the sacred plans. ${ }^{47}$

20 [... the $\mathrm{g} \mathrm{i} \mathrm{g} \mathrm{u]n} \mathrm{a,} \mathrm{its} \mathrm{offerings} \mathrm{...} \mathrm{the} \mathrm{rebellious} \mathrm{land} \mathrm{[ \ldots ],}$

21 At your [ $\mathrm{d}$ u b l a m]a h, the place where fate is determined,

22 All the gr[eat gods] determine the fate.

23 For Sumer and Akkad, for/among the black-headed people,

24 Su'en has chosen Urnamma in (his) heart.

25 The king, full of charms, who has covered the land with radiance,

26f. Let us extoll the lord, Urnamma, rightfully!

28 Urnamma, full of charms, who has covered the land with radiance,

29 Urnamma, AŠimbabbar has chosen in (his) heart!

$30 \mathrm{He}^{48}$ has put shackles on all (the foreign) lands,

\footnotetext{
47 Or, with a reading $-\mathrm{dab}_{5}$ ? (and omission of the ergative): "[ On the inside], the evil-doer cannot [seize? $]$ the sacred plans".

48 i.e. Urnamma.
} 
31 rev. 11 si-gar kala-ga im-mi-in-gi ${ }_{16}$-ba lugal dsu'en-ra tum t $_{2}$-ma-am

32 rev. 12 nigh 2 -NE.RU igi-ni-še ${ }_{3}$ nu-dib ${ }_{2}-$ be $_{2}$ (E 27')

33 rev. 13 nig $\hat{g}_{2}-$ si-sa $_{2}$ dur-dnamma nig $\hat{g}_{2}-$ gur $_{11}$ sa $_{2}$ bi $_{2}-$ in-du $_{11}$ (E 27'-28')

34 rev. 14 za-pa-ağ $\hat{2}_{2}-\hat{g a ~}_{2}$-ni-ŠE $E_{3}$ kur NE.RU-ma bi ${ }_{2}$-in-gar

35 rev. 15 ki-bala-bi mu-un-ŠUM ${ }_{2}{ }^{d}$ ur-dnamma maškim im-me (E 32')

36 rev. 16 lugal-e e ${ }_{2}^{\text {dsu'en-na-ke }}$ (E 33') $^{\prime}$ (E

37 rev. $17 \quad i_{7}$ idigna $i_{7}$ buranun $d u r-<d>$ namma-ke ${ }_{4} /$ nam mu-ni-ib $b_{2}-B I-t a r-$ re!(GI?) (E 35'-36')

38 rev. $18 \quad{ }^{d}$ utu $?$ an-ur - -ta $e_{3}$-a-ba

39 rev. 19 [nam-l] $\mathrm{u}_{2}-\mathrm{ulu}_{3}$ hu-mu-ši-ib ${ }_{2}$-daĝal-e-ne

40 rev. 20 [dumu? d]nin-sumun 2 -ka hu-mu-ni-in-dab ${ }_{5}-$ dab $_{5}-$ be $_{2} \mathrm{u}_{6}$ di-x

41 rev. 21 [nin-b]i nin nig $\hat{g}_{2}-$ gur $_{11}$-e ki-ag $\hat{g}_{2}$ (E 37')

42 rev. 22 [ki-a] $\hat{g}_{2}-\mathrm{ga}_{2}$-na-ke ${ }_{4}$ dur-d namma-ke ${ }_{4}$ nam mu-ni-ib-tar-re (E (37'-)38')

43 rev. $23[\mathrm{x}] \mathrm{x}(-)$ gal nin-bi nin nig $_{2}-$ gur $_{11}$-e ki-ag $\hat{g}_{2}$

44 rev. 24 [munus a] nun-na-ke ${ }_{4}$ dur-dnamma-ke nig $_{2}-$ gur $_{11}$-e ki-ag $\hat{g}_{2}(\mathrm{E}$ 39')

45 rev. 25 [sip]a dur-dnamma-ke ${ }_{4} I_{2}\left(\right.$ dubsig $\left._{\mathrm{x}}\right) \mathrm{e}_{2} \mathrm{~d}_{\text {su'en-na-še }}$ su $_{6} \quad$ za-gin $_{3}$ $\mathrm{su}_{13}-\mathrm{su}_{13}\left(\mathrm{E} 40^{\prime}\right)$

46 rev. $26[\ldots]$ AN nin x hu-mu-ni-ib-dab ${ }_{5}-$ dab $_{5}-$ be $_{2}$

47 rev. $27 \quad[\ldots]$ du $_{10}-$ ga-am 3 hii-li-ba $k_{7}-k_{7}$-dam-nu

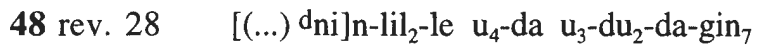

49 rev. $29\left[\left(\mathrm{ku}_{3}{ }^{?}\right) \mathrm{d}_{\mathrm{ni}}\right] \mathrm{n}-\mathrm{sumun}_{2}-\mathrm{na}-\mathrm{ke}_{4}$ za-e hu-mu-ra- $\mathrm{u}_{3}-\mathrm{du}_{2}$ 
31 He has blocked (them) with a strong bolt, he is the king who is worthy of Su'en.

32 Evil does not pass before him.

33 (Rather) Urnamma has imposed justice on property (matters).

34 He has set $<\ldots>^{49}$ as his roar on the enemy land.

35 He has imposed it on that rebellious land, Urnamma is in charge.

36 For the king, for Su'en's temple,

37 For the Tigris and the Euphrates, for Urnamma she determines the fate.

38 When Utu rises from the horizon,

39 May [the peo]ple spread out before him!

40 May the [son?] of Ninsumun take hold of it ${ }^{50}$ there, invoking? admiration.

41 Tha[t lady], the lady who loves treasures,

42 Determines the fate for Urnamma, her [belo]ved!.

43 ..., that lady, the lady who loves treasures,

44 [The woman] of noble [stock], she who loves treasures, <determines the fate $>$ for Urnamma.

$45 \mathrm{f}$. May [shephe]rd Urnamma take hold of the (work) basket for Su'en's temple, wearing a long lapis lazuli beard ...., [...].

$47[\ldots]$ is pleasant, is it not sweet in its attractiveness?

48 Like [...] whom [Ni]nlil gave birth to daily,

49 [(Dazzling?) Ni]nsumun has indeed given birth to you!

\footnotetext{
49 Perhaps referring to Urnamma's command, cf. the commentary ad 34-35, p. 288.

50 Perhaps referring to the (work) basket (cf. lines 45-46) with incorrect -in- before the verbal base (cf. line 17), or referring to the people of line 39.
} 
50 rev. 30 sipa-da an $\mathrm{ku}_{3}$-ga hu-m[u-...]

51 rev. 31 sipa dur-dnamma-da sag $[\ldots]^{51}$

šir $_{3}$-nam-šub-dnanna- ${ }^{-} \mathrm{kam} \Gamma / 51$ ? mu-bi

\subsection{A Synopsis of Urnamma EF: Recensions $E$ and $F$}

The line numbering follows Urnamma $\mathrm{F}$ (source B). The lines in Urnamma $\mathrm{E}$ that are lacking in Urnamma $F$ are given lower case letters ( $a, b$, etc.). Note that they have been fitted in with the line sequence of Urnamma F arbitrarily (cf. especially lines $24 \mathrm{a}-\mathrm{g}$ and $34 \mathrm{a}-\mathrm{c})$.

1 obv. 1 [uru ${ }_{2}$ ?(x)] bad ${ }_{3} ? \mathrm{ku}_{3}$-ga-ta hii-li $\operatorname{guru}_{3}{ }^{\mathrm{ru}}$

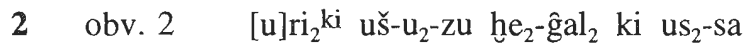

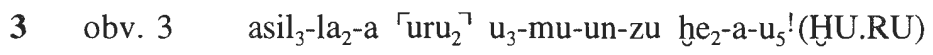

4 obv. 4 dur-d ${ }^{n}$ namma ${ }^{\top}$ he $_{2}-\mathrm{a}-\mathrm{u}_{5} !(\mathrm{HU} . \mathrm{RU})$

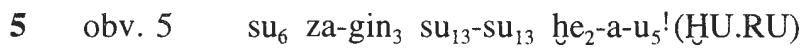

6 obv. 6 gu 2 -en- ${ }^{\ulcorner}$ta en $\urcorner$sukud-da $e_{3}$-de ${ }_{3}$-bi-ta nir gala ${ }_{2}$

7 obv. 7 abulla-zu $e_{3}$ a mah gaba-šu-gar nu-tuku obv. 1' [abul]la-zu $\left.\Gamma^{\prime}\right\urcorner[\ldots$

8 obv. 8 eš uri $_{2} \mathrm{ki}$ ša $_{3}$-zu kur he $_{2}$-ĝal ${ }_{2}$ bar-zu x x (x)

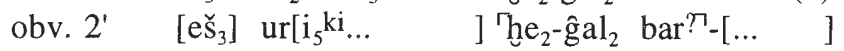

9 obv. 9 $\mathrm{e}_{2}$-kiš-nu-ĝal ${ }_{2}$ huur-saĝ galam-ma $\mathrm{s̆a}_{3}$-bi $\mathrm{lu}_{2}$ nu-zu

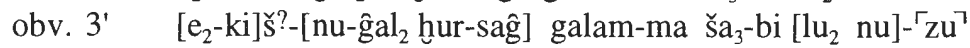

10 obv. 10 e $e_{2}$-zu!(SU) kur ge-rin-na mu-zu ša $a_{3}$ gur-ra obv. 4' ki ut-ti-z[u? kur? šem?] ğeš eren-na mu-zu-še ${ }_{3}$ UN ${ }^{\ulcorner} \mathrm{x}(\mathrm{x}){ }^{\urcorner}$

11 obv. 11 en-zu en sa $\mathrm{sa}_{7}$-ga mu $\mathrm{pa}_{3}$-da obv. $5^{\prime}$ en-zu en sa-ga mu $\mathrm{pa}_{3}$-da 
50 With the shepherd in the brilliant heaven indeed she [...]!

51 With the shepherd Urnamma [...] the head!

(It is a $\breve{s}$ i r n a m š u b of Nanna, it has 51 ? lines)

1 [City?], at/from the splendid wall?, full of charms,

2 Ur, your foundations (are) abundance, firmly secured.

3 In jubilation, o city, your lord is indeed riding high!

$4 \quad$ Urnamma is indeed riding high!

5 The one wearing a long lapis lazuli beard is indeed riding high!

6 Placing confidence in the assembly and the eminent lord coming forth there of.

7 Whatever leaves your (city-)gate (is) a flood which has no counterpart. [...] your [(city-)ga]te [...].

8 Sanctuary Ur, your interior (is) a mountain (of) abundance, your façade is a ...,

[Sanctuary] Ur, [...] abundance, [...] façade? [...],

9 Ekišnugal, skilfully built mountain (range) whose interior nobody fathoms, [Eki]š[nugal], skilfully built [mountain (range)] whose interior [nobody] fathoms,

10 Your house is a blossoming mountain, your name is merciful. Your? place where daylight breaks, (is) a [mountain? of fragrant?] cedar, at your name, the people/land. . ..

11 Your lord, the comely lord, who is called by name, Your lord, the comely lord, who is called by name, 
12 obv. 12 dumu dnin-sumun 2 me-te kur-kur-ra obv. 6' dumu dnin-' ${ }^{\prime}$ sumun $_{2}$-ka me-te kur-kur-ra

13 obv. 13 e $e_{2}$ me gal-zu rab digir-re-e-ne kalam-ma $\operatorname{la}_{2}-\mathrm{am}_{3}$ obv. $7^{\prime}-8^{\prime}$ uri ${ }_{5} \mathrm{ki}$ me gal-zu a-ra ${ }_{2}$-ab digir-re- nel kalam-ma gal ${ }_{2}$-la

a obv. 8' ' teš $\left._{2}\right\urcorner$ mu-zu he he $_{2}$-i-i

14 obv. $14 \quad \mathrm{KA}_{2}$-zu an-zu an $\mathrm{sa}_{7}$-ga mu $\mathrm{pa}_{3}$-da obv. 9' $9^{\prime} \mathrm{KA}_{2}-\mathrm{zu} \quad$ an $\mathrm{sa}_{7}-\mathrm{ga}$ su-zi $\mathrm{guru}_{3}{ }^{{ } \mathrm{ru}}{ }^{\top}$

15 obv. 15 gal gaKA $_{4}$-TAKA TA $_{4}$ ga dutu an- ur $_{2}$ - ta $u_{4}$ mi-ni-in-gar-ra obv. 10' gal $_{2}-\mathrm{TAKA}_{4} \cdot \mathrm{TAKA}_{4}$-ga dutu an- ${ }^{\ulcorner} \mathrm{ur}_{2}{ }^{\urcorner}$-ta $\mathrm{u}_{4}$ mi-'ne ${ }^{752}$-gar-ra-ta

16 obv. 16 ' $\mathrm{gi}^{\text {? }}$-sa ${ }_{2}$-zu ki nam tar-ra digirir-re-e-ne di! si-sa ${ }_{2}$ kud-ru-de ${ }_{3}$ obv. 11'f. gi-ša $\mathrm{a}_{3}$-zu-ta ki nam tar-re diĝir-re- ne / di si-sa $\mathrm{ku}_{5}$ !-me-en

a obv. 12' te $\check{s}_{2}$ mu-zu he $\mathrm{he}_{2}-\mathrm{i}-\mathrm{i}$

17 obv. 17 [da-nu]n-na diĝir an-ki-ka ad mi-ni-in-ge-ge- $\ulcorner$ ne

18 obv. 18 [...](-) $)^{\Gamma} x^{\urcorner}$-zu-ta munus zi gir ${ }_{17}-z a l-a-a ~ g u_{2}$ peš-a

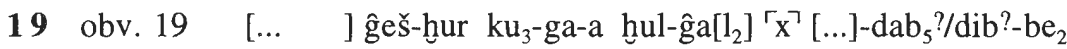
obv. 13' ša ${ }_{3}$-ga-ta ĝeš-hुur zi-da hul-ĝal ${ }_{2}$ nu-[dib?- $\quad$ b]e $e_{2}$

a obv. 14' $\mathrm{e}_{2}$-kiš-nu-ĝal ${ }_{2}$ ša $_{3}$-zu ušumgal ḩul-ĝal ${ }_{2}$ nu-[u]n-zu

20 obv. 20 [...gi-gu]n $n_{4}$-na inda ${ }_{3}$-ba!-bi ki-bala IŠ $\Gamma_{\mathrm{x}}{ }^{\urcorner} \quad[\ldots]$

obv. 15' e $_{2}$ gi-gun 4 -na-zu nidba-zu LIL LIM/GIR $_{2}$ ? den-[li] $l_{2}$ ? sud deru $_{4}$

21 rev. 1 [dub-la $-m$ ] ah ki nam tar-re-za

obv. 16' dub-la ${ }_{2}-$ mah ki nam tar-re-za

22 rev. 2 [diĝir ga]l-gal-e-ne nam mi-ni- tar-re-ne obv. 16'f. digir gal-gal-e-ne I nam mi-ni-ib-tar-re-ne

23 rev. 3 ki -en-gi ki-uri ug $\hat{g}_{3}$ sag gi $\mathrm{i}_{6}$-ga 
12 (Is) the son of Ninsumun, the adornment of all (the foreign) lands.

(Is) the son of Ninsumun, the adornment of all (the foreign) lands.

13 House, your great $m \mathrm{e}$, the shackles of the gods, are suspended over the land. Ur, your great $\mathrm{m}$ e, the shackles of the gods, are positioned over the land.

a $\quad \mathrm{He}^{53}$ reveals? your vigour and name indeed!

14 Your gate (is) your heaven, an azure heaven which is called by name.

Your gate (is) the azure heaven, full of awe.

15 When Utu has set light from the horizon in the openings, After Utu has set light from the horizon in the openings,

16 At your platform?, the place of fate determined by the gods, you render just judgments.

At your platform?, the place where fate is determined by the gods, you render just judgments.

a He reveals? your vigour and name indeed!

17 [The Anu]na, the gods of heaven and earth, confer with each other there.

18 At your [...] the good and proud woman has stiffened (her) neck,

19 [On the inside], the evil-doer does [not] have access? to the sacred plans. ${ }^{54}$ On! the inside, the evil-doer does not [have access?] to the righteous plans. ${ }^{55}$

a Ekišnugal, your interior (is) a dragon, the evil-doer cannot fathom it.

20 [...the $\mathrm{g}$ i $\mathrm{g} \mathrm{u}$ ]n a, its offerings ... the rebellious land [...], House, your g i g u n a ... your offerings... lengthens,

21 At your [ $\mathrm{d} \mathrm{u} \mathrm{b} \mathrm{l} \mathrm{a} \mathrm{m]a} \mathrm{h,} \mathrm{the} \mathrm{place} \mathrm{where} \mathrm{fate} \mathrm{is} \mathrm{determined,}$ At your $\mathrm{d} \mathrm{u} \mathrm{b} \mathrm{l}$ a $\mathrm{m}$ a h, the place where fate is determined,

22 All the gr[eat gods] determine the fate.

All the great gods determine the fate.

23 For Sumer and Akkad, for/among the black-headed people,

\footnotetext{
53 i.e. Urnamma.

$54 \mathrm{Or}$, with a reading $-\mathrm{dab}_{5}$ ? (and omission of the ergative): "[ On the inside], the evil-doer cannot [seize? $\mathrm{e}^{\text {? }}$ the sacred plans".

55 Or, with a restoration $-\mathrm{dab}_{5}$ ? (and omission of the ergative): "On! the inside, the evil-doer cannot [ seize?] the righteous plans".
} 
24 rev. 4 dur-dnamma dsu'en ša ${ }_{3}$-ge ba-ni-in-pa ${ }_{3}^{56}$

a obv. 18' $\mathrm{e}_{2}$-temen- $\mathrm{ni}_{2}-{ }^{-}$guru $_{3}$ ru’ tum $_{2}$ !-ma

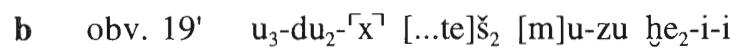

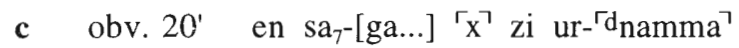

d obv. $21^{\prime} \quad$ ur $\left[\mathrm{i}_{5}{ }^{\mathrm{ki}} \ldots\right]$

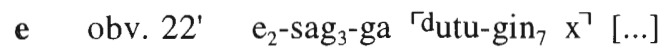

f rev. 1 teš $\check{2}_{2}$ mu-zu hye $\mathrm{e}_{2}-\mathrm{i}-\mathrm{i}$ ur-dnamma! $\left\ulcorner_{\mathrm{X}} \mathrm{x}^{\urcorner}[\ldots]\right.$

g rev. $2 \quad \mathrm{su}_{6} \quad \mathrm{za}^{\mathrm{gin}} \mathrm{gu}_{3}-\mathrm{su}_{3} \mathrm{su} \mathrm{x}[\ldots]^{57}$

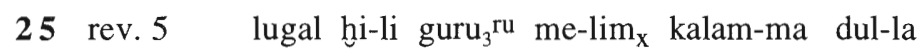

rev. 3 lugal hi-li guru ${ }_{3}^{\text {ru }}$ me-lim $x$ k[alam-ma dul-la]

26 rev. 6 me-e(-)EN u $u_{3}$-mu-un-ra mi $_{2} \quad$ zi-de $_{3}$-eš

27 rev. 7 dur-dnamma ga-an-i-i-de

28 rev. 8 dur-dnamma hil-li guru ${ }_{3}^{\text {ru }}$ me-lim ${ }_{x}$ kalam-ma dul-la

29 rev. 9 dur-dnamma dAŠ-im ${ }_{2}$-babbar ša ${ }_{3}$ ge ba-ni-in-pa

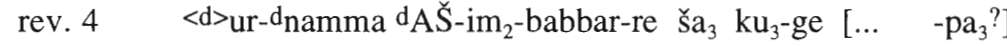

30 rev. 10 ĝešrab-ba kur-kur-ra im-mi-in-ĝar

31 rev. 11 si-ĝar kala-ga im-mi-in-gi ${ }_{16}$-ba lugal dsu'en-ra tum ${ }_{2}-$ ma-am $_{3}$

32 rev. 12 nig $\hat{g}_{2}$-NE.RU igi-ni-še $e_{3}$ nu-dib ${ }_{2}-$ be $_{2}$

rev. 5 niğ ${ }_{2}$-NE.RU igi-ni-šs ${ }_{3}$ nu-dib-ba

33 rev. 13 nig $\hat{g}_{2}-$ si-sa $_{2}$ dur-dnamma nig $\hat{g}_{2}-$ gur $_{11} \quad \mathrm{sa}_{2} \quad$ bi $_{2}-$ in-du $_{11}$

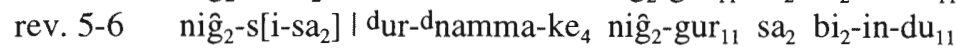


24 Su'en has chosen Urnamma in (his) heart.

a The one worthy of the Etemenniguru,

b Born [...]. He reveals? your [vigo]ur and [na]me indeed!

c The comely lord [...], the faithful . .., Urnamma,

d Ur $[\ldots]$.

e The Esaga, like Utu ... [...].

f He reveals? your vigour and name indeed! Urnamma . . . [...],

g Wearing a long lapis lazuli beard ... [...].

25 The king, full of charms, who has covered the land with radiance, The king, full of charms, who has [covered the la]nd with radiance,

26f. Let us extoll the lord, Urnamma, rightfully!

28 Urnamma, full of charms, who has covered the land with radiance,

29 Urnamma, AŠimbabbar has chosen in (his) heart!

Urnamma, AŠimbabbar [has chosen?] in (his) precious heart!

$30 \mathrm{He}^{58}$ has put shackles on all (the foreign) lands,

31 He has blocked (them) with a strong bolt, he is the king who is worthy of Su'en.

32 Evil does not pass before him.

Evil does not pass before him.

33 (Rather) Urnamma has imposed justice on property (matters).

(Rather) Urnamma has imposed jus[tice] on property (matters). 


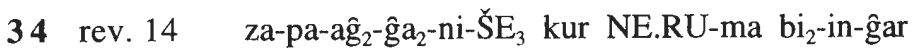

a rev. $7 \quad\ulcorner$ lugal-e $\urcorner$ pa mul pa mul- $\left.\mathrm{zu}^{\mathrm{r}}\right\urcorner$

b rev. 8 dur-dnamma-ke ${ }_{4}$ maš-gi-i(-)i-'im?-me

c rev.9 enim zu EN( uru $\left._{16}\right)$-na-ke ${ }_{4}$ pa mul pa ${ }^{\top}$ mul ${ }^{-}$-zu

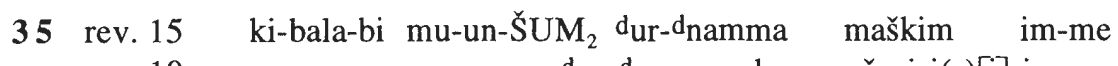
rev. 10 dur-dnamma-ke ${ }_{4}$ maš-gi-i(-) ${ }^{r} i-i m-m e$

36 rev. 16 lugal-e $e_{2} d_{\text {su'en-na-ke }}$ rev. 11 lugal-e ${ }^{e_{2}}{ }^{\urcorner} \mathrm{d} \Gamma$ su'en-na'-ke ${ }_{4}$

a rev. 12 dur-dnamma- ${ }^{-\mathrm{ke}_{4}} \mathrm{ni}_{2} \mathrm{hge}_{2}{ }^{\urcorner}$-eb-ši-ib $\mathrm{b}_{2}$-te-en-te

37 rev. $17 \quad i_{7}$ idigna $i_{7}$ buranun dur- $<\mathrm{d}>$ namma-ke ${ }_{4} /$ nam mu-ni$\mathrm{ib}_{2}$-BI- tar-re!(GI?)

rev. 13-14 lugal-e $i_{7}$ idigna $i_{7}$ buran[u]n-ke $\left.\right|_{4}$ dur-d namma-ke ${ }_{4}$ nam mu- ${ }^{-}$i? ib!?(ZU)-ta[r-r]e

38 rev. 18 rdutu? an-ur ${ }_{2}$-ta $e_{3}$-a-ba

39 rev. 19 [nam-l] $\mathrm{u}_{2}$-ulu $\mathrm{u}_{3}$ hu-mu-ši-ib ${ }_{2}$-daĝal-e-ne

40 rev. 20 [dumu? d] nin-sumun ${ }_{2}$-ka hu-mu-ni-in-dab ${ }_{5}-$ dab $_{5}-$-be $_{2} \mathrm{u}_{6}$ di-x

41 rev. 21 [nin-b]i nin nig $_{2}-$ gur $_{11}-\mathrm{e} \quad \mathrm{ki}-\mathrm{ag} \hat{g}_{2}$

rev. 15 nin-bi nin nig $\hat{g}_{2}-$ gur $_{11}-\mathrm{ra}^{-\mathrm{ke}_{4}}$ nin $\mathrm{e}_{2}(-)[\ldots]$

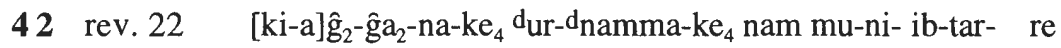

rev. 16 dur-d namma-ke $_{4}$ nam mu-ni- $-1 \mathrm{ib}-\operatorname{tar} ?$-[re]

43 rev. 23 [x] x(-)gal nin-bi nin nig $\hat{g}_{2}-\operatorname{gur}_{11}-\mathrm{e}$ ki-ag $\hat{g}_{2}$

44 rev. 24 [munus a] nun-na-ke ${ }_{4}{ }^{d}{ }_{u r-d}{ }^{d}$ amma-ke ${ }_{4}$ nig $\hat{g}_{2}-$ gur $_{11}$-e ki-ag $\hat{g}_{2}$ rev. 17 munus a ${ }^{\top n u n-n a\urcorner-k_{4}}$ mi $_{2}$ zi-de $_{3}-{ }^{\Gamma} \mathrm{es}^{\top}[\ldots]$ 
34 He has set $\langle\ldots\rangle^{59}$ as his roar on the enemy land.

a The king - under your ${ }^{60}$ ramifying branches -

b Urnamma is in charge,

c The eloquent facing the obstinate - under your ramifying branches -

35 He has imposed it on that rebellious land, Urnamma is in charge.

Urnamma is in charge.

36 For the king, for Su'en's temple, May the king, at Su'en's temple,

a May Urnamma refresh himself!

37 For the Tigris and the Euphrates, for Urnamma she determines the fate.

For the king, the Tigris and the Euphrates, ${ }^{61}$ for Urnamma she determines the fate.

38 When Utu rises from the horizon,

39 May [the peo]ple spread out before him!

40 May the [son?] of Ninsumun take hold of $i t^{62}$ there, invoking? admiration.

41 Tha[t lady], the lady who loves treasures,

That lady, the lady of treasures, the lady of . . . [...],

42 Determines the fate for Urnamma, her [belo]ved!

Determines the fate for Urnamma!

43 ..., that lady, the lady who loves treasures,

44 [The woman] of noble [stock], she who loves treasures, <determines the fate > for Urnamma.

The woman of noble stock appropriately [...],

59 Perhaps referring to Urnamma's command, cf. the commentary ad 34-35, p. 288.

60 i.e. the Ekiš nuĝal.

61 Faulty ${ }_{i}$ idigna $i_{\text {b }}$ buranun-ke $e_{4}$ is perhaps contaminated by the following ${ }{ }_{u r}-d_{\text {namma-ke }}$. Alternatively: "For the king, for the one of the Tigris and Euphrates".

62 Perhaps referring to the (work) basket (cf. lines 45-46) with incorrect -in- before the verbal base (cf. line 17), or referring to the people of line 39 . 
45 rev. 25 [sip]a dur-dnamma-ke ${ }_{4} I L_{2}\left(\right.$ dubsig $\left._{\mathrm{x}}\right) \mathrm{e}_{2} \mathrm{~d}_{\text {su'en-na-še }_{3}} \mathrm{su}_{6} \quad \mathrm{za}^{\prime} \mathrm{gin}_{3}$ $\begin{array}{ccc}\text { rev. } 18 & \mathrm{su}_{13}-\mathrm{su}_{13} \\ \mathrm{~d}\left[\mathrm{ur}-\mathrm{d}_{\text {namma-k]e }}\right. & \text { GA }_{2} \cdot \mathrm{NE} . \mathrm{N}[\mathrm{A} . . .]\end{array}$

46 rev. 26 [...] AN nin x hu-mu-ni-ib-dab - dab $_{5}-$ be $_{2}$

47 rev. 27 [...] du du $_{10}$ ga-am ${ }_{3}$ hi-li-ba $k_{7}-k_{7}$-dam-nu

48 rev. $28 \quad\left[(\ldots) d_{\text {ni }}\right]$ n-lil 2 -le $u_{4}$-da $u_{3}$-du - da-gin 7

49 rev. $29\left[\left(\mathrm{ku}_{3}\right.\right.$ ?) dni]n-sumun ${ }_{2}-$ na-ke $_{4}$ za-e hu-mu-ra- $\mathrm{u}_{3}-\mathrm{du}_{2}$

50 rev. 30 sipa-da an $\mathrm{ku}_{3}$-ga hu-m[u-...

51 rev. 31 sipa dur-dnamma-da sag $[\ldots]^{63}$ $\breve{s i r}_{3}$-nam-šub-dnanna- 'kam! / 51? mu-bi 
45f. May [shephe]rd Urnamma take hold of the (work) basket for Su'en's temple, wearing a long lapis lazuli beard . . ., [...].

(For/) [Urnamma] ... . [...].

$47[\ldots]$ is pleasant, is it not sweet in its attractiveness?

48 Like [...] whom [Ni]nlil gave birth to daily,

49 [(Dazzling?) Ni]nsumun has indeed given birth to you!

50 With the shepherd in the brilliant heaven indeed she [...]!

51 With the shepherd Urnamma [...] the head!

(It is a $\breve{s}$ i r n a m š u b of Nanna, it has 51 ? lines) 


\subsection{Collective Philological Commentary}

As in the synopsis, line numbers refer to Urnamma F (source B), lower case letters to Urnamma E (source A).

1 The restoration $\mathrm{u} \mathrm{r} \mathrm{u}_{2}$ "city" is very uncertain but would be a plausible parallel to $\mathrm{u} \mathrm{r} \mathrm{i}_{2} \mathrm{k} \mathrm{i}$ "Ur" in line 2.

2 Note the unusual writing u $\check{s}-\mathrm{u}_{2}$ for u $\check{\mathrm{s}} u \check{s ̌ s} u$ "foundations".

$\mathrm{he}_{2}-\mathrm{gaI}_{2} \quad \mathrm{ki} \quad \mathrm{us}_{2}-\mathrm{s} \mathrm{a}$ appears in similar context in Sulgi $\mathrm{O} 3$

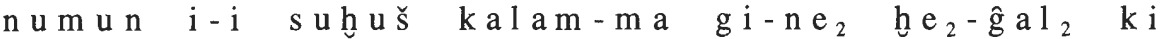
$\mathrm{u} \mathrm{s}_{2}-\mathrm{s}$ a "It (= the sanctuary Ur) makes the seed come forth, makes the foundation of the land firm, (is) abundance, firmly secured".

3 The verb $\mathrm{u}_{5}$ has the meanings a.) "to mount" rakābu, with (locative-) terminative, in parallelism with $\mathrm{z} \mathrm{i} \mathrm{.} \mathrm{g}$ "to raise, to lift"; as result of the action $\mathrm{b}$.) "to be mounted, to be seated, to ride (high)", with locative, in parallelism with $\mathrm{du} \mathrm{r}_{2}$ g a r "to be seated, to sit", and c.) "to lift, to carry high", with absolutive, in parallelism with $\mathrm{g} \mathrm{u} \mathrm{r} \mathrm{u}_{3}$ "to carry". In particular, $\mathrm{u}_{5}$ is used in the sense of 1 . "to ride away" i.e. "to flee", with ablative infix: cf. e.g. the references in Michalowski, Lamentation 94 ad 271-276; 2. "to copulate", said of animals: e.g. Enl.sudr. 152; 3. "to embark", with (locative-)terminative, "to sail (on a boat)", with locative: cf. e.g. the references in Römer, AOAT 232 (1993) 350ff.; 4. "to be mounted, to be seated on", with locative(-terminative), i.e. on concrete objects, like animals: e.g. Ninmešara 14, Ininšagura 105, Römer, Studies Kraus (1982) 303 (= CT 15 15f.) obv. 9; waves and floods: e.g. Kramer, Studies Birot (1986) 120 (= BM 86535) ii obv. 103-iii obv. 104, Sjöberg, OrSuec 19/20 (1970/1) 142 (= UM 29-13-609) ii obv. 21'; storm: e.g. Römer, ibid. 303 (=CT 15 15f.) obv. 8; on abstract objects, like the m e: cf. Klein, Studies Tadmor (1991) 306 ad 3 with previous literature; 5. "to carry high", with absolutive, i.e. abstract objects, like awe: Gudea, Cyl. B 13:18. In this line the object on which Urnamma rides high is not mentioned. Maybe the connotation is that Urnamma is firmly established as the lord of the Ekišnugal, cf. above ad b.).

6 e n s u k u d-d a "eminent lord" also appears in Šūilišu A (= Isin *4) 8 e n s u kud-da ka la-ga ki š i b- $1 \mathrm{a}_{2}(-\mathrm{e})$ t u ku n a - m e e $\mathrm{n}$ e - r a n u - g u b - b u "Eminent and strong lord, having a wrist (= strength), whom nobody can withstand".

9 The tentative restorations in Urnamma E $3^{\prime}$ are solely based on the parallel version of Urnamma F 9.

10 For the uncertain restoration [.. k u r ? š e m ?] ĝ e š e r e n- $\mathrm{n}$ a " mountain? of fragrant? cedar" in Urnamma E 4', based on Urnamma F 10, and said of the Ekišnughal, cf. Charpin, Clergé 290 ad 5 with literature. ĝ e š e r e n "cedar" might be attracted by image (cf. e.g. Enlil and Sud 148) and sound to g e - 


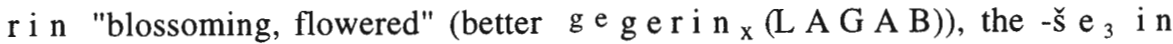

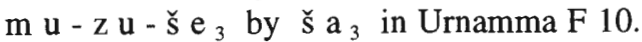

Cohen, JAOS 95 (1975) 598 ad 4 interpreted $\mathrm{k} \mathrm{i} \mathrm{u} \mathrm{t}-\mathrm{t} \mathrm{i}$ as a non-standard writing of $\mathrm{k} \mathrm{i} \quad \mathrm{u}_{6} \quad \mathrm{di}$ "place of admiration". I tentatively suggest a non-standard writing for $\mathrm{ki}{\mathrm{dut} \mathrm{u} / \mathrm{u}_{4}}_{\mathrm{e}_{3}}(-\mathrm{a})$ "place where the sun rises/the daylight breaks" on the following grounds: the close association with $\mathrm{k} \mathrm{u} \mathrm{r}$ s e m g e š e r e n - n a (cf. Sjöberg, TCS 3 [1969] 90 ad 192), should the restoration indeed be correct; the context, in general, which centres on the Ekišnugal as a place where the wicked await judgment and justice is administered, but specifically line 10 ' where Utu, the judge who perceives everything, illuminates the entryways (for temple gates and the $\mathrm{kid} \mathrm{u} \mathrm{u/} \mathrm{u} \mathrm{u}_{4} \quad \mathrm{e}_{3}(-\mathrm{a})$ as places of judgment, cf. the commentary ad Urnamma A 58 and 211); other references for $\mathrm{k} \mathrm{i} \mathrm{d} \mathrm{u} \mathrm{t} \mathrm{u} \mathrm{/} \mathrm{u}{ }_{4}$ $\mathrm{e}_{3}$ ( - a ) in association with a temple (e.g. Temple Hymns 192, Nungal 9).

13 For ( $\hat{\mathrm{g}} \mathrm{e} \check{\mathrm{s}}$ ) $\mathrm{r}$ a b rappu, a restraining device, hence translated here as "shackle", of which a - $\mathrm{ra}_{2}-\mathrm{a}$ b in Urnamma E 7' is presumably a non-standard writing, cf. most recently Civil, Studies Hallo (1993) 74 ad 31.

$14 \mathrm{a} \mathrm{n}-\mathrm{zu}$ a $\mathrm{n} \cdot \mathrm{s}_{7}-\mathrm{g}$ a is influenced by $\mathrm{e} \mathrm{n}-\mathrm{zu}$ e $\mathrm{n} \quad \mathrm{s} \mathrm{a}_{7}-\mathrm{g}$ a in line 11. Because a $\mathrm{n} \mathrm{s} \mathrm{a}_{7}-\mathrm{g}$ a "azure heaven", whether likened to a gate (e.g. Nungal 13), some part of it (e.g. Gudea, Cyl. A 21:13-14) or the temple in general (e.g. Gudea, Cyl. A 21:7-8, Cyl. B 16:10) is such a common topos I read a n "heaven" rather than d i g i r "god" (pace Cohen, JAOS 95 [1975] 598 ad 9). Compare also Urnamma C 4 i ri an-gin $\mathrm{s} \mathrm{a}_{7}-\mathrm{ga} \quad \mathrm{hi}-1 \mathrm{i} \quad \mathrm{guru}{ }_{3}^{\mathrm{ru}}$ "City, azure like the heavens, full of luxuriance".

16 As Cohen suggests $\mathrm{g} \mathrm{i}$ ? $-\mathrm{s} \mathrm{a}_{2}$ and $\mathrm{g} \mathrm{i}-\check{\mathrm{s}} \mathrm{a}_{3}$ may be connected with the well attested / kissa/, written $\mathrm{ki}-\mathrm{s} \mathrm{a}_{2} /{ }_{5}$ and $\mathrm{kiss}$ (K I . S E S . K A K . A) "platform" for which cf. now Suter, ZA 87 (1997) 6ff. The Ekišnugal's description continues from a general to a more detailed interior view, first describing the sanctuary as a whole and then the gate. Note that in UET $610514 \mathrm{ff}$. (Charpin, Clergé 287) the / k i s s a / is the platform for the Abzu, presumably a reed hut with a water basin that one reached after entering the gate and the courtyard and which was situated in front of the main cella (cf. Sallaberger, Kalender 184, and fn. 872 with literature; also Frayne, BiOr. 45 [1988] 354 ad "p. $\left.335^{\prime \prime}\right)$. As in our passage, the / $\mathrm{k}$ i s s a / is preceded by terms describing parts of the gate. "The place where the gods determine fate" is otherwise said of the $\mathrm{d} \mathrm{u} \mathrm{b}$ $1 \mathrm{a}_{2}-\mathrm{m}$ a h (cf. lines 21-22 = Urnamma E 16'-17'; in general Charpin, Clergé 332 and Michalowski, Lamentation 103 ad 438) from which one had access to the ziggurat (cf. Urnamma E 18'). Perhaps there was confusion between / k i s s a / and $\mathrm{du} \mathrm{b}-1 \mathrm{a}_{2}$ which can follow terms for parts of gates (e.g. Nungal 14ff.; Temple Hymns 30ff.), or this inner part of the Ekišnugal, perhaps the location of the Abzu, was indeed a place where justice was administered (e.g. Enki's Journey to Nippur 44).

In view of Urnamma $\mathrm{E} \mathrm{12'} \mathrm{k} \mathrm{u}_{5}-\mathrm{m} \mathrm{e}-\mathrm{e} \mathrm{n}, \mathrm{k} \mathrm{u} \mathrm{d}-\mathrm{r} \mathrm{u}-\mathrm{de}_{3}$ stands probably for $\mathrm{k} \mathrm{u} \mathrm{d-ru-de}{ }_{3}-\mathrm{e} \mathrm{n} \mathrm{/} \mathrm{k} \mathrm{u} \mathrm{d} \mathrm{r} \mathrm{u} \mathrm{de} \mathrm{(n} \mathrm{)/,} \mathrm{cf.} \mathrm{Attinger,} \mathrm{Eléments} \mathrm{194,} \S$ 
126 with literature. For temples or places which render judgments, cf. e.g. Temple Hymns 496.

$17 \mathrm{a} \mathrm{n-ki-ka} \mathrm{is} \mathrm{probably} \mathrm{a} \mathrm{n-ki-ka(m)} \mathrm{for} \mathrm{expected} \mathrm{a} \mathrm{n-ki} \mathrm{-}$ $\mathrm{ke}_{4}-\mathrm{n}$ e (collective with plural in the verbal form). Note also - $\mathrm{n}-$, instead of - $b$-, before the verbal base (also in line 40 vs line 46 ).

18 This line has many problems and the translation offered is tentative. For g i $\mathrm{r}_{17}-\mathrm{zal}-\mathrm{a}-\mathrm{a}=\mathrm{g} \mathrm{ir}_{17}-\mathrm{zal}-1 \mathrm{a}-\mathrm{am}$ and $\mathrm{pes} \breve{s}-\mathrm{a}=\mathrm{pes}-\mathrm{am}_{3}$, cf. lines $30 \mathrm{~g}$ e š $\mathrm{rab}-\mathrm{b}$ a and $31 \mathrm{im}-\mathrm{mi}-\mathrm{in}-\mathrm{gi}_{16}-\mathrm{b}$. For $\mathrm{gi}_{17}-\mathrm{zal}-$ $\mathrm{a}-\mathrm{a}$ determining munus $\mathrm{zi}$.d (in parallelism with hu $\mathrm{h}-\mathrm{g} \mathrm{al}_{2}$ "evildoer"), cf. s u 1 g i $\mathbf{r}_{17}-\mathrm{za} 1$ ( - 1 a ) "the proud young man", commented on by Volk, FAOS 18 (1989) 217 ad 20.

19 Instead of the faulty $\breve{s} a_{3}-g a-t a$ in Urnamma E 13' $\mathrm{s} \mathrm{a}_{3}-\mathrm{zu}-\mathrm{t}$ a in analogy to $\mathrm{g} \mathrm{i}-\breve{s}_{\mathrm{a}}-\mathrm{zu}-\mathrm{t}$ a in line 11' is expected (the copy seems to rule out a reading $\check{s} \mathrm{a}_{3}-\mathrm{b} \mathrm{i}-\mathrm{t}$ a which would also be semantically unsatisfactory).

20 In view of $\mathrm{n} \mathrm{idb}$ a in Urnamma E 15', a reading in $\mathrm{da}_{3}-\mathrm{b}$ a is more likely than $\mathrm{n} \mathrm{i} \hat{\mathrm{g}}_{2}-\mathrm{b}$ a. Note that the sign after $\mathrm{n} \hat{\mathrm{g}}_{2}$ is not $\mathrm{a}$ clear $-\mathrm{b} \mathrm{a}$ on the copy (photo hardly legible).

$24 \mathrm{e} \mathrm{e}_{2}-\mathrm{s} \mathrm{a} \mathrm{g}_{3}-\mathrm{g}$ a is enigmatic. v. Dijk, Sagesse 63 ad 26 proposes an equation with $\mathrm{e}_{2} \mathrm{~s}$ i-g a "silenced house".

26-27 $\mathrm{m} \mathrm{i}_{2} \mathrm{zi}-\mathrm{de}_{3}$-e š i - i "to extoll rightfully" can be compared with $\mathrm{m} \mathrm{i}_{2}$ - b i i - i, for which cf. Attinger, Eléments 612, § 646. For final dropping of $/ \mathrm{n} /$ in $\mathrm{ga}-\mathrm{an}-\mathrm{i}-\mathrm{i}-\mathrm{de}_{3}$, cf. the commentary ad 16 .

$\mathrm{me}-\mathrm{e}(-) \mathrm{EN}$ is unclear to me. One expects a form like $\mathrm{me}-\mathrm{e} \mathrm{n}-\mathrm{de}_{3}$.

29 Note that the king's name is deified in the second $\mathrm{k}$ i r u g u section of Urnamma $\mathrm{E}$ (lines $28^{\prime}, 30^{\prime}, 32^{\prime}, 34^{\prime}, 36^{\prime}, 38^{\prime}, 40^{\prime}$ ) in contrast to the first $\mathrm{k}$ i $\mathrm{r} u \mathrm{~g} \mathrm{u}$ section, perhaps indicating that Urnamma $\mathrm{E}$ was compiled from two different models. In line 26' the scribe still seems to have been influenced by line $24 \mathrm{f}$ which has $\mathrm{ur}-\mathrm{d} \mathrm{n} \mathrm{a} \mathrm{m} \mathrm{m}$ a and thus omitted the determinative.

34-35 The object of $\hat{g}$ a r "to set" in line 34 and $\breve{S} U_{2}$ "to impose" in line 35 seems to have been omitted in the process of transmission. I tentatively suggest e $\mathrm{n}$ i $\mathrm{m}$ "word, command" in view of Urnamma E 31' (with reinterpretation), cf. immediately below, line $34 \mathrm{~b} / 35$.

$34 \mathrm{a} / \mathrm{c} \mathrm{p}$ a $\mathrm{m} \mathrm{u} l \mathrm{p} \mathrm{a} \mathrm{m} \mathrm{u}-\mathrm{zu}$ "under/at your ramifying branches" in Urnamma E 29' $\| 3^{\prime}$ ' may be an insertion in 2 nd person referring to and anticipating "Su'en's temple", i.e. the Ekišnugal, in line 33'. For pa (-) m u 1 in association with a temple, rather than referring to kings or gods, compare perhaps Enmerkar and the Lord of Aratta 342-343 || 384-385 p a m u 1 - m u 1 - 1 a - b i $\mathrm{e}^{\mathrm{s}_{3}} \mathrm{e}_{2}-\mathrm{an}-\mathrm{na}-\mathrm{ke}_{4}(/ \mathrm{ka}) / \mathrm{ku}_{3} \quad \mathrm{~d} \mathrm{inana}-\mathrm{ke}_{4} \quad \mathrm{ni}_{2} \quad \mathrm{i} \mathrm{m}-\check{\mathrm{s}} \mathrm{i}-$ $\mathrm{i} b-\mathrm{t}$ e - e $\mathrm{n}-\mathrm{t} \mathrm{e}$ "Under its (= Enmerkar's sceptre) ramifying branches - (being) the sanctuary Eana - dazzling Inana refreshes herself" (S. Cohen, ELA $129 \| 131$, accepted by Powell, BSA 6 [1992] 100, contra Jacobsen, Harps 302). For the topos of refreshing oneself under the shade of a building, cf. Sulgi G 61-62 and Klein, Studies Tadmor (1991) 312f. ad 60-62. 
For e $\mathrm{n} \mathrm{i} \mathrm{m} \mathrm{z} \mathrm{u}$ "the one who knows the word/the affairs = eloquent" in Urnamma E 31', cf. Volk, FAOS 18 (1989) 219 ad 24 with previous literature.

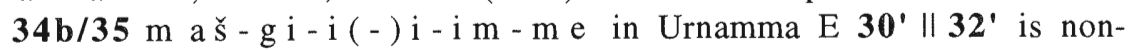
standard and Sandhi-writing of $\mathrm{m}$ a š k i m i m-m e in Urnamma F 35.

$\mathrm{ki}-\mathrm{b}$ al a-bi $\mathrm{mu}-\mathrm{u} \mathrm{n}-\breve{\mathrm{S}} \mathrm{UM}_{2}$ may be associated with e $\mathrm{n}$ i m $\mathrm{z} \mathrm{u}$

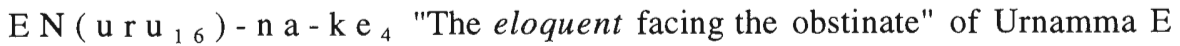
31', with EN ( $\left.\mathrm{u} \mathrm{r} \mathrm{u}_{16}\right)$ - $\mathrm{na}(-\mathrm{k})$ reflecting $\mathrm{ki}-\mathrm{bal}$ a and $\mathrm{e} \mathrm{im}$ "word, command" being the omitted object of $\breve{S} \mathrm{UM}_{2}$. $\breve{S} \mathrm{UM}_{2}$ has either a reading $\mathrm{s} \mathrm{i}_{3}$. g "to throw", or $\check{\mathrm{s}} \mathrm{u} \mathrm{\textrm {m } _ { 2 }}$ "to give".

36 Note that $\mathrm{e}_{2} \mathrm{~d}_{\mathrm{S} \mathrm{u}}$ ' $\mathrm{e} \mathrm{n}-\mathrm{n} \mathrm{a}-\mathrm{k} \mathrm{e}_{4}$ has been reinterpreted differently in $\mathrm{E}$ and $F$, i.e. it shows a different syntactical function in Urnamma $E$ 33' (in view of the added succeeding line $36 \mathrm{a}=\mathrm{E} 34^{\prime}$ ) than in Urnamma $\mathrm{F} 36$.

40 For [ $\mathrm{du} \mathrm{m} \mathrm{u}$ ? d ] n i n - s u m u n ${ }_{2}-\mathrm{ka}$ ( $\left.\mathrm{m}\right)$, cf. above, line 17. The restoration [ $\mathrm{du} \mathrm{m} \mathrm{u}$ ? ] is very uncertain.

41 The epithet $\mathrm{nin} \mathrm{ni} \hat{g}_{2}-\mathrm{g} \mathrm{ur}_{11}-\mathrm{e} \mathrm{ki}-\mathrm{ag}{ }_{2}$ "the lady who loves treasures" exhibits the same word formation and shares a common semantic field with $\mathrm{nin} \mathrm{s}$ a g - e $\mathrm{ki}-\mathrm{a} \mathrm{g}_{2}$, an epithet of Ba'u, and $\mathrm{ur}-\mathrm{s}$ a g $\mathrm{n} \mathrm{i} \hat{\mathrm{g}}_{2}$ $\mathrm{b}$ a - e k i - a $\hat{g}_{2}$, said of Ningirsu, and discussed in Steible, FAOS 9/2 (1991) 45 ad 4. Both $\mathrm{n}$ i $\mathrm{n} \mathrm{n} \mathrm{i} \hat{\mathrm{g}}_{2}-\mathrm{g} \mathrm{ur}_{11}-\mathrm{e} \mathrm{k} \mathrm{i}-\mathrm{a} \mathrm{g}_{2}$ "the lady who loves treasures" and $\mathrm{n} \mathrm{i} \mathrm{n} \mathrm{n} \mathrm{i} \hat{\mathrm{g}}_{2} \quad \mathrm{~g} \mathrm{u} \mathrm{r}_{11}-\mathrm{r}$ a "the lady of treasures" in Urnamma $\mathrm{E} \mathrm{37}$ ' look like a re- or misinterpretation of $\mathrm{d} N \mathrm{~N} \mathrm{~N}-\mathrm{n}$ i g a r ( $\mathrm{g}$ a $\mathrm{r} / \mathrm{m}$ a $\mathrm{r}-\mathrm{r}$ a), a goddess associated with Ningal and Ninsumun in SF I i 13-15 (cf. also Krebernik, ZA 76 [1986] 199 s.v. dNIN-nigar) and also with Inana (Krecher, Kultlyrik 128ff. ad II 13, Black, ASJ 7 [1985] 43 ad 163, and Sallaberger, Kalender 129 and vol. II 129, chart 75). d N I N-n i g a r ( $\mathrm{g}$ a r / ma r - r a ) takes her name from the $\left(\mathrm{e}_{2}\right)$ $\mathrm{n}$ i g a r ( $\hat{\mathrm{g}}$ a $\mathrm{r} / \mathrm{m}$ a $\mathrm{r}-\mathrm{r}$ a ), probably a shrine as part of cult places known from various localities and of which the $\mathrm{e}_{2} \quad \mathrm{ni}_{3}-\mathrm{g} \mathrm{a}_{2}-\mathrm{r}$ a in Sulgi Y 23, part of Ningal's temple complex in Nippur, is a non-standard writing (cf. Sjöberg, TCS 3 [1969] 92f. ad 206 and Black, ibid.).

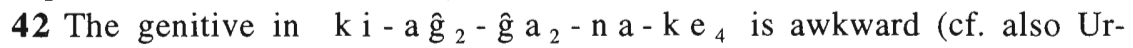
namma $\mathrm{E} \mathrm{35}$ ). In view of $\mathrm{n}$ i $\mathrm{n} \quad \mathrm{e}_{2}(-)$ [ . . . ] "the lady of [...]" in Urnamma $\mathrm{E}$ 37', Urnamma F may have omitted a syntagm in the process of transmission (cf. also lines 34-35 above).

44 a n u n-n a "the one(s) of noble stock" follows Edzard, ZA 78 (1988) 142.

Is "she determines the fate" included in this line or do we have a line omission?

45-46 The translation offered is very tentative in view of the strange word order.

$47 \mathrm{ku}_{7}-\mathrm{ku}_{7}-\mathrm{dam}-\mathrm{nu}$ is unclear $(-\mathrm{nu}$ as negative copula after the copula!).

49 As $\mathrm{u}_{3}-\mathrm{du}_{2} . \mathrm{d}$ "to give birth" is constructed with the absolutive, the ablative - $\mathrm{r}$ a - infix in the verbal chain stands perhaps for $\{\mathrm{T} \mathrm{A}\}$ but is still difficult to explain. Another possibility is to translate "[Ni]nsumun has indeed given birth to [...] for you", in which case $\mathrm{z}$ a - e is an error for $\mathrm{z} \mathrm{a}-\mathrm{r}$ a. 


\section{U R N A M M A G}

\subsection{Introduction}

\section{Manuscript}

The only source for this $\mathrm{b}$ a l b a le of Enlil is an unnumbered text of unknown provenance in the Oriental Institute, columns ii-iii. J.A. Brinkman kindly permitted me to collate this text and a description of the tablet and a transliteration of the lines have been made available to me by M. Civil (letter 1/26/94). This is what he writes: "Lower part of a tablet of unknown origin. The convex side has two columns ca. $50 \mathrm{~mm}$ wide, the flat side has three columns of 27 to $29 \mathrm{~mm}$. The column length can be estimated at ca. 34 lines, at least on the flat side, judging from the duplicate text (see below). The convex side has to be considered the obverse and the flat one the reverse.

On the convex side, the left column contains a text almost identical to Sulgi Z (S.N. Kramer, Iraq 31 [1969] 18-23), but substitutes Su-Suen's name for that of Šulgi; the right column contains the Urnamma text which apparently ends in the rightmost column of the flat side, leaving the rest of this column uninscribed. The two left columns of the flat side must have been ca. 34 lines long and duplicate the Nanna song published by Åke Sjöberg in MNS 1 13ff. (Nanna A:3-9, 38-56)."

This tablet then seems to have contained at least two b a l b a l e compositions of different deities, namely Enlil and Nanna, and possibly a third, probably of Inana: the subscript for Sulgi $\mathrm{Z}$ is missing but it is very likely that this hymn about Inana and Šūsu'en, respectively Sulgi, was a b a l b a l $\mathrm{e}^{1}$ of Inana. Additional, indirect evidence comes from the entries in the literary catalogue TMH $N F 354$ (HS 1504) which lists Nanna A, the b a 1 b a l e of Nanna in $T M H N F$ 47 ii 67-iii 106 in lines 2-3, followed by the incipit of Sulgi Z. ${ }^{2}$

\section{Structural Analysis}

The first six lines of this short $\mathrm{b}$ a l b a le of Enlil are broken but must have contained a kind of narrative introduction (in 3rd person) that continues to line 8.

\footnotetext{
1 Cf. already Wilcke, Kollationen 41 ad III 54: HS 1504 ad line 4.

2 Cf. also IV 3.1, p. 76 , fn. 211.
} 
Enlil has supplied Urnamma with agricultural prosperity. Lines $9 \mathrm{ff}$. set off a praise (in 2nd person) of Urnamma as the faithful farmer who keeps his fields well. This section which presumably continues to the end of the composition shows a formal pattern with line pairs exhibiting the alternation epithet/PN, e.g. lines 13-14, 16$17,19-20,22-23$. Note that between every line pair falls one line of a descriptive, rather than poetic nature, though line 15 takes up the refrain $\mathrm{G} \mathrm{ANA}_{2}$ () $\mathrm{g} a \mathrm{r}-\mathrm{zu} \mathrm{du} \mathrm{u}_{10}-\mathrm{g} \mathrm{a}-\mathrm{a} \mathrm{m}_{3}$ "your prepared field is good" which is introduced in line 10 and repeated in lines 13-15. Refrains are a common feature in b a $l$ b a $l$ e compositions. ${ }^{3}$

\section{Source}

Unknown:

A/ unnumbered, columns ii-iii convex side ii $7^{\prime}-23^{\prime}=\mathbf{7 - 2 3}$

flat side iii $1^{\prime}-2^{\prime}=\mathbf{2 6 - 2 7}$

collation: E. Flückiger-Hawker, cf. pl. 25.

photos could not be made available due to reconstruction work at the Oriental Institute Museum. 


\subsection{Transliteration and Translation ${ }^{4}$}

\section{1-6 ii $1^{\prime}-6{ }^{\prime} \quad[\ldots]$}

7 ii $7^{\prime}$ den-lil $1_{2}-$ le dur!-dnamma-ra m[u-...]

8 ii $8^{\prime} \quad$ a-eštub dezina 2 še gu-nu saĝ-e-eš hye ${ }_{2}-{ }^{-}$mu-rig ${ }_{7}$

9 ii 9' dur-dnamma ug $\hat{g}_{3}$-e nam-hुe ${ }_{2}$-a $\quad$ gu ${ }_{2}$ hu-mu-u ${ }_{8}$-di-ni-ib-mar-re

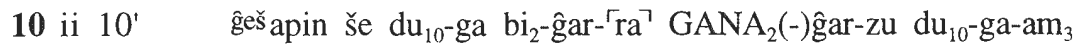

11 ii $11^{\prime}$ geš numun $\mathrm{se}^{5} \mathrm{du}_{10}$ geš apin ${ }^{6} \mathrm{GANA}_{2}$ nam $\mathrm{bi}_{2}{ }^{7}-\mathrm{du}_{10}$-ge

$\mathbf{1 2}^{7}$ ii $12^{\prime}$ gešapin še $\mathrm{du}_{10}$-ge ki? kur? $\mathrm{x}(\mathrm{x}) \mathrm{GANA}_{2}$ nam $\left.{ }^{\mathrm{bi}} \mathrm{i}_{2}-\mathrm{x}-\mathrm{x}\right\urcorner$

13 ii $13^{\prime} \quad$ lugal gud-de ${ }_{3}$ GANA $_{2}$ gar-am ${ }_{3}-$ ma GANA $_{2}(-)^{\Gamma}$ garr ${ }^{\top}-\mathrm{zu} \mathrm{du}_{10}$-ga-am $_{3}$

14 ii $14^{\prime}$ dur-dnamma GANA gar-am $_{3}$-ma $\left.{ }^{\ulcorner} \mathrm{GANA}_{2}\right\urcorner(-)$ gar-zu du ${ }_{10}$-ga-am

15 ii $15^{\prime} \quad$ GANA $_{2}$ gar-ra-za gud-de ${ }_{3}$ ba-sa GANA $_{2}(-)$ gar-za du ${ }_{10}$-ga-am 3

16 ii $16^{\prime} \quad$ lugal-ĝu $u_{10}$ GANA $_{2}$ den-lil $1_{2}-\mathrm{la}_{2}-\mathrm{ka}_{2}$ šu ḩa-ba-e-ni-du

17 ii 17 ur-dnamma GANA ${ }_{2}$ den-lil $1_{2}-\mathrm{la}_{2}-$-ka a $_{2} \Gamma_{\text {š ha }}{ }^{\urcorner}$-ba-e-ni-du

18 ii $18^{\prime} \quad$ ab- $\sin _{2}$ gub-ba-zu im an-na si $\mathrm{hge}_{2}-\mathrm{em}^{\urcorner}-\mathrm{ma}-\mathrm{ni}-\mathrm{in}^{\prime}-\mathrm{sa}_{2}$

19 ii $19^{\prime}$ lugal engar zi $\mathrm{GANA}_{2}$ dagal-la $\mathrm{eg}_{2} \mathrm{pa}_{5}$-re ki ${ }^{\mathrm{x}}{ }^{\urcorner}[\ldots]$

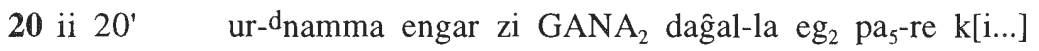

21 ii $21^{\prime} \quad$ eg $_{2} \mathrm{pa}_{5}$-re dutu $\mathrm{e}_{3}-\mathrm{gin}_{7}$ igi-bi $\mathrm{m}[\mathrm{u}-\ldots]$

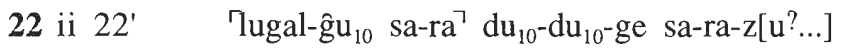

\footnotetext{
4 Due to many difficulties encountered in this text the translation given here is very provisional. 5 Written over an erasure.

6 Between apin and GANA 2 probably erasure or gap where at least two signs could have been placed.

7 This line in smaller script has been squeezed in after finishing the text.
} 


\section{1-6 [six lines not preserved]}

7 Enlil has for Urnamma [...].

8 He has indeed presented (him) with the early flood, wheat and mottled barley.

9 O Urnamma, may he ${ }^{8}$ make the people thrive? in abundance with you!

10 The plough that you have prepared for? the good barley and your prepared field are good.

11 Wood, seeds, good barley, the plough and the field - (all) these you? make good,

12 The plough making the barley good,$^{10}$ the ground? ..., and the field - (all) these you?....

13 O Lord, prepare the field for the oxen, your prepared field is good,

14 O Urnamma, prepare the field, your prepared field is good!

15 In the field which you have prepared the oxen are doing well, in your prepared field they are good!

16 O my lord, you have indeed done all necessary work for/in the field of Enlil,

17 O Urnamma, you have indeed done all necessary work for/in the field of Enlil.

$18 \mathrm{He}^{11}$ indeed directed the rain of heaven right into the furrow which you have drawn.

19 O Lord, faithful farmer of the broad fields, [you] ... [...] embankments and ditches,

20 O Urnamma, faithful farmer of the broad fields, [you...] embankments and ditches.

21 (For) embankments and ditches, like the rising sun, [you] have . . [...]. ${ }^{12}$

22 O my lord, making the ... good, your? ... [...],

\footnotetext{
8 i.e. Enlil.

9 Or: "O Urnamma, he (= Enlil) verily makes the people thrive? in abundance with you!".

10 Or: "The plough for the good barley $(\ldots)^{\prime}$.

11 i.e. Enlil.

12 Or: "Embankments and ditches, like the rising sun, have . . . [...]".
} 
23 ii $23^{\prime} \quad$ [ur-dnamma sa-ra du $\mathrm{du}_{10}$-d] $\mathrm{u}_{10}$-ge sa-ra- ${ }^{\mathrm{zu}} \mathrm{zu} \mathrm{x}^{\urcorner}[\ldots]$

24 ii $24^{\prime} \quad$ [...]

25 ii $25^{\prime} \quad[\ldots]$

26 iii $1^{\prime} \quad[\ldots]$ si $\mathrm{i}[\mathrm{n}-\ldots]$

27 iii $2^{\prime} \quad{ }^{\prime} \mathrm{x}-\mathrm{mu} \mathrm{u}^{\top}$-ra-an-gur ${ }^{\mathrm{x}} \mathrm{x} \cdot[\ldots]^{13}$

'bal -bal-e den-lil ${ }_{2}-\left[\mathrm{la}_{2}-\mathrm{kam}\right] / 27$ [mu?-bi?]

13 Civil notes that "it seems unlikely that the line has to be read ${ }^{r} \mathrm{x}-\mathrm{mu}^{\top}-\mathrm{ra}{ }^{\mathrm{d}} \mathrm{ur}$ !- ${ }^{\mathrm{rd}}[\mathrm{namma} . .$.$] ; the sign GUR is$ here quite different from the preceding URs". 
23 [O Urnamma, making the ... g]ood, your? ... [...].

24-27 [Four lines not preserved or too broken to translate]

(It is a b a $1 \mathrm{~b}$ a $1 \mathrm{e}$ of Enlil, [it has?] 27 [lines?]) 


\subsection{Philological Commentary}

8 For this topos, cf. the commentary ad Urnamma C 20-23. As Urnamma is presumably the receiver, one expects a prefix chain $-\mathrm{m} \mathrm{u}-\mathrm{n} \mathrm{i}-$ instead of the awkward - $\mathrm{m}$ u -.

9 For this line with the enigmatic $\mathrm{g} \mathrm{u}_{2} \mathrm{~m}$ ar (- $\left.\mathrm{m} \mathrm{ar}\right)$, cf. the commentary ad Urnamma B 14-16 where we encounter the same verbal form.

$10 \mathrm{G} \mathrm{A} \mathrm{NA}_{2}$ ( - ) g a r, here probably a "compound noun" (of the $\mathrm{sa}_{2}-\mathrm{du}_{11^{-}}$ type), is attested in Enlil and Ninlil 9 (=merreštu) and designates a certain quality of field. G A N A 2 g a r is also found in SP Coll. 2159 (cf. Falkowitz, Sumerian Rhetoric Collections 281f., 487, 544) where $\mathrm{g}$ a r refers to an action preceding ploughing ( $\mathrm{u} \mathrm{r} \mathrm{u}_{4}$ ).

18 Compare the similar content in Urnamma C 20-21.

19-20 e $\mathrm{ng}$ a r $\mathrm{zi}$. d "faithful farmer" as an epithet of a king is attested in royal inscriptions (cf. also Falkenstein, $S G L 52$ ad 60 with previous literature) of Lipiteštar (RIME 4.1.5.1:4-6 II), Nūradad (RIME 4.2.8.5:3) and Rīmsîn (RIME 4.2.14.17:27 II). It is used as an epithet of Ninurta in Farmer's Almanac 109, Lugale 727 and possibly in the Song of the Plowing Oxen 4, restored according to Civil, AOAT 25 (1976) 87.

22-23 s a - $r$ a as a noun appears also in Išmedagān A 320 (unpub. sources) $d_{i} \check{s}-m e-d a-g a n-\mathrm{m} \mathrm{e}-\mathrm{e} \mathrm{n} \quad \mathrm{s} \mathrm{a}-\mathrm{r} \mathrm{a}-\mathrm{g} \mathrm{u} \quad \mathrm{h}_{\mathrm{e}}{ }_{2}-\mathrm{s} \mathrm{a}_{6}$ "I am Išmedagān, may my ... be pleasant!". It may be the same noun as in the term $\mathrm{s}$ a (-) $\mathrm{r}$ a A $\mathrm{K}$ which is found in connection with rites during the cutting of barley, in Sallaberger, Kalender 267, and fn. 1252. 


\section{UR N A M M H}

\subsection{Introduction}

\section{Previous studies ${ }^{I}$ and manuscripts}

The fragmentary source A was mistakenly considered as a royal inscription of Urnamma and numbered 37 in W.W Hallo, HUCA 33 (1962) 28. I. Kärki transliterated and translated the fragment in StOr. 58 (1986) 24. H. Steible defines source A as possibly literary and Old Babylonian in FAOS 9/2 (1991) 143. It is not clear if source $B$, also in a fragmentary state, is actually part of the composition. The last line of source B could be the catchline of A. In the following transliteration, source B follows source A. Both sources were kindly collated by Ph. Jones and S. Tinney.

\section{Sources}

Nippur:

A CBS 15046

obv. $1-4=\mathbf{1 - 4}$

copy: A. Poebel, PBS 5 (19) 40.

collations: $\mathrm{Ph}$. Jones, S. Tinney.

B N 1511 (unpub.)

obv. $1^{\prime}-6^{\prime}=\mathbf{5 - 1 0}$

collations: $\mathrm{Ph}$. Jones, S. Tinney. 


\subsection{Transliteration and Translation}

1 A obv. 1 ur-dnamma lugal [kalam-ma (...)]

2 A obv. 2 sud-ra 2 bad-DU $\ulcorner x\urcorner[\ldots]$

3 A obv. 3 ĝeš esi $\left\ulcorner^{S A R}-x(-)[\ldots]\right.$

4 A obv. 4 'KA?-ge-zu? [...]

[break of unknown length]

5 B obv. 1' [...] 'HUR ${ }^{\prime}$ [...]

6 B obv. 2' [...k] $\mathrm{u}_{3}$ za-gin ${ }_{3}$-na $n[a m . .$.

$7 \mathrm{~B}$ obv. 3' $[\ldots \mathrm{k}] \mathrm{u}_{3}-\mathrm{gin}_{7}$ kalam-ma $[\ldots]$

8 B obv. 4' [...] x 'HUU?.UD $[x]$ edin-n[a...

$9 \mathrm{~B}$ obv. 5' [piri]g? 'ušumgal! igi ${ }^{\Upsilon 2} \mathrm{il}_{2}$ KA-ni [...]

10 B obv. 6' [ur-d]namma luga[l] 'kalam? ${ }^{\top}$-ma $\Gamma^{\top}$ sud-ra ${ }^{\urcorner}$[bad-DU] 
1 Urnamma, king [of the land (...)],

$2 \quad[\ldots]$ long and remote $[\ldots]$.

3 Ebony ... [...].

$4 \quad \ldots[\ldots]$.

$5 \quad[\ldots] \ldots[\ldots]$.

$6[\ldots]$ of silver and lapis lazuli [...],

$7 \quad[\ldots]$ like silver/. . . in the land [...].

$8 \quad[\ldots] \ldots$ of $/$ in the steppe $[\ldots]$.

$9 \quad[\operatorname{Lio}] n(\mathrm{~s})$ ? and dragon(s), looking at . . . [...].

10 [Ur]namma, king of the land, long and [remote...]. 


\section{A LEXICAL INDEX OF URNAMMA C OMPOS ITION S}

The following lexical index is a list of all words and idiomatic expressions or compounds found in compositions pertaining to Urnamma. These include the hymns, the royal inscriptions, the year names, the prologue of Codex Urnamma, and the so-called Cadaster text. Also included are ISET 1119 (p. 177) = Ni. 4375 and IB 1537 rev. v'-vi', an Old Babylonian copy of a royal inscription, published by C. Wilcke in B. Hrouda (ed.), Isin-Išān Bahrīyāat III, Die Ergebnisse der Ausgrabungen 1983-84, ABAW NF 94, München (1987) 109 and pl. 44. The indexing of the royal inscriptions is based on $\mathrm{H}$. Steible, Die neusumerischen Bauund Weihinschriften, Teil 2: Kommentar zu den Gudea-Statuen, Inschriften der III. Dynastie von Ur, Inschriften der IV. und "V." Dynastie von Uruk, Varia, FAOS 9/2, Stuttgart (1991) 93-152, with the addition of Al-Rawi, Sumer 46 (1989-90) $84 f$., that of the year names on M. Sigrist, T. Gomi, The Comprehensive Catalogue of Published Ur III Tablets, Bethesda (1991) 319f., except that the numbers 1-17 appear in quotation marks (cf. I 1., p. 5, fn. 37). The indexing of the prologue of Codex Urnamma follows the latest edition of D.R. Frayne, RIME 3/2 (1997) 46-49. The Cadaster text is cited according to F. Kraus, "Provinzen des neusumerischen Reiches von Ur", ZA 51 (1955) 46-48 (copies tbls. I-IV). Alphabetization follows common practice as e.g. apparent in the PSD. Syntagms composed of noun + adjective and noun + genitive have been indexed alphabetically under their initial word and indented. The genitive (-k) has been been noted only if attested in the text. For practical reasons the syntagm noun + verb has generally not been treated as the above mentioned syntagms but rather as separate entry, except in some cases with one or only a few noun + verb syntagms under the initial word, where it seemed appropriate to index the syntagm under the noun and indent it. In these cases convention rather than consistency is followed. Subsequent words are referred to $(\rightarrow)$ the initial word and in turn listed alphabetically if there are numerous entries. References are also made to non-standard writings and variants. Postpositions (except the absolutive) are generally given in the translation of verbs to show their grammatical construction. A, B, C, D, E, F, G, and $\mathrm{H}$ refer to the hymns followed by the line number. The Susa version of Urnamma A is specifically marked with (Susa) after the line number, as are the recensions of Urnamma D with (Ni) and (Ur) respectively. A capital letter in parenthesis, referring to the source, gives the textual variant (if noteworthy) to the line of the specific hymn in question. CU followed by the line number refers to Codex Urnamma. Bold numbers followed by (column and) line numbers indicate royal inscriptions. "year name" followed by a number stands for "Urnamma year name 
$\mathrm{x}^{\prime \prime}$. An asterisk * after the line number indicates that the entry is discussed in the commentary to that line.

Note further the following abbreviations:

\begin{tabular}{|c|c|}
\hline abl. & ablative \\
\hline abs. & absolutive \\
\hline broken & $\operatorname{sign}(\mathrm{s})$ broken or restored \\
\hline $\mathrm{CN}$ & canal name \\
\hline com. & comitative \\
\hline dat. & dative \\
\hline $\mathrm{DN}$ & divine name \\
\hline ep. $x$ & epithet of $\mathrm{x}$ \\
\hline $\mathrm{ES}$ & Emesal \\
\hline GN & geographical name \\
\hline h. & hamtu \\
\hline loc. & locative \\
\hline loc.-term. & locative-terminative \\
\hline$m$ & marû \\
\hline obscure & context broken and therefore obscure \\
\hline pl. & plural \\
\hline PN & proper name \\
\hline poss. & possessive \\
\hline sg. & singular \\
\hline suff. & suffix \\
\hline term. & terminative \\
\hline $\mathrm{TN}$ & temple name \\
\hline var. & variant \\
\hline$\rightarrow$ & refer to $\mathrm{x}$ \\
\hline$\|$ & parallel with $x$ \\
\hline $\mathrm{x}$ & unreadable sign \\
\hline$x^{*}$ & word discussed in the commentary to that line \\
\hline
\end{tabular}

a A

1. "water, drink":

2. "offspring, seed, semen":
a kur-ra
a mah
"the drink of the netherworld": A 83
a dnin-tu.r
"flood": $\mathbf{F} 7$
a nun
"Nintur's water": $\rightarrow \mathrm{i}_{7}$-a-d nin-tu.r
"noble stock": $\rightarrow$ munus a nun-na(-k)

a B

"O!" (exclamation): $\rightarrow$ non-standard $\mathrm{a}_{2} \mathrm{~A}$

a lu lugal-ĝu $_{10} \quad$ "O my man/lord!": A 186

a ša $\mathrm{a}_{3}-\mathrm{gu}_{10} \mathrm{du}_{11} \cdot \mathrm{g} \quad$ "to say 'O my heart!'": A $16 ; \rightarrow$ var. $\mathrm{a}_{2} \breve{s ̆}_{3}-\mathrm{guu}_{10} \mathrm{du} \mathrm{u}_{11} \cdot \mathrm{g}$

a-a

"father": $\rightarrow$ kur-gal a-a den-lil 2

$a-a b(-b a)(-k)$

"sea waters": 28, 1:14; $\rightarrow$ gaba a-ab-ka(-k) 


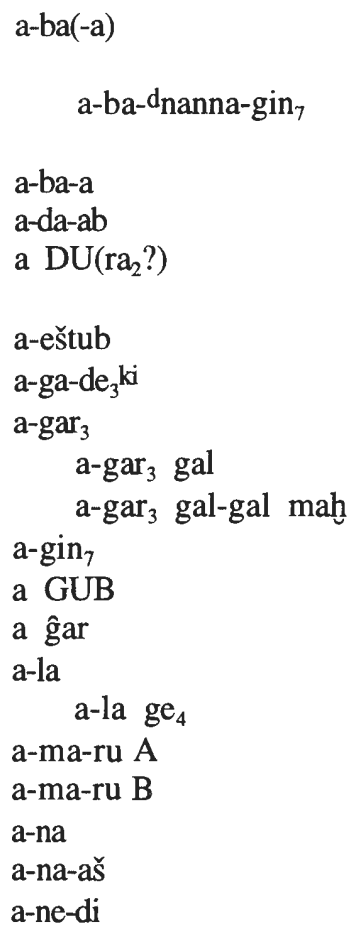

a ru

a-RU.b/-ub

a-ša $a_{3} \cdot g$ a-ša ${ }_{3}$-d nu-muš-da kiri ${ }_{8}$-tabki a-ša ${ }_{3}$-dsu'en

a ša $\mathbf{k u}_{3}$-ge ri

a šu ba.r "who?": A 208 || 209; D (Ni) 1-4; D (Ur) 1' (broken)5'; 7'; 9'

"Who-is-like-Nanna?" (name of embankment): 27, 2:7 (broken)

"back side": Cadaster A ii 18; iii 13; iv 2

"a d a b-instrument": A 187*

"to carry water": D (Ni) 25 ॥ 26*; 33 (broken) ॥ 34; D (Ur) 32'; 34'

"early flood": A 22; C 23*; G 8

GN Agade: $\rightarrow$ ma-da a-ga-de ${ }_{3} \mathbf{k i}$

"arable tracts, fields": A 23

"large arable tract(s)": D (Ur) 37'

"all the large and grand arable tracts": A 226

"thus": A 58* (broken)

uncertain meaning: A 203

"to irrigate": D (Ur) 4'; $\rightarrow$ i $_{7}(-) \hat{G E S ̌ . B I . G ̂ E S ̌(-) a(-) g a r-r a ~}$

"vitality, happiness": A 51; $\rightarrow$ var. alan

"to bring pleasure": A $151^{*} ; \rightarrow$ var. la-la-bi ge $_{4}$

"storm, flood": A 237; C 57*

non-standard "quiver": A 88* (Susa); $\rightarrow \mathrm{e}_{2}$-mar-uru

"what?": A 162

"why?": A 213 (C, F)

$\rightarrow \mathrm{ki}$ a/e-ne-di/de ${ }_{3}$ gal $_{2}$-la; $\rightarrow$ e-ne-di hul hla; $_{2} \rightarrow$ nonstandard e-ne-de 3

"to follow joyfully, to relax": C 81 *

"lament": A 193; 220; 242; $\rightarrow$ i-lu a-nir nig ${ }_{2}$ gig-ga; $\rightarrow$ $\mathrm{u}_{2}$ a-nir

"to set up laments": A 10

DN Anuna(-gods): A 53; 131 (broken); 135 (Susa); 158; F 17 (broken)

GN Apiak: Cadaster A ii 21

non-standard "fame": B $62 \|$ $64 ; \rightarrow \mathrm{ar}_{2}$

GN Arali: A 62; $\rightarrow$ dumu? a-ra-li

"the state of the land": A 46 (Susa); 46a (Susa); $\rightarrow$ var. me-dim 2

non-standard "shackles of the gods": E $7^{*} ; \rightarrow$ rab digirre-e-ne

"to make a votive gift": $47,2: 6$ (broken); $\rightarrow$ nam-til $_{3^{-}}$ la-ni-še ${ }_{3}$ a ru; $\rightarrow$ nam-til $_{3}$ ur-dnamma(...)-šs ${ }_{3}$ a ru

"pitfall": A 184

"field": C 52; 55; CU 88; 27, 1:11

-k) GN Field of Numušda of Kiritab: Cadaster A i 13

GN Field of Su'en: Cadaster A iv 8; 9

"to ejaculate semen into the pure womb": C 43

"to release water": C 83 


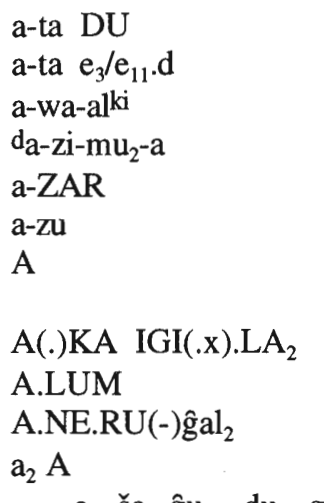

$\mathrm{a}_{2} \mathrm{~B}$

$\mathrm{a}_{2} \quad \mathrm{ag}_{2}$ "to drain": 27, 2:1-2 (broken)

"to drain" (said of canebrakes): A 227 (broken)

GN Awal: IB 1537 rev. v' 16'

DN Azimua: $\rightarrow$ nin(-)da-zi-mu ma $^{-a}$

GN: Cadaster A iii 25; 26

$\rightarrow$ dnin-a-zu

obscure: A $31 ; 32 ; 69 ; 117 ; 203 ; 204 ;$ C $40 ; \rightarrow$ IGI.

MIN/A?; $\rightarrow \mathrm{LA}_{2}$.A.BA

uncertain meaning: C 52

$\rightarrow$ udu A.LUM

$\rightarrow \mathrm{gu}_{2}$ A.NE.RU(-)gal

non-standard "O!" (exclamation): $\rightarrow$ var. a B

"to say 'O my heart!'": A 16 (Susa); $\rightarrow$ var. a ša $\mathrm{a}_{3}-\mathrm{gu}_{10}$ $\mathrm{du}_{11} \cdot \mathrm{g}$

"side, arm, strength, might": Cadaster A ii 17

"to give instructions, to commission (+ loc.)": A 31 ;

B 10

$\mathrm{a}_{2}$ nig $_{2}$-hul $\operatorname{dim}_{2}$-ma ag $\hat{g}_{2} \quad$ "to give an order to commit a sacrilege": 29,b 2:5'6' (broken); 47, 2:7-8

$\mathrm{a}_{2}-\mathrm{ag} \hat{g}_{2}-\hat{g a}_{2}$

"instruction": C 81*; CU 176 (broken)

$a_{2}$-dam

$\mathrm{a}_{2} \mathrm{gabu}_{3}$ bu gub

$\mathrm{a}_{2} \mathrm{mah}$

$\mathrm{a}_{2}$ nam-ur-saĝ-ĝa

$\mathrm{a}_{2}$ nun $\mathrm{ge}_{4}-\mathrm{a}$

$a_{2}$-še

$a_{2} \check{s} u d u_{7}$

$a_{2}$ šum $_{2}$

$a_{2}$-person-ta

$a_{2}$ tuku

$a_{2}$ tumu-gar ${ }_{7}-\mathrm{du}_{2}$

$a_{2}$ tumu-mir-ra

$a_{2}$ tumu-sa $a_{12}$-ti-um-ma

$\mathrm{a}_{2}$ tumu-ulu 3

$a_{2}$ zi.g

$a_{2}$ zi-da gub

$-a b$

$a b$

$\mathrm{ab}-\breve{s ̆}_{3} \cdot \mathrm{g}$ "settlement": A 229

"to stand at the left side": A 122 (Susa); $\rightarrow$ var. $\mathrm{za}_{3}$-ga gub

1. "to grant enormous power": B 38

2. "mighty arm": A 178

"valorous arm": A 93*

"of indomitable strength" (ep. Urnamma): C 14

"now, alas": A 166 (broken)

"to be well equipped, to do all necessary work": G 16 ॥ 17

"to give strength": C 29

"by the might of somebody": CU 82-83; 108-109; 131 $-132$

"mighty": $\rightarrow \mathrm{lu}_{2} \mathrm{a}_{2}$ tuku

"western side": Cadaster A i 12; <ii 19a>; iii 11; B ii 16 ; iv 28

"northern side": Cadaster A i 9 (broken); 31; iii 6

"eastern side": Cadaster A i 6; ii 3; iv 18-19

"southern side": Cadaster A i 3; ii 10; iii 30; B iii 20

$\rightarrow$ nig $_{2}-a_{2}-$ zi.g

"to stand at the right side": A 122 (Susa); $\rightarrow$ var. $\mathrm{za}_{3}$-ga gub

non-standard copula: D (Ur) 32' || 33' || 34'; $\rightarrow-\mathrm{am}_{3}$

"sea": $\rightarrow$ a-ab(-ba)(-k)

"depths of the sea": C 9* 
ab-sin $\operatorname{sub}_{2}$

$\mathrm{AB}$

$\mathrm{ab}_{2}$

$a b_{2}$ dugud

$\mathrm{ab}_{2}-\mathrm{gal}$

abulla

abzu-ta $\mathrm{mu}_{2}$

ad ge(-ge)

ad-da

addir

aga

AGA gar

$\mathrm{ag}_{2}$

$\mathrm{AG}_{2}$

AK

akšakki

alan

alim

am

$-\mathrm{am}_{3}$

ama

amar

ama-ar $\mathrm{ge}_{4}-\mathrm{ge}_{4}$

ama-ar ge $_{4}$ gar

ama gal $\mathrm{d}_{\text {nin- }}-\mathrm{ii}_{2}$

ama lugal-la

ama dnin-a-zu

ama $d_{\text {nin-sumun }}(-k)$

amar banda da an-na amar banda ${ }_{3}$ da SES.KI

amaš

amaš tab

AMBAR

an "to draw a furrow": G 18

obscure: A 26 (Susa, broken)

"cow": A 29; 30; D (Ni) 29 || 30

"heavy cow": A 29 (Susa)

$\rightarrow \mathrm{i}_{7}-\mathrm{ab}_{2}$-gal

"(city-)gate": E 1' (broken) \| F 7; $\rightarrow \mathrm{KA}_{2}$ (.)GAL

"to grow from the Abzu": C 3

non-standard "to confer, to consult": F 17

"father": $\mathbf{3 5 : 8}$ (broken)

"ferry (traffic)": CU 154 (broken)

"crown": D (Ur) 16'*

"to set axes?": A $47 *$ (Susa); $\rightarrow$ var. GIN 2 gar

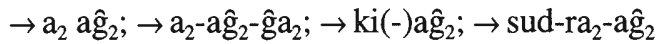

obscure: A 78a (Susa, broken)

"to make, to do, to treat, to rage": A 156; 195; B 52 ॥

53; Ni. 4375 v 9' (obscure); $\rightarrow$ dag-si AK; $\rightarrow$ eg $_{2} \mathrm{AK}$;

$\rightarrow \mathrm{gi}_{16}$-sa-aš $\mathrm{AK} ; \rightarrow$ in kur $_{2} \mathrm{AK} ; \rightarrow$ nam-ra-aš $\mathrm{AK} ; \rightarrow$

nam-urdu $\mathrm{AK} ; \rightarrow$ nig $_{2}-\mathrm{ku}_{5} \mathrm{AK} ; \rightarrow\left(\right.$ nig $\left._{2}-\mathrm{si}-\mathrm{sa}_{2}-\mathrm{e}\right)$ pa-e $\mathrm{e}_{3}$

$\mathrm{AK} ; \rightarrow$ sag $\mathrm{AK} ; \rightarrow \mathrm{u}_{4}$ nam-he ${ }_{2}-\mathrm{a} \mathrm{AK} ; \rightarrow$ non-standard ra

$(?) ; \rightarrow$ non-standard ša-aš; $\rightarrow$ (var.) non-standard ša-ša

GN Akšak: CU 126

"figure, appearance": A 51* (Susa); $\rightarrow$ var. a-la

"bison": A 121

"wild bull": A 170

copula: $\rightarrow$ non-standard $-\mathrm{ab} ; \rightarrow$ muš $_{3}$ ?-am 3

"mother": A 15; CU 173

"to exempt from obligations": C 56

"to release": CU 133-134

"great mother Ninlil": B 32

"mother of the king" (ep. Ninsumun): A 16

"mother of Ninazu" (ep. Ereškigal): A 100

"mother Ninsumun": C 48

"calf": A 30

"impetuous calf of An" (ep.Nanna): 25:2; $\rightarrow$ var. amar banda ${ }_{3}$ da SES.KI

\section{an-na}

"sheepfold": C 26; $\rightarrow$ tur $_{3}$ amaš daĝal

"to devastate the sheepfold": A 206*; 237

$\rightarrow$ URU.AMBAR

1. DN An: A 8; 54; 207; C 20; CU 31; 47, $1: 5$

2. "heaven(s), sky": A 212 (C, F); C 114 (broken); $\rightarrow$

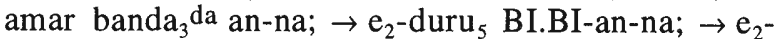
TU.NI-ga-an-na; $\rightarrow$ en-nir-gal ${ }_{2}$-an-na; $\rightarrow$ enim $\mathrm{ku}_{3}$ ?! anna(-k); $\rightarrow\left(\right.$ eš $\left._{3}\right) e_{2}$-an-na; $\rightarrow$ dgeštin-an-ka; $\rightarrow$ d geštin-an- 


\author{
an $\mathrm{ku}_{3} \cdot \mathrm{g}$ \\ an lugal \\ an $\mathrm{sa}_{7} \cdot \mathrm{g}$ \\ an dub $_{2}$ \\ $\operatorname{an}_{-g i n} \mathrm{sa}_{7} . \mathrm{g}$ \\ an-gin $\mathrm{su}_{3}$-ud \\ an-ki \\ an-ki lugal $[. .$. \\ an-ki $\check{s ̆}_{2}$ \\ an-na $e_{3}$ \\ an-ša $\mathbf{a}_{(4)}$-anki \\ an-ša $\mathrm{a}_{3} \cdot \mathrm{g}$ \\ an- ̌̌ $\mathrm{e}_{3}$ \\ $\begin{array}{lll}\text { an-še } & \mathrm{gu}_{2} & \mathrm{us}_{2}\end{array}$ \\ $\begin{array}{lll}\mathrm{an}-\mathrm{Še}_{3} & \mathrm{mu}_{2}\end{array}$ \\ an-ta \\ an-ur 2 \\ an-ur ${ }_{2}$-ta $e_{3}$ \\ an-za-gar 3 \\ an-za-gar ${ }_{3}$-dumu-lugal-ka

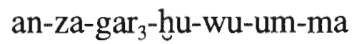 \\ an-za-gar ${ }_{3}$-hur-saĝ-ĝa \\ an-za-gar ${ }_{3}$-dnu-muš-da-ka \\ an-za. ${ }_{3} \cdot g$ \\ AN
}

AN.BIR

AN.USAN

anše

anše dab $_{5}$ anše edin-na

ANŠE.KI

ANŠE.LIBIR

ANŠE.NITA?

ANŠE.PIRIĜ

anzumušen.d na; $\rightarrow$ i-mi-tum/ĝešmitum pirî̉ an-na; $\rightarrow$ im an-na; $\rightarrow$ im an-ta šeg $\hat{g}_{3} ; \rightarrow$ ki-tuš an den-lil $1_{2}-\mathrm{la}_{2} ; \rightarrow$ lugal an $\left(/-\right.$ ne $\left._{2}\right)$

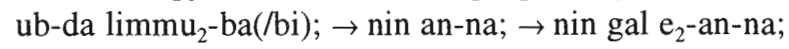
$\rightarrow$ sag an-šs ${ }_{3} \mathrm{il}_{2} ; \rightarrow$ USAR.x.GABA-an-na

"brilliant heaven": F 50

"king An": A 209

"azure heaven": E 9' || F 14*; $\rightarrow$ an-gin $7 \mathrm{sa}_{7} . \mathrm{g}$

"to make heaven tremble": A 205

"to be azure like the heavens": C $4 * ; \rightarrow$ an $\mathrm{sa}_{7}$. $\mathrm{g}$

"to be far as heaven": A 161

"heaven and earth, universe": C 30; $\rightarrow$ diĝir an-ki(-k); $\rightarrow$ dur-an-ki; $\rightarrow$ mar-uru $_{5}$ an-ki

"lord of heaven and earth [...]" (ep. Enlil/Nunamnir): B 3

"to cover heaven and earth": C 30

"to rise in the sky" (said of Utu): A 14

GN Anšan: CU 130

"midst of the sky": C 8

"heavenward": $\rightarrow$ saĝ an-še ${ }_{3} \mathrm{il}_{2}$

"to raise the neck heavenward": B 42 || 48

"to grow heavenward": B 20

"from heaven, above": C 114 (broken); $\rightarrow \mathrm{gu}_{2}$ an-ta; $\rightarrow$ im an-ta še $\hat{g}_{3}$

"horizon": E 10' || F 15

"to rise from the horizon" (said of Utu): F 38

"fortified village": A 229

GN: Cadaster B iv 5; 6

GN: Cadaster B iv $13 ; 14$

GN: Cadaster A i 20; 21

GN: Cadaster A i 1; 11; 17; ii 19

"horizon": B 45 || 51

obscure: C 94 || 95; F 46; CU 9; 14; 71; Ni. 4375 iv $15^{\prime} ; \rightarrow$ LAGAR.AN. 'IGI?

GN: Cadaster B iii 9; 10

"evening, twilight": $\rightarrow$ ša $_{3}$ usan $_{\mathrm{x}}$ ?(AN.USAN)

"donkey, ass": A $70 \| 71 ; 116 ; 173 ; \rightarrow$ anš enisku(m) (PIRIG)

"to hold asses": CU 95 (broken); 121

"wild ass": A 183

"... donkey": A 115

type of mule: IB 1537 rev. vi' 3'

type of mule: A 116 (Susa, broken)

"thoroughbred donkey": $\rightarrow$ anš enisku(m)(PIRIĜ)

"Anzû-bird": B 24 


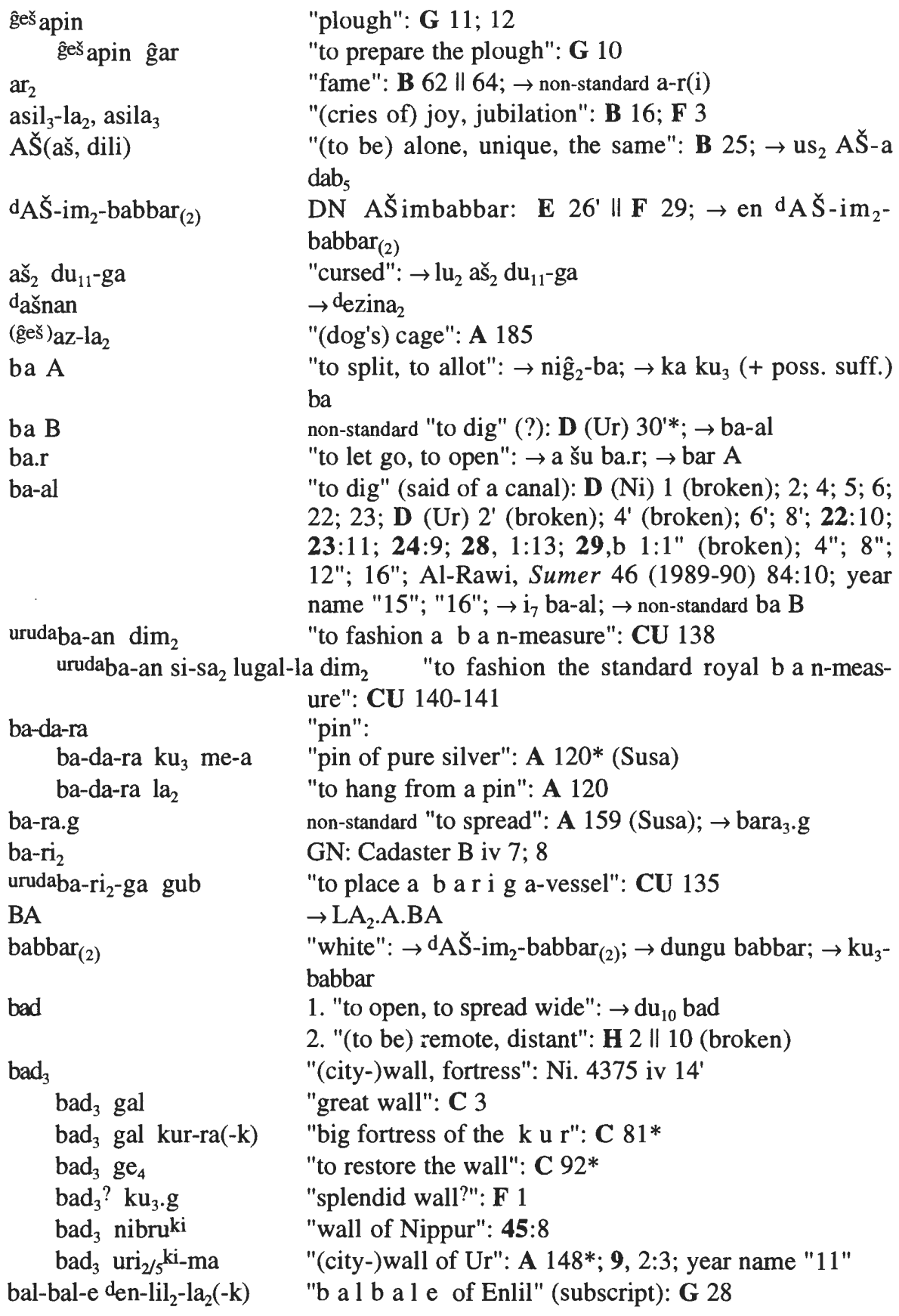


bala

balaĝ-di

banda $_{3}{ }^{\mathrm{da}}$

ĝešbansur sikil

bar A

bar B

bar $\mathrm{su}_{3} . \mathrm{g}$

bar tam

bar-ta gub

bara $_{2} \cdot \mathrm{g}$

bara $_{3} . \mathrm{g}$

BI

BI.BI

$\mathrm{dbil}_{3 / 4}$-ga-mes

BIR

dbil $_{3}$-ga-mes

bu-ul

BU(bu.r?) A

BU B

BU kalam-ma(-k)

bulug $_{3}$

bur-šagan šu $d u_{7}$-a

$\mathrm{i}_{7}$ buranun

buru $_{14}$ mah

-da

da-a-ri

da-na

da-ri

da-ri ${ }_{2}$

DA

DA.RA.g

$\mathrm{da}_{6} \cdot \mathrm{g}$

$\mathrm{dab}_{5}$ "to turn (over), to cross over (a canal), to pass, to uproot": A 46a (Susa); 48; 57; 72; D (Ur) 30'* (obscure); Cadaster A i 27; ii 7; iii 22; iv 6; B i 10; $\rightarrow$ ki-bala; $\rightarrow$ nam bala; $\rightarrow$ šu lul bala

"dirge singer": $\rightarrow$ i-lu balaĝ-di

"impetuous": $\rightarrow$ amar banda $\mathrm{da}_{3}$ an-na; $\rightarrow$ amar banda $\mathrm{da}_{3}$ SES.KI

"pure (offering) table": C 11 || 12

"to let go": $\rightarrow$ eš-bar; $\rightarrow$ igi zi bar; $\rightarrow$ ka-aš bar; $\rightarrow$ saĝ-

ki zalag bar; $\rightarrow$ za $_{3}(-)$ bar-ra; $\rightarrow$ ba.r

"exterior, outskirts, façade": E 2' I| F 8

"desolate exterior": $\rightarrow$ edin bar $\mathrm{su}_{3}$-ga(-k)

"to stand aside": A 176

"to clear up the matter": 28, 1:17

$\rightarrow$ para $_{10} \cdot \mathrm{g}$

"to spread": $\rightarrow$ geš-nu ${ }_{2}$ u $_{2}$ za-gin ${ }_{3}$ bara $_{3} . \mathrm{g} ; \rightarrow$ non-standard ba-ra.g

obscure: CU 8 (broken); $\rightarrow \mathrm{i}_{7}(-)$ ĜEŠ.BI.ĜEŠ(-)a(-)gar$\mathrm{ra} ; \rightarrow$ NAGAR.BI

$\rightarrow \mathrm{e}_{2}$-duru BI.BI-an-na

PN Gilgameš: A 95; 143; 40:14; $\rightarrow$ ses dbil $_{3}$-ga-mes

.GIGki PN Gilgameš of ENDIMGIG: 40:1-2

$\rightarrow$ AN.BIR

GN: Cadaster B iv $9 ; 10$

"to uproot, to tear (out)": A 38 (obscure); 212 (Susa, obscure); $\rightarrow$ var. $\mathrm{ge}_{4}(?)$

$\rightarrow \mathrm{su}_{13}(\mathrm{BU})$

". . . of the land": A 27 (Susa); $\rightarrow$ var. umuš kalam-ma "to grow up": A 153

"š a g a n-bowl of perfect make": A 97*

CN Euphrates: E 35' II F 37; $\rightarrow \mathrm{gu}_{2}{ }^{i_{7} \text { buranun }}$

"enormous harvest": C 80

$\rightarrow \mathrm{gu}_{2}$-da $\mathrm{la}_{2} ; \rightarrow \mathrm{gu}_{2}$-da šu ${ }_{2} ; \rightarrow \mathrm{gi}_{6}$-da gub; $\rightarrow$ itu-da; $\rightarrow$ lugal an $\left(/\right.$-ne $\left._{2}\right)$ ub-da limmu ${ }_{2}$-ba(/bi); $\rightarrow \mathrm{u}_{4}$-da gub; $\rightarrow$ $\mathrm{u}_{18}$-lu-da dul; $\rightarrow$ ur $_{5}$-bi-da

non-standard "lasting": $\rightarrow$ lugal mu da-a-ri; $\rightarrow$ da-ri $(2)$

"d a n a" (measuring unit): 27, 2:3 (broken)

non-standard "lasting": $\rightarrow$ mu da-ri

"lasting": $\rightarrow$ mu da-ri ${ }_{2}$

obscure: A 210 (Susa); $\rightarrow$ NIĜ. $\hat{G}_{2}$.DA.TAG.GA

uncertain meaning: $\mathbf{C} 10$

$\rightarrow \mathrm{lu}_{2}$ nam-da $-\mathrm{ga}$

"to take hold of (+ loc.(-term.)), to catch, to snatch a-

way, to seize": A $21 *$; 185; B 25; F 19 (broken, read perhaps $\rightarrow$ dib); F 40; 46; $\rightarrow$ anše dab ${ }_{5} ; \rightarrow$ gud dab ${ }_{5} ; \rightarrow$ 


dadag
dag
dag-dag
dag-si AK
DAG
dagal

daĝal tag
dalla dalla $e_{3}$
dam A

dam ki-aĝ $\hat{g}_{2}$ dinana

dam (d)nam-tar-ra dam B

de

$\mathrm{de}_{2}$

$\mathrm{de}_{6}$

di.d A
di.d B
di nig $\hat{g}_{2}$ ge-na dutu di $\mathrm{ku}_{5}$.r
di gal $\mathrm{ku}_{5}, \mathrm{r}$
di kur-ra $\mathrm{ku}_{5}$.d/.r
di si-sa $\mathrm{ku}_{5}\left(-\mathrm{ku}_{5} \cdot \mathrm{r}\right)$ di zu

DI

$\mathrm{di}_{4}-\mathrm{di}_{4} \cdot 1$

dib

$\mathrm{dib}_{2}$

diĝir maš $_{2}$-e dab $b_{5} ; \rightarrow$ šu dab ${ }_{5} ; \rightarrow$ udu dab ${ }_{5} ; \rightarrow$ us $_{2}$ A $\breve{S}-a_{\text {dab }} ; \rightarrow$ var. DI

"(to be) bright": C 52

$\rightarrow$ ga $a_{2}$-la nu-dag

uncertain meaning: $28,2: 12$

"to make for the saddle(-hook)": A $92 *$

uncertain meaning: C 41

"(to be(come)) vast, large, broad, wide, to spread out, to expand": C 26; F 39; $\rightarrow$ engar zi GANA 2 daĝal-la; $\rightarrow$ geštu ${ }_{2}$ daĝal; $\rightarrow$ iri? daĝal; $\rightarrow$ niĝ $\hat{g}_{2}$-daĝal; $\rightarrow$ sila daĝal; $\rightarrow$ še daĝal; $\rightarrow \operatorname{tur}_{3}$ amaš daĝal; $\rightarrow$ ug $\hat{g}_{3}$ daĝal

"to stretch out wide": B 28

"resplendent": A 99

"to be/make resplendent": B 41 || 47; 43 || 49

"spouse, husband, wife": A 50; 151; 193; $\rightarrow$ var. nitadam

"beloved husband of Inana" (ep. Dumuzi): A 104; $\rightarrow$ var. nitadam ki-ag $\hat{g}_{2}$ dinana

"Namtar's wife" (ep. Hušbisag): A 112

$\rightarrow \mathrm{a}_{2}$-dam

$\rightarrow$ si si-DI( $\left(\mathrm{sa}_{2} / \mathrm{de}\right)$

"to pour out, to pour into (+ loc.), to libate": A $22 ; \rightarrow$

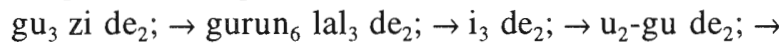
ug-gu de $\mathrm{d}_{2} ; \rightarrow$ var., non-standard $\mathrm{de}_{6}$

$\rightarrow$ DU A; $\rightarrow$ var., non-standard de 2

$\rightarrow \mathrm{du}_{11} . \mathrm{g}(h$.$) , e (m$.$) , di.d; \rightarrow$ balaĝ-di; $\rightarrow$ geš-gu ${ }_{3}$-di; $\rightarrow$ $\mathrm{u}_{6}$ di- $\mathrm{s}_{3}$ gub

"judgment, case, verdict": A 196

"just verdict of Utu": 28, 1:15-16; 47, 2:1-2

"to pronounce judgment, to render a verdict": C 28; 34

"to render important verdicts": B 31

"to pass the judgment of the netherworld": A 144

"to render just judgment(s)": A 239; E 12'* || F 16

"to know judgment": B 13

obscure: A 185 (Susa); 186* (broken); $\rightarrow$ di ku $5 . \mathrm{r} ; \rightarrow$ si si-DI( $\left(\mathrm{sa}_{2} / \mathrm{de}\right) ; \rightarrow$ var. dab ${ }_{5}$

"young(sters)": $\rightarrow \operatorname{nin}_{9} \mathrm{di}_{4}-\mathrm{di}_{4} \cdot 1$

"to pass, to tread, to have access to (+ loc.)": $\mathbf{E} 27^{\prime} ; \mathbf{F}$

19 (broken, read perhaps $\rightarrow$ dab $_{5}$ ); $\rightarrow$ var. dib $_{2}$

"to pass, to tread": F 32; $\rightarrow$ giri $_{3}$ dib $_{2} ; \rightarrow$ var. dib

"(personal) god(dess)": A 157; 160; 15 obv. $2 ; \rightarrow$ a-ra $_{2}-$ ab digirir-re-ne; $\rightarrow$ gaba digirir-re-e-ne; $\rightarrow$ lugal digirir-re(-e)ne; $\rightarrow$ ki nam tar-ra/(re) (digirir-re(-e)-ne); $\rightarrow$ ki u $\mathrm{u}_{4} \mathrm{e}_{3}$ diĝirre-e-ne; $\rightarrow$ NIN-diĝir; $\rightarrow$ rab digirir-re-e-ne

digir an-ki(-k) "gods of heaven and earth" (ep. Anuna): F 17* 


\author{
digir gal-gal

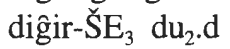 \\ DIĜIR-ba-ni \\ dili \\ dilmunki \\ $\operatorname{dim}$ \\ DIM \\ $\operatorname{dim}_{2}\left(-\operatorname{dim}_{2}\right)$
}

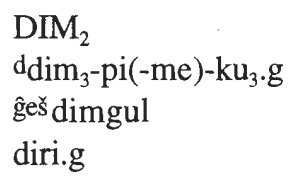

diri gal $_{2}$

DIŠ

DIŠ gud ĝeššudul ${ }_{4}$-a DIŠ DIŠ

du A

du B

du C

$\mathrm{du} \mathrm{D}$

du $\mathrm{E}$

du-di-da

DU A $\left(\right.$ de $_{6} /$ tum $\left._{2}\right)$ (h. sg. $)$, $\operatorname{tum}_{3 / 4}\left(m . s g\right.$.), lah ${ }_{4 / 5}$ (pl.) "to bring, to carry, to lead, to come upon, to line up (+ term.), to deliver, to hover, to settle in, to lay out (said of a garden, a pit), to stand, to come forth (said of abundance)": A 6; 30 (obscure), 54 (Susa); 63, $69 ; 87$ (+ Susa); 128a (Susa, broken); 161 (Susa, obscure); 183; 199* (broken, read perhaps $\rightarrow \mathrm{ku}_{4} . \mathrm{r} ; \rightarrow$ gur A); 238 (A, obscure); B 63 ॥ 65; C 21; 66; 92 (obscure); D (Ur) 18; D (Ni) 33 (broken) ॥ 34; D (Ur) 35'; Cadaster A i 29; IB 1537 rev. vi' 9'; $\rightarrow$ a-ta DU; $\rightarrow$ ĝeš-la ${ }_{2}$-bi DU; $\rightarrow$ ki tum ${ }_{2} ; \rightarrow$ geš kiri ${ }_{6}$ DU; $\rightarrow$ me $_{3}$-še ${ }_{3}$ DU; $\rightarrow$ nindan $_{\mathrm{x}}\left(\right.$ NINDA.DU) $\rightarrow$ nir-gal ${ }_{2}$-bi DU; $\rightarrow$ ša $_{3}(-$ ge/ga) DU; $\rightarrow$ ul DU; $\rightarrow$ non-standard ša-aš; $\rightarrow$ var. TUŠ

$\mathrm{DU}\left(\mathrm{ra}_{2}\right.$ ?) B

"all the great gods": E 16' || F 22 (broken)

"to be born as/to be a god": A 238* (A); C 70

$\rightarrow \mathrm{i}_{7}$-DIĜIR-ba-ni

"(to be) alone, unique": $\rightarrow$ A $\breve{S}($ aš, dili)

GN Dilmun: A $65^{*}$

$\rightarrow$ dnu-dim $(2)$-mud

obscure: E $15^{\prime}$

"to create, to form (meticulously), to fashion": A 157

(Susa, obscure); C 24*; $\rightarrow$ a $_{2}$ nig $\hat{g}_{2}$-hul dim dima a $_{2}$; $\rightarrow$ urudaba-an (si-sa 2 lugal-la) $\operatorname{dim}_{2} ; \rightarrow$ me-dim ${ }_{2} ; \rightarrow$ dnu$\operatorname{dim}_{(2)}$-mud; $\rightarrow$ sila $_{3}$ zabar $\operatorname{dim}_{2}$

$\rightarrow$ dbil $_{3}$-ga-meš ${ }_{3}$ EN.DIM ${ }_{2}$.GIGki

DN Dimpi(me)kug: A $122 *$

"mooring pole": A 182

1. "to set adrift" (said of a boat), "to glide" (said of birds): A 182; D (Ni) $25 \| 26^{*}$; $\rightarrow$ non-standard te-li

2. "to exceed something (+ loc.)": $\rightarrow$ kur-kur-ra diri.g

"to increase": $\rightarrow$ udu diri gal $_{2}$

"one, single": $\rightarrow$ gi(-)DIŠ-ninda

"single bull under a yoke": C 10*

"on the one hand - on the other hand": A 220

"to go, to come (from)": $\rightarrow$ gen

non-standard "to sweep away": B 59 \| 61; $\rightarrow$ su-ub

non-standard "(to be) perfect, worthy, to perfect ": $\rightarrow \mathrm{du}_{7}$

$\mathrm{A} ; \rightarrow \mathrm{ka}-\mathrm{ke} \mathrm{du} ; \rightarrow \mathrm{maš}_{2}$ du-du

non-standard in $\rightarrow \mathrm{sa}_{2}$ du "to arrive, to reach": $\rightarrow \mathrm{sa}_{2}$ $\mathrm{du}_{11} \cdot \mathrm{g}$

non-standard in $\rightarrow$ igi du "to see": $\rightarrow$ igi du $8 . r$

"toggle pin": A $121^{*}$ (Susa); $\rightarrow$ var. tu-di-da; $\rightarrow$ var. tudi-tum

"to carry": $\rightarrow$ a DU( $\mathrm{ra}_{2}$ ?) 
$\mathrm{du}_{2} \cdot \mathrm{d}, \mathrm{u}_{3}-\mathrm{du}_{2} \cdot \mathrm{d}$

$\mathrm{du}_{3}$

$\mathrm{du}_{3}-\mathrm{a}$

$\mathrm{DU}_{3}$

du $_{6}$-gu-zu-ma-ka

du $_{6}$-lugal-iri-ka

$\mathrm{du}_{7} \mathrm{~A}$

$\mathrm{du}_{7} \mathrm{~B}$

$\mathrm{du}_{8} \mathrm{~A}$

$\mathrm{du}_{8} \mathrm{~B}$

$\mathrm{du}_{8} \cdot \mathrm{r}$

$\mathrm{DU}_{8}$

$\mathrm{du}_{10} . \mathrm{b}$

$\mathrm{du}_{10}$-ba/be ${ }_{2}$ peš

$\mathrm{du}_{10}$-ba $\breve{S}_{3}$ (pešx ?)

$\mathrm{du}_{10}$ bad

$\mathrm{du}_{10} \mathrm{gal}_{2}$

$\mathrm{du}_{10} \cdot \mathrm{g}, \operatorname{dug}_{3}$

$\mathrm{du}_{11} \cdot \mathrm{g}($ h. $), \mathrm{e}(m)$, di.d "to be born, to bear, to give birth, to create, to produce, to procreate": C $20 ; 47^{*} ; \mathbf{E} 19^{\prime} ; \mathbf{F} 48 ; 49^{*} ; \rightarrow$ diĝir$\breve{S} E_{3} d_{2} \cdot d ; \rightarrow$ dumu du ${ }_{2}$-da (dnin-sumun $\left.{ }_{2}-k a\right) ; \rightarrow$ zi u $u_{3}-$ $\mathrm{du}_{2} \cdot \mathrm{d}$

"to build, to (im)plant, to fix": A $8 ; 9 ; 149 ;$ C 108 ; D (Ni) $27 \| 28 ; 1: 4 ; 2: 4 ; 3: 5 ; 4: 6 ; 5: 8 ; 6: 7 ; 7,2: 4$; $8: 7 ; 9,2: 2 ; 9,2: 4 ; 10: 12 ; 11: 8 ; 12: 8 ; 13$ rev. $2 ; 14$ rev. $1 ; 15$ rev. $2 ; 16: 10 ; 17: 10 ; 18: 8 ; 19: 8 ; 21: 8$; 23:8; 25:10; 26, 1:10; 28, 1:9; 38:6 (broken); 40:9; 45:9; 46:8; 47, 1:13; year name "6"; "11"; $\rightarrow$ en-nu($\left.\mathrm{ug}_{3}\right) \mathrm{du}_{3} ; \rightarrow$ ezem-gin $\mathrm{du}_{3} ; \rightarrow \mathrm{ki} \mathrm{ku}_{3}-\mathrm{ga} \mathrm{du}_{3} ; \rightarrow$ peš du "all": $\rightarrow \mathrm{gu}_{2} \mathrm{i}_{7} \mathrm{du}_{3}-\mathrm{a}$

obscure: A 66

GN: Cadaster B iv 17; 18

GN: Cadaster B iii 28; 29

"(to be) perfect, worthy, to perfect": $\rightarrow$ gud du $7 \rightarrow \rightarrow$ he $_{2}$ $\mathrm{du}_{7} ; \rightarrow$ ka-ge du $\mathrm{du}_{7} ; \mathrm{maš}_{2} \mathrm{du}_{7} ; \rightarrow$ non-standard du C

$\rightarrow$ šu du

$\rightarrow$ šu urin-na du

$\rightarrow$ tuh

$\rightarrow$ igi du ${ }_{8} . r ; \rightarrow$ non-standard du E

$\rightarrow \mathrm{ME}(.) \mathrm{ME}(.) \mathrm{DU}_{8}$

"knee":

"to raise on the knees": A 152; C 25*

non-standard "to raise? on the knees": A 152 (Susa)

"to go swiftly, to spread the talons": A 170 (broken); B 24

"to relax, to prosper": B 33*

"(to be(come)/make) sweet, good, pleasant, well, to please": C 82; 96 (broken, obscure); 115; D (Ni) 37; (Ni) $41 \|$ (Ur) 41'; F 47; G 10; 11; $13 \| 14 ; 15 ; 22$ ॥ 23 (broken); Ni. 4375 vi 6 ; $\rightarrow$ iri me du $\mathrm{du}_{10}-\mathrm{du}_{10}$-ga; $\rightarrow$ ki-nu $\mathrm{du}_{10} . \mathrm{g} ; \rightarrow \mathrm{mu} \mathrm{du}_{10} \mathrm{se}_{21} ; \rightarrow$ nam du $\mathrm{du}_{10} . \mathrm{g} ; \rightarrow$ nam $\mathrm{du}_{10}$ tar; $\rightarrow \mathrm{NI}_{3}\left(\mathrm{inda}_{3} /\right.$ nig $\left._{2}\right)$ mah du $\mathrm{du}_{10}$.g; $\rightarrow$ sizkur $_{2}$ nig $_{2}$ $\mathrm{du}_{10} . \mathrm{g} ; \rightarrow$ še $\mathrm{du}_{10} . \mathrm{g} ; \rightarrow \mathrm{u}_{3} \mathrm{du}_{10} \mathrm{ku}-\mathrm{ku} ; \rightarrow \mathrm{u}_{4} \mathrm{du}_{10}-\mathrm{du} \mathrm{u}_{10} \mathrm{~g} ; \rightarrow$ uš(8) $\operatorname{dug}_{3}$

"to say, to utter": A 19 (A); 60; 194; 209 (Susa); $\rightarrow$ $\mathrm{a}_{(2)} \mathrm{š}_{3}-\mathrm{gu}_{10} \mathrm{du}_{11} \cdot \mathrm{g} ; \rightarrow$ a-ne hul ${ }_{2}-\mathrm{la} \mathrm{du}_{11} \cdot \mathrm{g} ; \rightarrow$ balag $-\mathrm{di} ; \rightarrow$ enim $\mathrm{du}_{11} . \mathrm{g} ; \rightarrow \mathrm{gu}_{2}-\mathrm{guru}_{5} \mathrm{du}_{11} . \mathrm{g} ; \rightarrow \mathrm{gu}_{2}$ nun $\mathrm{du}_{11} . \mathrm{g} ; \rightarrow$ gur $_{5}$-ru-uš du ${ }_{11} . \mathrm{g} ; \rightarrow$ geš-gu - $_{3}$-di; $\rightarrow$ ĝiri $_{3}$-saga ${ }_{11}$ du $_{11} . \mathrm{g} ; \rightarrow$ i-lu nig $\hat{g}_{2}(-)$ me-gar du $\mathrm{u}_{11} . \mathrm{g} ; \rightarrow$ maš-gi-i du $\mathrm{u}_{11} . \mathrm{g} ; \rightarrow$ maškim $\mathrm{du}_{11} . \mathrm{g} ; \rightarrow$ mi-ri-e-zi-ka du ${ }_{11} . \mathrm{g} ; \rightarrow \mathrm{mi}_{2}$ zi du $\mathrm{du}_{11} \mathrm{~g} ; \rightarrow \mathrm{sa}_{2}$ $\mathrm{du}_{11} . \mathrm{g} ; \rightarrow \mathrm{sa}_{2}-\mathrm{du}_{11}-\check{\mathrm{s}}_{3}$ gar; $\rightarrow$ si du ${ }_{11} . \mathrm{g} ; \rightarrow$ še-er-ka-an $\mathrm{du}_{11} . \mathrm{g} ; \rightarrow \mathrm{u}_{6} \mathrm{du}_{11} . \mathrm{g} ; \rightarrow$ a-ne-di; $\rightarrow$ e-ne-de ${ }_{3} ; \rightarrow$ e-ne-di 
$\mathrm{du}_{11}-\mathrm{ga}$

dub A

dub B

DUB

dub-ba-an

dub-la

dub-la - -mah

dub-sar

dub-sar mah

dub-šen

$\operatorname{dub}_{2}\left(-\mathrm{dub}_{2}\right)$

('geš) dubsig

dug gaz

$\operatorname{dug}_{3}$

dugud

tug $_{2}$ dugud

dul

$\mathrm{dul}_{3}$

dumu

dumu? a-ra-li

"spoken, appointed, utterance, command": $\rightarrow$ enim $\mathrm{du}_{11} . \mathrm{g} ; \rightarrow \mathrm{lu}_{2} \mathrm{aš}_{2} \mathrm{du}_{11}-\mathrm{ga} ; \rightarrow \mathrm{nig}_{2} \mathrm{du}_{11}-\mathrm{ga} ; \rightarrow$ šu-du${ }_{11}-\mathrm{ga} ;$ $\rightarrow \mathrm{u}_{4} \mathrm{du}_{11}$-ga

"proper utterance and decision": B 40 \| 46

"to chant": A 194

"to pile up": $\rightarrow$ saĝ sahar-re-eš dub; $\rightarrow$ non-standard (-e)d$\mathrm{b}(\mathrm{u}) ; \rightarrow$ non-standard tu.b B

"tablet": $\rightarrow$ gi dub-ba

"(treasure) chest": A 110*; $\rightarrow$ var. dub-šen

"fence": C $110^{*}$

"d u b l a": C 7*

"d u b l a m a hु": E 16' || F 21 (broken)

"scribe": $\rightarrow$ nig $_{2}$-nam dub-sar-ra(-k)

"chief scribe" (ep. Ninazimua/Ĝeštinana): A 127* (broken)

"treasure chest": A 110* (Susa); $\rightarrow$ var. DUB

"to (make) tremble, to hurl": C $32 ; \rightarrow$ an dub $_{2}$; $\rightarrow$ igi $\mathrm{dub}_{2}-\mathrm{dub}_{2} ; \rightarrow$ in-ŠE $\mathrm{S}_{3} \mathrm{dub}_{2}$

"(work) basket": C 89; D (Ni) 33 ॥ 34; F 45

"broken jar": A 58

$\rightarrow \mathrm{du}_{10} \cdot \mathrm{g}$

"heavy": $\rightarrow \mathrm{ab}_{2}$ dugud; $\rightarrow$ šu dugud

"heavy garment": A 98

"to cover something $(+$ loc.) with something (+ abs./ com.)": $\rightarrow$ me-lim $\mathrm{x}$ kalam-ma dul; $\rightarrow \mathrm{u}_{18}$-lu-da dul

"protective": $\rightarrow$ šu dul $\mathrm{dra}_{3}$

"child, son, citizen, denizen": A 15; 152; 193; 240

"denizen? of Arali" (ep. Ninazimua/Ĝeštinana): A 127 (broken)

dumu $\mathrm{du}_{2}$-da $\mathrm{d}_{\text {nin-sumun }}$-ka "natural son of Ninsumun" (ep. Urnamma): $\mathbf{C}$ 113 (broken); CU 37-38

dumu gal dsu'en-na "eldest child of Su'en" (ep. Inana): A 204

dumu ki-a. $\hat{g}_{2}$

"beloved child": 35:11

dumu d nin-sumun 2 (-ka) "son of Ninsumun" (ep. Urnamma): A 63; E 6' || F $12 ;$ F $40^{*}$ (broken)

dumu sag den-lil $1_{2}-\mathrm{la}_{2}$ "first-born (child) of Enlil" (ep. Nanna): 10:2-3; 25:3-

$4 ; 26,1: 2-3 ; 27,1: 2-3 ; 28,1: 2$

dumu ur-dnamma lugal "son of king Urnamma": year name " 8 "

dumu $\mathrm{KIG}_{2}$ ?

dumu lugal

dumu-uku$u_{2}$-ra

dumu-zi.d

dungu babbar

dur-an-ki

$\operatorname{dur}_{2}$ (m. sg.) "working? citizen": C 89* (broken)

"prince": $\rightarrow$ an-za-gar ${ }_{3}$-dumu-lugal-ka

"poor": C 56

DN Dumuzi: A 104

"white clouds": C 8

GN Duranki: B 20

$\rightarrow$ tuš, dur $_{2}$, durun 


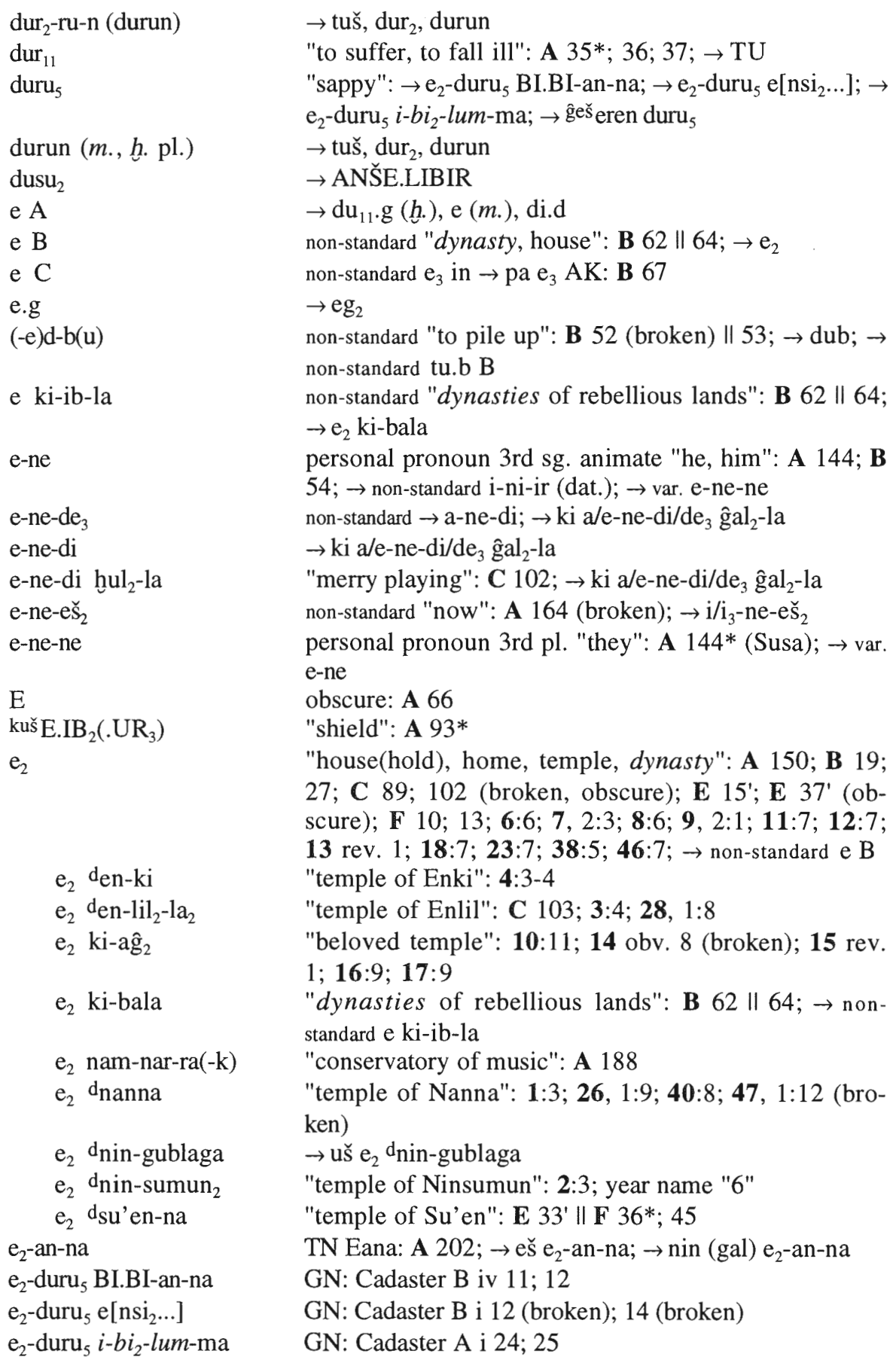


$e_{2}$-gal

$\mathrm{e}_{2}$-gal-gibil

$\mathrm{e}_{2}$-gal mah

$\mathrm{e}_{2}-$ - $-\mathrm{r}_{8}$

$\mathrm{e}_{2}$ ?-keš(i) $)_{3} \mathrm{ki}$

$\mathrm{e}_{2}$-kiš-nu-gुal ${ }_{2}$

$\mathrm{e}_{2}$-kur

$\mathrm{e}_{2}$-kur mah

$\mathrm{e}_{2}$-kur-re

$\mathrm{e}_{2}$-kur-za-gin ${ }_{3}$

$\mathrm{e}_{2}$-mah

$\mathrm{e}_{2}$-mar-uru

$\mathrm{e}_{2}$-mud-kur-ra(-k)

$\mathrm{e}_{2}$-dnin-SAR-ka

$\mathrm{e}_{2}$-sag $-\mathrm{ga}$

$\mathrm{e}_{2}$-sumur-ra

$\mathrm{e}_{2}$-šu-tum ki-a $\hat{g}_{2}$

$\mathrm{e}_{2}$-temen-ni ${ }_{2}$-guru ${ }_{3}$ (ru)

$\mathrm{e}_{2}$-temen-ni ${ }_{2}$-guru ${ }_{3}$ ru tum ${ }_{2}$ "to be worthy of the Etemenniguru" (ep. Ur-

$\mathrm{e}_{2}$-TU.NI-ga-an-na

$\mathrm{e}_{2}-\mathrm{Zu}_{2}$-ra-ah

$\mathrm{E}_{2} \times \mathrm{KASKAL}$ ?

$\mathrm{e}_{3} . \varnothing / . \mathrm{d}$

$e_{4}$

$\mathrm{e}_{11} \cdot \mathrm{d}$

edin, $\operatorname{edim}_{\mathrm{x}}(\mathrm{EDIN})$

edin bar $\mathrm{su}_{3}-\mathrm{ga}(-\mathrm{k})$ namma): $\mathbf{E} 18^{\prime}$

"palace" : A 2; 42; 48; 91 || 96 || 101 || 105 || 109 || 113 || 119 || 122a (Susa) || 128 || 131a (Susa); 224; C $108^{*} ; \rightarrow{ }_{\text {nin }}-\mathrm{e}_{2}$-gal

"magnificent palace, greatest palace": B 31; C 6

"New Palace": A 149*

"wall": $\rightarrow \mathrm{za}_{3} \mathrm{e}_{2}$-gar -e us $_{2}$

TN Ekeš(i): 14 obv. 7 (broken)

TN Ekišnuĝal: C 6; 12; 42; 109; D (Ur) 35'; E 3'

(broken) II F 9; E 14'; Ni. 4375 v 5' (broken)

TN Ekur: B 8; 10; 35; 16:8; $\rightarrow$ šeg $_{12} \mathrm{e}_{2}$-kur-ra(-k)

"magnificent Ekur": B 20; 41 || 47

GN: Cadaster B iii 3; 4

TN Shining Ekur: A 199

TN Emah: 15 obv. 7

"quiver": A 88; $\rightarrow$ non-standard a-ma-ru B

TN Emudkura: D (Ni) 14* $\|$ D (Ur) 14'

GN: Cadaster B iii 5; 6

TN Esaga: E 22*

TN "Furious House": A 40*

"beloved storeroom (?)": 21:7

TN Etemenniguru: 10:10; $25: 9$

GN: Cadaster B iv $3 ; 4$

TN "... House": A $41^{*}$

uncertain meaning: CU 155-156

"to come out/forth, to bring out, to emerge from (+ abl., + loc., + term.), to make leave, to loose, to escape, to rise" (said of the sun): A $6 \|$ 7; 18; 23 (Susa); 51; 180; 201 (broken, read perhaps $\rightarrow \mathrm{e}_{11} . \mathrm{d}$ ); 202; C 30; 49; F 6; 7; $\rightarrow$ a-ta e $e_{3} / e_{11}$.d; $\rightarrow$ an-na $e_{3} ; \rightarrow$ an- $\mathrm{ur}_{2}$-ta $\mathrm{e}_{3} ; \rightarrow$ dalla $\mathrm{e}_{3} ; \rightarrow$ ki sur-ra dmes-lam-ta- $\mathrm{e}_{3}-\mathrm{a} ; \rightarrow \mathrm{pa}_{3} ; \rightarrow \mathrm{u}_{4} \mathrm{e}_{3}(-$ a); $\rightarrow$ dutu $e_{3} ; \rightarrow$ dutu-gin kalam-ma $_{3} ; \rightarrow$ var. $e_{11}$.d; $\rightarrow$ var. $\mathrm{mu}_{2}, \mathrm{mu}_{2}-\mathrm{mu}_{2} ; \rightarrow$ non-standard $(\mathrm{t}) \mathrm{i}$

$\rightarrow \mathrm{a}$

"to ascend, to descend, to come forth, to bring out": A 201 (broken, read perhaps $\left.\rightarrow \mathrm{e}_{3} . \varnothing / . \mathrm{d}\right) ; 236$; C 114; $\rightarrow$ ata $\mathrm{e}_{3} / \mathrm{e}_{11} . \mathrm{d} ; \rightarrow$ var. $\mathrm{e}_{3} . \varnothing / . \mathrm{d}$

"steppe": A 5 (broken, read perhaps $\rightarrow \mathrm{ki}$ ); 28; 214; C $54 * ;$ H 8 ; $\rightarrow$ anše edin-na; $\rightarrow \mathrm{i}_{7}$-edin-mah; $\rightarrow$ KI.KALedin

"steppe of the desolate exterior, i.e. open, desolate steppe": A 192 
$\mathrm{eg}_{2}$

$\mathrm{eg}_{2} \mathrm{AK}$

$\mathrm{eg}_{2}(-)$ gibil

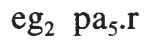

egir

elam

$\mathrm{emedu}_{2} \quad \mathrm{ki}-\mathrm{ag} \hat{g}_{2}$

en

den-[...]

den-ki(-k)

den-ki-im-du

den-lil ${ }_{2}$ "embankment": 27, 2:7

"to make embankments": 27, 2:3-4 (broken)

"new embankment", GN: Cadaster B iii 11; 12

"embankments and ditches": A 25; G 19 || 20; 21; $\rightarrow$ lugal eg $\mathrm{pa}_{5}$-ra

"rear side": $\rightarrow$ nig $\hat{2}_{2}$-egir

GN Elam, Elamites: IB 1537 rev. v' 8'; $\rightarrow$ ma-da kurelamki-ma

"beloved house-born slave": CU 39-40

"lord, e n-priest" (ep. Urnamma): B 2 (ep. Enlil); C 69; Ni. 4375 iv 7'; $\rightarrow$ gu $_{2}$-en; $\rightarrow$ ki-en-gi.r (?); $\rightarrow$ namen; $\rightarrow$ EN

en dAŠ-im 2 -babbar $(2)$ "lord AŠimbabbar": A 179* ॥ 235 (broken); D (Ni) 7 ॥ $8 ; 18$

en geštu ${ }_{2}$ daĝal-la "lord of broad understanding" (ep. Urnamma): B 13 (broken)

"e n-priest of Inana": year name "8"

"e n-priestess of Nanna" (ep. Ennirgalana): 35:10 (broken)

"lord Ningešzida": A 217 (broken); 240

"lord Nunamnir" : A 232; B 54 || 56

"comely lord" (ep. Urnamma): E 5' II F 11; E 20'

"eminent lord" (ep. Urnamma): F 6*

"e n of Uruk" (ep. Urnamma): 10:7; 34:5

"unswerving lord" (ep. Urnamma): B 44* || 50

C 14 (broken, obscure)

DN Enki: A 11; 180 ॥ 236; B 19; C 23; D (Ni) 21; 12:1; 46: 1

DN Enkimdu: A 25; C 75

DN Enlil: A 9; 197; 208; B 1; 14; 33; 69; C 22; 46;

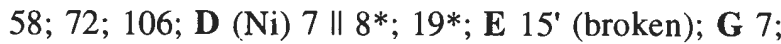
CU $32 ; 16: 1 ; 22: 1 ; 23: 1 ; 45: 1 ; 47,1: 6 ;$ IB 1537 rev. v' 7'; rev. vi' 6'; $\rightarrow$ bal-bal-e den- $\operatorname{lil}_{2}-\mathrm{la}_{2}(-\mathrm{k}) ; \rightarrow$ dumu sag den-lil $\mathrm{l}_{2}-\mathrm{la}_{2} ; \rightarrow \mathrm{e}_{2}$ den-lil $\mathrm{I}_{2}-\mathrm{la}_{2} ; \rightarrow$ enim den-lil ${ }_{2}$ $\mathrm{la}_{2} \mathrm{du}_{11}$-ga; $\rightarrow \mathrm{GANA}_{2}$ den-lil ${ }_{2}-\mathrm{la}_{2} ; \rightarrow$ guruš? $\mathrm{gu}_{2}$ tuku den-lil ${ }_{2}-\mathrm{la}_{2} ; \rightarrow \mathrm{i}_{7}$-me-den-lil ${ }_{2}-\mathrm{la}_{2} ; \rightarrow$ kar-geštin-na den-lil ${ }_{2}$ $\mathrm{la}_{2} ; \rightarrow$ ki-ag ${ }_{2}$ den-lil ${ }_{2}-\mathrm{la}_{2} ; \rightarrow$ ki-tuš an den- $\mathrm{lil}_{2}-\mathrm{la}_{2} ; \rightarrow$ kurgal (UD) den-lil ${ }_{2}$; $\rightarrow$ kur-gal a-a den-lil ${ }_{2}$; $\rightarrow$ saĝ-ki huš den-lil $-1 a_{2} ; \rightarrow$ ša $_{3}$ den-lil ${ }_{2}-1 a_{2} ; \rightarrow$ še-ga den-lil $l_{2}-1 a_{2} ; \rightarrow$ tigi $_{2}$ den-lil ${ }_{2}-\mathrm{la}_{2}(-\mathrm{k})$

den-lil 2 kur-ra en-na (+ verb-a)

en-nir-gal ${ }_{2}$-an-na en-nu(-ug $\left.\hat{g}_{3}\right) \mathrm{du}_{3}$
"Enlil of the Netherworld" (ep. Nergal): A 90

"so far as, as many as": A $87^{*} ; 139 ; 140 ; \rightarrow$ nonstandard in-na

PN Ennirgalana: 35:9

"to set up a guard, to guard": A 184* 
$\mathrm{EN}\left(\mathrm{uru}_{16} \cdot \mathrm{n}\right)$

EN.DIM ${ }_{2}$ GIGki

EN $\times \mathrm{GANA}_{2}$-t.

dEN.ZU

engar

engar zi GANA 2 daghal-la "faithful farmer of the broad fields" (ep. Urnamma): G 19* || 20

enim

"word, speech, matter, pronouncement": $\rightarrow \mathrm{KA}(\mathrm{enim})$

$\mathrm{ge}_{4}$

enim gal-gal "very important matter": A 197

enim ge-na dutu "firm pronouncement of Utu": CU 110-111 (broken)

enim $\mathrm{ku}_{3} \cdot \mathrm{g}$

enim $\mathrm{ku}_{3}$ ?! an-na(-k)

enim $\mathrm{du}_{11} \cdot \mathrm{g}$

"valiant, obstinate": C $14 * ; \mathbf{E} 31^{*} ; \rightarrow \mathrm{i}_{7}$ - E N $\left(. \mathrm{EREN}_{2}\right) . \mathrm{NUN} ; \rightarrow \mathrm{i}_{7}$-EN.URU $\mathrm{E}_{3}$.GAL; $\rightarrow$ me-e(-)EN; $\rightarrow$ nam-EN-na tag; $\rightarrow$ en; $\rightarrow$ uru $_{16}$.n

GN: $\rightarrow$ dbil $_{3}$-ga-mes EN.DIM 2 .GIGki

"staff": $\rightarrow$ šibir

DN Su'en: $\rightarrow{ }^{\text {dsu'en }}$

"farmer": A 24

"precious pronouncement: A $8^{*}$

"An's precious? pronouncement": A 13*

"to utter words":

enim du du $_{11}$-ga dereš-ki-gal-la-ka "command of Ereškigal": A 138

enim den-lil ${ }_{2}-\mathrm{la}_{2} \mathrm{du}_{11}-\mathrm{ga}$ "Enlil's command": A 55

enim mah $\mathrm{du}_{11}$.g "to utter the sublime word": A 209

enim ge/i.n

enim gal $_{2}$

enim kur $_{2}$

enim šu $\mathrm{ge}_{4}$

enim zu

enkum

ensi $_{2}$ $\rightarrow$ KA ge/i.n

"to let orders be, to put orders into something (+ loc.)":

C $27 ; \rightarrow \mathrm{KA}\left(\right.$ enim?) $\mathrm{gal}_{2} \mathrm{ku}_{3}$ zi.d

"to change the word": A 208 \| 209; 47, 2:9-10 (broken)

"to answer, to respond": A 181

"eloquent": E 31'*

"e n k u m": B 18

"e $\mathrm{n} \mathrm{i}_{2}$ " (independent ruler): 28, 2:5; $\rightarrow \mathrm{e}_{2}$ - duru $_{5}$ $\mathrm{e}\left[\mathrm{nsi}_{2} \ldots\right] ; \rightarrow$ ur-ab-ba ensi ${ }_{2}$

ensi $_{2}$ gal irigal ()$_{(2)}-\mathrm{la}(-\mathrm{k})$ "the great e $\mathrm{n} \mathrm{s}_{2}$ of the underworld" (ep. Anuna): A 134 (broken)

ensi $_{2}$ gal kur-ra

"the great e $\mathrm{n} \mathrm{i}_{2}$ of the netherworld" (ep. Anuna): A 131

$\mathrm{der}_{3}$-ra

ensi $_{2}$ lagaški(-k)

geš eren

gešeren duru 5

geš eren? kalam-ma

EREN

eren $_{2}$

EREN $_{2}$

eren $_{2}$ silim-ma

dereš-ki-gal "e $\mathrm{n} \mathrm{s}$ i $_{2}$ of Lagaš": CU 76-77

DN Erra: $\rightarrow \mathrm{i}_{7}$-ši-ma-at-der ${ }_{3}$-ra

"cedar tree": $\rightarrow$ kur šem ĝeš eren-na

"sappy cedar tree": A 48*

"cedar tree? of the land": A 46a* (Susa)

$\rightarrow$ PUZUR $_{4} \cdot{ }^{\mathrm{d}} \mathrm{MUS}_{3} \cdot \mathrm{EREN}(-\mathrm{k})$

"troops, soldiers": A $64 ; 139 ; \rightarrow \mathrm{lu}_{2}$ eren $_{2}$-e ki-a $\hat{g}_{2} ; \rightarrow$ var. lu $_{2}$ geš tukul-la

"vigorous troops": C 72

$\rightarrow \mathrm{i}_{7}$-EN.EREN 2 .NUN; $\rightarrow$ sig?("EREN ${ }_{2}$ ")

DN Ereškigal: A 100; $\rightarrow$ enim du ${ }_{11}$-ga dereš-ki-gal-la$\mathrm{ka} ; \rightarrow$ nig ${ }_{2}$ ki-a $\hat{\mathrm{g}}_{2}$ dereš-ki-gal-la 
eri $_{11}$

eriduki

$\operatorname{erim}_{2}-\hat{g a l}_{2}$

gešesi

eš-bar

eš́- $\check{g a n a}_{2}$ za-gin

eš $\check{2}_{2}$-nun-naki

$\mathrm{eš}_{3}$

eš e $_{2}$-an-na

$\mathrm{ešs}_{3}$ mah

$\mathrm{ešs}_{3} \mathrm{uri}_{2 / 5} \mathrm{ki}$

ešs-bur

ešgiri(U.EN $\times G A N A_{2}$-t.)

eštub

ezem-gin $\mathrm{du}_{3}$

dezina $_{2}$

ga-eš

ga-ri nu-tuku

ĝeš ga-rig 2 $\rightarrow \mathrm{d}^{\mathrm{ne}} \mathrm{e}_{3}-\mathrm{eri}_{11}$-gal

GN Eridu: 4:5; $\rightarrow \mathrm{i}_{7}-\mathrm{gu}_{2}$-bi eriduki-ga; $\rightarrow$ geš ig gal eriduki_ga; $\rightarrow$ lugal eriduki-ga

"enemy, hostile": $\rightarrow$ kur erim ${ }_{2}-\mathrm{gal}_{2} ; \rightarrow \mathrm{lu}_{2}$ erim $_{2}-\mathrm{gal}_{2} ; \rightarrow$ non-standard i-ri-ĝa $a_{2}-\mathrm{al} ; \rightarrow$ non-standard i-ri-im-ma- $\left(\mathrm{ga}_{2}-\mathrm{l}(\mathrm{a})\right)$

"ebony": H 3

"decision": $\rightarrow$ du $_{11}$-ga eš-bar zi.d

"surveying tape made of lapis lazuli": A $125^{*}$

GN Ešnuna: $\rightarrow$ ma-da eš $\check{2}_{2}$-nun-naki

"sanctuary, shrine":

"sanctuary Eana": A 212

"magnificent shrine" (ep. Ekur): B 8

"sanctuary Ur": C 2; 5; 92; E 2' (broken) II F 8

TN Ešbur: 17:8

"nose-leash": A 103a (Susa); D (Ni) 17 II (Ur) 18' (broken)

"carp": $\rightarrow$ a-eštub

"to prepare something as for a festival": C 54*

"wheat": C 23; G 8

$\rightarrow$ nam-ga-eš

"to have no equal": C 24*; $\rightarrow$ gaba-ri nu-tuku "comb":

geš ga-rig 2 nam-munus-a "comb of womanly fashion": A 111

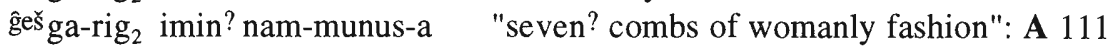

(Susa)

gaba

1. "coast":

gaba a-ab-ka(-k)

"coast of the sea waters": $\mathbf{2 6}, 2: 2$

gaba digirir-re-e-ne

gaba-ri nu-tuku

gaba-šu-ĝar nu-tuku

GABA

$\mathrm{gabu}_{3}$ bu

gada $1 a_{2}$

geš gag

geš gag-pana

geš gag(-)ti

gal

2. "chest": C 55

"chest of the gods": A 107

"to have no equal": C 77; $\rightarrow$ ga-ri nu-tuku

"to have no counterpart": F 7

$\rightarrow$ USAR.x.GABA-an-na

"left": $\rightarrow \mathrm{a}_{2}$ gabu $_{3}$ bu gub

"to put on a linen garment: C 73

"peg": A 125 (Susa)

"arrow": A 88; $\rightarrow$ var. ĝeš gag(-)ti

"arrow": A 88 (Susa); $\rightarrow$ var. ĝeš gag-pana

"big, large, important, great": F 43 (obscure); $\rightarrow$ a-gar ${ }_{3}$ gal; $\rightarrow$ ama gal dnin-lil ${ }_{2} ; \rightarrow$ bad $_{3}$ gal; $\rightarrow$ di gal ku gu $_{5}$; $\rightarrow$

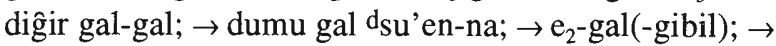
enim gal-gal; $\rightarrow$ ensi $_{2}{\text { gal } \text { irigal }_{(2)}-\mathrm{la}(-\mathrm{k}) ; \rightarrow \text { ensi }_{2} \text { gal }}$ kur-ra; $\rightarrow$ gu $_{2}$-gal; $\rightarrow$ geš-nu - $_{11}$ gal; $\rightarrow$ giri ${ }_{2}-z_{2}$ gal; $\rightarrow$ gišsbun gal-gal; $\rightarrow$ hur-sag gal-gal; $\rightarrow \mathrm{i}_{3}-\mathrm{du}_{8}$ gal; $\rightarrow \mathrm{i}_{7^{-}}$

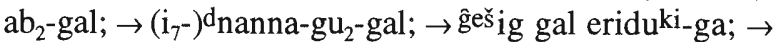
irigal, irigal ${ }_{2}$ gal $; \rightarrow \mathrm{KA}_{2}$ (.)GAL; $\rightarrow$ ki-gal; $\rightarrow$ ki-gal-2- 


gal-bi
GAL
galam
GAM
gana 2
GANA 2
\[ \text { GANA }_{2} \text { dagal } \]
GANA $_{2}$ den-lil ${ }_{2}-\mathrm{la}_{2}$
GANA $_{2}$ zi.d
GANA
GARA $(-)$ gar
gaz

ge

ge.n

ge-rin $\left(\right.$ ge $\left._{\text {gerin }}\right)$

$\mathrm{ge}_{4}, \mathrm{ge}_{4}-\mathrm{ge}_{4}$

gi

gi hulu

gi.r

gi dub-ba

gi-gun $_{4}$-na kam-ma; $\rightarrow$ kur-gal; $\rightarrow$ ma $_{2}$-lah ${ }_{5}$ gal; $\rightarrow$ maš $_{2}$-gal kur-ra; $\rightarrow$ me gal; $\rightarrow$ nam gal tar; $\rightarrow$ nam-nun gal; $\rightarrow$ dne $_{3}$-eri ${ }_{11^{-}}$ gal; $\rightarrow$ ni $_{2}$ gal ri; $\rightarrow$ dnin-gal; $\rightarrow$ nin gal $e_{2}$-an-na; $\rightarrow$ gešpana gal; $\rightarrow$ para $_{10}$ gal kur-ra(-k); $\rightarrow \mathrm{UL}_{4}$-gal ki-en-gi$\mathrm{ra} ; \rightarrow \mathrm{unu}_{2}$ gal

"in grandiose fashion": A 59

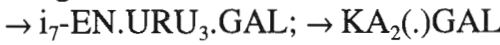

"(to) skilfully built(/d), (to) artfully fashion(ed), cunning": $\rightarrow$ giri ${ }_{2}-\mathrm{zu}_{2}$ galam; $\rightarrow$ hur-sag $(-)$ galam(-ma); $\rightarrow$ nam(-ĝeš)-šub galam

"to bend down": A 38 (Susa, obscure); 201; 238

$\rightarrow$ eš $_{2}$-gana 2 za-gin 3 ; $\rightarrow$ maš-gan 2

1. "g a n a" (field measuring unit): 27, 1:12

2. "field, ground": C 53; G 11

"broad field": $\rightarrow$ engar zi GANA 2 dagal-la

"the field of Enlil": G 16 || 17

"cultivated field": A 24

"to prepare a field, prepared field": G 10*; 13 || 14; 15 uncertain meaning: 47, 3:1 (obscure)

"to break, to smash, to slaughter, to kill": $\rightarrow$ dug gaz; $\rightarrow$ gud gaz - udu šar 2

non-standard "to send, to return": $\mathbf{A} 170$ (obscure, read perhaps $\left.\rightarrow \mathrm{ge}_{4}\right) ; \rightarrow$ ad ge $(-\mathrm{ge}) ; \rightarrow \mathrm{kig}_{2}-\mathrm{ge}_{4}-\mathrm{a} \mathrm{ge}_{(4)} ; \rightarrow \mathrm{ge}_{4}$

"(to be/make/hold) firm, to support, to confirm, to standardize": A 215; 222 (broken, obscure); $\rightarrow$ di nig $_{2}$ ge-na dutu; $\rightarrow$ enim ge-na dutu; $\rightarrow$ gi $_{16}$-sa ge.n; $\rightarrow$ KA ge/i.n; $\rightarrow$ ma-na ge.n; $\rightarrow$ na $_{4}$ ge.n; $\rightarrow$ nig $_{2}$ ge-na; $\rightarrow$ saĝ$\hat{\text { ga }}_{2}$ ge.n; $\rightarrow$ sila $_{3}$ ge.n; $\rightarrow$ suhuš ge.n; $\rightarrow$ ur $_{2}$ ge.n

"flowered, blossoming, blooming": $\rightarrow$ ĝeš-nu 2 ge-rin; $\rightarrow$ kur ge-rin

"to send, to (make) return to somewhere (+ loc. (term.)), to recede": A 170 (obscure, read perhaps $\rightarrow$ ge); 212 (A, broken, obscure); 226; C 57; 87*; 88; 89; 91; CU 84; 116; Ni. 4375 iv 6' (broken); 29, b 2:4' (obscure); $\rightarrow$ a-la ge ge $_{4} \rightarrow \mathrm{a}_{2}$ nun ge $\mathrm{ge}_{4}$-a; $\rightarrow$ ama-ar $\mathrm{ge}_{4}-\mathrm{ge}_{4}$; $\rightarrow$ ama-ar ge $_{4}$ gar; $\rightarrow$ bad $_{3}$ ge $_{4} ; \rightarrow$ enim šu ge $_{4} ; \rightarrow$ gu $_{2}$-bi ge $_{4} ; \rightarrow \mathrm{KA}(\mathrm{enim}) \mathrm{ge}_{4} ; \rightarrow \mathrm{ki}-\mathrm{bi} \mathrm{ge}_{4} ; \rightarrow \mathrm{kig}_{2}-\mathrm{ge}_{4}-\mathrm{a} \mathrm{ge}_{(4)} ; \rightarrow$ la-la-bi ge ge $_{4} \rightarrow$ šu-a ge ge $_{4}-$ ge $\left._{4}\right) ; \rightarrow$ non-standard ge; $\rightarrow$ var. BU

(bu.r?) A (?)

"reed": A 238; $\rightarrow$ geš-gi

"bad reeds": C 53

$\rightarrow$ ki-en-gi.r; $\rightarrow$ dsul-gi.r

"stylus": A 124

"g i g u n a": B 29; C 8; 110; E 15' || F 20 (broken) 


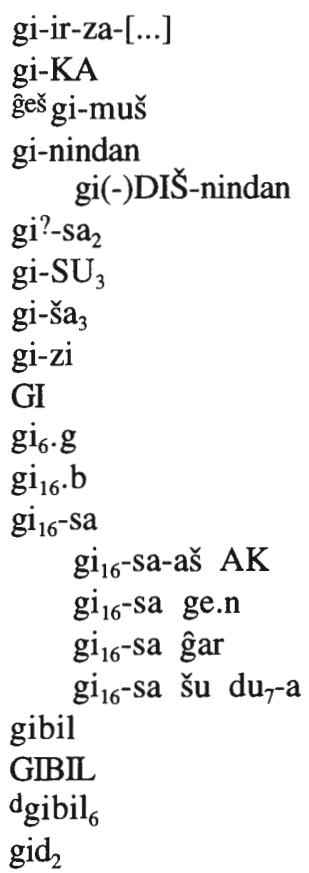

geř gid $_{2}$-da

gig

GIG

ĝeš gigir

dgilgameš

$\operatorname{gin}_{2}$ $\operatorname{gin}_{2} \quad \mathrm{ku}_{3} \cdot \mathrm{g}$

$\mathrm{GIN}_{2}$ gar

$-\operatorname{gin}_{7}$

$\operatorname{gir}_{5}$

$\operatorname{gir}_{17}$-zal

(-i)g-ru

gu-la

gu-nu

gu-ti-umki non-standard "delight": B 71; $\rightarrow$ gir $_{17}$-zal

uncertain meaning: 28, 2:11

"punting pole": A 67

"(n i n d a n) measuring rod": A 125 (Susa)

"measuring rod of one $\mathrm{n}$ i $\mathrm{n}$ d a n": A 125*

non-standard "platform?": F 16* (broken); $\rightarrow$ var. gi-ša

". . . flute": A 187*

non-standard "platform?": E 11'*; $\rightarrow$ var. gi?-sa

"reed fodder": D (Ni) 29* \|| 30

obscure: D (Ur) 25'*; 29,b 2:3" (broken)

"black": $\rightarrow\left(\right.$ ug $\left._{3}\right)$ sag gi $_{6} \cdot g$

"to block, to bolt": F 31

"jewellery, treasures":

"to make permanent": 27, 2:5-6 (broken)

"to firmly place treasures": A 159 (Susa)

"to place treasures": A 159

"perfectly wrought jewellery": A 106

"new": $\rightarrow \mathrm{e}_{2}$-gal-gibil; $\rightarrow \mathrm{eg}_{2}(-)$ gibil

uncertain meaning: 28, 2:10

DN Gibil: C 39

"to stretch out, to make long": $\rightarrow$ sa-gid 2 -da; $\rightarrow$ saĝ-ki $\operatorname{gid}_{2} ; \rightarrow$ šu $\operatorname{gid}_{2}$

"spear": A 92*

"sick, bitter": A 169 (broken); $\rightarrow$ (i-lu a-nir) nig ${ }_{2}$ gigga; $\rightarrow$ ir $_{2}$ gig še $e_{8}-\check{s ̌ e}_{8} / \check{s i}$-ši; $\rightarrow$ šu gig gid $_{2}$

$\rightarrow$ dbil $_{3}$-ga-meš $\check{S}_{3}$ EN.DIM ${ }_{2}$.GIGki

"chariot": A 74 ॥ 75*

$\rightarrow$ dbil $_{4}$-ga-mes

"shekel": $\rightarrow \mathrm{lu}_{2} 1 \mathrm{gin}_{2}$

"pure shekel (weight)": CU 147

"to set axes against something (+ loc.(-term.))": A $47^{*}$; $\rightarrow$ AGA gar

$\rightarrow$ a-ba-dnanna-gin $7 \rightarrow$ a-gin $7 \rightarrow$ an-gin 7 sa $_{7} . g ; \rightarrow$ an-

$\operatorname{gin}_{7} \mathrm{su}_{3}$-ud; $\rightarrow$ ezem-gin du $_{3} ; \rightarrow$ gest tir-gin ${ }_{7}$ su; $\rightarrow u_{2^{-}}$

šem-gin $\mathrm{mu}_{2} ; \rightarrow \mathrm{u}_{4}-\mathrm{gin}_{7} \mathrm{kar}_{2} ; \rightarrow \mathrm{ur}_{5}-$ gin $_{7} ; \rightarrow$ dutu-gin 7

kalam-ma $e_{3}$

$\rightarrow \mathrm{lu}_{2} \mathrm{gir}_{5}$-ra

"delight(ful), proud one": B 71; C 82; $\rightarrow$ ki-tuš gir $_{17^{-}}$

zal; $\rightarrow$ munus zi gir ${ }_{17}$-zal; $\rightarrow$ non-standard gi-ir-za-[...]

$\rightarrow$ non-standard ni(-i)g-ru

"eldest": C 112

"mottled": $\rightarrow$ še gu-nu

GN Gutium, the Guti: C 90; Ni. 4375 iv 4' 
geš gu-za

geš gu-za za-gin 3 gu-zu-ma $\mathrm{gu}_{2}$

$\mathrm{gu}_{2} \mathrm{i}_{7}$ buranun

$\mathrm{gu}_{2} \mathrm{i}_{7} \mathrm{du}_{3}-\mathrm{a}$

$\mathrm{gu}_{2} \mathrm{i}_{7}$ idigna

$\mathrm{gu}_{2}$ A.NE.RU(-)gal ${ }_{2}$

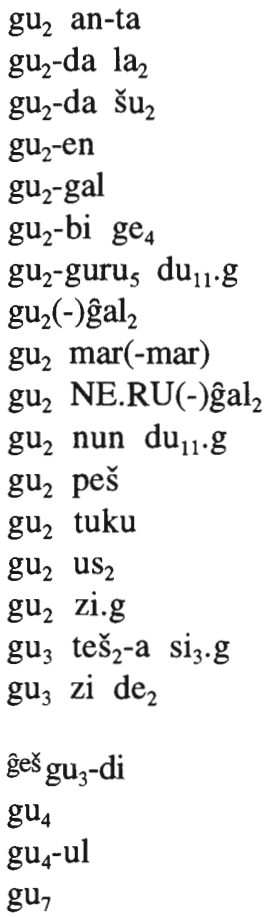

gub

GUB

gublaga "throne": A 189; D (Ni) 15 (broken) II D (Ur) 15'; 47, 4:5 (broken)

"lapis lazuli throne": A 159 (Susa)

$\rightarrow$ du $_{6}$-gu-zu-ma-ka

"neck, bank (of a canal)": C 35; 83; D (Ur) 36'; Cadaster A ii 5; 24; iii $12 ; 29$; iv $1 ; 14$; B i 4; 13; 15 ; $16 ; 21 ; \rightarrow \mathrm{i}_{7}-\mathrm{gu}_{2}$-bi eriduki-ga; $\rightarrow \mathrm{i}_{7}-\mathrm{gu}_{2}-[\mathrm{x}]-\mathrm{ur}_{2}$ ?(-) dningir $_{2}$-su; $\rightarrow$ nam-gu mah

"banks of the Euphrates": CU 152

"the banks of all rivers": CU 153

"banks of the Tigris": CU 151

"(to be) rebellious, hostile": B 52 \|I 53 (D); $\rightarrow \mathrm{gu}_{2} \mathrm{NE}$.

RU(-)gal ${ }_{2}$; $\rightarrow$ var. kur erim ${ }_{2}-$ gal $_{2}$

uncertain meaning: B 44 \| 50

"to embrace, to join": A 50

uncertain meaning: D (Ur) 28'*

"assembly": F 6

"foremost": C $2 ; \rightarrow\left(\mathrm{i}_{7^{-}}\right)^{\mathrm{d}}$ nanna-gu $\mathrm{2}_{2}$-gal

"to close hermetically": A 11

"to (be) strip(ped)": A 67

$\rightarrow$ saĝ(-)gu $\mathrm{gu}_{2}(-) \mathrm{gal}_{2}$

"to thrive?": B 16*; G 9

"(to be) rebellious": B $14\left(\mathrm{C}_{2}\right)$; $\rightarrow$ ki-bala NE.RU-gal ${ }_{2}$ non-standard "to bray loudly": A 116* (Susa)

"to stiffen the neck": F 18

"perfect": $\rightarrow$ guruš? gu $_{2}$ tuku den- $\mathrm{lil}_{2}-\mathrm{la}_{2}$

"to raise the neck": $\rightarrow$ an-še ${ }_{3}$ gu $_{2}$ us $_{2}$

"to lift the neck": A 43; $\rightarrow$ var. ur $_{5}$ zi.g

"to make of one mind, to make obedient": C 28*; 39

"to speak authoritatively to something, somebody (+ loc.(-term.))": C 59

"musical instrument": $\rightarrow$ geš-gu ${ }_{3}$-di

$\rightarrow$ gud

non-standard "to destroy": B 58 \| 60; $\rightarrow$ gul

"to eat, to eat of (+ loc.-term.)": C 75; D (Ni) 29 || 30; D (Ur) 36'

"to stand (by), to stand on (+ loc.(-term.)), to place, to establish, to serve somebody (+ dat.)": A 24*; 54; 157; 210; C 40 (obscure); 47; D (Ur) 29'; CU 176a (broken); $\rightarrow a_{2}$ gabu $_{3}$ bu gub; $\rightarrow a_{2}$ zi-da gub; $\rightarrow$ ab-sin 2 gub; $\rightarrow$ urudaba-ri $\mathrm{i}_{2}$-ga gub; $\rightarrow$ bar-ta gub; $\rightarrow$ gi $\mathrm{i}_{6}$-da gub; $\rightarrow$ giri ${ }_{3}$ gub; $\rightarrow$ ki-a gub; $\rightarrow$ ki-gal-la gub; $\rightarrow \mathrm{u}_{4}$-da gub; $\rightarrow$ $\mathrm{u}_{6}$ di-še ${ }_{3}$ gub; $\rightarrow \mathrm{za}_{3}$-ga gub

$\rightarrow$ a GUB; $\rightarrow$ KI.LUGAL.GUB.1

$\rightarrow$ dnin-gublaga 
gud

gud $\mathrm{dab}_{5}$ gud $\mathrm{du}_{7}$ gud gaz - udu šar

gud mah

gud $\mathrm{sa}_{7} \cdot \mathrm{g}$

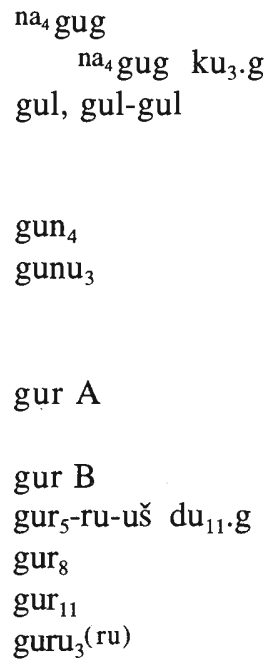

guru $_{5}$

gurun $_{6} \quad \operatorname{lal}_{3} \quad \mathrm{de}_{2}$ $\hat{\mathrm{ga}} \mathrm{a}_{2}, \hat{\mathrm{ge}}_{26}-\mathrm{e}$

ga $a_{2}(-1)$, ga $a_{2}-\mathrm{al}$

ga $a_{2}-\hat{g} e s ̌-s ̌ u_{2}-a$

ga $a_{2}$-la nu-dag

ga $a_{2}$-nun

$\hat{\mathrm{GA}}$

$\mathrm{gal}_{2}$ "ox(en), bull, cattle": G 13; 15; $\rightarrow$ DIŠ gud geš šudul 4 -a; $\rightarrow \mathrm{lu}_{2} 1$ gud

"to hold cattle": CU 94 (broken); 120 "perfect bulls": A 87; $\rightarrow$ var. gud sa ${ }_{7} . \mathrm{g}$

"to slaughter numerous bulls and sheep"(hendiadys): $\mathbf{A}$ 81

"mighty bull": A 171

"magnificent bulls": A 87 (Susa); 128a (Susa, broken); 129 (Susa, broken); $\rightarrow$ var. gud du 7

"carnelian-stone": A 107 (D)

"pure? carnelian-stone": A 107

1. "to (completely) destroy": A 5; 29; B 58 ॥ 60; C 92 (obscure); $\rightarrow$ tur $_{3}$ gul; $\rightarrow$ non-standard gu $_{4}$-ul

2. "to cut away": A $45 *$

$\rightarrow$ gi-gun ${ }_{4}$-na

"(to be) iridiscent, multicoloured, dappled, painted with (+ abl.)": C 4; $\rightarrow$ ku $_{3}$-sig 17 -ta gunu g $_{3} \rightarrow$ kušlu-ub gunu $_{3}$; $\rightarrow$ ur $_{2}$ gunu $_{3}-$ gunu $_{3}$

"to (re)turn": $\mathbf{A}$ 199* (broken, read perhaps $\rightarrow \mathrm{ku}_{4} \cdot \mathrm{r}$; $\rightarrow$ DU A); G 27 (obscure); $\rightarrow$ ša ${ }_{3}$ gur; $\rightarrow$ ur $_{2}$ gur-ra "g u r" (measuring unit): CU 26

"to rush forth against somebody (+ com.)": C $37 *$

$\rightarrow \mathrm{ma}_{2}-$ gur $_{8}(-\mathrm{ra})$

$\rightarrow$ nig $_{2}$ - ur $_{11}$

"to carry, to be laden with, to imbue with, to be full of": D (Ur) 26' (broken, obscure); $\rightarrow \mathrm{e}_{2}$-temen-ni ${ }_{2}$-guru gu $_{3}$; $\rightarrow$ hi-li guru ${ }_{3}^{\mathrm{ru}} ; \rightarrow \mathrm{ni}_{2}$ guru $_{3}{ }^{\mathrm{ru}} ; \rightarrow$ su-zi guru ${ }_{3}{ }^{\mathrm{ru}} ; \rightarrow$ nonstandard ni(-i)g-ru

$\rightarrow \mathrm{gu}_{2}-\mathrm{guru}_{5} \mathrm{du}_{11} \cdot \mathrm{g}$

"to libate liquors and syrup": C 106*

personal pronoun 1st common sg. "I, me": A 156; 213 ; B $40 \|$ II ; C 24; 51; 59; 62; D (Ni) $11 ; 22 ; 25$;

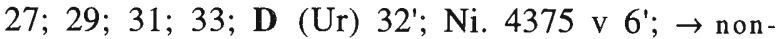
standard me B; $\rightarrow$ non-standard na(-)

non-standard "to exist, to cause to be": $\rightarrow \mathrm{gal}_{2} ; \rightarrow$ i-ri-ĝa $a_{2}$ al; $\rightarrow$ kur i-ri-im-ma(-ĝa $\left.a_{2}-1(a)\right)$

TN Gagê̌šua (in the Ekur complex in Nippur): B 31 "to cease not, to be incessant": Ni. 4375 iv 9' (broken) "granary": C 88

obscure: E $40^{\prime}$

"to exist, to cause to be, to wear at, to reach (+ term.)": A 55; 67; 211; B 45 II 51; C 26 (broken, obscure); D (Ur) 25' (obscure); CU 89; 92; 96 (broken); Ni. $4375 \mathrm{v}$ $9^{\prime}$ (broken); $\rightarrow$ du $_{10}$ gal $_{2} ; \rightarrow \mathrm{e}_{2}$-kiš-nu-ĝal ${ }_{2} ; \rightarrow$ enim gal $_{2}$;

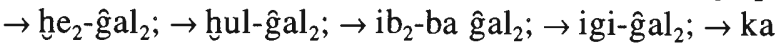


$\mathrm{gal}_{2} \mathrm{taka}_{4}$

$\mathrm{gal}_{2}$-TAKA 4 -TAKA 4 -ga

$\mathrm{GAL}_{2}$

gar (h. $), \mathrm{ga}_{2}-\mathrm{ga}_{2}(m$.
GAAR

$\operatorname{gar}_{7}-\mathrm{du}_{2}$

garza kur-ra(-k)

$\mathrm{ge}_{26}-\mathrm{e}$

gen $(h$.$) , du (m.), re 7$ (h. pl.)

geš

ĝě̌-gi

geš-gu ${ }_{3}$-di

geš-hur

geš-ḩur $\mathrm{ku}_{3} \cdot \mathrm{g}$

geš-ḩur zi.d

geš-keš

geš $1 a_{2}$

geš-la $a_{2}$-bi DU

geš-nu

geš-nu 2 ge-rin

geš-nu $u_{2}$ za-gin ${ }_{3}$ bara geš-nu ${ }_{11}$

geš-nu $u_{11}$-gal

geš-šub

geš tag mud-gal ${ }_{2}$ ki-en-gi-ra; $\rightarrow$ kalam-ma gal ${ }_{2} ; \rightarrow \mathrm{KA}($ enim?) gal $_{2} \mathrm{ku}_{3}$ zi.d; $\rightarrow$ ki a/e-ne-di/de 3 gal $_{2}$-la; $\rightarrow$ ki-ur gala $_{2} ; \rightarrow$ $\mathrm{ku}_{3}-\mathrm{gal}_{2} ; \rightarrow$ nam-he $\left(-\mathrm{gal}_{2}\right) ; \rightarrow$ NE.RU(-) gal $_{2} ; \rightarrow \operatorname{nir}(-)$ $\mathrm{gal}_{2} ; \rightarrow \mathrm{sag}(-) \mathrm{gu}_{2} / \mathrm{ku}_{3}(-) \mathrm{gal}_{2} ; \rightarrow$ sag $-\mathrm{ga}_{2} \mathrm{gal}_{2} ; \rightarrow$ su-zi gal $_{2} ; \rightarrow$ šu zi gal $; \rightarrow$ udu diri gal gal $_{2} \rightarrow$ usu gal ${ }_{2} ; \rightarrow$ nonstandard $\mathrm{ga}_{2}(-\mathrm{l}), \mathrm{g} \mathrm{a}_{2}-\mathrm{al}$

"to open": C 77

"openings": E 10' || F 15

obscure: A 238

"to set, to put aside, to lay, to organize": A 37 (Susa); $60 ; 69 ; 183 ;$ C 102; F 30; CU 165; 168; 171; $\rightarrow$ a gar; $\rightarrow$ a-nir gar; $\rightarrow$ ama-ar ge ${ }_{4}$ gar; $\rightarrow$ gešapin gar; $\rightarrow$ gaba-šu-gar nu-tuku; $\rightarrow$ GANA $_{2}(-)$ gar $; \rightarrow$ gi $16^{-}$-sa gar; $\rightarrow$ GIN $_{2}$ gar; $\rightarrow i_{7}(-)$ GEEŠ.BI.ĜEŠ(-)a(-)gar-ra; $\rightarrow$ igi gar; $\rightarrow$ ki gar; $\rightarrow$ ki šub-ba ĝar; $\rightarrow$ ki-tuš gar; $\rightarrow$ ki-ur 3 gar; $\rightarrow$ kig $\hat{g}_{2}$ gar; $\rightarrow$ me-a gar; $\rightarrow$ ni $\hat{g}_{2}$-ba-a gar; $\rightarrow$ nig. $\hat{g}_{2}(-)$ me-gar; $\rightarrow$ nig $_{2}-$ si-sa $_{2}$ gar; $\rightarrow$ sa-gar-ra; $\rightarrow \mathrm{sa}_{2}-\mathrm{du}_{11}-\mathrm{Se}_{3}$ gar; $\rightarrow \mathrm{u}_{4}$ gar; $\rightarrow$ za-pa-ag $\hat{g}_{2}\left(-\mathrm{SE}_{3}\right)$ gar; $\rightarrow$ var. TAR obscure: D (Ur) 40'

$\rightarrow \mathrm{a}_{2}$ tumu-gar $\mathrm{gr}_{7}-\mathrm{du}_{2}$

"the cultic norms of the netherworld": A $84 ; 84$ a (Susa) $\rightarrow \mathrm{gaa}_{2}, \mathrm{ge}_{26}-\mathrm{e}$

from": A 41 (Susa); 59; 64; $79 \|$ 80; C 56; $\rightarrow$ DU A $\left(\mathrm{de}_{6} / \mathrm{tum}_{2}\right) ; \rightarrow$ var. šeg $\hat{\mathrm{S}}_{3}$

"wood, tree": C 83; G 11; $\rightarrow$ ga $a_{2}$-ĝeš-šu $\mathrm{u}_{2}-\mathrm{a} ; \rightarrow$ dnin-ĝešzi-da

"canebrake": A 227

"musical instrument": A 188*

"rules, plan, scheme": A 210; $\rightarrow$ var. ' ${ }^{\mathrm{X}}$ '- bur $_{2}$

"sacred plans": F 19; $\rightarrow$ var. geš-hur zi.d

"righteous plans": E 13'; $\rightarrow$ var. geš-hur $\mathrm{ku}_{3} . \mathrm{g}$

"container": A $97 *$

"to pay heed": A $186^{*}$

"to settle in (said of) deathly silence": A 44*

"bed": A 191

"flowered bed": C 74

"light": A $103^{*}$ (Susa)

"alabaster": A 123

$\rightarrow \mathrm{i}_{7}$-ĝě̌-šub-ba; $\rightarrow$ nam-ĝeš-šub galam

"to sacrifice, to offer as a sacrifice": A 85 ॥ 86; 91* ॥

96 || 101 (broken) || 105 || 109 || 113 || 119 || 122a

(Susa, broken) || 128 || 131a (Susa) 


\section{ĜEŠ.BI.ĜEŠ}

geštin

dgeštin-an-ka

dgeštin-an-na $\rightarrow \mathrm{i}_{7}(-)$ ĜEŠ.BI.ĜEŠ(-)a(-)ĝar-ra

"wine": $\rightarrow$ kar-ĝeštin-na den-lil ${ }_{2}-1 a_{2}$

GN: Cadaster B iii 15; 16

DN Ĝeštinana (wife of Ninĝešzida): A $127 a^{*}$ (Susa); $\rightarrow$ $\mathrm{KA}_{2}$-dĝeštin-an-na-ka

dgeštin-an-na-hi-ba-ri $i_{2}$-tum-ma-ka GN: Cadaster A ii 29-30; 31-32

geštu

ĝeštu ${ }_{2}$ daĝal

"wisdom, ears":

"broad wisdom, broad understanding": C 60; D (Ni) 21; $\rightarrow$ en geštu 2 daĝal-la

geštu ${ }_{2}$ mah $l_{2} \quad$ zu "great ears of a sage": A 123 gi $\mathrm{i}_{6}$-da gub

$\mathrm{gi}_{6}-\operatorname{par}_{3 / 4}$

$\hat{g} i_{6}-\operatorname{par}_{4} \mathrm{ku}_{3} \cdot \mathrm{g}$

$\mathrm{gi}_{6}-\operatorname{par}_{3}-\mathrm{ku}_{3} \cdot \mathrm{g}$

(geš) ĝidri

(̣̂eš) ĝidri $\mathrm{ku}_{3} \cdot \mathrm{g}$ "occupied with the night, serving by night": A $163 *$

"ĝ i p a r": C 5*; 73; 29,b 2:2' (broken)

"precious $\hat{g}$ i p a r" (part of the Eana): A 212

TN Ĝiparku (in Ur): 19:7

"sceptre":

"dazzling sceptre": A 223 (broken); D (Ni) 16 || D (Ur) 17

ĝidri $\mathrm{ku}_{3}$-sig ${ }_{17}$ nam-en-na "golden sceptre of e n-ship": A 103 ; $\rightarrow$ var. ĝeš manu nam-en-na(-k)

$\mathrm{gir}_{2}$

$\hat{\mathrm{G}} \mathrm{R}_{2}$-kalki

ĜIR $2 \cdot \mathrm{NITA}_{2}$

giri ${ }_{2}$

giri $_{2}-\mathrm{Zu}_{2}$ gal

giri $_{2}-\mathrm{Zu}_{2}$ galam

giri ${ }_{3} \operatorname{dib}_{2}$

giri $_{3}$ gub

giri $_{3}-$ saga $_{11} \quad$ du $_{11} \cdot \mathrm{g}$

giiri ${ }_{3}$ si $\mathrm{sa}_{2}$

giri $_{3}\left[\mathrm{ki}^{?}\right] \mathrm{us}_{2}$

ğeš ğisal

ĝišbun

ĝišbun gal-gal

gi iškim $\mathrm{sa}_{6} \cdot \mathrm{g}$

$-\mathrm{gu}_{10}$

$\rightarrow$ nim gir $_{2}-$ gir $_{2}$

GN ĜIRkal: CU 127

"general": CU 172

"dagger":

"large .. . dagger": A 88 (Susa); $\rightarrow$ var. girii ${ }_{2}-\mathrm{zu}_{2}$ galam

"artfully fashioned . . . dagger": A $88^{*} ; \rightarrow$ var. ĝiri ${ }_{2}-\mathbf{z u}_{2}$ gal

"to tread with the feet": A $37^{*}$

"to put the foot on something (+ loc.)": C 35

"to trample": B 55 ॥ 57; $\rightarrow$ non-standard mi-ri-e-zi-ka

$\mathrm{du}_{11} \cdot \mathrm{g}$

"to put the roads in order": C 19; 54; year name "4"

"to make one's way": A 70 (Susa, broken)

"oar": A 67

"banquet, festive meal": C 101*

"huge banquet-tables": A 82

"favourable portent": A 161

possessive pronoun 1st common sg. "my": $\rightarrow \mathrm{a} \mathrm{lu}_{2} /$ lugal-ĝ $\mathrm{u}_{10} ; \rightarrow \mathrm{a}_{(2)} \mathrm{sa}_{3}-\mathrm{gu}_{10} \mathrm{du}_{11} \cdot \mathrm{g} ; \rightarrow \mathrm{lu}_{(2)^{-}}$ga-al-ĝu $\mathrm{u}_{10} ; \rightarrow$ lugal-ĝ $u_{10} ; \rightarrow$ nam-ĝu $u_{10} ; \rightarrow$ nin- $\hat{g} u_{10}$

guruš? $\mathrm{gu}_{2}$ tuku den-lil $1_{2}-\mathrm{la}_{2}$ "perfect workman? of Enlil": C 93

ha-šu-ur

ha-za

har $\mathrm{ku}_{3}-\mathrm{sig}_{17}$

har-ra-an "hु a š u r-tree": $\rightarrow$ (geš) tir ḩa-šu-ur ${ }_{2}(-$ ra)

$\rightarrow$ saĝ(-ĝa $\left.a_{2}\right)$ ha-za

"golden ring": A 106

"road": A 74 || 75 
he $_{2}-\mathrm{a}$

he $_{2}-\mathrm{du}_{7}$

he $_{2}$-em

he $_{2}-$ gala $_{2}$

he $_{2}-$ galal $_{2}-1 \mathrm{a} \mathrm{pa} \mathrm{e}_{3}$ he $_{2}-$ gal $_{2}$ pa $e_{3} \mathrm{AK}$

he $_{2}$-na

hil-ba-ri $i_{2}$-tum

hii-li

hii-li guru $_{3}{ }^{\text {ru }}$

hi-li-a/e $\mathrm{ku}_{4} \cdot \mathrm{r}$

hii-li til

hil-rit-tum

$\mathrm{HI}$

HI.r

huu-ri-in

hu-š(a)

hu-ur-ĝa $a_{2}-1(a)$

hu-wu-um

HU?.UD

hul-gala ${ }_{2}$

$$
\text { hul-ĝal } 2 \text {-la tušs? }
$$

hul $_{2}$

hulu

hulu til ${ }_{3}$ hur "may he/it be(come)!": B 6*; C 107; 28, 2:4-5 (broken); 47, 4:12; $\rightarrow$ var. he ${ }_{2}$-na

"adornment" (ep. Urnamma): C 13

"may he/it be": B 44* || 50

"abundance": C 21; 103; D (Ur) 35'; E 2'; F 2*; $\rightarrow \mathrm{i}_{7}$

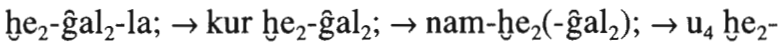
gal $_{2}-\mathrm{la}$

"to reveal abundance": A $158 ; \rightarrow$ var. he $_{2}-\mathrm{gal}_{2} \mathrm{pa} \mathrm{e}_{3} \mathrm{AK}$ "to reveal abundance": A 158 (Susa); $\rightarrow$ var. h. $\mathrm{he}_{2}$-gal ${ }_{2}$-la pa $e_{3}$

"may he/it be(come)!": 28, 2:8 (broken); 2:14; $\rightarrow$ var. he $e_{2}$-a

GN: Cadaster A ii 26; iv 12; 13; 16-17; $\rightarrow$ dĝeštin-anna-hi-ba-rit-tum-ma-ka

"(sexual) charm, attractiveness, luxuriance, physical prime": A $63 ;$ F 47

"to be full of charms, to be full of luxuriance": $\mathbf{C} 4 ; \mathbf{F}$ $1 ; \mathbf{E} 25^{\prime}$ || $\mathbf{F} 25$ || 28

1. "to turn somebody into a darling": C 45

2. "to bring in sexual charm": A 213

"to bring the attractiveness (of a person) to maturity, to exhaust the luxuriance (of something)": A 153*; 189

GN: Cadaster A iii 14; 15

obscure: $\mathbf{C} 68$

uncertain meaning: A 240

"eagle": B 25

non-standard "frightful": B 62 ॥ 64; $\rightarrow$ huš

non-standard "evil": B $58 \|$ || 60; $\rightarrow$ hul-ĝal ${ }_{2}$

$\rightarrow$ an-za-gar ${ }_{3}$-hu-wu-um-ma

obscure: $\mathbf{H} 8$ (broken)

"evil(-doer)": A 6*; B 58 ॥ 60; E 13' || F 19; E 14'; $\rightarrow$ $\mathrm{lu}_{2}$ ḩul-ga $\mathrm{l}_{2} ; \rightarrow$ non-standard hu-ur-ga $a_{2}-1(\mathrm{a})$

"to sit? in a wretched state": A 15 (Susa); $\rightarrow$ var. hulu $\mathrm{til}_{3}$

"(to be) glad, joyful, to delight in, to enjoy, to rejoice": A $149 ; 174 ;$ B 35; C 42; $\rightarrow$ a-ne hul hla du $_{11}$.g; $\rightarrow$ e-nedi hul ${ }_{2}-l a ; ~ \rightarrow$ ki-tuš ša ${ }_{3}$ hul $_{2}$-la; $\rightarrow$ var. ša hul $_{2}$ "(to be) bad, perilous, evil, to destroy": A 174; $\rightarrow \mathrm{a}_{2}$ niğ $\hat{g}_{2}$-hul $\operatorname{dim}_{2}$-ma ag $\hat{g}_{2} ; \rightarrow$ gi hulu; $\rightarrow \mathrm{PU}_{2}$ h̆ulu; $\rightarrow$ dudug hulu

"to be miserable": A $15 ; \rightarrow$ var. hul-ĝal ${ }_{2}$-la tuš?

"to trace, to draw, to device": $\mathbf{B} 7^{*} ; \rightarrow$ geš-hur 
huur-saĝ

hur-sag gal-gal

hur-saĝ galam

hur-sag $\mathrm{sa}_{7} \cdot \mathrm{g}$

hur-saĝ-galam-ma

hur-sag-nam-til ${ }_{3}$-la(-k)

hur - si-tum

HUR

huš

dhušs-bi-sa. g

i-bi $i_{2}$-lum

i-da-um-ma

$\mathrm{i}-\mathrm{i}$

i-lu

i-lu a-nir nig $\hat{2}_{2}$ gig-ga

i-lu balaĝ-di

i-lu kur-ku-ku

i-lu ni $_{2}(-)$ me-gar du ${ }_{11}$.g "to utter a silence-imposing lament": A $155^{*}$

i-mi-tum pirig an-na

$\mathrm{i} / \mathrm{i}_{3}$-ne-eš

i-ni-ir

i-ri-ĝa $a_{2}-\mathrm{al}$

i-ri-im-ma $\left(-g \mathrm{ga}_{2}-1(\mathrm{a})\right)$

i-si-iš

i-si-iš ki-en-gi-ra

i-si-iš la $\mathrm{la}_{2}$

i-ti

i-dutu

$\mathrm{i}_{3}$

$\mathrm{i}_{3} \mathrm{de}_{2}$

$i_{3}$ SAR

$\mathrm{i}_{3}-\mathrm{du}_{8}$ gal

$i_{3}-\mathrm{du}_{8}$ gal kur-ra imin-bi "the seven chief porters of the netherworld": A $76^{*}$ $i_{3}-l i_{2}$

$\mathrm{i}_{3} / \mathrm{i}$-ne-eš

$\mathrm{i}_{3}$-nun

1. "mountain (range)": A 45; 212; $\rightarrow$ var. an

2. GN: Cadaster A ii 16; 17; 18; $\rightarrow$ an-za-gar ${ }_{3}$-hur-saĝga $a_{2} ; \rightarrow$ dnin-hur-saĝ(-ka)

"all the big mountain ranges": A 197 (Susa); $\rightarrow$ var. kur-kur

"skilfully built mountain (range)": E 3' (broken) || F 9

"verdant mountain": C 109

Hursaĝgalama (ziggurat in Nippur): B 22*; 29

TN (?) Hursaĝnamtila: D (Ni) $12 * \| \mathbf{D}(\mathrm{Ur}) 13^{\prime}$

GN: Cadaster A iii 16; 17

obscure: $\mathbf{H} 5$

"frightful, fierce, terrible": B 62 ॥ 64; $\rightarrow$ ni $_{2}$ huš ri; $\rightarrow$ saĝ-ki hušs den-lil ${ }_{2}-\mathrm{la}_{2} ; \rightarrow \mathrm{u}_{4}$ hušs; $\rightarrow$ non-standard huu-š(a)

DN Hušbisag (wife of Namtar): A 112

$\rightarrow \mathrm{e}_{2}$-duru ${ }_{5} i$-bi $i_{2}$-lum-ma

$\mathrm{i}_{7}-i-d a-u m-\mathrm{ma}$

"to reveal?, to praise, to extoll": $\rightarrow \mathrm{mi}_{2} \mathrm{zi}_{-}-\mathrm{de}_{3}-\mathrm{eš} \mathrm{i}-\mathrm{i} ; \rightarrow$ me-teš $\check{2}_{2} \mathrm{i}-\mathrm{i} ; \rightarrow$ tešs $_{2}$ mu i-i

"lament, wail, lamentation": A 21; 241

"bitter wailing and lamentation": A 167* || 175

"lamentation and dirge singers": A 194

"to observe attentively a lament": A $216^{*}$

"i m i t u m-weapon (with) a celestial lion": A 92*; $\rightarrow$ gešmitum piriĝ an-na

"now": $\rightarrow$ non-standard e-ne-eš

non-standard personal pronoun 3rd sg. dat. "him": $\rightarrow$ e-ne non-standard "evil": $\rightarrow$ lu i-ri-ĝa ${ }_{2}$-al; $\rightarrow$ erim $_{2}$-ğal ${ }_{2}$

non-standard "enemy, hostile": $\rightarrow$ kur i-ri-im-ma(-ga $\left.a_{2}-1(a)\right)$ "wail, sorrow":

"wails of Sumer": A 146 || 147

"to be full of sorrow": A 14

non-standard "moonlight": C 57; $\rightarrow \mathrm{iti}_{6}$

"cry of the oppressed": C 91; CU 179; $\rightarrow \mathrm{lu}_{2}$ i-dutu-ka "oil":

"to pour oil": A 97; $\rightarrow$ var. $i_{3}$ SAR

obscure: A $97^{*}$ (Susa); $\rightarrow$ var. $\mathrm{i}_{3} \mathrm{de}_{2}$

"chief porter": A 76a (Susa)

$\rightarrow$ me-en- $i_{3}-l i_{2}$

$\rightarrow \mathrm{i}$-ne-eš $\check{2}_{2}$

"butter": CU 28 
$\mathrm{i}_{7} . \mathrm{d}$

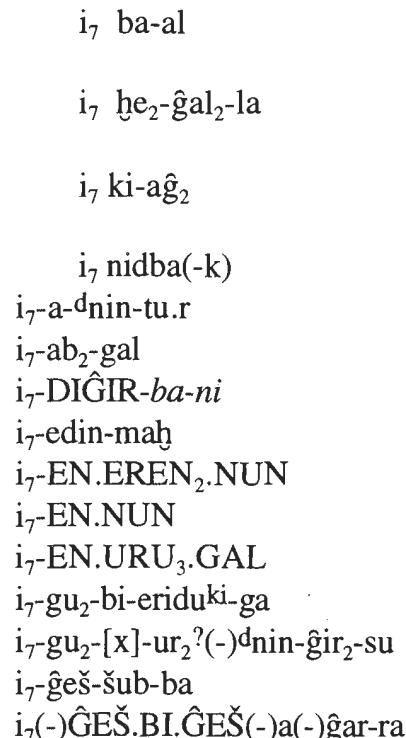

"river, canal": A 22; C 83; D (Ni) 24; 27; $33 \| 34 ; \rightarrow$ $\mathrm{i}_{7}$ buranun; $\rightarrow \mathrm{gu}_{2} \mathrm{i}_{7} \mathrm{du}_{3}$-a; $\rightarrow \mathrm{i}_{7}$ idigna; $\rightarrow($ gešs $) \mathrm{ma}_{2} \mathrm{i}_{7}$-da

"to dig canal(s)": A 225; D (Ni) 1 (broken); 3; 4; D (Ur) 1' (broken); 3'; 5'; 7'; $9^{\prime}$

"canal of abundance": D (Ni) 22 (broken) II 23; $\rightarrow$ var. $\mathrm{u}_{4} \mathrm{he}_{2}-\mathrm{gal}_{2}-\mathrm{la}$

"beloved canal": 24:8; Al-Rawi, Sumer 46 (1989-90) $84: 9$

"canal of/for sacrificial offerings": 22:9; 23:10

$\mathrm{CN}$ : year name "15"

CN: Cadaster A i $26 ; 27$; ii $5 ; 7$

$\mathrm{CN}$ : Cadaster $\mathrm{A}$ ii $5-6$

CN: Cadaster B i 12 (broken); 15

CN: 23:9; $\rightarrow$ var. $i_{7}$-EN.NUN

$\mathrm{CN}: \rightarrow$ var. $\mathrm{i}_{7}$-EN.EREN 2 .NUN

CN: Al-Rawi, Sumer 46 (1989-90) 84:8

$\mathrm{CN}: \mathbf{2 9}$,b 1:13"

". . o of Ninĝirsu-Canal", or CN?: 29,b 1:14"-15"

$\mathrm{CN}$ : year name "16"

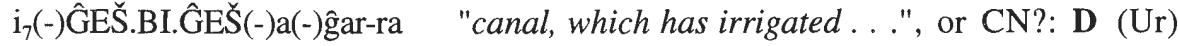

$\mathrm{i}_{7}-i-d a-u m-\mathrm{ma}$

$4^{\prime *} ; \rightarrow$ a gar

$\mathrm{i}_{7}$-IM.NI-a

$\mathrm{CN}$ : Cadaster $\mathrm{A}$ ii 8

$i_{7}$-ir-ni-na

$\mathrm{i}_{7}$-ka-zal-luki(-k)

$\mathrm{i}_{7}-\mathrm{KE}_{2} \breve{S}_{2}-\mathrm{ku}_{3} \cdot \mathrm{g}$

$\mathrm{i}_{7} \mathrm{ki}$ sur-ra(-k)

$\mathrm{i}_{7}$ ki sur-ra dnin-giri ${ }_{2}$-su

$\mathrm{i}_{7}$-lugal(-la(-k))

CN: Cadaster A ii $9 ; 11$

CN: Cadaster A iii 10; 12; 22; iv 5 (broken); 6; 7

$\mathrm{CN}$ : Cadaster A i 5; 7

CN: D (Ni) 2* (broken); 22 ॥ 23; D (Ur) 30'; 33'

"boundary canal": 28, 1:12

$\mathrm{i}_{7}(-) \mathrm{x}-\mathrm{x}$ ?(-)mah(-)dnanna

$\mathrm{i}_{7}$-me-den-lil ${ }_{2}-\mathrm{la}_{2}$

$\mathrm{i}_{7}$-dnanna-gu $\mathrm{d}_{2}$-gal

$\mathrm{i}_{7}$-nun

$\mathrm{i}_{7}-\mathrm{pa}_{4 / 5}$-bi-luh

$\mathrm{i}_{7}$-sahar

$\mathrm{i}_{7}$-še-er-us $\mathrm{s}_{2}$-sa

$\mathrm{i}_{7}-\breve{s i}-m a-a t-[\ldots]$

$\mathrm{i}_{7}$-ši-ma-at-der ${ }_{3}-\mathrm{ra}$

$\mathrm{i}_{7}-$-ur-ša-tum

$\mathrm{i}_{7}$-uri ${ }_{5}^{\mathrm{ki}}$-ma

$\mathrm{i}_{7}$-zubi

$\mathrm{ia}_{2}$

$\mathrm{ib}_{2}$-ba $\mathrm{gal}_{2}$

CN Royal Canal: C 103*

"Great...Canal (of) Nanna", or CN?: 29,b 1:6"-7" (broken)

$\mathrm{CN}$ : Cadaster B i 4; 9

CN: 29,b 1:9"

CN: 24:7

CN: D (Ur) 2'* (broken); 31'; 34'; $\rightarrow$ luh; $\rightarrow$ pa $_{5}$. r

CN: Cadaster B iv $15 ; 16$

$\mathrm{CN}$ : Cadaster A i $22 ; 23$

$\mathrm{CN}$ : Cadaster A iii 23

$\mathrm{CN}$ : Cadaster A iv 25-26

CN: Cadaster A i 28

CN: 22:8

$\mathrm{CN}$ : Cadaster $\mathrm{A}$ ii 25 ; iii 29 ; iv $1 ; 15$

"five": $\rightarrow \mathrm{u}_{4} \mathrm{ia}_{2}$

"to wear at the hip": A 89 


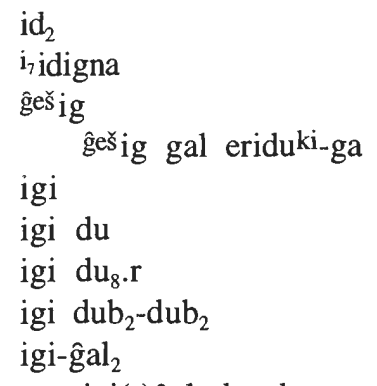

igi(-)gal ${ }_{2}$ kur-kur-ra

igi gar

igi $\mathrm{il}_{2}$

igi nim

igi (+ poss. suff.)-še igi zi bar

IGI

IGI.MIN/A?

$\mathrm{il}_{2}$

$\begin{array}{ll}\mathrm{IL}_{2} & \\ \mathrm{im} & \\ & \text { im an-na } \\ & \text { im an-ta še }{ }_{3}\end{array}$

IM

IM.A

IM.NI

IM.UD $\operatorname{sir}_{2}$-da

$\mathrm{im}_{2}$

imin

in- $\mathrm{di}_{3}$

in-dub ki-en-gi-ra

in kur $_{2} \mathrm{AK}$

in-na

in- $\breve{S E}_{3} \quad \mathrm{dub}_{2}$

dinana

inda $a_{3}$ inda $\mathrm{aba}_{3}$ $\rightarrow \mathrm{i}_{7} \cdot \mathrm{d}$

CN Tigris: E 35' || F 37; $\rightarrow \mathrm{gu}_{2}{ } \mathrm{i}_{7}$ idigna

"door": B 26

"great door of Eridu": A 11

"eye, face": G 21 (obscure); $\rightarrow$ ugur $_{2}$-igi

non-standard "to see": A 202 (Susa, broken); $\rightarrow$ igi du du $_{8}$.

"to see": A 202 (broken); $\rightarrow$ non-standard igi du

uncertain meaning: A 200*

"insight, intelligence": A 56; C 60

"overseer of all (the foreign) lands" (ep. Urnamma): A 44

"to set the gaze": A 198

"to look at somebody, something (+ loc.(-term.)), to select": B 4*; D (Ni) 10 \| D (Ur) 11'; H 9

"above": Cadaster A ii 25; iv 15; B i 6 ; $\rightarrow$ sig-ta igi nim-še ${ }_{3}$

"before, in front of": C 71; E 27' II F 32

"to look at somebody (+ dat.) approvingly": B 36

obscure: A 173 (broken); Ni. 4375 v 8'; $\rightarrow$ A(.)KA IGI (.x).LA ${ }_{2} ; \rightarrow$ KA.IGI; $\rightarrow$ LAGAR.AN.'IGI?

obscure: A 69

"to lift, to promote, to gather": CU 78; $\rightarrow$ igi $\mathrm{il}_{2} ; \rightarrow$ $\mathrm{ni}_{2}$-bi il $; \rightarrow$ sag $\mathrm{il}_{2} ; \rightarrow \mathrm{u}_{2} \mathrm{il}_{2}$

$\rightarrow($ ğeš $)$ dubsig $_{x}$

"rain": $\rightarrow$ den-ki-im-du

"rain of heaven": $\mathbf{G} 18$

"to make rain fall from the skies": A 164*

obscure: 29,b 1:3'

"rain(storm)": C 20*

$\rightarrow \mathrm{i}_{7}$-IM.NI-a

"cumulated cloud": A 59*

"to run": $\rightarrow$ dA $\breve{S}_{-1 m_{2}}$-babbar $(2)$

"seven": CU 73; $\rightarrow$ ĝeš ga-rig 2 imin? nam-munus-a; $\rightarrow$

$\mathrm{i}_{3}-\mathrm{du}_{8}$ gal kur-ra imin-bi; $\rightarrow \mathrm{u}_{4}$ imin

"stretch of road": A 73; $\rightarrow$ var. ki-in-du

"(border) territory of Sumer": Ni. 4375 v 12'

"to gravely insult": A 207 (Susa); $\rightarrow$ var. in-ŠE dub $_{2}$

non-standard "so far as": A 139*; 140; $\rightarrow$ en-na

"to hurl as an insult": A 207; $\rightarrow$ var. in kur 2 AK

DN Inana: A 196; 199; 204; 206; 216; 6:1; 7,1:1;

8:1(!); 13 obv. 1; 17:1; Al-Rawi, Sumer 46 (1989-90)

$84: 1 ; \rightarrow$ en dinana; $\rightarrow$ lu $_{2}$-mah dinana; $\rightarrow$ nitadam/dam $\mathrm{ki}-\mathrm{ag}_{2} \mathrm{~d}_{\text {inana }}$

"food, offerings": $\rightarrow \mathrm{NI}_{3}\left(\mathrm{inda}_{3} /\right.$ nig $_{2}$ )

"offerings": F 20*; $\rightarrow$ var. nidba 


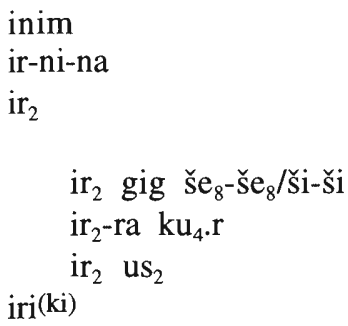

iri? dagal

iri me $\mathrm{du}_{10}-\mathrm{du}_{10}-\mathrm{ga}$

iri-maš-tab

irigal, irigal $_{2}$ gal (Susa)

geš isimu $_{3}$ SAR

IŠ

išib

iti $_{6}$

iti $_{6}-\check{S}_{3}$

itimama(-k)

ITIMA-še ššig

itu-da

ka.k

ka-aš bar

ka-aš kur-ra bar

ka-ge du

ka-ke du

ka $\mathrm{ku}_{3}$ (+ poss. suff.) ba ka mud-gal ${ }_{2}$ ki-en-gi-ra

ka-na-m(a)

ka tab

ka-zal-luki

KA

$\mathrm{KA} \times$ MA $\breve{S}$

$\mathrm{KA}(\mathrm{enim}) \mathrm{ge}_{4}$

$\mathrm{KA}$ ge/i.n $\rightarrow$ enim

$\rightarrow \mathrm{i}_{7}$-ir-ni-na

"crying, tears": A 187 (Susa, obscure); 193; 220 (broken); $241 ; 242$

"to weep bitter tears": A 19 (/Susa); 154 (broken)

"to turn into tears": A 187*

"to shed tears": A 64*

"city": A 5*; 43* (Susa); 239; C 3; 4; 15; 31; 82; 92

(obscure); 101; D (Ni) 22; 25; 29; D (Ur) 32'; 33'*;

28, $2: 11$; 47, 4:2; 4:7 (broken); $\rightarrow$ du $_{6}$-lugal-iri-ka; $\rightarrow$ dlamma iri-ga $a_{2}$

"broad city?": C 15 (broken)

"city of all good $\mathrm{m}$ e": C 1

GN: Cadaster B iii 17; 18

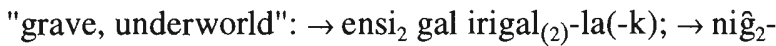
nam $\operatorname{irigal}_{(2}$ gal $)-(1) a$

"shoot": A 172

obscure: F 20; $\rightarrow$ sahar

"i š i b-priest": A 78

"moonlight": D (Ur) 40' (broken); $\rightarrow$ non-standard i-ti

"as the moonlight": D (Ni) 39

"bedchamber": A 12

uncertain meaning: C $87 *$

"on a monthly basis": CU 25

"mouth, outlet (of a canal)": C 27; 91; Cadaster A i 28 ; ii 5; 7; iii 23 (broken); iv 25; B i 5; 11

"to render decisions": A 144* (Susa)

"to render decisions of the netherworld": A 144

"(to be made) worthy to be praised": D (Ni) 20* (broken); 24; $\rightarrow$ non-standard ka-ke du

non-standard "(to be made) worthy to be praised": D (Ur) 31 '; $\rightarrow$ ka-ge du

"to open the pure mouth": C 20

"advocate of Sumer" (ep. Urnamma): A 33 || 34* (broken)

non-standard "land"; $\rightarrow$ lu ${ }_{2}$ ?-gal ka-na-ma(-k); $\rightarrow$ kalam

"to block": $\rightarrow$ ša $_{3}(-)$ ka-tab

GN: CU 128; Cadaster B i 2; iv 26; $\rightarrow \mathrm{i}_{7}$-ka-zal-luki(-k)

obscure: C 40; H 4 (broken); 9; $\rightarrow$ A.KA IGI(.x).LA;

$\rightarrow$ gi-KA

uncertain meaning: $\mathbf{C} 77^{*}$

"to reject (+ loc.(-term.))": A 53*; $\rightarrow$ var. šu gid

"to confirm" (in connection with border regions): 28, $1: 18$; 47, 2:3; Ni. 4375 v 13'; Cadaster A i 15 || ii 22 II iv 22 (broken) II iv 31 
$\mathrm{KA}\left(\right.$ enim?) $\mathrm{gal}_{2} \mathrm{ku}_{3}$ zi.d KA.IGI

$\mathrm{KA}_{2} \cdot \mathrm{n}$

$\mathrm{KA}_{2}(.) \mathrm{GAL}$

$\mathrm{KA}_{2}$-dgeštin-an-na-ka

$\mathrm{KA}_{2}$-mah

$\mathrm{KA}_{2}$-silim-ma

$\mathrm{KA}_{2}(-)$ še-nu-ku ${ }_{5} \cdot \mathrm{d}$

$\mathrm{KAD}$ ?.n

kadra $_{2}{ }^{a}$

kala.g, kalag

KAL

KALAG

kalam kalam-ma dul

kalam-ma gal ${ }_{2}$

kalam-ma $\mathrm{la}_{2}$

kar A

kalam teš

kar B

$$
\text { kar si.g }
$$

kar-ĝeštin-na den-lil ${ }_{2}-\mathrm{la}_{2}$

kar-za-gin ${ }_{3}(-)^{d}$ nanna(-k)

$\operatorname{kar}_{2}, \operatorname{kar}_{2}-\operatorname{kar}_{2}(m$. $)$

kaskal kur-ra

KASKAL

$\mathrm{KAS}_{4}$

$\mathrm{KES}_{2}$

keše $_{2} \cdot \mathrm{d}$

keš(i) $)_{3} \mathrm{ki}$

ki "to let spendid and proper notions be": B 9*

GN: Cadaster B iii 7; 8

"gate, door": E 9' || F 14

"Great Gate": B 22*; $\rightarrow$ abulla

GN: Cadaster A iii 5 (broken); 7

"August Gate": B 22*

"Gate of Salvation": B 22*

"Gate That Does Not Hold Off Grain": B 22 uncertain meaning: A 125 (Susa)

"gift": A 53

"(to be) strong, to strenghten": A 182; 214;217; $\rightarrow$ nita $_{(2)}$ kala.g; $\rightarrow$ si-ĝar kala.g

A 238 (G, obscure); $\rightarrow$ KI.KAL-edin

$\rightarrow r i_{2}-i g-m u-u \check{s}$-KALAG

"land": A 27 (broken); 72 (obscure); 210; B 11; 43 ॥ 49; C 51; 65 (obscure); 72*; H 7; CU 24 (broken); 113 (broken); 181 ; $\rightarrow$ a-ra $_{2}$ kalam-ma; $\rightarrow$ BU kalamma(-k); $\rightarrow$ ĝeš eren? kalam-ma; $\rightarrow$ ki(-)saĝ-ki kalam-ma; $\rightarrow$ lugal kalam-ma(-k); $\rightarrow$ teš $\check{2}_{2}$ kalam-ma; $\rightarrow$ umuš kalam -ma; $\rightarrow$ dutu-gin kalam-ma $_{3}$; $\rightarrow$ zi kalam-ma; $\rightarrow$ nonstandard ka-na-m(a)

"to cover the land": $\rightarrow$ me-lim kalam-ma dul

"to be positioned over the land" (said of shackles): E 8'; $\rightarrow$ var. kalam-ma la ${ }_{2}$

"to be suspended over the land" (said of shackles): $\mathbf{F}$ $13 ; \rightarrow$ var. kalam-ma gal 2

"even land": A $1 *$

"to take away from (+ abl.)": A $25 ; \rightarrow \mathrm{lu}_{2}$ kar

"harbour, quay":

"calm harbour": A 215

"Wine Quay of Enlil": C 104*

"Shining Quay of Nanna": C 105*

"to (make) shine forth, to radiate": $\rightarrow \operatorname{suh}_{10} \mathrm{kar}_{2}-\mathrm{kar}_{2}-\mathrm{ka}$; $\rightarrow \mathrm{u}_{4}-$ gin $_{7} \mathrm{kar}_{2}$

"journey to the netherworld": A 71 (Susa); 73 (broken)

$\rightarrow \mathrm{E}_{2} \times \mathrm{KASKAL}$ ?

$\rightarrow \mathrm{lu}_{2} \mathrm{KAS}_{4}$

$\rightarrow \mathrm{i}_{7}-\mathrm{KES}_{2}-\mathrm{ku}_{3} \cdot \mathrm{g}$

"to fix, to attach": $\rightarrow$ g geš-kešs-da

GN Keš(i): $\rightarrow e_{2}$ ?-keš(i) $)_{3}$ ki

"earth, ground": A $5^{*}$ (broken, read perhaps $\rightarrow$ edin); $\mathbf{G}$ 12; 19 \| 20 (broken, obscure); $\rightarrow$ an-ki; $\rightarrow$ digirir anki(k); $\rightarrow$ den-ki(-k); $\rightarrow$ mar-uru $_{5}$ an-ki; $\rightarrow$ saĝ-ki

"good place": A 177 (E, obscure)

"untouched ground": 5:7 


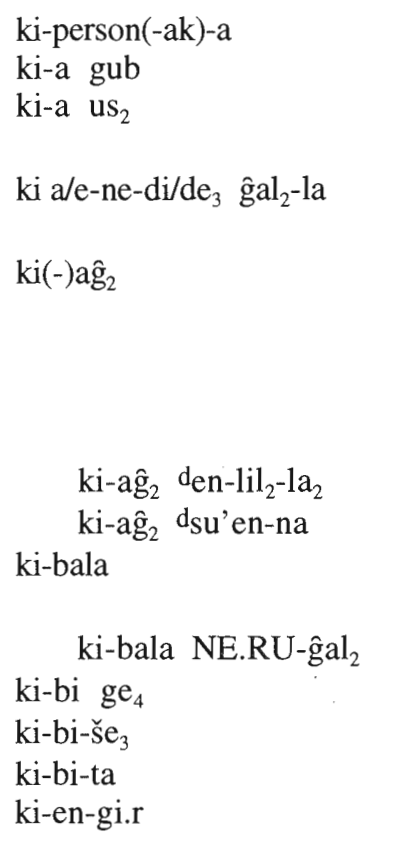

"in the presence of somebody": B 69

"to assist": A 160; $\rightarrow$ ki gub

"to firmly found, to set firmly on the ground": $\mathbf{B} 66^{*}$; $\rightarrow$ ki us 2

"place where merriment reigns": A 19 (/Susa); $\rightarrow$ e-nedi hul ${ }_{2}$-la

"to love (+ loc.-term.), beloved": A 56; F 42*; $\rightarrow$ dumu ki-a g $\hat{g}_{2} ; \rightarrow \mathrm{e}_{2}$ ki-a $\hat{g}_{2} ; \rightarrow \mathrm{e}_{2}$-šu-tum ki-a $\hat{g}_{2} ; \rightarrow$ emedu $_{2}$

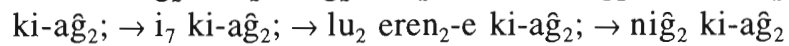
dereš-ki-gal-la; $\rightarrow$ nin nig $\hat{g}_{2}$-gur ${ }_{11}$-e ki-ağ $\hat{g}_{2} ; \rightarrow$ nitadam/

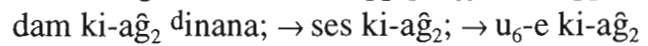
"beloved of Enlil" (ep. Urnamma): D (Ur) 39' "beloved of Su'en" (ep. Ekišnuĝal): C $11 \| 12$ "rebellious land(s), enemy land(s)": B 52 ॥ 53; F 20; $35 ; \rightarrow \mathrm{e}_{2}$ ki-bala; $\rightarrow$ non-standard ki-ib-la

"hostile and rebellious land(s)": B 14

"to restore": 10:13; 13 rev. 3

"there": A 142

"from there": A 198

GN Sumer: A 4; B 15; C 2; 59; 62 (broken); 83; Ni. 4375 vi 8 ; $\rightarrow$ i-si-iš ki-en-gi-ra; $\rightarrow$ in-dub ki-en-gi-ra; $\rightarrow$ ka mud-gal ${ }_{2}$ ki-en-gi-ra; $\rightarrow$ ki sur-ra ki-en-gi-ra; $\rightarrow$ massu ki-en-gi-ra; $\rightarrow \mathrm{UL}_{4}$-gal ki-en-gi-ra

ki-en-gi ki-uri

ki-en-gi uri ki-gal

GN Sumer and Akkad: A 224 (broken); C 28; 34; D (Ni) 11; F 23; CU 123 (broken); $\rightarrow$ lugal ki-en-gi kiuri(-k); $\rightarrow$ ma-da ki-en-gi ki-uri; $\rightarrow \mathrm{u}_{2}$-a ki-en-gi ki-uri

GN Sumer and Akkad: D (Ur) 12'

1. (building) platform, foundation platform, postament": C $4 *$

2. "Great Place": $\rightarrow$ dereš-ki-gal

3. GN: Cadaster B i 1 ; iv $21 ; 22 ; 25$

ki-gal-la gub ki-gal-2-kam-ma ki gar

"to erect something on a foundation platform": C 109 GN: Cadaster B iv 23; 24

"to (firmly) found" (said of constructions), "to settle" (said of persons): C 3; 5; CU 175 (broken); year name "17"

ki-ib-la

non-standard "enemy land(s), rebellious land(s)": B 52 (broken) I| 53; $62 \|$ 64; $\rightarrow$ e ki-ib-la; $\rightarrow$ ki-bala

ki-in-du

ki-is-ma-arki

"stretch of road": A 73 (Susa); $\rightarrow$ var. in-di $i_{3}$

GN: IB 1537 rev. v' 17'

ki $\mathrm{ku}_{3}-\mathrm{ga} \mathrm{du}_{3}$

ki-lul-la

"to build on splendid ground": C 2*

"Place of Treachery": A 58*

ki nam tar-ra/(re) (digirir-re(-e)-ne) "place of fate determined (by the gods), place where fate is determined (by the gods)": $\mathbf{E} 11^{\prime *} \| \mathbf{F} 16$; E $16^{\prime} \| \mathbf{F} 21$

ki nu-zu "unknown place": A $65^{*}$ 


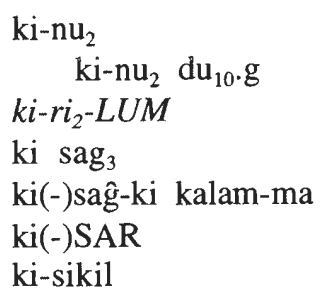

ki sur-ra "resting place, sleeping place": A 49; 191

"sweet resting place": C 74

GN: Cadaster A iv 10; 11

"to make the earth shake": A 205

". . -place of the land" (ep. Arali): A 62*

uncertain meaning: CU 79; 26, 2:3

"young woman" (ep. Inana): A 196 (Susa); $\rightarrow$ var. saĝkal

"(demarcated) territory, region": Cadaster A i 30; ii 1; B i 1 ; iv $25 ; \rightarrow \mathrm{i}_{7}$ ki sur-ra(-k)

ki sur-ra ki-en-gi-ra "region of Sumer": C $82 *$

ki sur-ra dlugal-mara 2 -da(-k) "(demarcated) territory of Lugalmarada": Cadaster B iv 29

ki sur-ra $\mathrm{ma}_{2} \mathrm{ma}_{2}$-ganki "(demarcated) territory of the Magan-boats": $\mathbf{4 7}$, $1: 3-4$

ki sur-ra dmes-lam-ta-e ${ }_{3}$-a "(demarcated) territory of Meslamtaea": Cadaster A ii 20 $\mathrm{ki}-\mathrm{še}_{3}$

ki sur-ra dsu'en(-k) "(demarcated) territory of Su'en": Cadaster A iv 20 "into the earth": C 21

"to establish abandoned places" : A 4

"to put on the ground, to plant": A 26

"to bury": A 70 || 71

"dwelling place":

ki-tuš

ki-tuš an den-lil ${ }_{2}-\mathrm{la}_{2}$

ki-tuš gir $_{17}$-zal

ki-tuš gar

"dwelling place of An and Enlil": C 5*

"delightful dwelling place": A 47

"to set up a dwelling place": A 137

ki-tuš $\mathrm{ku}_{3}$ kur-gal-la

ki-tuš dnanna(-k)

"precious dwelling of Great Mountain": B 29

"dwelling place of Nanna": 28, 2:9

ki-tuš ša hul $_{2}$-la

ki $\mathrm{u}_{4} \mathrm{e}_{3}(-\mathrm{a})$

ki $u_{4} e_{3}$ digirir-re-e-ne ki-ur ${ }_{3}$

ki-ur ${ }_{3}$ gal $_{2}$

$\mathrm{ki}^{-\mathrm{ur}_{3}}$ gar

ki ur $_{5} \quad \mathrm{sa}_{6} \cdot \mathrm{g}$

ki-uri

ki $\mathrm{us}_{2}$

ki ut-ti

$\mathrm{KI}$

KI.KAL-edin KI.LUGAL.GUB.1 "dwelling of the joyful heart" (perhaps ep. Etemenniguru): D (Ur) 26'

"place where daylight breaks": $\rightarrow$ non-standard ki ut-ti

"place of the gods where daylight breaks": A $211^{*}$

"home":

"to provide somebody with a home": A 157

"to install a home": A 157 (Susa)

"source of happiness": C 51

GN Akkad: $\rightarrow$ ki-en-gi ki-uri

"to touch the ground, to (firmly) press to the ground" (said of a shield), "to be firmly secured": A 93; B 30; F $2 * ; \rightarrow$ giri $_{3}\left[\mathrm{ki}^{\text {? }}\right] \mathrm{us}_{2} ; \rightarrow \mathrm{ki}-\mathrm{a} \mathrm{us}_{2}$ non-standard "place where daylight breaks": E $4^{*} * ; \rightarrow \mathrm{ki}$ $\mathrm{u}_{4} \mathrm{e}_{3}(-\mathrm{a})$

obscure: 29,b 2:1'; $\rightarrow$ ANŠE.KI

GN: Cadaster B iii $1 ; 2$

uncertain meaning: C $13 *$ 
kig. $\hat{g}_{2}$ gar

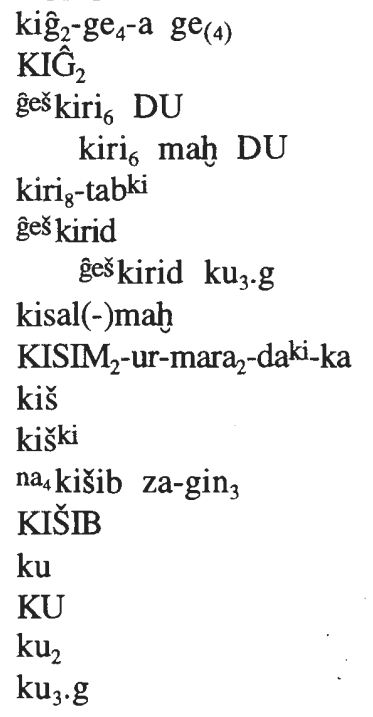

$\mathrm{ku}_{3} \mathrm{me}(-\mathrm{a})$

$\mathrm{ku}_{3}$-babbar

$\mathrm{ku}_{3}-\mathrm{gal}_{2}$

$\mathrm{ku}_{3} \mathrm{~d}_{\text {nin-sumun }}(-\mathrm{na}-\mathrm{k})$

$\mathrm{ku}_{3}-\mathrm{sig}_{17}, \mathrm{ku}_{3}-\mathrm{si}_{2}(\mathrm{ZI}) . \mathrm{g}$

$\mathrm{ku}_{3}-$ sig $_{17}$-ta gunu $_{3}$ $\mathrm{ku}_{3}$ tuku

$\mathrm{ku}_{3}-\mathrm{zu}$

$\mathrm{ku}_{4} \cdot \mathrm{r}$ "to impose work": CU 176b

"to send a message": A 197 (/Susa)

$\rightarrow$ dumu $\mathrm{KIG}_{2}$

"to lay out gardens": CU 158-160 (broken)

"to lay out huge gardens": 5:5-6

$\mathrm{GN}: \rightarrow$ a-ša ${ }_{3} \mathrm{~d}_{\text {nu-muš-da kiri }}$-tabki(-k)

"hair clasp": A 111* (Susa)

"silver hair clasp": A 111

"main courtyard": C 13*

GN: Cadaster B iii 26, 27

$\rightarrow \mathrm{e}_{2}$-kiš-nu-gal ${ }_{2}$

GN: Cadaster B i 2; iv 27

"lapis lazuli seal": A 120

uncertain meaning: A 68

$\rightarrow \mathrm{i}$-lu kur-ku-ku; $\rightarrow \mathrm{u}_{3} \mathrm{ku}$

obscure: A 193 (Susa)

$\rightarrow \mathrm{gu}_{7}$

"splendid, brilliant, precious, dazzling, pure, silver": A 172 (broken, obscure); 238 (A, broken, obscure); C 10 (obscure); 70; H 6 (broken); 7 (broken); $\rightarrow$ a ša $-\mathrm{ku}_{3}$-ge

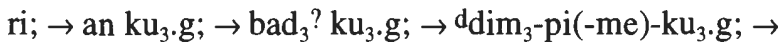
enim $\mathrm{ku}_{3} . \mathrm{g} ; \rightarrow$ enim $\mathrm{ku}_{3}$ ?! an-na(-k); $\rightarrow \mathrm{gin}_{2} \mathrm{ku}_{3}$.g; $\rightarrow$

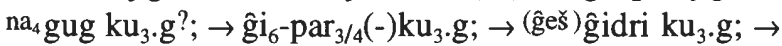
geš-ḩur $\mathrm{ku}_{3} . \mathrm{g} ; \rightarrow \mathrm{i}_{7}-\mathrm{KES}_{2}-\mathrm{ku}_{3} . \mathrm{g} ; \rightarrow \mathrm{ka} \mathrm{ku_{3 }}$ (+ poss. suff.) ba; $\rightarrow \mathrm{KA}$ (enim?) $\mathrm{gal}_{2} \mathrm{ku}_{3}$ zi.d; $\rightarrow$ ki ku - $_{3}$ ga du ; $_{3}$; $\rightarrow$ ki-tuš ku$u_{3}$ kur-gal-la; $\rightarrow$ geš kirid $\mathrm{ku}_{3} . \mathrm{g} ; \rightarrow$ nin $\mathrm{ku}_{3}$ nun-na; $\rightarrow$ sag $(-) \mathrm{ku}_{3}(-) \mathrm{gal}_{2} ; \rightarrow \mathrm{s̆a}_{3} \mathrm{ku}_{3}$-ge $\mathrm{pa}_{3} . \mathrm{d} ; \rightarrow$ temen $\mathrm{ku}_{3} \operatorname{sig}_{9}$

"pure silver": B 23; $\rightarrow$ ba-da-ra ku $\mathrm{ku}_{3}$ me-a

"silver": D (Ur) 29'; $\rightarrow$ tu-di-da ku kig $_{17}$ ku $_{3}$-babbar

"(canal-)inspector": A $22 ; \rightarrow \operatorname{sag}(-) k_{3}(-)$ gal $_{2}$

"dazzling Ninsumun": A 16*; F 49 (broken); $\rightarrow{ }^{d_{\text {nin- }}}$ $\operatorname{sumun}_{2}(-$ na-k)

"gold": A 120 (Susa); C 110; D (Ur) 29'* (broken); $\rightarrow$ gidri $\mathrm{ku}_{3}$-sig ${ }_{17}$ nam-en-na; $\rightarrow$ h har $\mathrm{ku}_{3}$-sig ${ }_{17} ; \rightarrow$ tu-di-da $\mathrm{ku}_{3}-\mathrm{sig}_{17} \mathrm{ku}_{3}$-babbar

"to be painted with gold" (said of a chariot): A 114 "wealthy one": D (Ni) 5* \| (Ur) 6'

"wise ": $\rightarrow$ sipa $\mathrm{ku}_{3}-\mathrm{zu}$

"to enter (+ loc./term.), to turn into (+ loc.), to bring in": A 12; 41; 131 (Susa); 199* (broken, read perhaps $\rightarrow$ gur; $\rightarrow$ DU A); 213; C 103; $\rightarrow$ hi-li-a/e ku $4 . r ; ~ \rightarrow i r_{2}-$ ra ku $4 . \mathrm{r} ; \rightarrow$ var. šum $2 ; \rightarrow \mathrm{TU}$ 


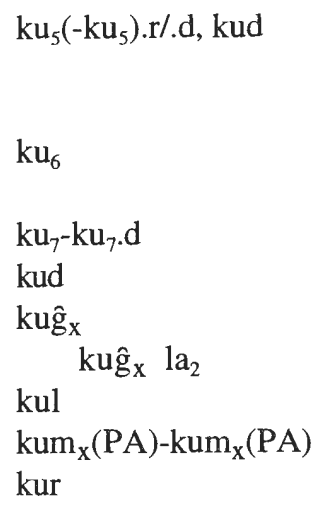

kur erim $_{2}-\mathrm{gal}_{2}$

kur ge-rin

kur i-ri-im-ma(-ga $a_{2}-1(a)$ )

kur NE.RU.m

kur? šem? ĝeš eren-na kur-elamki

kur-gal

kur-gal den-lil 2

kur-gal a-a den-lil 2 kur-gal UD den-lil ${ }_{2}$

kur he he $_{2}-\mathrm{gal}_{2}$

kur-ku-ku

kur-kur

kur-kur-ra diri.g kur tu.b
1. "to cut off, to break, to decide" (said of judgments):

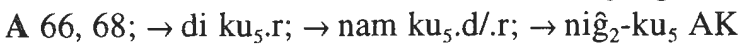

2. "to hold off": $\rightarrow \mathrm{KA}_{2}(-)$ še-nu-ku $\mathrm{ku}_{5} \cdot \mathrm{d}$

"fish": D (Ni) 25 || 26; 31 (obscure); D (Ur) 32' || 33' ||

$34^{\prime} ; 35^{*} ; \rightarrow$ suhurku $_{6}$

"to be sweet": F 47*

$\rightarrow \mathrm{ku}_{5}\left(-\mathrm{ku}_{5}\right) \cdot \mathrm{r} / \mathrm{d}$, kud

"outlet (of a canal)": Cadaster A iv 5; 7

"to make the outlet reach": $\mathbf{2 8 , 1 : 1 4}$

$\rightarrow$ gešs saĝ-kul

"to sparkle": C 9*

1. "netherworld": A 79 || 80; 132 (obscure) || 133 (obscure); 137; 161 (Susa); $\rightarrow$ a kur-ra; $\rightarrow$ di kur-ra $\mathrm{ku}_{5} . \mathrm{d} / . \mathrm{r} ; \rightarrow$ den-lil ${ }_{2}$ kur-ra; $\rightarrow$ ensi ${ }_{2}$ gal kur-ra; $\rightarrow$ garza kur-ra(-k); $\rightarrow \mathrm{i}_{3}$-du 8 gal kur-ra imin-bi; $\rightarrow$ ka-aš kur-ra bar; $\rightarrow$ kaskal kur-ra; $\rightarrow$ lugal kur-ra; $\rightarrow$ me kur-ra; $\rightarrow$ nidba kur-ra(-k); $\rightarrow$ para $_{10}$ gal kur-ra(-k); $\rightarrow \mathrm{u}_{2}$ kur-ra

2. "mountain, (foreign) land": A 65*; C 85 (obscure); 87; G 12 (obscure); Ni. 4375 iv 6'; $\rightarrow \mathrm{e}_{2}$-kur(-za-gin 3 ); $\rightarrow \mathrm{e}_{2}$-kur-re; $\rightarrow \mathrm{e}_{2}$-mud-kur-ra(-k); $\rightarrow$ kur-kur; $\rightarrow$ maš $_{2}$-gal kur-ra

$\rightarrow$ bad $_{3}$ gal kur-ra(-k)

"enemy lands": B 52* $\| 53$; $\rightarrow$ var. gu 2 A.NE.RU-ĝal ${ }_{2}$; $\rightarrow$ non-standard kur i-ri-im-ma(-ĝga $\left.{ }_{2}-1(\mathrm{a})\right)$; $\rightarrow$ kur NE.RU.m "blossoming mountain": F 10

non-standard "enemy lands": B 52* || 53; $\rightarrow$ kur erim $_{2}-$ gall $_{2}$

"enemy land": F 34; $\rightarrow$ kur erim - $_{2} \mathrm{gl}_{2}$

"mountain? of fragrant? cedar": E 4'* (broken)

GN land of Elam: $\rightarrow$ elam; $\rightarrow$ ma-da kur-elamki-ma

DN Great Mountain (ep. Enlil): B 29; 37; $\rightarrow$ ki-tuš ku kur-gal-la

DN Great Mountain Enlil: B 5; 8; D (Ni) 10; $\rightarrow$ var. kur-gal UD den-lil 2

DN Great Mountain, father Enlil: B 46

"shining Great Mountain Enlil": D (Ur) 11'*; $\rightarrow$ var. kur-gal den-lil 2

"mountain (of) abundance": F 8

"to observe attentively"; $\rightarrow \mathrm{i}-\mathrm{lu}$ kur-ku-ku

"all (the foreign) lands": A 197; C 41; F 30; $\rightarrow$ igi(-) gal $_{2}$ kur-kur-ra; $\rightarrow$ lugal kur-kur-ra; $\rightarrow$ me-te kur-kur-ra; $\rightarrow$ var. hur-sag gal-gal

"to exceed all (the foreign) lands": $\mathbf{C} 7$

non-standard "to heap up the foreign land": B 55 ॥ 57; $\rightarrow$ kur tu $\mathrm{tu}_{11} \cdot \mathrm{b}$ 
kur $\mathrm{tu}_{11} \cdot \mathrm{b}$

kur-ur ${ }_{2}$

kur $_{2}$

la-1(a)

$l a-b a$

la-la-bi $\mathrm{ge}_{4}$

$\mathrm{la}_{2}$

\section{$\mathrm{LA}_{2}$}

$\mathrm{LA}_{2}$.A.BA

\section{LAGAR.AN.'TGI?}

lagaški

$\operatorname{lah}_{4}\left(-\operatorname{lah}_{4}\right), \operatorname{lah}_{5}$

$\mathrm{lal}_{3}$

lam

dlamma

dlamma iri-ĝa $a_{2}$

dlamma $\mathrm{sa}_{6} \cdot \mathrm{g}$

li.b

lib

libir

$\mathrm{lil}_{2}$

$\mathrm{LIL}_{2}$

$\lim _{\mathrm{x}}$

$\operatorname{limmu}_{2}$

lu A

lu B

lu-ga-l(a)

lu i-ri-ga $a_{2}$-al "to heap up the foreign land": B $55 \|$ || 57; $\rightarrow$ non-standard kur tu.b

"foot of the mountains": B 45 || 51

"(to be) different, (to be) inimicable, to act inimicably (against somebody), to change, to be altered": A 8; 46; 46a (Susa); 56; 72; 209; B $40 \|$ 46; 28, 2:3; $\rightarrow$ enim $\operatorname{kur}_{2} ; \rightarrow$ in kur $_{2} \mathrm{AK} ; \rightarrow$ var. suh $_{3}$ non-standard "wind": B $59 \| 61 ; \rightarrow \mathrm{lil}_{2}$

$\rightarrow$ šar-ru-la-ba

"to bring pleasure": A 151 (Susa); $\rightarrow$ var. a-la ge ${ }_{4}$

1."to hang (from), to be suspended over something (+ loc.), to stretch": A 210 (Susa, obscure); 219 (obscure); $\rightarrow$ (̂̀eš) az-la $_{2} ; \rightarrow$ ba-da-ra la $a_{2} ; \rightarrow$ gada $\mathrm{la}_{2} ; \rightarrow$ $\mathrm{gu}_{2}$-da la $\mathrm{a}_{2} ; \rightarrow \mathrm{i}$-si-iš la $\mathrm{l}_{2} ; \rightarrow$ kalam-ma la $\mathrm{a}_{2} \rightarrow$ kug $_{\mathrm{x}} \mathrm{la}_{2}$

2. "to bind together" (said of a fence): C 110

3. "to load" (said of barley on to ships): $\rightarrow$ še $\mathrm{la}_{2}$

4. "to place at the disposal of somebody (+ dat.)": D (Ni) $33 * \| 34$

$\rightarrow$ geš la $a_{2} ; \rightarrow$ geš-la $a_{2}$-bi DU; $\rightarrow$ dub-la $(-$ mah $)$

$\rightarrow$ A.KA IGI(.x).LA $2 ; \rightarrow \mathrm{ZA}_{3} \cdot \mathrm{LA}_{2}$

obscure: A 10 (broken)

GN: Cadaster B ii $1 ; 2$

$\rightarrow$ ensi $_{2}$ lagaški(-k)

"to bring, to lead": $\rightarrow$ DU A $\left(\mathrm{de}_{6} / \mathrm{tum}_{2}\right) ; \rightarrow \mathrm{ma}_{2}-\mathrm{lah}_{5}$ gal

"(honey-)sweet, syrup": D (Ni) 29 ॥ 30; $\rightarrow$ gurun $_{6}$ lal $_{3}$ $\mathrm{de}_{2} ; \rightarrow \mathrm{u}_{2}-\mathrm{lal}_{3}$

$\rightarrow$ dmes-lam-ta-e $e_{3}-\mathrm{a}$

"guardian-spirit" (ep. Urnamma): C 50

"guardian-spirit of my city" (ep. Urnamma): C 31

"benevolent guardian-spirit": A 177* (broken)

"bliss(fulness)": A 20*; $\rightarrow$ var. lib

"daze, illusion": A $20^{*}$ (Susa) ; $\rightarrow$ var. li.b

"(to become) old": $\rightarrow$ ma-za-ru-um-libir

"wind": B $59 \|$ $61 ; \rightarrow$ den-lil $_{2} ; \rightarrow{ }^{\text {dnin-lil }}{ }_{2} ; \rightarrow$ nonstandard la-l(a)

obscure: E 15'

$\rightarrow$ me- $\lim _{\mathrm{x}}$

"four": $\rightarrow$ lugal an(/-ne 2$)$ ub-da limmu 2 -ba(/bi)

"to multiply, to be numerous, plentiful, many": C 53; D (Ni) $17 \|$ (Ur) 18' (broken); $\rightarrow$ non-standard lu ${ }_{2}$ B non-standard "person": $\rightarrow$ non-standard lu i-ri-g $\mathrm{ga}_{2}$-al; $\rightarrow$ $\mathrm{lu}_{2} \mathrm{~A}$

non-standard "king, lord": $\rightarrow \operatorname{lu}_{(2)^{-}}{ }^{-g a-a l-g u_{10}} ; \rightarrow$ pa-ra nalu-ga-la(-k); $\rightarrow$ lugal

non-standard "evil person": B $63 \|$ 65; $\rightarrow \operatorname{lu}_{2}$ erimm $_{2}$-gall ${ }_{2}$ 


$$
\begin{aligned}
& \text { kušlu-ub } \\
& \text { kušlu-ub } b_{2} \quad \text { gunu }_{3} \\
& \mathrm{lu}_{2} \mathrm{~A}
\end{aligned}
$$$$
l_{u_{2}} a_{2} \text { tuku }
$$$$
\mathrm{lu}_{2} \mathrm{aš}_{2} \mathrm{du}_{11} \text {-ga }
$$$$
\mathrm{lu}_{2} \text { eren }_{2} \text {-e ki-ag } \hat{g}_{2}
$$$$
\mathrm{lu}_{2} \quad \operatorname{erim}_{2}-\mathrm{gal}_{2}
$$$$
\mathrm{lu}_{2} \quad 1 \quad \operatorname{gin}_{2}
$$$$
\mathrm{Iu}_{2} \operatorname{gir}_{5} \text {-ra }
$$$$
\mathrm{lu}_{2} \quad 1 \text { gud }
$$$$
\mathrm{lu}_{2} \text { hul-gal }
$$$$
\mathrm{lu}_{2} \text { i-dutu-ka }
$$$$
\mathrm{lu}_{2} \mathrm{kar}
$$$$
\mathrm{lu}_{2} \mathrm{KAS}_{4}
$$$$
\mathrm{lu}_{2} 1 \text { ma-na }
$$$$
\mathrm{lu}_{2} \text { nam- } \mathrm{da}_{6}-\mathrm{ga}
$$$$
\mathrm{lu}_{2} \text { nam tar-tar-ra }
$$$$
\mathrm{lu}_{2} \text { NE.RU }
$$$$
\mathrm{lu}_{2} \quad \text { nig } \hat{g}_{2} \text { tuku }
$$$$
\mathrm{lu}_{2} \mathrm{nu}-\mathrm{zu}
$$$$
\mathrm{lu}_{2} \text { geš tukul-la }
$$$$
\mathrm{lu}_{2} \quad 1 \mathrm{udu}
$$$$
\mathrm{lu}_{2} \mathrm{zu}
$$$$
\mathrm{lu}_{2} \mathrm{~B}
$$$$
\mathrm{lu}_{(2)} \text {-ga-al-ĝ } \mathrm{u}_{10}
$$$$
\text { lu }{ }_{2} \text { ?-gal ka-na-ma(-k) }
$$

$\mathrm{lu}_{2}-\mathrm{mah}$ $\mathrm{lu}_{2}$-mah dinana

$\mathrm{LU}_{2} \cdot \mathrm{LU}_{2}$ $\mathrm{LU}_{2} . \mathrm{SA}_{3} \times \mathrm{TAR}$ ?.A(-k) lugal "leather-bag": A 92*

"multicoloured leather-bag": A 89

"man, person, somebody, they (impersonal), who": A 43 (Susa); 183; 184; 185; 190; 192; 194; C 30; 55; E 3' (broken) II F 9; 1:3; 2:3; 3:4; 4:3; 26,1:9; 28, 2:1; 29,b $2: 5^{\prime} ; 40: 12 ; 47,2: 7 ; 2: 9 ; \rightarrow$ a lu $_{2} /$ lugal-gu $u_{10} ; \rightarrow$ nam- $-\mathrm{lu}_{2}-\mathrm{ulu}_{3} / \mathrm{u}_{18}-\mathrm{lu}_{7} ; \rightarrow$ non-standard $\mathrm{lu} \mathrm{B}$

"mighty person": CU 164

"cursed person": 28, 2:6

"beloved of troops" (ep. Urnamma): A 43*

"evil person": B $63 \|$ I 65; $\rightarrow \mathrm{lu}_{2}$ NE.RU; $\rightarrow$ non-standard lu i-ri-ĝa $a_{2}$-al

"person with one shekel": CU 166

uncertain meaning: CU 122 (broken)

"man with one ox": CU 170

"evil person, evil one": Ni. 4375 iv 5' (broken)

"oppressor": C 35

"fugitive": C 37

uncertain meaning: CU 122 (broken)

"person with one m a n a": CU 167

"sinner": A 140

"who holds all the decreed fates" (ep. Namtar): A 108

"malefactor": B 25; $\rightarrow$ lu $_{2}$ erim $_{2}$-ĝal

"wealthy person": CU 162

"stranger": A 57

"man of arms": A 139 (Susa); $\rightarrow$ var. eren 2

"person with one sheep": CU 169

"sage": $\rightarrow$ geštu mah $\mathrm{lu}_{2} \mathrm{zu}$

non-standard "to be numerous, plentiful": D (Ur) 36'*; $\rightarrow$ lu A

non-standard "my lord": B 52 (broken); $\rightarrow$ lugal-ĝu $\mathrm{u}_{10}$

non-standard "king of the land": B 68; $\rightarrow$ lugal kalam$\mathrm{ma}(-\mathrm{k})$

"1 u m a h-priest": A 78

"1 u m a h-priest of Inana": year name "9"

IB 1537 rev. v' 23' (broken)

"captive": C 90*

"king, lord": A 33; 39; 64; 70; 74; 79; 81; 84 (Susa); 85; 99 (Susa, obscure); 132 (broken); 141; 146 (Susa);

B 11; 69 (ep. Enlil); C 13; 61; D (Ni) 9; 35 (ep. Enki); E 25' \| F 25; E 29'; F 31; E 33' \| F 36; E 35; G 13; 19; CU 161; 5:2; 9,1:2; 10:4; 11:2; 12:2; 16:3; 22:3; 23:3; 24:2; 25:5; 26,1:4; 27,1:4; 28,1:3; 2:4; 29,b 2:3" (broken); b 2:5"; b 2:7"; 30:2; $32: 2,33: 2 ; 34: 2 ; 40: 3 ; 44: 2 ; 45: 3 ; 46: 2 ; 47,1: 2$; 
Ni. 4375 iv 3'; iv 7'; v 9'; IB 1537 rev. v' 14'; year name "4"; $\rightarrow$ ama lugal-la; $\rightarrow$ an lugal; $\rightarrow$ an-ki lugal [...]; $\rightarrow$ an-za-gar -dumu-lugal-ka; $\rightarrow$ urudaba-an si-sa $_{2}$ lugal-la $\operatorname{dim}_{2} ; \rightarrow$ du $_{6}$-lugal-iri-ka; $\rightarrow \mathrm{i}_{7}$-lugal(-la(-k)); $\rightarrow$ nam-lugal; $\rightarrow$ nin $_{9}$ lugal-la; $\rightarrow$ ur-dnamma lugal; $\rightarrow$ nonstandard lu-ga-l(a)

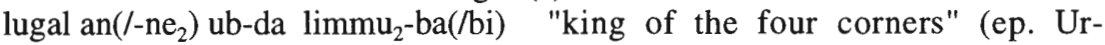
namma): D (Ni) $37 \|$ (Ur) 38'

lugal digirir-re(-e)-ne lugal eg $_{2} \quad \mathrm{pa}_{5}$-ra

lugal eriduki-ga lugal-ĝ $\mathrm{u}_{10}$

lugal kalam-ma(-k) lugal ki-en-gi ki-uri(-k) "lord of the gods" (ep. An): A 207; 5:1

"lord of embankments and ditches" (ep. Enkimdu): A 25

"lord of Eridu" (ep. Enki): A 180 || 236; D (Ni) 35 || 36

"my lord" (ep. Urnamma): A 146; 154; 241; B 52; C 108 (ep. Nanna); D (Ni) 7 (ep. Nanna-Su'en); G 16; 22; CU 83 (ep. Nanna); 109 (broken) (ep. Nanna); 132 (ep. Nanna); IB 1537 rev. vi' 7' (ep. Enlil); $\rightarrow$ a $\mathrm{Iu}_{2} /$ lugal-ĝu $\mathrm{u}_{10} ; \rightarrow$ non-standard $\mathrm{lu}_{(2)}$-ga-al-ĝ $\mathrm{g}_{10}$

"king of the land" (ep. Urnamma): A 40; B 68; C 25; H 1 (broken) II 10; $\rightarrow$ non-standard lu $_{2}$ ?-gal ka-na-ma(-k)

lugal kur-ra lugal kur-kur-ra

lugal mu da-a-ri lugal mu tuku lugal uri $_{2 / 5} \mathrm{ki}_{\text {-ma }}$

dlugal-mara 2 -da(-k) LUGAL

luh lul "king of Sumer and Akkad" (ep. Urnamma): CU $13 ; 107$ (broken); 3:3; 7, 2:2; 10:9; 11:6; 12:6; 13 obv. $7 ; 14$ obv. $6 ; 15$ obv. $6 ; 16: 7 ; 17: 7 ; 18: 6 ;$ $19: 6 ; 21: 6 ; 22: 7 ; 23: 6 ; 24: 6 ; 26,1: 8 ; 27,1: 8 ; 28$, $1: 7 ; 31: 6 ; 32: 6 ; 33: 6 ; 34: 7 ; 35: 7 ; \mathbf{4 0 : 7} ; \mathbf{4 5}: 7$ 46:6; 47, 1:11; Al-Rawi, Sumer 46 (1989-90) 84:7; IB 1537 rev. v' 4'

"king of all (the foreign) lands" (ep. Enlil): 16:2; $22: 2 ; 23: 2 ; 45: 2$

"king with a lasting name" (ep. Urnamma): D (Ur) 41' "famous king": A 77

"king of Ur" (ep. Urnamma): C 19; 31; D (Ni) 41; CU 12 (broken); 106 (broken); 1:2; 2:2; 3:2; 4:2;

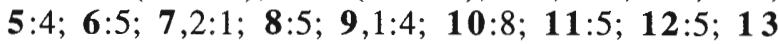
obv. $6 ; 14$ obv. $5 ; 15$ obv. $5 ; 16: 6 ; 17: 6 ; 18: 5$; $19: 5 ; 21: 5 ; 22: 6 ; 23: 5 ; 24: 5 ; 25: 8 ; 26,1: 7 ; 27,1: 7$; $28,1: 6 ; 29$, a:2; 31:5; 32:5; 33:5; 34:6 (broken); 35:6 (broken); 38:4 (broken); 39:4' (broken); 40:6; 42:4' (broken); 43,2:1; 45:6; 46:5; 47,1:10; AlRawi, Sumer 46 (1989-90) 84:6; IB 1537 rev. v' $3^{\prime}$

DN Lugalmarada: $\rightarrow$ ki sur-ra dlugal-mara 2 -da(-k) IB 1537 rev. vi' 1' (obscure); $\rightarrow$ KI.LUGAL.GUB.1; $\rightarrow$ maš-kan ${ }_{2}$-LUGALki

"to (be) clean": D (Ni) 4*; 24; $\rightarrow \mathrm{i}_{7}-\mathrm{pa}_{4 / 5}$-bi-luh "treacherous, deceitful": $\rightarrow$ ki-lul-la; $\rightarrow$ šu lul bala "king of the netherworld" (ep. Gilgameš): A 95 
ma-da

ma-da a-ga-de ${ }_{3}^{\mathrm{ki}}$

"land, territory": C 41

ma-da ešs-nun-naki

GN territory of Agade: IB 1537 rev. v' 22'

ma-da ki-en-gi ki-uri

ma-da kur-elamki-ma

ma-da tu-tu-ub ${ }_{2}^{\text {ki }}$

ma-da zi-mu-darki

ma-he $(/ a)$

GN territory of Ešnuna: IB 1537 rev. v' 19'

"Land Sumer and Akkad": C 50*

GN territory of the land of Elam: IB 1537 rev. v' 11'

GN territory of Tutub: IB 1537 rev. v' 20'

GN territory of Zimudar: IB 1537 rev. $v^{\prime} 21^{\prime}$

non-standard "great, magnificent, huge": $\rightarrow$ na- $\mathrm{gu}_{4}-\mathrm{u}_{8}$ ma-

$\mathrm{h}(\mathrm{a}) ; \rightarrow \mathrm{u}_{2}$-tu-ug ma-he; $\rightarrow$ mah

ma-na

"m a n a": CU 148; $\rightarrow \mathrm{lu}_{2} 1$ ma-na

gešma-nu

ma-na ge.n

"to standardize as a $\mathrm{m}$ a $\mathrm{n}$ a": CU 145-146

"m a n u-wood":

gešma-nu nam-en-na(-k) "made of m a n u-wood of e n-ship": A 103

(Susa); $\rightarrow$ var. gidri $\mathrm{ku}_{3}-$ sig $_{17}$ nam-en-na

gešma-nu nam-sipa-da "(staff) made of $\mathrm{m}$ a $\mathrm{n}$ u-wood of shepherdship": A 103a (Susa)

ma-za-ru-um

$m a-z a-r u-u m$-libir

$\mathrm{ma}_{2}$

$\mathrm{ma}_{2}-\mathrm{gan}(\mathrm{ki})$

$\mathrm{ma}_{2}-$ gur $_{8}(-\mathrm{ra})$

(geses) $\mathrm{ma}_{2} \mathrm{i}_{7}$-da

$\mathrm{ma}_{2}-\mathrm{lah}_{5}$ gal

$\mathrm{ma}_{2} \mathrm{ma}_{2}$-gan

GN: Cadaster A ii 24 ; iv 14

GN: Cadaster $A$ ii $27 ; 28$

"boat, ship": A 65; 182

GN Magan: $\rightarrow$ ki sur-ra $\mathrm{ma}_{2} \mathrm{ma}_{2}$-ganki; $\rightarrow \mathrm{ma}_{2} \mathrm{ma}_{2}$-gan

"cargo boat": A 106 (broken, obscure); C 88

"river boat": A 215

"chief sea-captains": CU 91; 118

"Magan-boats": 26, 2:4; $\rightarrow$ ki sur-ra $\mathrm{ma}_{2} \mathrm{ma}_{2}$-ganki

$\mathrm{ma}_{2} \mathrm{ma}_{2}$-ganki-na dnanna "Magan-boats of Nanna": CU 80-81

$\mathrm{ma}_{2} \mathrm{ri}$

mah

"to navigate a ship to (+ term.)": C 104 || 105

"(to be) very big, huge, greatest, main, magnificent, enormous, sublime, to make eminent": B 1; 11;26; $27 ; \rightarrow$ a mah; $\rightarrow$ a-gar ${ }_{3}$ gal-gal mah; $\rightarrow a_{2}$ mah; $\rightarrow$ buru $_{14}$ mah; $\rightarrow$ dub-la 2 -mah; $\rightarrow$ dub-sar mah; $\rightarrow \mathrm{e}_{2}$-gal mah; $\rightarrow$ $\mathrm{e}_{2}$-kur mah; $\rightarrow$ enim mah du $\mathrm{du}_{11} \mathrm{~g} ; \rightarrow \mathrm{es}_{3}$ mah; $\rightarrow$ gud

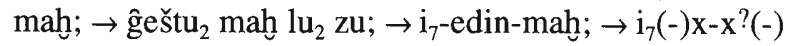
mah(-)dnanna; $\rightarrow \mathrm{KA}_{2}$-mah; $\rightarrow$ kiri $_{6}$ mah DU; $\rightarrow$ kisal(-) mah; $\rightarrow \mathrm{lu}_{2}$-mah; $\rightarrow$ mu mah pa a $_{3}$.d $\rightarrow$ nam-gu mah; $_{2} \rightarrow$ $\mathrm{NI}_{3}$ mah du $_{10} . \mathrm{g} ; \rightarrow$ dnin-mah; $\rightarrow$ para $_{10}$ mah nam-lugalla; $\rightarrow \mathrm{u}_{18}$-ru mah; $\rightarrow$ utug $_{2}\left(\operatorname{tug}_{2}\right)$ mah; $\rightarrow$ non-standard mahe(/a)

$\operatorname{mar}$
mar-ru
$\quad$ mar-uru $_{5}$ an-ki
mara $_{2}$-daki

mas-su ki-en-gi-ra maš- $\operatorname{gan}_{2}$ $\rightarrow \mathrm{gu}_{2}$ mar(-mar)

"deluge, tempest": A 237 (G); $\rightarrow \mathrm{e}_{2}$-mar-uru "deluge (of) heaven and earth" (ep. Enki): 46:1

GN Marada: CU 127; Cadaster B iv 30; $\rightarrow$ ki sur-ra dlugal-mara 2 -da(-k); $\rightarrow$ KISIM $_{2}$-ur-mara ${ }_{2}$-daki-ka "leader of Sumer" (ep. Urnamma): A 35 "settlement": CU 128a 
maš-gi-i $\quad \mathrm{du}_{11} \cdot \mathrm{g}$

maš-kan ${ }_{2}$-LUGAL ki

maš-tab

MAS̆

maš $_{2}$

maš $\check{s}_{2}$ du-du

$\mathrm{mas}_{2} \mathrm{du}_{7}$ $\mathrm{mas}_{2}$-e $\mathrm{dab}_{5}$ $\mathrm{maš}_{2}-\mathrm{e} \mathrm{pa}_{3}$.d maš $\check{s}_{2}$-gal kur-ra maškim $\mathrm{du}_{11} \mathrm{~g}$

me $A$

me $B$

me C

me $\mathrm{du}_{10}-\mathrm{du}_{10} \mathrm{~g}$

me gal

me-den-lil $-1 a_{2}$

me kur-ra

me D

me-a gar

me(-a) $\mathrm{E}$

me-e(-)EN

me-en- $i_{3}-l i_{2}$

me-dim 2

me-li-e-a

me- $\lim _{\mathrm{x}}$

me-lim ${ }_{x}$ tuh-tuh

me-- $\lim _{\mathrm{x}}$ kalam-ma dul

me-te

me-te kur-kur-ra

me-te? unken-na

me-tešs $\check{S}_{2} \mathrm{~A}$

me-teš $\mathrm{i}-\mathrm{i}$

me-tešs $\mathrm{B}$

me-teš 2 nam-lugal-la

ME

$\mathrm{ME}(.) \mathrm{ME}(.) \mathrm{DU}_{8}$ non-standard "to be in charge": E 30'* || 32'; $\rightarrow$ var. maškim $\mathrm{du}_{11} \cdot \mathrm{g}$

GN Maškanšarrum: IB 1537 rev. v' 18'

$\rightarrow$ iri-maš-tab

$\rightarrow \mathrm{KA} \times \mathrm{MAS}$

"buck":

non-standard "perfect bucks": A 87 (Susa); 128a (Susa, broken); 129 (Susa); $\rightarrow$ var. maš $_{2} \mathrm{du}_{7}$

"perfect bucks": A $87 ; \rightarrow$ non-standard maš ${ }_{2}$ du-du

"to choose by extispicy": A 78*

"to designate by extispicy": C 58; year name "8"; "9"

"mountain he-goats": A 102 (Susa)

"to be in charge": F 35; $\rightarrow$ var., non-standard maš-gi-i

$\mathrm{du}_{11} \mathrm{~g}$

"to be": 27, 1:10

non-standard personal pronoun 1st common sg. "me": D

(Ur) $12 *$; $\rightarrow$ var. $\mathrm{ga}_{2}, \mathrm{ge}_{26}-\mathrm{e} ; \rightarrow \mathrm{na}(-)$

"m e": B 7; $\rightarrow$ ddim 3 -pi(-me)-ku .g

"all good $\mathrm{m} \mathrm{e} ": \rightarrow$ iri me $\mathrm{du}_{10}-\mathrm{du}_{10^{-}} \mathrm{ga}$

"great $\mathrm{m} \mathrm{e}$ ": E 7' || F 13

$\rightarrow \mathrm{i}_{7}$-me-den-lil $\mathrm{l}_{2}-\mathrm{la}_{2}$

"m e of the netherworld": A 99

"silence": $\rightarrow$ nig $_{2}(-)$ me-gar

"to reduce to silence, to silence": A 185

"pure" (said of silver): $\rightarrow \mathrm{ku}_{3} \mathrm{me}(-\mathrm{a})$

obscure: F $26^{*}$

GN: Cadaster A ii 2; 4 ; B iv $1 ; 2$

"appearance": A $46 ; \rightarrow$ var. a-ra kalam-ma

"alas!": A 61; 165 (broken); 193

"radiance, awe": D (Ur) 16'*

"to (be) laden with radiance": C 7

"to cover the land with radiance": E 25' (broken) II

F 25 || 28

"adornment": $\rightarrow$ me-tešs 2 B

"adornment of all (the foreign) lands" (ep. Urnamma):

E 6' || F 12

"adornment? of the assembly" (ep. Urnamma): A 33

(broken) II 34*

"appeal and vigour":

"to duly praise": B 18

non-standard "adornment": $\rightarrow$ me-te

"adornment of kingship": D (Ur) 16*

$\rightarrow$ SAĜ?.ME

obscure: C 40 
$\mathrm{me}_{3}$

$\mathrm{me}_{3}-\breve{s e}_{3} \mathrm{DU}$

$\mathrm{me}_{3}$ šen-šen

mes

dmes-lam-ta-e $e_{3}-a$

mi-ir-mi.r

mi-ri-e-zi-ka du ${ }_{11} \cdot g$

MI

$\mathrm{mi}_{2}$

$\mathrm{mi}_{2} \mathrm{zi} \mathrm{du}_{11} \cdot \mathrm{g}$

$\mathrm{mi}_{2}$ zi-de ${ }_{3}$-eš

$\mathrm{mi}_{2}$ zi-de ${ }_{3}$-eš i-i

geš middu ${ }_{2}$

MIN

mir

gešmitum piriĝ an-na

mu A

mu B

$\mathrm{mu} \mathrm{C}$

mu da-a-ri

mu da-ri

$\mathrm{mu}$ da-ri ${ }_{2}$

$\mathrm{mu} \ldots-\mathrm{a}-\mathrm{še}_{3}$

mu i-i

$\mathrm{mu} \mathrm{pa}_{3} \cdot \mathrm{d}$

mu mah $\mathrm{pa}_{3} \cdot \mathrm{d}$ "battle": A 196; C 30

"to line up for battle": IB 1537 rev. v' 12'-13'

"battle and combat": A 32 (broken)

$\rightarrow \mathrm{dbil}_{3} / \mathrm{L}_{4}$-ga-mes

DN Meslamtaea: $\rightarrow$ ki sur-ra ${ }^{d}$ mes-lam-ta- $e_{3}-a$

uncertain meaning: D (Ur) 29'*

non-standard "to trample": B 55 \| 57; $\rightarrow$ ĝiri ${ }_{3}-$ saga $_{11}$ $\mathrm{du}_{11} \cdot \mathrm{g}$

(non-standard) "to be sweet": $\rightarrow$ nam MI

$\rightarrow \mathrm{za}_{3}-\mathrm{mi}_{2} ; \rightarrow \mathrm{za}_{3}-\mathrm{za}_{3} \cdot \mathrm{m}\left(/-\mathrm{mi}_{2}\right)$

"to praise deservingly, to approve of, to duly look after (+ abl.) ": A 239; C 18; 22; 23

"appropriately": E 39' (obscure)

"to extoll rightfully": F 26-27*

"mace": A 88

$\rightarrow$ IGI.MIN/A?

$\rightarrow \mathrm{a}_{2}$ tumu-mir-ra

"m i t u m-weapon (with) a celestial lion": A 92 (Susa); $\rightarrow$ var. i-mi-tum piriĝ an-na

"line": F 52; G 28 (broken)

"year": year names "1-17"

"name, renown, reputation": B 45 || 51; E 4' || F 10;

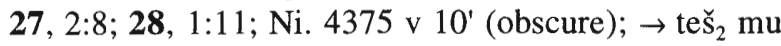
$\mathrm{i}-\mathrm{i}$

non-standard "lasting name": $\rightarrow$ lugal mu da-a-ri; $\rightarrow$ mu da-rí $(2)$

non-standard "lasting name": D (Ur) 31'; $\rightarrow$ var. mu da-ri ${ }_{2}$

"lasting name": D (Ni) 20; 24; $\rightarrow$ non-standard mu da-ri;

$\rightarrow$ non-standard mu da-a-ri

"because": A 18

"to reveal? the name": $\rightarrow$ teš 2 mu i-i

"to call the name, to mention, to call by name": A 231; B 34; E 5' || F 11; 14

"to call the sublime name": A $222 *$

mu sar-ra (+ loc.) šu ur $_{3} / \mathrm{uru}_{12}$ "to erase an inscription": 29,b 2:7'-8' (broken); 40:12-13

mu-su-ur

non-standard "liquorice": D (Ur, C) 36'; $\rightarrow \mathrm{u}_{2}$ munzer (UD. dNANNA)

$\mathrm{mu} \check{\text { še }}$

mu-še-n(a)

non-standard "to name": D (Ur) 30'; 31'; $\rightarrow$ mu še $\mathrm{e}_{21}$

non-standard "bird, fowl": D (Ur, B) 32' || 33' || 34'; $\rightarrow$

mušen; $\rightarrow$ non-standard mu-ši-x

$\mathrm{mu} \breve{s} \mathrm{e}_{21}$

"to name": $\mathbf{D}(\mathrm{Ni}) 22$ \| 23*; $\rightarrow$ non-standard mu še

$\mathrm{mu} \mathrm{du}_{10} \check{s ̌ e}_{21}$

mu-ši-X "to give a good name": C 46

non-standard "bird, fowl": D (Ur, C) 33' || 34'; $\rightarrow$ mušen; $\rightarrow$ non-standard mu-še-n(a) 
mu tuku

$\mathrm{mu}_{2}, \mathrm{mu}_{2}-\mathrm{mu}_{2}$

mud

mul

mud-gal

$\operatorname{mun}_{4}(-n a)$

munus

munus a nun-na(-k)

munus zi $\operatorname{gir}_{17}-\mathrm{zal}$

$\mathrm{u}_{2}$ munzer(UD.dNANNA)

muš

$\mathrm{mušs}_{3}$ ?-am 3

dMUŠ

mušen

na(-)

NA

na- $\mathrm{gu}_{4}-\mathrm{u}_{8}$ ma-h $(\mathrm{a})$

na-lu-ga-1(a)

$\mathrm{na}_{2}$

$\mathrm{na}_{4}$ ge.n

NAGAR.BI

NAGAR.BI-4-kam-ma

naĝ-ĝa

nam

nam bala

nam-da. $\mathrm{g}$

nam $d_{10} \cdot g$

nam-en

nam-en-na tum 2

nam-EN-na tag

nam-ga-ešs

nam-ga-eš "famous": $\rightarrow$ lugal mu tuku

"to grow (tall), to sprout": A 23; 28; C 53; D (Ur)

37 '; $\rightarrow$ abzu-ta $\mathrm{mu}_{2} ; \rightarrow$ an-še $\mathrm{mu}_{2} ; \rightarrow \operatorname{nin}(-)^{d a-z i}-\mathrm{mu}_{2}-\mathrm{a}$;

$\rightarrow \mathrm{u}_{2}$-šem-gin $\mathrm{mu}_{2} ; \rightarrow$ var. $\mathrm{e}_{3} . \varnothing / . \mathrm{d} ; \rightarrow$ SAR

"to bring forth, to produce": A 140 (Susa); $\rightarrow \mathrm{e}_{2}$-mudkur-ra(-k); $\rightarrow d_{\text {nu-dim }}(2)$-mud; $\rightarrow$ var. zu

$\rightarrow$ ka mud-gal ${ }_{2}$ ki-en-gi-ra

"ramifying": $\rightarrow$ pa mul

"bitter, salty": A 83; $\rightarrow$ ses B

"woman": $\rightarrow$ geš ga-rig $($ imin?) nam-munus-a

"woman of noble stock": E 39' || F 44* (broken)

"good and proud woman": F 18*

"liquorice": D (Ur, B) 36'*; $\rightarrow$ non-standard mu-su-ur

"snake": C 36; $\rightarrow$ ĝeš gi-muš

exclamation used to express or seek compassion: $\mathbf{A}$ $54 *$ (broken)

$\rightarrow$ PUZUR $_{4} \cdot \mathrm{dMUS}_{3} \cdot \mathrm{EREN}(-\mathrm{k})$

"bird, fowl": D (Ni) 24; 25 || 26; D (Ur) 35*; $\rightarrow$ nonstandard mu-še-n(a); $\rightarrow$ non-standard mu-ši-x

non-standard personal pronoun 1 st common $\mathrm{sg}$. "me" (?):

D (Ur) $30^{\prime *}$ (obscure); $\rightarrow \mathrm{ga}_{2}, \mathrm{ge}_{26}-\mathrm{e} ; \rightarrow$ me B

obscure: E 40' (broken)

non-standard "great oppression": B 59 \| 61; $\rightarrow$ nam-gu mah

non-standard "kingship": $\rightarrow$ pa-ra na-lu-ga-la(-k); $\rightarrow$ namlugal

$\rightarrow \mathrm{nu}_{2}$

"to standardize a (weight) stone": CU 147-149

GN: Cadaster A ii $12 ; 13$

GN: Cadaster B iii 13; 14

"watering places": $\rightarrow \mathrm{u}_{2}$ nag $-\hat{g} a_{2}$

"quality, state, (all) these": C 16 (broken, obscure); G $11 ; 12 ;$ H 6 (broken, obscure); $\rightarrow$ ni $\hat{g}_{2}$-nam

"to overturn (somebody's) destiny": A 17* (Susa); $\rightarrow$ var. nam tar

"sin": $\rightarrow \mathrm{lu}_{2}$ nam-da - ga

"to make the destiny pleasing": D (Ni) 12 ; $\rightarrow$ (nonstandard) nam MI

"e n-ship": Ni. 4375 v 2'; $\rightarrow$ gidri $\mathrm{ku}_{3}$-sig 17 nam-en-na;

$\rightarrow$ gešma-nu nam-en-na(-k); $\rightarrow$ numun nam-en-na

"to be worthy of e n-ship": A 103a (Susa)

uncertain meaning: C 79*

"trade": CU 90; 117

"to restore trade": 26, 2:3 


\author{
nam-gu mah \\ nam-ĝeš-šub galam \\ nam-ĝu $\mathrm{u}_{10}$ \\ nam-ha-ni \\ nam-he ${ }_{2}\left(-\mathrm{gal}_{2}\right)$ \\ nam-hyi-i \\ nam $\mathrm{ku}_{5} \cdot \mathrm{d} / \mathrm{r}$ \\ nam- $l u_{2}-u_{l} u_{3} / u_{18}-1 u_{7}$ \\ nam-lugal
}

nam-lugal šum nam-lugal uri ${ }_{5}$ ki-ma šum nam MI

nam-munus

nam-nar

nam-nin

nam-nir

nam-nun gal

nam-ra-aš $\mathrm{AK}$

nam-sipa.d

nam-šub

nam-šub galam

nam tar

\section{dnam-tar}

nam $\mathrm{du}_{10}$ tar

nam gal tar

nam(-)tar-ra

nam tar-ra $\mathrm{sa}_{6} . \mathrm{g}$

nam tar-tar-ra

nam-til ${ }_{3}$

nam-til ${ }_{3}$-la-ni-še ${ }_{3}$ a ru

\section{1:7-8; 33:7-8 (broken); 34:8-9; 40:10-11; IB 1537} rev. v' 5'-6'

nam-til ${ }_{3}$ ur-dnamma(...)-šs ${ }_{3}$ a ru "to make a votive gift for the life of Urnamma (...)": 35:3-12 "great oppression": B $59 \| 61$; $\rightarrow$ non-standard na-gu $-\mathrm{u}_{8}$ ma-h(a)

"cunning spell": B 19*; $\rightarrow$ var. nam-šub galam

"what is it to me? what is it that?": A 61

PN Namhani: CU 75

"abundance, prosperity": A 211; G 9; $\rightarrow \mathrm{u}_{4}$ nam-he $_{2}$-a $\mathrm{AK} ; \rightarrow$ non-standard nam-hi-i

non-standard "abundance": B 71; $\rightarrow$ nam-he n $_{2}\left(-\right.$ gal $\left._{2}\right)$

"to curse": 29,b 2:10" (broken); 40:15

"people, mankind": A 20; 56 (broken); 230; F 39 (broken)

"kingship": B 44 II 50; C 114; Ni 4375 iv 11'; $\rightarrow$ meteš $\check{2}_{2}$ nam-lugal-la; $\rightarrow$ para $_{10}$ (mah) nam-lugal-la(-k); $\rightarrow$ non-standard na-lu-ga-l(a)

"to give kingship": D (Ni) 13

(non-standard) "to make the destiny pleasing": D (Ur) $13^{\prime *} ; \rightarrow$ var. nam $\mathrm{du}_{10}$. $\mathrm{g}$

"womenly fashion": $\rightarrow$ geš ga-rig 2 (imin?) nam-munus-a

"activity of the musician, music": $\rightarrow \mathrm{e}_{2}$ nam-nar-ra(-k)

"queenship, fit for a queen": $\rightarrow$ tug $_{2}$ pala $_{3}$ nam-nin-a

"confidence": D (Ni) 9 || D (Ur) 10'; $\rightarrow$ (en) dnu-namnir

"great nobility": B 2

"to take as booty": IB 1537 rev. vi' 4'-5'

"shepherdship": $\rightarrow$ ĝešma-nu nam-sipa-da

"spell, lot": $\rightarrow$ šir $_{3}$-nam-šub-d nanna(-k)

"cunning spell": B 19* $\left(\mathrm{C}_{2}\right)$; $\rightarrow$ var. nam-ĝeš-šub galam "to determine, to decree, to allot fate": $\mathbf{A ~} 17 * ; 221 ; \mathbf{B}$ 70; C 6; D (Ni) 9 || D (Ur) 10'; E 17' || F 22; E 36' \|| F 37; E 38' II F 42; $\rightarrow$ ki nam tar-ra/(re) (diĝir-re(-e)ne) $\rightarrow \mathrm{lu}_{2}$ nam tar-tar-ra; $\rightarrow$ šu nam tar-ra; $\rightarrow$ var. nam bala

"to determine an auspicious fate": C 19

"to decree a great fate": B 37

"decreed fate": A 9*; Ni. 4375 v 4'

"propitious fate": C 49

"all the decreed fates": $\rightarrow l_{2}$ nam tar-tar-ra

DN Namtar: A 108; $\rightarrow$ dam (d)nam-tar-ra

"life": 28, 2:13; $\rightarrow$ hur-saĝ-nam-til ${ }_{3}$-la(-k)

"to make a votive gift for his (= Urnamma's) life": 
nam-ur-sag

nam-urdu AK

nam-zi-um

$\mathrm{d}_{\text {namma }}$

dnanna

dnanna-gu $_{2}$-gal
dNANNA
nar
-ne-e
NE

NE.RU-du, NE.RU.m

NE.RU(-) ga ${ }_{2}$

$\mathrm{d}_{\mathrm{ne}_{3}}$-eri ${ }_{11}$-gal

ni(-i)g-ru

ni-is-kum

$\mathrm{ni}_{2}$

ni $_{2}$-ba
ni ${ }_{2}$-bi $\mathrm{il}_{2}$
$\mathrm{ni}_{2}$-te
ni $_{2}$ te-en-te

$\mathrm{ni}_{2} \operatorname{guru}_{3} \mathrm{ru}$

$\mathrm{ni}_{2}$ ri

$\mathrm{ni}_{2}$ gal ri

$\mathrm{ni}_{2}$ ḩuš ri

$\mathrm{ni}_{2}$ su-e $\mathrm{us}_{2}$

$\mathrm{ni}_{2}$ te $($ h. $)$, te.g $(m$.

$\mathrm{ni}_{2} \mathrm{zu}$

$\mathrm{ni}_{2}$-zuh

$\mathrm{NI}_{3}\left(\right.$ inda $_{3} /$ nig $\left._{2}\right)$

$\mathrm{NI}_{3}$ mah $\mathrm{du}_{10} \cdot \mathrm{g}$

$\mathrm{NI}_{3}$ šu tag

$n \mathrm{ni}_{10}-\mathrm{ni}_{10}$ "valour, warriorship": $\rightarrow \mathrm{a}_{2}$ nam-ur-saĝ-ĝa $a_{2}$

"to enslave": CU 130

GN: Cadaster A iii $20 ; 21$

$\rightarrow$ (sipa) (d)ur-dnamma(-k)

DN Nanna: A $13 ; 179 \| 235 ;$ C $42 ; 45^{*} ; 108 ; 111^{*}$;

CU $33 ; 82 ; 131 ; \mathbf{9}, 1: 1 ; \mathbf{1 0}: 1 ; \mathbf{2 5}: 1 ; \mathbf{2 6}, 1: 1 ; \mathbf{2 7}, 1: 1$;

28, $1: 1 ; 2: 2 ; 2: 7 ; 30: 1 ; 33: 1 ; 44: 1$ (broken); 47, 1:1;

$2: 11 ; \rightarrow$ a-ba-dnanna-gin ${ }_{7} ; \rightarrow \mathrm{e}_{2} \mathrm{~d}_{\text {nanna; }} \rightarrow$ en dnanna; $\rightarrow$ $\mathrm{i}_{7}(-) \mathrm{x}-\mathrm{x}$ ?(-)mah(-)dnanna; $\rightarrow$ kar-za-gin ${ }_{3}(-)$ dnanna(-k); $\rightarrow$ ki-tuš dnanna(-k); $\rightarrow$ ma $_{2}$ ma $_{2}$-ganki-na dnanna; $\rightarrow$ šir $_{3^{-}}$ nam-šub-dnanna(-k)

CN: 28, 1:11; $\rightarrow \mathrm{i}_{7}$ - $\mathrm{d}_{\text {nanna-gu }}$-gal

$\rightarrow \mathrm{u}_{2}$ munzer(UD.dNANNA)

"musician": $\rightarrow \mathrm{e}_{2}$ nam-nar-ra(-k)

demonstrative pronoun: $\rightarrow$ nig $\hat{g}_{2}$-ne-e

obscure: A 156 (D)

"malefactor, evil, enemy": C 36; $\rightarrow \mathrm{lu}_{2}$ NE.RU; $\rightarrow$ kur NE.RU.m; $\rightarrow$ nig $_{2}$-NE.RU

"(to be) rebellious": $\rightarrow \mathrm{gu}_{2}$ (A.)NE.RU-gal ${ }_{2}$; $\rightarrow$ ki-bala

NE.RU-gal $;$; $\rightarrow$ erim $_{2}$ - gal $_{2}$

DN Nergal: A $90^{*}$

non-standard "to imbue with awe": B 68; $\rightarrow$ ni $_{2}$ guru $_{3}{ }^{\text {ru }}$

"nisku-people": CU 88

1. "self (of a person)": A 41 (Susa), 200 (Susa, obscure)

"by itself, spontaneously": A 168*; IB 1537 rev. v' 12'

"to raise itself high": C 80

"(him)self": A 155; C 18 (broken)

"to refresh oneself": E 34'

2. "awe, splendour, fear":

"to imbue with awe": B $68 ; \rightarrow \mathrm{e}_{2}$-temen-ni $\mathrm{i}_{2}$-guru ${ }_{3}$ (ru);

$\rightarrow$ non-standard ni(-i)g-ru

"to inspire awe, to be laden with splendor":

"to grandly inspire awe ": B 28

"to be laden with a terrible splendour, to invest somebody with a terrible splendour": B 6

"to inspire fear": C $33^{*}$

"to be seized with panic, to spread panic, to be afraid":

A $3 ; 5$

"to experience fear": A 156 (Susa)

"thief": C 35

"meals, offerings":

"to have huge quantities of food tastily prepared": B 35

"to seize offerings": A 135 (Susa)

$\rightarrow$ šu ni ${ }_{10}-$ ni $_{10}$ 
nibruki

nidba

niga

ni $\hat{g}_{2}$

nig. $\hat{g}_{2}-\mathbf{a}_{2}-\mathrm{zi} . \mathrm{g}$

nig. $\hat{g}_{2}-\mathrm{ba}$ ni $\hat{g}_{2}$-ba-a gar

ni $\hat{g}_{2}$-ba šum 2 nig $\hat{g}_{2}$-daĝal

$\mathrm{ni}_{2} \mathrm{du}_{10} \cdot \mathrm{g}$

nig. $\hat{g}_{2}$-egir

niğ ${ }_{2}$ ge-na

nig $\hat{g}_{2}$ gig-ga

nig $_{2}$-gur 11

nig $\hat{g}_{2}-$ gur $_{11}$-e ki-a $\hat{g}_{2}$

nig. $\hat{g}_{2}$-hul $\operatorname{dim}_{2}$-ma
GN Nippur: D (Ni) 12 || D (Ur) 13'*; IB 1537 rev. vi' 8 '; $\rightarrow$ bad $_{3}$ nibruki; $\rightarrow \mathrm{u}_{2}$-a nibruki

"sacrifices, (sacrificial) offerings": C 42; 93* (obscure);

E $15^{\prime *} ; \rightarrow \mathrm{i}_{7}$ nidba(-k); $\rightarrow$ var. inda 3 -ba

"sacrifices for/of the netherworld": A 85 || 86

"fattened": $\rightarrow$ udu niga

"thing(s), something, which, what, anything": A 107;

159 (Susa, obscure); 161; 194; B $40 \|$ 46; CU 130

"violence": CU 178

"gift, present": C 107

"to make a present, to give as a present": IB 1537 rev. vi' 13 '-14'

"to give presents": A 76

"vastness": A 5*

"something pleasing": $\rightarrow \operatorname{sizkur}_{2}$ nig $_{2} \mathrm{du}_{10} \cdot \mathrm{g}$

"rest": IB 1537 rev. vi' 11'

"truth": CU 42 (broken); $\rightarrow$ di niĝ 2 ge-na dutu

"something bitter": 28, 2:13; $\rightarrow$ i-lu a-nir nig ${ }_{2}$ gig-ga

"property (matters), treasures": E 28' || F 33; $\rightarrow$ nin nig. $\hat{g}_{2}$-gur ${ }_{11}$-e ki-ag $\hat{g}_{2} ; \rightarrow$ nin nig $\hat{g}_{2}$-gur ${ }_{11}$-ra(-k)

"to love treasures": $\mathbf{F} 44 ; \rightarrow$ nin nig $\hat{g}_{2}-\operatorname{gur}_{11}$-e ki-a $\hat{g}_{2}$

"committed sacrilege": $\rightarrow \mathrm{a}_{2}$ ni $_{2}$-hul dim $_{2}$-ma a $\hat{g}_{2}$

niğ $\hat{g}_{2}$ ki-ag $\hat{g}_{2}$ dereš-ki-gal-la "Ereškigal's favourite": A 94

$\mathrm{ni}_{2}-\mathrm{ku}_{5} \mathrm{AK}$

"to tax": C 80*

"stillness, silence": $\rightarrow$ i-lu niğ ${ }_{2}(-)$ me-gar du ${ }_{11} \cdot \mathrm{g}$

"everything":

nig $\hat{g}_{2}$-nam

nig $\hat{g}_{2}$-nam dub-sar-ra(-k)

"everything (concerning) the scribe": A 124*

nig ${ }_{2}$-nam irigal ${ }_{2} \mathrm{gal}_{-}$(l)a "everything (concerning) the underworld": A $110^{*}$

nig $\hat{g}_{2}$-ne-e

"all this": A 156

nig g $_{2}$-NE.RU "evil, wickedness": E 27' || F 32; CU 177

ni $\hat{g}_{2}$-NE.RU $\mathrm{sa}_{2} \mathrm{du}_{11}$.g "to subdue evil": $\mathbf{C} 38$ nig $\hat{g}_{2}-\mathrm{si}_{-} \mathrm{sa}_{2}$

nig $\hat{g}_{2}$-si-sa ${ }_{2}$ gar $\quad$ "to establish justice": CU 112-113 (broken); 180-181

nig $\hat{g}_{2}$-si-sa $\mathrm{sa}_{2}$ pa $\mathrm{e}_{3} \mathrm{AK}$ "to make justice appear": C 38

nig. $_{2}-\mathrm{si}^{-} \mathrm{sa}_{2} \mathrm{sa}_{2} \mathrm{du}_{11} \mathrm{~g}$ "to impose justice": $\mathbf{E} 27^{\prime}-28^{\prime} \| \mathbf{F} 33$

$\operatorname{nig}_{2} \check{s a}_{3} \cdot g$

ges ni $\hat{g}_{2}$-šu.k

nig $\hat{g}_{2}$ tuku

"desirable things": A 60

"chariot": A 114

"rich one, wealthy" (ep. Urnamma): D (Ni) 6* $\|$ D (Ur) $8^{\prime} ; \rightarrow \operatorname{lu}_{2}$ nig $_{2}$ tuku

nig $\hat{g}_{2}$ ul-li ${ }_{2}-\mathrm{a}_{-}-\mathrm{ke}_{4}$ pa $\mathrm{e}_{3} \quad$ "to make the ancient/traditional things/rights manifest":

$\mathrm{NIG}_{2}$

26, 2:1

$\rightarrow \mathrm{NI}_{3}\left(\mathrm{inda}_{3} / \mathrm{ni}_{2}\right)$

$\mathrm{NIG}_{2} \cdot$ DA.TAG.GA

$\mathrm{NIG}_{2} . \breve{S} \mathrm{U}(.) \mathrm{PI}$ uncertain meaning: IB 1537 rev. v' 9'

obscure: A 99* (Susa) 
nim

nim gir $_{2}-\mathrm{gir}_{2}$

$\operatorname{nin}$ $\rightarrow$ igi nim; $\rightarrow$ sig-ta igi nim-še $e_{3}$

"flashing lightening": C 9

"lady, mistress, queen": A 196*; E 37'* II F 41 (broken) $\| 43 ; 46$ (obscure); 6:3; 7,1:2; 8:3; 13 obv. 3; 14 obv. $2 ; \mathbf{1 7}: 3 ; \mathbf{1 8}: 2 ; \mathbf{1 9}: 2 ; \mathbf{2 1}: 2 ; \mathbf{2 9}$,b 2:9"; $31: 2$; 35:2; 38:2; 42:1'; Al-Rawi, Sumer 46 (1989-90) $84: 3 ; \rightarrow$ tug $_{2}$ pala $_{3}$ nam-nin-a

nin an-na

$\operatorname{nin} e_{2}$-an-na

nin gal $e_{2}$-an-na

nin-ĝ $\mathrm{u}_{10}$

$\operatorname{nin} \mathrm{ku}_{3}$ nun-na

"queen of heaven" (ep. Inana): 8:2

"lady of the Eana" (ep. Inana): 14 obv. 2; Al-Rawi, Sumer 46 (1989-90) 84:2

"great lady of the Eana" (ep. Inana): A 201

"my lady" (ep. Inana): A 203

"dazzling, princely lady"/Ninkununa (ep. Inana): 6:2; $17: 2 ; \rightarrow$ var. nin nun-na

nin nig $_{2}-$ gur $_{11}$-e ki-ag $\hat{g}_{2} \quad$ "lady who loves treasures" (ep. Inana?): F 41* \| 43; $\rightarrow$ var. nin nig $\hat{g}_{2}$-gur 11 -ra(-k)

nin nig $\hat{2}_{2}-$ gur $_{11}-\mathrm{ra}(-\mathrm{k}) \quad$ "lady of treasures" (ep. Inana?): E $37^{*} ; \rightarrow$ var. nin nig $\hat{2}_{2}$ gur $_{11}$-e ki-ag 2

nin nun-na

$\operatorname{nin}(-)^{d} a-z i-m u_{2}-a$

dnin-a-zu

$\mathrm{d}_{\text {nin- }}$ - -gal

$\mathrm{d}_{\text {nin-gal }}$

dnin-gublaga

dnin-ĝě̌-zi-da

dnin-girir - su

dnin-ḩur-sag

dnin-hur-saĝ-ka

$\mathrm{d}_{\text {nin- }-\mathrm{lil}_{2}}$

dnin-mah

dnin-SAR

$\mathrm{d}_{\text {nin-sumun }}(-$-na-k)

$d_{\text {nin-ša }}$-ge-pa ${ }_{3}-d a$

dnin-tu.r

NIN-digir

$\operatorname{nin}_{9}$

$\operatorname{nin}_{9} \operatorname{di}_{4}-\mathrm{di}_{4} \cdot \mathrm{I}$

$\operatorname{nin}_{9}$ lugal-la

$\operatorname{nin}_{9}$ tur "princely lady" (ep. Inana): 17:2; $\rightarrow$ var. nin $\mathrm{ku}_{3}$ nun-na DN Ninazimua (wife of Ningešzida): A 126*

DN Ninazu: $\rightarrow$ ama dnin-a-zu

DN Ninegal: 18:1

DN Ningal: 19:1; 31:1; 35:1

DN Ningublaga: C 29; $\rightarrow$ uš $e_{2}$ dnin-gublaga

DN Ningešzida: A 217 (broken); $\rightarrow$ en dnin-ĝeš-zi-da; $\rightarrow$ sul ur-saĝ dnin-geš-zi-da

DN Ningirsu: $\rightarrow \mathrm{i}_{7}-\mathrm{gu}_{2}-[\mathrm{x}]-\mathrm{ur}_{2}{ }^{?}(-)^{\mathrm{d}}$ nin- $\mathrm{gir}_{2}-\mathrm{su} ; \rightarrow \mathrm{i}_{7}$ kisur-ra dnin-ğir ${ }_{2}$-su

DN Ninhursag: 14 obv. 1

GN: Cadaster B iii $19 ; 21$

DN Ninlil: B 33; F 48 (broken); 21:1; $\rightarrow$ ama gal $\mathrm{d}_{\text {nin-lil }}$

GN Ninmah: A 10

$\rightarrow \mathrm{e}_{2}$-d nin-SAR-ka

DN Ninsumun: A $178 ; 15$ obv. $1 ; \rightarrow$ ama dnin$\operatorname{sumun}_{2}(-\mathrm{k}) ; \rightarrow$ dumu $\left(\mathrm{du}_{2}\right.$-da) dnin-sumun $2(-\mathrm{ka}) ; \rightarrow \mathrm{e}_{2}$ $\mathrm{d}_{\text {nin-sumun }} ; \rightarrow \mathrm{ku}_{3} \mathrm{~d}_{\text {nin-sumun }}$ (-na-k)

DN Ninšagepada: 38:1

DN Nintur: C $24 ; 47 ; \rightarrow \mathrm{i}_{7}$-a-dnin-tu.r

"N I N di g i r-priestess": A 78*

"sister":

"young sisters": A 153; $\rightarrow$ var. nin 9 tur

"the king's sister" (ep. Ninazimua/Ĝeštinana): A 126*

(Susa); 127a* (Susa)

"young sister": A 153 (Susa); $\rightarrow$ var. $\operatorname{nin}_{9} \mathrm{di}_{4}$-di ${ }_{4} \cdot 1$ 


\author{
nindan \\ nindan $_{\mathrm{x}}(\mathrm{NINDA} . \mathrm{DU})$ \\ ninkum \\ nir \\ $\operatorname{nir}(-) \mathrm{gal}_{2}$
}

$\quad$ nir-ĝal 2 -bi DU
anše $_{\text {nisku(m)(PIRIG) }}$ (P)
nita $_{(2)}$ kala.g

NITA

$\mathrm{NITA}_{2}$

nitadam

nitadam ki-a $\hat{g}_{2}$ dinana

dnu-dim(2)-mud

nu-mu-un-KUŠ

dnu-muš-da(-k)

nu-na-am-ni-r(a)

dnu-nam-nir

nu-siki

nu-tuku

nu-zu

$\mathrm{nu}_{2}$

$\mathrm{nu}_{11}$

numun

numun nam-en-na nun

NUN "n i n d a n" (measuring unit): $\rightarrow$ gi-nindan

"n i n d a n" (measuring unit)": 27, 2:3 (broken)

"n i n k u m": B 18

$\rightarrow$ nam-nir

"to put trust into someone (+ com.), to place confidence in something ( + com.), to trust, trusting, noble, tasty" (said of food): B 12; C 17; F 6; $\rightarrow$ en-nirgal $_{2}$-an-na; $\rightarrow \mathrm{u}_{2}$ nir-ĝal 2

"to stand confidently" (said of people): C 55

"thoroughbred donkey": A 115*

"strong man" (ep. Urnamma): CU 11 (broken); 105 (broken); $7,1: 4 ; \mathbf{1 0 : 6 ; 1 1 : 4 ; 1 2 : 4 ; 1 3 ~ o b v . ~} 5 ; 14$ obv. $4 ; \mathbf{1 5}$ obv. $4 ; \mathbf{1 6}: 5 ; \mathbf{1 7}: 5 ; \mathbf{1 8}: 4 ; \mathbf{1 9}: 4 ; \mathbf{2 1 : 4}$; $\mathbf{2 2}: 5 ; \mathbf{2 4}: 4 ; \mathbf{2 5 : 7} ; \mathbf{2 6}, 1: 6 ; \mathbf{2 7}, 1: 6 ; \mathbf{2 8}, 1: 5 ; \mathbf{3 1}: 4$; 32:4; 33:4; 34:4; 35:5 (broken); 39:3' (broken); 40:5; 42:3'; 43,1:2 (broken); 45:5; 46:4; 47,1:9 (broken); Al-Rawi, Sumer 46 (1989-90) 84:5; IB 1537 rev. $\mathrm{v}^{\prime} 2^{\prime}$

$\rightarrow$ ANŠE.NITA?

$\rightarrow \mathrm{GIR}_{2} \cdot \mathrm{NITA}_{2}$

"spouse, wife, husband": A 49; 126 (broken); 166; $174 ; \rightarrow$ var. dam A

"beloved husband of Inana" (ep. Dumuzi): A 104 (D); $\rightarrow$ var. dam ki-a $\hat{g}_{2}$ dinana

DN Nudimmud: A $12 ; \mathbf{D}$ (Ni) 36

"widow": A 166; CU 164

DN Numušda: Cadaster A i $14 ; \rightarrow$ a-ša ${ }_{3}$ dnu-muš-da kiri $_{8}$-tabki(-k); $\rightarrow$ an-za-gar ${ }_{3}$-dnu-muš-da-ka; $\rightarrow$ para $_{10^{-}}$ dnu-muš-da-ka

non-standard DN Nunamnir: B $54 \| 56$; $\rightarrow$ dnu-nam-nir DN Nunamnir: B 3; 6; 12; 34; 40; D (Ni) $11 \|$ D (Ur) $12^{\prime} ; \rightarrow$ en dnu-nam-nir; $\rightarrow$ non-standard nu-na-am-ni-r(a) "orphan": CU 162

$\rightarrow$ ga-ri nu-tuku; $\rightarrow$ gaba-ri nu-tuku

"unknown": $\rightarrow$ ki nu-zu; $\rightarrow \mathrm{lu}_{2}$ nu-zu

"to lie (down)": A 12; 35 || 36 || 37; 42; 44; 48 (broken); 192; C 74; $\rightarrow$ ĝeš-nu 2 ; $\rightarrow$ ki-nu $2 ; \rightarrow$ var. šub

$\rightarrow$ geš-nu ${ }_{11}(-\mathrm{gal})$

"seed": G 11

"seed of e n-ship": C 113; Ni. 4375 iv 12' (broken)

"high, low, prince(ly), noble": $\rightarrow{ }^{d a-n u n-n a(-k) ; ~} \rightarrow a_{2}$ nun $\mathrm{ge}_{4}$-a; $\rightarrow \mathrm{es}_{2}$-nun-naki; $\rightarrow \mathrm{gu}_{2}$ nun $\mathrm{du}_{11} . \mathrm{g} ; \rightarrow \mathrm{ga}_{2}$-nun; $\mathrm{i}_{3}$-nun; $\rightarrow \mathrm{i}_{7}$-nun; $\rightarrow$ munus a nun-na(-k); $\rightarrow$ nam-nun gal; $\rightarrow$ nin $\mathrm{ku}_{3}$ nun-na; $\rightarrow$ nin nun-na

$\rightarrow \mathrm{i}_{7}$-EN(.EREN $\left.{ }_{2}\right) \cdot \mathrm{NUN}$ 
pa $\mathrm{e}_{3}$

$$
\text { pa } \mathrm{e}_{3} \mathrm{AK}
$$

pa mul

pa-ra na-lu-ga-la(-k)

PA-a

PA.PA

PA.USAN

$\mathrm{pa}_{3} \cdot \mathrm{d}$

$\mathrm{pa}_{5} \cdot \mathrm{r}$

$\mathrm{pa}_{5}$-urdu-šum-ma

tug $_{2}$ pala $_{3}$ nam-nin-a

pana

gešpana gal

$\operatorname{par}_{3 / 4}$

$\operatorname{para}_{10} \cdot \mathrm{g}$

para $_{10}$ gal kur-ra(-k)

"to make appear, to show, to reveal": $\mathbf{C ~} 16 ; \rightarrow$ he $_{2}-$ gal $_{2-}$ la pa $e_{3} ; \rightarrow$ nig $\hat{2}_{2}$ ul- $\mathrm{li}_{2}-\mathrm{a}-\mathrm{ke}_{4}$ pa $\mathrm{e}_{3}$

"to make appear, to reveal, to shine, to show": B 67;

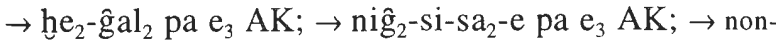
standard pe-e ša-aš

"ramifying branch": E 29'* || 31'

non-standard "dais of kingship": B $66 ; \rightarrow$ para $_{10}$ namlugal-la

"PA-a-cry": D (Ni) $35^{*} \| 36$

$\rightarrow \operatorname{kum}_{\mathrm{X}}(\mathrm{PA})-\mathrm{kum}_{\mathrm{X}}(\mathrm{PA})$

"herdsman": A 117*

"to call, to choose, to appoint": A 224; B 5 (broken);

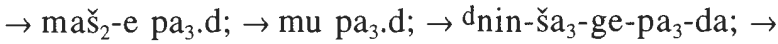

$\mathrm{s}_{3}$-ge $\mathrm{pa}_{3} \mathrm{~d}$

"ditch": D (Ni) 4*; 24; $\rightarrow$ eg ${ }_{2}$ pa $_{5}$. r $\rightarrow$ i $_{7}-$ pa $_{4 / 5}$-bi-luh

GN: Cadaster B iv 19; 20

"p a 1 a-robe fit for a queen": A 98

$\rightarrow$ geš gag-pana

"large bow": A 88

$\rightarrow \mathrm{gi}_{6}-\operatorname{par}_{3 / 4}$

"dais, throne": D (Ni) 7 || 8; 5:7

para $_{10}$ mah nam-lugal-la "highest dais of kingship": $\mathbf{C} 1$

para $_{10}$ nam-lugal-la(-k) "dais of kingship": B 66; $\rightarrow$ non-standard pa-ra na-luga-la(-k)

para $_{10}$-d nu-muš-da-ka

para $_{10^{-}}$d $_{\text {su'en }}$

pe-e ša-aš

peš A

peš B (?)

peš C

peř $\mathrm{du}_{3}$

$\operatorname{peš}_{\mathrm{X}} ?\left(\check{S}_{3}\right)$

PEŠ(.PEŠ)

-pi-

PI

pirig

pirig an-na

PIRIĜ

pu-uški

$\mathrm{PU}_{2}$ hulu
GN: Cadaster A i $2 ; 4 ; 18 ; 19$

GN: Cadaster A iii 27; 28

non-standard "to shine": B 67; $\rightarrow$ pa $\mathrm{e}_{3} \mathrm{AK}$

"to raise": $\rightarrow \mathrm{du}_{10}$-ba/be 2 peš; $\rightarrow \mathrm{gu}_{2}$ peš; $\rightarrow$ non-standard $\check{S}_{3}($ peš $\check{x}$ ?)

"to ...". Ni. 4375 v 10' (obscure)

"young date-plants":

"to plant with young date-plants": 27, 1:9

non-standard "to raise $e^{\text {": }} \rightarrow$ var. peš $\mathrm{A} ; \rightarrow \mathrm{du}_{10}$-ba $\breve{S}_{3}$

(pe $\check{S}_{\mathrm{x}}$ ?)

uncertain meaning: A 181 *

$\rightarrow \mathrm{ddim}_{3}$-pi(-me)-ku$\cdot \mathrm{g}$

$\rightarrow \mathrm{NIG}_{2} . \grave{S U}(.) \mathrm{PI}$

"lion": A 184; 238 (A); C 52; $\mathbf{H} 9$ (broken)

"celestial lion" (as part of a weapon): $\rightarrow$ i-mi-tum/

gešmitum piriĝ an-na

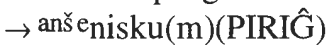

GN: Cadaster A iv 3; 4

"perilous pit": A 183* 


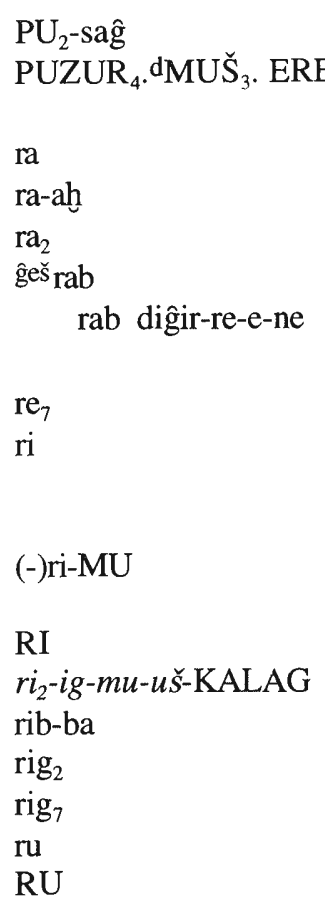

gešRU

sa-g(i)

sa-gid 2 -da

sa-gar-ra

sa-ha-ar

sa-ra

$\mathrm{sa}_{2}$

$\mathrm{sa}_{2} \mathrm{du}$

$\mathrm{sa}_{2} \mathrm{du}_{11} \cdot \mathrm{g}$

$\mathrm{sa}_{2}-\mathrm{du}_{11}-\mathrm{še}_{3}$ gar

$\mathrm{sa}_{6} \cdot \mathrm{g}$

$s a_{7} . g$ "pit": $\rightarrow$ sahar $\mathrm{PU}_{2}$-saĝ-ĝa $(-\mathrm{k})$

PN Puzur/Kutik-Inšušinak (of Elam): IB 1537 rev. $v^{\prime} 15$

non-standard "to make"(?): $\rightarrow$ šu dul $\mathrm{dra}_{3} \rightarrow \mathrm{AK}$

"to gnash": $\rightarrow \mathrm{e}_{2}-\mathrm{zu}_{2}-\mathrm{ra}-\mathrm{ah}$

"to carry"(?): $\rightarrow$ a DU( $\mathrm{ra}_{2}$ ?)

"shackle": F 30

"shackles of the gods": F 13*; $\rightarrow$ non-standard a-ra - -ab diĝir-re-ne

"to go" (h., pl.): $\rightarrow$ gen

"to throw, to inspire" (said of fear), "to ejaculate" (said of semen), "to navigate": $\rightarrow$ a ša $\mathrm{ku}_{3}$-ge ri; $\rightarrow$ ga-ri nutuku; $\rightarrow$ gaba-ri nu-tuku; $\rightarrow \mathrm{ma}_{2} \mathrm{ri} ; \rightarrow \mathrm{ni}_{2} \mathrm{ri} ; \rightarrow$ šu-ta ri non-standard "at Ur/in my city"(?): D (Ur, C) $30^{\prime *}$ (obscure)

obscure: Cadaster: A i 30; ii 1

GN: Cadaster A iii 8; 9

"mighty": A 232

$\rightarrow$ geš ga-rig 2

$\rightarrow \operatorname{sag}(-e)-e_{(2)} \operatorname{rig}_{7}$

$\rightarrow$ a ru

A 68 (Susa, obscure, broken); $\rightarrow$ NE.RU-du, NE. RU.m; $\rightarrow$ var. tab uncertain meaning: C 9*

non-standard "head": B 69; $\rightarrow$ sag

"s a g i da" (rubric): B 39

"s a g a r a" (rubric): B 72

non-standard "sand (dunes)": $\rightarrow$ si-im sa-ḩa-ar-e(-)ed-b(u)

uncertain meaning: G 22 || 23* (broken)

"to attain, to be zealous": A $162 ; \rightarrow$ si sa $a_{2} ; \rightarrow$ si si-DI $\left(\mathrm{sa}_{2} / \mathrm{de}\right) ; \rightarrow$ šu-a sa 2

non-standard "to arrive, to reach": A 51* (Susa); $\rightarrow \mathrm{sa}_{2}$ $\mathrm{du}_{11} \cdot \mathrm{g}$

"to arrive, to reach, to subdue (said of evil)": A 51; $146 \| 147 ; \rightarrow$ nig $_{2}$-NE.RU sa du $_{11} . \mathrm{g} ; \rightarrow$ nig $_{2}-\mathrm{si}_{-} \mathrm{sa}_{2} \mathrm{sa}_{2}$ $\mathrm{du}_{11} . \mathrm{g} ; \rightarrow \mathrm{u}_{4} \mathrm{sa}_{2} \mathrm{du}_{11}-\mathrm{ga} ; \rightarrow$ non-standard $\mathrm{sa}_{2} \mathrm{du} ; \rightarrow$ nonstandard si $\mathrm{du}_{11} \cdot \mathrm{g}$

"to establish as regular offerings": CU 29-30

"(to be) pleasant, good, fine, benevolent, favourable, propitious, beneficial, to do well": A 173 (broken, obscure); C 63; G 15; $\rightarrow$ giškim $\mathrm{sa}_{6} . \mathrm{g}$; $\rightarrow$ dhuš-bi-sa 6 .g; $\rightarrow$ ki sa $6 . \mathrm{g} ; \rightarrow \mathrm{ki} \mathrm{ur}_{5} \mathrm{sa}_{6} . \mathrm{g} ; \rightarrow$ dlamma sa $6 . \mathrm{g} ; \rightarrow$ nam tarra $s a_{6} . g ; \rightarrow u_{2} s a_{6} . g ; \rightarrow{ }^{d}$ udug $s_{6} . g$

"(to be) azure, green, verdant, magnificent, flourishing, comely, beautiful": A 106 (Susa); $\rightarrow$ an $\left(-\right.$ gin $\left._{7}\right)$ sa $_{7} . \mathrm{g} ; \rightarrow$ 
$s a_{12}-t i-u m-\mathrm{ma}$

$\mathrm{sag}_{3}$

saga $_{11}$

saĝ

\section{saĝ $\mathrm{gi}_{6} \cdot \mathrm{g}$ saĝ AK \\ saĝ(-e)-eš $(2)$ rig \\ $\operatorname{sag}(-) \mathrm{gu}_{2}(-) \mathrm{gal}_{2}$ \\ saĝ-ga $a_{2}$ ge.n \\ saĝ-ĝa gal $_{2}$ \\ geš sâิ-ĝu \\ saĝ(-ĝa $a_{2}$ ha-za}

sag $\mathrm{il}_{2}$

saĝ-kal

saĝ an-še ${ }_{3} \mathrm{il}_{2}$

saĝ-ki

saĝ-ki $\operatorname{gid}_{2}$

saĝ-ki huš den-lil ${ }_{2}-\mathrm{la}_{2}$ saĝ-ki zalag bar

saĝ(-)ku $3(-) \mathrm{gal}_{2}$

gešs saĝ-kul

saĝ saḩar-re-eš dub

saĝ sahar-eš tu.b

saĝ-ur-saĝ

saĝ us, saĝ-us uri $_{2}{ }^{\mathrm{ki}}$-ma

sag zi.g

SAĜ?.ME

tug $_{2}$ saĝšu en $\mathrm{sa}_{7} . \mathrm{g} ; \rightarrow$ gud $\mathrm{sa}_{7} . \mathrm{g} ; \rightarrow$ hur-sag $\mathrm{sa}_{7} . \mathrm{g} ; \rightarrow$ ul sa. $\mathrm{g} ; \rightarrow$ var. $\mathrm{si}_{3} . \mathrm{g} ? \mathrm{~B} ; \rightarrow$ var. sig? B

$\rightarrow \mathrm{a}_{2}$ tumu-sa $a_{12}$-ti-um-ma

"to demolish", "to strike, to fell" (said of a tree), "to (make) shake" (said of bodies, the earth): A 2; 46* (Susa); C 32; $\rightarrow \mathrm{e}_{2}-\mathrm{sag}_{3}$-ga; $\rightarrow$ ki sag $; \rightarrow$ var. su $_{3} . \mathrm{g}$

$\rightarrow$ giri $_{3}-$ saga $_{11}$ du $_{11}$.g

"head": A 121; D (Ur) 25'* (obscure); F 51 (obscure);

$\rightarrow$ dumu saĝ den-lil -la $_{2} ; \rightarrow$ hur-sag $; \rightarrow$ sahar $\mathrm{PU}_{2}$-saĝ-

$\mathrm{ga}_{2}(-\mathrm{k}) ; \rightarrow$ ur-sag $; \rightarrow \mathrm{uz}_{3}$-sag $; \rightarrow$ non-standard sa-g(i)

"Black-Headed": A 3; B 38; $\rightarrow$ ug $\hat{\text { }}_{3}$ sag gi $_{6} \cdot \mathrm{g}$

"to fully satisfy (+ loc.-term.)": A 150*; $\rightarrow$ var. šu dul ${ }_{3}$ ra

"to present with": B 69 (broken); C 23; D (Ni) 21 (broken); G 8; 47, 1:7

non-standard "proud one, noble one": A 42* (Susa); $\rightarrow$ saĝ(-) $\mathrm{ku}_{3}(-) \mathrm{gal}_{2}$

"to firmly rest on the head": A 178

"to place on the head": D (Ur) 16'

non-standard "bolt": A 68* (Susa); $\rightarrow$ ĝeš saĝ-kul

"to take care of somebody, to be at the disposal of": A $177 *$

"to raise the head, to lift the head": B $11 ; 68 ; \mathbf{D}(\mathrm{Ni}) 9$

II D (Ur) $10^{\prime}$

"to lift the head heavenward": B 10

"foremost" (ep. Inana): A 196; 237 (G); $\rightarrow$ var. ki-sikil

"frown, forehead": $\rightarrow$ ki(-)sa $\hat{g}-k i$ kalam-ma

"to look at somebody/something angrily, to frown": A

$13 ;$ C $39 ; 47,4: 3-4$

"Enlil's fierce forehead": A 200

"to turn the shining forehead toward somebody, to smile radiantly upon somebody": D (Ni) 13

"proud one, noble one": A 42*; $\rightarrow$ non-standard saĝ(-) $\mathrm{gu}_{2}(-) \mathrm{gal}_{2}$

"bolt": A 68; $\rightarrow$ non-standard ĝeš saĝ-ĝu ${ }_{10}$

"to pile up heads as sand dunes": B 52 ॥ 53; non-standard $\rightarrow$ si-im sa-ha-ar-e(-)ed-b(u)

non-standard "to pile up heads as sand dunes": B 52 || 53

(D)

"s a $\hat{g}$ u r s a ĝ": C $84^{*}$

"to provide, to support, to observe": A 210*

"supporter of Ur" (ep. Urnamma): D (Ni) 38

"to raise the head": A 208*

obscure: A 38 (broken)

"head-dress": A 123 
sahar

sahar $\mathrm{PU}_{2}$-saĝ-ĝa $a_{2}(-\mathrm{k})$

sahar-ra tuš

sahar ses

sar A

sar B

SAR

ses A

ses dbil $_{3}$-ga-mes

ses $\mathrm{ki}-\mathrm{ag}_{2}$

ses B

SES

SES.KI

si A

si B

si.g

si $\mathrm{du}_{11} \cdot \mathrm{g}$

si-ĝar kala.g

si-ig

si-im sa-ḩa-ar-e(-)ed-b(u)

si-pa ur-dna-na-ma(-k)

si $\mathrm{sa}_{2}$

si si-DI $\left(\mathrm{sa}_{2} / \mathrm{de}\right)$

si-un ${ }_{3}$-na

SI

SI.A

$\mathrm{si}_{2} \cdot \mathrm{g}$

$\mathrm{si}_{3} \cdot \mathrm{g} \mathrm{A}$ "sand (dunes), dust": $\rightarrow \mathrm{i}_{7}$-saharar; $\rightarrow$ saĝ saḩar-re-eš dub; $\rightarrow$ IS

"dust of a pit": A 190*

"to be set in the dust, to squat in the dust": $\mathbf{4 7 , 4 : 6}$ (broken)

"bitter dust, alkali": A 69

"to drive away": A 233

$\rightarrow$ dub-sar; $\rightarrow$ mu sar-ra (+ loc.) $\mathrm{su} \mathrm{ur}_{3} / \mathrm{uru}_{12}$

obscure: A 99; C $15 ; \mathbf{H}^{3} 3 ; \rightarrow \mathrm{e}_{2}$-dnin-SAR-ka; $\rightarrow \mathrm{i}_{3}$

$\mathrm{SAR} ; \rightarrow$ geš isimu $_{3}$ SAR; $\rightarrow$ ki(-)SAR; $\rightarrow \mathrm{mu}_{2}$

"brother, sweetheart": A 50*; CU 173

"brothers of Gilgameš": C 112

"beloved brother" (ep. Gilgameš): A 143

"bitter, bloody": A 83; $\rightarrow$ sahar ses; $\rightarrow$ munn $_{4}(-$ na $)$

obscure: A 171

$\rightarrow$ amar banda ${ }_{3}$ da SES.KI

"to fill something (+ loc.-term.) with something (+ abs.), to occupy, to be choked up, to fill up on": A 54; $154^{*} ; 186 ; \mathbf{B} 9 * ; \mathbf{C} 13 ; \mathbf{D}(\mathrm{Ni}) 27 \| 28 ; \rightarrow$ var. $\operatorname{sud}_{(4)}$.r , $\mathrm{su}_{3}$-ud

"horn": $\rightarrow$ dag-si AK

"to be(come) weary, to become silent, calm": A 22 ; $\rightarrow$ kar si.g

non-standard "to reach": A 146* || 147 (Susa); $\rightarrow \mathrm{sa}_{2}$ $\mathrm{du}_{11} \cdot \mathrm{g}$

"strong bolt": $\mathbf{F} 31$

"to tear out": A 181

non-standard "to pile up heads as sand dunes": B 52 || 53;

$\rightarrow$ saĝ sahar-re-eš dub

non-standard "shepherd Urnamma": B 53; 56; 60; 64; 68;

$\rightarrow$ sipa dur-dnamma(-k)

"to put in order, to administer, to provide for, to perform properly, to set aright, to make fall right into something (+ loc.-term), to be properly arranged, to prepare": A 132 || 133; 196 (Susa, broken); B 13; 14; C $21 ; 37 ; 71 ;$ G 18; 26 (broken); $\rightarrow$ urudaba-an si-sa lugal-la $\operatorname{dim}_{2} ; \rightarrow$ di si-sa ${ }_{2} \mathrm{ku}_{5}\left(-\mathrm{ku}_{5} . \mathrm{r}\right) ; \rightarrow$ giri $\mathrm{si} \mathrm{sa}_{2} ; \rightarrow$ nig $\hat{g}_{2}-\mathrm{si}^{-} \mathrm{sa}_{2}$

"to guide": D (Ni) 16 (broken) II (Ur) 17'*

"zenith": A 13

obscure: C 102 (broken)

obscure: A 32

$\rightarrow \mathrm{ku}_{3}-\mathrm{sig}_{17}, \mathrm{ku}_{3}-\mathrm{si}_{2}(\mathrm{ZI}) \cdot \mathrm{g}$

"to collapse, to throw": A $2 ; \rightarrow \mathrm{gu}_{3}$ teš $_{2}-\mathrm{a} \mathrm{si}_{3} . \mathrm{g} ; \rightarrow$ ŠUM ${ }_{2}$ 
$\mathrm{si}_{3} \cdot \mathrm{g}$ ? B

$\operatorname{sig} \mathrm{A}$

sig-ta igi nim-še sig?("EREN 2 ") B

$\mathrm{SIG}_{2}$.SUD

$\mathrm{sig}_{4}$

$\operatorname{sig}_{7}$

$\operatorname{sig}_{9}$

$\operatorname{sig}_{17}$

siki

sikil

sila A

sila B

sila daĝal sila $_{3}$

sila $_{3}$ ge.n

sila $_{3}$ zabar $\operatorname{dim}_{2}$ sila $_{x}$ (UBARA)

silim

sipa.d

sipa $\mathrm{ku}_{3}-\mathrm{zu}$

sipa ur-dnamma(-k)

sipa dur-dnamma(-k)

sipa zi.d

$\operatorname{sir}_{2} \cdot d / . r$

sipa zi ur-dnamma

$\begin{array}{lll}\operatorname{sizkur}_{2} & \text { nig } & \mathrm{du}_{10} \cdot \mathrm{g}\end{array}$

su A

su B

su C

su-a

su-ub "to provide with, to form as": A 106; $\rightarrow$ sig?("EREN 2 ") $\mathrm{B} ; \rightarrow$ var. $\mathrm{sa}_{7} . \mathrm{g}$

"(situated?) below, to be narrow": A 99 (Susa); Cadaster B i 19

"from below to above": A 223 (broken); year name "4" obscure: A $106 ; \rightarrow$ si $_{3} . g^{\text {? }} \mathrm{B}$; $\rightarrow$ var. sa. $\mathrm{g}$

$\rightarrow \operatorname{tug}_{2} \mathrm{z} / \mathrm{sulu}(\mathrm{m}) \mathrm{hu} / \mathrm{i}\left(\mathrm{SIG}_{2} . \mathrm{SUD}\right)$

$\rightarrow \check{s ̌ e g}_{12}$

$\rightarrow \mathrm{sa}_{7 .} \mathrm{g}$

"to drive in, to inlay": $\rightarrow$ temen $\mathrm{ku}_{3}$ sig $_{9}$; $\rightarrow$ ul-la sig

$\rightarrow \mathrm{ku}_{3}-\mathrm{sig}_{17}, \mathrm{ku}_{3}-\mathrm{si}_{2}(\mathrm{ZI}) . \mathrm{g}$

$\rightarrow$ nu-siki

"pure": $\rightarrow$ ĝeš bansur sikil; $\rightarrow$ ki(-)sikil

non-standard "joy": D (Ur) 40'; $\rightarrow$ sila $_{\mathbf{x}}$ (UBARA)

"street, square": $\rightarrow$ TAR

"broad square": A 19

"s i 1 a" (measuring unit): CU 28

"to standardize as a s i 1 a": CU 137; 139; 142 (broken)

"to fashion a bronze s i 1 a": CU 143-144

"joy": D (Ni) 40; $\rightarrow$ non-standard sila A

1. "to be vigorous, to make healthy, to restore": $\rightarrow$ eren $_{2}$ silim-ma; $\rightarrow$ nam-ga-eš $\check{~}_{8}$ silim

2. "salvation": $\rightarrow \mathrm{KA}_{2}$-silim-ma

"shepherd": A 117; 150; 213; B 6; C 78; F 50; $\rightarrow$ gešm ma-nu nam-sipa-da; $\rightarrow$ non-standard si-pa

"wise shepherd": A 31

"shepherd Urnamma": A 91; 96; 101 || 105 || 109 || 113 ||119 || 122a (Susa, broken) || 128 || 131a (Susa, broken); 234; B 68 (D); C 107; 115 (broken)

"shepherd Urnamma:" B $10 ; 14 ; 20 ; 36 ; 37 ; 53 ; 56$; $60 ; 64 ; 68$; F 45 (broken); 51 ; $\rightarrow$ non-standard si-pa urdna-na-ma(-k)

"faithful shepherd" (ep. Urnamma): A 6; 18; 21; 39; $84 ; 155 ; 202 ;$ C 76

"faithful shepherd Urnamma": A 7; B 4; 12

"to accumulate": $\rightarrow$ IM.UD $\operatorname{sir}_{2}$-da

"pleasing sacrifices": A 52

"to be(come) inundated, to sink": A 23 (A); $65 \rightarrow$ nonstandard $\mathrm{su}_{13}(\mathrm{BU})$

non-standard "to grow tall": $\rightarrow$ geš tir-gin 7 su; $\rightarrow \operatorname{sud}_{(4)} \cdot$, , $\mathrm{Su}_{3}$-ud

"body": C 32; $\rightarrow$ ni $_{2}$ su-e us ${ }_{2}$

"family": CU 174

"to sweep away": B 59 \| 61; $\rightarrow$ non-standard du B 


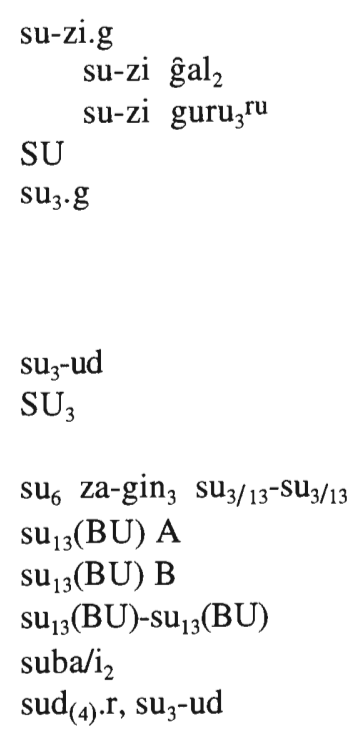

sud-ra $-\mathrm{ag}_{2}$

SUD

dsu'en(EN.ZU)

$\mathrm{d}_{\text {su'en-ra tum }}$

sug

suh

$\operatorname{sub}_{3}$

$\operatorname{suh}_{10}$

$\operatorname{suh}_{10} \mathrm{kar}_{2}-\mathrm{kar}_{2}-\mathrm{ka}$

suhurku

suhuš ge.n

sukud

sul

sul d su'en

sul ur-sag dnin-ĝeš-zi-da "youthful hero Ninĝešzida": A 118

sul zi.d

dsul-gi.r $\operatorname{sud}_{(4)} \cdot$ r, $\operatorname{su}_{3}$-ud "dread, awe":

"to be imbued with dread": B 27

"to be full of awe": E 9"

obscure: A 69

1."(to be) empty, desolate, to strip, to cut clear": A 8; $46 * ; 73 ; \rightarrow$ edin bar $\mathrm{su}_{3}-\mathrm{ga}(-\mathrm{k}) ; \rightarrow$ var. $\mathrm{sag}_{3} ; \rightarrow$ var

2. "to be full": $\rightarrow \mathrm{SU}_{3}$

$\rightarrow \operatorname{sud}_{(4)} \cdot r, \mathrm{su}_{3}$-ud

"to be full": $\mathbf{D}(\mathrm{Ni}) 35^{*} \| 36 ; \rightarrow \operatorname{sud}_{(4)} \cdot \mathrm{r}, \mathrm{su}_{3}$-ud; $\rightarrow$ $\mathrm{su}_{3} . \mathrm{g} ; \rightarrow \mathrm{gi}-\mathrm{SU}_{3}$

"to wear a long lapis lazuli beard": E 24'; F 5; 45

non-standard "to be(come) inundated": A 23 (B); $\rightarrow$ su A

$\rightarrow \operatorname{sud}_{(4)} \cdot \mathrm{r}, \mathrm{su}_{3}$-ud

$\rightarrow \mathrm{su}_{6} \mathrm{Za}-\mathrm{gin}_{3} \mathrm{su}_{3 / 13}-\mathrm{su}_{3 / 13}$

uncertain meaning: C 53*; 78

"(to be) long, far, to lengthen, to withdraw, to remove": A 27*; 54 (Susa); 73 (Susa); E 15'; H 2 ॥ 10;

$\rightarrow$ an-gin $7 \mathrm{su}_{3}$-ud; $\rightarrow \mathrm{su}_{6} \mathrm{Za} \mathrm{gin}_{3} \mathrm{su}_{3 / 13}-\mathrm{su}_{3 / 13} ; \rightarrow \mathrm{sa}_{3} \mathrm{su}_{3-}$ $\mathrm{ra} ; \rightarrow \mathrm{u}_{4}$ sud-ra $_{2}-\breve{\mathrm{se}}_{3} ; \rightarrow$ var. si $\mathrm{A} ; \rightarrow$ var. $\mathrm{su}_{3} . \mathrm{g} ; \rightarrow \mathrm{SU}_{3} ; \rightarrow$ non-standard $\mathrm{su}_{13}(\mathrm{BU})-\mathrm{su}_{13}(\mathrm{BU})$

"electrum ": B 23

$\rightarrow$ tug $_{2}$ zulu(m)hu/i(SIG $\left.2 . S U D\right) ; \rightarrow$ udu zulu(m)hu/i $\mathrm{i}_{\mathrm{x}}$ (TUG ${ }_{2} \cdot$ SUD)

DN Su'en: C 44; F 24; $\rightarrow$ a-ša ${ }_{3}$ d ${ }^{\text {d }}$ 'en; $\rightarrow$ dumu gal

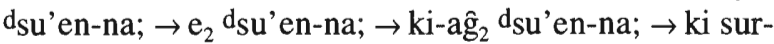
ra dsu'en(-k); $\rightarrow$ para $_{10^{-}}$d $_{\text {su'en; }} \rightarrow$ sul d su'en

"to be worthy of Su'en" (ep. Urnamma): F 31

"marsh(es)": 27, 1:9; 10

"to choose": D (Ni) 11; $\rightarrow$ var. suh $_{10}$

"to become troubled, confused, twisted" (said of roads):

A 46 (Susa); 74 II 75; $\rightarrow$ var. kur $_{2}$

"to choose": D (Ur) 12'; $\rightarrow$ var. suh

"radiant crown": B $42 * \| 48$

"s u h u r-fish": D (Ni) 27* || 28

"to make the foundation (of the throne) firm": D (Ni)

15 || D (Ur) 15'; $\rightarrow$ ur $_{2}$ ge.n

"eminent": $\rightarrow$ en sukud

"youth(ful)": D (Ni) 10 ॥ (Ur) 11'

"youthful Su'en": D (Ni) 8

"faithful young man, faithful youth" (ep. Urnamma): B 34; 43 ॥ 49; D (Ni) 6; $\rightarrow$ var. dsul-gi.r

PN Sulgi: D (Ur) $8^{\prime *} ; \rightarrow$ var. sul zi.d 


$\operatorname{sulu}_{(\mathrm{m})} \mathrm{hgu}_{(\mathrm{i}}(\mathrm{x})$
sumun $_{2}$
sumur, sumur $_{\mathrm{x}}$
sun $_{5}$-na-bi
sur
sur $_{2}$, sur $_{14}$
ša-aš
ša-ša $_{\text {ša }} \cdot \mathrm{g}$

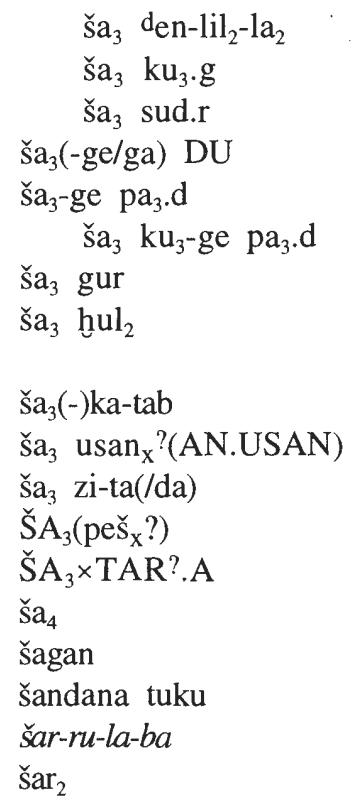

dšara

še A

še B
še daĝal
še $\mathrm{du}_{\mathrm{i} 0} \cdot \mathrm{g}$
še gu-nu
še $\mathrm{ku}_{5} \cdot \mathrm{d}$
še $l a_{2}$

$\rightarrow{ }^{\operatorname{tug}_{2} \mathrm{z} / \mathrm{sulu}(\mathrm{m}) \mathrm{hu} / \mathrm{i}_{(\mathrm{x})}}$

a wild bovine race: $\rightarrow \mathrm{d}_{\text {nin-sumun }}(-\mathrm{na}-\mathrm{k})$

"furious, gusty" (said of winds): $\rightarrow \mathrm{e}_{2}$-sumur-ra; $\rightarrow$ tumu $\operatorname{sumur}_{(\mathrm{x})}$

"humbly": A 199

"to mark off, to demarcate": $\rightarrow i_{7}$ ki sur-ra(-k); $\rightarrow$ ki surra

$\rightarrow$ sumur, sumur $\mathrm{x}$

non-standard "to deliver, to bring, to make": B $68 ; \rightarrow$ $\mathrm{AK} ; \rightarrow \mathrm{DU} ; \rightarrow$ non-standard pe-e ša-aš

(var.) non-standard "to rage": B $52 \| 53 ; \rightarrow \mathrm{AK}$

"heart, inside, stomach, womb, depth, midst, interior, centre": A 84; 84a (Susa); 154; 160; 222 (A, broken, obscure); B 30; C $6 ; 21 ; 37 ; 48 ; \mathbf{F} 8 ;$ E 3 ' II F 9; E $13^{\prime *} ; 14^{\prime} ; \mathbf{C U}$ 155-156; $\rightarrow \mathrm{a}_{(2)} \check{s}_{3}-\mathrm{gu}_{10} \mathrm{du}_{11} . \mathrm{g} ; \rightarrow \mathrm{ab}-$

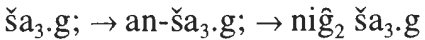

"heart of Enlil": D (Ni) 37

"pure womb": $\rightarrow$ a ša ${ }_{3} \mathrm{ku}_{3}$-ge ri

"impenetrable heart/inside": C 92 (obscure)

"to be moved": B 9*

"to choose in the heart": F 24;29; $\rightarrow{ }^{\text {dnin-ša }}$-ge-pa ${ }_{3}$-da

"to choose in the precious heart": E 26' (broken)

"to be merciful": F 10

"to be joyful, to delight": A 149 (Susa); $\rightarrow$ ki-tuš ša hul $_{2}$-la; $\rightarrow$ var. hul 2

"listless": A 12

"midst of the evening": $\mathbf{A}$ 8*

"from the true womb on": D (Ni) $9 \| \mathbf{D}$ (Ur) 10'

"to raise?": $\rightarrow \mathrm{du}_{10}$-ba ŠA ${ }_{3}$ (peš ${ }_{\mathrm{x}}$ ?)

$\rightarrow \mathrm{LU}_{2} . \mathrm{S}_{3} \times \mathrm{TAR}$ ?.A(-k)

$\rightarrow \mathrm{DU}$

$\rightarrow$ bur-šagan šu du $\mathrm{du}_{7}$-a

"to obtain gardeners": CU 161

GN: Cadaster A iii 18; 19

"to multiply, to be(come) innumerable": C 78; $\rightarrow$ gud gaz - udu šar ${ }_{2} ; \rightarrow$ ug $_{3}$ šar $_{2}\left(-\right.$ šar $\left._{2}\right)$

DN Šara: 32:1; 34:1 (broken, uncertain)

non-standard in $\rightarrow$ mu še "to name": $\rightarrow$ mu še ${ }_{21}$

"barley, grain": CU 26

"vast barley (fields)": A 228

"good barley, to make the barley good": G 10;11; 12

"mottled barley": A 23; C 23*; D (Ur) 37'; G 8

"to hold off grain": $\rightarrow \mathrm{KA}_{2}(-)$ še-nu-ku $\mathrm{ku}_{5} . \mathrm{d}$

"to load grain": C 88 
-še

še-er-ka-an du ${ }_{11} \cdot g$

še-er-us 2 -sa

še-ga den-lil ${ }_{2}-\mathrm{la}_{2}$

še-ri-im-tum

$-\check{\mathrm{S}} \mathrm{e}_{3}$

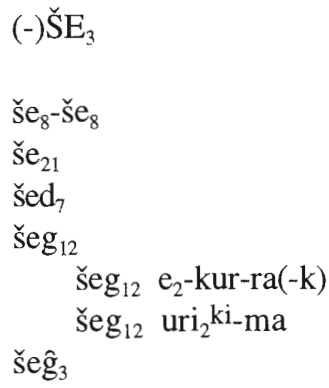

$\breve{s} \hat{g}_{7}$

šem

šen

šen-šen

šer $_{7}$-da

ši-ši

ši-ma-at

šibir $\left(\mathrm{EN} \times \mathrm{GANA}_{2}-\mathrm{t}\right.$.)

šibir $_{2}$

geš šinig?

šir $_{3}$-nam-šub-dnanna(-k)

šu A

šu B

šu dugud

šu nam? tar?-ra

šu za-gin ${ }_{3}$

šu za-gin ${ }_{3}$-na tum $_{2}$ šu-a $\mathrm{ge}_{4}\left(-\mathrm{ge}_{4}\right)$

šu-a $\mathrm{sa}_{2}$

šu ba.r $\rightarrow \mathrm{a}_{2}$-še

"to decorate something (+ loc.)": B 23

$\rightarrow \mathrm{i}_{7}$-še-er-us ${ }_{2}$-sa

"favourite of Enlil" (ep. Urnamma): D (Ur) 38'*

GN: Cadaster B iii 24; 25

$\rightarrow$ an-še ${ }_{3} ; \rightarrow$ igi (+ poss. suff.)-še $e_{3} ; \rightarrow$ ki-bi-še $e_{3} ; \rightarrow$ ki$\check{s ̌}_{3} ; \rightarrow \mathrm{me}_{3}-\check{\mathrm{se}}_{3}$ DU; $\rightarrow$ mu $\ldots$-a-še ${ }_{3} ; \rightarrow$ nam-til ${ }_{3}$-la-ni-še $e_{3}$ a ru; $\rightarrow$ nam-til ${ }_{3}$ ur-dnamma(...)-še ${ }_{3}$ a ru; $\rightarrow \mathrm{sa}_{2}-\mathrm{du}_{11}-\mathrm{še}_{3}$ gar; $\rightarrow$ sig-ta igi-nim-še ${ }_{3}$; $\rightarrow$ šu-(+ poss. pron. $)-\check{s ̌}_{3}$ šum $_{2} ; \rightarrow \mathrm{u}_{4}$ sud-ra $\mathrm{ra}_{2}-\check{\mathrm{se}}_{3} ; \rightarrow \mathrm{u}_{6}$ di-še $\mathrm{e}_{3}$ gub

A 66 (obscure, read perhaps $\rightarrow$ S U); $\rightarrow$ digirir- $\check{S}_{3} \mathrm{du}_{2}$.d; $\rightarrow$ in-ŠE dub $_{2} ; \rightarrow$ iti $_{6}-\breve{S L E}_{3} ; \rightarrow$ za-pa-ag $\hat{g}_{2}-\mathrm{SLE}_{3}$ gar

$\rightarrow \mathrm{ir}_{2}$ gig še $\mathrm{e}_{8}-\check{\mathrm{s}} \mathrm{e}_{8} / \check{\mathrm{s} i} \mathrm{i}-\mathrm{s} \mathrm{i}$

$\rightarrow$ mu še $21 ; \rightarrow$ non-standard še A

"to relieve, to appease": A 160

"brick(work)":

"Ekur's brickwork": B 7

"the brickwork of Ur": A 165

"to rain, to precipitate": A 59* (Susa); $\rightarrow$ im an-ta šeg ${ }_{3}$;

$\rightarrow$ var. gen

$\rightarrow \mathrm{im}$

"resin, perfume, fragrance": $\rightarrow$ kur šem ĝešeren-na; $\rightarrow \mathrm{u}_{2}-$ šem-gin $7 \mathrm{mu}_{2}$

$\rightarrow$ dub-šen

"combat": $\rightarrow \mathrm{me}_{3}$ šen-šen

"offense": C $32 *$

$\rightarrow \mathrm{ir}_{2}$ gig še $\mathrm{e}_{8}-\mathrm{s̆}_{8} / \check{\mathrm{s} i} \mathrm{i}-\mathrm{s} \mathrm{i}$

$\rightarrow \mathrm{i}_{7}-\breve{s i}-m a-a t-[\ldots] ; \rightarrow \mathrm{i}_{7}$-ši-ma-at-d $\mathrm{der}_{3}$-ra

"staff": A 103a (Susa); D (Ni) 17; $\rightarrow$ var. šibir 2

"staff": D (Ur) 18' (broken); $\rightarrow$ var. šibir

"tamarisks?": C 100

"š i r n a m š u b of Nanna" (subscript): F 52

non-standard "to give": B 54 \|| 56; $\rightarrow$ šum 2

"hand, handle": CU 18 (obscure); 124 (obscure); $\rightarrow$ gešniğ ${ }_{2}$-šu.k

"heavy hand": A 183

"hand of fate?": A 169 (broken, obscure)

"lapis lazuli handle" (of a treasure chest): A 110

"to be worthy of a shining hand": A 103 (Susa)

"to return to somebody/something's control, to keep secure": C 72*; 86; 26, 2:4; 47, 2:4; $\rightarrow$ šu ge $_{4}$ "to take possession": D (Ni) 16 (broken) || (Ur) 17'

"to release": $\rightarrow$ a šu ba.r 
šu $\mathrm{dab}_{5}$

šu $\mathrm{du}_{7}$

šu-du ${ }_{11}$-ga

šu $\mathrm{dul}_{3} \mathrm{ra}$

šu $\mathrm{ge}_{4}$

šu $\operatorname{gid}_{2}$

šu gar

šu $\operatorname{gig} \operatorname{gid}_{2}$

šu lul bala

šu $\mathrm{ni}_{10}-\mathrm{ni}_{10}$

"to seize with the hands": A 36; 60 (Susa); $\rightarrow$ var. šu $\operatorname{gid}_{2}$

"to equip, to make perfect, to put in full force": Ni. 4375 v $3^{\prime} ; \rightarrow a_{2}$ šu du ${ }_{7} ; \rightarrow$ bur-šagan šu du $u_{7}-\mathrm{a} ; \rightarrow g \mathrm{gi}_{16}$-sa šu $\mathrm{du}_{7}-\mathrm{a}$

"creature" (ep. Urnamma): C 111

"to put a protecting hand over somebody/something ( + loc.-term.)": A 150* (Susa); $\rightarrow$ var. sag AK

"to return, to turn back, to repay" $\rightarrow$ enim šu ge $e_{4} \rightarrow$ šu-a $\mathrm{ge}_{4}\left(-\mathrm{ge}_{4}\right)$

"to stretch out hands, to reach out": A 53 (Susa); 60*; C $36 ; \rightarrow$ var. šu dab $;$; $\rightarrow$ var. $\mathrm{KA}(\mathrm{enim}) \mathrm{ge}_{4}$

"to stretch out afflicted hands": A 52*

"to place the hand": $\rightarrow$ gaba-šu-ĝar nu-tuku

"to alter deceitfully": A 9

"to hurry along, to return quickly to (+ term.)": A 74 ॥ $75 ; 165$

šu-(+ poss. pron.)-šs ${ }_{3} \breve{s u m}_{2}$ "to give into the hands, to put something into somebody's control": A 141; C 61

šu $\check{s ̆}_{2}-\check{s ̆ u}_{2}$

šu-ta ri

"to clasp, to clamp down": C $36^{*}$

šu tag

uncertain meaning: A 179* ॥ 235 (broken)

1. "to seize": A 52 (Susa); $\rightarrow \mathrm{NI}_{3}$ šu tag; $\rightarrow$ var. tag

2. "to decorate with (+ abs.)": A 111

šu ti/te $(h)$, ti/te.ĝ $(m$.

šu-tum

šu urin-na $\mathrm{du}_{8}$

šu $\mathrm{ur}_{3} / \mathrm{uru}_{12}$

šu zi ĝal

ŠU

$\check{s ̆}_{2}$

$\check{S ̌ u}_{4}$

"to receive, to obtain, to take": A 162

$\rightarrow \mathrm{e}_{2}$-šu-tum ki-ag $\hat{\mathrm{g}}_{2}$

"to put in bloody fetters": C 90*

"to erase": $\rightarrow$ mu sar-ra (+ loc.) šu ur ${ }_{3} /$ uru $_{12}$

"to bestow": B 70* (broken)

obscure: A 66 (read perhaps $\rightarrow \mathrm{S}_{3}$ ); $\rightarrow \mathrm{NIG}_{2} . \breve{S} U(.) \mathrm{PI}$

"to cover, to give way": A 74 ॥ 75*; 135 (obscure); $\rightarrow$ an-ki šu ${ }_{2} ; \rightarrow \mathrm{gu}_{2}$-da šu ${ }_{2} ; \rightarrow \mathrm{gaa}_{2}$-ĝeš-šu ${ }_{2}$-a; $\rightarrow$ šu šu ${ }_{2}$-šu ${ }_{2}$; $\rightarrow$ var. šub

$\rightarrow \mathrm{za}_{3} \mathrm{su}_{4}$

"to fall, to fall into ( + loc.), to tear down" (said of a wall), "to be felled": A 45; 74 || 75 (Susa); 139 (Susa); 170; 184; 192 (Susa); C 92; $\rightarrow$ i $_{7}$-ĝeš-šub-ba; $\rightarrow$ ki šubba ĝar; $\rightarrow$ nam-ĝeš-šub galam; $\rightarrow$ nam-šub; $\rightarrow$ šir $_{3}$-namšub-dnanna(-k); $\rightarrow$ geš $\mathrm{u}_{3}$-šub-ba; $\rightarrow$ var. nu ${ }_{2} ; \rightarrow$ var. šu $\mathrm{u}_{2}$; $\rightarrow$ var. ug $_{5}$

gešsudul "yoke": $\rightarrow$ DIŠ gud ĝěšudul $4^{-a}$

geššudul ${ }_{4}$ zi.g "to lift the yoke": C 84

šum

$\rightarrow \mathrm{pa}_{5}$-urdu-šum-ma

"to give": A 122*; 131 (broken); B 54 ॥ 56; C 72; $\rightarrow$

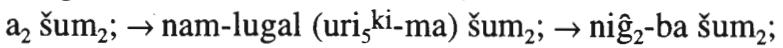


ŠUM,

- ta

tab

$\mathrm{TAB}$

tag

TAG

taka $_{4}$

$\mathrm{TAKA}_{4}$

tam

tar

TAR

ĝeštaškarin

te $(h)$, te. $\hat{\mathrm{g}}(m$.

te-en-te

te-li

temen

temen $\mathrm{ku}_{3} \mathrm{sig}_{9}$ tešs $2(-a)$

teš ${ }_{2}$ kalam-ma

teš $\check{S}_{2} \mathrm{mu} \mathrm{i-i}$

(t)i

ti

ti (h.), ti.g $(m$.

TI

tigi $_{2}$ til

$\mathrm{til}_{3}$ $\rightarrow$ šu-še ${ }_{3}$ šum $_{2} ; \rightarrow$ non-standard šu $\mathrm{A} ; \rightarrow$ var. $\mathrm{ku}_{4} \cdot \mathrm{r} ; \rightarrow$ ŠUM

"to impose": $\mathbf{F} 35^{*} ; \rightarrow \mathrm{si}_{3} \cdot \mathrm{g} \mathrm{A} ; \rightarrow$ s̆um $_{2}$

$\rightarrow$ a-ta DU; $\rightarrow$ a-ta $e_{3} / e_{11}$.d; $\rightarrow a_{2}$-person-ta; $\rightarrow$ abzu-ta

$\mathrm{mu}_{2} ; \rightarrow$ an-ta; $\rightarrow$ an-ur -ta $_{3}$; $\rightarrow$ bar-ta gub; $\rightarrow$ ki-bi-ta;

$\rightarrow \mathrm{ku}_{3}$-sig ${ }_{17}$-ta gunu $_{3} ; \rightarrow$ dmes-lam-ta-e ${ }_{3}$-a, $\rightarrow$ sig-ta igi nim-še $e_{3} ; \rightarrow \mathrm{sa}_{3}$ zi-ta(/da); $\rightarrow$ šu-ta ri

"to devastate, to double, to block": A 68 (obsure); $\rightarrow$ amaš tab; $\rightarrow$ iri-maš-tab; $\rightarrow$ kiri $_{8}$-tabki; $\rightarrow$ ša $_{3}(-)$ ka-tab; $\rightarrow$ var. RU

obscure: A 32

"to touch, to seize, to stretch out": A 52; $\rightarrow$ dagal tag;

$\rightarrow$ geš tag; $\rightarrow$ ki tag; $\rightarrow$ nam-EN-na tag; $\rightarrow$ var. šu tag

$\rightarrow \mathrm{NIG}_{2} \cdot$ DA.TAG.GA

"to abandon": A $58 ; \rightarrow$ gal $_{2}$ taka $_{4}$

$\rightarrow \mathrm{gal}_{2}-\mathrm{TAKA}_{4} \cdot \mathrm{TAKA}_{4}$-ga

$\rightarrow$ bar tam

"to cut (off)": $\rightarrow$ nam tar; $\rightarrow$ dnam-tar

obscure: A 69 (Susa); $\rightarrow \mathrm{LU}_{2} . \mathrm{SA}_{3} \times \mathrm{TAR}$ ?.A(-k); $\rightarrow$ var. gar; $\rightarrow$ sila $\mathrm{B} ; \rightarrow \mathrm{ku}_{5}\left(-\mathrm{ku}_{5}\right)$.r/.d, kud

"boxwood tree": A 47

"to (make) approach (+ loc.(-term.)), to be brought": A 40; 41; IB 1537 rev. v' 10'; $\rightarrow$ me-te; $\rightarrow$ ni $_{2}$-te; $\rightarrow$ ni $_{2}$ te, te. $\hat{\mathrm{g}} ; \rightarrow$ šu ti/te, ti/te. $\mathrm{g} ; \rightarrow$ ti, ti.g

"to refresh": $\rightarrow$ ni $_{2}$ te-en-te

non-standard "to drift (along)": D (Ur) 32' || 33' || 34'; $\rightarrow$

diri.g

"foundation (pegs)": $\rightarrow \mathrm{e}_{2}$-temen-ni ${ }_{2}$-guru ${ }_{3}(\mathrm{ru})$

"to drive in the sparkling foundation pegs": B 17

1. "vigour, shame"; $\rightarrow$ me-teš ${ }_{2} \mathrm{~A}$

2. "together, homogeneous": $\rightarrow \mathrm{gu}_{3}$ tešs $-\mathrm{a} \mathrm{si}_{3} . \mathrm{g} ; \rightarrow$ kalam teš

"the land's vigour" (ep. Urnamma): A 45*; 72

"to reveal" vigour and name": E $8^{\prime}$ || 12' || 19' || 23'

non-standard "to come out": $\rightarrow$ ki ut-ti; $\rightarrow \mathrm{e}_{3} . \varnothing / . \mathrm{d}$

"arrow": $\rightarrow$ ĝě̌ gag(-)ti

"to approach": $\rightarrow$ te, te. $\hat{\mathrm{g}} ; \rightarrow$ šu ti/te, ti/te.g

obscure: $\mathbf{4 7}, 4: 1$

"t i g i-instrument": A $187 *$

"t i g i of Enlil" (subscript): B 72 (broken)

"to finish, to complete, to come to an end, to exhaust, to spend": A $20 ; 148 ; 168 ; 191$ (obscure); $\rightarrow$ hi-li til;

$\rightarrow$ TUR til; $\rightarrow \mathrm{u}_{4}$ til

1. "life": $\mathbf{C} 107 ; \rightarrow$ nam-til $_{3}$ 
2. "to sit, to be present at (+ loc.), to live": A 196; $\rightarrow$ bुulu til $_{3}$

(ĝeš)tir

geštir-gin 7 su (ĝeš)tir ha-šu-ur 2 (-ra)

tu.b A

tu.b B

tu.r

TU

tu-di-da "grove, riverine thickets":

"to grow tall like riverine thickets": D (Ur) 37'*

"grove of h a š u r-trees": A $46^{*}$

non-standard "to heap up": $\rightarrow$ kur tu.b

non-standard in $\rightarrow$ sag sahar-eš tu.b "to pile up heads as sand dunes": $\rightarrow$ saĝ saḩar-re-eš dub; $\rightarrow$ non-standard (-e)d$\mathrm{b}(\mathrm{u})$

$\rightarrow$ dnin-tu.r

obscure: $\mathbf{A} 174 ; \rightarrow$ dur $_{11} ; \rightarrow \mathrm{ku}_{4}, \mathrm{r}$

"toggle pin": $\rightarrow$ var. tu-di-tum; $\rightarrow$ var. du-di-da

tu-di-da $\mathrm{ku}_{3}$-sig ${ }_{17} \mathrm{ku}_{3}$-babbar "toggle pin made of gold and silver": $\mathbf{A} 121$

tu-di-tum

tu-la $a_{2}-u m$

tu-tu-ub $\mathrm{b}_{2}$ i

$\mathrm{tu}_{11} \cdot \mathrm{b}$

$\operatorname{tug}_{2}$

$\mathrm{TUG}_{2} \cdot \mathrm{SUD}$

tuh

tuku, TUKU.TUKU

geš tukul

tum $_{2} \mathrm{~A}$

$\operatorname{tum}_{2} B$

$\operatorname{tum}_{3}$

tumu-gar ${ }_{7}-\mathrm{du}_{2}$

tumu-mir-ra

tumu-sa $a_{12}$-ti-um-ma

tumu $\operatorname{sumur}_{(\mathrm{x})}$

tumu-ulu $\mathrm{u}_{3}$

tur

TUR til

$\operatorname{tur}_{3}$

$\operatorname{tur}_{3}$ amaš daĝal

$\operatorname{tur}_{3}$ gul "toggle pin": A $121^{*}$; $\rightarrow$ var. du-di-da; $\rightarrow$ var. tu-di-da

GN: Cadaster B iv 33

GN Tutub: $\rightarrow$ ma-da tu-tu-ub ${ }_{2}$ ki

"to heap up": $\rightarrow$ kur tu $\mathrm{tu}_{11} . \mathrm{b}$; $\rightarrow$ non-standard tu.b A

"cloth, garment, robe": $\rightarrow$ tug $_{2}$ dugud; $\rightarrow$ tug $_{2}$ pala $_{3}$ namnin-a; $\rightarrow$ tug $_{2}$ Sagšu; $\rightarrow$ tug $_{2}$ zulu(m)hu/i(SIG 2. SUD)

$\rightarrow$ udu z/sulu(m)hu/i $\mathrm{i}_{\mathrm{x}}\left(\mathrm{TUG}_{2}\right.$.SUD)

"to open, to loosen, to release": C 85 ; $\rightarrow$ me- $\lim _{\mathrm{x}}$ tuhtuh

"to have, to possess, to get, to obtain": A 129 (Susa); 223; C 50; 60; $\rightarrow$ ga-ri nu-tuku; $\rightarrow$ gaba-ri nu-tuku; $\rightarrow$ gaba-šu-gar nu-tuku; $\rightarrow$ guruš? gu $\mathrm{gu}_{2}$ tuku den-lil $\mathrm{l}_{2}-\mathrm{la}_{2} ; \rightarrow$ $\mathrm{ku}_{3}$ tuku; $\rightarrow \mathrm{lu}_{2} \mathrm{a}_{2}$ tuku; $\rightarrow \mathrm{lu}_{2}$ nig $_{2}$ tuku; $\rightarrow$ lugal $\mathrm{mu}$ tuku; $\rightarrow$ šandana tuku

"weapon, arms": A 139; $\rightarrow \operatorname{lu}_{2}$ ĝeš tukul-la

$\rightarrow$ DU A

"to be worthy of somebody (+ dat.), something (+ loc.(-term.))": $\rightarrow \mathrm{e}_{2}$-temen-ni ${ }_{2}$-guru ${ }_{3}$ ru tum ${ }_{2} ; \rightarrow$ nam-enna tum ${ }_{2} ; \rightarrow$ d $_{\text {su'en-ra tum }} ; \rightarrow$ šu za-gin ${ }_{3}$-na tum tum $_{2}$

"to bring, to carry": $\rightarrow$ DU A

"western": $\rightarrow \mathrm{a}_{2}$ tumu-gar ${ }_{7}-\mathrm{du}_{2}$

"northern": $\rightarrow \mathrm{a}_{2}$ tumu-mir-ra

"eastern": $\rightarrow a_{2}$ tumu-sa $a_{12}$-ti-um-ma

"gusty winds": A 182

"southern": $\rightarrow \mathrm{a}_{2}$ tumu-ulu

1. "to diminish": $\mathbf{A} 24^{*}$

2. "young, small": A 153 (Susa, obscure); $\rightarrow \operatorname{nin}_{9}$ tur

"to exhaust ....": A 191

"cattle pen": A 29; C 26

"wide cattle pens and sheepfolds": C 77

"to destroy the cattle pen": A 206 
tuš (h. sg.), dur ${ }_{2}$ (m. sg.), durun $(m ., h . \mathrm{pl}$.)

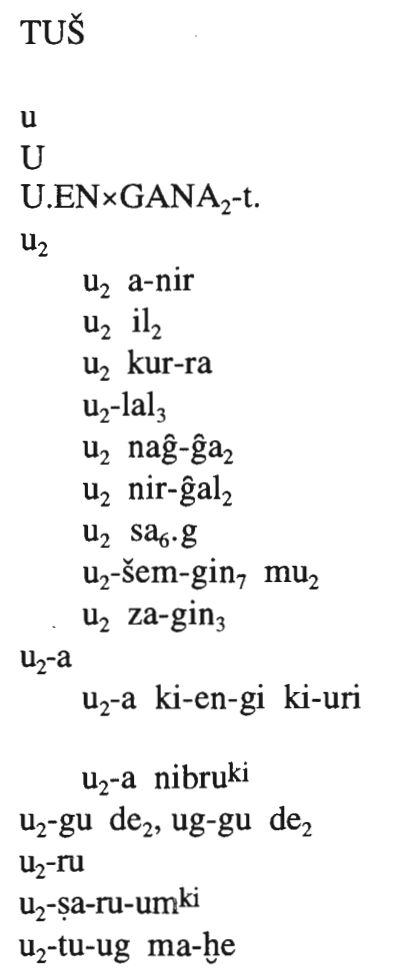

$\mathrm{u}_{3}$

$\mathrm{u}_{3}-\mathrm{du}_{2} \cdot \mathrm{d}$

$\mathrm{u}_{3} \mathrm{ku}$

$\mathrm{u}_{3} \mathrm{du}_{10} \mathrm{ku}-\mathrm{ku}$

$u_{3}$-mu-un

geš $u_{3}$-šub-ba

$\mathrm{u}_{4} \cdot \mathrm{d}$

$\mathrm{u}_{4} \mathrm{du}_{10}-\mathrm{du}_{10} \cdot \mathrm{g}$

$\mathrm{u}_{4}$ he $_{2}-\mathrm{gal}_{2}-\mathrm{la}$

$\mathrm{u}_{4}$ huš

$\mathrm{u}_{4} \mathrm{ia}_{2}$

$\mathrm{u}_{4}$ imin

$\mathrm{u}_{4} \quad \mathrm{u}$

$\mathrm{u}_{4}$-verb-a "to sit, to squat, to seat, to install, to dwell, to be

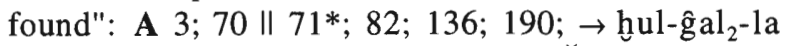
tuš?; $\rightarrow$ ki-tuš; $\rightarrow$ sahar-ra tuš; $\rightarrow$ var. TUŠ "to seat": A 69 (Susa); 136 (Susa); 190 (Susa); $\rightarrow$ var. tuš; $\rightarrow$ var. DU A

"ten": $\rightarrow \mathrm{u}_{4} \mathrm{u}$ uncertain meaning: A 234

"nose-leash": $\rightarrow$ ešgiri

"plant, herb, food, fuel":

"mourning grass": A 28

"to gather fuel": C 56

"the food of the netherworld": A 83

"honey-plant": D (Ni) 27 I| 28*; D (Ur) 36'

"pastures and watering places": C 78*

"splendid food, tasty food": A 27; C 75

"fine grass": A 28* (broken)

"to grow like herbs": A 214

"fresh herbs": $\rightarrow$ geš-nu ${ }_{2} \mathrm{u}_{2}$ za-gin $_{3}$ bara $_{3}$.g

"provider":

"provider for Sumer and Akkad" (ep. Urnamma): D (Ur) 39'

"provider for Nippur" (ep. Urnamma): D (Ni) 38

"to (make) disappear": A 27; CU 179

non-standard "storm": B 58 ॥ 60; $\rightarrow \mathrm{uru}_{2} \mathrm{~A}$

GN Ușarum: CU 129

non-standard "huge u t u g-weapon": B 52 ॥ 53 ; $\rightarrow$ utug $_{2}$ $\left(\right.$ tug $\left._{2}\right)$ mah

"and": A 120 (Susa); CU 128a; Cadaster B iv 27

"to create, to produce, to procreate": $\rightarrow \mathrm{du}_{2} \cdot \mathrm{d}, \mathrm{u}_{3}-\mathrm{du}_{2} \cdot \mathrm{d}$

"to fall asleep, to sleep": A 163

"to sleep soundly": A 20

ES "lord": F 3; 26

"brickmould": B 13

"day(light), time, storm": A 14; 54; D (Ur) 40'; $\rightarrow$ $\mathrm{UD} ; \rightarrow$ dutu

"very auspicious day": C 58

"days of abundance": D (Ur) 30*; $\rightarrow$ var. $\mathrm{i}_{7}$ he $_{2}$ - gal $_{2}$-la

"fierce storm" (ep. Inana): A 204*

"five days": A 145 (Susa); $\rightarrow$ var. $\mathrm{u}_{4}$ imin

"seven days": $\mathbf{A} 145 ; \rightarrow$ var. $\mathrm{u}_{4} \mathrm{ia}_{2}$

"ten days": A 145

"when": CU 31; 28, 1:8-9; 40:8-9; 47, 1:12-13 
$\mathrm{u}_{4}-\mathrm{ba}$

$\mathrm{u}_{4}-\mathrm{da}$

$\mathbf{u}_{4}$-da gub

$\mathrm{u}_{4} \mathrm{du}_{11}$-ga

$\mathrm{u}_{4} \mathrm{e}_{3}(-\mathrm{a})$

$\mathrm{u}_{4}-\operatorname{gin}_{7} \mathrm{kar}_{2}$

$\mathrm{u}_{4}$ gar

$\mathrm{u}_{4}$ nam-he $\mathrm{u}_{2}$-a AK

$\mathrm{u}_{4}$-ri-m(a)

$\mathrm{u}_{4} \mathrm{sa}_{2} \mathrm{du}_{11}-\mathrm{ga}$

$\mathrm{u}_{4}$ sud-ra ${ }_{2}-\mathrm{se}_{3}$

$u_{4}$ til

$\mathrm{u}_{4} \mathrm{zal}$

$\mathrm{u}_{5}$

$\mathrm{u}_{6} \mathrm{du}_{11} \cdot \mathrm{g}(\mathrm{h}),. \mathrm{e}(m$.$) , di.d$ $\mathrm{u}_{6} \mathrm{di}_{\mathrm{s}} \check{\mathrm{s}}_{3} \mathrm{gub}$

$\mathrm{u}_{6}$-e ki-a $\hat{g}_{2}$

$\mathrm{u}_{18}-\mathrm{lu}, \mathrm{ulu}_{3}$

$\quad \mathbf{u}_{18}$-lu-da dul
$\mathrm{u}_{18}$-lu
$\mathrm{u}_{18}$-ru mah
$\mathrm{ub}$
ub-ba
UB?
UBARA
UD

UD.dNANNA

udu

udu A.LUM

udu dab ${ }_{5}$

udu diri gal ${ }_{2}$

udu niga

dudug

udu z/sulu(m)hu/i $\mathbf{i}_{\mathbf{x}}\left(\mathrm{TUG}_{2}\right.$.SUD) "long-fleeced sheep": A 102*(Susa)

"at that time": CU 36; 87; 104 (broken); 125; 150;

182; IB 1537 rev. v' 7'

"daily": $\mathbf{F} 48$

"occupied with the day, serving by day": A $162 *$

"appointed time": A $51^{*}$ (broken); $\rightarrow$ var. $\mathrm{u}_{4} \mathrm{Sa}_{2} \mathrm{du}_{11}$-ga

"breaking daylight, rising day": A 211 (Susa); $\rightarrow$ ki u ${ }_{4}$ $\mathrm{e}_{3}(-\mathrm{a})$; $\rightarrow$ dutu $\mathrm{e}_{3} ; \rightarrow^{\text {dutu-gin }} 7$ kalam-ma $\mathrm{e}_{3}$; $\rightarrow$ nonstandard ut-ti

"to make shine forth like daylight": B 8

"to set light": E 10' || F 15

"prosperous times": B 15*

non-standard "Ur": B 67; $\rightarrow$ uri $_{2 / 5}$ ki.m

"appointed time": A 51 (Susa); $\rightarrow$ var. $\mathrm{u}_{4} \mathrm{du}_{11}$-ga

"for all time": B 12; 37; D (Ni) 18 (broken)

"to spend the time": A 163; $\rightarrow$ var. u $_{4}$ zal(-zal)

"to spend the day, to pass time": A $21 ; 145 ; 167$ ॥

175; D (Ni) 40; $\rightarrow$ non-standard za-e-en-za-e-1(e); $\rightarrow$ var. $\mathrm{u}_{4}$ til

"to ride high": $\mathbf{F} 3{ }^{*}-5$

"to look at in admiration, to be spectacular": A 230 (broken); C 8; F 40 (broken)

"to place something for admiration, to excite admiration": B 21

"to love marvellous things": C 44

"(sand)storm, Southern (wind/storm)": B $63 \| 65 ; \rightarrow \mathrm{a}_{2}$ tumu-ulu ${ }_{3}$

"to cover with a storm (from the South)": A 49

$\rightarrow$ nam- $-\mathrm{lu}_{2}-\mathrm{ulu}_{3} / \mathrm{u}_{18}-\mathrm{lu}_{7}$

"huge tornado": B 30*

"corner": $\rightarrow$ lugal an(/-ne 2$)$ ub-da limmu 2 -ba(/bi)

obscure, non-standard: D (Ur) 30'*

obscure: B 1 (broken)

$\rightarrow$ sila $_{\mathrm{x}}$ (UBARA)

$\rightarrow$ HU? .UD; $\rightarrow$ IM.UD sir $_{2}$-da; $\rightarrow$ kur-gal UD den-lil ${ }_{2} ; \rightarrow$ $\operatorname{babbar}_{(2)} ; \rightarrow \mathrm{u}_{4} \cdot \mathrm{d} ; \rightarrow$ zalag

"liquorice": $\rightarrow \mathrm{u}_{2}$ munzer

"sheep": CU 27; $\rightarrow$ gud gaz - udu šar ${ }_{2} ; \rightarrow \operatorname{lu}_{2} 1$ udu

"A L U M-sheep": A 102* (Susa)

"to hold sheep": CU 95 (broken); 120

"to increase the flock": C 76

"fattened sheep": A 87; 128a (Susa); 129 (Susa)

"u d u g-spirit"

"evil u du g-spirit": A 233

dudug $\mathrm{sa}_{6} \cdot \mathrm{g}$

"benevolent u du g-spirit": A 176* 


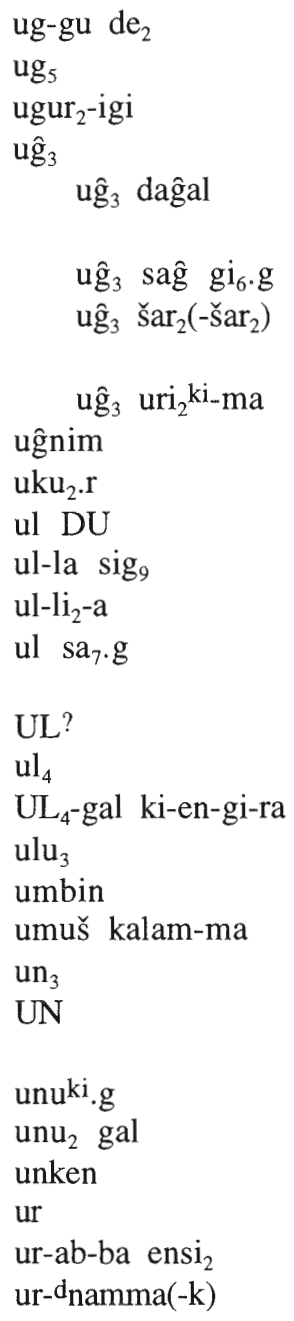

$\rightarrow \mathrm{u}_{2}$-gu de ${ }_{2}$, ug-gu de

"to die": A 77; 78; 139; 173; 218; $\rightarrow$ var. šub

"lintels": B 23

"people": A 5; 79 II 80; 203; B 4; 11; C 75; G 9

"widespread people, numerous people": A 26 (Susa); C 94; D (Ni) $17 \|$ (Ur) 18' (broken)

"black-headed people": F 23; $\rightarrow$ saĝ gi 6 .g

"innumerable people, endless multitude of people": B 5; $21 ; \mathbf{D}(\mathrm{Ni}) 16 \| \mathbf{D}(\mathrm{Ur}) 17^{\prime}$

"the people of Ur": $\mathbf{D}$ (Ni) 39

"troops, army": IB 1537 rev. vi' 12'

$\rightarrow$ dumu-uku ${ }_{2}$-ra

"to decorate": B 32*

"to inlay with blossoms": $\mathbf{B} 26^{*}$

$\rightarrow$ nig $\hat{g}_{2} \mathrm{ul}_{-} \mathrm{li}_{2}-\mathrm{a}_{-} \mathrm{ke}_{4} \mathrm{pa} \mathrm{e}_{3}$

"to (make) flourish, to ripen something (+ loc.-term.)":

B 19*

obscure: A 49 (B)

"to be quick, to rush (against)": A 3

". . . of Sumer" (ep. Urnamma): A 39*

$\rightarrow$ nam- $-\mathrm{lu}_{2}-\mathrm{ulu}_{3} / \mathrm{u}_{18}-\mathrm{lu}_{7}$

"wheel": A 114

"the senses of the land": A 27; $\rightarrow$ var. BU kalam-ma(-k) $\rightarrow$ si-un $_{3}$-na

obscure: C 22; 40; E 4'; Ni. 4375 v 7'; $\rightarrow$ kalam; $\rightarrow$ $\mathrm{ug}_{3}$

GN Uruk: year name "8"; $\rightarrow$ en unuki-ga

"large dining hall": B 34

"assembly": C 71 (broken); $\rightarrow$ me-te? unken-na

"dog": A 185; $\rightarrow$ KISIM $_{2}$-ur-mara 2 -daki-ka

"Uraba (was) e n s i 2 ": year name "3"

PN Urnamma: A 17; 34; 35 (Susa); 40; 41; 43; 58; 61; 63; 71; 75 (broken); 80; 82; 84a (Susa); 86; 133 (broken); 136; 142; 147; 210 (Susa); 216 (C); 218; 221 (broken), 222; 231; 242 (broken); B 4; C 14; 19; 31; 50; 70; D (Ur) 6'; 11'; 39'; 41'; E 20'; 23'; G 17; 20; 23 (broken); H 1 II 10; CU 10 (broken); 36; 104; $\mathbf{1}: 1 ; \mathbf{2}: 1 ; \mathbf{3}: 1 ; \mathbf{4}: 1 ; \mathbf{5}: 3 ; \mathbf{6}: 4 ; \mathbf{7}, 1: 3 ; \mathbf{8}: 4 ; \mathbf{9} 1: 3 ; \mathbf{1 0}: 5$; $11: 3 ; 12: 3 ; 13$ obv. $4 ; 14$ obv. $3 ; 15$ obv. $3 ; 16: 4$; $17: 4 ; 18: 3 ; 19: 3 ; 21: 3 ; 22: 4 ; 23: 4 ; 24: 3 ; 25: 6$; 26,1:5; 27,1:5; 28,1:4; 29, a:1; 30:3 (broken); 31:3; 32:3; 33:3; 34:3; 38:3 (broken); 39:2' (broken); 40:4; 42:2'; 43,1:1 (broken); 44:3 (broken); 45:4; 46:3; 47,1:8; Al-Rawi, Sumer 46 (1989-90) 84:4; IB 1537 rev. v' 1'; year name "4"; $\rightarrow$ nam-til $l_{3}$ ur-dnamma (...)-šse ${ }_{3}$ a ru; $\rightarrow$ sipa (zi) ur-dnamma(-k) 
ur-dnamma lugal

$\mathrm{d}_{\text {ur-d }}$ namma(-k)

ur-dna-na-ma(-k)

ur-sag

$u r$ - ̌̌a-tum

$\mathrm{ur}_{2}$

$\mathrm{ur}_{2}$ ge.n

$\mathrm{ur}_{2}$ gunu $_{3}-\mathrm{gunu}_{3}$

$\mathrm{ur}_{2}$ gur-ra

$\mathrm{ur}_{3}$

$\mathrm{ur}_{5}$

$u_{5}$-bi-da

ur $_{5}$ - gin $_{7}$

ur $_{5}$ zi.g

urdu

urdu-šum-ma

uri

$\mathrm{uri}_{2} \mathrm{ki} . \mathrm{m}$

$\mathrm{uri}_{5} \mathrm{ki}^{\mathrm{ki}} \mathrm{m}$

urin

uru(ki)

URU.AMBAR

$\mathrm{uru}_{2} \mathrm{~A}$

$\mathrm{uru}_{2} \mathrm{~B}$

uru $_{12}$

$\mathrm{uru}_{16} \cdot \mathrm{n}$ "king Urnamma": Cadaster A i 16 || ii 23 || iv 23 || B iv 32; year name "1"; $\rightarrow$ dumu ur-dnamma lugal

PN Urnamma: B $44 \|$ II 50; 71; D (Ni) $5 ; 10 ; 38 ; 41$; F $4 ; 24 ; 27 ; 28 ; \mathbf{E} 26^{\prime *}\left\|\mathbf{F} 29 ; \mathbf{E} 28^{\prime}\right\| \mathbf{~ F ~ 3 3 ; ~ E ~ 3 0 ' ; ~ E ~}$ 32' || F 35; E 34'; E 36' || F 37; E 38' || F 42; F 44; E 40' (broken); G 7; 9; 14; Ni. 4375 iv 2' (broken); iv 10' (broken); v 1'; v 11'; vi 7'; $\rightarrow$ sipa dur-dnamma; $\rightarrow$ non-standard ur-d na-na-ma(-k)

non-standard PN Urnamma: $\rightarrow$ si-pa ur-dna-na-ma(-k); $\rightarrow$ dur-dnamma(-k)

"warrior, hero" (ep. Urnamma): A 169; $\rightarrow \mathrm{a}_{2}$ nam-ursaĝ-ĝa $a_{2} \rightarrow$ saĝ-ur-saĝ; $\rightarrow$ sul ur-saĝ dnin-ĝeš-zi-da

$\mathrm{GN}: \rightarrow \mathrm{i}_{7}$-ur- ̌̌ $a$-tum

"lap, thigh, base, foundation, foot" (said of a moun-

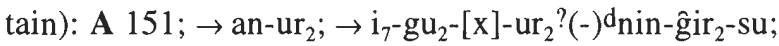
$\rightarrow$ kur-ur $_{2}$

"to make the foundation firm": D (Ur) 27'; $\rightarrow$ suhuš ge.n

"dappled thighs": A 116

"stumpy legs": C 10*

$\rightarrow$ mu sar-ra (+ loc.) šu ur ${ }_{3} /$ uru $_{12} ; \rightarrow$ ki-ur 3 ; $\rightarrow$ var. uru $u_{12}$

"liver": $\rightarrow \mathrm{ki} \mathrm{ur}_{5} \mathrm{sa}_{6} \cdot \mathrm{g}$

"with the same, together, common": Cadaster B i 3

"thus": A 195

"to raise oneself": A 43* (Susa); 55*; $\rightarrow$ var. gu 2 zi.g

"slave": $\rightarrow$ nam-urdu AK

$\rightarrow$ pa $_{5}$-urdu-šum-ma

"Akkad(ian)": CU 122; $\rightarrow$ ki-en-gi (ki-)uri

GN Ur: A 25 (broken); 41 (B, Susa); B 67 (A); 71; D

(Ni) $14^{*} ; 23$ (broken); 26;28;30;32;34;39; F 2

(broken); year name "6"; $\rightarrow$ bad $_{3}$ uri $_{2 / 5}$ ki-ma; $\rightarrow$ eš $_{3}$

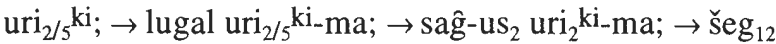
uri $_{2}$ ki-ma; $\rightarrow$ ug $_{3}$ uri $_{2}$ ki-ma; $\rightarrow$ non-standard $\mathrm{u}_{4}$-ri-m(a)

GN Ur: A 6; 41 (A); B 67 (D, broken); C 15 (broken); 41; 86; D (Ur) 14'; 40'; E 2' (broken); 7'; 21' (broken); CU $85 ; 27,2: 5$; Ni. 4375 iv 13' (broken, read perhaps $\rightarrow$ uri $\left._{2} \mathrm{ki} \mathrm{m}\right) ; \rightarrow \mathrm{bad}_{3} \mathrm{uri}_{2 / 5} \mathrm{ki}_{-} \mathrm{ma} ; \rightarrow \mathrm{es}_{3} \mathrm{uri}_{2 / 5} \mathrm{ki} \rightarrow \mathrm{i}_{7}$ uri $_{5} \mathrm{ki}_{-}$

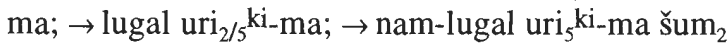
"bloody": $\rightarrow$ šu urin-na du $\mathrm{du}_{8}$; $\rightarrow$ ses B

$\rightarrow$ iri(ki)

GN: Cadaster A ii 14-15

"storm": B 58* || 60; $\rightarrow$ non-standard $\mathrm{u}_{2}$-ru

ES "city": F 1* (broken); 3

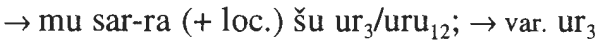

"massive, unswerving, valiant": $\rightarrow$ en uru $_{16} \cdot \mathrm{n} ; \rightarrow \mathrm{EN}$ 
$\mathrm{URU}_{3}$ urum $_{2} \mathrm{ki}^{2}$

$\mathrm{us}_{2}$

$u_{2}$ AŠ-a dab

$\mathrm{US}_{2}$

USAN

usan $_{\mathrm{x}}$ ?

USAR.x.GABA-an-na

usu gal ${ }_{2}$ ?

uš(8)

uš(8) $\operatorname{dug}_{3}$

uš $e_{2}$ dnin-gublaga

ušumgal

ut-ti

dutu

dutu $e_{3}$

dutu-gin ${ }_{7}$ kalam-ma $e_{3}$ $u_{\text {tug }}{ }_{2}\left(\operatorname{tug}_{2}\right)$ mah

$\mathrm{utul}_{4}$

$\mathrm{uz}_{3}$-saĝ

za-am-za-am

za-e

za-e-en-za-e-l(e)

$\left(\mathrm{na}_{4}\right)_{\text {Za-gin }}$

(ĝeš) za-ha-da

za-pa-a. $\hat{g}_{2}$

za-pa-ag $\hat{2}_{2}$ gar

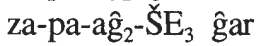

$\mathrm{za}_{3} \cdot \mathrm{g}$

$\mathrm{za}_{3}(-)$ bar-ra

$\mathrm{za}_{3} \mathrm{e}_{2}-\mathrm{gar}_{8}$-e $\mathrm{us}_{2}$ $\rightarrow \mathrm{i}_{7}$-EN.URU ${ }_{3}$.GAL

GN: Cadaster A iv 21 (broken)

"to (make) touch, to follow": A 71 (Susa); 117; IB

1537 rev. vi' 2' (obscure); $\rightarrow$ an-še ${ }_{3}$ gu $_{2}$ us $_{2} ; \rightarrow$ girii

[ki?] us $_{2} ; \rightarrow$ i $_{7}$-še-er-us ${ }_{2}$-sa; $\rightarrow$ ir $_{2}$ us $_{2} ; \rightarrow$ ki(-a) us us $_{2} ; \rightarrow$ ni $_{2}$ su-e us $\mathrm{us}_{2} ; \rightarrow$ sag us ${ }_{2} ; \rightarrow \mathrm{za}_{3} \mathrm{e}_{2}$ - gar $_{8}$-e us 2

"to hew to the one and same path": C 34

obscure: A 38 (Susa)

$\rightarrow$ PA.USAN; $\rightarrow \check{s ̌ a}_{3}$ usan $_{x}$ ?(AN.USAN)

$\rightarrow \mathrm{sa}_{3}$ usan $_{\mathrm{x}}$ ?(AN.USAN)

GN: Cadaster B iii $22 ; 23$

"to have? strength": A 168*

"foundations": $\mathbf{F} 2 *$

"to make the foundations well": B 17

"foundation of the temple of Ningublaga": year name

"17"

"dragon": C 52; E 14'; H 9

non-standard "breaking daylight": $\rightarrow$ ki ut-ti

DN Utu, "the sun": A 14; 186*; C 27; E 10' II F 15;

E 22'; F 38; 11:1; $\rightarrow$ di ni $\hat{g}_{2}$ ge-na dutu; $\rightarrow$ enim ge-na dutu; $\rightarrow\left(\mathrm{lu}_{2}\right)$ i-dutu(-ka); $\rightarrow \mathrm{u}_{4} \cdot \mathrm{d}$

"rising sun": $\mathbf{G} 21$

"to rise like the sun over the land": C 46

"huge u t u g-weapon": B $52 \| 53$; $\rightarrow$ non-standard $\mathrm{u}_{2}$-tuug ma-hुe

"herdsman": CU 93 (broken); 119

uncertain meaning (ep. Urnamma): C 62*

"z a m z a m-instrument, tambourine": A 187*; $\rightarrow$ nonstandard $\mathrm{za}_{3}-\mathrm{Za}_{3} \cdot \mathrm{m}\left(/-\mathrm{mi}_{2}\right)$

personal pronoun 2nd sg. "you": D (Ur) 40'; F 49*

non-standard in "to pass" (?): $\mathbf{D}(\mathrm{Ur}) 40^{*} ; \rightarrow \mathrm{u}_{4} \mathrm{zal}$

"(colour of) lapis lazuli, shining, fresh" (said of herbs):

A 111; C 110; H 6; $\rightarrow \mathrm{e}_{2}$-kur-za-gin ${ }_{3}$; $\rightarrow$ eš $_{2}$-gana ga- $_{2}$ za gin $_{3} ; \rightarrow$ ĝeš gu-za za-gin ${ }_{3} ; \rightarrow$ kar-za-gin ${ }_{3}(-)^{\text {dnanna }}(-\mathrm{k}) ; \rightarrow$ na $_{4}$ kišib za-gin ${ }_{3} ; \rightarrow$ geš-nu ${ }_{2} \mathrm{u}_{2}$ za-gin ${ }_{3}$ bara $_{3} . \mathrm{g} ; \rightarrow \mathrm{su}_{6}$ za-

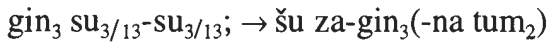

"battle-axe": A 94

"tumult, roar": A 38 (Susa)

"to set a tumult, to be(come) tumultuous": A 79 || 80

"to set as a roar": F 34*

"side, front, edge (of a seal)": A 120 (Susa); CU 148;

$\rightarrow$ an- $-\mathrm{za}_{3} \cdot \mathrm{g}$

uncertain meaning: A 124*

"to prop against the wall": A $188^{*}$ 
$\mathrm{za}_{3}$-ga gub

$\mathrm{za}_{3}-\mathrm{mi}_{2}$

$\mathrm{Za}_{3} \check{\mathrm{s}}_{4}$

$\mathrm{za}_{3}-\mathrm{za}_{3} \cdot \mathrm{m}\left(/-\mathrm{mi}_{2}\right)$

$\mathrm{ZA}_{3} \cdot \mathrm{LA}_{2}$

zabar

zal

zalag

zalag $_{2}$

zi

zi kalam-ma

zi $u_{3}-d u_{2} \cdot d$

zi.d

zi.g

geš zi-gan

zi-ka

zi-mu-darki

ZI

$\mathrm{zu}$

"to stand at the side": $\mathbf{A} 122 ; \rightarrow$ var. a $_{2}$ gabu $_{3}$ bu gub; $\rightarrow$ var. $\mathrm{a}_{2}$ zi-da gub

"praise": A 240; C 115; D (Ni) 41 || D (Ur) 41'; $\rightarrow$ non-standard $\mathrm{za}_{3}-\mathrm{za}_{3} \cdot \mathrm{m}\left(/-\mathrm{mi}_{2}\right)$

"to mark": IB 1537 rev. vi' 10'

non-standard "z a m z a m-instrument": A 187 (Susa); $\rightarrow$ var. za-am-za-am

uncertain meaning: C 85

"bronze": $\rightarrow$ sila $_{3}$ zabar $\operatorname{dim}_{2}$

"to flow, to pass": $\rightarrow$ gir $_{17}-\mathrm{zal} ; \rightarrow \mathrm{u}_{4} \mathrm{zal} ; \rightarrow$ non-standard za-e-en-za-e-1(e)

"(to be) shining": $\rightarrow$ saĝ-ki zalag bar

"to (make) shine": CU 86

"life": C 69 (broken, obscure); D (Ni) 18

"the life of the land": A 23

"to engender life": C 51*

"good, just, faithful, correct, right, proper, authoritative": C 26 (obscure); E 20' (obscure); $\rightarrow$ a $_{2}$ zi-da gub; $\rightarrow$ du $_{11}$-ga eš-bar zi.d; $\rightarrow$ ddumu-zi.d; $\rightarrow$ engar zi GANA daĝal-la; $\rightarrow$ GANA $_{2}$ zi.d; $\rightarrow$ gu $_{3}$ zi de ${ }_{2}$; $\rightarrow$ geš-hur zi.d; $\rightarrow$ igi zi bar; $\rightarrow \mathrm{KA}\left(\right.$ enim?) $\mathrm{gal}_{2} \mathrm{ku}_{3}$ zi.d; $\rightarrow \mathrm{mi}_{2}$ zi-de $\mathrm{d}_{3}$-eš $(\mathrm{i}-\mathrm{i}) ; \rightarrow \mathrm{mi}_{2} \mathrm{zi} \mathrm{du}_{11} . \mathrm{g} ; \rightarrow$ munus zi $\operatorname{gir}_{17}-\mathrm{zal} ; \rightarrow \operatorname{nin}(-)^{\mathrm{d} a-}$

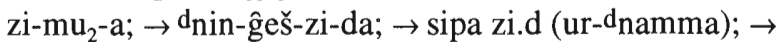
sul zi.d; $\rightarrow$ ša $\mathrm{s}_{3}$ zi-ta(/da); $\rightarrow$ šu zi gal ${ }_{2}$

"to raise, to elevate, to lift, to grow tall": C 55; 59; $83 ; \rightarrow$ gu $_{2}$ zi.g; $\rightarrow$ nig $_{2}$-a a $_{2}$-zi.g; $\rightarrow$ sag zi.g; $\rightarrow$ su-zi.g; $\rightarrow$ ĝeššudul $_{4}$ zi.g; $\rightarrow$ ur $_{5}$ zi.g

"rudder": A 67

$\rightarrow$ non-standard mi-ri-e-zi-ka du ${ }_{11}$.g

GN Zimudar: $\rightarrow$ ma-da zi-mu-darki

$\rightarrow \mathrm{ku}_{3}-\mathrm{sig}_{17}, \mathrm{ku}_{3}-\mathrm{Si}_{2}(\mathrm{ZI}) . \mathrm{g}$

"to know, to experience, to inform, to fathom": A 79 ॥ 80; 84; 84a (Susa); 140 (broken); 156 (D, Susa); E 3' II

F 9; E 14; $\rightarrow$ di zu; $\rightarrow$ enim zu; $\rightarrow$ geštu mah lu $_{2} z u ;$

$\rightarrow$ ki nu-zu; $\rightarrow \mathrm{lu}_{2}$ nu-zu; $\rightarrow$ ni $_{2} \mathrm{zu} ; \rightarrow$ var. mud

$\rightarrow \mathrm{ku}_{3}-\mathrm{zu}$

$\mathrm{Zu}_{2}$

$\rightarrow$ giri ${ }_{2}-\mathrm{zu}_{2}$ gal/galam

$\mathrm{zu}_{2}$ ra-ah

$\rightarrow \mathrm{e}_{2}-\mathrm{zu}_{2}-\mathrm{ra}-\mathrm{ah}$

zubi

$\rightarrow \mathrm{i}_{7}$-zubi

zuh

$\rightarrow \mathrm{ni}_{2}$-zuh

$\operatorname{tug}_{2} \mathrm{z} / \mathrm{sulu}(\mathrm{m}) \mathrm{hu} / \mathrm{i}\left(\mathrm{SIG}_{2}\right.$.SUD) "long-fleeced garment": A 98*

$\mathrm{z} / \operatorname{sulu}(\mathrm{m}) \mathrm{hu} / \mathrm{i}_{\mathrm{X}}\left(\mathrm{TUG}_{2}\right.$. SUD) "long-fleeced": $\rightarrow$ udu $\mathrm{z} / \mathrm{sulu}(\mathrm{m}) \mathrm{hu} / \mathrm{i}_{\mathbf{x}}\left(\mathrm{TUG}_{2}\right.$.SUD $)$

${ }_{\mathrm{X}}^{\mathrm{X}}$-bur ${ }_{2}$ ?

$\rightarrow$ USAR.x.GABA-an-na

obscure: A 210 (A); $\rightarrow$ var. ĝeš-ḩur 


\title{
INDEX OF PROPER NAMES
}

\author{
Personal Names
}

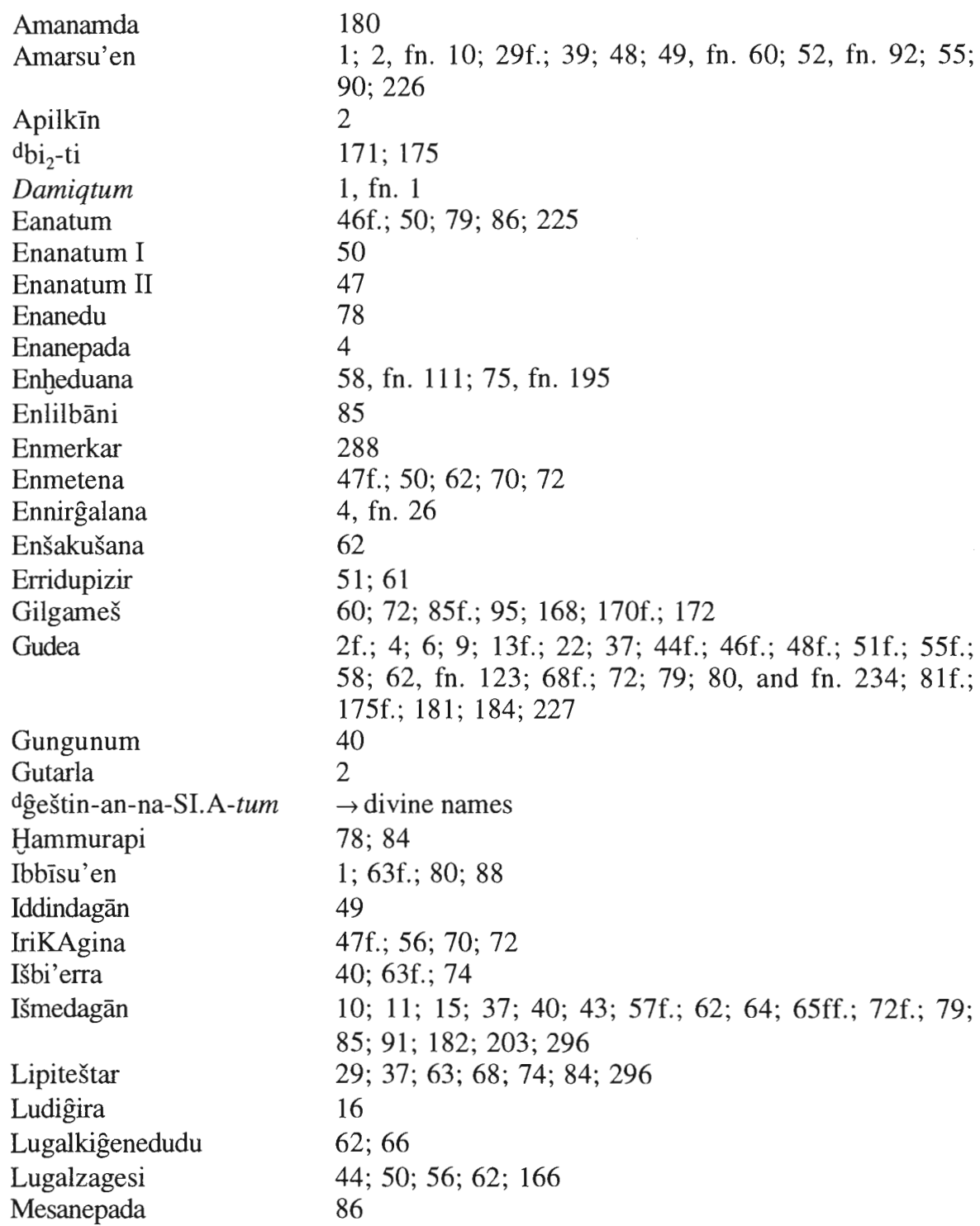




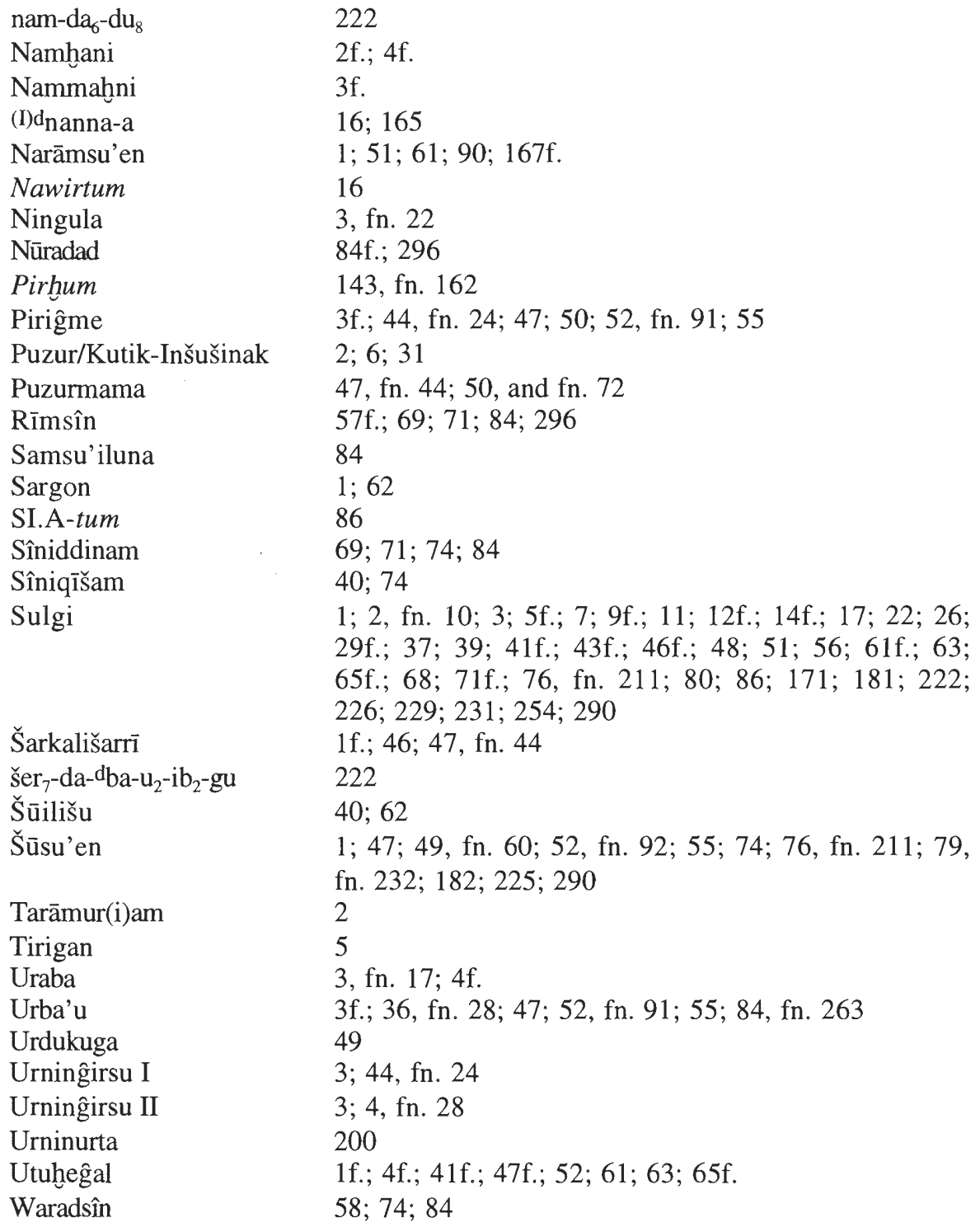

\section{Divine Names}

An

Anuna

AŠimbabbar
$34 ; 47 ; 63 ; 74 ; 77 ; 86 f . ; 88 ; 90 f . ; 150 ; 164 ; 205$ 63

178; 229f.; 231; $\rightarrow$ Nanna 


Azimua
Ba'u
Damu
Dimpi(me)kug
Dumuzi
Enki(-Nudimmud)
Enlil(-Nunamnir)

Ereškigal

${ }^{\mathrm{d}} \mathrm{GAN}-\operatorname{dim}_{3}(-\mathrm{me})-\mathrm{ku}_{3} \cdot \mathrm{g}$

Gatumdug

Ĝeštinana

dĝeštin-an-na-SI.A-tum

Hendursaĝa

Hušbisag

Inana

Inana-Ninkununa

Iškur

Ištaran

Lugalbanda

Lugalmarada

Meslamtaea

Namtar

Nanna(-Su'en)

Nanše

Nergal

Ninazimua

Ninazu

Ninegal

Ningal

Ningublaga

Ninĝešzida

Ningirsu

Ninhursag

Niniagara

Ninisina

Ninlil

Ninmah

dNIN-nigar(gar/mar-ra)

Ninsumun

Ninšagepada 175f.; $\rightarrow$ Ninazimua

$47 ; 168 ; 289$

$85 ; 87 ; 180 ; \rightarrow$ Dumuzi

96 , and fn. $10 ; 151 ; 175$

$12 ; 85 ; 86 ; 87 ; 95 ; 151 ; 167 ; 173 ; 175 ; 179 ; 180 ; 181$

$30 ; 35 ; 50 ; 63 ; 73 ; 95 ; 150 ; 169 ; 205 ; 229 \mathrm{f} ; 256$

14; 20f.; 29f.; 31; 33f.; 36f.; 40; 47f.; 49; 51; 58f.;

62, and fn. 128; 63f.; 65; 67; 71f.; 72f.; 74; 77; 79;

81; 83; 86f.; 88; 90f.; 93f.; 96; 150f.; 164; 168; 179f.;

184f.; 186; 205; 222; 226; 229f.; 231; 256; $290 \mathrm{f}$.

$95 ; 173$

175

58

$86 ; 151 ; 175 f$.

86

50

95

$12 ; 16 ; 19 ; 30 ; 33 ; 35 f . ; 47 ; 49 f$.; $58 ; 73 f . ; 82$, fn. 249; 86f.; 87, fn. 292; 88; 91; 93f.; 96; 150f.; 166; 172f.; 175; 176; 178f.; 180f.; $289 f$.

$35 \mathrm{f}$.

173

46 , fn. 40

$63 ; 86$

32

32

$95 ; 151 ; 175$

14; 21; 29f.; 32; 34f.; 36f.; 39f.; 47; 58; 63f.; 73f.;

$75 ; 77 ; 81 ; 87$, fn. $292 ; 95 ; 150 ; 204 f$; 206; 223;

226; 227; 229f.; 231; 262f.; 290

$47 ; 80$

$95 ; 172$

$86 ; 96 ; 151 ; \mathbf{1 7 5 f}$; $\rightarrow$ Geštinana

173

$30 ; 36$

$30 ; 36 ; 40 ; 75 ;$ fn $195 ; 87$, fn. $292 ; 88 ; 90 ; 289$

$30 ; 36 ; 204 f$.

$85 ; 91 ; 93 ; 95 f . ; 97 ; 152 ; 174 f . ; 176 ; 180 f$.

47f.; 50; 70; 80f.; 201; 227; 289

$30 ; 36 ; 47$, fn. 44

91

$47 ; 91$

29f.; 36; 40; 47; 58; 71; 73f.; 77; 79; 184

$95 ; 150$

289

$30 ; 35 f . ; 59 ; 67 ; 86 ; 95 ; 150 ; 165 ; 222 ; 289$

$30 ; 35$ 
Nintur

Ninurta

Nisaba

Numušda

Nungal

Nuska

Utu
$46 ; 74 ; 205$

$40 ; 74 ; 169 ; 296$

$74 ; 175$

32

73

74

7 , fn. $62 ; 30 ; 36 ; 47 ; 50 ; 73 ; 95 ; 150 ; 167 ; 169$; 204f.; 259; 287

\section{INDEX OF TEXTS QUOTED}

\begin{tabular}{|c|c|}
\hline 6 N-T 908a (t) & $\begin{array}{l}2, \text { and fn. } \\
11 ; 18 \text {, and } \\
\text { fn. } 53\end{array}$ \\
\hline Angim 173 & 225 \\
\hline BM 100042 obv. ii $41^{\circ}$ & 182 \\
\hline Cavigneaux, AUWE 23 & \\
\hline (1996) 45 , no. 83 rev. 4 & $20 ; 231 \mathrm{f}$. \\
\hline CBS 342 obv. 6 & 201 \\
\hline CBS 808612 & $21 ; 265$ \\
\hline Codex Urnamma & $\rightarrow$ gen. ind. \\
\hline $75-78$ & 2, fn. 13 \\
\hline $162-165$ & 56 \\
\hline $177-181$ & 222 \\
\hline Cohen, Eršemma no. & \\
\hline 60, p. $91: 16 \| 17$ & $166 f$. \\
\hline Creation of the Hoe 13 & 175 \\
\hline$C T 164: 153$ & 177 \\
\hline Curse of Agade & $\rightarrow$ gen. ind. \\
\hline $43-44$ & 224 \\
\hline 122 & 167 \\
\hline 268 & 89 \\
\hline
\end{tabular}

Death of Gilgameš A $62 \mathrm{ff}$.

Dialogue 3 obv. ii 22

Dumuzi-Inana $\mathrm{H}$ rev. $19^{\prime} \| 21^{\prime}$

Ean. 2, 6:8 166 175

181

eden-na $u_{2}$ saĝ-ĝa $a_{2}$ 225

85 , and fn. 273

e-ne-eg. ${ }_{3}-\mathrm{gaa}_{2}-$ ni i-lu i-lu 86 , and fn. 285

Enki and the World Order 374
447-448

$178 \mathrm{f}$.

Enki's Journey to Nippur 6-10 202 113 256

Enmerkar and the Lord of Aratta 342-343 || 384-385 288

Ent. 32, 1:2"-3" 48

Geller, $U H F$ 22:48 261, fn. 16

Gudam A 2

Gudea A $\rightarrow$ STVC 36

Gudea, Cyl. A 11:7-8 56

Gudea, Cyl. B

$\begin{array}{ll}13: 23 & 173 \\ 17: 12-14 & 80 \\ 18: 6-7 & 56\end{array}$

Gudea, Stat. B

$6: 77-7: 4$

$\rightarrow$ gen. ind.

$7: 6$

80

7:14-17

$7: 42-43$

$81 ; 227$

9:10-11

56

179

Gudea, Stat. E 9:1-3 81

Hoe and Plow $153 \quad 56$, fn. 103

IB 1537

2 , and fn. 4;

62

rev. 16'-23' 6

Ibbīsu'en A 9-10:67-70 79, fn. 230

Inana and Ebih

50 (II 109)

181

125

258

Isin *4:8

286

Isin *13b:9-10 202f.

Isin $* 28$ obv. $11 \quad 258$ 


\begin{tabular}{|c|c|c|c|}
\hline Isin $* 30$ obv. 19 & 200 & 2.1 .1 i $3^{\prime}-7^{\prime}$ & 61, fn. 120 \\
\hline Išmedagān A & $\rightarrow$ gen. ind. & RIME 4 & \\
\hline 43-45 & 67 & 1.3.2:14 & 50 \\
\hline 45 & 223 & $1.5 .8: 3-4$ & 47, fn. 43 \\
\hline $91-92$ & $67 \mathrm{f}$. & 1.6 .2 ii $18^{\prime}-21^{\prime}$ & 48 \\
\hline $118-123$ & $66 f$. & $1.10 .1: 12-13$ & 47 \\
\hline $224-225$ & 67 & $1.13 .1: 19-20$ & 49 \\
\hline 239 & 182 & 2.8.1:7-10 & 47 \\
\hline 320 & 296 & $2.13 .21: 39$ & 224 \\
\hline Išmedagān AB 56 & 180 & 2.13.27:27-29 & 50 \\
\hline Išmedagān $F_{B} 9-10$ & $202 \mathrm{f}$ & $2.14 .8 \| 11: 16$ & \\
\hline Išmedagān S 11 & $57 ; \rightarrow$ gen. & $\begin{array}{l}\text { || } 20-21 \\
2.14 .9 \text { || 10:31-32 }\end{array}$ & 57 \\
\hline K. $7856+$ K. 6323 & & || 30 & 47, fn. 43 \\
\hline i $13^{\prime}-14^{\prime}$ & 174 & $2.14 .15: 27$ & 58 \\
\hline Lugalbanda I & & $3.9 .2: 23^{\prime}$ & 224 \\
\hline $33-34$ & 169 & SKL i 40-41 & $42 ; \rightarrow$ gen \\
\hline 166 & 171 & & ind. \\
\hline Luzag. & & $S T V C$ & \\
\hline 1, 2:10-11 & 56 & $36(=$ Gudea $\mathrm{A})$ & $9 ; 13 ; 55$ \\
\hline $1,3: 27-31$ & $56 \mathrm{f}$. & & $68 ; 94$ \\
\hline $1,3: 35-36$ & 166 & 41 rev.? i' 3 & $20 ; 231$ \\
\hline MSL 1254 (Proto-Lu) & & Sulgi 544 & $\rightarrow \mathrm{Ur} \mathrm{C} 1$ \\
\hline $588-90$ & 261, fn. 21 & Sulgi B 244-245 & 57 \\
\hline MSL 13 177f::10-15 & 169 & Sulgi D 388 & 202 \\
\hline MSL SS 129 (Sag B) & & Sulgi E & \\
\hline 38 & 170 & 58 & 79, fn. 230 \\
\hline$M V N 6320$ i 10 & 222 & 214 & 171 \\
\hline N $2230+$ N 4006 & 2 , and fn. 8 & Sulgi G & \\
\hline Nammahni 4:12-13 & 81, fn. 241 & 41 & 71 \\
\hline Ni. 4375 & $\begin{array}{l}\rightarrow \text { gen. ind; } \\
\rightarrow \text { Appendix }\end{array}$ & $\begin{array}{l}47 \\
52-53\end{array}$ & $\begin{array}{l}71 \\
71\end{array}$ \\
\hline iv $6^{\prime}$ & 225 & Sulgi O & $\rightarrow$ gen. ind. \\
\hline v $1^{\prime}-5^{\prime}$ & 38 & 3 & 286 \\
\hline Ninĝešzida A rev. 4'-5' & 13, fn. 13 & 83 & 176 \\
\hline Nippur Lament & & Sulgi P b 61 & 51, fn. 82 \\
\hline 77 & 88 & Sulgi R 67 & $226 ; \rightarrow$ gen \\
\hline 111 & 88 & & ind. \\
\hline 114 & 88 & Sumer and Ur Lament & \\
\hline Nisaba Hymn & & 295 & 177 \\
\hline 43 & 254 & 332 & 171 \\
\hline 80 & 257 & 410 & $90 f$. \\
\hline RIME 2 & & Šūilišu A 8 & 286 \\
\hline $1.2 .2001: 2^{\prime}-3^{\prime}$ & 47, fn. 45 & $T C L$ & \\
\hline $4^{\prime}-5^{\prime}$ & 49, fn. 60 & $158 / /$ & 85 , and fn \\
\hline $1.3 .2: 5-8$ & 49, fn. 60 & & $274 ; \quad 87$ \\
\hline 1.4 .3 rev. iii $1-3$ & 51, fn. 81 & & $173 ; 180$ \\
\hline rev. v 1-4 & 51, fn. 84 & & \\
\hline
\end{tabular}




\begin{tabular}{|c|c|c|c|}
\hline 1528 & $\begin{array}{l}80, \text { and fn. } \\
238\end{array}$ & $\begin{array}{l}25 \\
27-28\end{array}$ & $\begin{array}{l}47 \\
68\end{array}$ \\
\hline \multirow[t]{2}{*}{ TMH NF $44 / /$} & 86 , and fn. & 31 & 46 \\
\hline & 275 & 33 & 27 \\
\hline TMH NF 47 & $\rightarrow$ gen. ind. & 43 & 46 \\
\hline iii 105 & 16, fn. 41 & 46 & 49 \\
\hline iv $186 / /$ & 75, fn. 202 & $46-49$ & 67 \\
\hline iv $187 / /$ & 75, fn. 199 & 47 & $46 \mathrm{f}$. \\
\hline \multirow[t]{2}{*}{ iv 190-196 } & $75 f . ; \quad 231 ;$ & 50 & 46 \\
\hline & 256 & 54 & 56 \\
\hline UET 6102 23-24 & 57 & 55 & 67 \\
\hline \multirow[t]{2}{*}{ Ur C 1 = Sulgi 544} & 8 , and fn. & 57 & 27 \\
\hline & 68 & $57-58$ & $41 ; 64$ \\
\hline Ur Lament & & $57-59$ & 67 \\
\hline 87 & 177 & 70 & $46 ; 181 f$. \\
\hline 231 & 89 & 75 & 46 \\
\hline 285 & 171 & 78 & 27 \\
\hline $359-360$ & 90 & 81 & 22 \\
\hline 388 & 164 & $107-108$ & 81 \\
\hline 409 & 177 & 111 & 23 \\
\hline Urnamma A & $\rightarrow$ gen. ind. & 114 & $41 \mathrm{f}$ \\
\hline $6-7$ & 88 & Urnamma D & $\rightarrow$ gen. ind. \\
\hline 17 & 23 & (Ni) $9-11$ & $48 \mathrm{f}$ \\
\hline 19 & 22 & (Ni) 13 & 49 \\
\hline 20 & $58 ; 89$ & Urnamma E & $\rightarrow$ gen. ind. \\
\hline 27 & 89 & $26^{\prime}$ & 47 \\
\hline 28 & 89 & Urnamma F & $\rightarrow$ gen. ind. \\
\hline 45 & 89 & 23-24 & 47 \\
\hline 46 & 89 & 29 & 47 \\
\hline $46 \mathrm{a}$ & 89 & Urnamma G & $\rightarrow$ gen. ind. \\
\hline $157-159$ & 57 & 9 & $200 \mathrm{f}$ \\
\hline 163 & 57 & Uruk Lament 3. 23-24 & 89 \\
\hline 187 & 90 & $\mathrm{u}_{3}-\mathrm{u}_{8} \mathrm{ga}-\mathrm{am}_{3}-\mathrm{du}_{11}$ & 86 , and fn. \\
\hline $189-190$ & 90 & & 285 \\
\hline 238 & 46 & YBC & \\
\hline $241-242$ & 16 & 3654 ii 17 & $21 ; 265$ \\
\hline Urnamma B & $\rightarrow$ gen. ind. & $5641: 6-7$ & 181 \\
\hline $4-5$ & 48 & & \\
\hline 7 & 72, fn. 175 & & \\
\hline 34 & $27 ; 49$ & & \\
\hline 35 & 23 & & \\
\hline 36 & 49 & & \\
\hline 61 & 23 & & \\
\hline Urnamma C & $\rightarrow$ gen. ind. & & \\
\hline 4 & 287 & & \\
\hline 19 & 56 & & \\
\hline $20-21$ & 56 & & \\
\hline 24 & 46 & & \\
\hline
\end{tabular}




\section{GENER AL INDEX}

\author{
adaption, literary \\ Akkade - Ur III \\ chronology \\ balaĝ-, eršema-songs \\ content \\ date \\ balbale (compositions) \\ Cadaster Text \\ Catalogues \\ city laments \\ content \\ Codex Urnamma \\ Curse of Agade \\ divine hymns \\ original Ur III \\ relation to royal hymns \\ divinity of king \\ Ekišnuĝal
}

Ekur

Eme-sal
en-priest(ess), en-ship

eršema-songs

first-fruit offerings

formula

funerary cult

gedim "spirit"
$11 ; 15 ; 68 ; 74 ; 77 ; 82 ; 84 f . ; 228 ; 262$

1 , and fn. 2

77 ; 86; 87ff.; 90f.; 261, fns. 10 and 13;

262 , and fns. 28f.; 265 , fn. 37

87f.; 262

91

13 , and fns. 9 and $13 ; 15$, and fn. $26 ; 16$, fn. 41; 57f.; 74ff.; 228; 231f.; 256f.; $290 f$.

6 , and fn. $45 ; 10 ; 29 ; 31 \mathrm{f} ; 36 \mathrm{f}$

17 , and fn. 48 ; 20f.; 22 , and fn. 66f.; 80 , and fn. $238 ; 76$, fn. $211 ; 82 ; 231 \mathrm{f}$; 261f.; 265; 290

$11 ; 94 ; \rightarrow$ Urnamma $A$, relation to city laments

87ff.; 164; 168

3 ; 4, and fn. 30; 5f.; 10; 29f.; 31f.; 33;

$36 ; 39 ; 56 ; 58 f ; 62 ; 68 ; 83$

11 ; 16; 88f.; 90f.; 94; 164; 167f.

$12 ; 15$

$15 ; 68$

$11 ; 12 ; 15 ; 68 ; 73 f f . ; 262 ; \rightarrow$ adaption, literary

46; 79f.; $181 \mathrm{f}$.

20f.; 35f.; 38f.; 72; 77; 81f.; 169; 204f.; 220f.; 226; 230; 255; 262f.; 286f.; $\rightarrow$ temple construction

5; 14; 19; 29; 36f.; 63; 65; 71f.; 73; 79; 94; 96; 150; 184f.; 201; 223f.; $\rightarrow$ temple construction

261 , fn. $13 ; 262 ; 264$, and fn. 33

4 , and fn. $26 ; 38 ; 59 ; 62 ; 65 f . ; 78 ; 86$, and fn. 281; 171; 180; 205; 220f.; 224;

$\rightarrow$ "sacred marriage"

$\rightarrow$ balaĝ-, eršema-songs

30; 39f.; 51; 64; 81; 206; $226 f$.

$\rightarrow$ style, topos/topoi

$79 f$., and fn. $235 ; 86 ; 181 ; \rightarrow$ divinity of king; $\rightarrow$ ki-a-nag

7 , fn. $62 ; 169 f$. 
grammar

absence of postposition
alternation
assimilation
contamination
final consonant dropping
gloss(es)
interchange
$\quad$ of postpositions
preradical, of verbal prefixes
$\quad$ vowel and consonant
Sandhi-writing

Gudea, Stat. B

Guti, Gutian, Gutium

gipar

hymns

im gid $_{2}$-da

inscriptions

artefact

royal

basic components

use of persons

statue and stela

copies of

function

relation to royal hymns

themes

Irrigation projects

$\mathrm{i}_{7}$-nun

keškug and pabiluh

Nannagugal

Išmedagān $\mathrm{A}$ content

Išmedagān I

function

Išmedagān $\mathrm{S}$

structure
$94 ; 149 ; 165 ; 172 ; 273$, fn. 47

8 , fn. $67 ; 26 ; 203$; $\rightarrow$ grammar, interchange

$9,23,26 ; 202 ; 215$, fn. $15 ; 255$

167 f.; $176 ; 220 ; 224 ; 271$, fn. 45

105 , fn. $36 ; 148 ; 168 ; 171 ; 180 ; 200$; $203 ; 288$

$27 ; 127$, fn. $109 ; 129$, fn. $118 ; 210$, fn.

$9 ; 212$, fn. $10 ; 222$ f; 257

$148 ; 265$

$148 \mathrm{f}$.

$24 \mathrm{f}$.

23f.; 25, fn. $78 ; 26 ; 176 ; 203 ; 231 ; 254$; 255f.; 289

$37 ; 80 \mathrm{ff}$.

1f; $3 ; \mathbf{5 f} ; 7$, fn. $63 ; 31 ; 36$ f.; 51; 61; 164; 205f.; $224 \mathrm{f}$.

38; 72f.; 180; 220; 224; $\rightarrow$ Ekišnuĝal;

$\rightarrow$ "sacred marriage"

$\rightarrow$ divine hymns; $\rightarrow$ royal hymns; $\rightarrow$ selflaudatory hymns

$143 ; 186$

11; 44f.; 47f.; 51f.; 55; 58; 69ff.; 72; $84 \mathrm{f}$; $\rightarrow$ royal hymns, relation to artefact inscriptions

$10 ; 18 ; 29 ; 35 f . ; 37 ; 39 ; 43 ; 44 f . ; 51$;

$56 ; 58 ; 61 ; 69 ; 81 f ; 296$

$83 \mathrm{f}$.

$84 \mathrm{f}$.

$11 ;$ 44f.; 51f.; 55; 58; 69; $78 f f$.

$45 ; 53 \mathrm{f}$; 55

$79 f$.

$\rightarrow$ royal hymns, relation to statue and stela inscriptions

$80 \mathrm{f}$.

5; 7; 30f.; 33f.; 35; 43

$34 ; 72 ; 77$

33f.; 229f; 254

$5 ; 32 ; 34 ; 42$

65; 66ff.; 78f.; 80; 82; 223f.

$72 \mathrm{f} ; 79$

$12 ; 14 ; 69 \mathrm{f}$.

72

$45 ; 68$

83 
ki-a-naĝ

Lagaš - Ur III

chronology

relations

lamentation, laments

motif

mouth-opening ritual

Nanna A content

Nanna's Journey to Nippur

narrative material, narratives common sequence development of

netherworld

boat trip to

deities of

Ni. 4375

Nippur

journey to

non-standard orthography

due to phonetic affinity

semantically conditioned

Nungal Hymn

structure

orthography

RIME 4.2.9.2 and 4.2.9.6 (Sîniddinam)

RIME 4.2.14.15 (Rīmsîn)

structure

routes, maintenance of

royal achievements

royal hymns

classification

copies of

function

imitation

line format

literary dependence
$80 ; \rightarrow$ funerary cult

2f.; $42 ; 44$

4f.; 42

$\rightarrow$ balaĝ-, eršema-songs; $\rightarrow$ city laments;

$\rightarrow$ Urnamma A, relation to lamentation literature

$\rightarrow$ style, topos/topoi

79f., fn. 234

75; 290; $\rightarrow$ TMH NF 47

$76 \mathrm{f}$.

206, fn. 6; 227; 231; $254 f$.

$11 ; 43 ; 80 \mathrm{ff}$.

$69 \mathrm{ff}$.

$55 ; 58 ; 72 ; 78 ; 84 ; \rightarrow$ royal achievements

19; 30; 86; 88; 90f.; 94f.; 167; 169f.;

171f.; 173; 176; 179f.; 220

95, fn. $9 ; 151 ; 170$

19; 94; 95f.; 149; 150f.; 171f.; $175 f$.

$17 \mathrm{f}$., and fn. 49 ; fns. 51f.; $37 \mathrm{f}$.

$17 ; \mathbf{6 3 f}$; $65 ; 77$

$37 ; 39 ; 51 ; 206$, and fn. $6 ; 226 f . ; \rightarrow$ first-fruit offerings

8f.; 10; 23ff.; 148; 231

25f.; 129, fn. 121; 148; 152; 165; 167f.; 169 ; 171; 173f.; 231; 254; 257; 259; 286f.; $\rightarrow$ scribal errors

24 , and fn. $73 ; 25$, and fn. $79 ; 26$, fn. $81 \mathrm{f} . ; 152 ; 172 ; 231 ; 257$

15 , and fn. 32

73

$\rightarrow$ non-standard orthography

71

$70 \mathrm{f}$.

$31 ; 39 ; 43 ; 56 ; 81 \mathrm{f}$.

15; 55ff.; 79ff.; 204; $\rightarrow$ narrative material, narratives

9f.; $12 ; 44 ; \rightarrow$ self-laudatory hymns

9; 12ff.; 69; 83; $\rightarrow$ royal hymns, typology

$9 ; 11 ; 17 ; 45 ; 68 ; 82 ; 78 ; 85 ; 186$ $79 \mathrm{f}$.

14, fn. 24; 43f.; 65 ff.

17 , and fn. $50 ; 78 ; 82 ; 100 ; 186$, and fn.

$16 ; 265$

$\rightarrow$ imitation 
original Ur III

relation to artefact inscriptions

relation to statue and stela ins

rubrics

subscripts

tradition

typology, type $\mathrm{x}$ hymn

use of persons

$\mathrm{za}_{3}-\mathrm{mi}_{2}$ doxology

"sacred marriage"

scribal errors

self-laudatory hymns

širnamgala

širnamšub (compositions) relation to balaĝ- and eršema-songs style

parallelism, poetic

pun

repetition, ornamental

similes

sound play

topos, topoi

Sulgi O

distribution during periods

relation to historical events

content

Sulgi $R$

function

structure

Sulgi V

structure
$15 ; 17 ; 22 ; 45 ; 78 ; 68 ; 186$

11; 70ff.; 84

11; 45; 51f.; 53, fn. 95; 54, fn. 97; 55;

68f.; 78ff.; 80; 82f.

13f.; 15f.; 19; 21; 72; 75; 82; 84; 262

13ff.; $19 ; 21 ; 68 ; 260 f$.

9,$13 ; 14$, fn. $18 ; 15 ; 29 ; 42$ f.; 44;

50f.; 66 ; $68 \mathrm{f} . ; 228$

10; 12ff.; 28; 43; 68; 73f.; 77; 78f.;

$80 ; 82 ; 85$; $\rightarrow$ royal hymns, classifi-

cation; $\rightarrow$ Urnamma A/B/C/D/EF, typology

84

13; 15; 16f.; 19f.; 73f.; 93; 204; 206; 228f.; 230

15 , fn. $26 ; 38 ; 73 ; 86$, fn. $281 ; 87 ; \rightarrow$ en-priest(ess), en-ship

23; 149; 152; 165; 176; 222f.; 224;

231 ; $\rightarrow$ grammar, contamination; $\rightarrow$ nonstandard orthography, due to phonetic affinity

10 ; 15, and fn. 30f.; 17f.; 37f.; 45; 72ff.; 78ff.; 82; $\rightarrow$ Urnamma $\mathrm{C}$; $\rightarrow$ Išmedagān $A ; \rightarrow$ Nungal Hymn

261 , fn. $14 ; 262$, and fn. 27

14 ; 68; 77; 260ff.; $\rightarrow$ Urnamma EF

$77 ; 262$

15 , and fn. 26; 43; 74f.; 81; 150; 184f.; $228 ; 264 ; 291 ; \rightarrow$ repetition, ornamental 25 , fn. $79 ; 49 ; 167 ; 171 ; 201 ; 203 ; 224$

94,$184 ; 264 ; 291 ; \rightarrow$ parallelism, poetic 94; 96f.; 151; 169; 177f.; 181; 217 , fn. 23

24 , fn. $76 ; 224 ; 256 ; 286$ f.

28; 42ff.; 66; 68; 71; 74; 87; 89f.; 130 , fn. $123 ; 164 ; 169 ; 173 ; 176 ; 184$; 222; 230; 254; 256f.; 258; 261; 287f.; 296

44ff.; $51 ; 56 \mathrm{ff}$.

$42 \mathrm{ff}$.

$41 ; 80 ; 204$

72

$12 ; 14 ; 69 f$.

72

70

45

83 
Sumerian King List temple construction text types

TMH NF 47

Urnamma

death, burial events of reign family

genealogy, divine name relationship with Inana

rise to kingship synchronisms territorial expansion titulary, epithets wife

Urnamma A

content

manuscripts

recensions

relation to city laments relation to Curse of Agade relation to Death of Gilgameš palace

11; 41ff.; 51; 224; 227

29f.; 35f.; 39; $\rightarrow$ Ekišnuĝal; $\rightarrow$ Ekur 11; 43; 44ff.; 51f.; 55; 72; 78f.; 80; $\rightarrow$ inscriptions, artefact / statue and stela 15 , fn. $27 ; 16$, fn. $41 ; 57 ; 75$ f.; 231 ; 256f.; 290; $\rightarrow$ Nanna A; $\rightarrow$ index of texts quoted

$7 ; 85 ; 87 ; 89 ; 94 ; 151 ; 164 ; 170 ; 176 f$. 29ff.; 39; 204f.

1 , and fn. $1 ; 2 ; 4$, fn. $26 ; 86 ; \rightarrow \mathrm{Ur}-$ namma, wife

$86 ; 205 f$.

$8 \mathrm{f}$.

$170 ; 176$

65, fn. 153; 86f.; 91; 94; 96f.; 176; $179 ; 181$

$1 ; 4 \mathrm{f}$; $42 ; 61 ; 64 ; 66 ; 185 ; 229 ; 262$

$2 \mathrm{f}$.

$6 \mathrm{f} . ; 31 ; 36 \mathrm{f}$

4; 31; 35; 38; 46; 58ff.; 165f.; 181f.

$86 ; 88 ; 94 ; 95$, fn. 7f.; $179 ; 181$

$18 \mathrm{f}$.

$7 ; 35 ; 94 f \mathbf{f}$.

$97 ; 143 \mathrm{f}$.

97, 143f.; 150; $152 \mathrm{f}$.

$85 ; 87 f f . ; 94 ; 164 ; 168$

16 ; 88ff.; 94; 164f.; $167 f$.

$16 ; 85 ; 166 ; 168 ; 170 f$.; 172

relation to Dumuzi/Damu/Ningešzida texts 85ff.; 179f.; 180f.

relation to "hymnic epics"

relation to Inana's Descent

$16 \mathrm{f}$.

172f.; 176

$11 ; 16 ; 85 f f . ; 164$; $\rightarrow$ Urnamma A, relation to city laments

relation to Two Elegies

structure, division

Susa variations

typology

$16 ; 85 ; 166$

$93 \mathrm{ff}$.

$144 \mathrm{ff}$.

$16 \mathrm{f}$.

$14 ; 19$

$\rightarrow$ structure, division

72

$26 ; 186$

69ff.; 83f.

70f.; 83f.; 183ff.

14

$10 ; 19 f$.

37ff.; 51 ; $\rightarrow$ structure, division

relation to other hymns/compositions

15; 38f.; 41f.; 66ff.; 72f.; 81f.; $223 \mathrm{f}$. 
structure, division typology

Urnamma D

content

date

manuscripts

recensions

relation to balbales

structure, division

typology

Urnamma EF

function

manuscripts

recensions

relation to divine hymns

relation to balaĝ-, eršema-songs

structure, division

typology

Urnamma G

manuscript

structure

Urnamma $\mathrm{H}$

wall construction

year names
73; $204 \mathrm{ff}$.

15

$11 ; 20 ; 68$

$\rightarrow$ structure, division

231

$230 f$.

75; 228ff.; 230ff.; 257

15; 74ff.; 231; 256f.

$74 ; 228 \mathrm{ff}$.

14f.; 74

20f.; 68

$77 ; 263$

$264 f$.

260; 264f.; 288

$77 ; 262$

$77 ; 262$; $\rightarrow$ balaĝ-, eršema-songs; $\rightarrow$ širnamšub (compositions)

$263 f$.

14

15 , fn. $26 ; 21 ; 37 ; 63 ; 74$

290

$290 f$.

$21 ; 297$

$33 ; 36 ; 176 ; 226$

5, and fn. 37; 7; 10;36; 37f.; 39f.; 64; $176 ; 226$ 


\section{SELECTIVE B IBLIOGR APH Y}
F. Al-Rawi,
"En-Urigal: Another Canal Dug by Ur-Nammu", Sumer 46 (1989-1990) 84f. cf. A. Cavigneaux.
B. Alster, "Sumerian Love Songs", RA 79 (1985) 127-59.
"The Manchester Tammuz", ASJ 14 (1992) 1-46.
"Some Ur III Literary Texts and Other Sumerian Texts in Yale and Philadelphia", ASJ 15 (1993) 1-10.
P. Attinger, Eléments de linguistique sumérienne, la construction de $d u_{11} / e / d i$ "dire", OBO Sonderband, Fribourg-Göttingen (1993).
cf. W. Sallaberger.
R.E. Averbeck,
A Preliminary Study of Ritual and Structure in the Cylinders of Gudea, Ph.D. Thesis The Dropsie College (1987).
M.-T. Barrelet, $\quad$ cf. M. Civil.
R.D. Biggs, cf. P. Steinkeller.
J. Black,
"Eme-sal Cult Songs and Prayers", Studies Civil (1991) 23-36.

J. Boese, W. Sallaberger, "Apil-kīn von Mari und die Könige der III. Dynastie von Ur", AoF 23 (1996) 24-39.

W. Burkert, cf. D.O. Edzard.

J.V. Canby,

"A Monumental Puzzle, Reconstructing the Ur-Nammu Stele", Expedition 29/1 (1987) 54-64.

F. Carroué,

"Etudes de Géographie et de Topographie III, L'Iturungal et le Sud Sumérien", ASJ 15 (1993) 7-69.

"La Situation Chronologique de Lagaš II, Un Élément du Dossier", ASJ 16 (1994) 47-75.

"Lagaš II et Nippur", ASJ 17 (1995) 41-74.

G. Castellino, "Urnammu, Three Religious Texts", ZA 52 (N.F. 18) (1957) 1-57.

"Urnammu, Three Religious Texts", ZA 53 (N.F. 19) (1959) 106-32.
A. Cavigneaux,
A. Cavigneaux, F. Al-Rawi,
D. Charpin, "Notes Sumérologiques", ASJ 9 (1987) 45-66. "New Sumerian Literary Texts from Tell Haddad (Ancient Meturan): A First Survey", Iraq 55 (1993) 91-105. Le Clergé d'Ur au siècle d'Hammurabi, Paris-Genève (1986). 
E. Chiera,

M. Civil,

M.E. Cohen,

J.S. Cooper,

J.J.A. v. Dijk,

J.-M. Durand,

D.O. Edzard,
"Critical Notes, Corrections to Langdon's 'Sumerian Liturgical Texts"', ASJL 36 (1919/29) 236-38 (Text 6).

"Un nouveau synchronisme Mari - IIIe dynastie d'Ur", $R A$ 56 (1962) 213.

"On Some Texts Mentioning Urnamma", Or. 54 (1985) 27-45.

"Les limites de l'information textuelle", in M.-T. Barrelet (ed.), L'archéologie de l'Iraq: Perspectives et limites de l'interprétation anthropologique des documents, Paris (1980) 225-32 (Colloques internationaux du C.N.R.S., no. $580)$.

"Literary Text About Ur-Namma", AulOr. 14 (1996) 16367.

"The Incantation-Hymn: Incantation or Hymn?", JAOS 95 (1975) 592-611.

Sumerian Hymnology: The Eršemma, HUCA Suppl. 2, Cincinnati (1981).

The Curse of Agade, The Johns Hopkins Near Eastern Studies, Baltimore-London (1983).

Sumerian and Akkadian Royal Inscriptions, Presargonic Inscriptions, AOS Translation Series vol. I, New Haven, Connecticut (1986).

"Sacred Marriage and Popular Cult in Early Mesopotamia", in E. Matsushima (ed.), Official Cult and Popular Religion in the Ancient Near East, Heidelberg (1993) 81-96.

"Paradigm and Propaganda, The Dynasty of Akkade in the 21 st Century", in M. Liverani (ed.), Akkad, the First World Empire: Structure, Ideology, Tradition, History of the Ancient Near East 5, Padua (1993) 11-23.

Sumerische Götterlieder, 2. Teil, AHAW Phil.-hist. Klasse 1960/1, Heidelberg (1960).

"Note on Si 277, a Tablet of the 'Urnammu Codex"', Or. 52 (1983) 457.

"La situation historique des Šakkanakku: nouvelle approche", M.A.R.I. 4 (1985) 147-72.

Die 'Zweite Zwischenzeit' Babyloniens, Wiesbaden (1957). RlA 6 (1980-83) 59-65, s.v. "Königsinschriften, A. Sumerisch".

"Gilgameš und Huwawa A. I. Teil", ZA 80 (1991) 165203.

"Gilgameš und Huwawa A. II. Teil", ZA 81 (1992) 165233. 

A. Falkenstein,
J.J. Finkelstein,
S. Franke,

D.R. Frayne,

M.J. Geller,

McG. Gibson, J.-J. Glassner,
"Sumerische und akkadische Hymnen", in W. Burkert, F. Stolz (eds.), Hymnen der Alten Welt im Kulturvergleich, OBO 131, Fribourg-Göttingen (1994) 19-31.

Sumerische Götterlieder, 1. Teil, AHAW Phil.-hist. Klasse 1959/1, Heidelberg (1959).

in S.N. Kramer, Or. 23 (1954) 49-51 (Appendix).

"The Laws of Ur-Nammu", JCS 22 (1968/69) 66-82.

"The Laws of Ur-Nammu", ANET3 (1969) 523-25.

Königsinschriften und Königsideologie, Die Könige von Akkade zwischen Tradition und Neuerung, Altorientalistik Band 1, Hamburg (1995).

The Historical Correlations of the Sumerian Royal Hymns (2400-1900 B.C.), Ph.D. Thesis Yale University (1981).

"Notes on the Sacred Marriage Rite", BiOr. 42 (1985) 522.

Royal Inscriptions of Mesopotamia, Early Periods (= RIME), vol. 4: Old Babylonian Period (2003-1595 BC), Toronto-Buffalo-London (1990).

Book review of R. Kutscher, The Brockmon Tablets of the University of Haifa, Royal Inscriptions, Haifa, Wiesbaden (1989), in BiOr. 48 (1991) 378-409.

The Early Dynastic List of Geographical Names, AOS 74, New Haven, Connecticut (1992).

Royal Inscriptions of Mesopotamia, Early Periods (= RIME), vol. 2: Sargonic and Gutian Periods (2334-2113 $B C)$, Toronto-Buffalo-London (1993).

Royal Inscriptions of Mesopotamia, Early Periods (= RIME), vol. 3/2: Ur III Period (2112-2004 B.C.), TorontoBuffalo-London (1997).

Book review of McG. Gibson, R.D. Biggs (eds.), The Organization of Power, Aspects of Bureaucracy in the Ancient Near East, SAOC 46, Chicago, Illinois (1987), in ZA 81 (1991) 144-46.

cf. P. Steinkeller.

Book review of P. Steinkeller, Sale Documents of the Ur III-Period, FAOS 17, Stuttgart (1989), in OLZ 88 (1993) 381-85.

Chroniques mésopotamiennes, Paris (1993).

"La fin d'Akkadē: approche chronologique", N.A.B.U. 1994/9.

O.R. Gurney, S.N. Kramer, "Two Fragments of Sumerian Laws", AS 16 (1965) 13-19.

M.G. Hall,
A Study of the Sumerian Moon-God, Nanna/Suen, Ph.D. Thesis University of Pennsylvania (1985). 
W.W. Hallo,

B. Hrouda,

I. Kärki,

J. Klein,

S.N. Kramer,
Early Mesopotamian Royal Titles: A Philologic and Historical Analysis, AOS 43, New Haven, Connecticut (1957).

"The Coronation of Urnammu", JCS 20 (1966) 133-41.

"Individual Prayer in Sumerian: The Continuity of a Tradition", JAOS 88 (1968) 71-89.

"The Cultic Setting of Sumerian Poetry", CRRAI 17 (1970) 116-34.

"The Limits of Skepticism", JAOS 110 (1990) 187-99.

cf. C. Wilcke.

Die sumerischen und akkadischen Königsinschriften der altbabylonischen Zeit, I. Isin, Larsa, Uruk, StOr. 49, Helsinki (1980).

"The Royal Hymns of Shulgi, King of Ur: Man's Quest for Immortal Fame", TAPS $71 / 7$ (1981).

Three Šulgi Hymns, Sumerian Royal Hymns Glorifying King Šulgi of Ur, Bar-Ilan Studies in Near Eastern Languages and Cultures, Ramat Gan (1981).

"Šulgi and Išmedagan: Runners in the Service of the Gods (SRT 13)", Beer-Sheva 2 (1985) 7*-38*.

"Building and Dedication Hymns in Sumerian Literature", ASJ 11 (1989) 27-62.

"From Gudea to Šulgi: Continuity and Change in Sumer ian Literary Tradition", Studies Sjöberg (1989) 289-301.

"Šulgi and Išmedagan: Originality and Dependence in Sumerian Royal Hymnology", Studies Artzi (1990) 65-136.

"The Coronation and Consecration of Šulgi in the Ekur" (Šulgi G), Studies Tadmor (1991) 292-313.

"Urnammu Law Code", Or. 23 (1954) 40-51 (Pls. IV and V).

"The Death of Urnammu and His Descent to the Netherworld", JCS 21 (1967) 104-22.

"Corrections and Additions to SRT", ZA 52 (1957).

"Corrections to CBS 4560", in G. Castellino, ZA 52 (1957) 15-17.

"Sumerian Literature and the British Museum: The Promise of the Future", PAPS 124/4 (1980) 295-312.

"The Ur-Nammu Law Code: Who Was Its Author?", Or. 52 (1983) 453-56.

"The Death of Ur-Nammu", Studies Mikasa (1991) 193214.

"Ur-Nammu Hymn: Building of the Ekur and Blessing by Enlil", ANET3 (1959) $583 \mathrm{f}$.

cf. O.R. Gurney. 
F.R. Kraus,

J. Krecher,

R. Kutscher,

B. Lafont,

M. Lambert,

W.G. Lambert,

S. Langdon,

M. Liverani,

M.-C. Ludwig,

T. Maeda,

E. Matsushima,

P. Michalowski,

P. Michalowski,

C.B.F. Walker,

S.F. Monaco,

E. Quintana,

W.H.Ph. Römer,
"Zur Chronologie der Könige Ur-Nammu und Sulgi von Ur", Or. 20 (1951) 385-98.

"Provinzen des neusumerischen Reiches von Ur", ZA 51 (N.F. 17) (1955) 45-75.

Sumerische Kultlyrik, Wiesbaden (1966).

cf. D.R. Frayne.

Review of H. Steible, Die neusumerischen Bau- und Weihinschriften, FAOS 9/1-2, Stuttgart (1991), in BiOr. 50 (1993) 675-81.

"La Cité Sainte d'Our à l'époque d'Our III", Sumer 6 (1950) 149-64.

"The Akkadianization of Susiana under the Sukkalmahs", CRRAI 36, Ghent (1991) 53-57.

"Sumerian Liturgical Texts", PBS 10/2 (1917) 127-36.

cf. J.S. Cooper.

Untersuchungen zu den Hymnen des Išme-Dagan von Isin, SANTAG 2, Wiesbaden (1990).

"Two Rulers by the Name of Ur-Ningirsu in Pre-Ur III Lagash", ASJ 10 (1988) 19-35.

"The Defense Zone during the Rule of the Ur III Dynasty", ASJ 14 (1992) 135-72.

"Monaco's "Notes" on Pre-Ur III Lagaš Chronology" ASJ 15 (1993) 294-97.

cf. J.S. Cooper.

The Royal Correspondence of Ur, Ph.D. Thesis Yale University (1976).

"Royal Women of the Ur III Period - Part III", ASJ 4 (1982) 129-39.

"Mental Maps and Ideology: Reflections on Subartu", in H. Weiss (ed.), The Origins of Cities in Dry-Farming Syria and Mesopotamia in the Third Millennium B.C., Guilford, Connecticut (1986) 129-56.

"Sin-iddinam and Iškur", Sachs Memorial Vol. $=O P B F 9$, Philadelphia (1988) 265-75.

The Lamentation over the Destruction of Sumer and Ur, MC 3, Winona Lake, Indiana (1989).

"A New Sumerian 'Law Code'", Studies Sjöberg (1989) 383-96.

"Two Notes on ASJ 10, 1988", ASJ 12 (1990) 89-105.

"Nuevas consideraciones sobre la cronología de Gudea", N.A.B.U. $1997 / 71$.

Sumerische 'Königshymnen' der Isin-Zeit, Leiden (1965).

"Aus den Gesetzen des Königs Urnammu von Ur", TUAT V/, Gütersloh (1982) 17-23. 
M.T. Roth,

W. Sallaberger,

C. Saporetti,

H. Sauren,

Y. Sefati,

M. Sigrist, T. Gomi,

Å.W. Sjöberg,

Å.W. Sjöberg et al.,

E. Sollberger,
Law Collections from Mesopotamia and Asia Minor, SBL (Writings from the Ancient World Series) 6, Atlanta, Georgia (1995).

Der kultische Kalender der Ur III-Zeit, Teile 1-2, UAVA 7/1-2, Berlin, New York (1993).

"Urkunden aus der Zeit der Dritten Dynastie von Ur, eine Einführung", in P. Attinger, M. Wäfler (eds.), Mesopotamien, Akkade-Zeit und Ur III-Zeit, Annäherungen 3, OBO $\mathrm{XXX}$ (in preparation).

cf. J. Boese.

Le leggi della Mesopotamia, Tradotte dai testo originali, Studi e Manuali di Archeologia 2, Firenze (1984).

"Zur Datierung Gudeas von Lagaš", ZDMG Suppl. I/1 (1969) 115-29.

"The Nannagugal, A Frontier-Canal", ASJ 2 (1980) 14152.

"Trois tablettes d'une collection belge et le code d'Ur", OLP 20 (1989) 5-21.

Love-Songs in Sumerian Literature, A Critical Edition of the Dumuzi Inanna Songs, unpub. Ph.D. Thesis Bar-Ilan University, in Hebrew, Ramat Gan (1985). [cf. now the published form as "Love Songs in Sumerian Literature, Critical Edition of the Dumuzi-Inanna Songs, Bar-Ilan Studies in Near Eastern Languages and Culture, Ramat Gan (1998)].

The Comprehensive Catalogue of Published Ur III Tablets, Bethesda (1991).

Der Mondgott Nanna-Suen in der sumerischen Überlieferung, I. Teil: Texte, Stockholm (1960).

"Ein syllabisch geschriebener Urnammu-Text", OrSuec 10 (1961) 3-12.

"Die göttliche Abstammung der sumerisch-babylonischen Herrscher", OrSuec 21 (1972) 87-112.

"The Ape from the Mountain who Became the King of Isin", Studies Hallo (1993) 211-20.

The Sumerian Dictionary of the University Museum of the University of Pennsylvania, Volumes B, Philadelphia (1984), A/I, Philadelphia (1992) and A/II, Philadelphia (1994).

"Sur la chronologie des rois d'Ur et quelques problèmes connexes", AfO 17 (1954-56) 10-48.

"Ladies of the Ur III Empire", RA 61 (1967) 69f. 
H. Steible,

Die neusumerischen Bau- und Weihinschriften, Teil 1: Inschriften der II. Dynastie von Lagaš, FAOS 9/1, Stuttgart (1991).

Die neusumerischen Bau- und Weihinschriften, Teil 2: Kommentar zu den Gudea-Statuen, Inschriften der III. Dynastie von Ur, Inschriften der IV. und "V." Dynastie von Uruk, Varia, FAOS 9/2, Stuttgart (1991).

H. Steible, H. Behrens, Die altsumserischen Bau-und Weihinschriften, Teil 1: Inschriften aus 'Lagaš'; Teil 2: Kommentar zu den Inschriften aus 'Lagaš', Inschriften ausserhalb von 'Lagaš', FAOS 5, Wiesbaden (1982).

Glossar zu den altsumerischen Bau-und Weihinschriften, FAOS 6, Wiesbaden (1983).

G. Steiner, "Nippur und die sumerische Königsliste", CRRAI 35, Philadelphia (1992) 261-79.

P. Steinkeller, "On the Reading and Location of the Toponyms ÚR $\times$ Ú.KI and A.HA.KI", JCS 32 (1980) 23-33.

"More on the Ur III Royal Wives", ASJ 3 (1981) 77-92.

"The Administrative and Economic Organization of the Ur III State: The Core and the Periphery", in McG. Gibson, R.D. Biggs (eds.), The Organization of Power, Aspects of Bureaucracy in the Ancient Near East, SAOC 46, Chicago, Illinois (1987) 19-41.

"The Date of Gudea and his Dynasty", JCS 40 (1988) 4753.

F. Stolz, cf. D.O. Edzard.

S. Tinney,

F. Vallat, K. Volk,

M. Wäfler, H. Waetzoldt,

C.B.F. Walker, "On the Poetry for King Išme-Dagan", OLZ 90 (1995) 526.

The Nippur Lament, Royal Rhetoric and Divine Legitimation in the Reign of Išme-Dagan of Isin (19531935 B.C.), Occasional Publications of the Samuel Noah Kramer Fund 16, Philadelphia (1996).

"La date du règne de Gudea", N.A.B.U. 1997/37.

Die Balaĝ-Komposition úru-àm-ma-ir-ra-bi, Rekonstruktion und Bearbeitung der Tafeln 18 (19'ff.), 19, 20 und 21 der späten, kanonischen Version, FAOS 18, Stuttgart (1989).

cf. W. Sallaberger.

"Zu einigen Jahresdaten Urnammus", N.A.B.U. 1990/6.

Book review of McG. Gibson, R.D. Biggs (eds.), The Organization of Power, Aspects of Bureaucracy in the Ancient Near East, SAOC 46, Chicago, Illinois (1987), in JAOS 111 (1991) 637-41.

cf. P. Michalowski. 
H. Weiss,

C. Wilcke,

I.J. Winter,

F. Yildiz, cf. P. Michalowski.

"Eine Schicksalsentscheidung für den toten Urnammu", CRRAI 17, Ham-sur-Heure (1970) 81-92.

"Drei Phasen des Niedergangs des Reiches von Ur III", ZA 60 (1970) 54-69.

Urnammus Tod, Tod und Bestattung eines Königs in neusumerischer Zeit, unpub. Habilitationsschrift (1972).

RlA 4 (1972-75) 539-44, s.v. "Hymne, A. Nach sumerischen Quellen".

"Zum Königtum in der Ur III-Zeit", CRRAI 19, Paris (1974) 177-232.

"Formale Gesichtspunkte in der Sumerischen Literatur", AS 20 (1975) 205-316.

Kollationen zu den sumerischen literarischen Texten aus Nippur in der Hilprecht-Sammlung Jena, ASAW Phil.hist. Klasse 65/4 (1976).

Kindlers Literatur Lexikon im dtv, Band 10 (1986) 90999100, s.v. "Sumerische Königshymnen".

Die Inschriftenfunde der 7. und 8. Kampagne, in B. Hrouda (ed.), Isin-Išān Baḥrīyāt III, Die Ergebnisse der Ausgrabungen 1983-84, ABAW NF 94, München (1987) 10811.

"Die Sumerische Königsliste und erzählte Vergangenheit", in J. v. Ungern-Sternberg, H. Reinau (eds.), Vergangenheit in mündlicher Überlieferung, Colloquium Rauricum 1, Stuttgart (1988) 113-40.

"Genealogical and Geographical Thought in the Sumerian King List", Studies Sjöberg (1989) 557-69.

"Politik im Spiegel der Literatur, Literatur als Mittel der Politik im älteren Babylonien", in K. Raaflaub (ed.), Anfänge politischen Denkens in der Antike, die nahöstlichen Kulturen und die Griechen, Schriften des Historischen Kollegs, Kolloquien 24, München (1993) 2975.

"'Idols of the King': Royal Images as Recipients of Ritual Action in Ancient Mesopotamia", Journal of Ritual Studies 9 (1992) 13-42.

"A Tablet of Codex Ur-Nammu from Sippar", Or. 50 (1981) 87-97 (Pls. II-IV). 
A P P EN DIX

Ni. $4375=$ ISET $1(1969 / 71)$ p. 177 (no. 119)

Transliteration and Translation

\begin{tabular}{|c|c|c|c|}
\hline iv & $1^{\prime}$ & $r_{x}^{\urcorner}[\ldots]$ & $\ldots[\ldots]$ \\
\hline iv & $2^{\prime}$ & d[ur-dnamma] & [ I? Urnamma], \\
\hline iv & $3^{\prime}$ & lugal $[\ldots]$ & the king $[\ldots]$, \\
\hline iv & $4^{\prime}$ & gu-ti-[umki $(\ldots)]$ & made the Guti $[(\ldots)]$, \\
\hline iv & $5^{\prime}$ & $\mathrm{lu}_{2}$ hul!!-[gal $\left.{ }_{2} ?(\ldots)\right]$ & the evil ones $[(\ldots)]$ \\
\hline iv & $6^{\prime}$ & kur- ${ }^{-} a^{?}$ im-m[i-ge $\left.{ }_{4}\right]$ & [return] to their? country. \\
\hline iv & $7^{\prime}$ & en lugal $[\ldots]$ & e $\mathrm{n}$ and king $[\ldots]$ \\
\hline iv & $8^{\prime}$ & 「x?-bi $[\ldots]$ & {$[\ldots]$ its $[\ldots]$} \\
\hline iv & $9^{\prime}$ & $\mathrm{ga}_{2}$-la nu-[dag-ge (...)] & ince $[\operatorname{ssant}(1 y)(\ldots)]$ \\
\hline iv & $10^{\prime}$ & $\mathrm{d} u[\mathrm{r}-\mathrm{d}$ namma $]$ & I? U[rnamma] \\
\hline iv & $11^{\prime}$ & nam-luga[1...] & [...] kingship, \\
\hline iv & $12^{\prime}$ & numun na[m-en-na (...)] & the offspring of [e n-shi]p. \\
\hline iv & $13^{\prime}$ & $\operatorname{ur}\left[\mathrm{i}_{2} / 5 \mathrm{ki}_{\ldots} ..\right]$ & {$[\ldots]$ Ur $[\ldots]$} \\
\hline iv & $14^{\prime}$ & $\operatorname{bad}_{3}\ulcorner x\urcorner[\ldots]$ & {$[\ldots]$ the wall. } \\
\hline iv & $15^{\prime}$ & $A N\ulcorner x\urcorner[\ldots]$ & $\ldots[\ldots]$ \\
\hline iv & $16^{\prime}$ & $\Gamma_{\mathrm{X}}(\mathrm{x}){ }^{\urcorner}[\ldots]$ & $\ldots[\ldots]$ \\
\hline iv & $17^{\prime} \mathrm{ff}$. & {$[\ldots]$} & {$[\ldots]$} \\
\hline $\mathrm{v}$ & $1^{\prime}$ & {$\left[\ldots \mathrm{d}_{\mathrm{u}}\right] \mathrm{r}-\mathrm{Cd}_{\text {namma }}{ }^{\top}$} & [... I Ur]namma \\
\hline $\mathrm{V}$ & $2^{\prime}$ & $\ulcorner\mathrm{x} x\urcorner$ nam-en-ni & . . . put verily his/her \\
\hline $\mathrm{v}$ & $3^{\prime}$ & šu he $e_{2}-b i_{2}-d u_{7}$ & e n-ship in full force. \\
\hline $\mathrm{v}$ & $4^{\prime}$ & nam(-)tar-ra $\Gamma_{x} x^{\urcorner}-n i ?$ & Decreed fate . . . \\
\hline $\mathrm{v}$ & $5^{\prime}$ & $e_{2}-k i s ̌-\left[n u-g a_{2}\right]-l ?$ & in? the Ekiš[nuĝal]. \\
\hline $\mathrm{v}$ & $6^{\prime}$ & $\left.\mathrm{ge}_{26}-\mathrm{e}\left\ulcorner_{\mathrm{X}}\right\urcorner[\ldots]{ }^{\prime} \mathrm{x}\right\urcorner$ & It is me who $[\ldots]$ \\
\hline $\mathrm{v}$ & $7^{\prime}$ & $\ulcorner\mathrm{UN}\urcorner[\ldots]\ulcorner\mathrm{x}\urcorner$ & $\ldots[\ldots] \ldots$ \\
\hline $\mathrm{v}$ & $8^{\prime}$ & IGI $[\ldots]\left\ulcorner x{ }^{\prime}\right\urcorner$ & $\ldots[\ldots] \ldots$ \\
\hline $\mathrm{v}$ & $9^{\prime}$ & $\left\lceil\right.$ lugal $[\ldots \mathrm{g}] \mathrm{al}_{2} ? \mathrm{AK}$ & The king, making? [...]. \\
\hline $\mathrm{v}$ & $10^{\prime}$ & mu- $\left.{ }^{\circ} \mathrm{gu}_{10}\right\urcorner[\ldots]$ peš-a & My reputation which ... [...], \\
\hline $\mathrm{v}$ & $11^{\prime}$ & dur-dnamma & I, Urnamma, \\
\hline $\mathrm{v}$ & $12^{\prime}$ & in-dub ki-en-gi-ra & when I had confirmed \\
\hline $\mathrm{v}$ & $13^{\prime}$ & $\mathrm{KA}$ ba?!(ZU)-ge-na-ba & the (border) territory of Sumer, \\
\hline $\mathrm{v}$ & $14^{\prime}$ & {$[\ldots]{ }^{\ulcorner} \times x \times(x)^{\top \mathrm{ki}}-\mathrm{a}-\mathrm{ke}_{4}$} & {$[\ldots] \ldots$} \\
\hline $\mathrm{v}$ & $15^{\prime} \mathrm{ff}$. & {$[\ldots]$} & {$[\ldots]$} \\
\hline vi & $1^{\prime}$ & {$[\ldots]^{\ulcorner} x^{\urcorner}$} & {$[\ldots]$. } \\
\hline
\end{tabular}




\begin{tabular}{|c|c|c|c|}
\hline vi & $2^{\prime}$ & {$[\ldots]{ }^{\ulcorner} x^{\urcorner}$} & {$[\ldots] \ldots$} \\
\hline vi & $3^{\prime}$ & {$[\ldots]\ulcorner x\urcorner$} & {$[\ldots] \ldots$} \\
\hline vi & $4^{\prime}$ & {$[\ldots]-\ulcorner a ?-m e-\ulcorner e n\urcorner$} & {$[\ldots]$ am I. } \\
\hline vi & $5^{\prime}$ & {$[\ldots]-\mathrm{ba}$} & {$[\ldots] \ldots$} \\
\hline vi & $6^{\prime}$ & {$[\ldots]-\mathrm{du}_{10} ?$-me-en } & {$[\ldots]$ sweet? $[\ldots]$ am I. } \\
\hline $\mathrm{vi}$ & $7^{\prime}$ & {$\left[\ldots d_{\text {ur }}\right]-\left\ulcorner{ }_{\text {namma }}\right.$} & {$[\ldots U r] n a m m a$} \\
\hline vi & $8^{\prime}$ & [... ki]-en-gi-ra & {$[\ldots$ of? Su $]$ mer } \\
\hline vi & $9^{\prime}$ & {$[\ldots]-\ulcorner x\urcorner-m e-e n$} & {$[\ldots]$ am I. } \\
\hline vi & $10^{\prime}$ & {$[\ldots]{ }^{\ulcorner} x^{\urcorner}-d a$} & {$[\ldots] \ldots$} \\
\hline vi & $11^{\prime}$ & {$[\ldots-\mathrm{me}]-\ulcorner\mathrm{en}\urcorner$} & {$[\ldots$ am $] \mathrm{I}$.} \\
\hline
\end{tabular}


P L A TES 

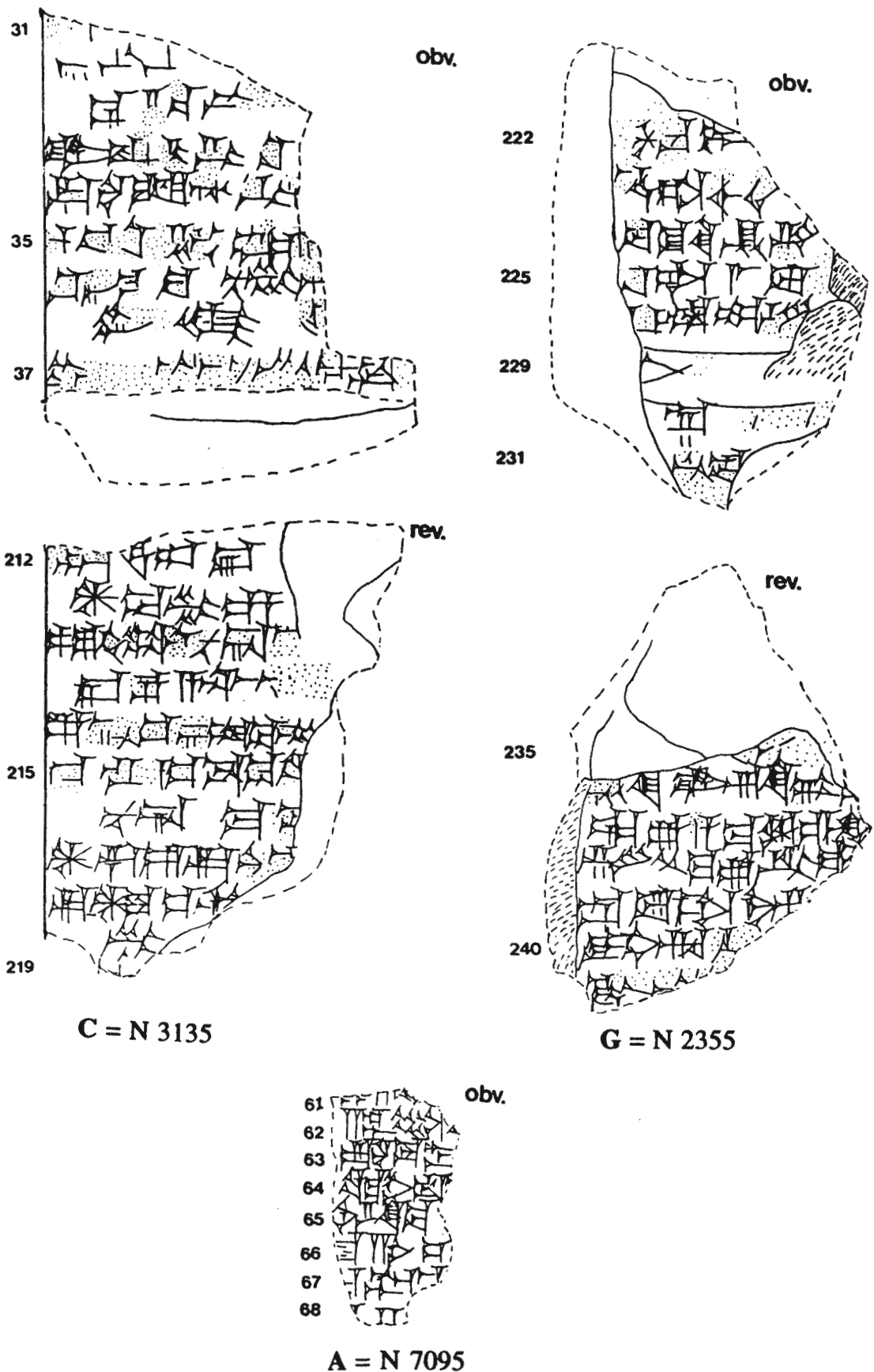

1.

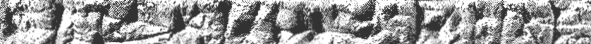

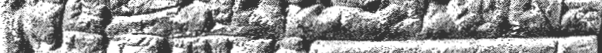

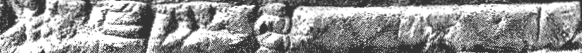
2.5.

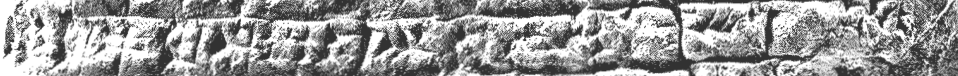

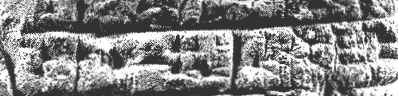

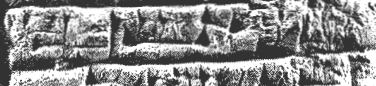
7. 1.

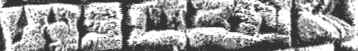

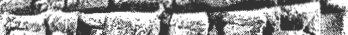

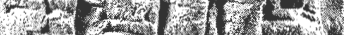

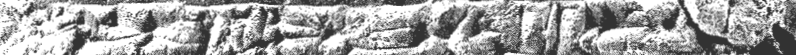

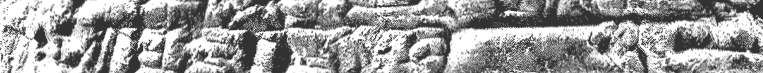

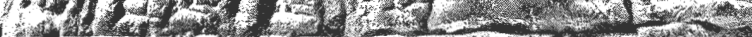
W

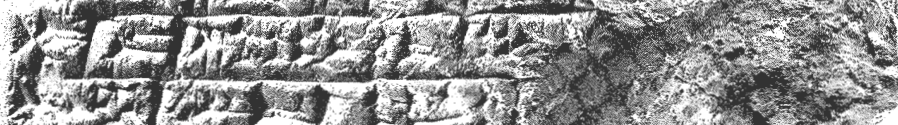

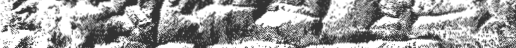

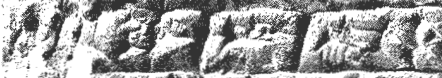

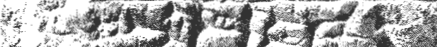

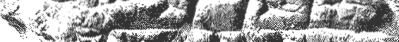

(3)

$x^{2}$

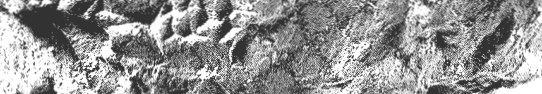

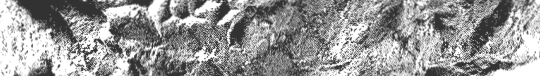

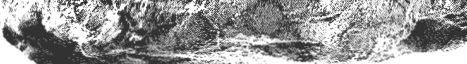

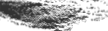

$\mathbf{S b}_{\mathbf{1}}=\mathrm{Sb}$ 12363, obverse 


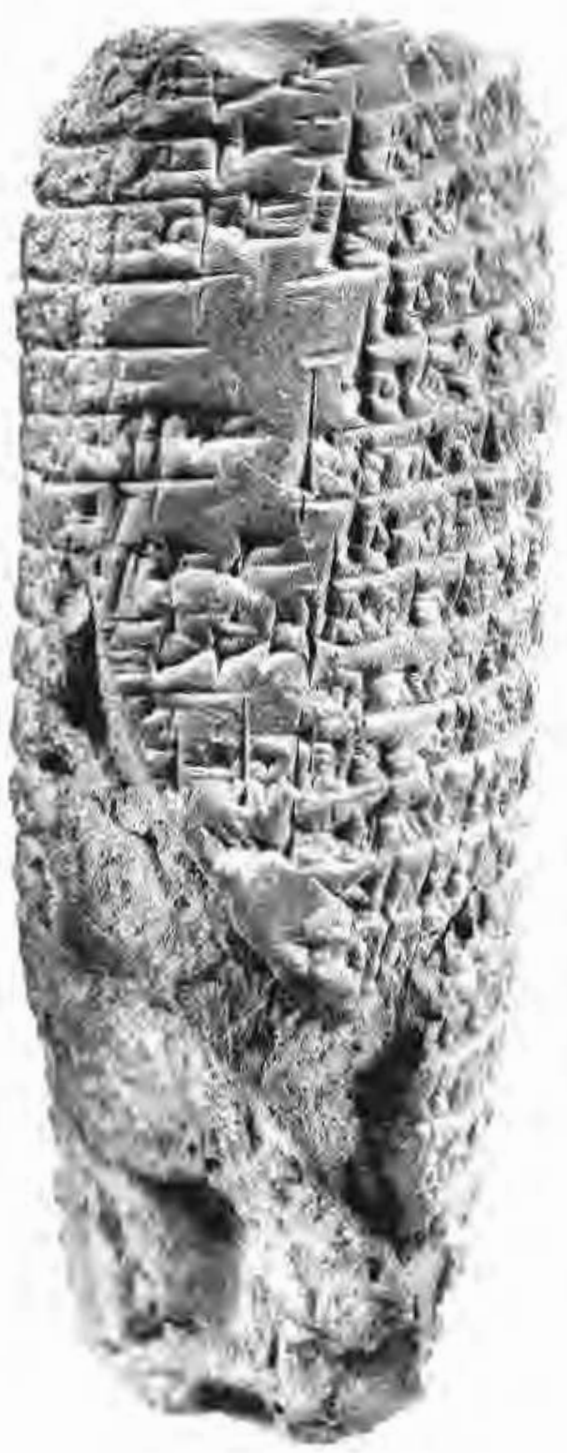

$$
\mathbf{S b}_{1}=\text { Sb 12363, edge }
$$




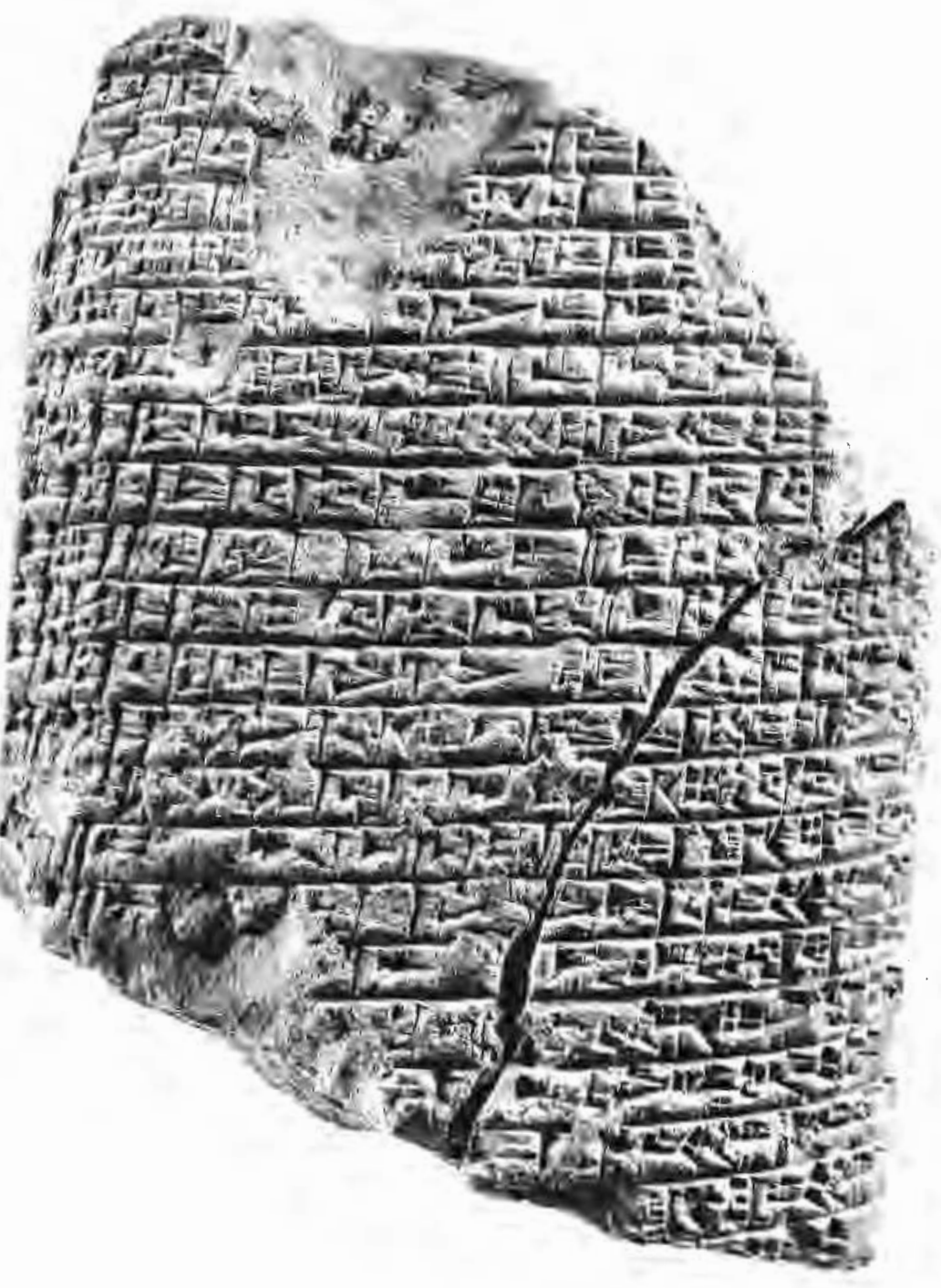

$\mathbf{S b}_{1}=\mathbf{S b} 12363$, reverse 
Susa Version

Plate 5

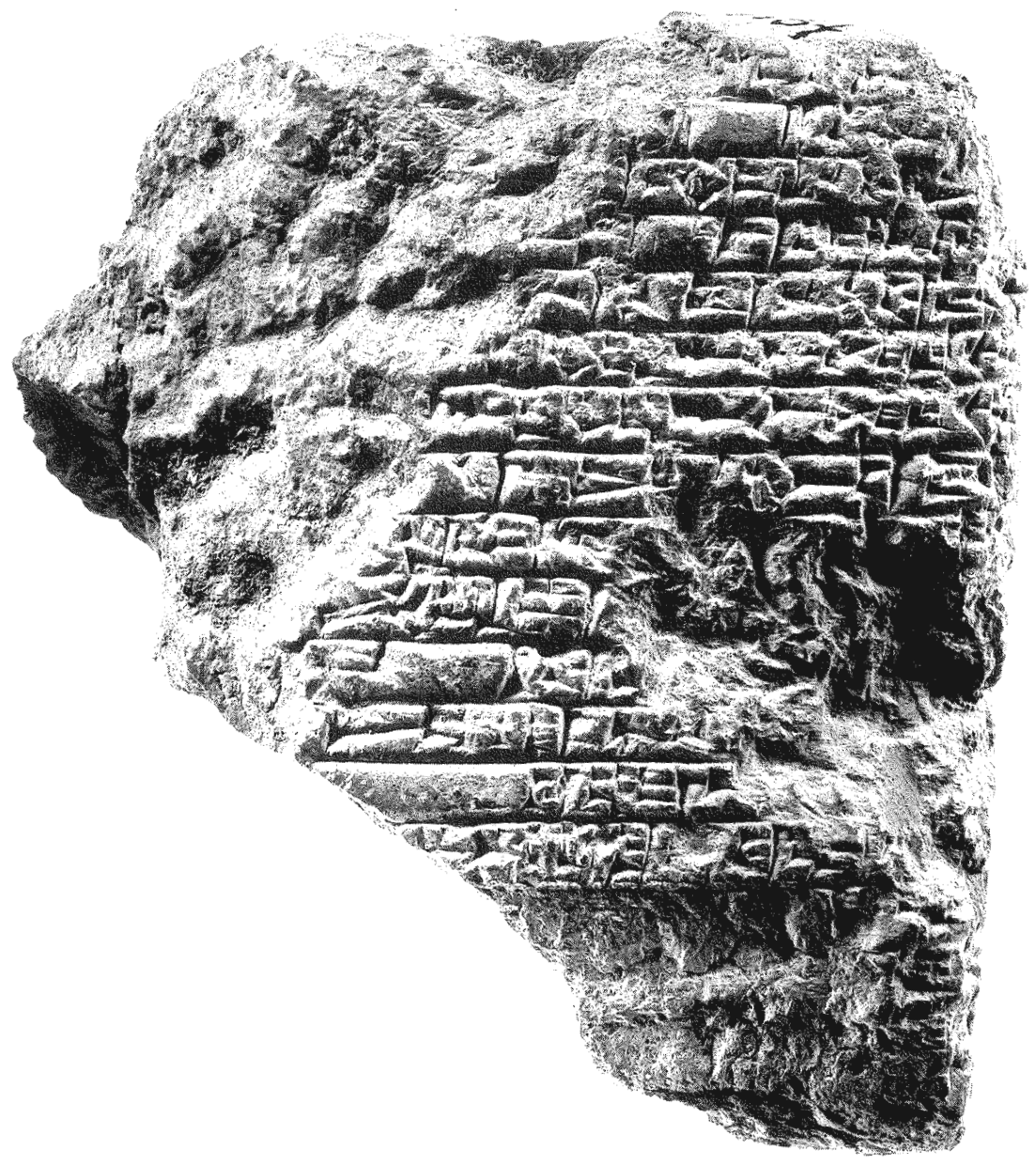

$\mathbf{S b}_{\mathbf{2}}=\mathbf{S b} 14137$, obverse 


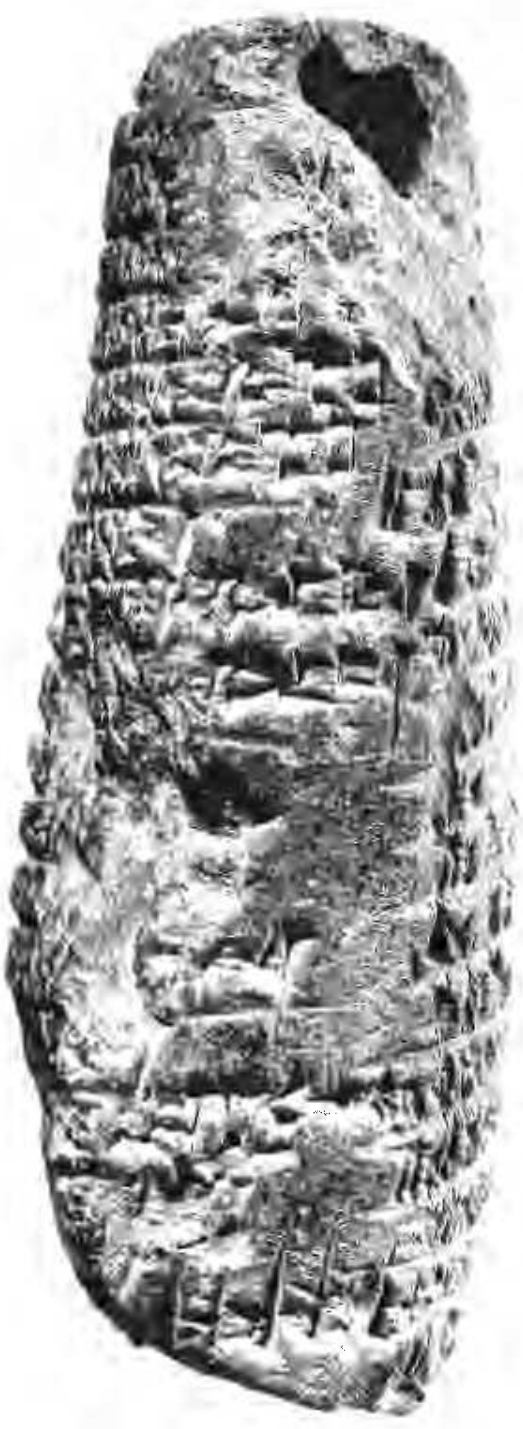

$\mathbf{S b}_{2}=$ Sb 14137, edge 


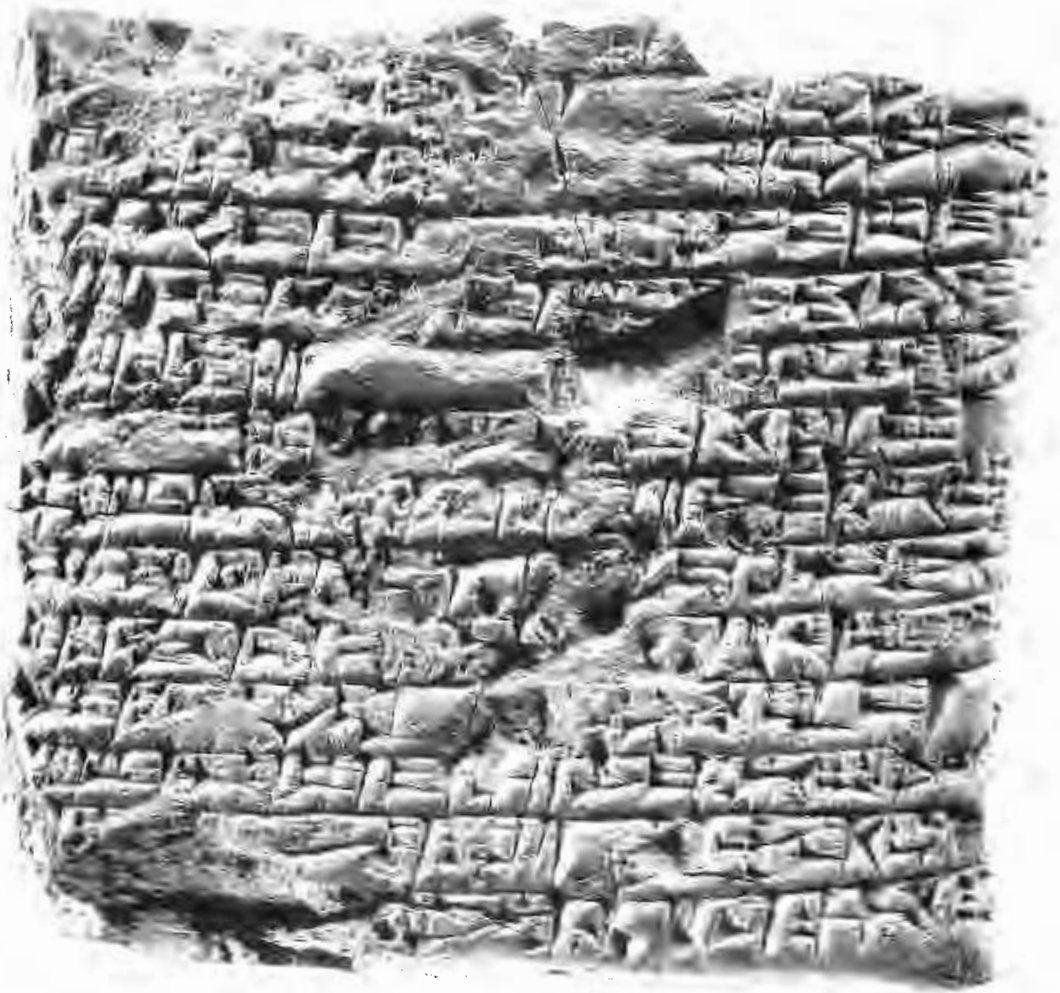

$\mathbf{S b}_{2}=\mathbf{S b} 14083$, obverse 


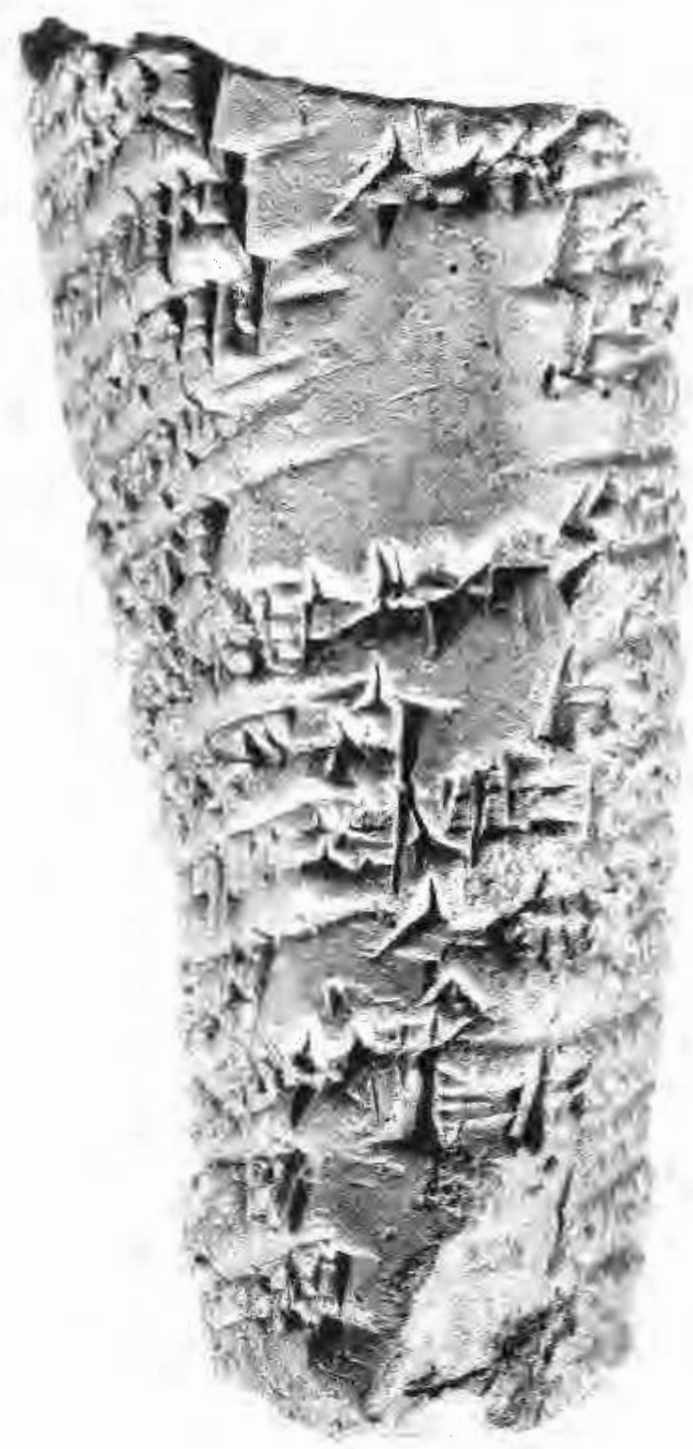

$\mathbf{S b}_{2}=\mathrm{Sb} 14083$, edge 
Susa Version

Plate 9

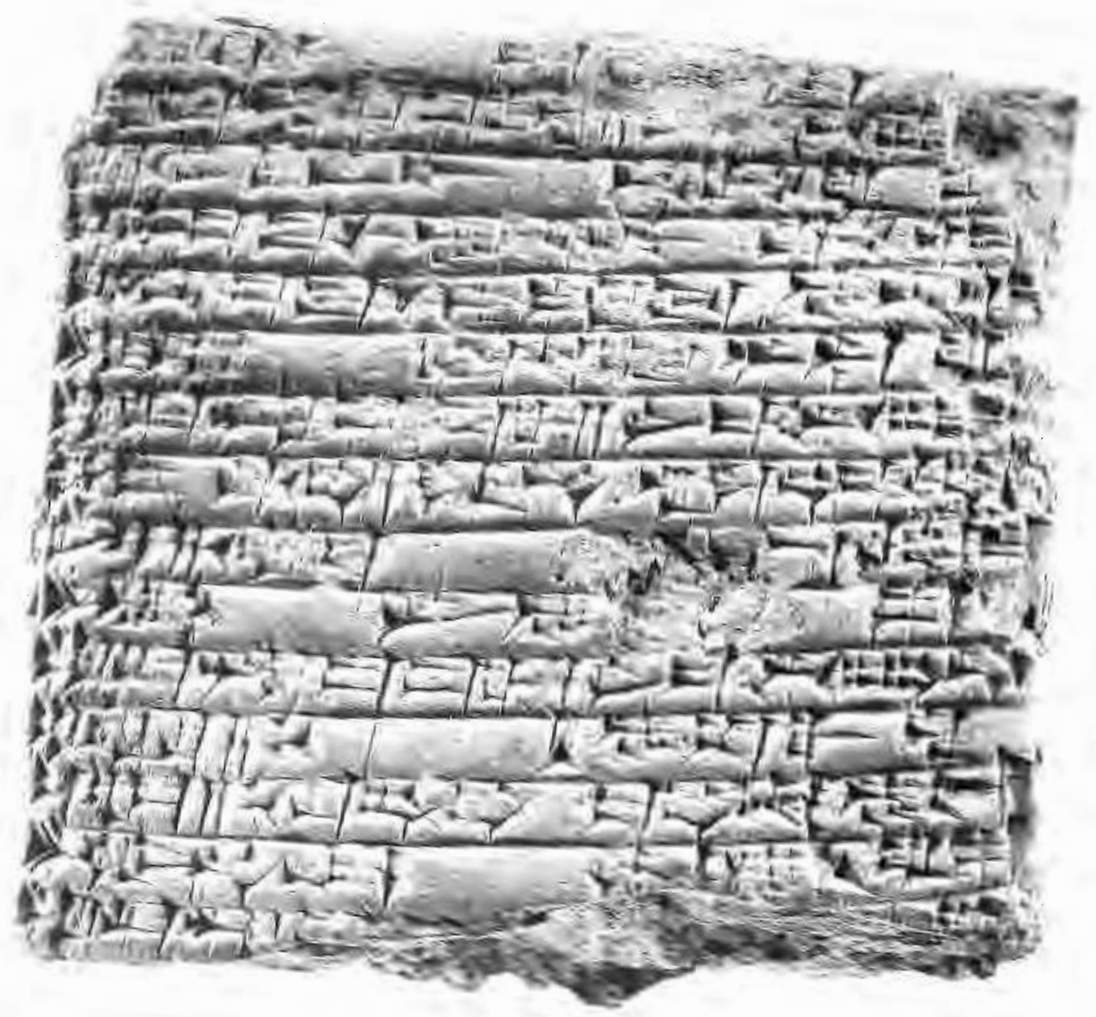

$S b_{2}=S b$ 14083, reverse 
Plate 10

\section{Susa Version}

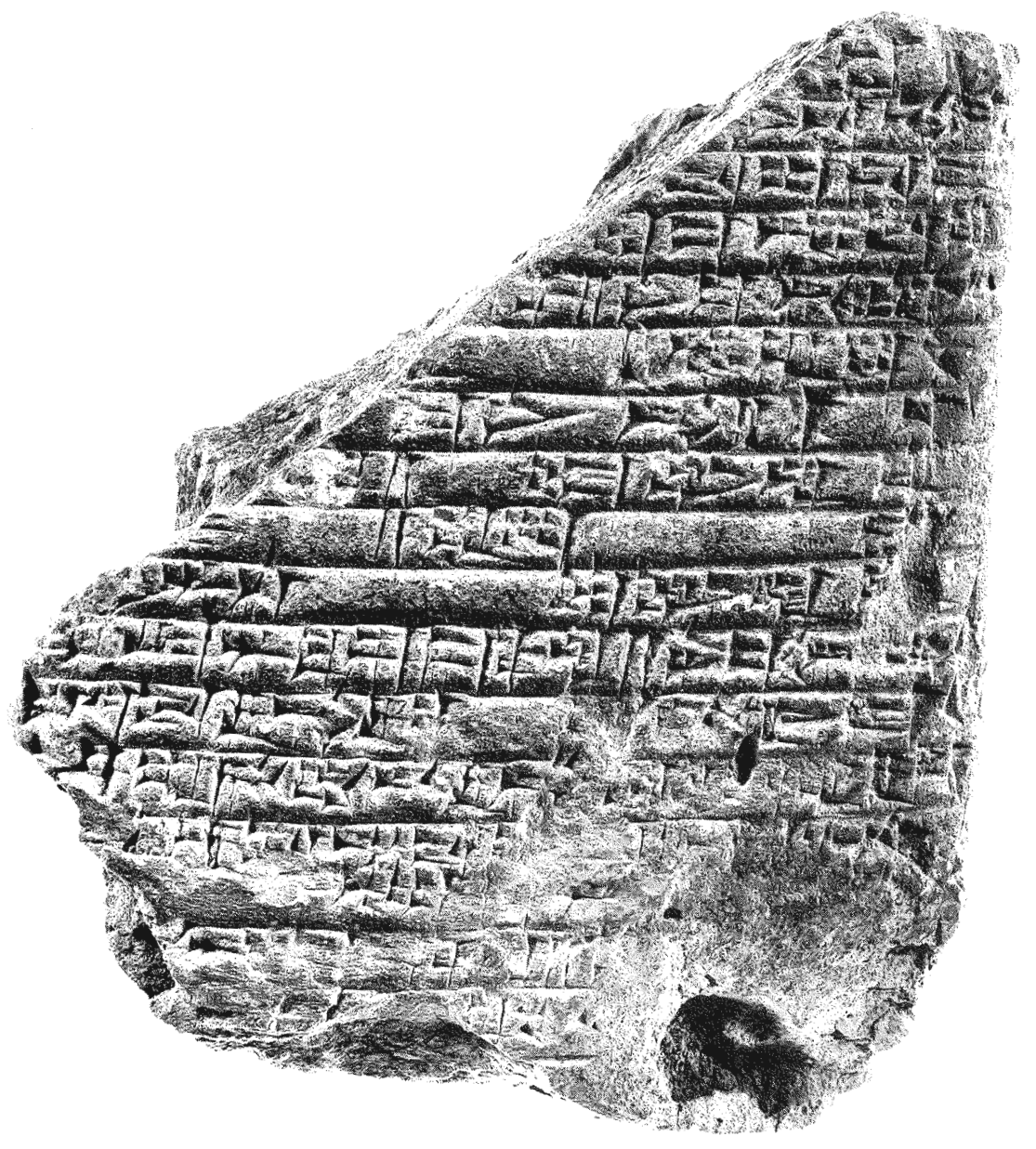

$\mathbf{S b}_{2}=\mathrm{Sb} 14137$, reverse 


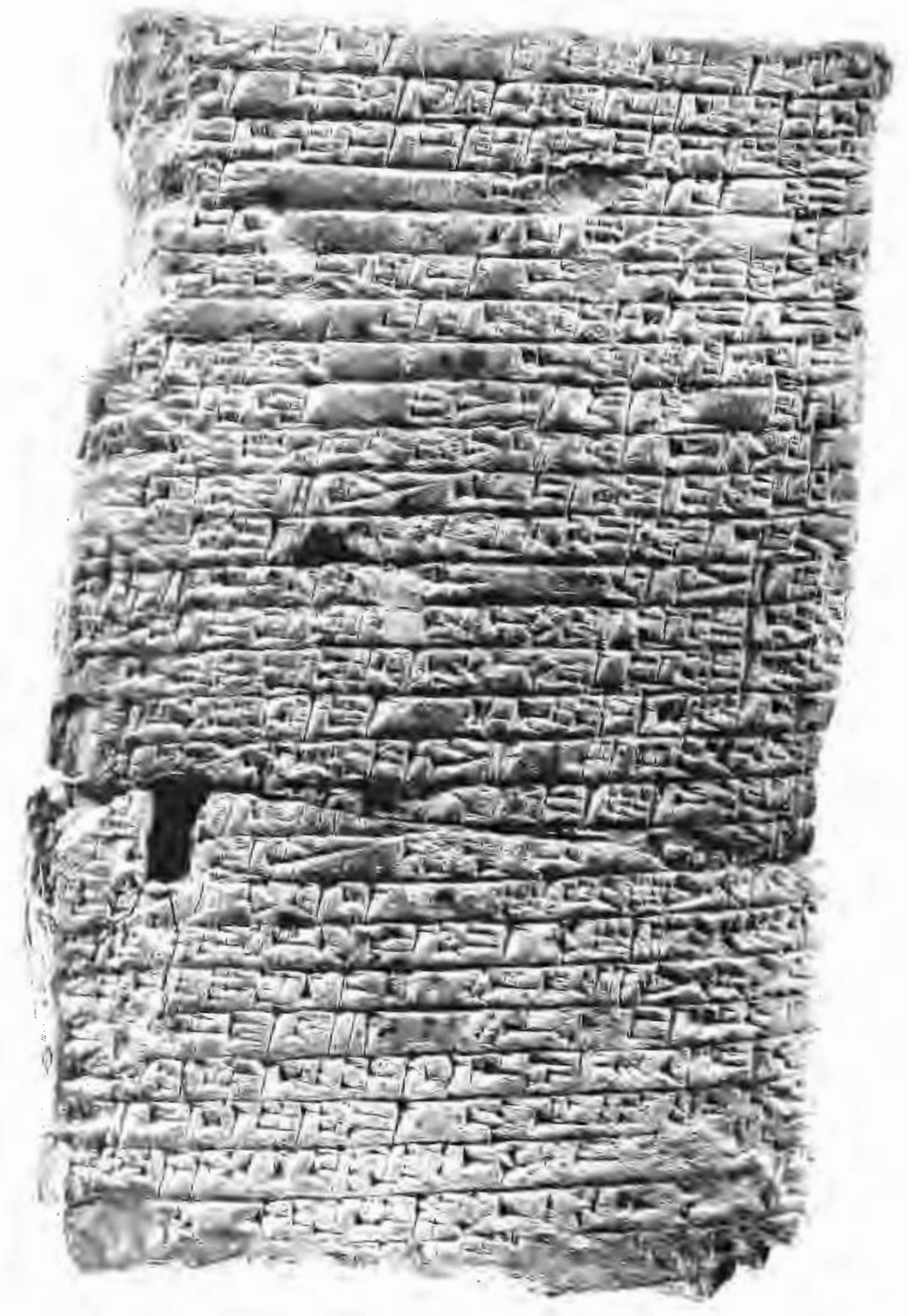

$\mathbf{S b}_{\mathbf{3}}=\mathbf{S b} 12358+$ Sb 12362, obverse 


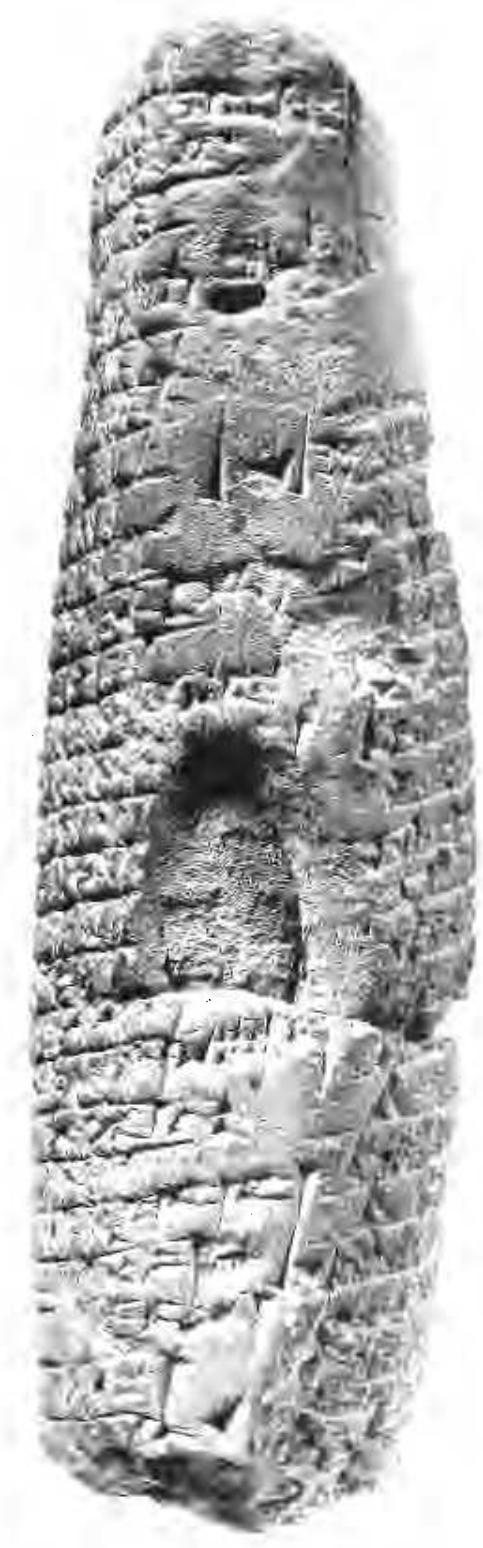

$\mathbf{S b}_{\mathbf{3}}=\mathrm{Sb} 12358+\mathrm{Sb} 12362$, edge 


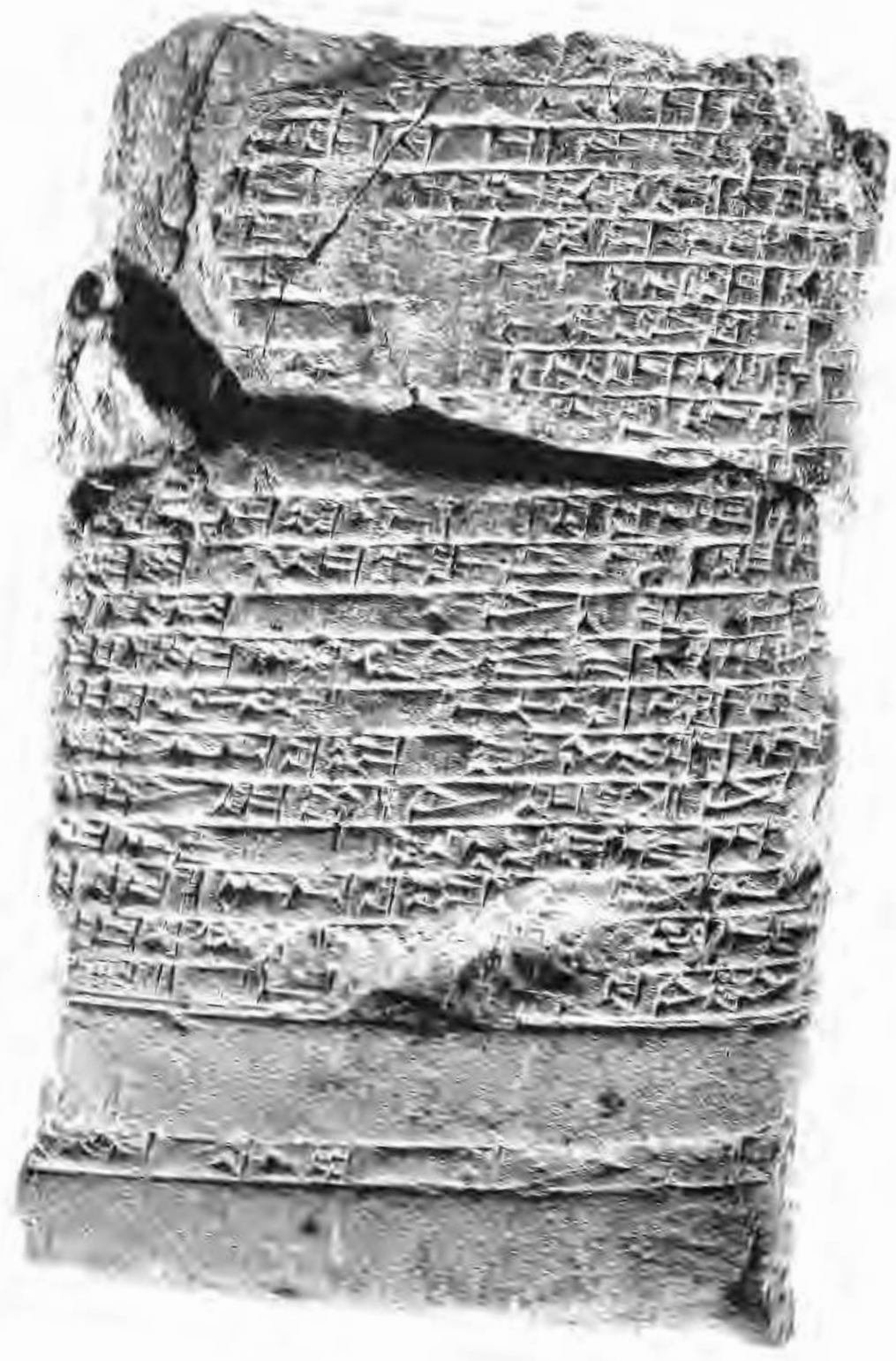

$\mathbf{S b}_{\mathbf{3}}=\mathrm{Sb} 12358+\mathrm{Sb} 12362$, reverse 


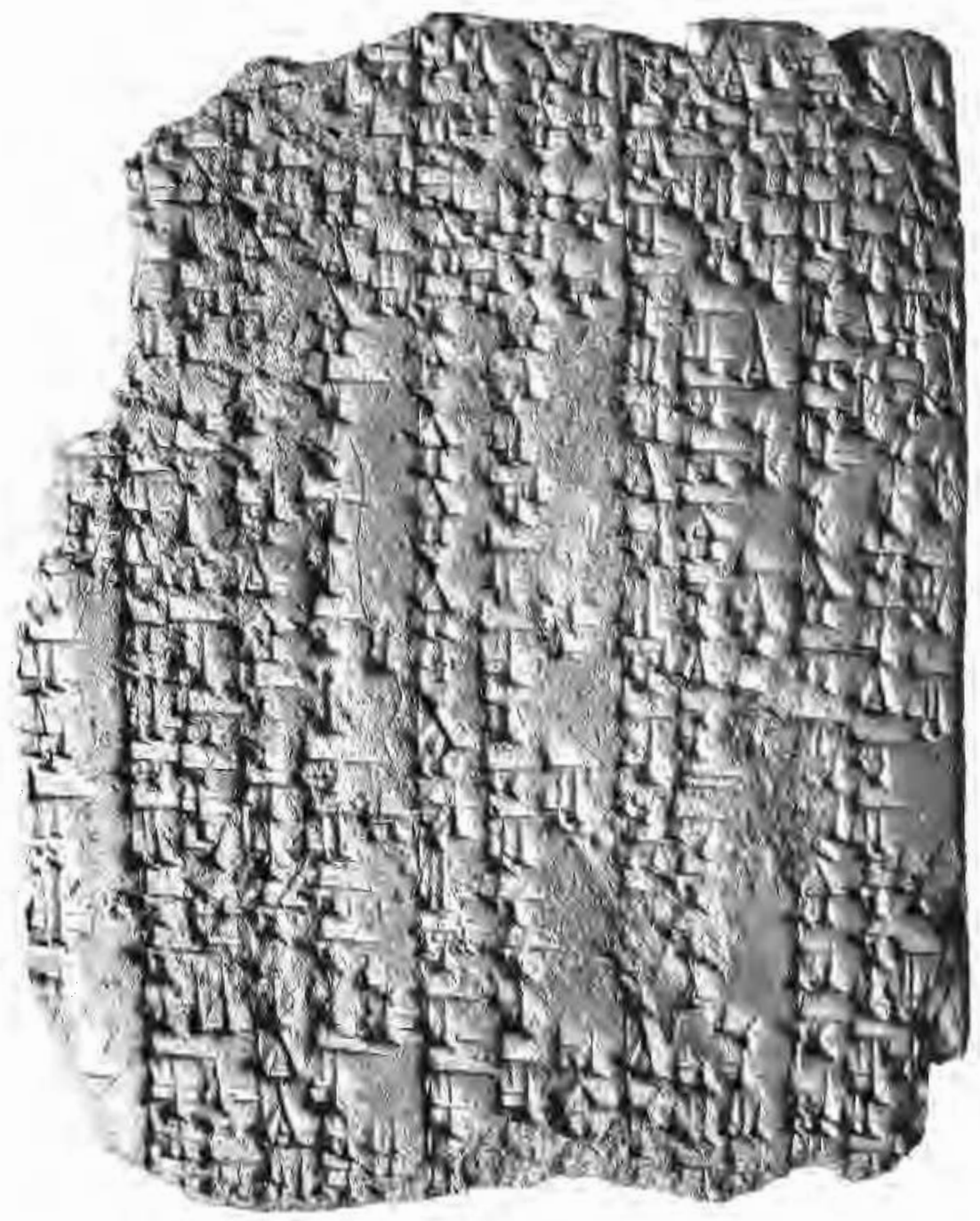

$\mathbf{B}=\mathrm{AO} 6316$, obverse 


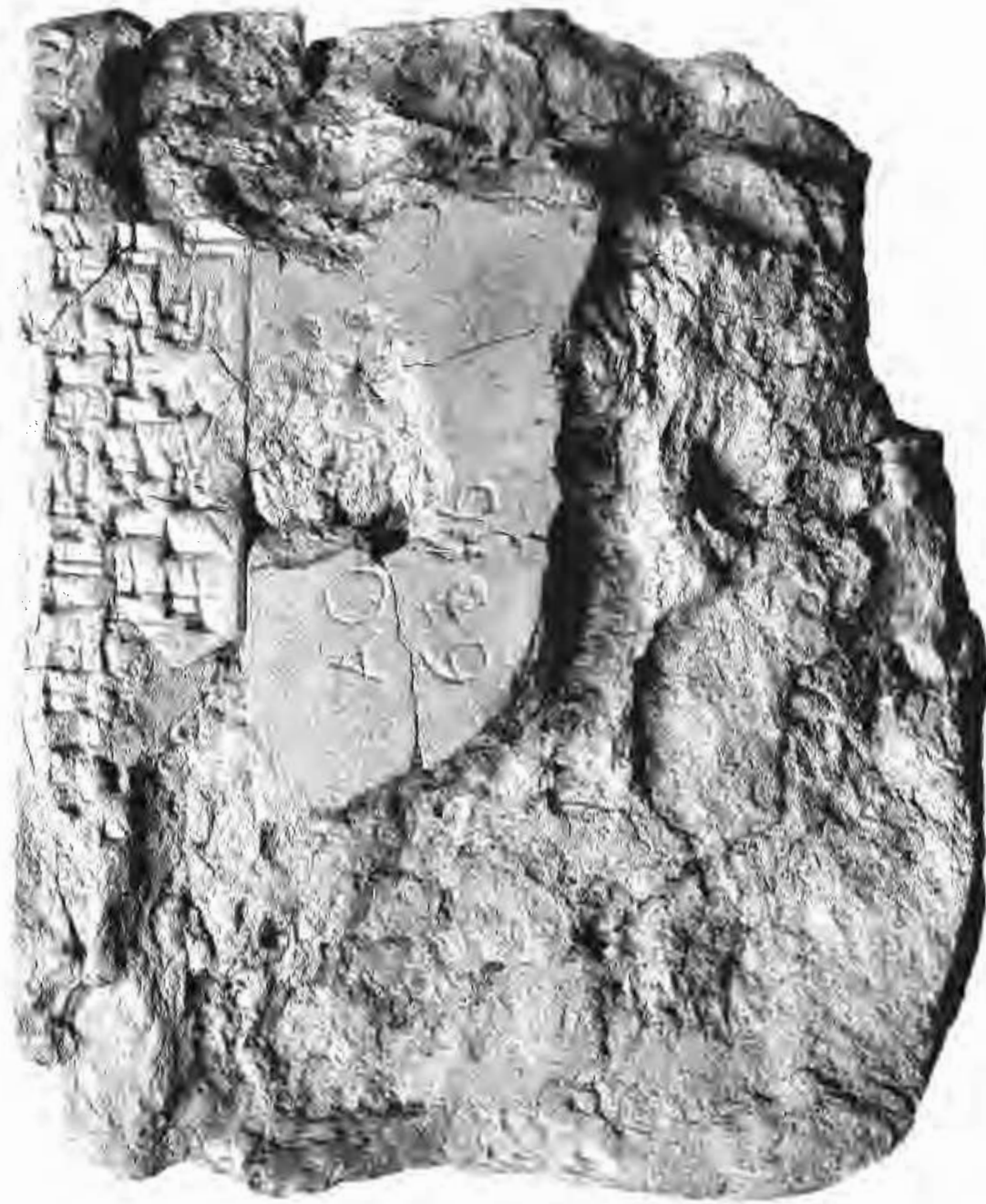

$\mathbf{B}=\mathrm{AO} 6316$, reverse 
Plate 16

URNAMMA C

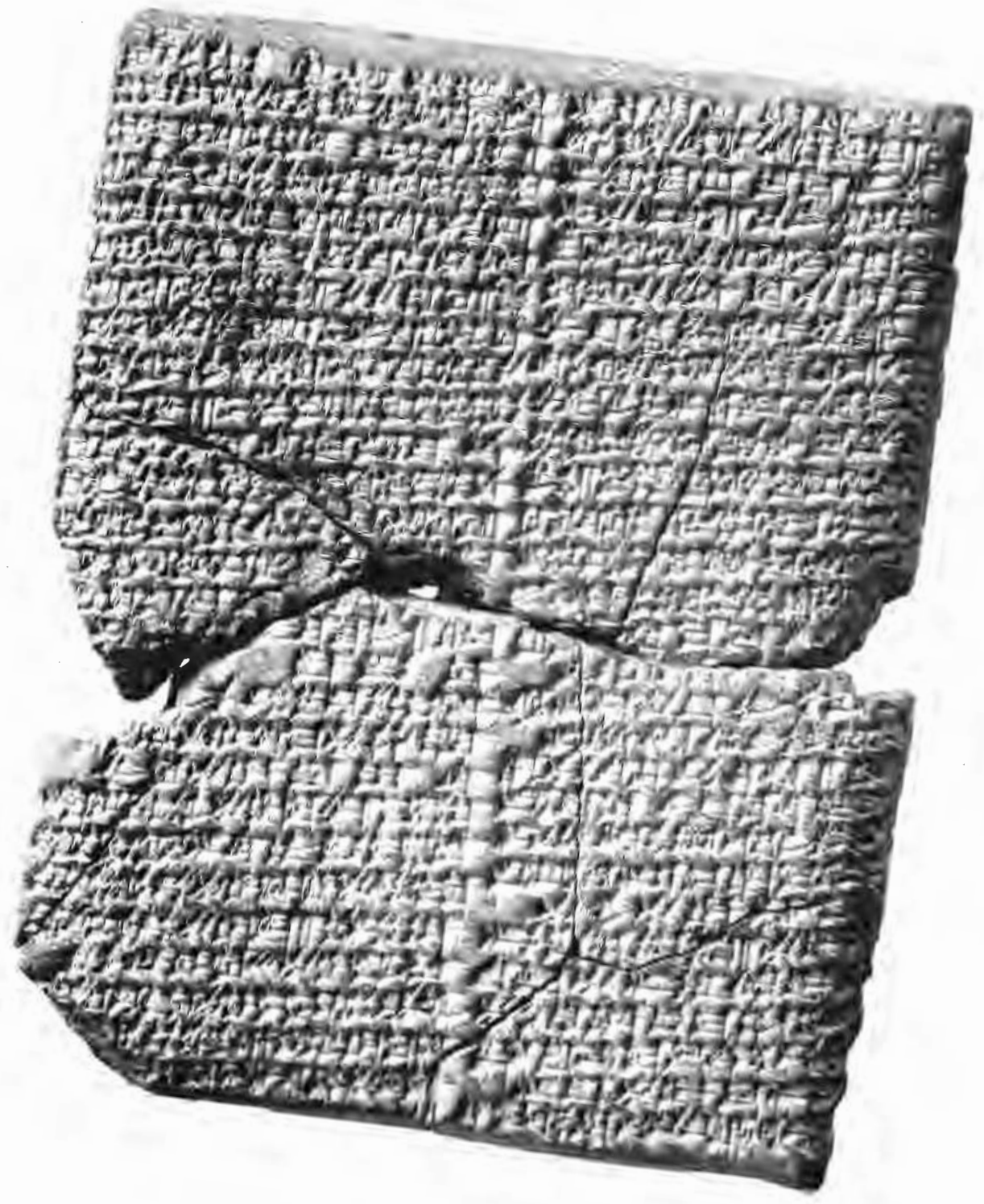

AO 5378, obverse 


\section{URNAMMA C}

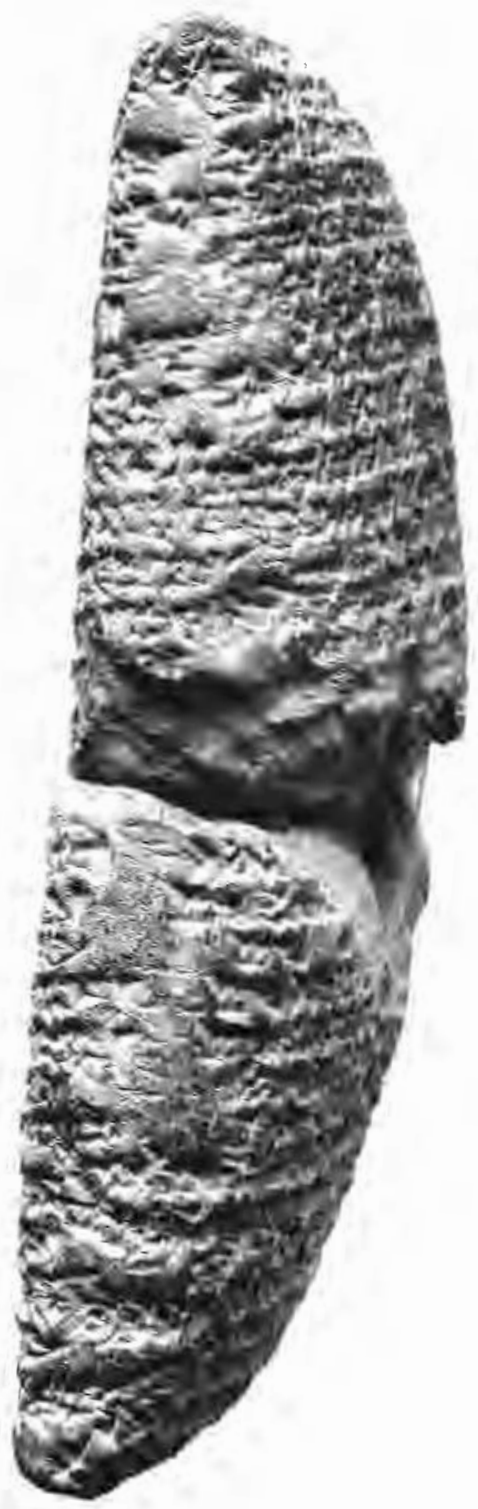

AO 5378, edge 
Plate 18

URNAMMA C

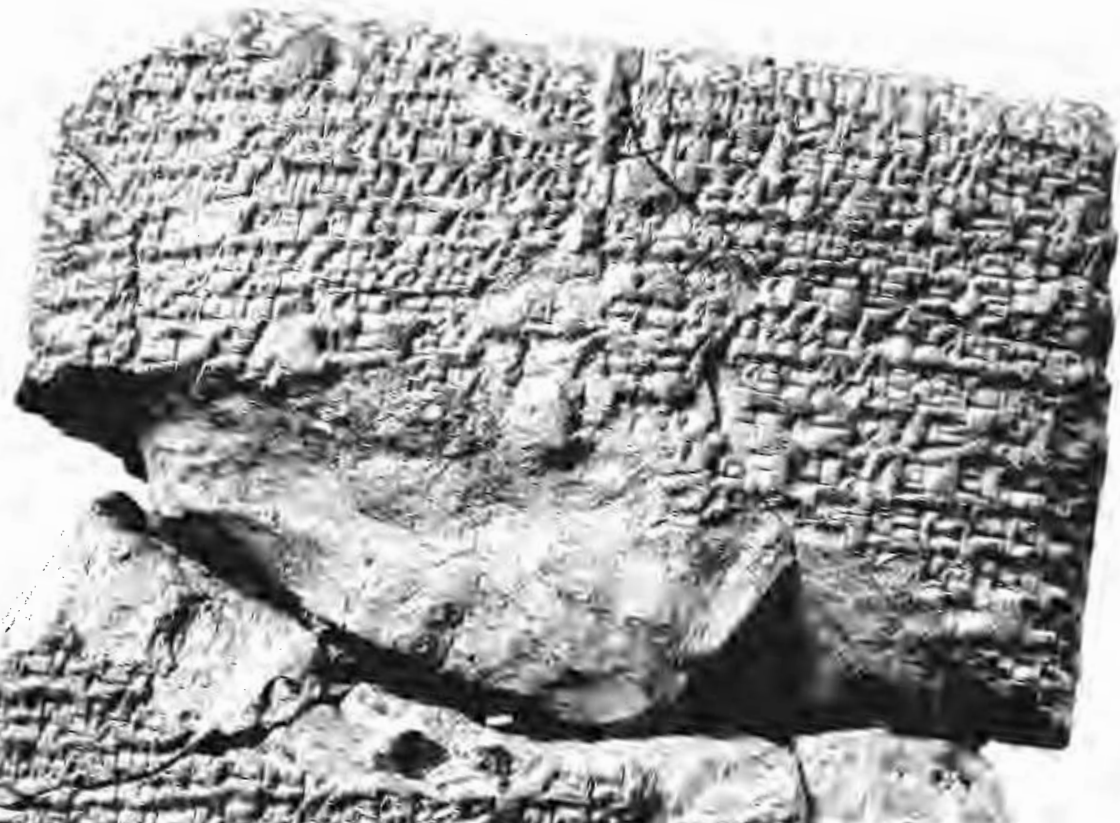

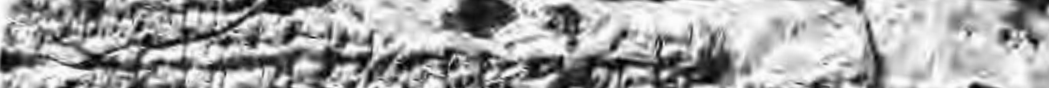

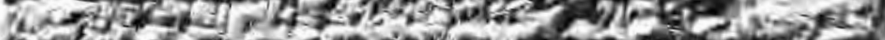

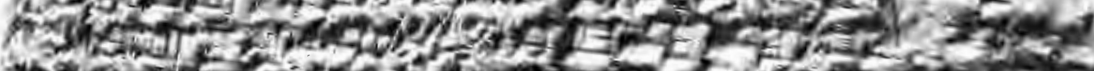

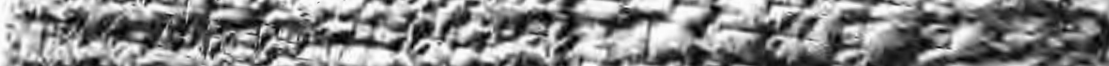

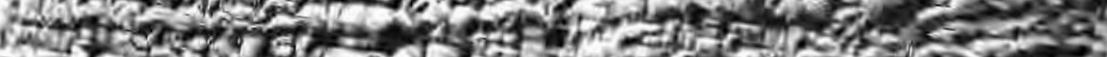

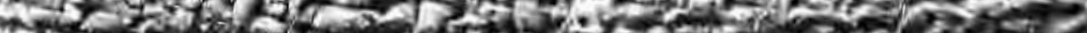

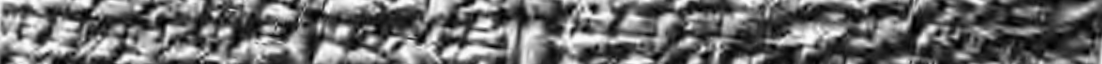

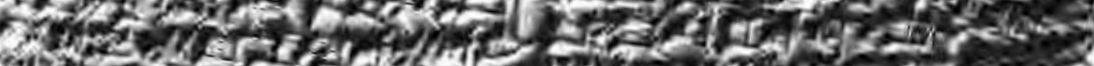

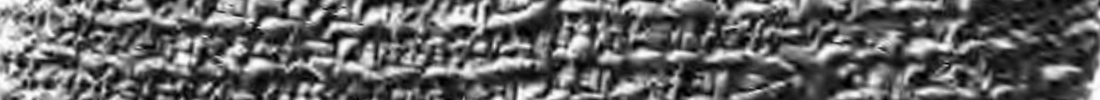

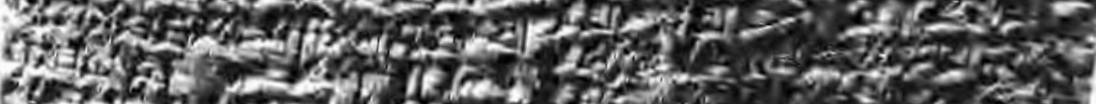

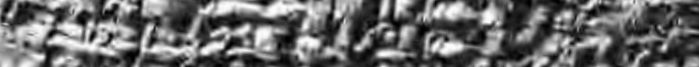

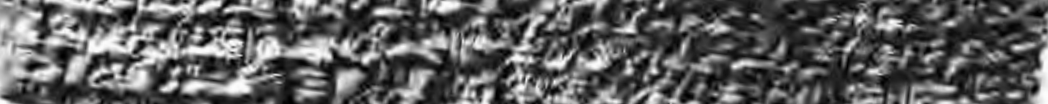

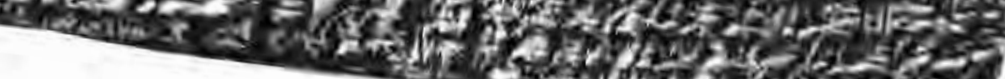

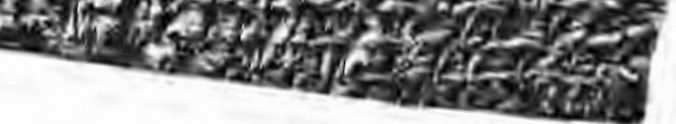

AO 5378, reverse 


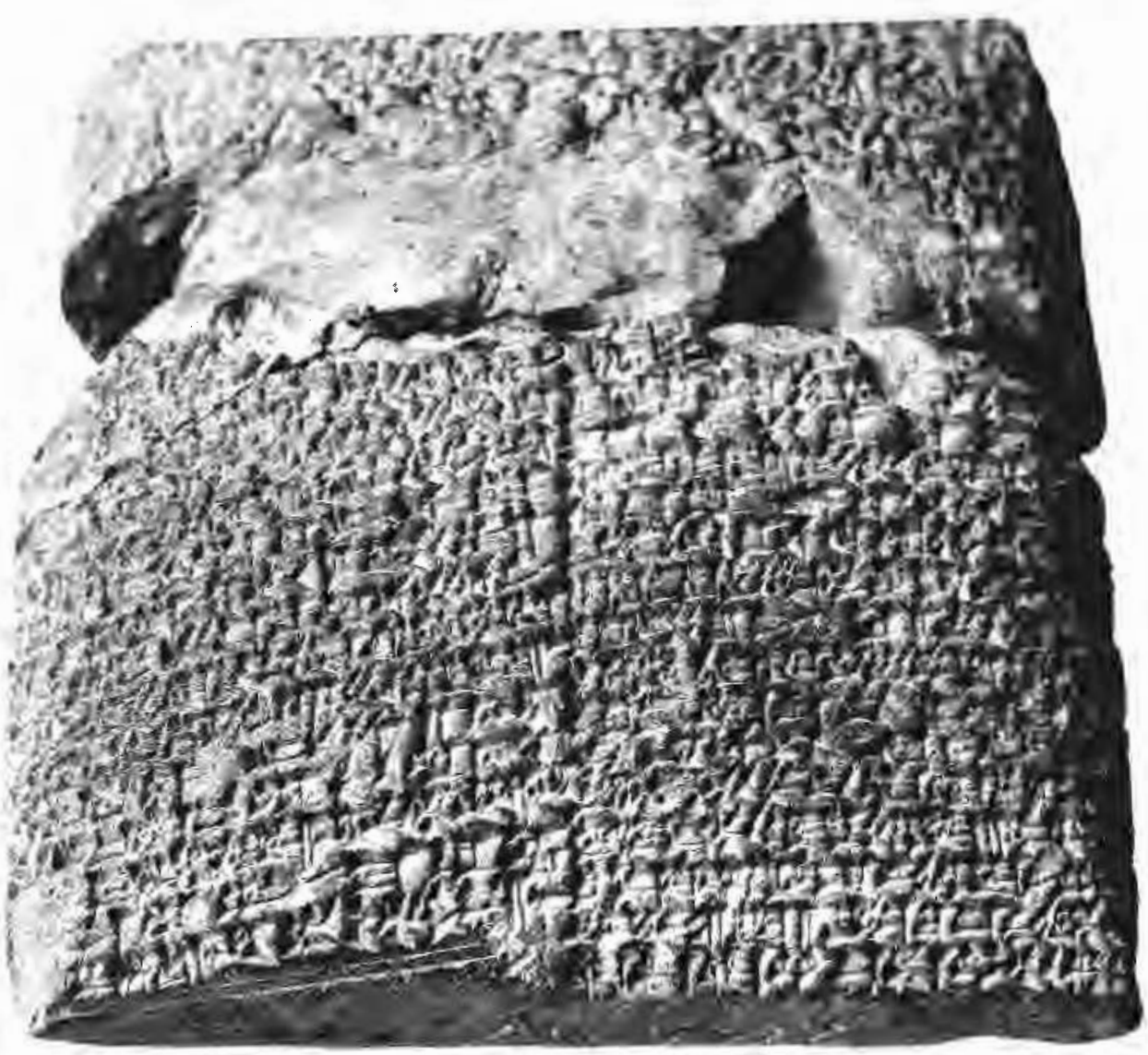

AO 5378, lower reverse 


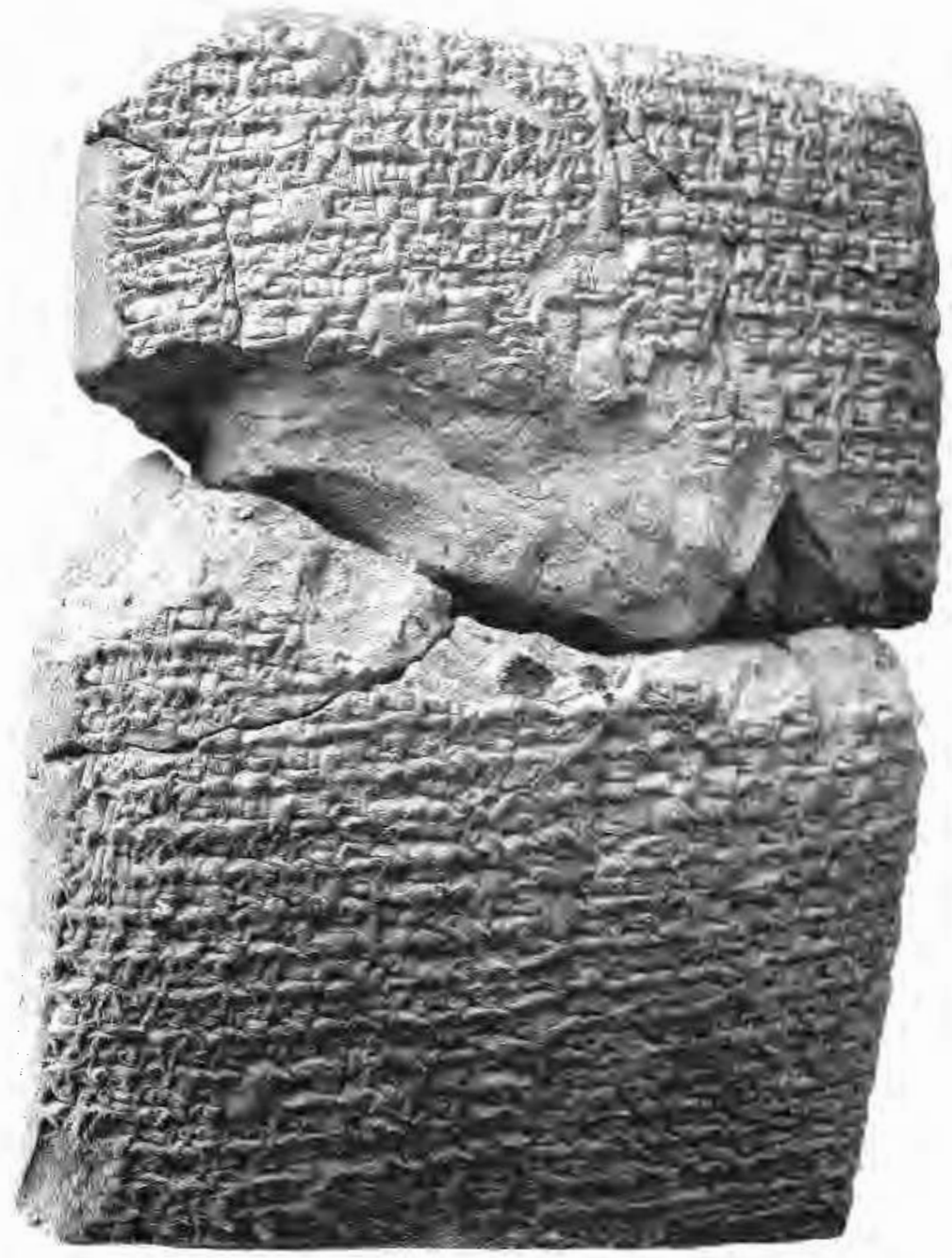

AO 5378, reverse 


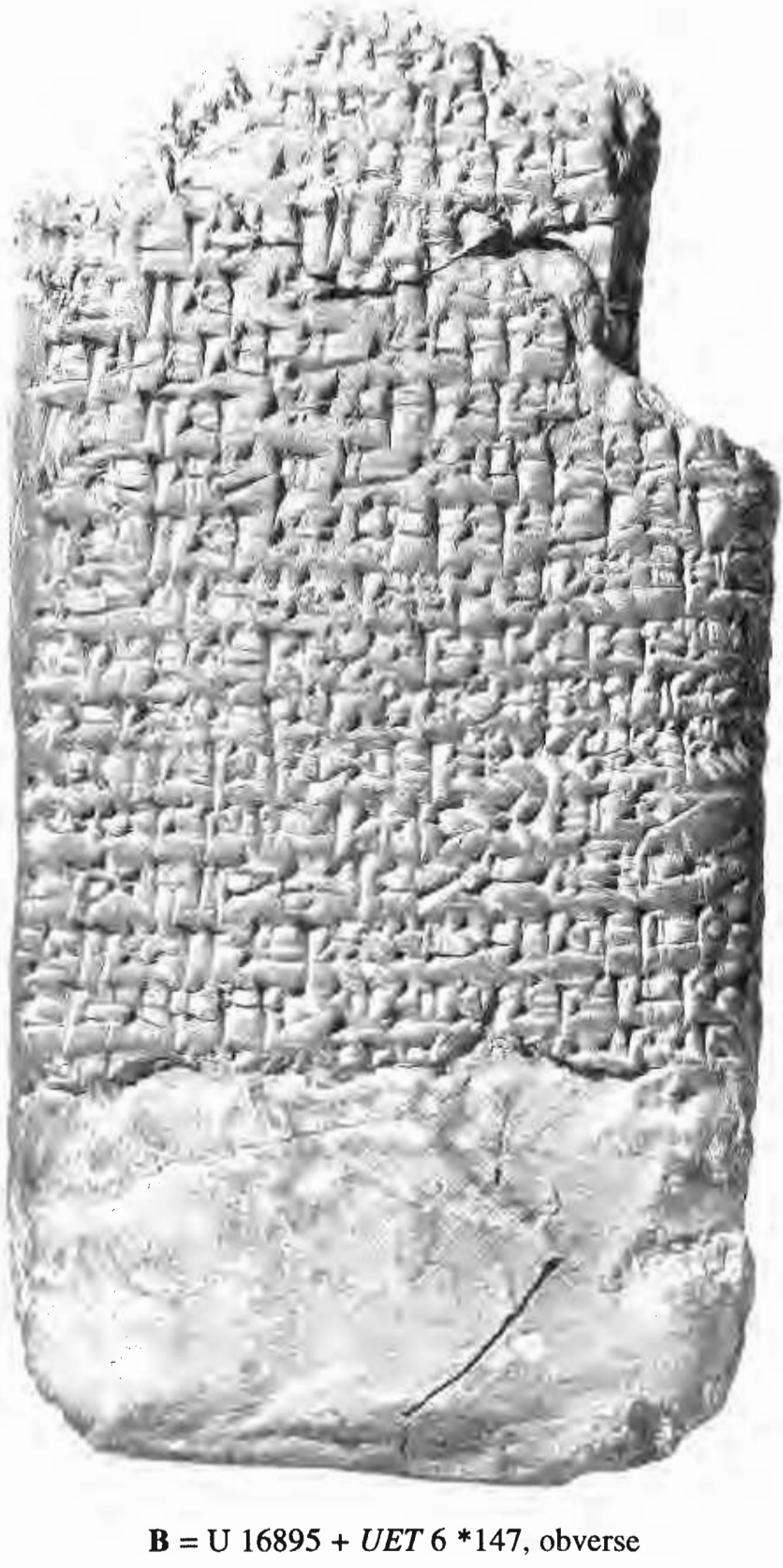


Plate 22

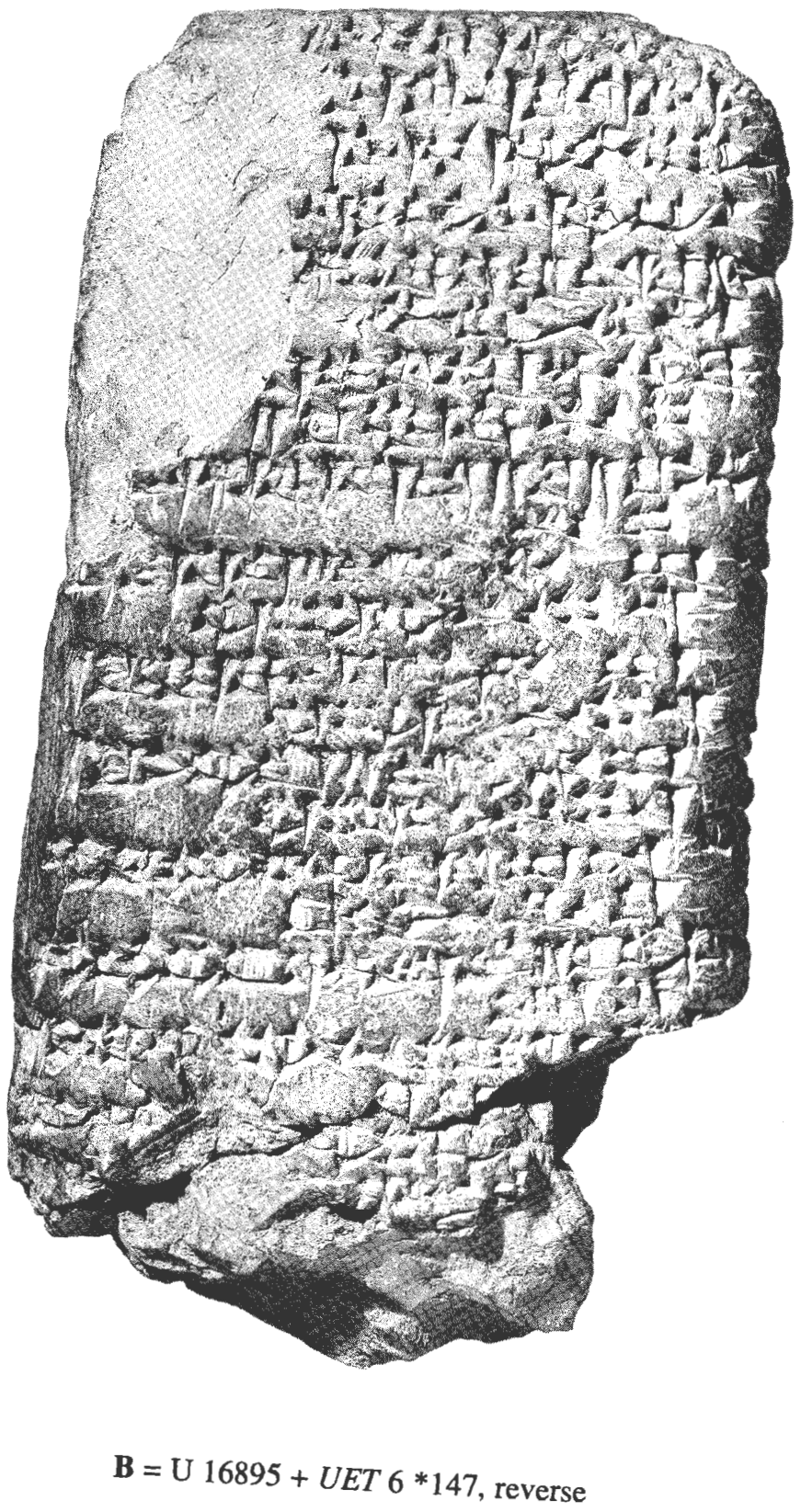




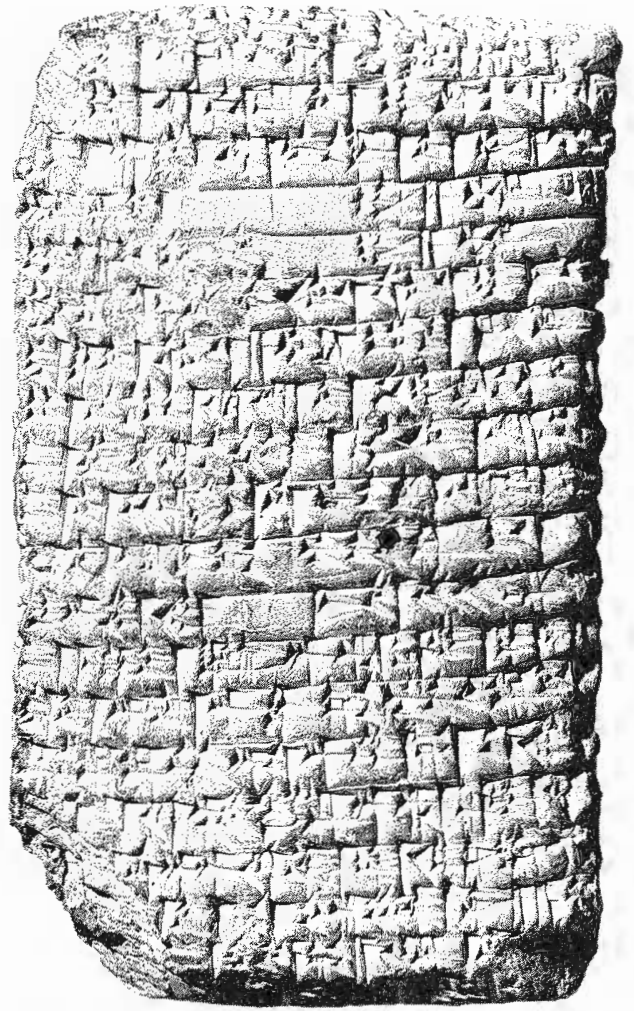

URNAMMA F, B = BM 78183, obverse

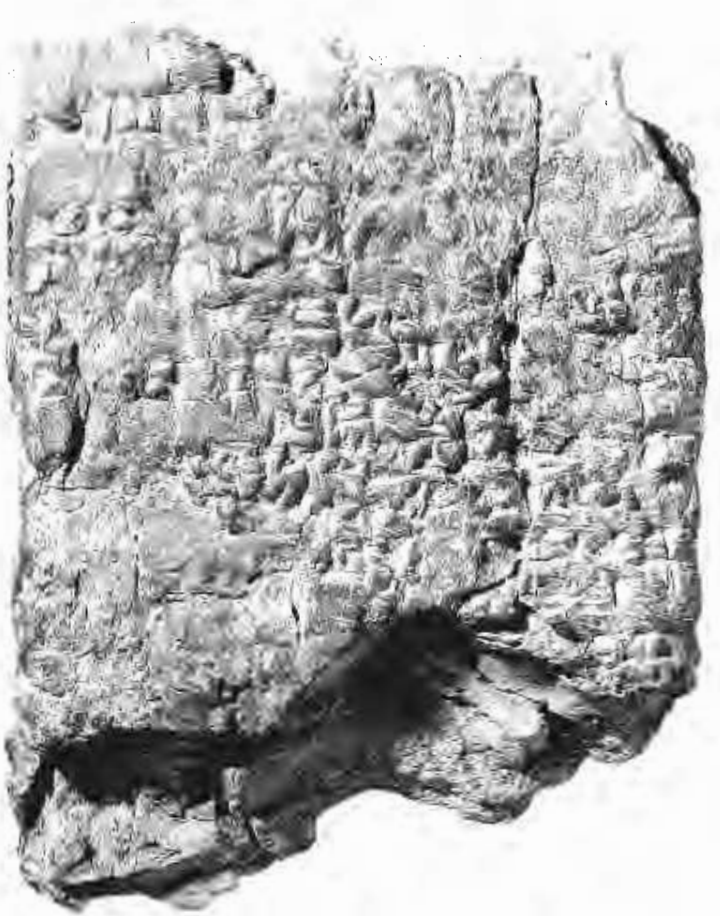

URNAMMA D, $C=U$ 16860, obverse 


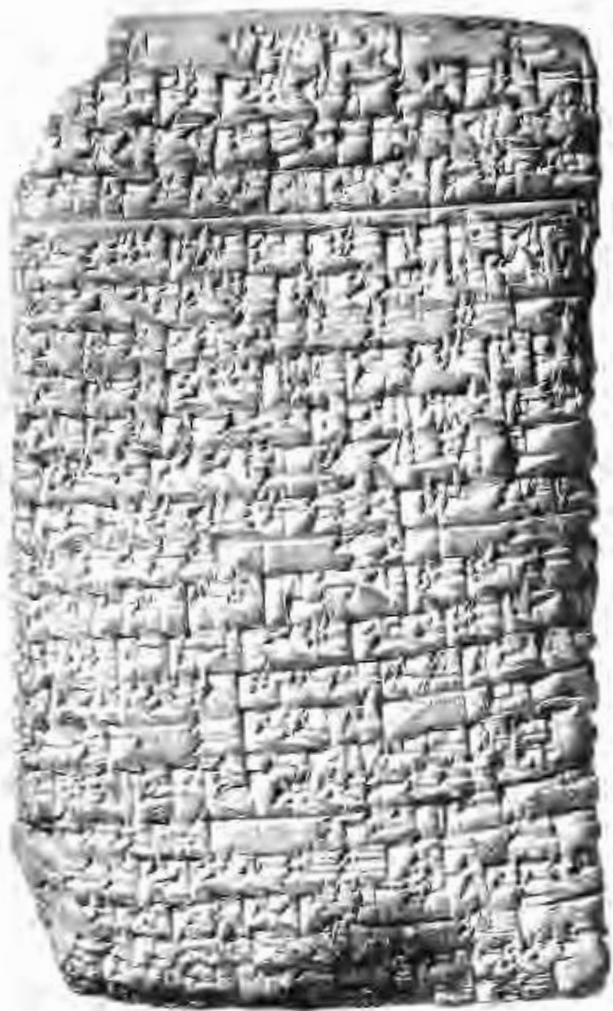

URNAMMA F, $\mathbf{B}=\mathrm{BM} 78183$, reverse

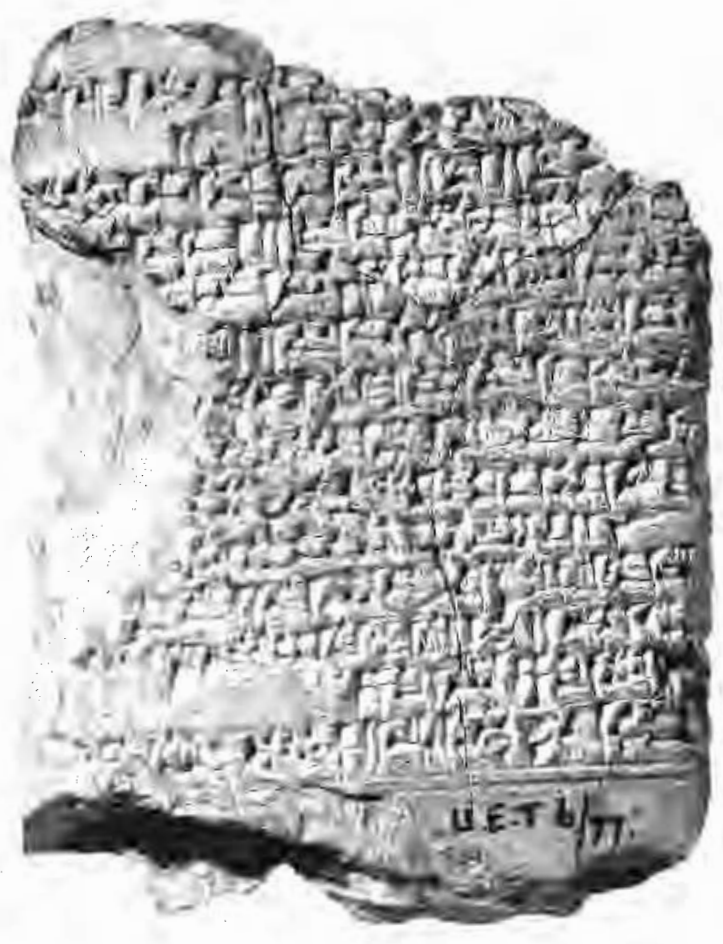

URNAMMA D, C $=$ U 16860, reverse 
collations

\section{convex side}

$r \quad 1-5$

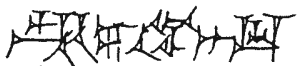

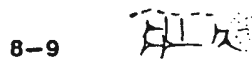

8, 11-13

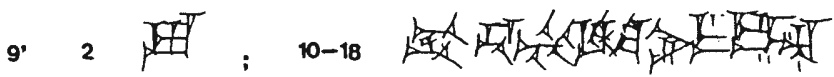

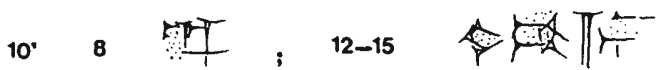

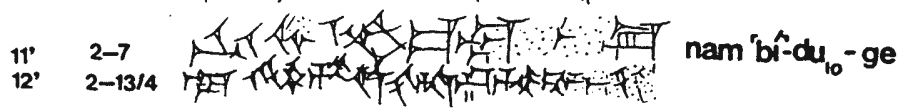

13, 10-11 $d u_{10}-9 a-a ̀ m$

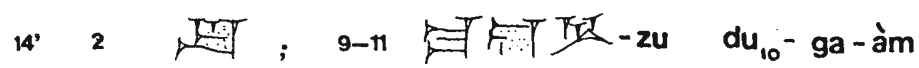

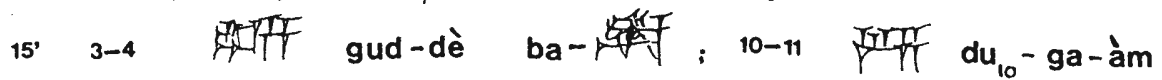

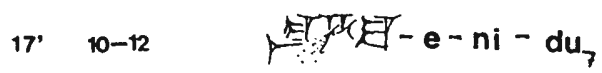

18, 10-15

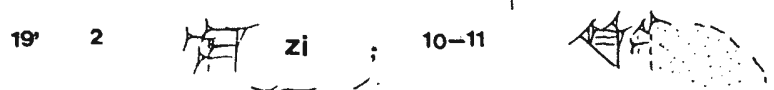

20, 11-12 付这:

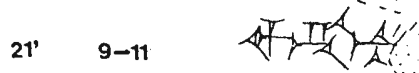

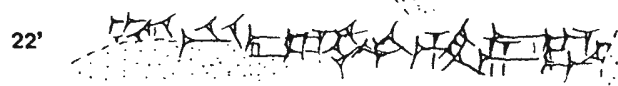

23'

\section{Tr太芷 ADET}

\section{flat side}

1

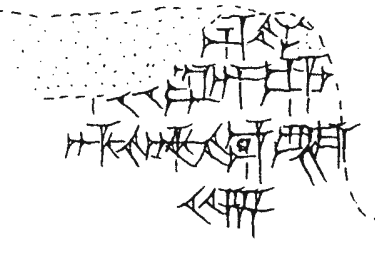


Bd. 25/1a MICHAEL LATTKE: Die Oden Salomos in ibrer Bedeutung für Neues Testament und Gnosis. Band Ia. Der syrische Text der Edition in Estrangela Faksimile des griechischen Papyrus Bodmer XI. 68 Seiten. 1980.

Bd. 25/2 MICHAEL LATTKE: Die Oden Salomos in ibrer Bedeutung für Neues Testament und Gnosis. Band II. Vollständige Wortkonkordanz zur handschriftlichen, griechischen, koptischen, lateinischen und syrischen Überlieferung der Oden Salomos. Mit einem Faksimile des Kodex N. XVI-201 Seiten. 1979.

Bd. 25/3 MICHAEL LATTKE: Die Oden Salomos in ibrer Bedeutung fïr Neues Testament und Gnosis. Band III. XXXIV -478 Seiten. 1986.

Bd. 25/4 MICHAEL LATTKE: Die Oden Salomos in ibrer Bedeutung für Neues Testament und Gnosis. Band IV. XII-284 Seiten. 1998.

Bd. 46 ERIK HORNUNG: Der ägyptische Mythos von der Himmelskuh. Eine Ätiologie des Unvollkommenen. Unter Mitarbeit von Andreas Brodbeck, Hermann Schlögl und Elisabeth Staehelin und mit einem Beitrag von Gerhard Fecht. XII-129 Seiten, 10 Abbildungen. 1991. Dritte Auflage.

Bd. 50/1 DOMINIQUE BARTHÉLEMY: Critique textuelle de l'Ancien Testament. 1. Josué, Juges, Ruth, Samuel, Rois, Chroniques, Esdras, Néhémie, Esther. Rapport final du Comité pour l'analyse textuelle de l'Ancien Testament hébreu institué par l'Alliance Biblique Universelle, établi en coopération avec Alexander R. Hulst †, Norbert Lohfink, William D. McHardy, H. Peter Rüger, coéditeur, James A. Sanders, coéditeur. 812 pages. 1982.

Bd. 50/2 DOMINIQUE BARTHÉLEMY: Critique textuelle de l'Ancien Testament. 2. Isaïe, Jérémie, Lamentations. Rapport final du Comité pour l'analyse textuelle de l'Ancien Testament hébreu institué par l'Alliance Biblique Universelle, établi en coopération avec Alexander R. Hulst $\dagger$, Norbert Lohfink, William D. McHardy, H. Peter Rüger, coéditeur, James A. Sanders, coéditeur. 1112 pages. 1986.

Bd. 50/3 DOMINIQUE BARTHÉLEMY: Critique textuelle de l'Ancien Testament. Tome 3. Ezéchiel, Daniel et les 12 Prophètes. Rapport final du Comité pour l'analyse textuelle de l'Ancien Testament hébreu institué par l'Alliance Biblique Universelle, établi en coopération avec Alexander R. Hulst $\dagger$, Norbert Lohfink, William D. McHardy, H. Peter Rügert $\uparrow$, coéditeur, James A. Sanders, coéditeur. 1424 pages. 1992.

Bd. 53 URS WINTER: Frau und Göttin. Exegetische und ikonographische Studien zum weiblichen Gottesbild im Alten Israel und in dessen Umwelt. XVIII-928 Seiten, 520 Abbildungen.1983. 2. Auflage 1987. Mit einem Nachwort zur 2. Auflage.

Bd. 55 PETER FREI / KLAUS KOCH: Reichsidee und Reichsorganisation im Perserreich. 352 Seiten, 17 Abbildungen. 1996. Zweite, bearbeitete und erweiterte Auflage.

Bd. 67 OTHMAR KEEL / SILVIA SCHROER: Studien zu den Stempelsiegeln aus PalästinalIsrael. Band I. 115 Seiten, 103 Abbildungen. 1985.

Bd. 71 HANS-PETER MATHYS: Liebe deinen Nächsten wie dich selbst. Untersuchungen zum alttestamentlichen Gebot der Nächstenliebe (Lev 19,18). XII-204 Seiten. 1986. 2. verbesserte Auflage 1990. 
Bd. 76 JOŽE KRAS̆OVEC: La justice (Sdq) de Dieu dans la Bible bébraïque et l'interprétation juive et cbrétienne. 456 pages. 1988.

Bd. 77 HELMUT UTZSCHNEIDER: Das Heiligtum und das Gesetz. Studien zur Bedeutung der sinaitischen Heiligtumstexte (Ez 25-40; Lev 8-9). XIV-326 Seiten. 1988.

Bd. 78 BERNARD GOSSE: Isaie 13,1 14,23. Dans la tradition littéraire du livre d'Isaïe et dans la tradition des oracles contre les nations. 308 pages. 1988.

Bd. 79 INKE W. SCHUMACHER: Der Gott Sopdu - Der Herr der Fremdländer. XV1-364 Seiten, 6 Abbildungen. 1988.

Bd. 80 HELLMUT BRUNNER: Das börende Herz. Kleine Schriften zur Religions- und Geistesgeschichte Ägyptens. Herausgegeben von Wolfgang Röllig. 449 Seiten, 55 Abbildungen. 1988.

Bd. 81 WALTER BEYERLIN: Bleilot, Brecheisen oder was sonst? Revision einer Amos-Vision. 68 Seiten. 1988.

Bd. 82 MANFRED HUTTER: Behexung, Entsübnung und Heilung. Das Ritual der Tuunawiya für ein Königspaar aus mittelhethitischer Zeit (KBo XXI 1 - KUB IX 34 - KBo XXI 6). 186 Seiten. 1988.

Bd. 83 RAPHAEL GIVEON: Scarabs from Recent Excavations in Israel. 114 pages with numerous illustrations and 9 plates. 1988.

Bd. 84 MIRIAM LICHTHEIM: Ancient Egyptian Autobiograpbies chiefly of the Middle Kingdom. A Study and an Anthology. 200 pages, 10 pages with illustrations. 1988.

Bd. 85 ECKART OTTO: Rechtsgeschichte der Redaktionen im Kodex Ešnunna und im «Bundesbuch». Eine redaktionsgeschichtliche und rechtsvergleichende Studie zu altbabylonischen und altisraelitischen Rechtsüberlieferungen. 220 Seiten. 1989.

Bd. 86 ANDRZEJ NIWIŃSKI: Studies on the Illustrated Theban Funerary Papyri of the 11th and 10th Centuries B.C. 488 pages, 80 plates. 1989.

Bd. 87 URSULA SEIDL: Die babylonischen Kudurru-Reliefs. Symbole mesopotamischer Gottheiten. 236 Seiten, 33 Tafeln und 2 Tabellen. 1989.

Bd. 88 OTHMAR KEEL / HILDI KEEL-LEU / SILVIA SCHROER: Studien zu den Stempelsiegeln aus Palästina/Israel. Band II. 364 Seiten, 652 Abbildungen. 1989.

Bd. 89 FRIEDRICH ABITZ: Baugeschichte und Dekoration des Grabes Ramses' VI. 202 Seiten, 39 Abbildungen. 1989.

Bd. 90 JOSEPH HENNINGER SVD: Arabica varia. Aufsätze zur Kulturgeschichte Arabiens und seiner Randgebiete. Contributions à l'histoire culturelle de l'Arabie et de ses régions limitrophes. 504 pages. 1989.

Bd. 91 GEORG FISCHER: Jabwe unser Gott. Sprache, Aufbau und Erzähltechnik in der Berufung des Mose (Ex. 3-4). 276 Seiten. 1989.

Bd. 92 MARK A. O’BRIEN: The Deuteronomistic History Hypothesis. A Reassessment. 340 pages. 1989.

Bd. 93 WALTER BEYERLIN: Reflexe der Amosvisionen im Jeremiabuch. 120 Seiten. 1989.

Bd. 94 ENZO CORTESE: Josua 13-21. Ein priesterschriftlicher Abschnitt im deuteronomistischen Geschichtswerk. 136 Seiten. 1990.

Bd. 96 ANDRÉ WIESE: Zum Bild des Königs auf ägyptischen Siegelamuletten. 264 Seiten mit zahlreichen Abbildungen im Text und 32 Tafeln. 1990. 
Bd. 97 WOLFGANG ZWICKEL: Räucherkult und Räuchergeräte. Exegetische und archäologische Studien zum Räucheropfer im Alten Testament. 372 Seiten. Mit zahlreichen Abbildungen im Text. 1990.

Bd. 98 AARON SCHART: Mose und Israel im Konflikt. Eine redaktionsgeschichtliche Studie zu den Wüstenerzählungen. 296 Seiten. 1990.

Bd. 99 THOMAS RÖMER: Israels Väter. Untersuchungen zur Väterthematik im Deuteronomium und in der deuteronomistischen Tradition. 664 Seiten. 1990.

Bd. 100 O'THMAR KEEL / MENAKHEM SHUVAL / CHRISTOPH UEHLINGER: Studien $z u$ den Stempelsiegeln aus Palästina / Israel Band III. Die Frühe Eisenzeit. Ein Workshop. XIV-456 Seiten. Mit zahlreichen Abbildungen im Text und 22 Tafeln. 1990.

Bd. 101 CHRISTOPH UEHLINGER: Weltreich und «eine Rede». Eine neue Deutung der sogenannten Turmbauerzählung (Gen 11,1-9). XVI-654 Seiten.1990.

Bd. 102 BENJAMIN SASS: Studia Alphabetica. On the Origin and Early History of the Northwest Semitic, South Semitic and Greek Alphabets. X-120 pages. 16 pages with illustrations. 2 tables. 1991.

Bd. 103 ADRIAN SCHENKER: Text und Sinn im Alten Testament. Textgeschichtliche und bibeltheologische Studien. VIII-312 Seiten. 1991.

Bd. 104 DANIEL BODI: The Book of Ezekiel and the Poem of Erra. IV-332 pages. 1991.

Bd. 105 YUICHI OSUMI: Die Kompositionsgeschichte des Bundesbuches Exodus 20,22b-23,33. XII-284 Seiten. 1991.

Bd. 106 RUDOLF WERNER: Kleine Einfübrung ins Hieroglyphen-Luwische. XII-112 Seiten. 1991.

Bd. 107 THOMAS STAUBLI: Das Image der Nomaden im Alten Israel und in der Ikonograpbie seiner sessbaften Nacbbarn. XII-408 Seiten. 145 Abb. und 3 Falttafeln. 1991.

Bd. 108 MOSHÉ ANBAR: Les tribus amurrites de Mari. VIII-256 pages. 1991.

Bd. 109 GÉRARD J. NORTON / STEPHEN PISANO (eds.): Tradition of the Text. Studies offered to Dominique Barthélemy in Celebration of his 70th Birthday. 336 pages. 1991.

Bd. 110 HILDI KEEL-LEU: Vorderasiatische Stempelsiegel. Die Sammlung des Biblischen Instituts der Universität Freiburg Schweiz. 180 Seiten. 24 Tafeln. 1991.

Bd. 111 NORBERT LOHFINK: Die Väter Israels im Deuteronomium. Mit einer Stellungnahme von Thomas Römer. 152 Seiten. 1991.

Bd. 113 CHARLES MAYSTRE: Les grands prêtres de Ptah de Memphis. XIV-474 pages, 2 planches. 1992.

Bd. 114 THOMAS SCHNEIDER: Asiatische Personennamen in ägyptischen Quellen des Neuen Reiches. 480 Seiten. 1992.

Bd. 115 ECKHARD VON NORDHEIM: Die Selbstbehauptung Israels in der Welt des Alten Orients. Religionsgeschichtlicher Vergleich anhand von Gen 15/22/28, dem Aufenthalt Israels in Ägypten, 2 Sam 7, 1 Kön 19 und Psalm 104. 240 Seiten. 1992.

Bd. 116 DONALD M. MATTHEWS: The Kassite Glyptic of Nippur. 208 pages, 210 figures. 1992.

Bd. 117 FIONA V. RICHARDS: Scarab Seals from a Middle to Late Bronze Age Tomb at Pella in Jordan. XII-152 pages, 16 plates. 1992.

Bd. 118 YOHANAN GOLDMAN: Prophétie et royauté au retour de l'exil. Les origines littéraires de la forme massorétique du livre de Jérémie. XIV-270 pages. 1992. 
Bd. 119 THOMAS M. KRAPF: Die Priesterschrift und die vorexilische Zeit. Yehezkel Kaufmanns vernachlässigter Beitrag zur Geschichte der biblischen Religion. XX-364 Seiten. 1992.

Bd. 120 MIRIAM LICHTHEIM: Maat in Egyptian Autobiograpbies and Related Studies. 236 pages, 8 plates. 1992.

Bd. 121 ULRICH HÜBNER: Spiele und Spielzeug im antiken Palästina. 256 Seiten. 58 Abbildungen. 1992.

Bd. 122 OTHMAR KEEL: Das Recht der Bilder, gesehen zu werden. Drei Fallstudien zur Methode der Interpretation altorientalischer Bilder. 332 Seiten, 286 Abbildungen. 1992.

Bd. 123 WOLFGANG ZWICKEL (Hrsg.): Biblische Welten. Festschrift für Martin Metzger zu seinem 65. Geburtstag. 268 Seiten, 19 Abbildungen. 1993.

Bd. 125 BENJAMIN SASS / CHRISTOPH UEHLINGER (eds.): Studies in the Iconograpby of Northwest Semitic Inscribed Seals. Proceedings of a symposium held in Fribourg on April 17-20, 1991. 368 pages, 532 illustrations. 1993.

Bd. 126 RÜDIGER BARTELMUS / THOMAS KRÜGER / HELMUT UTZSCHNEIDER (Hrsg.): Konsequente Traditionsgeschicbte. Festschrift für Klaus Baltzer zum 65. Geburtstag. 418 Seiten. 1993.

Bd. 127 ASKOLD I. IVANTCHIK: Les Cimmériens au Proche-Orient. 336 pages. 1993.

Bd. 128 JENS VOSS: Die Menora. Gestalt und Funktion des Leuchters im Tempel zu Jerusalem. 124 Seiten. 1993.

Bd. 129 BERND JANOWSKI / KLAUS KOCH / GERNOT WILHELM (Hrsg.): Religionsgescbicbtliche Beziehungen zwischen Kleinasien, Nordsyrien und dem Alten Testament. Internationales Symposion Hamburg 17.-21. März 1990. 572 Seiten. 1993.

Bd. 130 NILI SHUPAK: Where can Wisdom be found? The Sage's Language in the Bible and in Ancient Egyptian Literature. XXXII-516 pages. 1993.

Bd. 131 WALTER BURKERT / FRITZ STOLZ (Hrsg.): Hymnen der Alten Welt im Kulturvergleich. 134 Seiten. 1994.

Bd. 132 HANS-PETER MATHYS: Dichter und Beter. Theologen aus spätalttestamentlicher Zeit. 392 Seiten. 1994.

Bd. 133 REINHARD G. LEHMANN: Friedrich Delitzsch und der Babel-Bibel-Streit. 472 Seiten, 13 Tafeln. 1994.

Bd. 135 OTHMAR KEEL: Studien zu den Stempelsiegeln aus Palästina/Israel. Band IV. Mit Registern zu den Bänden I-IV. XII-340 Seiten mit Abbildungen, 24 Seiten Tafeln. 1994.

Bd. 136 HERMANN-JOSEF STIPP: Das masoretische und alexandrinische Sondergut des Jeremiabuches. Textgeschichtlicher Rang, Eigenarten, Triebkräfte. VII-196 Seiten. 1994.

Bd. 137 PETER ESCHWEILER: Bildzauber im alten Ägypten. Die Verwendung von Bildern und Gegenständen in magischen Handlungen nach den Texten des Mittleren und Neuen Reiches. X-380 Seiten, 28 Seiten Tafeln. 1994.

Bd. 138 CHRISTIAN HERRMANN: ̈̈gyptische Amulette aus Palästina/Israel. Mit einem Ausblick auf ihre Rezeption durch das Alte Testament. XXIV-1000 Seiten, 70 Seiten Bildtafeln. 1994. 
Bd. 140 IZAK CORNELIUS: The Iconography of the Canaanite Gods Reshef and Ba'al. Late Bronze and Iron Age I Periods (c $1500-1000$ BCE). XII-326 pages with illustrations, 56 plates. 1994.

Bd. 141 JOACHIM FRIEDRICH QUACK: Die Lebren des Ani. Ein neuägyptischer Weisheitstext in seinem kulturellen Umfeld. X-344 Seiten, 2 Bildtafeln. 1994.

Bd. 142 ORLY GOLDWASSER: From Icon to Metaphor. Studies in the Semiotics of the Hieroglyphs. $\mathrm{X}-194$ pages. 1995.

Bd. 143 KLAUS BIEBERSTEIN: Josua-Jordan-Jericbo. Archäologie, Geschichte und Theologie der Landnahmeerzählungen Josua 1-6. XII-494 Seiten. 1995.

Bd. 144 CHRISTL MAIER: Die «fremde Frau» in Proverbien 1-9. Eine exegetische und sozialgeschichtliche Studie. XII-304 Seiten. 1995.

Bd. 145 HANS ULRICH STEYMANS: Deuteronomium 28 und die adê zur Thronfolgeregelung Asarbaddons. Segen und Fluch im Alten Orient und in Israel. XII-436 Seiten. 1995.

Bd. 146 FRIEDRICH ABITZ: Pharao als Gott in den Unterweltsbüchern des Neuen Reiches. VIII-228 Seiten. 1995.

Bd. 147 GILLES ROULIN: Le Liure de la Nuit. Une composition égyptienne de l'au-delà. Ire partie: traduction et commentaire. XX-420 pages. II e partie: copie synoptique. X-169 pages, 21 planches. 1996.

Bd. 148 MANUEL BACHMANN: Die strukturalistische Artefakt- und Kunstanalyse. Exposition der Grundlagen anhand der vorderorientalischen, ägyptischen und griechischen Kunst. 88 Seiten mit 40 Abbildungen. 1996.

Bd. 150 ELISABETH STAEHELIN / BERTRAND JAEGER (Hrsg.): Ägypten-Bilder. Akten des «Symposions zur Ägypten-Rezeption», Augst bei Basel, vom 9.-11. September 1993. 384 Seiten Text, 108 Seiten mit Abbildungen. 1997.

Bd. 151 DAVID A.WARBURTON: State and Economy in Ancient Egypt. Fiscal Vocabulary of the New Kingdom. 392 pages. 1996.

Bd. 152 FRANÇOIS ROSSIER SM: L'intercession entre les bommes dans la Bible bébrä̈que. L'intercession entre les hommes aux origines de l'intercession auprès de Dieu. 408 pages. 1996.

Bd. 153 REINHARD GREGOR KRATZ / THOMAS KRÜGER (Hrsg.): Rezeption und Auslegung im Alten Testament und in seinem Umfeld. Ein Symposion aus Anlass des 60. Geburtstags von Odil Hannes Steck. 148 Seiten. 1997.

Bd. 154 ERICH BOSSHARD-NEPUSTIL: Rezeptionen von Jesaja 1-39 im Zwölfprophetenbuch. Untersuchungen zur literarischen Verbindung von Prophetenbüchern in babylonischer und persischer Zeit. XIV-534 Seiten. 1997.

Bd. 155 MIRIAM LICHTHEIM: Moral Values in Ancient Egypt. 136 pages. 1997.

Bd. 156 ANDREAS WAGNER (Hrsg.): Studien zur hebräischen Grammatik. VIII-212 Seiten. 1997.

Bd. 157 OLIVIER ARTUS: Etudes sur le livre des Nombres. Récit, Histoire et Loi en Nb 13,1-20,13. X-310 pages. 1997.

Bd. 158 DIETER BÖHLER: Die heilige Stadt in Esdras $\alpha$ und Esra-Nehemia. Zwei Konzeptionen der Wiederherstellung Israels. XIV-464 Seiten. 1997. 
Bd. 159 WOLFGANG OSWALD: Israel am Gottesberg. Eine Untersuchung zur Literargeschichte der vorderen Sinaiperikope Ex 19-24 und deren historischem Hintergrund. X-300 Seiten. 1998.

Bd. 160/1 JOSEF BAUER / ROBERT K. ENGLUND / MANFRED KREBERNIK: Mesopotamien: Späturuk-Zeit und Frühdynastische Zeit. Annäherungen 1. Herausgegeben von Pascal Attinger und Markus Wäfler. 640 Seiten. 1998.

Bd. 160/3 WALTHER SALLABERGER / AAGE WESTENHOLZ: Mesopotamien: Akkade-Zeit und Ur III-Zeit. Annäherungen 3. Herausgegeben von Pascal Attinger und Markus Wäfler. 424 Seiten. 1999.

Bd. 161 MONIKA BERNETT / OTHMAR KEEL: Mond, Stier und Kult am Stadttor. Die Stele von Betsaida (et-Tell). 175 Seiten mit 121 Abbildungen. 1998.

Bd. 162 ANGELIKA BERLEJUNG: Die Theologie der Bilder. Herstellung und Einweihung von Kultbildern in Mesopotamien und die alttestamentliche Bilderpolemik. 1998. XII-560 Seiten. 1998.

Bd. 163 SOPHIA K. BIETENHARD: Des Königs General. Die Heerführertraditionen in der vorstaatlichen und frühen staatlichen Zeit und die Joabgestalt in 2 Sam 2-20; 1 Kön 1-2. 388 Seiten. 1998.

Bd. 164 JOACHIM BRAUN: Die Musikkultur Altisraels/Palästinas. Studien zu archäologischen, schriftlichen und vergleichenden Quellen. XII-372 Seiten, 288 Abbildungen. 1999.

Bd. 165 SOPHIE LAFONT: Femmes, Droit et Justice dans l'Antiquité orientale. Contribution à l'étude du droit pénal au Proche-Orient ancien. XVI-576 pages. 1999.

Bd. 166 ESTHER FLÜCKIGER-HAWKER: Urnamma of Ur in Sumerian Literary Tradition. XVIII426 pages, 25 plates. 1999.

Weitere Informationen zur Reihe OBO: http://www.unifr.ch/bif/obo/obo.html 
Bd. 1 JACQUES BRIEND / JEAN-BAPTISTE HUMBERT (Ed.): Tell Keisan (1971-1976), une cité phénicienne en Galilée. 392 pages, 142 planches. 1980.

Bd. 2 BERTRAND JAEGER: Essai de classification et datation des scarabées Menkbéperrê. 455 pages avec 1007 illustrations, 26 planches avec 443 figures. 1982.

Bd. 3 RAPHAEL GIVEON: Egyptian Scarabs from Western Asia from the Collections of the British Museum. 202 pages, 457 figures. 1985.

Bd. 4 SEYYARE EICHLER / MARKUS WÄFLER: Tall al-Hamidiya 1. Vorbericht 1984. 360 Seiten, 104 Tafeln, 4 Seiten Illustrationen, 4 Faltpläne, 1 vierfarbige Tafel. 1985.

Bd. 5 CLAUDIA MÜLLER-WINKLER: Die ägyptischen Objekt-Amulette. Mit Publikation der Sammlung des Biblischen Instituts der Universität Freiburg Schweiz, ehemals Sammlung Fouad S. Matouk. 590 Seiten, 40 Tafeln. 1987.

Bd. 6 SEYYARE EICHLER / MARKUS W ÄFLER / DAVID WARBURTON: Tall al-Hamidiya 2. Symposium Recent Excavations in the Upper Khabur Region. 492 Seiten, 20 Seiten Illustrationen, 2 Falttafeln, 1 vierfarbige Tafel. 1990.

Bd. 7 HERMANN A. SCHLÖGL / ANDREAS BRODBECK: Ägyptische Totenfiguren aus öffentlichen und privaten Sammlungen der Schweiz. 356 Seiten mit 1041 Photos. 1990.

Bd. 8 DONALD M. MATTHEWS: Principles of composition in Near Eastern glyptic of the later second millennium B.C. 176 pages, 39 pages with drawings, 14 plates. 1990.

Bd. 9 CLAUDE DOUMET: Sceaux et cylindres orientaux: la collection Cbiba. Préface de Pierre Amiet. 220 pages, 24 pages d'illustrations. 1992.

Bd. 10 OTHMAR KEEL: Corpus der Stempelsiegel-Amulette aus Palästina/Israel. Von den Anfängen bis zur Perserzeit. Einleitung. 376 Seiten mit 603 Abbildungen im Text. 1995.

Bd. 11 BEATRICE TEISSIER: Egyptian Iconograpby on Syro-Palestinian Cylinder Seals of the Middle Bronze Age. XII-224 pages with numerous illustrations, 5 plates. 1996.

Bd. 12 ANDRÉ B. WIESE: Die Anfänge der ägyptischen Stempelsiegel-Amulette. Eine typologische und religionsgeschichtliche Untersuchung zu den «Knopfsiegeln» und verwandten Objekten der 6. bis frühen 12. Dynastie. XXII-366 Seiten mit 1426 Abbildungen. 1996.

Bd. 13 OTHMAR KEEL: Corpus der Stempelsiegel-Amulette aus Palästina/Israel. Von den Anfängen bis zur Perserzeit. Katalog Band I. Von Tell Abu Farağ bis 'Atlit. VIII - 808 Seiten mit 375 Phototafeln. 1997.

Bd. 14 PIERRE AMIET / JACQUES BRIEND / LILIANE COURTOIS / JEAN-BERNARD DUMORTIER: Tell el Far'ab. Histoire, glyptique et céramologique. 100 pages. 1996. 
Bd. 15 DONALD M. MATTHEWS: The Early Glyptic of Tell Brak. Cylinder Seals of Third Millennium Syria. XIV-312 pages, 59 plates. 1997.

Bd. 16 SHUA AMORAI-STARK: Wolfe Family Collection of Near Eastern Prebistoric Stamp Seals. 216 pages. 1998.

Bd. 17 OLEG BERLEV / SVETLANA HODJASH: Catalogue of the Monuments of Ancient Egypt. From the Museums of the Russian Federation, Ukraine, Bielorussia, Caucasus, Middle Asia and the Baltic States. XIV-336 pages 208 plates. 1998. 


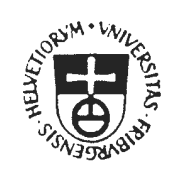

\title{
UNIVERSITÄT FREIBURG SCHWEIZ
}

\author{
BIBLISCHES INSTITUT
}

Das Biblische Institut in Freiburg Schweiz bietet lhnen die Möglichkeit, im Anschluß an ein Diplom oder Lizentiat in Theologie, Bibelwissenschaft, Altertumskunde Palästinas/Israels, Vorderasiatischer Archäologie oder einen gleichwertigen Leistungsausweis im Rahmen eines Studienjahres (Oktober - Juni) ein

\section{Spezialisierungszeugnis BIBEL UND ARCHÄOLOGIE}

(Feldarchäologie, Ikonographie, Epigraphik,

Religionsgeschichte Palästinas/Israels)

zu erwerben.

Das Studienjahr wird in Verbindung mit der Universität Bern (25 Min. Fahrzeit) organisiert. Es bietet Ihnen die Möglichkeit,

eine Auswahl einschlägiger Vorlesungen, Seminare und Übungen im Bereich "Bibel und Archäologie" bei Walter Dietrich, Othmar Keel, Ernst Axel Knauf, Max Küchler, Silvia Schroer und Christoph Uehlinger zu belegen;

diese Veranstaltungen durch solche in Ägyptologie (Hermann A. Schlögl, Freiburg), Vorderasiatischer Archäologie (Markus Wäfler, Bern) und altorientalischer Philologie (Pascal Attinger, Esther Flückiger, beide Bern) zu ergänzen;

die einschlägigen Dokumentationen des Biblischen Instituts zur palästinisch-israelischen Miniaturkunst aus wissenschaftlichen Grabungen (Photos, Abdrücke, Kartei) und die zugehörigen Fachbibliotheken zu benutzen;

$\leftrightarrow$ mit den großen Sammlungen (über 10'000 Stück) von Originalen altorientalischer Minia turkunst des Biblischen Instituts (Rollsiegel, Skarabäen und andere Stempelsiegel, Amu lette, Terrakotten, palästinische Keramik, Münzen usw.) zu arbeiten und sich eine eigene Dokumentation (Abdrücke, Dias) anzulegen;

während der Sommerferien an einer Ausgrabung in Palästina/Israel teilzunehmen, wobei die Möglichkeit besteht, mindestens das Flugticket vergütet zu bekommen.

Um das Spezialisierungszeugnis zu erhalten, müssen zwei benotete Jahresexamen abgelegt, zwei Seminarscheine erworben und eine schriftliche wissenschaftliche Arbeit im Umfange eines Zeitschriftenartikels verfaßt werden.

Interessenten und Interessentinnen wenden sich bitte an den Curator des Instituts:

PD Dr. Christoph Uehlinger

Biblisches Institut

Universität, Miséricorde

CH-1700 Freiburg / Schweiz

Fax $+41-(0) 26-3009754$ 


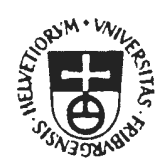

UNIVERSITÉ DE FRIBOURG EN SUISSE

INSTITUT BIBLIQUE

L'Institut Biblique de l'Université de Fribourg en Suisse offre la possibilité d'acquérir un

\title{
certificat de spécialisation \\ CRITIQUE TEXTUELLE ET HISTOIRE DU TEXTE ET DE L'EXÉGÈSE DE L'ANCIEN TESTAMENT
}

\author{
(Spezialisierungszeugnis Textkritik und Geschichte des Textes \\ und der Interpretation des Alten Testamentes)
}

en une année académique (octobre à juin). Toutes les personnes ayant obtenu une licence en théologie ou un grade académique équivalent peuvent en bénéficier.

Cette année d'études peut être organisée

autour de la critique textuelle proprement dite (méthodes, histoire du texte, instruments de travail, édition critique de la Bible);

$\square$ autour des témoins principaux du texte biblique (texte masorétique et masore, textes bibliques de Qumran, Septante, traductions hexaplaires, Vulgate, Targoums) et leurs langues (hébreu, araméen, grec, latin, syriaque, copte), enseignées en collaboration avec les chaires de patrologie et d'histoire ancienne, ou

autour de l'histoire de l'exégèse juive (en hébreu et en judéo-arabe) et chrétienne (en collaboration avec la patrologie et l'histoire de l'Eglise).

L'Institut dispose d'une bibliothèque spécialisée dans ces domaines. Les deux chercheurs consacrés à ces travaux sont Adrian Schenker et Yohanan Goldman.

Pour l'obtention du certificat, deux examens annuels, deux séminaires et un travail écrit équivalent à un article sont requis. Les personnes intéressées peuvent obtenir des informations sup plémentaires auprès du responsable du programme:

Prof. Dr. Adrian Schenker Institut Biblique

Université, Miséricorde

CH-1700 Fribourg / Suisse

Fax $+41-(0) 26-3009754$ 


\section{Summary}

This book presents new standard editions of all the hitherto known hymns of Urnamma, the founder of the Third Dynasty of Ur ( $\mathrm{fl}$. 2100 B.C.), and adds new perspectives to the composition and development of the genre of Sumerian royal hymns in general. The first chapter (I) is introductory in nature (historical background, the reading of the name Urnamma, Sumerian royal hymns). The second chapter (II) presents a general survey of Urnamma's hymnic corpus, including arguments for a broader definition of Sumerian royal hymns and an attempt at classifying the non-standard orthography found in Urnamma's hymns. The third chapter (III) deals with correlations of Urnamma's hymns with other textual sources pertaining to him. A fourth chapter (IV) is devoted to aspects of continuity and change in royal hymnography by analysing the Urnamma hymns in relation to other royal hymns and related genres. A discussion of topoi of legitimation and kingship and narrative materials in different text types during different periods of time and other findings concerning statues, stelas and royal hymns add new perspectives to the ongoing discussion of the original setting of royal hymns. Also, reasons are given why a version of the Sumerian King List may well be dated to Urnamma and the thesis advanced that Išmédagan of Isin was not only an imitator of sulgi but also of Urnamma. The final of the chapter IV shows that Urnamma A, also known as Urnamma's Death, uses the language of lamentation literature and Curse of Agade which describe the destruction of cities, and applies it to the death of a king. The last chapter $(\mathrm{V})$ presents critical editions of Urnamma hymns A-H. 